Universidad Politécnica de Madrid

Escuela Técnica Superior de Arquitectura

\title{
Huellas de lo vernáculo en Team 10 Alison y Peter Smithson, Aldo van Eyck, José Antonio Coderch
}

\author{
Tesis Doctoral \\ Ana Rodríguez García, Arquitecta \\ 2016
}



Departamento de Proyectos Arquitectónicos

Escuela Técnica Superior de Arquitectura

\section{Huellas de lo vernáculo en Team 10 \\ Alison y Peter Smithson, Aldo van Eyck, José Antonio Coderch}

Tesis Doctoral

Ana Rodríguez García, Arquitecta

Dirigida por:

Carmen Espegel Alonso, Doctora Arquitecta

2016 

Tribunal nombrado por el Mgfco. Y Excmo. Sr. Rector de la Universidad Politécnica de Madrid, el día

Presidente D.

Vocal D.

Vocal D.

Vocal D.

Secretario D.

Realizado el acto de defensa y lectura de Tesis el día en la Escuela Técnica Superior de Arquitectura de Madrid

Calificación:

EL PRESIDENTE

LOS VOCALES

EL SECRETARIO 

Índice de la Tesis 



\section{Índice Sintético}

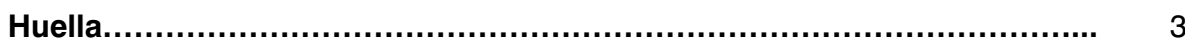

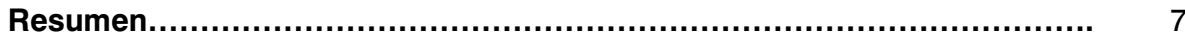

Abstract......................................................................................... 11

Introducción......................................................................... 13

\section{Capítulo 1}

Vernáculo, primitivo y popular.

1.1. Significado de Vernáculo, Primitivo y Popular............................. 31

1.2. Mito, Topos, typos, y tekton. Parámetros de análisis de lo vernáculo.......... 43

1.3. Apuntes y huellas de lo vernáculo.................................... 59

\section{Capítulo 2}

El jardín de los Smithson: El Upper Lawn Folly Solar Pavilion 83

2.1. Los Smithsons y lo vernáculo.

Found y As found, lo vernáculo así encontrado y el ojo alerta. ............... 89

2.2. The Green Man y Jack the Frost en el Upper Lawn Pavilion................. 114

2.3. El jardín inglés de los Smithsons........................................... $\quad 120$

2.4. «Upper Lawn, a Folly Solar Pavilion» heredero del jardín Arts and Crafts... $\quad 170$

2.5. Piedra, madera y aluminio: Ios Smithsons artesanos modernos.......... 185

\section{Capítulo 3}

La casa del martín pescador, entre un roble y un cañaveral.

Aldo van Eyck y Gerrit Rietveld en la Casa Visser de Bergeijk................. 22

3.1. Aldo van Eyck y lo vernáculo.

The Vernacular of the Heart y los Círculos de Otterlo. ...................... 225

3.2. El circulo condensador de significados................................... 256

3.3. Lugar e identidad. Aldo van Eyck y el territorio de los Países Bajos,

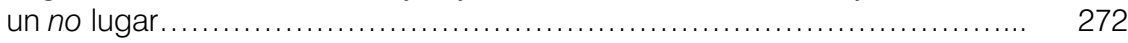

3.4. Una Kiva de los Indios Pueblo en Holanda.............................. 301

3.5. Ladrillo, madera y vidrio ............................................ 330

Capítulo 4

El hogar de Coderch: la casa de Espolla. ...................................... 337

4.1. José Antonio Coderch y lo popular.

Tradición viva y "No son genios los que necesitamos ahora"............... 344

4.2. Cardos para ahuyentar los malos espíritus ............................ 385

4.3. Espolla y Coderch.................................................. 391

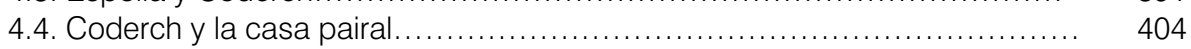

4.5. Piedra y madera.Interpretaciones modernas
de la tradición vernácula en la Casa de Espolla $\ldots \ldots \ldots \ldots \ldots \ldots \ldots \ldots \ldots \ldots \ldots \ldots$

Análisis comparado y Conclusiones......................................... 449

Fuentes documentales y Bibliografía..................................... 467

\section{Apéndices documentales}





\section{Índice Analítico}

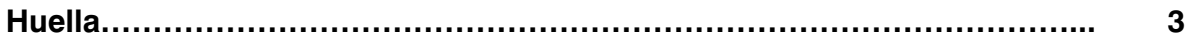

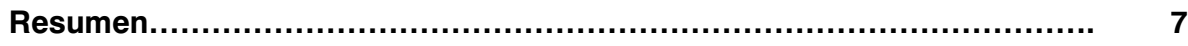

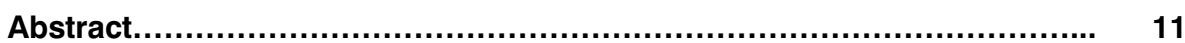

Introducción.............................................................................. 13

Capítulo 1

Vernáculo, primitivo y popular........................................................ 25

1.1. Significado de Vernáculo, Primitivo y Popular................................ 31

1.1.1. Amos Rapoport................................................... 33

1.1.2. Kenneth Frampton: clima, cultura, mito y artesanía........................ 33

1.1.3. Leopoldo Torres Balbás y La Vivienda Popular en España......................... 34

1.1.4. Lo primitivo y lo profesional........................................ 38

1.1.5. Sigfried Giedion, Espacio, Tiempo y Arquitectura........................ 39

1.2. Mito, Topos, typos, y tekton. Parámetros de análisis de lo vernáculo.. $\quad 43$

1.2.1. Mito ............................................................. 44

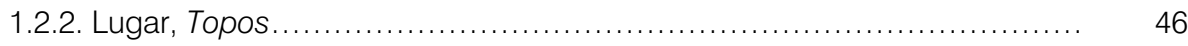

1.2.2.1. Topografía. ........................................... 47

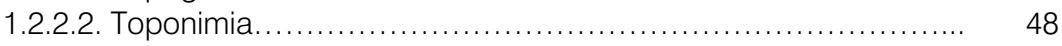

1.2.2.3. Topofilia .............................................. 48

1.2.2.4. Topiaria. ................................................... 50

1.2.3. Tipo, Typos. ................................................ 52

1.2.4. Materialidad, Tekton ............................................. 53

1.2.4.1. Construcción moderna y construcción tradicional................ 53

1.2.4.2. Pensar con el ojo, pensr con la mano.......................... 55

1.2.4.3. Conciencia material:

Metamorfosis, presencia y antropomorfismo................... 55

1.3. Apuntes y huellas de lo vernáculo........................................ 69

1.3.1. Casa Sommerfeld, Berlin 1920-1922. W. Gropius y A. Meyer................. 61

1.3.2. Casa para Tristan Tzara en París, 1926-1927. Adolf Loos......................... 63

1.3.3. Casas para fin de semana en Garraf, Barcelona, 1935.
Josep Lluis Sert y Josep Torres Clavé................................... 65

1.3.4. Casa de verano en Stennas, Isla de Lisön, 1937.
Erik Gunnar Asplund........................................... 67

1.3.5. Hogar para niños en Mümliswil, Suiza, 1938-1939. Hannes Meyer........ 69

1.3.6. Casa de verano en Holanda, 1940-1941. Gerrit Rietveld ...................... 71

1.3.7. Casa Villinger, Bremgarten, Suiza, 1942. Max Bill......................... 73

1.3.8. Casas Jaoul, Neyilly-sur-Seine, 1952. Le Corbusier........................ 75

1.3.9. Entorno arqueológico de la Acrópolis y colina de Philopappou en
Atenas, 1951-1957. Dimitris Pikionis....................................... 77

1.3.10. Casa de vacaciones Quinta da Cavada, San Salvador de Briteiros, Guimaraes, 1989-1990. Fernando Távora................................ 79 


\section{Capítulo 2}

2.1 Los Smithsons y lo vernáculo.

Found y As found, lo vernáculo así encontrado y el ojo alerta.

2.1.1. Los Smithsons y la herencia de lo vernáculo en la cultura inglesa.

Tradición y modernidad en la posguerra británica......................... 89

2.1.2. Los Smithsons y Team 10: Modelos vernáculos y escalas de asociación.... 96

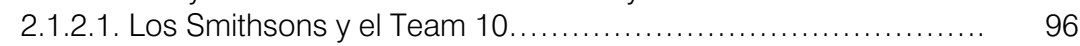

2.1.2.2. Los Smithsons en el CIAM X en Dubrovnik..................... 98

2.1.2.3. Modelos vernáculos y escalas de asociación.................... 102

2.1.3. Found y As found: Una manera de ver el mundo y también lo vernáculo.... 107

2.1.3.1. "As found" $y$ "found".

El "según se encuentra" y "lo encontrado" 107

2.1.3.2. "As found" y "found" en Upper Lawn.......................... 111

2.2. The Green Man y Jack Frost en el Upper Lawn Pavilion.................. 114

[Mito]

2.2.1. Upper Lawn en el corazón de Inglaterra............................... 114

2.2.2. The Green Man, Puck y Jack the Frost.............................................. 115

2.3. El jardín inglés de los Smithson........................................... 120

[Lugar, Topos: Toponimia, Topografía, Topiaria, Topofilia]

2.3.1. Upper Lawn Farm, la Granja del Prado Alto.

Etimología y significado «Lawn» en la cultura inglesa...................... 121

[Toponimia].

2.3.2. El paisaje pintoresco de William Beckford en Fonthill a finales de XVIII.

Un fragmento de un enclave........................................ 128

[Topografía]

2.3.2.1. Fonthill, breve historia de la finca............................ 130

2.3.2.2. Fonthill y el jardín inglés.................................... 132

2.3.2.3. Fonthill y los Smithson..................................... 134

2.3.2.4. Una topografía con espesor. La memoria del lugar................ 140

2.3.3. Upper Lawn como experiencia arquitectónica y vital de los Smithson....... 148

[Topofilia]

2.3.3.1. La elección de Upper Lawn. ................................... 148

2.3.3.2. El Upper Lawn Pavilion: un lugar "jerónimo", fragmento de un enclave, en busca del pabellón de nuestro tiempo.............. 151

2.3.4. Un pavo real en el muro de Upper Lawn................................ 160

[Topiaria]

2.3.4.1. Notas sobre la topiaria en la jardinería inglesa................. 163

2.3.4.2. Pavos reales y topiaria en el cottage-garden inglés............... 167

2.4. «Upper Lawn, a Folly Solar Pavilion»

heredero del jardín Arts and Crafts...................................... 172

[Tipo]

2.4.1. Un cluster como tipo de asentamiento vernáculo........................ 172

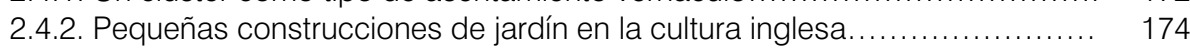

2.4.3. ¿Folly, Gazebo o Pavilion? Construcciones sobre un muro................ 176

2.4.4. Glassroom, garden room: Vivir en el jardín.............................. 179

2.5. Piedra, madera y aluminio: los Smithsons artesanos modernos........ 185

[Materialidad]

2.5.1. Piedras y adoquines. Continuidad en las acciones realizadas

en la transformación del muro y en el pavimento del jardín................. 188

2.5.2. El entramado de madera del Upper Lawn Pavilion.

Una interpretación moderna de técnicas tradicionales..................... 199

2.5.2.1. Breve recorrido por las técnicas de muros de entramado

de madera en Gran Bretaña y Estados Unidos......

2.5.2.2. El entramado de madera del Upper Lawn Pavilion...................

2.5.2.3. Una interpretación moderna de técnicas tradicionales.............. 211

2.5.3. El aluminio en el Upper Lawn Pavilion .................................. 212 
Capítulo 3

La casa del martín pescador, entre un roble y un cañaveral.

Aldo van Eyck y Gerrit Rietveld en la Casa Visser de Bergeijk..................

3.1. Aldo van Eyck y lo vernáculo.

The Vernacular of the Heart y los Círculos de Otterlo

3.1.1. Surinam y la herencia tropical de Aldo van Eyck

3.1.2. Aldo van Eyck y el Team 10. Culturas primitivas e identidad .................. 237

3.1.2.1. La Historia de Otra Idea». Forum 1959-1963................... 237

3.1.2.2. Aldo van Eyck y el CIAM X en Dubrovnik. Identidad versus escalas de asociación. Los viajes de Aldo Van Eyck al Norte de Africa, playgrounds y la experiencia de Nagele.......... 242

3.1.3. Los Círculos de Otterlo y la tradición vernácula .......................... 246

\subsection{El circulo condensador de significados en la obra de Van Eyck........ 256}

[Mito]

3.2.1. El circulo condensador de lo elemental y lo simbólico.................... 258

3.2.2. Interpretación de una kiva como espacio simbólico para el arte.............. 263

\subsection{Lugar e identidad. Aldo van Eyck y el territorio de los Países Bajos,} un no lugar.

[Lugar, Topos: Toponimia, Topografía, Topofilia]

3.3.1. La casa del martín pescador, entre un roble y un cañaveral.

3.3.2. Aldo van Eyck, Gerrit Rietveld y Martin Visser, 1954-2000.

[Topofilia]

3.3.3. El "desierto" de los Países Bajos

[Topografía]

3.3.2.1. Identidad neerlandesa. El territorio de los Países Bajos.......... 274

3.3.2.2. Polder y paisaje en la cultura holandesa ....................... 279

3.3.2.3. Culturas primitivas en territorios inhóspitos. 283

Los viajes de Aldo van Eyck en busca de lo elemental..............

3.3.4. El arbolado protector.

3.3.4.1. El tratamiento escultórico del arbolado ............................ 291

3.3.4.2. La "Fine Dutch Tradition" y el jardín holandés del XVII............ 294

3.4. Una Kiva de los Indios Pueblo en Holanda.

[Tipo]

3.4.1. Evolución de la Casa Visser 1955-2000.................................. 303

3.4.1.1. La Casa Visser de Rietveld, 1955-1956....................... 307

3.4.1.2. La ampliación como una kiva por Aldo van Eyck, 1967-1969.... 310

3.4.1.3. La segunda ampliación por Aldo van Eyck y Theo Bosch en 1971

3.4.1.4. Una propuesta no realizada y el homenaje póstumo de Martin Visser a Aldo van Eyck en 2000

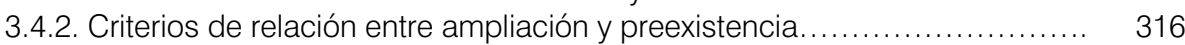

3.4 .2 .1 El círculo y el centro....................................... 320

3.4.2.2 El espacio in-between ....................................... 323

3.4.2.3 Transparencia.............................................. 326

3.5. Ladrillo, madera y vidrio

330

[Materialidad]

3.5.1. Continuidad en la forma de construir, a partir de la casa de Rietveld......... 330

3.5.2. Las vigas de madera de una kiva ..................................... 330

3.5.3. La transparencia del in-between ..................................... 332

3.5.4. El color diferenciador .................................................... 334 
Tradición viva y "No son genios los que necesitamos ahora".

4.1.1. Coderch y la herencia de la arquitectura popular en España.

4.1.1.1. Lo popular, las vanguardias

y el Movimiento Moderno español en los años 30.

4.1.1.2. Lo popular en la generación de José Antonio Coderch.

Ser moderno y no parecerlo o no ser moderno y parecerlo...... 355

4.1.1.3. La relación con Italia y la Trienal de Milán de 1951 ............... 360

4.1.2. Tradición viva, y «No son genios los que necesitamos ahora» en el contexto de Team 10

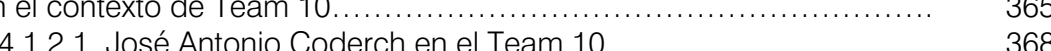

4.1.2.2. Algunas reflexiones sobre No son genios........................ 377

4.1.2.3. Cronología no exhaustiva de publicaciones de No son genios... 382

4.2. Cardos para ahuyentar los malos espíritus

[Mito]

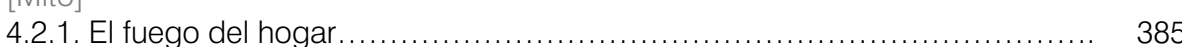

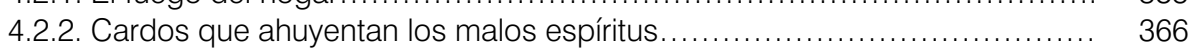

4.3. Espolla y Coderch............................................................. 391

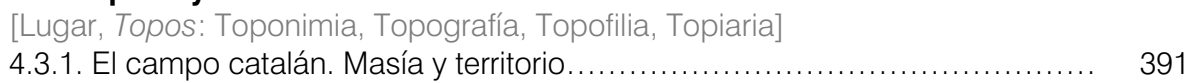

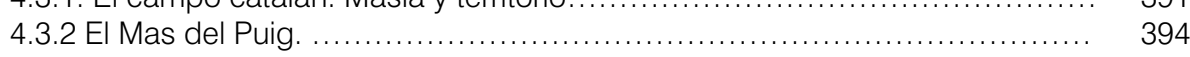

[Toponimia]

4.3.3. La tierra de Espolla. 24 fotografías de Catalá Roca ....................... 394

[Topografía]

4.3.4. En busca de las raíces. Espolla: vivir, trabajar, morir..................... 400

Topofília.

4.3.4.1. La recuperación de la casa familiar .......................... 400

4.3.5. Cipreses, frutales y el bosquecillo de pinos........................... 402

[Topiaria]

4.4. Coderch y la casa pairal.................................................. 404

[Tipo]

4.4.1. La masía catalana..................................................... 405

4.4.2. Desarrollo de la solución dada a la casa a partir de 40 fotografías inéditas realizadas por Coderch durante el proceso...................... 410

4.4.2.1. Análisis de las imágenes y el proceso.......................... 413

4.4.3. La transgresión del tipo tradicional..................................... 426

\subsection{Piedra y madera.}

Interpretaciones modernas de la tradición vernácula......................... 431

[Materialidad]

4.5.1. La construcción ensamblada.......................................... 433

4.5.1.1. La persiana de lamas. De la persiana tradicional de tablillas

a la Llambí de tabla ancha. Descripción y variaciones... 433

4.5.1.2. La casa persiana........................................ 435

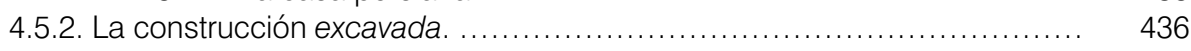

4.5.2.1. La casa excavada.......................................... 439

4.5.2.2. La casa de Espolla tallada en la roca........................ 441

Análisis comparado y Conclusiones.......................................... 449

Fuentes documentales y Bibliografía........................................ 467

\section{Apéndices Documentales}




\section{Agradecimientos}

A mi directora de tesis, la profesora Carmen Espegel de la Universidad Politécnica de Madrid, por su confianza, apoyo, optimismo y acertados consejos en los momentos precisos.

A Ana y José Antonio Coderch Giménez, por su apoyo y la ayuda recibida permitiéndome el acceso al Archivo Coderch en un momento de cambio en su gestión. En especial a Ana Coderch, por mantener impecable la casa de su padre en Espolla y y permitirme entrar a un espacio familiar. Su visita ha sido una de las experiencias más intensas de esta tesis.

A Joke van der Heijden, viuda de Martin Visser y actual propietaria de la Casa Visser por permitirme la visita a su propia vivienda y por los planos y fotografias facilitados sobre el proyecto de Rietveld y los realizados por Van Eyck.

Sin la ayuda de la familia Coderch y de Joke Visser, esta tesis no habría sido posible.

Al profesor Santiago Huerta de la Universidad Politécnica de Madrid, por enseñarme a entender las construcciones antiguas, por iniciarme en la investigación científica y en la historia de la construcción. Su conocimiento, rigor y honestidad son un modelo para mí.

Al profesor Francis Strauven de la Ghent University, por su respaldo en la elección de la Casa Visser como caso de estudio, por su ayuda con las gestiones para visitarla y por su gran generosidad al facilitarme la serie de croquis de Aldo van Eyck sobre el proceso de desarrollo del proyecto, inéditos hasta ahora, y que esta tesis saca a la luz.

Al profesor Max Risselada del TU Delft, por compartir conversaciones sobre los Smithsons y por facilitarme una copia digitalizada en alta calidad de los planos del Upper Lawn Pavilion.

Al profesor Carlos Puente por dejarme sus diapositivas del Upper Lawn Pavilion antes de ir a visitarlo.

A Mónica, mi amiga y compañera en la UAH, por su ánimo, disponibilidad y ayudarme con las clases en la recta final de la tesis.

A mi gran amiga Grietje Bouwmeester, que además de traducirme algunos textos del holandés, comparte conmigo desde hace años, casas, amigos, cultura y forma de ser holandesa

A Maite y Chema, nuestros inseparables amigos desde la ETSAM. Ahora que Chema no está, a Maite, por su fortaleza, generosidad y compartir una actitud ante la vida y la arquitectura.

A Fernando, nuestro gran amigo, por sus consejos, generosidad, capacidad intelectual, y conocimiento de la arquitectura; pero sobre todo, por su cariño y estar tan cerca.

A Rafa, por todo, compartiendo vida, conocimiento y pasión por la arquitectura.

A mis padres 

Huellas de lo vernáculo en Team 10
Alison y Peter Smithson, Aldo van Eyck, José Antonio Coderch 
Huella 


\section{Huella}

Huella, marca, señal, impronta, indicio, traza, vestigio..., es lo que queda por efecto de una acción o un suceso después que pasan. Esta segunda acepción de María Moliner, extensión de la primera que define su significado como «la señal que dejan en el terreno por donde pasan o en el sitio donde se posan, la planta del pie, la pezuña de un animal, la rueda de un carro o cualquier otra cosa», es más profunda e implica un amplio gradiente de intensidades.. La riqueza del término incluye significados aparentemente contradictorios: mientras que la marca de una pezuña en la tierra desaparece con rapidez, huellas aparentemente invisibles perduran en el tiempo. En este sentido la huella, sea más o menos explícita, puede ser evocadora siendo leve y difusa.

Federico García Lorca en el poema Mi pueblo dice: «cuando yo era un niño vivía en un pueblecito muy callado y oloroso de la vega de Granada. Todo lo que en él ocurría y todos sus sentires pasan hoy por mí, velados por la nostalgia de la niñez y por el tiempo» «en este pueblo yo nací y se despertó mi corazón. En ese pueblo tuve mi primer ensueño de lejanías. En ese pueblo yo seré tierra y flores»

El poder evocador de una leve huella queda, intensa y certeramente interpretado en la obra del artista Philippe Parreno para la Exposición Everstill / Siempretodavía, Artistas contemporáneos en la Huerta de San. Vicente.

Celebrada en Granada durante 2007 y 2008, veintiocho artistas visitaron durante dos años la casa de García Lorca así como la ciudad y todo aquello que le rodeó, con el objeto de producir una obra que conviviera crítica y respetuosamente con sus muebles, objetos y obras de arte originales, en un homenaje a la vez que una sutil conversación.

Philippe Parreno intervino en un cristal de la ventana de la escalera, sustituyéndolo por otro en el que se había grabado un efecto de vaho, evocando como el propio Lorca habría jugado y dibujado en la condensación de los cristales, en lo que Enrique VilaMatas ${ }^{1}$ ha llamado una «infraleve intervención», «la traza de un aliento en un cristal de la casa familiar»
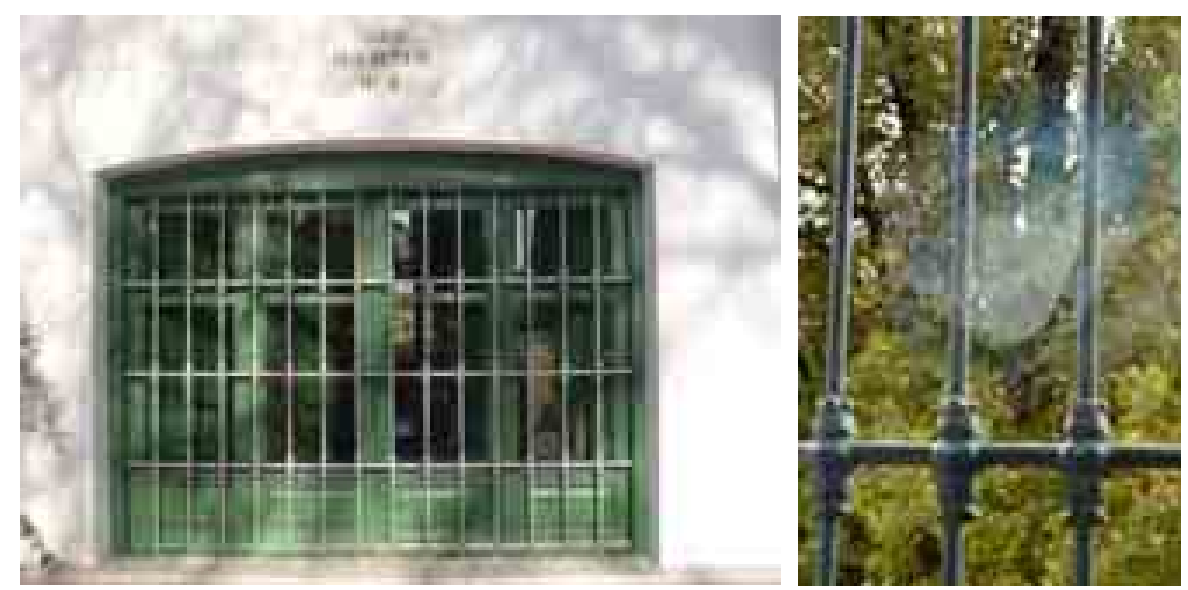

Figura 01

Obra del artista Philippe Parreno en la Exposición Everstill / Siempretodavía, Artistas contemporáneos en la Huerta de San Vicente ${ }^{1} .27$ de noviembre de 2007 al 20 de Julio de2008. Fundación Federico García Lorca y la Sociedad Estatal de Conmemoraciones Culturales. Comisario Hand Ulrich Obrist.

\footnotetext{
${ }^{1}$ Enrique Vila-Matas en El Santo Grial en París, en El País, 6 de noviembre de 2013
} 
Resumen 


\section{Resumen}

La huella de lo vernáculo en el Upper Lawn Pavilion (1959-1962) de Alison y Peter Smithson (1928-1993 + 1923-2003), en la ampliación de la Casa Visser(1967-1969) de Aldo van Eyck (1918-1999), y en la Casa de Espolla (1963-1964) de José Antonio Coderch (1913-1984), es el objeto de esta tesis.

Las tres casas, brillantes interpretaciones modernas de la tradición, se realizan en 10 años, herederas del momento social, cultural, e industrial de la posguerra europea. Es un periodo de gran desarrollo que también evidenciará, seguramente por contraposición, un revivido interés por la tradición. Cómo abordar esta dicotomía es una cuestión central del debate arquitectónico del momento, y es el ámbito de estudio en el que se enmarca esta investigación.

Alison y Peter Smithson, Aldo van Eyck y José Antonio Coderch, miembros principales del Team 10 desde el congreso fundacional en Otterlo en 1959, inician su actividad profesional en un contexto arquitectónico de revisión crítica del Movimiento Moderno. Durante los años cincuenta y sesenta desarrollan una parte significativa de su obra y discurso teórico, en diálogo con la tradición.

En la obra de los Smithsons, es fundamental en este proceso, el Upper Lawn Pavilion, su casa de fin de semana en el campo, en el condado de Wiltshire. Un pequeño pabellón, de madera, vidrio y aluminio, construido en gran medida por ellos mismos de forma experimental, en un «cottage» inglés del siglo XVIII con un recinto conformado por un muro de mampostería de piedra sobre el que se apoya.

Coderch, es a partir de 1951 cuando alcanza una comprensión de la tradición exenta de mimetismos con obras como el Pabellón de España en IX Trienal de Milán, que obtuvo el Premio Internacional y Medalla de Oro, y el edificio de viviendas en la Barceloneta en el que la reinterpretación de un sistema anónimo y vernáculo de control solar en el mediterráneo como la persiana mallorquina alcanzan su mejor expresión. En 1963 recupera la casa de origen medieval de sus antepasados en Espolla, un pueblo del Alto Ampurdan. La conexión con sus raíces, convierten a la Casa de Espolla, en la obra más importante de su vida, en palabras del propio Coderch.

En 1968. Martin Visser (1922-2009), coleccionista de arte y diseñador de mobiliario, encarga a Aldo van Eyck una ampliación de su casa, construida en 1954 por Gerrit Rietveld (1888-1964), iniciando una continuada y recíproca serie de propuestas, no todas construidas, que se prolongará hasta incluso después de la muerte de van Eyck. La primera será la determinante: un in-between nuevo, singular y extraordinario se configura entre la preexistencia y la estancia circular de ampliación. La extensión de la Casa Visser materializa en Holanda la interpretación de una kiva de los Indios Pueblo, invirtiendo la relación habitual entre preexistencia y nueva construcción: aquí la preexistencia es canónicamente moderna y la ampliación vernácula:

Fueron para sus autores una experiencia vital personal de búsqueda e investigación empírica, con una intensa relación afectiva y emocional en los tres casos, que sin duda les permitió una libertad de exploración inusual a lo largo de largos periodos, convirtiéndolas en material idóneo de investigación. Tres respuestas diferentes a una misma actitud representativa de Team 10, sobre cómo abordar las relaciones entre tradición y modernidad, culturas vernáculas y arquitectura moderna, construcción artesanal y construcción industrial.

El método de trabajo propuesto trata de sistematizar el análisis de lo vernáculo en los casos a estudiar, determinando los parámetros que le son consustanciales: mito, topos -toponimia, topografía, topofilia y topiaria- typo y tekton. El método es lo suficientemente determinado para sistematizar los casos de estudio y otros posibles, pero lo suficientemente flexible para dar cabida a las singularidades y circunstancias particulares de cada proyecto. También abre un camino a perfeccionar a partir de la estructura básica desarrollada en la tesis. 


\section{Abstract}

The trace of the vernacular in the Upper Lawn Pavilion (1959-1962) by Alison and Peter Smithson (1928-1993 + 1923-2003), in the extension of the Visser House (1967-1969) by Aldo van Eyck (1918-1999) and in the House in Espolla (1963-1964) by José Antonio Coderch (1913-1984), is the subject of this thesis.

The three houses, brilliant modern interpretations of tradition, are built in 10 years, and are product of social, cultural and industrial time of postwar Europe. It is a period of great industrial development that also evidenced, probably by contrast, a revived interest in tradition. Addressing this dichotomy is central to the architectural debate of the moment, and the field of study that is part of this research.

Alison and Peter Smithson, Aldo van Eyck and José Antonio Coderch, core figures in Team 10, since the founding congress held in Otterlo in 1959 began their professional activities in an international context mired in a critical revision of the Modern Movement. During the nineteen-fifties and -sixties, they developed a major part of their theoretical discourse and their oeuvre, in constant dialogue with tradition.

In the work of the Smithsons, a fundamental part of this process can be seen at Upper Lawn (1959-1962), their weekend home in Fonthill, in the county of Wiltshire. A small pavilion in wood, glass and aluminium, constructed to a large extent by the architects themselves as an experiment with an English country cottage from the eighteenth century in a compound with its boundaries marked by a stone masonry wall on which the pavilion rests.

Coderch manages to understand a tradition free of mimetism since 1951. For instance, the Spanish Pavilion presented at the IX Triennale di Milano received the International Prize and the Golden Medal, and in the apartment building in Barceloneta the reinterpretation of Mallorquina shutters, an anonymous vernacular shading system used in the Mediterranean Area, reaches its highest expression. In 1963, he bought back the medieval house of his ancestors in Espolla, a village in Alto Ampurdam. The connection to their roots makes the House in Espolla into the most important work of his life, in the words of Coderch himself.

In 1967, Martin Visser (1922-2009), art collector and designer of furniture, commited an extension of his house -built in 1954 by Gerrit Rietveld (1888-1964)- to Aldo van Eyck , initiating an ongoing and reciprocal series of proposals, not all built, which will last until even after van Eyck's death. The first will be decisive: a new, unique and extraordinary in-between is set between the pre-existing and the expansion circular room. The enlargement of the Visser House materializes the interpretation of a kiva Pueblo Indians in Holland, reversing the usual relationship between pre-existing and new construction: here the pre-existence is canonically modern, and the expansion is vernacular.

For the authors, these houses were a vital personal experience based on a quest and empirical research, with an intense affective and emotional relationship in the three cases, which undoubtedly allowed them an unusual freedom to explore over long periods, making them ideal material for researching. Three different answers to the same attitude, representative of Team 10, on how to address the relationship between tradition and modernity, vernacular cultures and modern architecture, traditional construction and industrial construction

The proposed working method tries to systematize the analysis of the vernacular in the cases studied, determining the parameters that are inherent: myth, topos, -toponymy, topography, topophilia and topiary- typo and tekton. The method is sufficiently specific to systematize case studies and other possible, but flexible enough to accommodate the peculiarities and circumstances of each project. It also opens a path to perfect from the basic structure developed in this thesis. 
Introducción 


\section{Presentación}

La huella de lo vernáculo en el Upper Lawn Pavilion (1959-1962) de Alison y Peter Smithson (1928-1993 + 1923-2003), en la ampliación de la Casa Visser(1967-1969) de Aldo van Eyck (1918-1999) y en la Casa de Espolla (1963-1964) de José Antonio Coderch (1913-1984), es el objeto de esta tesis.

Las obras se realizan en un periodo de 10 años, herederas del momento social, cultural, e industrial de la posguerra europea -marco en el que se encuadra la tesis-, y sus autores inician la actividad profesional en un contexto arquitectónico de revisión crítica del Movimiento Moderno: la reconstrucción ya había empezado a dar ejemplos no lo suficientemente satisfactorios sobre cómo debían ser los nuevos barrios y ciudades. Es un periodo de gran desarrollo industrial que también evidenciará, seguramente por contraposición, un revivido interés por la tradición. Cómo abordar esta dicotomía es una cuestión central del debate arquitectónico del momento, y es el ámbito de estudio en el que se enmarca esta tesis.

La relación entre las cosas, más que los objetos en sí, fundamenta los planteamientos arquitectónicos y urbanos de Team 10, postura que también se trasladará a la composición del grupo, en el que la heterogeneidad es uno de sus rasgos característicos y seguramente la clave de la fuerza.

La elección como ejemplos de estudio del Upper Lawn Pavilion, la ampliación de la Casa Visser y la Casa de Espolla, todos proyectos realizados a partir de una preexistencia, se fundamenta intencionadamente en esta idea. Tres respuestas diferentes a una misma actitud representativa de Team 10, sobre cómo abordar las relaciones entre tradición y modernidad, culturas vernáculas y arquitectura moderna, construcción artesanal y construcción industrial.

Los ejemplos y autores escogidos en la investigación no son los únicos que podrían haber sido; tampoco los primeros ni los últimos, pero ninguno tendría que faltar en un trabajo sobre el tema. Fueron para sus autores una experiencia vital personal de búsqueda e investigación empírica, con una intensa relación afectiva y emocional en los tres casos. Ser la vivienda propia de los Smithsons y Coderch, y la estrecha amistad de Van Eyck con Martin Visser, sin duda les permitió una libertad de exploración inusual a lo largo de largos periodos vitales, convirtiéndolas en material idóneo para el análisis.

No es una tesis histórica, aunque se utilizan referencias históricas para entender el contexto cultural de cada autor.

No es una tesis que poniendo en valor lo vernáculo, quiera denostar la arquitectura del Movimiento Moderno, sino que considera que es parte integrante de ella.

Es una tesis que quiere formar parte del proyecto moderno poniendo en valor algunos valores poco estudiados y que en cierta forma nunca dejaron de estar: las huellas de lo vernáculo se intuyen desde los orígenes del Movimiento Moderno y con más o menos intensidad se encuentran en arquitectos con vocación de hacer, siempre en proyectos construidos. Una actitud atenta al abordar encargos concretos en determinados contextos y la fuerza de la realidad física de lo existente posibilitaron actuaciones sensibles a esta cuestión al margen de debates teóricos.

Se ha manejado una amplia bibliografía sobre los autores y obras elegidas, y en coherencia con ellos, se ha puesto el acento en el estudio de fuentes primarias: textos originales de Alison y Peter Smithson, Aldo Van Eyck y José Antonio Coderch, y sobre todo las obras, visitadas con tiempo en su contexto, territorio y cultura. No se ha podido entender de otro modo, estudiando a arquitectos que siempre prefirieron construir a teorizar, como lo evidencian, entre otros, varios testimonios de Peter tras la muerte de Alison. Aunque también fueron grandes divulgadores de su obra, algo por lo que han sido frecuentemente criticados, su mayor interés declarado fue la realización de encargos. Para ellos la verdad está en los edificios, más que en las palabras. 
A su vez, para la consulta de documentación original, se ha trabajado en varios archivos que se relacionan en el apartado de bibliografía.

La tesis se estructura en cuatro capítulos.

En el Capitulo primero se aborda el tratamiento de lo vernáculo, primitivo y popular, términos relacionados que se emplean con frecuencia intercambiadamente, así como los parámetros consustanciales y necesarios para establecer un método de trabajo para el estudio de lo vernáculo, como se detallará a continuación en la explicación pormenorizada de la metodología.

También se esboza la aportación de autores relevantes en el tema: Amos Rapoport, Leopoldo Torres Balbás, Sigfried Giedion, Kenneth Frampton, Walter Gropius, Adolf Loos, Josep Lluis Sert, Erik Gunnar Asplund, Hannes Meyer, Gerrit Rietveld, Max Bill, Le Corbusier, Dimitris pikionis y Fernando Távora entre otros, conforman el estado de la cuestión conjuntamente desde la teoría -apuntes- y la practica -huellas-. La relación no pretende ser exhaustiva, sino testimoniar con una visión panorámica de la primera mitad del siglo $X X$, esa línea de pensamiento que aunque irregularmente recorre la historia del Movimiento Moderno, para eclosionar en el contexto de la posguerra europea y muy significativamente en Team 10.

Los capitulos segundo, tercero y cuarto, todos estructurados, con cinco epígrafes principales, desarrollan el análisis pormenorizado del Uper Lawn Pavilion, de la Ampliación de la Casa Visser y de la Casa Coderch en Espolla. En el primer epígrafe de cada capítulo se abordan las relaciones del autor con lo vernáculo en el contexto de Team 10, tratando a su vez tres temas: primero la tradición vernácula y herencia recibida en su contexto cultural y político -Inglaterra, Holanda y España-; segundo aportaciones relevantes de cada uno sobre lo vernáculo en el grupo; y por último sus planteamientos teóricos en relación con lo vernáculo. De esta manera se explora "Found y As Found" de los Smithsons como una manera de ver el mundo y también lo vernáculo, "Los Círculos de Otterlo" de Van Eyck, y la tradición viva de Coderch en "No son genios lo que necesitamos ahora".

Los cuatro epígrafes restantes se corresponden con los parámetros establecidos para el análisis, mito, topos tipo y tekton, aplicándose a cada una de las obras de forma sistemática. 


\section{Team 10 y lo vernáculo en el contexto arquitectónico de la posguerra europea: Gran Bretaña, España, Paises Bajos.}

Se reseñan de forma no exhaustiva algunos acontecimientos relacionados con las obras o los autores de estudio para dibujar el interés por lo vernáculo, lo primitivo y lo popular en el contexto de posguerra en Europa. Lo rural, lo vernáculo, lo espontaneo y la artesanía tendrán una fuerte presencia en la en las revistas del momento. Además de lo ya comentado en AR, las páginas de Domus, Spazio y Forum entre otras así lo reflejan. En este contexto, podemos decir que la convivencia entre tradición, vernáculo y modernidad "esta en el aire".

No es un tema nuevo, pues desde los orígenes de la arquitectura moderna, se encuentran manifestaciones en ese sentido, una de las más potentes en el Movimiento Moderno español con Fernando García Mercadal y Jose Lluis Sert al frente y que se explicará a continuación, pero es en los cincuenta y sesenta cuando la manifestación de este planteamiento florece por toda Europa extraordinariamente teniendo, aunque no exclusivamente, un papel relevante los miembros de Team 10. Dan soporte teórico y crítico, - los Círculos de Otterlo de van Eyck son posiblemente la primera formulación teórica del tema -, y sobre todo materializan diversas exploraciones en proyectos construidos

\section{Gran Bretaña}

En enero de 1947, la revista Architectural Review, publica por su cincuenta aniversario dos artículos editoriales firmados por los cuatro editores James. M. Richards, Nikolaus Pevsner, Osbert Lancaster y Hubert de Cronin Hastings, que recogen una evaluación retrospectiva de la revista en doce líneas de trabajo resumidas a modo de ficha con un texto explicativo, abundante material grafico de apoyo, y extensos pies de foto. Un mero repaso a sus títulos permite entender hasta que punto tradición y vanguardia están intencionadamente presentes en sus páginas.

En su mención expresa a la importancia del arte popular y bajo el titulo "Architectural Review llama la atención sobre la importancia del arte popular, urbano y rural" dice:

«El arte popular representa el esfuerzo colectivo de una gente o comunidad no educada en la rutina académica para expresar sus necesidades más intimas. Es significativo porque representa lo inconsciente y por tanto lo inherente más que las necesidades y deseos adquiridos. Es una expresión de las emociones comunes a todos nosotros, sofisticadas y no sofisticadas.»

«Por estas razones es de intenso interés sicológico; una ciencia de la arquitectura moderna debe estudiarlo lo primero de todo.»

En junio del mismo año, se publica el artículo "The New Empiricism: Sweden's latest style", ilustrado por tres viviendas de Sven Markelius, Sture Frolen y la famosa The Box de Ralph Erskine, ampliándose la información sobre el tema con varios artículos publicados en enero del año siguiente, entre los que destaca el de Eric de Maré "The New Empiricism: The Antecedents and Origins of Sweden's latest style".

Subyace una idea idílica de lo rural basada en la yuxtaposición antagónica de campo y ciudad $^{1}$ que aunque se remonta hasta la antigüedad, se intensifica a partir de la revolución industrial y en el siglo XX. No es casual que en Inglaterra, su país de origen, lo industrial y moderno coexiste con lo rural y tradicional como en pocos países. En la sociedad de posguerra este sentimiento se intensifica al poner en valor "lo nacional",

${ }^{1}$ Sobre el campo y la ciudad en la Inglaterra moderna Raymond Williams (1921-1988) El Campo y la Ciudad. 
en un momento todavía de restricciones y racionamiento para la mayor parte de la población.

El Festival of Britain ${ }^{2}$ celebrado en 1951 y pensado en origen para conmemorar el centenario de la The Great Exhibition of the Works of Industry of all Nations, celebrada en Hyde Park en $1851^{3}$, fue un buen ejemplo de ello, conviviendo en sus exposiciones por todo el país, lo más novedoso con elementos pertenecientes a la cultura rural.

\section{España}

En el mismo año, 1951, José Antonio Coderch se encarga del Pabellón de España en IX Trienal de Milán, obteniendo el Premio Internacional y Medalla de Oro-

Un paño-expositor de fotografías, reinterpretación modificada de la persiana de lamas de madera y una superficie revestida con alfombrillas de paja larga usadas en preservar el lomo de los animales de carga, con varios estantes de vidrio, conforman dos de los tres paramentos que configuran el pequeño espacio de exposición en el que conviven objetos de artesanía popular y obras de Miró y Oteiza entre otros artistas. Coderch y su colaborador el poeta Santos Torroella, dan así respuesta a la convocatoria del evento que precisaba: «ltalia invita a todas las naciones a presentar a la Triennale di Milano la documentación de las obras con las cuales la civilización moderna se expresa en arquitectura, en las industrias del arte y en el artesanado", «solo se admitirán obras de inspiración moderna, de efectiva originalidad y ejemplar factura. Quedarán excluidas las copias, las imitaciones y los productos que no respondan al uso y al gusto modernos»

El pabellón, que tuvo un gran éxito y despertó el interés de Max Bill y Aldo van Eyck que estaban representando a sus países, significará un punto de inflexión en la obra de Coderch, alcanzando una comprensión de la tradición exenta de mimetismos.

Las particulares circunstancias de la arquitectura española por la situación política del país, merecen un comentario específico: El aislamiento político español después del año 1939 y la dificultad que supone para los arquitectos contactar con los movimientos culturales europeos, junto con la situación de carestía económica y la postura oficial del nuevo régimen político que prefirió ensalzar otra visión de la arquitectura frente a la desconfianza que le producía la arquitectura moderna, representada ideológicamente con claridad durante la Segunda República a través del GATEPAC y la Generación del 25, y sobre la que hace caer un manto de silencio, determinan poderosamente el marco de actuación de los arquitectos en la década de los cuarenta y primeros cincuenta. Se produce una arquitectura de tintes nacionalistas, formalmente ecléctica, y el ya conocido resurgimiento de algunas técnicas de construcción tradicionales, en especial la bóveda tabicada, ante la carestía de acero y cemento de calidad.

Sin embargo, el respeto y admiración por la arquitectura popular en España, viene de antes, siendo una de las características de nuestro Movimiento Moderno, necesaria de reivindicar: en los años 30 , las páginas de la revista $A C$, instrumento de difusión del

\footnotetext{
${ }^{2}$ La idea primera fue hacer una exposición internacional para conmemorar el centenario de la Gran Exposición de 1851, pero en un momento en que la reconstrucción era prioritaria, se decidió, debido a su coste, sustituirla por una serie de muestras sobre las artes, la arquitectura, la ciencia, la tecnología y el diseño industrial, bajo el título "Festival of Great Britain 1951". Fue un intento de dar a los británicos una sensación de recuperación y progreso; una celebración en todo el país de la historia, los logros de Gran Bretaña y su cultura. Un evento popular que contribuyera a la reconstrucción de la moral de posguerra. Gerald Barry, el director del Festival, lo describió como «un tónico para la nación».

${ }^{3}$ The Great Exhibition of the Works of Industry of all Nations o The Great Exhibition, fue la exposición internacional celebrada en Hyde Park entre mayo y octubre de 1851, y la primera de una serie de ferias mundiales sobre cultura e industria en el siglo XIX. Se desarrolló en el Crystal Palace de Joseph Paxton construido a tal efecto y alcanzando tal fama que también se la conoce como The Crystal Palace Exhibition.
} 
GATEPAC, ya muestran el universo de Coderch en el Pabellón de España de la Trienal de Milán de 1951.

De esta manera, en la posguerra española coinciden en el tiempo aunque ideológicamente opuestas, la tradición moderna anterior a la Guerra Civil de reconocimiento de los valores verdaderos de la arquitectura popular, con el resurgimiento de una arquitectura regionalista de exaltación nacional impulsada por el régimen franquista. A pesar de las limitaciones del momento y del ambiente arquitectónico imperante, varios arquitectos de la misma generación de Coderch, como Francisco de Asís Cabrero, Rafael Aburto, Fernández del Amo o Alejandro de la Sota entre otros, desarrollaran una obra relevante a partir del estudio de la arquitectura popular, fundamentalmente a través de los poblados de colonización. Se podría decir que en cierta forma, así podían ser modernos sin parecerlo.

Probablemente el interés de estos arquitectos por lo vernáculo, proviene intuitivamente de su capacidad de observación de lo popular, favoreciendo su desarrollo el particular contexto español de posguerra aunque sus objetivos sean diametralmente opuestos. En algunos casos como en Coderch, esa vía de investigación a partir de la arquitectura popular, también se transmitirá silenciosa y clandestinamente desde de los números de la revista $\mathrm{AC}$. Conocemos su reconocimiento reiterado y explícito a los artículos de la revista, cuando en una entrevista realizada el 22 de julio de 1967 por Baltasar Porcel para la revista Destino de Barcelona explica que todavía siendo estudiante por la interrupción de la guerra y quedándole dos cursos para terminar la carrera, le ocurrió un hecho decisivo en su formación:

"Por un extraño instinto fui al local del GATCPAC. Yo era teniente. Hice la guerra con los nacionales. Me presenté de uniforme y me llevé las revistas que había editado el grupo y que seguían allí. Estudiarlas me dio algo así como una conciencia ordenada, razonada, de lo que nebulosamente había pensado yo" o como en otra ocasión su socio Manuel Valls declaró que para ellos la revista AC era "como el pan nuestro de cada dia" (Armesto y Diez 2008, 46, 90)

\section{Países Bajos}

El polder del Nordeste Noord-Oost-Polder, se drenó durante la Segunda Guerra Mundial, como una gran extensión de producción agrícola, dentro del proyecto de grandes reclamaciones de terreno en el Zuiderzee. Para su colonización, posible gracias al Plan Marshall, se contaba con la experiencia inmediatamente anterior del Wieringenmeer-polder, para el que se había creado la Junta Ejecutiva de Wieringermeer, cuya filosofía sobre la materialización física de los pueblos se basaba en el texto publicado en 1929 por D. Hudig Het toekomstig landschap der Zuiderzeepolders, El futuro paisaje de los polders del Zuiderzee, que adaptaba los principios de Camilo Sitte a la situación holandesa, sentando las bases para su aplicación en los asentamientos y paisajes rurales de los nuevos polders. Fueron necesarias la ingeniería y las técnicas más avanzadas del momento para la polderización de superficies tan extensas, pero se abogaba una arquitectura emuladora de la tradicional ${ }^{4}$ - Delft School- con la que se realizaron todos los asentamientos bajo la supervisión de Grandpré Moliere y P.Verhagen (Strauven 1998). Nagele, fue el último en acometerse y la única excepción. El proceso de búsqueda de van Eyck y de 8 en Opbouw, para dotar de identidad al nuevo asentamiento frente a la

${ }^{4}$ El debate arquitectónico de poguerra es la construcción de vivienda a gran escala, lo que implica estrategias para la realización no solo de nuevos barrios de crecimiento en las ciudades sino también nuevos asentamientos de población en el campo. La construcción de new towns al igual que las poblaciones ex novo realizadas en los Paises Bajos, con excepción de Nagele reprodujeron superficialmente y en su peor versión parte de ese sentir colectivo de las bondades del campo, lo rural y la tradición vernácula frente a la ciudad y lo moderno. 
condición de no lugar del polder, de territorio sin atributos, se convertirá en fundamental y decisivo. El análisis y comprensión de Nagele es indispensable para entender a Van Eyck, pues por primera vez cerrará el círculo de las tres tradiciones: la moderna de Nagele, la clásica de la jardinería holandesa del XVII, y la vernácula de la arquitectura del desierto argelino.

Team 10

Team 10 nace dentro de los CIAM, como continuación y desarrollo de las ideas del Movimiento Moderno. Le Corbusier, alma y autoridad moral de la organización, se había conformado como una de sus columnas vertebradoras desde su fundación en La Sarraz en 1928, hasta que un grupo de jóvenes con gran incidencia de los Smithson, Van Eyck y Bakema, libres de la carga de haber tenido que formular una nueva arquitectura en las décadas anteriores, toman el relevo en los años cincuenta, con planteamientos renovados. Anhelan una arquitectura y urbanismo mejores, capaces de dar respuesta al fracaso de muchas de las grandes extensiones de vivienda realizadas en el contexto de la reconstrucción después de la Segunda Guerra Mundial.

El fin de los CIAM y la sucesión del Team 10 quedan confirmados en 1959 durante el congreso de Otterlo, celebrado en los Paises Bajos en el Museo Kröller Muller de Van de Velde, como culminación de las crecientes discrepancias entre generaciones desde 1947 en el CIAM VI de Bridgwater; pero es el décimo congreso celebrado en Dubrovnik en 1956 el considerado el último oficial, con un número importante de miembros históricos ausentes. Le Corbusier desde Roquebrune Cap Martin, envió al congreso "Message de Le Corbusier adressé au X Congrès CIAM à Dubrovnik", al que pertenece el fragmento citado a continuación, transcripción literal del original en francés ${ }^{5}$. Leido por Josep Lluis Sert como Presidente del CIAM, el 6 de agosto de 1956 en la apertura de las actas del congreso, constata moralmente el final de un ciclo y el comienzo de otro nuevo. Un relevo sin duda doloroso, al que Le Corbusier da paso.

Francis Strauven en Aldo van Eyck, the Shape of Relativity expone como el mensaje de Le Corbusier, supuso un reconocimiento para el Team 10, y cómo es en Dubrovnik donde las diferencias de pensamiento se agrandan de forma determinante.

Alison y Peter Smithson presentaron 5 grids para tipos de comunidad: aislada, pequeña, grande, pueblo y ciudad, con cinco proyectos de vivienda para cada escala de asociación según el lugar ${ }^{6}$, todos ellos encabezados por ejemplos vernáculos, verdaderos fragmentos de la historia británica e inglesa, como modelo a seguir Simultáneamente, Van Eyck y De 8 en Opbouw, investigan sobre como conferir identidad a los nuevos asentamientos en los polder. Bakema expuso la última versión del Alexander Polder y Van Eyck una serie de playgrounds en Amsterdam y el nuevo asentamiento de Nagele, evidenciándose los diferentes planteamientos de los grupos inglés y holandés ${ }^{7}$. No es casualidad, que las dos "grid" presentadas por Van Eyck, aborden el tema con independencia de la escala ${ }^{8}$, en contraposición al planteamiento de los Smithsons. En la primera, varios ejemplos de playgrounds en Ámsterdam, con el título The child and the city, expone el problema de la identidad perdida, lost identity, aportando como contribución la experiencia de Amsterdam. En la segunda, como

\footnotetext{
${ }^{5}$ CIAM Archive, ETH/gta en Zurich.

${ }^{6}$ Burrows Lee Farm, los Galeon Cottages, las Fold Houses, las Cllose Houses y las Terraced Houses

${ }^{7}$ A pesar de las diferencias y el debate, Peter Smithson quedó fuertemente impresionado por los playgrounds presentados por Van Eyck, impresión por otra parte generalizada entre los miembros de Team 10, y a Van Eyck le interesaron dos de los proyectos presentados por los Smithsons: The Close Housing y The Terrraced Houses. (Strauven 1998)

8 Durante los años de Nagele, Van Eyck, trabaja simultáneamente con dos escalas extraordinariamente antagónicas, la de un asentamiento completo y la de un juego de arena. En ambas persiguiendo materializar el concepto de identidad, antes que el de escalas de asociación.
} 
integrante del grupo de 8, presenta Nagele. «a large territory claimed from the sea; man made, geometric -visually unlimited- windswept». De esta forma, mientras los proyectos británicos responden a la especificidad de un pueblo o ciudad concreto, los de los holandeses, situados en la nada de los territorios recientemente polderizados, tendían a establecer los nuevos asentamientos a partir de un explícito lenguaje geométrico y universal. (Strauven 1998)

Jose Antonio Coderch fue introducido en los CIAM por Josep Lluis Sert, asistiendo por primera vez al Congreso de Otterlo en 1959. Desde entonces hasta el final, consta explícitamente en la documentación del grupo y en las revisiones que hace Alison Smithson para editar Team 10 Primer y Team 10 meetings, como miembro de Team 10 o perteneciente a los "core participants".

Después de Otterlo, donde presentó con gran éxito el truncado encargo de Torre Valentina, Coderch participa con dos proyectos de vivienda de bajo coste. en la reunión de Royaumont en septiembre de 1962: el famoso edificio de bloque de viviendas de pescadores en la Barceloneta construido para el ISM Instituto Social de la Marina, y una propuesta de conjunto urbano mediante unidades de vivienda para realizar en serie, basado en un estudio realizado en junio de 1952 con el nombre Memoria estudio sobre una posible solución del problema de las barracas, en que plantea con el ingeniero Eustaquio Ugalde ${ }^{9}$, una solución realizada con piezas prefabricadas en hormigón pretensado con forma de $U$ y tapial encalado con diferentes colores construido por los propios usuarios.

Para explicar la idea, preparó un fotomontaje que presentó en Royaumont, y que posteriormente llegaría a ser muy conocido. En 1969 fue portada del número 14 de la revista Auca en Santiago de Chile, y a él se refiere en varias ocasiones como en la respuesta 1 y 2 de su escrito Cuestionario I, aludiendo la reunión de Team 10:

....Como decía con ocasión de nuestras últimas reuniones en Royaumont, no tenemos vitalidad suficiente para "parir" 1000 viviendas realmente vivas, ....(comillas en el original)

...He hecho un fotomontaje muy arbitrario con las casas de un mismo pueblo, todas semejantes unas a otras, privándolas de toda relación entre ellas y con el paisaje. El conjunto conservaba, sin embargo toda su vitalidad y frescura. Si los arquitectos hubieran decidido arbitrariamente pequeñas diferencias entre las viviendas, no habría obtenido yo sino un resultado pobre y desolador. Este es el caso de la casi totalidad de los conjuntos residenciales modernos.....

(Fochs 1989, 217).

\footnotetext{
${ }^{9}$ Amigo personal de Coderch, le había encargado en 1951 -el mismo año de la Trienal de Milánla Casa Ugalde
} 


\section{Documentación inédita aportada}

\subsection{Casa Visser y Aldo van Eyck}

* Documentación digitalizada del Archivo Van Eyck, aportada por Francis Strauven

1. Serie de 5 croquis en color del desarrollo en planta de la Casa Visser

2. Serie de 6 croquis en BN del desarrollo en planta de la Casa Visser

3. Planta del cuarto proyecto no construido (2 círculos). Copia en papel A1

* Documentación aportada por Joke Visser

1. Planta del cuarto proyecto no construido (2 círculos). Copia en papel A1

2. Planta de cubierta del cuarto proyecto no construido. Copia en papel A1, coloreada con lápiz de color.

3. Planta de la $2^{\circ}$ ampliación con la pavimentación alrededor de la casa.

4. Planta detalle de la ampliación circular a escala 1/50. Copia de trabajo con anotaciones

5. Planta, Alzados y detalles de la $3^{\mathrm{a}}$ ampliación, firmado por Aldo van Eyck y Theo Bosch. Copia en papel.

6. 2 planos con plantas y alzados del proyecto de Rietveld. Copias en papel

7. Sección constructiva del espacio cilíndrico y su relación con la casa de Rietveld. Copia en papel

8. 1 fotografia en blanco y negro de la casas de Rietveld sin ampliar con la familia Visser en el jardín

9. 1 fotografía en blanco y negro de la cubierta y el lucernario del espacio cilíndrico.

10. 6 fotografías en blanco y negro del interior del espacio cilíndrico, una con Martin Visser en primer plano. De estas puede que no todas sean inéditas.

\subsection{Team 10 y Alison y Peter Smithson}

* Documentación Archivo Team 10 de Alison y Peter Smithson en el NAi, Rotterdam

1. 33 diapositivas de la obra de Coderch fotografiada por Peter Smithson ${ }^{10}$ :

- Edificio de la Barceloneta, 5 diapositivas

- $\quad$ Viviendas de pescadores cerca del puerto, 1952, 2 diapositivas

- Instituto francés, 2 diapositivas

- $\quad$ Casa Güell en Barcelona, 1 diapositivas

- Viviendas Banco Utquijo, 13 diapositivas

- Viviendas en Cocheras, 2 diapositivas

- $\quad$ Casa-estudio Tapies, 7 diapositivas

2. Texto mecanografiado con correcciones sobre Team X, de Peter Smithson, fechado en julio de 1961

3. Texto mecanografiado de 8 páginas titulado Team 10: The myth and the message, de Alison Smithson

4. Carta de Peter Smithson a Bakema, en relación a gestiones con la Rockefeller Foundation con un dibujo de Peter que alude al de Le Corbusier sobre el fin de los Ciam y el nacimiento de Team 10

5. Dibujo de los miembros de Team 10, seguramente hecho por alguno de los hijos de loa Smithsons

${ }^{10}$ Colección personal de Peter Smithson de diapositivas con obra de los integrantes del grupo. 204 diapositivas con obra de Bakema, De Carlo, Candilis, Coderch, Van Eyck, Guedes y una miscelánea de congresos de Team 10 


\subsection{Casa Coderch en Espolla y Jose Antonio Coderch}

* Documentación Archivo Coderch

1. 24 fotografías de Catalá Roca encargadas por Coderch sobre el territorio y el paisaje de Espolla

2. 24 fotografías de la casa en construcción, realizadas por José Antonio Coderch

3. Carta de Jaime Viñas, aparejador de Figueras, sobre como atendió a Catalá Roca cuando va a hacer las fotografías del campo de Espolla, y le acompaña el Secretario de Ayuntamiento y otro concejal.

4. Borrador de carta manuscrita de Coderch, dirigida a una alta instancia de la Administración, posiblemente del ejecito, para conseguir que quiten el campo de tiro militar de la zona, en defensa del medio ambiente.

* Documentación Archivo Team 10 de Bakema en el NAi en Rotterdam

1. Carta de Coderch a Bakema, fechada el 22 de mayo de 1962 en la que se traslucen las fuertes polémicas en el congreso de Otterlo 
Introducción 
Capítulo 1

Vernáculo, Primitivo, Popular 
Mi pueblo

Federico García Lorca

Cuando yo era un niño vivía en un pueblecito muy callado y oloroso de la vega de Granada. Todo lo que en él ocurría y todos sus sentires pasan hoy por mí, velados por la nostalgia de la niñez y por el tiempo. Yo quiero decir lo que sentía de su vida y sus leyendas. Yo quiero expresar lo que pasó por mí a través de otro temperamento. Yo ansío referir las lejanas modulaciones de mi otro corazón. Esto que yo hago es puro sentimiento y vago recuerdo de mi alma de cristal...Todas las figuras que desfilen por estas hojas desabridas, unas habrán muerto, otras están ya transformadas y el pueblo es otro completamente distinto...El monstruo de la política le quitó su virginidad y su luz. En este pueblo yo nací y se despertó mi corazón. En ese pueblo tuve mi primer ensueño de lejanías. En ese pueblo yo seré tierra y flores...Sus calles, sus gentes, sus costumbres, su poesía y su maldad será, como el andamio donde anidarán mis ideas de niño, fundidas en el crisol de la pubertad. Oid... 


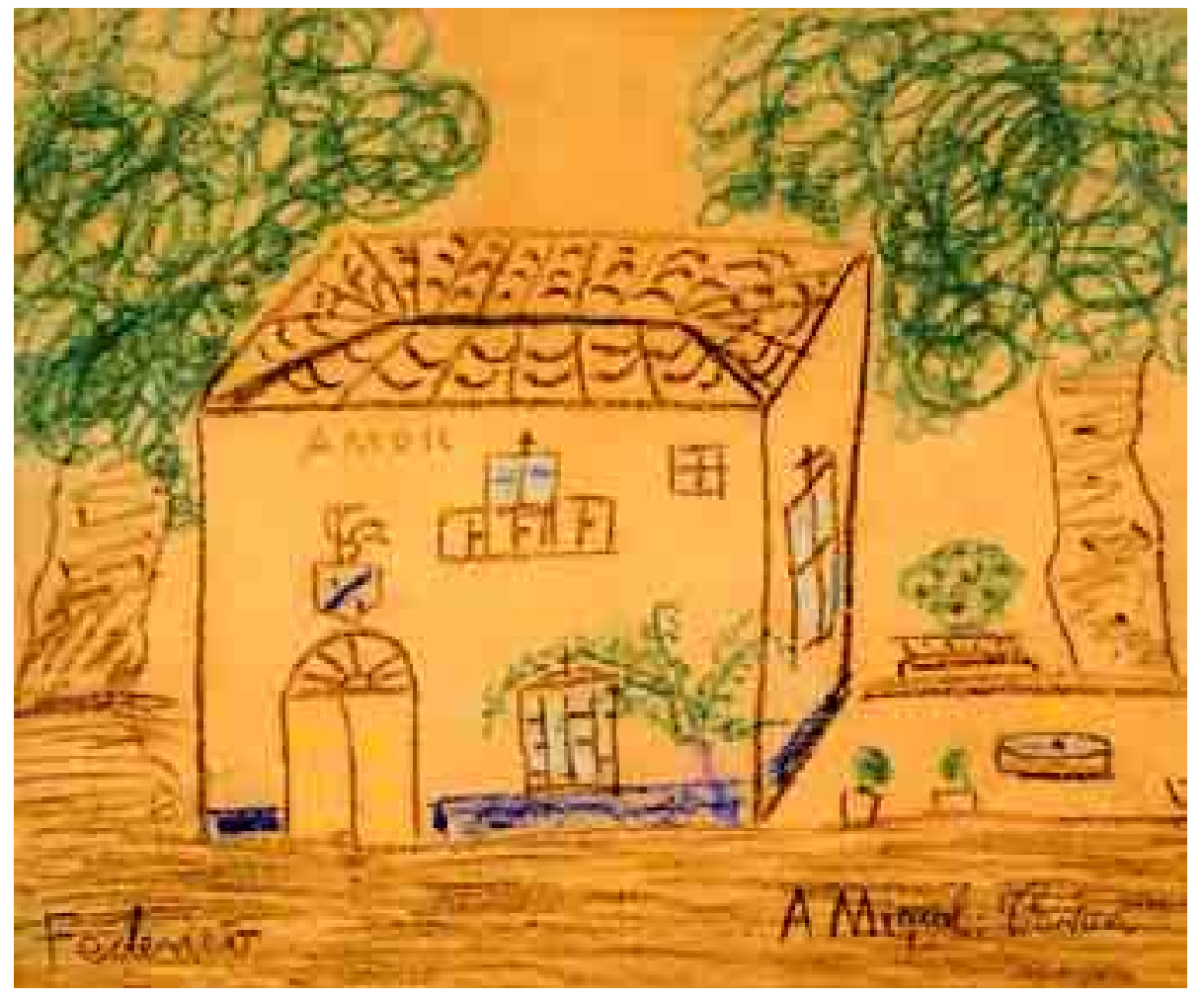

Figura 1.1

Dibujo de Federico García Lorca.

Colección Huerta de San Vicente. Ayuntamiento de Granada (García Lorca 2014) 


\section{Capítulo 1 \\ Vernáculo, Primitivo y Popular}

Las reflexiones realizadas en este capítulo pretenden únicamente hacer una modesta, breve, y limitada, introducción a los casos de estudio.

Cada uno de los epígrafes señalados a continuación, abre extensísimos ámbitos de trabajo, inabordables de forma exhaustiva. Por ello, es sencillamente una declaración de intenciones en la que exponer los puntos de vista y los parámetros con los que se ha trabajado en la tesis.

Según la Carta del Patrimonio Vernáculo Construido del ICOMOS ${ }^{1}$, el Patrimonio Tradicional ocupa un privilegiado lugar en el afecto y cariño de todos los pueblos. Aparece como un característico y atractivo resultado de la sociedad. Se muestra aparentemente irregular y sin embargo ordenado. Es utilitario y al mismo tiempo posee interés y belleza. Es un lugar de vida contemporánea y a su vez, una remembranza de la historia de la sociedad. Es tanto el trabajo del hombre como creación del tiempo. Sería muy digno para la memoria de la humanidad si se tuviera cuidado en conservar esa tradicional armonía que constituye la referencia de su propia existencia.

El Patrimonio Tradicional o Vernáculo construido es la expresión fundamental de la identidad de una comunidad, de sus relaciones con el territorio y al mismo tiempo, la expresión de la diversidad cultural del mundo. Constituye el modo natural y tradicional en que las comunidades han producido su propio hábitat. Forma parte de un proceso continuo, que incluye cambios necesarios y una continua adaptación como respuesta a los requerimientos sociales y ambientales. La continuidad de esa tradición se ve amenazada en todo el mundo por las fuerzas de la homogeneización cultural y arquitectónica. Debido a esa homogeneización de la cultura y a la globalización socioeconómica, las estructuras vernáculas son, en todo el mundo, extremadamente vulnerables y se enfrentan a serios problemas de obsolescencia, equilibrio interno e integración.

\subsection{Significado de vernáculo, primitivo y popular}

El uso del término «vernáculo» no es reciente y según el diccionario Merriam-Webster, aparece por primera vez utilizado en el idioma inglés en 1601, en referencia a la lengua propia hablada en un territorio o por un grupo determinado.

Proveniente del latín vernaculus con el significado de «nativo», etimológicamente deriva de vernus y verna, un esclavo o esclava nacido en la casa del amo. De esta manera, el lenguaje de los esclavos se diferenciaba del latín, el idioma culto de la clase dominante, y así, como un acto de afirmación de la identidad, la lengua vernácula era la propia, en contraposición al latín, máxime si el esclavo lo era en su tierra de origen sometida por el imperio romano.

Una de las cuestiones que ofrece mayor dificultad en cuanto a la definición del término vernáculo, es la variación de matices del significado según el idioma.

Actualmente, aunque su uso está cada vez más extendido, es un término empleado en países anglosajones, y fundamentalmente en Gran Bretaña. En países donde la romanización fue leve, como es el caso de Holanda, no existe como tal el término «vernáculo» o »vernacular«, aunque de forma culta y muy poco habitual se emplea la palabra vernaculaire, un galicismo que llega al idioma neerlandés por la parte francófona de Bélgica.

\footnotetext{
1 ICOMOS: International Council on Monuments and Sites. La Carta del Patrimonio Vernáculo construido, fue ratificada por la 12ª Asamblea General en México, en octubre de 1999.
} 
En España ocurre algo similar. El Diccionario Crítico Etimológico de la Lengua Castellana de Joan Corominas, dice:

«el termino vernáculo del latín. Vernaculus "indígena", "nacional", derivado de verna "esclavo nacido en casa de su dueño", "nacido en el país, indígena". $1^{a}$ doc.: Acad. 1884, no 1843.

Poco usado y muy culto»

Los conceptos de vernáculo, primitivo y popular, aceptados entre especialistas e interesados en la materia, en el lenguaje coloquial se intercambian frecuentemente, especialmente los dos últimos, a causa de diferencias culturales, idiomáticas y temporales sincrónicas/diacrónicas².

El término vernáculo de origen latino parece ser empleado mayoritariamente, al menos hasta ahora ${ }^{3}$, en el mundo anglosajón, mientras que en España el término utilizado es popular. Esta cuestión es relevante e ineludiblemente relacionada con el nivel de riqueza: mientras que en Inglaterra, además del rural, existe un vernáculo urbano, y el término también abarca construcciones ricas, en nuestro país la construcción popular es esencialmente pobre, como lo era mayoritariamente el mundo rural español ${ }^{4}$, y aspecto sobre el que se profundiza a continuación, en el epígrafe sobre Leopoldo Torres Balbás.

Una consideración más. Aldo van Eyck nunca utilizó la palabra primitivo para referirse a esas culturas, a las que consideraba tan sofisticadas como la occidental en sus manifestaciones artísticas y de lenguaje, acuñando la expresión «Vernacular of the Hearth» que forma parte de los Círculos de Otterlo, Francis Strauven lo explica en Aldo van Eyck: The Shape of Relativity y en la introducción del capítulo 9 de Aldo van Eyck Writings. Van Eyck era alérgico al significado desdeñoso del término y no quería establecer ninguna desigualdad en categoría con la tradición clásica y la moderna. Cuando le era inevitable se refería a ellas como «archaic o distanct cultures».

Se puede decir por tanto que, aunque con los matices expuestos, vernáculo y popular, son términos bastante parecidos. Su uso vendrá determinado en esta tesis por el sentido de la cultura donde se emplean de forma habitual. También se acepta el termino vernáculo como más genérico, que en cierta forma puede englobar todos, adoptando así el sentido dado por de Van Eyck.

De esta forma, la tesis explora las huellas de lo vernáculo en su acepción más general, y de forma más precisa y matizada, la huella de lo vernáculo en el Upper Lawn Pavilion de los Smithsons, la huella de lo primitivo en la ampliación de la casa Visser, y la huella de lo popular en la Casa Coderch en Espolla.

\footnotetext{
${ }^{2}$ Hasta hace muy poco e incluso actualmente en países del tercer mundo se sigue construyendo de forma vernácula. Por otra parte en muchos países del Centro y Sudamérica, las construcciones vernáculas se refieren a las realizadas con materiales naturales, casi exclusivamente de origen vegetal.

${ }^{3}$ Actualmente parece estar de moda, siendo un término cada vez más empleado.

${ }^{4}$ Leopoldo Torres Balbás en "Arquitectura popular española" citado en dicho artículo: «considera que la característica esencial de esta es la permanencia de formas, independientemente de modas o estilos, que son por esencia lujos, y por lo tanto, extraños a la pobreza de la cual participa"

Es nuestro país es más usado el termino popular, habitualmente empleado desde los años veinte y treinta del siglo XX en los textos específicos sobre la materia, como La casa popular en España de Fernando Garcia Mercadal, publicada en 1930 a partir de una memoria de 1923 de Leopoldo Torres Balbas, y sobre la que este publicara muy ampliada en 1933 -en el tercer tomo la enciclopedia Folklore y costumbres de España de Carreras Candí- La vivienda popular en España, con numerosas referencias a y a la obra de Vicente Lamperez y Romea, Arquitectura civil española de los siglos I al XVIII, aunque en ella se refiere a la «arquitectura rústica».
} 


\subsubsection{Amos Rapoport}

Según Amos Rapoport (1929- ) en su libro de 1969 Vivienda y Cultura, lo primitivo es más fácil de definir que lo vernáculo. La construcción primitiva es la producida por sociedades consideradas antropológicamente como tal. No se refiere a voluntades individuales, sino a la del grupo en que se construyen. Alude a Redfield quien explica que en dichas comunidades, los conocimientos están difundidos entre todos y la totalidad de aspectos de la vida de la tribu conciernen a todo el mundo. De esta manera, las viviendas son básicamente idénticas, pues a lo largo del tiempo se van depurando y ajustando, llegándose a establecer ciertas formas que resisten fuertemente a los cambios, pues son sociedades muy tradicionales.

Cuando se utilizan profesionales para la construcción de la mayoría de las viviendas, se puede decir que la construcción primitiva cede su puesto a la vernácula preindustrial, aunque el usuario no es un mero consumidor y sigue participando en el diseño. Este cambio inicia un proceso de especialización, aunque al principio el profesional lo es solo en parte y sigue siendo también campesino. En la cultura vernácula preindustrial existe todavía la forma aceptada. Se basa en unos modelos con ajustes y variantes, y contiene más diferenciación individual que la primitiva. Dichas variaciones de producen en lo individual, no en el tipo, quedando por determinar lo específico: las exigencias de la familia, el tamaño según la riqueza, y la relación con el lugar y el microclima. La forma se ajusta a unos problemas concretos dados y a los medios disponibles sin esfuerzos estéticos conscientes o intereses estilísticos.

La diferencia, mucho más difusa, entre vernácula preindustrial y popular se explica en "En torno a la masía" editorial de la revista 2 C Construcción de la Ciudad en su número 17-18, monográfico dedicado a la masía, coincidente con las tesis de Rapoport. Siendo términos bastantes similares, parece que en lo popular existe una cierta tendencia predominante del uso y la construcción, más que en lo vernáculo preindustrial, donde parece anteponerse una mayor influencia de la "cultura estatal".

\subsubsection{Kenneth Frampton: clima cultura mito y artesanía.}

El término acuñado por Kenneth Frampton "Regionalismo crítico" no tiene como intención denotar lo vernacular tal como era producido en tiempos por la interacción combinada del clima, la cultura, el mito y la artesanía, que se producía de forma espontánea, sino más bien para identificar aquellas "escuelas" regionales recientes cuyo objetivo principal ha sido el reflejar y servir a los limitados elementos constitutivos en los que se basan. Según Frampton, los factores que contribuyen a la emergencia de un regionalismo son: cierta prosperidad, y una especie de consenso anticentrista como aspiración de tener una forma de independencia cultural, económica y social. Desde el punto de vista de la teoría crítica tenemos que entender la cultura regional no como algo dado y relativamente inmutable, sino más bien como algo que tiene, al menos hoy en día, que ser cultivado de forma consciente. Alguno de los autores citados por Frampton en relación a este concepto son Utzon, el Grupo R, Ricardo Bofill, Siza, Alvar Aalto, y termina Raimund Abraham o Coderch. Sobre Coderch dice:

«La carrera del arquitecto barcelonés J. A. Coderch ha sido típicamente "regionalista", en cuanto ha oscilado, hasta fecha reciente, entre un tipo mediterraneizado de obra vista vernácula que formula por primera vez en su casa para el ISM, de ocho plantas, construida en el Paseo Nacional de Barcelona en 1951 (articulada de forma "tradicional" como la casa Borsalino, con persianas de techo a suelo y finos aleros sobresalientes), y la composición vanguardista, neo-plasticista y a la vez miesiana de su Casa Catasús, construida en Sitges en 1956» 


\subsubsection{Leopoldo Torres Balbás y La Vivienda popular en España}

En 1923 Leopoldo Torres Balbás (1888-1960) se presentó al premio Charro-Hidalgo, convocado por el Ateneo de Madrid, con el tema «La arquitectura popular en las distintas regiones de España», memoria que fue premiada, que completada y ampliada, fue la base del libro La Vivienda Popular en España. Antes y autorizado para ello también la utilizó Fernando García Mercadal para la publicación de La casa popular en España, en palabras de Torres Balbás «interesante y desordenado».

Texto fundamental, que dio soporte a una extraordinaria línea de trabajo sobre la materia en España en el ámbito de la arquitectura, que continuara en Fernando García Mercadal $^{5}$, Luis Feduchi o Carlos Flores, por citar algunos, y complementará la desarrollada por diversos autores de otros campos de nuestra cultura: Cossio, Francisco y Hermenegildo Giner de los Rios, Azorín, Caro Baroja, u Ortega y Gasset, relacionados con la Institución Libre de Enseñanza ${ }^{6}$.

Centrándose en el caso de España y en el concepto de lo popular, Leopoldo Torres Balbás ya adelanta los planteamientos de Amos Rapoport cincuenta años antes.

Coincide con Rapoport en señalar que si bien estas arquitecturas son deudoras de las condiciones físicas como el clima y el territorio, no lo son de forma determinante, sino que responden a una interacción recíproca entre el medio físico y el hombre, aunque cuanto más primitiva es la sociedad, más dependiente es de su entorno natural:

«las vivienda humildes de campos y aldeas, obras que, como más primitivas y elementales, están menos emancipadas de la servidumbre del medio geográfico, que dirige, no arrastra: la tierra influye n el hombre, pero éste a su vez, reacciona transformando aquella. Modificando más o menos profundamente el medio de su provecho. La casa popular, pues, no es un producto exclusivamente geográfico ni puramente humano: sus formas llevan impresa la marca del medio geográfico y del factor humano; no depende solo de la herencia o sólo del medio, sino de ambos a la vez.» (Torres Balbás 1930, 148)

\footnotetext{
${ }^{5}$ El papel en este terreno de Fernando García Mercadal (1896-1985) es especialmente relevante, por ser uno de los introductores del Movimiento Moderno en España, trabajando a lo largo de su vida de forma complementaria y no excluyente en la arquitectura moderna y datando la arquitectura popular, cuestión a la que se volverá en el capítulo 4.

Entre sus trabajos destacan la ya mencionada La casa popular en España de 1930, reeditado por GGi en 1981, y Arquitecturas regionales españolas, editado por la Comunidad de Madrid en 1984 con motivo de una serie de homenajes a Fernando García Mercadal, un año antes de su muerte. En esta última, al comienzo del libro, se aborda el tema a partir de la «Introducción al estudio de las arquitecturas regionales españolas", texto completísimo de FGM en el que expone sus antecedentes y fuentes de estudio. (Garcia Mercadal 1984, 13-19)

${ }^{6}$ Una de las actividades que fomentó la Institución Libre de Enseñanza (1876-1936), fue el conocimiento del medio físico y el territorio, entre otros a través de los viajes y excursiones. En este sentido, una figura clave será Rafael Torres Campos (1853-1904) uno de los geógrafos españoles más importantes del siglo XIX y padre de Leopoldo Torres Balbás. Discípulo de Hermenegildo Giner de los Rios, desarrollo entre otras, una importante labor de educación y difusión de la geografía desde dicha institución, fomentando el excursionismo, en la misma línea que las actividades llevadas a cabo en otros países.

En este sentido, cabe destacar que la primera asociación excursionista en España se constituye en Cataluña en 1876, el mismo año de fundación de la Institución Libre de Enseñanza. El Centre Excursionista de Catalunya CEC, desde el que se llevó a cabo entre 1923 y 1936 un estudio fundamental sobre la masía catalana con el nombre Estudi de la Masía Catalana, bajo la dirección de Josep Donás i Torras (1895-1955) y el mecenazgo de Rafael Patxot i Jubert (1872-1964). El fondo fotográfico obtenido en esos años, consta de 7.705 imágenes de unas 1500 masías en Cataluña y las Islas Baleares, realizadas por importantes fotógrafos con gran valor arquitectónico y etnográfico. Datos sobre el estudio obtenidos del Centre Excursionista de Catalunya CEC http://www.cec.cat
} 
También aborda la permanencia del tipo como algo característico de estas arquitecturas produciéndose pequeñas variaciones en los detalles, en la misma línea que lo hará posteriormente Rapoport. En las vivienda rurales de cada zona, existe un tipo de casa que se remite desde fecha remota, al que todas más o menos responden. Presentan características comunes, con los mismos materiales utilizados de la misma forma y con el mismo aspecto, lo que sin embargo no implica que sean idénticas. De hecho no se encuentran dos iguales. De tradición centenaria, se repite a través de generaciones sucesivas. Idea sobre la que Torres Balbás reitera su discurso en varias partes del libro:

«Esta permanencia dista mucho de ser caprichosa: es el resultado de una experiencia remota que ha demostrado las ventajas de las disposiciones y procedimientos adoptados. Surge así la gran diversidad de tipos de viviendas populares que se encuentran en todas las naciones» (Torres Balbás 1930, 149)

«los aldeanos tenían su banco de carpintero y sus herramientas; sabían así mimos construir muros de tapial o de mampostería, levantar una armadura, retejar. Cada cual labrase su propio hogar y este era por ello obra de verdadero amor. Cada cual edificaba atendiendo principalmente a sus necesidades y a sus gustos personales, con los materiales del país, no resultando nunca dos casas completamente iguales: todas tenían su personalidad, su alma. Eran obras espontaneas en las que, a falta de otros conocimientos, había que echar mano de la ingeniosidad, de la habilidad y del esfuerzo; obras humildes de las gentes que trabajan y penan en silencio a lo largo de los años y de los siglos", citando a Azorin: «masa anónima, paciente, incansable...formadora de pueblos, plasmadora de civilizaciones, correinte eterna a lo largo del tiempo, hacia lo ideal» (Torres Balbás 1930, 156)

Un aspecto muy relevante del trabajo de Torres Balbás, es que aunque sin utilizar el término «vernáculo», sino el de «arquitecturas regionales», establece una diferencia clara con lo «popular», esencialmente pobre, cuando dice: «Característica de la arquitectura popular es la permanencia de sus formas, independientes de modas, pasajeras, y estilos, que son por esencia lujo y, por lo tanto, extraños a la pobreza, por la que aquella principia. No es que el pueblo ame la eliminación del lujo: es que no puede usarlo».

Incidiendo sobre la pobreza como parámetro diferenciador de lo popular -algo sobre lo que también incidirá posteriormente Carlos Flores- frente a otras manifestaciones a las que llama «arquitecturas regionales», para referirse a las viviendas burguesas y los palacios dice:

«Pero ni las casonas montañesas, ni los pazos gallegos, ni las viviendas aragonesas con luna, alero tallado y galería de ladrillo, ni muchas masías catalanas, son obras de arte popular. En algunas de ellas tropezamos con temas elaborados por el pueblo, pero sus formas son, sobre todo, degeneraciones de las cultas y eruditas aportadas por los llamados estilos históricos y nunca resultado de una depuración de las populares; consecuencias últimas de aquellas, no refinamiento y elevación de estas. (...) lo estrictamente popular, son obras de arte humilde, pobre y austero, lo que no las hace menos interesantes, pues son como la célula originaria que, por transformaciones, lentas, seculares, adquiriendo cada vez más complejidad, da origen a los grandes edificios que llenan la historia de la arquitectura» (Torres Balbás 1930, 154)

«Tampoco el concepto de lo popular lleva implícita la idea de primitivismo, aunque con frecuencia suelen coincidir. Primitivo es lo no elaborado, lo que 
está en los comienzos de su desarrollo por razón de juventud o por haberse fijado en ese primer grado evolutivo. Primitivas son las viviendas troglodíticas, los abrigos de piedras sueltas, las chozas y las barracas. No lo son, en cambio, entre otros muchos ejemplos que pudieran citarse, los caseríos vascos, los cortijos andaluces, las viviendas montañesas, frutos seculares, todos ellos, de un lento trabajo de adaptación y depuración.»

La arquitectura popular, lleva implícita una idea de permanencia en el tiempo de un tipo y de permanencia en el tiempo de cada una de las construcciones de dicho tipo. Frente a las habituales renovaciones que se hacen en la vivienda de la ciudad, en el mundo rural, ámbito al que pertenece por antonomasia la arquitectura popular, las viviendas humildes apenas se renuevan y duran lo que sus propios materiales permites. De esta forma, las construcciones populares alcanzan como mucho quinientos o seiscientos años, que es límite máximo de que perdura su pobre construcción. Es en palabras de Cossio, al que de nuevo cita Torres Balbás «Perpetuidad no estática, sino evolutiva, aunque tan mansa evolución como el lento cambio de la naturaleza» (Torres Balbás 1930, 153)

Torres Balbás, no subordina el arte popular al culto. Al igual que Aldo Van Eyck en los Círculos de Otterlo equiparará las tres tradiciones: la clásica, la vernácula y la moderna, Torres Balbás lo hace entre el arte popular y el gran arte, que no quiere identificar necesariamente como culto, ya que hacerlo significaría calificar el popular de inculto, cuando simplemente es otra cultura diferente. Torres Balbás citando a Henri Focillon ${ }^{7}$ dice:

«No hay que considerar el arte popular como un movimiento secundario, consecuencia del gran arte que, algo impropiamente, pudiera llamarse culto, sino como un orden que tiene sus leyes especiales, como un lenguaje humano distinto del aristocrático y que recibe su caudal de otras regiones de la vida. Tal vez esté justificada la creencia de que no se trata de dos ramas situadas a distinto nivel, sino de diferentes aspectos humanos. Ha habido épocas y medios en los que estos dos artes aparecen mezclados, en los que el arte popular era una trasposición fiel del culto en materiales humildes, por medio de técnicas rápidas y sencillas» (Torres Balbás 1930, 165)

«No hay que hacer de él ni un mito de intangible belleza y sabiduría, ni suponerlo producto inferior y bastardo, negando por completo su originalidad. Es, sencillamente, obra humana, natural, colectiva y humilde de la que podemos deducir una profunda lección de disciplina y armonía, provechosa siempre, pero todavía más cuando la arquitectura culta se pierde en divagaciones abstractas y se complica en retorcimientos ilógicos de formas» (Torres Balbás 1930, 153)

\footnotetext{
7 Art populaire, travaux artisitques et scientifiques du premier Congres International des Arts populaires, Prague, MDCCCCXXVIII. Tome I, París. Introducción de Henri Focillon.

Torres Balbás cita varias veces la introducción de Henri Focillon a esta obra. En este caso para referirse a la existencia en nuestro país de numerosos ejemplos de la mezcla de las arquitecturas culta y popular, donde el elemento popular, especialmente en la región central, tuvo durante la edad media gran influencia, poniendo por ejemplo la arquitectura morisca de ladrillo como resultado de una técnica y un espíritu popular influidos por formas cultas.
} 
Torres Balbás también incide en la completa ausencia de recopilación y sistematización de la arquitectura popular española, con una referencia expresa a Vicente Lamperez ${ }^{8}$ que en su obra Arquitectura civil española de los siglos I al XVIII, dedico unas pocas páginas a tema. Insiste Torres Balbás sobre este aspecto, destacando que en España apenas ha comenzado un interés por datar y archivar como se hace en otros países «el caudal enorme de este mundo extraño, obscuro y desdeñado, descubierto por el siglo XIX, de las formas populares». Ya en ese momento, tiene perfecta consciencia de que la radical y rápida transformación de la sociedad moderna, los tradicionales tipos de viviendas populares, "tan diferenciadas", «divina variedad, inactual y anacrónica, tienden a desaparecer»

La conciencia de la desaparición de una tradición centenaria, es sin duda el prisma bajo el que se desarrollan los trabajos realizados por Fernando García Mercadal, ya mencionados, y está muy presente en los integrantes de la vanguardia arquitectónica ${ }^{9}$ del momento. No es casualidad que ya en 1930, Torres Balbás apuntaba su conexión con la arquitectura moderna cuando dice: «En esta arquitectura popular llena de vida desparece todo lo que puede haber de personal y caprichoso en la de los llamados "estilos históricos". Es función de sus materiales y de su destino, lo que la aproxima a las tendencias arquitectónicas más modernas» (Torres Balbás 1930, 151)

Llegados a este punto se puede concluir que el trabajo de Leopoldo Torres Balbás sobre la vivienda popular es una pieza fundamental, siendo uno de los textos más claros sobre el tema, al establecer el parámetro de pobreza como determinante para la arquitectura popular. Aunque puede parecer obvio, es necesario su explicitación precisa. Además Torres Balbás aborda otras cuestiones muy significativas como la necesidad de datación ante su irremediable desaparición, o su conexión con la arquitectura moderna. Así, su trabajo se convierte sin duda en un referente fundamental y sin el que no se puede explicar adecuadamente la relación e interés de los arquitectos de Movimiento Moderno en España por la arquitectura popular.

\footnotetext{
${ }^{8}$ Anteriormente Vicente Lamperez en 1922 en su Arquitectura civil Española de los siglos I al XVIII, habla de "arquitectura rústica" aunque el epígrafe correspondiente es "arquitectura rústica y popular»

${ }^{9}$ En este sentido Martín Domínguez, en su artículo «Le Corbusier, en recuerdos y presupuestos personales» relata dos interesantes anécdotas ocurridas con Le Corbusier, cuando vino invitado por García Mercadal a dar dos conferencias en 1928 a la Residencia de Estudiantes, y aunque un poco extensas de contar, se considera relevante hacerlo por su relación con Le Corbusier. Según Martín Domínguez, al terminar la primera, muchos de los asistentes formaron corro alrededor de Le Corbusier, que hablaba sorprendido como mucho de lo que el consideraba haber sido su contribución al lenguaje de la arquitectura moderna, como las formas sencillas y los muros blancos encalados en los que los huecos son expresivamente rotundos, lo había podido ver desde el tren en el viaje a Madrid, y pueblo tras pueblo, realizado de forma anónima en la arquitectura popular española, ante lo cual Manuel Cossio, uno de los asistentes, le respondió: «señor, su asombro se debe a que en España no le hemos rendido todavía el elogio que le debemos a Nuestra Señora la Santa Pobreza» (Domínguez [1966] 2010, 278).

Martin Domínguez sigue explicando cómo Le Corbusier lo pasó realmente bien en Madrid, disfrutando de todos los sitios a los que le llevaron, desde el Museo del Prado, hasta el inevitable y nocturno tablao flamenco. Después y aquel mismo verano Domínguez fue a visitarlo en Paris, conociendo su obra de primera mano, gracias a las gestiones hechas por el propio Le Corbusier para visitarlas. Agradeciéndole sus atenciones, Domínguez le animó a volver a España a conocer Andalucía y el sur en verano -había estado en nuestro país primavera- para comprender realmente cuando la cultura andaluza alcanzaba su autentico sentido. Así, para sorpresa de Domínguez, Le Corbusier se presentó en Madrid en agosto de ese mismo año con Pierre Jeanneret y Fernand Léger, a su vuelta del citado viaje al sur. En una cena al aire libre en el Pardo, comentando las impresiones y sensaciones que habían tenido, Domínguez cuenta sobre Le Corbusier: "Como inevitable era, según Le Corbusier, la rápida desaparición de aquellos valores definitivos de la vida civilizada de España en cuyo comentario, entre plato y plato, nos entreteníamos: desaparición que veía acelerarse por un progreso al que yo, como decía él por jarana, estaba contribuyendo al construir para el Patronato Nacional de Turismo su primer programa de Albergues de Carretera, por entonces en ejecución. Augurando que el aluvión de turistas acabaría rápidamente con todo aquello que tanto le gustaba»

(Domínguez [1966] 2010, 280)
} 


\subsubsection{John Berger. Lo primitivo y lo profesional}

John Berger en su libro Mirar de1980, marca la distinción entre lo «primitivo» y lo profesional, en el ámbito del estatus social en un breve texto de 1976.

El término primitivo que se origina en el siglo XIX, aparece cuando el arte profesional pone por primera vez en tela de juicio sus propios objetivos convencional en el Salon des Refuses en 1863, aunque lo que realmente propició su aparición fue la obligatoriedad de la escuela primaria, una mayor movilidad geográfica por los medios de transporte como el ferrocarril, y la difusión del periodismo popular, aspectos todos ellos que en definitiva ayudaron al estimulo de una conciencia de clase.

Ha sido utilizado en la historia del arte con tres sentidos diferentes. Por una parte para describir el arte anterior a Raphael, que marca el cambio entre el Renacimiento y las tradiciones medievales; también para referirse a los «trofeos» traídos de las colonias de África, El Caribe y el Pacífico Sur a las grandes ciudades de los imperios colonizadores; y finalmente "para poner en su lugar el arte de los hombres y mujeres de las clases trabajadoras -proletarios, campesinos y pequeños burgueses- que al no convertirse en artistas profesionales, no abandonaron su clase»

A diferencia de los artistas profesionales que empiezan muy jóvenes, los artistas primitivos suelen empezar su arte cuando son adultos o incluso viejos, ya que se deriva sobre todo de su experiencia personal y suele nacer precisamente de la profundidad o intensidad de la experiencia.

Así, «lo primitivo se define como lo no profesional». La diferenciación entre artista profesional y maestro artesano, empieza a clarificarse en el siglo XVII, aunque dependiendo de los países puede tardar hasta el XIX, como en la Europa del Este, y según Berger:

«El primitivo comienza solo: no hereda practica alguna. Por esta razón, a primera vista puede parecer que el empleo del término está justificado. No utiliza la gramática pictórica de la tradición: por eso es incorrecto. No ha aprendido las técnicas que han evolucionado con las convenciones: por eso es torpe. Cuando descubre por si solo una solución para un determinado problema pictórico, suele utilizarla una y otra vez: por eso es ingenuo. Pero ¿por qué rechaza la tradición? (...) Porque sabe de antemano que su experiencia, esa experiencia que le fuerza a hacer arte, no tiene lugar en esa tradición (..) Lo sabe porque esa experiencia vivida le enseña que en la sociedad en la que vive siempre ha estado excluido del poder, y ahora se da cuenta por la compulsión que siente de que en el arte hay también un tipo de poder. La voluntad de los primitivos se deriva de la fé en su propia experiencia y de su profundo escepticismo con respecto a la sociedad que han encontrado (...) la "torpeza" del arte primitivo es la precondición de su elocuencia. Lo que nos dice este arte no podría decirse mediante unas técnicas convencionales o heredadas, pues, de acuerdo con el sistema cultural de clases, nunca se pensó que pudiera decirse tales cosas» (Berger 1980, 74)

El sentido despectivo del término, incisivamente enunciado así por John Berger explica el rechazo ya comentado por Aldo van Eyck a emplearlo para calificar a las culturas que el prefiere designar como arcaicas y vernáculas. 


\subsubsection{Sigfried Giedion: Espacio, Tiempo y Arquitectura}

Las distintas ediciones de la obra de Sigfried Giedion (1888-1968), ESPACIO, TIEMPO y arquitectura. Origen y desarrollo de una nueva tradición ${ }^{10}$, fueron incorporando cambios de diversa entidad desde la primera en 1941 hasta la quinta y definitiva en 1967 poco antes de su muerte en 1968. Este proceso que por su envergadura va más allá de una simple revisión editorial, puede dar una idea de cómo parte de lo que ahora entendemos con normalidad, se fue conformando y clarificando en la década de los cincuenta y sesenta, en el mismo contexto en el que se enmarca esta tesis.

Las diferencias más relevantes entre ediciones se traducen en nuevos capítulos que de forma significativa tienen que ver, mayoritaria aunque no exclusivamente, con la actitud de la arquitectura moderna y contemporánea hacia el pasado y lo vernáculo: en sentido amplio como lo refiere Aldo van Eyck, relativo a culturas primitivas o arcaicas, y en sentido más literal al hacerlo con respecto a la influencia e importancia de lo local.

Así, en la tercera edición se incorpora un capítulo sobre Alvar Aalto (1898-1976) como crisol precursor de «lo primitivo y lo actual», como máximo exponente de la combinación de «estandarización e irracionalidad», en la que la primera está al servicio a la segunda. Explica como la fuerza moral que alienta el desarrollo de la arquitectura en la segunda mitad del siglo XX, radica precisamente en la preocupación de «restablecer la unión entre la vida y la arquitectura», siendo Aalto uno de las figuras clave de este impulso, en un momento en torno a 1930 en el que pintores como Joan Miró y Paul Klee, con obras estrechamente ligadas a lo orgánico y lo racional, también se estaban dando a conocer. Giedion dice:

«Finlandia estaba con Aalto dondequiera que fuese; le proporcionaba esa energía interior que siempre fluye por su obra; era lo mismo que España para Pablo Picasso o Irlanda para James Joyce. Parte de la esencia del arte actual es que sus verdaderos representantes surgieron de un entorno humano definido y su obra no está creada en el vacío. Pero también es parte de esa esencia el hecho de que se han derribado las barreras entre el futuro y el pasado, y con un audaz movimiento se ha abarcado nuestro periodo, el mundo en su conjunto y toda la historia. Georges Braque lo expresó a la manera de Henri Bergson en su cuaderno de dibujo: "El futuro es la proyección del pasado, condicionada por el presente ${ }^{11 "}$.

Tal vez épocas posteriores observarán que una de nuestras buenas cualidades era esforzarnos por combinar lo técnico con lo primigenio. El mismo fenómeno aparecía en todas las artes: desde los estratos olvidados de la conciencia, los elementos del hombre primitivo que todavía permanecían latentes entre nosotros volvían a salir a la luz, y al mismo tiempo se buscaba la unidad con el tiempo presente» (Giedion [1941] 2009, 599)

En la última edición se añaden los capítulos sobre de la tercera generación, ejemplificada por Jørn Utzon, y otro breve sobre la historia de los CIAM.

\footnotetext{
${ }^{10}$ Se han manejado dos ediciones en español: la sexta, editada por Dossat y reimpresa por última vez hace treinta años, y la definitiva editada en 2009 por la editorial Reverté. Las diferencias son importantes, pues la de Dossat, traducida al castellano desde la edición italiana, estaba traducida al igual que la mayoría de ediciones y reediciones en otros idiomas a partir de la cuarta, realizada en 1962. La edición del año 2009 de Reverté, calificad como definitiva, se realiza y traduce al castellano desde la última versión original, la quinta, hecha por Giedion en Estados Unidos en 1967, incorporando añadidos importantes.

11 Cahiers de George Braque 1917-1947. París 1948. En la edición de Dossat de 1982 la cita de Braque se mantiene en francés: «L'avenir est la projection du passé, conditionneé par le présent»(Giedion [1941] 1982, 599)
} 
De entre las características que establece Giedion como propias de la tercera generación, la que entra en acción en los años cincuenta, en comparación con las anteriores es especialmente relevante con respecto a este trabajo, la que define como: «una relación más fuerte con el pasado, no expresada en las formas, sino en el sentido de una relación interna y un deseo de continuidad»

Tras un justificado distanciamiento en el origen de la arquitectura contemporánea, para poder autoafirmarse frente a la historia -con la excepción de Le Corbusier al que Giedeon señala como el único pionero que nunca interrumpió su contacto con el pasado- era el momento de poder volver a sentir «esa reserva de la experiencia humana». En este proceso, alerta del peligro de lo que llama «seudo-relaciones con el pasado", poniendo el ejemplo de la experiencia arquitectos de la segunda generación en Estados Unidos que trataron de incorporar detalles decorativos con fragmentos estilísticos aislados, en una actitud que no establece ninguna relación con la tradición, sino que «conduce únicamente a una arquitectura decadente que deleita al público y a la prensa, pues le recuerda esos ideales, enterrados solo a medias, del siglo XIX»

En contraposición, Giedion describe las relaciones de la tercera generación con el pasado como muy diferentes. Su claridad y certeza en los términos para explicar cuestiones bastante inaprensibles, le convierten posiblemente en uno de los mejores narradores de esta relación. Es capaz de enunciar sentimientos y aspectos intangibles sin renunciar a lo racional y objetivo. Giedion dice:

«La relación de la tercera generación con el pasado se expresa de un modo diferente; aparece en su actitud hacia las construcciones anónimas que en todas partes son vínculos vivos con el pasado. La generación anterior -con ciertas excepciones ${ }^{12}$ - se mostró indiferente con respecto a la arquitectura anónima. Con la tercera generación la cosa es muy distinta. Dondequiera que vayamos encontramos un renacer del deseo de vivir en un lapso de tiempo más amplio; esta generación se rebela ante la insensata destrucción de los edificios antiguos en un periodo de gran prosperidad.» (...) «La actitud de la tercera generación con respecto al pasado no consiste en extraer detalles de su contexto original. Se trata más bien de una afinidad interior, un reconocimiento espiritual de lo que, en la abundancia del conocimiento arquitectónico, está relacionado con el tiempo presente y es capaz, en cierto sentido, de reforzar nuestra seguridad interna.» (Giedion [1941] 2009, 643)

Su definición de arquitectura vernácula, sin emplear este término -de dificultad ya explicada- con la frase «construcciones anónimas que en todas partes son vínculos vivos con el pasado», abarca las culturas primitivas y las posteriores -a las que Rapoport llama vernáculas preindustriales- sin establecer necesariamente un orden temporal, lo que redunda en reforzar la concepción no jerárquica del arte moderno al que aspiran en arquitectura los miembros de Team 10, pertenecientes a la tercera generación.

12 Al referirse a la generación anterior, como en general indiferente a estas arquitecturas anónimas, introduce un matiz al decir «con ciertas excepciones» aunque no explica cuales. Con probabilidad se refiere a la arquitectura del movimiento moderno español en su singularidad por haber incorporado desde sus inicios lo popular, a diferencia de otros y como algo consustancial al mismo -un repaso a las páginas de AC así lo corrobora-. Personalizado en el exilio por Josep Lluis Sert y en España por Fernando García Mercadal, se hace referencia más extensa al mismo en el capítulo sobre la Casa en Espolla de José Antonio Coderch de esta tesis. En caso contrario, se estaría cometiendo un error importante, y es difícil suponer que Giedion desconociera esta significativa característica de nuestro movimiento moderno, máxime cuando conocía con cercanía a Sert, uno de sus protagonistas. Su no mención explícita, al igual que la ausencia casi completa de referencias a la arquitectura española -con la excepción de Sert y Gaudí-, tiene sin duda diversos motivos que exceden el ámbito de este trabajo. Nos aventuramos a proponer, entre otros, un motivo político relacionado con la dictadura del general Franco. 
Giedion establece la fundamental diferencia de actitud hacia el pasado entre los historiadores ${ }^{13}$ y los arquitectos de la tercera generación. A estos no les interesa saber datos del edificio como su fecha de construcción o quien lo realizó, sino el qué quiso lograr su autor y cómo lo hizo:

«En otras palabras, lo que le interesa a los arquitectos es examinar el conocimiento arquitectónico anterior, de modo que puedan comparar inmediatamente los objetivos arquitectónicos coetáneos con los de un periodo previo» (...) La aproximación al pasado siempre gira en torno a la misma pregunta: ¿cómo resolvió el hombre, en otros tiempos y en otras circunstancias, determinados problemas, y cuáles eran estos? Los edificios de los pueblos primitivos a menudo están más próximos a los arquitectos actuales que las construcciones de culturas posteriores.» (...) Esto significa, entre otras cosas, que hay cierto instinto que está alerta para penetrar en la atmósfera histórica de una ciudad y, en cierto sentido, en su genius loci, en el espíritu del lugar, sin sumergirse en la concepción espacial o los detalles del periodo pasado.» (Giedion [1941] 2009, 643-644)

La arquitectura moderna se caracteriza por lo que Giedion llama «tendencias universales, problemas locales». Volviendo a poner a Aalto como ejemplo dice:

« La arquitectura moderna (...) es el producto de toda nuestra época y por eso no puede dejar de mostrar algunas tendencias universales: pero, por otro lado, está demasiado preocupada por los problemas de la vida real como para desatender las diferencias locales en necesidades, costumbres y materiales. Bajo el liderazgo de Alvar Aalto, Finlandia ha mostrado cómo pueden hacerse aportaciones a la arquitectura de un modo universal mediante soluciones adaptadas a las condiciones específicas de su entorno autóctono.» (Giedion [1941] 2009, 675)

ESPACIO, TIEMPO y arquitectura además de una historia de la arquitectura del Movimiento Moderno, incide desde el mismo título en sus claves y significado. La aportación más relevante del texto, es la incorporación, desde el mismo título, del concepto espacio-tiempo que enunció el Cubismo, y característico del siglo XX. Para Giedion, frente a la prevalencia del espacio exterior de la arquitectura de la Antigüedad y la de los grandes espacios interiores de la arquitectura posterior hasta el Barroco, la nueva noción espacial que aporta la arquitectura moderna, reside en la intensificación de las relaciones interior-exterior, en la coordinación de distintos niveles, y en como tensiona al usuario para desplazarse y abarcar estos aspectos, introduciendo así la variable tiempo.

Relaciones no jerárquicas y policéntricas, relaciones interior-exterior, y la configuración de una nueva tradición, están presentes en el diagrama Brubeck de los Smithson, en las obras de Richard Paul Lohse y en los tapices Bakuba escogidos por Aldo van Eyck para expresar la misma idea, en la contraposición de opuestos, en los espacios inbetween, así como en la «tradición viva» que busca Coderch.

\footnotetext{
${ }^{13}$ Giedion aclara: «al menos la de esos historiadores que carecen de una relación con el escenario coetáneo». De esta forma se excluye de ese grupo que señala de no interés para los arquitectos de la tercera generación y anteriores, a los que él conocía personalmente, con los que tenía relación de forma mayoritaria, y en los que con esta aclaración parece querer englobarse. El conocimiento personal de los protagonistas de la historia, sin duda confiere un plus de intensidad al libro.
} 


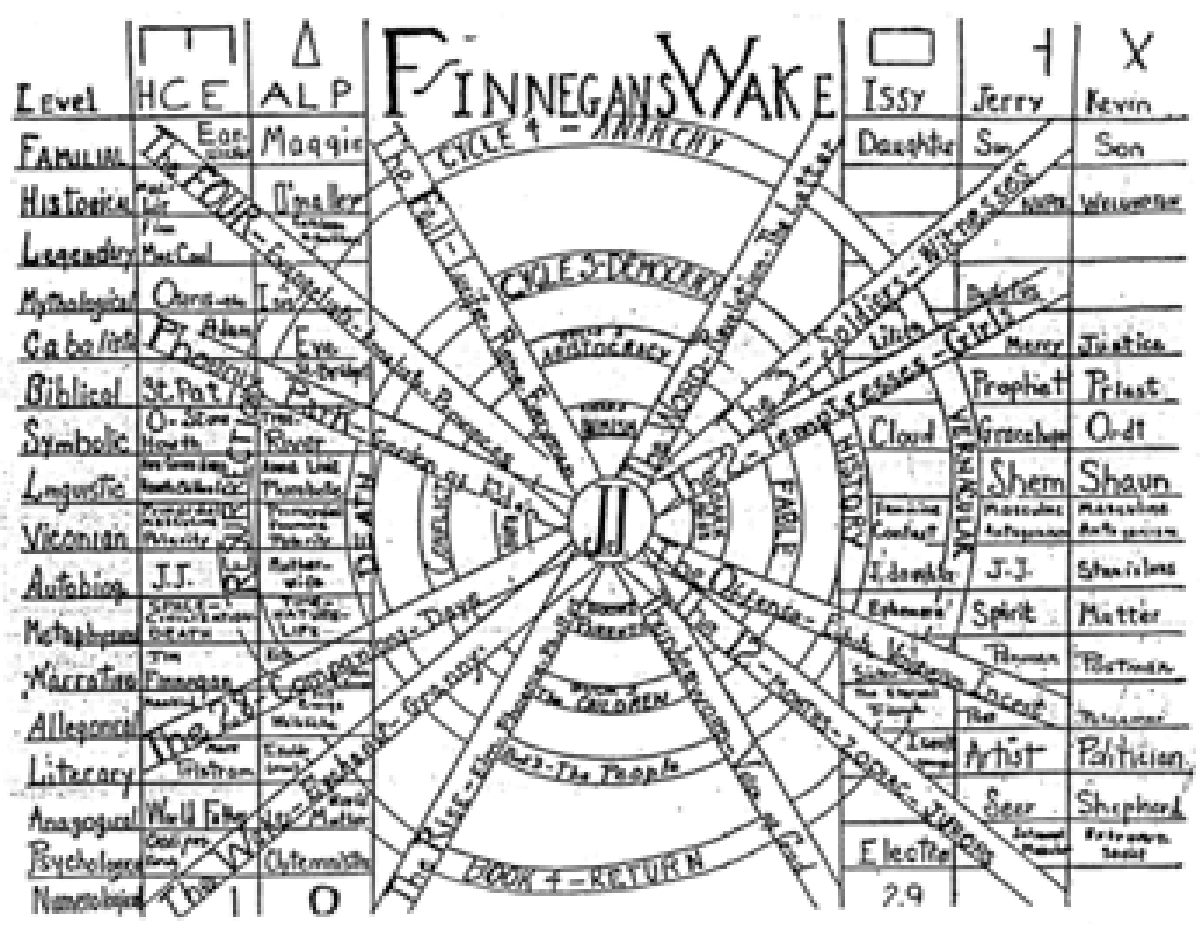

Figura 1.2

Lo vernáculo como parte integrante de la vanguardia.

Representación visual del libro de James Joyce Finnegans Wake, publicada por László MoholyNagy (1895-1946) en su libro Vision in motion, resultado de su trabajo al frente del Institute of Design en Chicago durante el periodo 1937-1946, y que refleja su filosofía educativa fundamentada en los principios de la Bauhaus.

El diagrama aparece junto con otro también explicativo del Ulises, del mismo autor, y va acompañado del siguiente pie de foto:

«In its efforts to integrate the arts, the Institute of Design brings before the students the great creative writers in lectura series. For a better understanding of the work of James Joyce, Leslie L. Lewis prepared charts disclosing the structure of the books "Ulysses" and "Finnegans's Wake". 
1.2. Mito, Topos, Tipo y Tekton. Parámetros de análisis de lo vernáculo.

Como método de trabajo se ha tratado de sistematizar el análisis de lo vernáculo en los casos a estudiar, determinando los parámetros que le son consustanciales: mito, topos, typo y tekton, aludiendo a los empleados por Kenneth Frampton, en la definición de vernáculo, dada por negación cuando habla de regionalismo crítico. Refiriéndose a este dice: «no tiene como intención denotar lo vernacular tal y como era producido en tiempos por la interacción combinada del clima, la cultura, el mito, y la artesanía»

Con ellos, se intenta compensar la falta de referentes claros, ya que los textos específicos manejados sobre el tema de lo vernáculo -en general de autores no arquitectos- en unos casos tratan de definir en qué consiste, y en otros suelen hacer clasificaciones por culturas y lugares geográficos.

Team 10 y sus miembros abordan estas cuestiones desde la arquitectura, y en concreto desde la arquitectura moderna, a través del estudio de ejemplos con la ciudad como principal referente, en sentido amplio y en todas sus escalas.

De ahí surge este trabajo, pues parece pertinente ver en qué manera buscaban, voluntaria e intencionadamente, ser influenciados. En este sentido, la tesis aborda simultáneamente en qué consiste lo vernáculo, para luego hacer un análisis crítico arquitectónico de su influencia en el Upper Lawn Pavilion de Alison y Peter Smithson, en la Ampliación de la Casa Visser Aldo van Eyck y en la Casa de Espolla de José Antonio Coderch.

Los parámetros de análisis establecidos, no se pretenden en absoluto determinantes. Únicamente han sido la herramienta para poder desarrollar la investigación. Nacen de la autentica necesidad de dar una estructura reconocible al trabajo, y de poder abordar la mayor cantidad y diversidad de variables que conforman la aproximación a lo vernáculo, que aquí se propone.

Es una aproximación desde la arquitectura, de manera que aspectos sociológicos, antropológicos o de otra índole, se articulan a través de los vectores de mito, lugar, tipo, y materialidad.

Si bien la interacción combinada del topos, del typos y del tekton, dan lugar en general a lo construido, las arquitecturas vernáculas, primitivas, y populares, están especialmente ligadas al lugar, son especialmente representativas de tipos arquitectónicos y resultan especialmente expresivas de, y por, lo material, siendo la asunción de el mito, como parte consustancial de una cultura determinada, lo que especialmente caracteriza a la arquitectura vernácula respecto de otras manifestaciones arquitectónicas.

Es una cuestión de intensidad. No es que otras arquitecturas no participen de dichos parámetros, sino que las arquitecturas vernáculas lo hacen especialmente.

En este sentido, el factor tiempo es fundamental, ya que sus características y singularidades, resultan de una evolución lenta y paulatina, en la que los cambios se producen de forma tan menor y tan prolongada en el tiempo, que son imperceptibles sincrónicamente. A su vez, dichos procesos centenarios, les confieren un grado de esencialidad e intensidad que es lo que en gran medida las define.

Finalmente cabe decir, que el método es lo suficientemente determinado para sistematizar los casos de estudio y otros posibles, pero lo suficientemente flexible para dar cabida al universo de singularidades y circunstancias particulares de cada proyecto. También abre un camino a perfeccionar, a partir de la estructura básica desarrollada en la tesis. 


\subsubsection{Mito}

El mito como relato de algo fabuloso que se supone acontecido en un pasado remoto casi siempre impreciso, es consustancial a lo vernáculo, y está presente en las obras de estudio, las cuales además se encuentran en lugares con una fuerte carga simbólica. Upper Lawn está muy cerca de Stonehenge y Avebury, considerándose el condado de Wiltshire como el territorio origen de Inglaterra. En Espolla se encuentran un gran número de dólmenes y menhires, dándose en la sierra de L'Albera una de las concentraciones de monumentos megalíticos más importantes de Cataluña, y la casa Visser está a muy poca distancia del mayor cementerio merovingio del norte de Brabantia. Hasta qué punto es casualidad esta coincidencia es imposible de determinar, pero si podemos afirmar que en la intencionada elección del lugar, especialmente en Upper Lawn y Espolla, va implícita la aceptación de ese universo de leyenda, fábula y mito, quedando conscientemente testimoniado por los Smithsons, Van Eyck y Coderch en textos y fotografías de las casas y el territorio.

Según el Diccionario de Filosofía de José Ferrater Mora. Editorial Sudamericana, Buenos Aires

"Se llama "mito" a un relato de algo fabuloso que se supone acontecido en un pasado remoto y casi siempre impreciso.

Los mitos pueden referirse a grandes hechos heroicos (en el sentido griego de 'heroicos') que con frecuencia son considerados como el fundamento y el comienzo de la historia de una comunidad o del género humano en general. Pueden tener como contenido fenómenos naturales, en cuyo caso suelen ser presentados en forma alegórica (como ocurre con "los mitos solares").

Muy a menudo los mitos comportan la personificación de cosas o acontecimientos. Puede creerse de buena fe, y hasta literalmente, en el contenido de un mito, o tomarlo como relato alegórico, o desecharlo alegando que todo lo mítico es falso.

Cuando el mito es tomado alegóricamente, se convierte en un relato que tiene dos aspectos, ambos igualmente necesarios: lo ficticio y lo real. Lo ficticio consiste en que, de hecho, no ha ocurrido lo que dice el relato mítico. Lo real consiste en que de algún modo lo que dice el relato mítico responde a la realidad. El mito es como un relato de lo que podría haber ocurrido si la realidad coincidiera con el paradigma de la realidad. Por eso ha escrito José Echeverría que "el mito ha de expresar en forma sucesiva y anecdótica lo que es supratemporal y permanente, lo que jamás deja de ocurrir y que, como paradigma, vale para todos los tiempos. Mediante el mito queda fijada la esencia de una situación cósmica o de una estructura de lo real. Pero como el modo de fijarla es un relato, hay que encontrar un modo de indicar al auditor o lector más lúcido que el tiempo en que se desenvuelven los hechos es un -falso tiempo, hay que saber incitarlo a que busque, más allá de este tiempo en que lo relatado parece transcurrir, lo arquetípico, lo siempre presente, lo que no transcurre" »

Los presocráticos consideraron el mito de un modo ambivalente. Por un lado, descartaron el mythos en nombre del lagos. Por otro lado, hicieron crecer este logas sobre el suelo de un previo mythos. Lo más frecuente fue entrelazar los dos, cuando menos en el lenguaje.

Los sofistas, en cambio, tendieron a separar el mito de la razón, pero no siempre para sacrificar enteramente el primero, pues con frecuencia admitieron la narración mitológica como envoltura de la verdad filosófica.

Esta concepción fue retomada por Platón, especialmente en tanto que consideró el mito como un modo de expresar ciertas verdades que escapan al razonamiento. En este sentido, el mito no puede ser eliminado de la filosofía 
platónica, pues, como indica Victor Brochard, desaparecían entonces de ella la doctrina del mundo, del alma y de Dios, así como parte de la teoría de las ideas. El mito es, pues, para Platón con frecuencia algo más que una opinión probable. Pero a la vez el mito aparece en Platón como un modo de expresar el reino del devenir.

Varios autores neoplatónicos trataron de la cuestión de la naturaleza y clases de mitos, así como de la justificación (filosófica) del carácter divino de los mitos.

En la Antigüedad y en la Edad Media se prestó particular atención al contenido mismo de los mitos y a su poder explicativo.

Desde el Renacimiento se abrió paso un problema que, aunque ya tratado en la Antigüedad, había quedado un poco a trasmano: el problema de la realidad, y, de consiguiente, el problema de la verdad, o grado de verdad, de los mitos. En la medida en que múltiples tendencias escépticas mordieron sobre no pocas creencias, mordieron asimismo sobre los mitos.

No pocos autores modernos se negaron a considerar los mitos como dignos de mención; la "verdadera historia", proclamaron, no tiene nada de mítico. Por eso el historiador debe depurar la historia de mitos y leyendas. Así pensó, por ejemplo, entre otros, Voltaire, y todos los "ilustrados" del siglo xvm. Sin embargo, a medida que se intentó estudiar la historia empíricamente, se advirtió que los mitos pueden no ser "verdaderos" en lo que cuentan, pero que son "verdaderos" en otro sentido: en que cuentan algo realmente acontecido en la historia, es decir, la creencia en mitos. En otras palabras, los mitos fueron considerados como "hechos históricos": su "verdad" es una "verdad histórica". Así pensó (también) Voltaire, quien, no obstante su mitofobia, no descuidó los mitos cuando se trataba de describir el pasado histórico.

Dos autores modernos dieron gran importancia al fenómeno del mito y de los mitos: Vico y Schelling.

Vico fundamentó epistemológicamente la actitud antes reseñada de que el mito es "una verdad histórica"; en efecto, el mito es para Vico un modo de pensar que tiene sus propias características y que condiciona, o por lo menos expresa, ciertas formas de vida humana básicas. Vico identificó el modo de pensar mítico con el modo de pensar "poético" (Scienza Nuova, VI).

Schelling estimó que la mitología es una forma de pensamiento que representa uno de los modos como se revela el Absoluto en el proceso histórico: el mito es, por tanto, revelación divina (Philosophie der Mythologie, ptwsi'm).

En la época contemporánea ha prevalecido el estudio del mito como elemento posible, y en todo caso ilustrativo, de la historia humana y de ciertas formas de comunidad humana. El mito no es objeto de pura investigación empíricodescriptiva, ni es tampoco manifestación histórica de ningún Absoluto: es (especialmente en autores como Cassirer) modo de ser o forma de una conciencia: la "conciencia mítica". Ahora bien, esta conciencia tiene un principio que puede investigarse mediante un tipo de análisis que no es ni empírico ni metafísico, sino —en un sentido muy amplio_ epistemológico. Pero como a la vez la conciencia mítica es una de las formas de la conciencia humana, el examen de los mitos ilumina la estructura de tal conciencia. Lo que se investiga de este modo es la función del mito en la conciencia y en la cultura. Pues, según dicho autor, hay un principio de formación de los mitos que hace de éstos algo más que un conjunto accidental de imaginaciones. La formación de mitos obedece a una cierta especie de necesidad: la necesidad de la conciencia cultural. Los mitos pueden ser, pues, considerados como supuestos culturales. 


\subsubsection{Lugar, Topos}

Topografía, Toponimia, Topiaria, Topofilia

Según el María Moliner, Topos, lugar en griego, genera a través de su raíz Topo- una familia de palabras cultas, como topografía, toponimia o utopía

El topos se refiere al ámbito donde se habita.

Abarca desde su acepción más sencilla y material -que puede ser entendida como la mera descripción física de una porción de terreno concreto y que tiene que ver con el término sitio del latín situs- hasta el concepto de lugar, del latín locus, cuando adquiere significados más profundos.

Aldo Rossi en la Arquitectura de la ciudad, define el valor del locus como «aquella relación singular y sin embargo universal que existe entre cierta situación local y las construcciones que están en aquel lugar» Refiriéndose al mundo clásico, Rossi explica la importancia de la elección del lugar para una construcción o ciudad concretas: «la situación, el sitio, estaba gobernado por el genius locit ${ }^{14}$, por la divinidad local, una divinidad precisamente de tipo intermedio que presidia cuanto se desarrollaba en ese mismo lugar» (Rossi [1971]1982, 185)

Aunque la explicación de Rossi viene referida a la tradición clásica, el «genio del lugar» también está presente en la tradición vernácula

Como se ha avanzado al comienzo del capítulo, no se pretende hacer una disertación exhaustiva sobre el concepto de lugar, inviable desde esta tesis y seguramente falto de interés frente a los estudios ya realizados por diversos autores.

Únicamente reseñar que se ha escogido topos por abarcar otros conceptos mas parciales pero inherentes, que se entienden necesarios y permiten abordar la cuestión de forma más estructurada.

Así, Topos, incluye a su vez cuatro aspectos referidos al lugar:

Topografía en lo referente lo referente a la configuración física del terreno y el territorio, así como la datación, conocimiento e interpretación del lugar

Toponimia en lo referente a los nombre propios de los lugares;

Topofilia enunciada por Yi Fu Tuan como el lazo afectivo entre las personas y el lugar o el ambiente circundante. Difuso como concepto, vivido y concreto en cuanto experiencia personal;

Topiaria referido en un sentido amplio al tratamiento de lo vegetal y la jardinería, e incluyendo el significado literal de técnica de la jardinería que se encarga del cuidado de las plantas podándolas con diversas formas geométricas o de seres animados: esculturas vegetales, íntimamente unidas a la historia del jardín.

14 Ver tambien Norberg-Schulz, Christian.1980. Genius Loci: Towards a Phenomenology of Architecture. New York: Rizzoli 


\subsubsection{Topografía}

Del griego topos-lugar y grafía- descripción, la topografía es en sentido estricto, el arte de representar un terreno en un plano, con su forma, dimensiones y relieve, y topógrafo es la persona que se dedica a la topografía, es decir a hacer mediciones sobre el terreno para trazar planos o mapas, y a dibujarlas.

El trabajo del topógrafo tiene una doble vertiente.

Por un lado, primero hace una toma de datos in situ para su posterior interpretación y representación grafica en el despacho. Por otro, la labor del topógrafo también tiene la secuencia inversa. Es decir, traslada el trabajo realizado en gabinete a la realidad física del terreno in situ, a través del replanteo.

Aunque en su sentido de herramienta estricta, también es consustancial a la arquitectura, nos referiremos a una interpretación más profunda y cargada de significado, que a su vez abarca diversos aspectos de los que queremos señalar especialmente dos: Su carácter de aprensión del lugar como un acto de afirmación y, por extensión de su sentido más instrumental, como la capacidad de datar e interpretar todas las características y esencialidades de un lugar.

Kenneth Frampton se refiere a ellas a través de dos citas que por su precisión, aquí se reproducen. En relación con el primero, como apropiación, Vittorio Gregotti, citado por Frampton en Estudios sobre la cultura tectónica dice:

«A través del concepto de sitio y el principio de asentamiento, el entorno se convierte [por el contrario] en la esencia de la producción arquitectónica. Desde esta posición estratégica pueden argumentarse principios y métodos nuevos. Principios y métodos quedan precedencia al asentamiento en un área específica. Se trata de un acto de conocimiento del contexto que se origina en su modificación arquitectónica. El origen de la arquitectura no es la cabaña primitiva, la cueva o la mítica "casa de Adán y Eva en el Paraíso".

Antes de transformar un soporte en columna, un tejado en un tímpano y antes de colocar una piedra sobre otra, el hombre puso una piedra en el suelo para reconocer un sitio en medio de un universo desconocido: así podía tenerlo en cuenta y modificarlo. Este acto, al igual que cualquier otro acto de afirmación, requería ciertos cambios radicales y una aparente simplicidad. Desde este punto de vista, solo existen dos actitudes fundamentales hacia el contexto. Las herramientas de la primera son la mimesis o imitación orgánica y la exposición de la complejidad. Las herramientas de la segunda son la afirmación de las relaciones físicas o definición formal de la complejidad» (Frampton [1995] 1999, 18)

Respecto a su entendimiento como interpretación global del lugar, cita la idea de Topografia Sentimental del ensayo de Dimitris Pikionis en 1933:

«Nos regocijamos ante el progreso de nuestro cuerpo a lo largo de la superficie desigual de la tierra, y nuestro espíritu se alegra con la interacción infinita de las tres dimensiones que nos encontramos a cada paso.... Aquí el suelo es duro, pétreo, escarpado y la tierra es frágil y seca. Allá el suelo está nivelado y el agua mana de pequeños huecos cubiertos de musgo. Más allá, la brisa, la altitud y configuración del terreno anuncian la vecindad del mar» (Frampton [1995] 1999, 18)

Al igual que el topógrafo, la labor del arquitecto en relación al lugar, es de ida y vuelta. En principio es necesario el conocimiento profundo del lugar, a través del trabajo de campo en su sentido más amplio, para su posterior interpretación en el proyecto realizado en el despacho, y que se materializará volviendo al lugar para re-interpretarlo y transformarlo. 


\subsubsection{Toponimia}

De la raíz topo- y ónoma u onim, es el conjunto de los nombres geográficos de un país o región, así como el estudio del origen y significado de estos nombres.

Por la fuerte condición rural de lo vernáculo, el estudio de la toponimia es especialmente válido para el análisis.

\subsubsection{Topofilia}

La Topofilia, es el lazo afectivo entre las personas y el lugar o el ambiente circundante. Difuso como concepto, vivido y concreto en cuanto experiencia personal.

Yi Fu-Tuan sobre este término dice: «puede definirse vagamente como todo lo que está relacionado con las conexiones emocionales entre el entorno físico y los seres humanos»

La topofilia adquiere diversas formas y varía considerablemente tanto en grado como en intensidad emocional. Describir estos sentimientos es, al menos un comienzo: la fugacidad del placer visual; la delicia sensual del contacto físico; el amor por el lugar que nos es familiar, porque es nuestro hogar o porque representa el pasado, o porque suscita el orgullo de la propiedad o de la creación; el regocijo en las cosas por simples razones de salud y de vitalidad animal. (Tuan [1974] 2007, 13 y 333)

El concepto de Topofilia desarrollado más extensamente por Tuan en 1974, con la publicación del libro del mismo nombre parte del término acuñado en 1957 por Gaston Bachelard en la introducción de La poétique de l'espace, para aludir a las imágenes de lo que denomina espacio feliz en contraposición a los espacios de hostilidad

(...) solo queremos examinar imágenes muy sencillas, las imágenes del espacio feliz. Nuestras encuestas merecerían en esta orientación, el nombre de topofilia. Aspiran a determinar el valor humano de los espacios de posesión, de los espacios defendidos contra fuerzas adversas, de los espacios amados (donde...) a su valor de protección, que puede ser positivo, se adhieren también valores imaginados, y dichos valores son, muy pronto, valores dominantes. El espacio captado por la imaginación no puede seguir siendo el espacio indiferente entregado a la medida y a la reflexión del geómetra. Es vívido, y es vivido no en su positividad, sino con todas las parcialidades de la imaginación (Bachelard [1957] 2004, 28)

Al estudiar las relaciones entre hombre y entorno, trata de manera solapada de percepciones, actitudes, valoraciones y cosmovisiones, que Tuan define como:

\section{Percepción}

Es tanto la respuesta de los sentidos a los estímulos externos como el proceso específico por el cual ciertos fenómenos se registran claramente mientras que otros se pierden en las sombras o se eliminan. Mucho de lo que percibimos tiene valor para nosotros, tanto para nuestra supervivencia biológica como para brindarnos ciertas satisfacciones que están enraizadas con la cultura.

\section{Actitud}

es fundamentalmente una perspectiva cultural, una postura que se toma con respecto al mundo. Es más estable que la percepción y se forma a través de una larga sucesión de percepciones, esto es por la experiencia. Los bebés perciben, pero no tienen actitudes bien formadas, excepto aquellas que les proporciona la biología. Las actitudes suponen experiencia y una cierta solidez de intereses y valores. Los bebés viven en un ambiente, pero apenas si poseen un mundo y carecen de una cosmovisión. 


\section{Visión del mundo o cosmovisión}

es la experiencia conceptualizada. Es en parte personal, pero en su mayor parte es social. Es una actitud y un sistema de creencias, en donde la palabra sistema supone que las actitudes y las creencias están estructuradas, por más que sus conexiones pueden parecer arbitrarias desde un punto de vista impersonal u objetivo.

Las cosmovisiones de las sociedades no alfabetizadas y tradicionales difieren apreciablemente de las del hombre moderno que ha estado bajo la influencia, de forma directa o indirecta, de la ciencia y la tecnología. A menudo se ha afirmado que en la era pre-científica el hombre se adaptaba a la naturaleza, mientras que hoy se dice que la domina. Una distinción más exacta deberá tener en cuenta que los pueblos primitivos y tradicionales vivían en un mundo vertical, rotatorio y altamente simbólico, mientras que el mundo del hombre moderno tiende a una amplia superficie y con un techo bajo, aparte de no ser rotatorio y sí, en cambio, estético y profano. En Europa, este cambio se produjo gradualmente desde 1500 en adelante, y afectó no solo a la ciencia sino al arte, la literatura, la arquitectura y el paisajismo. (Tuan [1974] 2007, 334) 


\subsubsection{Topiaria}

Etimología y origen

La topiaria es una práctica de jardinería que se encarga del cuidado de las plantas podándolas con diversas formas geométricas o de seres animados: esculturas vegetales, íntimamente unidas a la historia del jardín.

Etimológicamente ${ }^{15}$ topia, término latino que deriva del griego tópia, de tópos «lugar», significa «cuadros de paisajes», «jardines artísticos». Topiarius, «jardinero decorador», y topiaria «jardinería», «trabajo o arte de jardinero decorador»

Los jardines egipcios son los más antiguos históricamente datados, y debido al alto grado de desarrollo y a la larga duración de su cultura, tuvieron gran influencia en Grecia y Roma.

Posiblemente los egipcios ya recortaban setos en sus jardines, pero la información que tenemos sobre ellos proviene únicamente de pinturas y bajorrelieves en tumbas y monumentos funerarios, con un carácter más simbólico que representativo, que no permite una certeza absoluta sobre su existencia.

Será en los jardines de la antigua Roma, donde se desarrolle la topiaria, hasta convertirse las plantaciones podadas en uno de sus elementos más característicos. Esta técnica específica para conseguir las formas deseadas en los elementos vegetales de forma permanente, se denominaba ars topiaria, y el operario que la practicaba topiarius. Aunque este término solo se refiere al jardinero del jardín de recreo en contraposición al hortus, su consideración era tan importante que acabó por extensión significando jardinero.

Una carta de Cicerón a su hermano Quinto, fechada en el año 54 a.C., nos brinda la cita más antigua conocida sobre el ars topiaria:

«He presentado mis cumplidos al topiarius: ha revestido de hiedra, tanto la terraza sobre la que se levanta la villa, como los espacios entre columnas del paseo, tan bien que, finalmente, las estatuas griegas tienen el aire de practicar el ars topiaria y de vender hiedra» (Segura Munguía 2005, 98).

Plinio el Viejo en el Libro XII de su Historia Natural, cuando escribe sobre «Quién fue el primero que instituyó la poda en los arbolados» dice: «El primero que ideó los bosques artificiales fue Gayo Macio, del orden ecuestre, amigo del Divino Augusto, hace ya ochenta años» ${ }^{16}$ (V.AA 2010, 20)

El opus topiarium, fué la técnica romana específica para para dar forma decorativa mediante cortes, a algunas plantas y arbustos, de hoja normalmente menuda y perenne, como la encina, el ciprés, el laurel, el boj, y el mirto. Así lo recogen Santiago Segura Munguía, ya citado, «se llegaban a componer cacerías o flotas enteras. Los árboles recortados y modelados de forma caprichosa se llamaban nemora tonsilia y no existían aún en tiempos de Cicerón» y Francesco Fariello en sus respectivos textos. Este último, en La arquitectura de los jardines: de la antigüedad al siglo XX, hace hincapié en el carácter artificial y permanente de la técnica topiaria.

\footnotetext{
${ }^{15}$ Del Diccionario Crítico Etimológico de la Lengua Castellana de Joan Corominas

${ }^{16}$ Coincide con la nota 55 de los traductores en la que exponen que aceptando el 77 como año de publicación de la Historia Natural de Plinio el viejo, la invención de estos «bosques artificiales», nemora tonsilia, parece remontarse hasta el año 4 a.C. Existió un Gayo Macio, con el sobrenombre de Calvena, conocido por Cesar y Cicerón (este lo menciona con frecuencia en su correspondencia. Pero el dato cronológico de Plinio, «hace ya ochenta años», si es que no es erróneo, lo haría excesivamente longevo: la opinión común es que alude a un hijo de dicho Macio o a un homónimo. Sin embargo pudo escribir esta parte del Libro XII mucho antes del año 77, y el dato de los «Ochenta años» no debió de ser corregido en el momento de su publicación; tal es la opinión de Grimal, que concluye que la fecha debe de rondar el año 20 a.C.
} 
Algunos de estos trabajos llamados nemora tonsilia o viridia tonsa, no se limitaban a formas geométricas sencillas como esferas y pirámides, sino que se convertían en verdaderos bosques artificiales recortados. Auténticos conjuntos escultóricos vegetales de gran entidad y complejidad que representaban divinidades, figuras humanas y paisajes fantásticos; incluso episodios de guerra y escenas mitológicas.

«Recuperada en la Edad Media, tendrá después una tradición ininterrumpida con exuberantes manifestaciones en el jardín italiano del siglo XV y el jardín holandés del siglo XVII, y acompañará siempre, con aplicaciones puramente geométricas, a cualquier forma de jardín de concepción arquitectónica» (Fariello [1967] 2004, 42).

Esta técnica, que también se da en culturas orientales, fue extendida por el imperio romano y se mantendrá, aunque con altibajos, fuertemente arraigada en la tradición jardinera europea, con variantes según la época y las características de lugares tan diferentes como el mediterráneo o el norte de Europa.

El jardín francés de André Le Nôtre en el Barroco, los jardines hispanomusulmanes en España, o los renacentistas en Italia son importantes ejemplos de su arraigo. Aunque este es especialmente más evidente en países romanizados, no es condición estrictamente necesaria como lo demuestra el jardín holandés del XVII, anteriormente citado, que tuvo gran influencia en la topiaria inglesa, más ampliamente tratada en el siguiente epígrafe.
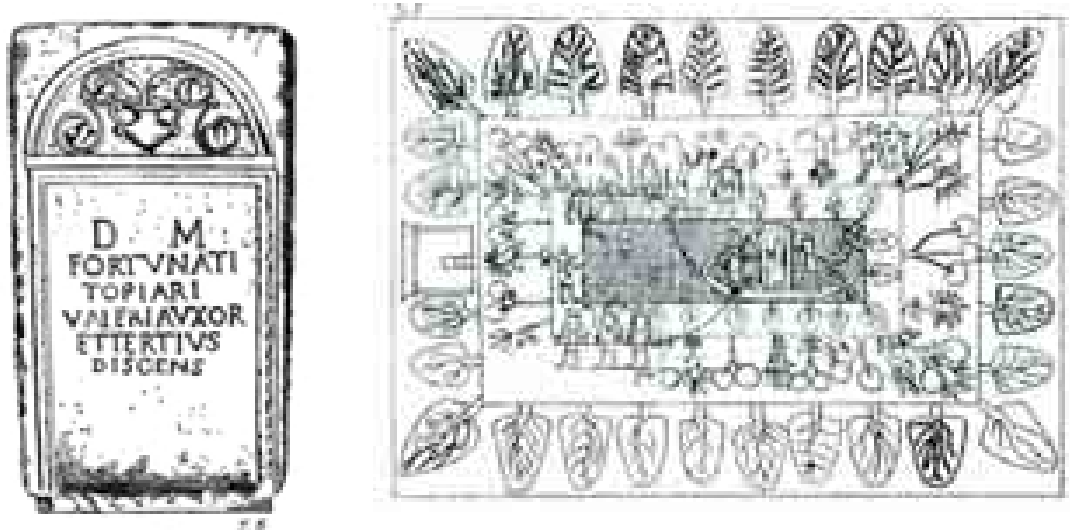

Figura 1.3

* Izquierda

Estela sepulcral dedicada a los dioses «Manes» del «Topiarius» Fortunatus por su esposa Valeria y su aprendiz Tertius. (Segura Munguía 2005, 98).

* Derecha

El jardín egipcio. Bajorrelieve de una tumba (Fariello [1967] 2004) 


\subsubsection{Tipo, Typos.}

El María Moliner define «tipo» como el ejemplar una especie, teórico o existente en la realidad, que reúne en el más alto grado y con la mayor pureza las cualidades peculiares de ella. También como el modelo que sirve para valorar o graduar las cosas de la misma especie que él, o la clase, modalidad, grado o categoría de ciertas cosas. Como reseña Carlos Martí, en el lenguaje no especializado, «tipo es sinónimo de clase, familia, o género...; es decir, es una categoría que resulta de aplicar a un conjunto de objetos, un procedimiento clasificatorio»

Con respecto al concepto de tipo arquitectónico empleado en la tesis, es el definido y desarrollado por Carlos Martí Arís:

«Nuestra definición de tipo, expresada en los más escuetos términos, dice así: UN TIPO ARQUITECTÓNICO ES UN CONCEPTO QUE DESCRIBE UNA ESTRUCTURA FORMAL.

Esta definición implica tres corolarios de capital importancia, a saber:

- el tipo es de naturaleza conceptual, no objetual: engloba a una familia de objetos que poseen todos la misma condición esencial pero no se corresponde con ninguno de ellos en particular;

- el tipo comporta una descripción por medio de la cual es posible reconocer a los objetos que lo constituyen: es un enunciado lógico que se identifica con la forma general de dichos objetos;

- el tipo se refiere a la estructura formal: no le incumben, por tanto, los aspectos fisionómicos de la arquitectura; hablamos de tipos desde el momento en que reconocemos la existencia de "similitudes estructurales" entre ciertos objetos arquitectónicos, al margen de sus diferencias en el nivel más aparente o epitelial» (Martí Arís 1993, 16)

La arquitectura vernácula queda caracterizada por la pervivencia del tipo.

Como desarrolla Rapoport en Vivienda y sociedad, en las culturas primitivas todas las viviendas son iguales, mientras que en las vernáculas preindustriales, aunque contienen más diferenciación individual que las primeras, en ellas existe todavía la forma aceptada. Se basa en unos modelos con ajustes y variantes, y contiene más diferenciación individual que la primitiva. Dichas variaciones de producen en lo individual, no en el tipo, quedando por determinar lo específico: las exigencias de la familia, el tamaño normalmente unido a la riqueza, y la relación con el lugar y el microclima. La forma se ajusta a unos problemas concretos dados y a los medios disponibles sin esfuerzos estéticos conscientes o intereses estilísticos.

En el trabajo se abordan los diferentes tipos vernáculos inspiradores de los casos de estudio a diferentes escalas, desde la vivienda al pequeño asentamiento. Así, en la Casa de Espolla de Coderch, es conocido como la casa parte del tipo de la masía catalana. En el Upper Lawn Pavilion se propone el análisis, de forma novedosa, a partir de los diferentes tipos de construcciones para jardín en Inglaterra, y a escala mayor de la agrupación tipo cluster, muy característica de micro aldeas rurales formada por agrupación de dos o tres granjas. Por último en la Ampliación de la Casa Visser de Aldo van Eyck, se desarrolla, también de forma inédita, un análisis a partir de las kivas de los Indios Pueblos como tipo en el que se basa la ampliación de la casa de Rietveld.

Finalmente la investigación, está salpicada de imágenes arquetípicas, como las de San Jerónimo en su estudio, San Jerónimo en la gruta, o distintas representaciones de la construcción del Arca de Noé con estructuras de entramado de madera, a partir de la descripción hecha en la biblia en la que se narra como con varias plantas 


\subsubsection{Materialidad, Tekton}

\subsubsection{Construcción moderna y construcción tradicional.}

La buena arquitectura no se ha hecho nunca por fórmula ni siguiendo al pie de la letra una doctrina: sería demasiado sencillo...

Podemos, para obtener esto, aprovechar todos los medios que tenemos a mano, desde los más tradicionales a los más modernos; desde la piedra al ladrillo y hormigón armado, el acero y el cristal, siempre que estén controlados por un espíritu de orden, claridad y respeto a las construcciones milenarias, osatura espiritual de todas las grandes creaciones arquitectónicas...(Sert 1934)

El mundo moderno colocó al arquitecto en una posición completamente nueva frente a la construcción arquitectónica. La enorme variedad de materiales y sistemas de la construcción moderna y contemporánea, requieren, como nunca antes había ocurrido, un arquitecto con la formación y el criterio necesarios para poder adoptar intencionadas decisiones técnicas y constructivas.

La construcción con estructuras de fabrica (muros, arcos, bóvedas..) se había mantenido de forma generalizada hasta finales del siglo XIX. En ese momento, con la aparición de nuevos materiales, acero y hormigón moderno, comienza el desarrollo de nuevos sistemas constructivos que irán desplazando el empleo de los sistemas tradicionales ya mencionados.

Otto Wagner, Berlage, y los grandes maestros en el cambio de siglo, los pioneros de la arquitectura moderna, inician el camino de una nueva arquitectura, desde el análisis, entendimiento, e interpretación de los materiales y sistemas constructivos tradicionales, con un criterio de sinceridad constructiva y estructural.

Es un proceso de búsqueda que mantendrán a lo largo de su vida, que comienza en su juventud y y posteriormente mantendrán a lo largo de su vida junto con el desarrollo de nuevos materiales y sistemas constructivos. 

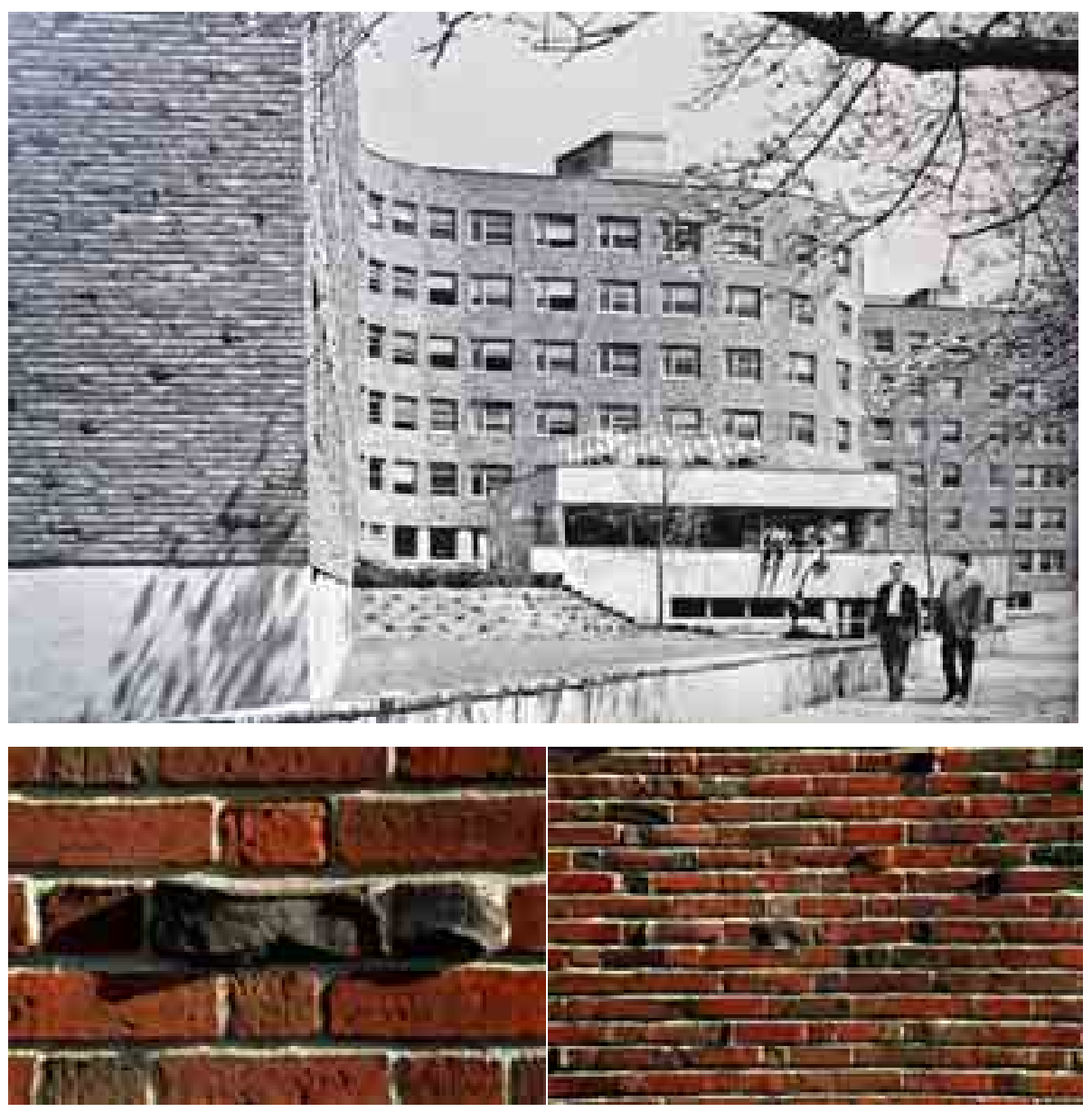

Figura 1.4

* Superior: Baker House (1946-1949) en el Massachussets Institute of Technology MIT, Alvar Aalto

* Inferior de izquierda a derecha:

Detalle del ladrillo en la Baker House. Imágenes publicadas en Brick, Phaidon Ed., James Campbell (Campbell 2003) 


\subsubsection{Pensar con el ojo, pensar con la mano}

La expresión pensar con el ojo, pensar con la mano, hace referencia a la dicotomía establecida, supuestamente irreconciliable, entre el pensamiento intelectual y la practica material, entre pensar y hacer; en definitiva entre teoría y práctica. Los términos «thought of the eye» and «thought of the hand» fueron enunciados por el filósofo e historiador alemán Oswald Spengler (1880-1936) en su ensayo de 1931 Der Mensch und die Technik. Beitrag zu einer Philosophie des Lebens, en ingles Man and Technics. A Contribution to a Philosophy of Life, pero su significado tiene hondas raíces en la historia de la civilización occidental, acentuándose extraordinariamente a partir de la revolución industrial, y alcanzando su mayor diferenciación desde el siglo XX hasta nuestros días.

Hacer es pensar. Esta contundente afirmación realizada por Richard Sennett en entrevista concedida al diario El Pais el 22 de diciembre de 2009, con motivo de la presentación en Barcelona de la versión en castellano de su libro The Craftsman, sintetiza en tres palabras su teoría sobre la artesanía, a la que designa como «un impulso humano, duradero y básico: el deseo de realizar una tarea sin más» y es válida para cualificar incluso los trabajos considerados habitualmente como no cualificados.

Discípulo de Hannah Arendt, discrepa con ella en la distinción que realiza entre animal laborans y homo faber. Según Sennett, Arendt establece que para el primero solo existe la pregunta ¿cómo? y para el segundo la pregunta es ¿por qué?. Para el animal laborans el trabajo es un fin en sí mismo, mientras que el homo faber es el juez de dicho trabajo y está en un plano superior. De esta forma, el animal laborans queda reducido a una bestia de carga, un siervo condenado a la rutina. Para Sennett, esta división es falsa, porque infravalora el valor de la práctica. En su opinión

«el Animal laborans tiene capacidad de pensar; el productor mantiene discusiones mentales con los materiales mucho más que otras personas», «para Arendt, la mente entra en funcionamiento una vez terminado el trabajo. Más equilibrada es la versión según la cual en el proceso de producción están integrados el pensar y el sentir» (Sennett 2008)

El libro explora la íntima relación entre la mano y la cabeza, que la civilización occidental históricamente ha minusvalorado, así como la habilidad, compromiso y juicio del trabajador artesano.

«Todo buen artesano mantiene un dialogo entre unas prácticas concretas y el pensamiento; este dialogo evoluciona hasta convertirse en hábitos, los que establecen a su vez el ritmo entre la solución y el descubrimiento de problemas»

\subsubsection{Conciencia material: Metamorfosis, presencia y antropomorfismo.}

Los artesanos tienen «conciencia material»; es decir toman conciencia a partir de los materiales de tres maneras: alterándolos «metamorfosis», marcándolos «presencia» o identificándolos con nosotros «antropomorfosis» que atribuye metafóricamente cualidades humanas a cosas inanimadas, como hablar de la honestidad de los materiales.

Sennett analiza como muestra de antropomorfosis, el tipo de ladrillo utilizado por Alvar Aalto en la Baker House (1946-1949) en el Massachusetts Institute of Technology. Su fabricación intencionadamente artesanal, sin desechar las piezas defectuosas, permite a Aalto mostrar la honestidad del material. Mediante el contraste que se establece entre los ladrillos imperfectos, excesivamente quemados, distorsionados, ennegrecidos y combados, hace que los ladrillos regulares parezcan nuevos al espectador. 

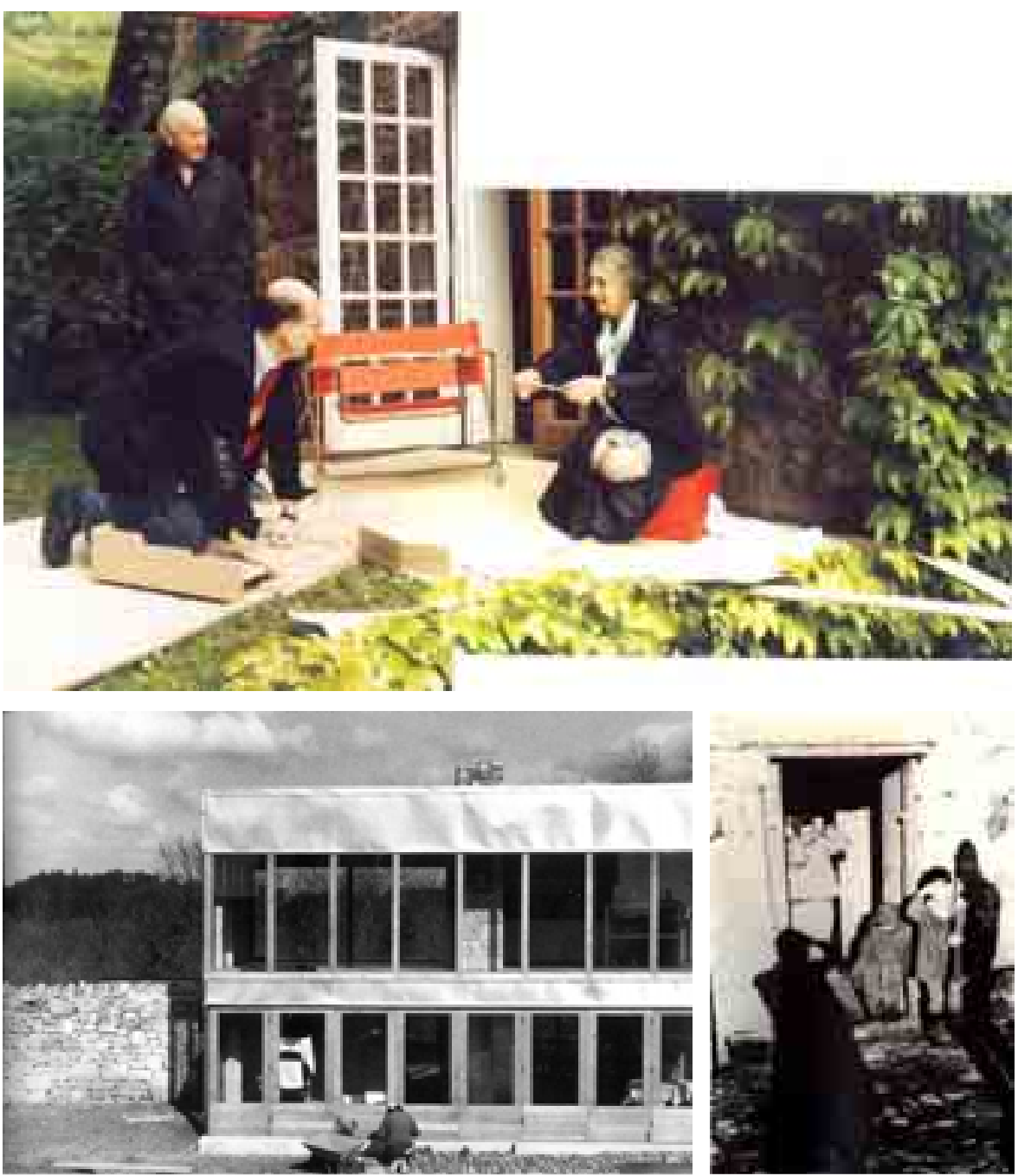

Figura 1.5

* Superior:

Alison and Axel Bruchhäuser midiendo la cimentación del Porche de Axel en la Hexens House (Van den Heuvel and Risselada 2004).

* Inferior de izquierda a derecha:

Alison pavimentando con adoquín de piedra en el encuentro entre el nuevo pabellón y el empedrado preexistente de la antigua granja, 1962. Fotografía de Peter Smithson.

Alison y los niños preparados para trabajar limpiando y retirando sobre el antiguo pavimento 
«El contraste acentúa el carácter de unos y otros. De esta manera estamos preparados para pensar qué es el ladillo, es decir hacer una reflexión sobre el material, que no se nos habría ocurrido si todos los ladrillos fueran de imperturbable y uniforme perfección»

«Cuando lo natural y lo artificial se plantean como opuestos, es posible asociar la virtud humana a lo primero y la libertad a lo segundo. Las habilidades artesanales son necesarias para establecer estas asociaciones y para realizar así el valor consciente de los objetos» (Sennett 2008)

El arquitecto finlandés Juhani Pallasmaa, seguidor de Richard Sennett, es autor de varios libros en los que reivindica la puesta en valor del conocimiento sensorial, frente a la hegemonía de la educación intelectual y visual que recibimos, como se comprueba repasando la arquitectura occidental.

En The thinking hand. Existencial and Embodied Wisdom in Architecture, Pallasmaa analiza el distanciamiento que se ha producido desde el Renacimiento entre el concepto de oficio y la profesión de arquitecto. Este predominio de lo intelectual, junto con la creciente especialización y división del trabajo han significado un alejamiento cada vez mayor entre el proceso de proyecto y el resultado final, debilitando enormemente la esencia artesanal del trabajo de arquitecto.

«Generar expresión arquitectónica a partir de realidades incuestionables de la construcción tiene una larga tradición en el arte de la arquitectura. El lenguaje tectónico de la arquitectura, la lógica interna de la propia construcción, expresa la gravedad y la estructura, el lenguaje de los materiales, así como los procesos de construcción y los detalles de unión de os materiales entre sí»

«Las obras de arquitectura de la era moderna, al igual que la de nuestro tiempo, que se hacen eco de los temblores de los orígenes -como por ejemplo, las obras de Sigurd Lewerentz, Louis I. Kahn, Aldo van Eyck y Peter Zumthorproyectan un resplandor de autoridad y una profundidad de sentimientos. Tales obras no están siempre necesariamente y estéticamente pulidas en tanto que plantean un poder emotivo profundo y perturbador y sugieren preguntas en lugar de proporcionar respuestas bien formuladas» (Pallasmaa 2009)

Jorge Luis Borges, Antón Chejov, Igor Stravinsky, Tapio Wirkkala, Alvar Aalto, Constantin Brancusi, son citados entre otros por Pallasmaa como artistas de disciplinas muy diferentes que se consideran a sí mismos artesanos.

Este es el prisma bajo el que se propone analizar el trabajo de los Smithson: como artesanos de la arquitectura, en gran medida herederos de la tradición británica del movimiento Arts and Crafts. Un repaso a su obra revela el valor que dan a lo hecho manualmente y su puesta en práctica cotidiana: recortables, felicitaciones navideñas, improvisados juguetes con materiales reciclados, Alison colocando adoquín de piedra, Alison y Peter replanteando con Axel Bruchhäuser el porche de la Hexen House...

Recordar el significado que los Smithson dan al desvirtuado término New Brutalism, permite aclarar, entre otros, su posición respecto al tratamiento de los materiales. En abril de 1951, publican en Architectural Design una pequeña reseña bajo el titulo "Alison and Peter Smithson: Answer on the New Brutalism", incidiendo en que no es un estilo, sino una actitud ética.

«Any discussion of Brutalism will miss the point if it does not take into account Brutalism's attempt to be objective about "reality" the cultural objectives of society, its urges, its techniques, and so on. Brutalism tries to face up to a mass-production society, and drag a rough poetry out of the confused and powerful forces which are at work. Up to now Brutalism has been discussed stylistically, whereas its essence is ethical» (Smithson and Smithson 1957) 
Quaderns:

«Nosotros somos gente educada dentro de los principios del movimiento moderno, y queríamos preguntarte, a ti que has conocido todos los maestros importantes del movimiento, si eran gente que conocía muy bien la arquitectura clásica.»

Sert:

«Eran gente que habían nacido en una época que se conocía muy bien la arquitectura clásica. Ellos no lo escondían. Y el Mies también. Estaban muy influenciados también de cosas populares y no lo ocultaban de ninguna manera. A nosotros nos pasó algo parecido. Yo encuentro, sin querer herir a nadie, que han eliminado los estudios históricos, y ha venido una generación de gente -y no es precisamente la vuestra- que está reaccionando contra esto, que son completamente analfabetos en arquitectura. Hacen cosas de gente ignorante, sacadas de catálogos de construcciones sin tener sensibilidad ni idea de lo que se está haciendo. Esto que se está haciendo de volver a estudiar historia espero que ayude. Lo encuentro muy bien. Lo que no encuentro tan bien es tratar de aplicar cosas que no sean aplicables. Se tienen que resignar.»

De la entrevista realizada a Josep Lluis Sert por la revista Quaderns d'arquitectura i urbanisme. en 1982, «L 'Avantguarda lúcida. Una conversa amb Josep-Lluís Sert»

(Sert 1892, 77) 


\subsection{Huellas y apuntes de lo vernaculo}

Huellas, interpretaciones, miradas, fuente de conocimiento, reflexiones,

En contexto sin mimetismo

Significativos y relevantes.

1920-1990

La obra construida de un significativo y relevante número de arquitectos modernos de varias generaciones, muestra como la tradición en general y lo vernáculo en particular, forman también parte de la arquitectura moderna, prácticamente desde su origen, incluso dentro del contexto arquitectónico del periodo inicial mas radical de formulación teórica del nuevo lenguaje arquitectónico.

Son indiscutiblemente modernos, por su rechazo a los estilos historicistas y por la búsqueda de un nuevo lenguaje en la arquitectura, acorde a los tiempos modernos.

Rechazo de los estilos historicistas y reconocimiento por la cultura constructiva y espacial de las tradiciones clásica y vernácula, las cuales se convierten en fuente de aprendizaje y conocimiento en su búsqueda por una arquitectura honesta, esencial y verdadera.

\subsection{1.}

Casa Sommerfeld, Berlin, 1920-1922.

WALTER GROPIUS y ADOLF MEYER.

1.3.2.

Casa de Tristan Tzara, Avenue Junot 15, Paris, 1926-27

ADOLF LOOS (1870-1933)

1.3.3.

Casas para fin de semana en Garraf, Barcelona, 1935

Vivienda Tipo C

JOSEP LLUIS SERT (1902-1983) Y JOSEP TORRES CLAVÉ (1906-1939)

1.3.4.

Casa de verano en Stennäs,1937

GUNNAR ASPLUND (1885-1940)

1.3.5.

Hogar para niños en Mümliswil, Suiza, 1938-1939

HANNES MEYER (1889-1954)

1.3.6.

Casa de verano, 1940-1941

GERRIT RIETLVELD (1888-1964)

1.3.7.

Casa Villiger, Bremgarten, Suiza, 1942

MAX BILL (1908-1994)

1.3.8.

Casas Jaoul en Neyilly-sur-Seine, 1952

LE CORBUSIER (1887-1965)

1.3.9.

Intervenciones en entorno arqueológico de la Acrópolis y colina de Philopappou en Atenas, 1951-57

DIMITRI PIKIONIS (1887-1968)

1.3 .10

Casa de vacaciones Quinta da Cavada, San Salvador de Briteiros, Guimaraes, 1989-1990.

FERNANDO TÁVORA. Potugal 
«Formamos pues una nueva corporación de artesanos, pero sin aquella arrogancia de clase que pretende levantar una pared de soberbia entre artesanos y artistas. Todos juntos ponemos nuestra voluntad, nuestra inventiva, nuestra creatividad al servicio de la nueva actividad constructiva del futuro, actividad que será "todo" en una sola forma: arquitectura, escultura y pintura, y , realizada por millonesde manos artesanas, se alzará al cielo como un símbolo cristalino de una nueva fe que está naciendo»

Del primer programa de la Bauhaus de Weimar

«Siempre he combatido est expresión, porque pienso que el punto de partida es consecuencia, mas bien, del respeto a las condiciones regionales y no a la fidelidad de determinados preceptos internacionales»

Sobre el termino International Style, y en relación con su casa de Lincoln, Massachusetts, 1937,

hecha en colaboración con Marcel Breuer. 
Casa Sommerfeld, 1921 en Dahlem, Berlín

WALTER GROPIUS y ADOLF MEYER

Fotografía de fachada principal Walter Gropius (GG), p.39-40

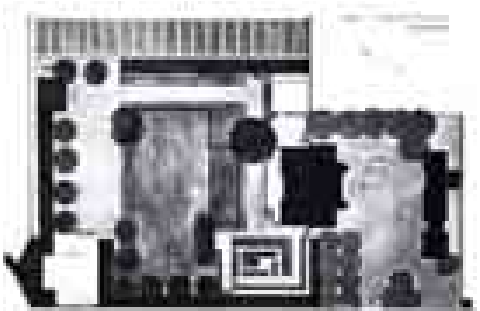

Planta de situación Walter Gropius (GG), p.39-40

Fotografía fachada posterior Walter Gropius (GG), p.39

Los relieves representan los distintos sectores de la empresa de carpintería de Sommerfled, simbolizándolos mediante mecanismos $y$ encajes típicos de los trabajos de carpinteria

Esbozo del vestíbulo Balaustrada de Schmidt Walter Gropius (GG), p.41

Vidrieras en el vestíbulo
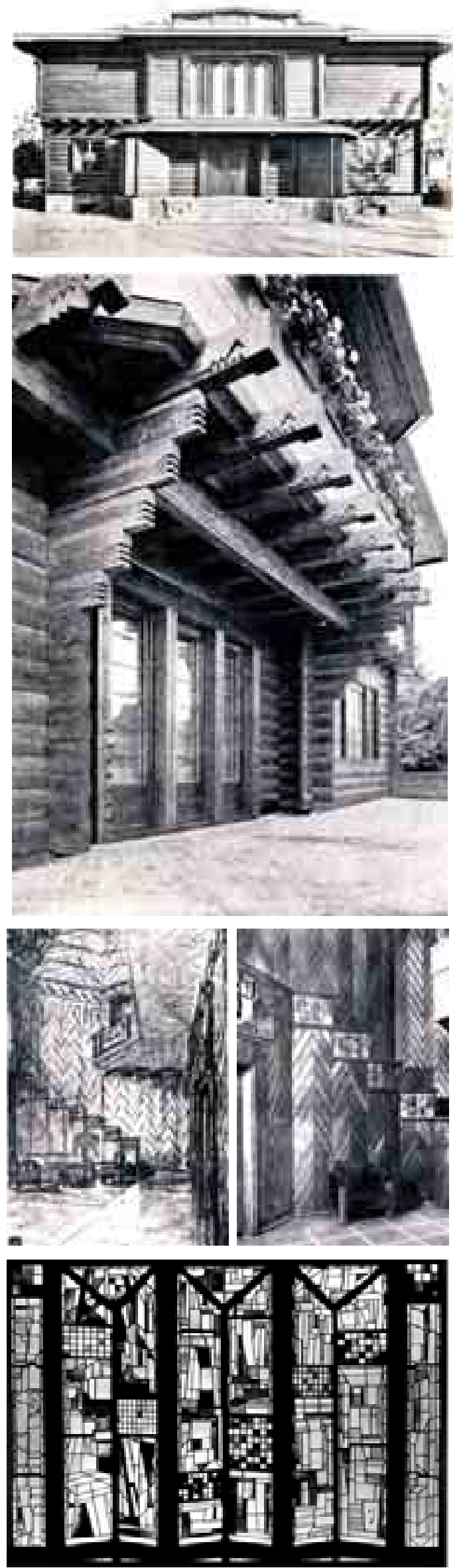
«No construyas pintoresco. Deja tal efecto para los muros, las montañas y el sol. El hombre que se viste de manera pintoresca no es pintoresco, sino un payaso. El campesino no viste de manera pintoresca, sino que lo es (...)

(...) Habla con los campesinos en tu lengua. El abogado vienés que habla con el campesino en el dialecto del picapedrero tiene que desaparecer.

Fíjate en las formas en las que construye el campesino. Pues son de la sustancia acumulada de la sabiduría de los antepasados. Pero busca el porqué de la forma. Si los adelantos de la técnica han hecho posible mejorar esa forma, empléese siempre esa mejora. La hoz sustituida por la trilladora (...)

iSé veraz! La naturaleza solo se vincula con la verdad. Vive en buena armonía con puentes de hierro entramados, pero a los arcos góticos con saeteras los rechaza.

No temas ser tachado de inmoderno. Sólo se permiten cambios en la antigua manera de construir si representan una mejora, si no, quédate con lo antiguo. Pues la verdad, aunque tenga cintos de años, tiene más relación íntima con nosotros que la mentira que avanza a nuestro lado.»

Adolf Loos 1913

Del escrito «Reglas para quien construya en las montañas» «Reglen für den, der in den Bergen baut Jahrbuch der Schwarzwald'schen Schulanstalien» 
Casa de Tristan Tzara Avenue Junot 15, Paris

1926-27

\section{ADOLF LOOS}
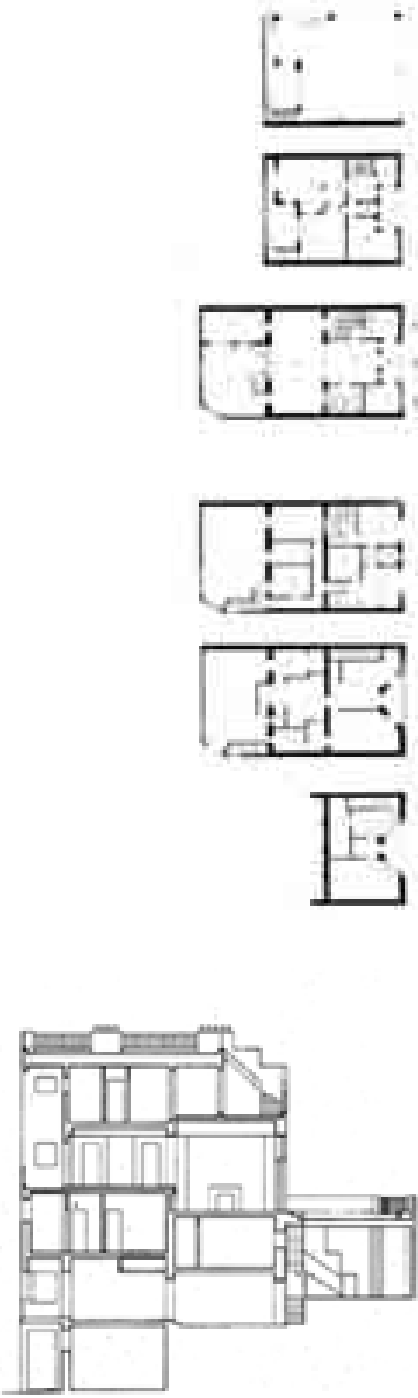

* Superior derecha Alzado a Avenida Junot Fachada al jardín e interior de la escalera.

* Superior izquierda Plantas y sección

Adolf Loos Teoria y obras (Nerea) p.188, 189, 190

Fachada a la Avenue Junot.

Adolf Loos. (GG) p.149
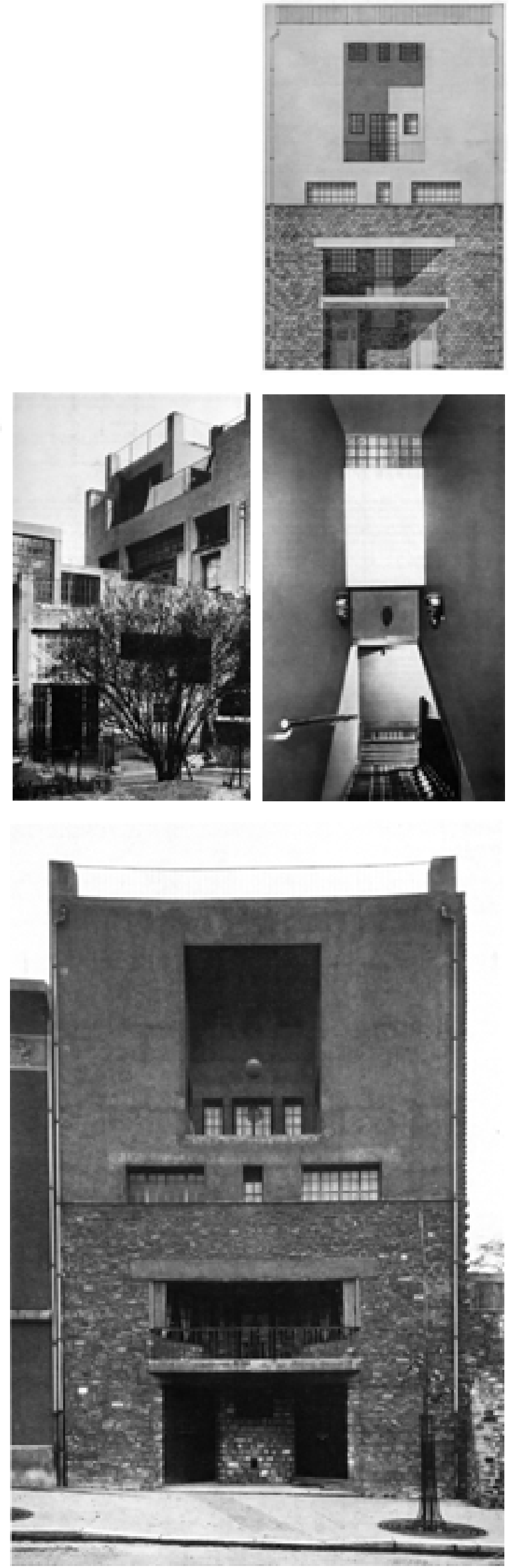
«La buena arquitectura no se ha hecho nunca por fórmula ni siguiendo al pie de la letra una doctrina: sería demasiado sencillo...

...Podemos, para obtener esto, aprovechar todos los medios que tenemos a mano, desde los más tradicionales a los más modernos; desde la piedra al ladrillo y hormigón armado, el acero y el cristal, siempre que estén controlados por un espiritu de orden, claridad y respeto a las construcciones milenarias, osatura espiritual de todas las grandes creaciones arquitectónicas...»

Josep Lluis Sert 1934 
Casas para fin de semana en Garraf, Barcelona

1935

Vivienda Tipo C

JOSEP LLUIS SERT y JOSEP TORRES CLAVÉ

Vivienda tipo C construida con bóveda tabicada

García-Quiñones. 2005

AC. Publicación del G.A.T.E.P.A.C.

Edición facsímil de los

25 números de la revista publicados entre 1931 y 1937
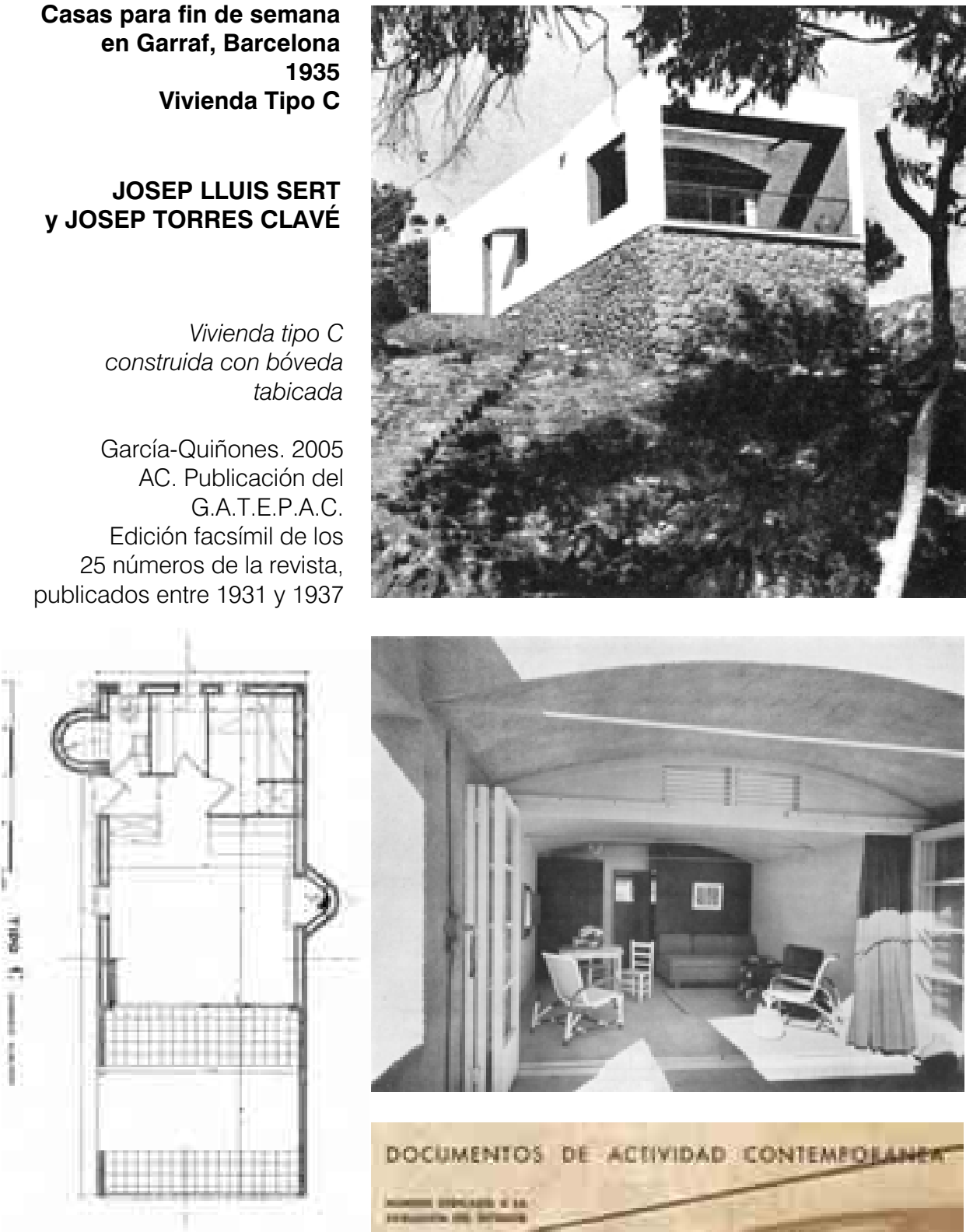

La casa tipo C de Garraf, imagen de portada del numero 19 de la revista A.C., en 1935.

Claroreferente de plantear arquitectura moderna y construirla con materiales tradicionales. En este caso, con bóveda tabicada.

García-Quiñones. 2005 AC. Publicación del G.A.T.E.P.A.C. Edición facsímil de los 25 números de la revista, publicados entre 1931 y 1937 p. 953

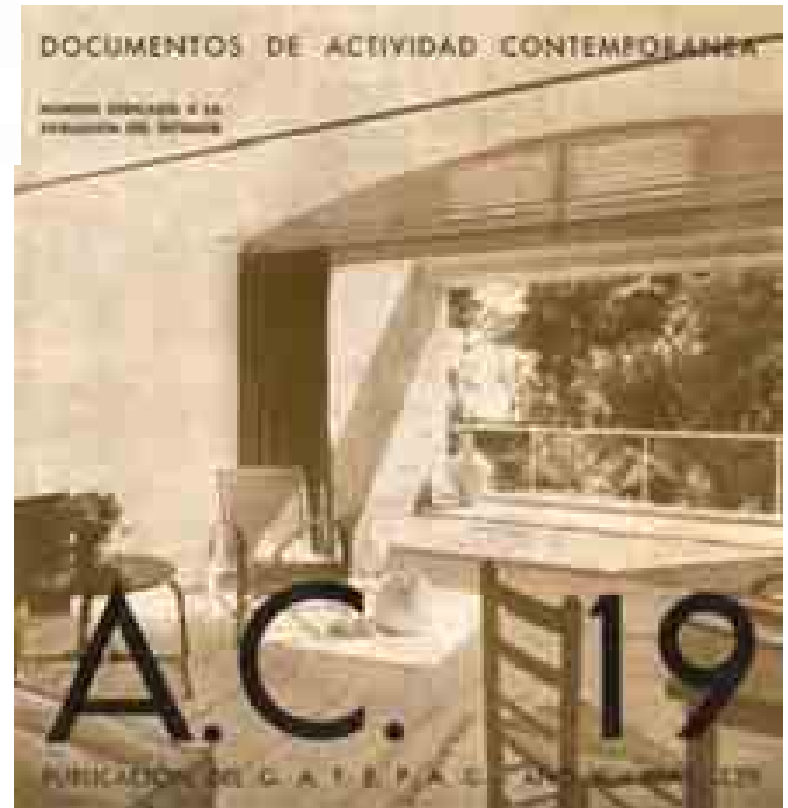


«Finlandia estaba con Aalto dondequiera que fuese; le proporcionaba esa energía interior que siempre fluye por su obra; era lo mismo que España para Pablo Picasso o Irlanda para James Joyce. Parte de la esencia del arte actual es que sus verdaderos representantes surgieron de un entorno humano definido y su obra no está creada en el vacío. Pero también es parte de esa esencia el hecho de que se han derribado las barreras entre el futuro y el pasado, y con un audaz movimiento se ha abarcado nuestro periodo, el mundo en su conjunto y toda la historia. Georges Braque lo expresó a la manera de Henri Bergson en su cuaderno de dibujo: "El futuro es la proyección del pasado, condicionada por el presente".

Tal vez épocas posteriores observarán que una de nuestras buenas cualidades era esforzarnos por combinar lo técnico con lo primigenio. El mismo fenómeno aparecía en todas las artes: desde los estratos olvidados de la conciencia, los elementos del hombre primitivo que todavía permanecían latentes entre nosotros volvían a salir a la luz, y al mismo tiempo se buscaba la unidad con el tiempo presente»

(Giedion [1941] 2009, 599) 
Casa de verano familiar en Stennäs, 1937

Sorunda, Isla de Lisön, archipiélago de Estocolmo

ERIK GUNNAR ASPLUND
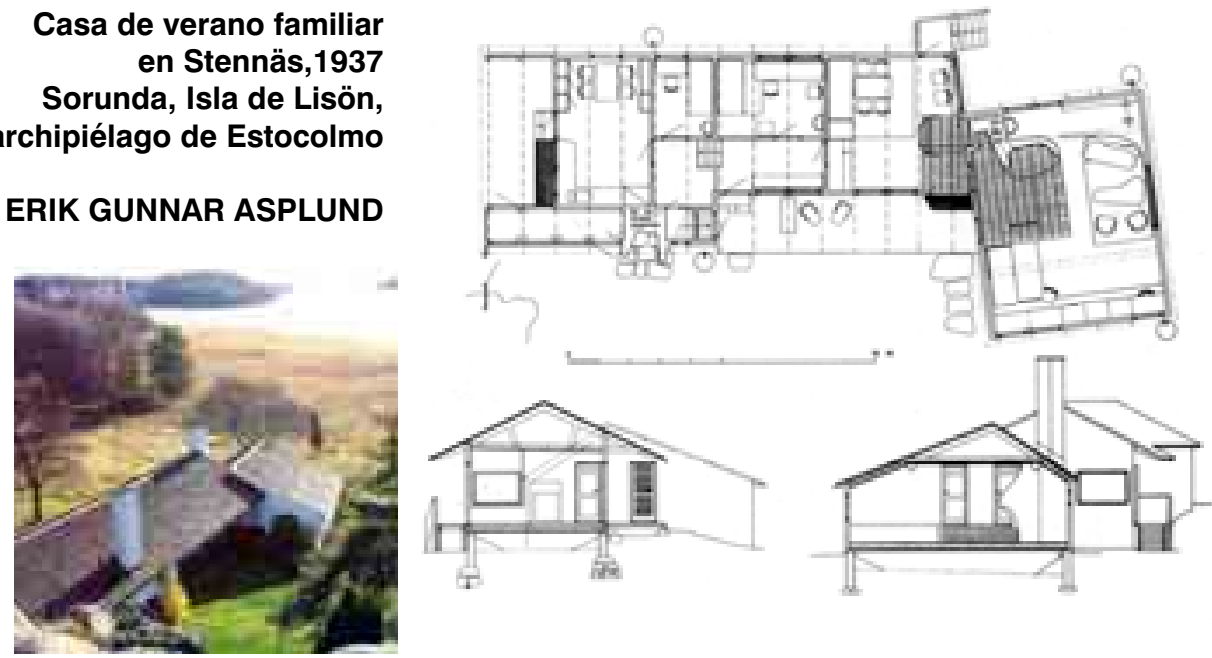

La casa domina la ensenada de Hästnäsviken, y se situa delante de un macizo granítico

Gunnar Asplund architect p. 178

Estar-comedor

Gunnar Asplund architect p.179

Estar-comedor

Gunnar Asplund architect
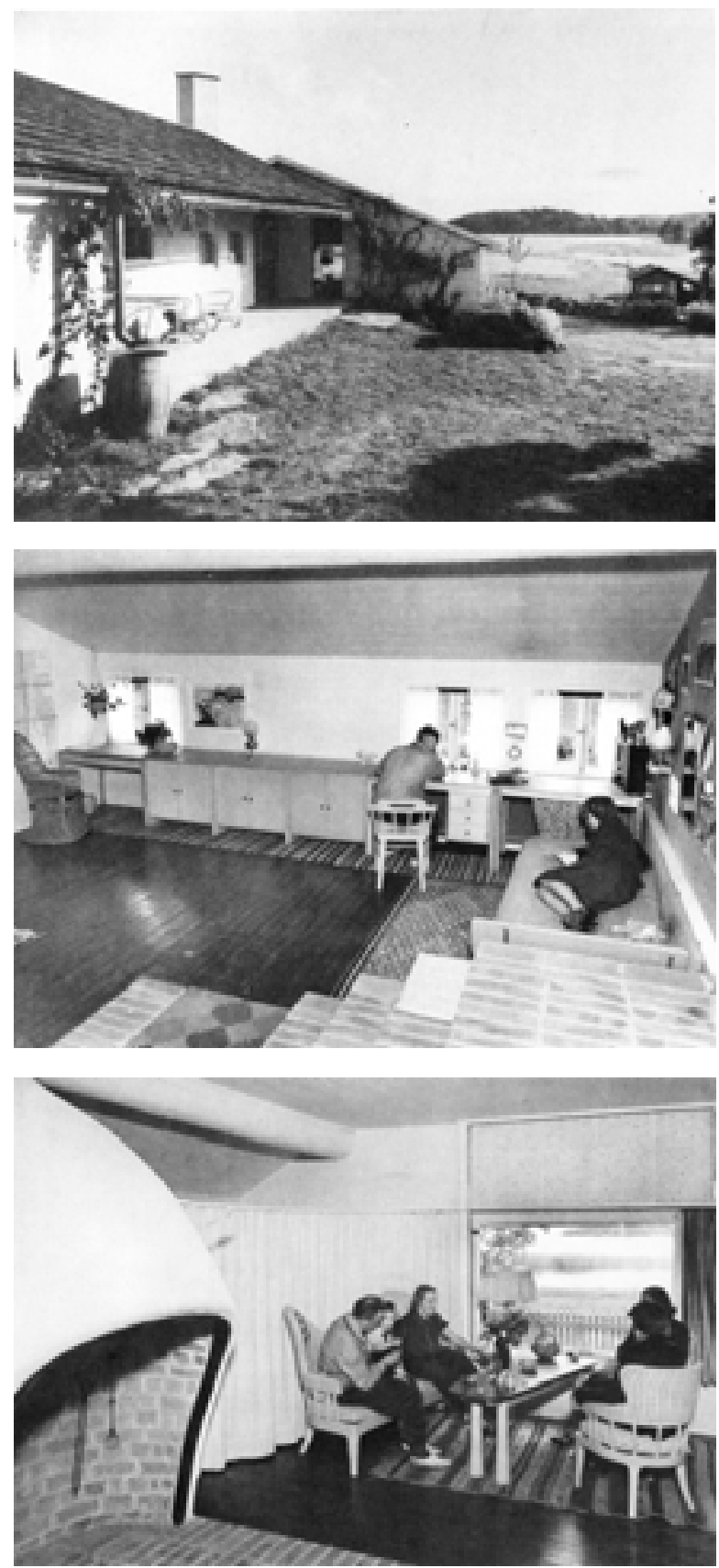

p.180 
« ¿Dónde podemos encontrar mayor claridad que en las viejas construcciones de madera? ¿Dónde, si no allí, descubrir tal grado de unidad entre el material, la construcción y la forma? iQué sensibilidad para el material y qué fuerza expresiva muestran esas construcciones! iQué ardor y belleza contienen! iSe diría ecos de inmemoriales canciones! »

Mies van der Rohe, citado por James Johnson Sweeney en el acto en Memoria de Mies van der Rohe con motivo de su fallecimiento, celebrado el 25 de octubre de 1969 en el Crown Hall de Chicago.

(Spaeth [1985] 1986, 197) 
Hogar para niños en Mümliswil, Suiza. 1938-1939

HANNES MEYER

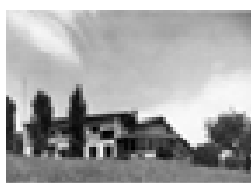

Vista noroeste y sur Hannes Meyer

Buildings, projects and writings p.78

Zona de juegos cubierta Hannes Mever 1889-1954, pp.305,312

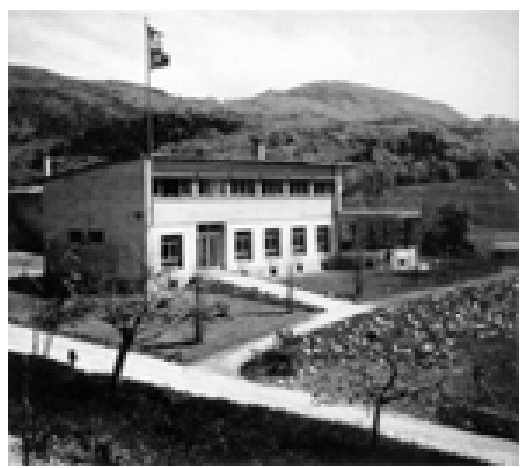

Vista suroeste. Hannes Meyer Buildings, projects and writings p.78

Zona de juegos cubierta Hannes Meyer 1889-1954, pp.305,312

Detalle construccion de zona cubierta Hannes Meyer 1889-1954, pp.312

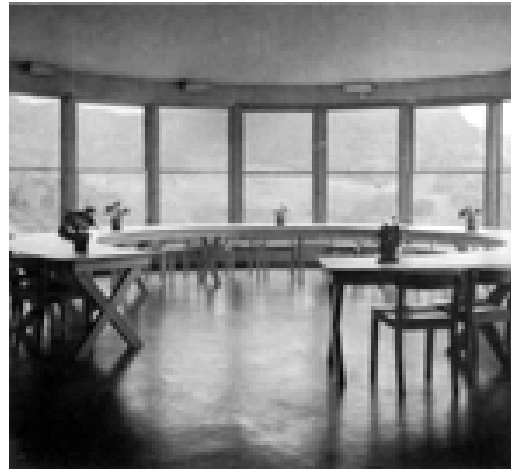

Inteirior sala circular Hannes Meyer 1889-1954, pp.308

Zona cubierta Hannes Meyer 1889-1954, pp.313
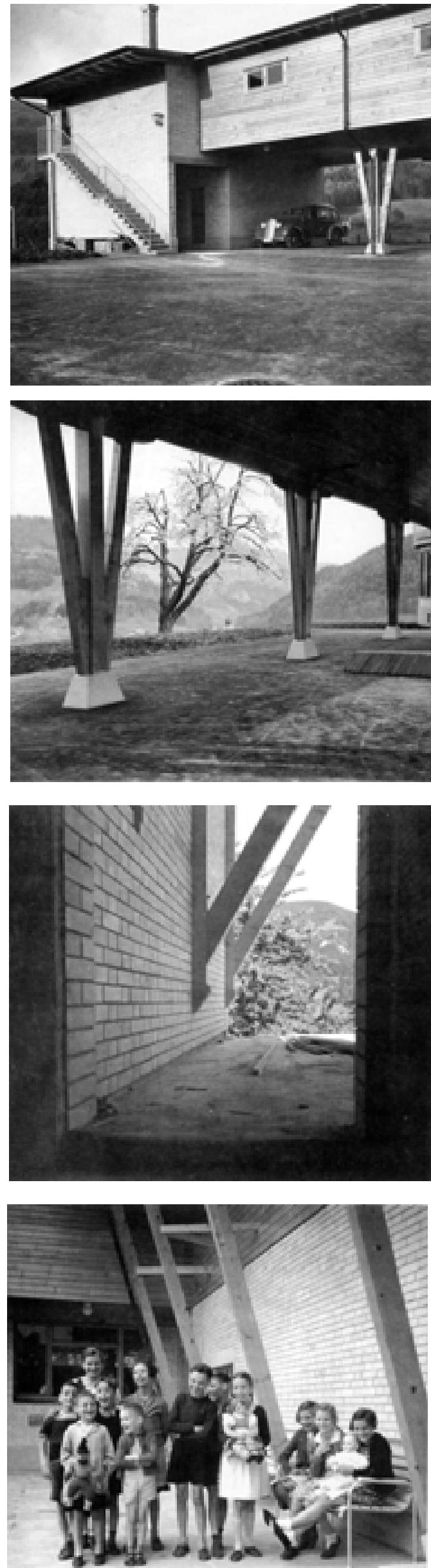
"La vida es multidimensional. No vivimos horizontal o verticalmente, sino que también pasamos por diagonales y curvas, que no pueden determinarse matemáticamente (...)

No percibimos restricción vertical ni horizontal, sino que nos sentimos como si estuviéramos en el es pacio »

Aquí crece la sensación de poder respirar con libertad $y$, al mismo tiempo, de tranquilidad.

\section{Jaap Bakema}

Sobre la Casa de verano Verrijn Stuart.

En De 8 en Opbouw, num, agosto de 1941 


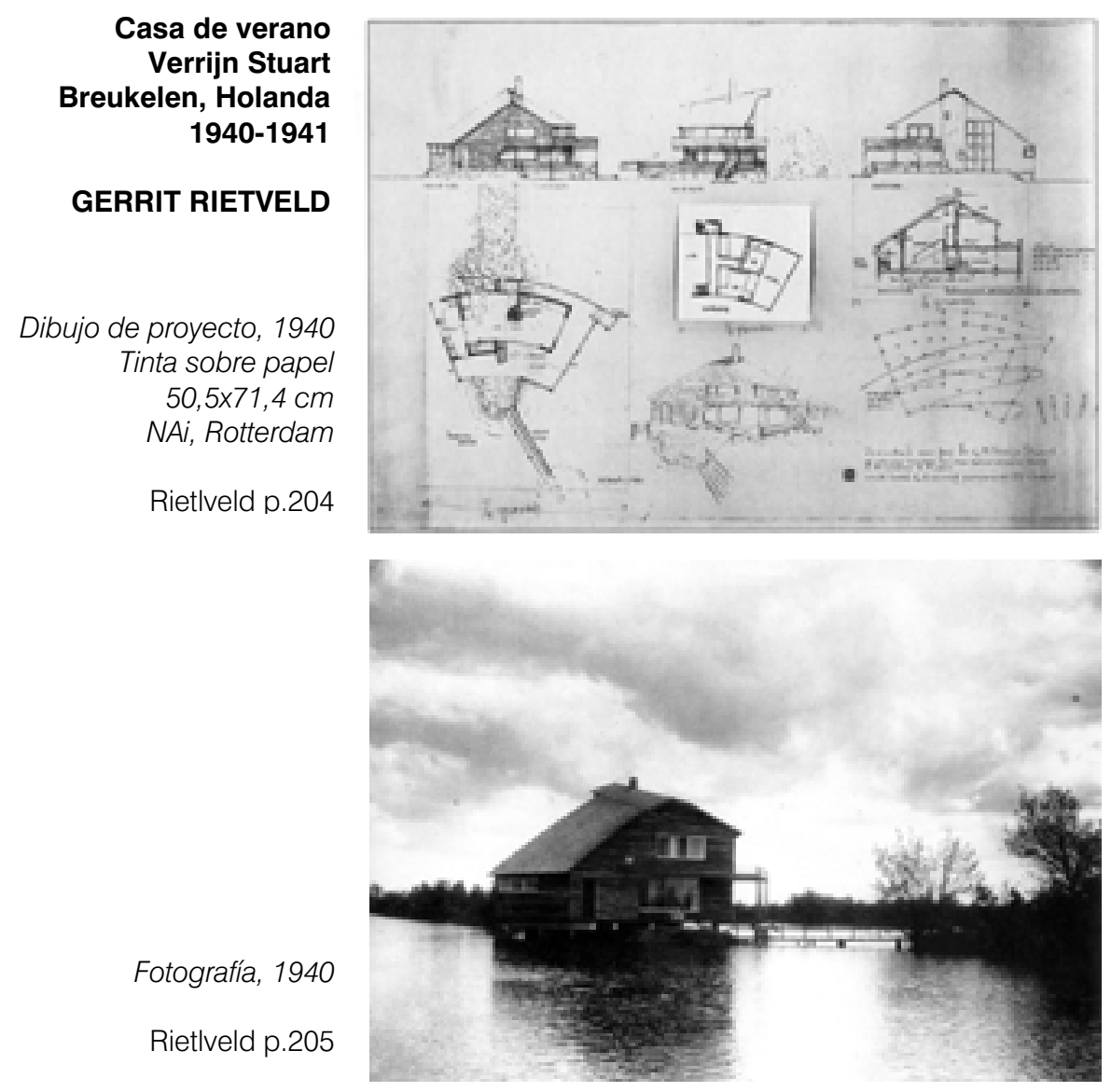

Verrijn Stuart

, Holanda

\section{GRRIT RIETVELD}

2.

Rietlveld p.205

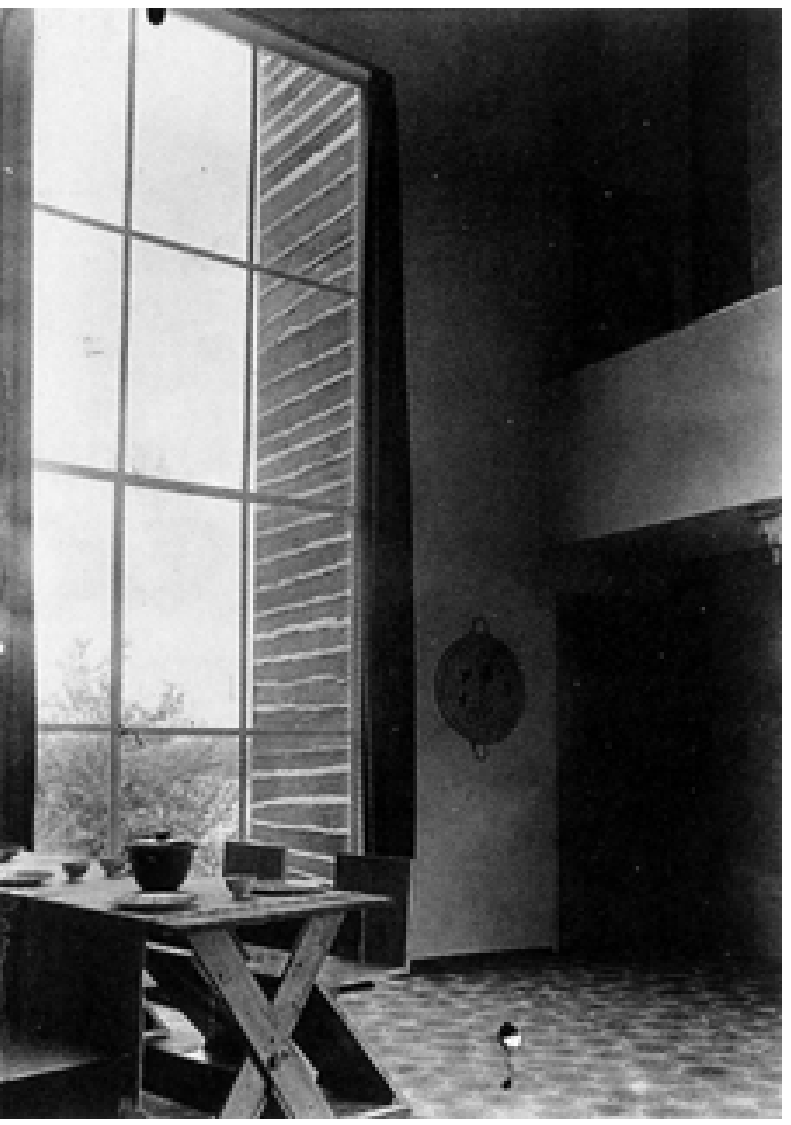

Rietlveld p.205 
«A la edad de tres años viví esa vida colmada de libertad, de aire, de luz, de olores y de afecto. Descubrí el amor hacia la naturaleza en armonía con las estaciones, la cabeza cerca de las estrellas, y el respeto por todos los campesinos del mundo, los mas anclados a la tierra»

Charlotte Perriand

citada por Carmen Espegel en

Heroínas del Espacio, p.228, 2006 
Casa Villiqer, Bremqarten. Suiza,1942. Demolición 1978. MAX BILL

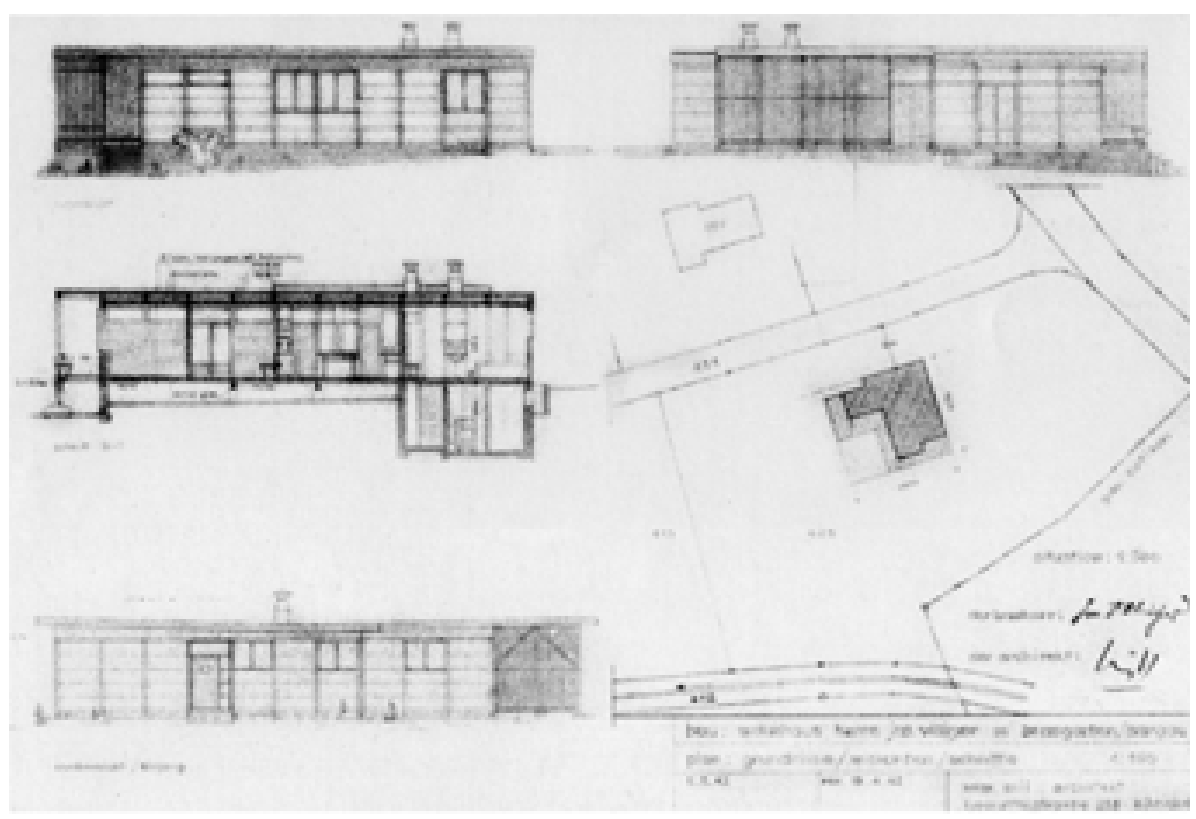

Dibujo de proyecto

2G Max Bill Arquitecto p.93

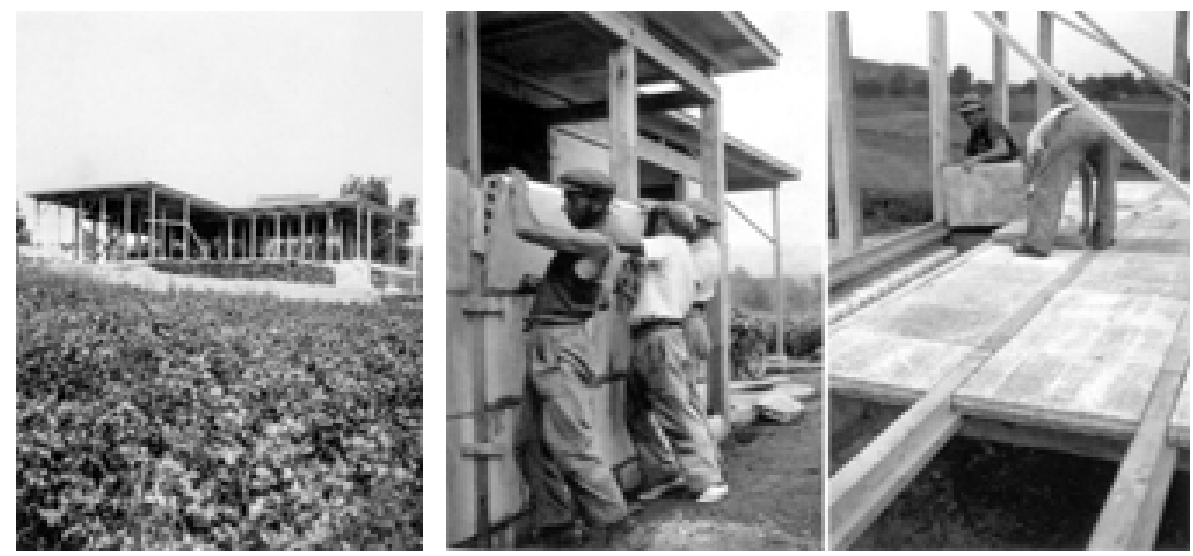

Colocación de los elementos de hormigón ligero Durisol sobre estructura comun de maderal. Paneles estandar de la empresa Durisol AG de Dietkon Zurich, que hasta entonces solo se habian utilizado en edificos industriales

2G Max Bill Arquitecto p.49

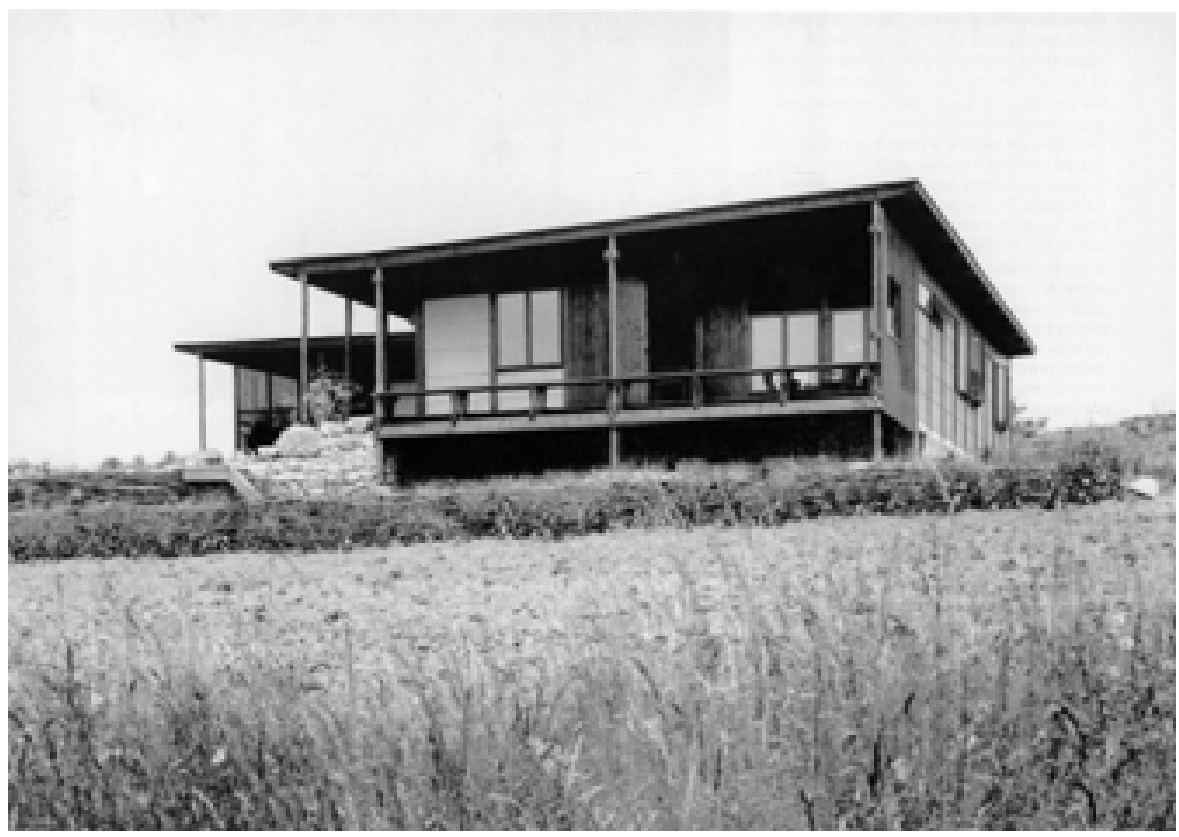


«Pienso que vuestro país es un lugar idóneo para dar vida a las nuevas ideas de la arquitectura (..)] La arquitectura que yo propongo es fundamentalmente latina, porque en su interior contiene relaciones matemáticas y posee gran claridad de concepción. ¿Comprendéis así por que pienso que es adecuada a vuestra tierra donde existen soluciones estructurales claras y bien resueltas?»

«un azote que deberemos soportar en todos los países es el de los arquitectos mal orientados. iObservad que imagen despreciable presentan, en estas calles, las casas construidas con intenciones artísticas! Estos son los cadáveres recientes fruto de la retórica de las academias; [..] Estas casas de los pescadores de Sitges en las que no se halla la mano del arquitecto, pero que son arquitectura»

«la tosquedad de los materiales no constituye, en absoluto, un impedimento para la manifestación de una organización clara y para el ejercicio de una estética moderna.»

\section{Le Corbusier}

Artículo publicado en la Veu de Catalunya redactado con la firma de Marius Gifreda, con el título "Le Corbusier en Barcelona. El célebre arquitecto comenta la ciutat", 1928

Segundo párrafo referido a un recorrido por las calles de Sitges.

Citado por R.Gulli en Las bóvedas de Guastavino en América, p.84 


\section{Casas Jaoul en Neyilly-sur-Seine \\ 1952}

LE CORBUSIER

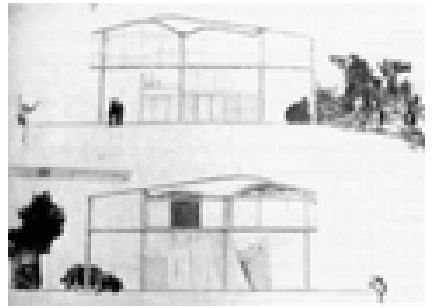

Bonet Castellana, dibujo casa Jaoul, 1937

Le Corbusier decidió emplear los materiales mas elementales: ladrillo, rasilla, bóvedas "a la catalana" (hechas sin necesidad de encofrado), con rasilla a la vista, cubiertas con hierba.

Le Corbusier Oeuvre complète Volume 6 1952-57,

p.216

En el cuaderno E21 se puede leer «bóvedas catalanas, Sert, Escorsa, 48 Bd. de Geneve Béziers -9 julio 51-29, 14. $1,5=$ ladrillo yeso-15 cm/mcer debajo, cimbra móvil cada fila, tirante de hierro, 1 ladrillo fijado con yeso para sostener el liste/»

Las Bóvedas de Guastavino en America (Gulli 2002, 78)

Interior de la casa Jaoul, donde se ve el intradós de la bóveda

Las Bóvedas de Guastavino en America (Gulli 2002, 84)

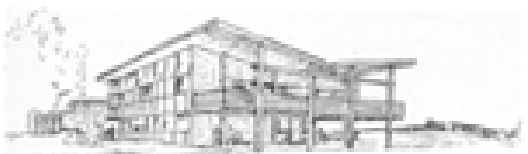

LC proyecto casa Jaoul, 1937
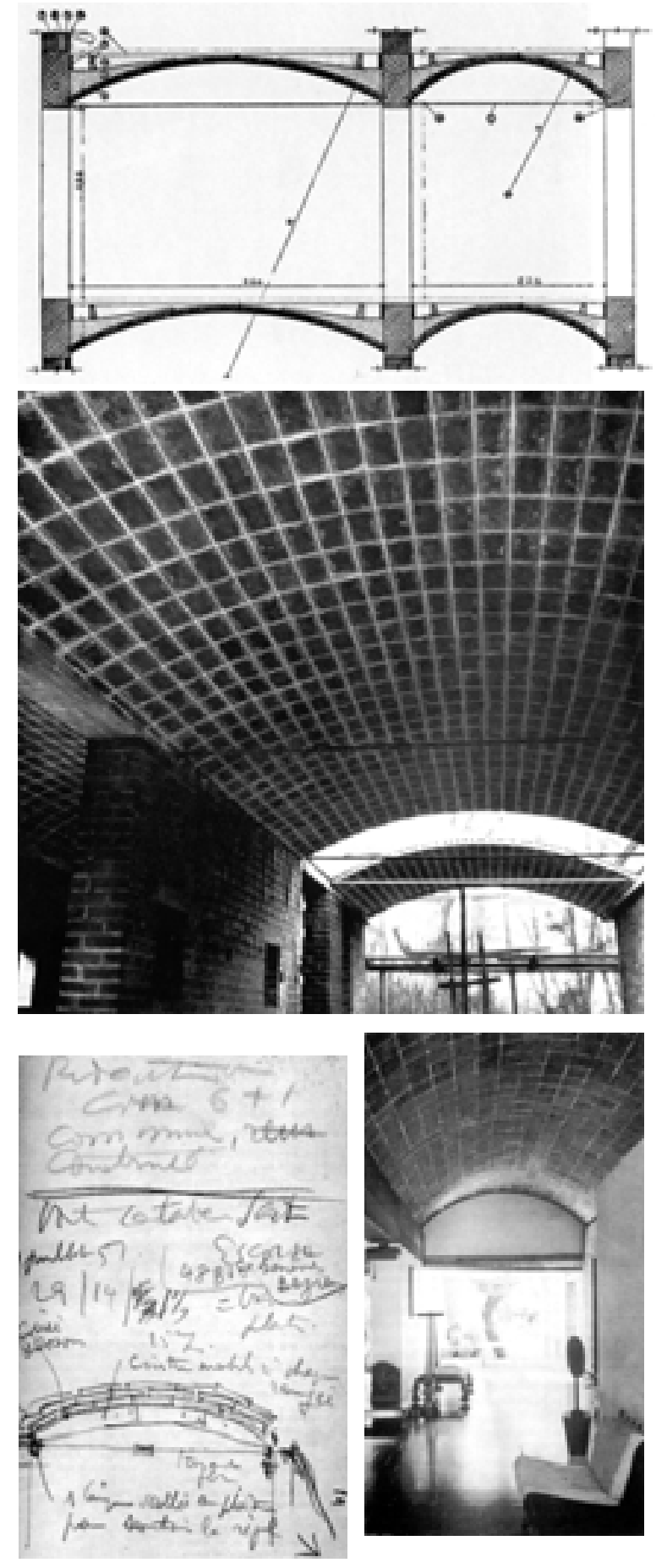
«Siento dentro de mí una necesidad acuciante: la de encontrar la única, indivisible tradición del mundo»

Dimitris Pikionis

citado por Carlos Puente en Otras vías. 1 Homenaje a Pikionis, 2005

« No recuerdo con exactitud la fecha de mi primera subida al camino a pie de la Acrópolis de Pikionis en Atenas. Ciertamente, en 1951 había una carretera de coches asfaltada, de ingeniero, después de la guerra civil, con casi todo taxis, bastante vacía, muy inquietante; un lugar plano en el brillante recuerdo de una primera visita a Grecia.

El camino de Pikionis, en el cambio, era casi igual de pertubador: ¿Por qué rastrear obras de demolición de la Atenas Neoclásica buscando antiguas pilas de mármol y lavamanos y salpicaderos para pavimentar un sendero de subida a la Acrópolis?

Encontrar bajo el pie una voluta jónica, utilizada como una piedra entre otras reutilizadas, en una calle detrás de las murallas de Estambul para sentir la historia: Estar de pie sobre un desagüe de lavabo colocado en las laderas de la Acrópolis por un arquitecto con desconocidas intenciones, es sentirse desubicado; tomar parte en una historia con la intención de difuminar el tiempo, no consolidarlo»

Peter Smithson 1989

En Dimitris Pikionis, Architect 1887-1968. A sentimental topography. Architectural Association 
Intervenciones en entorno arqueológico de la Acrópolis y colina de Philopappou en Atenas, 1951-57

DIMITRIS PIKIONIS

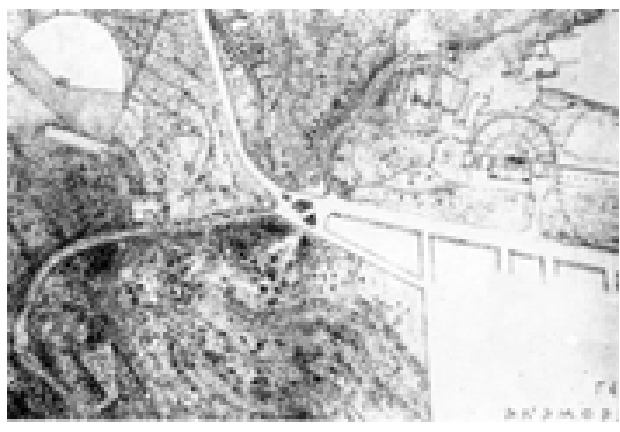

Entre 1951 y 1957, Pikionis estuvo trabajando en el tratamiento paisajistico de la Acrópolis, la Colina de Philopappou. Como parte del proyecto, renovó la iglesia existente de St. Dimitris Loumbardiaris y construyó un nuevo pabellón adyacente a ella.

Dimitris Pikionis 1887-1968, p.290

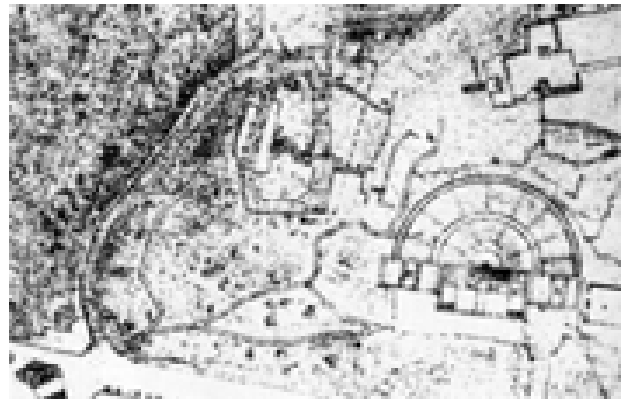

Tratamiento del recorrido a pie de llegada a la Acrópolis y

Vista el Partenón desde el cerro de la Muse Dimitris Pikionis 1887-1968, p.238 y 249
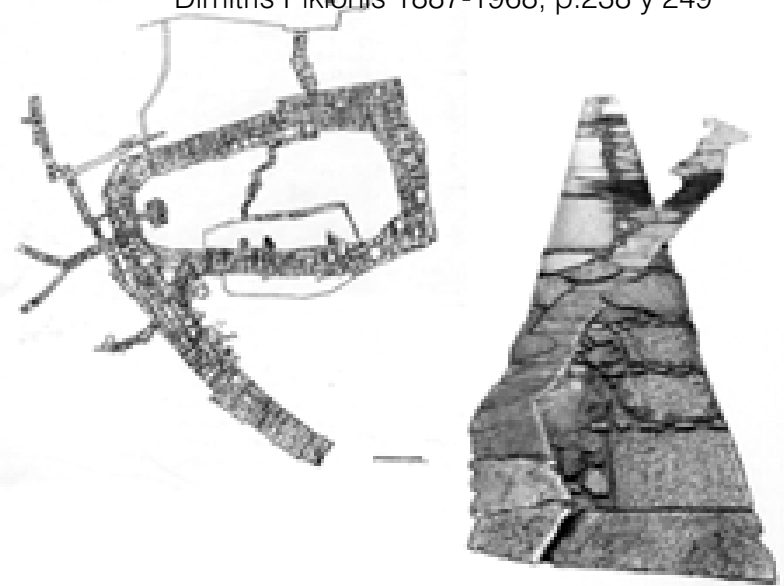

Detalles del pavimento de piedra.

Dimitris Pikionis 1887-1968, p.238 y 242, y Otras Vias 1. Homenaje a Pikionis, p.16
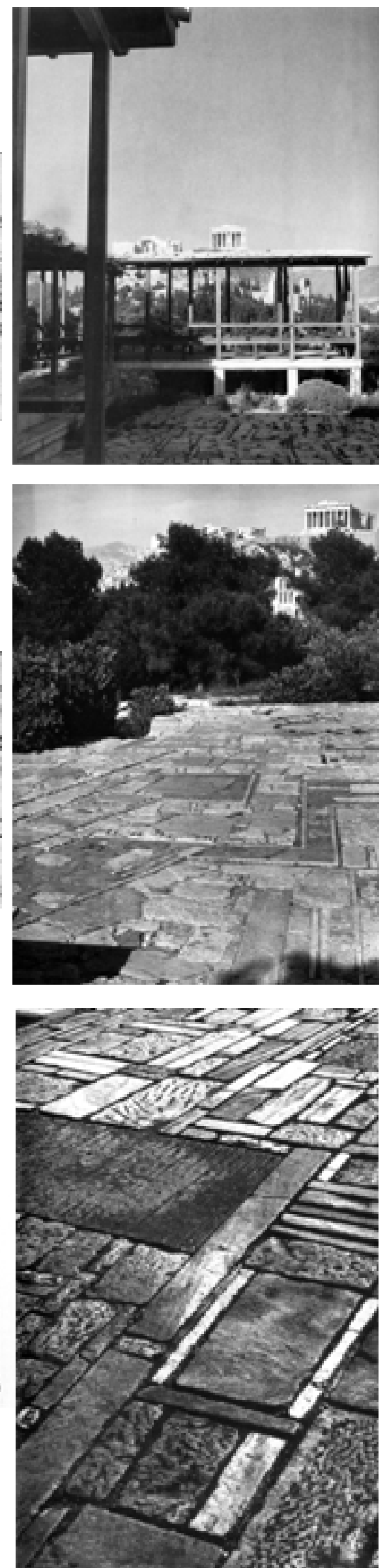
«Hace mucho tiempo que nos conocíamos...

Yo sabía algo de su alma y de su cuerpo. Sabía que había sido iniciada por Joäo, el maestro de escuela y embajador que murió de nostalgia y tristeza, enriquecida por Francisca que había nacido en Baía, ennoblecida por el descendiente de Bernardo, el secretario del infante que no llegó a morir en Alcácer, hecha renacer por los doblones de Luis Antonio de Saö Joaö de Rei, despertada por las iras de otro Antonio, el canónigo miguelista que fue vencido, conservada por el austero Adelino, y tan amada por José.

Yo la sabía fuerte y segura, en sus gruesas paredes de granito o en sus estructuras de castaño, pero le descubría ya algunas cicatrices, fruto de sucesivas ampliaciones o de agravios del tiempo que, tampoco a ella supo perdonar.

Yo amaba su pobre riqueza, su avenida, su portal con muro, sus campos, su jardín que en otro tiempo fue de boj, algunas de sus fuentes sun agua, su viejo nogal, la belleza de sus camelias en Febrero.

Hace mucho que nos conocíamos...

Pero solo empecé a conocerla mejor cuando juntos iniciamos el romance de su -y nuestratransformación. Había que tocarla y tocarla fue un acto de amor, largo y lento, persistente y cuidadoso, con dudas y certezas, fue un proceso sinuoso y flexible y no un proyecto de tablero de dibujo, fue un proyecto de hombre apasionado y no de frio tecnócrata, fue un dibujo hecho con un gesto pero no un dibujo en un papel.

Pasaron, así, diez años de muy largos gestos y de algún pequeño papel, diez años fijando y decidiendo con cautela las transformaciones que ambos -ella y yo- íbamos amorosamente aceptando.

Así entrecruzamos nuestras vidas: hoy ella está allí prosiguiendo en su espacio y en su tiempo y su dibujo está aquí escribiendo y recordando la historia de nuestro romance.

Hace mucho que nos conocíamos..

Sea como sea, ahora nos conocemso mejor, y ambos somos distintos a como éramos.»

Fernando Távora

Texto escrito en 1990 a propósito de su casa en Covilhä, Guimaräes, 1973-1979.

(Tavora 1990)

Tavora, Fernando. 1990. «Hace tiempo que nos concíamos...». Tavora, Documents de Projectes dÁrquitectura DPA 14, Diciembre 1998, p.72 
Casa de verano en Briteiros Guimaraes 1989-1990

FERNANDO TÁVORA

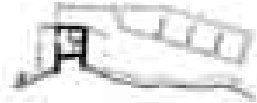

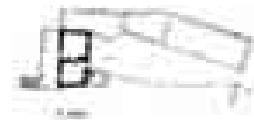<smiles>C[C+]C</smiles>

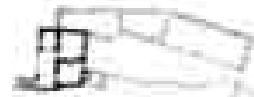<smiles>C[B]C1CCCO1</smiles>

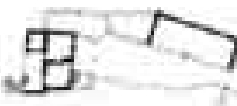<smiles></smiles><smiles>CCCC=[TeH]</smiles><smiles>C[14C]1=[14CH][14CH]=[14CH][14CH2]1</smiles><smiles>[14CH3]</smiles>

Crecimento planimetría Fernando Távora (Ed. Blau), p.160

Fotografías del patio y de la zona de acceso Fernando Távora (Ed. Blau), p.161-163
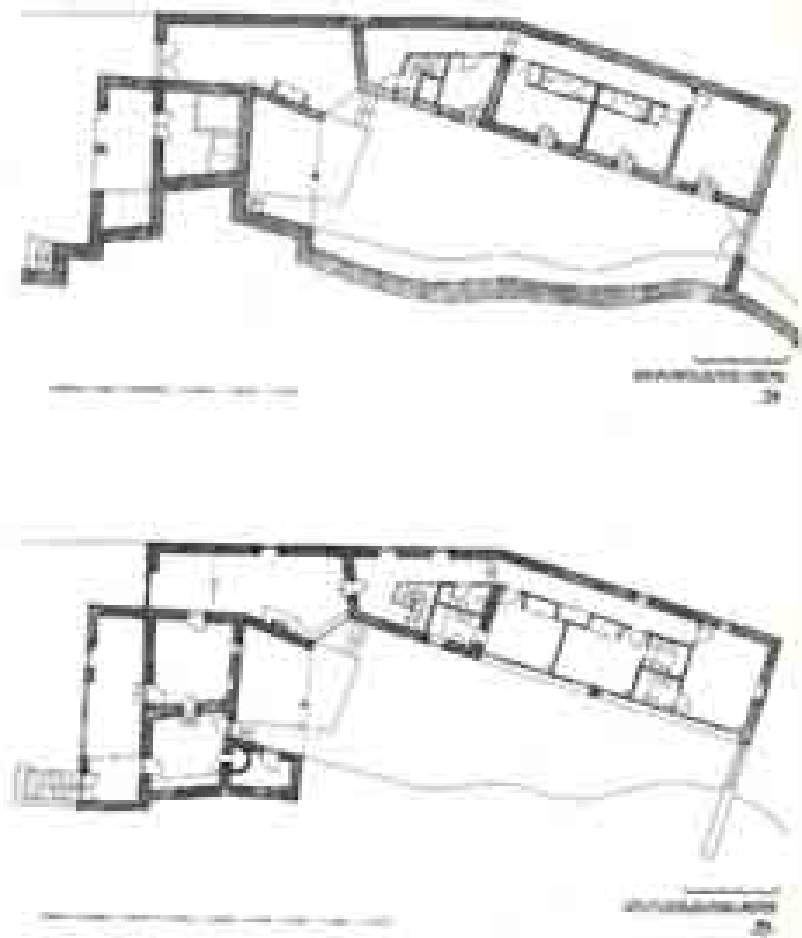

Plantas Baja y Primera Fernando Távora (Ed. Blau), p.161-163

Fotografía del comedor desde la cocina
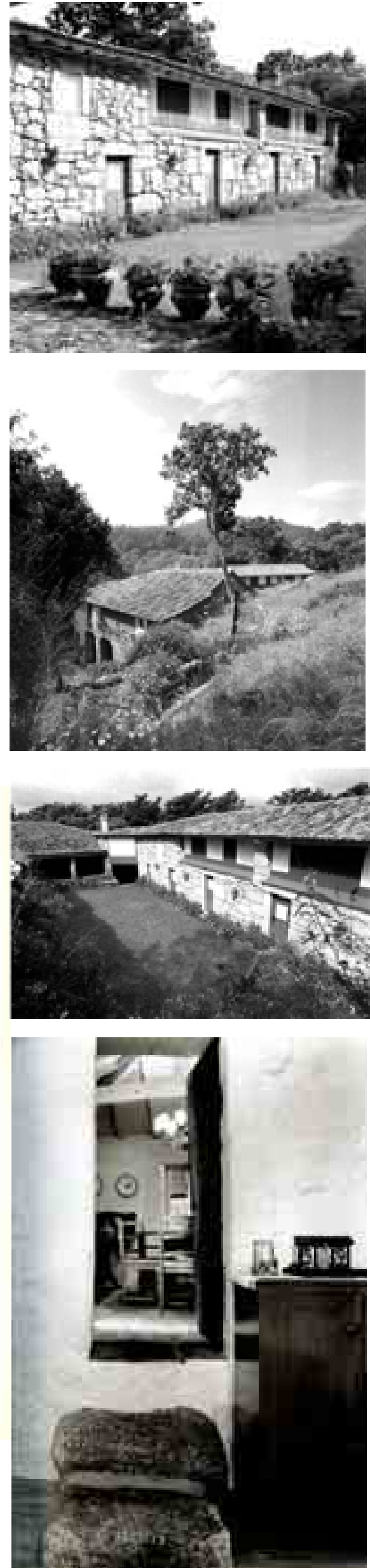


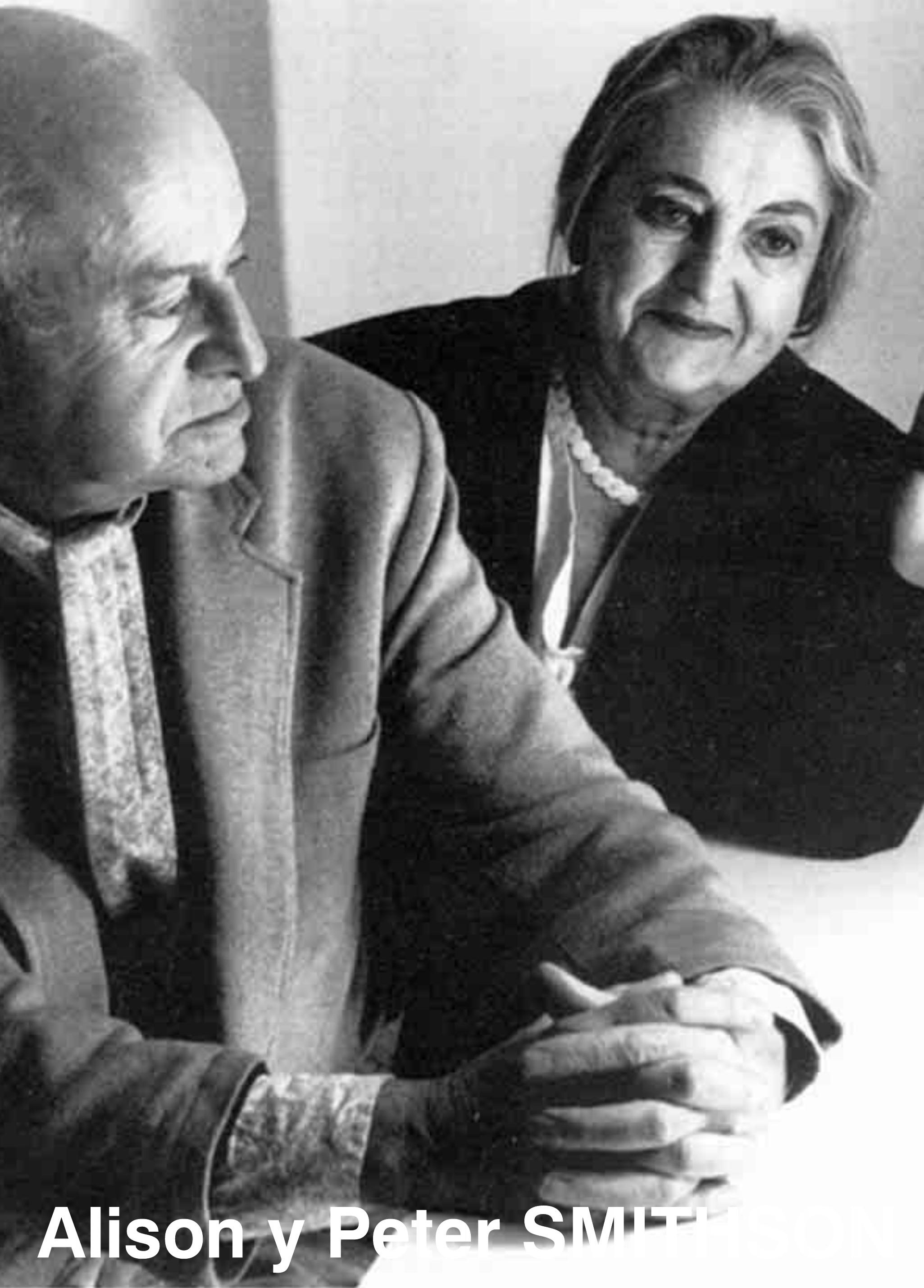




\section{Capítulo 2}

El jardín de los Smithson: El Upper Lawn Folly Solar Pavilion 


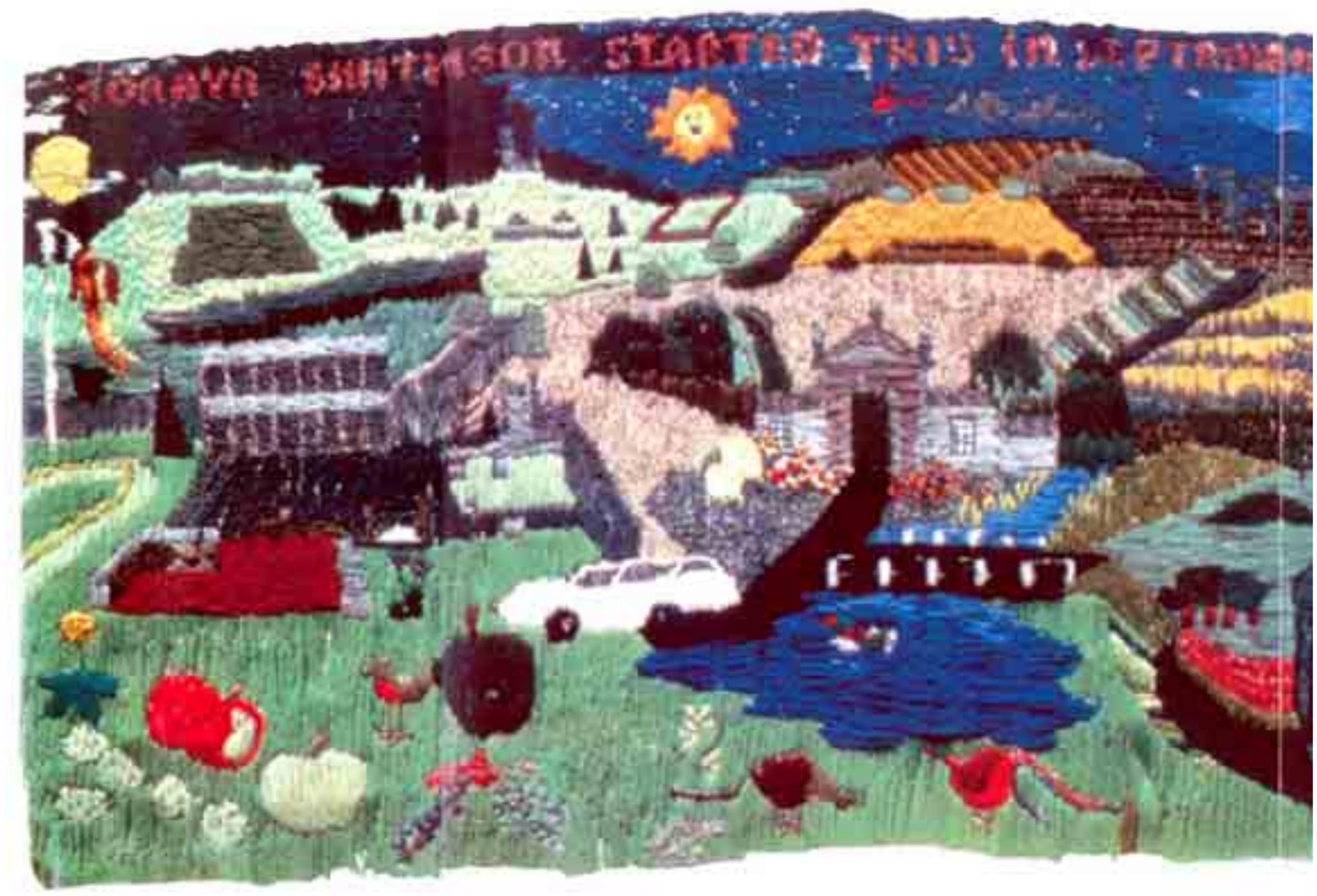




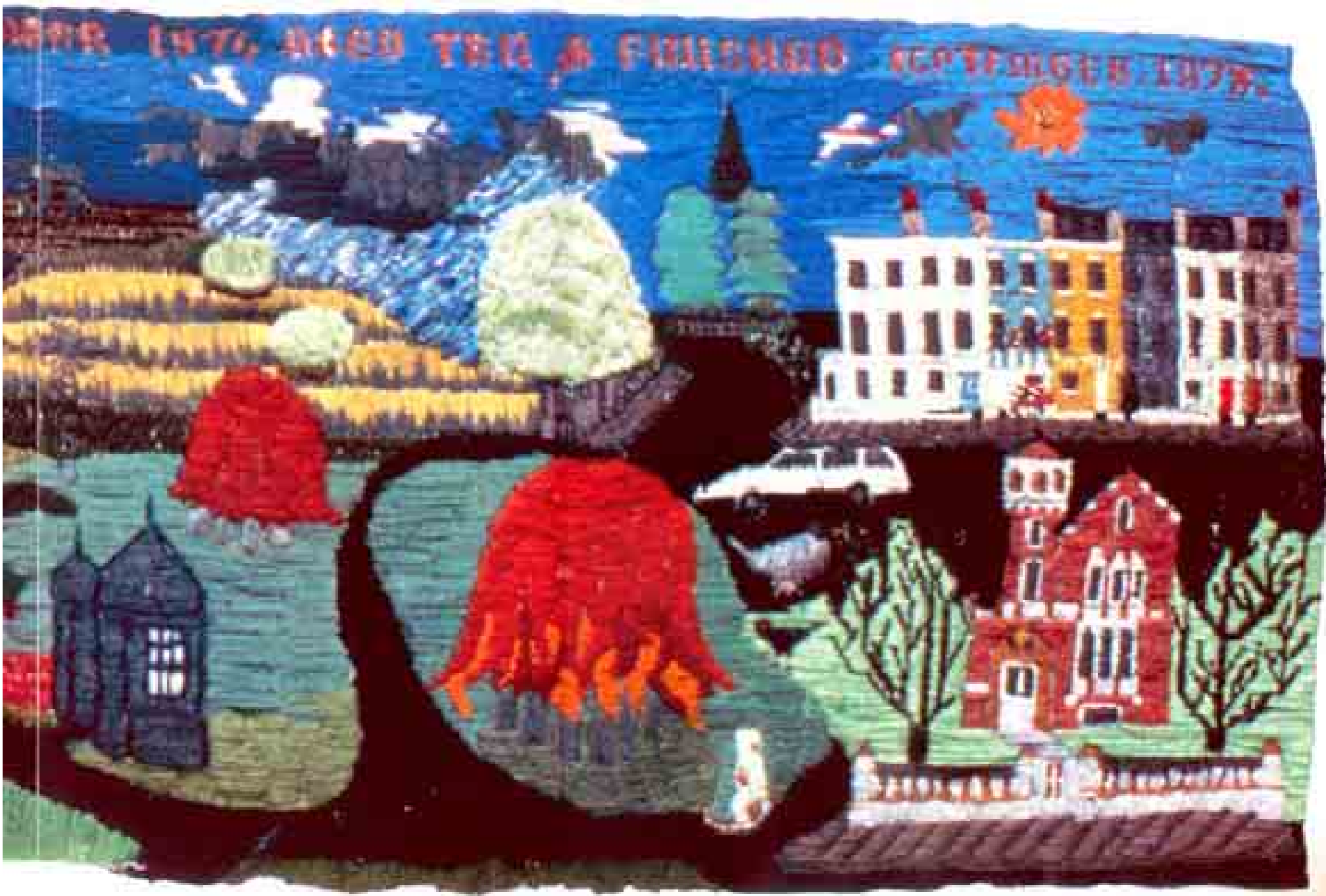

Figura 2.1

Imagen del texto Upper Lawn, Folly Solar Pavilion. Última página doble, con el siguiente pie de foto:

Tapiz que reproduce el camino entre Upper Lawn y Londres. 164 kilómetros de puerta a puerta; tejido en Londres por So.S. de Septiembre de 1974 a Septiembre de 1978.

En la parte superior del tapiz está escrito:

«Soraya Smithson started this in September 1974, aged ten \& finished September 1978

Soraya Smithson empezó esto en Septiembre 1974, a la edad de 10 años \& terminó Septiembre 1978" 
Capitulo 2. El Jardín de los Smithsons. El Upper Lawn Folly Solar Pavilion 


\section{Capítulo 2 \\ EI Jardín de los Smithsons. El Upper Lawn Folly Solar Pavilion.}

«Se halla situado en un paisaje inglés del siglo XVIII con la deliberada intención de disfrutar de sus placeres y de su historia y de someterse a sus estaciones, admitiendo la melancolía que la quietud y dichos cambios estacionales puedan entrañar.

Este pabellón es auténtico heredero de la tradición poética inglesa: en él hemos vivido parte de nuestras vidas de un modo especial. El pabellón fue proyectado como un aparato cuyo esquema de habitabilidad podía variar con el tiempo...una distribución de habitaciones y pequeños espacios de jardín que irían sintonizando con el paso de las estaciones, con los cambios en la utilización familiar, con las variaciones en la sensibilidad propia.

Upper Lawn era un aparato con el que experimentar cosas en uno mismo.

Fue allí donde exploramos los pequeños ajustes, los adornos temporales, la invención de aquellos signos de cambio que más tarde llegaríamos a reconocer como la necesaria labor de la cuarta generación del Movimiento Moderno.» (Smithson y Smithson 1986).

En este pequeño párrafo de la introducción a la monografía publicada en Barcelona en 1986 sobre Upper Lawn, y escrita a modo de diario familiar, los Smithson relatan su relación con la casa en los veinte años vividos en ella.

El libro, como este fragmento, es personal, preciso y evocador. Refleja con intensidad su modo de ver el mundo, de vivir y trabajar. Refleja la esencia del Pabellón Upper Lawn. Nada mejor que sus palabras para explicar este proyecto.

Alison y Peter Smithson (Reino Unido 1928-1993+1923-2003), miembros fundadores y muy activos de Team $X$, inician su actividad profesional en un contexto internacional de posguerra y de revisión crítica del Movimiento Moderno con una nueva actitud hacia la tradición. En los años cincuenta y sesenta desarrollan una parte muy significativa de su obra y las líneas fundamentales de su discurso teórico, desde una relación de diálogo con la tradición.

En este proceso, es indispensable Upper Lawn (1958-1962) ${ }^{1}$, su casa de fin de semana en el campo. Un pequeño pabellón de madera, vidrio y aluminio, construido en un cottage inglés del siglo XVIII; una modesta casa rural medieval inglesa con un recinto conformado por un muro de mampostería de piedra sobre el que se apoya.

Conviven en igualdad y mostrando sus cualidades naturales, materiales industriales novedosos del momento, junto a intencionadas preexistencias de construcción vernácula.

...«Una 'folly' que se implanta en los límites de los 'lawns' originales de la Folly de Beckford en Fonthill.

Aquí basta decir que es un pabellón en un recinto, tratado en superficie mitad con pavimento 'as found' y mitad con pradera; un pabellón en el que disfrutar de las estaciones; un pabellón solar y primitivo, cuya fina piel forma un espacio nuevo en contraposición a los gruesos muros norte de fabrica de los cottages originales y sus terrenos del siglo XVIII y anteriores”²... (Smithson 2001, 238).

\footnotetext{
${ }^{1}$ Los Smithson compraron la casa en 1959, pero ya hay un croquis de Alison con las primeras ideas de proyecto en 1958.

${ }^{2}$ Traducción al castellano de la autora
} 

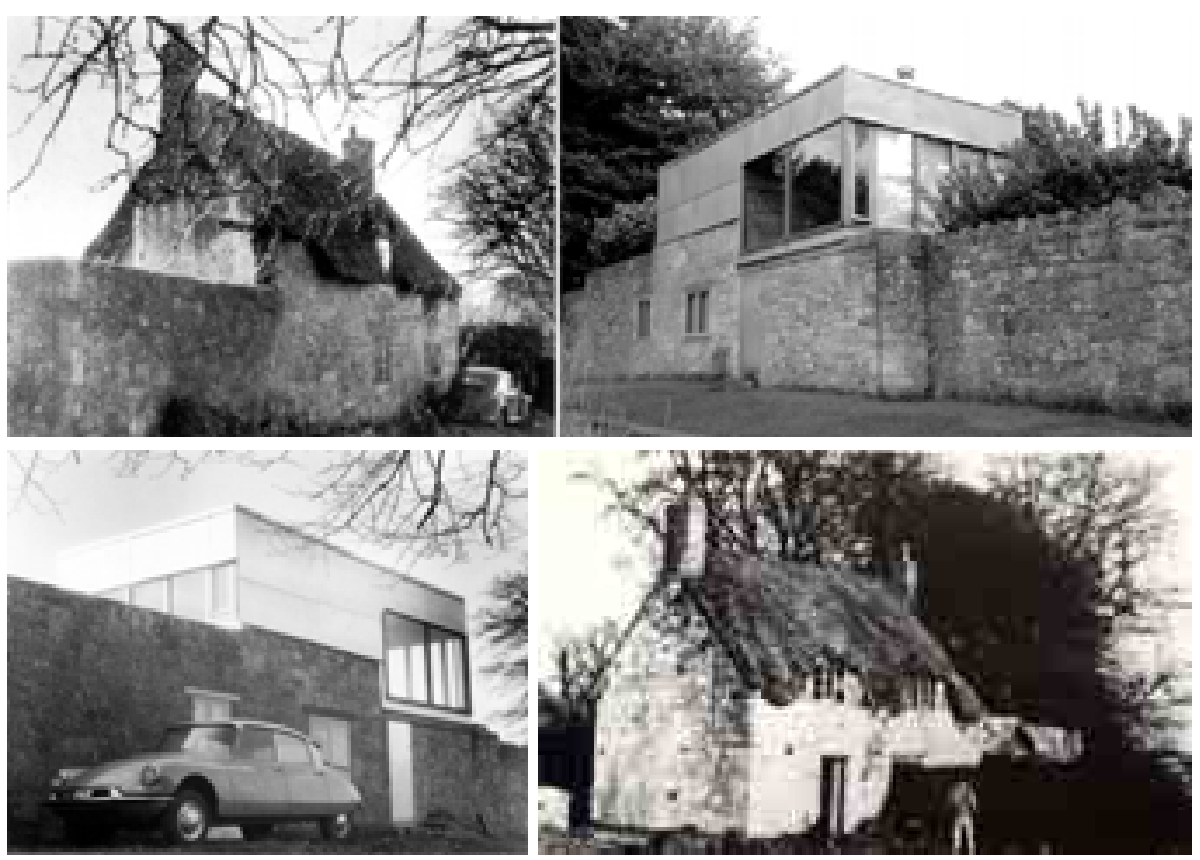

Figura 2.2

El Upper Lawn Pavilion de Alison y Peter Smithson, antes y después de la intervención realizada por ellos.

* Superior izquierda: Vista desde el borde de la carretera. Imagen del cottage original (Smithson y Smithson, 1986)

* Superior derecha: Upper Lawn en agosto de 2010. Fotografía de Ana Rodríguez

* Inferior izquierda: Upper Lawn desde el camino con el Citroen ID 19.PS en 1962 (Smithson 2001, 239)

* Inferior derecha: Upper Lawn desde el interior de la parcela. Imagen del cottage original, en el que se aprecia el testero que mantuvieron e incorporaron al proyecto por su mejor calidad y estado de conservación. (Smithson y Smithson, 1986) 


\subsection{Los Smithson y lo vernáculo. Found y As found, lo vernáculo así encontrado y el ojo alerta.}

\subsubsection{Los Smithsons y la herencia de lo vernáculo en la cultura inglesa. Tradición y modernidad en la posguerra británica}

"Campo" y "ciudad" son dos palabras muy potentes, y esto no debería resultar sorprendente si recordamos todo lo que parecen representar en la experiencia de las comunidades humanas. En inglés, la palabra country se emplea tanto para referirse al país como a una parte de la "tierra", the country puede significar la sociedad en su conjunto o su zona rural. En la larga historia de los asentamientos humanos, siempre se reconoció profundamente esta conexión entre el campo del que todos, directa o indirectamente, obtenemos lo necesario para vivir y los logros de la sociedad. Y uno de esos logros fue la ciudad: la capital, el pueblo grande, una forma distintiva de civilización. (Williams [1973] 2001)

Así comienza el primer capítulo de la obra del autor galés Raymond Williams (19211988) El Campo y la Ciudad ${ }^{3}$. La yuxtaposición antagónica de ambos conceptos proporciona una idea idílica de lo rural que se remonta hasta la antigüedad, pero que especialmente se intensifica a partir de la revolución industrial y en el siglo XX. No es casual que en Inglaterra, su país de origen, el campo, lo rural y lo vernáculo, está presente en todas sus manifestaciones culturales. En la cultura inglesa lo industrial y moderno coexiste con lo rural y tradicional posiblemente como en ningún otro país.

En la sociedad de posguerra este sentimiento se intensifica al poner en valor "lo nacional", en un momento todavía de restricciones y racionamiento para la mayor parte de la población. El Festival of Britain ${ }^{4}$ celebrado en $1951^{5}$, es buena muestra de ello.

Figura 2.3

Páginas LVIII y LIX de la Guia Oficial de Festival of Britain en 1951.

Anuncio de equipamiento de precisión para navegación de la compañía Sperry, en el que se vuelven a contraponer tradición y modernidad.

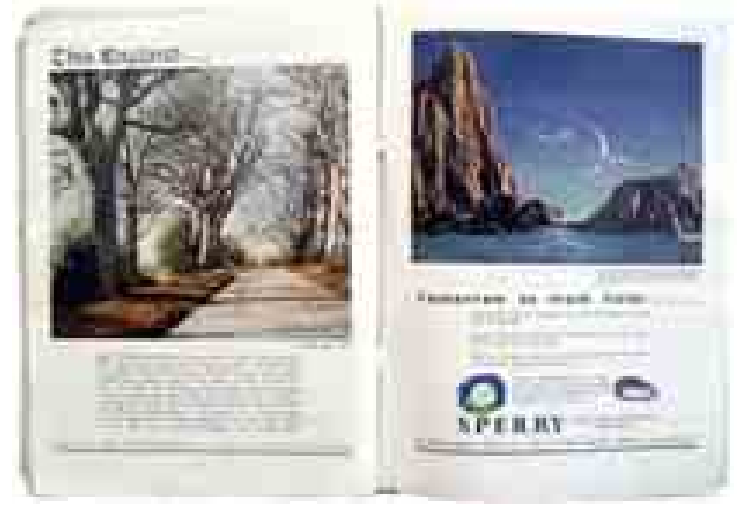

3 El campo y la ciudad edición en castellano publicada en 2001 por Paidos con traducción de Alcira Bixio. Versión original The Country and the City. Oxford University Press, 1973

${ }^{4}$ En un principio, la idea fue hacer una exposición internacional para conmemorar el centenario de la Gran Exposición de 1851, aunque posteriormente y en un momento en que la reconstrucción era prioritaria, se decidió no continuar, debido a su coste, y sustituirla por una serie de muestras sobre las artes, la arquitectura, la ciencia, la tecnología y el diseño industrial, bajo el título "Festival of Great Britain 1951". Fue un intento de dar a los británicos una sensación de recuperación y progreso; una celebración en todo el país de la historia, los logros de Gran Bretaña y su cultura. Un evento popular que ayudaría a los británicos olvidar el trauma de la guerra y contribuyera a la a la reconstrucción de la moral de posguerra. Gerald Barry, el director del Festival, lo describió como «un tónico para la nación».

5 The Great Exhibition of the Works of Industry of all Nations o The Great Exhibition, fue la exposición internacional celebrada en Hyde Park entre mayo y octubre de 1851, y la primera de una serie de ferias mundiales sobre cultura e industria en el siglo XIX. Se desarrolló en el Crystal Palace de Joseph Paxton construido a tal efecto y alcanzando tal fama que también se la conoce como The Crystal Palace Exhibition. 
En enero de 1947 la revista Architectural Review publica por su cincuenta aniversario ${ }^{6}$ un número cuya portada es el detalle del motivo de un panel pintado de William Morris para la Armería del St. James Palace, sobre el que también se publica un artículo de Charles Mitchell. Este trabajo hecho por Philip Web para Morris, Marshall y Faulkner, es unos treinta años más antiguo que la fundación de la revista, explicando su conexión por ser posiblemente la primera vez que se trataba un tema de la firma fundada por Morris desde una perspectiva de investigación histórica. Es decir, el equipo editorial consideró relevante llamar la atención sobre el hecho que el periodo inmediatamente anterior a Architectural Review, ya se consideraba histórico en 1947.

En relación con el aniversario, publican dos artículos editoriales titulados "The Second Half Century" y "The First Half Century". Tras el primero a modo de prologo, firmado por los cuatro editores de ese periodo James. M. Richards, Nikolaus Pevsner, Osbert Lancaster y Hubert de Cronin Hastings, se recoge una evaluación retrospectiva de las referencias más importantes de la revista en esos cincuenta años, desde el re-vival neo-Georgiano hasta el establecimiento de una nueva arquitectura, y su mayor augurio para el futuro en el empeño en recorrer la historia, para «to re-establish the supremacy of the eye».

Doce líneas de trabajo de la revista son resumidas a modo de ficha con un texto explicativo y abundante material grafico de apoyo, con extensos pies de foto. Un mero repaso a sus títulos permite entender hasta que punto tradición y vanguardia están intencionadamente presentes en sus páginas: A Architectural Review registra la revolución en dos actos y distingue la trama principal», "Architectural Review describe la evolución del idioma moderno», «Architectural Review encuentra en los productos de la ciencia materia prima para una nueva estética arquitectónica», "Architectural Review demuestra la antigüedad de la tradición funcional», "Architectural Review registra el impacto de la revolución en el entorno humano», «Architectural Review emplea tácticas de shook para estimular la conciencia visual», «Architectural Review perfora la cortina de humo de anticuario», "Architectural Review llama la atención sobre la importancia del arte popular, urbano y rural», «Architectural Review revive el atractivo de criterios no visuales», "Architectural Review traza las repercusiones de la revolución a través de todas las artes», "Architectural Review restablece la crítica con el arma de la nueva visión»,y «Architectural Review esboza un acto más de la trama principal»»

En su mención expresa a la importancia del arte popular dice:

«El arte popular representa el esfuerzo colectivo de una gente o comunidad no educada en la rutina académica para expresar sus necesidades más intimas. Es significativo porque representa lo inconsciente y por tanto lo inherente más que las necesidades y deseos adquiridos. Es una expresión de las emociones comunes a todos nosotros, sofisticadas y no sofisticadas.»

«Por estas razones es de intenso interés sicológico; una ciencia de la arquitectura moderna debe estudiarlo lo primero de todo.»

\footnotetext{
${ }^{6}$ La revista fundada en 1896 cumplió los cincuenta años en diciembre de 1946.

7 Traducción de Ana Rodríguez: «The Architectural Review records the revolution in two acts and distinguishes the main plot», "The Architectural Review traces the development of the modern idiom», "The Architectural Review finds in the products of science raw material for a new architectural aesthetic», "The Architectural Review demostrates the antiquity of the functional tradition", "The Architectural Review records the impact of the revolution on the human environment", "The Architectural Review employs shook tactics to stimulate visual awareness" «The Architectural Review pierces the antiquarían smoke-screen», «The Architectural Review draws attention to the significance of popular art, urban and rural», «The Architectural Review revives the appeal of non-visual criteria», "The Architectural Review traces the repercussions of the revolution through all the arts", «The Architectural Review re-establishes criticism with the weapon of the new visión», The Architectural Review outlines a further act for the main plot.
} 
En el ultimo de las doce principales referencias de la revista «Architectural Review esboza un acto más de la trama principal» pone de relieve que el desafío para la arquitectura moderna, «dominada por el planeamiento» es dar respuesta adecuada a la escala urbana y el paisaje, mostrando como oportunidad establecer una continuidad con la tradición, y poniendo para ello el ejemplo del Pintoresquismo, una de las grandes contribuciones inglesas al arte del paisajismo. La política de la revista había sido dar al paisajismo un espacio importante por entender que era necesario estudiarlo en relación a los nuevos problemas del paisaje urbano, y un ojo bien entrenado para discriminar sin prejuicios puede tener en la historia un referente valido. Este argumento se reitera en el número especial dedicado al Festival of Britain publicado en Agosto de 1951 en el que se presenta la Exposición como un paisaje, con un artículo del mismo nombre «1951 August: The Exhibition as Landscape», en el que con un formato de tour ilustrado, se analizan los efectos visuales resultantes de la aplicación de los principio del Pintoresquismo al trazado del South Bank ${ }^{8}$.

En el prologo ya se expone el argumento principal basado en que aunque el planeamiento del South Bank en el Festival of Britain era revolucionario, no lo era el principio en el que se basaba, sino solo su aplicación urbana. Era bien conocido en la planificación del paisaje y fue la base de la teoría del Pintoresquismo desarrollado por la jardinería inglesa en el siglo XVIII, ampliamente reconocida como una de las mayores aportaciones británicas al arte Europeo. Se fundamentaba en explotar al máximo las posibilidades concretas para generar un orden característico, específico y único para cada lugar; lo opuesto a los planteamientos renacentistas de superponer un nuevo carácter mediante la utilización de rígidas formas geométricas. El paisaje pintoresco era tan irregular, tan rico en sorpresas como hábil en el empleo de un feliz accidente como si fuera natural. Verdaderamente, en lo que a Inglaterra concierne, se recreaba la naturaleza misma. Lo que a menudo consideramos bellezas naturales de la típica campiña inglesa, de hecho es el resultado muy depurado de las actuaciones y mejoras pintoresquistas del siglo XVIII.
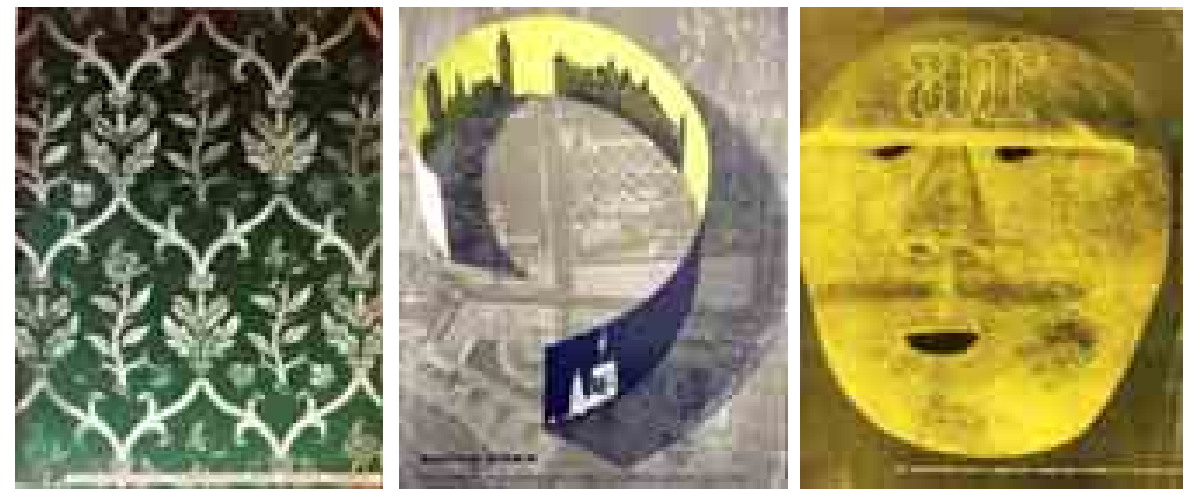

Figura 2.4

Portadas de Architectural Review

* Izquierda: Portada en enero de 1947. Motivo del panel decorativo para la Armería de St James's Palace de William Morris, en el numero conmemorativo del cincuenta aniversario de la revista.

* Centro: Portada de agosto de 1951. Numero conmemorativo del Festival of Britain, en el que la revista presentó la exposición como un paisaje según los principios de la tradición del Pintoresquismo ingles.

* Derecha: Portada de octubre de1953. Fotogarfia de la talla esquimal de un rostro tallado sobre hueso de ballena, perteneciente a la exposición Parallel of Life and Art.

${ }^{8}$ El South Bank, o Ribera Sur fue la ubicación de una de las exposiciones con el mismo nombre. Se construyó generando un nuevo espacio público en una zona donde anteriormente había almacenes y vivienda obrera. El trazado pretendía mostrar los principios de diseño urbano para la reconstrucción de Londres y new towns. 
En este contexto, podemos decir que la convivencia entre tradición, vernáculo y modernidad "esta en el aire".

Los anuncios publicados son frecuentemente reflejo de este interés. Un caso interesante por su singularidad es el de la empresa norteamericana Reynolds para anunciar el empleo del aluminio en construcción, desarrollado más extensamente en el epígrafe 4.5.3. de este capítulo, donde se analiza la utilización del aluminio como revestimiento en Upper Lawn.

Para publicitar el empleo de un material moderno y novedoso, proveniente de una industria fuertemente desarrollada obligada a abrir el mercado tras la Segunda Guerra Mundial y reorientar su producción, el recurso empleado por la compañia Reynolds consistió en una serie de anuncios basados en proverbios populares de distintas culturas, estableciendo algún tipo de asociación con las bondades del aluminio, aunando de esta manera tradición con modernidad.
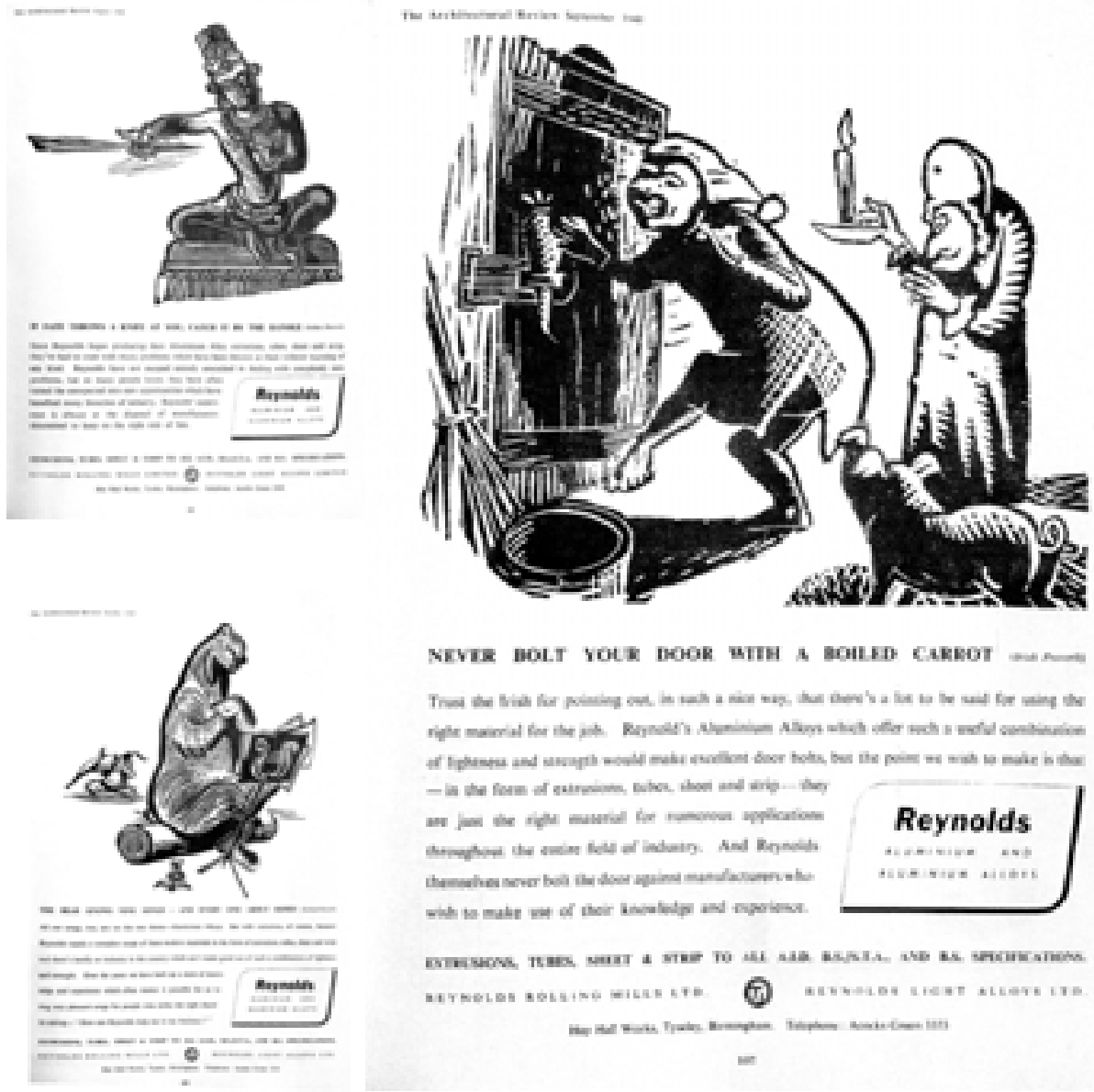

Figura 2.5

Alguno de los anuncios de la compañía de aluminio Reynolds en Architectural Review en 1948, aunando modernidad y tradición, utilizando para ello proverbios populares.

* Izquierda superior: «lf fate throws a knife at you, cath it by the handle» (Indian Proverb)

* Izquierda inferior: "The bear knows nine songs and every one about honey (Turkish Proverb)».

* Derecha «Never bolt your door with a boiled carrot (Irish Proverb)

\footnotetext{
9 En junio de 1947 publica el artículo "The New Empiricism: Sweden's latest style", ilustrado por tres viviendas de Sven Markelius, Sture Frolen y la famosa The Box de Ralph Erskine, ampliándose la información sobre el tema con varios artículos publicados en enero del año siguiente en 1948, entre los que destaca el de Eric de Maré "The New Empiricism: The Antecedents and Origins of Sweden's latest style",
} 
La generación de arquitectos británicos de posguerra, y en especial los Smithson ${ }^{10}$ incorporaron intencionadamente al proceso de proyecto lo popular y lo vernáculo, tanto en su versión más modesta y rural como en la vertiente más histórica de las tradiciones inglesas en general.

En Upper Lawn cristalizan los planteamientos arquitectónicos de los Smithson sobre como la arquitectura continuadora del Movimiento Moderno debía de implementarse, incorporando y explicitando determinados valores para mejorar la forma de habitar de las personas. Es un banco de pruebas, donde lo pequeño, lo ordinario, lo cotidiano, el collage, una visión multifocal, la relación entre campo y ciudad, lo hecho a mano, lo industrial, lo vernáculo, lo moderno..., se superponen y yuxtaponen en igualdad de condiciones. Pero Upper Lawn Pavilion no es un acercamiento ex novo a estos temas, sino la culminación de varias experiencias anteriores.

Francisco González de Canales en su libro Experimentos con la vida misma. Arquitecturas domésticas radicales entre 1937 y 1959, recoge parte su tesis doctoral e incorpora dos nuevos artículos, uno de los cuales Una estancia el exterior. Estampas de Puck y arquitecturas análogas sobre el Upper Lawn Pavilion, centra su interés por su carácter de proyecto abierto en el tiempo durante los 20 años de vida y experimentación de los Smithson sobre la forma de habitar (González Canales 2012). A su vez, relaciona un conjunto de obras realizadas entre 1953 y 1959 como experiencias de su acercamiento a la cultura rural inglesa.

En esta relación de obras citadas por González de Canales y formada por la Casa Bates en Burrows Lea Farm en Surrey (1953-1954) -presentada en el CIAM 10 celebrado en Dubrovnik-, el Bark Place Mews en Londres (1953-1956), la casa Sugden en Watford (1955-1956), los estudios sobre las Casas Electrodomesticos -The Appliance Houses- (1956-1958), los croquis para una English Climate House (1957) y el Wayland Young Pavilion en Bayswater, Londres (1959), es necesario incluir los proyectos no construidos de la Casa Losey en Minfford, Gales (1959-1960), para el director de cine estadounidense Joseph Losey, establecido en Londres desde 1953 victima de la política censora del senador McCarthy acusado de mantener actividades antiamericanas, y la Casa Acantilado - Cliff House -, en Devon (1959-1960), ambas especialmente pertinentes por tratarse de viviendas unifamiliares sobre terrenos con fuertes preexistencias vernáculas, y excluir The Appliance Houses por no pertenecer al ámbito de este trabajo.

En la Casa Acantilado, a orillas del mar, estudian cómo tratar las ruinas de una antigua construcción, así como los linderos y muros de mampostería de piedra existentes en la zona, proponiendo una nueva construcción también en mampostería de piedra, longitudinal y marcadamente horizontal, de una sola planta que se adapta al terreno como si fuera parte del desnivel de la costa, es decir la casa es el acantilado. Su posición respecto al agua, algo más avanzada que la ruina preexistente, hizo que no se construyera por la prohibición de la administración local a construir tan cerca del mar. En realidad, su propuesta tiene una voluntad clara de integrarse cuidadosamente en el territorio, recogiendo e incorporando los elementos locales preexistentes, las condiciones del lugar, con referencias de la cultura inglesa. «La casa hubiese parecido una embarcación volcada que alguien convirtiera en otra cosa. En David Copperfield hay un personaje que vive en un sitio similar. O asemejaría uno de esos inmensos esqueletos de ballena que se ven en los museos mostrando las costillas» (Vidotto 1997).

10 Los Smithsons, a diferencia de la mayoría de los artistas y arquitectos con los que se relacionaron en Indepent Group y otros, pertenecían a familias de clase obrera y fueron siempre muy conscientes de sus orígenes en una sociedad muy jerarquizada como la inglesa. 
La planta del proyecto de la Casa Losey se desarrolla a partir de los restos un antiguo cottage, cuyos muros quedan incorporados en la zona central, como núcleo a partir del cual crecen dos nuevas alas con muros quebrados, construidos también con mampostería de piedra, que en sus extremos se despegan del terreno, diferenciando la fábrica de los muros antiguos, trabajando siempre a compresión, de los construidos nuevos, que parecen flotar.

Ejemplos no construidos de cómo abordar el tratamiento de esas preexistencias vernáculas como una parte relevante del proyecto, sin mimetismos, estableciendo relaciones de diálogo que en su conjunto den como resultado algo totalmente nuevo y diferente, en definitiva moderno, y que logran brillantemente en Upper Lawn.

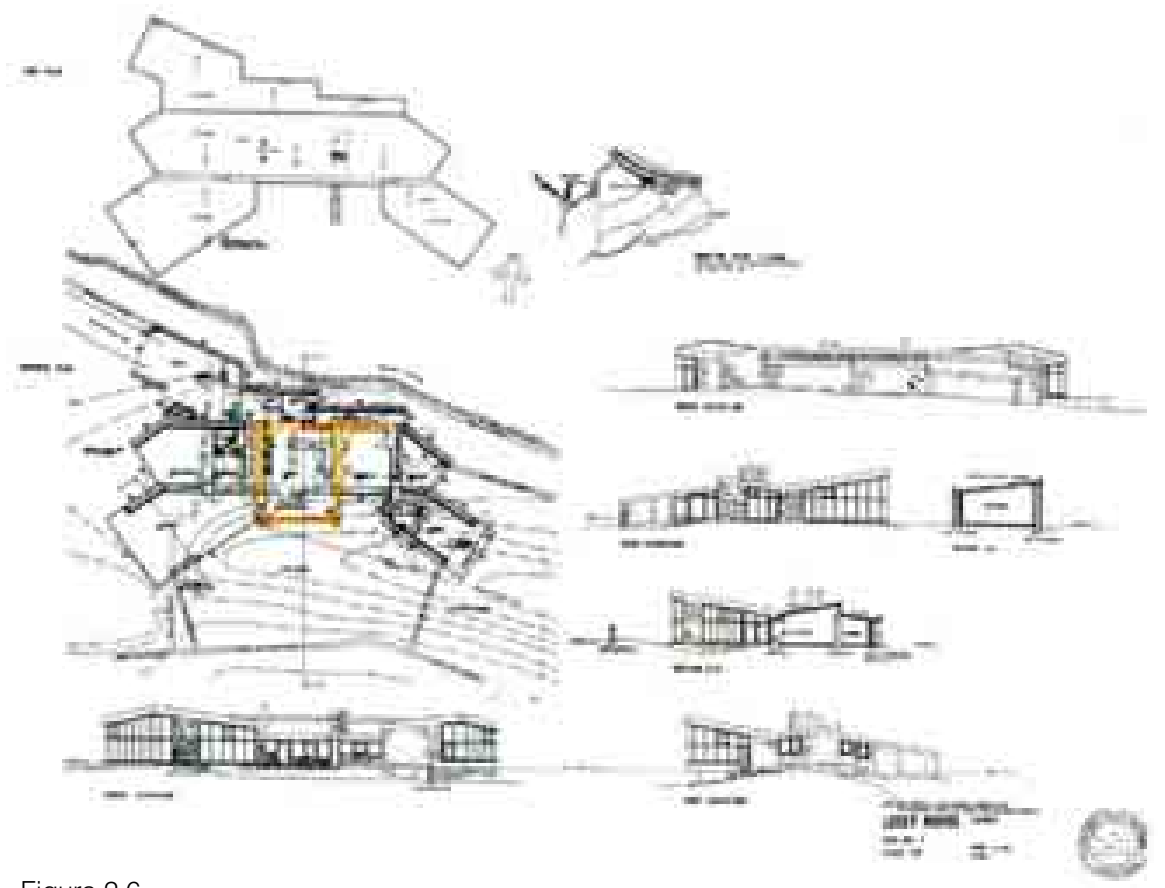

Figura 2.6

Casa Losey en Minfford, Gales. Proyecto 1959-1960 (Smithson 2001)

Relación de la nueva construcción con la preexistencia. Resaltado en color por Ana Rodríguez

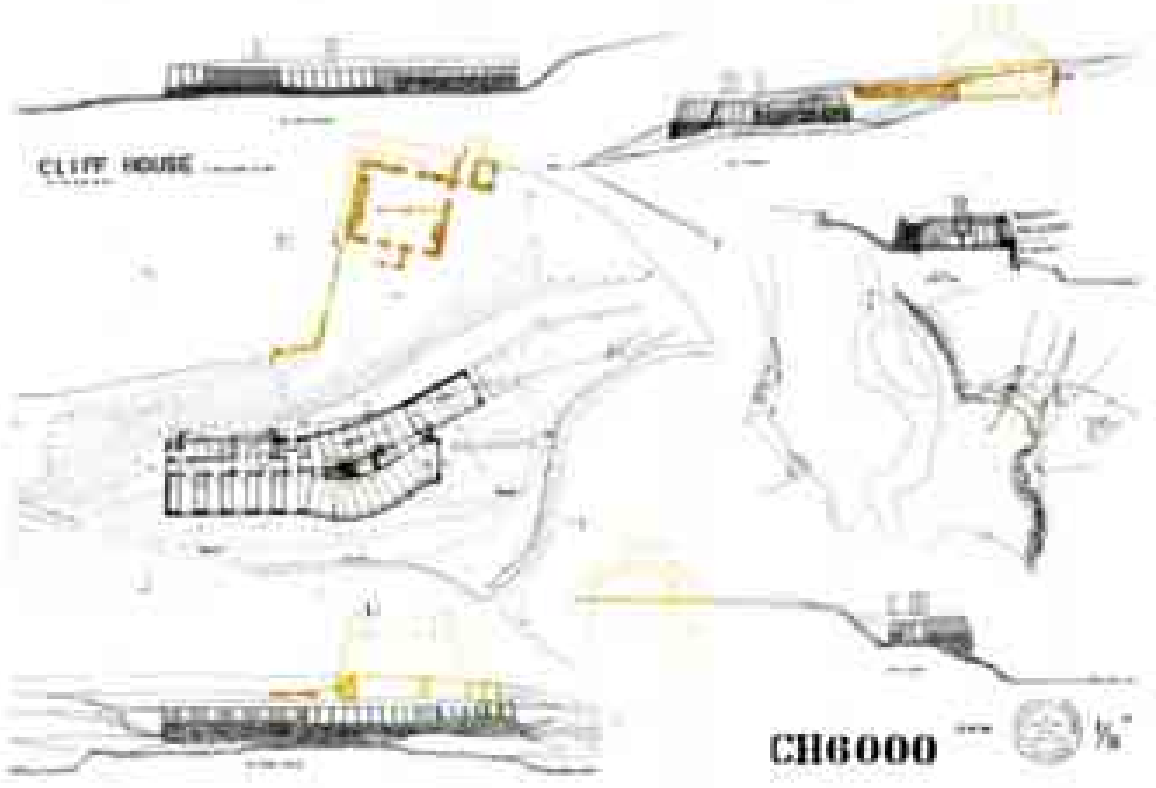

Figura 2.7

La Casa Acantilado - Cliff House -, en Devon. Proyecto 1959-1960 (Smithson 2001)

Relación de la nueva construcción con la preexistencia. Resaltado en color por Ana Rodríguez 
La intensidad que destila el Pabellón, propia del trabajo de los Smithson, con seguridad se ve acrecentada por el hecho de ser su propia casa de vacaciones, y por tanto donde poder experimentar a distintos niveles y con plena libertad.

En este sentido la elección del lugar, una antigua granja perteneciente al territorio de la finca Fonthill, es determinante.

¿Por qué allí y no en otro lugar?

¿Por qué sobre una antigua y modesta construcción rural en vez de en un terreno libre?

En los textos que a continuación se desarrollan, se intenta dar respuesta a las dos preguntas, especialmente pertinentes para explicar el interés de los Smithson por lo vernáculo y la cultura rural inglesa. Preguntas no planteadas en los importantes trabajos realizados sobre los Smithson, los más específicos sobre esta obra los de Bruno Krucker y el ya mencionado de Francisco González de Canales.

Para ello se profundiza en algunos aspectos poco estudiados, quizá por parecer periféricos o fuera del ámbito de la arquitectura. La intencionada amplitud de los mismos, permitirá una aproximación a su mundo personal que refleje la transversalidad y multifocalidad del pensamiento arquitectónico de Alison y Peter Smithson, y su interés por lo vernáculo.

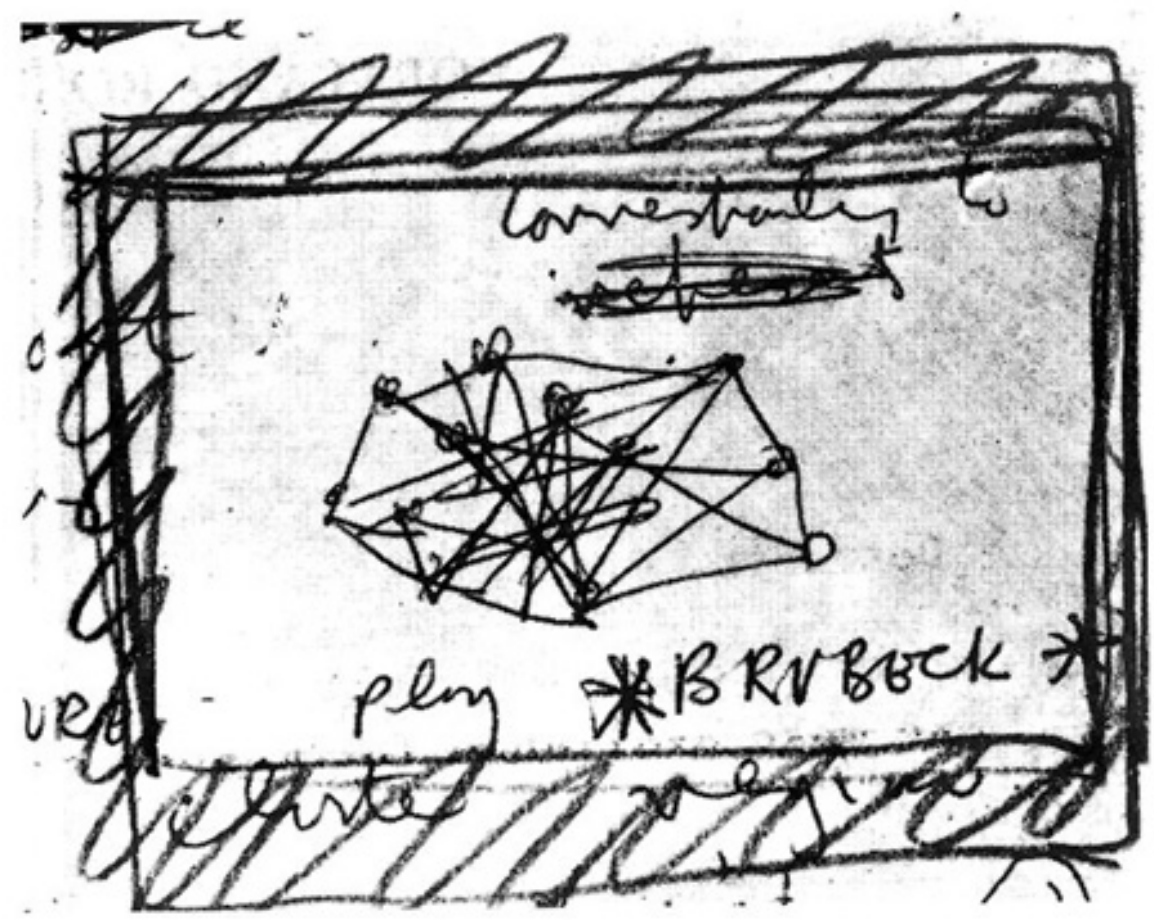

Figura 2.8

Ideograma «Play Brubeck» realizado por Peter Smithson en 1962 (Smithson 1974) 


\subsubsection{Los Smithsons y el Team 10. Modelos vernáculos y escalas de asociación.}

\subsubsection{Los Smithsons y el Team 10.}

El diagrama «Play Brubeck ${ }^{11} »$ realizado en 1962 por Peter Smithson, fue publicado por primera vez en Team 10 Primer $^{12}$ con el pie de foto: "Ideogram of net of human relations. P.D.S. A constellation with different values of different parts in an immensely complicated web crossing and recrossing. Brubeck! a pattern can emerge ». Muy expresivo, es capaz de representar certeramente el planteamiento de trabajo e investigación multifocal de los Smithson y el Team $10^{13}$.

Podemos entender Team 10 Primer como un manifiesto de los planteamientos y forma de actuar del grupo según la mirada de Alison. En este sentido merece la pena recordar unas breves notas aclaratorias al comienzo del libro en inglés, francés y español. Bajo el título "Explicación de la cartilla en lengua extranjera", Alison dice:

«El objeto de la cartilla es coleccionar en un solo volumen textos sueltos, corridos y al contrapunto, los diversos escritos de personas que constituyeron la familia confusa que se titulan Grupo 10.

Ninguno de los textos fue escrito específicamente tomando en consideración el Grupo 10, sino que formaban parte del proceso de construcción y esfuerzos para mejorar el trabajo.

Toda la esencia está en el espíritu y sazón de las piezas individuales escogidas para ser ligadas formando una unidad nueva, algo nuevo como Annie Albers. Se propone ser un Calidoscopio de pensamientos, ideas, opiniones, temores, preguntas dudas, exámenes; al resumir no quedaría nada de esta calidad cambiante y pasajera. ¿Cómo podríamos resumir un juguete o una película de Eames?

Podría hacerlo un extraño y pueden hacerlo los críticos más adelante. Pero si se ofreciese un resumen junto con este documento la gente lo leería, formaría sus opiniones según el resumen, leería el texto y miraría los diagramas bajo la influencia del resumen y llevaría el a cabo discusiones con la ayuda del mismo. Tal apoyo o ayuda violaría el fin de este libro».

El texto explica con certeza la intensidad de los planteamientos de los Smithsons. Intensidad que no se circunscribe al trabajo, sino que se interrelaciona con su vida personal; llegando a ser en cierta forma lo mismo. En una entrevista concedida por Peter Smithson a Simona Pierini en 2003, después de la muerte de Alison, Peter dice: «El Team X era, para Alison y para mi, algo completamente central, emotivamente. Aldo van Eyck decía, cuando estaba enfadado, que no quisiera haber oído hablar nunca del Team X. Para Alison y para mí, esto era inconcebible. Para nosotros el Team X era como un proceso. Explico: llegábamos con un huevo y salíamos con una gallina. Nosotros identificábamos nuestras ideas en el Team X. Es por esto que estábamos tan enfrentados con los periodistas. Ellos no traían huevos. No pretendían crecer». (Pierini 2003)

11 En de The Charged Void Peter Smithson explica su origen, como parte de la respuesta dada por Alison y él, a las notas de programa preparadas por Reyner Banham para la exposición "Extensions of Man", que pretendía eliminar el mal sabor de boca que había dejado la exposición Festival of Britain, y que se había estado discutiendo en una reunión en casa de Roland Penrose. La respuesta preparada por los Smithsons constaba de 2 páginas, una de ideogramas, y una página de texto con el diagrama (Smithson 2001)

12 Team 10 Primer, editado por Alison Smithson, sobre el trabajo y el espíritu del grupo fue publicado por primera vez en 1968 en el numero de Architectural Design, y posteriormente como libro en rustica por MIT Press en 1974.

${ }^{13}$ El proyecto Team 10 on-line tiene como logo este diagrama por su representatividad. 


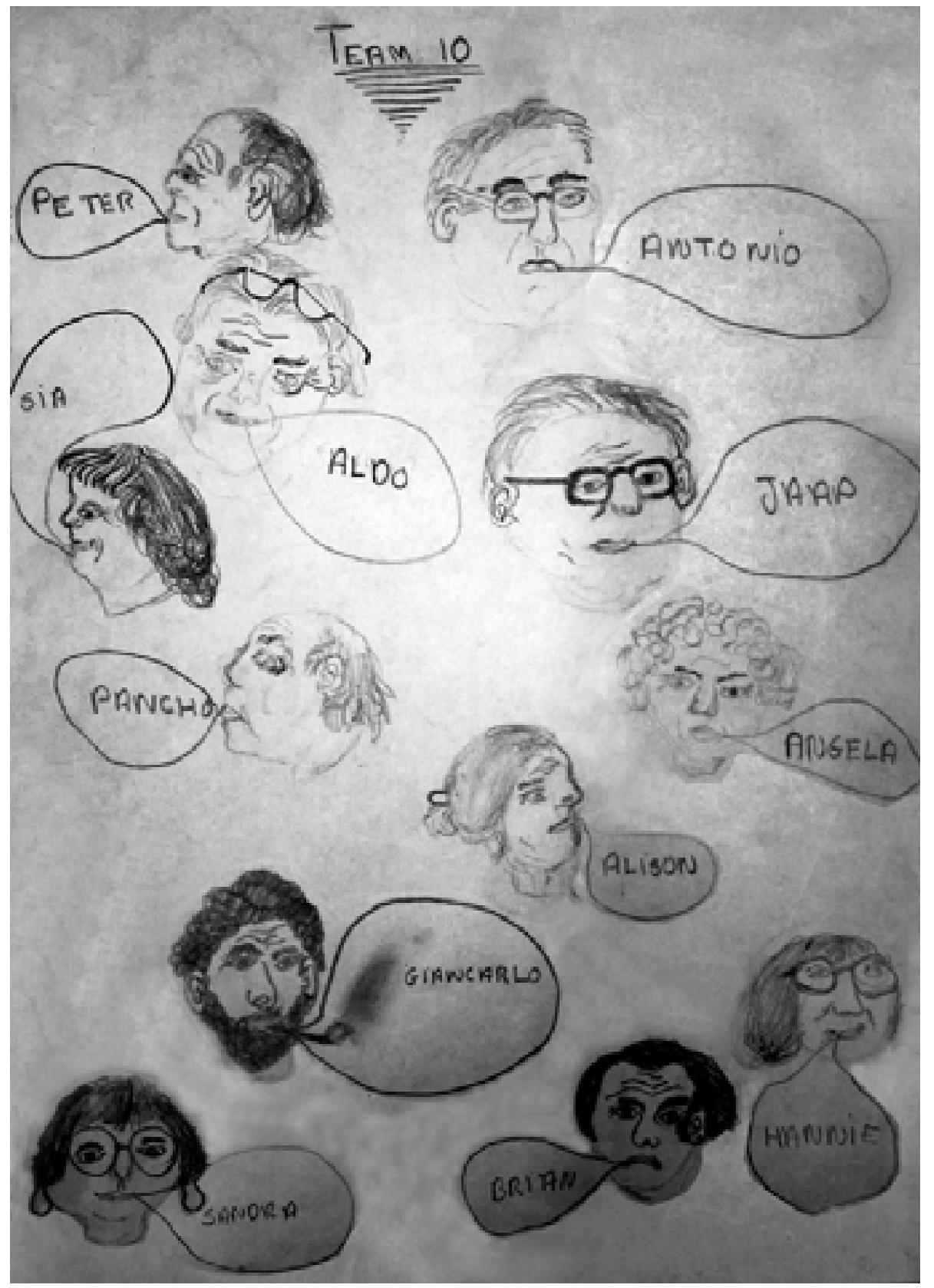

Figura 2.9

Dibujo representado el Team 10 del Archivo Smithson Team 10 en el NAi de Rotterdam.

Anónimo, pero muy posiblemente dibujado por alguno de los hijos de los Smithsons: Simon, Samantha o Soraya.

Team 10 Alison and Peter Smithson Archive. NAi. Rotterdam 


\subsubsection{Los Smithsons en el CIAM X en Dubrovnik.}

Team 10 nace dentro de los CIAM, como continuación y desarrollo de las ideas del Movimiento Moderno. Le Corbusier, alma y autoridad moral de la organización, se había conformado como una de sus columnas vertebradoras desde su fundación en La Sarraz en 1928, hasta que un grupo de jóvenes con gran incidencia de los Smithson, Van Eyck y Bakema, libres de la carga de haber tenido que formular una nueva arquitectura en las décadas anteriores, toman el relevo en los años cincuenta, con planteamientos renovados. Anhelan una arquitectura y urbanismo mejores, capaces de dar respuesta al fracaso de muchas de las grandes extensiones de vivienda realizadas en el contexto de la reconstrucción después de la Segunda Guerra Mundial.

El fin de los CIAM y la sucesión del Team 10 quedan confirmados en 1959 durante el congreso de Otterlo, celebrado en los Paises Bajos en el Museo Kröller Muller de Van de Velde, como culminación de las crecientes discrepancias entre generaciones desde 1947 en el CIAM VI de Bridgwater; pero es el décimo congreso celebrado en Dubrovnik en 1956 el considerado el último oficial, con un número importante de miembros históricos ausentes. Le Corbusier desde Roquebrune Cap Martin, envíó al congreso "Message de Le Corbusier adressé au X Congrès CIAM à Dubrovnik", al que pertenece el fragmento citado a continuación, transcripción literal del original en francés ${ }^{14}$. Leido por Josep Lluis Sert como Presidente del CIAM, el 6 de agosto de 1956 en la apertura de las actas del congreso, constata moralmente el final de un ciclo y el comienzo de otro nuevo. Un relevo sin duda doloroso, al que Le Corbusier da paso:

«Pendant ces meme trente années ont pris rang ceux qui sont nés dans

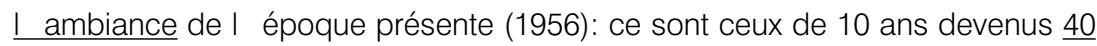

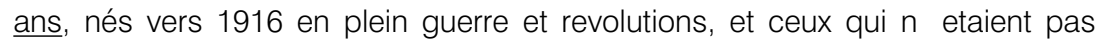
encore nés, devenus 25 ans, nés vers 1930 en pleine fermentation d une nouvelle guerre et au milieu des plusgrandes crises économique, sociologique et polítique, -se trouvant sinsi en plein coeur de I époque présente (1956) et seuls aptes à ressentir intimement, profondément, les problems presents, les buts à poursuivre, les moyens pour y atteindre, I urgence pathétique dictée par la conjuncture. Eux sont dans le bain. Leurs prédécesseurs n y sont plus, ils en sont sortis, ils se trouvent hors des coups directs de la conjoncture» ${ }^{15}$

En la misma linea del mensaje, el 5 de Julio de 1961, Le Corbusier escribe unas palabras de agradecimiento por el ejemplar recibido, a Karl Kramer editor de "CIAM 59 in Otterlo", enviando también copia ${ }^{16}$ a Bakema, como secretario del Team 10. La breve nota incluye con sentido del humor un irónico y expresivo dibujo sobre el nacimiento del grupo a partir de los CIAM.

Los hechos son sabidos, pero estos dos documentos, un mensaje y un dibujo, explican con certeza, generosidad, e ironia ese momento de cambio y su significado. Su capacidad expresiva, además de enunciar los acontecimientos, explica mejor que otros la cualidad e intensidad del momento. A pesar de lo traumatico de la ruptura, revelan la generosidad de la generación de los mayores reconocida por el propio Peter Smithson ${ }^{17}$ poniendo de manifiesto el respeto de los jóvenes hacia ellos.

\footnotetext{
${ }^{14}$ CIAM Archive, ETH/gta en Zurich. (poner ferencia del archivo)

${ }^{15}$ Traduciones mas o menos libres han sido publicadas por diversos autores en varios idiomas, entre ellos Kenneth Frampton en Historia crítica de la arquitectura moderna y Francis Strauven en The Shape of Relativity.

${ }^{16}$ Team 10 Bakema Archive en NAi Collection and Archives en Rotterdam.

${ }^{17}$ En relación con este tema Peter Smithon en Conversaciones con estudiantes dice: «En la era moderna no había ningún enfrentamiento. Lo que resulta difícil de entender es que las generaciones continuaron con una amistad muy fuerte hasta la muerte. Tanto Segfried Gideon como Le Corbusier fueron extremadamente amables con la generación mas joven. Supongo que simplemente eran héroes extremistas» (Spellman y Unglaub 2004)
} 
Tambien evidencia la voluntad de Le Corbusier por dejar constancia de su protagonismo en esta transición. Su intencionada ausencia en Dubrovnik y el mensaje, refuerzan la idea de fin de clclo.

Aunque ambos documentos se conocen, hasta ahora no se ha incidido en la estrecha relación entre ambos que aquí proponemos. De hecho el dibujo es la representación grafica e irónica del mensaje enviado por Le Corbusier cinco años antes, y corrobora el deseo por dejar huella de su papel una vez consolidado el Team 10 despues del Congreso de Otterlo. Por ello es significativa la copia que envía a Bakema como secretario del grupo de la nota enviada a Karl Kramer, en la que además de darle las gracias, muestra su opnión positiva por la actitud tomada en Otterlo por el nuevo grupo ya consolidado. Le Corbusier expone que cada generación necesita ocupar su propio espacio mientras son jóvenes y tienen la energía para cambiar las cosas:

\footnotetext{
Monsieur,

Je vous accuse réception de votre ouvrage "CIAM 59 IN OTTERLO". Ce livre me parait très bien fait et $d$ ' un excelent esprit.

Je suis très content de voir la ligne de conduite adoptée par les gens d Otterlo. II faut que chaque génération prenne sa place à I'heure utile.

Veuillez agréer, Monsieur, mes salutations les meilleures ${ }^{18}$.
}

Acompañando el texto un dibujo con dos personajes centrales uno subido encima del otro. La altura de los hombros del de abajo divide la composición en dos partes, en el año 1958: En la parte inferior el hombre, que parece ir vestido con levita, tiene una gran espalda y lleva en la mano derecha un cartel que dice, "couillonnades»"19; a la izquierda, un rayo descediendo y sobrepuesto "les emmerdeurs»" Representa el periodo desde la creación del CIAM en 1928, 30 años de trabajo sobre los que hay un nubarrón negro. En contraposición, en la zona superior, sin nada que lo constriña y bajo un gran sol radiante, el hombre que subido sobre los hombros del de abajo, parece joven, desnudo y esbelto, enarbola en alto, en su mano derecha la bandera de la verdad; a la izquierda un texto dice «L 'avenir est á "NOUS" ${ }^{21}$. En medio del dibujo el hombre de abajo, que representa las primeras generaciones del Movimiento Moderno - podría ser el mismo Le Corbusier-, dice «on monte sur le épaules mais on ne dites pas mercí»?22

A su vez proponemos la relación con un tercer dibujo inédito de Peter Smithson. En una carta sobre la posibilidad de aprovechar la ayuda de la Fundacion Rockefeller para hacer una reunión del grupo ${ }^{23}$, dirigida a Bakema y fechada el 30 de mayo de 1962, aproximadamente un año después, Peter reinterpreta el dibujo de Le Corbusier, también con dos personajes uno subido encima del otro. En este caso el de abajo subido sobre el pódium del Art Noveau, esta diciendo al de arriba que se baje, y este a su vez pide ayuda. La parte inferior se corresponde con un periodo de 50 de años arquitectura moderna, 1908-1958, y la superior, todavía con poca altura y en la que está Peter, con el tiempo que comienza en 1958.

\footnotetext{
${ }^{18}$ Señor, Acuso recibo de su libro "CIAM OTTERLO EN 59". Este libro parece muy bien hecho y de un espíritu excelente. Estoy muy contento de ver el enfoque adoptado por la gente de Otterlo. Es necesario que cada generación tome su lugar en el tiempo útil. Reciba, Señor, mis mejores deseos. Traducción al castellano de Ana Rodríguez.

19 «couillonnades» estúpidos, pringados, primos, huevazos. .

20 «les emmerdeurs», los idiotas, los imbéciles, los cabrones, los molestos, los que dan la lata...

${ }^{21}$ "L`avenir est á "NOUS"», El porvenir es NUESTRO.

${ }_{22}$ "On monte sur le épaules mais on ne dites pas mercí», se suben en los hombros, pero no dicen gracias.

${ }^{23}$ Se trataba de ampliar el espectro de invitados, arquitectos, historiadores y científicos sociales, interesados en temas urbanos, y que normalmente no asistían a las reuniones de Team 10. Así lo explica Bakema en el texto publicado en la pagina 74 de Forum en el numero 1 de 1962, en el que bajo el titulo "Post Box for the development of the Habitat", también explica la publicación en ese mismo numero del dibujo de Le Corbusier y la carta a Karl Kramer- posiblemente sea la primera que se publicó-
} 

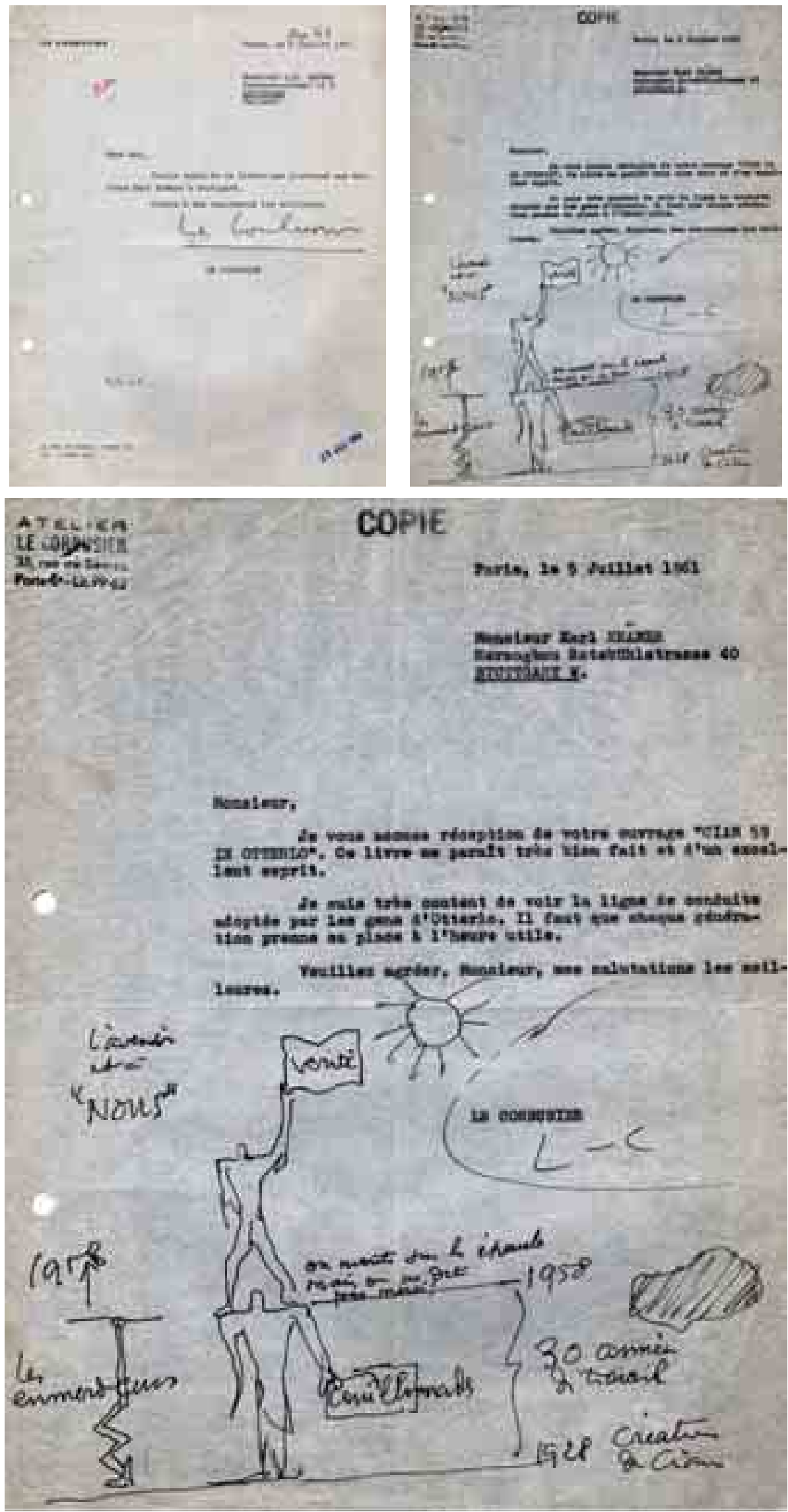

Figura 2.10

Carta a Bakema, como secretario del Team 10, de Le Corbusier con la copia de la enviada a Karl Kramer editor de Ciam 59 in Otterlo.

Team 10 Bakema Archive en NAi Collection and Archives en Rotterdam 

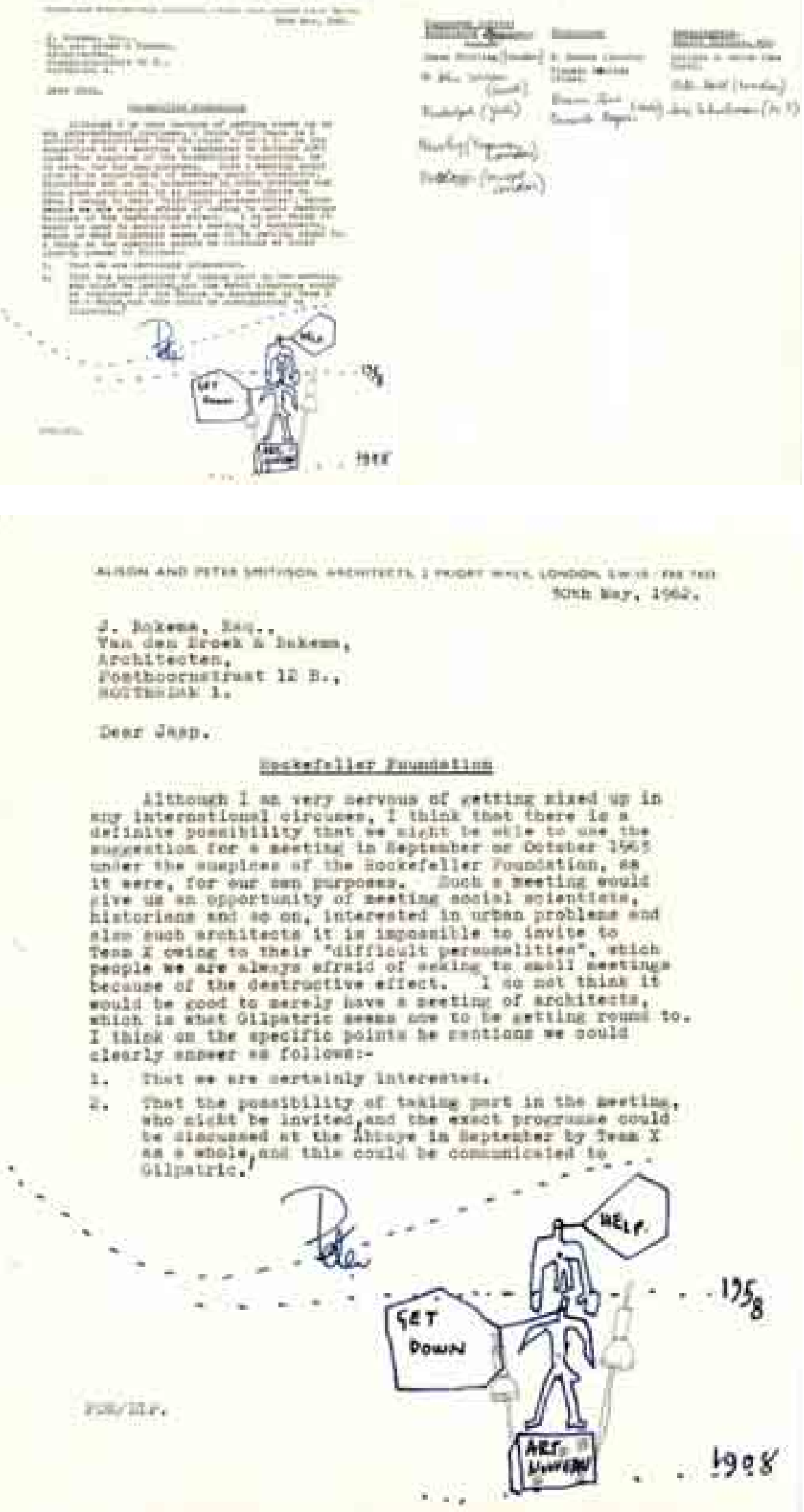

Figura 2.11

Carta a Bakema de Peter Smithson, un año después de la de Le Corbusier, con un dibujo que reinterpretándolo.

Team 10 Bakema Archive en NAi Collection and Archives en Rotterdam

Documento inédito. 


\subsubsection{Modelos vernáculos y escalas de asociación.}

Francis Strauven en Aldo van Eyck, the Shape of Relativity expone como el mensaje de Le Corbusier, supuso un reconocimiento para el Team 10: «they once more enjoyed the backing of Le Corbusier», y como es en Dubrovnik donde las diferencias de pensamiento se agrandan de forma determinante. Los miembros del grupo estaban molestos por la actitud condescendiente de los mayores, que después de su escepticismo hacia las nuevas ideas, posterirmente quisieron hacerlas suyas e incorporarlas a su "legado". Por ello habían decidido tomar allí su propio camino de acuerdo al trabajo preparatorio desarrollado en los dos años anteriores, y en realidad el Team 10 desarrolló su propio ${ }^{24}$ congreso dentro del CIAM 10. Ignorando los debates de la rama oficial, se expusieron 39 grids de acuerdo con las escalas de asociación del diagrama de Doorn, organizadas en 4 grupos.

Alison y Peter Smithson presentaron al menos 5 grids para diferentes tipos de comunidad: aislada, pequeña, grande, pueblo y ciudad, acompañados de cinco proyectos de vivienda ${ }^{25}$ correspondientes a cada escala de asociación. En misma línea presentaron Voelcker y Howell, mientras que Bakema expuso la última versión del Alexander Polder y Van Eyck una serie de playgrounds en Amsterdam y el nuevo asentamiento de Nagele, evidenciándose los diferentes planteamientos de los grupos inglés y holandés ${ }^{26}$.

Mientras los proyectos británicos responden a la especifidad de un pueblo o ciudad concreta y por tanto su carácter es fragmentario, y en algunos casos, regionalista, los de los holandeses, situados en la nada de los territorios recientemente polderizados, tendían a establecer los nuevos asentamientos a partir de un explícito lenguaje geométrico y universal.

Los Smithsons, que defendían la necesidad de desarrollar nuevas formas de hábitat o «nuevos modelos de comunidad», consideraban que los holandeses solo estaban comprometidos en «un estudio sistematico de las "relaciones" que podía conseguirse con nuevas disposiciones de los tipos existentes de vivienda". Los holandeses por su parte, pensaban que los ingleses estaban enredados en un regionalismo sentimental.

El pensamiento británico era esencialmente empírico e inductivo, primordialmente dirigido a introducir cambios estructurales locales en un contexto existente, mientras que el holandés se caractizaba por una forma deductiva e ideal, intentando desarrollar sistemas diferenciados sobre la base de principios generales. (Strauven 1998)

Es interesante reseñar que el planteamiento anteriormente descrito, de los participantes ingleses y de los Smithson en particular, es en gran parte heredero de las bases paisajistas del Pintoresquismo ingles del siglo XVIII, tal como se desbribe desde las paginas de Architectura Review en el editorial del 50 aniversario de la revista y en el numero especial sobre el Festival of Britain en 1951, ya comentadas anteriormente.

\footnotetext{
24 Peter Smithson explica como acordaron que cada representante de un grupo nacional aceptaría destruirlo para que otro equipo pudiera empezar. Tambien contribuyó el idioma: frente a la organización francesa de los CIAM, se comprometieron a hacer los debates en inglés, aprovechando la circunstancia de su auge después de la II Guerra Mundial, cuando los aliados propiciaron su utilización como idioma internacional. (Spellman y Unglaub 2004)

${ }^{25}$ El debate arquitectónico de posguerra es la construcción de vivienda a gran escala, lo que implica estrategias para la realización no solo de nuevos barrios de crecimiento en las ciudades sino también nuevos asentamientos de población en el campo. La construcción de new towns al igual que las poblaciones ex novo realizadas en los Paises Bajos, con excepción de Nagele (ver epigrafe 3.3 del capitulo siguiente) reprodujeron superficialmente y en su peor versión parte de ese sentir colectivo de las bondades del campo, lo rural y la tradición vernácula frente a la ciudad y lo moderno.

${ }^{26}$ A pesar de las diferencias y el debate, Peter Smithson quedó fuertmente impresionado por los playgrounds presentados por Van Eyck, impresión por otra parte generalizada entre los miembros de Team 10, y a Van Eyck le interesaron dos de los proyectos presentados por los Smithsons: The Close Housing y The Terrraced Houses. (Strauven 1998)
} 
En este sentido podemos decir que la relación cultural con el paisaje y el territorio de cada país, no solo ha sido determinante históricamente sino también muy influyente en los planteamientos urbanos y arquitectónicos del Team 10, y aunque con los mismos objetivos generales, mientras que los Smithson están trabajando sobre nuevos tipos de vivienda y sus escalas de asociación según el lugar, Van Eyck y De 8 en Opbouw, investigan sobre como conferir identidad a los nuevos asentamientos en los polder. Es decir el lugar es siempre determinante aunque con dos estrategias diferentes: por acción positiva cargada de matices y siginificado en la cultura inglesa y por omisión en la cultura polder en los Paises Bajos.

Los proyectos presentados por los Smithsons, estructurados en cinco grids con cuatro paneles cada uno y organizados verticalmente a modo de scroll, comenzaban en todos los casos con ejemplos y referencias vernáculas como modelos a seguir para los distintos tipos de vivienda. Aspecto que consideramos relevante y sobre el que no se ha incidido suficiente a pesar de los numerosos estudios realizados de estos proyectos.

Burrows Lee Farm, un proyecto de 1953 para una casa de campo aislada en Surrey; los Galeon Cottages, como modelo de crecimiento para un pueblo pequeño; las Fold Houses o casas redil, tipos de vivienda individual en un pueblo grande, pensadas para vacios de tejidos ya consolidados; las Close Houses, un grupo de viviendas bajas concebidas como parte de una new town rural y ligadas a un pasaje cubierto peatonal; y por ultimo las Terraced Houses, un conjunto de bloques de vivienda en un barrio industrial de una gran ciudad con forma de media luna.

Sin pretender hacer un análisis exhaustivo de los ejemplos utilizados por los Smithson, si es interesante señalar que excepto los ejemplos no ingleses dados en las Close Houses $^{27}$ y no especialmente referidos al tipo de vivienda, todos los demás no son ejemplos al azar, sino verdaderos fragmentos de la historia británica e inglesa. Incluso las Terraces Houses, en las que aunque no lo proponen explícitamente, las referncias a los crescent en Bath son evidentes.

En el primer proyecto, la Burrows Lee Farm, una vivienda aislada en el campo, elevada en planta baja e inserta en un jardín artificial formado por un talud vegetal de forma circular $^{28}$, proponen como modelo histórico en el Castle Rising en Norkflok: «Historical parallel: a house isolated by a circular earthwork»

Es una fortaleza medieval de las más importantes y mejor conservada en Inglaterra, con un sistema de murallas exteriores, defensas y fosos ataluzados realizados mediante imponentes movimientos de tierra, considerados por los historiadores entre los más impresionantes de Gran Bretaña ${ }^{29}$. Con una ocupación de 20 hectáreas, en el centro se asienta el castillo, sobre la elevación principal de forma sensiblemente circular formada por taludes de hasta 18 metros de altura desde el fondo del foso.

\footnotetext{
${ }^{27}$ Proponen varios ejemplos como referente de su pasaje cubierto peatonal: un conjunto de perforaciones de agua en el Sahara, los patrones seguidos por las tiendas de campaña en los campamentos de la guerra de Crimea o patios holandeses

${ }^{28}$ El interés de los Smithson por trabajar con movimientos de tierra confirando el entorno sobre le que asienta el edificio, esta presente en muchos de sus obras.

${ }^{29}$ Los primeros castillos en Inglaterra, precursores de los medievales, no fueron construidos en piedra, pero tenían considerables defensas hechas de tierra herederas de sus antecesores prehistóricos. Sus edificios eran de madera y muchos de fueron reconstruidos sucesivamente por lo que apenas son rastreables bajo las sustituciones posteriores. Sin embargo las imponentes configuraciones realizadas mediante movimientos de tierra, sobre los que se construyeron todavía sobreviven, en unas 700 fortificaciones solo en Inglaterra, clasificadas en dos tipos principales: ringworks, que son defensas simples normalmente circulares y los mottes, que son montículos circulares con superficie plana en la cima.
} 
El segundo proyecto presentado por los Smithson fue una propuesta de crecimiento para una pequeña población, al que llamaron Galleon Cottages o «village unité», unidad de aldea. Planteada como alternativa a las viviendas suburbanas convencionales normalmente ajenas a cualquier relación con el lugar en el que se construyen, las Casa Galeon consisten en una hilera formada por cinco viviendas, diferentes entre si, pero con unidad arquitectónica, cuya caracterísitca principal es una buena implantación en el paisaje rural resultado de la solución dada a los jardines y su relación con el campo abierto y vías del entorno. Para ello ponen como modelo vernáculo la población de Staithes, en North Riding of Yorkshire y sus primeras actuaciones de crecimiento en el siglo XIX sobre el acantilado.

Staithes se ubica en El Parque Nord York Moors National Park y se conforma de manera espectacular por la topografía costera circundante rodeada de acantilados. Su principal interés reside en el patrón de asentamiento y su relación con el territorio, así como en el valor global de su paisaje urbano, más que en edificaciones concretas.

La población se divide en dos áreas principales: la mas antigua de pescadores en la parte inferior, y la superior sobre el acantilado que se desarrolló a finales del siglo XIX y principios del siglo XX en un momento de expansión económica de la zona ligado a su pasado minero y el advenimiento de la vía férrea, y a a que se refieren los Smithson.

En las Fold Houses proponen como modelo el pueblo de Tiree en la Isla de Tiree en las Highlands de Escocia, una aldea conformada por pequeñas granjas sueltas «a croft community» en un espacio urbano cubierto de hierba, sin distinción de calles, aceras, o propiedades privadas, al que los Smithsons hacen referencia «preservation of the terrain and herbage». Los cottages tradicionales, de una sola planta y poca altura, se caracterizan por una singular técnica constructiva de cubiertas de paja, thatch, y muros de piedra en seco, parcialmente revestidos. Los muros, de gran espesor, comúnmente seis pies de espesor, tienen ventanas de inserción profunda y una puerta. La estructura de cubierta se apoya en la hoja interior más gruesa y el agua de lluvia de la cubierta evacua entre las dos capas de piedra. Hierba o flores, crecían en la coronación de estos gruesos muros o «tobhta» siendo habitual que perros, gallinas e incluso ovejas subieran a ellos. Este muro ciego que rodea las viviendas en la propuesta de los Smithsons, que según su posición permite un patio y diferentes variantes del tipo, es sin duda una interpretación de los dobles muros de Tiree.

Tambien muestran una fotografía de West Burton, en North Riding Yorkshire, al que se considera uno de los pueblos más bonitos del Parque Nacional de Yorkshire Dales, con un gran green peatonal sin tráfico de vehículos.

Tiree, West Burton y Staithes son modelos muy diferentes de asentamiento, pero con la característica común de haber dado una respuesta urbana adecuada a las necesidades de crecimiento en épocas de prosperidad económica durante los siglos XVIII y XIX, basada normalmente en el auge de la minería y el ferrocarril, y en relación con la Revoiución Industrial. 

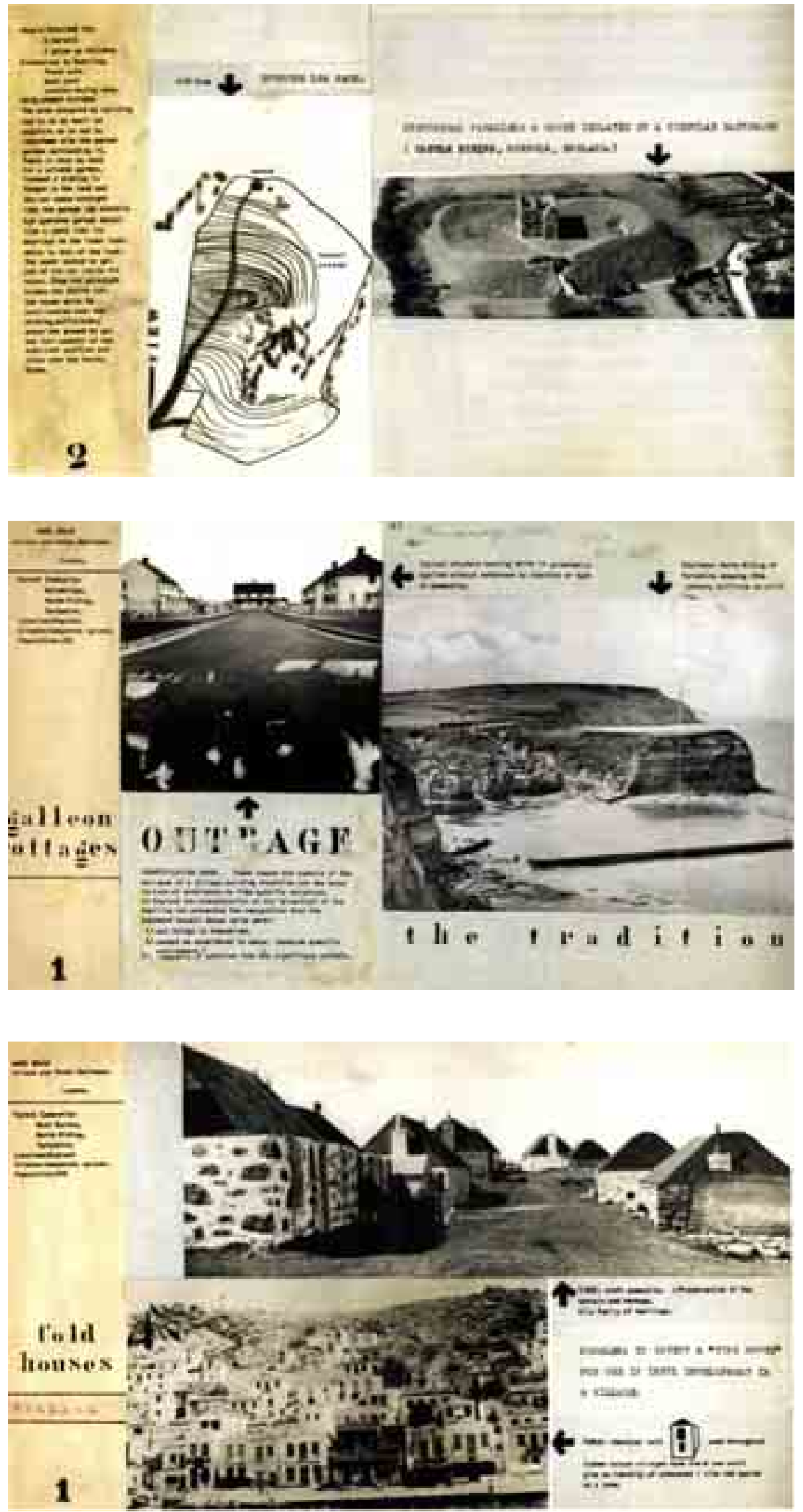

Figura 2.12

Detalle de modelos vernáculos para los proyectos presentados por los Smithson en el CIAM X de Dubrovnik, para las distintas escalas de asociación. 

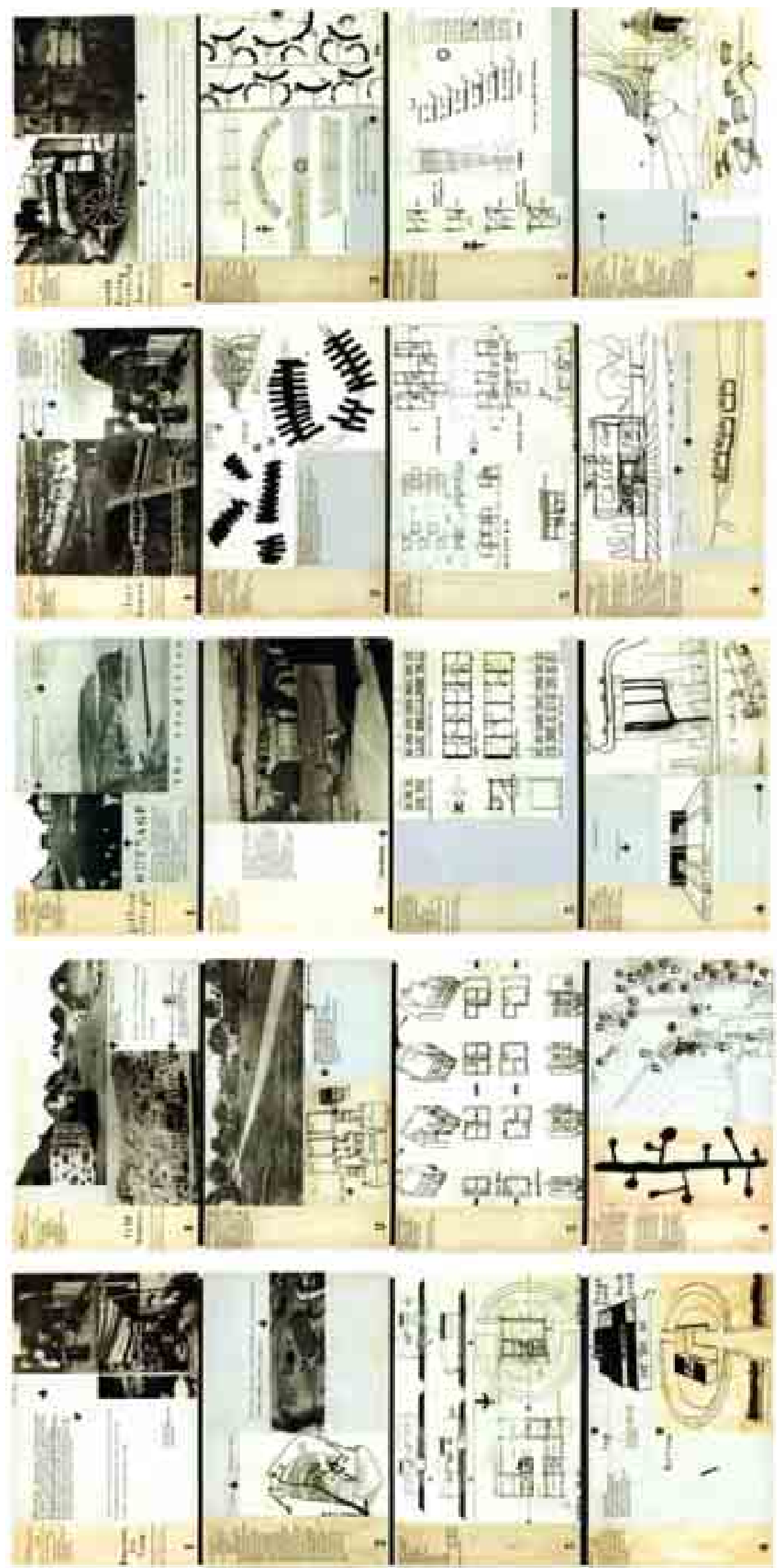

Figura 2.13

Modelos vernáculos para los proyectos presentados por los Smithson en el CIAM X de Dubrovnik, para las distintas escalas de asociación. Estructurados en cinco grids con cuatro paneles cada uno y organizados verticalmente a modo de scroll, comenzaban en todos los casos con ejemplos y referencias vernáculas como modelos a seguir para los distintos tipos de 


\subsubsection{As found y Found: una manera de ver el mundo y también lo vernáculo.}

\subsubsection{1. "As found" y "found". El "según se encuentra" y "lo encontrado".}

En 1990 Alison and Peter Smithson publican "The as found and the found " en The Independent Group: Postwar Britain and the aesthetics of plenty, catálogo de la exposición ${ }^{30}$ de el mismo nombre editado por The MIT Press Cambridge (Mass), a cargo de David Robbins. Los Smithson escriben:

Visto desde finales de los 80

El "según se encuentra", donde el arte está en recoger, dar la vuelta y poner con... y "lo encontrado", donde el arte está en el proceso y en el ojo observador...

\section{Con mirada retrospectiva... El "Según se encuentra" en Arquitectura:}

En arquitectura, le estética del "según se encuentra" era algo a lo que pensábamos que le habiámos puesto nombre al principio de los 50 cuando conocimos a Nigel Henderson y vimos en sus fotografías un reconocimiento perceptivo de la realidad que había alrededor de su casa de Bethnal Green: graficos de juegos de niños en la calzada; repetición de "kind" en puertas utilizadas como vallas protectoras de solares; los objetos de los detritos de sitios bombardeados, como la bota vieja, montones de clavos, trozos de saco o de malla, etc.

Asignándonos a nosotros mismos la tarea de repensar la arquitectura a principios de los años cincuenta, con "según se encuentra" nos referíamos no solo a edificios adyacentes sino a todas aquellas señales que constituyen los recuerdos de un lugar y que hay que leerlos averiguando cómo la construcción que hay en el lugar había llegado a estar como estaba. De aquí nuestro respeto por los árboles viejos como "estructura" existente de un lugar en el que el edificio sería el recién llegado...En cuanto la arquitectura empieza a ser pensada, su ideograma debería ser tan afectado por el según se encuentra como para convertirlo en específico del lugar. (Smithson y Smithson 1990, $201-$ 202)

Es sorprendente como uno de los planteamientos más conocidos y certeros de los Smithsons, no se publicara con una definición explícita hasta 1990.

Aun no habiendo sido explicitada con anteriordad, toda su obra plagada de testimonios "as found", siendo las exposiciones "Patio and Pavilion" en This is Tomorrow y Parrallel of life and art, hechas en el ámbito del Independent Group ${ }^{31}$ con Nigel Henderson y Eduardo Paolozzi, las primeras e impactantes muestras de ello.

\footnotetext{
${ }^{30}$ Exposición celebrada en Londres en el Institute of Contemporary Arts ICA, entre el 1 de febrero y el 1 abril. Del 12 de Junio al 26 de agosto de 1990 en el IVAM de Valencia, publicándose la edición en lengua española del catálogo El Independent Group: la posteguerra británica y la estética de la abundancia, segun tradución de Jorge García, Eusebi Moreno y Criso Renovell. Texto de consulta obligada en temas relacionados con el IG.

${ }^{31}$ Lawrence Alloway en unas notas sobre El Independet Group: La posguerra británica y la estética de la abundacia, publicado en el libro del mismo titulo mencionado anterioremente, dice sobre el IG:«Un sentido de aislamiento tanto geográfico como generacional en la Inglaterra de la posguerra condujo a la fundación del Institute of Contemporary Arts (cuya primera gran exposición fue "40.000 Years of Modern Art" en 1949") y a la posterior aparición del Independent Group»; «en torno a Reyner Banham había un grupo de arquitectos. Formaban un grupo tolerante y especulativo, próximo a las artes visuales pero no necesariamente procedentes de ellas, como muchos en el IG. Así, J.D.H. Catleugh, Peter Carter, Alison y Peter Smithson, James Stirling, John Voelcker y Colin St. John Wilson, relacionados todos con el IG, estaban en contacto con Banham, que trabajaba en revistas de arquitectura (era editor de Architectural Review y de Architects Journal), y a través del IG con Crosby, que era editor de Architectura Design. Crosby fue el principal organizador de This is Tomorrow en 1956, considerada generalmente como el fin del IG».
} 

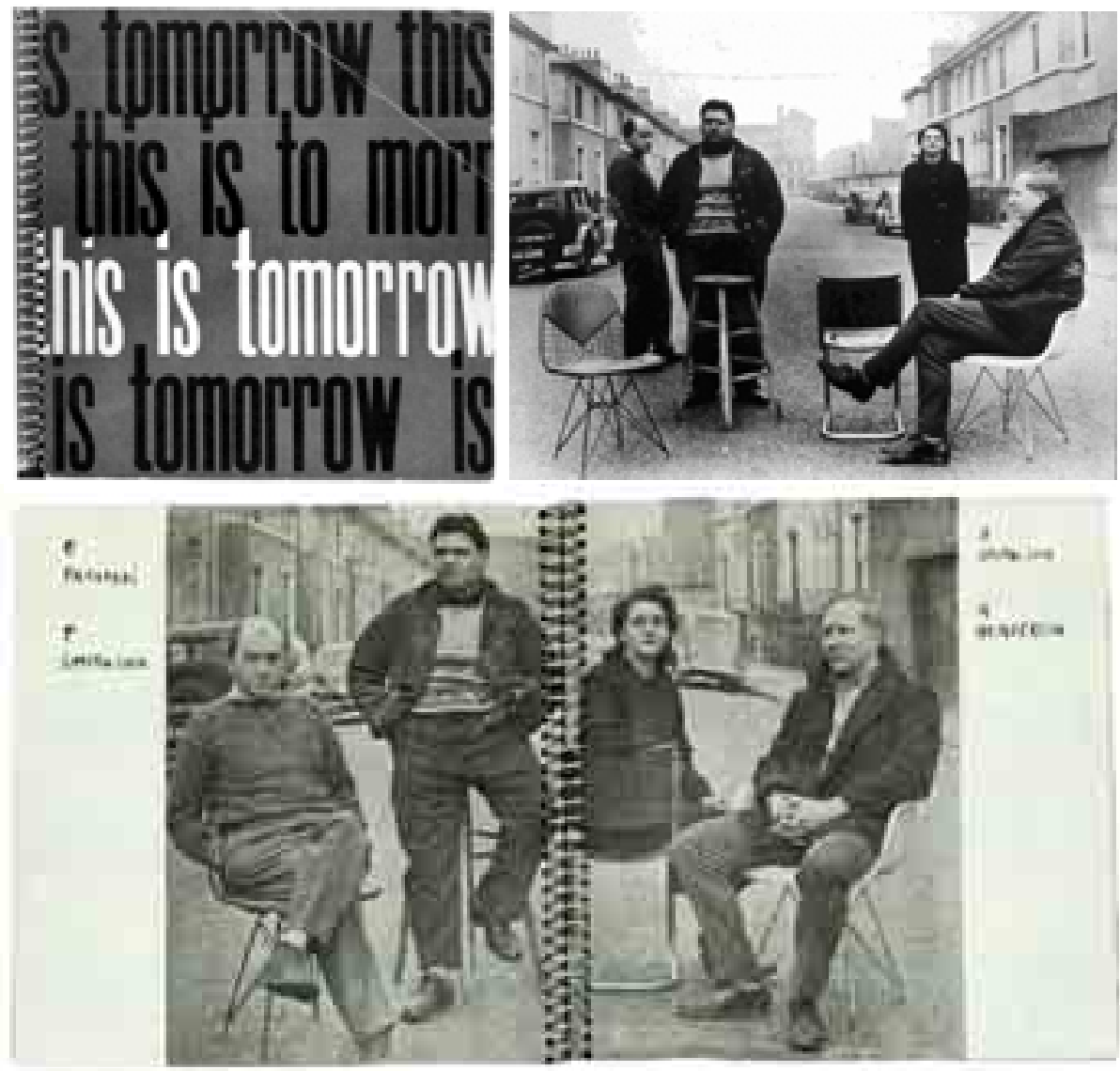

Figura 2.14

Catálogo de la Exposición This is Tomorrow. Londres, The whitechapel art gallery.

9 agosto - 9 septiembre 1956. El Grupo 6 (Peter Smithson, Eduardo Paolozzi, Alison Smithon y Nigel Henderson) de los doce participantes en la exposición fotografiados por Henderson en Limerston Street. La imagen superior derecha, no incluida en el catalogo, muestra las cuatro sillas, todas diferentes: una versión de la Ceska de 1928 de Marcel Breuer, la Wire Chair de 1951 de Charles and Ray Eames en su versión "bikini" con cojín en asiento y respaldo y la Plastic Armchair de 1950, también de los Eames y ambas con base Eiffell Tower. Junto a tres iconos del Movimiento Moderno, un humilde taburete, anónimo, rustico y popular, de madera y anea. (Robbins 1990 b, 155)

Parallel of life and art, and Exhibition of Landscape, Science and Art, celebrada en el ICA en septiembre de 1953, en un principio se iba a llamar Sources.

«El propósito de esta exposición es presentar material que pertenece íntimamente a los antecedentes culturales de quien busque observar las cosas de hoy»; «El método consistirá en yuxtaponer ampliaciones fotográficas de imágenes extraidas de la vida, la naturaleza, la industria, los edificios, y las artes, de fenómenos interrelacionados que integran el Nuevo Paisaje revelado por la ciencia experimental y creado por los artistas y los teoricos. Estas imágenes no pueden disponerse formando una relación consecutiva. Por el contrario, determinará una serie intrincada de relaciones cruzadas entre los distintos campos del arte y la técnica. Tocará un amplio espectro de asociaciones que ofrecerán analogías fructíferas...una especie de piedra Rosetta. Proporcionará, en definitiva un esbozo, una delineación fugaz de las características de nuestro tiempo, tal y como se presentan a un grupo específico que trabaja en unión» (Vidoto 1997) ${ }^{32}$

32 Traduccion del libro de GG. Textos originales en inglés en The Charged Void: Architecture, que son a su vez extracto de los documentos preparatorios de la exposición, conservados por los Smithsons y publicados en Robbins, David Ed. The Independent Group: Postwar Britain and the aesthetics of plenty. Cambridge (Mass): The MIT Press. 

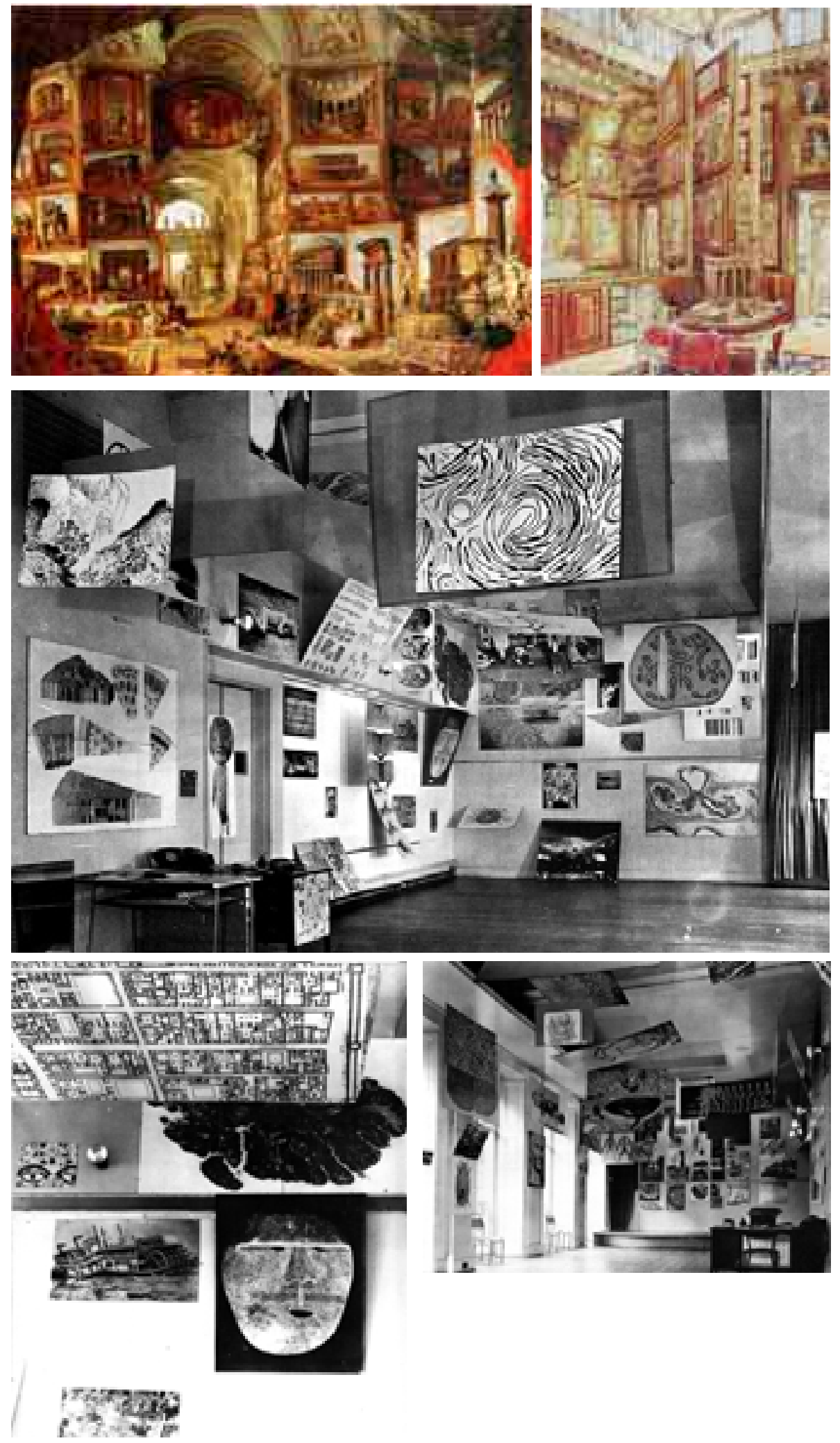

Figura 2.15

Superior izquierda Galería de vistas de la Roma Antigua, 1756-1757, de G.P.Panini (Marchan-Fiz 2010)

Superior derecha: Dibujo de la casa museo de John Soane en Londres.

Centro e inferior derecha: Vista general de la Exposicion Parallel of life and art.

Inferior izquierda: Detalle de un fragmento de la exposición en donde se pude apreciar la contraposición de imágenes, entre ellas la planta de una ciudad antigua y la talla esquimal en hueso de ballena, portada de AR en el numero octubre de1953, en el que se publicó Parallel of Life and Art. 
La forma de exponer con gran cantidad de imágenes, en gran parte suspendidas del techo y aparentemente colocadas sin relación entre si, como fragmentos amontonados, recuerdan el cuadro de G.P.Panini, Galería de vistas de la Roma Antigua, 1756-1757

No se trata en este trabajo de disertar sobre "as found" y "found", tema del que hay importantes textos ${ }^{34}$.

Lo que se propone desde este trabajo, es que la relación de los Smithsons con la historia y lo vernáculo, es parte del mismo planteamiento. La potencia de esta forma de mirar el mundo les permite abarcar todo: lo grande y lo pequeño, lo ordinario y lo excepcional, lo culto y lo popular y también lo vernáculo y lo moderno, estableciendo relaciones yuxtapuestas en muchas ocasiones basadas en el dialogo entre opuestos, donde la preexistencia vernácula es «as found» y la intervención «found».

Este es el caso del Pabellón Upper lawn, donde esa mirada abarca el conjunto de la obra, así como como fragmentos y vivencias a lo largo de veinte años.

Figura 2.16

Tarjeta de invitación para una visita privada a Opposing Forces, exposición celbrada en el ICA, entre enero y marzo de 1953.

(Robbins 1990 b, 24)

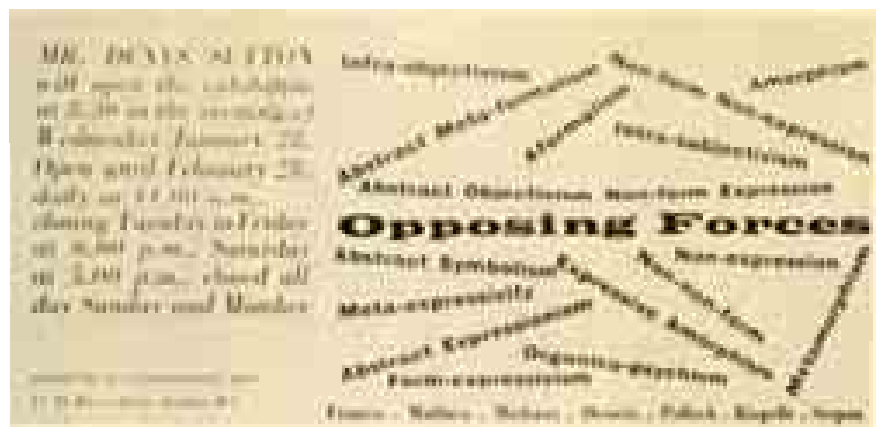

${ }^{33}$ Simón Marchan Fiz, en La disolución del clasicismo y la construcción de lo moderno

«...los viajeros y los paseantes que redescubrían hitos del paisaje que solían pasar un tanto desapercibidos y ahora eran reivindicados, una vez más, en virtud del papel que juega el nuevo espectador. Me refiero a la capacidad de este para percibir de modo inédito las ruinas como permanencias pasadas en las ciudades y los hitos que jalonan los horizontes del paisaje»

«Desde la órbita de nuestros días, podríamos comparar la ruina percibida en el paisaje natural con el moderno «objeto encontrado» de las corrientes dadaístas, si bien, más en consonancia con su condición, prefiero llamarla «fragmento encontrado" que nos cautiva por unas apariencias físicas pronto transfiguradas en estéticas»

«En esta dirección, al mismo tiempo que Canaletto se trasladaba a Escocia, otro italiano, el pintor y escenógrafo G.P.Panini, pintaba Roma antica (1756-1757), una galería de vistas en las que se reproducen por separado, a modo de pequeñas viñetas, los monumentos y las ruinas de antigua Roma en el estado en que se encontraban entonces"...

«De hecho, se trataba de una galería de cuadros reunidos en una sola pintura, colgados de manera amontonada y aislada en los paramentos simulados de una estancia...»

«La representación de cada uno de ellos como si fueran fragmentos encontrados semeja un collage pictórico que los insiere en un espacio irreal, completamente virtual, en donde conviven simultáneamente los hitos icónicos de las arquitecturas y las esculturas o sus fragmentos.

${ }^{34}$ Relación no exhaustiva de textos sobre as found y found:

- Smithson, Alison and Peter Smithson. 1956. "But Today We Collect Ads" Ark: the Journal of the Royal College of Art; $n^{\circ} 18$ November; pp. 185-186

- Smithson, Alison and Peter Smithson. 1990 a. "The as found and the found ". Robbins, David Ed. The Independent Group : Postwar Britain and the aesthetics of plenty. Cambridge (Mass): The MIT Press.

- Lichtenstein, Claude. 2001. As found: the discovery of the ordinary. Lars Muller Eds.edited by Claude Lichtenstein, Thomas Schregenberger

- Schregenberger, Thomas. 2003. "As Found is a small affair, it is about being careful". Werk, Bauen und Wohnen 6-2003, Zürich CH

- Van den Heuvel, Dirk. 2004. "Picking up, Turning over and Putting with...". Alison and Peter Smithson - from the House of the Future to a house of today, Rotterdam: 010 Publishers.

- Serrano Avilés, Ramón. 2009. " As found y experiencia del fragmento. Debate entre imagen y preexistencia en la producción artística británica de la inmediata posguerra". Cuaderno de Notas 12. Madrid: Departamento de Composición de la E.T.S. Arquitectura,UPM 


\subsubsection{2. "As found" y "found" en Upper Lawn.}

Joan Miró, durante sus estancias en Montroig ${ }^{35}$, iba todas las mañanas a la playa al amanecer, «para recoger cosas traídas por la marea. Las cosas estan allí, esperando que alguien descubra su personalidad». Los hallazgos se iban almacenando en el estudio, hasta que en un momento determinado trabajaba con ellos juntándolos en composiciones sorprendentes: «el artista se sorprende con frecuencia de las formas de su propia creación».

Al igual que Picasso y Braque, cuando en 1912 reuniendo restos de papel inventaron lo que llamaron collage, Kurt Schwitters, llevándolo al extremo y trabajando con despojos de la basura en el sentido más literal del término, consiguió exaltar los materiales mas toscos y sin ningún valor hasta la categoría de arte «con tal seriedad y novedad que obtuvo efectos de sorprendente belleza».

En 1914, cuando Marcel Duchamp expuso su Botellero, iniciando el arte de «lo concreto", al convertirse en icono y también en objeto de burla, lo despojó por completo de su realidad y significado intrisecos. Aunque se calificaba de «antiartista», con el objet trouvés6 inició un camino que recorre el arte moderno.

En realidad, estaban continuando la doctrina de los alquimistas medievales, que creían en el «espíritu de la materia» y para quienes «la búsqueda de objetos preciosos se ha de hacer en la basura» En la misma línea Kandinsky dice: «Todo lo que esta muerto palpita. No solo las cosas de la poesía, estrellas, luna, bosque, flores, sino aún un botón de calzoncillo brillando en el lodazal de la calle...Todo tiene un alma secreta, que guarda silencio con más frecuencia que habla» (Jaffé 1964, 253)

El universo as found y found de los Smithson es heredero de esta línea de pensamiento, en la que ellos hacen una brillante aportación cuando trascienden la escala y materializan en la arquitectura los hallazgos del arte moderno.

El Upper Lawn Pavilion, es un ejemplo paradigmático, donde la mirada as found y found lo abarca todo: la obra en su conjunto, así como como fragmentos y vivencias a lo largo de veinte años de los que quedan numerosos testimonios en Upper Lawn a Folly Solar Pavilion, su diario de la casa.

Volveremos al «espíritu de la materia» desde el concepto «conciencia material», definido por Richard Sennet en El Artesano, para analizar la materialidad de la casa en el epígrafe 2.5, pero antes, y a continuación una muestra de objetos encontrados, reciclados, buscados, expuestos, y vividos por la familia ${ }^{37}$ Smithson en Upper Lawn.

\footnotetext{
${ }^{35}$ Alex Fernandez de Castro también se refiere a este ritual de Joan Miró. Desde su primer verano en Montroig, cuando tenía dieciocho años, Miró bajaba por las mañanas temprano al mar, haciendo jogging -para sorpresa de sus vecinos-, por el camino desde la casa de sus padres hasta la playa de la Pixerota, y luego regresaba «cargado de objetos encontrados en la orilla». En 1911 la zona era todavía un enclave intacto, representativo de la más profunda tradición local y del pasiaje catalán. El cuadro de Miró La casa de la palmera, corresponde a una de las masias del camino, el Mas d' en Romeu. La Pixerota no estaba acondicionada prar el baño, y Fernandez de Castro, se refiere al estado de la zona a través de las fotografías de Ernst Schiedegger, de principios de los cincunta en las que «aparecia llena de pedruscos, ramas o raíces de cañas que el artista escudriñaba con la atención del buscador de oro» (Fernandez de Castro 2015, 24) Ver epígrafe 4.4.2. de la tesis y también, Fernández de Castro, Alex. 2015. La masía, un Miró para Mrs. Hemingway. Valencia: Publicacions de la Universitat de València

${ }^{36}$ Objeto «encontrado», «preparado» O «interpretado». Convertir en arte objetos cotidianos, en contraposición a lo que hasta entonces se consideraba arte.

${ }^{37}$ El mural de azulejos para el Old People's Club Room en los Robin Hood Garden, 1968-1970, formado por fragmentos recogidos en el terreno del proyecto por Alison y su hijo Simon y moldeados con cemento en la tapa de una caja de madera como encofrado (Robbins 1990 b, 200), corroboran la participación de los niños en actos as found.
} 


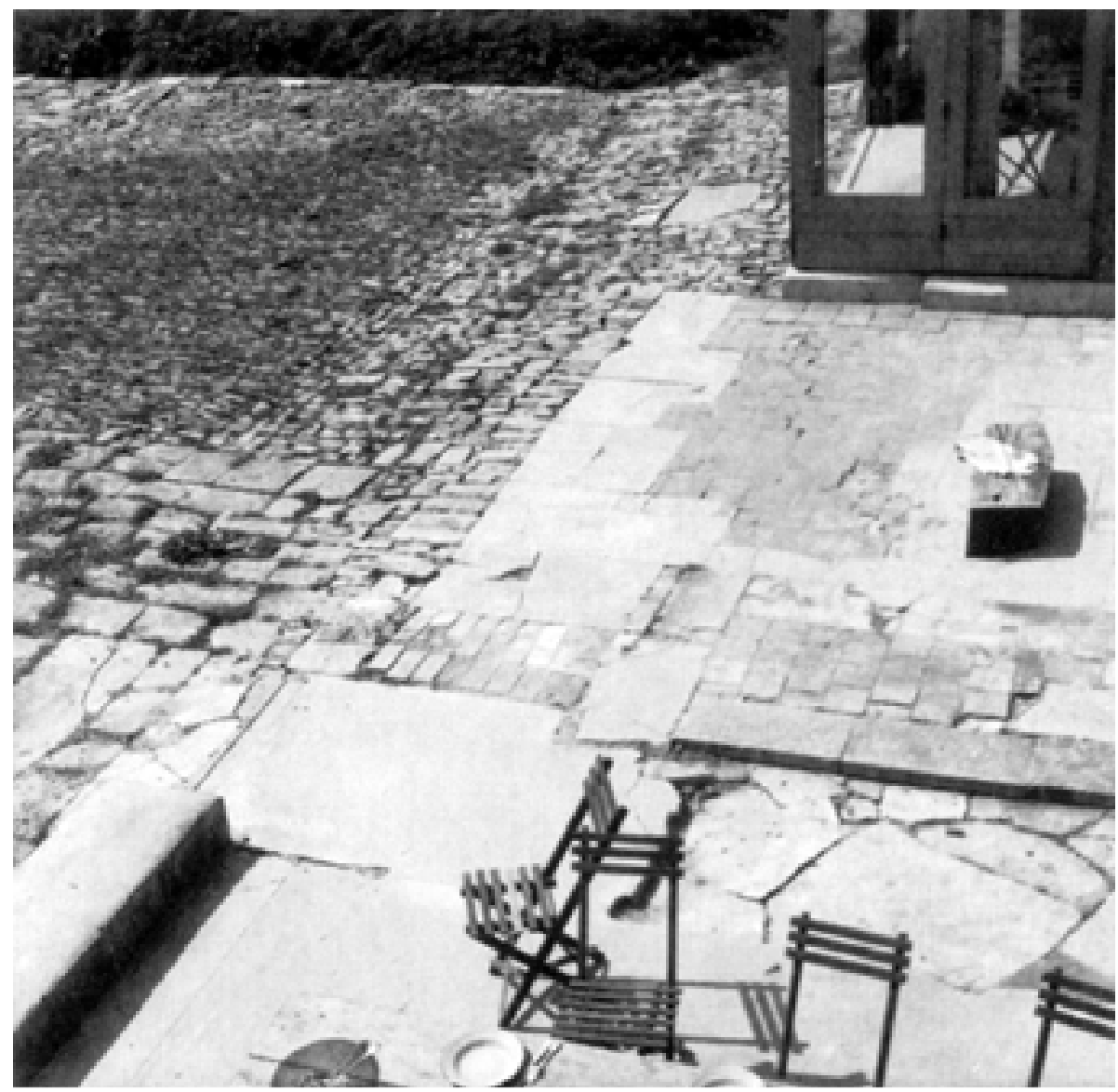

Figura 2.17

Huellas de lo vernáculo as found y found en el pavimento del Upper Lawn Pavilion.

Vista de pájaro del pavimento as found del recinto del Upper Lawn Pavilion y la huella de la antiqua edificación (Krucker 2002, 41)
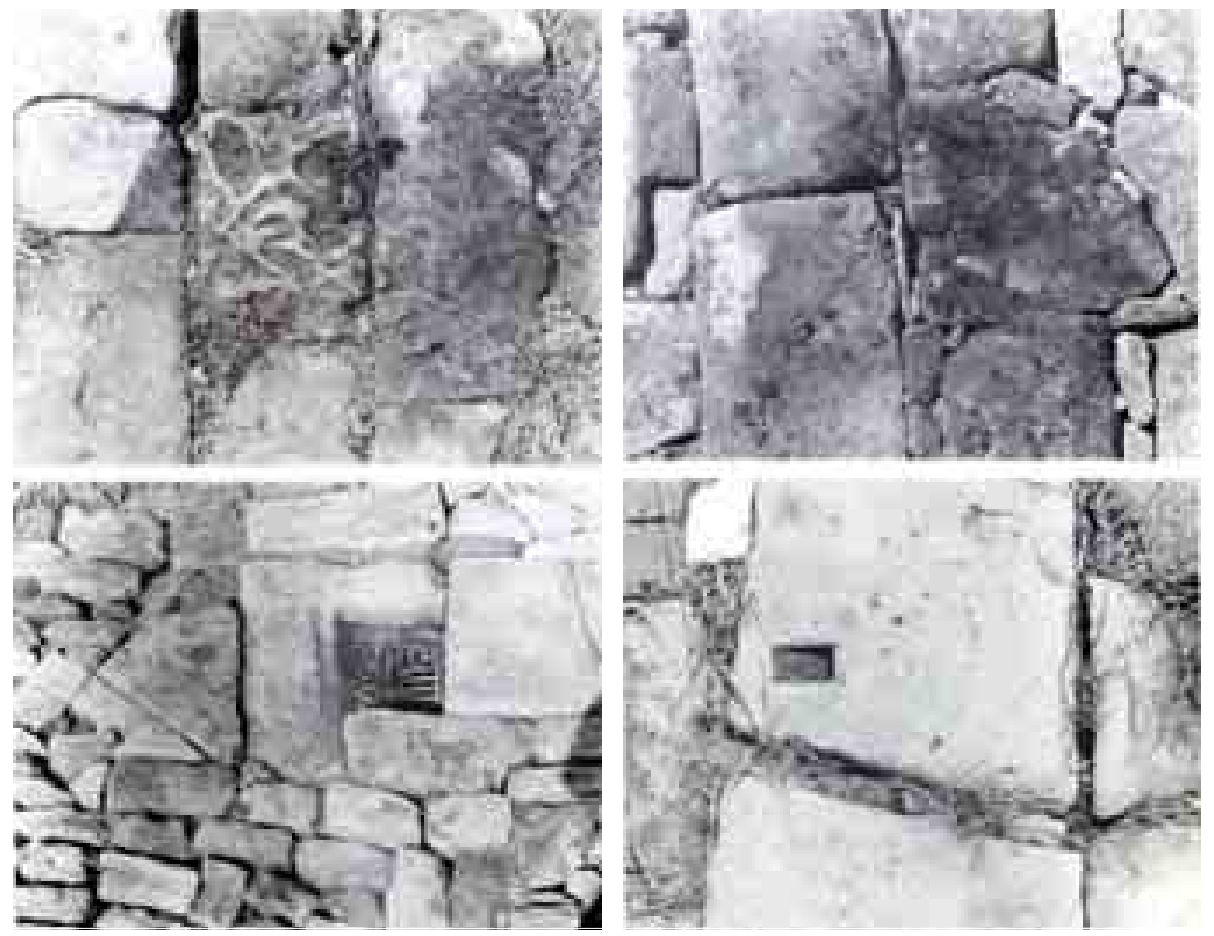

Figura 2.18

Huellas de lo vernáculo as found y found en el pavimento del Upper Lawn Pavilion, del diario de los Smithson sobre su vida en la casa. (Smithson y Smithson 1986).

De arriba abajo y de izquierda a derecha:

- El pavimento ante la granja de 1757, agosto de 1963

- El pavimneto restaurado en parte, por el deterioro de algunas piedras enterradas, agosto 1963

- El pavimento reparado junto a la rejilla de recogida de agua, agosto de 1963

- El umbral de entrada de una vieja granja, con el hueco donde apoyar el porche, agosto 163 

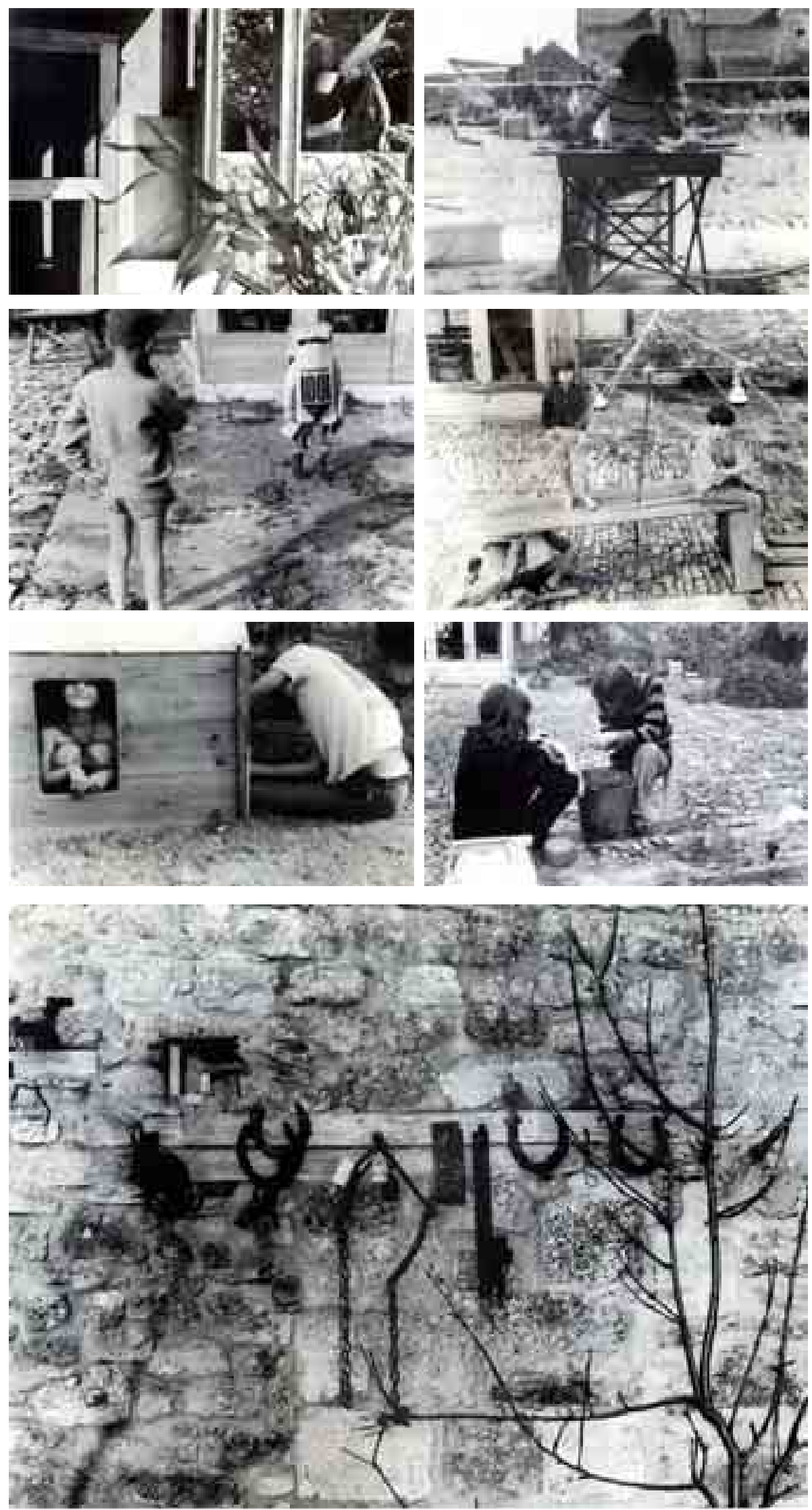

Figura 2.19

Huellas de lo vernáculo as found y found en el Upper Lawn Pavilion, del diario de los Smithson sobre su vida en la casa. (Smithson y Smithson 1986). De arriba abajo y de izquierda a derecha:

- Bambú hallado en el «Jardín Chino» de Fonthill, al borde la Plantación Americana, verano 1962

-Base plegable de mesa era el apoyo de un lavabo de lona que utilizaban en Birmania, junio 1964

- Caja de cartón de lámpara, reciclada como robot, noviembre 1962

- El «Barco Tisbury», lámparas fundidas de las incubadoras de la cercana granja de cerdo, 1964

- La primera encimera de la cocina, reciclada como casita de juegos, junio 1970

- Lavado de botellas y frgamentos de porcelana recogidos en terreno labrado, septiembre 1978

- Herraduras, arneses, objetos de hierro, cosas desenterradas...en exposición, diciembre 1968. 


\subsection{The Green Man y Jack Frost en el Upper Lawn Pavilion.} [Mito ]

\subsubsection{Upper Lawn en el corazón de Inglaterra}

El actual condado de Wilt o Wiltshire, fue considerado desde tiempos remotos el centro de Inglaterra. Ningun otro territorio británico, y pocos en Europa, tiene la concentración y relevancia de restos prehistóricos como los conjuntos neolíticos de Stonehenge y Avesbury, cercanos al Upper Lawn Pavilion. Es un condado poblado mayoritariamente por pueblos y aldeas enclavados en los valles de los rios, con Salisbury como única gran ciudad, y una arquitectura vernácula espectacular con diversidad de materiales.

En la población de Tisbury, demarcación administrativa a la que pertenece la finca Fonthill y Upper Lawn, se encuentra un granero del siglo XV, que con 200 pies de longitud es el más grande de Inglaterra, con una estructura de madera espléndida y «heroicamente» techado con la cubierta tradicional de paja de paja, «thatched». (Norwich 1985, 656)

A él se refieren los Smithson en Upper Lawn, Folly Solar Pavilion, en su descipción del conjunto de la antigua granja de Upper Lawn, en la que una de sus edificaciones es un granero, también del siglo XV, que fotografían en distintas ocasiones y al que le acaban de cambiar la cubierta-, que fue dependiente del citado Tisbury Tithe Barn, el Granero de Diezmos de Tisbury.

Tambien refieren en la misma publicación que la mayor parte de Imprint of India de Alison se preparó, entre otros, en Upper Lawn, y los padres de Rudyard Kipling «el poeta / celebrador del Imperio Britanico en la India» en palabras de los Smithsons, estan enterrados en el cementerio de Tisbury. De forma que »el pabellón y su recinto, hecho posible por un pacifico paisaje ingles, guiaron lecturas, gran cantidad de textos y trabajo editorial» (Smithon y Smithson 1986)

En el Upper Lawn Pavilion, los Smithsons intencionadamente criaron a sus tres hijos, mostrándoles la cultura, la historia y tradiciones de Inglaterra. En el interior de su jardín, cercado con una tosca mampostería de piedra almenada, mitad pavimentado as found y mitad lawn ${ }^{38}$ se recreaban pasajes de la cultura inglesa.

Un lugar especial en el corazón de Inglaterra, donde habita The Green Man, Puck o Jack Frost, personajes fantásticos del folklore inglés.
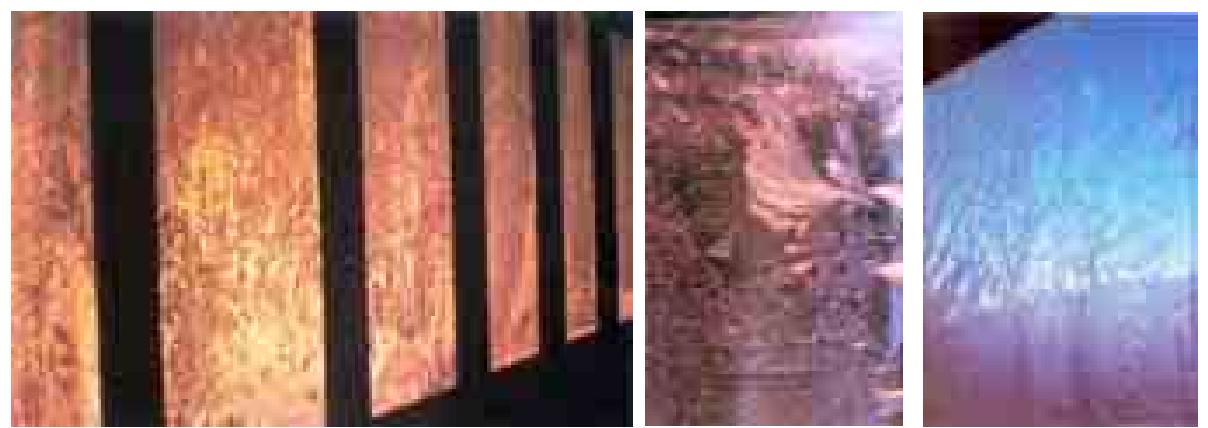

Figura 2.20

Huellas de Jack Frost en el Upper Lawn Pavilion. Imágenes publicadas por los Smithson en Upper Lawn, Folly Solar Pavilion, con los siguientes pies de foto:

Izquierda:

El amanecer iluminando a Jack Frost en las puertas a sur de la planta baja

* Centro

- Jack Frost sobre la ventana del piso de arriba al amanecer.

* Derecha:

Jack Frost sobre la gran ventana a norte del piso de arriba. (Smithson y Smithson 1986).

${ }_{38}$ Descrpcion hecha por Peter Smithson del Upper Lawn Pavilion SMITHSON, Peter. 2001. The Charged void: Architecture. Alison y Peter Smithson, New York: The Monacelli Press. 


\subsubsection{The Green Man, Puck, y Jack Frost en Upper Lawn}

Jack-Frost visitaba en invierno el Upper Lawn Pavilion, como los Smithson nos muestran a través de varias fotografías en Upper Lawn, Folly Solar Pavilion.

Jack Frost personifica la escarcha, el hielo y la nieve.

Es el responsable del cambio de color de las hojas en otoño y deja dibujos como hojas de helechos en la escarcha de los cristales de las ventanas cuando hace mucho frio. Pellizca o muerde la nariz y los dedos de los pies a la gente para darles escalofríos. Desde finales del XIX, se le ha ido identificando con una especie de duende o elfo. A veces se le identifica con otra personificación del invierno, el Old Man Winter, un anciano de larga barba y cabellera, blancas y onduladas, que sopla un viento congelador

Jack in the Green representa la primavera y participa en los desfiles del tradicional Dia de Mayo Ingles -English May Day-. Es un personaje de nueve pies, casi tres metros, con forma conica y cubierto de hojas, follaje y flores. Su origen parece provenir de los siglos XVI y XVII, cuando en Inglaterra se hacían guirnaldas de flores y hojas para el May Day, que se fueron sofisticando de tal manera que llegaron a cubrir todo el cuerpo.

Personajes fabulosos como Jack Frost o Jack in the Green, son personificaciones del invierno y la primavera. Muy arraigados en la cultura popular inglesa -tambien en otros países del norte de Europa de cultura celta-, cuentos y canciones hacen mención de ellos desde el siglo XVIII, y han llegado hasta a nuestros días ${ }^{39}$

The Green Man, o el Hombre Verde es un antiguo símbolo de la naturaleza, de la fertilidad y la vida salvaje, representado como una frondosa cabeza foliada. De origen pagano fue aceptado por el cristianismo y su imagen esta frecuentemente en iglesias y monasterios de toda Europa a partir del siglo XI, tallado en piedra en columnas, capiteles. Hay distintas representaciones de una variación extraordinaria: Una cara cubierta por hojas que salen de la boca y a veces también de ojos y orejas, caras con foma de hoja, o caras despejadas con el cuerpo cubierto de verde. Pueden ser benévolos o también algo demoniacos.

En Inglaterra es un símbolo ancestral tan arraigado en la cultura popular, que tiene diversas manifestaciones: The Green Man, Puck, Jack in the Green, Robin Goodfelow, Robin Hood..., todos comparten el espíritu del Hombre Verde.

También Simon Smithson disfrazado de Hombre Verde con un manto de seto en octubre de 1966, como dice el pie de foto de la imagen 56 en el diario de la casa.

En la literatura inglesa, el personaje de Puck aparece ya en 1595 en Sueño de una noche de verano de William Shakespeare, y en 1906 Rudyard Kipling escribe Puck of the Pook's Hill, una historia de Inglaterra para niños, protagonizada por ellos, -Dan y Una-, y presentada por el duendecillo Puck.

Francisco Gonzalez de Canales Ruiz, en su texto "Una estancia en el exterior. Estampas de Puck y arquitecturas análogas", posteriormente incluido en su libro Experimentos con la vida misma. Arquitecturas domésticas radicales entre 1937 y 1959 (Gonzalez de Canales 2012), ya citado en paginas anteriores, hace un brillante análisis comparativo entre episodios del libro de Kipling y algunas de las fotografías tomadas por Alison y Peter Smithson sobre su vida en la casa, y publicadas en Upper Lawn Folly, Solar Pavilion.

\footnotetext{
39 Jack Frost protagoniza actualmente películas, comics y videojuegos.

Respecto a The Green Man, numerosos pubs ingleses tienen su nombre y actualmente se ha convertido a veces en el icono no oficial de movimientos ecologistas.
} 

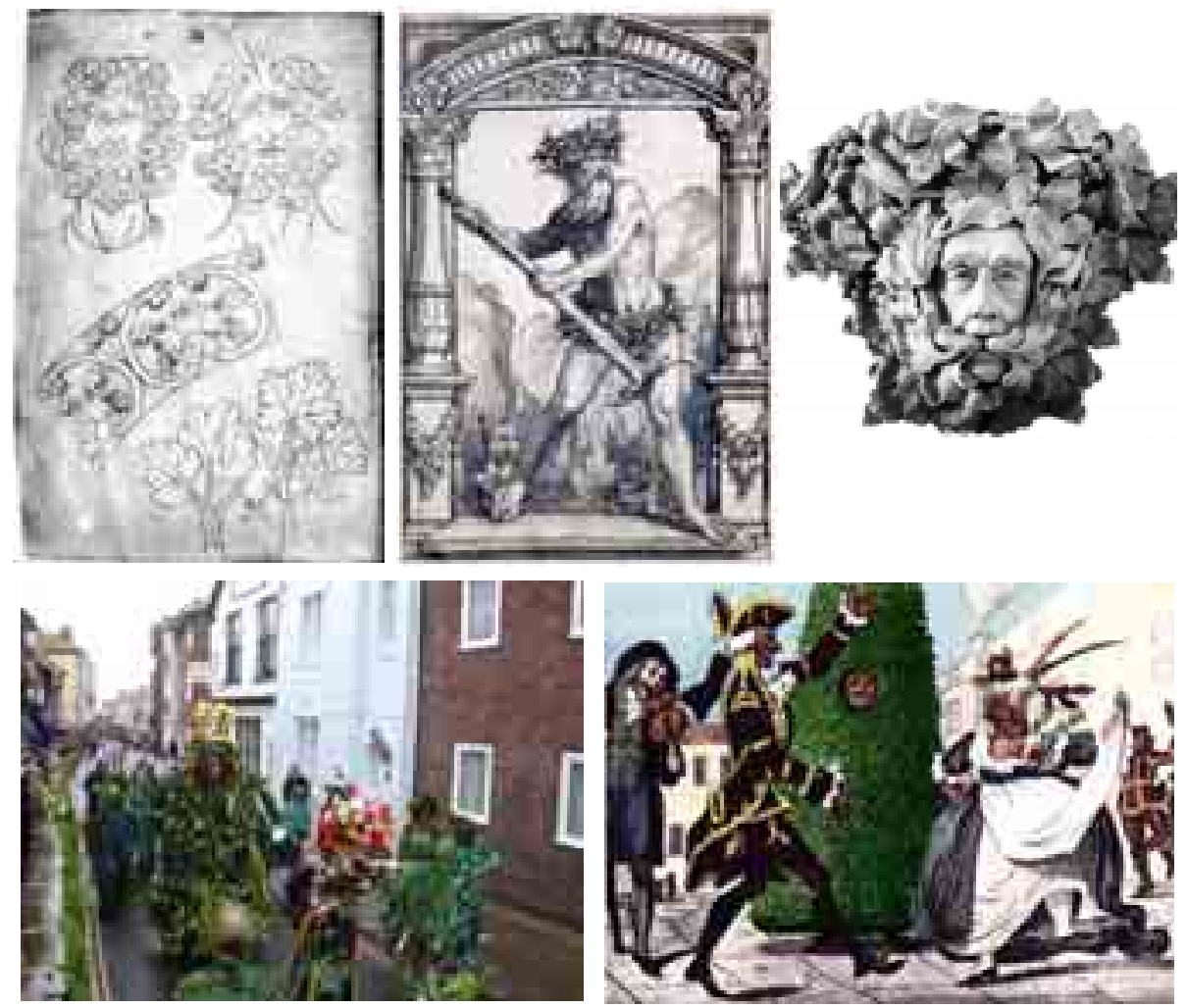

Figura 2.21

The green man, Robin Good-Felow, Puck

De arriba abajo y de izquierda a derecha:

1. Entre las representaciones medievales más antiguas, está la que aparece en los Cuadernos de Viaje de Villard d'Honnecourt. Lamina 10 (fol.6) del Cuaderno de Villard de Honnecourt, siglo XIII. Cabezas de hojarasca y dibujos ornamentales

2. Wild Man, 1528, de Hans Holbein el joven (1497/1498-1543). British Museum

La pintura muestra una representación de un hombre salvaje blandiendo una rama arrancada de un árbol

3. Green Man en la Igelsia de St. James' Church, Sutton Benger, en Wiltshire, el mismo condado del Upper Lawn Pavilion- Fotografia de Tina Negus.

4. Jack-in-the-Green y otros Green Man en el desfile del May Day en Hastings, Sussex, Inglaterra 5. Ilustracion del siglo XVIII, en Londres, el desollinador Jack in the Green danza con "Lord and Lady of the May" -el Señor y la Señora de Mayo, también desollinadore, probablemente representados ambos por hombress-, en una manifestacion de la alegría que significa la llegada de la primavera y la nueva vida de las plantas y animales.

Imágenes de 2 a 5, http://www.greenmanenigma.com 
Gonzalez de Canales dice:

«A través de Puck se abre la ventana a la Inglaterra mítica, de la que Puck es su presentador. El mito lo vivifican los niños, que ven, en su propia casa, en la colina de Pook, el riachuelo, la herrería o la granja de Lindens, las más fantásticas apariciones de caballeros medievales, centuriones romanos, artistas renacentistas..., como si pasado y presente se fundiera en la mirada de los niños.

La importancia de la vida en consonancia con un territorio no es una indagación banal en Inglaterra. Recordemos que en Inglaterra campo y país son la misma cosa. El territorio, o «estas tierras», como dice Puck, tienen toda la carga de vida, de años, de ruidos, de misterio. Es un todo apelmazado de historia» (Gonzalez de Canales 2003, 91)

Siendo el texto de González de Canales imprescindible para este trabajo, centra su interés en el carácter de proyecto abierto en el tiempo y la experimentación de los Smithson sobre la forma de habitar circunscribiéndose al libro de Kipling, mientras que desde esta tesis se entiende necesario, por las huellas de lo vernáculo, ampliar el campo de estudio al personaje de Shakespeare, incluyendo también algunas consideraciones sobre el territorio del Upper Lawn Pavilion

Sueño de una noche de verano, es un entretenimiento para la boda de una pareja noble, y un Shakespeare joven escribe una obra alegre y divertida, con juegos, canciones, danzas, y poesía. La acción discurre en un país imaginario que no se corresponde con lugar concreto, antiguo o moderno, con fairies -hadas-, elves -elfos-, y goblins- duendes-, criaturas imaginarias que viven en los bosques. Sus reyes, Oberon y Titania han discutido, y como resultado, el tiempo esta «molesto» y los cultivos se han estropeado. Así, Oberon llama a Puck -o Robin Goodfellow-, un espíritu travieso y muy bromista, al que ordena obtener una flor mágica cuya savia, puesta en los ojos de alguien dormido, hará que cuando despierte caiga localmente enamorado de la primera persona que vea al despertar. Así espera Oberon hechizar a Titania.

En el mundo rural de todas las culturas, tradicionalmente se ha creido en espíritus que favorecen o perjudican las cosechas, controlan el tiempo y hacen a los niños sanos o débiles. En Inglaterra, estos espíritus son las hadas y los elfos. Viven en los bosques, pero también van a los campos por la noche a bailar formando corros. Si les molestas pueden hacer mucho daño, pero si eres amable protegerán a los niños pequeños e incluso ayudarán con las tareas domésticas. Los duendes, llamados «Puck» o Robin Goodfellow, son bastante diferentes: feos, peludos y muy traviesos, también pueden aprender a ser buenos ${ }^{40}$ y ayudar. Puck es el más animado y rápido de todos los espíritus, que tienen en común ser muy pequeños -de hecho en Iranda todavía se les llama «little people», personitas -, por lo que seguramente Shakespeare tuviera que emplear niños de corta edad para estos personajes, haciendo la representación más divertida con sus canciones, bailes y poeticas descripciones de la vida en el campo. La acción se desarrolla en el bosque, donde los seres humanos estan bajo la influencia de la magia de Puck, y aunque es un mundo imaginario, los diálogos de las hadas y Puck describen la vida del campo en la Inglaterra de la época, las plantas y flores que crecen en verano, las pequeñas criaturas de bosques y campos, el trabajo y los juegos de los campesinos. Por ello, si las hadas, elfos y duendes forman parte de las creencias de la gente del campo, verdaderamente forman parte de ese mundo.

${ }^{40}$ Sobre Puck en Sueño de una noche de Verano: «Puck: Espíritu travieso. MND 5.1.431 ya que soy un Puck honesto; con nombre de un travieso duende imaginario o goblin, también llamado Robin Goodfellow y Hobgoblin. MND 2.1.40 Los que Hobgoblin te llamen, y dulce Puck»

«Puck: Mischievous spirit. MND 5.1.431 as I am an honest Puck; named of a fancied mischievous spirit or goblin, also called Robin Goodfellow and Hobgoblin. MND 2.1.40 Those that Hobgoblin call you, and sweet Puck.» (Onions 1986) Traduccion de Ana Rodríguez 

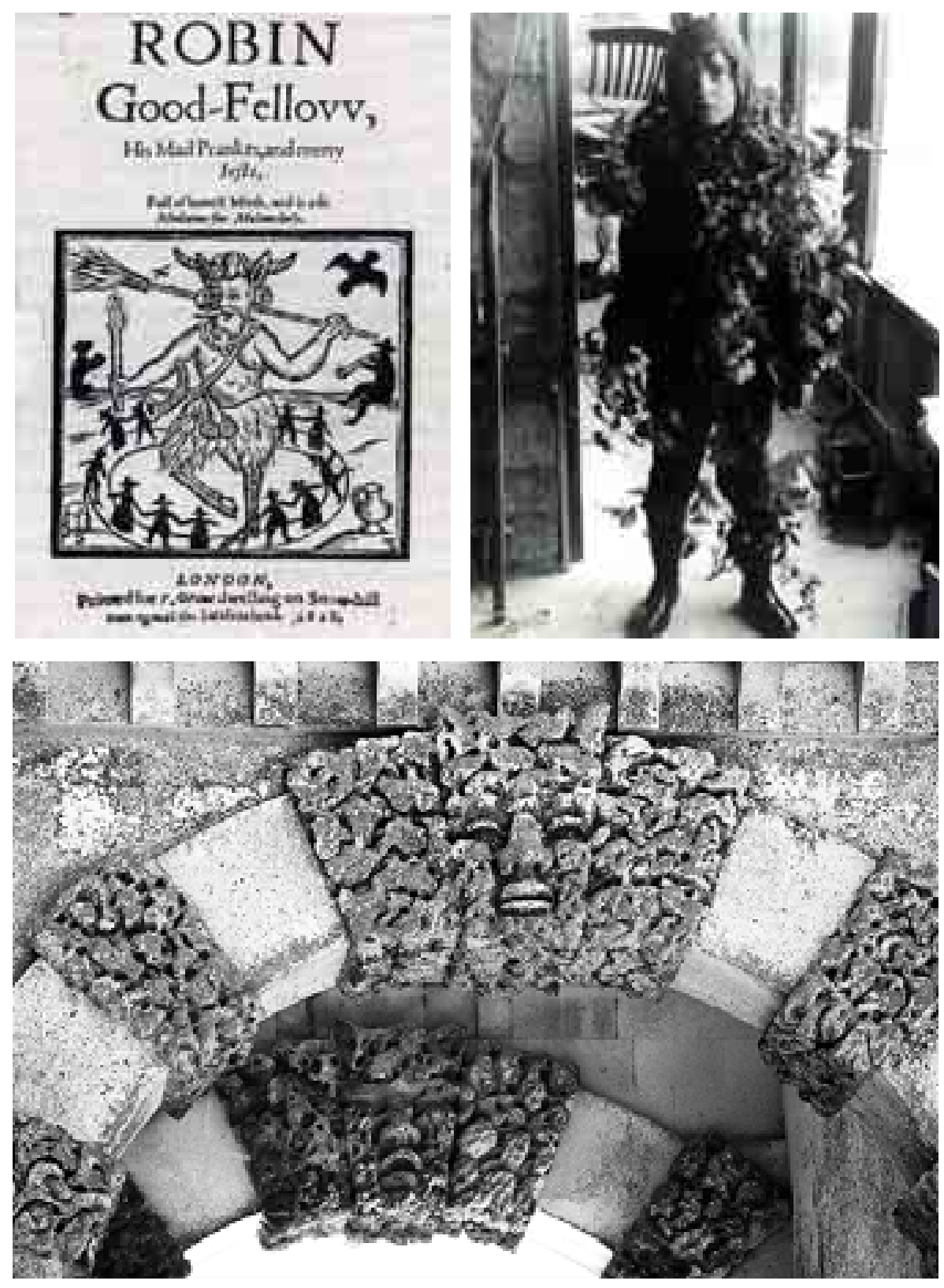

Figura 2.22

* Superior izquierda:

Representacion de Robin Goodfellow o Puck.

Portada de Robin Goodfellow: His Mad Pranks and Merry Jests (1629) -Robin Goodfellow: Sus Bromas Locas y Alegres Burlas-

* Superior derecha:

Un niño, seguramente Simon, disfrazado de Puck, correspondiente con la Figura 56 de Upper Lawn Folly Solar Pavilion, y el siguiente pie de foto:

The «Green man» exists in English folk-lore: here, a mantle from the hedgerow. October, 1966

El tema del «Hombre verde» existe en el folklore inglés: en este caso, un manto del seto. Octubre, 1966

* Inferior

«Arco» Fonthill Bishop, atribuido a Iñigo Jones, y del que los Smithson comentan que fue posiblemente construido como acceso a la casa isabelina original y que fue demolida por el padre de Beckford, quien construyó «Splendens».

Rematada en un frontón, la puerta está decorada con un almohadillado con bastante relieve por la textura de su acabado. A simple vista no es inmediato determinar el motivo de la decoración, pero una mirada atenta permite descubrir que son motivos vegetales, y que en las claves de los arcos de ambos lados de la puerta, una representación esculpida de The Green Man, preside el hueco. Fotografia de Ana Rodríguez. 
Cuando González de Canales dice que «los Smithson se lanzaron intuitivamente a la conquista de este nuevo territorio inexplorado por la cultura dominante», entendemos más certero decir intencionadamente. Como se explicará en los siguientes epígrafes, los Smithsons tenían la mirada puesta en esta zona bastante tiempo antes de comprar la antigua granja, desde principio de los cincuenta, y Alison lo conocía al menos desde 1945, como queda reseñado por ellos mismos en Upper Lawn Foly Solar Pavilion.

Es el lugar escogido para educar a sus hijos, en la naturaleza y en las tradiciones inglesas. La granja que compran reúne todos los requisitos que pudieran buscar para hacerlo: pertenece a un pequeño cluster de granjas, situado en lo alto de una suave colina, en la que tiene la posición mas privilegiada sobre el paisaje. Tenía un expediente de demolición que junto con su condición no urbana, seguramente evitaría problemas sobre una posible obligada conservación, y se encuentra enclavada frente a la finca Fonthill a la que en origen perteneció, formando parte de un universo de bosques, lagos, jardines, y campos de labor.

El entendimeinto del Upper Lawn Pavilion de los Smithsons es inseparable de Fonthill, porque son precisamente sus bosques y granjas los que conforman el territorio donde pueden vivir los duendes, en un ejemplo extraordinario de la cultura inglesa.

En definitiva, en un paradigma de lo vernáculo.

Al igual que a través Puck se abre la ventana a la Inglaterra mitica para los protagonistas del libro de Kipling Puck of the Pook's Hill -los niños Dan y Una-, Alison y Peter Smithson, con la elección del enclave del Upper Lawn Pavilion se la abren a sus hijos Simon, Soraya y Samantha.

Al llegar a Fonthill se pasa por el «Arco» Fonthill Bishop, atribuido a Iñigo Jones, y del que los Smithson comentan que fue posiblemente construido como acceso a la casa isabelina original y que fue demolida por el padre de Beckford, quien construyó «Splendens». (Smithson y Smithson 1989). Rematada en un frontón, la puerta está decorada con un almohadillado con bastante relieve por la textura de su acabado. A simple vista no es inmediato determinar el motivo de la decoración, pero una mirada atenta permite descubrir que son motivos vegetales, y que en las claves de los arcos de ambos lados de la puerta, una representación esculpida de The Green Man, preside el hueco.

De forma que cada vez que el Citroen DS de la familia, llegaba o se iba del Upper Lawn Pavilion, el Hombre Verde que custodia la finca Fonthill saludaba su llegada o partida. 


\subsection{El Jardín inglés de los Smithsons}

[ Lugar: Toponimia, Topografía, Topofília, Topiaria]

\section{Puck's Song ${ }^{41}$}

See you the dimpled track that runs, All hollow through the wheat?

O that was where they hauled the guns

That smote King Philip's fleet!

See you our little mill that clacks,

So busy by the brook?

She has ground her corn and paid her tax

Ever since Domesday Book.

See you our stilly woods of oak,

And the dread ditch beside?

O that was where the Saxons broke,

On the day that Harold died!

See you the windy levels spread

About the gates of Rye?

O that was where the Northmen fled,

When Alfred's ships came by!

See you our pastures wide and lone, Where the red oxen browse?

$\mathrm{O}$ there was a City thronged and known,

Ere London boasted a house!

And see you, after rain, the trace

Of mound and ditch and wall?

O that was a Legion's camping-place,

When Caesar sailed from Gaul!

\footnotetext{
${ }^{41}$ La Canción de Puck

¿Ves esa irregular senda que corre / paralela a los surcos de los trigos? / Ahí fue donde emplazaron los cañones / que al rey Felipe hundieron sus navíos.

¿Ves cómo gira el viejo molino, / movido por los aguas del riachuelo? / Moliendo grano su escote ha satisfecho / desde que el Domesday Book fue conocido.

¿Ves nuestros bosques de tranquilos robles / y las temidas charcas más allá? / En ellos sucumbieron los sajones / cuando Harold pasó o la eternidad.

¿Ves la llanura en vientos extendida / en donde pasta el buey de roja capa? / Fue la ciudad poblada y conocida / antes que Londres tuviese una casa.

¿Ves después de la lluvia los cimientos / de cisternas y tumbas funerarias? / Tal fue de las legiones campamento / cuando César llegó desde las Galias.

¿Ves esa señal fulgente y pálida / como una sombra sobre nuestra tierra? / Son muros que trazó el hombre de piedra / en protección de sus ciudades mágicas.

Caminos, campos y ciudades idos, / viejas artes que cesan, paces, guerras, / páramos donde hoy nos crece el trigo: / así, de pronto, nos nació Inglaterra.

Sus tierras y sus aguas son, en fin, / con bosques y sus aires aprendices / de los de Gramayre, la isla de Merlín, / donde tú y yo podemos ser felices.

KIPLING, Rudyard: «La canción de Puck», en Puck de la colina de Pook. versión en castellano de Jorge Ferrer-Vidal, Editorial Anaya, Madrid, 1987
} 


\subsubsection{Upper Lawn Farm, la Granja del Prado Alto. Etimología y significado de "Lawn" en la cultura inglesa. Toponimia}

Al comienzo del libro Upper Lawn, Folly Solar Pavilion, los Smithson describen la zona y los terrenos de la finca de William Beckford, recopilando referencias sobre Fonthill, entre autores y artistas británicos. Ilustraciones del libro de John Rutter de 1823, acuarelas de William Turner, extractos de The Beauties of Wiltshire de John Britton de 1801, y la descripción de Wiltshire hecha por Nicolas Pevsner en Buildings of England en 1963.

Su selección, es en sí misma una declaración de intenciones y pone de manifiesto el interés de los Smithson no solo por la tradición y cultura inglesa, sino por situar su casa de vacaciones como parte de ese contexto cultural.

En el pie de foto referido al plano de los terrenos de Fonthill según John Rutter, se explicita

Mapa de la Fonthill de Beckford del libro de Rutter

West Lawn Farm pasó a ser Upper Lawn.

Lawn Farm pasó a llamarse Lower Lawn cuando Middle Lawn (que no está en el mapa) pasó a llamarse Lawn Farm tras los Cercados (de los últimos que se hicieron en Inglaterra) y después de la introducción en el valle del Gran Ferrocarril del Oeste

Upper Lawn, Lower Lawn, Lawn Farm, Middle Lawn..., el nombre de granjas y casas quedan definidas toponímicamente, por su posición altimétrica en la colina y el término Lawn, y pueden comprobarse en caminos y desvíos en el recorrido de llegada a Upper Lawn, la más elevada de todas ellas, atravesando los terrenos de William Bedford.

Lawn:

Según The Oxford English Dictionary, «An area of short, regularly mown grass in the garden of a house or park» ${ }^{42}$

Definición similar a la dada en The Cambridge Advanced Learner's Dictionary \& Thesaurus, «an area of grass, especially near to a house or in a park, which is cut regularly to keep it short» ${ }^{43}$

En el Webster's 1913 Dictionary, dos acepciones

1. «An open space between woods» ${ }^{44}$

2. «Ground (generally in front of or around a house) covered with grass kept closely mown» ${ }^{45}$

Césped, pasto, pradera, prado..., todas sus acepciones bien como elemento o referidas a un lugar, siempre tienen en común la cualidad de ser hierba segada con mantenimiento, cortada casi a ras de suelo

En la cultura británica y por extensión en la norteamericana, actualmente Lawn es un área de césped o pradera con fines estéticos y recreativos. La plantación es siempre de gramíneas y esta cuidada de plagas y maleza para cuidar su color verde, y se siega regularmente para mantener una longitud corta y uniforme.

El termino en su sentido de terreno cuidado y con mantenimiento está unido a la expansión suburbana de vivienda, como interacción entre naturaleza y medio urbano construido.

\footnotetext{
${ }^{42}$ Un área de césped corto y regularmente podado en el jardín de una casa o parque.

${ }^{43}$ Área de hierba, especialmente cerca de una casa o en un parque, que se poda regularmente para mantenerla corta.

${ }^{44}$ Un espacio abierto en el bosque.

${ }^{45}$ Terreno (generalmente frente o alrededor de una casa) cubierto con césped que se mantiene segado corto.
} 
Los lawns tienen su origen como recintos cerrados con pasto en los asentamientos de la Alta Edad Media utilizados para el pastoreo comunal de ganado. Se tiene constancia de la palabra laune por primera vez en 1540. Etimológicamente ${ }^{46}$ probablemente relacionada con la palabra lan / Ilan de la lengua Celta Britónica", como "claro, espacio abierto en el bosque" delimitado normalmente en relación con un lugar de culto. También del inglés medieval Launde, del francés antiguo lande "páramo, páramo, tierra árida; despejada", del galo Breton lann "paramo, brezal", o de sus afines germánicas, todos con la misma raíz de la palabra inglesa land.

En el sentido de extensión de hierba que se mantiene cortada y cuidada, es un término relativamente moderno. La pequeña extensión de hierba o "tapis vert" realizada por André Le Nôtre en 1680 en la tercera etapa de construcción de los jardines de Versalles puede considerarse uno de los primeros ejemplos del césped como jardín moderno.

El lawn se hizo popular entre la aristocracia del centro y norte de Europa desde la Edad Media donde por clima el césped se cultiva bien, sin distinguirse claramente el concepto de jardín y el de campo de pastoreo, y diferenciándose de los jardines en otras culturas a las que no se extenderá hasta muy posteriormente.

De hecho, mantenerlo segado y uniforme hacía necesaria una mano de obra campesina para cortarlo manualmente con guadaña, convirtiéndose por ello en representación de un determinado status social y económico.

Normalmente también eran pastos mantenidos por el pastoreo de ovejas o ganado, de manera que dichas zonas se mantenían con la hierba corta y uniforme, casi a ras de suelo gracias a conejos, caballos, y ovejas, de forma análoga a un césped moderno, siendo este el origen de la palabra lawn y manteniéndose en la toponimia de muchos lugares como ya se ha mencionado en el caso de Upper Lawn y granjas de Fonthill, especialmente ligadas a zonas de pastoreo comunal. Otros ejemplos en Inglaterra son Balmer Lawn en el cercano New Forest.

A principios del siglo XVIII William Kent y Lancelot "Capability" Brown, recordado este como el jardinero más grande de Inglaterra, determinaron en sus más de 170 parques lo que se conoce como jardín inglés, o "romántico", caracterizado por suaves ondulaciones de pradera con grupos diseminados de arboles y lagos serpenteantes El "estilo Inglés" de parque abierto primero se extendió por Gran Bretaña e Irlanda, y luego en toda Europa y Norte América.

La invención de la cortadora de césped mecánica en 1830 por Edwin Beard Budding, es una fecha clave en el desarrollo del lawn moderno, ya que antes de la lawnmower, solo era posible el mantenimiento de las praderas en las fincas de la aristocracia y clases sociales ricas, pero con el cortacésped se democratizó el mantenimiento del césped. Aunque sus comienzos no fueron fáciles por la difícil maniobrabilidad de los modelos, muy pesados al estar construidos en hierro fundido, y su baja eficacia en el corte, rápidamente otras empresas, como Ransomes, Sims \& Jefferies, quizá la más importante, empezó en 1832 su producción, sucediéndose innovaciones y mejoras, hasta que en la década de 1850 Thomas Green Leeds presentó un modelo mucho más ligero llamado Silenos Messor (cuchilla silenciosa), propiciando una gran expansión a partir de 1860, y 1902, fecha en la que Ransomes produjo el primer cortacésped disponible en el mercado impulsado por un motor de gasolina.

\footnotetext{
${ }^{46}$ Online Etimology Dictionary.

${ }^{47}$ Las lenguas britónicas forman una de las dos subramas de las lenguas celtas insulares, siendo la otra las goidélicas. Incluye a lenguas actuales como el galés y el bretón y a otras extintas como el córnico (revivido durante el siglo XX) y el cúmbrico. El nombre (Brythonic en inglés), fue derivado por Sir John Rhys de la palabra galesa brython, 'indígena celta', a diferencia de un anglosajón o escoto. (wikipedia, buscar otra referencia, ver como citar)
} 
La evolución de la máquina cortacésped, se desarrolla paralelamente a un nuevo modelo social, en el que especialmente en Inglaterra se produce a principios del siglo XX y bajo la influencia del modelo de ciudad jardín de Ebenezer Howard, un gran desarrollo de la vivienda suburbana. En este modelo de ciudad, la incorporación de un pequeño jardín de césped bien cuidado representa ese cambio social y un estándar de vida más saludable.

Así mismo, el nacimiento y auge de actividades recreativas y deportes modernos, en campos de juego y canchas de césped como el futbol, los bolos, el tenis y otros, se desarrollaran unidos al lawn, dando lugar a nombre específicos como lawn tennis, lawn bowls, green, lawn sports, etc.

La cultura del Lawn se extendió por norte América desde el siglo XVIII con la llegada de los colonos, convirtiéndose la comunidad Shaker, a finales del siglo, en el productor principal de semillas de césped de alta calidad, lo que favoreció su uso en parques y aéreas residenciales

Paulatinamente fueron aumentando los espacios verdes con césped en las ciudades, muchas veces unidos a monumentos y conmemoraciones bélicas, como los cementerios para los soldados caídos en batalla.

La Casa Blanca como residencia presidencial desde John Adams en 1800 y Monticello de Thomas Jefferson en 1806, con su lawn de estilo inglés, representan un modelo de residencia para las clases más altas.

Con el tiempo, en Estados Unidos la cultura del césped ha llegado a ser la representación de la forma de vida americana, gracias a la confluencia de varios factores.

Desde la segunda mitad del siglo XIX, las publicaciones especializadas, revistas y catálogos, aconsejaban la importancia de un espacio de césped para que los niños jueguen. Además la normativa de planeamiento en el desarrollo de las zonas suburbanas establecía un espacio obligatorio de separación de 30 pies entre la acera y la posición de la vivienda, encontrando el jardín de césped el lugar idóneo para su asentamiento definitivo en la cultura doméstica norteamericana, dejando de ser únicamente un símbolo de status para asociarse a una estética del paisaje.

Las mejoras en la cortadora de césped y el abastecimiento de agua permitieron la difusión de la cultura de césped desde el noreste hacia el sur, donde la hierba crecía más deficiente, y la aprobación en 1938 de la semana laboral de 40 horas semanales, favoreció definitivamente el desarrollo de la cultura del lawn, al tener el medio día del sábado para cuidar sus jardines.

Durante la segunda Guerra Mundial el cuidado del lawn se convirtió no solo en un pasatiempo para combatir el estrés, sino como desarrolla Beatriz Colomina en El Lawn en Guerra $^{48}$, en un deber patriótico como una demostración de fuerza, moral y solidaridad en la retaguardia de cara al enemigo, reforzando su imagen idílica como representación de la seguridad, calma y felicidad del hogar.

El carácter ejemplarizante del cuidado del jardín es esencial, debiendo estar siempre segado corto y sin malas hierbas.

No son infrecuentes los ejemplos de recuperación de la memoria y alusión a su origen unido a animales de granja y domésticos, cuando la extensión es suficiente y la titularidad pública. Así, en Central Park el Sheep Meadow, el prado de ovejas, una de las zonas más populares del parque, con una larga tradición de manifestaciones, eventos y actos políticos, es el espacio abierto de pradera más grande planeado por Frederick Law Olmstead (1822-1903) y Calvert Vaux (1824-1895) en el diseño del parque, con una extensión de 15 acres (61.000 m2).

\footnotetext{
${ }^{48}$ El lawn en guerra. Beatriz Colomina
} 
Desde su origen fue ideado como su nombre indica para ser habitado por ovejas, lo que además de asegurar su cuidado, fertilizando el pasto y manteniéndolo corto, reforzaría la idea de tranquilidad que se quería transmitir con el lawn. Se instaló un rebaño de 200 ovejas, para las que se construyó un pabellón victoriano como aprisco que con el tiempo se convertiría en el legendario restaurante Tavern on the Green, abierto durante 75 años hasta su cierre a finales de 2009. Incluso se hizo un cruce para el rebaño, y dos veces al día un pastor detenía el tráfico, primero de carruajes y luego de automóviles para su paso hasta el prado. Las ovejas estuvieron pastando en el Sheep Meadow desde 1864 hasta 1934, cuando la Comisión de Parques y Jardines decidió trasladarlas primero a Brooklyn y más tarde a la montaña, por temor a que con la hambruna en los años de la Gran Depresión, fueran robadas para comida.

Las mascotas en la Casa Blanca son a menudo tan famosas como sus dueños.

Desde que John Adams, segundo presidente de los Estados Unidos, se trasladó en 1800 a vivir en la residencia presidencial todavía en obras ${ }^{49}$, la presencia de animales ha sido un signo de identidad, siempre relacionado con el lawn.

Todos los presidentes han tenido mascotas, la mayoría varias. Perros y gatos las más comunes, pero también y muy frecuentemente cabras y caballos, junto canarios, loros y animales de granja como pavos y conejos entre otros ${ }^{50}$, con numerosos documentos fotográficos que atestiguan esta relación. Son famosas las fotografías de la familia Kennedy, pero no las únicas.

Especialmente significativas son las imágenes existentes de la Casa Blanca durante la Primera Guerra Mundial, que reflejan como en un periodo de dificultad el lawn se mantuvo cuidado con ovejas como en el pasado.

Volviendo a Inglaterra, es pertinente reseñar la pervivencia de esta arraigada tradición vernácula. En la actualidad continúa la cultura del pastoreo conscientemente unida al mantenimiento del lawn moderno en las casas de campo inglesas. Son numerosas las grandes propiedades, que aunque actualmente han basculado su modelo productivo como lugares de ocio, mantienen de forma simultánea una importante producción agrícola y ganadera, como algo inherente e indisoluble a su esencia y significado en el territorio. Pertenecientes en origen a la aristocracia, pueden seguir en muchos casos perteneciendo a la misma familia.

Un buen ejemplo es Highclere Estate ${ }^{51}$, en el condado de Hampshire, cercano a Whiltshire, que toma nombre del Highclere Castle, actualmente hotel en parte, y más conocido por ser la localización donde se rueda la serie de televisión Downton Abbey.

Otro ejemplo actual, al que en origen perteneció Upper Lawn, y por ello especialmente relevante en su relación con los Smithson y su casa, es Fonthill Estate ${ }^{52}$, desde 1830 propiedad de la familia Morrison, que en 1965 adquirieron el título nobiliario de Barones de Margadale.

La finca descrita en su publicidad como «nueve mil hectáreas de gran belleza en el corazón de Wiltshire», consiste en bosques, jardines, tierras de cultivo, ovejas, caballos además de casas y locales de alquiler para vacaciones y eventos.

La actividad agrícola de la granja se dedica a la producción y almacenaje de grano principalmente de trigo, cebada y avena.

\footnotetext{
${ }^{49}$ El primer presidente George Washington eligió el lugar y comenzó las obras en 1792. El edificio ha tenido varias reformas, ampliaciones y rehabilitaciones importantes, pero ha sido siempre la residencia de todos los presidentes.

50 También ha habido exóticos como cocodrilos y serpientes. El presidente Calvin Coolidge (19231929) llegó a tener un verdadero zoo, con 25 animales, entre ellos un hipopótamo enano llamado Billy y un oso pardo.

${ }^{51}$ Información obtenida en Highclere Castle en www.highclerecastle.co.uk

52 Información obtenida de Fonthill Estate en www.fonthill.co.uk
} 
Desarrolla una importante actividad en silvicultura, especialmente en el cultivo de especies de hoja ancha para la conservación y mantenimiento del paisaje, aunque también comercializa maderas blandas y duras para aserrado, pulpa de madera para la fabricación de papel, viruta para la fabricación tableros y biocombustibles, material de cercado, leña, y servicios de consultoría forestal. La Cuadra Fonthill dedica 80 hectáreas al pastoreo, situadas en el corazón de la finca y caracterizada por su privilegiado paisaje pintoresco, a la cría y entrenamiento de purasangres de competición y caballos para la venta, además de estar especializada en la recuperación de ejemplares después de lesiones. Los caballos y también las ovejas, pastan en libertad en sus lawns.

Paisaje, granjas, agricultura, ovejas, caballos, bosques..., en el pasado y en el presente, conforman la seña de identidad estas fincas que representan la vida rural inglesa.

Estas grandes propiedades, son fragmentos del territorio con un ecosistema originalmente en equilibrio y en gran medida autosuficiente, formado a través de siglos, en los que actualmente y manteniendo una actividad económica de negocio, pervive el sentimiento de responsabilidad respecto al legado histórico de la cultura vernácula rural inglesa. Permanecen, conviven y explotan los elementos esenciales que la configuran: el paisaje romántico, sus castillos y grandes casas palaciegas, con formas de producción agrícola y ganadera tradicionales, especialmente relacionadas con el mantenimiento del lawn, que se articulan a través de las granjas que se implantan en ellos. Tradicionalmente entienden la preservación del patrimonio y la cultura rural conservando la tierra productiva, buscando un equilibrio entre agricultura y conservación de la naturaleza. Mantienen una importante actividad agrícola y ganadera de la que hacen gala como parte de una postura responsable de aprovechamiento de los recursos naturales frente a la historia y al medioambiente, permitiendo una lectura histórica y cultural del territorio.

Y en el caso de Fonthill, Upper Lawn pertenece por voluntad y se integra en ella El intencionado reconocimiento de esta tradición por parte de los Smithson es relevante en el Upper Lawn Pavilion.

No solo se mantiene en la toponimia, sino en las alusiones que hacen a estas tradiciones y a los lawns de Beckford en los años que habitaron en el Pabellón del Prado Alto.
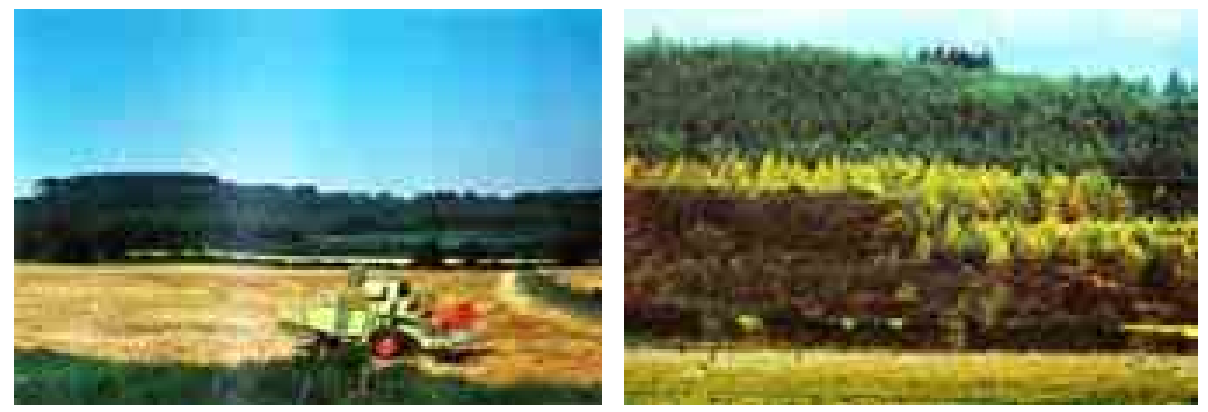

Figura 2.23

* Izquierda

Pie de foto de la Figura 33 del Upper Lawn Solar Pavilion.

La nueva cosechadora alemana, verano 1973

Cita de la necrológica de Charles Eames, escrita por P.S. en Upper Lawn en 1978 «Durante la semana de la muerte de Eames, la cosecha de los terrenos de alrededor fue realizada -como todos los años- por un americano medio, delgado, tostado, gris, rapado, callado. Al contemplar el trabajo de este hombre y su máquina se tiene la sensación de que esta gente posee unos circuitos cerebrales que ningún europeo tiene. Trabajan con un estilo que es a la vez artesano y principesco»

* Derecha

En marzo de 1982, los Smithson pasan su último fin de semana en Upper Lawn. Puede apreciarse tristeza y melancolía en las imágenes escogidas y los pies de foto que las ilustran. La mayoría de las imágenes se refieren a las vistas que se tienen desde la casa hacia el exterior. La figura 65, de octubre de 1981 (ver imagen) cita «ovejas en el campo delante de Upper Lawn; los bosques de Fonthill bajo el sol.

También las figuras $64,69,70,72$ 

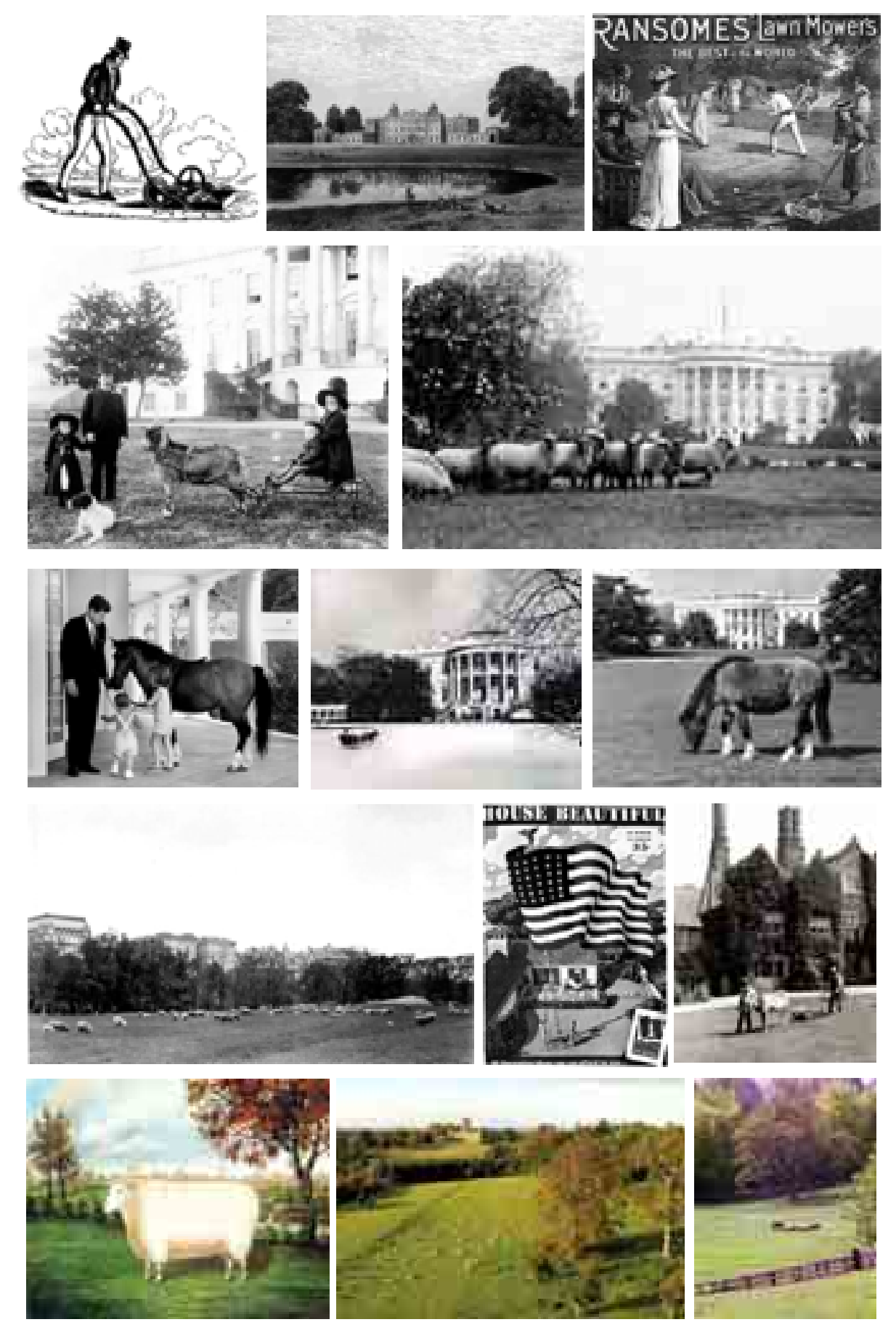
Figura 2.24

1. Ilustración de la revista The Gardener's Magazine, 1832, recogida por Charles Quest-Ritson en The English Garden. A social history. El invento de la cortadora de césped mecánica diseñada en 1830 por Edwin Beard Budding, permitió a los caballeros disfrutar activamente en el jardin.

2. Publicidad de la empresa Ransomes en torno a 1867. Muestra un tennis lawn que está siendo segado por una niña, en alusión a su fácil manejo, con una cortadora de césped de la compañia, por ser este uno de los mayores inconvenientes de las primeras máquinas.

3. Imagen de Badminton House en el condado de Gloucestershire en el siglo XIX. Proyecto de Lancelot "Capability" Brown (1715-1783), arquitecto paisajista recordado como el jardinero más grande de Inglaterra, en el que se reflejan las principales características del paisajismo browniano.

Animales domésticos en el Lawn de la Casa Blanca. Pervivencia de la tradición entre lawns y animales domésticos como ovejas, cabras y caballos.

4.La familia del 23 presidente Benjamin Harrison posa en el Lawn Sur de la Casa Blanca. El nieto del presidente conduce un cochecito tirado por su querida mascota la cabra. His Whiskers (sus bigotes) u Old Whiskers, según las fuentes. Fotografía tomada entre 1889 y 1893.

Colección Frances Benjamin Johnston Collection, Biblioteca del Congreso de los Estados Unidos

5. Vista del Lawn Sur de la Casa Blanca con ovejas pastando para su mantenimiento durante la Primera Guerra Mundial.

Fotografía en blanco y negro tomada sobre negativo de vidrio entre 1916 y 1919

Colección Harris \& Ewing Collection, Biblioteca del Congreso de los Estados Unidos

6. El presidente Kennedy con su hijo John Jr., su hija Caroline y su famoso pony Macaroni Imagen de 1962 tomada por Robert Knudsen y perteneciente a la Biblioteca John Fitzgerald Kennedy en Boston

7. Tarjeta de Navidad de la Casa Blanca en 1962. La imagen muestra a la Señora Kennedy y a sus hijos John Jr. y Caroline, en un trineo arrastrado por su pony Macaroni, sobre el lawn sur nevado. Fotografía tomada el 25 de diciembre de 1962

John F. Kennedy Presidential Library and Museum, Boston, Massachusetts

8 El pony Macaroni, una de las mascotas más famosas de la Casa Blanca, fue un regalo del vicepresidente Lyndon B. Johnson a Caroline, la hija de J.F. Kennedy. Montado por la niña fue portada de Life y recibía cientos de cartas de sus fans. Con frecuencia se le podía ver pastando libremente por el lawn de la casa presidencial.

9. Fotogarfia postal de Thaddeus Wilkerson 'Sheep Fold, Central Park, New York', 1909-1916

10. Portada de House Beautiful, verano de 1942 (El Lawn en Guerra, Beatriz Colomina)

11. En Spains Hall, Essex un burro bien entrenado, calmadamente corta el césped. En torno a 1900, en algunos jardines se empezó a reemplazar a burros y caballos por maquinas impulsadas a vapor. (Bradley-Hole 2004,11$)$

12. Desde 1750 en adelante, la ganadería llegó a ser uno de los grandes intereses de los propietarios de tierras. Este carnero campeón Old Lincoln fue pintado por W. Adamson en 1835. Colección privada, Bridgeman Art Library. (Quest-Ritson 2003, 141)

13. Highclere Castle, proyectado por Charles Barry. Los jardines y el lawn fueron diseñados originalmente por Lancelot Brown a finales del siglo XVIII. Actualmente es un hotel, en el que se rueda la serie Downton Abbey.

14. Imagen de la finca Fonthill. Caballos pastando en un lawn, en un claro del bosque. 


\subsubsection{El paisaje pintoresco de William Beckford en Fonthill a finales de XVIII. [Topografía]}

El Pabellón Solar Upper Lawn está situado en Tisbury, en Whiltshire, cerca de las ruinas de la abadía de Fonthill, en unos terrenos en los que William Beckford creó un paisaje pintoresco a finales del siglo XVIII, y a los que se accede a través de una puerta monumental, que indica la pertenencia a un enclave, a un lugar con personalidad propia, en el que conviven estampas del jardín inglés, campos de labor, bosques, grandes praderas, jugadores de críquet y tractores.

Whiltshire, o Condado de Wilts es uno de los condados tradicionales ${ }^{53}$ del Suroeste de Inglaterra. Se caracteriza por sus amplios valles y downs suaves colinas cubiertas de pasto y la gran llanura de Salisbury en la que se sitúan los asentamientos neolíticos de Stonehenge y Avebury. Nikolas Pevsner en la introducción del volumen dedicado a este condado de su obra Buildings of England resalta especialmente esta característica de su paisaje de downs ${ }^{54}$.

«Wiltshire, as one travels in the county, seems larger than it is....

... The illusion of distances is due to the solitude of the downs, but also many changes from character to character and from landscape to landscape. Most people, if Wiltshire is mentioned, just think of Salisbury Plain, but is unfortunate considering how the military have treated it. The Marlborough Downs have preserved their solemnity far more nobly and there are stretches of unspoilt downs also of the Nadder between Wilton and Tisbury. The most characteristic feature of Wiltshire is indeed the alternation between the villages and downs". (Pevsner )

Al igual que todo el suroeste de Inglaterra, tiene un clima generalmente más húmedo y suave que el resto del país. Tiene importantes casas de campo, muchas actualmente abiertas al público. Es parte del territorio que describe Jane Austen ${ }^{55}$ (1775-1817) en sus novelas donde describe con precisión la sociedad rural inglesa de finales del siglo $\mathrm{XVIII} \mathrm{y} \mathrm{principios} \mathrm{del} \mathrm{XIX.}$

Es en ese periodo cuando se producen importantes cambios en la sociedad agrícola inglesa hacia la modernidad, fundamentados principalmente en dos factores.

El primero, la revolución agrícola británica que comprende desde el siglo XVIII hasta mediados del siglo XIX, etapa en la que se produjo un importante aumento de la productividad agrícola con altos rendimientos gracias a innovaciones en las técnicas de cultivo. Este incremento de la producción permitió un crecimiento espectacular de la población que podía ser alimentada y ya no necesariamente ligada al campo, conformándose así la mano de obra necesaria para la Revolución Industrial con un gran movimiento de población del campo a las ciudades.

\footnotetext{
${ }^{53}$ Es un «ceremonial county», áreas que no coinciden con la división administrativa actual del Reino Unido, y en la mayoría de los casos coincidentes con los condados tradicionales o históricos, anteriores a la reforma administrativa de 1974.

Los condados ceremoniales de Inglaterra a menudo se usan en un contexto geográfico, pues su tamaño y homogeneidad son más adecuados para ello que la de los condados administrativos, razón por la que también son llamados condados geográficos "geographic counties"

${ }^{54}$ Colinas bajas cubiertas de pradera. Término especialmente utilizado en los nombres de dos áreas del sureste de Inglaterra: the North Downs y the South Downs.

55 Jane Austen nació en Steventon y murió en Winchester, ambas poblaciones del condado de Hampshire, colindante al de Wiltshire. Toda su vida se desarrolló en un área de unos $100 \mathrm{~km}$ de Fonthill, tomando este como centro.
} 
La nueva organización social ${ }^{56}$ posibilitó nuevas formas de adquirir riqueza, que hasta entonces prácticamente solo poseía la nobleza transmitiéndose por herencia, y propició como clase social influyente a la alta burguesía agraria.

El segundo, el colonialismo del imperio británico en ultramar.

Ambos factores confluyen en Fonthill. Su construcción y algunas características no provienen de la riqueza de la nobleza histórica, sino del dinero de las plantaciones de azúcar de Jamaica. Una increíble historia, acorde con una singular obra, en la que es pertinente profundizar algo más.
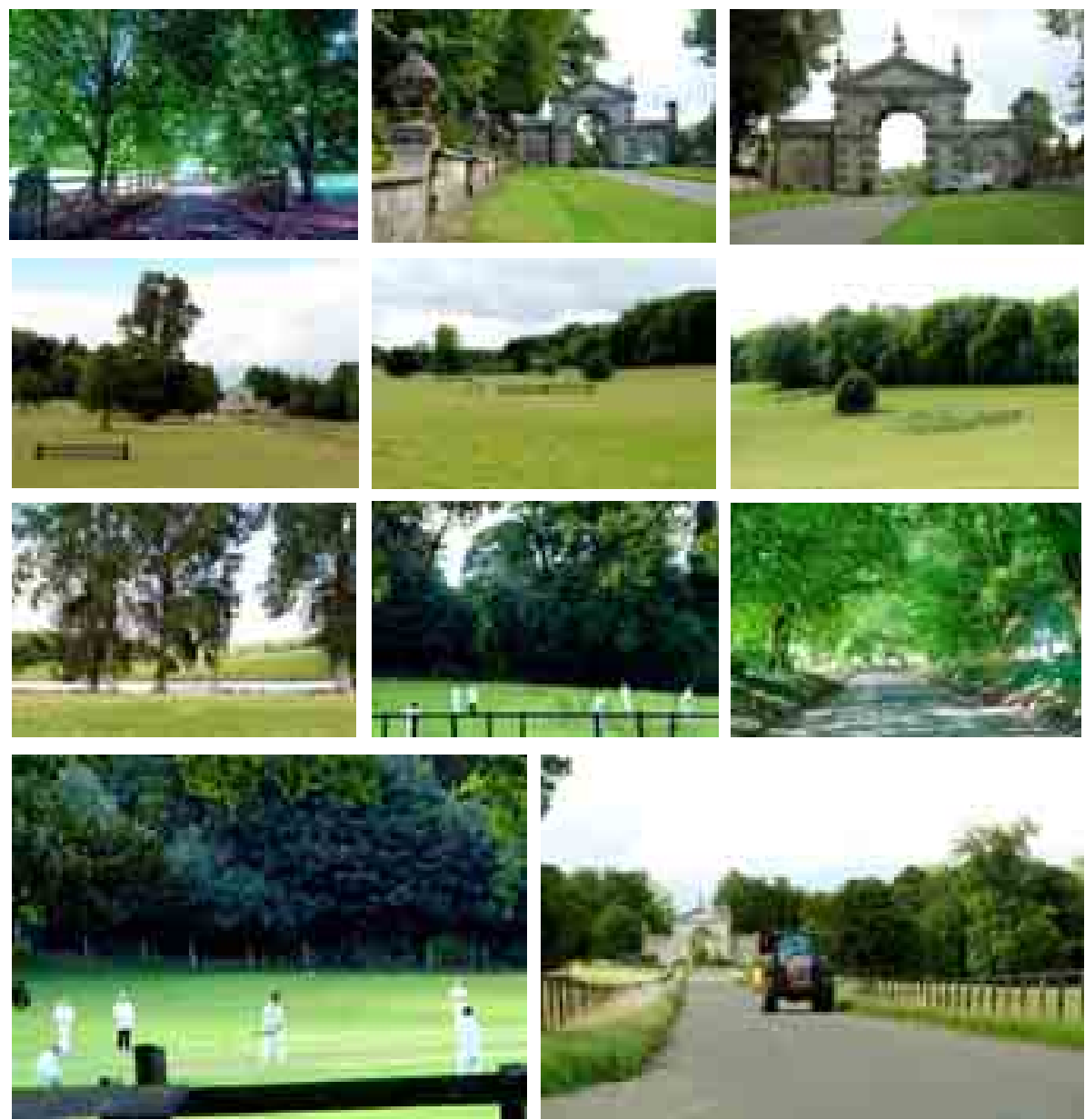

Figura 2.25

Estampas de Fonthill en el camino para llegar a Upper Lawn: el Arco de entrada, bosques, praderas, rediles para caballos, obstaculos de salto, un lago, jugadores de criquet y tractores. Fotografías de Ana Rodríguez en Agosto de 2010.

${ }^{56}$ Nikolas Pevsner hace referencia a este proceso en la introducción de la obra citada, poniendo algunos ejemplos entre los que se encuentra William Beckford. «The merchant class was also among the patrons for whom mansions were built in the country, though they were rather Londoners than local men: a Hoare of Hoare's Bank at Stourhead, Alderman Beckford at Fonthill (the house preceding Fonthill Abbey), Sir Peter Vandeput, a London merchant, at Standlynch (later called Trafalgar House)» (Pevsner , 46) 


\subsubsection{Fonthill, breve historia de la finca.}

La finca Fonthill ha tenido una historia compleja, con varios propietarios que han modificado en el tiempo sus límites y extensión. Está incluida en el Register of Historic Parks and Gardens del English Heritage por su especial interés histórico.

La primera constancia data de 1553 cuando Sir John Mervyn compró el núcleo de la finca, una casa rodeada por un parque, que fué adquirida y ampliada en 1631 por Sir Francis Cottington, diplomático en España y canciller de hacienda con el rey Carlos I. En este tiempo la Fonthill House también es conocida como Fonthill Antiquus. Desde entonces, sucesivas casas fueron construidas, demolidas, ampliadas y modificadas en un entorno de menos de $1 \mathrm{~km}$.

En 1736 William Beckford ${ }^{57}$ (1709-1770) lord-mayor de Londres, compró la propiedad ampliando y modificando la casa existente, conocida también como Fonthill Redivivus, la cual se quemó en 1755, siendo reemplazada por una nueva mansión conocida como Fonthill Splendens que estuvo terminada en 1770.

Su hijo William Thomas Beckford (1760-1844), el más famoso William Beckford, y fue el principal artífice de la finca Fonthill en su máximo esplendor. Encargó a James Wyatt la construcción de la famosa neogótica Fonthill Abbey, terminándose en 1817, en la que se empleó como material gran parte de Fonthill Splendens. Beckford la vendió en 1822 a John Farquhar, un contratista de pólvora de la India, y se trasladó a Bath donde vivió hasta su muerte. La torre principal de la abadía de Fonthill se derrumbó en 1825, y gran parte de la gran estructura fue demolida, quedando sólo el extremo oeste de la abadía, incluyendo el Oratorio, Santuario y la Torre Lancaster ${ }^{58}$.

Farquhar trató de vender toda su tierra, pero murió en 1826 sin testar, y tras un largo proceso legal, sus herederos la vendieron a James Morrison, un rico comerciante de textiles y mercería que llegó a pertenecer a la Cámara de los Comunes y fue descrito en su momento como el "Napoleón de tenderos". Desde esa fecha, la finca pertenece a la misma familia que, como ya se ha mencionado anteriormente, desde 1965 ostentan el titulo de Barones de Margadale ${ }^{59}$.

Cuando se vendió, Fonthill House ya era sólo la parte oeste de la casa original construida por Beckford y se hizo conoció como The Pavilion.

Actualmente la propiedad con usos diversos ya mencionados, principalmente zonas verdes, bosques y agricultura, tiene varias residencias separadas, y la actual Fonthill House no se encuentra dentro del área de la finca antigua de Beckford, ni tiene ninguna relación con ese patrimonio.

\section{William Thomas Beckford}

William Thomas Beckford (1760-1844), escritor, músico, político, crítico de arte, y coleccionista, especialmente interesado en el arte y la arquitectura, dedicó su inmensa fortuna a lo que realmente le hizo famoso: su gran colección de arte y la construcción de Fonthill Abbey para albergarla, junto con el extraordinario jardín en que convirtió la finca Fonthill.

Cuando él nació Fonthill ya era propiedad de su padre, también William Beckford, de la adinerada familia Beckford, propietarios de plantaciones de azúcar en el las Indias Occidentales Británicas en el Caribe. A la edad de 10 años heredó, al morir su padre, la considerada en su tiempo mayor fortuna personal de Inglaterra y puede que del mundo, consistente en 1 millón de libras esterlinas en efectivo, los terrenos de Fonthill y varias plantaciones de azúcar en Jamaica trabajadas por esclavos que le reportaban unos ingresos estimados en 100.000 libras anuales. Lord Byron (1788-1824) le llamó el «England's wealthiest son».

\footnotetext{
${ }^{57}$ William Beckford (1709-1770), padre de William Thomas Beckford (1760-1844)

${ }^{58}$ Datos obtenidos del English Heritage

${ }^{59}$ Datos obtenidos de la empresa Fonthill Estate
} 
Conocido como William Beckford, o William Beckford de Fonthill, para diferenciarlo de su primo William Beckford de Somerley ${ }^{60}$, se crió y vivió en Inglaterra, no llegando a ir nunca a sus propiedades de Jamaica. En 1787, después de verse implicado en el famoso escándalo Courtenay, acusado de mantener relaciones homosexuales con William Courtenay, menor de edad, inició un viaje a tal efecto, que no llegó a completar. Sí viajó desde Inglaterra hasta el sur de Italia, y también España y Portugal donde residió durante 2 años. Después de 6 años por el continente, regresó a Inglaterra y comenzó el periodo de plantación masiva en Fonthill.

Tuvo como maestro de dibujo a Alexander Cozens ${ }^{61}$, con el que estuvo en Italia en 1782 donde pintó varias vistas del lago Nemi con el palacio de Castelgandolfo, imágenes que retuvo como modelos inspiradores para Fonthill Abbey y su posición elevada en el territorio.

Sus títulos más relevantes como escritor son: la novela gótica Vathek, escrita originalmente en francés en 1782 y publicada en 1786; Memoirs of Extraordinary Painters (1780); Letters from Italy with Sketches of Spain and Portugal (1835); Dreams, Waking Thoughts and Incidents (1783); Modern Novel Writing; The Elegant Enthusiast (1796); y Recollections of an Excursion to the Monasteries of Alcobaca and Batalha (1835).

En 1822, habiendo perdido sus plantaciones de Jamaica y con problemas económicos, puso a la venta Fonthill Abbey. Se vendieron 72.000 copias a una guinea, del catalogo ilustrado de la casa de subastas Christie's preparado para la venta, cifra que ayuda a entender la magnitud de su patrimonio.

Se trasladó a Bath, donde vivió los últimos años hasta su muerte, en Lansdown Crescent. Fue comprando varias casas del conjunto, primero en $n^{0} 20$ y el $n^{0} 1$ de Lansdon Place West, que unió con un paso elevado sobre la calle, y posteriormente en 1836 los números 18 y 19, para asegurarse tranquilidad. También construyó otra espectacular folly en el límite más elevado de su propiedad en Lansdown Hill, realizada por el arquitecto Henry Goodridge. La Lansdown Tower, actualmente conocida como la Beckford's Tower, es ahora de propiedad pública y alberga un museo sobre William Beckford gestionado por el Bath Preservation Trust.

Las reseñas sobre él inciden en que su fama no fue tanta por su obra literaria, sino como coleccionista y constructor de Fonthill Abbey.

Doscientos años después, quizá podríamos asegurar que su mayor legado es la finca Fonthill y sus bosques. Fue un hombre rico, excéntrico y culto, cuya fortuna le permitió vivir y actuar en un ámbito de privilegios accesible a muy pocos. Sin embargo, no deja de ser excepcional acometer un proyecto personal no lucrativo de esta magnitud, invirtiendo para ello su fortuna. La plantación de más de un millón de arboles, sus bosques con lawns y lagos...Aunque las construcciones originales y los jardines menores hayan desaparecido en su mayoría, la estructura general de la transformación de una parte del territorio permanece, y es un patrimonio natural y cultural extraordinario. Un legado cuya influencia en la cultura británica han representado desde William Turner hasta los Smithson.

${ }^{60}$ (Comprobar información en el Dictionary of National Biography DNB, base del Oxford Dictionary of National Biography )

William Beckford de Somerley (?-1799) conocido así por su residencia en Suffolk, fue hijo ilegítimo de Richard Beckford, uno de los tres hermanos del concejal William Beckford. Perteneciente a la influyente familia Beckford, heredó plantaciones de azúcar en Jamaica, La Roaring River Estate en Westmoreland, en el extremo oeste de la isla, que el supervisaba personalmente y donde vivió más de diez años hasta que perdió sus plantaciones y volvió a Inglaterra para intentar volver a hacerse nombre y fortuna. En su tiempo se le conoció como el "historiador de Jamaica" por su libro A Descriptive Account of the Island of Jamaica escrito en 1790, y por su defensa del sistema de esclavitud en el Caribe en Remakes upon the Situation of Negroes in Jamaica de 1788.

${ }^{61}$ Alexander Cozens (1717-1786), pintor paisajista británico, en 1785 publicó A New Method of Assisting the Invention in Drawing Original Compositions of Landscape. 


\subsubsection{Fonthill y el jardín inglés}

El Oxford Dictionary of English Etymology, define la palabra «garden» como «enclosed cultivated ground».

La palabra «paraíso» viene del término persa que significa «recinto».

Jardín y paraíso, frecuentemente interrelacionados, están siempre unidos al concepto de lugar delimitado.

El paisaje del enorme jardín paradisiaco que es la finca Fonthill, se desarrolló en el periodo propiedad de Beckford padre e hijo, especialmente entre 1793 y 1813 cuando con este último alcanza su máximo esplendor.

En 1793, William Beckford hijo rodeó una importante área de la finca con un muro delimitador para evitar que sus vecinos cazaran a través de sus tierras, habiendo cercado 800 hectáreas en 1797.

Ambas zonas, la interior y exterior estaban recorridas por $40 \mathrm{~km}$ de caminos y senderos, algunos de los cuales actualmente se han perdido, al igual que la mayoría de los jardines pequeños e invernaderos que desparecieron con la abadía. También la mayor parte del muro que fue posteriormente demolido, excepto en la zona del acceso principal, constituido por una gran puerta de entrada a la que se accede a través de un arco rematado por un frontón decorado.

Christopher Thacker en The History of Gardens describe Fonthill Abbey como más grande que la mayoría de las catedrales, con la aguja más alta de Inglaterra, y la mayor de las follies en audacia, en lo extravagante de su concepto y construcción, en su tamaño, en su aislamiento y en su final.

La finca se extendía ampliamente, ${ }^{62}$ más allá del área delimitada por el muro de la zona central. En ella se construyeron lagos artificiales, una presa, un canal de piedra labrada, puentes y grutas, algunas en 3 niveles con varias entradas y cámaras. También distintos tipos de jardín: un jardín de flores, el Jardín Alpino, una cabaña noruega, un jardín de espinos, un jardín de herbáceas, invernaderos, una rosaleda, y sobre todo grandes zonas de bosque para aislarse de las propiedades colindantes, con claros y praderas de pasto ${ }^{63}$. En la década de 1790, la plantación de árboles era muy extensa, habiendo plantando de forma heroica ${ }^{64}$ «por encima de un millón de árboles» en 1796.

«Beckford's Fonthill is a turning point in garden history. It marks the absolute limit of the English landscape garden, and from this point a return to less absolute and less deeply philosophical garden convictions occurs. From now on, gardens such as Beckford's are acknowledged to be possible only in fantasy, and in fiction ${ }^{65}$, (Thacker 1979)

Entre las nuevas plantaciones destaca la llamada «The American Plantations», en donde Beckford plantó especies de árboles y arbustos recién introducidos en Inglaterra: cedro deodar o del Himalaya, secuoya gigante o Wellingtonia, ciprés de los pantanos, y araucaria entre otros. Situada a uno de los lados de Bitham Lake cercano a la abadía, sus exóticos colores destacaban en contraposición con el verde oscuro de las coníferas, dominante en las otras vertientes.

62 En esos terrenos es donde se asientan la mayoría de los lawns y las granjas, entre las que se encuentra Upper Lawn.

${ }^{63}$ Las zonas de pasto o lawns, constan en todas las descripciones de la finca por los autores más reconocidos sobre el tema como Christopher Tacker. Tambien los Smithson se refieren a estas zonas como los «lawns de Beckford» a los que pertenece Upper Lawn.

${ }^{64}$ Recogiendo el término empleado por Thacker? Para expresar lo extraordinario de la empresa realizada por Beckford

${ }^{65}$ Fonthill de Beckford es un punto de inflexión en la historia del jardín. Marca el límite absoluto del jardín paisajista inglés...................

del Traducción al castellano de la autora 
Jill H. Casid en el capítulo «The William Beckfords and the West Indies: Hybrydization and the transculturation of British Empire», dedicado a Fonthill de su libro Sowing Empire. Landscape and Colonization, hace un amplio y profundo estudio sobre la relación de hibridación entre las colonias del Caribe Británico y el paisajismo inglés, y en concreto del creado por los William Beckford, padre e hijo en la finca Fonthill.

Explica como la plantación de Las Plantaciones Americanas incluía varios tipos de coníferas oscuras y arbustos ornamentales de Norteamérica: rododrendro occidental, alamo carolino o americano, magnolio, azalea, rosa carolina, arbol de Angélica, calycanthus floridus, y laurel de Portugal del sur de Europa.

El traslado a Inglaterra desde las colonias incluido el Caribe, se efectuaba mediante un traslado previo desde las zonas del sur de América hacia el norte y desde allí a Inglaterra. Las reproducciones de los bosques de coníferas de Norteamérica y los Alpes Suizos se entremezclaban con vegetación del sur de Europa y Norteamérica, produciendo un híbrido entre norte y sur que oscureció el resto de plantaciones de Beckford. Paradójicamente, se creó la ilusión que las especies exóticas habían crecido naturalmente. Las guías y descripciones de la finca a principios de siglo XIX, señalaban la sensación de antigüedad, pureza y preservación de los valores nacionales esenciales.

Los datos de venta en 1829 describen la finca como «Si Elysium se puede contemplar en la tierra, los reclamos de Fonthill serían irresistibles» y el paisaje de la finca aún se considera un «idilio de Arcadia».

En el cuento de Edgar Allan Poe Domains of Arnheim or the Landscape Garden (1884), Ellison, su protagonista, busca el lugar ideal para un jardín, para el Paraíso de Arnheim. Tiene muchas similitudes con la historia de William Beckford. Ambos heredan una inmensa fortuna que emplean en realizar un paisaje extraordinario. Las descripciones de Ellison, hacen referencia a Fonthill.

«Era un poeta, en el sentido más amplio y más noble de la palabra. Poseía, además, el verdadero carácter, los augustos propósitos, la suprema majestad y dignidad del sentimiento poético. Instintivamente ponía en la creación de nuevas formas de belleza la satisfacción más completa, si no la única, de este sentimiento"

«Pero Ellison sostenía que el campo más rico, el más verdadero y el más natural, si no el más extenso, había sido inexplicablemente descuidado. Ninguna definición hablaba del jardinero-paisajista como del poeta; sin embargo, mi amigo opinaba que la creación del jardín-paisaje ofrecía a la Musa correspondiente la más espléndida de las oportunidades. Allí, en efecto, se hallaba el más hermoso campo para el despliegue de la imaginación en la interminable combinación de formas de belleza nueva; pues los elementos que entran en la combinación son, por su gran superioridad, los más espléndidos que la tierra puede brindar».

«Por mis observaciones anteriores -dijo Ellison- usted comprenderá que rechazo la idea, expresada aquí, de recordar la belleza original del campo. La belleza original nunca es tan grande como la creada»

«Sólo a fines del cuarto año de búsqueda encontramos una localidad con la que Ellison se declaró satisfecho. Es innecesario decir, por supuesto, dónde estaba la localidad. La muerte reciente de mi amigo, al abrir sus puertas a cierta clase de visitantes, ha dado a Arnheim una especie de celebridad secreta y privada, si no solemne, similar en cierto modo, aunque en un grado infinitamente superior, a la que durante tanto tiempo distinguió a Fonthill» (Versión castellana de Julio Cortázar)

La descripción de lugares fantásticos con jardines paradisiacos, como el descrito en el cuento de Poe, ya se había dado en 1798 cuando Coleridge describe Xanadú en Kubla Khan. Unidos a lugares lejanos y exóticos, son extraordinarios pero imaginarios. Eso es lo que les diferencia de Fonthill, que es real. (Thacker ) 


\subsubsection{Fonthill y los Smithson}

Al comienzo del libro Upper Lawn, Folly Solar Pavilion, los Smithson describen la zona y los terrenos de la finca de William Beckford, recopilando referencias sobre Fonthill, entre autores y artistas británicos. Ilustraciones del libro de John Rutter de 1823, acuarelas de William Turner, extractos de The Beauties of Wiltshire de John Britton de 1801, y la descripción de Wiltshire hecha por Nicolas Pevsner en Buildings of England en 1963. Todas obras reconocidas como las más importantes sobre Fonthill.

Su selección, es en sí misma una declaración de intenciones y pone de manifiesto el interés de los Smithson no solo por la tradición y cultura inglesa, sino por situar su casa de vacaciones y ellos mismos como parte de ese contexto cultural.

El mapa de Fonthill realizado para la History and Description of Fonthill Abbey de John Rutter y también publicado en Delineations of Fonthill and Its Abbey del mismo autor, ambos en 1823, muestra la extensión de la propiedad y sus elementos principales. Al ser un plano con gran detalle y probablemente el único tan completo del dominio, ha sido reproducido con frecuencia, tanto en las publicaciones referidas a la finca desde un punto de vista paisajístico, como en las monografías sobre los Smithson de diversos autores al referirse a Upper Lawn, y por los propios Smithsons en Upper Lawn. Folly Solar Pavilion.

Las publicaciones impresas en papel de principios del XIX se coloreaban a mano convirtiéndose necesariamente en ejemplares especiales.

La excepcionalidad del plano de Fonthill queda ratificada al ser la única lámina coloreada del libro, con un formato extra que requiere varias plegaduras. El color es sumamente relevante en este caso, ya que permite entender y analizar caminos, recorridos y limites señalados en distintos tonos. Sin embrago su reproducción es mayoritariamente en blanco y negro, incluida la del libre de los Smithson. Una de las pocas encontradas que referencian el color es la impresa en el libro Sowing Empire. Landscape and Colonization, de Jill H. Casid, publicado por la Universidad de Minnesota en 2005, en el que se describe como está señalado el muro de 12 pies de altura y 7 millas que delimita el área principal del dominio, la Abadía Neogótica y la residencia de Beckford en color rojo, mientras que el paseo pedestre perimetral, el lago artificial y las Plantaciones Americanas en azul.

La imprevisible existencia de un ejemplar del libro de John Rutter, Delineations of Fonthill and Its Abbey, en la Biblioteca de la Escuela Técnica Superior de Arquitectura de Madrid, perteneciente al legado Cebrián, ha permitido su consulta directa.

El libro de $35 \mathrm{~cm}, 127$ páginas y 25 láminas, publicado en 1823 por la editorial Charles Knight and Co. de Londres, se encuentra en perfecto estado, aunque las plegaduras de la lámina principal, han originado una pequeña rasgadura en el encuentro de los cuatro pliegues en la zona central. Está catalogado con la signatura Cebrian 333.

Figura 2.26

RUTTER John 1823

Delineations of Fonthill and its abbey, Charles Knight and Co.

Ejemplar del legado Cebrian de la biblioteca de la Escuela Tecnica Superior de Araquitectura de Madrid, con la sigantura CEBRIAN 333

Fotografias de Ana Rodríguez realizadas en 2014

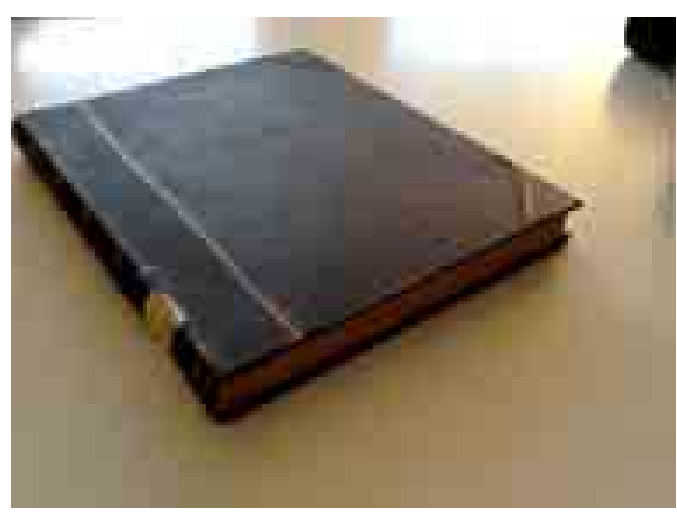



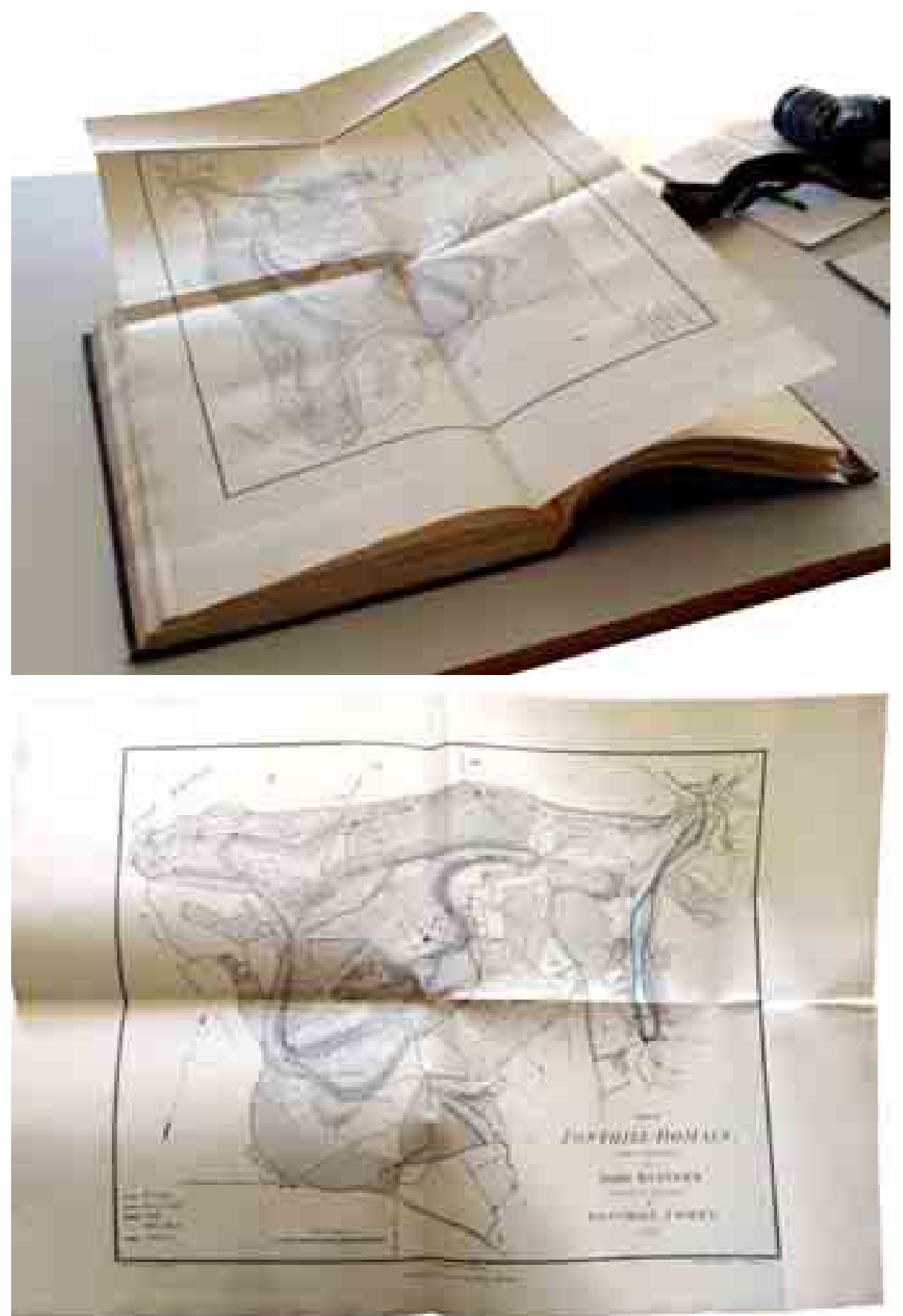

Figura 2.27

RUTTER John 1823.

Delineations of Fonthill and its abbey, Charles Knight and Co

Ejemplar del legado Cebrian de la biblioteca de la Escuela Tecnica Superior de Araquitectura de Madrid, con la sigantura CEBRIAN 333

Fntnorafias de Ana Rndrínı ıe7 realizadas en 2014 
El libro de los Smithson, Upper Lawn, Folly Solar Pavilion, como ya hemos citado, es el documento más importante sobre Upper Lawn.

Se estructura en dos partes.

En la primera, se relatan los antecedentes, las referencias históricas sobre Fonthill, sus intenciones, las ideas de proyecto, el proceso de construcción y las comprobaciones realizadas los dos primeros años una vez terminada «la casa climática».

La segunda es el diario de su vida en Upper Lawn. Desde junio de 1962, cada año tiene unos pequeños textos significativos de cada mes, ilustrados con fotografías en blanco y negro y color ${ }^{66}$ de actividades cotidianas, las distintas estaciones, el juego de Simon, Samantha y Soraya Smithson, y especialmente de la relación de la casa con el entorno de Fonthill. Al final del libro, los mismos textos se cruzan en una lectura transversal por meses del año. Así, de cada mes, se pueden consultar de forma correlativa todos los años allí vividos.

La figura 16 en blanco y negro de dicho libro, corresponde a la primera imagen de la casa totalmente terminada de marzo de 1962. Es una de las famosas fotografías con el Citroen DS aparcado delante de la puerta. Sin embargo, su pie de foto no hace referencia ni al pabellón ni al vehículo, sino a un pequeño carromato que se ve al fondo «Corrugated-iron caravan for shepherd at lambing time, traditional to the west country: mentioned in novels of Thomas Hardy (architect). Junto a ella la figura 17, también en blanco y negro, sorprende por ser una de las imágenes más repetidas del interior del extremo de una de las alas de la derruida Fonthill Abbey. Corresponde a un grabado en blanco y negro de George Cattermole, del extremo sur de la St. Michael's Gallery, en el que los Smithson hacen un fotomontaje sustituyendo el paisaje de Fonthill que se ve al fondo, a través del ventanal neogótico, por otro con El Pabellón Upper Lawn terminado, situado en esa misma dirección.

El pie de foto explicita «Fotomontaje: Upper Lawn como se vería desde la Abadía, es decir colocada dentro de un gravado que hizo Cattermole de una ventana de Fonthill Abbey. Primeros 60»

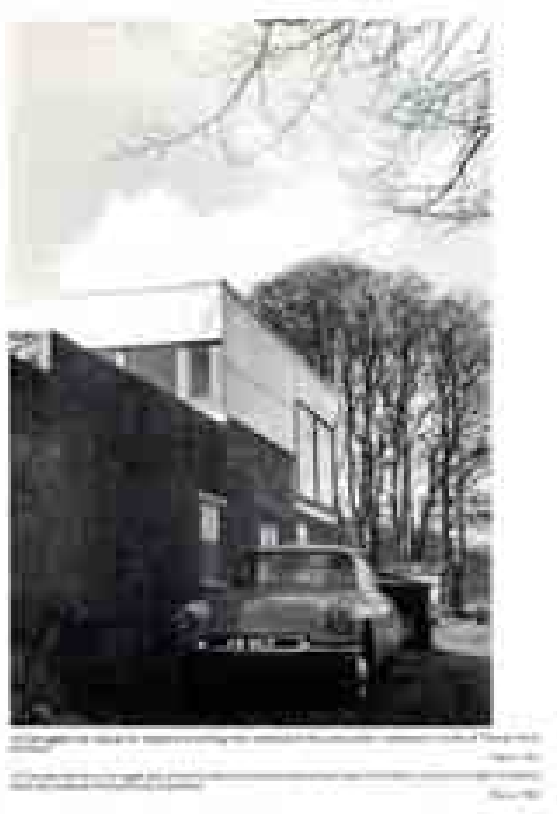

Figura 2.28

Figuras 16 y 17 de la página del libro de los Smithson, Upper Lawn, Folly Solar Pavilion.

El pabellón recién terminado, el Citroen DS y un fotomontaje de los Smithson situando su casa de vacaciones, El Upper Lawn Pavilion en la historia inglesa.

${ }^{60}$ Las imágenes en blanco y negro y color no se mezclan. Primero se agrupan las de blanco y negro y después todas juntas las de color. Es una decisión compositiva, ya que las fechas indican que frecuentemente se hacían las mismas fotografías o similares de ambas formas en el mismo momento. 

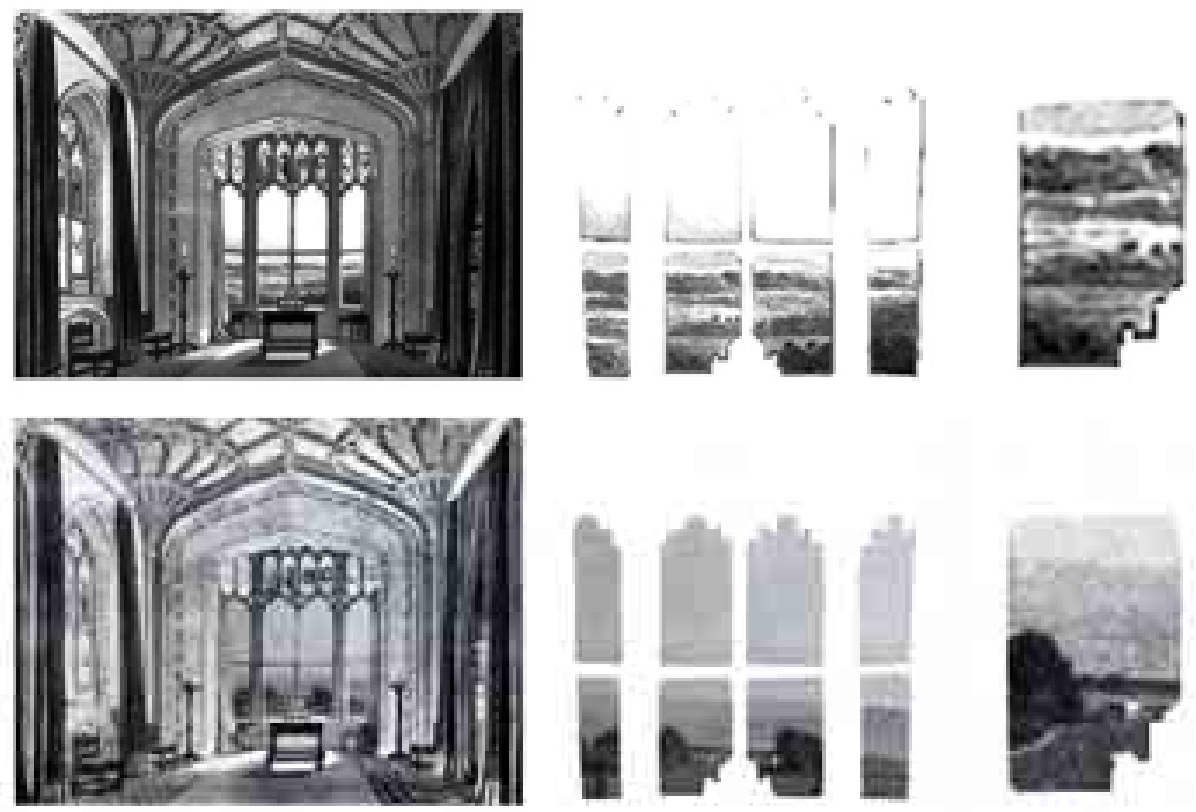

Figura 2.29

Comparación del Fotomontaje realizado a principios de los 60 por los Smithson, en el que incorporan cómo se vería Upper Lawn desde la Fonthill Abbey sobre un grabado de George Cattermole, con la obra original.

Analisis comparativo de Ana Rodríguez, a partir de la figura anterior.

* Superior

Grabado de George Cattermole

Extremo sur de la St. Michael's Gallery en la Abadia de Fonthill. Ilustración del libro de Joahn Britton Graphic and Literary Illustrations of Fonthill Abbey. Gravado en color por George Cattermole en 1823 a partir del anterior de M. Dubourg. The Stapleton Collection, The Bridgeman Art Library

* Inferior

Fotomontaje de los Smithson sustituyendo la imagen que se ve a través de la ventana del grabado de Cattermole situada frente a Upper Lawn, por como se vería desde la Abadia de Fonthill, la vista del Upper Lawn Pavilion.

Figura 2.30

Detalle del Fotomontaje realizado a principios de los 60 por los Smithson, sobre como se veria el Upper Lawn Pavilion desde Fonthill Abbey.

Detalle recortado del fotomontaje de los Smithsons, por Ana Rodríguez.

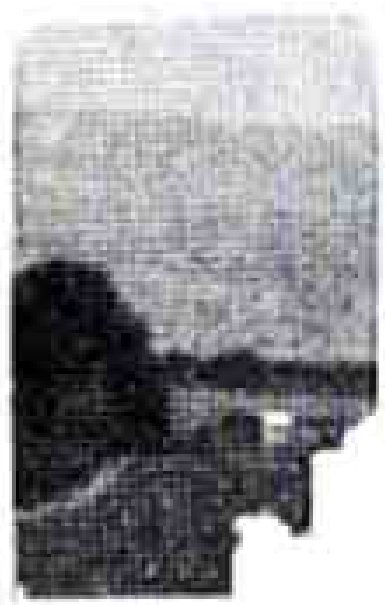



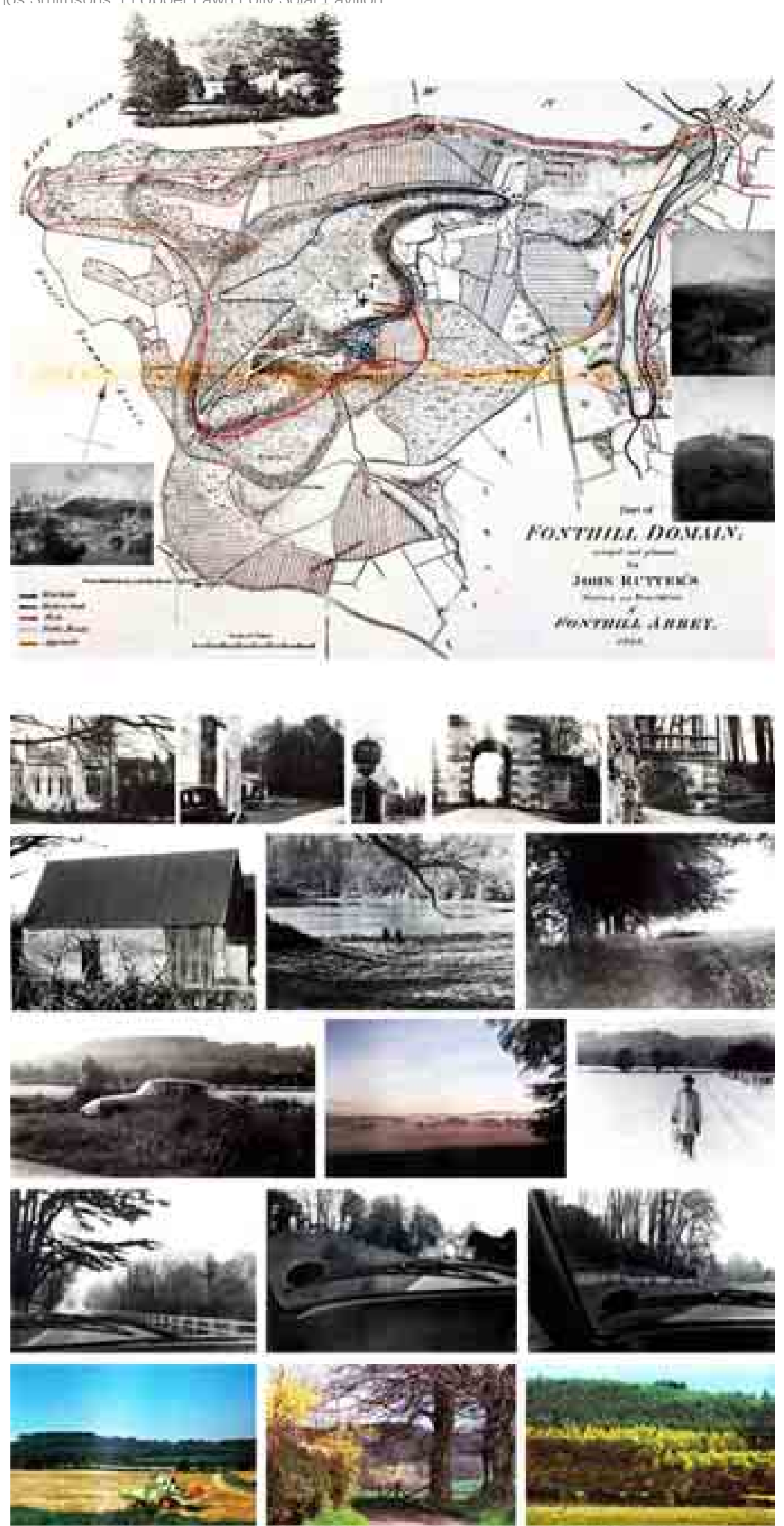

Figura 2.31

Fonthill y los Smithsons.

* Superior. Plano de la finca Fonthill de John Rutter, 1823, referenciado por los Smithsons en al comienzo de Upper Lawn, Folly Solar Pavilion. Las imágenes perimetrales son las acuarelas de

Turner sobre vistas de finca y el grabado de la Plantación Americana, también de Rutter.

* Inferior: Selección no exhaustiva de imágenes de Fonthill, realizada por Ana Rodríguez, de las publicadas por los Smithson en el mismo texto, como muestra de su interés por explorar la finca. 

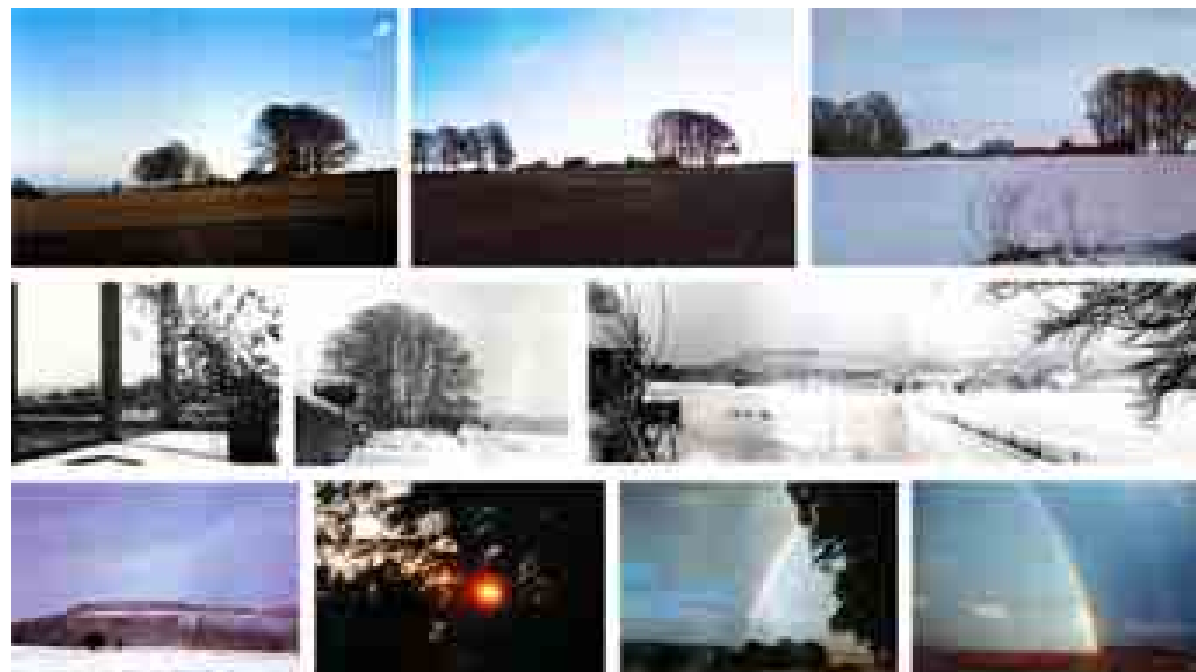

esere
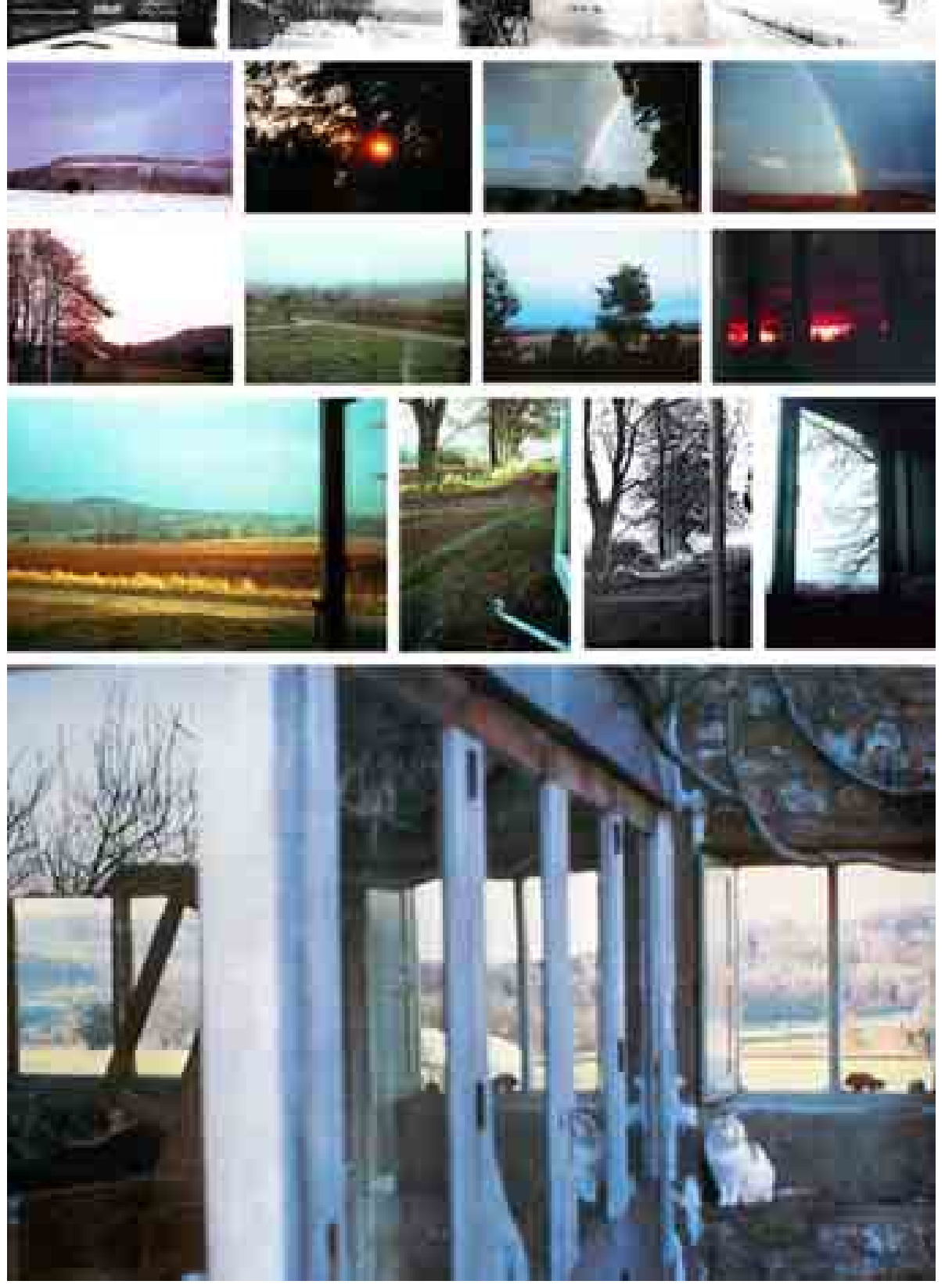

Figura 2.32

El Upper Lawn Pavilion y su relación con el territorio de la finca Fonthill.

Selección no exhaustiva de imágenes, realizada por Ana Rodríguez, a partir de las publicadas por los Smithsons en Upper Lawn, Folly Solar Pavilion, en las que se aprecia el interés de los Smithsons por las relaciones que establecen estre la casa y el territorio, su implantación en el paisaje, y la percepción del mismo desde el interior del pabellón. 


\subsubsection{La memoria del lugar en Upper Lawn. Una topografía con espesor.}

"As found" y "found". El "según se encuentra" y "lo encontrado".

«El "según se encuentra", donde el arte consiste en recoger, dar la vuelta y poner con... y "lo encontrado", donde el arte está en el proceso y en el ojo observador...

...Con "según se encuentra" nos referíamos no solo a edificios adyacentes sino a todas aquellas señales que constituyen los recuerdos de un lugar y que hay que leerlos averiguando cómo la construcción que hay en el lugar había llegado a estar como estaba. De aquí nuestro respeto por los árboles viejos como "estructura" existente de un lugar en el que el edificio sería el recién llegado...» (Smithson y Smithson 1990, 201-202)
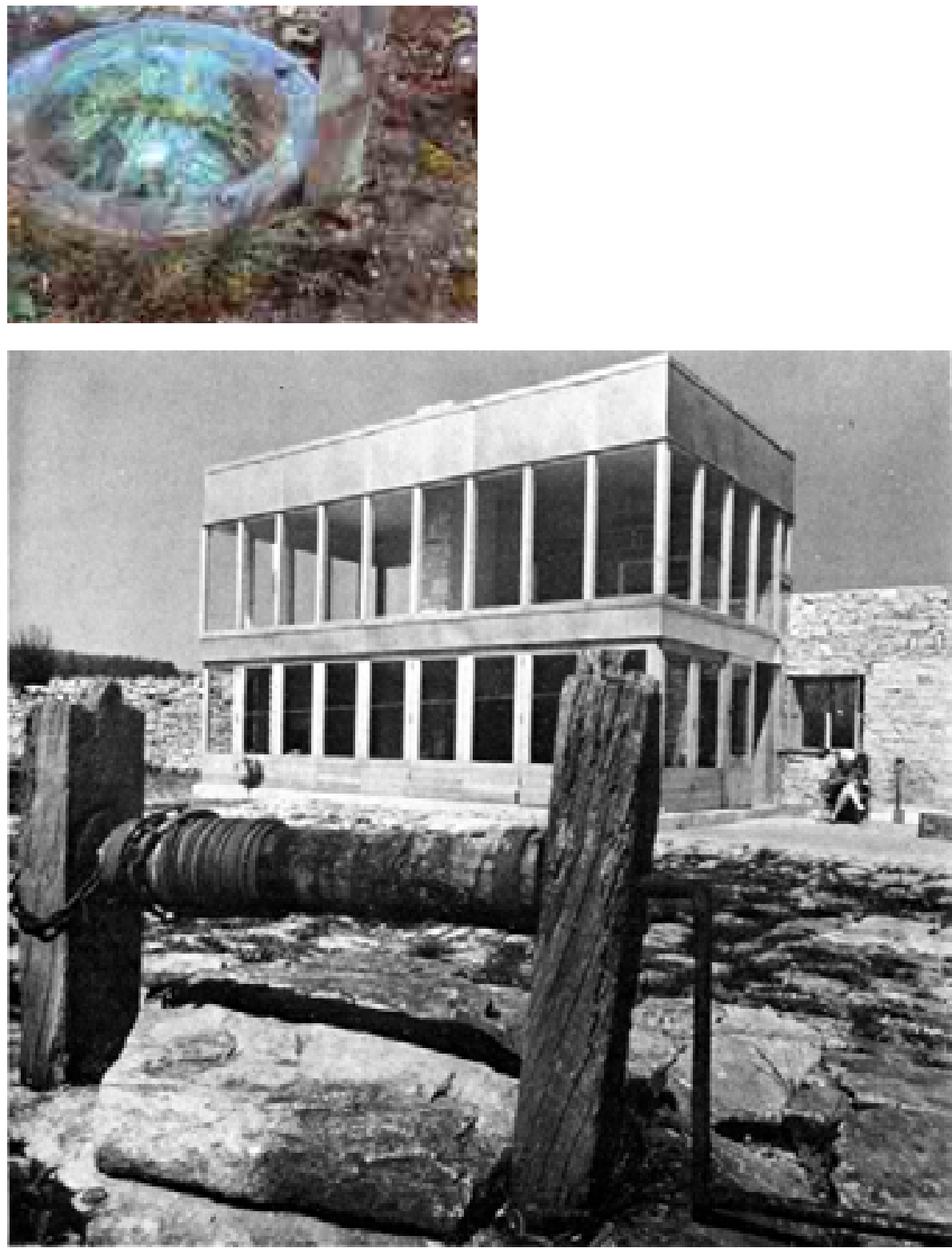

Figura 2.33

* Inferior: el pozo "as found" cubierto por una piedra, antes de instalar la pequeña claraboya acrílica que se colocó posteriormente en 1970. Fotografia de Brugh Galweyen Pentecostés de 1962. (Smithson y Smithson, 1986)

* Superior: claraboya acrílica colocada en 1970 sobre la boca del pozo, y la vegetación crecida en el interior, junio de 1979 (Smithson y Smithson, 1986) 


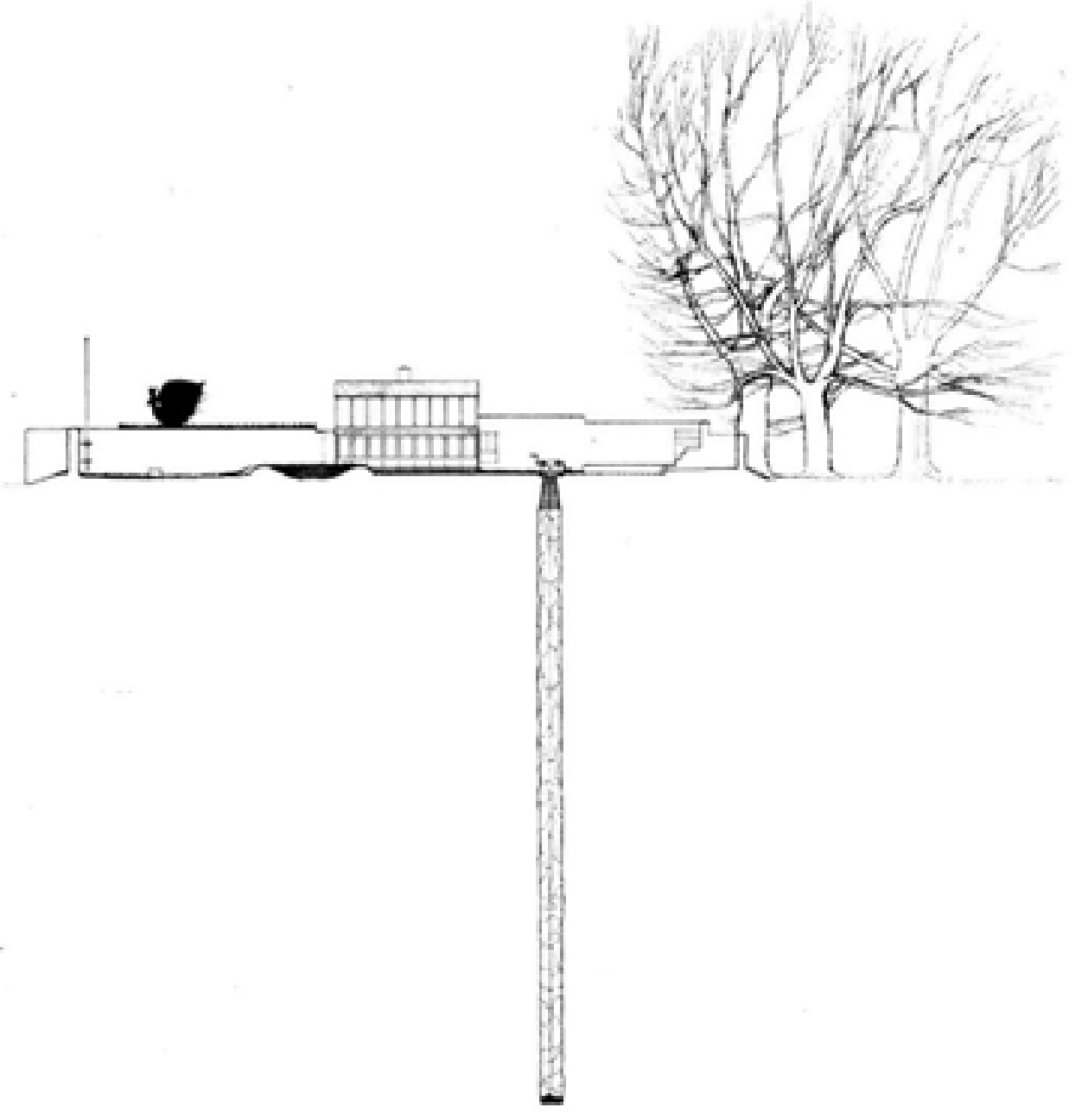

Figura 2.34

Sección longitudinal de Upper Lawn por el pozo (Smithson y Smithson, 1986) 
En la parcela cercada existían dos antiguos cottages formando parte de un pequeño cluster entorno a un granero del siglo XV, que en origen era el granero rural periférico dependiente del Granero de Diezmos de Tisbury, el mayor de Inglaterra.

El recinto está delimitado por muros mampostería de piedra, más alto y de mejor calidad en el lado norte, en el frente principal de la granja. Sobre él se elevaba la construcción del antiguo cottage preexistente del siglo XVIII y anteriores, que estaba en ruinas.

Una modesta construcción con cubierta de paja, huecos pequeños y muros de piedra que en el lado norte se eleva sobre el del enclave en continuidad con él.

En el lado sur, frente a él, los restos de otra pequeña granja. En el espacio libre interior una parte pavimentada con un adoquinado de piedra antiguo y la otra mitad de pradera.

El dibujo más famoso de Upper Lawn, es una sección longitudinal del recinto, con el alzado sur del pabellón, transparente en contraposición a los muros de mampostería de piedra que delimitan la parcela, y en relación con tres preexistencias del lugar: un grupo de hayas, un pozo de agua y un arbusto silvestre sobre el muro norte.

Su intencionada integración y puesta en valor caracterizan e intensifican poderosamente el proyecto. Forman parte del mismo, en igualdad de condiciones con el nuevo pabellón y los muros del recinto, configurando una imagen indivisible del conjunto.

The Well, fue dibujado por Peter Smithson en 1975 «for my own pleasure»67 transcurridos más de diez años de vida en Upper Lawn.

La sección por el pozo muestra la profundidad medida por los Smithson y el nivel freático de su momento, en relación con la amplitud del enclave y el tamaño de las hayas (Smithson y Smithson, 1986).

Su representación, muy intencionada como todo el dibujo, es cuidada y meticulosa, con la textura del material, la cuerda y el sistema de elevación en la boca formado por dos mangos giratorios de hierro forjado.

El terreno tiene espesor ${ }^{68}$, fundamentalmente por la profundidad que el pozo confiere al dibujo, pero también por el dique cerrado en forma de óvalo, hecho con la tierra y restos retirados que se había acumulado en el tiempo sobre las zonas pavimentadas con adoquín. «El antiguo patio, al descubierto en los lugares de máximo uso -desde la verja a la puerta- resultó muy extenso: el montón de tierra/basura formó al principio una pequeña muralla que dividía el territorio, sin embargo a medida que continuó la excavación, sus extremos fueron curvándose hasta formar un óvalo completo.»(Smithson y Smithson, 1986).

\footnotetext{
${ }^{67}$ Peter Smithson en una carta del 6 de octubre de 2000. Referenciado por Bruno Krucker en Complex Ordinariness. The Upper Lawn Pavilion by Alison and Peter Smiyhson, gta Verlag, ETH Zurich 2002

68 El interés por expresar la profundidad de los terrenos, vuelve a mencionarse en Territory of the Pavilion, extracts from a lecture, el 30 de Octubre de 1984, publicado en 1994 en Alison and Peter Smithson. Changing the Art of Inhabitation, Artemis London Ltd 1994 «The territories have a sense of vertical depth: in the Farnsworth, the water level then the riverbed of the Fox; in the Eames, the drop from the its ledge to the beach and the ocean (as well as the protective height of the bluff above; the Solar Pavilion in its 125-foot-deep well (the same dimension as the length of the compound)»; «Los territorios poseen sentido de profundidad vertical; en la Farnsworth, el nivel del agua y luego el lecho del rio Fox; en la Eames, la caída dede su cornisa a la playa y al oceano (así como la altura protectora del acantilado sobre el que se sitúa), en el Solar Pavilion el pozo de 38 metros de profundidad (la misma medida que la longitud de la parcela)» versión castellana de Sofía Estevez en la edición castellana Alison y Peter Smithson, Cambiando el arte de habitar, Gustavo Gili, Barcelona 2001
} 
A la derecha del dibujo, el grupo de hayas, sin pertenecer a la parcela, definen el enclave por su cualidad, no por sus límites administrativos.

A la izquierda, un arbusto podado en forma de pájaro posado sobre el muro, posteriormente desarrollará varias "personalidades" en el tiempo: ave de muro nevada, desde el exterior un pavo en febrero de 1963, ave de verano, verde y con cresta en octubre de 1973, ave de muro del equinoccio, podada y transformándose en pavo real en octubre de 1979. «...El arbusto en forma de pájaro es un ejemplo del "arte" del "como estaba": el arbusto de espino, crecido espontáneamente, resultó demasiado verde y grueso como para serrarlo contra el muro almenado, por lo que se podó dándole la forma ya sugerida por P.S.» (Smithson y Smithson, 1986).

El carácter lineal del pozo y su situación central y descendente, protagonista del dibujo.

La superficie de las hayas en el extremo derecho, ocupando más de la tercera parte de la dimensión total.

El pájaro podado en el arbusto de espino, una figura recortada sobre el fondo del cielo, un punto de color negro en contraposición con la transparencia de las hayas, representadas sin hojas. Situado a la izquierda en la coronación del cerramiento, sobre una línea de más intensidad también en color negro, que representa la terminación "almenada" del muro.

Las tres preexistencias, establecen un triangulo de acentos e intensidades diametralmente opuestos que se contraponen y equilibran entre sí.

Un sencillo dibujo a línea, en blanco y negro, expresa la cualidad sensorial de cada elemento del conjunto y transmite con emoción la atmósfera del lugar.

El único dibujo en alzado o sección de Upper Lawn con la parcela, con su entorno cercano, es el descrito anteriormente. En ninguna publicación o monografía posterior se ha vuelto a redibujar o representar. En los planos del proyecto, el ULO0 fechado en Noviembre de 1959, muestra una versión del alzado, anterior a la finalmente realizada, en la que se indica la posición y relación del pabellón con la tapia de mampostería preexistente. Aunque parcial y no definitiva, es el dibujo más parecido a un alzado completo de los existentes.

En la monografía sobre el Upper Lawn Pavilion de Bruno Krucker tampoco.

Redibuja con gran precisión, la parcela completa en planta y varios dibujos del pabellón que incluye el alzado norte con una porción de tapia, pero no el alzado completo, equivalente a la evocadora sección del pozo y las hayas.

No se considera una cuestión menor en esta investigación, y por ello se ha dibujado por primera vez el alzado completo, entendiendo la tapia de mampostería como una entidad completa, que ayuda a entender el pabellón y su relación con el territorio en el que se implanta.

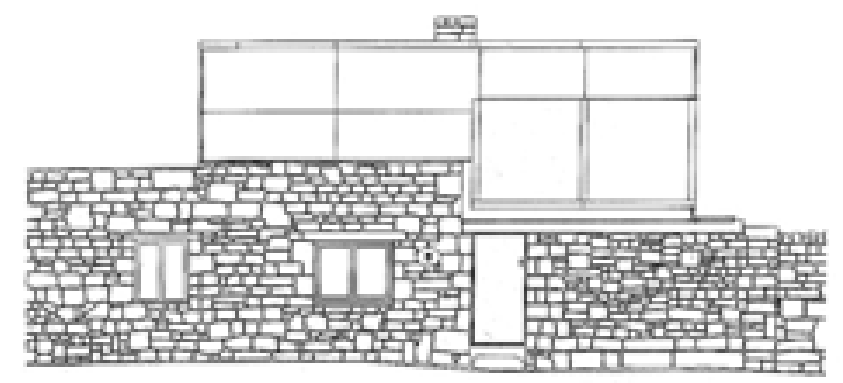

Figura 2.35

Alzado norte dibujado por Bruno Krucker en Complex Ordinariness: the Upper Lawn Pavilion by Alison and Peter Smithson (Krucker 2002) 


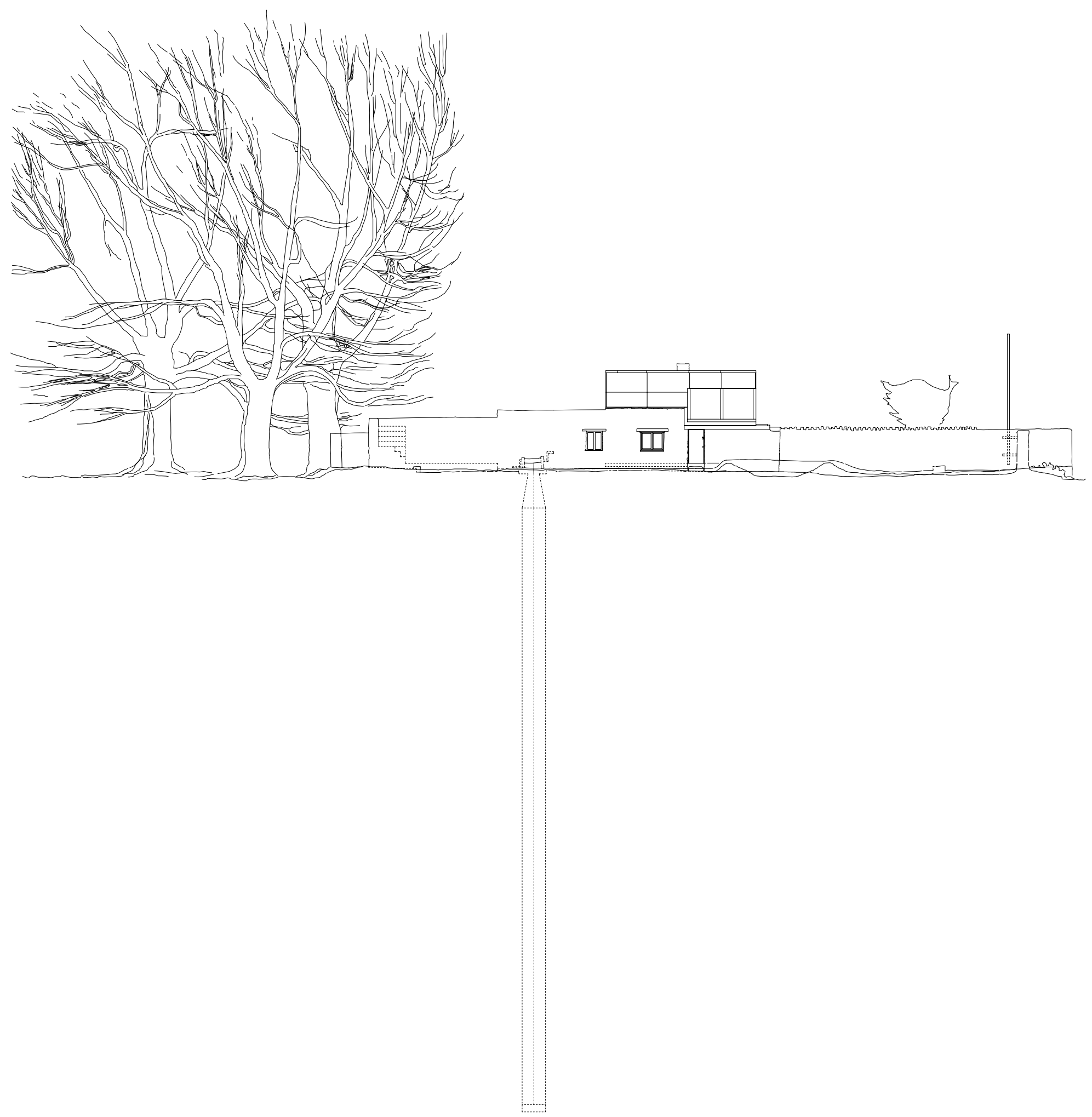




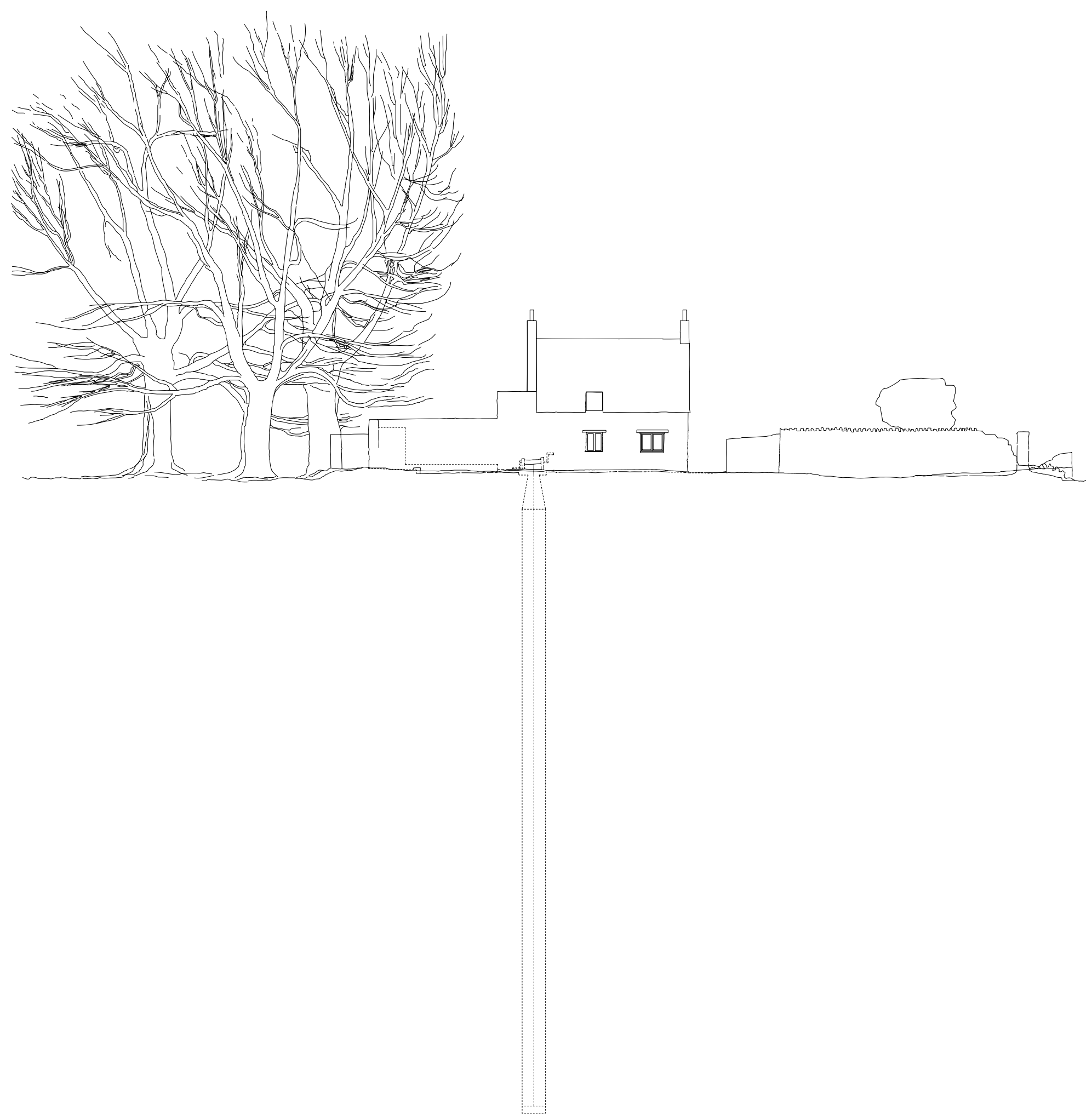

Figura 2.37

Alzado norte inédito del Upper Lawn Pavilion. Construcción preexistente en el conjunto de la parcela. Dibujo de Ana Rodríguez. Escala 1/300 


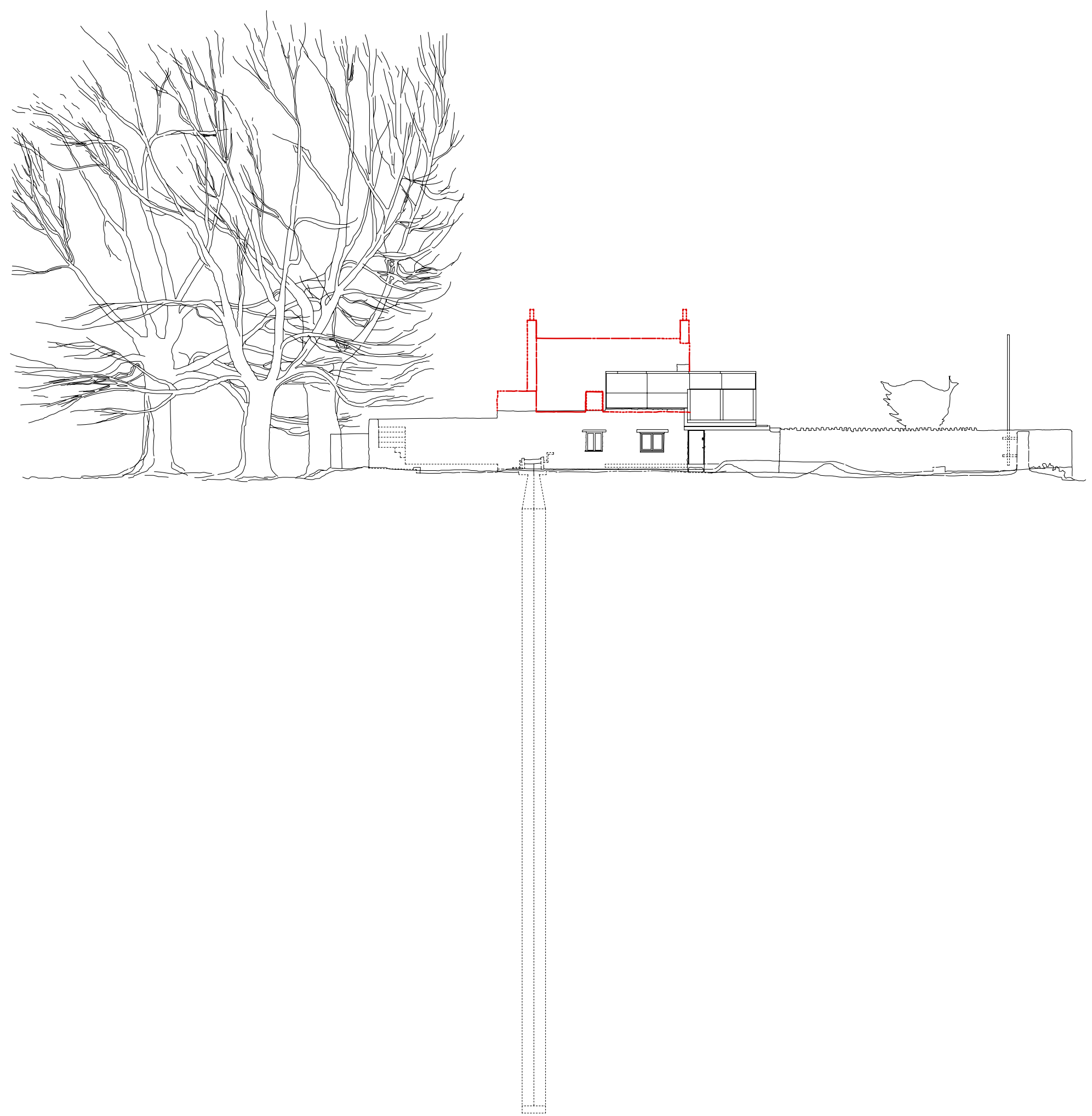

Figura 2.38

Alzado norte inédito del Upper Lawn Pavilion. Análisis comparativo de la volumetria y ocupación de parcela entre la intervención de los Smithsons y la construcción preexistente. Dibujo de Ana Rodríguez. Escala 1/300 


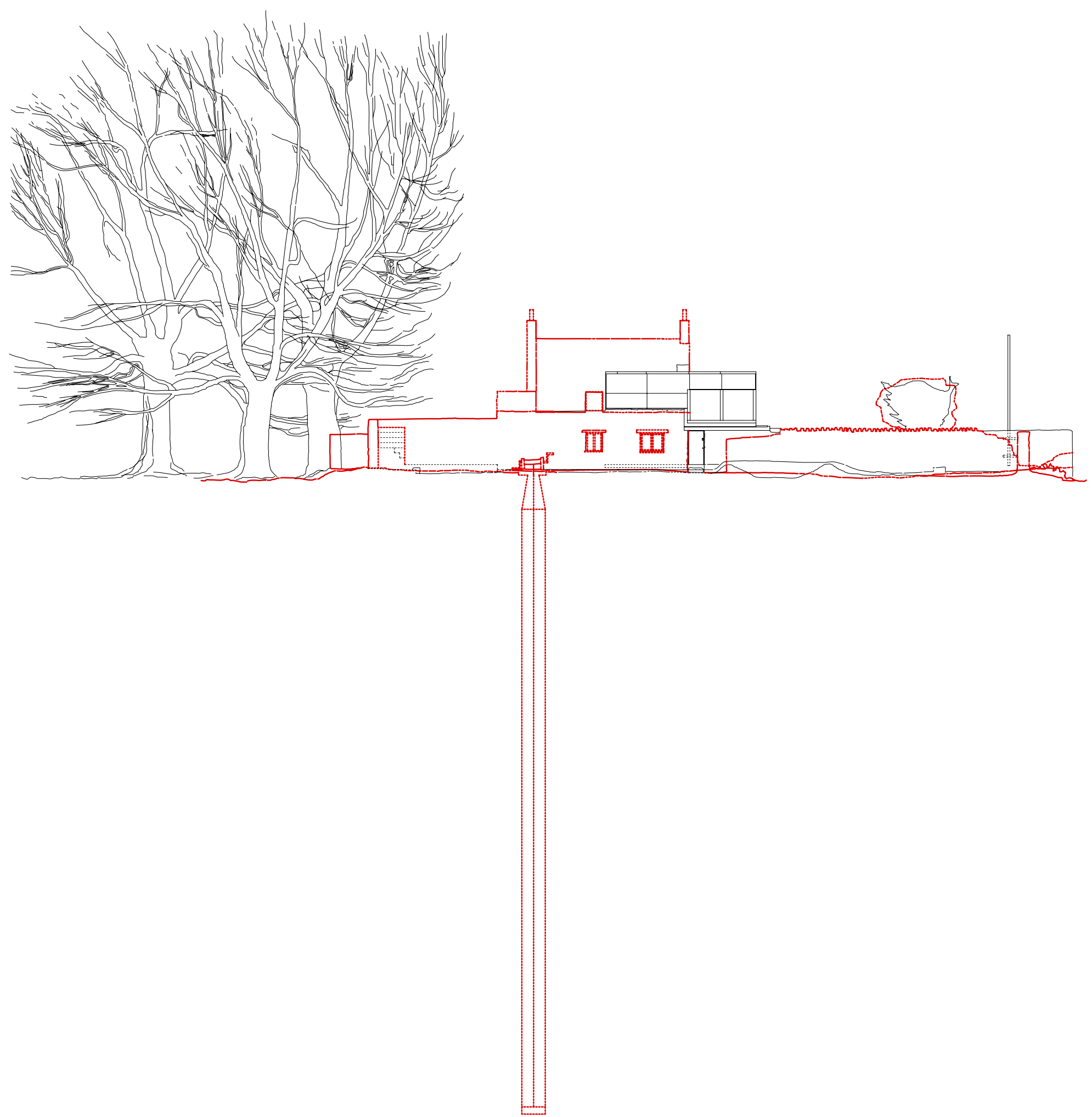

Figura 2.39

Alzado norte inédito del Upper Lawn Pavilion. Análisis comparativo de la volumetria y ocupación de parcela entre la intervención de los Smithsons y la construcción preexistente.

Dibujo de Ana Rodríguez. Escala 1/300 


\subsection{3.. Upper Lawn como experiencia arquitectónica y vital de los Smithson [Topofilia]}

\subsubsection{La elección de Upper Lawn}

«Los lugares nos arrastran por motivos que están más allá de las sensaciones derivadas de los cinco sentidos [...] Algún reconocimiento más profundo está implícito, sentido a través de una sensibilidad animal inagotable»

(Smithson y Smithson 1993, 32) y (Spellman y Unglaub 2004, 49)

El proyecto es de 1959, cuando compran la granja, pero ya en 1958 hay un croquis de Alison con las primeras ideas para el acceso.

La construcción, realizada en parte por ellos mismos, se completa en 1962, pero los veinte años hasta su venta en 1982 se convierten en un proceso continuo de experimentación, en el que van haciendo pequeños cambios y matizando soluciones «En un principio colocamos las cañerías sobre la superficie de la mampostería y, más tarde, las tapamos, porque cuando lo utilizabas irritaba bastante la condensación en superficie, algo que no encontramos aquí. Así se trata del segundo proceso, cuando eliminas elementos conflictivos» (Spellman y Unglaub 2004, 77).

Los cambios más significativos son el traslado de la cocina en planta baja al extremo opuesto al original y el cambio de orientación de la escalera. En el exterior, en el jardín entre muros, se producen transformaciones permanentes como la construcción de la plataforma sobre la cocina de la antigua granja y su acceso escalonado de hormigón, pero también la evolución de la jardinería, cambiante en el tiempo y con las estaciones, como las distintas variaciones en la silueta podada de un pavo real en el arbusto silvestre sobre el muro de piedra, que será durante mucho tiempo y hasta su desaparición, uno de los iconos de Upper Lawn.

Es el lugar escogido para educar a sus hijos, en la naturaleza y en las tradiciones inglesas, como ya se ha comentado anteriormente, y lo conocían anteriomente, desde bastante tiempo antes de comprar la granja.

«La primera visita del descubrimiento (realizada por A.S. en el verano de 1945) fue como en el cuento de la Bella Durmiente, cuando el príncipe ha de ir abriéndose camino a machetazos a través de zarzales y masas de espino hasta descubrir el castillo; en este caso, la Abadía no estaba intacta, pero como los libros decían que prácticamente no quedaba piedra sobre piedra, fue verdaderamente mágico, cuando el coche consiguió penetrar a ciegas por el camino invadido de vegetación salvaje, el hallar el edificio compacto sin rastro de daños o reparaciones. No se ha hallado explicación para esto. Pevsner lo acepta así; y sin embargo, el fragmento no parece encajar en las plantas» (Smithson 1986)

Bruno Krucker, en Complex Ordinariness. The Upper Lawn Pavilion by Alison and Peter Smithson, reseña que los Smithson habían visitado el lugar ya en 1950, y posteriormente en conversación con Peter Smithson el 5 de octubre de 2000, este mencionó que Alison lo había conocido cuando era niña (Krucker 2002, 29)

En la cita de Upper Lawn, Folly Solar Pavilion, arriba referenciada y única anotación encontrada sobre esta cuestion ${ }^{69}$, los Smithson hablan de 1945 como fecha de la primera visita de Alison. Alison nació en 1928, luego en 1950 tenía 22 años, y en 1945 17 años. Cuando Peter se refiere a «cuando era niña», puede referirse a esa edad de o quizá aún mas niña.

${ }^{69}$ La nota 89 del libro de Krucker, que se refiere a la fecha de 1945 mencionada por los Smithsons. 


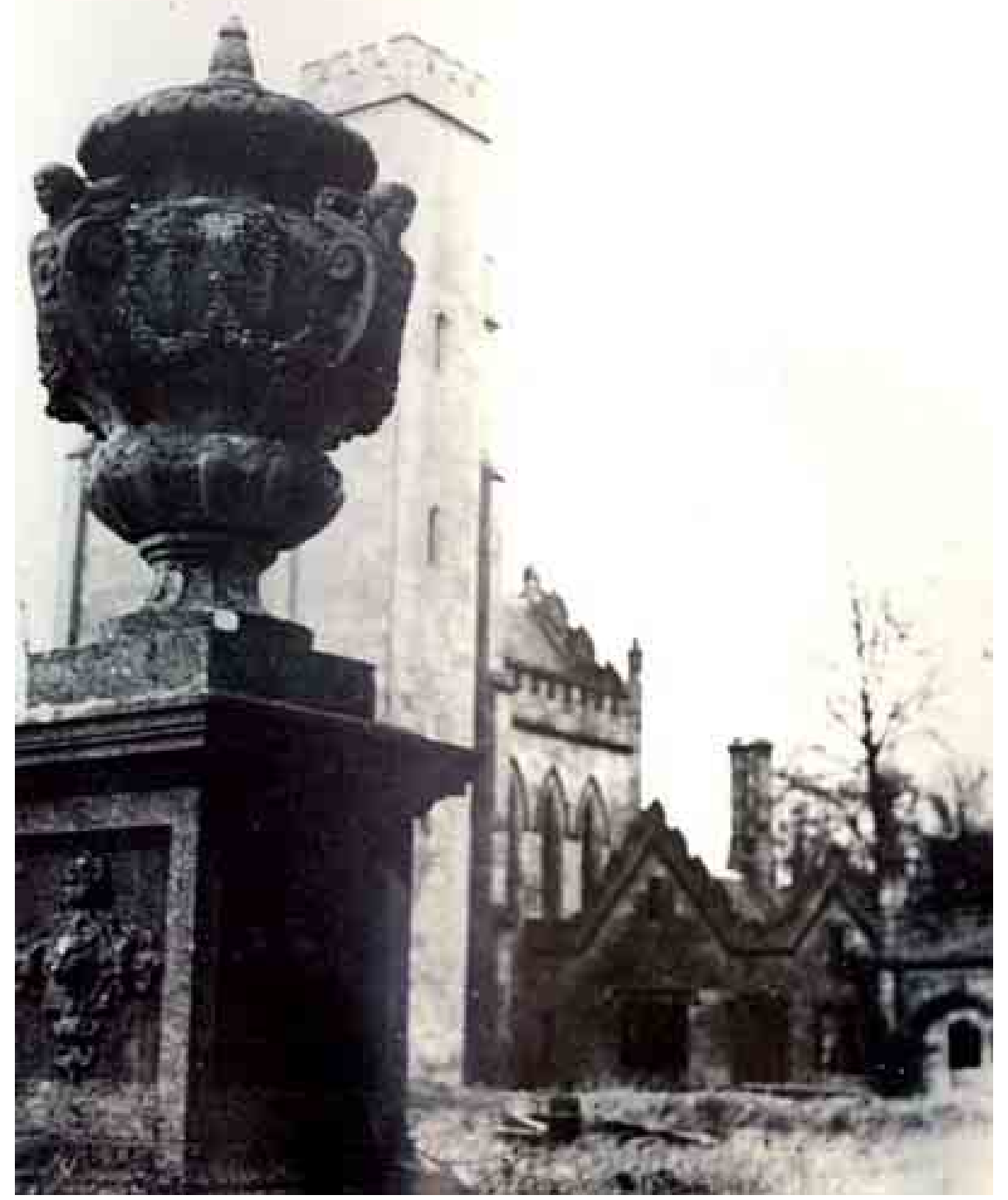

Figura 2.40

Corresponde a la figura 8* en Upper Lawn: Folly Solar Pavilion. Fotografía de Peter Smithson Fonthill Abbey, la urna se ubica al borde de un dique curvo que debió de formarse tras el hundimiento.

* de la primera parte, en blanco y negro, del libro. 

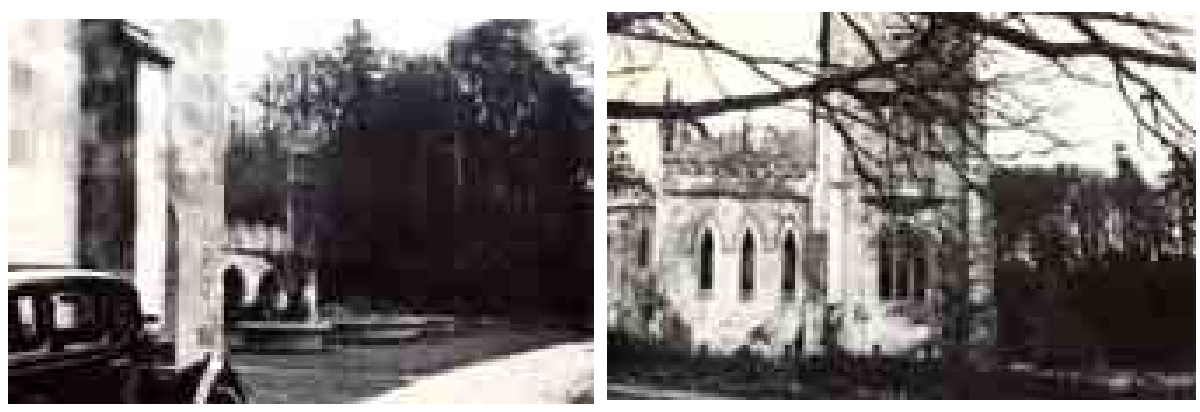

Figura 2.41

Izquierda, corresponde a la figura $7^{\star}$ en Upper Lawn: Folly Solar Pavilion. Fotografía de Peter Smithson.

Cestos de flores esculpidos en piedra - con un cierto estilo Regencia-, tal vez en su situación original. Durante los años setenta, la parte del claustro se sumió en la ruina. Pascua 1950.

Derecha, corresponde a la figura $6^{\star}$ en Upper Lawn: Folly Solar Pavilion. Fotografía de Peter Smithson.

Parte occidental de los restos de Fonthill en una segunda visita...en muchas de las visitas, al mirar a través de las ventanas podía verse en el interior una maqueta de madera oscura. Pascua 1950

( ${ }^{\star}$ de la primera parte, en blanco y negro, del libro)
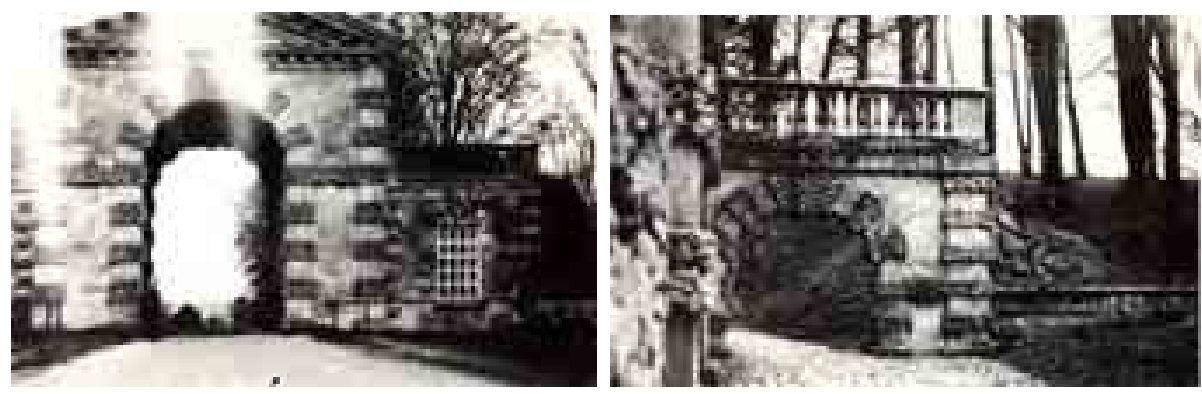

Figura 2.42

Izquierda, corresponde a la figura 9* en Upper Lawn: Folly Solar Pavilion.

El «Arco» Fonthill Bishop posiblemente construido en principio como acceso a la casa isabelina original -cuyo emplazamiento, en un valle lateral, es probablemente localizable junto a un jardín trasero vallado- que fue demolida por el padre de Beckford, quien construyó «Splendens». Fotografía de Alison Smithson. Pascua 1950.

Derecha, corresponde a la figura 10* en Upper Lawn: Folly Solar Pavilion.

Arco lateral del «Arco»/Puerta. Fonthill Bishop: el extremo del haya que "cuelga» al fondo. La idea de de estos cinturones de árboles se introdujo en nuestra estética paisajística en Churchill College. 1958.

Fotografía de Alison Smithson. Pascua 1950.

( ${ }^{*}$ de la primera parte, en blanco y negro, del libro) 


\subsubsection{El Pabellón Upper Lawn y los habitats de San Jerónimo. Un fragmento de un enclave, en busca del Pabellón de nuestro tiempo.}

Los hábitats de San Jerónimo según Alison Smithson.

En 1990 Alison Smithson publica por primera vez Saint Jerome. The Desert. The Study, basado en conferencias impartidas en 1985 en Barcelona y 1986 en Estocolmo. Editado como opúsculo por la firma de mobiliario TECTA para su distribución en su stand de la Feria de Milán en abril de 1991, el texto también está incluido por Dirk van den Heuvel y Max Risselada en Alison and Peter Smithson. From the House of the Future to a house of today, y en su edición española publicada por Polígrafa Alison y Peter Smithson. De la Casa del Futuro a la casa de hoy.

Alison hace un estudio sobre los hábitats de San Jerónimo:

San Jerónimo en el desierto, San Jerónimo en su estudio y San Jerónimo y la gruta. Analiza su significado alegórico y su representación en la pintura de los siglos XV, XVI y $X V I I$, ilustrado por obras de Rembrandt, Antonello de Messina, Lorenzo Monaco, la Escuela de Colonia, Albrecht Dürer, Joost van Cleeve el Viejo, Andrea Mantenga, el estudio de Giovanni Bellini, y Bartolommeo Bellano.

El hábitat de San Jerónimo en el desierto, se caracteriza por cómo el hombre «permanece en solitario entre la tierra y el cielo, rodeado de horizontes que podrían constituir el infinito", " un lugar para un vida de ascetismo con pocas tentaciones materiales, con una naturaleza tan inmutable, tan omnipresente, que el hombre se ve relevado de su responsabilidad». Representa la idea de «sitio inexplorado» como fuente de energía creativa, «el deseo de alejarse de la vida urbana para estar solo en 'tierra de nadie' parece una prolongación natural de la vida nómada y pastoril»

«San Jerónimo en el desierto expresa el deseo humano de libertad que parece encontrarse en la naturaleza; la irreducible vivacidad del complejo ciclo de renovación de su orden y equilibrio. Con el cambio de siglo, solo podremos disfrutar de los sublimes placeres ascéticos que muchos encontramos en la naturaleza si somos capaces de desarrollar una verdadera 'conciencia ecológica'»

San Jerónimo en su estudio ya no se encuentra expuesto, sino en un interior, que en palabras de Alison

«representa una alegoría del deseo de disfrutar de un orden construido; el apoyo de los servicios civiles: el hecho de protegerse de las inclemencias del tiempo, la capacidad para atemperar el clima; una mejor suficiencia en el lugar funcional de trabajo, con acceso a las herramientas propias de la profesión, el oficio, el hogar»

«The Jerome Study is allegory for perfection of thought; for the creation of the perfected object; for deliberated choice.

Jerome in his Study reaches out to those who would think of what kind of fragment of an enclave would give us quietude. A reinstatement of a sense of the inviolate that Jerome's Study represents -and its consort, unspoilt naturewe propose as the likely aspirations of the next century. Whether in an urban setting or in nature, all creative activity relies on being cocooned. Such a sense of inviolability relies on its fragment of functional space being within an enclave 
encapsuled in its turn within a protective territory ${ }^{70}$ » (Van den Heuvel y Risselada 2004)

Por último, en San Jerónimo y la gruta, se aúnan la cueva excavada en roca como refugio de animales y también representación de la Natividad cristiana, con la idea existente en todas las culturas de «recinto rocoso que encierra una gruta natural que se nutre de la nueva sabiduría», «hábitat del hombre justo, sabio, mágico, eremita».

En cierta forma es la adaptación de la imagen de san Jerónimo en su estudio a su retiro en el desierto. Al llevar sus libros con él, hace que la vida ascética y retirada en el desierto, sea inseparable de su vida académica. «No podría haber soportado mi vida allí sin mi biblioteca que había reunido con tanto ardor y esfuerzo en Roma» le escribe en una de sus cartas a su esposa Eustaquia.

Alison explica como razonable, la utilización de Jerónimo de una cueva en el desierto para protegerse del clima del Mediterráneo oriental «la transformación del desierto en un estudio dentro de una gruta»

«Así, la inserción del desierto en el estudio se hizo realidad en el último hábitat de san Jerónimo. Visto de este modo, no parece que exista una división tan radical entre las dos alternativas de san Jerónimo como nos ha hecho creer la polaridad del arte renacentista. Si en el futuro inmediato empezamos a crear fragmentos de enclaves que protejan nuestro hábitat, quizá podamos llegar a acercarnos al idilio representado en el Renacimiento por los dos hábitats de san Jerónimo»

Dos ideas claras enuncia Alison en el texto sobre el significado de los habitats de san Jerónimo, que resumen las dos imágenes escogidas para la portada y contraportada del opúsculo editado por TECTA: "The energising cell", encabeza la muy conocida representación de San Jerónimo en su estudio, de Antonello da Messina, 1456-1460, " posiblemente el estudio más famoso, meticulosa y misteriosamente formado y que abarca desde la mentalidad del Gótico a la del Renacimiento", y "The restorative place in nature" sobre San Jerónimo junto a un sauce desmochado, de Rembrandt, Harmensz van Rijn, 1648, «El estudio está en plena naturaleza; protegido, tranquilo, alimentado y refrescado por la corriente... sin duda el sueño europeo del Paraíso» Ambas inciden sobre la capacidad de condensación que tienen en común las representaciones pictóricas renacentistas de las moradas de San Jerónimo, considerándolas alegorías de «la capacidad restauradora de la naturaleza y sobre la energía de la celda presente en el orden urbano».

Dos habitats contrapuestos, pero que proporcionan el mismo ámbito placentero de tranquilidad, protección y bienestar para el estudio. Opciones que indistintamente ha podido disfrutar el hombre europeo en la segunda mitad del siglo XX, y que Alison ve peligrar por el ruido mecánico y la contaminación crecientes, y que imposibilitan «mantener un espacio del que podamos tomar posesión con todos nuestros sentidos. Ya sea en la naturaleza o en un entorno urbano, el espacio para la actividad creativa tendrá que seguir basándose en un fragmento espacial situado en un enclave encapsulado dentro de un territorio protegido».

70 «El estudio de San Jerónimo es una alegoría de la perfección del pensamiento, de la creación del objeto perfeccionado, de la elección deliberada.

La representación de Jerónimo en su estudio se dirige a aquellos que se plantean qué clase de fragmento en un enclave puede proporcionarles cierto sosiego. Nuestra propuesta para el próximo siglo es restablecer el sentido de lo inviolado que representa el estudio de Jerónimo, y su equivalente, la naturaleza no dañada. Ya sea en un entorno urbano o en la naturaleza, cualquier actividad creativa debe estar resguardada. Este sentimiento de inviolabilidad se basa en la posibilidad de que su fragmento de espacio funcional esté situado en un enclave, encapsulado a su vez en un territorio protegido»

Traducción de Jacobo García en Alison y Peter Smithson. De la Casa del Futuro a la casa de hoy, edición española publicada por Polígrafa de Alison y Peter Smithson. From the House of the Future to a house of today, editado por Dirk van den Heuvel y Max Risselada en 010 Publishers. 

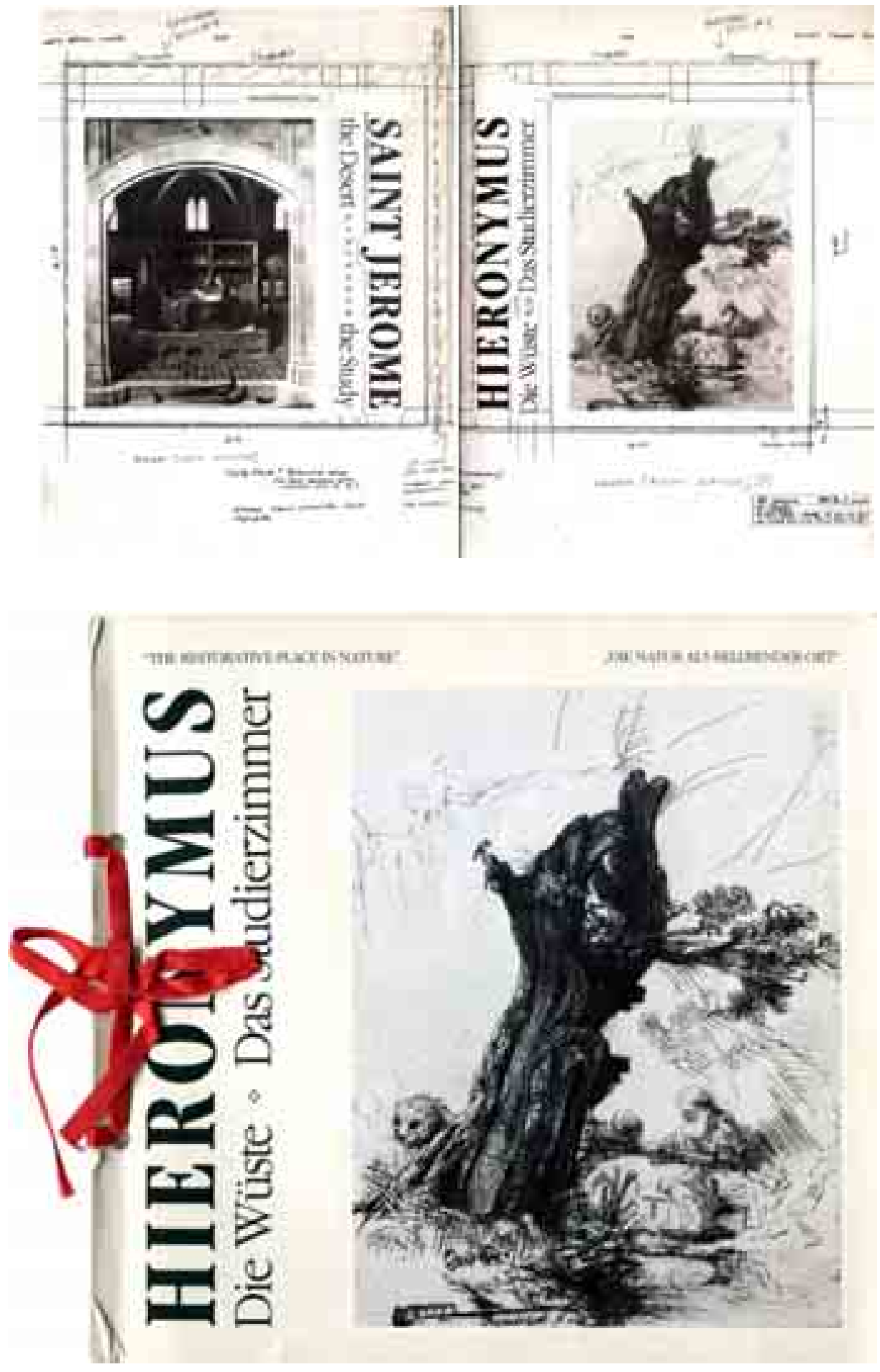

Figura 2.43

Imágenes de la portada y contraportada del opúsculo editado por TECTA, reflejando las dos ideas que enuncia Alison Smithson en el texto sobre el significado de los habitats de san Jerónimo: : "The energising cell", encabeza la muy conocida representación de San Jerónimo en su estudio, de Antonello da Messina, 1456-1460, " posiblemente el estudio más famoso, meticulosa y misteriosamente formado y que abarca desde la mentalidad del Gótico a la del Renacimiento", y "The restorative place in nature" sobre San Jerónimo junto a un sauce desmochado, de Rembrandt, Harmensz van Rijn, 1648, «El estudio está en plena naturaleza; protegido, tranquilo, alimentado y refrescado por la corriente... sin duda el sueño europeo del Paraíso» 


\section{Un fragmento de un enclave}

Existe una estrecha relación entre el texto de Alison sobre San Jerónimo y Upper Lawn. La idea de pabellón como lugar de retiro reparador, esta presente en más obras de los Smithson, junto con el tema de la interrelación entre campo y ciudad, como certeramente apunta Max Risselada en Another Shift ${ }^{71}$.

Bruno Krucker también se refiere a ello, al plantear el pabellón del Fonthill como un lugar "Jerónimo" «may also regarded as a Hieronymus place, as a place of retreat and free in the dessert, in the midst of nature» 0 «a Hieronymus place, exposed to nature and yet protected, with the DS as modern cell12 of enligthenment». (Krucker 2002, 46)

Ahora se propone incidir en esa relación explicitando algunas cuestiones, no señaladas por otros autores, y especialmente relevantes desde el punto de vista de este trabajo. También establecer un vínculo innegable entre la publicación de Upper Lawn. Folly Solar Pavilion en 1986 y la de Saint Jerome. The Desert. The Study, en 1990, entendiendo que el segundo es claramente deudor del primero y del final de la experiencia vital de Upper Lawn ${ }^{73}$.
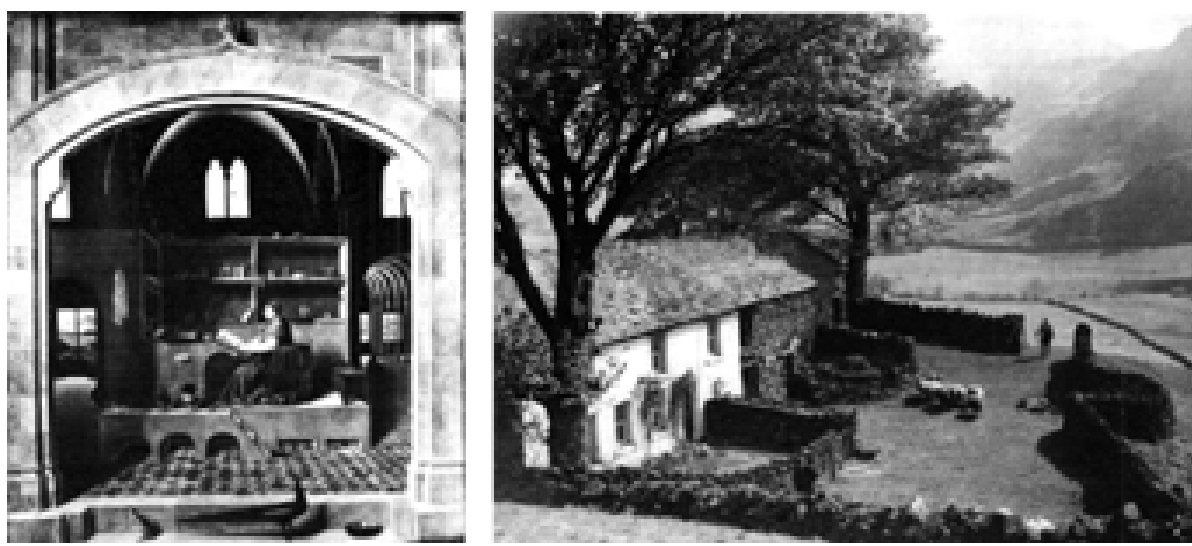

Figura 2.44

* Izquierda:

Detalle de San Jerónimo en su estudio, de Antonello da Messina, 1456-1460, " posiblemente el estudio más famoso, meticulosa y misteriosamente formado y que abarca desde la mentalidad del Gótico a la del Renacimiento», tal y como aparece en, 1970, en la figura 62 en la pagina 75 de Ordinariness and light, urban theories 1952-1960 and their application in a building Project 1963-1970, de Aliosn y Peter Smithson, con el siguiente irónico pie de foto: «Nada esta mas ordenado que el apartamento de un bachiller», "Nothing is more ordered tan a bachelor's apartment» (Smithson y Smithson 1970, 75)

\section{* Derecha}

Imagen correspondiente a la figura 3 en la pagina 20 de Ordinariness and light, urban theories 1952-1960 and their application in a building Project 1963-1970, de Aliosn y Peter Smithson, con el siguiente pie de foto: «Una casa para uno mismo en la naturaleza. Granja sobre los paramos de Westmorland, cerca de Ullswater», "A home for oneself in nature. Farm on the Westmorland Falls, near Ullswater» (Smithson y Smithson 1970, 20)

\footnotetext{
${ }_{11}$ Publicado en el mismo libro que la nota anterior ¿ lbid?.

Patio \& Pavilion, la Casa Amarilla, y las diversas intervenciones en la Hexenhaus, así como el artículo The Pavilion and the Route de 1965.

${ }^{72}$ Sobre esta última afirmación, consideramos necesario aclarar que en lo referente al Citroen DS, los Smithson siempre identifican la célula con el pabellón, no con el coche.

73 Si bien, una imagen de San Jerónimo ya aparece en 1970 en Ordinariness and light, urban theories 1952-1960 and their application in a building Project 1963-1970, el desarrollo de este tema parece producirse en paralelo y/o como consecuencia de la venta de Upper Lawn en marzo de 1982 por al aumento del ruido con la llegada de nuevos vecinos y la consiguiente pérdida de tranquilidad y de lo idílico del lugar.
} 
Upper Lawn es para los Smithson la conjunción de "la célula energizante" y "el lugar reparador en la naturaleza" que Alison describe en el texto de san Jerónimo como alegorías de lugares idílicos para el desarrollo de una actividad de estudio y producción intelectual. Así, es en precisamente en su casa de vacaciones, en su lugar de descanso, donde desarrollaron parte importante de sus publicaciones.

Alison escribe:

«Ya en otoño de 1962 la bolsa de documentos empezó a ser una parte usual del equipaje...la tranquilidad del campo por la noche, sentados en el sol afuera, protegidos del viento en el interior del recinto; el sol bajo penetrando en el interior (los cielos ingleses, cubiertos a menudo en verano, son particularmente límpios de Octubre a Mayo, el piso de arriba era una «tostadora»).

De este modo, el pabellón y su recinto, hecho posible por un pacífico paisaje ingles, guiaron lecturas, gran cantidad de textos y trabajo editorial; para citar algunos: Ios artículos para Architectural Design, las pruebas de imprenta de Without Rhetoric, la mayor parte del trabajo sobre la Imprint of India + 1916 a.s.o. que gradualmente se transformó en evocación de Sensibilidades; el diario del jardín de Upper Lawn (de donde estos extractos proceden); La Paradis Eloigne, Maigret's Map... fueron total o parcialmente escritos en o reescritos en los años en Upper Lawn.

El lento desarrollo de estos documentos nos ayudó intelectual y emocionalmente a llenar los vacios entre la arquitectura urbanismo sobre la que estábamos trabajando» (Smithson 1986)

Sin embargo, no es hasta después de la venta de la casa, en marzo de 1982, cuando los Smithson, y sobre todo Alison, producen los trabajos más importantes sobre Upper Lawn, a partir del diario del jardín, fotografías familiares y el material generado a lo largo de veinte años.

Con anterioridad, y a pesar de su gran actividad divulgativa, el Pabellón solo había sido publicado parcialmente en relación a otros temas, sin protagonismo, como en The pavilion and the route en las páginas de Architectural Design en marzo de $1965^{74}$, y tampoco apareció referenciado en 1966 en el The New Brutalism, de Reyner Banham, con el que tenían relación, e invitado en Upper Lawn en varias ocasiones.

Es entre 1984 y 1986, con ese periodo vital y experimental ya cerrado, cuando el trabajo de Alison tiene la clara voluntad de situarlo en la historia de la arquitectura del Movimiento Moderno, y en la de la cultura británica.

En este sentido, fue decisivo el seminario impartido por Alison en Escuela Técnica Superior de Arquitectura de Barcelona durante el curso 1985-1986, invitada por Enric Miralles. La coincidencia con la reconstrucción del Pabellón de Barcelona de Mies van der Rohe, propició que el seminario llevase como título Fragmento de un enclave...el equivalente de los últimos 80 de lo que fue el pabellón de Barcelona ${ }^{75}$.

La estancia de Alison en Barcelona, dio a lugar a varias conferencias sobre el tema, como Territory of the Pavilion en octubre de 1984 y Three Pavilions of the Twentieth Century: The Farnsworth, the Eames, Upper Lawn en el otoño de 1985, compiladas en 1994 por Peter Smithson en Changing the Art of Inhabitation, en las que la casa

${ }^{74}$ Así lo expresa Enric Miralles en el texto de presentación de Upper Lawn. Folly Solar Pavilion: «Upper Lawn nos fue presentado entre las ideas que seguían el escrito The Pavilion \& the Route, ahora este libro aparece tras la edición del diario de viaje $A D$ in $D S$ publicado por la universidad de Delft. Aparece paralelamente al seminario de la ETSAB donde Alison Smithson nos ha transmitido el sentido de esa ventana abierta entre las últimas ilustraciones, al proponernos pensar nuestro pabellón como un lugar protegido: A Fragment of an enclave... The piece of territory that can support and became the mid-1980's equivalent to the idyll of the 'restorative place-in-nature', that for the last two centuries has taken forms of pavilions within the landscaped parks»

${ }^{75}$ En las primeras páginas de Upper Lawn. Folly Solar Pavilion, antes de presentación de Enric Miralles. (Nótese que es una publicación sin numerar) 
Farnsworth de Mies van der Rohe, la casa de los Eames y Upper Lawn, representan tres ejemplos de pabellones "Jerónimos", que con los cambios producidos en su entorno, han perdido su capacidad energizante y reparadora en la naturaleza. Algunos de sus fragmentos expresan con claridad la pérdida del "idilio".

«La definición de 'idilio' según el diccionario es la siguiente: una descripción de una escena o incidente pintorescos, en especial en la vida de campo; un episodio adecuado a ese concepto.

Estos tres pabellones encarnan el idilio como un lugar donde renovarse; como una fuente de energía propia. Por lo tanto, se considera al pabellón como un lugar hecho idilio; un sueño de un estilo de vida sin estrés, un dominio (a menudo un gran jardín) que suele estar en lo pretendidamente salvaje, es decir, en la naturaleza.

Los tres pabellones son eficaces invenciones formales para el lugar en la naturaleza: el fragmento de un enclave imaginario cuya integridad depende del comportamiento decente de los otros. En el sentido de Jerónimo, un estudio desde donde estimar, contemplar, considerar y evaluar la ciudad»

«Dos de los tres pabellones han pasado a ser inhabitables, como idilio, debido al ruido»

«El tercer pabellón ${ }^{76}$ también tiene un segundo dueño, ya que el terreno alrededor de la pequeña finca dentro de un enclave de tierra de cultivo se ha convertido en un lugar hostil para el habitante, es decir, se ha visto ocupado por vaqueros mecánicos»

«El territorio resulta necesario para mantener el pabellón como idilio, para permitir la ilusión de una vida idílica. El pabellón en un enclave en un dominio, esto es lo importante en toda esta historia, no las soluciones formales, que son muy personales y que ya son historia” (Smithson 1994, 2001, 141)

El seminario Fragmento de un enclave...el equivalente de los últimos 80 de lo que fue el pabellón de Barcelona, además de las conferencias mencionadas, sobre todo posibilitó la publicación del texto más importante sobre Upper Lawn, el ya citado Upper Lawn. Folly Solar Pavilion editado por la ETSAB y la Politécnica de Cataluña en 1986, en el que los Smithson vinculan ambos pabellones, designando el de Upper Lawn como «el nieto neobrutalista» del de Mies van der Rohe.

También acuñó la expresión "fragmento de un enclave"77, escogida desde entonces por los Smithson como determinante y más significativa para explicar Upper lawn.

A partir de los años ochenta se repite sistemáticamente en todos los textos citados sobre la casa, y también en el de san Jerónimo, para definir el lugar idílico al que se refieren las alegorías de los distintos hábitats del santo.

La alteración de las condiciones en el territorio que rodea el enclave, significó la pérdida del lugar idílico, conduciendo a los Smithson a la venta de Upper Lawn, y a una profunda reflexión que cristalizará en los textos explicados, entre ellos el ensayo sobre los Habitats de San Jerónimo.

\footnotetext{
76 Upper Lawn Pavilion

77 Enclave es un lugar claramente diferenciado siempre dentro de otro territorio. Según el Diccionario de la Real Academia de la Lengua Española DRAE, en su primera acepción, enclave es un territorio incluido en otro con diferentes características políticas, administrativas, geográficas, etc, y según el María Moliner es un galicismo que se refiere a un Territorio de un país rodeado por el de otro.

El término es idéntico en francés, español, portugués e inglés, con el significado de rodeado, incluido, incorporado; siempre referido a un territorio totalmente rodeado de otro territorio; en el sentido de lugar, cualidad, u objeto, aislado o encapsulado, término también utilizado por Alison.
} 
Peter Smithson en el texto Introducción a Upper Lawn para su publicación en Barcelona, 1985-6, fechado el 13 de octubre de 1985 y publicado en Upper Lawn: Folly Solar Pavilion, escribe:

«El ruido, la sensación de territorio invadido, no parece algo a lo que someterse con facilidad. No podemos combatirlo como hacemos hoy en día con el frío, apretando un botón; tampoco es como la soledad, que puede ser mitigada por la presencia de una cabina de teléfono junto a la carretera o la posibilidad de coger el coche para ir al hospital del pueblo.

El ruido, la intrusión, despojan al pabellón situado en esa Naturaleza domada, del poder regenerador de un aislamiento libremente elegido...porque tal libertad ya no existe.

En el clima maquinista de hoy en día, con nuestra capacidad para desplazarnos tan fácilmente, con la aparente extinción de un cierto «sentimiento mutuo» hacia el territorio, ¿Cuál es ahora la esencia de ese lugar de retiro o regeneración?

Si quisiéramos ofrecer un «ejemplo desarrollado» para las postrimerías del siglo XX o demostrar la posibilidad de un lugar así mediante una «presencia» equivalente a la del Pabellón de Barcelona, ¿Cuál sería su esencia?

No hay duda de que «lo poético» en Barcelona y «lo práctico» en Berlín constituyeron dos aspectos distintos de una misma intención.

La intención es ahora la de establecer un territorio bajo el control de un mismo o del grupo escogido por uno.

Por ello es por que utilizamos la expresión «fragmento de un enclave» como vehículo hacia el «pabellón» de nuestro tiempo.

\section{Algunas reflexiones sobre Upper Lawn como fragmento de un enclave}

Matices no desarrollados por otros autores, relevantes en tesis, se enumeran sintéticamente a continuación

1. En Upper Lawn, primero construyeron, vivieron, experimentaron y transformaron durante más de veinte años. Luego escribieron sobre ello.

Son numerosas las ocasiones en que los Smithson se refieren a su interés por hacer, más que por hablar, y un buen ejemplo es Upper Lawn, los textos sobre el mismo y su interrelación con los hábitats de San Jerónimo.

Podríamos decir que los Smithson proponen un modelo para el pabellón de nuestro tiempo interpretando los hábitats de San Jerónimo, pero sobre todo es a partir de su experiencia vital en Upper Lawn.

La alegoría del santo y sus moradas, analizadas por Alison a través de las representaciones pictóricas del Renacimiento, les permiten dar forma a un modelo teórico, que especialmente se conforma a través de sus vivencias personales en Fonthill.

Primero y sobre todo hacen

2. Los años que el pequeño pabellón fue parte de su vida, entre 1959 y 1982, son descritos por Alison como el periodo en que «jeronimizaron» 78 .

Upper Lawn, la casita familiar de vacaciones, es el lugar de descanso, "la célula energizante" y "el lugar reparador en la naturaleza"; pero también de forma muy

\footnotetext{
${ }^{78}$ De una conferencia sin publicar de Alison Smithson, titulada «At the time of the presentation of Upper Lawn Book:Barcelona», impartida en Barcelona en diciembre de 1986. La expresión está recogida por Max Risselada en el texto Another Shitt, en Alison y Peter Smithson. From the House of the Future to a house of today.
} 
destacada, el lugar de retiro para el estudio, donde los Smithson realizaron gran parte de sus publicaciones.

Los Smithson fueron ante todo grandes trabajadores. Al igual que en una granja donde siempre hay trabajos que realizar, la vida en Upper Lawn nos es mostrada por las fotografías de Peter, como placentera, tranquila, reparadora, en contacto con la naturaleza, las tradiciones y la historia, pero nunca indolente. Los miembros de la familia, limpian el terreno, construyen la casa, buscan objetos, recogen fruta o hacen sus propios juguetes a partir de materiales reciclados «as found». Alison lee, estudia, o escribe al mismo tiempo que cuida de Soraya siendo bebe, pero también recoge fruta o coloca adoquín.

Trabajo manual e intelectual se muestran intencionadamente inseparables en las páginas del diario Upper Lawn.

3. Los Smithson muestran una clara voluntad por situar su casa, en la historia de la cultura inglesa como ya se ha explicado en puntos anteriores, y también en la historia del Movimiento Moderno.

Su comparación con la Casa Farnsworth de Mies van der Rohe y la Casa de los Eames en Los Angeles formando la trilogía de los tres pabellones y desarrollada en varios textos, así lo demuestra. Siendo tres obras muy diferentes entre sí, tres «fragmentos de enclaves» diversos, comparten dar respuesta a la idea de "la célula energizante" y "el lugar reparador en la naturaleza".

La respuesta de los Smithson, se diferencia claramente en la elección del lugar. No es un lugar indeterminado en la naturaleza, sino una pequeña granja fuertemente condicionada y representativa de la cultural rural inglesa. Frente a las otras dos obras, no es de nueva planta. Su transformación en el pabellón de nuestro tiempo, se autoimpone necesariamente un dialogo con la preexistencia del cottage del siglo XVII, y es un intencionado tributo a la cultura vernácula, sus tradiciones, y formas de construir.

4. Las representaciones del Estudio de San Jerónimo, suelen mostrar un ideal espacial. Una estancia construida y protegida del exterior, en relación con la naturaleza y también con lo urbano.

En el interior, San Jerónimo aparece concentrado, desarrollando un trabajo intelectual, rodeado de flores, animales de compañía, y todo tipo de comodidades para que, aunque de pequeño tamaño, sea un espacio placentero en el que vivir y estudiar.

De la misma manera se nos muestra a Alison trabajando en Upper Lawn, con algo de comida, bebida y rodeada de objetos domésticos y personales.

Así lo explica en su disertación, referenciándolo nuevamente con el Movimiento Moderno.

«La atemporalidad del ideal se encuentra en muchas imágenes del estudio de san Jerónimo. El estudio retratado por los pintores contiene todo tipo de comodidades: agua fresca, palangana de bellas proporciones, toalla limpia, flores cultivadas, pájaros y animales de compañía, libros, material de escritura, alacenas, alfombras orientales, ropa de abrigo, vino. El estudio como «máquina de vivir» fue reconocido en aquellos textos del periodo heroico del Movimiento Moderno interesados en elevar la celda mínima a la categoría de arte»

5. Upper Lawn entendido como fragmento de un enclave, es un fragmento moderno, del enclave vernáculo que es la granja y su cercado, rodeada por los terrenos del dominio de la finca Fonthill, que es a su vez un fragmento significativo de la cultura inglesa, sus tradiciones y forma de vida, en el que lo cotidiano se eleva a la misma categoría que lo intelectual.

Sin Upper Lawn no puede entenderse a los Smithson ni su obra, y es la intencionada elección de este lugar, con todo su significado histórico y de tradición vernacular, lo verdaderamente relevante. 

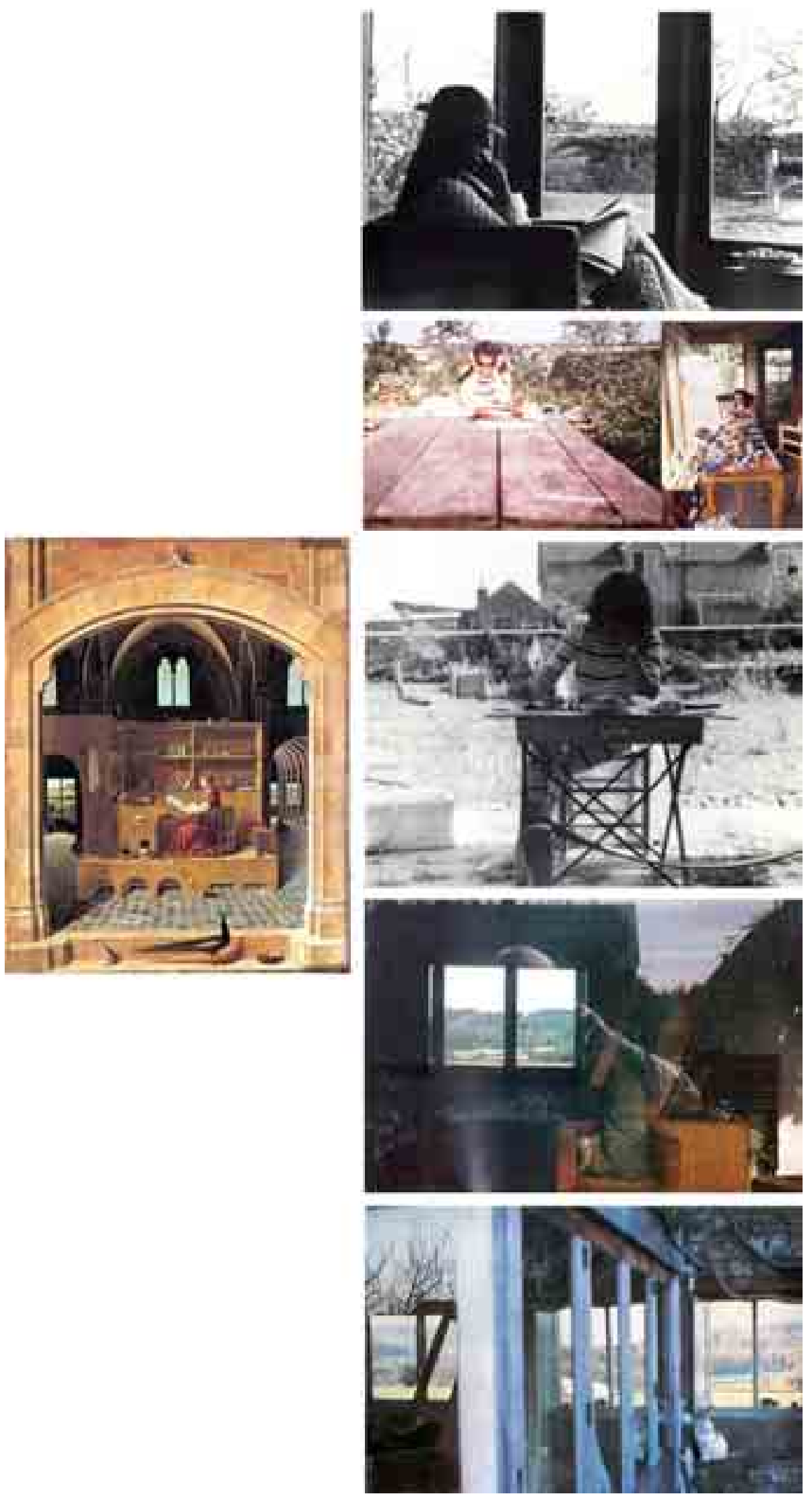

Figura 2.45

Imágenes del Upper Lawn Pavilion como lugar «jerónimo»

* Izquierda: San Jerónimo en su estudio, de Antonello de Mesina

* Derecha: Selección no exhaustiva de imágenes, realizada por Ana Rodríguez, a partir de las publicadas por los Smithsons en Upper Lawn, Folly Solar Pavilion, en las que se aprecia el Upper Lawn Pavilion como lugar «jeronimo» 


\subsubsection{Un pavo real en el muro de Upper Lawn \\ Topiaria.}

Uno de los elementos más singulares del Upper Lawn Pavilion, es la figura topiaria de pavo real posado, a la derecha de la casa, sobre el muro norte de mampostería de piedra. Podado a partir de un arbusto silvestre de espino blanco y casi de igual altura que la planta superior del pabellón, caracteriza poderosamente la imagen del conjunto.

Los Smithson le dedican pocas referencias explícitas. En Upper Lawn. Folly Solar Pavilion, su diario vital en la casa y la publicación más importante sobre la misma, únicamente dos intencionadas fotografías ${ }^{79}$ : una en blanco y negro con el paisaje nevado en febrero de 1978, comenta la altura alcanzada por el abeto junto a la casa -al que irónicamente llaman árbol de navidad- y otra en color, de octubre de 1973, en referencia a las tonalidades del otoño, en la que el verde oscuro del espino blanco, contrasta con las hojas de las grosellas trepadoras sobre el muro del jardín, cuyo amarillo dorado anuncia su pronta caída.

Sin embargo, el pavo real protagoniza la portada interior del libro, con tres imágenes recortadas de épocas distintas, que ponen de manifiesto el interés de los Smithson por su cualidad cambiante, no estática, desarrollando varias "personalidades" en el tiempo: ave de muro nevada, desde el exterior un pavo en febrero de 1963, ave de verano, verde y con cresta en octubre de 1973, ave de muro del equinoccio, podada y transformándose en pavo real en octubre de 1979.

En las páginas siguientes, al referirse al famoso dibujo que representa la parcela seccionada, con la casa y los elementos definidores del entorno -el pozo, el dique, las hayas y el pájaro- una pequeña nota hace referencia a su origen.

" The topiary bird being an example of the "art" of the "as found", since the self-seeded hawthorn bush, growing too green and thick to saw through against the crellalated wall top, was pruned to the shape it suggested P.S. 1960 ' s»80 (Smithson y Smithson, 1986).

Esta breve anotación manifiesta su continua búsqueda para la compresión y puesta en valor de la memoria del lugar, así como la curiosidad y capacidad de su mirada para descubrir las claves latentes en él. La existencia del arbusto silvestre sobre el muro y su forma aleatoria, son las que permiten la existencia del pájaro y sugieren la forma. Podándolo se potencia y reafirma.

Además, esta acción de los Smithson, no hace sino dar continuidad a una larga tradición del empleo de la topiaria en la jardinería inglesa y en el cottage-garden en particular.

Un breve repaso a algunos antecedentes históricos permitirá contextualizar, el pájaro podado en Upper Lawn, dentro esta tradición culta y popular a la vez, con un referente especialmente relevante en los arquitectos del Movimiento Arts and Crafts y en la obra de Gertrude Jekyll, así como en sus pavos reales y otras formas topiarias tratadas como elementos singulares del jardín, a partir de las siluetas sugeridas por los arbustos como una especie de guiño culto y juguetón, a esta cultura popular de tradición vernácula.

\footnotetext{
${ }^{79}$ No publicarán imágenes diferentes en otras publicaciones.

80 «...el arbusto en forma de pájaro es un ejemplo del "arte" del "como estaba": el arbusto de espino, crecido espontáneamente, resultó demasiado verde y grueso como para serrarlo contra el muro almenado, por lo que se podó dándole la forma ya sugerida por P.S. Años sesenta" Traducción de la publicación bilingüe del mismo libro.

Conviene hacer mención al uso explícito de topiary para definir la figura del pájaro, matiz omitido en la traducción. Los Smithson son sumamente precisos con el lenguaje y su empleo específico alude implícitamente a la tradición de esta técnica que recorre la historia de la jardinería inglesa.
} 


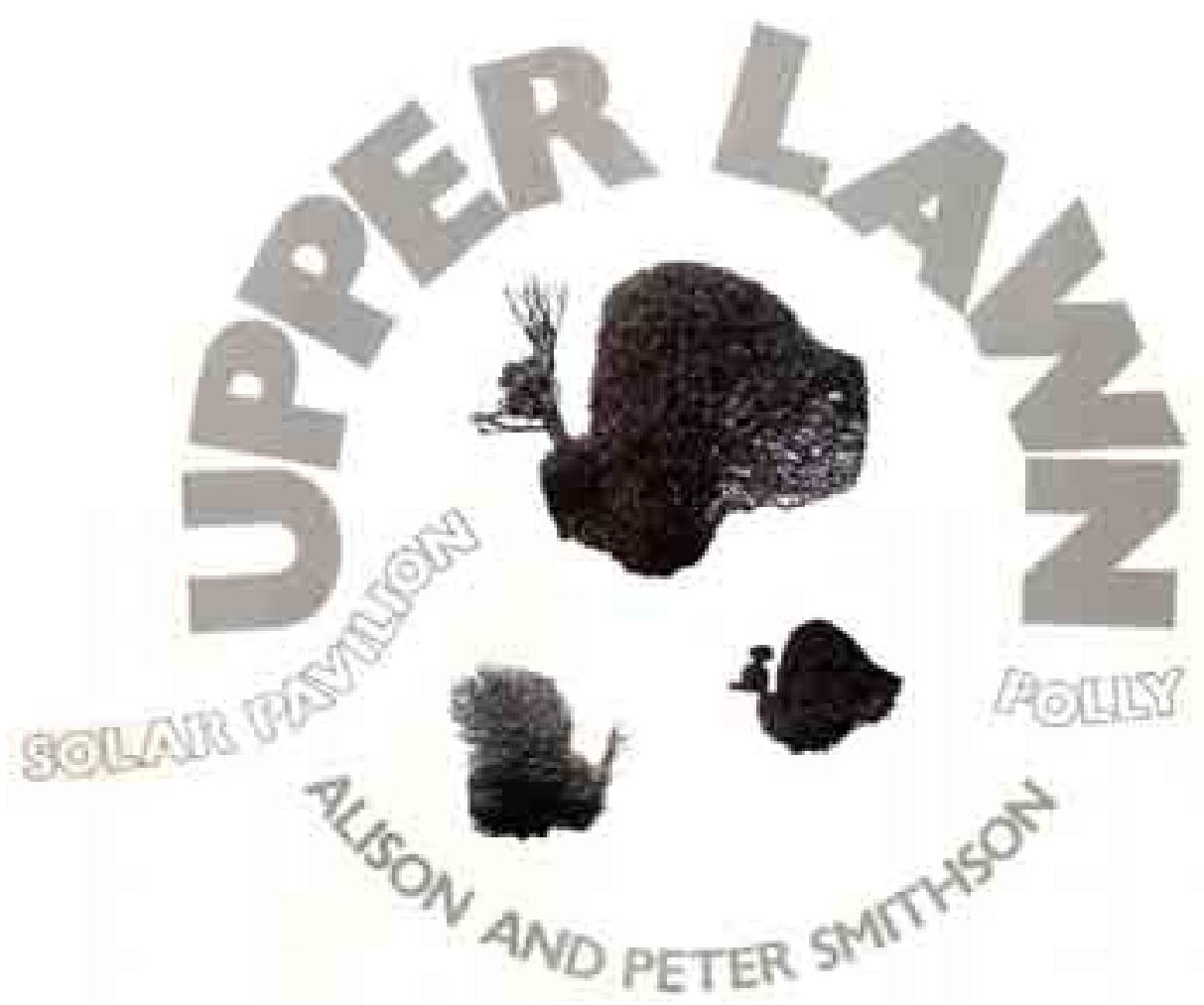

Figura 2.46

Portada interior del libro Upper Lawn: Folly Solar Pavilion, con el siguiente pie de foto:

Ave de muro del equinoccio, podada y transformándose en pavo real. Octubre 1979

Ave de verano, verde y con cresta. Octubre 1973

Ave de muro nevada, desde el exterior un pavo. Octubre 1963 
Los Pavos Reales en la tradición topiaria de la jardinería inglesa

«De todas las ideas anticuadas que los humanistas remozaron, hubo una por la que los ingleses se mostraron apasionados: tal fue las fantasías del arte topiaria, ya citada, en la que los holandeses desde hacia tiempo pasaban por ser maestros, haciendo de los arboles por ellos tallados un gran comercio; y así ocurre que cuando Guillermo III de Holanda ocupó el trono de Inglaterra en 1689 , todos los jardines ingleses fueron puestos a la moda holandesa, lo que ocasionó la ruina de la vieja tradición» (García Mercadal [1949] 2003, 174)
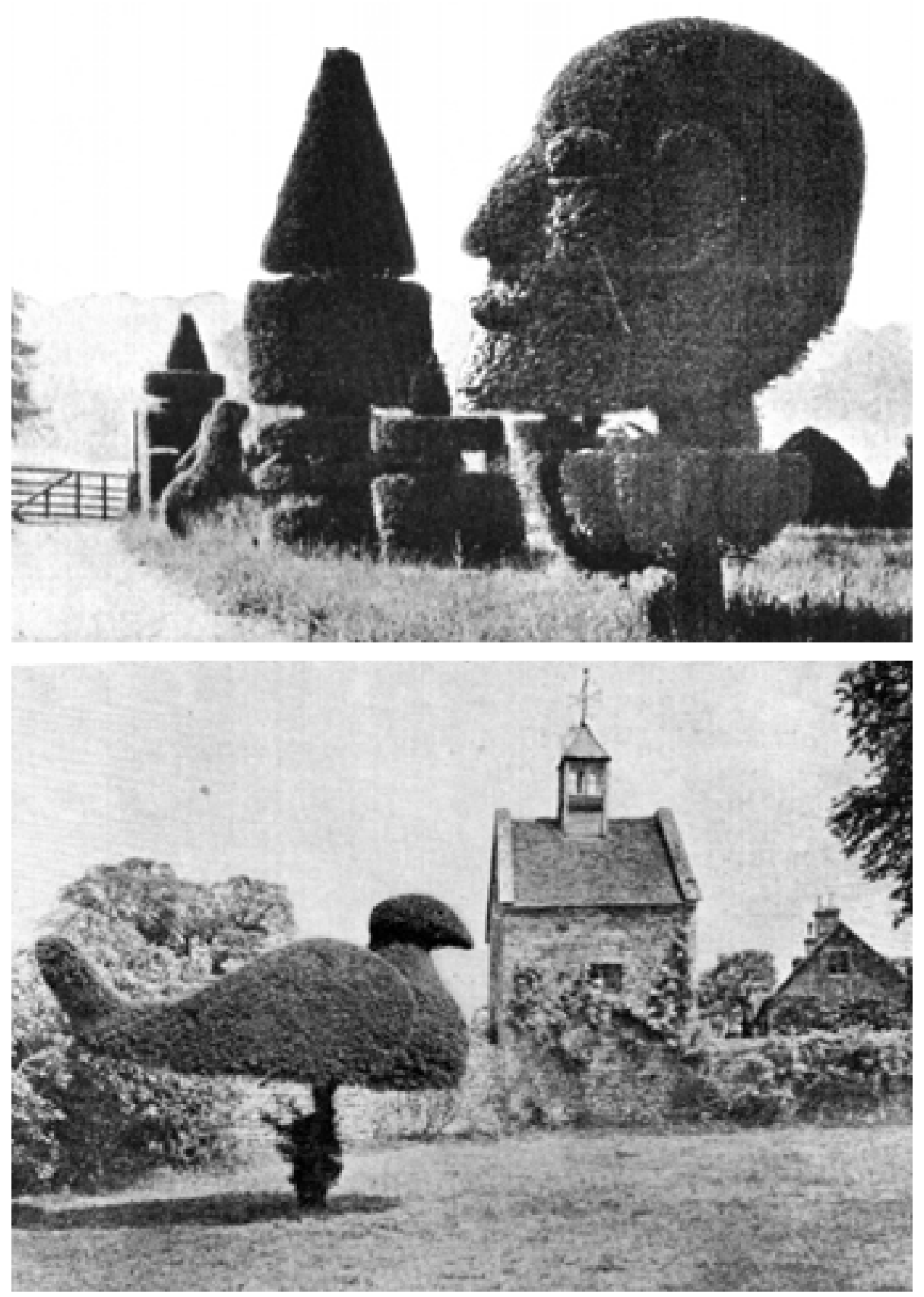

Figura 2.47

Superior, figura de la pagina 179 con el pie de foto: Shakespeare en el arte topiaria inglés Inferior, figura de la pagina 178 con el pie de foto: El arte topiaria en un jardín inglés

(García Mercadal [1949] 2003, 178-179) 
La aguda e irónica mirada de Fernando García Mercadal recoge en 1946, en el capítulo dedicado a «El Jardín Inglés o paisajista» del siglo XVIII de su libro Parques y Jardines. Su historia y sus trazados, reeditado en 2003 por la Institución Fernando el Católico con motivo del 75 aniversario del Rincón de Goya en Zaragoza, dos imágenes de la topiaria inglesa.

Sorprendentes e inusuales desde nuestra cultura, representan con gran certeza un aspecto fundamental de la topiaria vernácula inglesa: su fuerte arraigo popular en los pequeños jardines de los cottages.

En la imagen superior, una cabeza de Shakespeare de considerable tamaño, realizada con gran detalle, se encuentra rodeada de plantaciones recortadas con formas geométricas y animales. Ningún elemento de la fotografía nos hace pensar en un jardín formal, culto o institucional. El camino de tierra, la puerta construida con travesaños de madera con la forma natural de las ramas y las montañas al fondo, nos indican un lugar en el campo.

En la imagen inferior la figura de un pájaro, protagoniza un típico jardín inglés de pequeñas dimensiones, en un ámbito rural, cercado con una valla de piedra que se convierte en el soporte de plantaciones diversas, con una pequeña construcción construida en el mismo plano del muro perimetral y un lawn perfectamente cuidado.

Pero, ¿de dónde proviene esta fuerte tradición en Inglaterra?. Un breve repaso a la historia de la topiaria en este pais, pone de manifiesto el arraigo de esta práctica que llega hasta nuestros días y que los Smithson intencionadamente recuperan y rinden tributo en el pavo real podado de Upper Lawn.

\subsubsection{Notas sobre la historia de la topiaria en Inglaterra}

Ethne Clarke y George Wright en su libro English Topiary Gardens, señalan la topiaria, como posiblemente el único de los elementos conformadores del jardín, que actúa de enlace entre los diferentes periodos de la historia de la jardinería, remontándose desde los jardines más arcaicos hasta los actuales en los que sigue vigente. (Clarke y Wright 1988, 9)

Es en el siglo XVI cuando se produce el primer gran periodo de desarrollo de la jardinería inglesa y también de la topiaria, aunque en la Edad Media se encuentran referencias de su pervivencia y uso ocasional, principalmente en jardines interiores de monasterios, como podemos comprobar en algunas ilustraciones del Breviario Grimani ${ }^{81}$ del siglo XV.

El jardinero inglés del Renacimiento, encontró en las traducciones de los textos clásicos numerosas referencias a la topiaria, produciéndose un redescubrimiento de esta técnica. Pero fue la influencia holandesa la que condujo a uno de los momentos de mayor esplendor para la topiaria en Inglaterra a finales del siglo XVII y principios del XVIII. El importante desarrollo de esta técnica en Holanda durante el siglo XVII, influyó significativamente en la jardinería europea del momento, siendo además el principal exportador de plantaciones cultivadas en invernadero del momento ${ }^{82}$.

George London (1640-1714) y Henry Wise (1653-1738) , los cultivadores más famosos de ese periodo y grandes partidarios del empleo de la topiaria en el diseño de jardines, importaban de Holanda la mayor parte de su stock de especies aptas para su

${ }^{81}$ El códice llamado Breviario Grimani, datado en torno a 1510-1520, se considera como la obra posiblemente más importante del arte de la miniatura flamenca del Renacimiento, no solo por la calidad artística y riqueza de sus láminas, sino por los temas escogidos religiosos y profanos. Estos últimos representan escenas de la vida en el campo, actividades cotidianas, banquetes y pasatiempos de la burguesía flamenca, etc.

${ }^{82}$ Holanda sigue siendo en la actualidad uno de los mayores exportadores de flores frescas del mundo. 
tratamiento topiario. Es también en este periodo cuando la publicación de Sylva or a discourse of Forrest Trees, en 1662 por John Evelyn (1620-1706), promovió el empleo del tejo ${ }^{83}$ frente al boj que había predominado históricamente, consolidándose como quizá la especie para la poda más común en Inglaterra.

Las grandes casas de Inglaterra construidas en ese tiempo por John Vanbrugh (16641726) y Christopher Wren (1632 -1723), fueron realizadas con jardines formales en los que la topiaria formaba parte esencial de setos, parterres y pérgolas. (Clarke y Wright 1988)

Los años de reinado en Inglaterra de Guillermo III de Holanda de 1689 a 1702 favorecieron esta influencia, convirtiéndose el «Dutch Garden» en uno de los modelos a seguir, perdurando hasta nuestros días, y al que volveremos a hacer referencia.

En este periodo, la moda de la topiaria alcanzó tal éxito en la jardinería inglesa que Francesco Fariello se refiere a ello como «el jardín renacentista se afianzó definitivamente a principios del siglo XVIII, tras el viaje de Iñigo Jones a Italia. La influencia francesa prevaleció en la segunda mitad del siglo, y a esta siguió una manera de hacer procedente de Holanda, caracterizada por el empleo incontrolado de formas topiarias»; o «El jardín paisajista europeo nació y tuvo su primera formulación en Inglaterra, en un ambiente que había aceptado casi pasivamente el estilo clásico sin asimilar su intima esencia, y que además había tolerado como una moda las extravagancias topiarias de la jardinería holandesa, tan en boga hacia finales del siglo XVII. (Fariello [1967] 2004, 189-192, 214)

Tras las transformaciones que se produjeron en el XVIII, que convirtieron en jardín paisajista prácticamente la totalidad de los jardines de Inglaterra, contados ejemplos de jardines ingleses del XVII han llegado hasta nuestros días para dar testimonio de la relevancia en ellos de las formas topiarias,

Lancelot "Capability" Brown ${ }^{84}$ (1715-1738), al que ya nos hemos referido en epígrafes anteriores, llevó al extremo estos planteamientos. Discípulo de William Kent (16851748), empezó como simple jardinero en Woodstock y llegó a trabajar como arquitecto de los jardines reales gracias a su habilidad. Alcanzó un enorme éxito en vida, llegándosele a conocer como el jardinero más grande de Inglaterra, aunque posteriormente su obra ha sido fuertemente criticada ${ }^{85}$. Las transformaciones sistemáticas que llevó a cabo en todos los parques y jardines en los que trabajó, destruyeron sin respeto alguno las obras preexistentes, desapareciendo de este modo la mayoría de jardines renacentistas en Inglaterra.

\footnotetext{
${ }^{83}$ Según la división en el Reino Unido de The European Boxwood \& Topiary Society, esta técnica, presente en los jardines de la antigüedad, está indivisiblemente unida al descubrimiento y cultivo del boj buxus y del tejo taxus. Web, http://www.ebts.org

${ }^{84}$ Artista excepcional, no tenía la cultura y el refinamiento de su maestro, pero poseía el genio de su oficio; y por tales dotes tuvo ese apelativo de "Capability" (capacidad) Brown (Fariello [1967] 2004, 225)

${ }^{85}$ Ya en 1794 Uvedale Price (1747-1829) escribió An Essay on the Picturesque, as Compared with the Sublime and The Beautiful, condenando a Brown y a Repton por su acción destructora: «l may perhaps have spoken feeling on this subject for having done myself what I so condem in others, destroyed an old fashion garden»
} 
Uno de los escasos y muy significativos ejemplos es Levens Hall, Westmorland ${ }^{86}$, una manor house en el Valle de Kent, al sur del condado de Cumbria al norte de Inglaterra. Es famosa especialmente por la topiaria de sus jardines, que ha sobrevivido y se ha mantenido prácticamente intacta durante tres siglos, desde su creación entre 1689 y 1712 por el jardinero francés Guillaume Beaumont.

Se le considera el jardín topiario, más antiguo, extenso y mejor en el mundo, con más de 100 piezas podadas con diseños singulares.

La mayoría de las piezas de topiaria que lo conforman son formas abstractas o geométricas pero también se pueden encontrar piezas de ajedrez como el Rey y la Reina, la Peluca de los Jueces, el león Howard, el Gran Paraguas, la Reina Elizabeth y sus Damas de Honor, y cuatro pavos reales.

«Trough the whole of England, there remains scarcely more than one private garden presenting in all its parts an entire and true example of the old designs; this is the fine old seat at Levens... There along a wide extend of terraced walks and walls, eagles of holly and peacocks of yew still find each returning summer their wings clipped and their talons pared ${ }^{87}$ » (Quest-Ritson 2003, 201)

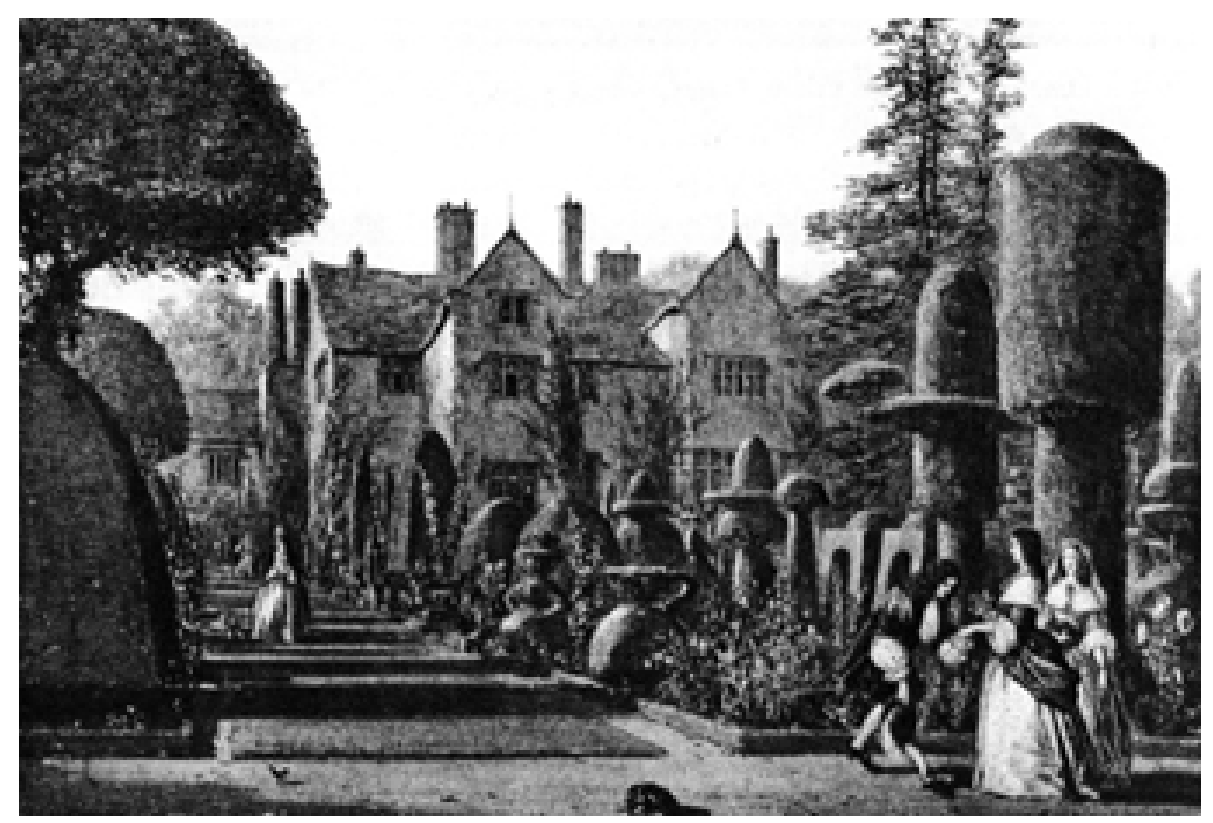

Figura 2.48

Los jardines del antiguo estilo fueron admirados como la encarnación de las virtudes inglesas antiguas y un marcado carácter nacional.

Visión romántica de Levens Hall, Westmorland, de John Nash, en The Mansions of England in the Olden Times, 1849 (Quest-Ritson 2003, 200)

\footnotetext{
${ }^{86}$ Westmorland, la misma población de la imagen del cottage vernáculo elegido por los Smithson como representación del retiro ideal en comparación con la de San Jerónimo en su estudio de Antonello de Messina. Ver pagina...

${ }^{87}$ «Por toda Inglaterra, apenas queda más que un jardín privado que presente en todas sus partes un verdadero ejemplo completo de los antiguos diseños; este es la refinada antigua sede en Levens ... Allí, a lo largo de una amplia extensión de paseos y muros escalonados, águilas de acebo y pavos reales de tejo todavía encuentran, cada verano que vuelve, sus alas cortadas y sus garras recortadas» Traducción de la autora. Cita del historiador Lord Stanhope en la revista Country Life, 1899, p.624, reseñada por Charles Quest-Ritson en The English Garden. A Social History.
} 
El siglo XIX y especialmente el Movimiento Arts and Crafts supondrán la puesta en valor del jardín doméstico con la intervención significativa de arquitectos. Una serie de importantes cambios sociales conducentes a una sociedad moderna, como el desarrollo de las clases medias y profesionales, el crecimiento de la población y la revolución industrial, favorecieron el desarrollo del cottage garden, además de la tradición de los grandes parques y jardines que en el caso de Inglaterra serán en gran medida de carácter público ${ }^{88}$.. De esta forma, se produce un retorno a las formas clásicas como reacción al pintoresquismo romántico extremo, y al mismo tiempo una reivindicación de un jardín natural. La convivencia de estos dos planteamientos, vista por algunos autores como falta de ideas ${ }^{89}$, en realidad pone de manifiesto el comienzo de una sociedad donde los valores individuales cobrarán cada vez más importancia.

La publicación de una serie influyentes textos, pondrán de manifiesto virulentamente esta diferencia de posturas.

Garden Craft Old and New, publicado en 1891 por John Dando Sedding (1838-1891) y The Formal Garden in England, primer libro en investigar los jardines formales desaparecidos en Inglaterra, publicado en 1892 por Reginald Blomfield (1856-1942), sentarán las bases de la recuperación de la práctica topiaria en la jardinería británica. Las teorías de Sedding y Blomfield, fueron ridiculizadas ${ }^{90}$ por William Robinson (18381935) en Garden Design and Architect's Gardens, publicado en 1892, donde comparaba la topiaria con la costumbre china de vendar y deformar los pies femeninos. Pocos años antes, William Robinson había publicado en 1883 The English Flower Garden, en el que se opone a todo formalismo y a la pretensión de ver el jardín como una naturaleza espontanea e innata. Frente a ello, propugna la elección, con un criterio artístico y gusto colorista, de plantas y flores seleccionadas. En un momento caracterizado por el desarrollo de la botánica, la horticultura y la introducción de especies de importación, fue el impulsor del empleo de flores en los jardines, que habían sido relegadas desde la Edad Media hasta el Renacimiento a recintos separados creados al efecto, principalmente bordeando paseos o agrupadas en macizos y en combinación con arbustos.

Esta confrontación, en realidad representa una nueva manera de ver el mundo más diversa y transversal, antesala del siglo XX. Una nueva visión de la naturaleza en el que el desarrollo de la ciencia y la historia natural fueron determinantes.

En un momento de cambio en el que la puesta en valor de lo domestico jugará un papel decisivo, el desarrollo del cottage-garden, el movimiento Arts and Crafts y los jardines de Gertrude Jekyll y Edwing Lutyens en particular, requieren un análisis detallado por su influencia en el Upper Lawn Pavilion de los Smithson. A ellos volveremos a referirnos en el siguiente epígrafe junto con la influyente figura de Joseph Paxton, aunque ahora nos circunscribamos al empleo de formas topiarias.

\footnotetext{
${ }^{88}$ Inglaterra fue la primera nación que por primera vez advirtió la necesidad de crear grandes parques al servicio de los habitantes de las ciudades, y Londres, ya hacia mediados de siglo, disponía de una extensión de jardines y parques públicos que se acercaba a las 600 hectáreas (Fariello [1967] 2004, 263)

89 "Y estas dos maneras de hacer -la "formal" y la "informal", a menudo emparejadas sin ningún nexo de unión y sin una visión estética- revelan una patente falta de inspiración» (Fariello [1967] 2004, 261)

«Hacia finales de siglo, el jardín se abandona en Inglaterra al más completo eclecticismo. Incluso en las grandes realizaciones falta una concepción unitaria y aparecen juntos elementos dispares, sin ningún nexo compositivo, por más que estos elementos con frecuencia estén diseñados individualmente con finura y distinción: motivos extraídos del jardín renacentista, obras topiarias, episodios paisajistas, rocas, paseos bordeados de setos con flores, etcétera" (Fariello [1967] 2004, 263)

${ }^{90}$ Una extensa narración con interesantes citas textuales puede ser consultada en English Topiary Gardens (Clarke y Wright 1988)
} 


\subsubsection{Pavos reales y topiaria en el cottage-garden inglés.}

Tradicionalmente considerado menor, el cottage-garden que ha sido frecuentemente excluido de la gran historia de los jardines, es uno de los elementos más característicos de la cultura inglesa.

Como muestra de su menor consideración, Franceso Fariello escribe:

«William Robinson, un hábil arboricultor que alcanzó notoriedad por sus enseñanzas sobre el uso de materiales vegetales en los jardines pequeños o cottage gardens»

«Seguidora de Robinson fue Gertrude Jekyll, que puso de manifiesto los valores lumínicos de las flores sugiriendo juiciosas combinaciones y estableciendo una verdadera paleta de colores que habría de aplicarse a los jardines mediante materiales vivos. Esta artista puede ser calificada como la primera jardinera impresionista, y su manera de hacer estuvo indudablemente influida por la pintura de sus contemporáneos Vincent van Gogh y Paul Gauguin.

Sin embargo, ni Robinson ni Jekyll pueden considerarse creadores de jardines propiamente dichos. Ambos se limitaron a diseñar cottages con su correspondiente entorno de vegetación exuberante y vistosa, y trataron sobre todo de fundir de manera pintoresca la casa con el jardín» (Fariello [1967] 2004, 263)

Los cottage-gardens del Arts and Crafts, incorporaron muy frecuentemente formas topiarias, más que por propugnar un tipo de jardín formal a la vieja usanza, seguramente por el interés en la práctica en sí de esta técnica artesana, explorando la incorporación de nuevas posibilidades formales en su puesta en valor de lo doméstico.

Según los ya citados Ethne Clarke y George Wright, el retorno de la topiaria se debió en gran medida al romanticismo de la Hermandad Pre-Rafaelita, y en particular a William Morris, interesado en esta técnica y en sus posibilidades arquitectónicas. Dichos autores consideran al Movimiento Arts and Crafts como el salvador de la topiaria, debido a la idealización que este grupo hizo de las destrezas artesanas de lo rural en la vieja Inglaterra.

También diferencian acertadamente dos manifestaciones de la topiaria, bajo los títulos «The Grand Maner» y «Teapots and Peacocks" ". El primero alude a los grandes jardines formales, mientras que el segundo, representa la tradición popular de las figuras podadas en los pequeños jardines del ámbito privado, haciendo referencia a dos de las figuras más características de los cottage-garden. De hecho, afirman que si bien el desarrollo de la topiaria ha estado unido a los grandes jardines de la aristocracia, la nobleza y la alta burguesía, han sido los pequeños jardines de las clases populares los que la han mantenido en periodos en los no estaba de moda. (Clarke y Wright 1988, 75)

Figura 2.49

Mosaicos de la villa «Erculia» de Piazza Armerima, Morsantina. Halcón, lagartija y pavo real. (Segura Munguía 2005, 125).

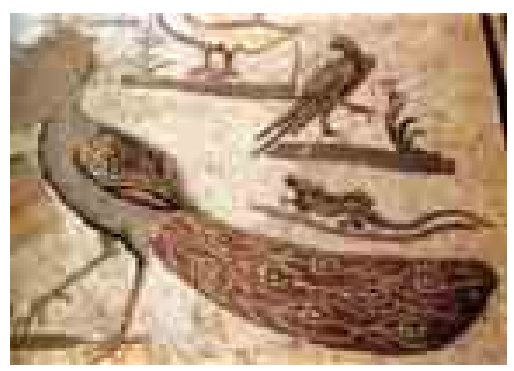

91 «Teteras y Pavos Reales» Traducción de la autora 
Las aves y en particular el pavo real, han estado presentes en la historia del jardín de forma muy significativa. La representación del ideal de jardín, en la Antigüedad y a lo largo de la historia, así lo demuestra. Desde los jardines romanos, en los que las pajareras eran uno de los elementos esenciales ${ }^{92}$, hasta la ya mencionada representación de San Jerónimo en su estudio pintada por Antonello de Messina ${ }^{93}$ 1456-1460, en la que aparece en primer término un pavo real.

El pavo real y otras aves en el jardín, siempre representaron riqueza, y por ello paulatinamente se introdujeron en los cottage-garden, según se fueron transformando, frente a su origen productivo, en lugares de recreo de pequeños propietarios prósperos.

La forma topiaria del pavo real posiblemente fue introducida por los Cruzados $^{94}$ a su retorno a Inglaterra, en una especie de versión pobre de aviarios y pajareras, emulando las especies exóticas y pavos reales de los jardines bizantinos, símbolos de gran riqueza y prosperidad. Fuera este $u$ otro su origen, pertenecen al imaginario vernáculo y hoy en día es frecuente encontrarlos en jardines grandes y pequeños, públicos y privados.

Kathryn Bradley-Hole, en el capítulo South West de su libro Lost Gardens of England from the Archives of Country Life, señala la importancia de la topiaria, tradicionalmente el oficio del jardinero de cottage, en los jardines de las casas de campo del suroeste de Inglaterra, la misma región del Upper Lawn Pavilion de los Smithson y reseña ampliamente Compton End, como uno de los pequeños jardines más interesantes de los archives de la revista Country Life, y uno de los mejor documentados.

Aparece por primera vez el 15 de diciembre de 1900 en el articulo principal titulado «New Homes in Old Houses», tema popular en la época, sobre cómo convertir granjas y cottages en «suitable for summer homes for people with country tastes, but whose business lay in town», antecedente de la preocupación actual con las remodelaciones rurales idílicas. (Bradley-Hole 2004)

Compton End, en el cercano condado de Hampshire, es una destacada casa de campo realizada sobre un cottage del siglo XVII, construido con entramado de madera, paños de ladrillo visto y cubiertas inclinadas de paja, que actualmente pertenece al Register of Historic Parks and Gardens del English Heritage ${ }^{95}$.

Tuvo intervenciones de los siglos XVIII y XIX y era conocida como Dummer's Farm.

En 1894 fue adquirida por George Herbert Kitchin (1870-1951), arquitecto del movimiento Arts and Craft, e hijo de George William Kitchin ${ }^{96}$ (1827-1912), primer Chancellor de la Universidad de Durham ${ }^{97}$ y Dean de la Catedral de Durham.

Entre 1895 y 1914 la rehabilitó, amplió y diseño los jardines alrededor de la casa, en la que vivió casi sesenta años hasta su muerte. La propiedad permaneció en la familia hasta 1993, y los jardines se mantuvieron con el diseño original, aunque en 1955 se vendió una parte de 0.2 hectáreas de la zona este.

El diseño de la casa y sus jardines, tuvieron gran éxito y fueron ampliamente publicados, entre ellos por H Avery Tipping en Gardens of Today en 1933 con sus planos decorando las guardas del libro.

\footnotetext{
92 En el jardín romano las pajareras podían ser de tres tipos: de recreo, para comida y urxnhasxnj

${ }^{93}$ Según Alison Smithson: «posiblemente el estudio más famoso, meticulosa y misteriosamente formado y que abarca desde la mentalidad del Gótico a la del Renacimiento» citado anteriormente en referencia a los hábitats de san Jerónimo.

${ }_{94}$ Apuntado por Cecil Stewart en Topiary 1954, y citado en English Topiary Gardens (Clarke y Wright 1988)

95 Datos obtenidos del English Heritage

${ }^{96}$ En Oxford, entre sus amigos se encontraban John Ruskin (1819-1900) y Lewis Carrol (Charles Lutwidge Dodgson 1832-1898), que fotografío a sus cuatro hijos, y en especial a Alexandra Rhoda Kitchin ('Xie', 1864-1925) una de sus modelos infantiles favoritas y que con más frecuencia aparece en su obra.

${ }_{97}$ Alison y Peter Smithson estudiaron en la Facultad de Arquitectura de la Universidad de Durham.
} 
Kitchin adquirió con la casa «some fine old yew trees and clipped boxes», y como el mismo apunta, la promesa de ayudarle en el jardín -con sus grandes tijeras de podar/esquilar- de un pastor que había vivido allí muchos años, de forma que en 1919 las formas topiarias habían madurado en pavos reales de cottage-garden. (BradleyHole 2004, 42)

El pavo real también está presente en los jardines de los arquitectos del Arts and Crafts, aunque la topiaria no es el motivo central de estos jardines. Suelen ser figuras aisladas dentro de un cottage-garden, conviviendo con un jardín mas silvestre donde los macizos de flores adquieren el protagonismo.

Gertrude Jekyll escribe:

«The garden is not one that is suited to the display of topiary work, and no such work was originally intended. But some yews at the end of a clump of shrubs grew into a form that suggested some kind of bold sculptural treatment, and already offered a plinth or base for some monumental figure. Hence the cat, which is best seen from some distance across the lawn ${ }^{98}$ » (Martin 2006, )
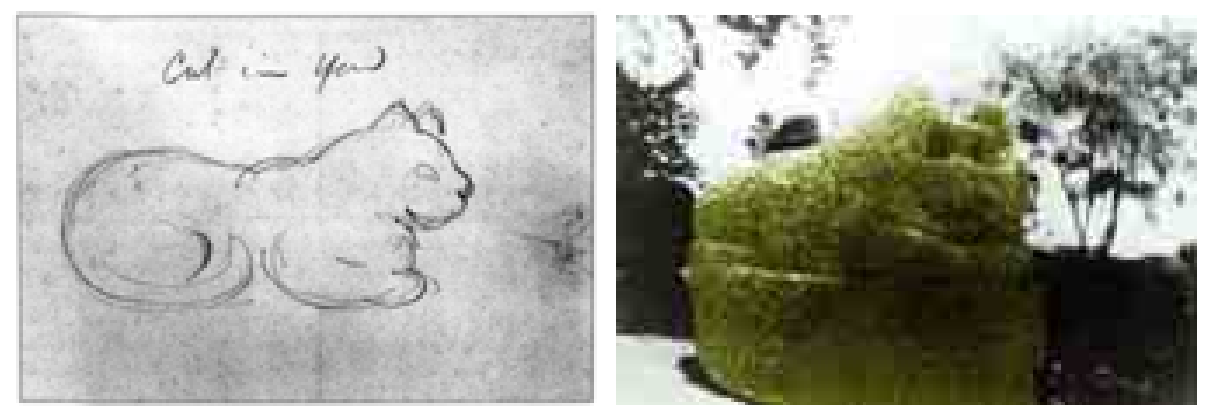

Figura 2.50

* Izquierda

Un boceto del gato topiario hecho para los jardineros para mostrar el efecto planeado.

* Derecha

El gato topiario* a final de los 20, una fotografía tomada por Frank Young, uno de los jardineros de Miss Jekyll.

Resaltado con color por Ana Rodríguez para favorecer su percepción

(Wood 2006)

El gato de Jekyll explica muy certeramente el sentido de la topiaria en sus jardines, como una especie de guiño lúdico y culto, a la cultura popular de tradición vernácula, alejándose de modas y de las reglas de un estilo determinado de jardín.

Esta actitud, retomada en el pavo real topiario de Upper lawn, a partir de la forma sugerida por el seto silvestre de espino blanco crecido sobre el muro, pone el acento en lo particular, en el estudio de cada caso concreto, en el lugar y en el «as found»

El empleo de la topiaria por los Smithson, asumiendo intencionadamente como propia esta fuerte tradición vernácula, no es un objetivo en sí mismo sino una herramienta transformadora, para implementarse en la memoria del lugar. Un reconocimiento a la historia de la jardinería culta y a la popular del cottage-garden, que de nuevo les permite posicionarse en la cultura inglesa desde la arquitectura del Movimiento Moderno.

\footnotetext{
98 «El jardín no es que se adapte a mostrar el trabajo de topiaria, y ningún tipo de trabajo fue pensado originalmente. Sin embargo, algunos tejos al final de un macizo de arbustos crecían de una forma que sugería algún tipo de tratamiento escultórico, y ya ofrecían un zócalo o base para una figura monumental. De ahí el gato, que se ve mejor desde una cierta distancia a través de el lawn» Traducción de la autora.
} 
Figura 2.51

Squire's Garden, Diseño para un cubrecama de C.F.A. Voysey

El Jardin del Hacendado

(Brown 1989, 119).
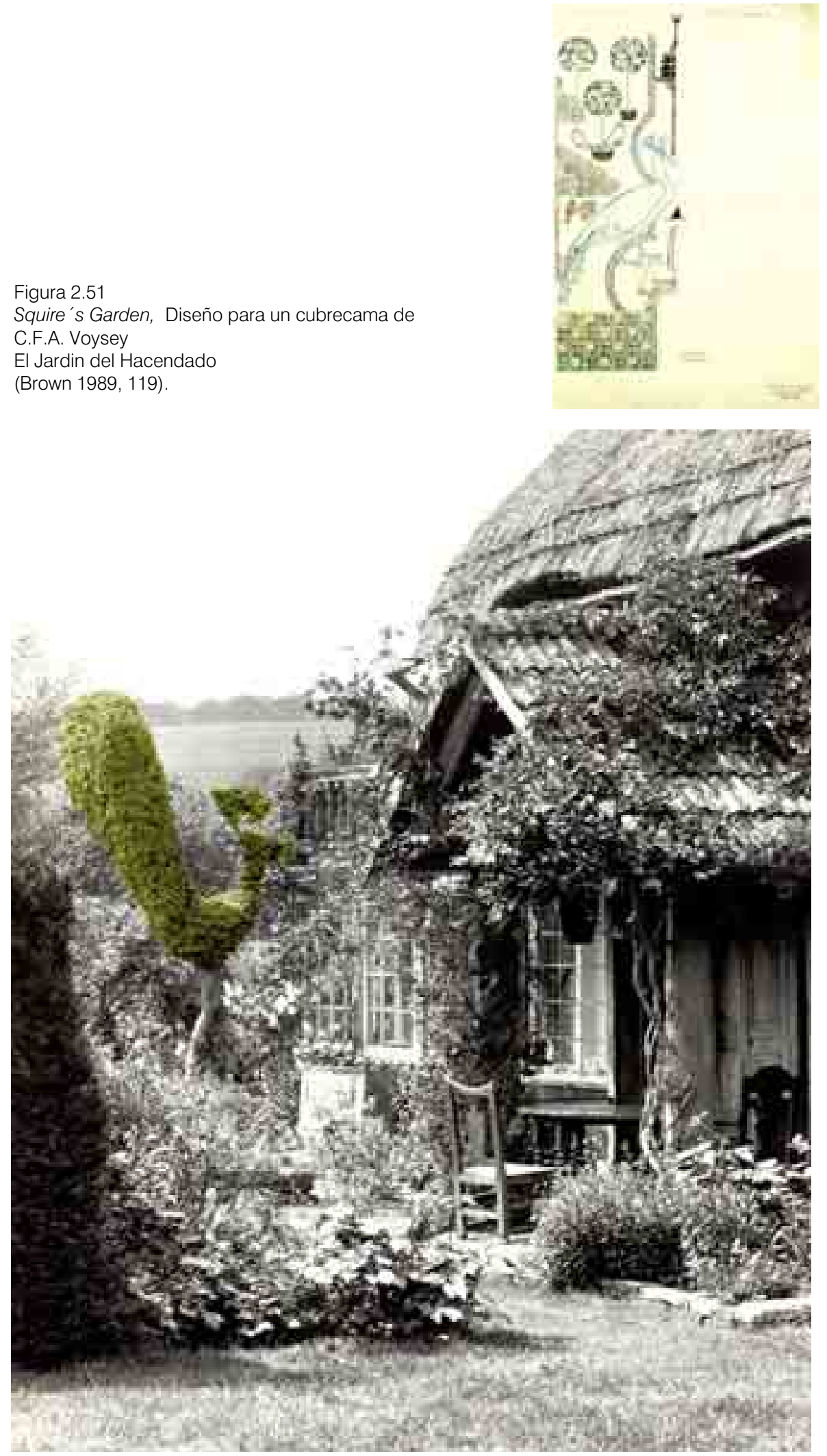

Figura 2.52

Compton End en Hampshire. (Bradley-Hole 2004 ,11)

Imagen del jardín junto a la casa, en la que aprecia la figura de un pavo real* podada a partir de un tejo, y la glass room en segundo plano detrás de los soportes del porche de entrada.

*coloreada por la autora para favorecer su visión 


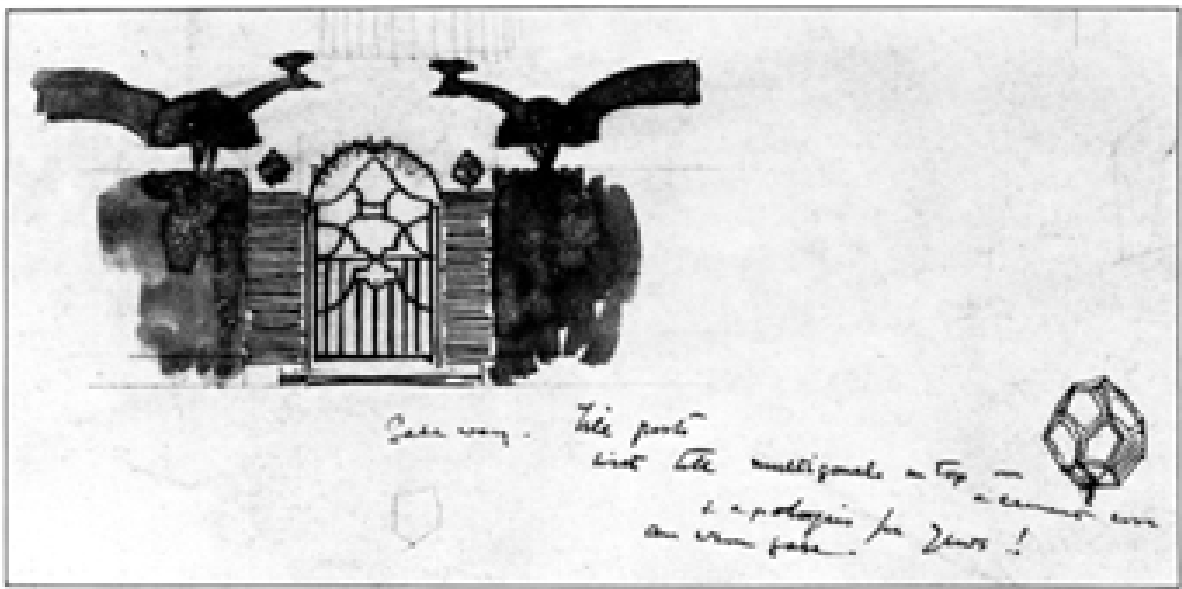

Figura 2.53

Entrada al Dutch Garden realizado en 1898 por Edwin Lutyens y Gertrude Jekyll, como parte de los jardines de la Finca Orchards en el condado de Surrey.

Boceto a tinta y acuarela de Lutyens con la siguiente anotación: «Tile posts with tile multigonals on top on a cement core and apologies for yews! An iron gate» (Brown 1982, 58)

La expresión defendida por tejos -apologies for yews-, se refiere a los pavos reales podados sobre setos de tejo, una de las especies más comunes en la topiaria inglesa.

Figura 2.54

IDerecha

El pavo real recortado en el arbusto de espino sobre el muro, en Upper Lawn.

La imagen corresponde a la figura $70^{*}$ en Upper Lawn: Folly Solar Pavilion, con el siguiente pie de foto: "Snowy wall-bird; Christmas tree grown above roof. February, 1978»

$\left({ }^{*}\right.$ de la primer parte, en blanco y negro, del libro)
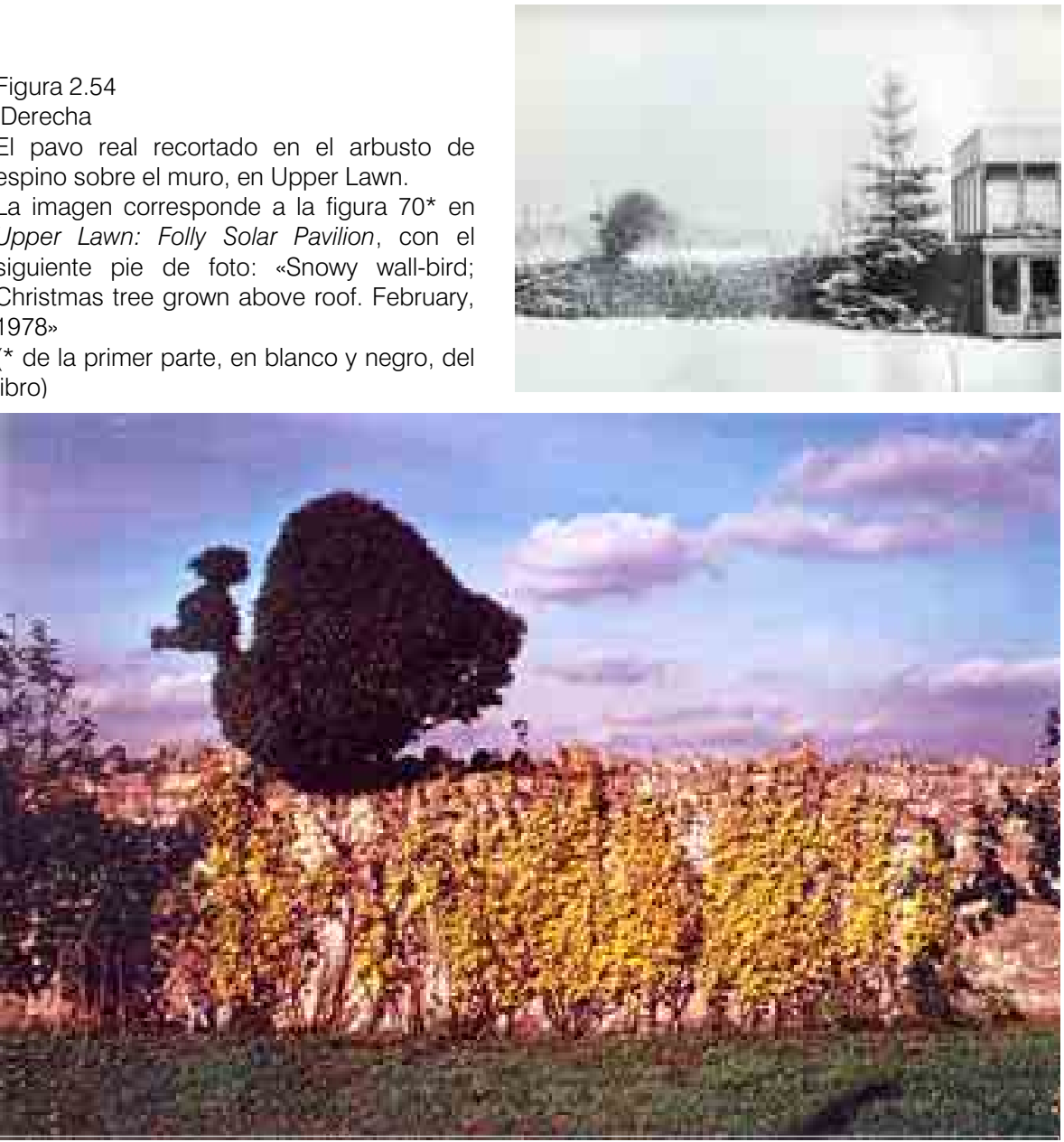

Figura 2.55

El pavo real recortado en el arbusto de espino sobre el muro, en Upper Lawn.

La imagen corresponde a la figura $35^{\star *}$ en Upper Lawn: Folly Solar Pavilion, con el siguiente pie de foto: «Autumn wall-bird above the currants: a crowned turkey becoming peacock. October, 1973».

(** de la segunda parte, en color, del libro) 


\subsection{Upper Lawn a Folly Solar Pavilion heredero del jardín Arts and Crafts.}

\subsubsection{La granja Upper Lawn. Un Cluster como tipo de asentamiento vernáculo}

En epígrafes anteriores se ha explicado como el Upper Lawn Pavilion es el lugar escogido por los Smithsons para educar a sus hijos, en la naturaleza y en las tradiciones inglesas. Admiraban la organización social y del trabajo de las granjas, agrupadas muy frecuentemente en Inglaterra en pequeños grupos de dos o tres, formando una especie de micro-aldea.

La granja que compran reúne todos los requisitos que pudieran buscar para hacerlo: pertenece a un pequeño c/uster de granjas, situado en lo alto de una suave colina, en la que tiene la posición mas privilegiada sobre el paisaje. Tenía un expediente de demolición que junto con su condición no urbana, seguramente evitaría problemas sobre una posible obligada conservación, y se encuentra enclavada frente a la finca Fonthill a la que en origen perteneció, formando parte de un universo de bosques, lagos, jardines, y campos de labor, en un ejemplo perfecto de la cultura inglesa y lo vernáculo.

Según R. W. Brunskill, en Inglaterra, la mayor parte de las granjas se localizan en tres tipos fundamentalmente:

- Asentamientos con una zona central entorno a la que se organizan las granjas y construcciones.

Sobreviven desde periodos con cultivos comunitarios en campos abiertos, o sistemas de agricultura relacionados.

- En grupos de dos o tras granjas formando una pequeña aldea

Las granjas localizadas en aldeas o como parte de muy pequeños grupos, están asociadas normalmente a granjas de pastoreo, o con actividades mixtas de cultivo pero con una actividad de pastoreo siempre muy elevada (por ejemplo hay pocos pueblos y muchas aldeas en la montañosa Gales). Pero en otras zonas pueden ser restos supervivientes de asentamientos mayores que fueron abandonados.

- De forma aislada.

Las granjas aisladas, usualmente representan la ocupación en un momento determinados de vastas tierras

Por ejemplo en la colonización isabelina de las laderas superiores de los valles, o en el sigo XIX. el cercado de tierra comunitaria con nuevas granjas establecidas en el centro de un grupo compacto de campos de labor con trazado regular cuadrados.

Con frecuencia la variedad de tipos híbridos es enorme: Entre los extremos de la edificación dispersa del campesino de la granja aislada en la colina y las filas cuidadosamente movilizados del "modelo Farmery", hay multitud de ejemplos.

La influencia de este tipo de micro-asentamientos rurales en las propuestas de los Smithsons para diferentes tipos urbanos, es muy significativa, tomándolos como modelos a seguir según las distintas escalas de asociación. 

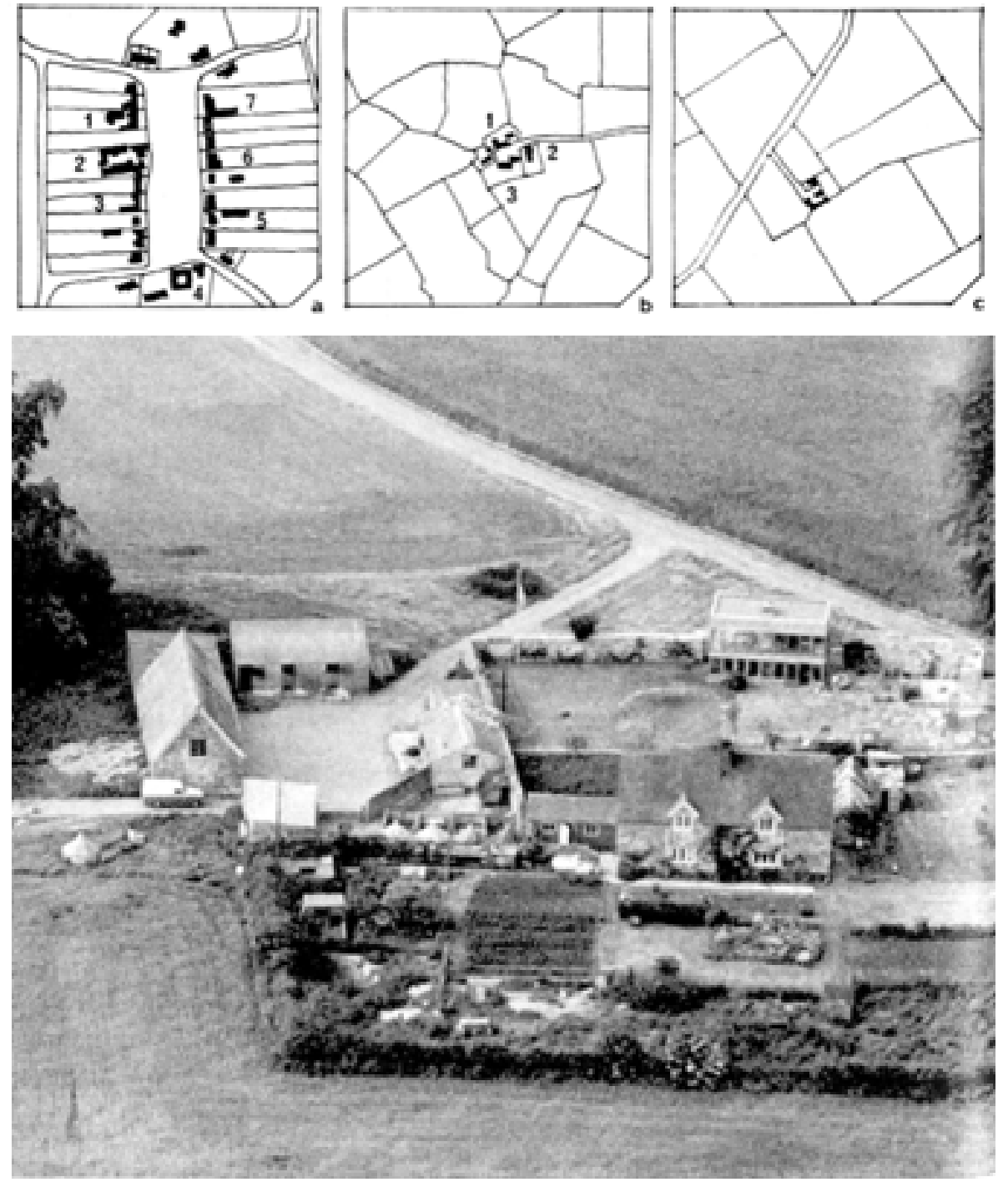

Figura 2.56

Comparación de Upper Lawn con los tipos vernáculos de asentamientos de granjas en el campo ingles.

\section{* Superior}

Tipos principales de ubicaciones de granjas según Brunskill

a. pueblo nucleado. Los números se corresponden con las granjas supervivientes.

b. aldea rodeada de los campos de un antiguo recinto cercado. Los números corresponden a tras granjas.

C. granja aislada en campos de un recinto reciente (con el trazado de los campos más regulares. (Brunskill [1971] 2000, 153)

\section{* Inferior}

Fotografia introductoria en color en Upper Lawn Folly Solar Pavilion.

Vista aérea en escorzo, desde el sur, del conjunto de Upper Lawn.. La Folly en su entorno.

En la parcela cercada existían dos antiguos cottages y forman parte de un pequeño cluster entorno a un granero del siglo XV, que en origen era el granero rural periférico dependiente del Granero de Diezmos de Tisbury, el mayor de Inglaterra.

Fotografia realizada entre el 29 de junio y el 13 de julio de 1964 por Skysviews and General Ltd (Smithson y Smithson 1986) 


\subsubsection{Pequeñas construcciones de jardín en la cultura inglesa}

«Los terrenos de Fonthill exhiben el verdadero espíritu de la jardinería inglesa, llevada a su máxima expresión con una simplicidad audaz y variada. Cada árbol, cada arbusto, y cada flor, han contribuido a la producción de un efecto de profusión salvaje sin igual. La madreselva y jazmín no sólo entrelazan los matorrales con sus zarcillos verdes y fragantes, sino que la rosa y el rododendro florecen bajo el alerce y espino.

Cruzamos el Lawn sur: la escena que tenemos ante nosotros es de una belleza incomparable. El Lawn está bordeado por plantaciones de roble, abeto, y el espino; ...Saliendo del Lawn, nos adentramos en un camino, cuyo curso se encuentra por debajo de un montículo de ruda pendiente de retama... el elástico musgo, todavía parece haber sido pisado únicamente por sus inquilinos nativos, los miles de intrépidas liebres y conejos.» ${ }^{99}$

Tom Turner en el prefacio de English Garden Design. History and styles since 1650 explica como Frank Clark, autor de uno de los mas fascinantes libros sobre jardinería The English Landscape Garden, en una ocasión se le pidió declarar en una investigación sobre el valor de preservar un jardín del XVIII amenazado por un proyecto del Ministerio de Transportes para construir una autopista.

La mala salud le impidió asistir, pero le dijo a sus estudiantes que hubiera declarado que las ideas que llevaron al diseño de estos jardines representan la contribución inglesa más importante a la cultura occidental, incluso mayor que las obras de Shakespeare o la poesía de Milton. Su razonamiento era simple: muchos países han dado grandes poetas, pero Inglaterra es el único país que ha producido una teoría completa sobre el diseño de exterior. La primera aplicación de esta filosofía fue en los jardines, pero como dice Christopher Hussey en The Picturesque, posteriormente tuvo un impacto dramático en las otras artes, desde la poesía misma, a la pintura, la literatura, la arquitectura y el planeamiento urbano. El análisis de Hussey ha sido ampliado por Davis Watkin en su libro The English Vision. (Turner 1986)

Jane Brown en The Art and Architecture of English Gardens aborda el estudio del jardín a través de los planos de proyecto existentes en la colección de dibujos de arquitectos del RIBA, la Drawing Colection of the Royal Institute of British Architects, haciendo énfasis en la relevante relación histórica entre arquitectos y jardineros, y en como los arquitectos han participado muy activamente en el diseño de jardines, especialmente en las construcciones del jardín. El gran numero de dibujos existentes en la colección de garden buildings lo corrobora.

Otro aspecto importante resultado del estudio de la colección, es como los arquitectos han desarrollado nuevas ideas y han experimentado con las construcciones de jardín. En 1968 Alister Rowan escribió un ensayo sobre su importancia en la colección, poniendo muy en evidencia la gran cantidad de "primeros" ejemplos de diferentes tipos de estas aparentemente insignificantes construcciones.

Por ello, y en palabras de Alister estos «irresponsible little buildings» no deberían ser menospreciados a la ligera, especialmente desde la perspectiva actual.

\footnotetext{
99 «The grounds of Fonthill exhibit the true spirit of English gardening, carried to its utmost extent of a bold and varied simplicity. Every tree, every shrub, and every flower, has contributed to the production of one unequalled effect of wild profusion. The woodbine and the jasmine not only interlace the thickets with their green and fragrant tendrils, but the rose and rhododendron bloom beneath the larch and the hawthorn...

We cross the southern Lawn: the scene before us is one of unrivalled beauty. The Lawn is skirted by plantations of oak, fir, and hawthorn;...Quitting the Lawn, we enter a path, whose course lies beneath a mound rude slope of furze... the elastic moss seems still to have been only trodden by its native tenants, the thousands of fearless hares and rabbits.»

Fragmento de Delineations of Fonthill and its Abbey, publicado por su autor en 1823, de John Rutter citado por los Smithsons (Smithson y Smithson 1986): Traducción de Ana Rodríguez.
} 
Su carácter muchas veces efímero, normalmente eran construidos por placer mas que para pasar a la posteridad, ha hecho que prácticamente no hayan sobrevivido ejemplos del siglo XVII, con la excepción algunos construidos en piedra, normalmente integrados como parte de los muros de piedra de la valla del jardín, como es el caso de los jardines de Montacute en Sommerset de Robert Smithson. La mayoría de ellos han llegado hasta nosotros gracias a la labor de los arquitectos del Movimiento Arts and Crafts y a su entusiasmo por estas construcciones, simultáneamente fuente de inspiración y también objeto de restauración, destacando la influencia de la William Morris's Society for the Protection of Ancient Buildings. (Brown 1989)

Cuatro términos parecen intercambiables para las construcciones de jardín: «garden house», «gazebo», «pavilion» y «temple»; sin embargo en una cultura tan desarrollada del jardín, cada uno se corresponde con variaciones en el tipo de edificio.

La idea de introducir edificios de lenguaje clásico en el jardín comenzó en el siglo XVIII a través del revival Paladiano de las realizaciones de Lord Burlington en la Chiswick House y sus construcciones en el jardín. Así, la incorporación del templo clásico trae un nuevo uso para el edificio del jardín, una cita o un alto en la deambulación o paseo en carruaje por el jardín o parque.

Una «garden house», implica modestia. Es el término mas apropiado para las pequeñas construcción del jardín Arts and Crafts, con sus adecuadas implicaciones de conveniencia, modesta comodidad, y escapada fugaz.

Un «gazebo», palabra cuyo origen etimológico proviene de la corrupción del termino «gaze-about» que significa literalmente mirar hacia afuera, es una construcción cubierta y abierta para mirar hacia afuera desde una posición elevada, normalmente una segunda planta.

Un «pavilion» implica una escapada real, una miniatura a menudo bastante imponente, que permite por un tiempo vivir la vida en libertad respectos a las reglas y convenciones de lo establecido. Es una idea que recorre la historia, como el Trianon que era un «Pavilion», o la «Hut» de Gertrude Jekill en Munstead Wood. Por ello la idea de pavilion conlleva una distancia real de la casa habitual.

Todos ellos son edificaciones para las personas, con el propósito de la contemplación del paisaje, encontrarse, o refugiarse de un chaparrón repentino, algo que seguro ha contribuido mucho a su popularidad en los jardines ingleses.

Pero además, también están las construcciones hechas para plantas: greenhouses, orangeries, conservatories, glass-houses..., unidos al desarrollo de la industria del vidrio y con un claro referente en el Crystal Palace de Joseph Paxton.

Lo que aquí se propone es el estudio del Upper Lawn Pavilion como una construcción de jardín, heredero de la cultura inglesa y del Arts and Crafts, con novedosas y sorprendentes referencias a Edwin Lutyen y Gertrude Jekill.

En las siguientes paginas veremos como los Smithsons hacen una reinterpretación intencionada de los tipos canónicos de los edificios del jardín, de forma que Upper Lawn, es simultáneamente una garden house, un gazebo, un pavilion, y una folly, pero además por su condición solar también es una glass-room.

Los propios Smithsons se refieren así a Upper Lawn; sin embargo ninguno de los estudios hechos sobre la casita familiar de fin de semana de los autores han incidido en este punto de vista, que recoge la mejor tradición vernácula inglesa. 


\subsection{3. ¿Folly, Gazebo o Pavilion? Construcciones sobre una tapia}

El testimonio de los Smithsons sobre los veinte años vividos en Upper Lawn, es el libro editado por la Universidad Politécnica de Cataluña, donde Alison Smithson hizo una estancia invitada por Enric Miralles.

Publicado en 1986, a modo de diario, con el título Upper Lawn. Folly Solar Pavilion, es sin ninguna duda el documento más importante sobre la casa.

Su título es revelador y una declaración de intenciones, siendo pertinente profundizar más en su significado.

En The Pavilion and the Route, uno de los escasos textos sobre Upper Lawn anteriores a 1986, año en el que se publica Upper Lawn, Folly Solar Pavilion, Ios Smithson se refieren a la casa como: «el Pabellón del Jardín en Fonthill», «el pabellón del jardín en Fonthill es una puerta. Una puerta a un jardín, a una situación abierta y cerrada. Una casa de juego, una folly» ${ }^{100}$

Posteriormente en Upper Lawn, Folly Solar Pavilion, hacen varias descripciones importantes de la casa, en la que vuelven a repetirse los términos folly, pavilion y gazebo.

\section{« UPPER LAWN: FOLLY}

Es la historia de un periodo de vida; y no debe leerse como una ilustración estática -un monumento, tal y como los edificios son presentados en los libros. Es una viñeta romántica de un juego de vida rural, de unos finales de semana eremíticos en una ermita que es una tienda permanente y cuyo paisaje

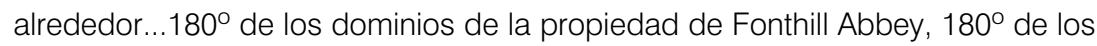
Downs que comienzan Cranbrook Chase...es el lugar rural para un «gazebo» desde donde observar los dibujos cambiantes del paso del tiempo y de las estaciones» ${ }^{101}$ (Smithson y Smithson 1986)

«FOLIA, UPPER LAWN, FONTHILL, WILTSHIRE

(...) Una extensión del sistema de organización de «pabellón junto al camino»: el pabellón se sitúa como una caseta de guarda a caballo sobre el antiguo acceso al conjunto.

(...) El mirador -para experimentar plenamente, durante las estancias breves, el paisaje desde los espacios del primer piso: al norte y al oeste, los bosques de Fonthill desde New Town (la «Castletown» de Beckford, que copia la forma de Ludow Castle) hasta Lawn Lodge; más lejos, al este y al sur, los Bosques de Wardour, con el perfil de las colinas al fondo „102 (Smithson y Smithson 1986)

DE «THE OXFORD ENGLISH DICTIONARY», VOLUMEN IV (F-G) (Reedición de 1970)

FOLLY:

Aún existen muchas casas en Francia que llevan el nombre de «La Folie» y hay alguna evidencia de que en algunas zonas de Inglaterra la expresión «the Folly» fue utilizada -hasta este siglo incluso- para denominar un jardín o parque público.

\footnotetext{
100 «the Garden Pavilion at Fonthill», «the garden pavilion at Fonthill is a gate. A gate to a garden, to an open and close situation. A play house, a folly» (Smithson y Smithson 1965, 145) Traduccion de Ana Rodríguez.

101 Texto de la traducción al castellano publicado en el libro.

102 Texto de la traducción al castellano publicado en el libro.
} 
1654... «Tuvo a bien dilapidarla (su riqueza) en construcciones innecesarias...que no llegaban a completarse y que las habladurías de sus vecinos daban en Ilamar su Folia.»

1772 «Un objeto en medio de los bosques, en el extremo de la colina; al preguntar por él les informaron que se llamaba la folia de Shenstone» ${ }^{103}$ (Smithson y Smithson 1986)

El hincapié de los Smithson en explicitar el significado de folly, denota un interés por matizarlo.

En inglés, la acepción más común de «folly», mantiene las connotaciones de tontería y locura, de acuerdo con el sentido general de la palabra francesa folie, de la que procede. Sin embargo, parece existir otro significado más antiguo, con el sentido de «delicia» 0 «morada preferida».

Según Marchan Fiz, las follies son el resultado de un proceso paulatino de predomino de los gustos individuales, y una experimentación formal a partir de ellos, antesala de lo moderno. Se puso de moda gracias al jardín paisajista inglés, el ámbito que significó la disolución del clasicismo, poblándose todo el país de cientos de estas construcciones. Antojos o desatinos, suelen ser edificios pequeños desprovistos de utilidad, que son reflejo sobre todo de las obsesiones del propietario o incluso «espejos de su alma». A diferencia del jardín francés, el jardín paisajístico inglés, no se rige por reglas universales o normativas, sino por las variaciones subjetivas del gusto, "que se entregan a explotar las virtualidades latentes en la naturaleza», de forma que en el jardín inglés confluyen: la contemplación estética de la naturaleza, de la que brota el descubrimiento moderno del paisaje; la conciencia de que la naturaleza puede ofrecer material para el arte, y del relativismo del gusto individual. (Marchan Fiz 2000, $166,156)$

La denominación de Folly para el Upper Lawn Pavilion, no puede considerarse en sentido peyorativo sino relacionada con su visión en el paisaje, dedicándole los Smithsons algunas fotos lejanas en las que la nueva construcción destaca del conjunto por el brillo del revestimiento de aluminio bajo el sol.

Simultáneamente, su condición no estrictamente necesaria, y su carácter lúdico, redundan en este significado. Pero sobre todo, la acepción con este nombre, es de nuevo un homenaje de los Smithson a la historia del jardín ingles y de Fonthill en particular, y nos está diciendo, que ante todo Upper Lawn hay que entenderlo como un jardín, el jardín de la finca Fonthill en la que Upper Lawn es a su vez otro jardín mas de los existentes en la finca: el jardín de los Smithsons.

Respecto a su condición de «pavilion», como el lugar que permite por un tiempo vivir la vida en libertad respecto a reglas y convenciones de lo establecido, y que conlleva implícita una distancia real de la casa habitual, un cierto distanciamiento, está ampliamente explicada en el epígrafe de los hábitats de San Jerónimo, entendiendo que el Upper Lawn Pavilion fue un lugar jerónimo, en una aproximación al pabellón de nuestro tiempo al igual que la Casa Farnsworth de Mies van der Rohe, y la Casa de los Eames en Los Ángeles. Así mismo, su condición de «gazebo» o mirador queda ratificada por los propis Smithsons en las citas reseñadas.

Por tanto, y llegados a este punto, se puede concluir que el Upper Lawn Pavilion de los Smithsons es simultáneamente un «pabellón» donde retirarse, una «folly» en el paisaje de Fonthill y un «gazebo» para contemplarlo.

\footnotetext{
${ }^{103}$ Texto de la traducción al castellano publicado en el libro.
} 

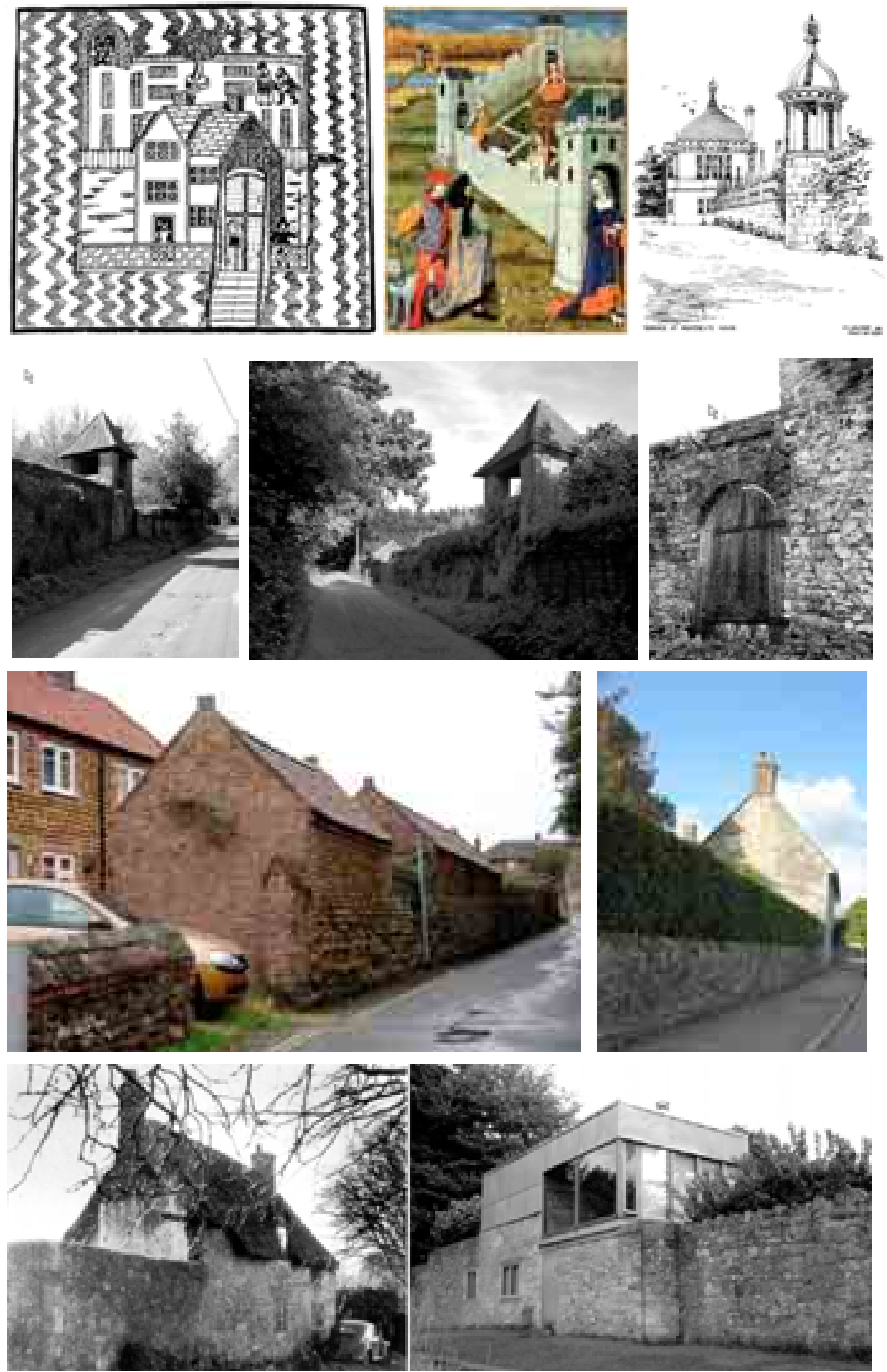

Figura 2.57

Construcciones sobre los muros perimetrales que definen el jardín. Un tipo de solución que se da por todo el país y que interesa especialmente a los Smithson, en el que la edificación se sitúa como prolongación del muro delimitador de la parcela.

De izquierda a derecha y de arriba abajo:

- Jardín de recreo rodeado por foso en Londres, de Anatomie of Abuses de Philip Stubbe, 1583

- Jardín medieval en recinto delimitado por muros, que en su parte superior son un «gazebo».

- «Gazebo» en los jardines de Montacute en en Sommerset de Robert Smithson

- Las tres imágenes siguientes pertenecen a Munstead Wood, la casa de Gertrude Jekill. Puerta secundaria de acceso al jardín y vistas de The Thunder House, o casa del trueno, el "gazebo» al que subía para contemplar el paisaje en los días de tormenta.

- Edificaciones de ladrillo en Sea Lane (camino del mar), en el casco antiguo de Hunstanton, cercano al nuevo crecimiento de esta población en la que los Smithson construyeron en 1948 la Escuela Secundaria de Hunstanton, en el Condado de Norkflok. Fotografía de Ana Rodríguez

- Vivienda construida con mampostería de piedra en la cercana población de Tisbury y en la que se repite el mismo tipo de organización. Fotografía de Ana Rodríguez

- Upper Lawn. Vista del cottage original, afectado por una Orden de Derribo cuando lo compraron, visto desde el borde de la carretera, en la que muestra el antiguo muro exterior mantenido como cerramiento norte del enclave. Foto B. Richards. Pascua 1959

- Reinterpretación de los Smithson a este tipo de construcción vernácula. Upper Lawn en agosto de 2010. Fotografía de Ana Rodríguez. 


\subsubsection{Glass room, garden room. Vivir en el jardín.}

"Solar», es el último de los términos a tratar, de los utilizados por los Smithson para definir su hogar en vacaciones bajo el título Upper Lawn. Folly Solar Pavilion

Al igual que con los otros -pabellón, folly, gazebo-, la condición solar y climática del pabellón queda reflejada en varios textos del libro, que por su relevancia con el tema, se datan a continuación. Los Smithson dicen:

«FOLIA, UPPER LAWN, FONTHILL, WILTSHIRE

(...) Para descubrir lo que es vivir todo el año en Inglaterra en una casa con fachadas de vidrio al sur, este y oeste, y comprobar si puede obtenerse la mayor parte del año suficiente calor solar como para compensar en cierta medida las perdidas térmicas.

(...) Un intento de crear una «casa climática» sencilla, en la que poder abrir las zonas de servicio de planta baja a las antiguas aéreas pavimentadas del jardín y poder cerrarlas rápidamente cuando cambie el tiempo »104 (Smithson y Smithson 1986)

\section{“COMPROBACION DE LA «CASA CLIMATICA»PRIMEROS DOS AÑOS}

1. En Inglaterra puede obtenerse calor solar durante todo el año, y tras los cristales, la sensación de «espacio cerrado» puede ser muy intensa, incluso en nuestros típicos días nublados con un deslumbrante cielo gris. También vimos este desagradable efecto en un cielo excesivamente brillante en Japón, donde el alero de las cubiertas soluciona ese problema, además de servir de protección contra la lluvia. Creíamos habernos protegido contra este deslumbramiento del cielo bajando hasta 1,75 la altura del dintel de la ventana de la planta de arriba. Pero aún podía bajarse mucho más, al nivel del puente de la nariz: 1,58 m. Incluso así, la posición de estar sentado resulta desprotegida. Sin embargo el alero no parece muy útil, ya que las casas japonesas tradicionales son muy oscuras y sus habitantes -especialmente cuando el tiempo es malo- suelen pasar muchas horas entregados a la lectura, por lo que necesitan el máximo de luz natural. Otro efecto secundario de tanta superficie de ventana son las condensaciones. El empleo de la doble hoja de vidrio resulta tan caro en Inglaterra que muchas casas modernas padecen este defecto. En algunos momentos del día durante ciertas épocas del año es imposible ver el exterior.

2. En el campo, y especialmente en nuestro emplazamiento en la cresta de una colina, las condiciones de viento se oponen a cualquier decisión libre entre «cerrado» o «abierto». Esto es algo que también comprobamos en nuestra visita a la Maison Carrée de Aalto, visita que estuvo orquestada con el acompañamiento de constantes portazos. Nuestras pesadas puertas de vidrio con carpintería de teca significan por tanto que vivimos en la casa como en un barco: toda entrada o salida se convierte en una rutina de acciones precisas. Para los niños no supone ningún problema, pero no nos atrevíamos a dejar la casa a otra familia. Para conseguir que una «casa climática funcione como una propuesta diaria y no como un juego, debería poderse abrir al primer toque, como de hecho sucede con las pantallas japonesas.

El revestimiento de aluminio ha mantenido su brillo en el aire impoluto. Pero en los días de viento fuerte, el crujir de sus láminas trae a la memoria las descripciones de los ruidos en los grandes barcos de vela. AMS. 12:7:63 „105 (Smithson y Smithson 1986)

\footnotetext{
104 Texto de la traducción al castellano publicado en el libro.

105 Texto de la traducción al castellano publicado en el libro.
} 

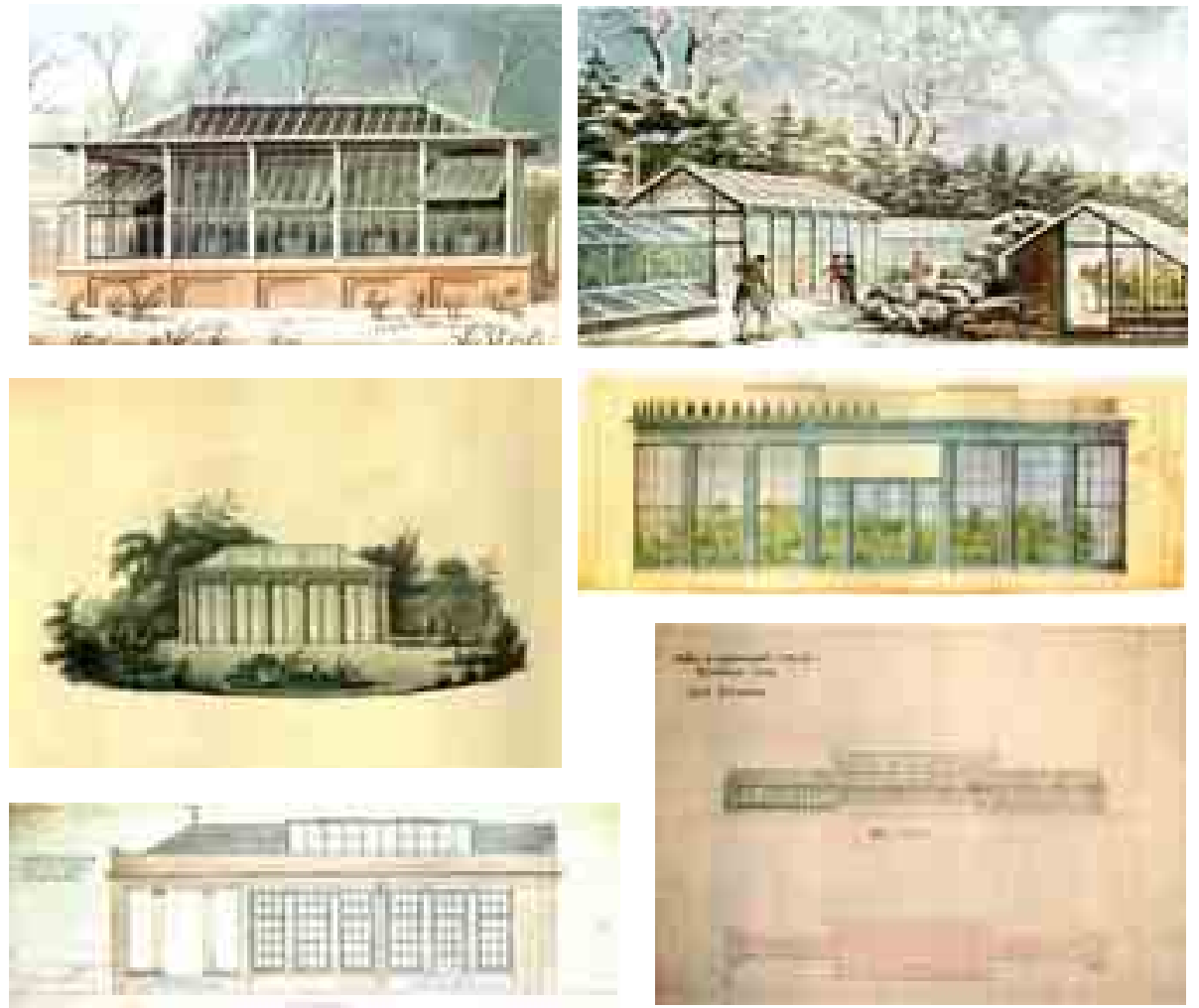

Figura 2.58

Ejemplos de pequeñas construcciones de jardín para el cuidado de las plantas.

La superior izquierda corresponde a la ilustración de Humphry Repton de The Forcing Garden de the Red Book for Woburn Abbey en 1805
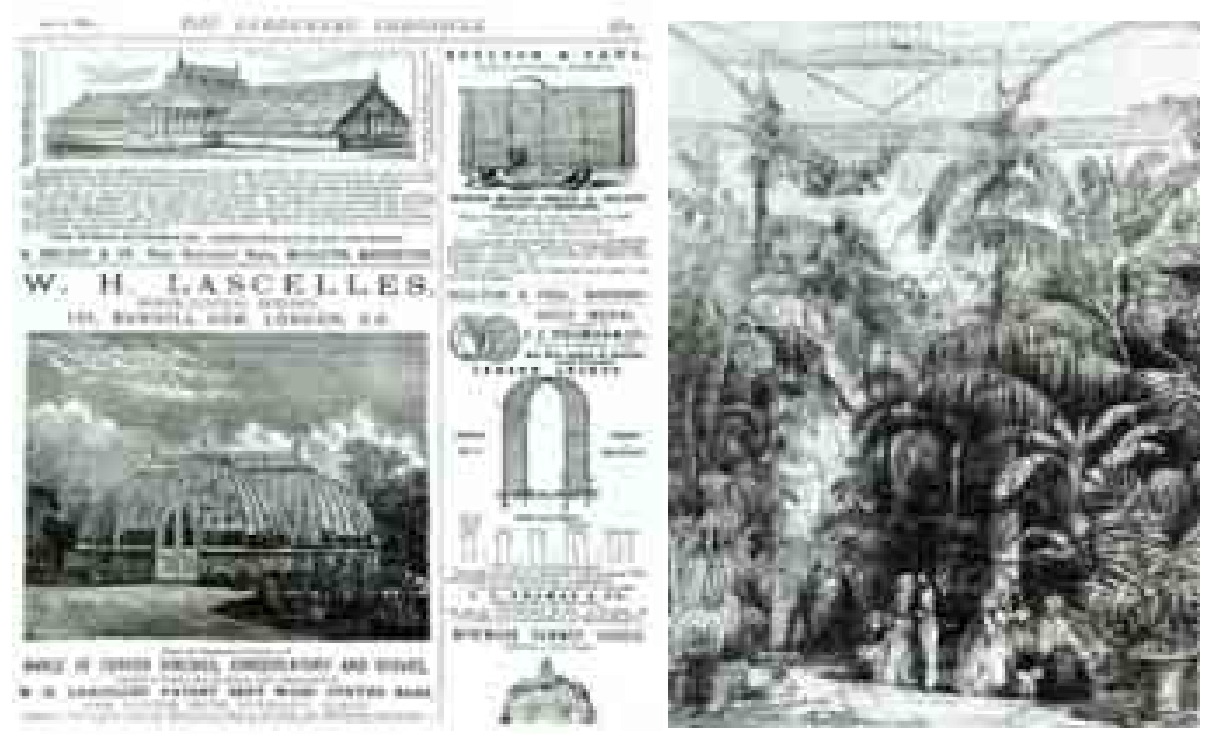

Figura 2.59

Después de la derogación de los impuestos al vidrio en 1845, y el gran éxito del Crystal Palace de Paxton en 1851, el mercado de invernaderos, glasshouses, cristaleras, terrazas interiores, y porches techados ornamentales, se disparó.

Revistas como The Gardener's Chronicle los promovía. (Quest-Ritson 2003, 191) 
La condición solar del pabellón, se materializa con la utilización de superficies acristaladas, con algunas consecuencias de cierta incomodidad relatadas por Alison, en el pasaje anterior, en el que evalúa dicha decisión.

La tradición de estancias acristaladas en el jardín, tiene una fuerte tradición en Inglaterra debido por una a parte a su clima, y por otro, al desarrollo de técnicas constructivas desarrolladas, como no podía ser de otra manera, en el país de la Revolución Industrial.

\section{Glass-rooms}

Al igual que se vio en epígrafes anteriores, cómo la invención y perfeccionamiento de las maquinas cortacésped había posibilitado a todas las clases sociales disfrutar de un lawn cuidado, las innovaciones técnicas también explican el desarrollo y difusión de las modernas superficies acristaladas en invernaderos y estancias del jardín a lo largo del siglo XIX.

Por una parte, la invención de sistemas de calefactado mediante conductos de agua caliente, permitió acondicionar los grandes edificios de vidrio como el Great Conservatory en Clatsworth y la Palm House en Kew, que de otra manera hubiera sido imposible haciéndolos inviables para el crecimiento de plantaciones.

Pero el hecho verdaderamente determinante fue que varios avances técnicos permitieron que el material propio de estas construcciones fuera asequible para la mayor parte de la población. La invención de la hoja de vidrio en 1833 con una longitud de treinta y seis pies, catorce pulgadas más larga que las anteriores, fue mejorada en por James Hartley en 1847, obteniendo panes de vidrio mayores, más finos y transparentes que los antiguos. A su vez se produjeron otras mejoras aparentemente menores pero igualmente fundamentales como la utilización de masilla flexible usando aceite de linaza que supuso una enorme diferencia respecto a las técnicas anteriores, ya que se evitaba en gran medida la rotura de los vidrios por dilatación ante los cambios de temperatura. Por último la invención por John Loudon en 1816 de un perfil para acristalamiento de hierro forjado, fuerte y ligero, permitió la construcción de los «Conservatories» Victorianos.

La construcción en 1851 del Crystal Palace de Joseph Paxton, el gran «Conservatory» por antonomasia, supuso una verdadera epopeya a todos los niveles, incluida su construcción en un tiempo record, gracias a la genialidad de un Paxton ${ }^{106}$ autodidacta. El gran éxito de la empresa a todos los niveles, orgullo nacional y símbolo de progreso, estimuló a los miles de visitantes y al público en general a construir sus propios “Conservatories» ${ }^{107}$ domesticos, disparándose el mercado de invernaderos y todo tipo de construcciones acristaladas para el jardín.

El entendimiento del Upper Lawn Pavilion en la tradición inglesa de las pequeñas construcciones para el jardín que desde este tesis se propone, pone de manifiesto que además de los tipos reseñados para el disfrute de las personas como la folly o el gazebo, también se percibe la influencia aún más evidente de los pensados para las plantas, como orangeries, greenhouses, glassrooms, etcétera.

La claridad de los referentes, pone en valor la hipótesis, que aun pareciendo evidente, no ha sido objeto de estudio.

\footnotetext{
106 Joseph Paxton (1803-1865) era un jardinero hijo de campesinos. Autodidacta de gran inteligencia y habilidad, realizó numerosas innovaciones en la construcción de invernaderos, las cuales permitieron la realización del Crystal Palace. Con una superficie de $70.000 m^{2}$, se construyó en seis meses formado por elementos prefabricados que permitían su desmontaje posterior como así sucedió.

107 Los Conservatories, son construcciones de mayor entidad e importancia, normalmente realizadas según el proyecto de un arquitecto. Cuando son más modestos, para pequeños jardines domésticos y sin la intervención de un arquitecto, reciben el nombre de glass-room
} 

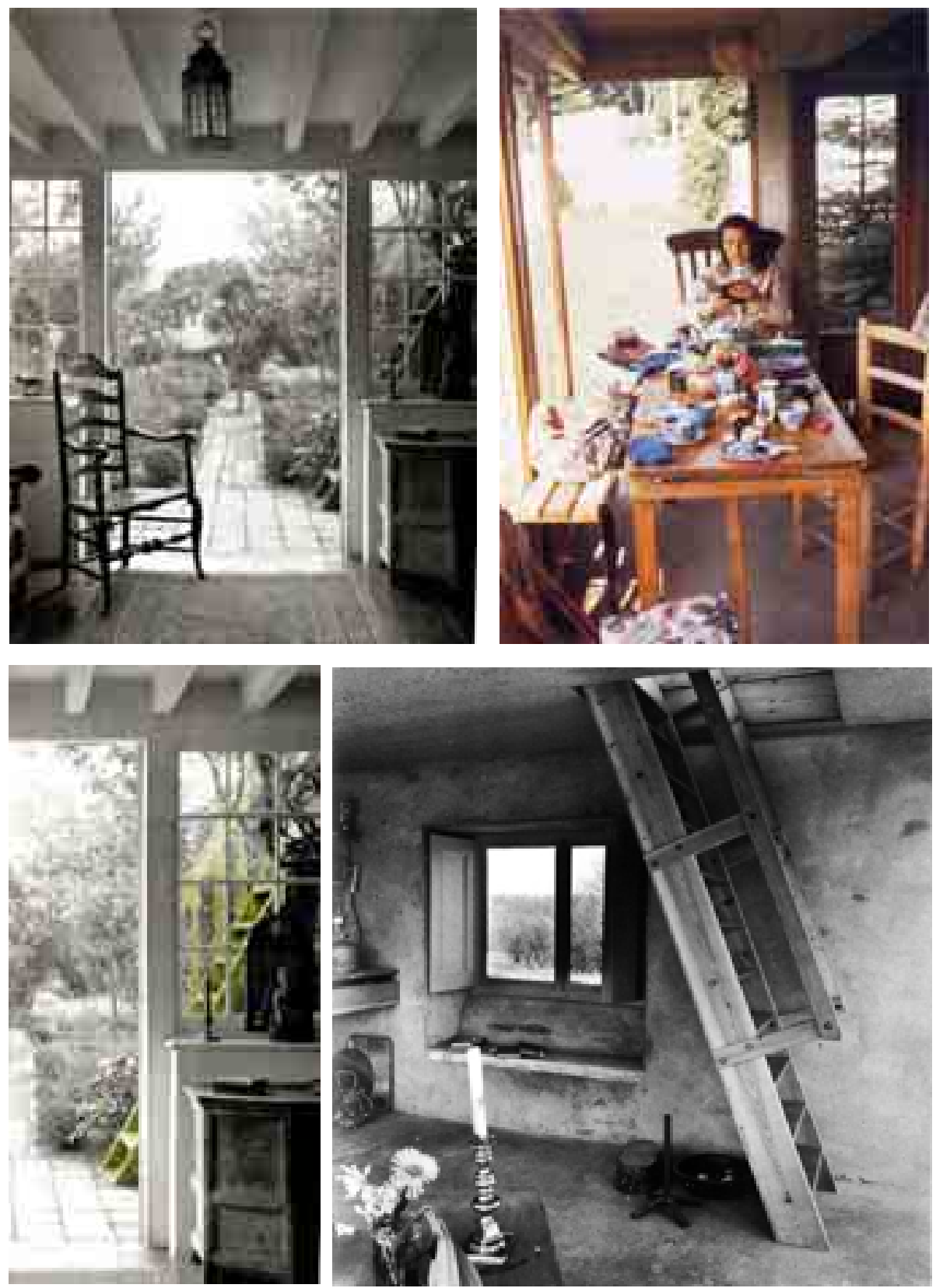

Figura 2.60

La comparación de Compton end (derecha superior e inferior) y el Upper Lawn Pavilion (izquierda superior e inferior), nos revela sorprendentes similitudes. 
Una vez analizado el Upper Lawn Pavilion bajo la influencia de los tipos descritos, se proponen a su vez dos referentes inéditos, de los que si bien no se han encontrado citas expresas de los Smithsons en relación a ellos, las evidencias parecen también claras.

En epígrafes anteriores, al hablar de la tradición topiaria del cottage-garden, y el tributo que a dicha tradición hacen los Smithsons con el Pabellón Upper Lawn, se ha citado la influencia del jardín Arts and Crafts, del que es sin duda heredero. Comparte con aquel, el especial interés de los arquitectos de dicho movimiento por potenciar las interrelaciones entre la casa y el jardín, característica consustancial también al pabellón de los Smithsons, que llevando al límite este planteamiento, construyen una infraestructura flexible que se expande o contrae a voluntad de los habitantes, diluyendo hasta su desaparición las diferencias entre la casa y el jardín cuando la carpintería de la planta baja se abre por completo.

En este sentido los dos referentes propuestos, ya mencionados son: su sorprendente relación con Compton End en el cercano condado de Hampshire, y las coincidencias con el trabajo de Edwin Lutyens en colaboración con Gertrude Jekill.

Entre las transformaciones hechas en Compton End a partir de 1894 por George Herbert Kitchin, arquitecto del movimiento Arts and Crafts, sobre el cottage del siglo XVII existente en la finca, destaca por lo agradable, una de sus primeras ampliaciones consistente en construir en planta baja de la fachada sur, una soleada garden room con una terraza superior, suelo de cerámica, y frentes acristalados al sur-este y suroeste, en este último caso con dobles puertas que se abren al jardín, las cuales estaban siempre abiertas, conectando directamente la estancia con el jardín. La nueva "garden-room» acristalada, se usaba constantemente y tenía la ventaja de su cubierta plana, la cual al recoger el agua de lluvia y el sol de la mañana, se convertía en un delicioso baño al aire libre (Bradley-Hole 2004, 45)

El asombroso parecido del espacio interior entre la garden-room de Compton End y la planta baja del Upper Lawn Pavilion, así como el muy similar carácter de la empinada escalera ${ }^{108}$ para acceder a la parte superior en ambas casas, es sorprendente como nos muestran las fotografías adjuntas.

El segundo referente es con carácter general, Lutyens, y en concreto algunas realizaciones menores, que resuelven un tipo de construcción apoyada asimétricamente en un lado en un muro, y en el otro en soportes puntuales.

108 Si bien la escalera de Compton End es exterior, la forma, construcción y carácter -muy empinada, casi como una escalera de mano- son los mismos que la del Upper Lawn Pavilion. Una mirada atenta a los planos de proyecto, permite comprobar que en las primeras versiones, estaba prevista una escalera de mano en el exterior, para acceder directamente a una de las ventanas de la planta superior, que finalmente no se realizó. 

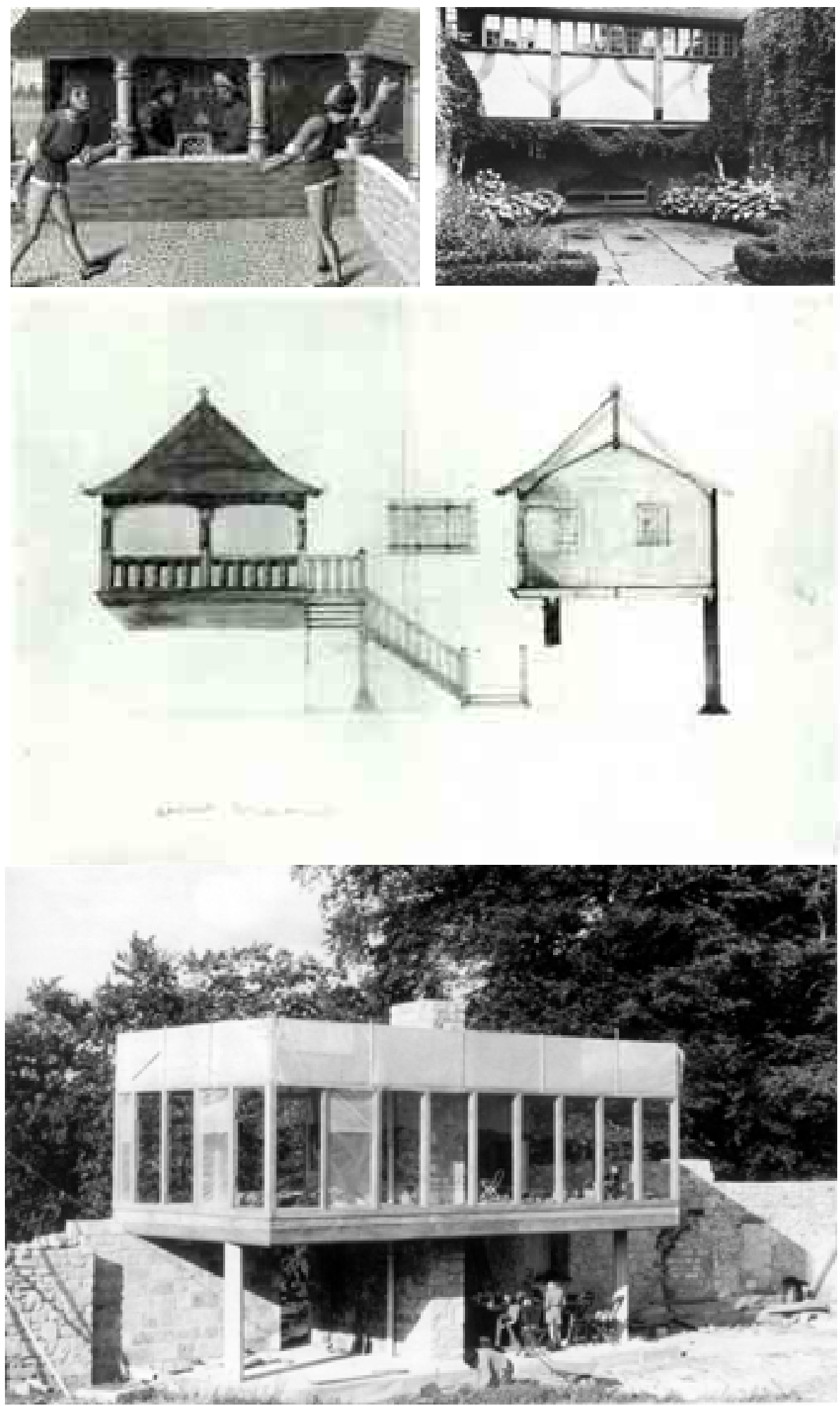

Figura 2.61

* Superior izquierda: Un pentice, o galería abierta donde se jugaba al ajedrez y al backgammon, mientras que un juego de pelota se desarrolla en el patio. Flamenco, siglo XV. (Landsberg 1995)

* Superior derecha: Galeria acristalada en el segundo piso dejando un porche abierto hacia el jardín en plantabaja, de Lutyens y Jekill, para Munstead Wood, la casa de Gertrude Jekill.

* Centro: A garden house proyectada por un joven Edwing Lutyens (1896-1944) para Harry Mangles, gran experto del momento en rododendros, en su casa de Littleworth Cross, cerca de Farnham en Surrey, para quien también había diseñado una casita de aves similar: mitad apoyada en el muro de la cocina del jardín, con la planta libre.

* Inferior: El volumen principal del Pabellón Upper Lawn apoyado sobre la tapia de piedra, antes de colocar la carpintería plegable de la planta baja. 


\title{
2.5. Piedra, madera y aluminio: los Smithsons artesanos modernos
}

\author{
[Materialidad, tekton ]
}

Alison y Peter Smithson siempre prefirieron construir a teorizar. Numerosos testimonios de Peter, tras la muerte de Alison, así lo evidencian. Aunque también fueron grandes divulgadores de su obra, algo por lo que han sido frecuentemente criticados, su mayor interés declarado fue la realización de encargos. Para ellos la verdad está en los edificios, más que en las palabras.

«Of course one has to be careful with words, they adumbrate, often falsely, the thoughts, or more critically, the posture of the speaker.

But buildings...think of Mies 'Farnsworth House, Le Corbuiser's Armé de Salut, Duiker's Zonnestraal, Kahn's Trenton Bath House.

Words may have helped (I doubt it), but it is the building that is the ethic» (Smithson 1997)

Razón por la cual el análisis de la materialidad de su propia casa de fin de semana, es relevante para entender modos de hacer. Upper Lawn, es un pequeño pabellón, de madera, vidrio y aluminio, construido en parte por ellos mismos de forma experimental, en un "Cottage» inglés del siglo XVIII con un recinto conformado por un muro de mampostería de piedra sobre el que se apoya. En Upper Lawn cristalizan muchos de sus planteamientos. Es un tributo de los Smithsons a la mejor tradición vernácula inglesa basado en el dialogo que se establece entre lo nuevo y modern con la preexistencia.

Se profundiza en los Smithson como arquitectos constructores. En su investigación y aportaciones, en su forma de entender la construcción y los materiales.

Se toma como marco de referencia el concepto «conciencia material» definido por el sociólogo Richard Sennett (Chicago 1943) como algo consustancial a todo buen artesano.

«Pero todavía es una verdadera obra brutalista; es decir, los viejos muros, la madera, el acero inoxidable, la piel de aluminio, la madera de teca -todos los materiales- se han utilizado para que se pueda sentir su cualidad» (Smithson, 2001: 77).

«Mientras viajaba, aquello que miraba también tenía que ver, en parte, con cómo se construían los edificios; no me refiero a la arquitectura, sino a la construcción.» (Spellman y Unglaub, 2004: 17).

... «Un edificio experimental donde poner a prueba algunos productos nuevos que aun no han sido permitidos por las autoridades de Londres»...

... «Para descubrir lo que es vivir todo el año en Inglaterra en una casa con fachadas de vidrio al sur, este y oeste y un muro macizo en casi toda la fachada norte (además de una cubierta aislada), es decir: verificar la afirmación de que puede obtenerse calor casi todo el año y de que este puede compensar las pérdidas térmicas»

...«Variaciones sobre el tema umbral/ventana en este escenario medio edificiomedio ruina"... (Smithson y Smithson 1986) 
...«Para experimentar en nosotros mismos ciertas aplicaciones y conjunciones de materiales que, si resultan acertadas, utilizaremos más adelante en los edificios de nuestros clientes, por ejemplo: recubrimiento de hojas de aluminio muy puro; puertas interiores y exteriores de madera contrachapada revestida de aluminio; aislamiento de poliestireno en muros y cubierta; conectores de madera en una estructura tipo balloon-frame americano en

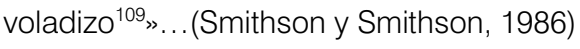

A su vez, se profundiza en la interpretación moderna de lo vernáculo que hacen los Smithson y en su entendimiento de la tradición sin mimetismos, a través del estudio de las soluciones constructivas utilizadas en este pabellón experimental.

Materiales industriales novedosos en aquel momento e intencionadas preexistencias, coexisten en igualdad y mostrando sus cualidades naturales, en un dialogo entre construcción moderna y vernácula, el cual ha convertido Upper Lawn en uno de los iconos arquitectónicos de la segunda mitad del siglo XX, incluyéndose en 2011 en The National Heritage List for England (NHLE) del English Heritage.

Se estructura a partir de las relaciones que se establecen entre preexistencia y nueva construcción. Del dialogo establecido a partir del material: piedra, madera y aluminio. Para ello se realiza un análisis de las acciones que se realizan en el muro de mampostería de piedra preexistente, que conforma el recinto y que es la base del pabellón; un análisis constructivo comparativo entre el proyecto los Smithson y las soluciones anglosajonas de entramado tradicional de madera tipo box-frame, y tipo balloon-frame, y un análisis constructivo contextualizado en la industria posbélica de los años cincuenta sobre el empleo del aluminio como revestimiento.

109 Incorporación de la expresión "en voladizo" por la autora, al haber sido omitida en la traducción castellana de la publicación bilingüe. Su no inclusión, desvirtúa el conocimiento de los Smithson sobre la incompatibilidad entre una estructura de balloon-frame tradicional y su posición en voladizo. 

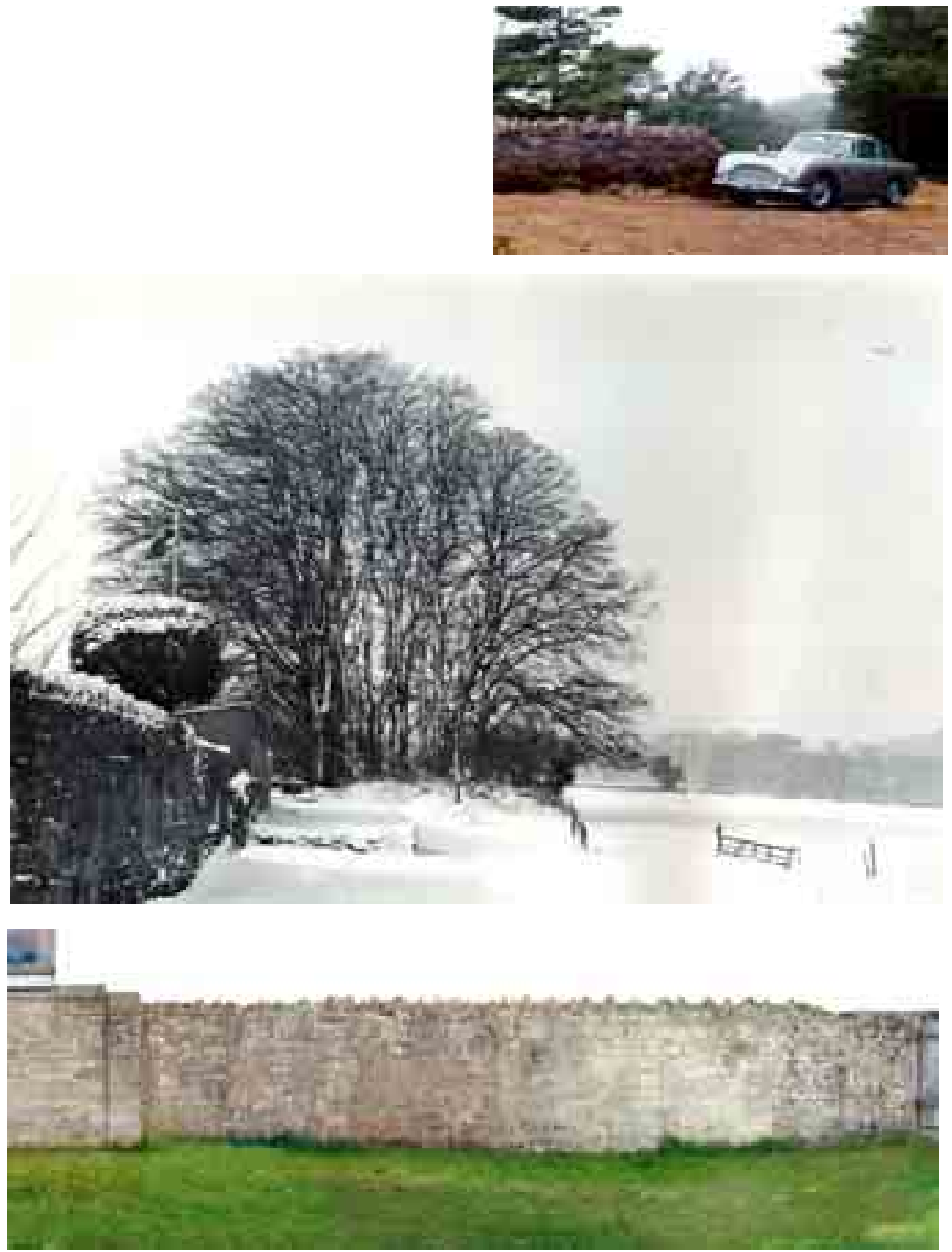

Figura 2.62

Superior derecha

Fotograma de Skyfall, vigesimotercera película de la serie cinematográfica de James Bond, dirigida por Sam Mendes en 2012.

007 para proteger a M, directora del MI6, viaja con ella a Skyfall, la mansión familiar de los Bond en Escocia. Fotograma llegando a la entrada de la finca en el coche privado de Bond, un Aston Martin DB5, clásico de los años cincuenta sin sistema de localización.

Los exteriores de la mansión se rodaron en la pequeña población de Glencoe, en las Highlands de Escocia (antes perteneciente al Condado de Argyll), bajo la supervisión del National Trust for Scotland NTS, organización para la conservación del patrimonio natural y cultural de Escocia. Aunque se construyó un decorado para gran parte de la edificación, el muro "almenado", similar al de Upper Lawn, fondo del Aston Martin es real.

Centro

Figura 68 de Upper Lawn, Folly Solar Pavilion con el siguiente pie de foto: Vista del muro rústico almenado de Beckfrod (los muros de Newtown eran iguales).

En numerosas ocasiones los Smithson se refieren al muro "almenado" de Upper Lawn.

Inferior

Alzado fotográfico del muro almenado de Upper Lawn, realizado con imágenes hechas por la autora en 2010

A la izquierda, encuentro con la parte nueva en esquina, para el cambio de dirección construido por los Smithson en la zona del pabellón. A la derecha, remate del muro en horizontal, realizado para completar una zona derruida del muro original y alojar la puerta de madera en el extremo de la parcela. 


\subsubsection{Piedras y adoquines. Continuidad en las acciones realizadas en la transformación del muro y en el pavimento del jardín.}

La ubicación desplazada del nuevo pabellón respecto al antiguo cottage, así como su carácter radicalmente moderno y diferente, son las decisiones determinantes del proyecto, así como del depurado proceso de transformación de lo existente y de las diferentes actitudes adoptadas en el mismo.

Si bien su posición se mantiene, como en la construcción preexistente, en el mismo plano del muro norte del enclave, elevándose en continuidad con él como interpretación de un tipo de solución que se da en distintas zonas del país y que interesa especialmente a los Smithson «Una extensión del sistema de organización de "pabellón junto al camino": El pabellón se sitúa como una caseta de guarda a caballo sobre el antiguo acceso al conjunto»110 (Smithson y Smithson, 1986), lateralmente se desplaza hasta convertir uno de los hastíales, recuperado por su calidad y buen estado, en el centro de la nueva casa y sobre el que se ubica la chimenea.

Este desplazamiento determina una serie de operaciones en el muro realizadas en continuidad con la mampostería de piedra preexistente.

1. Cambio de posición del nuevo pabellón respecto a la antigua construcción.

2. Desmontado de la parte central del lienzo coincidente con la posición del nuevo pabellón, desde el hastial reutilizado, y agrandando el hueco preexistente de acceso a la parcela, coincidente con el hueco de acceso actual.

3. Permanencia de las dos ventanas antiguas, similares pero diferentes en dimensión, proporción, construcción y carpintería de madera, quedando una de ellas fuera de la zona de la nueva casa, en el jardín, como un cuadro que enmarca el paisaje de los bosques de Fonthill.

4. Reconstrucción del muro de planta baja de la vivienda, sobre una nueva cimentación, de dos hojas con cámara para instalaciones.

Este lienzo, completamente nuevo cambia su dirección respecto al preexistente generando una quiebro ortogonal en su encuentro con el muro antiguo almenado. Al otro lado se resuelve en continuidad mediante una junta explicita.

5. Regularización de las alturas de coronación del muro en tres escalonamientos. Para ello se elimina parte de la mampostería de la planta superior de la casa antigua rematándose con una viga de hormigón el apoyo de la nueva edificación.

Esta solución difiere de la reflejada en un primer plano de proyecto, donde se acusaban más diferentes, en una opción más conservadora con parte de la mampostería preexistente (Rodríguez, 2011: 1207).

6. la chimenea

\footnotetext{
${ }^{110}$ Ver pagina---- el pabellón como gazebo heredero del de Gertrude Jekyll
} 

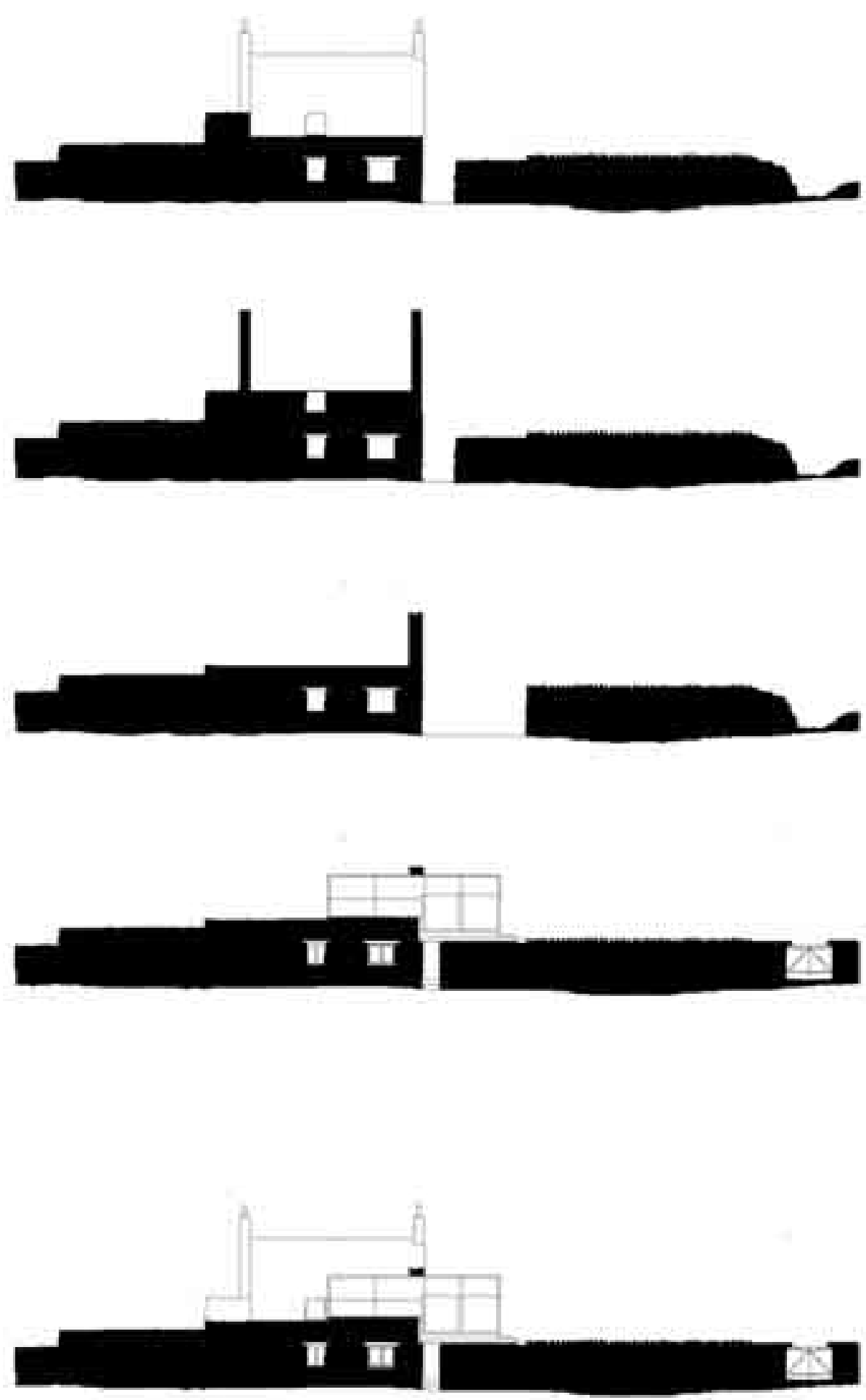

Figura 2.63

Análisis del proceso seguido en la transformación del muro norte: estado inicial, transformación del muro con eliminación y regularización de partes, y Upper Lawn terminado.

Dibujo de Ana Rodríguez 

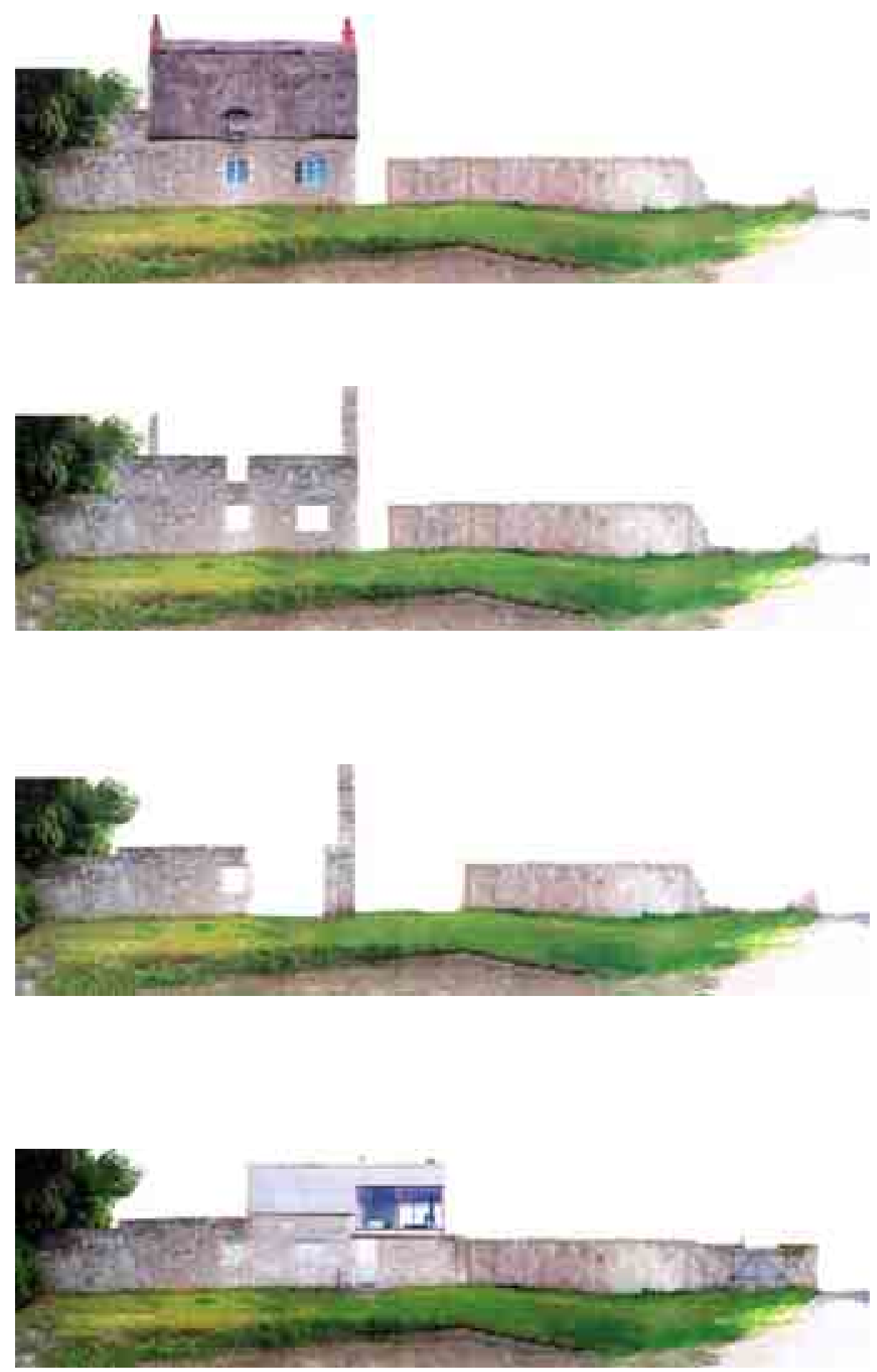

Figura 2.64

Análisis del proceso seguido en la transformación del muro norte:

2.64a. Estado inicial, 264 b-346 c. transformación del muro con eliminación y regularización de partes, y 264 d. el Upper Lawn Pavilion terminado.

Fotomontajes de Ana Rodríguez 


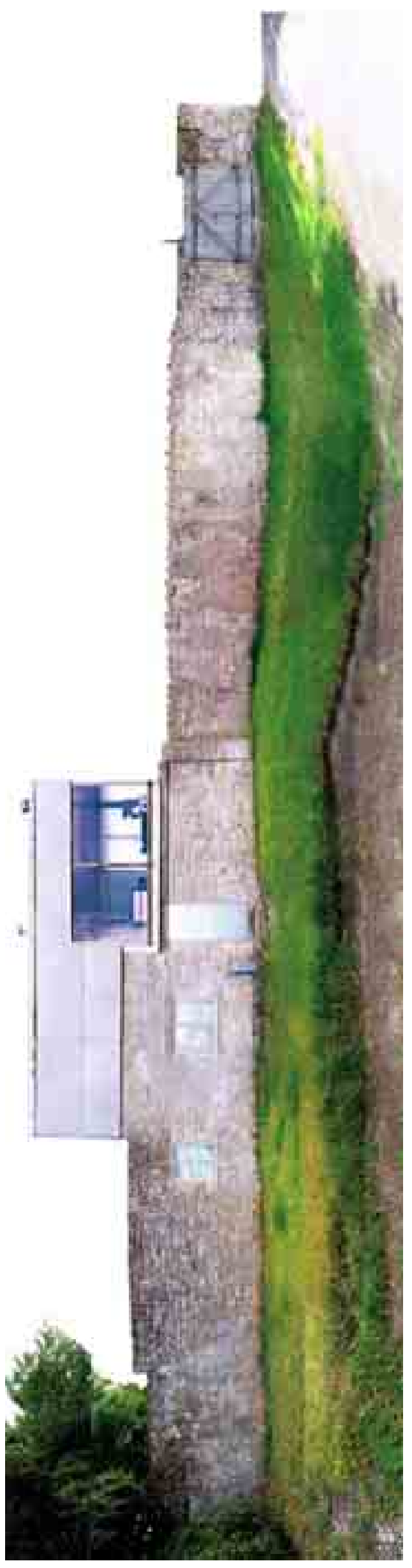

Figura $2.64 \mathrm{~d}$

Cualidad material del Alzado Norte del Upper Lawn Pavilion terminado. Fotomontaje de Ana Rodríguez 

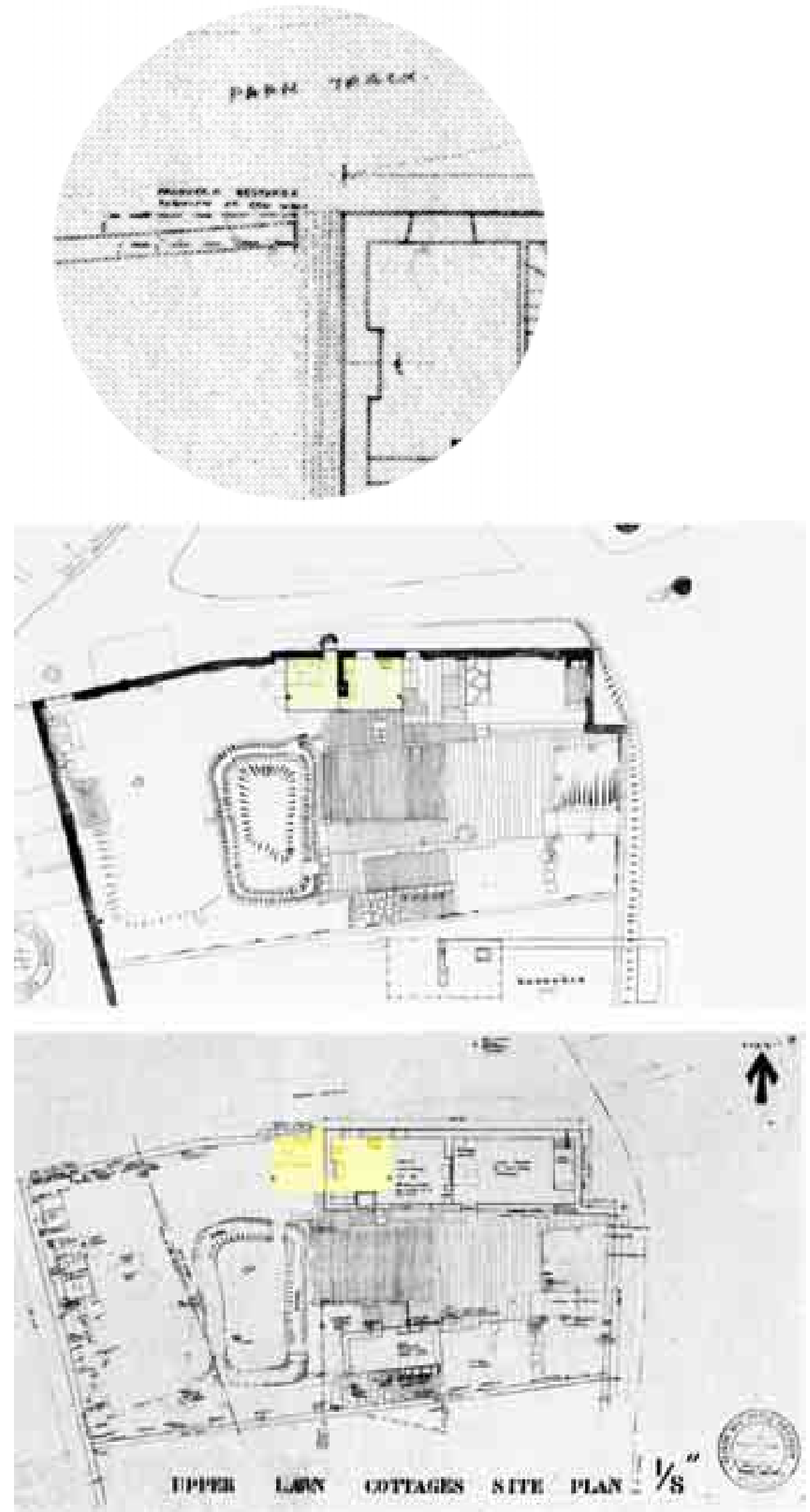

Figura 2.65

* Superior. Detalle de las anotaciones de los Smithsons en el plano de estado inicial de la parcela con los dos cottages preexistentes, de las modificaciones a realizar en la transformación del muro norte. A trazo discontinuo el nuevo trazado del muro.

* Centro: Upper Lawn Pavilion. Planta general de la intervención en la parcela.

* Inferior: Planta del estado inicial de los dos cottages preexistentes en la parcela. En color, la posición comparada del nuevo pabellón en relación a la preexistencia. 
Con estos planteamientos Upper Lawn reinterpreta unos de los tipos más universales de la construcción vernácula. Estructuras de entramado de madera en la planta superior sobre plantas bajas de gruesos muros de piedra o ladrillo, se dan dentro y fuera de Inglaterra (Rodriguez 2011). Así mismo, los Smithson explicitan reiteradamente su inclinación clásica. Estudian templos y ciudades griegas con grandes basamentos de piedra, estereotómicos, sobre los que apoyan construcciones adinteladas, con columnas (letra cursiva en el original) «Estudiamos los templos dóricos, desde los primeros -el Argive Heraeum- hasta los tardíos Nemea y las ciudades griegas» (Spellman y Unglaub 2004, 18).

Así, en la estructura conviven dos maneras de entender la materialidad construida: una construcción ensamblada y ligera, que se apoya sobre un basamento masivo y pesado.

La construcción masiva está formada por el muro norte de mampostería modificado con parte antigua y parte nueva, y el hastial ya existente recortado que servirá de arriostramiento al entramado de madera, mas dos soportes y una viga de hormigón armado junto con el durmiente/viga de remate del muro de piedra, también de hormigón con una sección en ambos casos de 9x10 pulgadas $(22,86 \times 25,40 \mathrm{~cm})$.

El vano de la viga se encastra en un cajeado en el hastial de piedra, posibilitando la misma sección casi cuadrada en todos los elementos de hormigón: durmiente, viga y soportes. Estos se colocan girados y con las esquinas redondeadas, primer indicio de un tipo de superficies que los Smithson desarrollan y alcanzan su definitiva forma constructiva en The Economist y a las designan «con las que se puede uno rozar» (Smithson y Smithson 1986).

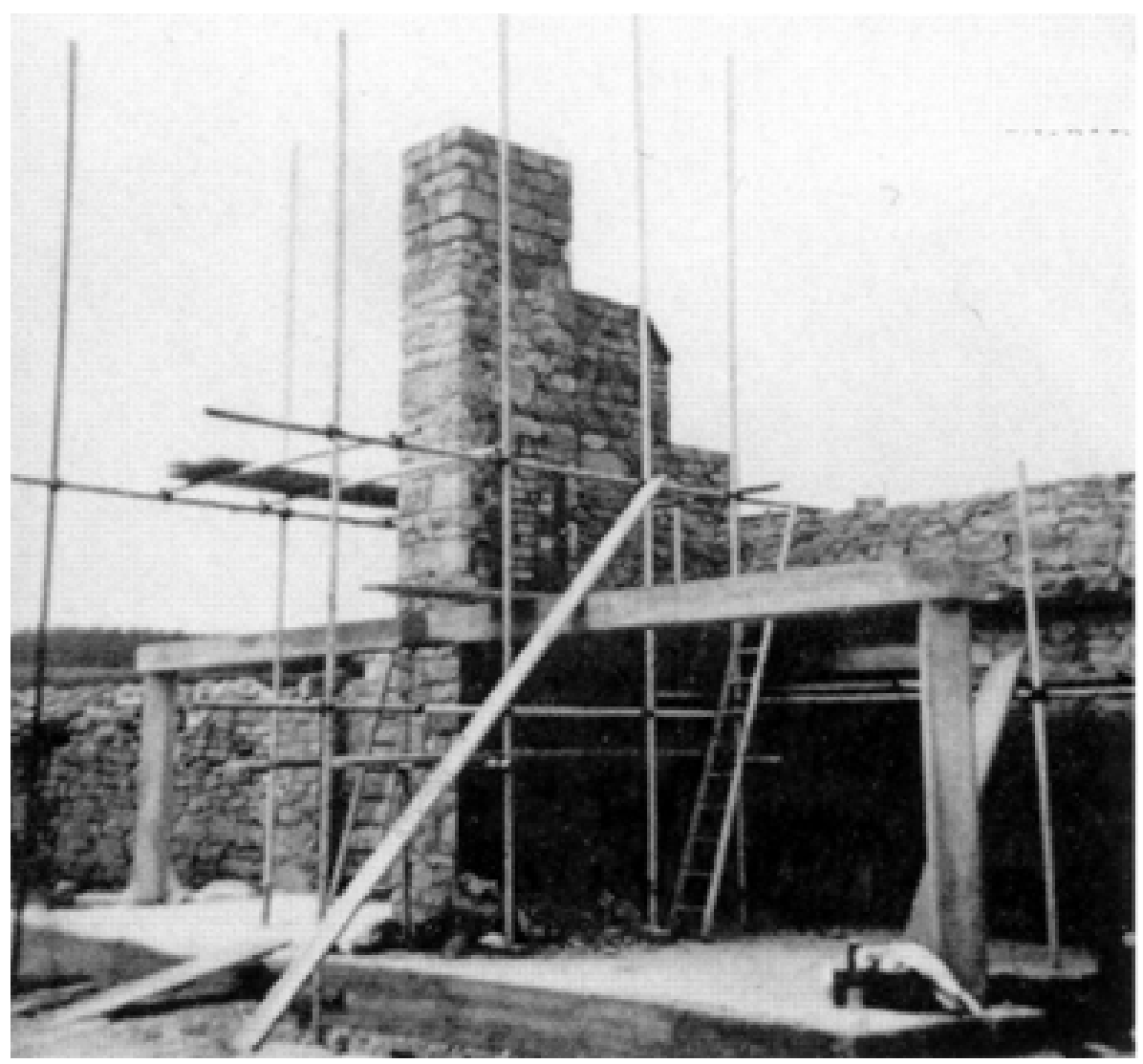

Figura 2.66

El pabellón en construcción. Construcción masiva (Smithson y Smithson 1986). 


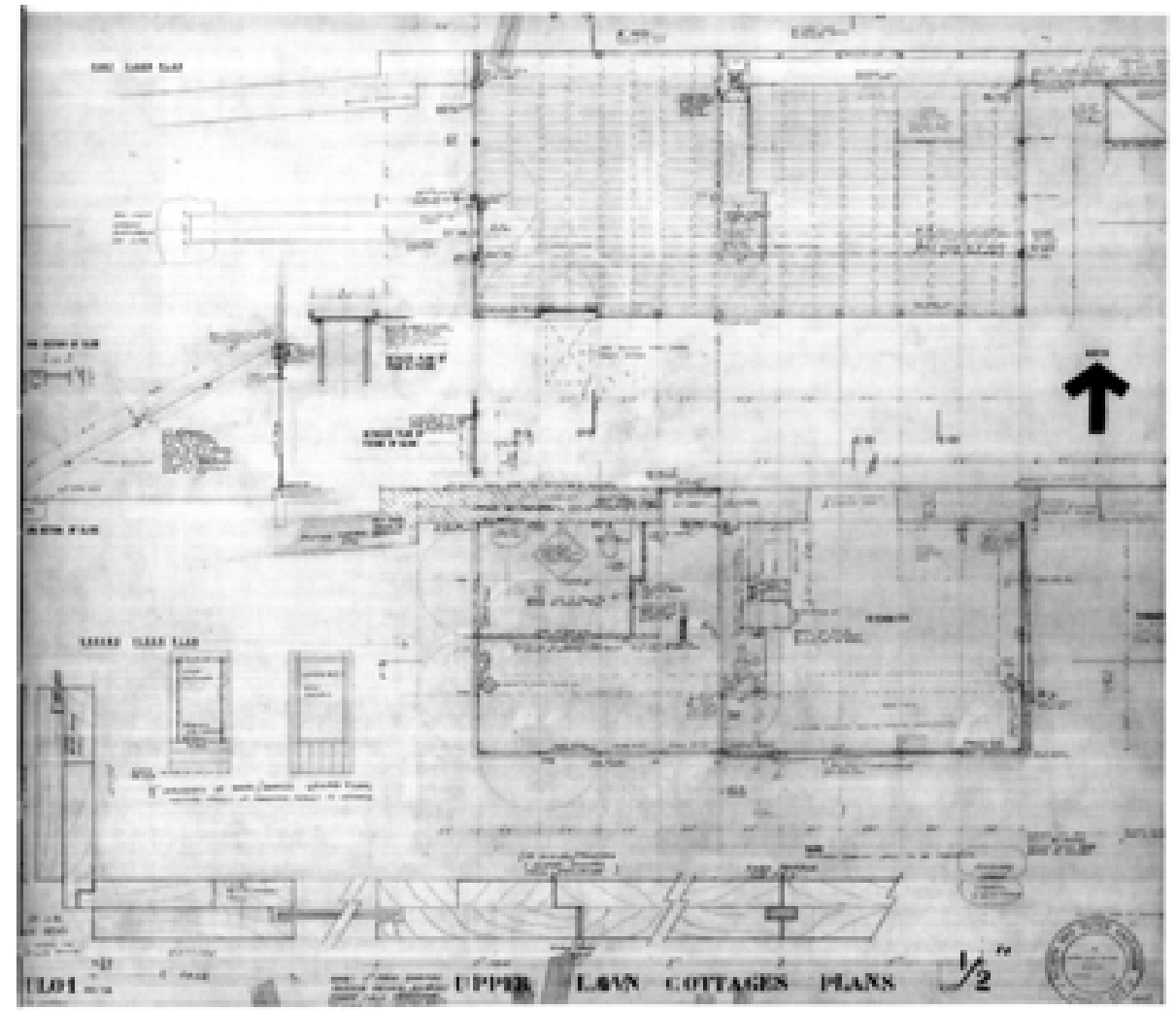

Figura 2.67

Upper Lawn. Plano UL01 del proyecto (Van den Heuvel y Risselada, 2004)

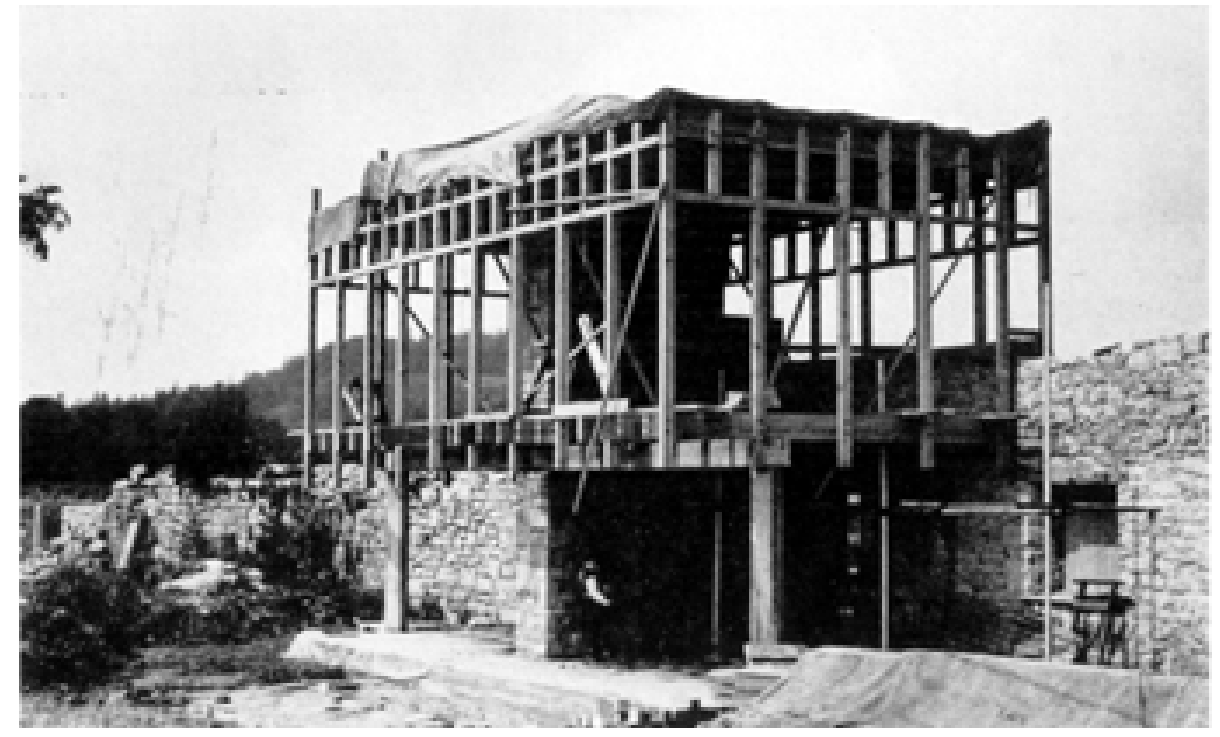

Figura 2.68

Construcción ligera con entramado de madera (Smithson y Smithson 1986). 
En ellos se apoya, en voladizo y liberando la planta baja, una construcción ligera de entramado de madera de pino tipo «balloon frame» con variaciones, ensamblada con espigas de madera. Está compuesta por 26 soportes 4×3 pulgadas de sección $(40,16 \times 7,62 \mathrm{~cm})$ todos dispuestos longitudinalmente con la dirección norte-sur. 10 en el lado sur, 8 en el norte, y 4 en las caras este y oeste. Al exterior se protegen con tabla de madera de teka de secciones $5 \times 1$ pulgada al norte-sur y $7 \times 1$ pulgadas al esteoeste, que a su vez rematan los encuentros de la estructura con los vidrios.

La disposición en planta está basada en un modulo de 3 pies $(91,44 \mathrm{~cm})$ que se repite sistemáticamente en todas las distancias a ejes entre montantes. Las caras norte y sur se conforman con 9 módulos y una longitud total de 8,22 m. En la norte, aunque se eliminan dos soportes para obtener los dos huecos mayores de los ventanales principales, se sigue manteniendo dicha modulación, con dos longitudes de 6 pies a ejes de montantes consecutivos. Los lados perpendiculares están formados por 4 módulos (3,65 m) mas la única distancia ajena al sistema, que no se acota en los planos del proyecto, ya que viene dada por el espesor del muro de fábrica existente sobre el que se apoya.

La intención y filosofía geométrica modular del sistema se definió con independencia de la sección estructural de los elementos de madera del entramado, como se puede comprobar en las repetidas anotaciones de los planos referidas a que las secciones de las vigas de madera están bien acotadas pero dibujadas más pequeñas, sin escala. Las viguetas del forjado inferior tienen una sección de 9x3 pulgadas $(22,86 \times 7,62 \mathrm{~cm})$ y las del forjado de cubierta de 6x2 pulgadas $(15,24 \times 5,08 \mathrm{~cm})$. Se disponen con una cara adosada a la cara interior del pie derecho, sucesivamente en cada soporte como criterio general, de forma que su distancia a ejes se mantiene en 3 pies. En cada vano entre soportes se dispone otra vigueta en el punto medio. Al llegar al extremo opuesto y en las variaciones producidas por el hueco de la escalera y la chimenea preexistente, la vigueta correspondiente se adosa a la otra cara del soporte, manteniendo en todos los casos el criterio del sistema planteado. En el contacto con la fabrica de la chimenea, el espacio que se genera entre el sistema modular y las dimensiones de esta, se solventa duplicando la vigueta con la doble intención de permitir puntualmente el paso de las instalaciones de la estancia superior y mejorar la unión con la fabrica que a su vez arriostrra el sistema.

El canto del durmiente, remate del muro de fabrica, y la viga de hormigón sobre los que se apoyan las viguetas de madera, establecen en sus caras inferiores la cota hasta la que descuelgan los pies derechos del entramado de madera, el cual queda en las partes opacas, siempre oculto; recubierto al exterior con el acabado de aluminio y al interior con tablero contrachapado. El contacto entre la madera y el hormigón en el apoyo, se cuida esmeradamente, con una interesante solución que incorpora embutidos en el hormigón, perfiles elásticos para mejorar dicho apoyo. También se coloca «bituminous DPC», abreviatura de damp-proof course, membrana impermeable para evitar humedades por capilaridad en la madera (Rodríguez, 2013: 938)

Sobre este armazón estructural de elementos nuevos y antiguos, tradicionales y modernos, terminan de conformar la construcción materiales y sistemas de carácter experimental como, el recubrimiento de hojas de aluminio muy puro, puertas interiores y exteriores de madera contrachapada revestida de aluminio, aislamiento de poliestireno en muros y cubiertas, conectores de madera para una típica estructura americana de «balloon frame», marcos de puertas de tablones laminados; puertas correderas plegables con pliegue final de $180^{\circ}$, que normalmente solo se usan en interiores y que aquí se probarán como cerramiento, canalones de desagüe de fibra asfáltica, cañerías y sifones de polietileno, hojas de «Visqueen DPC», depósitos de agua de poliester, tubos de salida de humos con acabado interno vidriado; todo ello conviviendo con la piedra antigua de la mampostería de los muros y del adoquinado del jardín. 


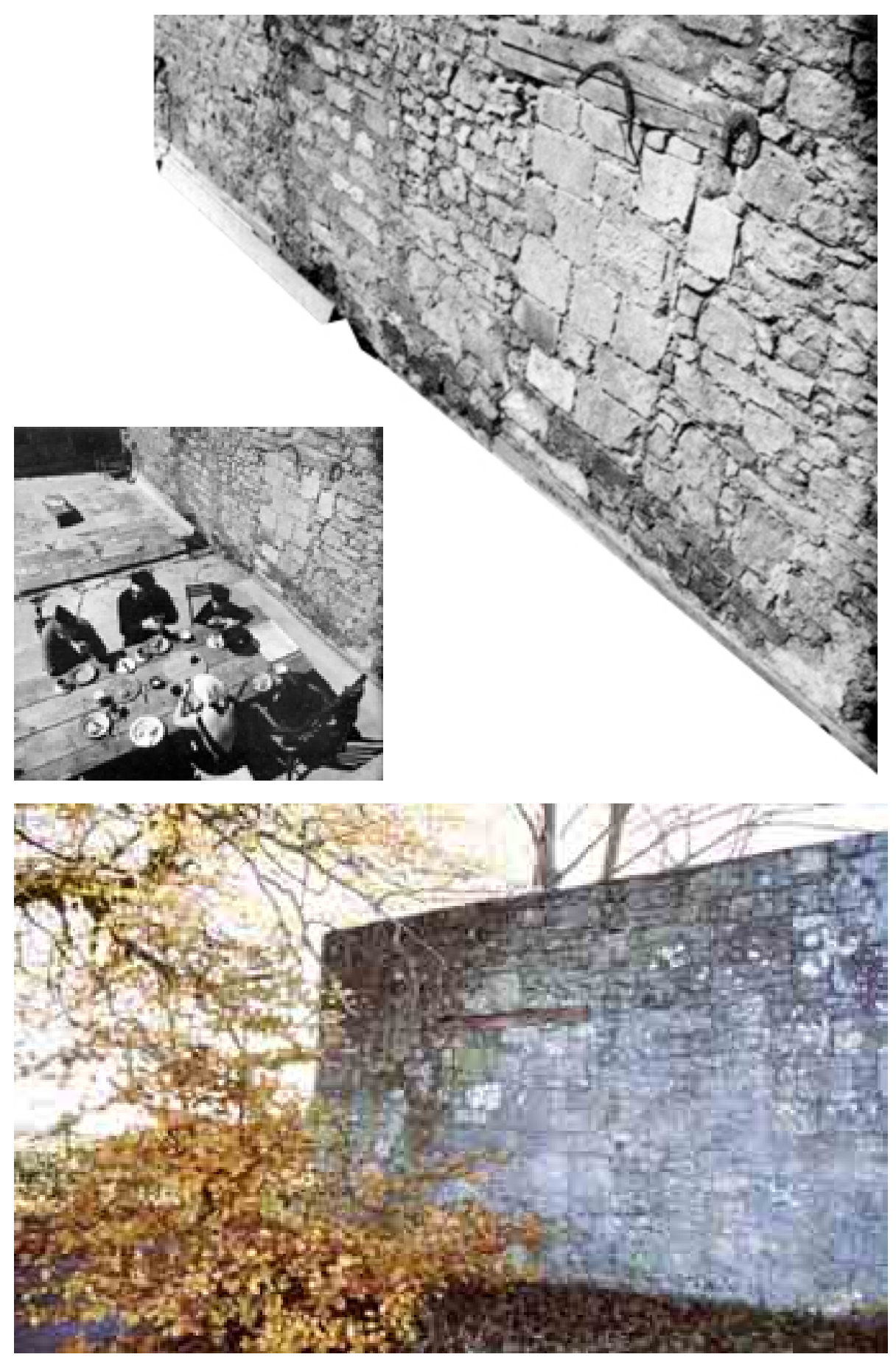

Figura 2.69

Huellas en el muro de mampostería de Upper Lawn de transformaciones anteriores a la realizada pos los Smithsons.

\section{* Centro}

Los Smithsons con Reyner Banham y Burg Galwey, fotógrafo de Architectural Review, en Petesotes de 1962

* Superior

Detalle de la fotografía central, en el que la pieza de madera de un dintel de una antigua puerta,

es utilizado como expositor de herramientas y utensilios as found de la vieja granja.

* Inferior

Dintel de madera desde el exterior. Fotografía de Carlos Puente 


\section{Reflexiones finales (muro)}

El pensamiento teórico enunciado por los Smithson a lo largo de su vida, desarrolla conceptos que confluyen y fructifican en Upper Lawn. Aquí el concepto de «as found» y «found» lo abarca todo; también la relación con el lugar, las marcas en el territorio, los signos de ocupación, el orden conglomerado, la influencia de la tradición, o la materialidad, se entrelazan con naturalidad, sin jerarquías.

Si bien no hay una única idea, sino un híbrido complejo de temas, en Upper Lawn el diálogo con la tradición, lo vernáculo y lo moderno, se establecen fundamentalmente a través de la materialidad, transformando la preexistencia del antiguo cottage.

La decisión de sustituir la antigua edificación por un pequeño pabellón prismático, apoyado sobre el muro, reinterpretando la antigua construcción, establece un dialogo entre opuestos claro y rotundo.

El muro antiguo: macizo, robusto, de mampostería de piedra, opaco, irregular, rugoso, grueso, extensión del terreno, estereotómico, arcaico.

En contraposición la nueva construcción: ligera, de madera y vidrio, modular y prismática, lisa, transparente en el vidrio y reflectante en el revestimiento de láminas de aluminio, fina, perteneciente al aire y al cielo, tectónica, moderna.

Una idea y dos estrategias contrapuestas para llevarla a cabo material y constructivamente.

Una pregunta y dos respuestas.

Un Qué y dos Cómo:

El más evidente de dialogo entre opuestos con la contraposición del nuevo pabellón y el antiguo muro de mampostería vernácula.

El más sutil, poco estudiado, de la continuidad en las acciones realizadas en el muro de piedra.

En el pasado, las técnicas tradicionales evolucionaban mediante pequeños cambios apenas perceptibles hasta pasado un periodo lo suficientemente amplio que posibilitara su visibilidad respecto al origen y que resulta de la suma de microacciones en el tiempo.

Aparentemente, el muro de mampostería se percibe de forma unitaria, como un todo homogéneo que siempre hubiera sido así, salvo la pequeña puerta metálica de acceso.

Sin embargo es el resultado de un número de modificaciones mayor del que en un principio pudiera parecer, que se suman de forma natural a otras acciones realizadas en el tiempo y que lo han convertido en lo que actualmente es.

El conjunto de estas acciones de eliminación, y de adición realizadas también con mampostería de piedra algo mas regular, mantienen la continuidad del muro.

Las nuevas modificaciones se integran con naturalidad y suavemente en la fábrica, junto a las de épocas anteriores, como la antigua puerta, tapiada cerca de la esquina, en la que se aprecia con calidad y embebido en la fábrica el dintel de madera y la formación de las jambas.

Esta puesta en valor de un modesto muro de mampostería no resulta de una actitud historicista conservacionista. En la arquitectura de los Smithson es igual de importante una brizna de hierba que un castillo. (Rodríguez, 2011: 1210) 


\subsubsection{El entramado de madera del Upper Lawn Pavilion. Una interpretación moderna de técnicas tradicionales}

Se profundiza en la materialidad construida en el trabajo de los Smithsons en relación con la estructura del pabellón, una construcción ligera de entramado de madera de pino tipo «balloon frame» con modificaciones.

Se plantea como método de trabajo un análisis constructivo comparativo entre el proyecto de los Smithson y las soluciones anglosajonas de entramado tradicional de madera tipo box-frame, y tipo balloon-frame, a partir de la documentación de Upper Lawn (planos originales del proyecto, fotografías y textos de los autores) y bibliografía específica sobre construcción tradicional con madera en Gran Bretaña y Estados Unidos.
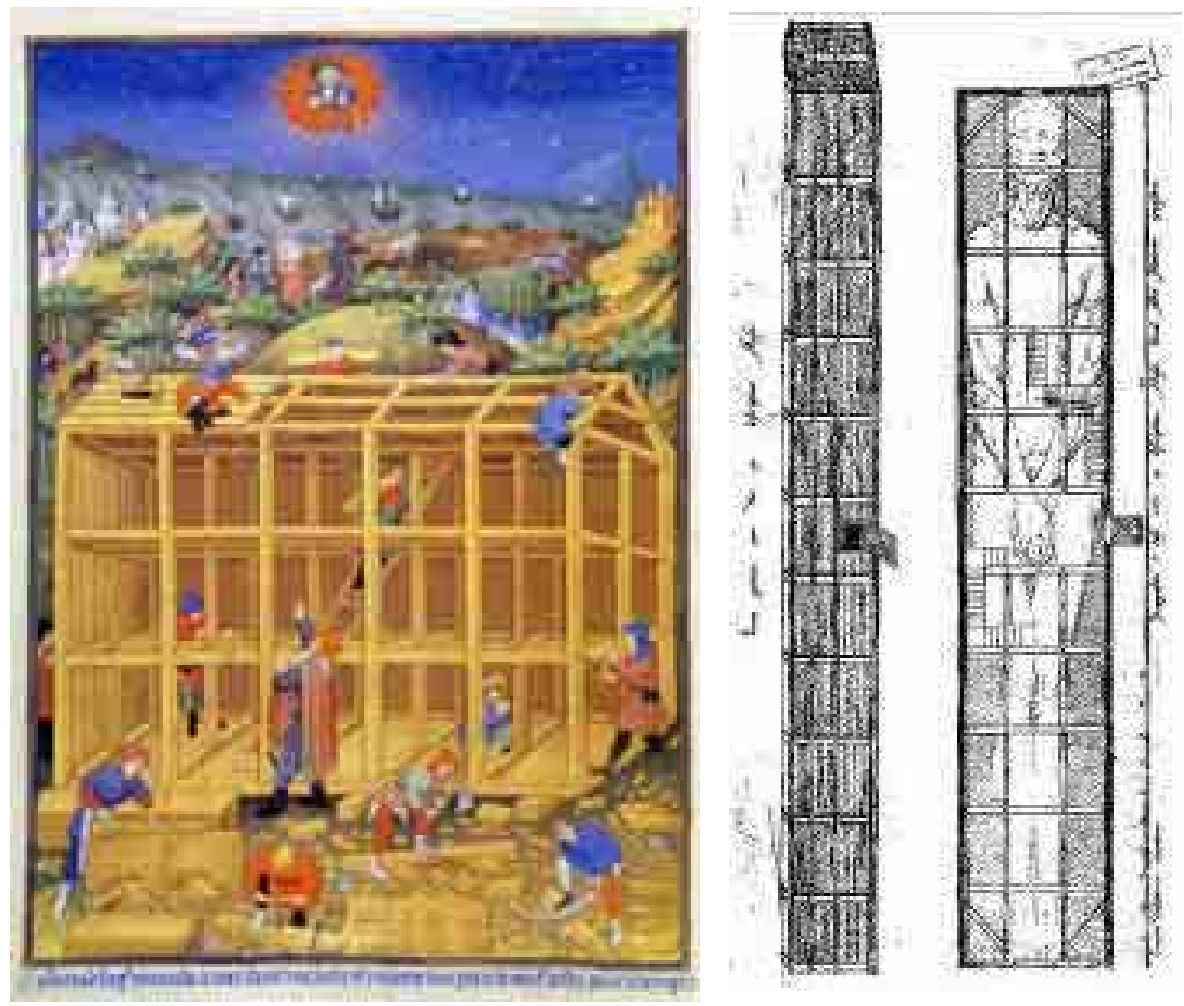

Figura 2.70

Imágenes arquetípicas de la construcción del Arca de Noé con estructura de entramado de madera.

* Izquierda: Noah building the ark. The Bedford Hours Primera mitad del siglo XV

* Derecha: Alzado y planta del Arca de Noé según la Biblia Políglota Sacra de Amberes (1572), de Benito Arias Montano (1527-1598) 


\subsubsection{Un breve recorrido por las técnicas de muros de entramado de madera en Gran Bretaña y Estados Unidos}

Muros de entramado de madera en Gran Bretaña. Los sistemas cruck-frame y box-frame.

Según Ronald Brunskill, autoridad en arquitectura vernácula británica, hay tres tipos principales de construcción de muros con entramado de madera que han sido utilizados en Europa. El primitivo sistema de troncos horizontales, en los que los muros componen de madera maciza apilada, una encima de otra y unidas en las esquinas; el sistema "post and plank» consistente en pesados tablones colocados entre pesados pies derechos; y el sistema de entramado de madera, en el que la estructura de madera se diferencia de las partes de cerramiento. Desde tiempos inmemoriales, no hay ejemplos de los dos primeros en Gran Bretaña, solo de entramado, construido casi invariablemente con madera. Son prácticamente inexistentes los ejemplos de construcción vernácula en los que se haya utilizado hierro.

La construcción de entramado en Gran Bretaña puede ser de dos tipos: el sistema cruck-frame o el sistema box-frame.
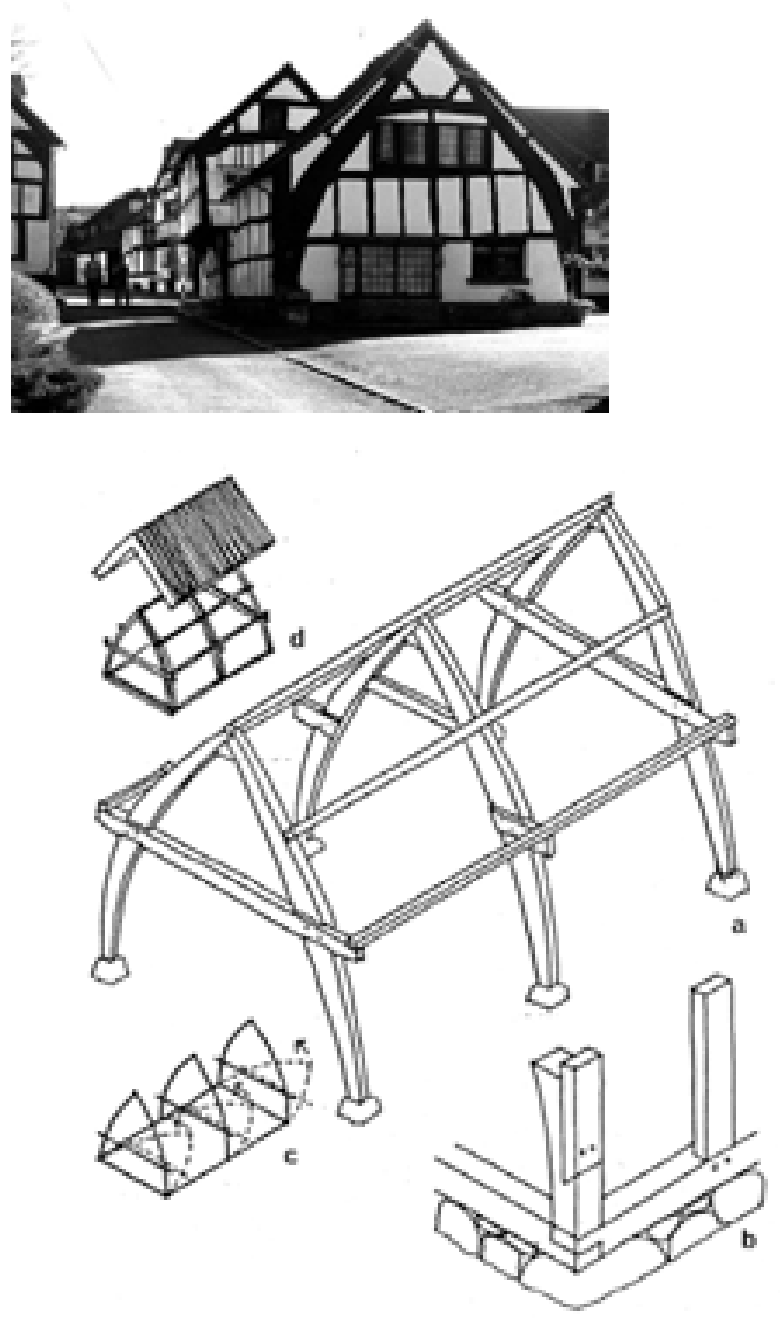

a. Diagram of cruck frame with two closed and one open truss.

b. Typical detail at corner showing cruck blade and wall post rising from a timber sill and stone plinth.

c. Rearing cruck trusses after assembly on the ground.

d. Roof covering in relation to cruck frame.

Figura 2.71

Sistema británico de entramado de madera Cruck-frame (Brunskill [1971] 2000) 

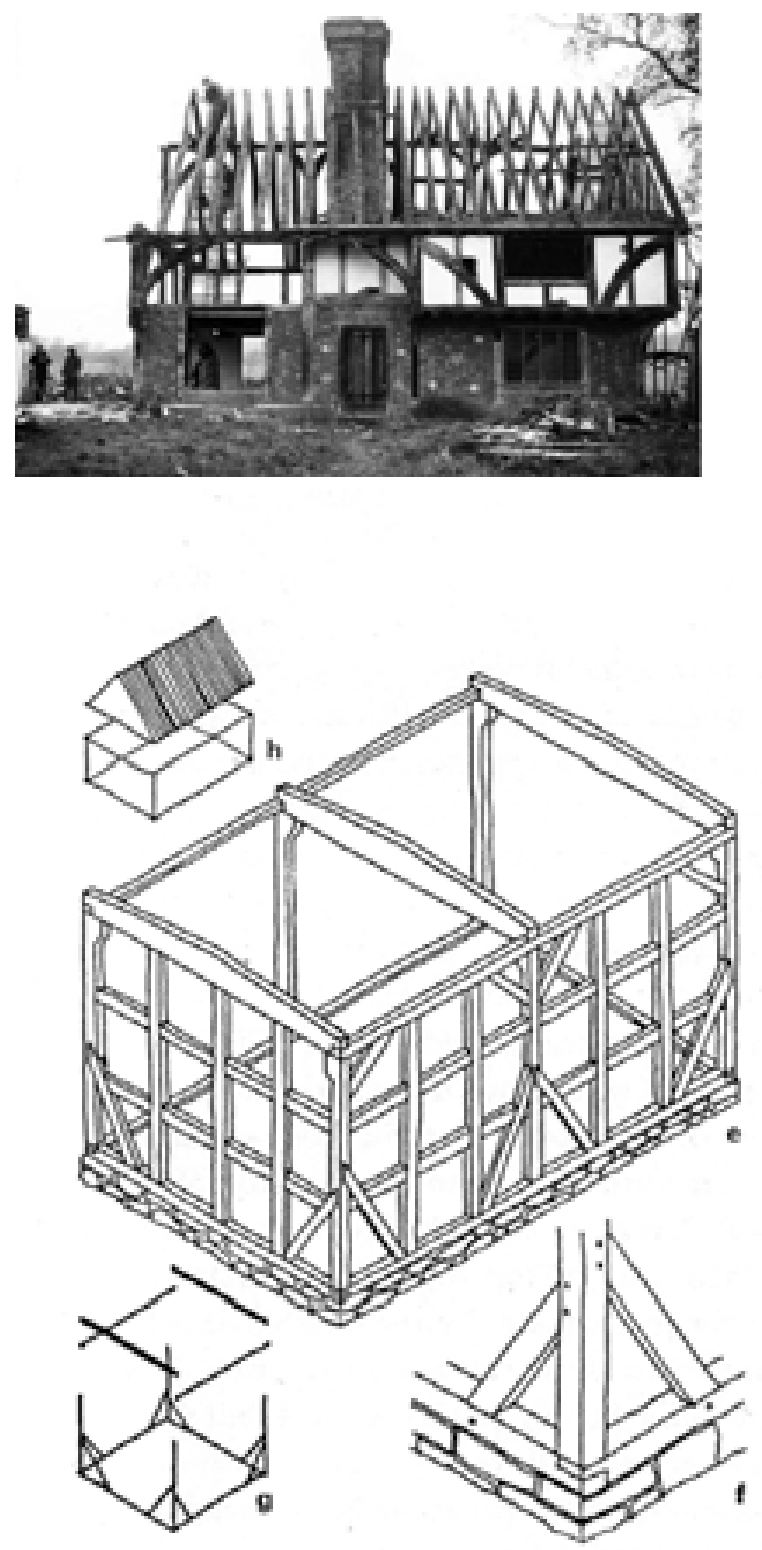

e. Diagram of boxframe two bays in length with posts and wall plates connected by tie beams and with a stud and rail infill wall.

t. Typical detail at corner showing post rising from a timber sill and supported by angle braces.

g. Diagram showing sequence of assembly.

h. Roof covering in relation to box-frame.

Figura 2.72

Sistema británico Box-frame (Brunskill [1971] 2000)

Imagen superior The Bayleaf en el proceso de derribo en el invierno de 1968/9 
La diferencia estructural entre ambos sistemas, consiste en que en el primero, las cargas de la cubierta se transmiten directamente al terreno a través de los cruck inclinados y curvos, mientras que en el segundo se transmiten a muros de entramado. La existencia de formas hibridas y todo lo que significa apoyar una cubierta de madera sobre un muro de cualquier material, tienden a oscurecer las diferencias entre ambas técnicas, pero son bastantes claras.

El proceso de la construcción también es radicalmente diferente en estas dos formas de entramado de madera. En la tipo cruck, los pórticos en forma de A, se montaban en el suelo y se izaban uno a uno a su posición vertical, de forma que la cumbrera, las correas laterales, y las soleras se colocan atando los pórticos. En las box-frame, en la mayoría de los casos, los soportes principales se izaban cada uno separadamente, con apeos temporales o con arriostramientos diagonales permanentes; a continuación, las carreras se colocaban sobre la parte superior de los pies derechos, y finalmente las vigas de atado o tirantes se colocaban en su posición, fijando simultáneamente pies derechos y carreras. Los pies derechos intermedios se colocaban pieza a pieza al mismo tiempo. Se daban algunas variaciones en esta práctica, como por ejemplo un mezcla de soportes y vigas de atado se elevaban un poco semejante a las tipo cruck, o también cuando un muro completo se montaba en el suelo y después se izaba, pero no era lo habitual.

Para identificar las juntas, se usaban marcas de carpintero, las cuales parecen haber variado con el tiempo y según los lugares. Estaban talladas y se basaban en series de números romanos o series de símbolos. A veces todas las juntas de cada cercha se marcaban por separado; alternativamente cada junta se le daba un numero correlativo desde un de los extremos del edificio hasta el otro. Probablemente ambos tipos se referían al orden de construcción.

El roble fue la madera predominantemente empleada en estructura, aunque el olmo y otras maderas blandas importadas fueron incrementando su uso.

Hubo una tendencia generalizada a usar madera más ligera según fueron mejorando las técnicas de carpintería, que posibilitaba madera adecuada de menor sección. En la tradición cruck-frame, esto condujo al empleo de piezas muy pobres y esbeltas, especialmente en las areas muy aisladas donde las cerchas cruck eran auxiliares de otra construcción de carga. En la tradición box-frame, el desarrollo de la técnica condujo a la eliminación de la distinción entre soportes de carga y pies derechos no de carga, dando lugar a muros completos de piezas de aproximadamente la misma sección trabajando juntas de forma unitaria. Este desarrollo parece haberse producido primero en los muros de atado y los linderos, extendiéndose después a los muros exteriores de edificios pequeños.

La posibilidad de maderas blandas en secciones uniformes y clavos baratos producidos de forma industrial, significo que las elaboradas juntas de las antiguas técnicas de entramado no fueran ya necesarias. Dos variaciones, la estructura de armazón y el balloon-frame, alcanzaron un uso universal en Estados Unidos en la segunda mitad del siglo XIX. La estructura de armazón, mantiene su uso de forma común en este país para construcciones modestas como garajes y cobertizos (Brunskill [1971] 2000).

Ademas del sistema cruck-frame y box-frame, el English Heritage en su libro de la colección «English Heritage. Practical Building Conservation» dedicado a la madera, introduce un tercer sistema el «post and truss frame», reseñando que la mayor parte de los edificios que han llegado hasta el presente son de este tipo, el cual consiste en que los muros de entramado, los elementos transversales y los elementos de la cubierta se combinan en una estructura integrada (McCaig y Ridout 2012). 
David Yeomans, en su libro «The repair of historic timber structures» insiste en que el box-frame es conceptualmente diferente del cruck-frame y no solo en el método de construcción. Aunque elementos transversales se pueden identificar, es fundamentalmente una estructura de muros de carga. Las carreras reciben el peso de la cubierta, que se soportan sobre el entramado de los muros bajo ellas. Se entiende el sistema por planos unitarios y plantea como habitual en este sistema ensamblar muros completos y levantarlos a su posición, uniéndolos entre sí con las vigas transversales del forjado y vigas de atado de la cubierta. El carpintero marcaría y fabricaría todos los entramados en el taller para ensamblarlos en la obra.

También detalla con claridad la forma de las uniones en este tipo de construcción, explicando la incidencia que tiene la pendiente de las cubiertas, originando empujes hacia el exterior en los muros que tienen que ser contrarrestados o atados. Richard Harris en 1989 señalaba que la diferencia entre los entramados ingleses y los del resto del continente estriba en la forma de atado de sus estructuras de cubierta. En Inglaterra, la viga de atado se conecta directamente a la carrera, resultando un unión compleja que incluye el soporte. Por contraste, la carpintería continental une la viga de atado al soporte, evitando así una unión tan complicada (Yeomans 2003).

Figura 2.73
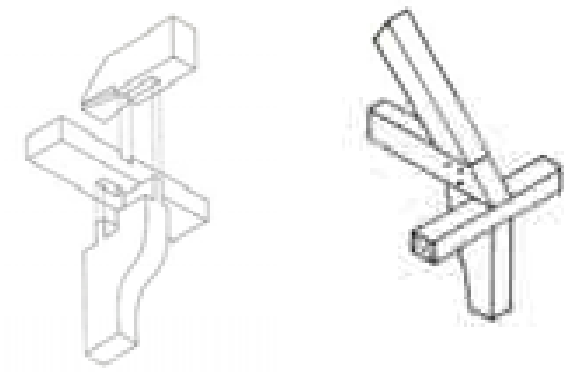

Centro y derecha, comparación de la forma de unión de las vigas de atado para contrarrestar los empujes de las cubiertas en Inglaterra y en el continente. Primera a la izquierda detalle de la complejidad de la unión de la viga de atado en el sistema inglés (Yeomans 2003)

Otro aspecto a reseñar es la solución constructiva de volúmenes salientes en este sistema de entramado, frecuentemente asociada a edificios con más de dos plantas. Cuando eran posibles grandes piezas de sección y longitud suficiente para abarcar toda la altura, no había problema aunque supusiera un coste considerable en madera. Pero debido a las limitaciones en los solares pequeños de las ciudades, y a la evidente ventaja de usar madera de menor longitud, se adoptó un tipo de construcción en voladizo, que se extendió como una moda por la mayor parte del país, de forma que las vigas del forjado estaban voladas para servir de apoyo al muro de cada piso superior (Brunskill [1971] 2000).
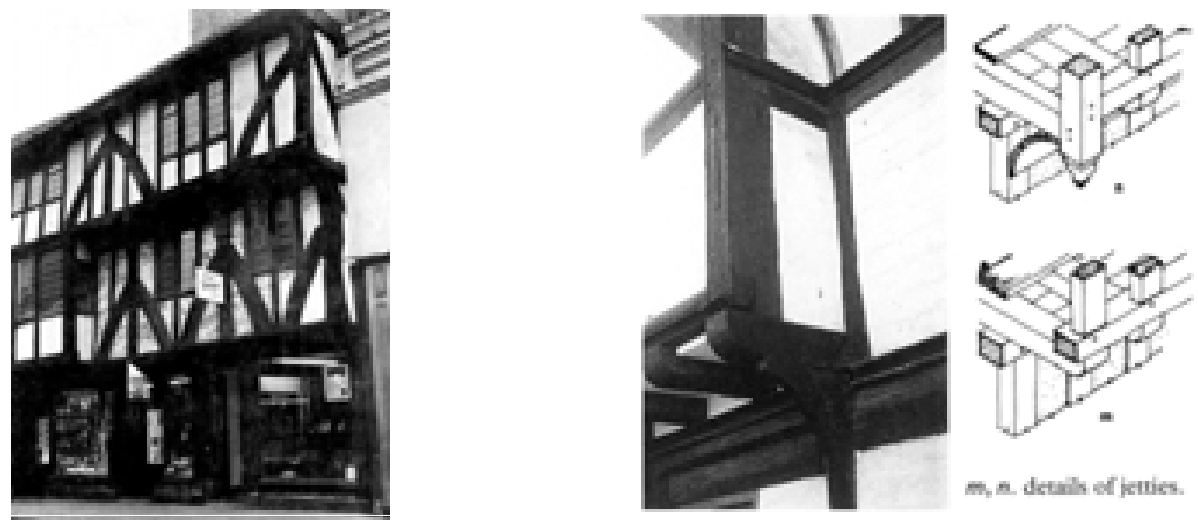

Figura 2.74

Izquierda: edificación entre medianeras con jetties en cada planta.

Derecha: detalles de voladizo en los volúmenes salientes en las plantas superiores (Brunskill [1971] 2000). 


\section{El sistema balloon-frame americano}

El concepto básico es la utilización de montantes «studs» que tienen la altura total del edificio, generalmente dos plantas, con las vigas del entrepiso sujetas en forma lateral a los montantes o pies derechos.

Andrea Deplazes en su libro Constructing Architecture. Materials Processes Structures. A Handbook define el balloon-frame, entramado formado por pies derechos, como el sistema que se compone de pies derechos estrechos, canteados y de secciones normalizadas, con una medida básica de 2x8 pulgadas, unos $5 \times 20 \mathrm{~cm}$, y dispuestos con gran proximidad. Para conseguir piezas de mayor sección, se unen dos o más elementos de la misma sección. Establece una equivalencia con el sistema europeo de entramado formado por pies derechos, en el que estos también están canteados y se colocan muy próximos recorriendo el mismo elemento las dos plantas. Las diferencias consisten en una menor normalización del sistema en Europa, y que en este las uniones no son clavadas, sino unidas mediante ensambles con espigas (Deplazes 2005).

Merece la pena poner en valor la importancia de esta diferencia, que aunque pudiera parecer menor, refleja en realidad dos filosofías constructivas completamente distintas. Mientras que en los sistemas europeos, cada unión se resuelve sin clavos, depuradamente y funciona independiente de las otras, en los sistema americanos el clavo se emplea en grandes cantidades y se distribuye por igual en toda la estructura, lo que Tom Peters Ilama «estadísticamente», empleando también la expresión «un clavo no es solo un clavo", cita de Heinz Ronner del ETH de Zurich que acuño este eslogan pedagógico para exagerar las propiedades estadísticas, como opuestas a las cualitativas, de las uniones clavadas.

En esta técnica realizada por personal no necesariamente muy especializado, y en la que no se requiere una buena ejecución ya que no queda nunca vista, el clavo es un conector «democrático» mas que «autocrático» y su éxito se basa en el «consenso» de funcionamiento, en su cantidad y en su distribución homogénea por toda la estructura, más que por su excelencia individual (Peters 2010).
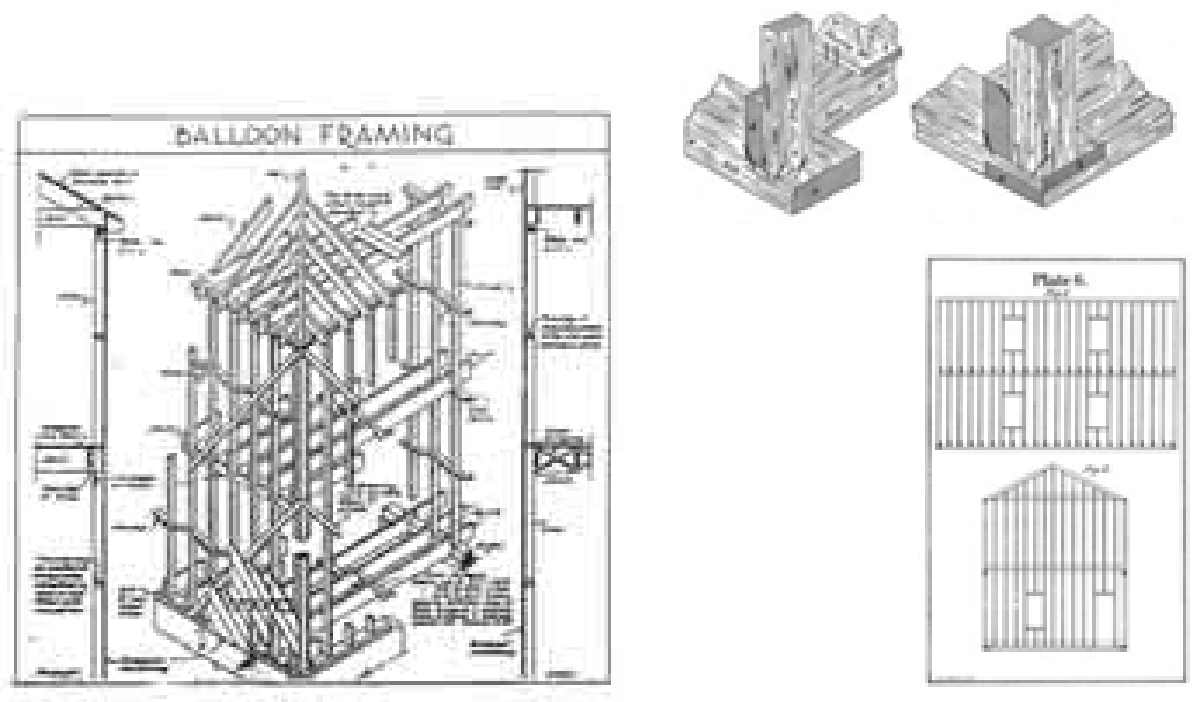

Figura 2.75

Izquierda: Sistema americano Balloon-frame (Araujo y Seco 1986).

Derecha inferior: Balloon frame de una casa de dos pisos en USA, en William E. Bell. Carpentry Made Easy, 1859

Derecha superior: Detalles de un entramado balloon americano. Uniones simplificadas y clavado R.S. Burns, Building Construction, London 1877 


\subsubsection{El entramado de madera del Upper Lawn Pavilion.}

El propio planteamiento de proyecto se entrelaza con la tradición popular y con la culta. Upper Lawn reinterpreta unos de los tipos más universales de la construcción vernácula. Estructuras de entramado de madera en la planta superior sobre plantas bajas de gruesos muros de piedra o ladrillo, se dan dentro y fuera de Inglaterra (Rodriguez 2011).

Así mismo, los Smithson explicitan reiteradamente su inclinación clásica. Estudian templos y ciudades griegas con grandes basamentos de piedra, estereotómicos, sobre los que apoyan construcciones tectónicas, adinteladas, con columnas (letra cursiva en el original) «Estudiamos los templos dóricos, desde los primeros -el Argive Heraeum- hasta los tardíos Nemea y las ciudades griegas» (Spellman y Unglaub 2004, 18).

En la estructura del pabellón convive construcción pesada y ligera.
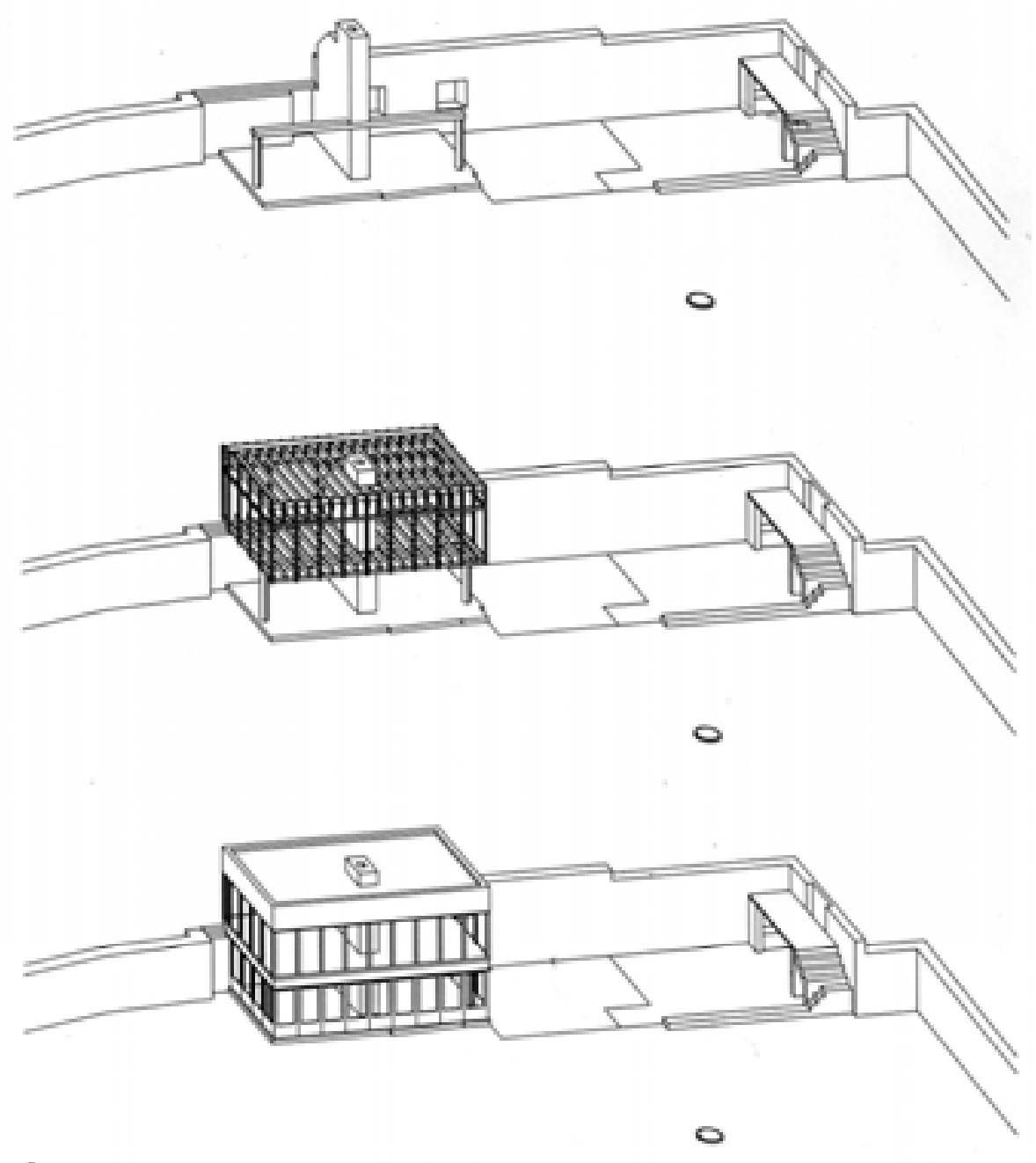

Figura 2.76

Upper Lawn. Esquemas del proceso (Krucker 2002). 
La construcción pesada está formada por el muro norte de mampostería modificado con parte antigua y parte nueva, y el hastial ya existente recortado que servirá de arriostramiento al entramado de madera, mas dos soportes y una viga de hormigón armado junto con el durmiente/viga de remate del muro de piedra, también de hormigón con una sección en ambos casos de 9x10 pulgadas $(22,86 \times 25,40 \mathrm{~cm}$ ) (figura 9). Estos soportes se colocan girados y con las esquinas redondeadas, primer indicio de un tipo de superficies que los Smithson desarrollan y alcanzan su definitiva forma constructiva en The Economist y a las designan "con las que se puede uno rozar» (Smithson y Smithson 1986).

En ellos se apoya, en voladizo y liberando la planta baja, una construcción ligera de entramado de madera de pino tipo «ballon frame» ensamblada con espigas de madera.

Está compuesta por 26 soportes 4 ×3 pulgadas de sección $(40,16 \times 7,62 \mathrm{~cm})$ todos dispuestos longitudinalmente con la dirección norte-sur. 10 en el lado sur, 8 en el norte, y 4 en las caras este y oeste. Al exterior se protegen con tabla de madera de teka de secciones $5 \times 1$ pulgada al norte-sur y 7x1 pulgadas al este-oeste, que a su vez rematan los encuentros de la estructura con los vidrios.

La disposición en planta está basada en un modulo de 3 pies $(91,44 \mathrm{~cm})$ que se repite sistemáticamente en todas las distancias a ejes entre montantes. Las caras norte y sur se conforman con 9 módulos y una longitud total de 8,22 m. En la norte, aunque se eliminan dos soportes para obtener los dos huecos mayores de los ventanales principales, se sigue manteniendo dicha modulación, con dos longitudes de 6 pies a ejes de montantes consecutivos.

Los lados perpendiculares están formados por 4 módulos $(3,65 \mathrm{~m})$ mas la única distancia ajena al sistema, que no se acota en los planos del proyecto, ya que viene dada por el espesor del muro de fábrica existente sobre el que se apoya.

Las viguetas del forjado inferior tienen una sección de 9x3 pulgadas $(22,86 \times 7,62 \mathrm{~cm})$ y las del forjado de cubierta de $6 \times 2$ pulgadas $(15,24 \times 5,08 \mathrm{~cm})$.

Se disponen con una cara adosada a la cara interior del pie derecho, sucesivamente en cada soporte como criterio general, de forma que su distancia a ejes se mantiene en 3 pies. En cada vano entre soportes se dispone otra vigueta en el punto medio. Al llegar al extremo opuesto y en las variaciones producidas por el hueco de la escalera y la chimenea preexistente, la vigueta correspondiente se adosa a la otra cara del soporte, pero manteniendo en todos los casos el criterio del sistema planteado.

En el contacto con la fabrica de la chimenea, el espacio que se genera entre el sistema modular y las dimensiones de esta, se solventa duplicando la vigueta con la doble intención de permitir puntualmente el paso de las instalaciones de la estancia superior y mejorar la unión con la fabrica que a su vez arriostrra el sistema.

La intención y filosofia geométrica modular del sistema se definió con independencia de la sección estructural de los elementos de madera del entramado, como se puede comprobar en las repetidas anotaciones de los planos referidas a que las secciones de las vigas de madera están bien acotadas pero dibujadas más pequeñas, sin escala.

El canto del durmiente, remate del muro de fabrica, y la viga de hormigón sobre los que se apoyan las viguetas de de madera, establecen en sus caras inferiores la cota hasta la que descuelgan los pies derechos del entramado de madera, el cual queda en las partes opacas, siempre oculto; recubierto al exterior con el acabado de aluminio y al interior con tablero contrachapado.

El contacto entre la madera y el hormigón en el apoyo, se cuida esmeradamente, con una interesante solución que incorpora embutidos en el hormigón unos perfiles elásticos para mejorar dicho apoyo. También se coloca «bituminous DPC», abreviatura de damp-proof course, es decir una membrana impermeable para evitar humedades por capilaridad en la madera. 


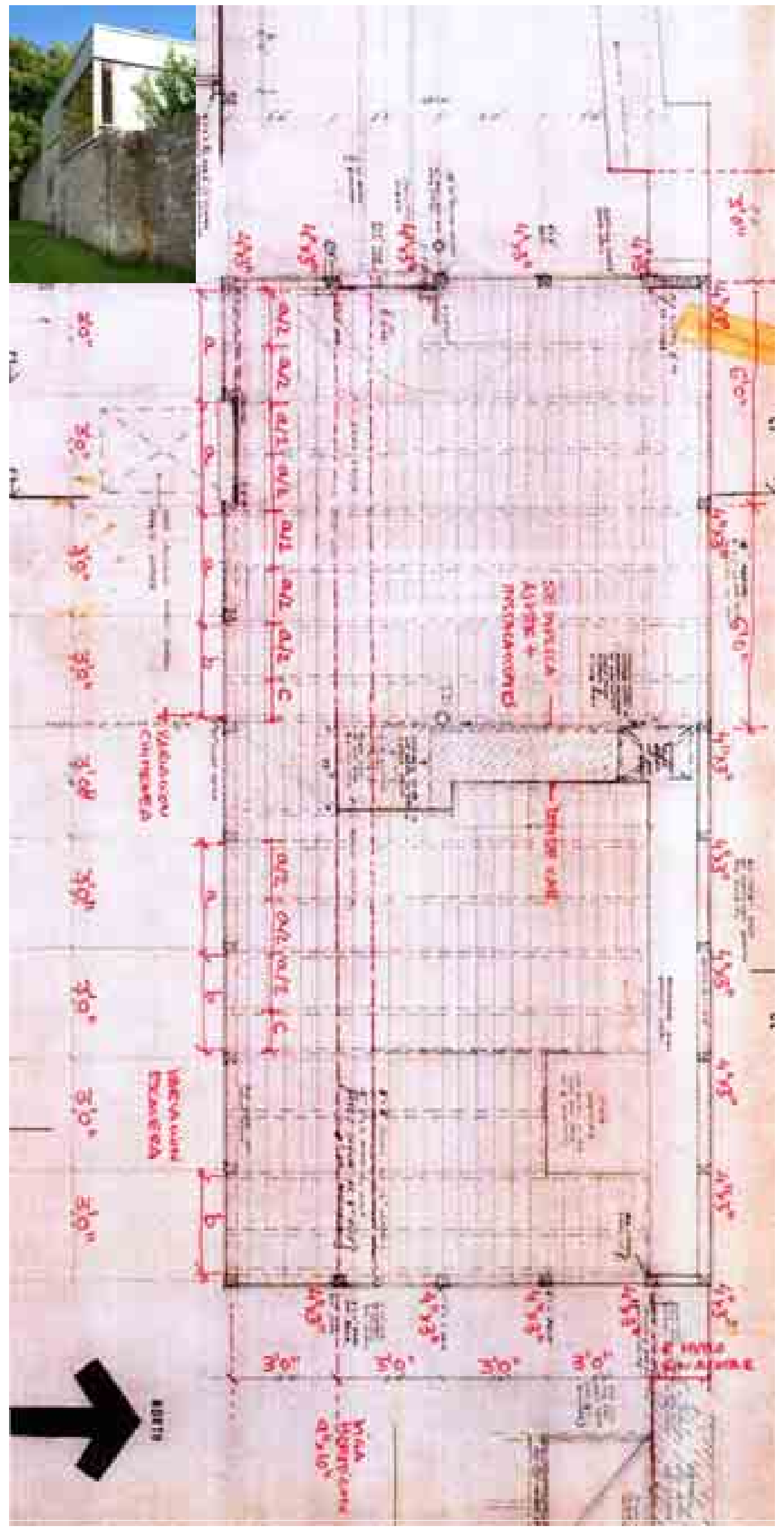

Figura 2.77

Upper Lawn. Detalle de Plano UL01 del proyecto (cortesia de Max Risselada). Sobre él, en color rojo, análisis modular del pabellón realizado por Ana Rodríguez.

Imagen superior izquierda: Upper Lawn en agosto de 2010. Fotografía de la autora. Variación en el modulo coincidente con el espesor del muro de mampostería de piedra. 

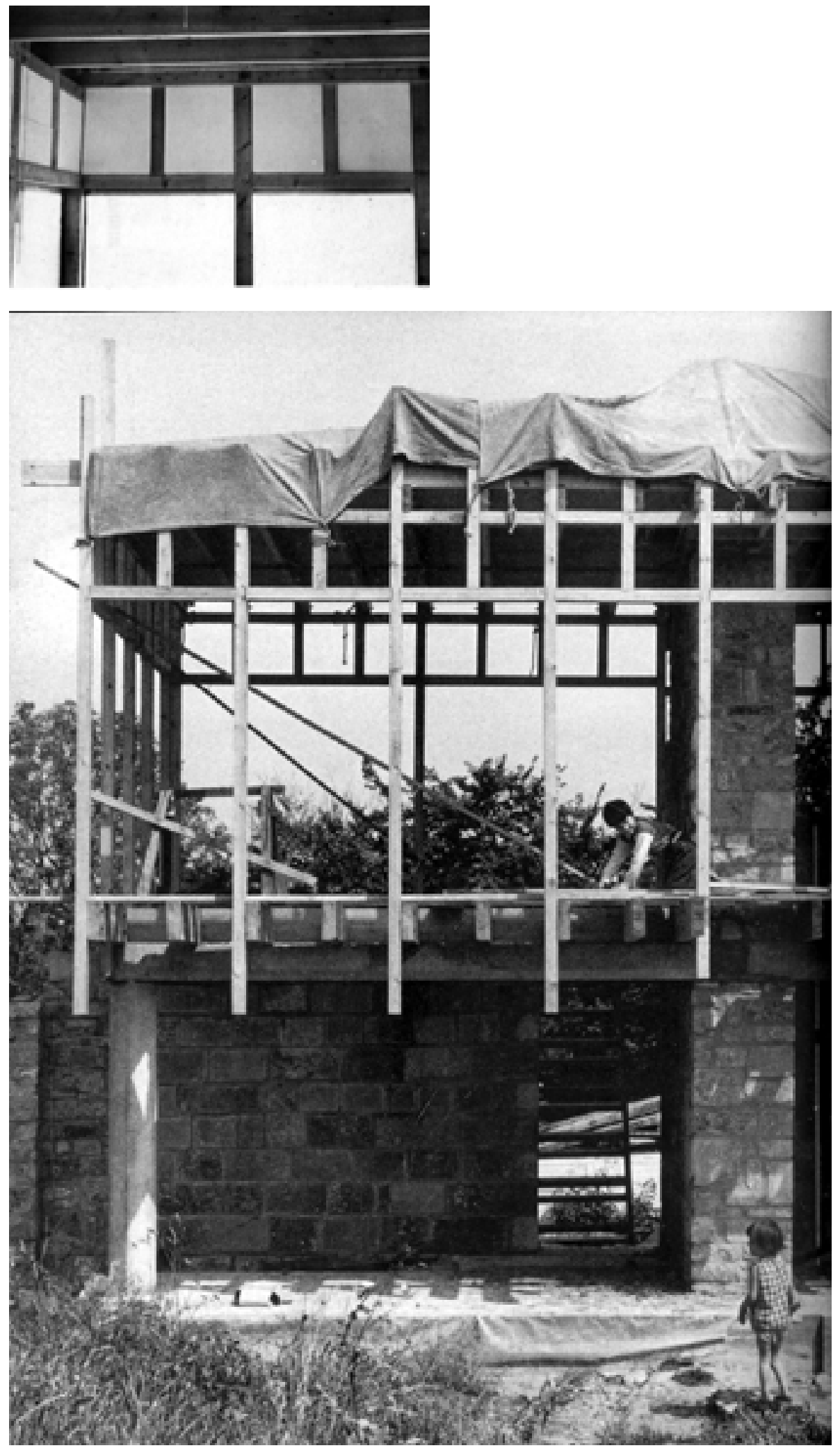

Figura 2.78

El pabellón en construcción. El pabellón en construcción. Construcción de ligera con entramado de madera (Smithson y Smithson 1986).

Imagen superior izquierda: El color claro de la nueva madera de pino se pone en evidencia al rellenar la estructura con hojas de polestireno y cubrir las ventanas con polietileno. Agosto 1961 

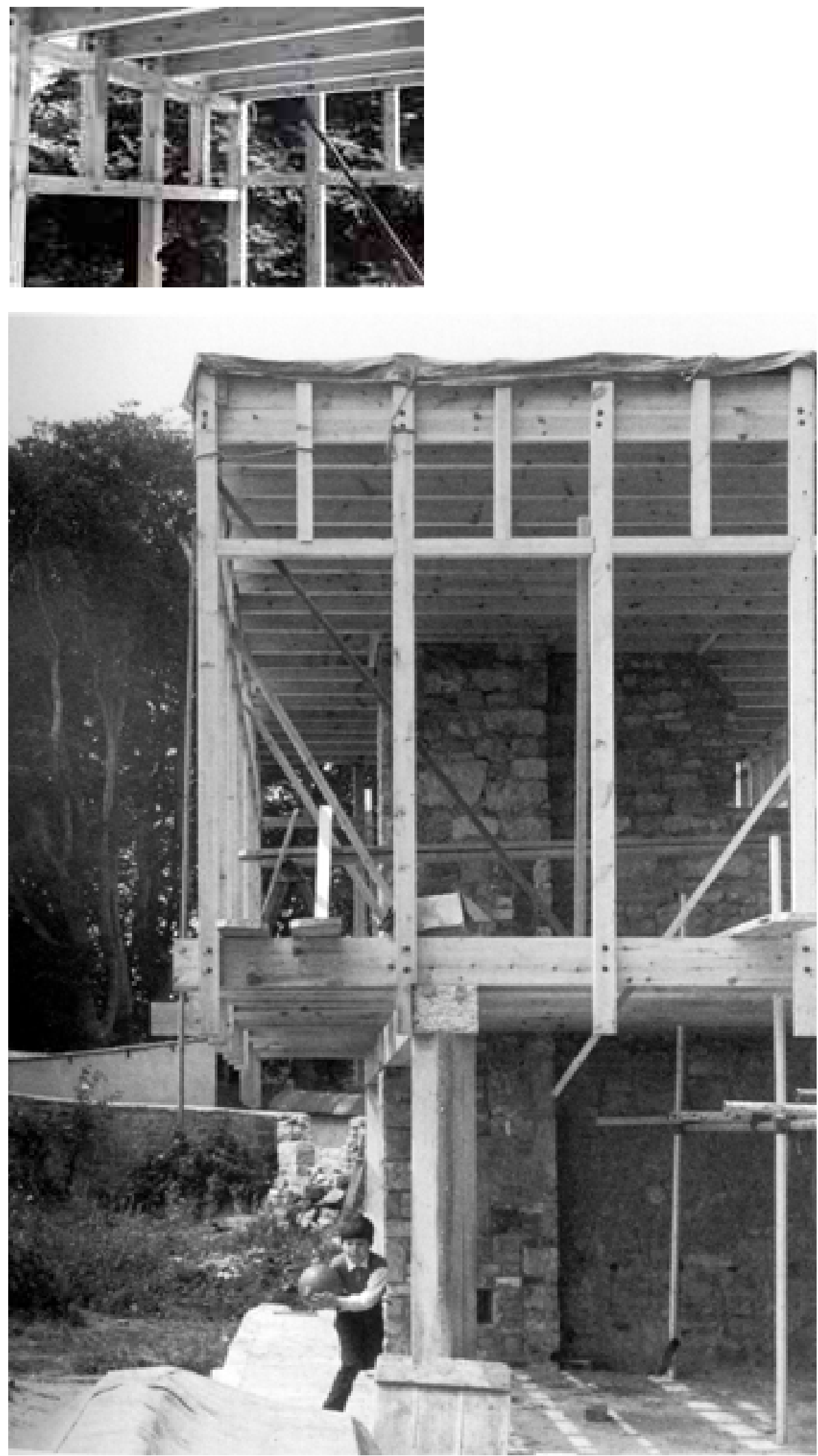

Figura 2.79

El pabellón en construcción. Construcción de ligera con entramado de madera. Simon Smithson jugando (Smithson y Smithson 1986).

(Smithson y Smithson 1986).

Imagen superior izquierda: La estructura descubierta sobre las ventanas de la planta alta. Julio 1961 

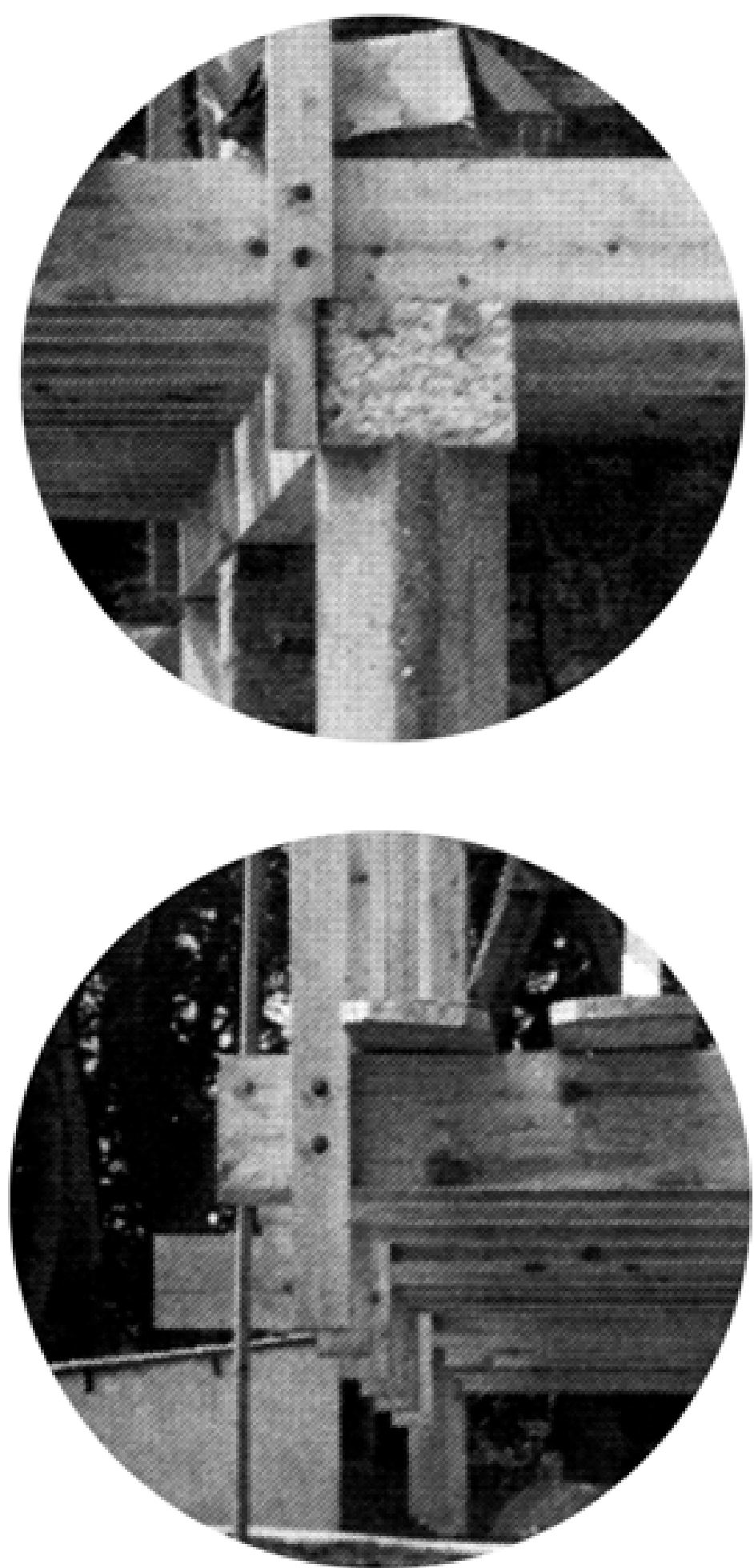

Figura 2.80

* Superior:

El pabellón en construcción. Detalles del apoyo del entramado de madera sobre la viga de hormigón armado. Simon Smithson jugando (Smithson y Smithson 1986).

* Inferior

El pabellón en construcción. Detalle del entramado de madera. Encuentro de las viguetas del forjado en voladizo con los pies derechos (Smithson y Smithson 1986). 


\subsubsection{Una interpretación moderna de técnicas tradicionales}

El Upper Lawn Pavilion de Alison y Peter Smithson, como ya se ha mencionado se incorporó en 2011 al The National Heritage List for England (NHLE) del English Heritage, que define el pequeño pabellón de entramado madera textualmente como «a timber American Balloon-frame», acepción también publicada en otros textos como una estructura basada en el balloon frame, o simplemente de balloon frame.

Ellos mismos la explican como

Para experimentar en nosotros mismos ciertas aplicaciones y conjunciones de materiales que, si resultan acertadas, utilizaremos más adelante en los edificios de nuestros clientes, por ejemplo: recubrimiento de hojas de alumnio muy puro; puertas interiores y exteriores de madera contrachapada revestida de aluminio; aislamiento de poliestireno en muros y cubierta; conectores de madera para una típica estructura americana de «balloon frame» (Smithson y Smithson 1986).

Así, la principal referencia es el balloon-frame americano, con una serie de características propias de este sistema y que consisten en que todos los soportes tienen la misma sección con medidas normalizadas, están canteados, y funcionan como un paño completo. Los pies derechos son continuos en toda su altura y se unen con las vigas por contacto entre caras.

Sin embargo mientras que en la técnica americana los soportes, apoyados en un durmiente sobre un pequeño zocalo sobre el suelo, son los que sustentan las viguetas de los forjados, en Upper Lawn se producen situaciones diferentes.

Los montantes de la estructura solo soportan las viguetas del forjado de cubierta junto con un sistema de divisiones menores que además de permitir oscurecer la parte superior del paño, permite sustentar las viguetas intermedias del forjado superior, colocadas en el vano entre cada par de soportes. A su vez y a diferencia del balloonframe, en el lado sur los pies derechos se sustentan en el borde del voladizo de las vigas del forjado inferior, que a su vez apoyan en la viga de hormigón.

Tampoco se pueden obviar las técnicas vernáculas que existen en Gran Bretaña y ya explicadas, especialmente la de box-frame, con una estructura de caja formada por muros entramados, autoportante y totalmente diferenciada de la estructura de la estructura de la cubierta que se superpone, porque las soluciones de Upper Lawn, también tienen relación con el sistema tradicional para la planta superior de una boxframe con cuerpos volados y sin cubierta inclinada.

Otra diferencia conceptual muy relevante es la decisión de hacer las uniones con espigas (figura 15), en vez de con clavos como en el balloon frame tradicional. ¿Por qué elegir esta opción, si la clavada es más sencilla y económica de construir, y más teniendo en cuenta que esta casa la construyeron con pocos medios, en gran medida ellos mismos y estas uniones no quedan nunca vistas?

Mientras que la influencia de las distintas técnicas tradicionales de entramado esta intencionadamente presente con independencia de su procedencia geográfica, la cultura tectónica en la que se enmarca esta construcción es claramente europea. Según Tom Peters, este enfoque en el que cada unión se realiza con calidad y puede funcionar por si misma e independiente de cualquier otra, es un enfoque muy diferente al americano, y tiene su origen en la tradición de la estática analítica del siglo XIX. «Una vez se ha descompuesto el todo en sus partes, son las uniones entre estas partes las que se consideran que dan continuidad estructural al sistema» (Peters 2010). 
Tampoco hay que olvidar, que en Europa la no existencia de clavos industriales en las soluciones anteriores al XIX, obligaba a depuradas técnicas de ensamblaje de tradición centenaria, que conceptualmente son la base profundamente enraizada de nuestra cultura tectónica, y subyace en la solución dada por los Smithson.

Las referencias a los sistemas de entramado de madera tradicionales son evidentes, pero no de una manera localista o historicista. Se plantean como un referencia en la investigación de nuevas soluciones en una construcción que tuvo mucho de experimental, utilizando sistemas modernos normalizados, y enriqueciéndolos con matices que reinterpretan los antiguos, independientemente del area geográfica de la que proceda el sistema constructivo.

Hay elementos americanos y locales, tiene relación con ambos pero no se parece a ninguno.

Se evidencia un interés por la cultura técnica y constructiva preindustrial y artesanal, como fuente de aprendizaje, incorporando matices que se hibridan de forma natural y refinadamente con los sistemas industriales modernos, resultando Upper Lawn un brillante ejemplo de esta fusión.

La integración del nuevo pabellón y la preexistencia transformada con la memoria del lugar, dan como resultado un conjunto excepcional, calmado, único y diferente a lo anteriormente existente.

Una modesta casa de campesinos, la más pobre de los tipos residenciales rurales tradicionales en Gran Bretaña, una antigua granja de cerdos cuando la compraron los Smithson, se convierte en un pequeño palacio moderno.

Un pabellón, junto con la casa Farnsworth y la vivienda-estudio de los Eames, que encarna el idilio como un lugar donde renovarse; como una fuente de energía propia. Por lo tanto se considera al Pabellón como un lugar hecho idilio; un sueño de un estilo de vida sin estrés, un dominio (a menudo un gran jardín) que suele estar en lo pretendidamente salvaje, es decir, en la naturaleza. (Smithson, 1994: 141)

«La intención es ahora la de establecer un territorio bajo el control de uno mismo o del grupo escogido por uno.

Por ello es por lo que utilizamos la expresión «fragmento de un enclave» como vehículo hacia el «pabellón» de nuestro tiempo.»

(Smithson y Smithson 1986) 


\subsubsection{El aluminio en el Upper Lawn Pavilion}

La reconstrucción en Europa y la necesidad de vivienda a gran escala permitieron la reconversión del desarrollo y producción alcanzados por la industria bélica durante la Segunda Guerra Mundial. Un ejemplo representativo fue la utilización del aluminio como material de construcción, aprovechando la infraestructura productiva de la industria aeronáutica, con una gran expansión de empresas suministradoras de este material como la norteamericana Reynolds. El revestimiento de hojas de aluminio del Upper Lawn Pavilion es sin duda heredero de este contexto industrial.

Simultáneamente, en el trabajo de los Smithson conviven en igualdad y mostrando sus cualidades naturales, materiales industriales novedosos del momento junto a intencionadas preexistencias. Construcción industrial, construcción vernácula preindustrial, y el dialogo entre ambas, ponen de manifiesto un gran interés por la cultura constructiva preindustrial y artesanal, como fuente de aprendizaje, al incorporar matices que se hibridan de forma natural y refinadamente con los sistemas industriales modernos, resultando esta obra un brillante ejemplo de esta fusión.
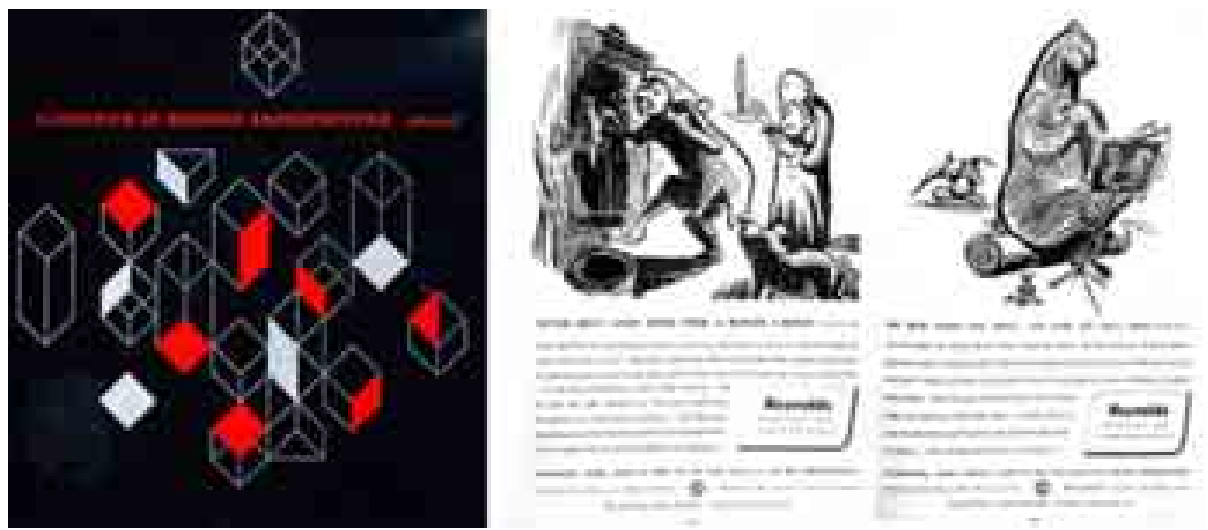

Figura 2.81

From left to right. First, cover of Aluminium in Modern Architecture Volume II, published by Reynolds Metal Company in 1957. Rest of the images correspond to Reynolds Metal Company announcements on the use of aluminum, published in Architectural Review in 1948. It aims to combine modernity and tradition, using popular proverbs. Second: «Never bolt your door with a boiled carrot (Irish Proverb)». Third: «The bear knows nine songs and every one about honey (Turkish Proverb)». 
Los paneles de aluminio con pinturas decorativas de 1895 en el techo de una capilla de la Church of St Edmund, King and Martyr, en Fenny Bentley, Derbyshire, UK, y el revestimiento exterior de la cúpula de la Iglesia de San Gioacchino in Rome de 1897, son los primeros ejemplos datados de utilización de aluminio en edificios, aunque será en 1906, la Postsparkasse en Vienna de Otto Wagner el primer edificio, arquitectónicamente relevante y pionero de su uso en la arquitectura moderna.

En este siglo de historia, su legado es amplio y diverso, con un momento especialmente interesante en la década de los cincuenta. La gran producción de aluminio para la industria bélica durante las dos guerras mundiales, generó un fuerte desarrollo de esta industria y la gran expansión de empresas como la norteamericana Reynolds. Tras la Segunda Guerra Mundial, la enorme demanda de materiales para la reconstrucción europea, propició la reconversión temporal de la potente infraestructura industrial del aluminio a la industria de la construcción de edificios y su uso en la arquitectura más moderna del momento. Entre 1939 y 1956 Estados Unidos multiplicó por diez su volumen de producción, mientras que la de acero apenas se duplicó, pudiéndose describir el periodo de posguerra como «the aluminium industry in search of a market» (Ashby 1999)

Experiencias innovadoras bien conocidas se desarrollan en Europa y Estado Unidos, como las Dymaxion de Buckmeister Fuller en los cuarenta; o las brillantes realizaciones de Jean Prouvé en la década de los cincuenta. También otras menos conocidas internacionalmente, como los comedores para operarios de la factoría de vehículos SEAT en la Zona Franca de Barcelona, obra de los arquitectos españoles César OrtizEchagüe, Manuel Barbero y Rafael de la Joya realizados con una estructura extra ligera de aluminio y que ganó en 1957 el primer certamen del R.S. Reynolds Memorial Award, concurso internacional convocado el American Institute of Architects.

En Inglaterra, entre 1950-1955, se construyeron 400 escuelas permanentes y entre 1945 y 1955 más de 150.000 viviendas prefabricadas temporales, incorporando el aluminio de forma significativa. Entre ellos el bungalow de aluminio AIROH B1 y B2, construidos hasta 1948 por la Aircraft Industries Research Organisation on Housing en 5 fabricas en el país, y posteriormente el BL8 (Addis 2011).

Aunque fue una pequeña cantidad frente al millón de viviendas construidas por métodos tradicionales, esta singular experiencia caracterizó la construcción de la posguerra británica. De entre las cualidades del aluminio como durabilidad, bajo mantenimiento, ligereza, reflexión térmica, diversidad de formatos e imagen moderna, será su ligereza el factor determinante, ya que solventa el principal problema para el transporte de viviendas prefabricadas.

En el siglo de historia del aluminio, y en proporción con otros usos, escasean ejemplos arquitectónicos significativos de viviendas unifamiliares. Quizá solo 2 antecedentes relevantes, ambos de los arquitectos A.Lawrence Kocher y Albert Frey: En 1931, the Aluminaire House, una casa construida principalmente con materiales industriales donados por grandes empresas como ALCOA y Westinghouse; y en 1934 la Weekend House en Long Island, también conocida como "Canvas House", realizada con un cerramiento extra-ligero y aluminium foil como aislamiento térmico por sus propiedades reflectantes. 

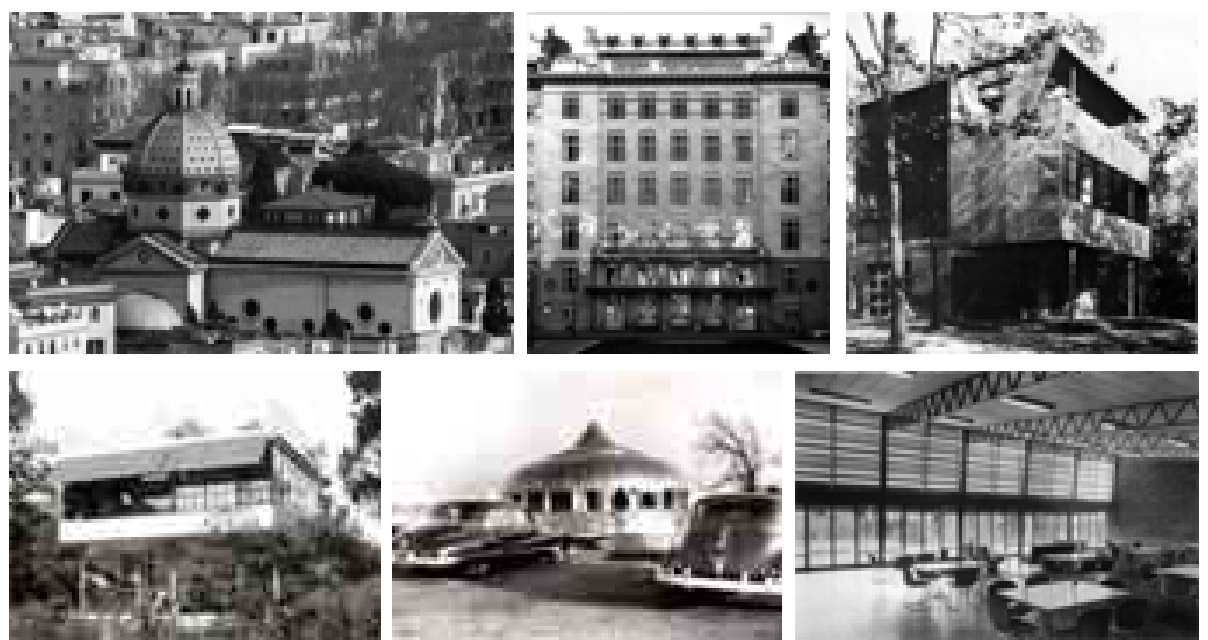

Figura

De izquierda a derecha: San Gioacchino en Roma 1897: Postsparkasse en Viena 1906, de Otto Wagner; Aluminaire House 1931 y Canvas House 1934, de A.Lawrence Kocher y Albert Frey; Wichita House de Buckmeister Fuller 1946; comedores de SEAT en Barcelona, 1957
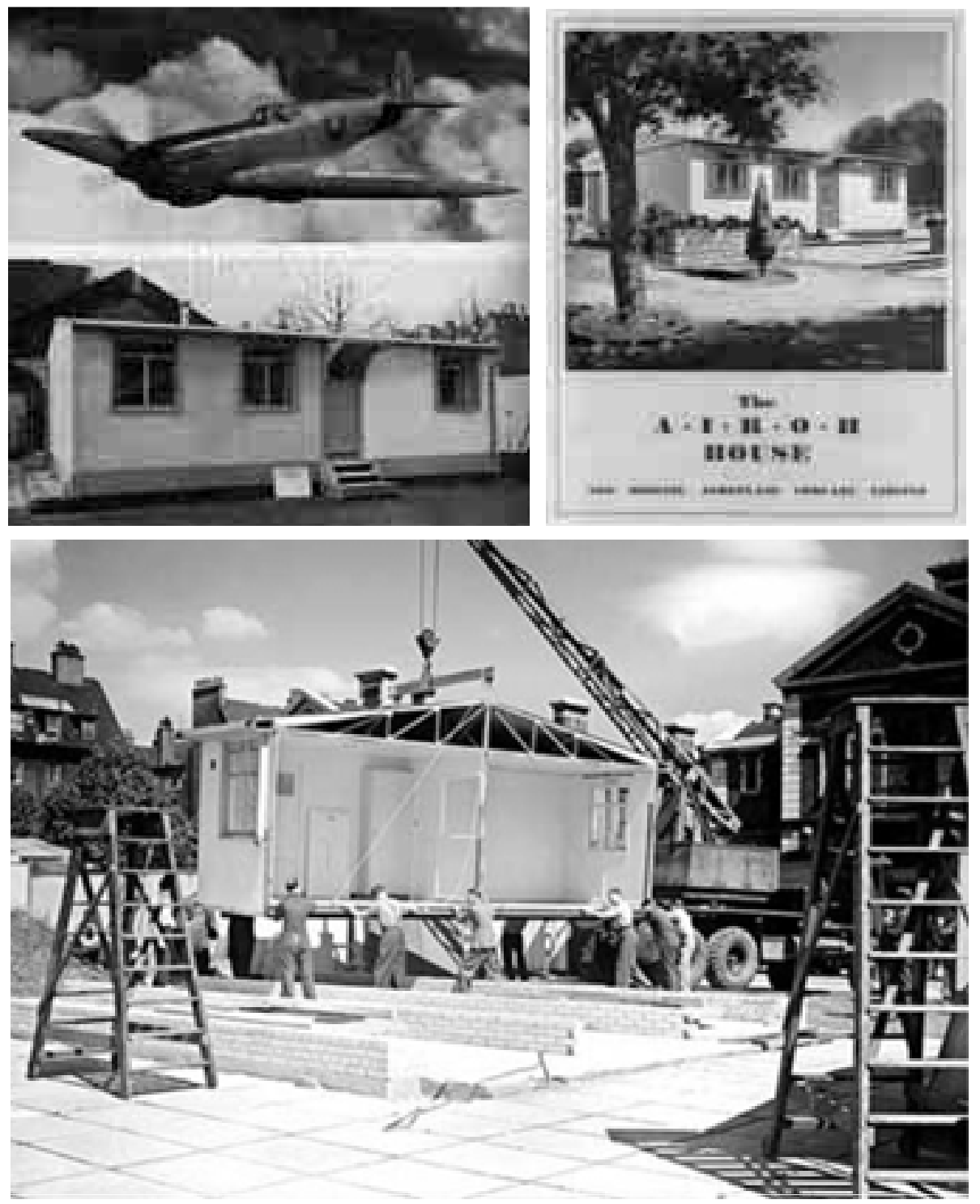

Figura 2.82

De izquierda a derecha: Casa prefabricada de aluminio AIROH y avión Supermarine Spitfire,

publicado en Architects' Journal, vol. 101, 1945, p. 290

Debajo transporte e instalación parcial de una de las unidades. 
El revestimiento de aluminio del Upper Lawn Pavilion se nos presenta como heredero de este contexto. Los Smithon dicen de él:

«First two years. The aluminium cladding has stayed bright in the unpolluted atmosphere. But in gale the crack of the sheeting recalls the descriptions of noises on big sailing ships»

«Upper Lawn was a device for trying things out on oneself»; «To test certain new products which are not yet permitted by the Authorities in the London area. Namely pitch fibre drain pipes, polythene pipes and bottle traps, Visqueen sheet DPC, polyester water tanks, salt glazed drain pipe in flue»; «To try out ourselves certain applications and assemblies of materials which if successful we will later use on clients' buildings. i. e. high purity aluminium sheet facing, external and internal doors in aluminium faced plywood, polystyrene insulation to walls and roof timer connectors on a cantilevered American-type balloon frame»(Smithson y Smithson1986)

Esta instalado en vertical con la técnica tradicional de junta alzada «pan type aluminum roofing", la misma que la empleada en la Iglesia de San Gioacchino, y las uniones son del tipo double lock-seam. Mediante plegaduras, se resuelven goterones, remates y encuentros. Las anotaciones de las secciones constructivas del proyecto indican «aluminium flashing» como el material de revestimiento. En el Volumen /l de Aluminum in Modern Architecture, se describe este material como:

« it costs less than other rustproof materials», «exposed surfaces do not require painting for weather protection. It is fire-resistant and makes an excellent termite shield», "aluminum flashing is easy to cut, shape and trim, and holds its shape indefinitely. It is neat in appearance. There is no coating or "outer layer" to wear or flake off. It is solid aluminum and weathers to a pleasing neutral finish» (Weidlinger 1956)
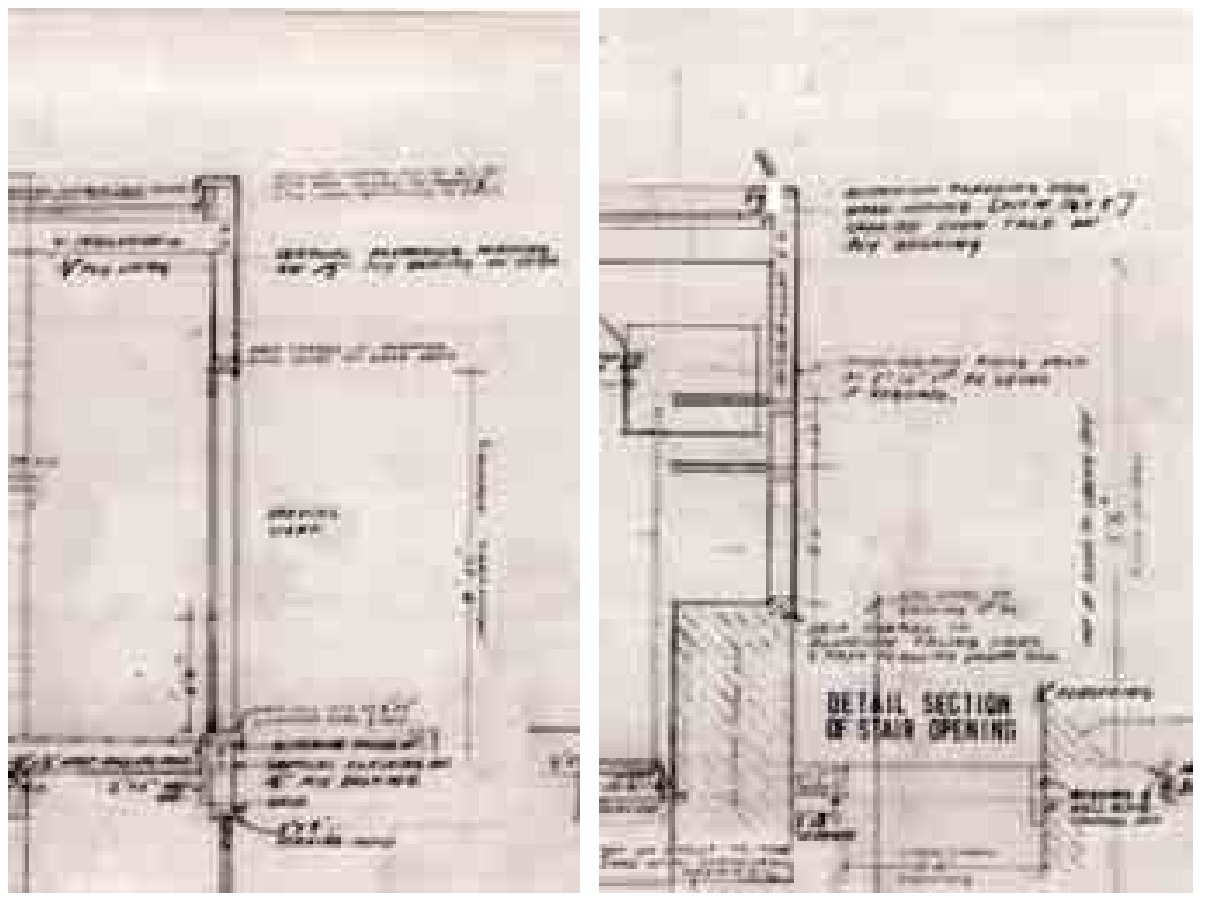

Figura 2.83

De izquierda a derecha: Casa prefabricada AIROH y avión Supermarine Spitfire, publicado en Architects' Journal, vol. 101, 1945, p. 290

Debajo transporte e instalación parcial de una de las unidades. 
La puerta de entrada, hecha de tablero, esta revestida con aluminio al exterior y al interior, con la misma idea que en la exposición Patio and Pavilion ${ }^{111}$, en la que planchas de aluminio delimitaban el espacio por sus cualidades reflectantes y en fuerte contraste con los otros materiales.
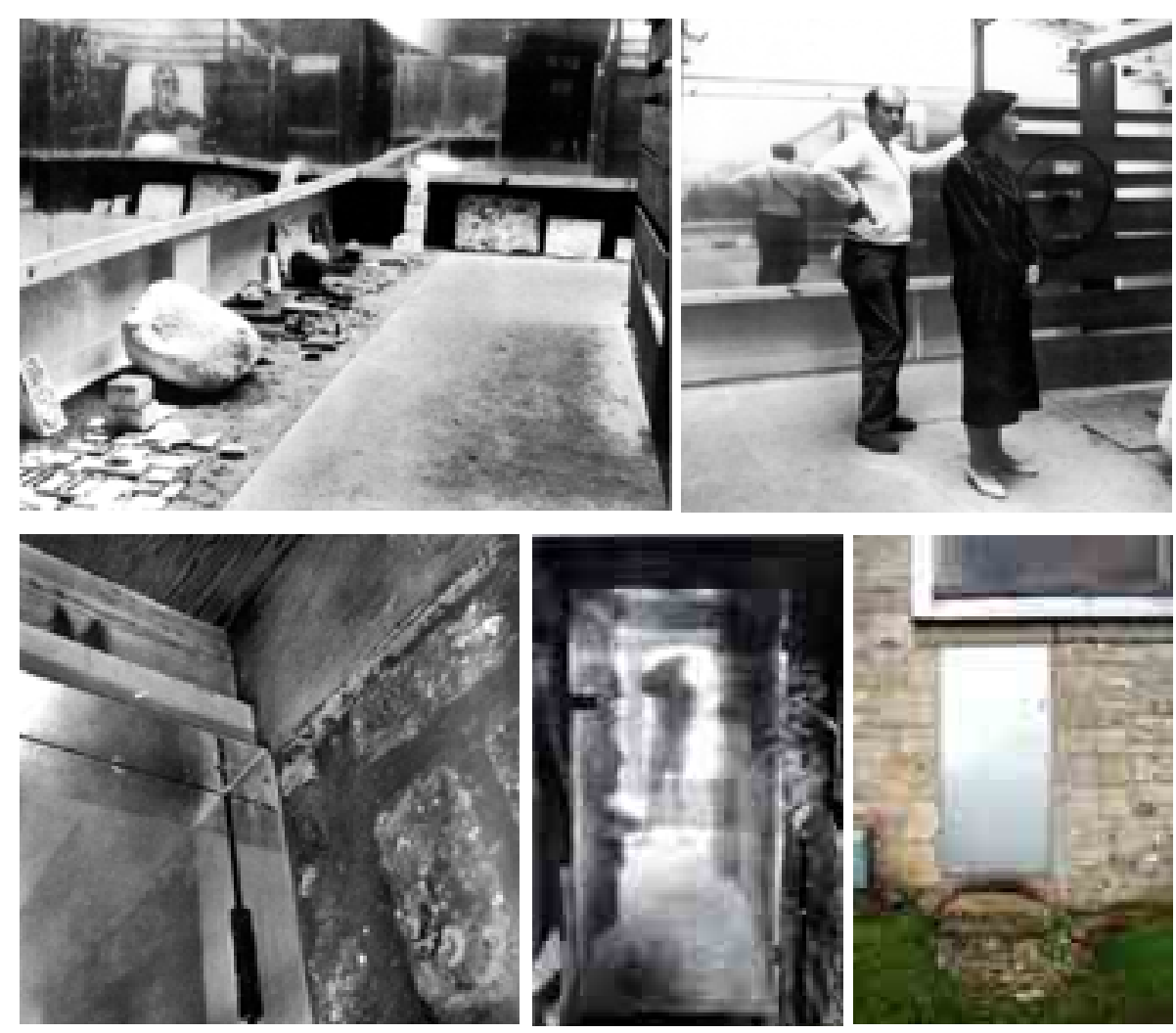

Figura 2.84

De izquierda a derecha

* Patio and Pavilion. Zona lateral del pabellón terminada con aluminio reflectante.

* Alison y Peter en Patio and Pavilion. La lamina de aluminio en el perímetro de la instalación reflejando el pabellón, los materiales y a ellos mismos.

* Upper Lawn Pavilion. Parte superior de la puerta de paso planta baja, junto a la salida de humos. Pentecostés 1962. (Smithson and Smithson 1986)

* Peter mostrando mediante su reflejo, las cualidades reflectantes del revestimiento de aluminio de las puertas.

Las puertas revestidas de aluminio con marco de aleación. Vista de la cara interior de la puerta exterior de acceso, desde la entrada del almacén, a la derecha del antiguo hastial. Invierno 1962/1963 (Smithson and Smithson 1986)

* Aluminio de la puerta de entrada y vierteaguas de remate, en relación con la preexistencia. La puerta con un nuevo pequeño ámbito de acceso semicircular, realizado con piezas de piedra irregulares en forma, tamaño y tipo, a modo de mosaico vernáculo bajo los pies, que te prepara o predispone para la experiencia Upper Lawn.

Otro ejemplo de «conciencia material» mediante el diálogo entre opuestos.

\footnotetext{
111 Instalación «Patio and Pavilion». en la Exposición This is Tomorrow Londres, The Whitechapel Art Gallery 9 agosto - 9 septiembre 1956. Trabajo realizado por Nigel Henderson, Eduardo Paolozzi, y Alison y Peter Sithson (grupo 6 de los doce participantes).
} 
Los Smithson, que trabajaron con todos los materiales modernos, incluso el plástico en la Casa del Futuro, buscan en Upper Lawn una solución sencilla y diferente de las experiencias prototípicas de Fuller o Prouvé, y encuentran la respuesta en la relación con el lugar. Deliberadamente se autoimponen los condicionantes de situar el pabellón entrelazado con la mampostería de piedra preexistente. El nuevo volumen prismático no solo se apoya en el muro, como en otros precedentes, sino que interactúa con él.

No buscan una construcción de paneles modulares, como los de las casas de Prouve, especialmente apropiados en construcciones prefabricadas para producción en serie y con una imagen fuertemente condicionada por su concepción modular, que sin duda no hubiera tenido sentido en un volumen cuya geometría está fuertemente condicionada por la preexistencia y sus leyes constructivas. Tampoco es comparable a las Dymaxion, DDu y Wichita House, de Fuller, pues aun compartiendo la técnica de revestimiento, esta responde a su particular geometría de tipo seriado. Son piezas unitarias de carácter prefabricado pensadas para cualquier ubicación.

El Upper Lawn Pavilion no podría estar en otra parte; de hecho, el proyecto se genera a partir del lugar. El aluminio parece más moderno y brillante por su contraste con la rugosidad de la mampostería de piedra. El dialogo de opuestos que se establece entre la preexistencia y lo nuevo (Rodriguez 2011), es un buen ejemplo del concepto de «conciencia material», y esencial en la forma de trabajar de los Smithson.

Pertenecientes a la tercera generación del Movimiento Moderno, se consideran con la misión de implementar y mejorar carencias anteriores. Su interés por las cualidades del material y la tectónica, encuentra en las construcciones del pasado y vernáculas, una fuente de aprendizaje para hacer arquitectura moderna, que en palabras de Pallasmaa «se hace eco de los temblores de los orígenes»

«n the fifties we were deliberately trying to look at the things in another way, to break the $\square$ set of the mind $\square$ which we had been taught or had inherited. A different way of thinking: turning things over in one's mind as if everything as one would a sherd on an archaeological site» (Smithson 1993, 68)

Upper Lawn es para los Smithson una experiencia vital personal de búsqueda e investigación empírica. Así, una modesta casa de campesinos, la más pobre de los tipos residenciales rurales tradicionales en Gran Bretaña, una antigua granja de cerdos cuando la compraron, se transforma en un paradigma de su tiempo sobre la forma de habitar y de investigar las claves para una construcción moderna.

Peter Smithson en una entrevista el 17 de noviembre de 1994 dice: nosotros intentamos hacer todos los elementos igualmente buenos. Ahí, hay un tipo de imperativo moral de Tomás Maldonado. Usted hace cada parte tan bien como usted pueda (citar autor)

Como un artesano.
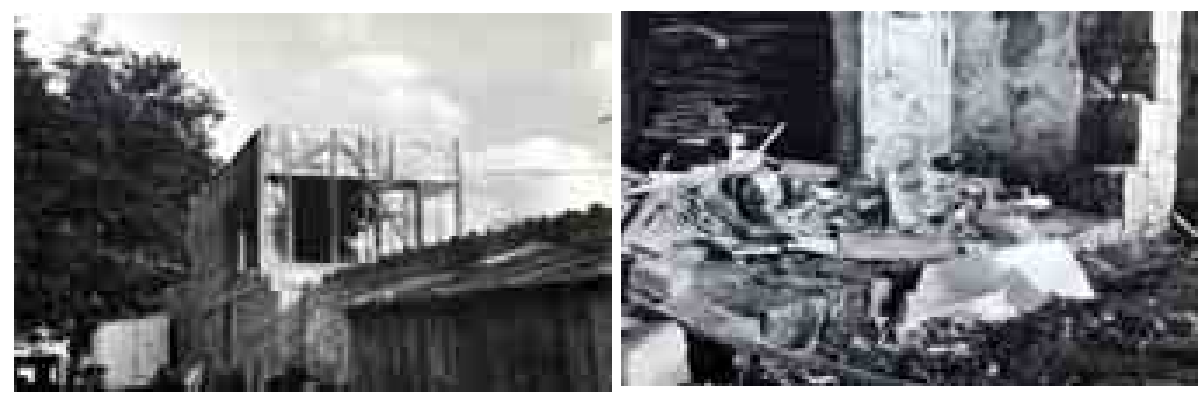

Figura 2.85

From left to right. First, Upper Lawn Pavilion under construction, folly part glazed, August 1961. Second, trimmings from aluminium sheet, October 1961. Third, aluminium faced doors in alloy angle frame: inside face of entrance door seen down entrance/storage passage, old gable wall on right, Winter 1962/63 (Smithson and Smithson 1986) 

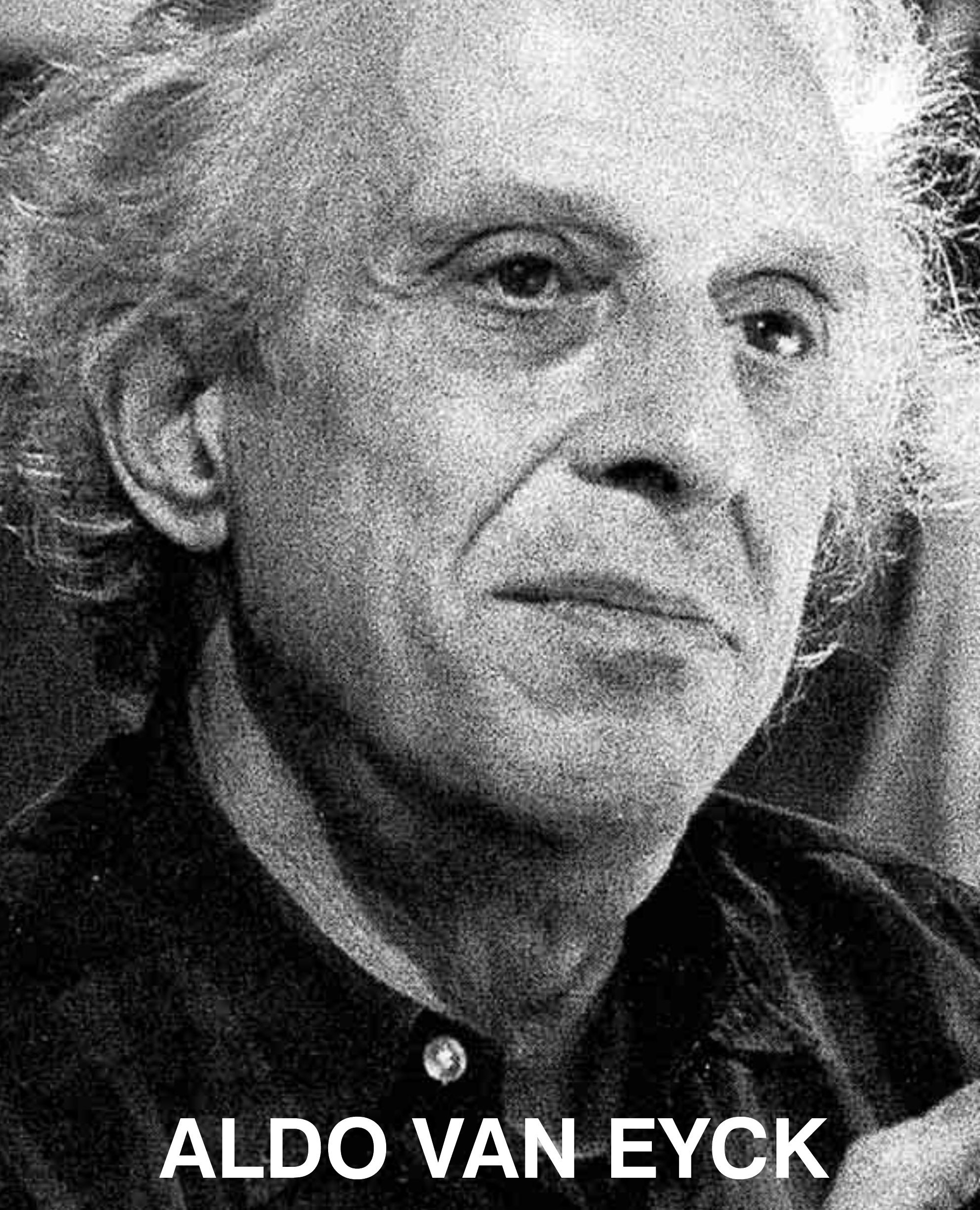



\section{Capítulo 3}

La casa del martín pescador, entre un roble y un cañaveral. Aldo van Eyck en la Casa Visser de Bergeijk 


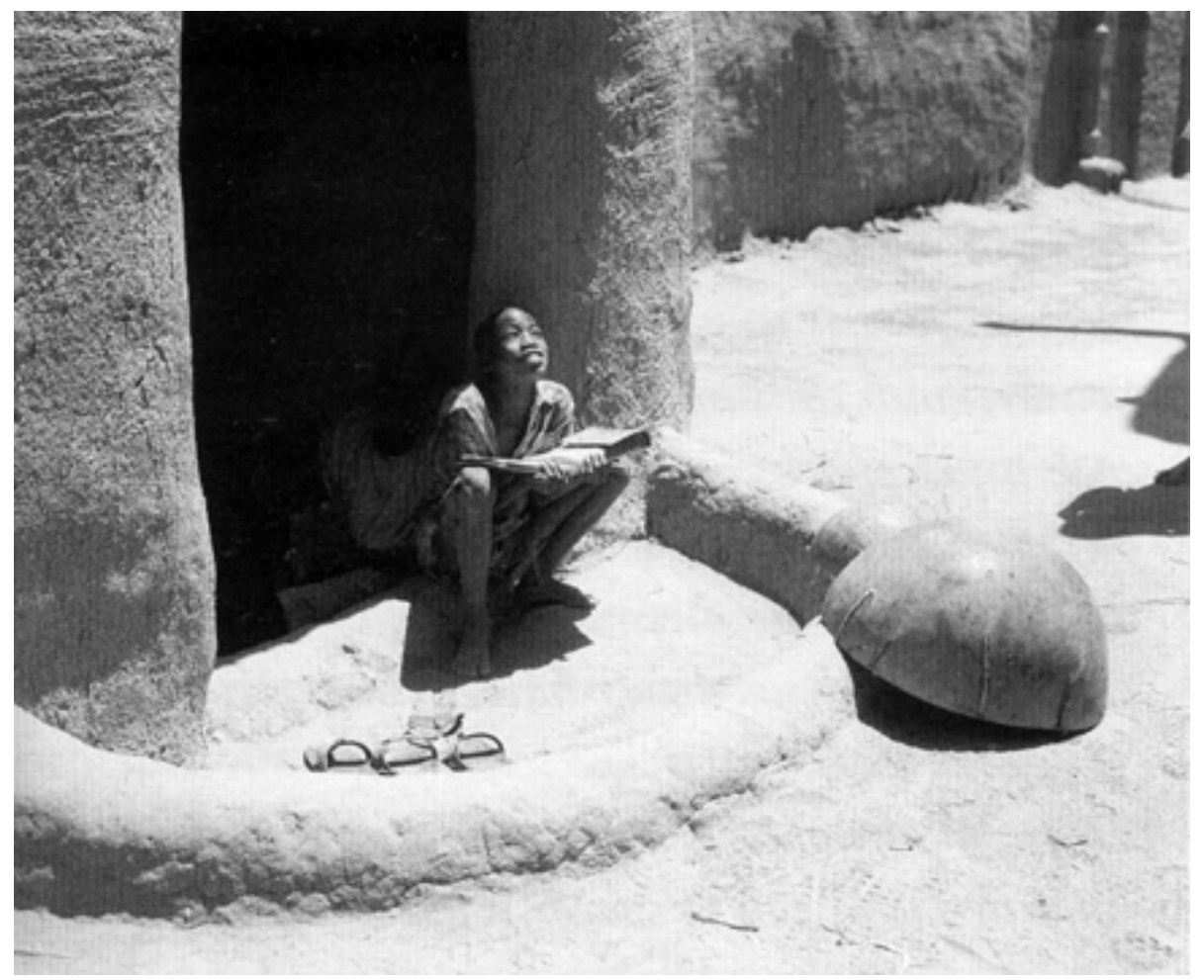

Figura 3.1

Muchacho Dogon en el umbral de su casa.

Concepto de Doorstep. (Strauven 1998, 359) 


\section{Capítulo 3}

\section{Aldo van Eyck en la Casa Visser de Bergeijk.}

\subsection{Aldo van Eyck y lo vernáculo. The vernacular of the Heart y los Círculos de Otterlo.}

El interés de Aldo van Eyck por el arte primitivo surge al final de sus estudios en el ETH de Zurich, a través de su inmersión en el arte moderno y en la vanguardia de principios del siglo XX; del Surrealismo, de André Breton y su círculo de influencia, particularmente interesados en el arte de las Islas del Pacífico. Su primer contacto con la cultura Dogon, se produce a través de un número monográfico de la revista surrealista Minotaure, dedicado a la expedición de estudios etnológicos realizada por Marcel Griaule (1898-1956) a través de Africa, que incluía un artículo sobre un ritual funerario Dogon y un reportaje fotográfico de máscaras y objetos de culto. Aldo van Eyck, al igual que Carola Giedion-Welcker (1885-1979), introductora de Van Eyck en el arte moderno, reconoció en el arte primitivo formas de expresión y arquetipos muy semejantes a los de Klee, Brancusi o Arp. Semejanzas no entendidas como influencias, sino como manifestaciones de la misma identidad humana que han perdurado en las culturas primitivas durante milenios y que el arte moderno había redescubierto de forma independiente.

Van Eyck profundiza en el conocimiento del arte primitivo para poner en práctica en la arquitectura los logros conseguidos por las vanguardias artísticas del siglo XX, entendiendo el patrimonio de las culturas arcaicas de igual importancia que la tradición clásica de la cultura occidental, y encontrando soporte a sus ideas en el trabajos de antropólogos como Franz Boas (1858-1942), Margaret Mead (1901-1978) y Ruth Benedict (1887-1948). Desarrolló la convicción sobre el igual valor de todas las culturas, no debiendo considerarse la civilización occidental como la mejor posible. Para Van Eyck, las llamadas culturas primitivas son tan desarrolladas y sofisticadas como la nuestra, en sus manifestaciones culturales como la lengua y el arte. Consideraba que la arquitectura, como ya lo había hecho la pintura desde el Cubismo, tenía que redescubrir los invariantes humanos fundamentales que las culturas arcaicas a los que habían dado forma desde tiempo inmemorial; lo que llamó principios arcaicos de la naturaleza humana: «the archaic principles of human nature» Como dijo en el congreso de Otterlo y dejo reflejado en la segunda versión del diagrama de los círculos con el mismo nombre, redescubrir implica el descubrimiento de algo nuevo:
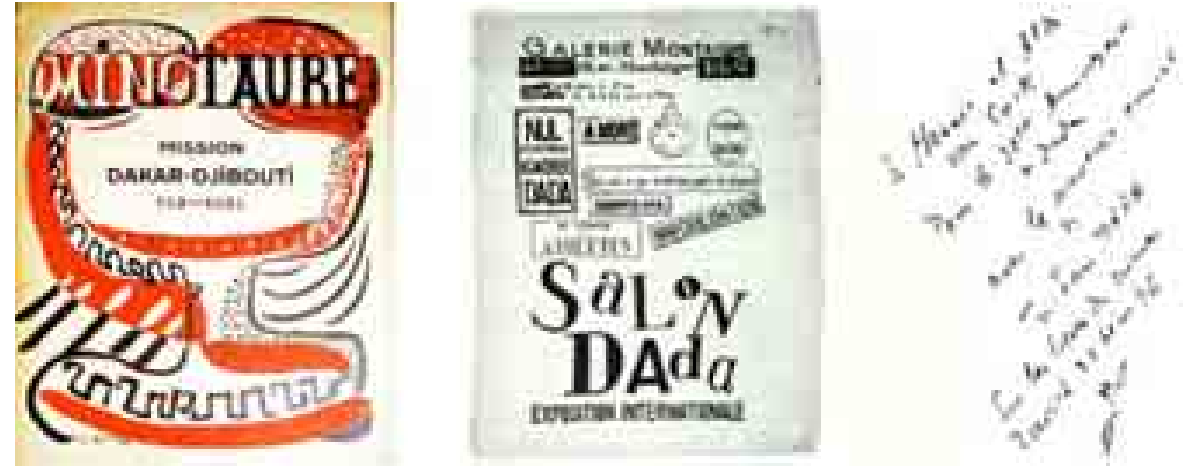

Figura 3.2

* Izquierda, portada del número 2 de la revista Minotaure. Mission Dakar-Djibuti 1931-1933, monografico dedicado a la expedición de estudios etnológicos realizada por Marcel Griaule a través de Africa (Ligtelijn y Strauven 2008, 24)

* Derecha, exposición Salon Dada, celebrada en la Galeria Montaigne. Dedicatoria de Tristan Tzara a Hannie y Aldo van Eyck, en 1946:: «Para Hannie y Aldo van Eyck por el 30 aniversario de Dada. Con el recuerdo amistoso de Tristan Tzara. En el lugar del crimen, Zurich 23 de febrero de 1946» (Van Eyck 1986, 13). Traducción de Ana Rodríguez. 
Aldo van Eyck poseía una solida formación clásica desde su infancia. La erudición de su padre Pierre N. van Eyck, poeta y filósofo, junto con la educación progresista no autoritaria recibida en Inglaterra ${ }^{1}$, en centros donde la literatura y el arte ocupaban un lugar preponderante, posibilitó que con solo 15 años Van Eyck ya tuviera una cultura literaria excepcional en holandés y en inglés, lenguas que dominaba profundamente, lo que le permitió escribir ${ }^{2}$ en ambas. En relación con su precoz conocimiento de la poesía inglesa, Francis Strauven apunta la poesía de William Blake (1757-1827), además de su educación bicultural, como una influencia temprana en el entendimiento de la mutua interacción entre opuestos. Posteriormente, en el ETH de Zurich, su cultura clásica ${ }^{3}$ se completa en el ámbito de la arquitectura con la enseñanza académica de los historiadores del arte Linus Birchler, que le introduce en el Barroco, y de Alphonse Laverrière en la composición Beaux Arts; especialmente este ultimo que con su curso de teoría y práctica de composición axial le proporcionó las herramientas para su utilización ulterior en composiciones multifocales no-clásicasEn este sentido, el papel desempeñado por Carola Giedion-Welcker, es decisivo en la formación intelectual ${ }^{4}$ de Van Eyck. Casi al final de sus estudios le pone en contacto con el arte moderno de vanguardia y su significado, abriéndole un campo de conocimiento verdaderamente revelador «a real breakthrough», que a su vez le descubrirá el arte primitivo. Carola Welcker o C.W. ${ }^{5}$, una de las primeras y más originales historiadoras del arte de las vanguardias del siglo $\mathrm{XX}$, a través de sus investigaciones -especialmente en pintura y escultura- había llegado a tener una relación muy cercana con artistas como Klee, Arp, Mondrian, Brancusi o Joyce, posibilitando su profundo conocimiento del arte moderno y el desarrollo de la idea de una nueva realidad «a new reality», consistente en que todas las corrientes artísticas del momento -Cubismo, Surrealismo, Dadaísmo, etcétera- eran en realidad componentes de un mismo movimiento, de una nueva manera de ver el mundo constitutiva de la cultura del siglo XX.

\footnotetext{
${ }^{1}$ Aldo van Eyck nació en Holanda pero se crió y formó en Inglaterra, en el King Alfred School en Hampstead y el Sidcot School en Somerset. Su padre trabajaba como corresponsal de un periódico de Rotterdam y aunque residente en Londres, fue una de las figuras principales de la literatura holandesa de entre guerras.

${ }^{2}$ Van Eyck pertenece al grupo de arquitectos que se expresaban construyendo y escribiendo. Para él la palabra escita era tan importante como la forma construida. Ver Ligtelijn y Strauven en la introducción a la primera edición en 2008 de The Child, the City and the Artist.

${ }^{3}$ La formación clásica era la común en las escuelas de arquitectura hasta ese momento. Respecto a este aspecto ver la entrevista a Sert «L 'Avantguarda lúcida. Una conversa amb Josep-Lluís Sert» en Quaderns d'arquitectura i urbanisme. n 152, 1982, en la que como respuesta a la pregunta sobre la formación clásica de los maestros de la arquitectura moderna, Sert dice: «Eran gente que había nacido en una época que se conocía muy bien la arquitectura clásica. Ellos no lo escondían. Y el Mies también. Estaban muy influenciados también de las cosas populares y no lo ocultaban de ninguna manera. A nosotros nos pasó algo parecido. Yo encuentro, sin querer herir a nadie, que han eliminado los estudios históricos, y ha venido una generación de gente -y no es precisamente la vuestra- que está reaccionando contra esto, que son completamente analfabetos en arquitectura. Hacen cosas de gente ignorante, sacadas de catálogos de construcciones sin tener sensibilidad ni idea de lo que se está haciendo. Esto que se está haciendo de volver a estudiar historia espero que ayude. Lo encuentro muy bien. Lo que no encuentro tan bien es tratar de aplicar cosas que no sean aplicables. Se tienen que resignar» Traducción de Ana Rodríguez.

${ }^{4}$ En relación con el fuerte componente intelectual de Van Eyck en Team 10, Peter Smithson dice en entrevista realizada por Simona Pierini y publicada en 2003 en el numero 110 de Circo, titulada Amigos de Coderch: «Aldo van Eyck era en parte hebreo; su padre escapó y encontró en Zurich otros refugiados. Era así también él un hombre de los años treinta, pero de otra forma, intelectual: Dada, James Joyce... Es decir que llevó algo distinto al Team X.» (Pierini 2003, 6). En dicha entrevista, Peter Smithson recuerda el papel y personalidad de miembros del grupo. Sobre Coderch capítulo 4

${ }^{5}$ Carola Welcker, esposa de Sigfried Giedion, y más conocida como Carola Giedion-Welcker o Carola Giedion, le gustaba que le llamasen C.W. en clara alusión a su apellido de soltera. Al respecto Aldo Van Eyck dice en "A tribute to Carola Giedion-Welcker": «C.W. (those that love Carola Giedion-Welcker call her so)», publicado por Van Eyck en Niet om het even... wel evenwaardig, van en over Aldo van Eyck, y anteriormente en Forum 9 en 1959 con el titulo A tribute to Carola Gideon-Welcker van Aldo van Eyck. (Van Eyck 1986, 10)
} 
Van Eyck se imbuirá en el núcleo de los círculos artísticos más importantes del momento a los que llamará The Great Gang, una especie de conspiración de artistas y científicos que habrían abierto con sus rompedoras ideas un esperanzador camino para una nueva cultura, bajo el prisma de la revolucionaria teoría de la relatividad que transformó el mundo. La relatividad, que se había manifestado simultáneamente a principio de siglo en el arte y en la ciencia, significaba un mundo policéntrico en el que todos los puntos de vista tienen igual valor, y la coherencia entre las cosas viene dada por relaciones de reciprocidad más que por subordinación jerárquica a un principio único.

Junto con el calificativo de The Great Gang, Van Eyck también utiliza el término The Great Riot, para referirse a la convulsión que significaron las vanguardias. Su significado literal, La Gran Revuelta tiene un matiz violento, de desorden público, pero coloquialmente significa desmadre, y en su significado más divertido la pera o la monda; es decir El Gran Desmadre o La Gran Monda. El término da nombre al segundo capítulo «The Great Riot. The Medicine of Reciprocity. The Impact of Relativity» del libro The Child, the City, and the Artist. An essay on architecture, escrito por Van Eyck en 1962 y editado por primera vez en 2008 por Vincent Ligtelijn y Francis Strauven, en el que bajo el titulo «Ordovico Viricordo" $"$, explica sus ideas sobre la nueva realidad, la ciencia y el arte modernos, a través de su homenaje a la figura de Carola Welcker. El agradecimiento y admiración de Van Eyck por ella, es intencionado y explicito en distintas publicaciones entre 1959 y 1986, basadas, con pequeñas variaciones, en el texto publicado en el numero 9 de Forum en 1959 con el titulo «A tribute to Carola Gideon-Welcker van Aldo van Eyck».

Es relevante la cita directa de algunos párrafos, ya que a través de su tributo a C.W., en realidad esta describiendo su visión del significado del arte moderno. Aldo van Eyck dice:

«Una fantástica señora que llevaba un enorme sombrero con largas plumas sobresaliendo. Ella comenzó atrayéndonos, a mi esposa y a mí, de inmediato, por así decirlo, a través de esos "senderos", que forman el otro lado. Habrá adivinado que la dama era Carola Giedion -Welcker o CW como le gustaba ser llamada. Muy poco después, nos quedó claro que su corazón y su mente, como su sombrero, eran también enormes. Abrió mis ventanas -y no las he cerrado desde entonces; ella afinó mis cuerdas - ninguna de ellas ha requerido nunca volver a afinarla. (...) Carola Giedion proporcionaba alimento para toda una vida» ${ }^{7}$

«La ciencia ha echado a un lado su pátina determinista. (...) Desde Einstein y Bergson a Klee y Apollinaire. Desde Brancusi y Mondrian a Joyce y Schönberg; ellos entre muchos otros, nos han legado un universo ampliado, han logrado detectar su ritmo, trazar su contorno. Hasta que aprendamos a encontrar nuestro camino por él, hasta que lo hagamos con gracia beneficiándonos de la gran metamorfosis implícita del espíritu, su amplitud seguirá siendo un horror vacui.

\footnotetext{
${ }^{6}$ Juego de palabras de James Joyce en The Finnegans Wake, que alude a varios significados y utilizado por Van Eyck como una especie de saludo ceremonial para iniciados. Tambien utiliza otras expresiones como «Allalivial, Allalluvial». Ver nota 15 del capítulo 2 en The Child, the City and the Artist (Ligtelijn y Strauven 2008, 226)

7 «A fantastic lady wearing a huge hat with long feathers sticking out. She began luring us, my wife and me, through those "door-ways", straight away, as it were, form the other side. The lady, you will have guessed, was Carola Giedion -Welcker or C.W. as she liked to be called. Very soon after that it bécame clear to us that her heart and mind, like her hat, were also huge. She opened my windows -and I haven't closed them since; she tuned my strings -nor did they ever require retuning. (...) Carola Giedion provided nourishment for a lifetime». (Ligtelijn y Strauven 2008, 18). Traduccion de Ana Rodríguez.
} 


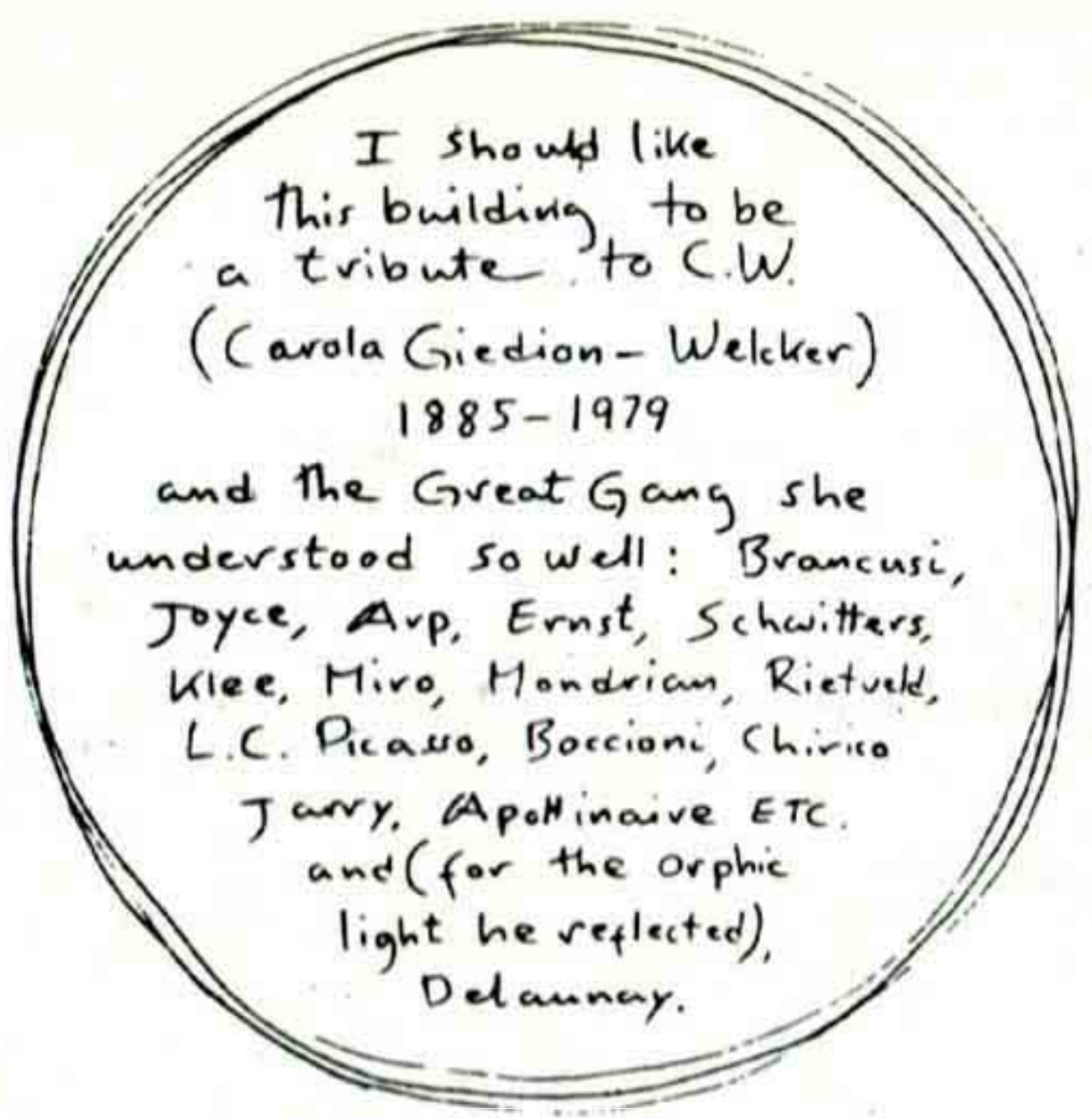

Figura 3.3

Diagrama realizado por Aldo van Eyck como homenaje a Carola Giedion-Welcker y a la vanguardia artística perteneciente a su círculo de amistades, y a los que Van Eyck llamaba la Gran Banda "The Great Gang». El edificio al que se refiere Van Eyck es la Hubertus House, después de su finalización.

Diagrama publicado en 1986 por el propio Van Eyck en Niet om het even... wel evenwaardig, van en over Aldo van Eyck, (Van Eyck 1986, 8).

Traducción de Ana Rodríguez

Me gustaría

que este edificio fuera

un tributo a C.W.

(Carola Giedion-Welcker)

1885-1979

y a la Gran Banda que ella

comprendía tan bien: Brancusi,

Joyce, Arp, Ernst, Schwitters,

Klee, Miró, Mondrian, Rietveld,

L.C., Picasso, Boccioni, Chirico,

Jarry, Apollinaire etc.

y (por la luz órfica

que reflejaba),

Delaunay 
Esto me lleva a Carola Giedion y Klee. Detrás de ellos, recordaré aunque sólo sea por mi propio beneficio, las figuras titánicas de James Joyce y Constantin Brancusi. Carola Giedion es una de las que nunca se han acercado a la transformación contemporánea del espíritu desde fuera. (...)

Para ella, la muerte de un amigo-artista -y ha habido muchas de hecho (de los que iniciaron The Great Riot sólo un quedan un puñado) - ha significado la pérdida de una parte de sí misma. Ella pertenece a su familia espiritual, ellos a la de ella. Ella los amaba y entendía como hermanos. (...)

Carola Giedion no contempla el tiempo como una línea recta. La eternidad no es un proceso aritmético para ella. Ella sabe, al igual que la mayoría de los artistas con los que se relaciona -y Klee es sin duda uno de ellos- que el cambio y la permanencia son uno en tiempo y espacio. Ella posee algo de la conciencia del hombre pre-especulativo para el que cada estrella y cada piedra es un espíritu, un "tú", no un "eso". Para ella, un mito es un quantum tan concreto como un miligramo o un milímetro. (...) Los artistas contemporáneos han puesto la eternidad en movimiento. (...)

Carola, yo soy tu embajador, tu eres el de Klee. Klee es el de ellos y -todos los demás que ya he mencionado o no- son los embajadores de una realidad ilimitada: el panorama completo ALLALIVIAL, ALLALLUVIAL» ${ }^{8}$

Aldo van Eyck se autoimpone la misión de llevar a la arquitectura moderna al camino iniciado con antelación por la ciencia con la teoría de la relatividad y por el arte de las vanguardias del siglo $\mathrm{XX}$, y del que la arquitectura parecía haberse parcialmente descolgado -en su sentido simbólico y espiritual-, al trabajar con grandes escalas urbanas y territoriales que debían dar respuesta a la enorme necesidad de vivienda de la sociedad moderna. Explora culturas primitivas con formas de vida ancestrales, cuya arquitectura aparentemente sencilla, esencial y simbólica, había sido capaz de dar respuesta a las necesidades vitales de sus habitantes a lo largo de siglos.

Una consideración más. Aldo van Eyck nunca utilizó la palabra primitivo para referirse a esas culturas, a las que consideraba tan sofisticadas como la occidental en sus manifestaciones artísticas y de lenguaje, acuñando la expresión «Vernacular of the Hearth» que forma parte de los Círculos de Otterlo, Francis Strauven lo explica en Aldo van Eyck: The Shape of Relativity y en la introducción del capítulo 9 de Aldo van Eyck Writtings. Van Eyck era alérgico al significado desdeñoso del término y no quería establecer ninguna desigualdad en categoría con la tradición clásica y la moderna. Cuando le era inevitable se refería a ellas como archaic o distanct cultures.

\footnotetext{
8 «Science has cast its determinist patina aside. (...) From Einstein and Bergson to Klee and Apollinaire, From Brancusi and Mondrian to Joyce and Schönberg; they among many others have left us with an expanded universe, have succeeded in detecting its rhythm, tracing its outline. Until we learn to find our way about in it, until we do so with grace benefitting from the vast metamorphosis of the spirit implied, its expanse will remain a horror vacui.

This brings me to Carola Giedion and Klee. Behind these two I shall keep in mind, if only for my own benefit, the titanic figures of James Joyce and Constantin Brancusi. Carola Giedion is one of those who have never approached the contemporary transformation of the spirit from without. (...) For her, the death of an artist-friend -and there have been many indeed (of those who initiated The Great Riot only a handful are left) - has meant the loss of a chunk of herself. She belongs to their spiritual familiy, they to hers. She loved them and understood them as brothers. (...) Carola Giedion never envisages time as a straight line. Eternity is no arithmetical process for her. She knows, as do the artists she is concerned with most - and Klee is certainly one of them- that change and permanence are one in time and space. She possesses something of the awareness of the pre-speculative man for whom each star and each stone is a spirit, a "thou", never an "it". For her, a myth is a much concrete quantum as a miligram or millimetre. Contemporary artists have set eternity in motion. (...) Carola, I am your ambassador, you are Klee's. Klee is their's and they -all the others I have either mentioned or not- are the ambassadors of a reality unlimited: the full panorama. ALLALIVIAL, ALLALLUVIAL.»

(Ligtelijn y Strauven 2008, 33-35). Traducción de Ana Rodríguez.
} 


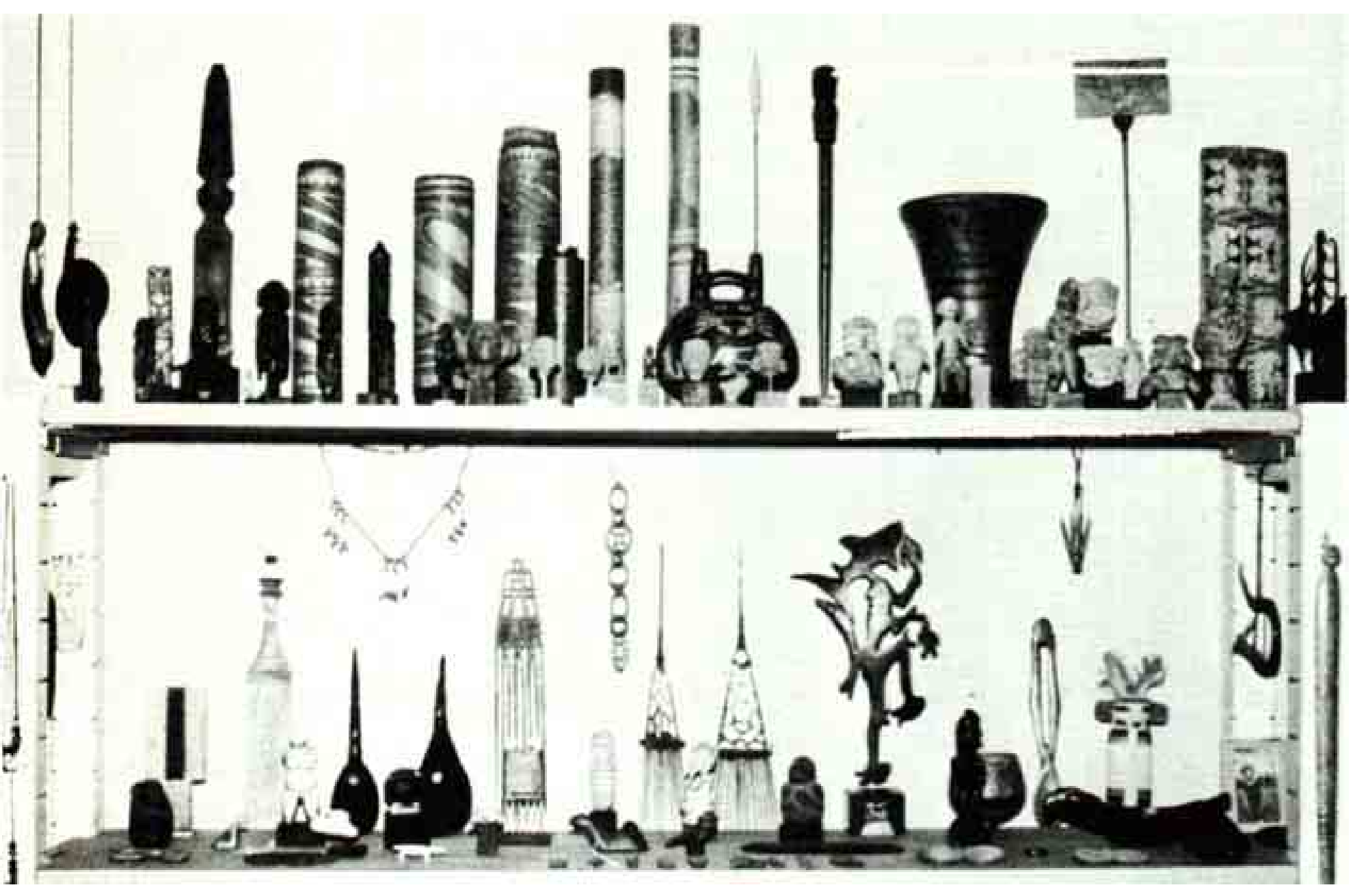




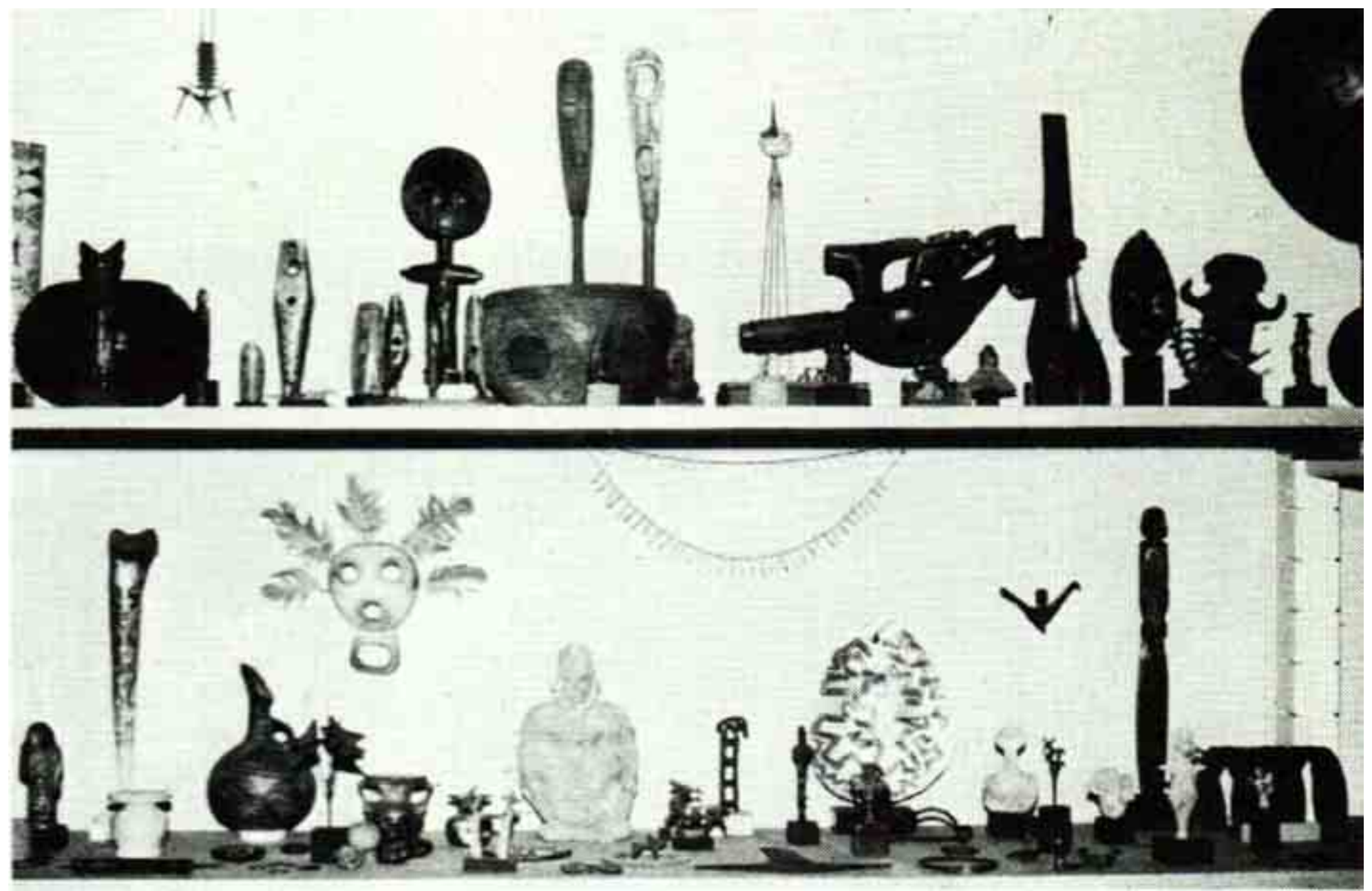

Figura 3.4

Imagen a doble página de parte de la colección de arte primitivo de Aldo Van Eyck.

Imágenes publicadas en 1986 por el propio Van Eyck en Niet om het even... wel evenwaardig,

van en over Aldo van Eyck, con el mismo formato y en continuidad una de otra como aquí se

presentan (Van Eyck 1986, 8) 


\subsubsection{Surinam y la herencia tropical de Aldo van Eyck.}

Aldo van Eyck, estableció una intensa conexión con el arte moderno al final de sus estudios de arquitectura en el ETH de Zurich, a través de Carola Welckler y las vanguardias -The Great Gang-. La comprensión de su significado le aportó una nueva forma de ver el mundo y el arte de las culturas primitivas, que posteriormente conseguiría plasmar en escritos, proyectos y en los Círculos de Otterlo. En el epígrafe anterior, se ha explicado como su primer contacto con la cultura Dogon se produjo por medio de la revista surrealista Minotaure, en un número monográfico dedicado a la expedición de estudios etnológicos realizada por Marcel Griaule a través de África. Sin duda esta experiencia fue reveladora para Van Eyck, porque de alguna manera, no solo le descubrió las conexiones entre el arte moderno y el de culturas arcaicas, sino que seguramente hizo vibrar algo en su interior, ayudándole a identificar y a redescubrir intelectualmente el legado tropical de parte de su universo infantil, heredado a través de su madre y su abuelo nacidos en Surinam. A conceptualizar algo adquirido intuitivamente.

La familia materna de Van Eyck era del Caribe. Su madre, Nelly van Eyck-Benjamins y su abuelo materno, Herman Daniel Benjamins, nacieron en Surinam, la antigua Guayana Holandesa, y su abuela Guilermina de Gouvea, provenía de la vecina Guayana Británica, de familia noble portuguesa.

Los recuerdos de Aldo van Eyck sobre su familia, nos han llegado a través de las conversaciones con Francis Strauven, recogidas en Aldo van Eyck. The Shape of Relativity. Van Eyck recordaba a su abuelo como un intelectual trabajador, un anciano académico que le gustaba trabajar por la noche, sentado en su escritorio con la espalda derecha, escribiendo entre un montón de libros, revistas y periódicos, y contrario a cualquier pomposidad académica. Un fascinante ${ }^{9}$ narrador de historias de sus expediciones a la selva y sus experiencias con los Maroons y los Indios, por quienes sentía una particular simpatía y a quienes defendió de la discriminación en varias ocasiones, dejando una profunda huella en su nieto. Desde su retiro en 1907 hasta su muerte en 1933, sus abuelos vivieron en Stadhoudersplein en La Haya, en una casa que respiraba el «aroma» de Surinam, «llena de laminas, antiguas fotografías color sepia, libros, objetos exóticos y otros recuerdos», que ponían de manifiesto la identificación de sus abuelos con el lugar donde habían vivido y trabajado toda su vida. Además, adquirieron una pequeña casa de vacaciones junto al mar en Kijkduin, area residencial recién construida en 1922 por Biejvoet y Duiker, en una manifestación temprana de arquitectura moderna. (Strauven 1998)

\footnotetext{
${ }^{9}$ Herman Daniel Benjamins (Paramaribo 1850-La Haya 1930) desarrolló su vida profesional al servicio de Surinam, lugar que siempre consideró su verdadera patria. Tras finalizar su doctorado en física en la Universidad de Leiden en 1875, regreso a Paramaribo donde trabajó treinta años cono inspector escolar, estando considerado como uno de los fundadores de la educación de aquel país. Al mismo tiempo, enseñó física y botánica, participando en varias expediciones al interior, combinando su trabajo como inspector con la investigación etnológica. También desempeñó la supervisión del Surinam Botanical Gardens y puestos de responsabilidad en la administración colonial. Después de su retiro en 1907, se instaló en La Haya y continuó trabajando como escritor científico, orientado de nuevo a Surinam: Con J.F. Snelleman, editó una Encyclopedie van Nederlands West-Indië - Enciclopedia de las Indias Occidentales Holandesas y más tarde participó en la constitución de la revista De West-Indische Gids - La Guía de las Indias Occidentales-, donde publico hasta su muerte artículos de temas diversos de Surinam: historia, política, etnología, salud, fauna y flora.

De su abuela, Strauven aporta pocos datos: Ella provenía de una familia noble portuguesa cuya antigua grandeza todavía se notaba, en su carácter reservado y sus aires nobles. Ella quedó mentalmente anclada a sus raíces en América del Sur. Tenía tan poco interés por su entorno holandés que prácticamente nunca salía de la casa durante veinte años que vivió en ella. Su mundo exterior se limitaba al servicio de Scheveningen de quienes aceptaba entregas y correspondencia en la puerta con pinzas de plata. (Strauven 1998, 18-20)
} 
En 1933, a la muerte de su abuelo, Van Eyck tenía 15 años, por lo que pasó toda su infancia y adolescencia visitando con frecuencia la que era su segunda casa, la casa de sus abuelos. Siempre que viajaban desde Londres y al menos tres veces al año pasaba las vacaciones allí. Vacaciones que además de acercarle a culturas lejanas y arcaicas a través del mundo de sus abuelos y de su propia madre, al mismo tiempo le proporcionaron un primer contacto con la arquitectura moderna.

La influencia de Surinam ${ }^{10}$ en Van Eyck, supuso sin duda más que una mera referencia familiar. Sin embargo, apenas queda reflejada en sus escritos, que dedica principalmente a sus viajes al norte de África, los Dogon y los Indios Pueblo. Una de las escasas, pero personal, referencias al lugar de origen de su familia materna es la que realiza con motivo de la crítica arquitectónica sobre la obra de Lucien Lafour (1942-...) en Surinam. Lafour había sido alumno suyo en el Amsterdam School of Applied Arts, y más tarde había trabajado con él y su socio Theo Bosch. Cuando a principios de los años setenta marcha a Surinam, donde permanecerá diez años hasta su vuelta a Holanda, Van Eyck le promete escribir un artículo sobre su primera obra, a la que cariñosamente se refiere como «primogénito tropical», en una buena revista. Bajo el titulo «By definition - on Lucien Lafour», Van Eyck publica un artículo en Forum, en junio de 1982, y más tarde en Architectural Review, en abril de 1984, en los a modo de introducción dice:

«Varias razones me impulsaron. En el fondo estaba el hecho de que los lugares y sociedades marginales - llámalas tribales o arcaicas - siempre me están haciendo señas. Ya sea en el Pacífico Sur o el Estrecho de Bering, trato de llegar allí. En el caso de Lafour, desde siempre estuve íntimamente familiarizado con el país al que se había ido, porque mi madre era de allí y mi abuelo, que sabía todo lo que había que saber sobre él, y lo mantuvo contando historias maravillosas sobre su selva -ríos, bestias y pueblos. Y así, desde entonces, la arquitectura en su horizonte más amplio ha mantenido un firme control sobre mí, abrazando, por supuesto, lo que es más cercano.»11

La experiencia de Lafour, no es única entre los arquitectos holandeses. En 1949, Rietveld hizo un viaje de estudio ${ }^{12}$ a las colonias holandesas en el Caribe: Surinam y a las Antillas Neerlandesas. Durante su estancia en la isla de Curaçao, entró en contacto con Chris Engels, físico que en palabras de Rietveld era el hombre de la isla refiriéndose a su influencia. Aunque el motivo oficial del viaje era aconsejar sobre la restauración de casas coloniales del siglo XVII y de la arquitectura tradicional de la isla,

\footnotetext{
10 Por su propio desarrollo histórico, la antigua Guayana Holandesa es una inusual amalgama de etnias, lenguas y culturas, sin una religión dominante. Tras la abolición de la esclavitud en las colonias de los Países Bajos en 1863, la mano de obra esclava fue reemplazada por una fuerte inmigración de hindúes, javaneses y chinos, de forma que además de la minoría blanca europea dominante y los indios americanos nativos, la población estaba compuesta por población de la India, mayoritaria y muy apegada a sus tradiciones, los ya mencionados chinos y javaneses procedentes de las antiguas Indias Orientales Holandesas, mulatos y criollos descendientes de esclavos, y cimarrones descendientes de esclavos africanos que lograron escapar asentándose en determinadas zonas del Caribe. Además, en el sudoeste de Surinam se encuentra uno de las últimas selvas tropicales más vírgenes del mundo, con una biodiversidad extraordinaria -en 2010 se descubrieron numerosas especies desconocidas de flora y fauna-, y tribus autóctonas han mantenido sus tradiciones hasta hace poco.

11 «Various reasons prompted me. In the background there was the fact that out of the way places and societies - call them tribal or archaic - are always beckoning me.

Whether en the South Pacific or the Bering Straits, I try to get there. In Lafour's case I was already intimately familiar from afar with the particular country he had gone, because my mother came from there and my grandfather, who knew all there was to know about it, kept telling wonderful stories about jungle -rivers, beast and peoples. And so, ever since, architecture along its widest horizon has kept a firm hold on me, embracing, of course, what is closer by.». (Ligtelijn y Strauven 2008, 590) Traducción de Ana Rodríguez.

12 Invitado por La Fundación para la Cooperación Cultural entre los Países Bajos, Indonesia, Surinam y las Antillas Neerlandesas
} 

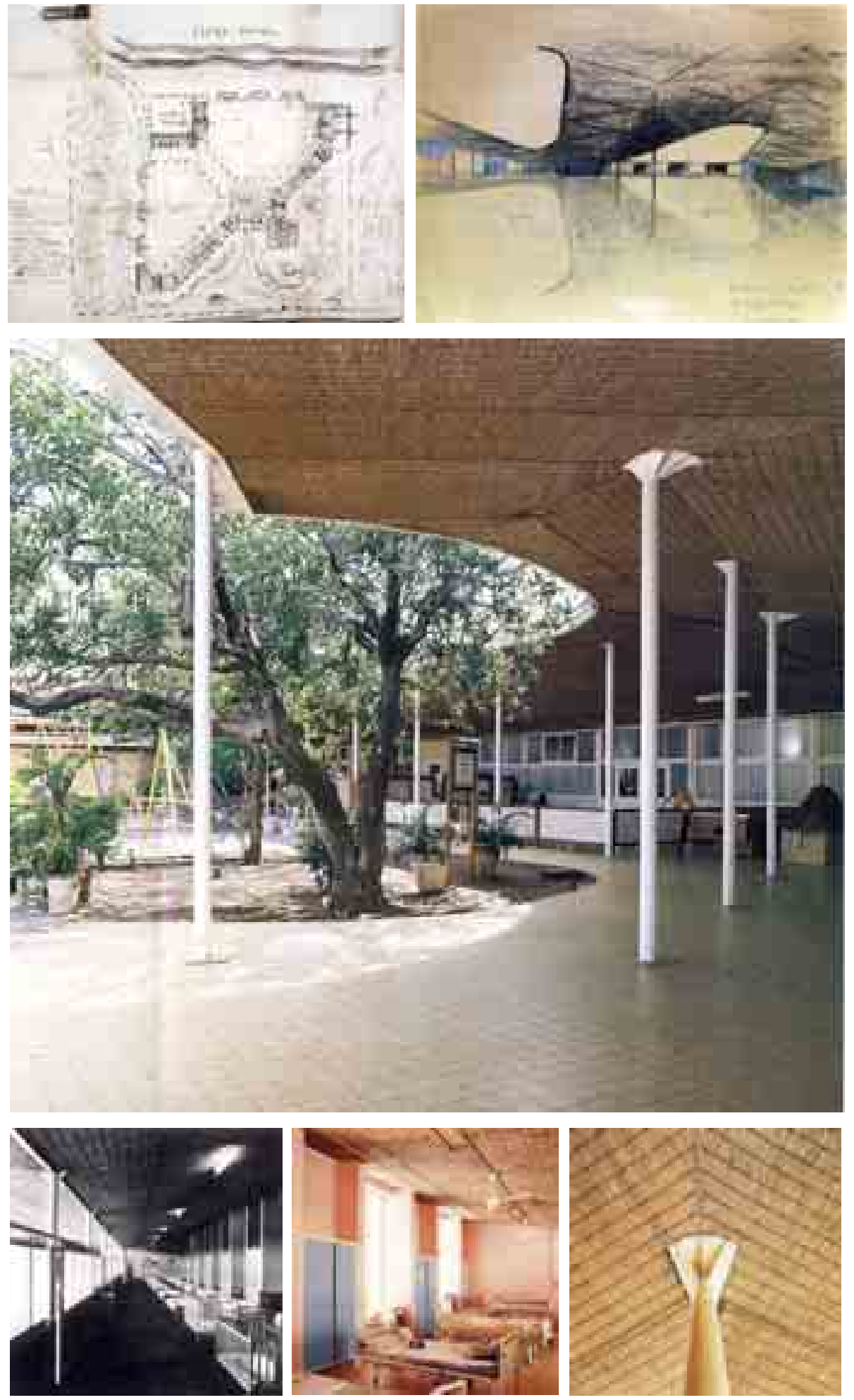

Figura 3.5

Instituto Monseñor Verriet en Curaçao, antiguas Antillas Neerlandesas, 1949-1952, de Gerrit Rietveld. Caracterizado por una gran cubierta abierta para favorecer la sombra y la ventilación en un clima tropical, est tiene sección invertida para recoger el agua de lluvia a modo de gran bandeja, y está terminada en su parte inferior con estera.

* Superior izquierda, planta del conjunto, no construido en su totalidad; derecha, croquis representativo de la sombra buscada a través de la gran cubierta protectora. Dibujos de Gerrit Rietveld en 1949. (Van Zijl 2010, 154).

* Centro e inferior, distintas imágenes de la galería y del interior de los dormitorios con ventanales de persiana de tablilla para ventilación. (Oku 2009, 237-239) 
la correspondencia entre ambos indica otro interés añadido: la construcción del hogar para niños discapacitados, que Engels encargo a Rietveld. El Instituto Monseñor Verriet es la única obra ${ }^{13}$ de cierta entidad realizada por Rietveld en un ambiente tropical. Una estructura completamente abierta, adaptada a las condiciones climáticas del lugar, y con protagonismo de un material local. Un proyecto con escasa repercusión ${ }^{14}$ en la obra de Rietveld, que sin embargo fue importante para Curaçao precisamente por el reconocimiento de una figura internacional hacia la cultura local. Los planos para el Monsignor P.I. Verriet Institute fueron realizados por Rietveld en 1949, durante un mes antes de su partida, y fue construido bajo la supervisión de Henk Nolte entre finales del mismo año y 1952 (Van Zijl 2010), aunque por cuestiones presupuestarias, no se construyó la totalidad del conjunto. Sobre el proyecto Rietveld dice:

«Propuse utilizar planchas de madera para el suelo, y el tratamiento de la cubierta como un cobijo para la galería; baja en el medio y ascendiendo hacia los lados - como el reverso de un tejado a dos aguas - y llevando las columnas y paredes hacia la zona interior para que no reflejan el sol en el medio del día y por lo tanto no se calientan demasiado. Todo el edificio se compone de esas galerías, limitadas al exterior, alternativamente por un tramo de pared y una abertura con persianas de tablilla (que permite que el viento del este pase a través de ellas) y en el interior sólo columnas con persianas que se pueden abrir. Las galerías son $17 \mathrm{~m}$ de ancho y se dividen en una franja al exterior para dormir, y otra con vistas al patio abierto para vivir (pequeñas mesas y sillas) ... También se puede considerar todo como un enorme techo de paja sobre un gran número de finos soportes circulares, en el que se han introducido dos pozos de luz realmente grandes. ${ }^{15}$

La gran pregunta es por qué Aldo van Eyck, con estos antecedentes culturales coloniales en el Caribe, además de su personal relación cercana y familiar con un territorio lejano de tradiciones primitivas que sin duda le influyeron en su infancia y adolescencia, todos sus escritos e investigaciones significativas sobre lo vernáculo, se refieren a otras culturas como la Bereber, la Dogon o la de los Pueblo. No hay ninguna investigación que dé respuesta explícita a esta pregunta, o siquiera la haya planteado, y es probable que en ella incidan varios factores. Desde esta tesis se propone que la elección de determinadas etnias no es casual, sino que se debe al interés de Van Eyck por culturas que habían sido capaces, mediante asentamientos construidos, de dejar una huella significativa e identitaria en territorios desérticos. En lugares inspiradores para dotar de identidad sus obras en la abstracción del territorio holandés. En el epígrafe 4.3.3.3. relativo a los viajes de Van Eyck, se trata de dar respuesta.

${ }^{13}$ Entre 1949 y 1962, Rietveld realizo otros cinco pequeños proyectos en Curaçao, pero de muy poca entidad y algunos no construidos, todos ellos relacionados con Chris Engels. El Verriet Institute, fue incluido en 2004 como patrimonio moderno de Curaçao, con el reconocimiento internacional del Docomomo.

${ }^{14}$ En el mismo periodo, unos años antes, Rietveld realiza otro proyecto singular en su obra: la casa de vacaciones Verrijn Stuart en 1940, ya mencionada en el primer capítulo. Construida por la normativa de la zona con materiales tradicionales y una gran cubierta inclinada de paja, hace una interpretación moderna de las casas de campo holandesas. La vivienda, tampoco tuvo mucha repercusión excepto en los círculos arquitectónicas donde fue muy alabada, entre otros por Bakema. (Ver capítulo 1)

15 «l proposed using woodblocks as a floor, and treating the roof as a shelter for the gallery; low in the middle and ascending towards the sides - so the reverse of saddleback roof - and bringing the columns and walls so far under the canopy that they do not reflect the sun in the middle of the day and thus do not become too hot.

The whole building is comprised of such galleries, bounded to the outside, alternately by a length of wall and an opening with shutters (which lets the east wind pass through) and on the inside only columns with shutters that can be opened. The galleries are $17 \mathrm{~m}$ across and are divided into a strip to the outside for sleeping and overlooking the open courtyard a strip to live (little tables and chairs)...You can also regard the whole thing as a huge thatched roof on a great many slender round columns, into which two really big lightwells have been introduced.» (Van Zijl, 2010, 156) Traducción de Ana Rodríguez. 

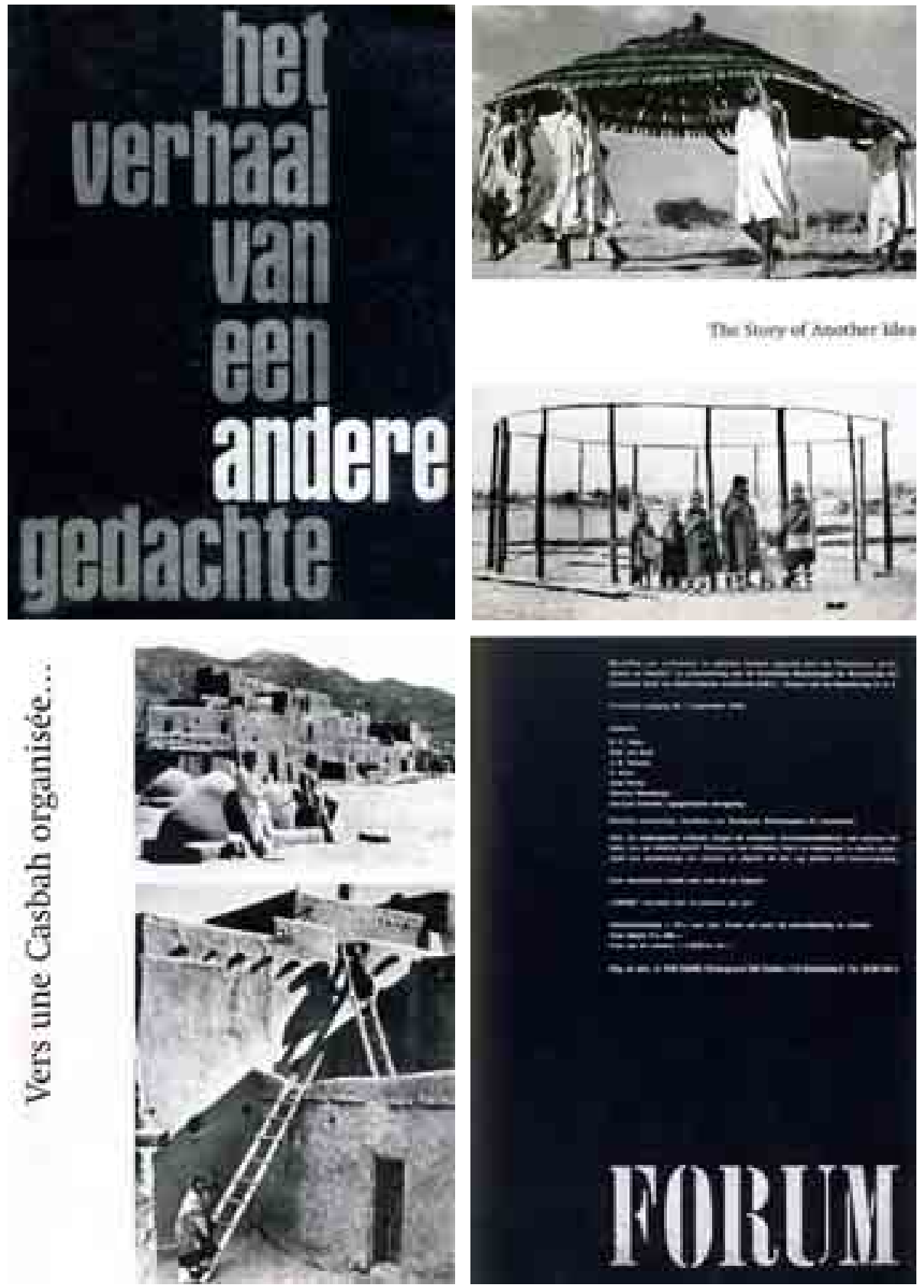

Figura 3.6

Imagen a doble página de parte de la colección de arte primitivo de Aldo Van Eyck. Imágenes publicadas, posiblemente las únicas, en 1986 por el propio Van Eyck en Niet om het even... wel evenwaardig, van en over Aldo van Eyck, con el mismo formato y en continuidad una de otra como aquí se presentan (Ligtelijn y Strauven 2008) 


\subsubsection{Aldo van Eyck y el Team 10. Culturas primitivas e identidad.}

\subsubsection{1.«La Historia de Otra Idea». Forum 1959-1963}

El compromiso de Aldo van Eyck con culturas arcaicas no occidentales, que se remonta a sus años de estudiante en Zurich y primeros viajes al norte de Africa, estuvo también presente en las reuniones del CIAM. Al principio, su postura crítica permitió introducir paulatinamente una línea de pensamiento en el debate, que terminaría culminando en los Círculos de Otterlo presentados en 1959 en el lugar que les da nombre y en Team 10.

Entre 1959 y 1963 la revista holandesa Forum, que había sido fundada en 1946 por la sociedad Architectura et Amicitia con el objetivo de dar soporte al debate entre diversas tendencias de pensamiento, queda a cargo de un joven y entusiasta equipo editorial compuesto por Jaap Bakema, Aldo van Eyck, Joop Hardy, Jurrian Schrofer y un recién graduado Herman Hertzberger que había llamado la atención de Van Eyck en el Politécnico de Delft. Al final de los cincuenta, la publicación había entrado paulatinamente en una dinámica más complaciente y el grupo directivo había decidido dar un giro innovador nombrando a este grupo de jóvenes con estrechas relaciones de amistad entre sí. Con una dinámica de trabajo ${ }^{16}$ informal, sin jerarquías y sin editor jefe, a pesar del liderazgo claro y compartido por Bakema y Van Eyck, dieron un vuelco a la revista con temáticas novedosas y una imagen visual potente, que a pesar de las criticas, en seguida tuvo amplia repercusión dentro y fuera de los Países Bajos, convirtiéndose en gran medida en el medio de expresión de lo que sería el grupo holandés de Team 10.

Siendo conscientes de que el primer número, en septiembre de 1959, debía ser reflejo del cambio, fue compuesto por Van Eyck bajo el título Het Verhaal Van Een Andere Gedachte -La Historia de Otra Idea-, comenzando con una afilada critica a la práctica dominante en la construcción y el planeamiento en Holanda, «que hacía gala de de una solida tradición de organización racional e implementación eficiente ${ }^{17}$ », y a los CIAM anteriores a la guerra. Aún reconociendo los avances conseguidos por estos, fundamentalmente consistentes en desentrañar e identificar las funciones de la ciudad del siglo XIX y re-evaluarlas con las técnicas modernas en la misma línea de los métodos analíticos del Cubismo, critica que no habían sido capaces, a diferencia de las vanguardias artísticas, de establecer una nueva síntesis no jerárquica, y haber caído precisamente en una nueva con cada una de las funciones.

Después de la polémica introducción se inicia verdaderamente "la historia de otra idea", que comienza en 1947 en el Congreso de Bridgewater ${ }^{18}$, el sexto de los CIAM, con la contribución de los jóvenes delegados holandeses Bakema y Van Eyck.

\footnotetext{
${ }^{16}$ Ver los detalles dados por Herman Hertzberger en la entrevista con Francis Strauven el 27 de noviembre de 1981, recogidos en. Aldo van Eyck. The Shape of Relativity (Strauven 1998, 338339).

17 «which boasted a firm tradition of rational organization and efficient implementations» (Ligtelijn y Strauven 2008, 217). Traducción de Ana Rodríguez.

18 La Segunda Guerra mundial supuso un periodo de 10 años entre el quinto y el sexto congreso, quedando los diferentes grupos nacionales aislados entre sí, aunque mantuvieron su actividad de forma independiente durante la guerra. En Nueva York Gropius, Neutra, Sert y Giedion, formaron entre otros la Sección de los CIAM para la liberación y la planificación de posguerra. En Inglaterra el gripo ingles de los CIAm adoptó el nombre de MARS Modern Architectural Research Group, con protagonismo en los desarrollos urbanísticos de posguerra, y en los Países Bajos los miembros del CIAM durante la ocupación alemana se reunieron en secreto preparando la reconstrucción de Rotterdam. Giedion lo explica en el capítulo de los CIAM de Espacio, Tiempo y Arquitectura, y como el congreso «quedó atónito al ver cómo el "desarrollo de una idea" había seguido líneas paralelas en grupos completamente separados». En este congreso, en el que Sert fue nombrado presidente, se abordó por primera vez la cuestión de la estética. (Giedion [1941] 2009, 669-670)
} 


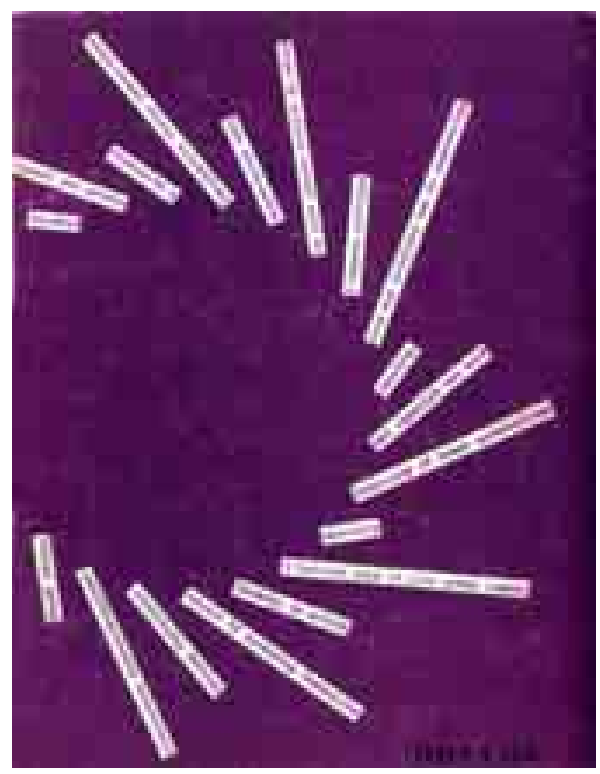

Figura 3.7

Revista Forum no7 de 1959

Cubierta del primer número de la etapa, en la que aparecen organizadas en forma de abanico los principales temas de Team 10, que constituyen la «otra idea»: (Ligtelijn y Strauven 2008)

\section{- visual group}

- differentitated housing unit

- identifying devices

- aspect of ascending dimensions

- harmony in motion

- I'habitat pour le gran nombre

- mobility

- Hierarchy of human associations

- the momento of core

- identity

- the city as the interior of the community

- I'espace corridor

- la plus grande réalité du seuil

- appreciated unit

- imagination versus common sense

- à mi-chemin

- change and movement

- cluster

\section{- grupo Visual}

- unidad de vivienda diferenciada

- dispositivos de identificación

- aspecto de dimensiones ascendentes

- armonía en movimiento

- el hábitat para muchos

- movilidad

- jerarquía de las asociaciones humanas

- el momento del corazón, de lo esencial

- identidad

- la ciudad como el interior de la comunidad

- espacio de corredor

- cuanto mayor es la realidad del umbral

- unidad valorada

- la imaginación contra el sentido común

- a medio camino

- cambio y movimiento

- racimo

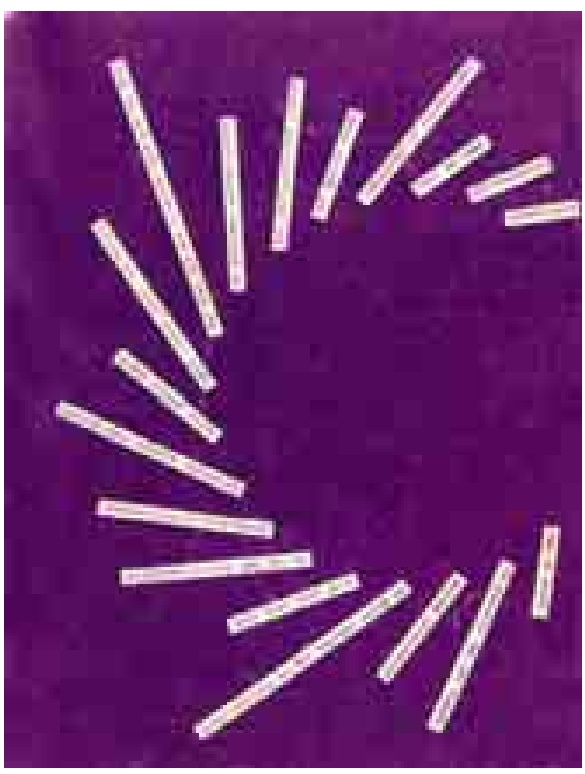

Figura 3.8

Revista Forum

Cubierta del último número editado en 1967 por el equipo editorial del Van Eyck.

En este caso el abanico es inverso, y en él aparecen las ideas desarrolladas en la revista en el periodo 1959-1963: (Ligtelijn y Strauven 2008)

- day and night

- the shape of in-between

- sulcus primigenius

- the mild gears of reciprocity

- place, place, place, place

- in praise of ambivalence

- encounter-threshold-kasbah

- schindler spangen zonnestraal

- split pueblo dogon

- carel visser, joost van roojen

- a city is a house, a house is a city

- the configurative discipline

- the other way of housing

- habitable or inhabitable

- door and window

- polivalence

- identity

- día y noche

- la forma del in-berween

- surco de partida

- los suaves engranajes de la reciprocidad

- lugar, lugar, lugar, lugar

- en alabanza de la ambivalencia

- encuentro umbral kasbah

- schindler spangen zonnestraal

- split pueblo dogon

- carel visser, joost van roojen

- una ciudad es una casa

una casa es una ciudad

- la disciplina configurativa

- la otra forma de vivienda

- habitable o inabiltable

- puerta y ventana

- polivalencia

- identidad- 
El primero impulsó la mejora de objetivos del CIAM para «para estimular el crecimiento espiritual del hombre» ${ }^{19}$ y el segundo instó al CIAM a abandonar su estrecho racionalismo y a identificarse con la nueva conciencia de la vanguardia del siglo XX, con la «cultura de las relaciones determinadas $»^{20}$ iniciadas por el arte y la ciencia.

En el Congreso de Hoddesdon en 1951, se aborda el concepto de «core» introducido por los organizadores, el Grupo MARS. Las cuatro nociones de la Carta de Atenas vivienda, trabajo, ocio y circulación- que habían sido eficaces en un primer análisis urbano, no eran suficientes para captar el espíritu de una ciudad (Giedion [1941] 2009). Giedion lo definió en términos sociológicos e históricos apuntando el ejemplo del ágora griega como una autentica manifestación del concepto de «core», no en sentido utilitario o comercial sino como un espacio urbano de encuentro en el que los ciudadanos podían identificarse como una comunidad. A su vez, Bakema explicitó su conexión con el concepto de relación: «Es el momento del corazón; el momento en el que tomamos conciencia de la riqueza de la vida, el momento en que descubrimos la maravilla de las relaciones entre los hombres y las cosas " ${ }^{21}$. Los resultados del congreso se publicaron en 1952 en The Hearth of the City a cargo de Jaqueline Tyrwhitt, Josep Lluis Sert y Ernesto N. Rogers. En la reunión intermedia de Sigtuna la contribución de Wim van Bodegraven y Aldo van Eyck se centró a la importancia del tiempo como factor esencial en el urbanismo, y la relatividad como fundamento de la nueva conciencia.

En el CIAM IX de 1953 en Aix-en-Provence, la comisión con el tema Role os Aesthetics in the Habita, de la que Van Eyck era copresidente, realizó una declaración sobre la Position on natural conditions and archaic civilizations que incidía en la necesidad de mantener una actitud de humildad para poder aprender de las «civilizaciones arcaicas». Otro grupo formado por estudiantes de París, presentó un estudio de los asentamientos tradicionales en África oriental con el titulo L'Habitat au Cameroun, diferenciándose estas posturas de otras contribuciones con actitudes paternalistas como la de algunos grupos argelinos y marroquíes sobre sus investigaciones en barrios autóctonos en Casablanca y Argel (Jaschke 2011).

La «historia de otra idea» se hace más evidente. Los Smithsons especificaron el concepto de «relación» cercano a las nociones de «identidad», «asociación humana»y «unidad valorada», y el grupo francés con Candilis, abrió significativamente el horizonte de los CIAM con el tema de la vivienda en civilizaciones arcaicas, formas de vida que aun pervivían encarnando una especie de armonía primigenia de contrastes; pero sobre todo estas manifestaciones evidenciaban, desde diferentes puntos de vista, un sentimiento compartido sobre la necesaria ampliación de horizontes en arquitectura, en línea con lo publicado por Van Eyck en 1959 en la "Historia de Otra Idea" cuando dice: «hasta ahora probablemente no ha habido nada que haya dado más impulso al desarrollo del CIAM que la confrontación con el problema de los países extranjeros y humildes»22 $\mathrm{O}$ «Y así en Aix, un cansado CIAM se encontró cara a cara, por fin, con los frágiles vestigios del hombre arcaico -con los últimos vestigios de genio extraño y humilde. EI CIAM reconoció, aunque demasiado tarde, la sencilla grandeza del gesto correcto y el andar derecho: la sencilla grandeza de una sociedad integrada» ${ }^{23}$

\footnotetext{
19 «to stimulate man's spiritual growth» (Strauven 1998, 343)

20 "Culture of determined relations»(Strauven 1998, 343)

21 "That is the moment of "core"; the moment in which we become aware of the fullness of life, the moment we discover the wonder of relationships between men and things" (Strauven 1998, 343). Traducción de Ana Rodríguez. Se ha traducido el término "core" como corazón en el sentido de lo esencial, por lo que también podría ser „Este es el momento de lo esencial; ...»

22 "Het Verhaal Van Een Andere Gedachte". Forum 14 nº (Jaschke 2011).

23 "and so at Aix tired CIAM was brought face to face, at last, which the frail vestiges of archaic man -with the last traces of strange and humble genius. CIAM acknowledged, albeit too late, the simple magnificence of the right gesture and the right gait: the simple grandeur of an integrated society» (Strauven 1998, 343). Traducción de Ana Rodríguez.
} 

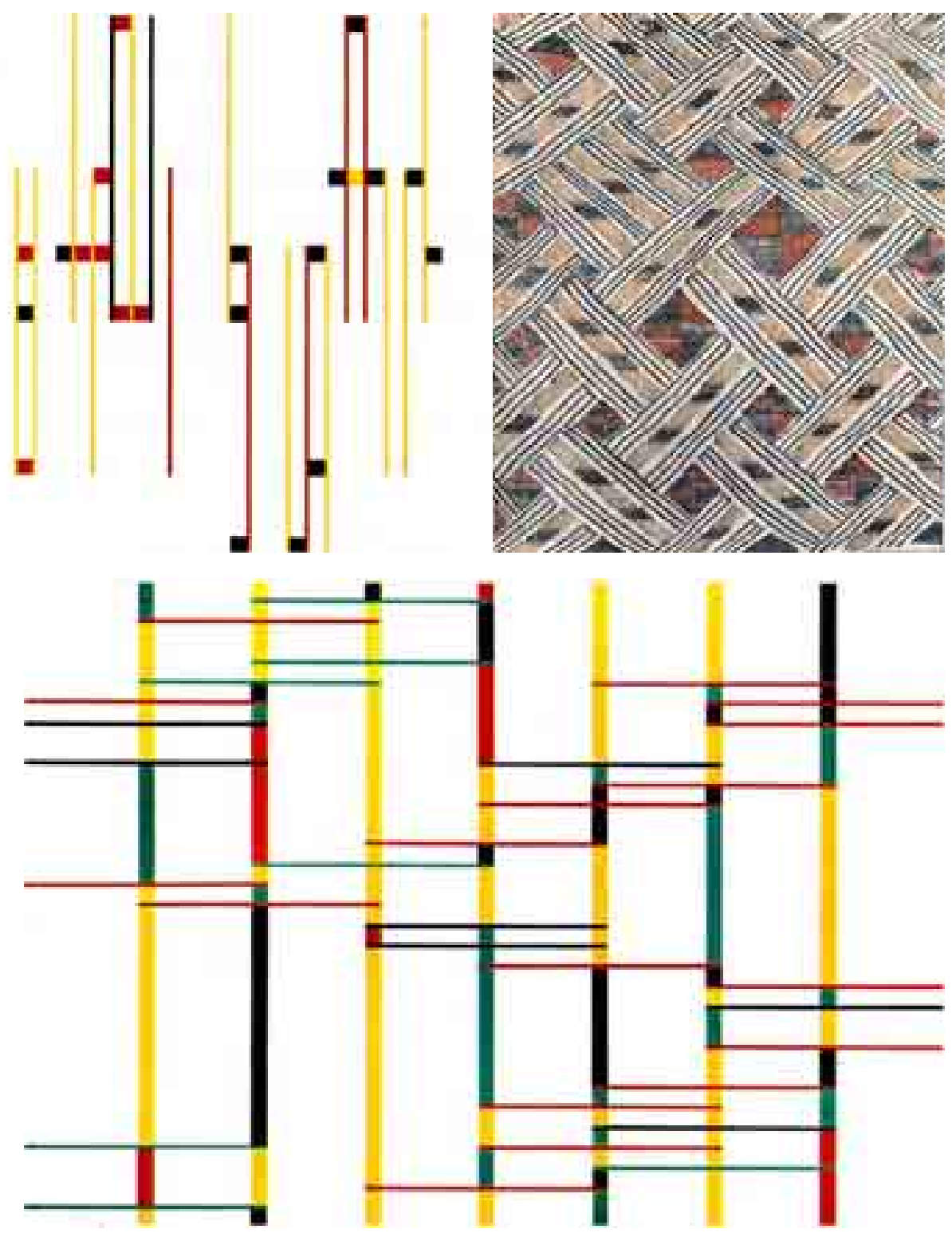

Figura 3.9

Para Aldo van Eyck, las formas y patrones primigenios en las que las civilizaciones arcaicas todavía se expresan debían ser consideradas entre los componentes elementales de la «new reality". Algo evidente ya en los inicios del nuevo lenguaje visual del Cubismo, y que Van Eyck identifica con su concepto de la estética del número, ilustrándolo simultáneamente con dos ejemplos: uno contemporáneo, las composiciones del artista suizo Richard Paul Lohse (19021988) , y otro vernáculo, un tapiz Bakuba.

* Superior izquierda, Konkretion I, 1945-46, de R.P. Lohse (Ligtelijn y Strauven 2008, 19)

* Inferior, Konkretion III, 1947, de R.P. Lohse (Ligtelijn y Strauven 2008, 19)

* Inferior, Textil Bakuba, Congo, que perteneció a la colección de Tristan Tzara, y fue reproducida en forma de láminas por Henri Clouzot en la publicación Tissus Nègres. (Clouzot 1925) 
Estos valores arquetípicos eran ilustrados con gran cantidad de fotografías de asentamientos arcaicos y tradicionales, imágenes que generalmente revelaban una interacción entre comportamiento y patrones ambientales.

Para Aldo van Eyck, las formas y patrones primigenios en las que las civilizaciones arcaicas todavía se expresan debían ser consideradas entre los componentes elementales de la «new reality». Algo evidente ya en los inicios del nuevo lenguaje visual del Cubismo, y que Van Eyck identifica con su concepto de la estética del número, ilustrándolo simultáneamente con dos ejemplos: uno contemporáneo, las composiciones de Lohse, y otro vernáculo, un tapiz Bakuba.

Esto va seguido de la formación de Team X, con la introducción del concepto de «human association» como principio fundamental en la declaración de Doorn en 1954.

En el siguiente congreso, el decimo, a celebrarse en Dubrovnik, cuya preparación fue encargada a los miembros del joven grupo, dimitió toda la organización anterior de los CIAM, quedando certificado su final con la carta enviada por Le Corbusier, como se ha reseñado en el capítulo anterior ${ }^{24}$. En él, también se explica la aportación de los Smithsons relativa a escalas de asociación, con diferencias significativas respecto a las del grupo holandés, especialmente interesado en el concepto de identidad, por su intima relación con la experiencia desarrollada en el nuevo asentamiento de Nagele, que junto los plaugrounds en Amsterdam, será presentada en Dubrovnik por Aldo van Eyck en representación de De 8 en Opbouw, y que es objeto del siguiente epígrafe en su condición de antecedente de los Círculos de Otterlo.

De esta forma, el desarrollo de la "otra idea», puede ser entendida como la versión holandesa de la idea de Team 10. El concepto relacional desde el punto de vista de Aldo van Eyck, basado en la idea que la esencia y lo que determina la identidad de una ciudad o un barrio, no puede definirse en términos funcionales, sino que necesita un análisis en términos de relaciones. El entorno construido representa en su forma y estructura, la materialización de relaciones humanas más o menos complejas entre individuos, entre individuos y grupos o entre grupos, conformando distintas escalas de asociación, y ne cada una de ellas un rango completo de funciones.

Este planteamiento de Team 10, adopta en el caso de Van Eyck unos fundamentos muy específicos al identificarlos con la actualización de la «cultura de relaciones determinadas» basada en las vanguardias artísticas de comienzos del siglo XX. Su punto de vista le conduce a territorios diferentes a otros miembros de Team 10: la vuelta a lo elemental, la reflexión sobre patrones relacionales arquetípicos en culturas arcaicas y tradicionales, una forma de pensamiento no-jerárquica y no-determinista, y en particular tres temas que se reflejarán en las páginas de Forum: la forma del inbetween, el tiempo como factor en el planeamiento urbano y el proyecto de grandes conjuntos de vivienda (Strauven 1998)

La posibilidad de publicar en Forum y marcar una determinada línea editorial, fue para Van Eyck una oportunidad excepcional que llegó en el momento oportuno. El periodo 1959-1963 es clave en su trayectoria. Ya tiene la experiencia de haber podido desarrollar y construir proyectos, entre ellos el Orfanato de Amsterdam que le proporcionará el reconocimiento internacional; se ha oficializado el nacimiento de Team 10 a partir de los CIAM, y tiene el importante background de las discusiones del grupo. Ha hecho los viajes más determinantes para él: los primeros al Norte de África y posteriormente a los asentamientos de los Indios Pueblo y los Dogon, y también es en esos años cuando escribe The Child, The City and the Artist, que junto con sus artículos en Forum constituyen la parte más importante de sus escritos. En ellos desarrollará tres conceptos fundamentales, que conformarán los Círculos de Otterlo: «The Shape of inbetween», «Steps towards a configurative discipline» $y$ «The vernacular of the Hearth».

\footnotetext{
${ }^{24}$ Ver epígrafe 3.1.2.2.del capítulo anterior.
} 


\subsubsection{Aldo van Eyck y el CIAM X en Dubrovnik. Identidad versus escalas de asociación. Los viajes de Aldo Van Eyck al Norte de Africa, playgrounds y la experiencia de Nagele.}

En el congreso de Dubrovnik, el decimo congreso CIAM, Aldo van Eyck presentó dos grid: Lost identity, formada por cuatro paneles y explicativa de su experiencia con los playgrounds en Amsterdam, y una segunda también formada por cuatro paneles sobre el proyecto de un nuevo asentamiento en Nagele, fruto del trabajo en equipo del grupo De 8 en Opbouw, en el recién drenado polder de noreste. En ambos proyectos se trabaja con el concepto de identidad, con diferencias significativas respecto a las de las presentadas por los Smithsons, especialmente interesados en las escalas de asociación.

Nagele se desarrolla en dos fases durante el periodo entre 1947 y 1954. La primera, 1947-1949, en la que el grupo de Amsterdam de 8, trabaja en la propuesta para un nuevo asentamiento con la premisa de 300 viviendas, como tema para desarrollar de cara al CIAM de 1949 a celebrarse en Bérgamo y dedicado a los asentamientos humanos. La segunda, entre 1952 y 1954, en la que ya con un encargo en firme para el desarrollo del proyecto y una previsión de 500 viviendas, se terminará de definir la morfología y organización de la estructura urbana definitiva, siendo desarrollada conjuntamente por de 8 en Opbouw ${ }^{25}$, en un singular proceso colectivo. Nagele es una experiencia excepcional del proyecto moderno. Un asentamiento agrícola en una sociedad altamente industrializada, aparente contradicción que caracteriza en gran medida los Países Bajos. Un proyecto comunitario del grupo De 8 en Opbouw en el periodo de reconstrucción europea posterior a la Segunda Guerra Mundial. Una experiencia seguramente imposible en otro momento y lugar. Su creación ex novo en un gran polder ganado al mar, más su condición moderna doblemente excepcional, por única entre los nuevos asentamientos realizados en el Zuiderzee, y por la arquitectura de los mejores exponentes de la Nueva Objetividad holandesa, lo hacen verdaderamente singular.

«Dios creó el mundo, pero los holandeses crearon Holanda ${ }^{26}$,. Un trayecto en coche hasta Nagele, indispensable para comprender la dimensión de la intervención humana en el territorio y como los holandeses verdaderamente han construido su país, impresiona al viajero extranjero.

Este trabajo plantea un punto de vista poco explorado en el análisis crítico ${ }^{27}$ del pensamiento de Aldo van Eyck en relación al binomio territorio-arquitectura, desarrollado más extensamente en el epígrafe siguiente, y que en gran medida se conforma durante los años del proyecto para el nuevo asentamiento de Nagele: El territorio como principal generador de su estructura urbana, por encima de cualquier otro parámetro, y cómo el proceso de desarrollo del proyecto del nuevo asentamiento influye en la formación del pensamiento de Van Eyck de forma determinante. En como el origen, la escala y la condición artificial del Noordoostpolder, son los condicionantes a partir de los que se genera y explica. En como las decisiones determinantes de la

${ }^{25}$ Inicialmente el equipo de trabajo estuvo formado por dieciséis miembros -casi la totalidad excepto Elza y Karmen-:del grupo de Amsterdam de 8: W. van Bodegraven, A. Bodon, J. Bijhouwer, C. van Eesteren; P. Elling; A. van Eyck, W. van Gelderen, M. Kamerling, J.P. Kloos, B. Merkelbach, J. Niegeman, G. Rietveld, M. Ruys, H. Salomonson, M. Stam y C. de Vries. En la segunda fase del proyecto (1952-1954) se le unieron cuatro miembros del grupo de Rotterdam Opbouw: Bakema, Hovens Greve, W.Boer and R.de Vries, formando de 8 en Opbouw. (Strauven 1998)

${ }^{26}$ Dicho popular holandés.

${ }^{27}$ El estudio más completo sobre Nagele es el desarrollado por Francis Strauven. Publicado en la monografía Aldo van Eyck. The Shape of Relativity, la calidad y densidad de la información que aporta, y la contextualización de los contenidos a través de bloques temáticos organizados cronológicamente, lo convierten en un texto de obligada consulta en cualquier acercamiento a la materia. 
solución finalmente adoptada gravitan de una u otra forma alrededor de esta idea. La cuestión no es menor, pues un repaso al resto de asentamientos realizados en condiciones similares, evidencia la excepcionalidad de Nagele $^{28}$, poniendo en valor el intenso trabajo a contracorriente, de debate y reflexión hasta la consecución de la configuración final. El proceso de búsqueda de De 8 en Opbouw y de Aldo van Eyck en particular para dotar de identidad al nuevo asentamiento frente a la condición de no lugar del polder, de territorio sin atributos, se convertirá en fundamental y decisivo.

Los siete años entre 1947 y 1954, en los que desarrolla el proyecto de Nagele, determinan un periodo característico en la vida de Aldo van Eyck. Además de establecer con Hannie van Roojen su residencia en Amsterdam después de la guerra, entre 1946 y 1951, año en que renuncia, trabaja en el Public Work Department de la municipalidad de Amsterdam, aunque como freelance seguirá siendo el arquitecto responsable del diseño de playgrounds hasta $1954^{29}$.

Por último, y fundamental en esos mismos años, son sus tres primeros viajes al norte de Africa entre 1947 y 1952 en busca de "lo elemental", de las formas primarias del lenguaje visual.

Durante los años de Nagele, Van Eyck, trabaja simultáneamente con dos escalas extraordinariamente antagónicas, la de un asentamiento completo y la de un juego de arena. En ambas persiguiendo materializar el concepto de identidad, antes que el de escalas de asociación ${ }^{30}$. No es casualidad, que las dos "grid" presentadas por van Eyck en Dubrovnik al CIAM X, se correspondan con esos proyectos y aborden el tema con independencia de la escala. En la primera, varios ejemplos de playgrounds en Ámsterdam, con el título The child and the city, expone el problema de la identidad perdida, lost identity, aportando como contribución la experiencia de Amsterdam. En la segunda, como integrante del grupo de 8, presenta Nagele. «a large territory claimed from the sea; man made, geometric -visually unlimited- windswept».

En la búsqueda de van Eyck y de 8 en Opbouw, para dotar de identidad al nuevo asentamiento frente a la condición de territorio sin atributos del polder, se proponen dos referencias: el jardín clásico holandés y la influencia de los viajes al Sahara, cerrando así el círculo de las tres tradiciones: la moderna de Nagele, la clásica de la jardinería holandesa del XVII, y la vernácula de la arquitectura del desierto argelino. En este sentido, la experiencia de Nagele y los playgrounds en Amsterdam, serán las primeras experiencias de envergadura, pioneras y resultado, de la interacción de las tres tradiciones que quedarán plasmadas en los Circulos de Otterlo.

\footnotetext{
${ }^{28}$ El polder del Nordeste Noord-Oost-Polder, se drenó durante la Segunda Guerra Mundial, como una gran extensión de producción agrícola, dentro del proyecto de grandes reclamaciones de terreno en el Zuiderzee. Para su colonización, se contaba con la experiencia inmediatamente anterior del Wieringenmeer-polder, para el que se había creado la Junta Ejecutiva de Wieringermeer, cuya filosofía sobre la materialización física de los pueblos se basaba en el texto publicado en 1929 por D. Hudig Het toekomstig landschap der Zuiderzeepolders, El futuro paisaje de los polders del Zuiderzee, adaptaba los principios de Camilo Sitte a la situación holandesa, sentando las bases para su aplicación en los asentamientos y paisajes rurales de los nuevos polders. Aunque fueron necesarias la ingeniería y las técnicas más avanzadas del momento para la polderización de superficies tan extensas, se abogaba una arquitectura emuladora de la tradicional28 - Delft School- con la que se realizaron todos los asentamientos bajo la supervisión de Grandpré Moliere y P.Verhagen (Strauven 1998). Nagele, fue el último en acometerse y la única excepción.

${ }^{29} \mathrm{El}$ excesivo retraso en la entrega de los encargos, es la queja expuesta por la administración, para a partir de esa fecha encargar menos proyectos a van Eyck y comenzar a contratar a otros arquitectos. Aunque su trabajo se prolongará hasta 1978, es el periodo entre 1947 y 1954, el más representativo y de más intensidad.

30 Tema abordado por Alison y Peter Smithson en Dubrovnik, donde presentaron diferentes tipo de comunidad: aislada, pequeña, grande, pueblo y ciudad, con los ejemplos respectivos de Burrows Lee Farm, Galleon Cpttages, Fold Houses, Close Houses y Terraced Houses
} 
Figura 3.10

Imagen a doble página de parte de la colección de arte primitivo de Aldo Van Eyck.

Imágenes

publicadas, posiblemente las únicas, en 1986 por el propio Van Eyck en Niet om het even... wel evenwaardig, van en over Aldo van Eyck, con el mismo formato y en continuidad una de otra como aquí se presentan (Van Eyck 1986, 8)
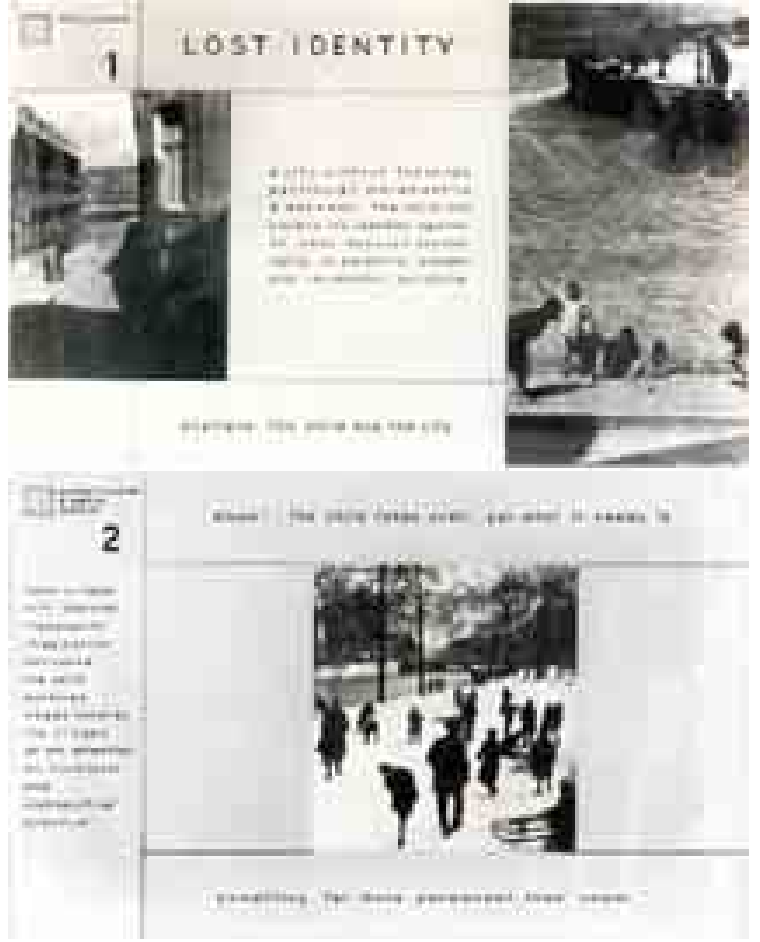

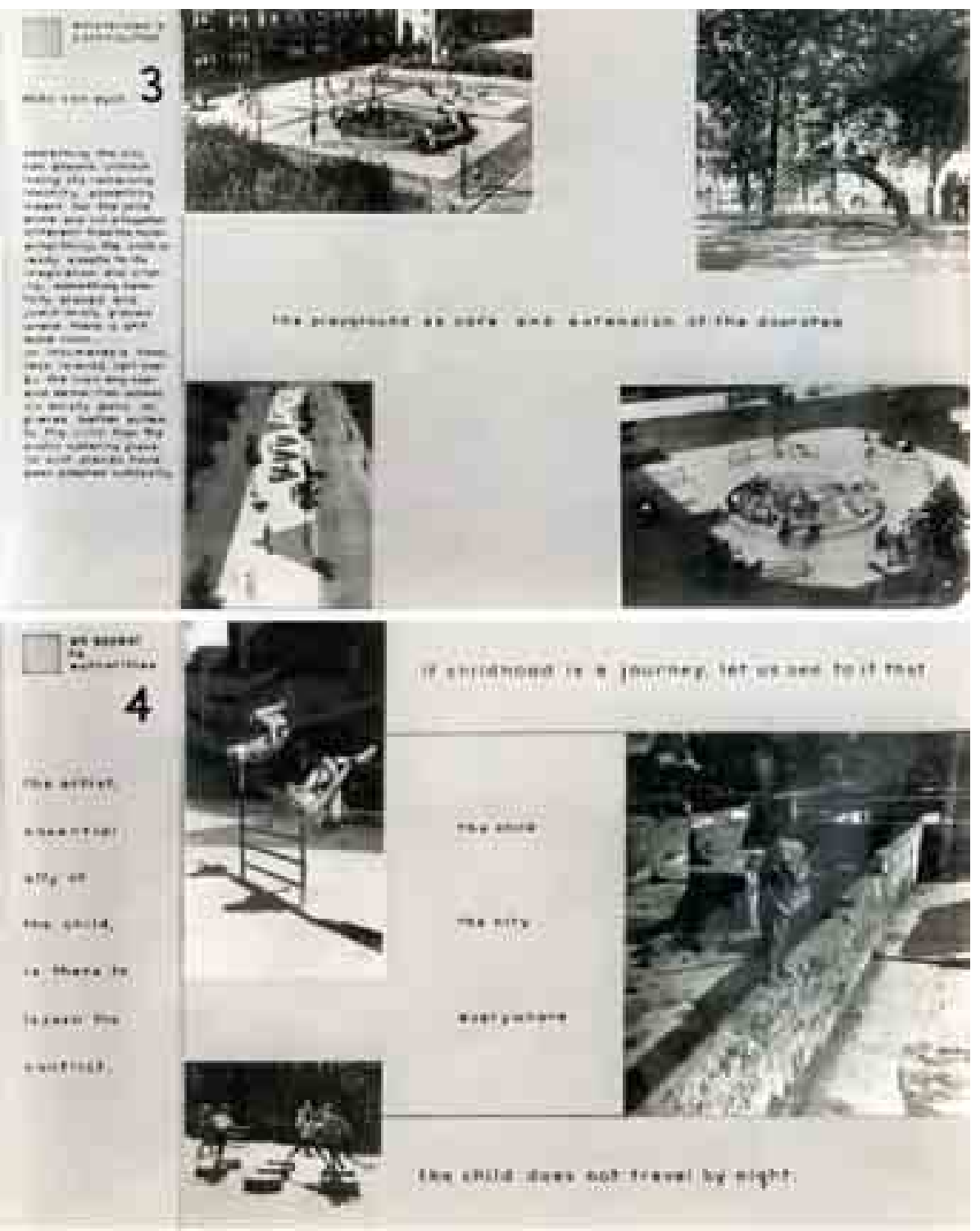




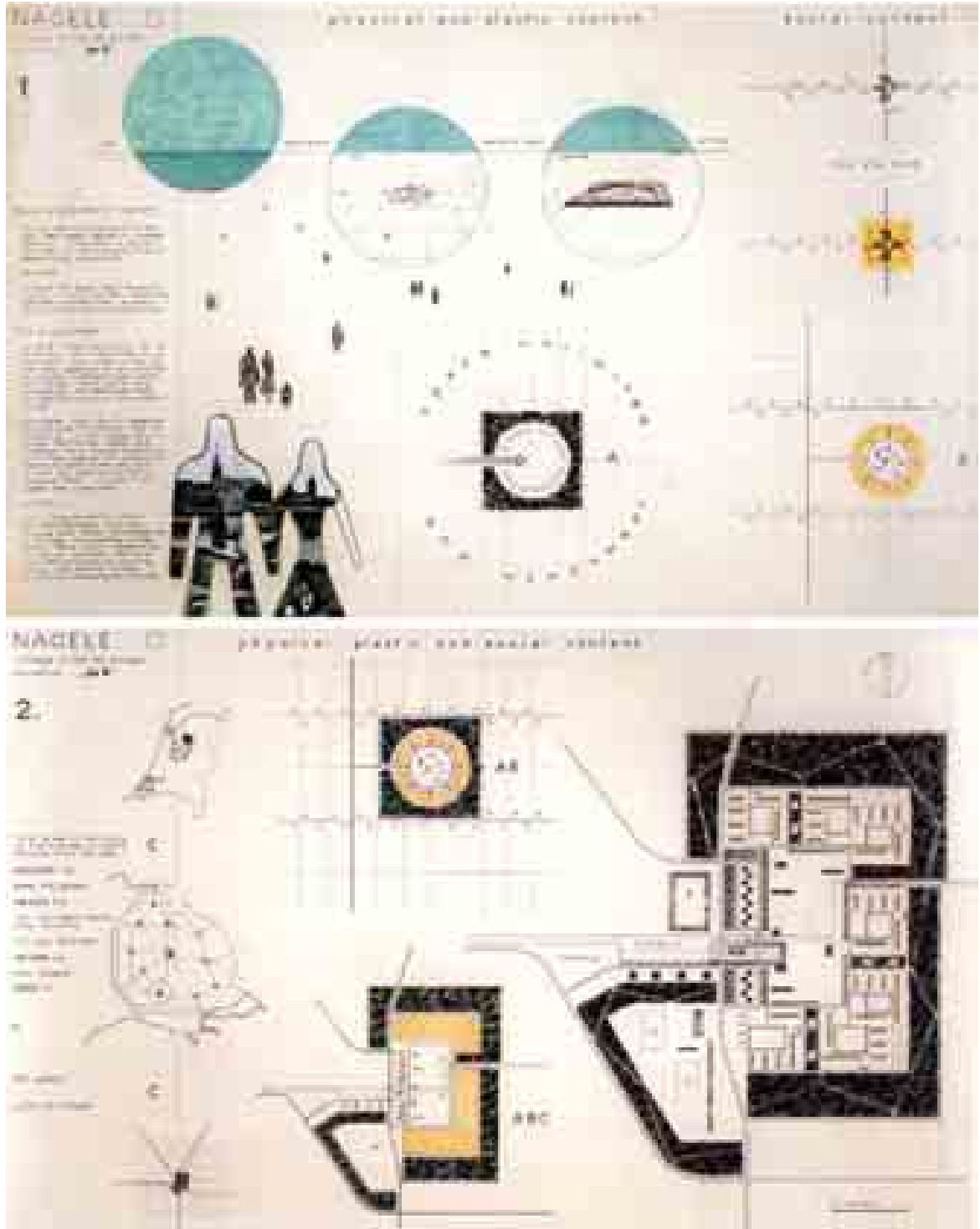

Figura 3.11

Imagen a doble página de parte de la colección de arte primitivo de Aldo Van Eyck.

Imágenes

publicadas,

posiblemente las únicas, en 1986 por el propio Van Eyck en

Niet om het even... wel

evenwaardig, van en over Aldo van Eyck, con el mismo formato $y$ en continuidad una de otra como aquí se presentan (Van Eyck 1986, 8)

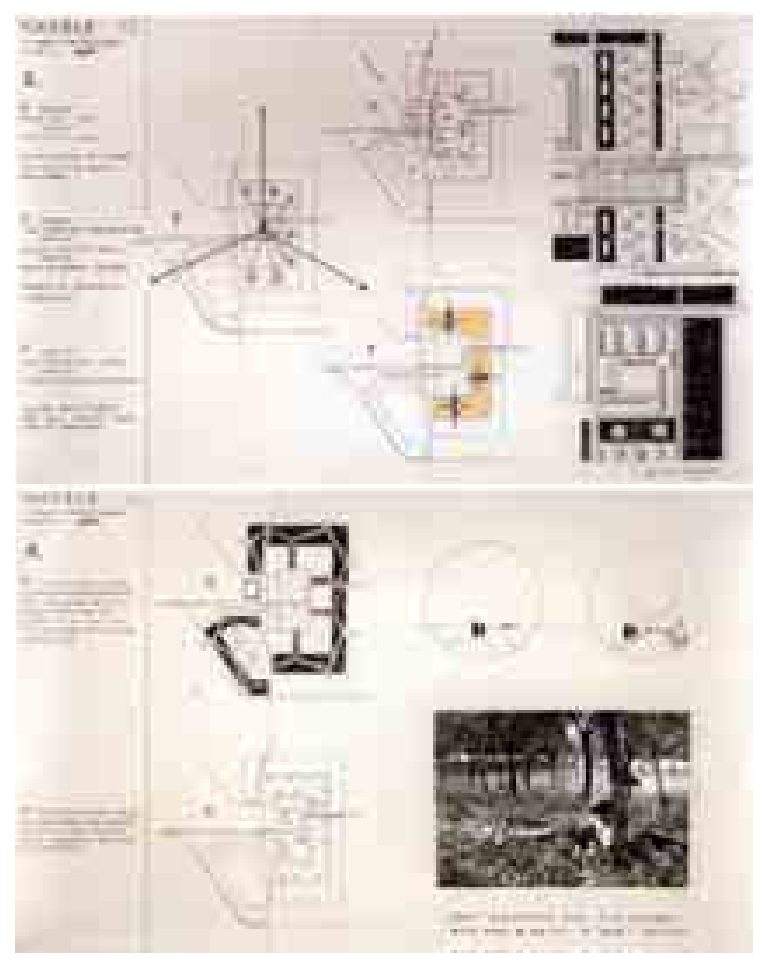




\subsubsection{Los Círculos de Otterlo y la tradición vernácula}

«El hombre es siempre el mismo y en todas partes esencialmente el mismo. Posee las mismas herramientas mentales, aunque las usa diversamente según su trasfondo cultural o social, de acuerdo con la particular modalidad de existencia de la que forma parte. La arquitectura moderna ha estado porfiando continuamente sobre lo que es diferente en nuestro tiempo, hasta el punto que incluso se ha perdido contacto con lo que no es diferente, con lo que siempre es esencialmente lo mismo» ${ }^{31}$

Después de la Segunda Guerra mundial, se planificaron y realizaron nuevos barrios excepcionalmente extensos, para dar respuesta a las necesidades de las ciudades modernas de proporcionar alojamiento digno, salubre, económico y rápido de construir. En Amsterdam se desarrollan 50.000 viviendas en 12 años, en el marco del Plan General de 1935 de C. Van Esteren. Estos nuevos fragmentos urbanos resultaron en muchos casos decepcionantes al no generar una ciudad con valores suficientemente positivos.

Aldo van Eyck enseguida comprende que las soluciones dadas no satisfacen las necesidades de la sociedad del momento, y en ese sentido percibe la incapacidad de la arquitectura para dar respuestas y soluciones adecuadas. Argumenta que la planificación holandesa de posguerra, en la que él mismo ha participado, ha producido únicamente el ninguna parte inhabitable organizado de la ciudad funcional. Identifica esa incapacidad de dar respuestas, como resultado del vacío cultural dejado por la pérdida de lo vernáculo, también había significado la desaparición del concepto de lugar. Teniendo constancia del problema, van Eyck investiga en el redescubrimiento e incorporación de lo que el llama «principios arcaicos de la naturaleza humana», que le abren nuevas direcciones en la búsqueda de respuestas a los problemas planteados, y refleja en los diagramas de los Circulos de Otterlo, que presenta en el congreso del mismo nombre, y en el que se consolida Team X como grupo de trabajo y reflexión, encabezado especialmente por Aldo van Eyck, y los Smithson.

Sus planteamientos se concentrarán principalmente en dos cuestiones: el concepto de relación que toma forma en "in between" y la configuración de número ${ }^{32}$.
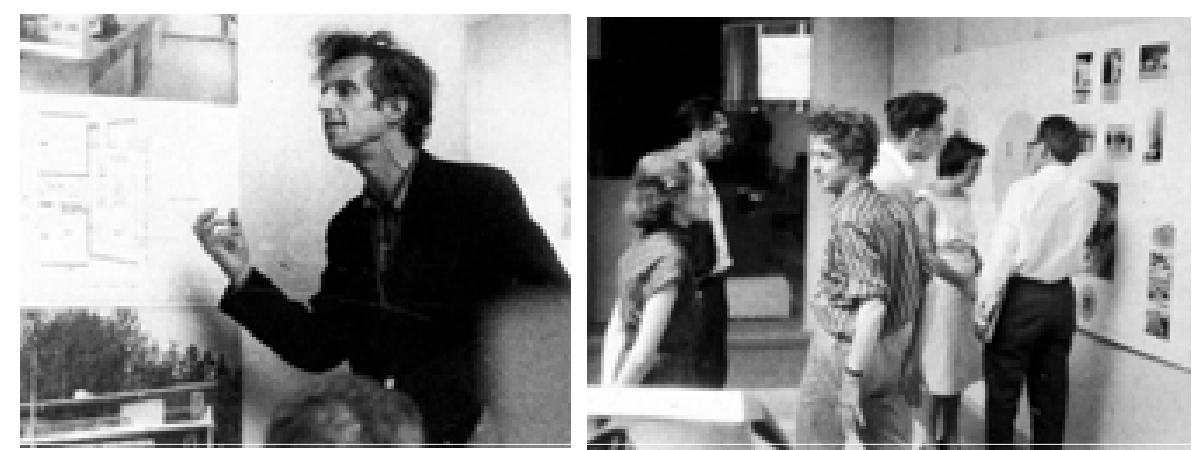

Figura 3.12

Imágenes del Congreso de Otterlo en 1959

A la izquierda, Aldo van Eyck en su presentación. A la derecha un grupo de asistentes, entre ellos Van Eyck, Alison Smithson y Coderch, observan la primera versión de los Circulos de Otterlo. (Strauven 1988)

\footnotetext{
31 «Man is always and everywhere essentially the same. He has the same mental equipment though he uses it differently according to his cultural or social background, according to the particular life pattern of which he happens to be a part. Modern architecture has been harping continually on what is different in our time to such an extent even that it has lost touch with what is not different, with what is always essentially the same» (Van Eyck 1959 b.)

Traduccion de Ana Rodríguez

${ }_{32}$ 'Para Van Eyck, lo intermedio entre dos, in-between, era una idea con la que estaba familiarizado a través de la poesía desde su juventud, y su preocupación por el número le relaciona con los primeros esfuerzos de Bakema en los proyectos del nuevo barrio de Rotterdam, y con el apasionado interes de Candilis por la construir para el mayor número.
} 
En septiembre de 1959 se celebró el Congreso de Otterlo en el Museo Kröller-Müller, construido por Henry van de Velde en 1937, donde también se celebraban de manera informal las reuniones editoriales de la revista Forum. De hecho, el primer número de la nueva etapa de la revista, "La Historia de Otra Idea» del que ya se ha hablado en epígrafes anteriores, se había previsto para ser una introducción de las ideas de Team $10^{33}$ para los participantes en el CIAM XI.

Durante seis de los ocho días de duración del congreso, cada participante exponía sus proyectos para ser debatidos en grupo apasionadamente, sin intervención de moderador $^{34}$. Esta frenetica actividad fue expresada por Alison Smithson como «el hambre o el agotamiento mental eran las únicas limitaciones aceptadas en el trabajo»35

Aldo van Eyck presentó en el congreso los proyectos del Orfanato de Amsterdam, el Centro de Congresos de Jerusalen, las esculeas de Nagele y el proyecto de Piet Blom «las ciudades serán habitadas como pueblos», pero antes hizo una brillante introducción en la que expuso sus ideas sobre «los principios arcaicos de la naturaleza humana»y sobre las tres tradiciones relacionadas entre si.

Para van Eyck, el mantenimiento de la dialéctica de partes opuestas es una condición necesaria para el desarrollo de una verdadera arquitectura contemporánea. Se identifica con la visión del mundo de la vanguardia del siglo XX, y a partir de este moderno punto de vista, desarrolla una original visión de la historia, basada en la interrelación o el in-between de las tres grandes tradiciones: la clásica, la moderna y la arcaica o vernacular.

Formula su teoría y la visualiza con un sorprendente diagrama de dos círculos, cuya primera versión fue primicia en el Congreo de Otterlo que les da nombre, y que probablmente sea la primera formulación teórica de las relaciones entre la arquitectura moderna con la tradición vernácula.

En su presentación empezó estableciendo dos maneras de ver el mundo: la euclidiana, que comprende prácticamente toda la historia de la humanidad y la contemporanea no-euclidiana bajo la que se desarrolla el arte moderno de las vanguardias de principio del siglo XX. Pero el hombre no es de ninguna de las dos maneras en particular. Sus problemas esenciales son los mismos que los de hombres arcaicos, y después de todo solo somos hombres arcaicos. Le interesan las culturas ancestrales y dice «personalmente, lo que quiero en arquitectura, es hacer apasionadamente lo antiguo» ${ }^{36}$. En el mundo moderno todo esta cerca, por lo que es posible decubrir y conocer culturas remotas que nos enriquezcan, «no para copiarlas, no por eclecticismo, sino para entender más profundamente el misterio del hombre» ${ }^{37}$ La utilización de tres imágenes arcaicas en el círculo de la derecha, que en la segunda versión de los círculos, serán sustituidas por una única fotografía de una danza de los indios Kayapó, representan precisamente eso: las relaciones y necesidades humanas inmanentes a todos los hombres, mujeres y niños constantes en espacio y tiempo, y a su vez constantemente cambiantes.

El círculo de la izquierda alberga tres imágenes históricas. La primera, una contraconstrucción de Theo van Doesburg, como símbolo del pensamiento noeuclidiano, representa la tradición moderna. Las otras dos, simbolizan «el maravilloso orden euclidiano» y correponden al fundamental deseo humano de límite. El hombre necesita espacio abierto y cerrado: El hombre respira hacia dentro y hacia fuera; no es posible hacerlo en un solo sentido.

${ }^{33}$ Para una detallada explicación sobre la escisión de Team 10 como grupo ver (Strauven 1998, 347)

${ }^{34}$ Ver capitulo siguiente sobre Coderch y el documento inédito de su carta enviada a Bakema, en la que habla de lo encendido y apasionado del debate.

35 «hunger or mental exhaustion were the only accepted limitation to work» (Strauven 1998, 347)

${ }^{36}$ «What I want in architecture personally, is passionately to do the old» (Van Eyck 1959 a)

${ }^{37}$ "not by copying, not by eclecticism, but by more deeply understanding the mystery of man" (Van Eyck 1959 a) 
Sobre estas tres imágenes, Van Eyck dice apasionadamente:

«las tres pequeñas fotografías unidas en el primer circulo son simbolos no de aspectos conflictivos, sino de aspectos parciales. Llevo enamorado de las tres durante hace años, con los valores divididos entre ellas. No puedo separarlas por más tiempo. Simplemente, no puedo. Se complementan entre si, van de la mano. (...) -y podemos empezar a reconciarlas - la esencia, no la forma-»38

Los dos círculos quedan unidos por la siguiente frase: «el hombre todavía respira hacia dentre y hacia fuera; ¿Cuándo la arquitectura va a hacer lo mismo?»39

La presentación de Van Eyck tuvo un fuerte impacto entre los asistentes. Al final de su introducción y antes de explicar los proyectos, fue interpelado por Wendell H. lowet, un arquitecto americano que dos días antes había presentado un proyecto de vivienda unifamiliar que fue severamente criticado por Peter Smithson y algo mas moderamente por el propio Van Eyck, con cierta critica por desviarse de las reglas establecidas para el congreso, exponiendo su filosofia personal en vez de los proyectos.

Ante lo cual, Alison Smithson respondió: «Aldo no está manifestando su filosofía individual, está enunciando nuestra filosofía, la filosofía del grupo»40

En la segunda versión del diagrama, preparada por Van Eyck en 1962 para su inclusión en The Child, the City and the Artist, se cambian algunas imágenes y su grafismo, manteniendo el mismo sentido.

En el primer círculo, a la izquierda, representa y caracteriza cada una de las tres tradiciones con una imagen paradigma:

- el paradigma clásico, "inmutabilidad y memoria", con el Partenón

- el paradigma moderno, "el cambio y el movimiento", con una contra-construcción de Van Doesburg

- el paradigma arcaico, "la lengua vernácula del corazón", con la planta de una aldea de los indios Pueblo.

Plantea la tesis de que estas tres tradiciones no deben considerarse mutuamente excluyentes, sino que deben conciliarse con el fin de desarrollar una arquitectura con un potencial formal y estructural suficientemente ricos para dar respuesta a la compleja realidad de la vida contemporánea. Los paradigmas de las tres tradiciones se unen en un gran círculo que representa el "reino de la arquitectura".

Este reino está claramente relacionado con otro diferente, la realidad de las relaciones humanas que se resume en el circulo de la derecha con una imagen de la danza de los indios Kayapó.

Los cuerpos de los bailarines forman un muro humano de forma circular - o más bien espiral - en torno a un centro abierto que se expande o se contrae según la espiral se relaja y tensa al ritmo de la danza.

La arquitectura tiene que hacer frente a esta "constante y en constante evolución» realidad humana, es decir, no sólo con lo que es diferente del pasado, sino también con lo que se ha mantenido igual.

\footnotetext{
38 «The three little photographs united in the first cicle are symbols not of conflicting aspects, but of partial aspects. I have been in love with all three for years, with the values divides between them. I can't separate them any more. I simply can't. They complement each other, belong together. (...) -and we can star reconciling them- the esssence, not the form-» (Van Eyck 1959 b)

${ }_{39}$ «Man still breathes both in and out; when is architecture going to do the same?» (Van Eyck 1959

b). Traducción de Ana Rodríguez.

${ }^{40}$ «Aldo is not stating his individual philosophy, he is stating our philosophy, the philosophy of the group» (Van Eyck 1959 b) Traducción de Ana Rodríguez.
} 

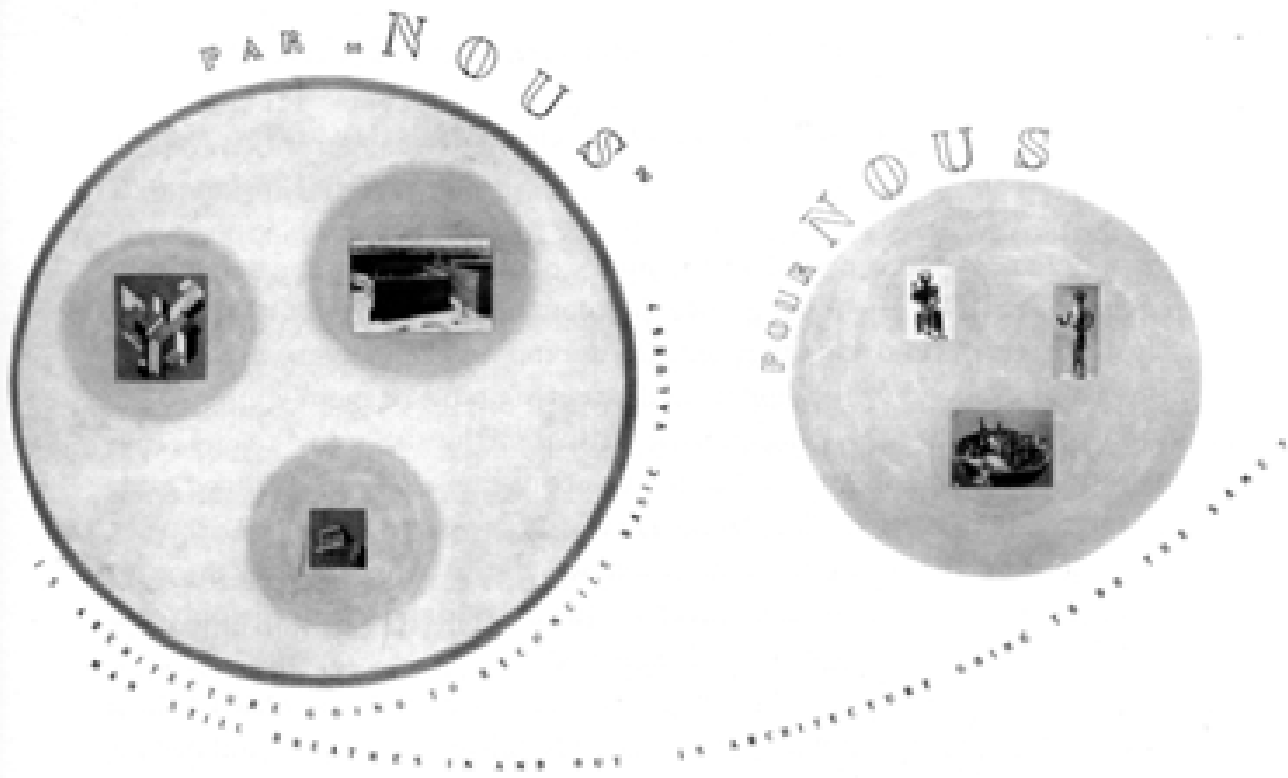

$1^{\circ}$ circulo

$2^{\circ}$ circulo

\section{PAR NOUS}

IS ARCHITECTURE GOING TO RECONCILE BASIC VALUES?

POR NOSOTROS

¿VA LA ARQUITECTURA A RECONCILIAR VALORES BÁSICOS?

\section{POUR NOUS}

MAN STILL BREATHES IN AND OUT. IS ARCHITECTURE GOING TO DO THE SAME?

\section{PARA NOSOTROS}

EI HOMBRE TODAVÍA ASPIRA Y EXPIRA. ¿VA A HACER LA ARQUITECTURA LO MISMO? 


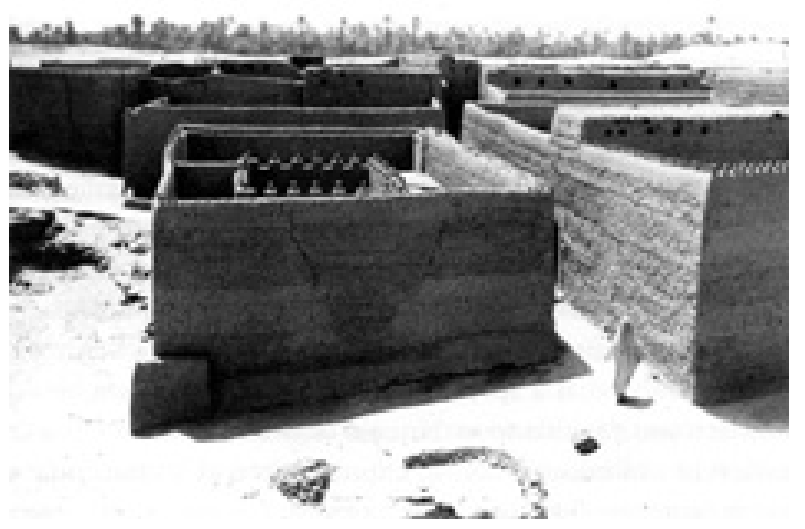

Tradición Vernácula

Construcción espontanea. Grupo de casas en el pueblo del Aoulef, Sahara argelino

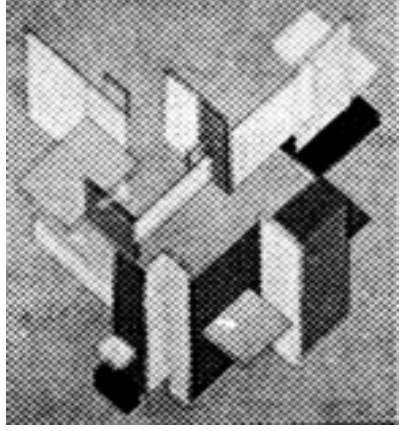

Tradición Moderna

Una contra-construcción de

Theo van Doesburg

Maison particulière 1923
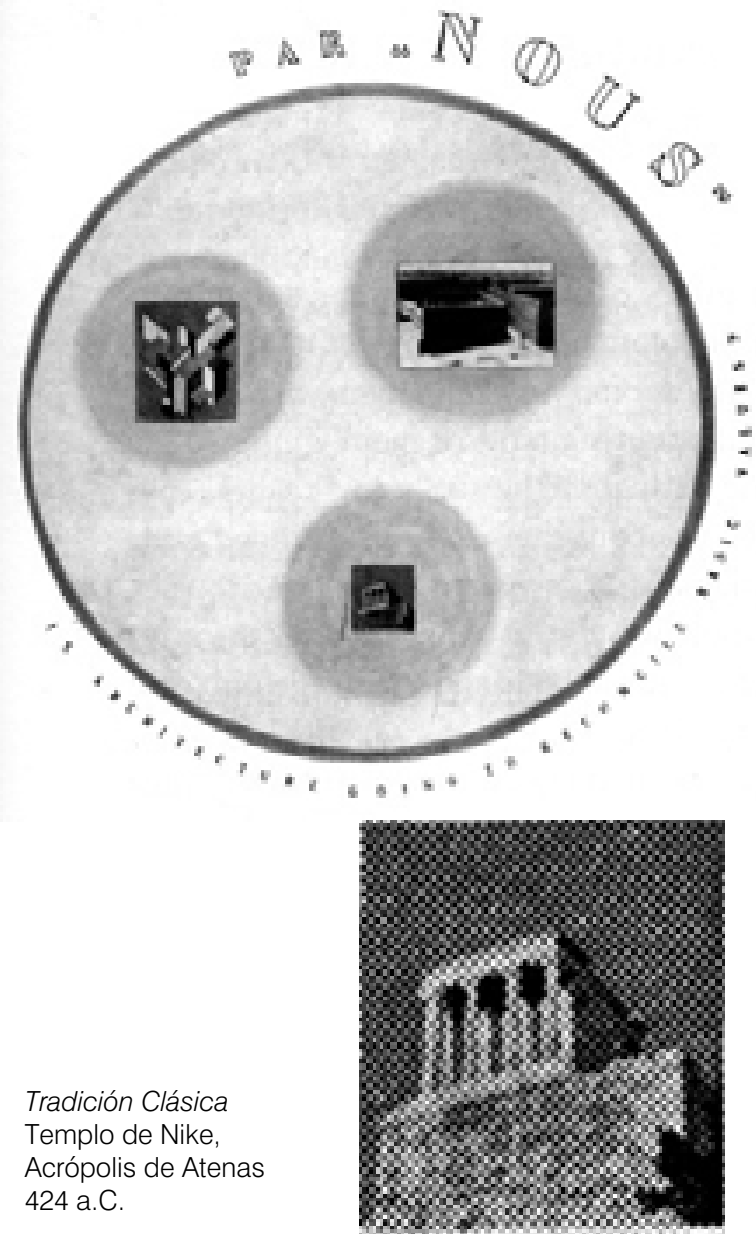

Figura 3.14

Primera versión de los Círculos de Otterlo, presentada por Aldo van Eyck en el congreso de Otterlo en 1959. Imágenes que componen el círculo izquierdo "Par Nous", aquí en el centro. (Ligtelijn y Strauven 2008, 201) 
Escultura de la edad de bronce

Estatuilla etrusca de un hombre de pie

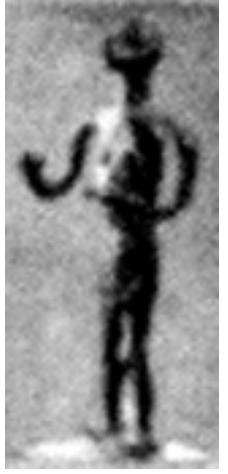

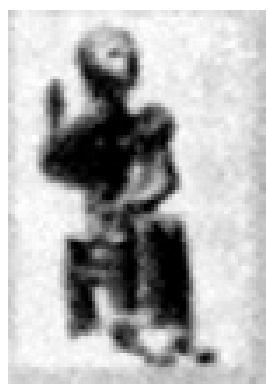

Escultura de la edad de bronce

Estatuilla Sardic de mujer sentada con niño
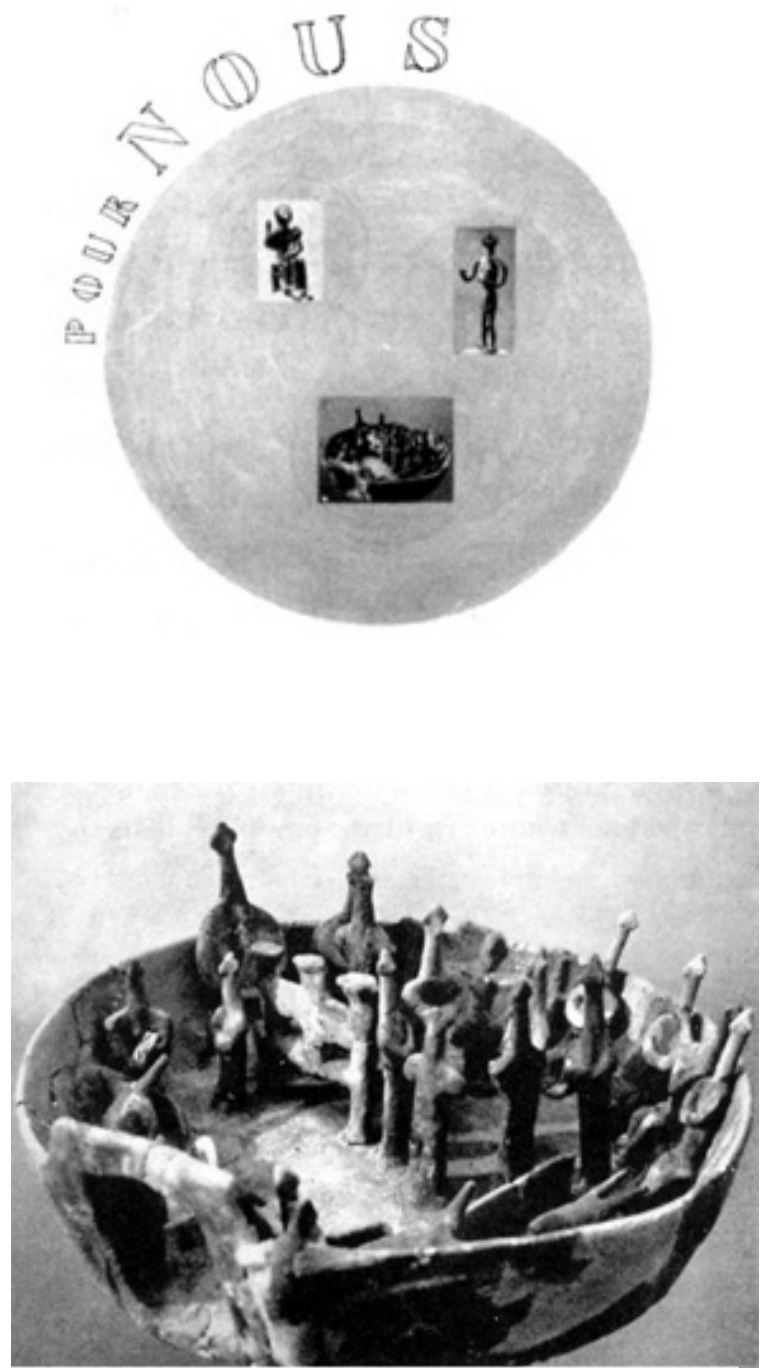

Escultura de la edad de bronce

Presente funerario en Chipre.

Plato circular decorado con una pequeña comunidad de personas

2100 a.C

Figura 3.15

Primera versión de los Círculos de Otterlo, presentada por Aldo van Eyck en el congreso de Otterlo en 1959. Imágenes que componen el círculo derecho "Pour Nous", aquí en el centro. (Ligtelijn y Strauven 2008, 201) 


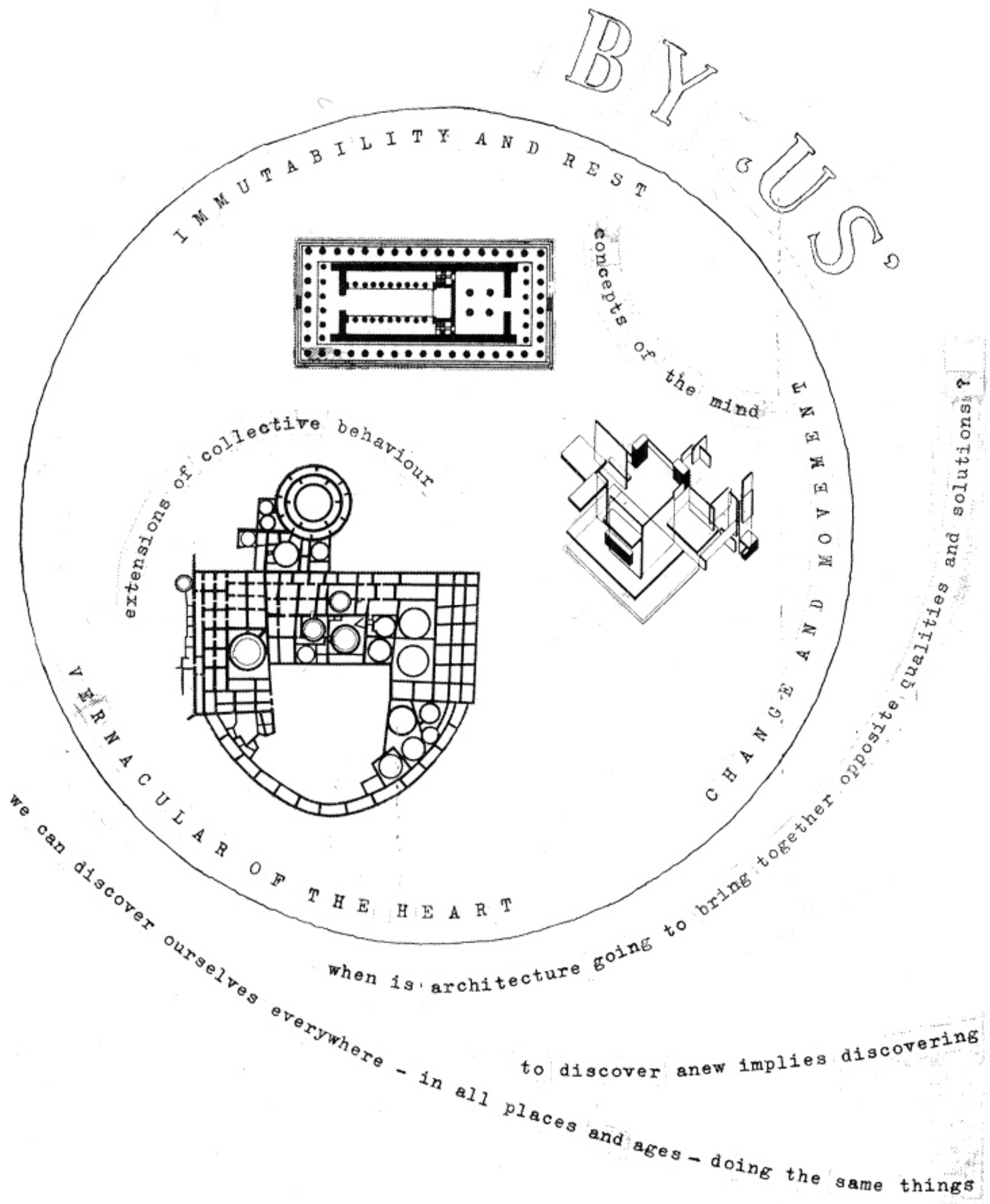




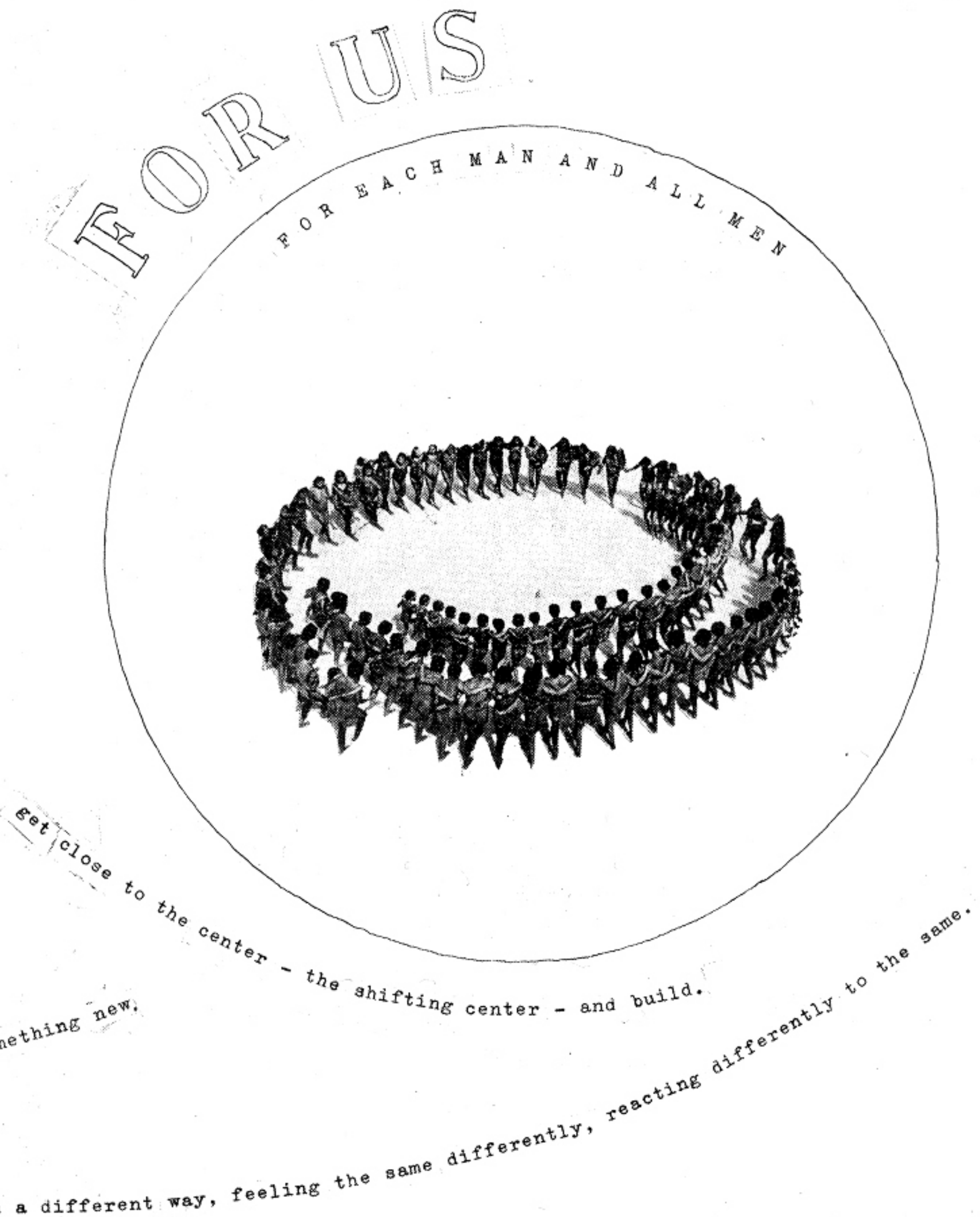

Figura 3.16

Diagrama de los Círculos de Otterlo, Segunda versión, preparada junto con el texto The Otterlo Circles para su inclusión en el libro The Child, the City and the Artist en 1962. El texto fue publicado por primera vez en Via 1, Ecology in Design, en1968, después de una versión reducida publicada en Forum en julio de 1967 (Ligtelijn y Strauven 2008, 467) 


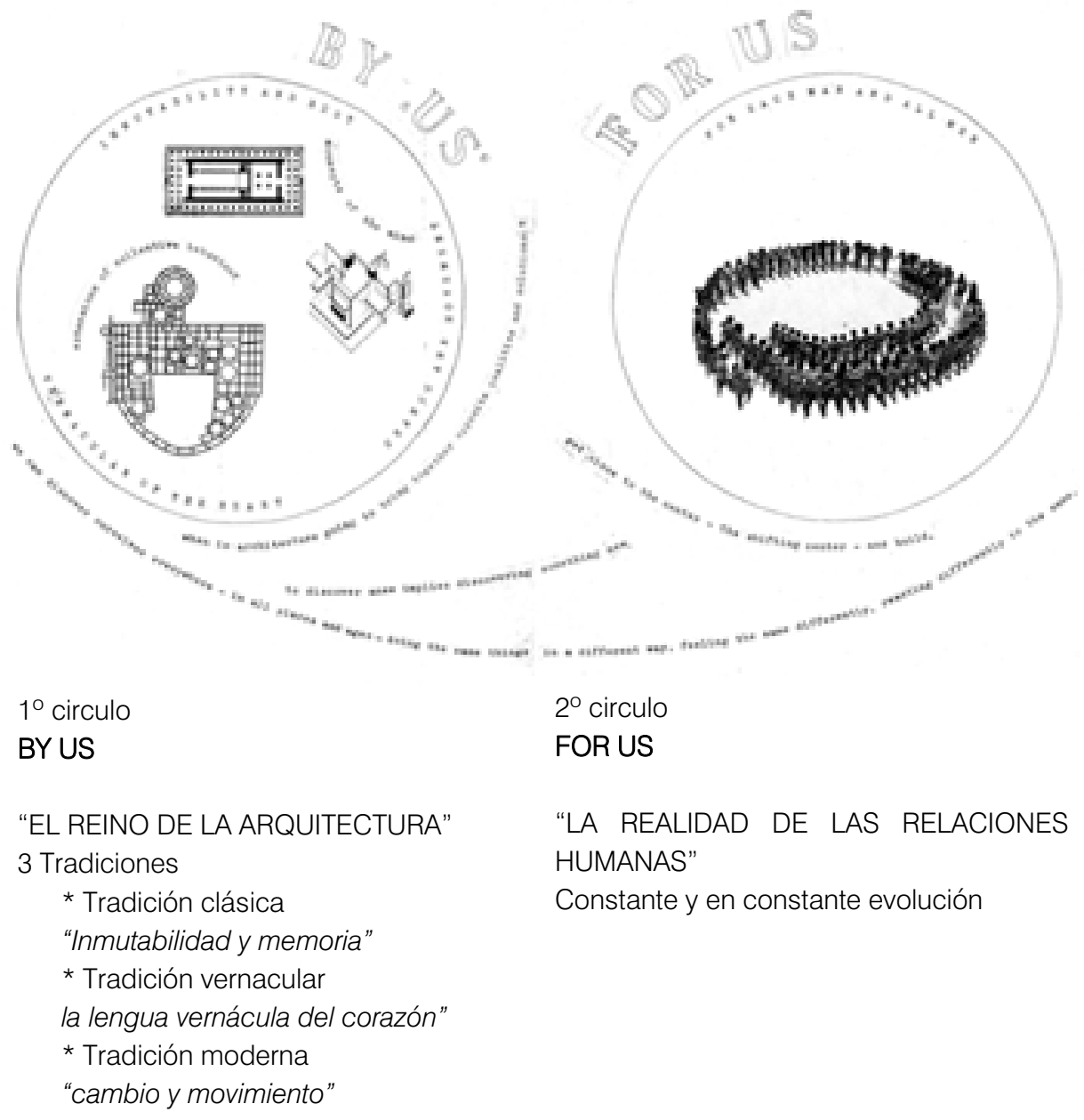

\section{BY US}

IMMUTABILITY AND REST

Concepts of the mind

CHANGE AND MOVEMENT

VERNACULAR OF THE HEART

Extensions of collective behavior

WHEN IS ARCHITECTURE GOING TO

BRING TOGETHER OPPOSITE QUALITIES

AND SOLUTIONS?

\section{POR NOSOTROS}

INALTERABILIDAD Y MEMORIA

(huella, alma, testimonio, vestigio, resto)

Conceptos intelectuales (de la mente)

(ideas producto del pensamiento)

CAMBIO Y MOVIMIENTO

VERNACULAR/VERNACULO DE EL

CORAZON

Prolongaciones del comportamiento

(conducta) colectivo

¿CUÁNDO VA LA ARQUITECTURA A AUNAR

CUALIDADES Y SOLUCIONES OPUESTAS?

\section{FOR US}

FOR EACH MAN AND ALL MEN

get close to the center -the shifting centerand build

TO DISCOVER A NEW IMPLIES

DISCOVERING SOMETHING NEW

\section{PARA NOSOTROS}

PARA CADA HOMBRE Y TODOS LOS HOMBRES

Acercarse al centro -el centro cambiante-y construir.

DESCUBRIR DE NUEVO (REDESCUBRIR) IMPLICA DESCUBRIR ALGO NUEVO.

Podemos descubrirnos a nosotros mismos en cualquier parte - en todos los lugares y en todos los tiempos - haciendo las mismas cosas de forma diferente, sintiendo lo mismo de forma diferente, reaccionando de forma diferente ante lo mismo.

Figura 3.17

Diagrama de los Círculos de Otterlo, Segunda versión

Detalle de los textos (Ligtelijn y Strauven 2008, 467). Traduciion Ana Rodríguez 
Tradición Clásica

Partenón, Atenas, 438 a.C.

Revista Forum 1959-1963

Tradición Vernácula

Pueblo Arroyo, Nuevo Méjico. Siglo XI

Revista Forum

1959-1963

Tradición Moderna

Una contra-construcción de Theo van Doesburg

Maison particulière 1923

Revista Forum

1959-1963
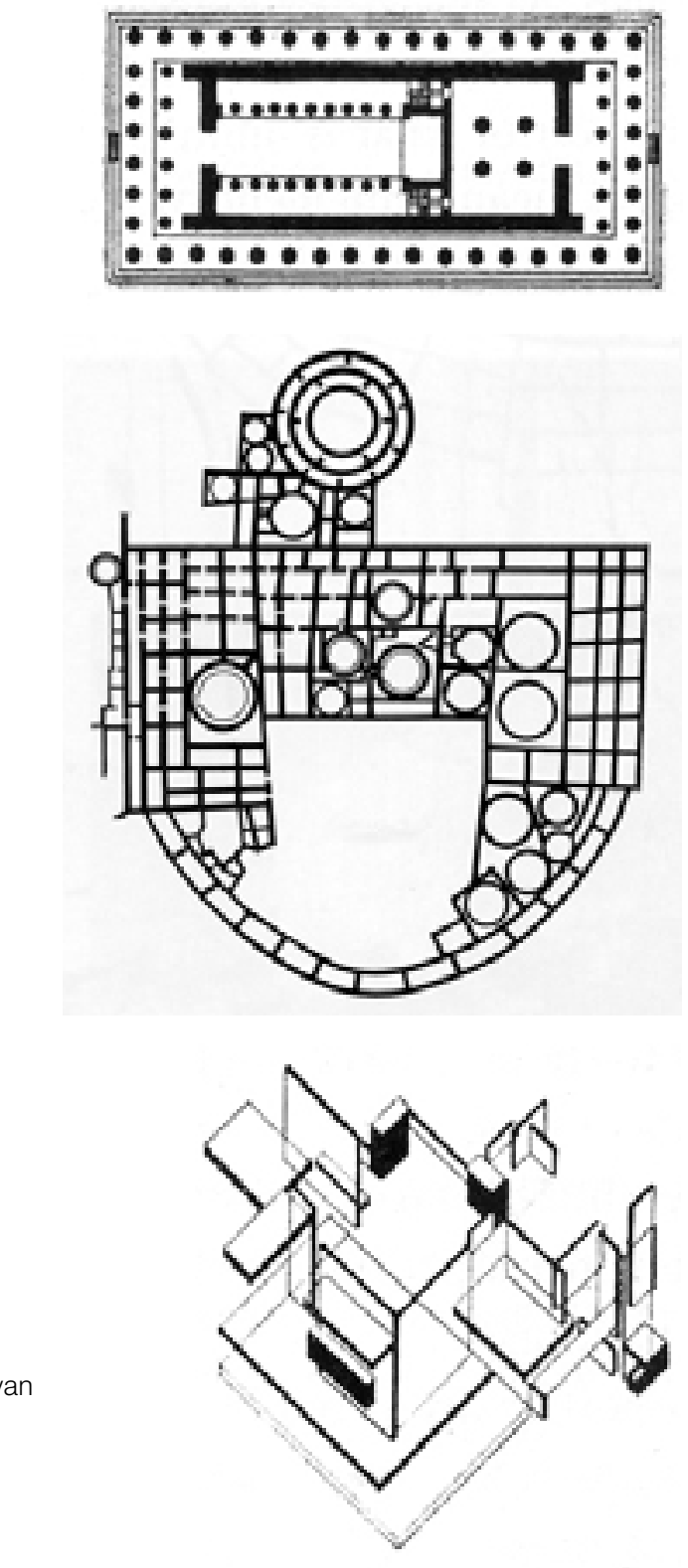

Danza de un grupo de indios Kayapo de la cuenca del Orinoco en Venezuela

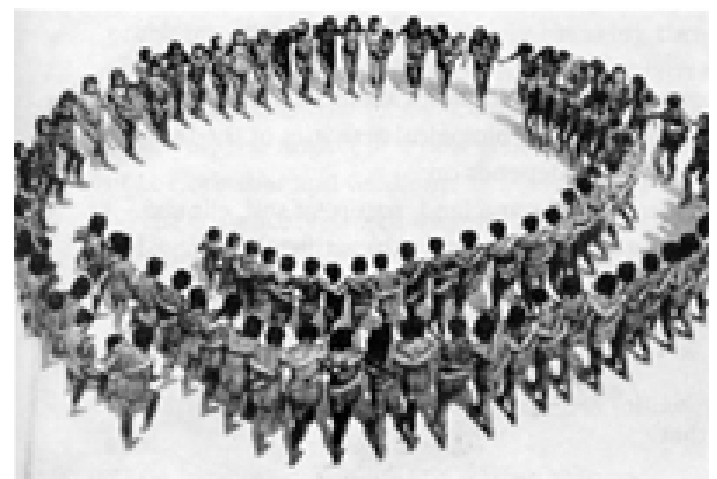

Revista Forum

1959-1963

Figura 3.18

Segunda versión de los Círculos de Otterlo, publicada por Aldo van Eyck en Forum.

Imágenes que componen el círculo izquierdo "Par Nous", aquí en el centro. (Ligtelijn y Strauven 2008, 469) 


\subsection{El circulo condensador de significados en la obra de Van Eyck.} [Mito]

El mito como relato de algo fabuloso que se supone acontecido en un pasado remoto casi siempre impreciso, es consustancial a lo vernáculo, y está presente en la obra de estudio $^{41}$, caracterizada por un espacio de planta circular concebido para albergar la colección de arte contemporáneo de Martin Visser, y en relación con la preexistencia de la vivienda construida por Rietveld, a la que transforma.

Es bien conocida la presencia de elementos circulares en la obra de Aldo van Eyck; tanto que incluso se tiende a identificarla con ellos. Sin embargo, en la historiografía sobre el arquitecto no se encuentra ningún estudio que analice e interprete este aspecto. Este trabajo realiza un primer acercamiento a la cuestión, aunque necesariamente de forma no exhaustiva por exceder la relevancia del tema el ámbito de la tesis, pero iniciando de esta manera un nuevo campo de trabajo para investigaciones posteriores.

Desde este punto de vista, un primer análisis de la obra de Van Eyck, nos muestra que a lo largo de su obra la utilización de la figura circular se intensifica y mayoritariamente se concentra en una serie de proyectos de la década de los sesenta, y que apenas se encuentran construidos formando un espacio cerrado de planta circular, siendo la Ampliación de la Casa Visser prácticamente la excepción.

Esta inesperada conclusión, nos conduce a la pregunta de por qué entonces está instalado en el imaginario colectivo la asociación círculos-Aldo van Eyck. La respuesta tiene dos vertientes. Por una parte la forma circular si está muy presente en su obra, evocando espacios, más que construyéndolos. A través de elementos aparentemente menores como formas en el pavimento y playgrounds, consigue generar lugares con identidad en el espacio público, y en otros casos con sus lucernarios circulares, acentúa el espacio construido con formas regulares ortogonales, generando siempre puntos de gran intensidad. En segundo lugar y en relación con esta capacidad evocadora, la fuerte carga simbólica de la forma circular y su certera destreza al emplearla -también los utiliza en ideogramas- , aprendida de lo vernáculo de culturas primitivas y a su vez presente en las vanguardias artísticas de la primera mitad del siglo $X X$, hacen que el impacto y repercusión sea mucho mayor de lo que en principio podría pensarse.

Carl Gustav Jung (1875-1961) ha señalado que «un verdadero símbolo aparece solamente cuando hay necesidad de expresar lo que el pensamiento no puede pensar o lo que solo se adivina o siente» (Jaffé 1964), siendo ese el propósito de los sencillos círculos en la obra de Aldo van Eyck.

Llegado a este punto, cabe preguntarse de dónde provienen las formas circulares en la obra de Aldo van Eyck.

El tema, no estudiado hasta ahora de forma explícita, se aborda en esta tesis, proponiendo como respuesta la influencia de las formas circulares de culturas primitivas, a su vez retomadas por las vanguardias artísticas de principios del siglo $X X$.

Cómo lo que empezó de forma intuitiva, Van Eyck reconoce e identifica en la arquitectura de los Dogon y los Pueblo, como expresión construida de las interpretaciones ya realizadas en la pintura y escultura modernas

Cuestiones que se desarrollan en los epígrafes siguientes.

\footnotetext{
${ }^{41}$ La casa Visser además se encuentra en un lugar con mayor carga simbólica de lo habitual en los Países Bajos, a muy poca distancia del mayor cementerio merovingio del norte de Brabantia.
} 

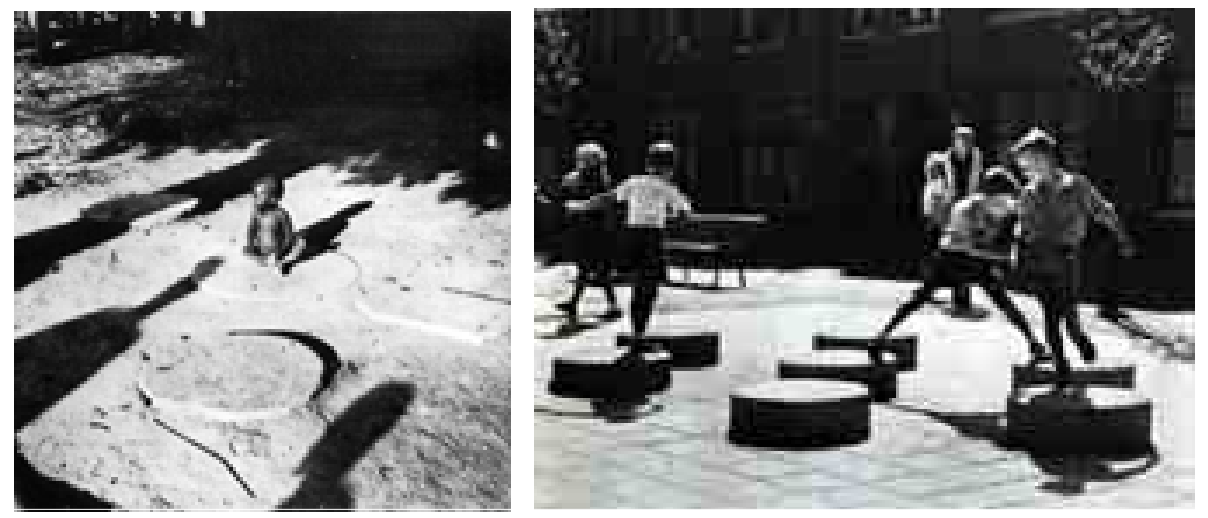

Figura 3.19

* Izquierda, niño sentado en una de plataforma de conversación en Mali: piedras circulares y planas que colocadas en el espacio público, simultáneamente favorecen el contacto social y delimitan un micro-ámbito de privacidad (Marc [1972] 1977, 129)

* Derecha, grupo de niños saltando en el playground de Zaanhof, Spaarndammerbuurt, Amsterdam-Oudwest. Famosa fotografía de 1950.
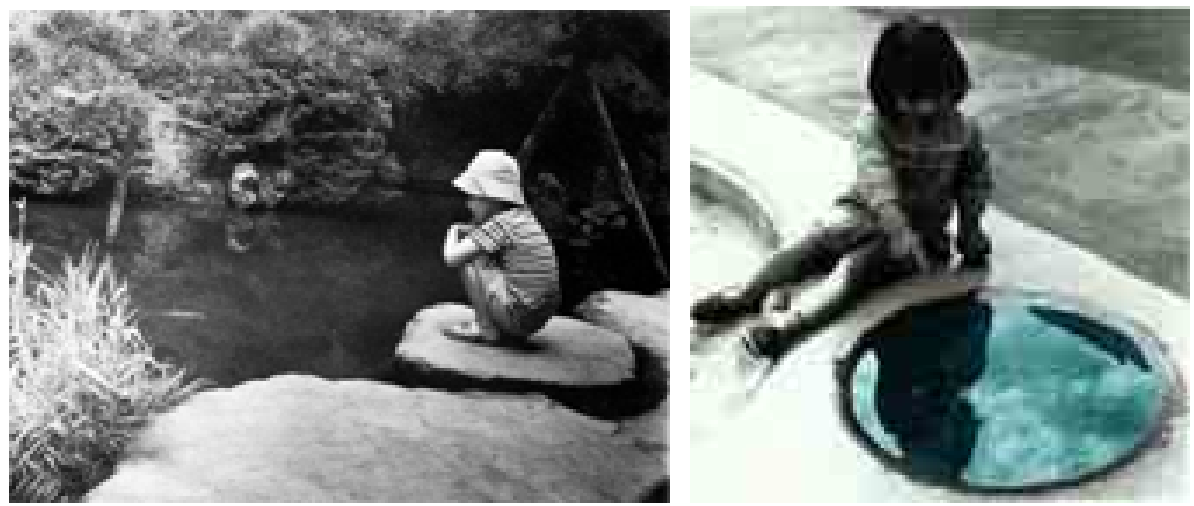

Figura 3.20

* Izquierda, niño sentado en un jardín japonés. La pequeña isla en el agua, pétrea y circular proporciona un espacio intimo de contemplación (Marc [1972] 1977, 133)

* Derecha, conocida fotografía de la niña Violette Cornelius tomada en 1960 en el Orfanato de Amsterdam. Las esquinas de la piscina de arena de la zona para niños entre 4 y 6 años, están marcadas con pequeños círculos que se transforman en un espejo mágico, tras la lluvia.

Imagen coloreada por Ana Rodríguez, a partir de la publicada por Van Eyck en The Child, the city and the artist 


\subsubsection{El circulo condensador de lo elemental y simbólico.}

La figura circular condensa como ninguna otra, significados con una fuerte carga simbólica. El circulo es homogéneo, centro y totalidad, por lo que se asocia y representa figurativamente entre otros al sol, al ojo o la boca, y entendido en tres dimensiones como espacio esférico, en su sentido más primigenio, al ovulo o a la cavidad del seno materno.

El significado simbólico del círculo en su sentido más amplio suele englobar al de la circunferencia y también el del movimiento circular, con los que a veces se confunde. Sin embargo hay particularidades que es necesario destacar, tal y como explica Juan Eduardo Cirlot en su Diccionario de símbolos. Según Cirlot, el círculo o disco como superficie de forma circular, emblema solar por excelencia, también tiene correspondencia con el número 10 como retorno a la unidad tras la multiplicidad, simbolizando frecuentemente el ciclo, la perfección y la eternidad.

La profunda implicación psicológica del significado del círculo como perfección, se explica con las tesis de Jung para el que el cuadrado, como número plural mínimo, representa el estado del hombre que no ha alcanzado la perfección de la unidad interior, frente al círculo que representa el estadio avanzado de dicha etapa final de perfección. Cirlot dice: «La relación del circulo y el cuadrado es frecuentísima en el mundo de la morfología espiritual universal, pero especialmente en los mandalas de la India y el Tibet o en los emblemas chinos». El Yang, la actividad, o principio masculino, se representa por un círculo blanco que simboliza el cielo, en contraposición con el Yin o principio femenino, la pasividad, representado por un cuadrado negro que simboliza la tierra. La interacción de esta dualidad es representada por el conocido círculo YangYin, divido por una línea sigmoidea que «simboliza el movimiento de comunicación y establece, como la esvástica, el sentido de rotación ideal que convierte en dinámicas y complementarias las cualidades del símbolo bipartido»

La circunferencia en su condición lineal, simboliza un límite infranqueable, la limitación adecuada, del mundo manifestado, de lo preciso y regular. Tiene un doble sentido dentro-fuera para los objetos o seres incluidos dentro de una circunferencia. Desde dentro implica limitación y determinación, y desde fuera la defensa de lo incluido dentro, de las amenazas exteriores, del caos, y de los peligros de ilimitación y disgregación. Es inmutable, sin variaciones y no tiene ni comienzo ni fin, por lo que uno de sus significados son las representaciones relacionadas con el tiempo, como las medievales del Año. (Cirlot 1979)

El circulo como condensador de lo elemental y simbólico, ha sido frecuentemente empleado para representar de forma idealizada lugares, míticos e inexistentes en la realidad como el paraíso terrenal o el Jardín del Edén, que más que aludir a un territorio concreto, aluden al concepto ideal que de él se tiene.

Volver al proceso de gestación del proyecto del nuevo asentamiento de Nagele, ya mencionado por formar parte del periodo de formación de Van Eyck en su planteamiento sobre el territorio holandés, nos brinda otro ejemplo de esta asociación de ideas en su obra e ideogramas. Si bien es difícil de determinar con exactitud la aportación de cada uno de los miembros del grupo formado para el desarrollo del proyecto de Nagele, así como los procesos de trabajo en un colectivo con figuras consagradas y jóvenes en sus comienzos, la influencia del trabajo de van Eyck, parece determinante en la fase conceptual del inicio, y al final del proceso en la elaboración del proyecto definitivo. Ya en la primera reunión del grupo, mes y medio después de su formación el 14 de enero de 1948, van Eyck presentó sus estudios sobre los asentamientos tradicionales y la dirección a seguir en los nuevos. 14 días antes, el grupo había visitado la zona del recién drenado polder donde fueron informados por el sociólogo S. Groenman y el arquitecto jefe A.D. van Eck sobre el planteamiento previsto en la colonización de Nagele. En la primera fase, los habitantes serian exclusivamente trabajadores del campo, asalariados en las granjas del entorno, que en 
la fase posterior serían desplazados a la periferia para dejar su lugar en el centro a comercio y clases medias, algo que van Eyck consideró totalmente inaceptable (Strauven 1998). Nada mejor para expresar su completo desacuerdo ante un planteamiento tan rígido y desigual socialmente, que los principios sintetizados en los paneles de presentación de Nagele en Dubrobnik al CIAM de 1956 con el titulo «social content»:

«Tierra Antigua: el trabajador local de granja, no tiene su vivienda en el pueblo sino en la granja; está atado al granjero y depende de la mano y el caballo para un incierto y escaso sustento; poco tiempo libre como proyecto para subsistir; por supuesto socialmente esta apenas "inter-graten"»

«Tierra nueva: el obrero del campo seleccionado de todo el país, tiene su vivienda en el pueblo: ya no está atado al granjero y depende de la maquina y la ciencia para su forma de vida habitual; se adapta a la nueva escala de vida pero mantiene su fe religiosa de granjero: socialmente ya se encuentra bien integrado»

«El Nuevo pueblo, principalmente un hogar para trabajadores del campo; centro y zona de vivienda desarrollados simultáneamente; a diferencia de las formas predominantes de población, requiere que no haya división entre el centro y la zona de vivienda circundante; toda la población debe ser expresión de unidad» ${ }^{42}$

Es decir, Nagele, un nuevo asentamiento agrícola producto de la sociedad industrial, prueba experimental y escaparate consciente del proyecto moderno, no solo debía promover la igualdad social, sino que su forma urbana debía transmitirlo. Los esquemas conceptuales de van Eyck, todos circulares, expresan esa idea. El circulo condensador, unitario e igualitario como representación de un ideal social. Volviendo al jardín del XVII como manifestación de la época dorada de los Países Bajos, proponemos una comparación con la quintaesencia del concepto idealizado de jardín holandés, que es mostrada en una popular imagen del XVII, usada en el velamen de navíos, heráldica y política, que representa Holanda entendida como un jardín. La obra de Willem Buytewech Allegory on the Twelfth Year's Truce ${ }^{43}$ en 1615 también conocida como Allegory of the Deceitfulness of Spain and the Freedom and Prosperity of the Dutch Republic, muestra un espacio delimitado, protegido del exterior mediante un cerramiento de jardín. En el interior la joven y virginal Holanda está rodeada por un ciudadano, un comerciante, un granjero y un soldado, con una rama de la Casa de Orange frente a ella. El león holandés defiende la entrada, protegiendo a sus habitantes y a los preciados parterres del jardín que están siendo cultivados, contra españoles y franceses por igual. La paz reina en el interior, simbolizando así su fuerza como nación marítima, mercantil y agrícola liderada por dirigentes con una aguda conciencia política internacional. El concepto idealizado de jardín y de nación, representada por sus símbolos: una sociedad cívica igualitaria, muestra un espacio sensiblemente circular que parcialmente se sale del encuadre, sin territorio alrededor.

\footnotetext{
42 "Old land: local farmhand, has his dwelling not in the village but on the farm; he is tied to the farmer and depends on an uncertain on scanty livelihood upon hand and horse; small spare time enterprise to make ends meet; socially he is of course hardly "inter-graten"»

«new land: field labourer selected from all over the country, has his dwelling in the village: he is no longer tied to the farmer and depends for a regular livelihood upon the machine and science; he adapts himself to the new scale of live but retains his farmer religious faith: socially is alredy well integrated"

«new village primarily a home for field labourers core and housing zone developed simultaneously; in contrast to prevailing village forms there need therefore be no schism between the core and the surrounding housing zone; the entire village should be the expression of unity»

Traducción de Ana Rodríguez.

${ }^{43}$ En DIXON HUNT, John. 1988. The Dutch Garden in the Seventeenth Century. Dumbarton oaks colloquium on the history of lasndcape architecture, XII. Washington DC: Dumbarton oaks trustees for Harvard University.
} 

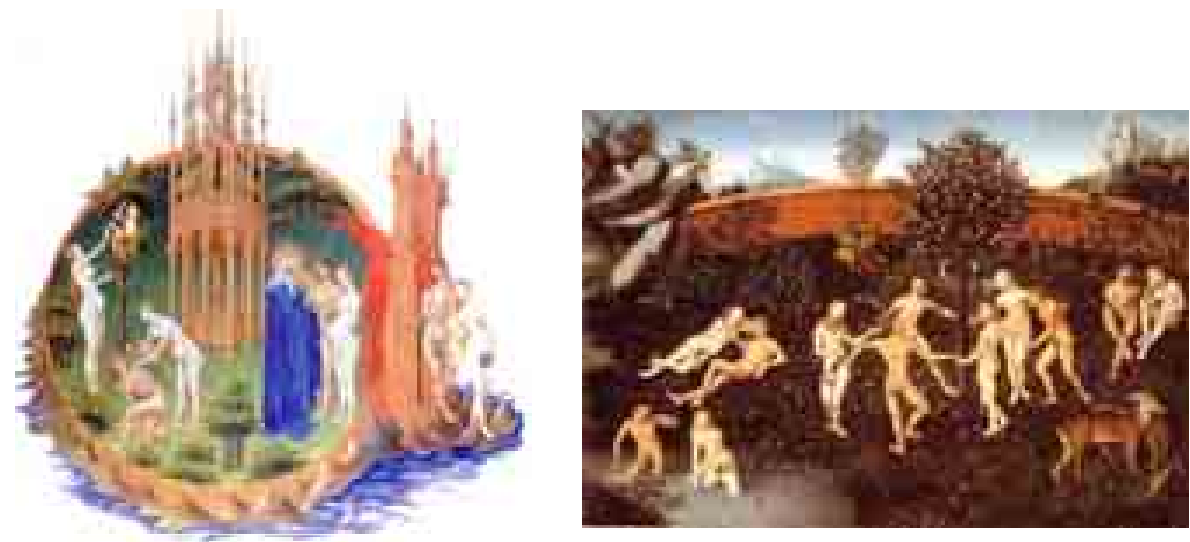

Figura 3.21

Representaciones del paraíso como un jardín delimitado en un recinto circular.

* Izquierda: Expulsión de Adán y Eva del jardín del Edén, siglo XV, representado como un recinto amurallado circular a modo de vientre, del que son expulsados del paraíso a una costa rocosa.

* Derecha: Representación del Jardín del Edén en la «edad de oro» de la ingenuidad primitiva. De nuevo el jardín está delimitado por un muro circular. Pintura de Lucas Cranach, el Viejo, siglo $\mathrm{XVI}$

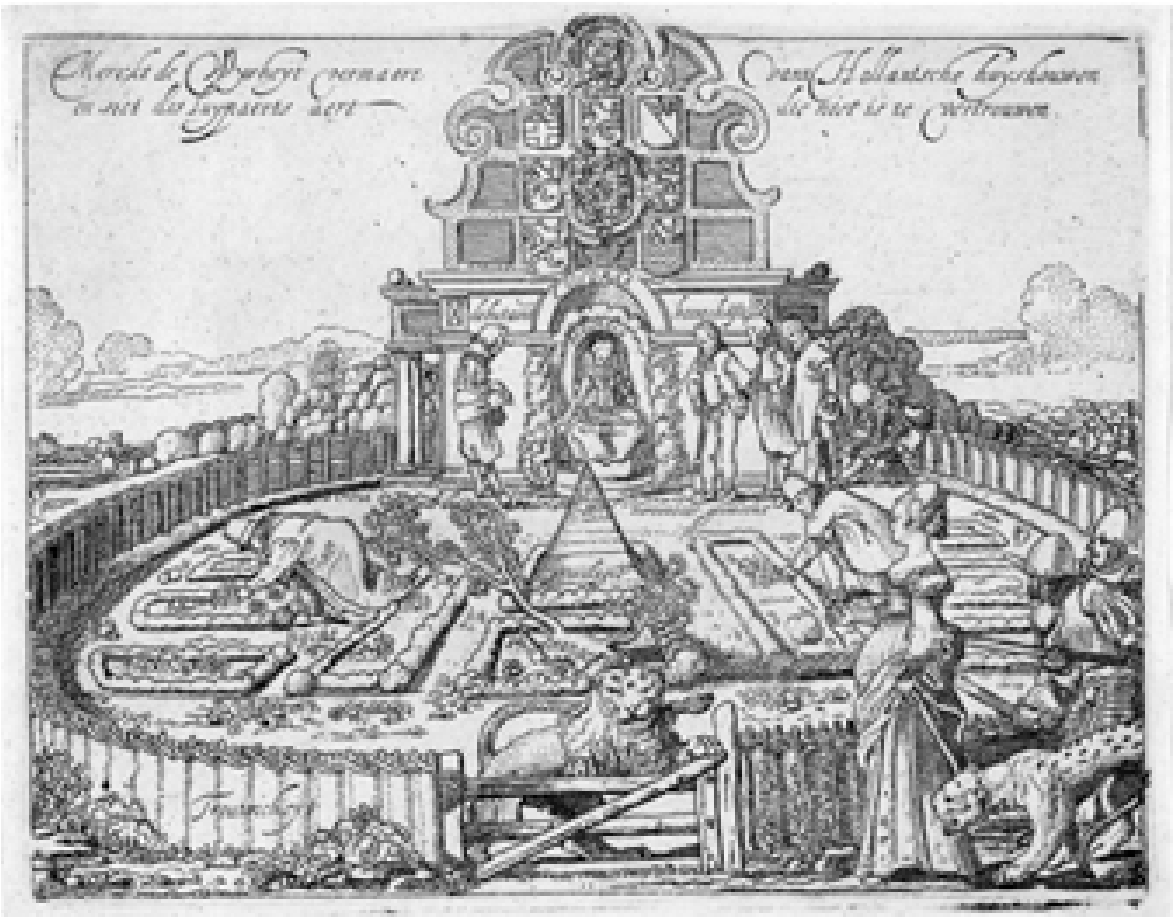

Figura 3.22

Allegory on the Twelfth Year's Truce. Willem Buytewech,1615. Aguafuerte. Rotterdam, Stichting Atlas van Stolk (Dixon Hunt 1988) 


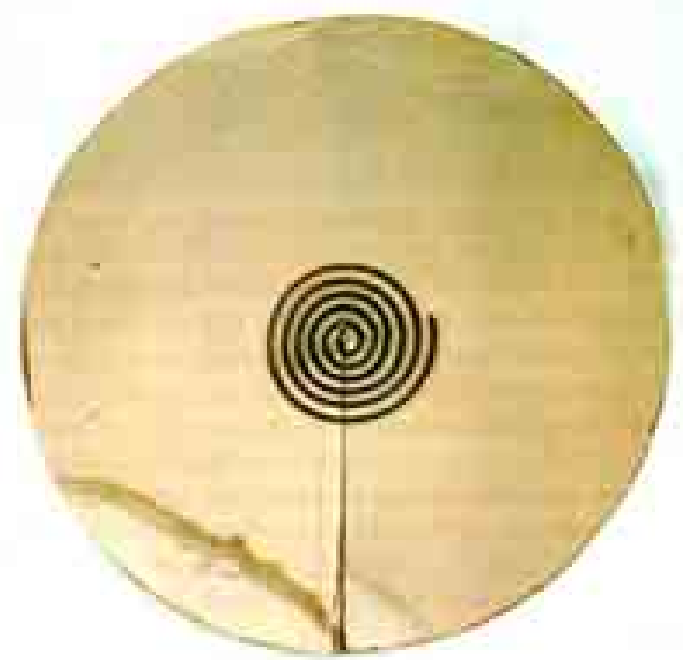

Figura 3.23

Retrato de James Joyce por Constantin Brancusi en 1929 (Strauven 1998, 481-482)

Interpretación tridimensional -cartón circular de 30 pulgadas, con un corte como radio y una espiral muy fina metálica en el centro- del dibujo realizado para el libro Tales Told of Shem and Shaun. Three Ffragments from Work in progress de James Joyce, publicado en 1929 por Black Sun Press. (Hulte, Dumitresco e Istrati 1987, 190 y 196)
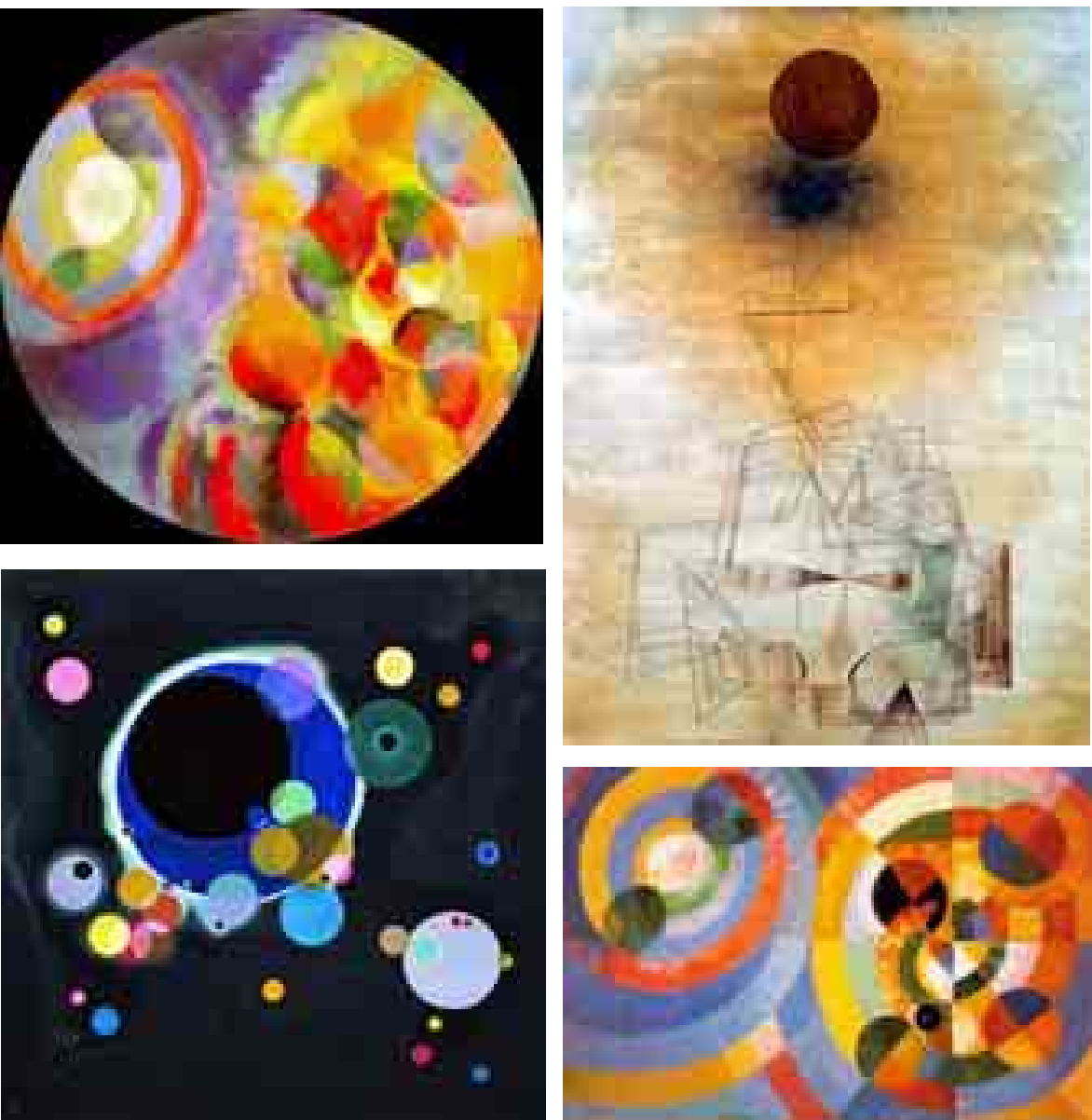

Figura 3.24

Relevancia del círculo como forma geométrica simbólica en los inicios del arte abstracto moderno de las vanguardias del siglo XX.

* Superior izquierda e Inferior derecha: Simultaneous Contrasts: Sun and Moon, 1912-13, y

Circle Forms, 1930, ambas de de Robert Delaunay.

* Superior derecha: Limites del entendimiento, 1927, de Paul Klee.

* Inferior izquierda: Algunos círculos, 1926, de Wassily Kandinsky. El propio formato del cuadro ,perfectamente cuadrado, forma parte de la composición abstracta de círculos. 
Marie Louis van Franz (1915-1998), citada por Aniela Jaffé (1903-1991) en "El simbolismo en las artes visuales", capítulo cuarto del libro de Carl Gustav Jung El hombre y sus símbolos ${ }^{44}$, explica el círculo como símbolo de "si-mismo", que expresa la totalidad de la psique incluyendo la relación entre el hombre y la naturaleza. Aparece en distintas culturas y periodos, representando siempre «el aspecto más vital de vida: su completamiento definitivo»

Según Jaffé, lo verdaderamente importante y que se repite a lo largo del tiempo, es la experiencia de una imagen interior arquetípica, con el ejemplo claro de las primitivas ruedas solares aparecen grabadas en la roca en el neolítico mucho antes del descubrimiento de la rueda, o de presencia en la pintura Zen. Al respecto y citando a un sacerdote zen sobre la pi tura El Círculo de Zen Sangai «en la secta zen, el circulo representa iluminación. Simboliza la perfección humana»

Una figura con tal carga simbólica recorre la historia del arte en todas las culturas. Un breve y simplificado repaso permite distinguir dos planteamientos radicalmente diferentes en la expresión artística. Según la terminología acuñada por Herbert Kühn (1895-1980), también citada por Jaffé, podemos diferenciarlas en estilo "sensorial" que generalmente hace una reproducción directa del tema a pintar o de la naturaleza, y el estilo "imaginativo" que expresa «una fantasía o experiencia del artista de una manera onírica y, a veces, "abstracta"». Así, en gran parte del arte de las culturas primitivas predomina el arte "imaginativo", al igual que en muchos autores de la Edad Media, e incluso en la obra de El Bosco en el siglo XV, cuando en el Renacimiento predominaba ampliamente el estilo sensorial. Este alcanzó tal desarrollo, perfección y profundidad que según Jaffé determinó el arte visual de los cinco siglos siguientes, con sus últimos grandes representantes en los impresionistas del XIX.

El arte imaginativo se remonta hasta los pueblos primitivos, considerándose hasta hace relativamente poco como poco evolucionado, sin comprender que no son el resultado de la falta de habilidad o de la ignorancia sino de modos de expresar emoción religiosa o espiritual. Su rehabilitación viene ocasionada en gran medida por el resurgimiento en las vanguardias de la primera mitad del siglo XX, de la forma de expresión artística que Kühn ha denominado imaginativa.

En el arte moderno del siglo XX, el círculo como figura geométrica simbólica ha vuelto a tener un papel relevante, aunque generalmente con variaciones respecto a las versiones más tradicionales en su representación. Es frecuente que no tenga una posición dominante, aparezca en grupos aparentemente disociados, o sea asimétrico, como en las pinturas de Robert Delaunay (1885-1941) y Wassily Kandinsky (18661944). También el cuadrado vuelve a tener un papel relevante en el arte imaginativo, abstracto o no figurativo del siglo XX, baste recordar el trabajo de Piet Mondrian (18721944), y la relación entre ambas está de nuevo presente con una frecuencia significativa. Según Jaffé «el círculo es un símbolo de la psique (hasta Platón describe la psique como una espera). El cuadrado (y con frecuencia el rectángulo) es un símbolo de materia terrenal, del cuerpo y de la realidad» (Jaffé 1964)

Contrastes simultáneos: El sol y la luna de Delaunay y Algunos círculos de Kandinsky son claros ejemplos de esta relación.

El conocido interés del arte moderno por el primitivo, o «vernacular of the hearth» en palabras de Aldo van Eyck reside en gran medida en su fuerte simbolismo desde lo elemental, sintetizado especialmente en el círculo solo o en relación con el cuadrado. El espacio de planta circular de la ampliación de la Casa Visser, realizado para albergar la colección de arte moderno de Martin Visser, más que un espacio expositivo, es un espacio simbólico de la obra de arte.

${ }^{44}$ El hombre y sus símbolos, última obra de Jung antes de su muerte en 1961. Planteada e iniciada en dicha fecha, fue publicada por primera vez en 1964. De los cinco capítulos que la componen, cuatro están realizados por colaboradores suyos: Joseph L. Henderson, Marie-Louise von Franz, Aniela Jaffé y Jolande Jacobi. 


\subsubsection{La ampliación de la Casa Visser. Interpretación de una kiva como espacio simbólico para el arte.}

La ampliación de la Casa Visser (1967-1968-69) supuso para Van Eyck el reto de dialogar con la vivienda construida por Gerrit Rietveld unos años antes.

Los caminos de Rietveld y Van Eyck se habían entrecruzado frecuentemente. Ambos tenían reconocimiento internacional como representantes de la arquitectura holandesa del momento, que en el caso de Rietveld, alcanzaba la categoría de maestro del Movimiento Moderno. En el desarrollo de Nagele, trabajaron juntos como integrantes del grupo De 8 en Amsterdam, y la amistad ${ }^{45}$ entre Aldo y Jan, el hijo mayor de Rietveld, se prolonga en el tiempo. A su vez, varios escritos de Van Eyck sobre Rietveld, y su inclusión en The Great Gang, el circulo homenaje a Carola Welcker -el único arquitecto junto con Le Corbusier-, ponen de manifiesto su admiración y respeto. El desafío era importante; sin embargo, y a pesar del riesgo y dificultad que entrañaba el trabajo, también supuso la oportunidad de materializar en una vivienda las investigaciones desarrolladas durante esos años y llevadas a cabo en edificios públicos.

La Ampliacion de la Casa Visser, pertenece a un grupo de proyectos realizados por Aldo Van Eyck en la década de los sesenta, principalmente entre 1963 y 1970. Después de sus esfuerzos para abordar la concreción del «problema del numero», una serie de encargos le van a permitir centrarse en el desarrollo espacial de edificios aislados y de menor escala. Proyectos de espacio público colectivo, con una fuerte carga simbólica y programas sin estrictas ataduras funcionales, que le dieron la oportunidad de materializar más libremente sus ideas sobre la nueva realidad: el proyecto «The Wheels of Heaven» -las ruedas del cielo- (1963-1964), la iglesia católica romana Pastoor van Ars Church en la Haya (1963-66, 1968-69) y el Sonsbeek Pavilion en Arnhem (1965-66), pabellón temporal de esculturas al aire libre, demolido en el mismo año 1966 y posteriormente reconstruido en Otterlo, cercano al de Rietveld. Lugares para el arte y dos espacios de culto que hay que entender en sentido amplio, como expresión de lo espiritual en el hombre, con una visión humanista y abierta de lo religioso, más que como expresión de una religión concreta.

Aquí se propone que, sin duda, también hay que añadir la Ampliación de la Casa Visser (1967, 1967-69), a este grupo de tres proyectos con interrelaciones más conocidas, y a su vez relacionarlos todos con sus viajes a la región Dogon en febrero de 1960 y en diciembre de 1962 a Nuevo Méjico para conocer de primera mano la cultura de los Indios Pueblo. Viajes que dieron lugar a varios textos publicados entre 1961 y 1967, y significaron una reafirmación de sus ideas, que este grupo de proyectos le permitió materializar.

Identidad, equilibrio, armonía, espiritualidad, simbolismo, esencialidad, arte, mito..., en palabras de Van Eyck «principios arcaicos de la naturaleza humana» y su expresión arquitectónica, se entrelazan en esos años, retroalimentándose entre sí, en proyectos, viajes y escritos.
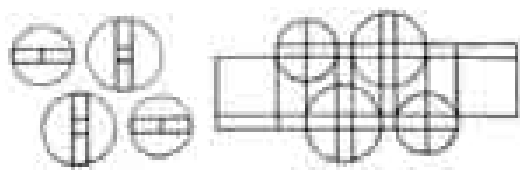

Figura 3.25

Estudios de Aldo van Eyck para el proyecto no construido «The Wheels of Heaven» -las ruedas del cielo- (19631964). (Strauven 1998, 481-482)

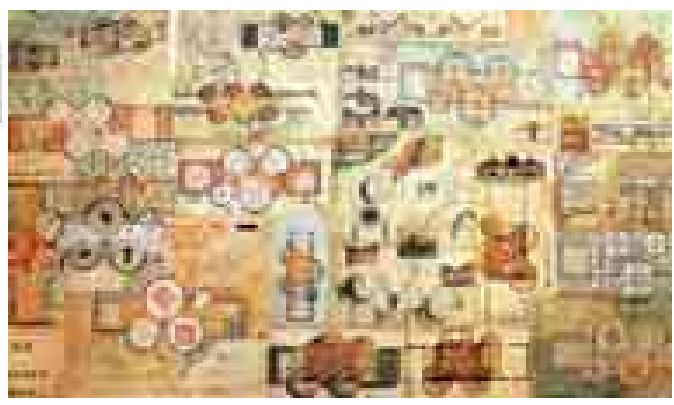

${ }^{45}$ Jan Rietveld viajo con Van Eyck en su primer e iniciático viaje al norte de África, trabajo en el proyecto colectivo de Nagele e hicieron en colaboración algunos proyectos como el Pabellón Holandes en la Trienal de Milán, la Damme House o 64 viviendas en Amsterdam, todos en 1951 

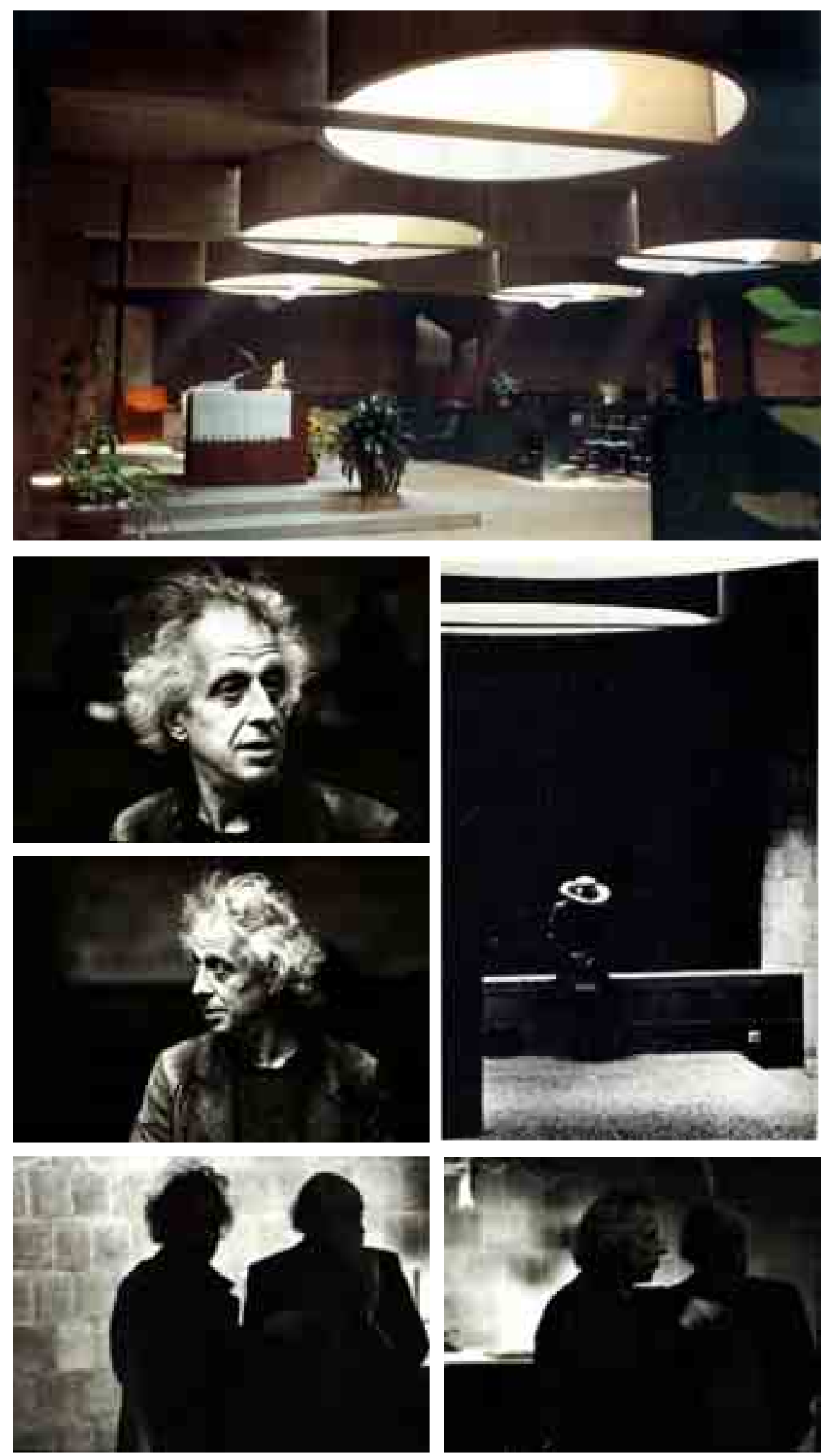

Figura 3.26

El circulo condensador de significados en la obra de Van Eyck: Ia Iglesia Católica en la Haya. Las imágenes, intencionadamente contrastadas bajo la luz de los lucernarios circulares, expresan la atmosfera del interior de la iglesia.

* Superior, interior de la Iglesia con sus círculos de luz cenital a través de los lucernarios de hormigón. Fotografía de Ana Rodríguez en el agosto de1990.

* Centro e inferiores, el Team 10 en visita a la obra de Van Eyck en 1973. Aldo van Eyck, Peter Smithson y Alison Smithson fotografiados por Sandra Lousada. Publicadas parcialmente por Peter Smithson en AD, (Smithson 1975, 345-350) y en 1991 por Alison Smithson en. Team 10 meetings. (Smithson 1991, 127-129), excepto las dos inferiores de Aldo y Peter y la inferior de Aldo. Archivo Team 10 Alison y Peter Smithson, NAi Rotterdam 
Una kiva es el lugar sagrado en las aldeas de los Indios Pueblo.

Ceremonias y ritos tradicionales se celebraban en ellas, poniendo de manifiesto la relación entre arquitectura y mito.

Lo que actualmente entendemos por Indios Pueblo, son los restos de una agrupación de poblaciones agrícolas sedentarias, cerca de veinticinco aldeas, en Arizona y Nuevo Méjico. Distribuidas territorialmente en dos grandes grupos, se encuentran mayoritariamente en los valles de Little Colorado y del alto Rio Grande. En la zona occidental predominan los hopis, y hacia el Este, los zuñi, en la frontera entre los dos estados. Fueron los colonizadores españoles, los que les dieron el nombre de «pueblos», y alcanzaron su máximo desarrollo en los siglos XII y XIII, seguido de una importante reducción en número y extensión, con modificaciones en las técnicas constructivas. En origen se empleaba el tapial formado por una argamasa de cal y guijo con paredes de hasta dos metros de espesor, evolucionando hacia la utilización de adobe. Hay constancia que a finales del siglo XVI, en la época de la conquista, los españoles encontraron al menos setenta asentamientos.

as aldeas, que identifican a los grupos, se construían preferentemente en los valles, Valley Pueblos, sobre las mesetas planas de las colinas, Mesa Pueblos, o al abrigo de formaciones naturales de difícil acceso, Cliff Dwellings. Sus necesidades defensivas caracterizan la vivienda, formada por la agrupación en fila o en altura hasta formar bloques compactos de varios pisos, de celdas simples, normalmente sin ventanas. El acceso se realiza desde huecos en la cubierta plana a los que se accede mediante escaleras exteriores de obra, o móviles que pueden ser retiradas.

Los Pueblos impresionaron a los conquistadores españoles. Posiblemente esa fuera la razón para llamarles como los pueblos de su país de origen. Van Eyck, en su escrito de 1962, referencia la descripción de una aldea hecha por Casteñeda, el cronista de la expedición de Coronedo en 1590:

«Es cuadrada y está construida sobre una gran mesa de roca con un amplio patio interior, en el que hay muchas kivas. Las casas son todas idénticas y cuatro pisos de altura. Uno puede caminar por encima de la aldea sin ser molestado por calles obstaculizadoras. En las primeras plantas hay terrazas que dan la vuelta. Se parecen a los balcones y las personas pueden cobijarse debajo. Las casas más bajas no tienen puertas, pero en cambio la gente usa escaleras, que empujan hacia arriba, como un puente levadizo. De esta manera llegan a las terrazas, que están situadas en el interior de la aldea. Debido a que las puertas de la casas se abren hacia las terrazas superiores, éstas sirven como calles» ${ }^{46}$

Las formas geométricas simples de los asentamientos son propias de los pueblos del llano, delimitadas por un muro perimetral defensivo a modo de muralla, y pudiendo ser circulares como el Pueblo Tyuonyi, semicirculares como Pueblo Bonito, o cuadradas como en Pueblo Aztec. Pero lo que es esencialmente significativo en todos los asentamientos, es que desde el perímetro defensivo y hacia el interior:

«las viviendas, con terraza, estaban escalonadas hacia un vasto espacio interior

\footnotetext{
${ }^{46}$ «lt is square and is built on a big table rock with a spacious inner-court in which there are many kivas. The houses are all identical and four stories high. One can walk high over the village without being bothered by impeding streets. On the first stories there are terraces that go round. They look like balconies and the people can shelter underneath. The lowest houses have no doors, but instead people use ladders, which they pull up, like a drawbridge. In this way they reach the terraces, which are situated on the inside of the village. Because the house-doors open onto the higher terraces, these serve as streets» (Ligtelijn y Strauven 2008, 353) Traducción de Ana Rodríguez.
} 

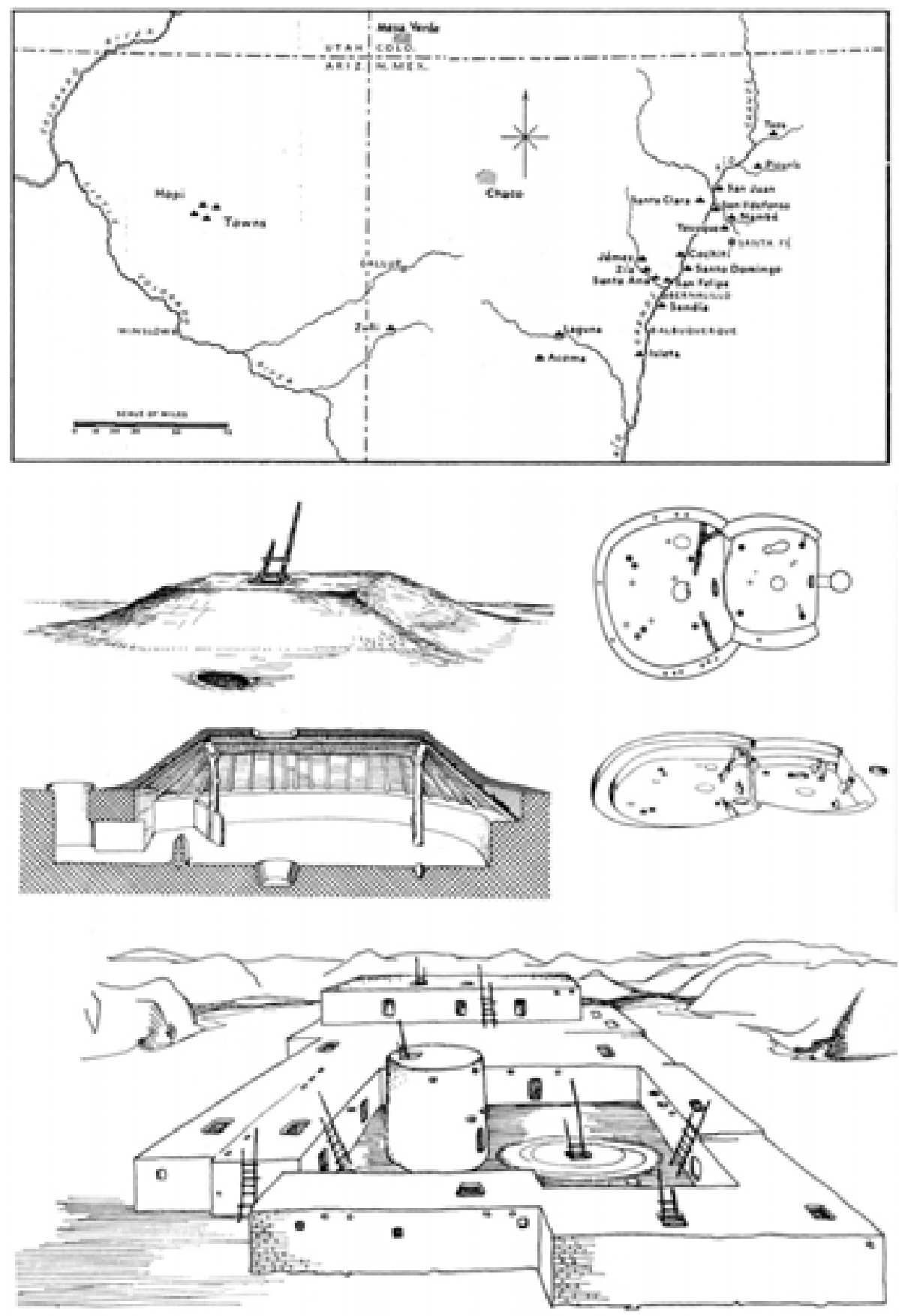

Figura 3.27

* Superior

Area de los Indios Pueblo en el sur-oeste de Estados Unidos. Zona semidesértica caracterizada por cañones excavados y singulares elevaciones montañosas con forma de mesa.

(Llgtelijn y Strauven 2008, 354)

* Centro

Casas "hundidas" -pithouses-en el area de Mesa Verde. Ejemplo tipo de cómo estaban realizadas en el área Four Corner, por los basketmakers, durante los siglos VI y VII. Cada casa albergaba a una familia, y se extendían diseminadas en grupos irregulares por las superficies horizontales de las elevaciones -mesas- formando unidades-aldea. Parte de sus características se mantendrán posteriormente en las kivas, o lugares ceremoniales sagrados.

Dibujos de G. Manten (LIgtelijn y Strauven 2008, 356)

* Inferior

Sun Point House, en el area de Mesa Verde

Inmediatamente anterior, pero también durante el Great Pueblo Period, se construyeron muchas unidades de este tipo, en la que la kiva, con su forma clásica se situa rodeada de un grupo de casas, estando la torre frecuentemente conectada bajo tierra con la kiva. Esta característica y la concentración de estas agrupaciones en unas pocas areas favorablemente situadas, indican la amaneza de tribus nómadas. (LIgtelijn y Strauven 2008, 356) 
para usos comunitarios y ceremoniales. Aquí, como en los mesa pueblos y el los cliff dwellings, se agrupaban los edificios sagrados (kiva) semisubterráneos, de planta circular y cubierta con trabes; la entrada se hacía por arriba, con una escalera; el hogar estaba situado en el centro; un pequeño hoyo en el pavimento (sipapu) representaba la entrada al mundo subterráneo. El significado de la kiva es claramente cosmológico (lugar de paso entre los tres mundos: el de los espíritus, abajo, el de los hombres, y el del cielo), los zunis celebraban en ellas complicidades ceremonias religiosas, y construían altares que pueden considerarse modelo del orden cósmico».(Guidoni [1975] 1977, 344)

Todo ello, refleja el deseo de ordenar el mundo del hombre en armonía con la dirección del espacio y del cosmos. En la cosmovisión de los Pueb/o, todas las variaciones cíclicas estacionales y lo relacionado con el mito está orientado a las líneas direccionales astronómicas fundamentales como son los cuatro puntos cardinales, más el cenit y el nadir. La kiva es el lugar sagrado donde se celebraban las ceremonias y ritos tradicionales y donde se pone de manifiesto la relación entre arquitectura y mito:

«El dios creador latiku, según la tradición mítica, tras haber enseñado a los hombres a construir la primera aldea, mostrándoles un modelo, les hizo erigir un altar, en torno al cual se colocan en orden los espíritus katchina, hacia los cuatro puntos cardinales; solo como acto final de su revelación les enseña a construir a modo de altar, la kiva. Lugar sagrado que sirve a los katchina para descansar durante sus visitas a los hombres. De este modo, los elementos arquitectónicos de la kiva llaman al mundo celeste de los espíritus a ponerse en contacto con el mundo terrestre. La cubierta es la Vía Lactea, la escalera de entrada representa al arco iris, el resalto que corre a lo largo de la pared es el banco de niebla sobre el que se sientan los katchina» (Guidoni [1975] 1977, 130)

Los Dogones, también fueron estudiados por Van Eyck. Asentados en la cuenca del alto Niger, en Mali, sus aldeas son un conjunto altamente organizado de viviendas unifamiliares o ginnas, graneros y edificios sagrados. Desde los fundamentales estudios de Griaule, la cultura Dogon y su arquitectura, se han convertido en un referente entre mito y arquitectura, antropomorfismo y geometría. El centro del territorio en el que se asientan, es también el centro y origen de un movimiento en espiral, que por obra de sus antepasados, da forma al espacio agrario y al espacio habitado. La aldea, tiene una organización en planta con forma antropomorfa, y en el centro de la misma puede estar representado el mundo celeste con los astros, en un espacio circular -Lébé dala-. (Guidoni [1975] 1977, 348).

Es decir, la agrupación de formas cuadradas y circulares es común en los asentamientos de diversas culturas primitivas como los Dogon y los Pueblo. La morfología del mismo, en ocasiones, también se basa en dichas formas geométricas como hemos visto en los segundos. Las relaciones urbanas se fundamentan en la contraposición de significados entre unas y otras: las formas cuadradas corresponden a dormitorios y unidades habitacionales de uso común, mientras que las circulares, en las que se celebran ritos y ceremonias o representan el mundo celeste, se identifican con lo sagrado, simbólico o espiritual.

Las formas circulares del proyecto «las ruedas del cielo», los lucernarios cilíndricos de la iglesia en La Haya y la Ampliación de la Casa Visser, tienen el mismo sentido: Ios círculos generan lugares de mayor intensidad y significado. En el caso concreto de la Casa Visser, Van Eyck trata de reinterpretar el simbolismo de una kiva como un espacio sagrado para el arte, sorprendiendo incluso la literalidad de algunos de sus elementos. 

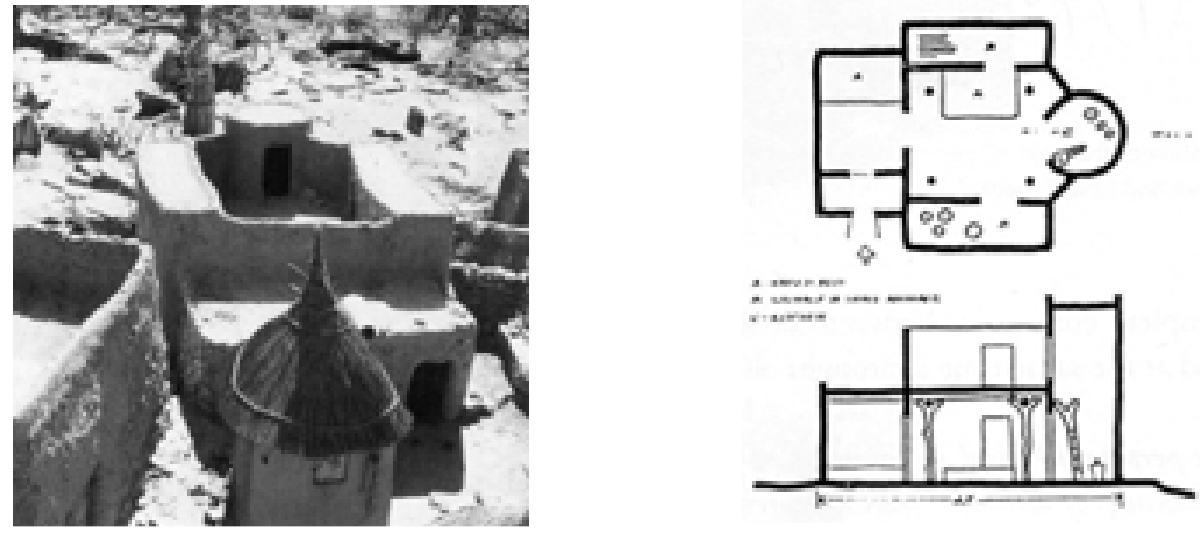

Figura 3.28

Dogones. Casa familiar de Bansiri en la aldea de Banani, en Mali. Dibujos y fotografía de van Eyck en 1960.(Strauven 1988)
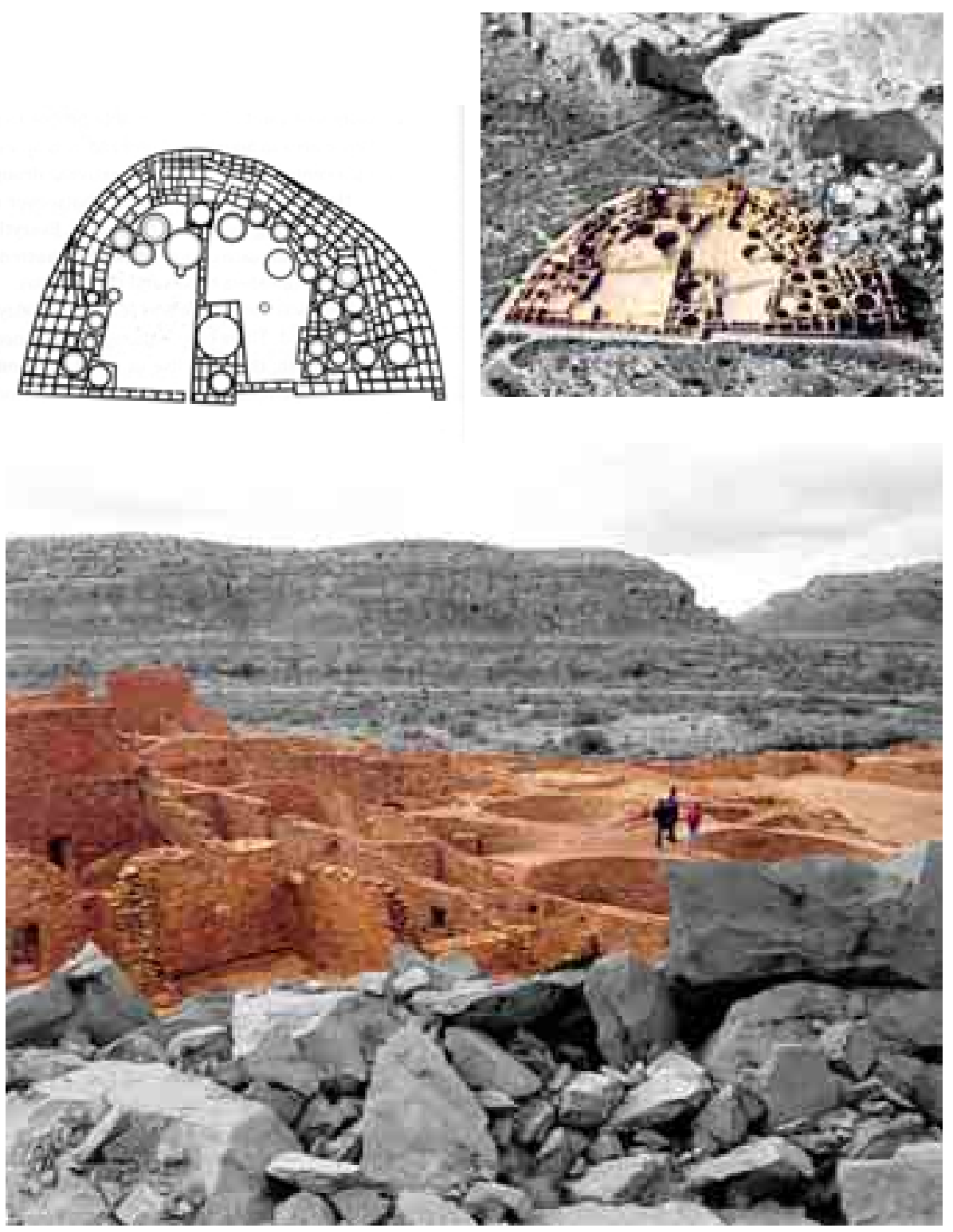

Figura 3.29

Pueblo Bonito en Chaco Canyon, Nuevo Méjico

* Superior

Planta de Pueblo Bonito en la que se ven varias kivas circulares en relación con las unidades habitacionales. Color de la fotografía manipulado por Ana Rodríguez

* Inferior:

Pueblo Bonito. Color manipulado por Ana Rodríguez sobre fotografía de Vincent Ligtelijn

(LIgtelijn y Strauven 2008, 360) 
La comparación entre una kiva y el espacio cilíndrico construido en contraposición a la vivienda realizada por Rietveld, permite ver las similitudes que indican cómo, efectivamente, Van Eyck está realizando un intencionado ejercicio de reinterpretación. Además de su forma circular, también tiene en la cubierta, como una kiva, un huecolucernario con formas ortogonales que caracteriza la iluminación interior en oposición al perímetro curvo. El cilindro de la ampliación está semienterrado como los lugares sagrados de los Pueblos. Estrategia que a su vez permite a Van Eyck que su cubierta quede a cota inferior de la marquesina de la casa preexistente -aunque su forma circular lo convierte en el lugar simbólico para el arte, en contraposición a la ortogonalidad de las habitaciones, este gesto denota una voluntad de respetuoso dialogo con Rietveld-. La tenue iluminación cenital sobre el espacio inferior al principal a través del moldeado de vidrio del lucernario secundario, enrasado con la cota del jardín, recuerda al sistema de ventilación de una kiva completamente enterrada, y la construcción del forjado de la cubierta con vigas y viguetas de madera laminada dividiendo el circulo en partes, evocan la geometría circular-ortogonal de la cubierta de vigas de madera de las kivas, y otras construcciones de los Mandanes y los Dogón ver estas comparaciones en imágenes de las páginas siguientes-.

La elección de esta obra de Van Eyck como una de las tres de estudio, se basó al comienzo de esta tesis doctoral, en la entonces vaga intuición de que la figura circular de la ampliación estaba relacionada con los lugares de especial significado en los asentamientos de culturas primitivas. La lectura de los escritos y dibujos de Van Eyck sobre los Indios Pueblos, rápidamente corroboraron que la intuición era acertada. Dos testimonios relevantes más, convirtieron la primera intuición en certeza.

Martin Visser, en entrevista realizada por Francis Strauven, lo dice de forma explícita. Ante el comentario del entrevistador sobre como la ampliación circular de Van Eyck, tapa la vista de la casa, el propietario dice:

« ¿ sabe usted lo que es? Yo solo lo entendí cuando estuve de viaje en Nuevo Méjico. Es como un "kiva" de los Indios Pueblo: un gran círculo, un poco enterrado. Entras por arriba. (Señalando hacia el lucernario)» ${ }^{47}$

En 1975, Peter Smithson publica "Church at The Hague by Aldo van Eyck", en el numero 6 de Architectural Design, única crítica arquitectónica encontrada que aborde dicha relación. En el artículo sobre la Iglesia de la Haya, ilustrado precisamente con una planta de Pueblo Bonito en Nuevo Méjico y fotografías de poblados Dogon, Smithson plantea como los viajes realizados por Van Eyck para estudiar estas culturas, ratifican y afianzan su expresión arquitectónica, latente desde sus primera obras, y que se expresa por primera vez de manera relevante en el Orfanato de Amsterdam, para cristalizar intensamente en la Iglesia de la Haya, en los mismos años de la Casa Visser.

Las similitudes y testimonios descritos corroboran que la decisión de realizan la ampliación con forma de circulo, va mas allá de una mera cuestión geométrica, de forma que el trabajo de Van Eyck en esta vivienda, consigue hacer realidad el aforismo «(...) una casa es una casa solo si es también una pequeña ciudad» de su diagrama árbol-hoja ${ }^{48}$ de 1962.

La Ampliación de la Casa Visser es como un pequeño asentamiento primitivo que no solo da respuesta funcional a cuestiones habitacionales funcionales, sino espirituales y simbólicas en este caso representadas por un espacio para el arte contemporáneo.

\footnotetext{
${ }^{47}$ «Weet $u$ wat het is? Dat heb ik pas begrepen toen ik eens op reís was in New Mexico. Het is net als een kiva bij de Pueblo-indianen: een grote cirkel, iets onder de grond. Je komt er van boven in. (Wijst naar het daklicht.)» Entrevista realizada en Bergeijk el 18 de mayo de 1982. Publicada en holandés (Van Eyck. 1986, 80-81), y parcialmente en ingles (Strauven 1998, 533). Traducción libre del holandés de Grietje Bouwmeester y Ana Rodríguez.

${ }^{48}$ Ver epígrafe 3.4. de este tesis.
} 

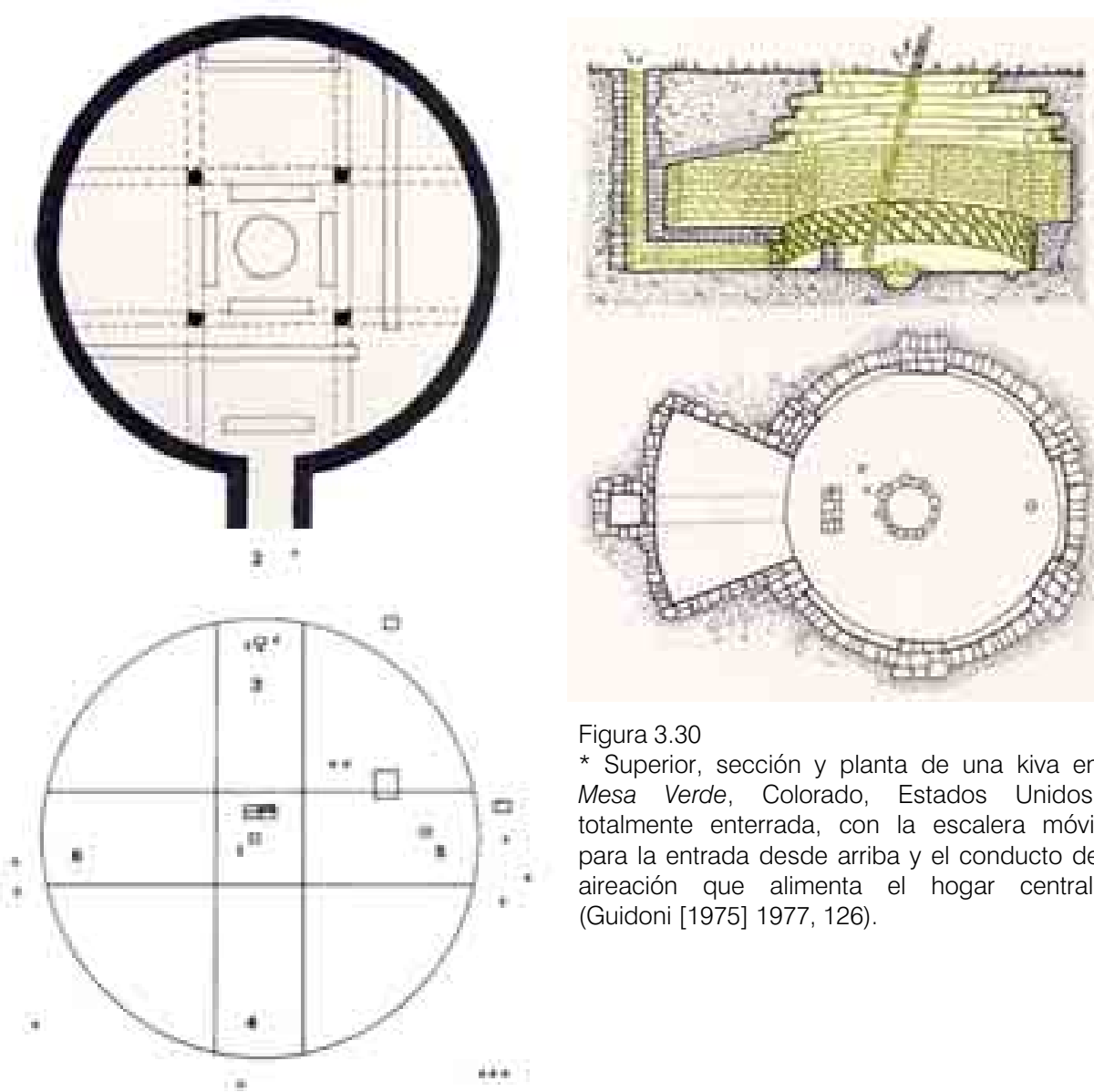

Figura 3.30

* Superior, sección y planta de una kiva en Mesa Verde, Colorado, Estados Unidos, totalmente enterrada, con la escalera móvil para la entrada desde arriba y el conducto de aireación que alimenta el hogar central. (Guidoni [1975] 1977, 126).

Figura 3.31

* Superior, Planta de vivienda de los Mandanes, pueblo del grupo siux en Estados Unidos. Las viviendas de planta circular, con una abertura cuadrada en el centro para el humo, tiene una estructura de cuatro postes delimitando un espacio central donde se colocaba el hogar. (Guidoni [1975] 1977, 117).

* Inferior, esquema planimétrico de Timbuctú, Mali, con su estructura simbólica. (Guidoni [1975] 1977, 312).
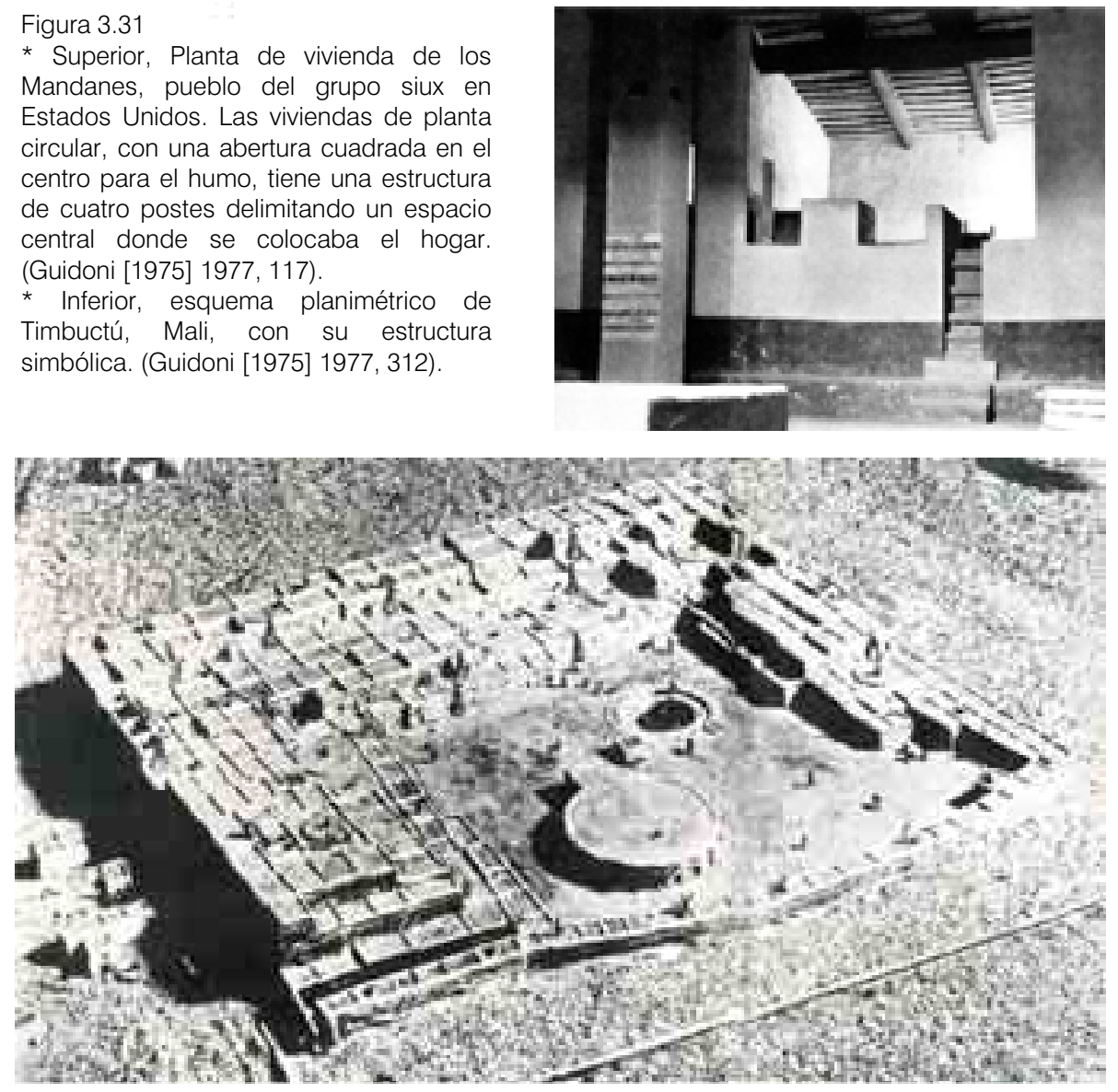

Figura 3.32

* Superior, interior de una kiva reconstruida. Aztec Pueblo al sur de Mesa Verde, Nuevo Méjico. (LIgtelijn y Strauven 2008, 363)

* Inferior, modelo del asentamiento de Aztec Pueblo en Nuevo Méjico, abandonado a finales del siglo XIII. (Guidoni [1975] 1977,120). 


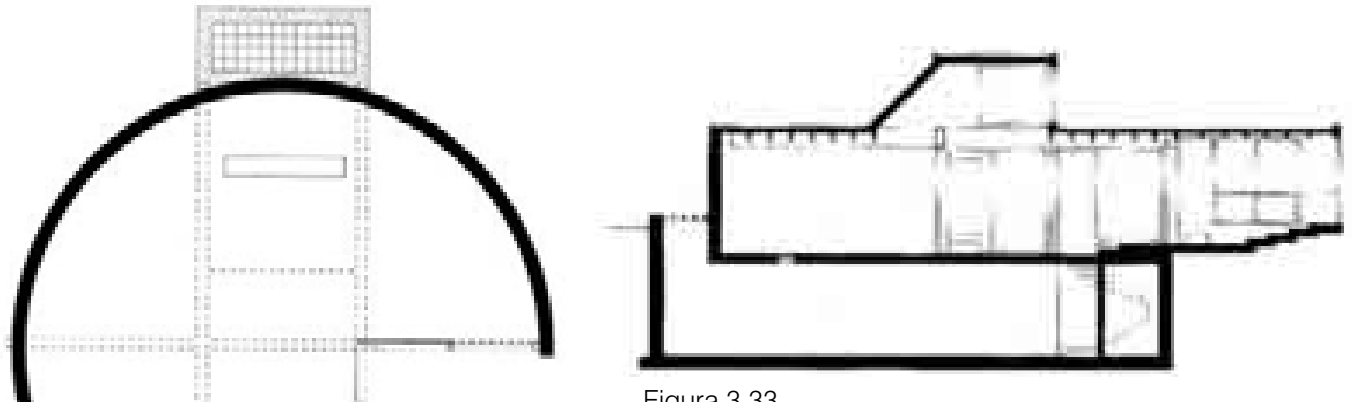

Figura 3.33

*Izquierda y superior

Planta y sección de la Ampliación de la

Casa Visser por Van Eyck, 1967-1969

Figura 3.34

* Derecha

Cubierta y lucernario de la Ampliación de la Casa Visser. Fotografía facilitada por Mrs. Joke Visser, segunda esposa de Martin Visser y actual propietaria de la casa.
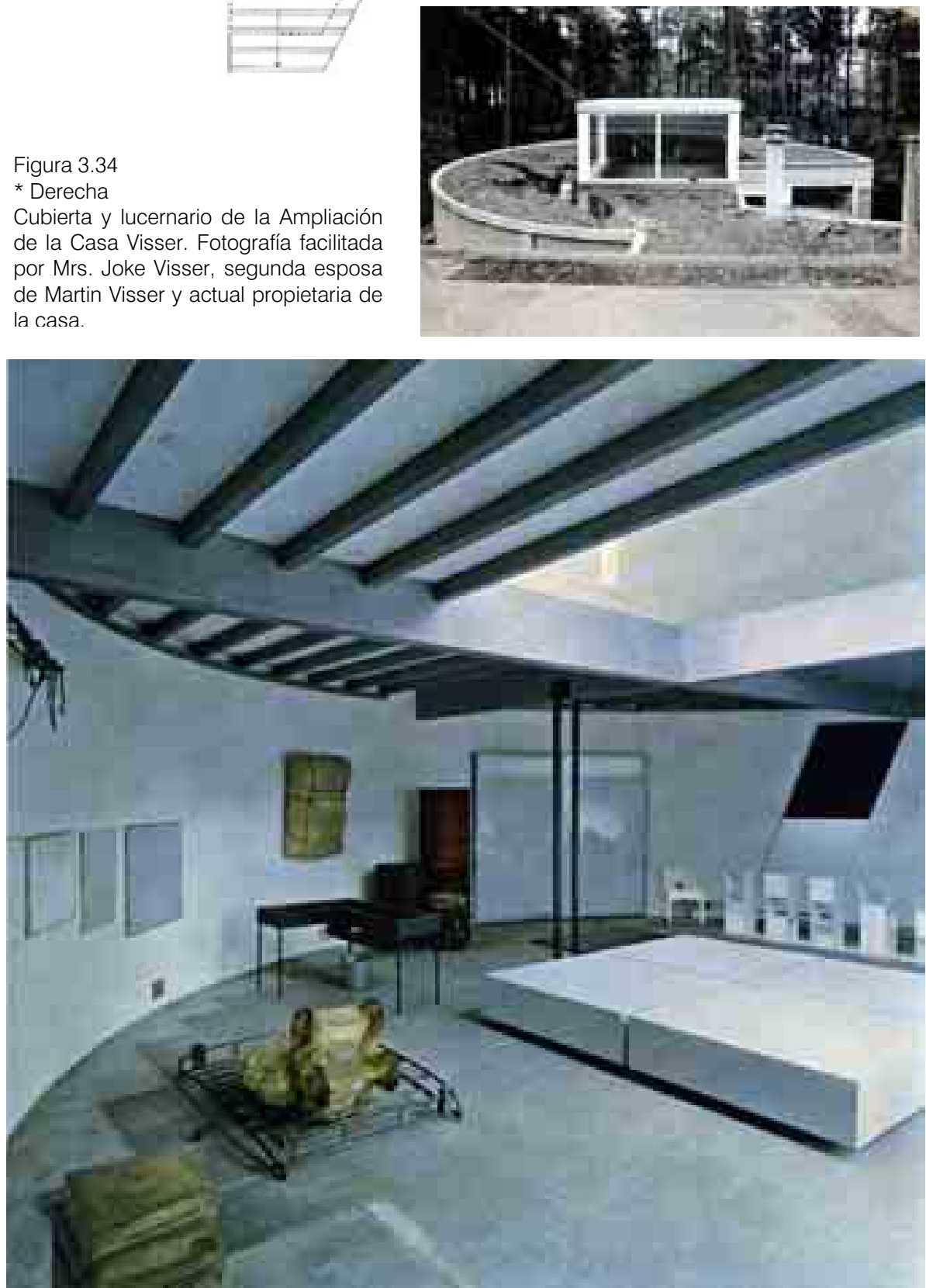

Figura 3.35

* Inferior

Interior del espacio cilíndrico en la ampliación de la Casa Visser. Fotografía de Jan Versnel (Restany 1970, 20). Las magníficas fotografías de la publicación en Domus, son posiblemente las únicas en color del momento, posteriormente reproducidas en diversas publicaciones en blanco y negro. 


\subsection{Lugar e identidad. Aldo van Eyck y el territorio de los Paises Bajos, un no lugar}

[Topos]

¿Por qué Van Eyck interpreta un tipo vernáculo del otro lado del mundo?

La respuesta, paradójicamente está también en la relación cultural con el lugar.

La relación cultural con el paisaje y el territorio de cada país, es determinante en los planteamientos urbanos y arquitectónicos de Team 10 como quedó certificado en el CIAM IX de Dubrovnik: Mientras que los Smithson están trabajando sobre nuevos tipos de vivienda y sus escalas de asociación según el lugar, Van Eyck y De 8 en Opbouw (algunos de cuyos miembros también viajaron con Van Eyck al Norte de Africa), investigan sobre como conferir identidad a los nuevos asentamientos en los polder.

Mientras los proyectos británicos responden a la especificidad de un pueblo o ciudad concreta, los de los holandeses, situados en la nada de los territorios recientemente drenados, tendían a establecer los nuevos asentamientos a partir de un explícito lenguaje geométrico y universal.

Las respuestas dadas por van Eyck a sus arquitecturas, están profundamente influenciadas por la necesidad de dotar a la arquitectura de identidad propia, lo cual a su vez viene condicionado por la condición de no lugar, de territorio sin atributos de los Países Bajos, una topografía generada por su lucha contra los elementos, con un paisaje horizontal, mayoritariamente artificial y construido por los propios holandeses. Esta relación con el territorio, propiciará en van Eyck, la utilización de sistemas compositivos con un fuerte componente geométrico. Su investigación le conducirá a explorar en la tradición clásica y vernácula como fuentes de conocimiento. En este proceso de indagación es fundamental el periodo entre 1947 y 1954, coincidente con su trabajo en la municipalidad de Amsterdam desarrollando los playgrounds, con la gestación y materialización del nuevo asentamiento de Nagele, y en que realizará sus primeros viajes al Norte de Africa en busca de "lo elemental", de las formas primarias del lenguaje visual que le conducirá a conocer de primera mano culturas no occidentales.

En los siguientes epígrafes se desarrollarán estos tres aspectos incidiendo en el proceso de Nagele, como fundamental. La necesidad de dar respuesta a su extrema condición de asentamiento ex-novo en un territorio completamente artificial, se convertirán en el banco de pruebas más extraordinario y posible para estudiar y poner en práctica sus ideas. Las experiencias de estos años -playgrounds, Nagele y viajes al Norte de Africa- conformarán sin lugar a duda el pensamiento y planteamiento de Aldo van Eyck.

Después de un primer viaje a Túnez en 1947, Aldo vuelve intencionadamente al Norte de Africa en 1951, en concreto al Sahara argelino en busca de "lo elemental", de las formas primarias del lenguaje visual que le conducirá a conocer de primera mano culturas no occidentales. En un territorio sin atributos, la abstracción geométrica permite a Van Eyck dotar de identidad a sus proyectos, buscando conscientemente referentes en culturas primitivas con territorios inhóspitos y desérticos: el Sahara argelino, los Dogón y los Indios Pueblo se convierten en fuentes de aprendizaje.

Se puede concluir, que a pesar de caracterizarse como un territorio artificial, sin atributos, la noción de lugar es también determinante aunque con una estrategia diferente a la habitual: mientras que en la cultura inglesa y catalana, el lugar determina por acción positiva cargada de matices y significado, en la cultura polder de los Países Bajos, será por omisión.

En los epígrafes siguientes se desarrollan estos planteamientos. 


\subsubsection{La casa del martín pescador, entre un roble y un cañaveral.}

[Toponimia]

Una casualidad:

Martin Visser $=$ martín pescador

Eyck $=$ roble $^{49}$

Riet-veld = campo de caña, cañaveral

\subsubsection{Aldo van Eyck, Gerrit Rietveld y Martin Visser, $1954-2000$}

\section{[Topofilia]}

Aldo van Eyck y Martin Visser fueron protagonistas de una historia singular de intensas relaciones entrecruzadas entre Martin Visser y van Eyck, con el telón de fondo de Gerrit Rietveld, las dos señoras Visser, Theo Bosch y Hannie van Eyck.

La red relaciones personales y profesionales se estrecha aún más por la cercana relación de Van Eyck con Carel Visser, escultor y diseñador gráfico con el que colabora en varias ocasiones y hermano de Martin Visser, y Jan Rietveld, hijo de Gerrit Rietveld con el que mantuvo amistad a lo largo de su vida, trabajando con él también en varias ocasiones como anteriormente ya se ha comentado.

Martin Visser (1922 Papendrecht - Bergeijk 2009), coleccionista de arte y diseñador de mobiliario para Spectrum, jugó un papel excepcional en los campos del arte, del diseño de mobiliario y de la arquitectura. La colección Visser es la colección privada de arte de neo vanguardia más importante de los Países Bajos, y sus diseños de mobiliario, entre los que se encuentra el icónico sofá-cama Bro2 realizado para Spectrum en 1958, están considerados como clásicos del diseño holandés.

Cuando en 1954 deja de trabajar en Bijenkorf, para hacerlo como diseñador de muebles en la fábrica De Ploeg en Bergeijk, compra una parcela arbolada para hacerse una casa. Parece que tras un desencuentro ${ }^{50}$ con Aldo van Eyck, al que inicialmente pensaba encargarle el trabajo, fue finalmente proyectada por Gerrit Rietveld ${ }^{51}$ en 1955-1956.

En 1967, tras la muerte de Rietveld, Martin Visser le encarga de nuevo una ampliación para su colección de arte, iniciando un intenso y singular proceso de modificaciones y adiciones, unas construidas y otras no, que se prolongará hasta incluso después de la muerte de van Eyck con una última intervención a cargo de Hannie van Eyck a modo de homenaje póstumo por parte de Martin Visser.

En 1958 van Eyck había formulado en los Círculos de Otterlo, su planteamiento para una nueva arquitectura basada en las relaciones entre las tres tradiciones: clásica, moderna, y vernácula. En este proyecto se enfrenta a intervenir en la obra de uno de sus maestros, que ya considera perteneciente a la tradición de la arquitectura moderna, planteando una respuesta desde lo vernáculo, e intensificando el importante papel jugado por, Rietveld y la familia Visser, en la historia de Bergeijk, en sintonía con los ideales de la compañía De Ploeg, al servicio del individuo y del bien común.

\footnotetext{
${ }^{49}$ En el holandés actual roble se traduce como eyk, pero etimológicamente tienen el mismo origen.

${ }^{50} \mathrm{El}$ desencuentro parece haber ocurrido en uno de las primeros contactos, cuando ante el presupuesto limitado para la casa, Van Eyck comentó suspirando a Hannie «otra vez unos clientes con poco dinero.... ante lo cual Visser se enfadó, abandonando la reunión, y contactó con Rietveld (Rietveld 2006, 182). La historia confirmada por Joke van der Heijden, segunda esposa de Martin Visser en entrevista mantenida en septiembre de 2013, no es relatada por el resto de autores, ni en la entrevista realizada a Martine Visser por Francis Strauven (Van Eyck 1986, 80-81) ${ }^{51}$ Rietvled tenía, a su vez, relación con la empresa construyendo también en Bergeijk, el edificio de la fábrica De Ploeg, en colaboración con el ingeniero G.Beltman, y la Casa Van Dalen para uno de sus directivos, ambas en1956-1958.
} 


\title{
3.3.3. El "desierto" de los Países Bajos
}

\author{
[Topografía]
}

\subsubsection{Identidad neerlandesa. El territorio de los Países Bajos.}

Un territorio que mayoritariamente se encuentra por debajo del nivel del mar, está indivisiblemente unido a su relación con el agua. La comunidad neerlandesa no solo ha superado una geografía adversa, sino que ha sido capaz de construir un universo cuyo centro es el agua. El agua identifica a los Países Bajos, y todas sus manifestaciones culturales están marcadas por este vínculo. Su paisaje, su urbanismo y su arquitectura son simultáneamente artífices y consecuencia de esta interdependencia de imposible división. Así mismo el desarrollo urbano, en su lucha contra los elementos, va unido a los avances en la ingeniería civil y al desarrollo tecnológico necesario para la preparación del terreno.

Fernande Lucretia Hooimeijer, en el análisis del paisaje holandés, establece seis fase $^{52}$ históricas en la gestión del agua y el territorio, determinadas por una cierta actitud de la comunidad y la tecnología utilizada: La natural hasta el año 1000, caracterizada por un territorio salvaje, en el que la acción humana prácticamente no ejercía ningún control sobre la naturaleza, siendo la zanja para drenar la tierra casi el único instrumento de intervención en el medio. Fuertes vientos y grandes inundaciones mantenían bajo el agua e inhabitable la mayor parte del país que actualmente conocemos. La defensiva entre 1000 y 1500, determinada por la introducción de diques como protección frente al agua. Su utilización generó la posibilidad de nuevos asentamientos: la ciudad tipo dam, caracterizada por la incorporación controlada del agua en los núcleos urbanos mediante diques, presas y puertos. La aparición en torno a 1500 del molino de viento para el bombeo de agua, como tecnología para su uso a gran escala en el territorio, marca un nuevo cambio de actitud: la fase ofensiva de 1500 a 1800, caracterizada por la consolidación de terrenos y primeras reclamaciones o recuperación de zonas inundadas, que generará la ciudad polder, siempre con un núcleo seco, origen del asentamiento, y zonas periféricas de crecimiento (polder) ya aptas para su cultivo, pero todavía no para su construcción. La revolución industrial y el desarrollo de la máquina de vapor marcan el inicio de la fase manipulativa desde 1800 hasta la actualidad, en la que la acción del hombre pasa a tener actitud activa de transformación y manipulación de la totalidad del sistema hídrico. Hooimeijer la divide a su vez en tres periodos: la manipulativa inicial de 18001890 en la que la aparición de la máquina de vapor permitió las primeras modificaciones importantes en el sistema del agua e introduce el principio de sistematización; la manipulativa de 1890 a 1990, en la que la energía eléctrica posibilitó el periodo de mayores transformaciones en número y extensión, estableciéndose, entre otros, el control del nivel hídrico del territorio a nivel nacional ${ }^{53}$. Esta fase, con los dos periodos posbélicos, se caracteriza por el principio de Maakbaardheid, o la capacidad del hombre para abordar cualquier empresa. Por último, la fase manipulativa adaptativa, desde 1990 hasta la actualidad, en la que los dos términos que la definen aparentemente contradictorios, representan una cambio de actitud hacia la ecología y el medio natural, así como la falta de claro consenso sobre las políticas a mantener frente al cambio climático. Algunas experiencias de

\footnotetext{
52 Hooimeijer se basa en las cuatro fases establecidas en 2002 por Willem van der Ham en "De Historie, Een wijd perpectief; een historische verkenning van het Nederlandse landschap in relatie tot het waterbeheer" (natural, defensiva, ofensiva y manipulativa), quien a su vez las elabora a partir de los criterios utilizados en 1977 por Bijhouwer, en "Het Nederlandse landschap", en 1993 por Van de Ven en "Man made Lowlands", y en 1971 por Lambert en "The Making of Dutch Landscape, an historical geography of the Netherlands" (Hooimeijer 2010)

${ }^{53}$ La regulación del nivel hídrico de todo el país, se controla mediante el Normaal Amsterdams Peil NAP (Nivel Normal de Amsterdam), que es el nivel de referencia 0 del mar, medido en Amsterdam en marea baja. Desde 1894 es el nivel normalizado y corregido, para el conjunto de los Países Bajos, del antiguo Amsterdam Peil o Nivel de la Ciudad, establecido en 1684.
} 
recuperación de los niveles hídricos primitivos, volviendo a inundar parcialmente zonas delimitadas dentro de parques naturales, se han llevado a cabo en el norte del país como muestra de este nuevo planteamiento.

El paisaje actual de los Países Bajos es el resultado histórico de sucesivas transformaciones naturales, generalmente traumáticas, e intervenciones humanas como réplica. Fuertes temporales desde el Mar del Norte e importantes crecidas fluviales han llenado la historia holandesa de inundaciones y catástrofes naturales ${ }^{54}$. La capacidad para darles respuesta, genera en el siglo XX actuaciones verdaderamente relevantes que permiten comprender el gran sentimiento de comunidad e identitario de la sociedad holandesa.

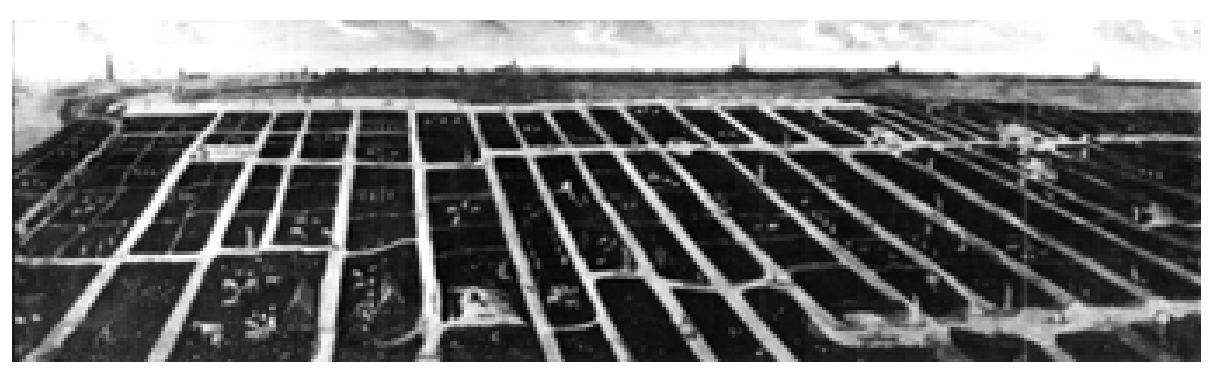

Figura 3.36

Polder Het Grootslag. Artista anónimo, 1616 (Reh, Wouter y Aten 2007)

\footnotetext{
${ }^{54}$ La última gran inundación, una de las más importantes de la historia conocida, se produjo el 1 de febrero de 1953: Una fuerte tormenta del noroeste y la confluencia de circunstancias climáticas inusualmente desfavorables generaron una subida del nivel del mar contra la costa oeste holandesa sin precedentes. Las protecciones existentes no fueron suficientes y los diques se rompieron en multitud de lugares con algunas brechas de dimensiones excepcionales. 160.000 hectáreas de la provincia de Zeeland se inundaron con agua salobre, muriendo 1800 personas y siendo evacuadas 70.000. La proporción del desastre, condujo a la aprobación en 1957 del Plan Delta, consistente en el cierre de cuatro brazos de mar anchos y profundos, y la construcción de diques secundarios más el refuerzo de los existentes, de forma que la mayoría de los estuarios en el sur del país quedaron cerrados. También se construyó una represa para temporales, que solo se cierra si el nivel del agua sube hasta determinado nivel. Para ello se emplea una compuerta de acero de 80 metros de ancho, 11,5 metros de altura y un peso de 635 toneladas.
} 

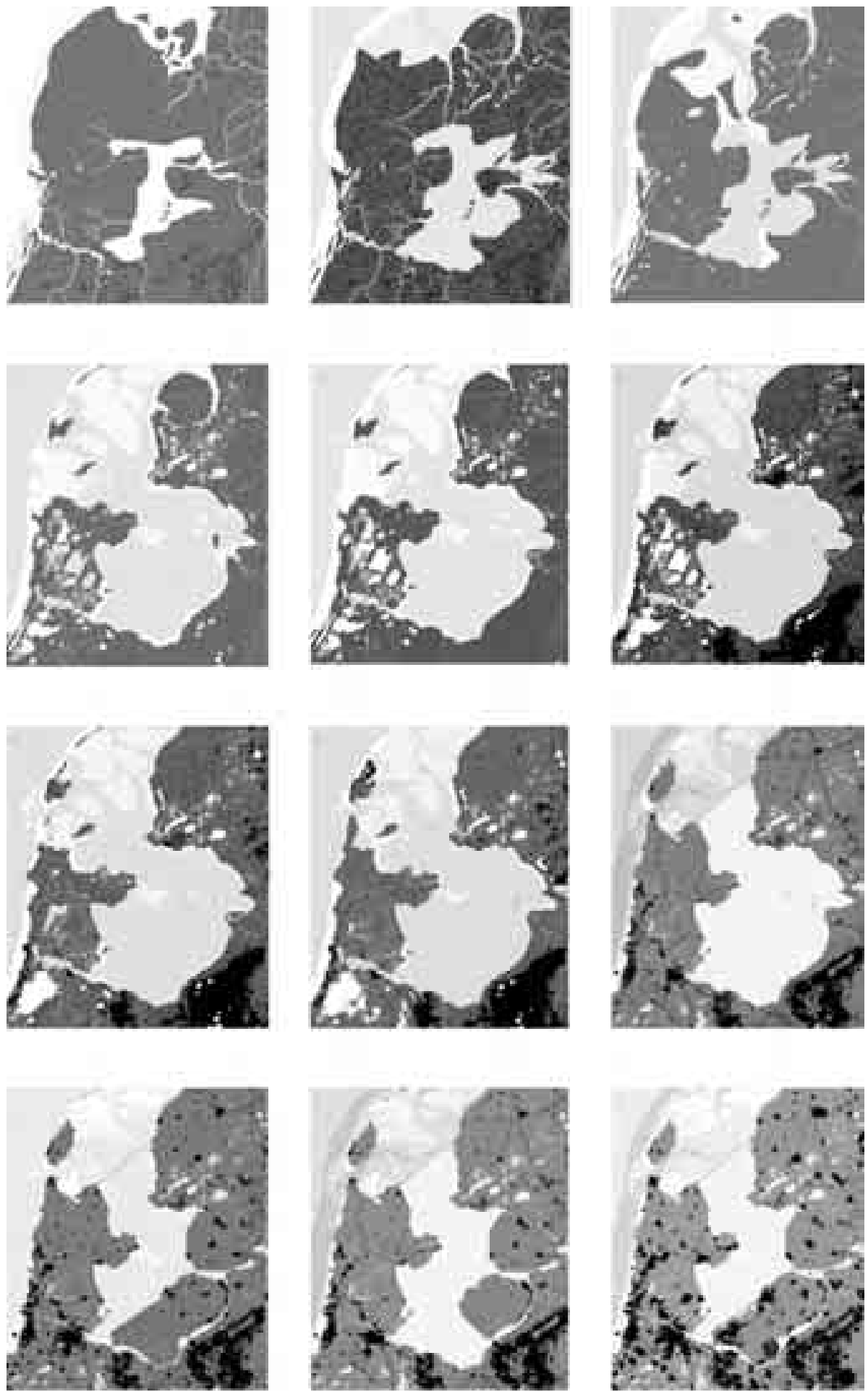

Figura 3.37

Morfogénesis del Zuiderzee.

Montaje de Ana Rodríguez a partir de la información publicada en la web del Museo del

Zuiderzee.

De izquierda a derecha y de arriba abajo:

- 1200 a.C., año 0, año 800

- año 1250, año1350, año 1570

- año 1630, año 1825, año 1935

- año1960, año 1975, año 2009 
Un poco de historia. El Zuiderzee y el Noordoostpolder

La historia del Zuiderzee ejemplifica el complejo proceso de morfogénesis del territorio holandés. Históricamente ha sido una zona de grandes fluctuaciones, con el mar avanzando progresivamente. El Zuiderzee o Mar del Sur fue un entrante del Mar del Norte, separado de este por la hilera de islas y dunas al norte del país. Una extensión de $5000 \mathrm{~km}^{2}$ y $300 \mathrm{~km}$ de costa con una profundidad entre 4 y cinco metros. En sus orígenes fue un lago interior de menor superficie, el lago Flevo en época romana, que se comunicaba con el mar por un estrecho paso. A partir del año 800 , se vivió un periodo de grandes inundaciones, sobre todo en los siglos XII y XIII, en los que se fue ampliando la conexión, proceso culminó en 1287 con la Inundación de Santa Lucia, en la que además de decenas de miles de muertos, el mar termino de arrasar diques y barreras naturales, ocupando amplias extensiones de tierra para formar el conocido desde entonces como Zuiderzee, que además de variar la morfología del territorio, generó por adaptación un cambio en la economía, convirtiéndose en un centro de relaciones comerciales y explotación pesquera. Gracias a la mejora de los diques de protección, el tamaño de este mar interior se mantuvo prácticamente estable a partir del siglo XV, aunque siempre fue objeto de preocupación y conocido como un mar tormentoso causante de catástrofes con muchas víctimas.

La inestabilidad de la zona propició la idea de su polderización ${ }^{55}$ según el proyecto del ingeniero civil Cornelis Lely (1854-1929) que se finalizó en 1891 siendo Ministro Transporte y Obras Publicas, comenzando las obras en 1920. El ambicioso proyecto se fundamenta en la construcción de un gran dique de cierre, Afs/uitdijk (1920-1932), de $32 \mathrm{~km}$ de longitud ${ }^{56} \mathrm{y}$ una anchura de $90 \mathrm{~m}$. El plan, preveía la realización de cinco grandes polders, desecando más de 200.000 hectáreas, convirtiendo el resto de la superficie en el lago Yjssel de agua dulce, ljsselmeer, en el que desemboca el rio del mismo nombre.

El polder del Nordeste Noord-Oost-Polder, se drenó durante la Segunda Guerra Mundial, como una gran extensión de producción agrícola. Para su colonización, posible gracias al Plan Marshall, se contaba con la experiencia inmediatamente anterior del Wieringenmeer-polder, para el que se había creado la Junta Ejecutiva de Wieringermeer, cuya filosofía sobre la materialización física de los pueblos se basaba en el texto publicado en 1929 por D. Hudig Het toekomstig landschap der Zuiderzeepolders, El futuro paisaje de los polders del Zuiderzee, que adaptaba los principios de Camilo Sitte a la situación holandesa, sentando las bases para su aplicación en los asentamientos y paisajes rurales de los nuevos polders. Fueron necesarias la ingeniería y las técnicas más avanzadas del momento para la polderización de superficies tan extensas, pero se abogaba una arquitectura emuladora de la tradicional - Delft School- con la que se realizaron todos los

\footnotetext{
${ }^{55}$ Debido a las frecuentes rupturas de los diques y al incremento progresivo de la salinidad de los terrenos agrícolas, Hendrik Stevin (1614-1668) consideró por primera vez el cierre del Zuiderzee en 1667 y su conversión en un polder, aunque la puesta en práctica de su idea de desecación no era posible con la tecnología del siglo XVII sin la existencia de estaciones de bombeo, la primera de las cuales se utilizó en Holanda entre 1848 y 1852 durante la polderización del Haarlemmermeer. La idea se retomó a finales del XIX, desarrollándose el proyecto de Cornelis Lely, no sin polémica y oposición por su elevado coste, especialmente entre el colectivo de pescadores, y a pesar de la aprobación de la reina para llevarlo a cabo en 1913, la Primera Guerra Mundial supuso su paralización. La escasez de grano que vivió el país en este periodo, junto con las inundaciones de 1916, acabaron con la resistencia de algunos sectores, aprobando el parlamento en 1918 el proyecto de cierre del Zuiderzee, comenzando las obras en 1920.

${ }^{56}$ El dique Afsluit tiene $30 \mathrm{~km}$ de longitud entre la isla de Wieringen y Friesland y 2,5 km entre Noord Holland y Wieringen. Este tramo corto fue construido antes de acometer la obra de mayor entidad llevada a cabo en el país hasta ese momento. La construcción tuvo mucho de experimental, sin referencias previas y se llevó a cabo, simultáneamente por tramos, teniendo que superar la enorme dificultad de trabajar con fuertes mareas. Finalmente se termino de cerrar aprovechando el breve intervalo entre flujo y reflujo, en el que el agua está tranquila, momento del que hay conocidas fotografías.
} 
asentamientos bajo la supervisión de Grandpré Moliere y P.Verhagen (Strauven 1998). Nagele, fue el último en acometerse y la única excepción.

El polder se organiza con una estructura jerárquica y concéntrica en varios niveles de canales y carreteras en torno a un centro, en el que se sitúa Emmerlord, la capital. A su alrededor y comunicadas radialmente con él, diez poblaciones a su vez unidas entre sí formando un anillo, con trayectos planificados ${ }^{57}$, todos abordables en bicicleta, ante la dificultad económica del momento de adquirir, granjeros y campesinos, un vehículo para desplazarse. Se complementa con una red de canales de similar disposición, que llega a cada aldea con un muelle ubicado en la zona de talleres siempre situada en el perímetro exterior del núcleo. Los canales, esencia misma del polder, fueron planificados y utilizados como medio de transporte de materiales y mercancías en la construcción de los núcleos urbanos.

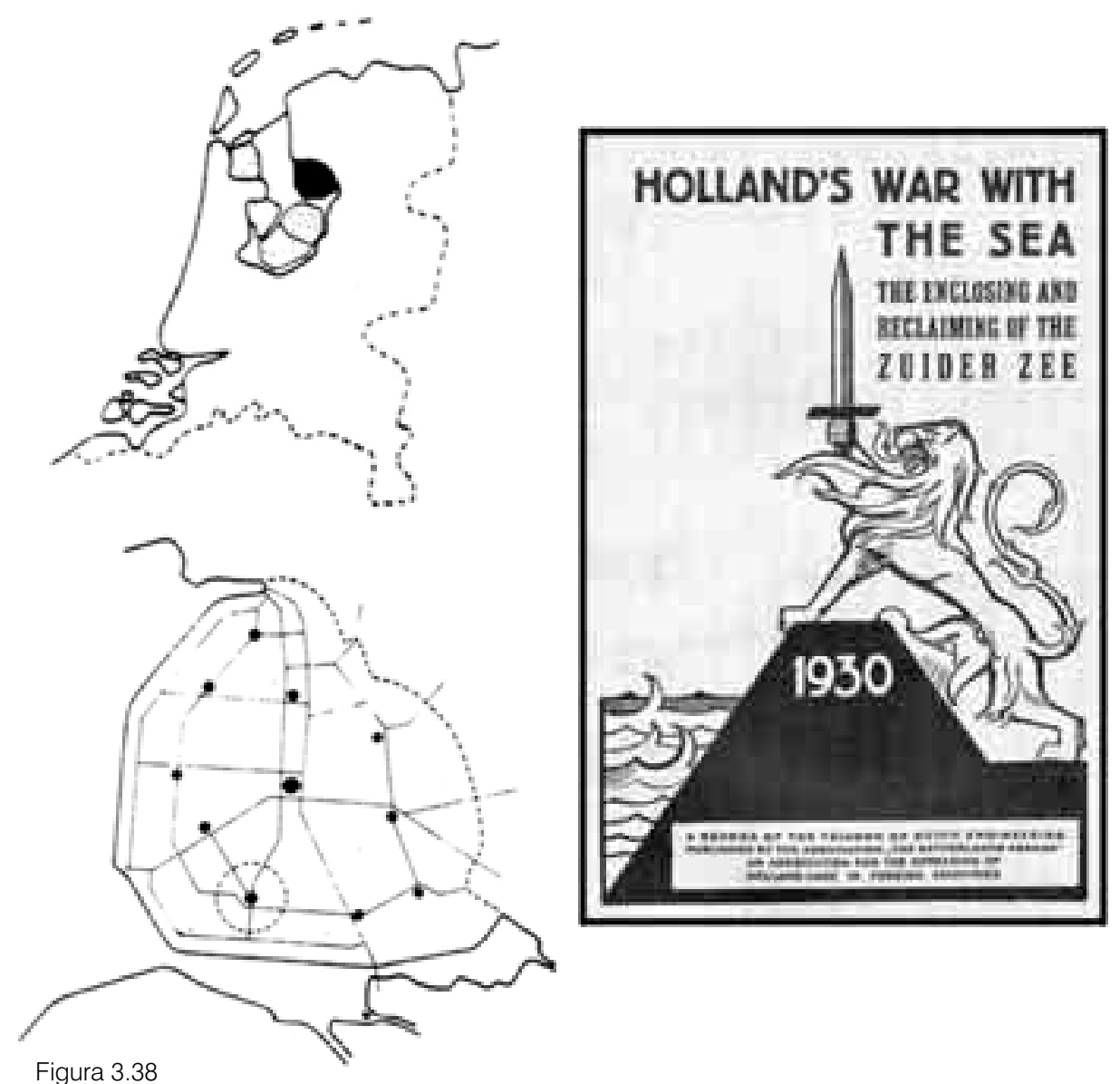

Figura 3.38

* Izquierda: Dibujos incluidos en el Panel 2 de la grid de presentación de Nagele, por Aldo van Eyck y de 8 en el CIAM X de Dubrovnik, 1956 (Strauven 1988).

Superior, Plan de reclamación de terrenos en el Zuiderzee. Los cinco polders, el Noordoostpolder en negro, y el dique de cierre Afsluitdijk, en el actual ljsselmeer.

Inferior, Estructura radial y concéntrica de colonización del Noordoostpolder. Nagele en un círculo.

* Derecha

Portada del libro Holland's War with the Sea: The Enclosing and Reclaiming of the Zuider Zee. A Record of the Triumph of Dutch Engineering. De H. S. M. Van Wickevoort Crommelin. Publicado en 1930 por la Asociación "The Netherlands Abroad".

\footnotetext{
${ }^{57}$ La distancia entre pueblos se planificó por consideraciones teóricas y técnicas agrícolas, con la experiencia anterior de los pueblos del polder Wieringermeer y la Teoria de los lugares centrales 1933, del geógrafo alemán Walter Christaler (1893-1969), Los lugares centrales en Alemania meridional. Fuente Proyecto de estudio sobre los pueblos del Polder del Nordeste 'DNA' van de Noordoostpolder-dorpen.
} 


\subsubsection{Polder y paisaje en la cultura holandesa.}

Polder, es el término holandés que define partes de territorio ganadas al mar. Los pólderes son típicos de zonas bajas costeras, llanuras fluviales, lagos poco profundos, lagunas y depresiones de tierras altas, que antes de su drenaje permanecían temporal o permanente inundadas. Una zona se convierte en pólder cuando se separa del régimen hidrológico circundante de forma que su nivel hídrico puede ser controlado independientemente de las zonas que lo rodean, condición que se lleva a cabo por diversas combinaciones de diques que la aíslan y de canales de drenaje para una constante evacuación mecánica del agua. La utilización de esta técnica se remonta, en sus formas más primitivas, al siglo XII, evolucionando pareja al desarrollo de las técnicas de elevación de agua, y generando un territorio de riguroso orden geométrico, basado en la división de las superficies de drenaje, a partir del cual el paisaje se construye de forma absolutamente artificial.

Los términos utilizados en Europa para definir paisaje, surgen de forma más o menos simultánea en los siglos XV-XVI, probablemente a partir del holandés landscap, actual landschap: el inglés landscape, el alemán landschaft, y el sueco landskap entre otros. Formado por land (país, tierra) más el sufijo -schap, equivalente al inglés -ship, que denota una cualidad, condición o relación, significaban en origen un lugar, tierra, provincia, o circunscripción. Sin embargo, la palabra española paisaje en su primera acepción según la RAE, significa una extensión de terreno que se ve desde un sitio, es decir una vista de una parte del territorio, como sus análogas en portugués paisagem, en italiano paesaggio y en france paysage, de la que proceden, formada por pays mas el sufijo -age, estos a su vez del latín ${ }^{58}$. Prevalece en ellas una cualidad visual o escénica frente de los términos anglosajones y germánicos.

No es menor que la primera palabra para enunciar paisaje en occidente sea holandesa, ni tampoco el tiempo de su origen. El siglo XVI es de gran pujanza en los Países Bajos, convirtiéndose en una gran potencia comercial y económica en el XVII y XVIII. La figura de Erasmo de Rotterdam (1466?-1536) y la fundación de la Universidad de Leiden en 1575 supondrán un desarrollo extraordinario y conjunto de ciencia, arte y humanidades. Humanismo unido a la necesidad de mejorar la gestión del agua, determinante para la supervivencia del país, supusieron la consolidación de una corriente de conocimiento orientada a la tecnología y las matemáticas con fuerte relación entre teoría y práctica, en la que destaca la figura de Simon Stevin ${ }^{59}$. Ciencia, arte, territorio y agua se consolidarán como indivisibles en la construcción del paisaje holandés a partir de la necesidad. Polder y paisaje. (Reh, Wouter y Aten 2007).

La fortaleza de esta comunión tiene una presencia determinante en diversas manifestaciones de la pintura holandesa y es transversal a épocas, estilos y temáticas: desde la Dutch Golden Age en el XVII a Jan Toorop, Karel Apple, o Piet Mondrian en el XX; la planeidad del paisaje en Hendrick Avercamp; el horizonte en las pinturas de Philips Konick; los cielos cambiantes de Jacob van Ruisdael y las estampas de su discípulo Meindert Hobbema; o la alusión a la cartografía en los cuadros de Johannes Vermeer. Vermeer no solo pinta El Geógrafo y El Astrónomo, profesionales hacedores de cartografías, sino que varios de sus cuadros como El arte de pintar, Mujer de azul leyendo una carta, y El oficial y muchacha riendo, muestran mapas de forma protagonista. Su obra transmite con intensidad la relación entre lo infinito del paisaje abierto y el recogimiento de los interiores domésticos, tema recurrente en la pintura paisajista holandesa del XVII.

${ }^{58}$ Lindón, Alicia y Daniel Hiernaux. 2006. Tratado de Geografía Humana, Editorial Anthropos y Online Etimology Dictionary.

${ }^{59}$ Simon Stevin (1548-1620) matemático, físico e ingeniero militar; padre de Hendrik Stevin, citado anteriormente por realizar el primer proyecto de polderización del Zuiderzee. 

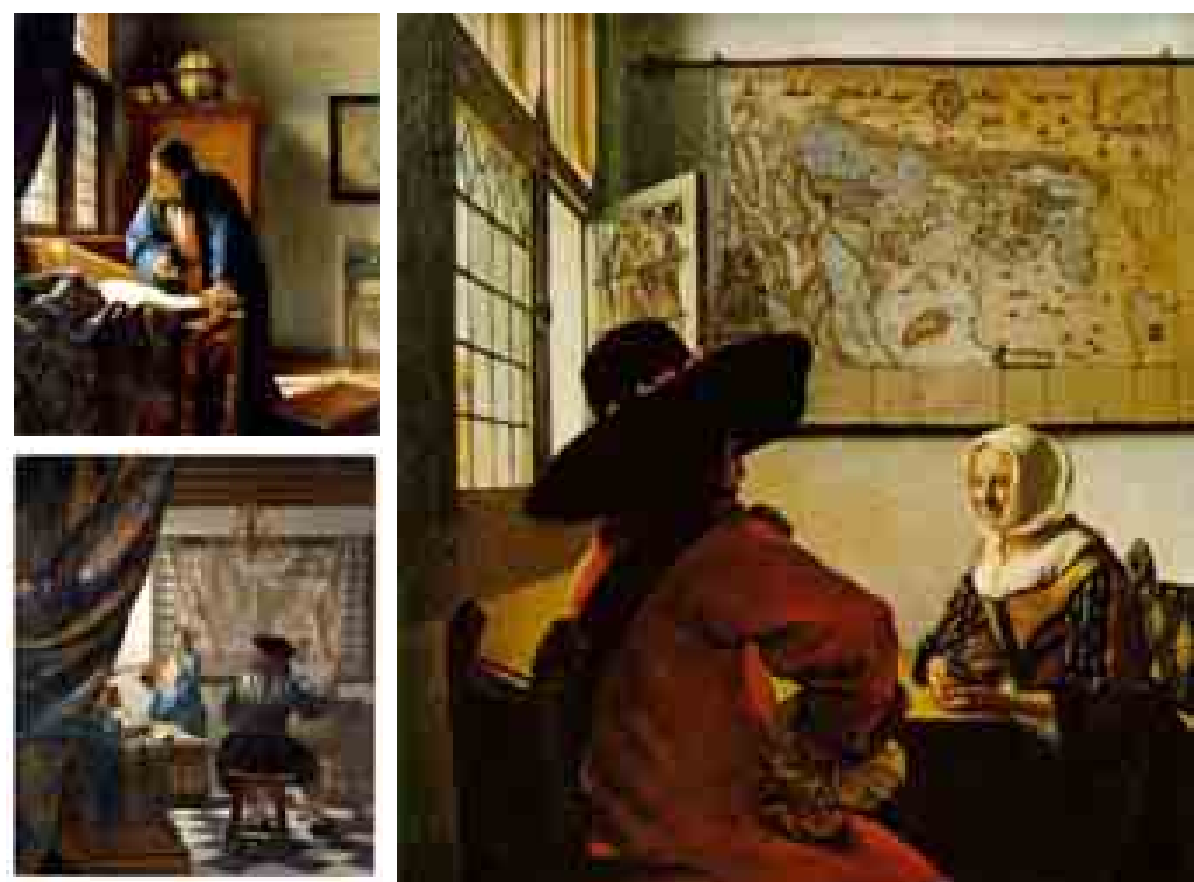

Figura 3.39

Johannes Vermeer (1632-1675)

* Izquierda superior: El Geógrafo (hacia 1668-1669)

* Izquierda inferior: El arte de la pintura -De Schilderkunst- (1666),

* Derecha: Oficial y muchacha riendo (1655-1660)

Muestran el interés por el territorio y la importancia de la cartografia en la Edad de Oro de los

Paises Bajos en el XVII 

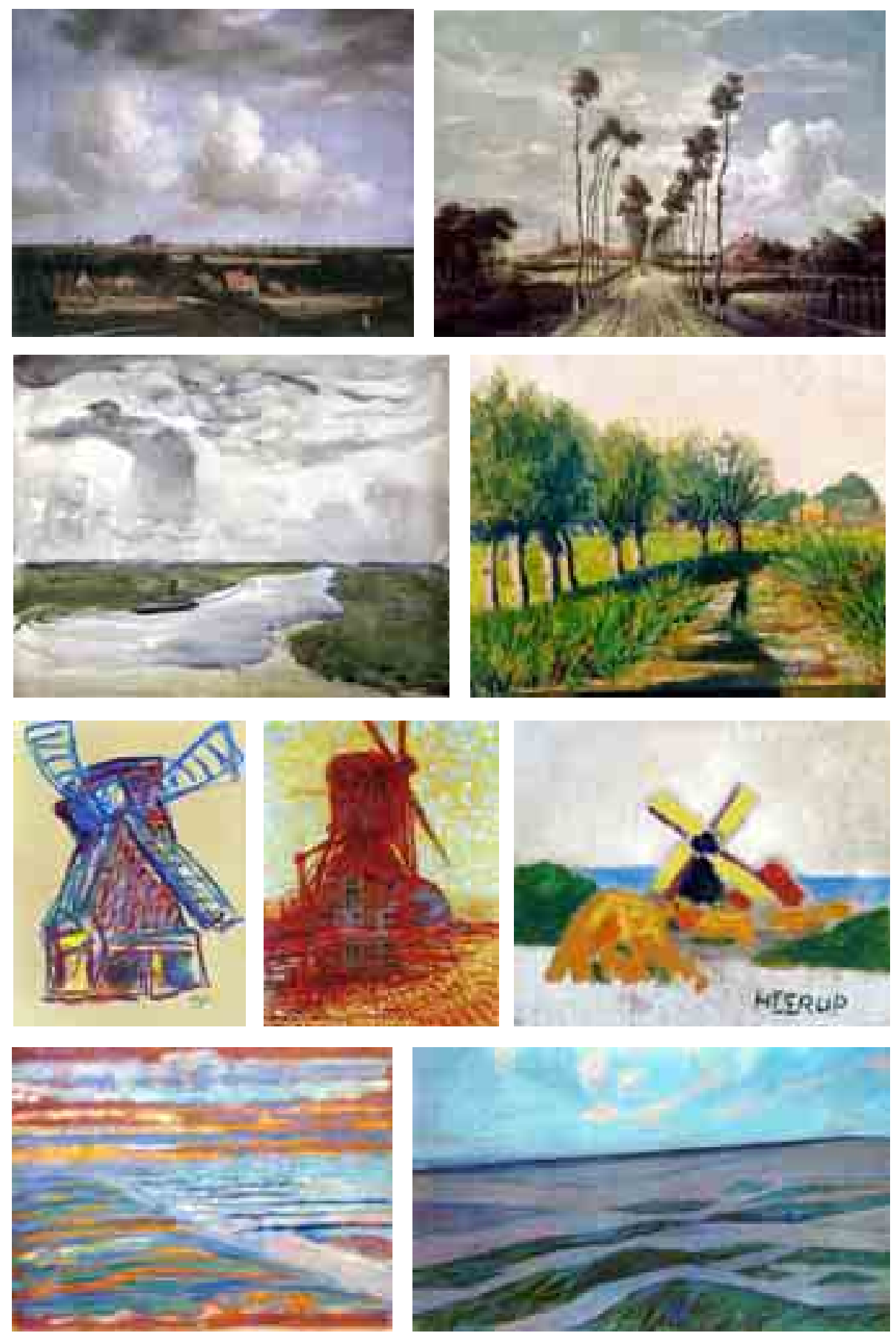

Figura 3.40

De izquierda a derecha y de arriba a abajo:

- Landscape with a View of Haarlem (1670-1675), Jacob Isaacksz van Ruisdael (1628/1629-1682)

- The Avenue at Middelharnis (1689), Meindert Hobbema (1638-1709)

- Meandering Landscape with River (1906-1907), Piet Mondrian (1872-1944)

- Polder Landscape (1940), Christiaan "Karel" Appel (1921-2006)

- Windmill (1984), Christiaan "Karel" Appel (1921-2006)

- Windmill in Sunlight (1908), Piet Mondrian (1872-1944)

- Windmill, Henry Heerup (1907-1993)

- View from the Dunes with Beach and Piers (1909), Piet Mondrian (1872-1944)

- Dune Landscape (1911), Piet Mondrian (1872-1944) 

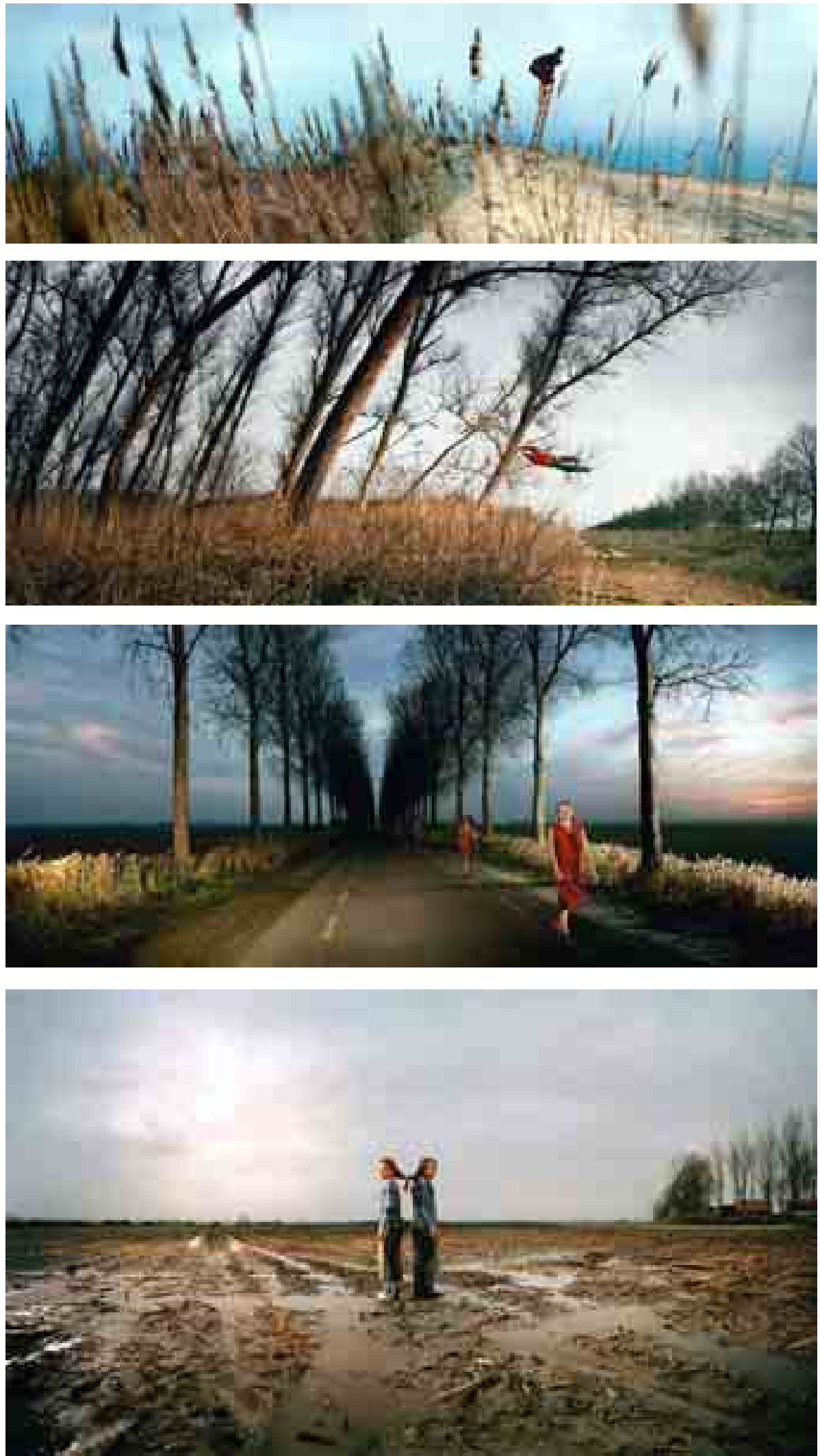

Figura 3.41

Imagenes de la fotográfa holandesa contemporánea Ellen Kooi (1962- )

De arriba a abajo:

- Nauema ladder (2006)

- Muiderzand wind (2006)

- - Abbekerk-tweeling, (klei), (2005) 


\title{
3.3.3.3. Culturas primitivas en territorios inhóspitos. Los viajes del Aldo van Eyck en busca de lo elemental.
}

\author{
Viajes al Norte de África
}

Entre 1947 y 1952, Aldo van Eyck viajo en busca de "lo elemental", de las formas primarias del lenguaje visual ${ }^{60}$ que le conducirá a conocer de primera mano culturas no occidentales. En este periodo, hizo tres viajes al norte de Africa. En el primero, recorrieron Túnez haciendo realidad un antiguo plan, seguramente más atraídos por lo exótico que por una intencionalidad expresa relacionada con la arquitectura. Sin embargo en los dos siguientes viajes al Sahara Argelino, realizados en 1951 y 1952, sí hubo el deseo intencionado de conocer, en palabras de Francis Strauven «primal elements of architectural language», en culturas que precisamente por lo extremo de su clima y su aislamiento, habían mantenido las formas de construir y habitar más elementales, al margen de la civilización occidental. En 1951 Aldo y Hannie viajaron en un viejo camión del ejército, con un grupo de ocho personas incluido un mecánico, recorriendo $4000 \mathrm{Km}$ por el desierto en una apasionante pero dura experiencia por el polvo y el calor. Van Eyck pudo experimentar una sensación opresiva por la ausencia absoluta de escala en extensiones llanas e inmensas de desierto. Así lo explica Jan Rietveld ${ }^{61}$, uno de los integrantes del grupo:

«The crazy thing about absolutely nothing is that you are totally surrounded by a continuos horizon, and you feel, as you ride in a truck, like the compas point at the centre of a gigantic and slowly moving circle. Aldo found it oppressive. At a certain point he leapt out the truck and walked some way off into the desert. He was trying to escape that compass point» (Strauven 1998)

En la primavera de1952, Aldo y Hannie hicieron un tercer viaje, con los Van Ginkels para recorrer el oasis rojo y otros menores en el Grand Erg Occidental ${ }^{62}$. Las famosas imágenes que ilustran el capítulo del libro de Strauven, corresponden a fotografías realizadas por Aldo van Eyck en este viaje, y fueron publicadas por primera vez por el mismo en la revista Forum, en el n¹ de 1953, como parte del artículo "Bouwen in de Zuidelijke Oasen"63 junto a las del viaje de 1952. Quince fotos y algunas notas, expresan las impresiones en ambos viajes. Despiertan especialmente su interés lo elemental de las formas cubicas de las casas, que con muros macizos de bordes y esquinas ligeramente redondeados, sin ángulos rectos, producen la impresión de organismos de gruesa piel; efecto aun más acusado en enterramientos y pequeñas construcciones funerarias. Un pequeño sepulcro aislado en el desierto cerca de Timoudi, que Strauven propone como evocadora de una escultura de Jean Arp y del diseño de algunos de los juegos de niños de Van Eyck en Amsterdam, llama poderosamente la atención de van Eyck.

60 En un principio los recorridos se centran en Europa y sus intereses incluyen lugares prehistóricos de Bretaña en Francia, que Hannie y él visitaron probablemente en el verano de 1947, en uno de sus primeros viajes juntos, pero también conocidas referencias de obras clásicas, como Versalles, o las plazas del XVIII en Nancy de Herné de Corny, visitadas con frecuencia en sus viajes desde Zurich. Llama especialmente su atención el conjunto de edificios que configuran la Place de la Carrière, con una apariencia exterior de bloque compacto cuando es vista desde el Parc de la Pépinière, pero que encierra un espacio interior, a su vez definido por dos impresionantes macizos vegetales formados por dos hileras dobles de arboles tratados escultóricamente como sólidos. En el mismo sentido, muestra interés en los jardines de Villa Giulia en Roma donde pasaron unas vacaciones ese periodo (Strauven 1998)

61 Jan Rietveld estaba trabajando en ese momento con Aldo van Eyck. La cita es parte de una entrevista mantenida por Francis Strauven con Jan Rietveld en Amsterdam, años después, el 4 de agosto de 1981, recogida por Strauven en Aldo van Eyck. The Shape of Relativity.

${ }^{62}$ El Western Sand Sea, el segundo desierto mayor del norte de Argelia, tras el Grand Erg Oriental.

63 Traducido al inglés "Building in the Southern Oases" e incluido en Aldo van Eyck Writtings.

Collected articles and other writtings 1947-1998. (Ligtelijn y Strauven. 2008) 
La extraordinaria coincidencia temporal y de temáticas de estudio entre estos viajes y el desarrollo del proyecto en el Noordoostpolder, no han sido objeto del análisis que aquí abiertamente se propone: la posible influencia de la abstracción de la arquitectura del desierto en la concepción unitaria de la estructura urbana de Nagele y su relación con el polder. Van Eyck viaja al Sahara en busca de lo elemental, de formas primarias del lenguaje visual que sinteticen los principios esenciales del hombre presentes en todas las culturas. La expresión arquitectónica de estos valores en los pueblos del desierto que van Eyck descubre, son formas básicas e icónicas, aisladas, cerradas y unitarias en su dialogo con el territorio que las rodea, como Nagele. El Noordoostpolser recién drenado es un desierto de barro: «una llanura interminable de tierra salobre con lodo ${ }^{64} »$, «un vasto territorio reclamado al mar: artificial - geométrico visualmente ilimitado - azotado por el viento» ${ }^{65}$

Van Eyck trabajó habitualmente con la combinación de formas elementales, cilindros y prismas, cuadrados y círculos, que se articulan en diferentes combinaciones y proporciones para generar lugares de relación entre ambos. Sin embargo, una mirada a sus proyectos, nos permite comprobar la rotunda y poco habitual forma rectangular de Nagele, consecuencia de su condición aislada en el territorio del polder. Al igual que la pequeña construcción funeraria cerca de Timoudi en el Sahara argelino, también única, aislada y rodeada por terreno desértico, fotografiada y publicada por van Eyck en Forum, Nagele es un prisma verde posado sobre el plano horizontal y artificial del Noordoostpolder, un lugar con identidad.

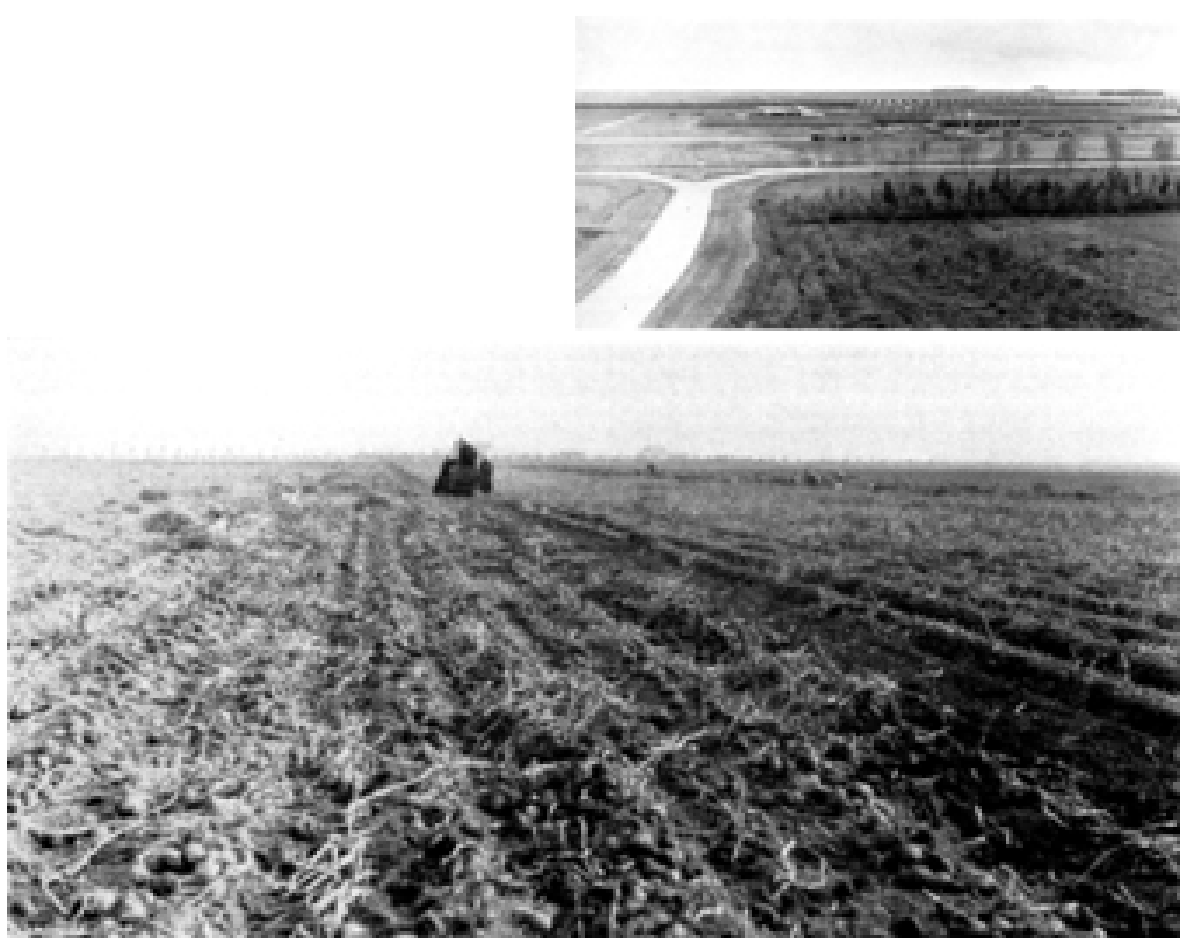

Figura 3.43

El "desierto" holandes del polder recien drenado.

* Superior, Nagele en construcción. Al fondo se ve el cinturón de arbolado del cementerio recién plantado

* Inferior, Paisaje tipico del polder del noroeste

Ambas publicadas en "Nagele, ein neues Dorf auf neuem Land", en Werk nº5, mayo 1961, p166

\footnotetext{
64 «an endless plain of muddy, brackish ground», de la primera visita realizada por el grupo de trabajo al polder recién drenado en 1948 (Strauven 1998). Traducción Ana Rodríguez

65 «large territory claimed from the sea: man-made - geometric- visually unlimited -windswept», del panel 1 de la grid de presentación de Nagele en Dubrovnik, en el CIAM X, 1956. Traducción Ana Rodríguez
} 

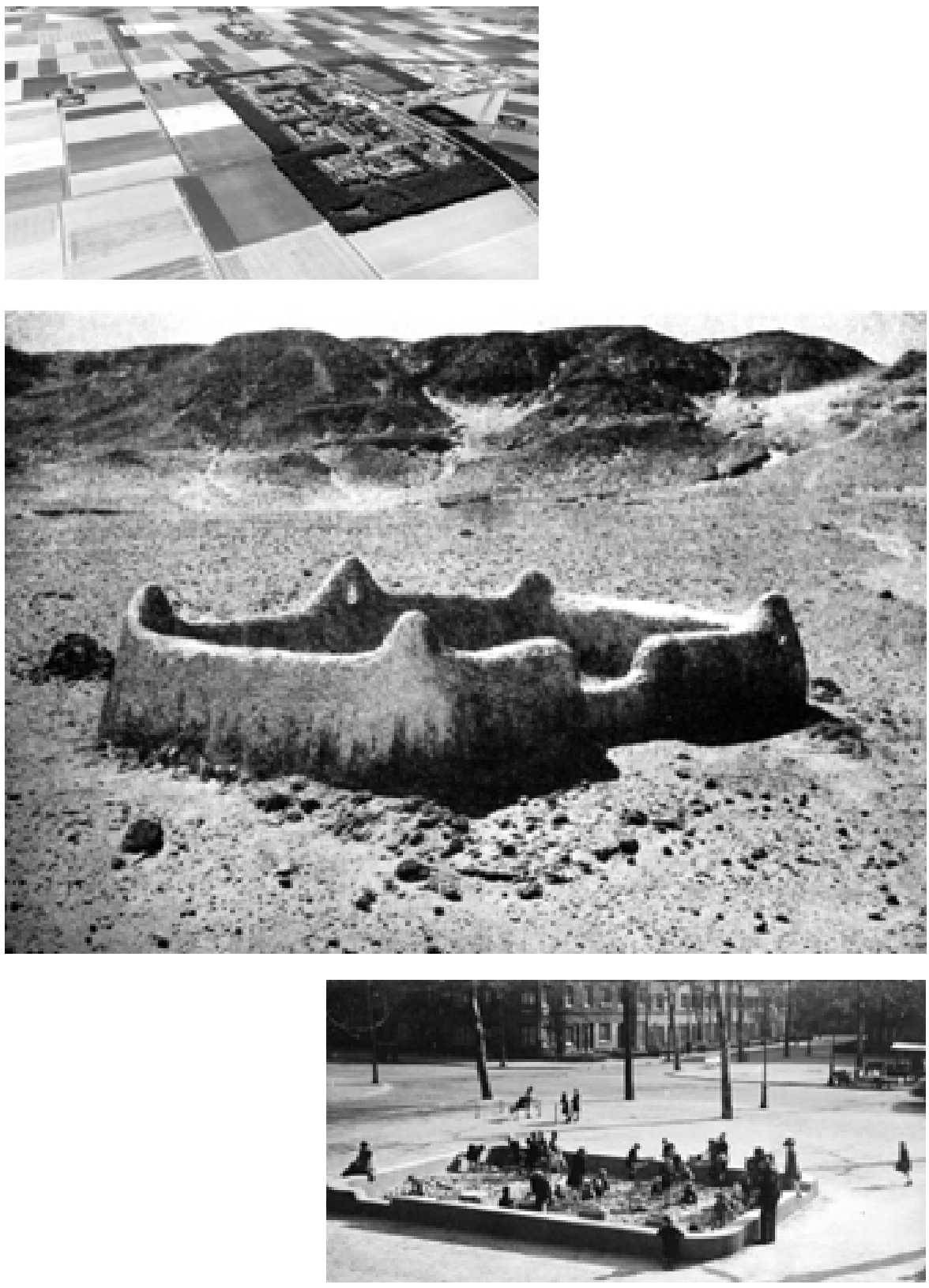

Figura 3.44

La arquitectura del Sahara argelino como referencia.

Selección comparada de imágenes por Ana Rodríguez a partir de la siguiente documentación

* Centro

Sepulcro aislado en el desierto cerca de Timoudi. Fotografía de Aldo van Eyck. Publicado por primera vez por Van Eyck en la revista Forum, en el n¹ de 1953, como parte del artículo "Bouwen in de Zuidelijke Oasen" (Van Eyck 1953)

* Inferior

Bertelmanplein playground, Amsterdam. Aldo van Eyck, 1947 (Strauven 1988)

* Superior

Vista aérea de Nagele. Punto de vista y encuadre de Ana Rodríguez a partir de imagen de Google Earth. 


\section{Los Dogon y los Indios Pueblo}

Desde sus primeros contactos con la revista Minotaure, Aldo Van Eyck fue configurando a lo largo de vente años, un amplio panorama antropológico de diversas culturas, investigando el significado de «los principios arcaicos de la naturaleza humana», de los valores esenciales que habían pervivido en culturas primitivas. Entre ellas, dos despiertan especialmente su interés: la cultura Dogon, localizada en lo que entonces era el Sudan Francés, y la de tribu Zuñi de los Indios Pueblo en Nuevo Méjico, a la que había llegado a través de Patterns of Culture de Ruth Benedict.

Por su lejanía geográfica, en principio pueden parecer muy diferentes, pero un estudio detallado muestra que tienen más en común de lo que en principio pudiera parecer. Ambas son culturas primitivas que han sido capaces de mantener su identidad primigenia, incluso frente a la presión exterior de otras culturas -como la de los conquistadores españoles con los Indios Pueblo a los que dieron nombre-, a costa de una existencia retirada en un lugar desértico y naturalmente inhóspito. Los asentamientos Dogon, cuelgan de los precipicios de Bandiagara y los poblados Zuñi están rodeados de desierto o semidesierto. Situaciones que precisamente por su dificultad, favorecen una visión clara de lo realmente importante y esencial. Ambas son sociedades estructuradas no jerárquicamente, que viven en una red de pequeños asentamientos dispersos, que se rigen por una visión de la vida social y religiosa compartida, por una fuerte unidad, y por una identificación entre mente y materia, entre sujeto y universo, entre lo grande y lo pequeño. Ambas culturas comparten la creencia del deber del hombre de estar en armonía con la naturaleza y el orden cósmico, y contribuye a ello con el mantenimiento ancestral de ritos, que se expresan a través de danzas rituales y también, y de forma muy especial, en la morfología urbana de sus asentamientos. (Strauven 1998)

A mediados de febrero de 1960, poco después de terminar el Orfanato de Amsterdam, Van Eyck viajó por primera vez con Hannie a África Occidental, a la región Dogon, donde conoció a dos psicoanalistas suizos, Paul Parin y Frtiz Morgenthaler, en Ogol uno de los poblados gemelos más grandes. Su conocimiento de la mitología, rituales y vocabulario simbólico, ayudaron a Van Eyck a una mejor comprensión de las imágenes que ya conocía a través de publicaciones, además de ponerles en contacto con algunos individuos del poblado: «esto me ayudo a llegar a conocer no solo las casas y pueblos que admiraba desde hace tanto, sino también a sus constructores. Lo considero un especial privilegio»66

La experiencia le marcó profundamente y le permitió identificar ideas con las que había estado trabajando desde hacía tiempo. En un primer momento, publicó un artículo corto en Forum en 1961, pero no fue hasta 1967 cuando escribió uno más extenso que enfatiza sobre todo la identificación de lo pequeño con lo grande y el hombre con el asentamiento, y en el que el principio de dualidad desempeña un papel fundamental de equilibrio. Sobre la cosmovisión de los Dogon, Van Eyck dice que «these astounding people» -estas gentes asombrosas- ven el mundo:

"como un organismo humano gigantesco, y todas sus partes son como reproducciones de la misma imagen en menor o mayor escala» (..)

«Hacen aprehensible el sistema del mundo, traen el universo dentro de sus límites mensurables; hacen que el mundo sea un lugar habitable, traen lo que está "fuera", " dentro" „,67

\footnotetext{
66 «This helped me to get to know not only the houses and villages I had admires for so long, but their builders also. This I regard as a special privilege." (Ligtelijn y Strauven. 2008, 374). Traducción Ana Rodríguez.

${ }^{67}$ «as a gigantic human organism, and all its parts as being reproductions of the same image on a smaller or larger scale» (..) «made the world system graspable, they brought the universe within their measurables confines; they made the world a habitable place, they brought what was
} 
«Lo que es cierto de la cesta de Dogon, es también verdad de la casa Dogon y del pueblo Dogon; su significado simbólico es igualmente extraordinariamente expansivo. No exagero cuando digo que los todos los objetos materiales, desde el más pequeño hasta el más grande, que dan soporte a la vida cotidiana se cargan de significado adicional y se identifican en estadios con el total de la creación. Un patrón secuencial de identificación en expansión y que, por último, se corresponde con el orden universal.»68

El universo entero en la piscina de arena de un playground, y en la forma unitaria rectangular de la planta del asentamiento de Nagele, en el polder recién drenado. Lo explorado por Van Eyck en estas obras, donde la búsqueda de identidad se antepone a la escala de la actuación, inspirándose en la abstracción de las arquitecturas vistas años antes en sus viajes al Norte de Africa, se ratifica en la cosmovisión de los Dogon, en la que el orden universal se encuentra indistintamente y de la misma forma en una cesta y en la planta de un poblado.

Yi-Fu Tuan, en su libro Topofilia, afirma que salvo que se derive de una cultura extranjera, la cosmovisión de un pueblo, es decir su concepción del mundo, está estrechamente relacionada su entorno natural, con su realidad física y social, y refleja los ritmos y las limitaciones de su ambiente natural. Para ilustrarlo, establece la comparación entre la diferente cosmovisión de dos culturas con entornos naturales muy diferentes: la selva de los pigmeos bambuti en el Congo y el semidesierto de los Indios Pueblo.

El rasgo fundamental que caracteriza la selva es su capacidad para envolverlo todo sin referencias, sin cielo, ni tierra, y sobre todo sin horizonte. No hay ningún árbol aislado como un baobá en las llanuras africanas. Tuan dice:

«Los pigmeos bambuti de la selva pluvial del Congo no viven tanto en la tierra, con los cielos arriba y el averno abajo, como dentro de un elemento que todo lo abarca. Las estrellas no figuran en su cosmografía. El mismo Sol no es un disco resplandeciente que sigue una trayectoria en el cielo, sino fragmentos de una luz temblorosa en el suelo de la selva. De las doscientas o más leyendas recogidas por los pigmeos, solo tres tiene que ver con la creación del mundo o con las estrellas y el cielo, y parecerían influidas por leyendas provenientes de otros pueblos africanos» (Tuan [1974] 2007, 113)

Todo se ve en cercanía, y al no existir vistas en la distancia, una consecuencia en la percepción es el acortamiento de la perspectiva. Fuera de su hábitat los pigmeos quedan aturdidos por las distancias y la falta de arboles, incapaces de comprender la scala real de los animales cuando están lejos, pudiendo llegar a confundir búfalos con mosquitos $^{69}$.

"outside", "inside"» Aldo van Eyck en Forum, julio 1967 p.35, versión inglesa en Via n¹ p.15 y citado por Francis Strauven en Aldo van Eyck. The Shape of Relativity (Strauven 1998, 387). Traducción Ana Rodríguez.

${ }^{68}$ «What is true of the Dogon basket is also true of the Dogon house and the Dogon village; their simbolic meaning is likewise extraordinarily expansive. I am not exaggerating when I say the all the material objects, from the smallest to the largest, which support daily life are charged with extra meaning and are identified in stages with the totally of creation. A sequential pattern of identification expanding and, finally, corresponding with the universal order.» Van Eyck, Aldo. 1967. «Dogon: Mand-Huis-Dorp-Wereld». Forum, julio 1967. Reeditado en «A Miracle of Moderation» (Ligtelijn y Strauven. 2008, 389). Traducción Ana Rodríguez.

69 Tuan se refiere a la perplejidad de un pigmeo, descrita por Colin Turnbull, cuando lo llevaron a los abiertos pastizales cercanos al lago Edward, al ser incapaz de comprender que lo que creía mosquitos, eran en realidad una manada de búfalos que se divisaba en la lejanía. (Tuan [1974] 2007, 113-114) 
En contraposición, la cosmovisión de los Indios Pueblos del suroeste de Norteamérica, es la antítesis de la de los pigmeos bambuti. El entorno natural de los Pueblo es bien definido y contrastado. En la meseta semidesértica en la que se asientan existen fuertes puntos de referencia como mesas y desfiladeros. El Sol es omnipresente, incidiendo con una luz de contrastes, y rige el calendario agrícola y ceremonial. El Sol, el cielo, la tierra y el maíz, son protagonistas en su mitología, y lugar, ubicación y dirección constituyen variables significativas en su cosmovisión. (Tuan [1974] 2007)

Estas apreciaciones refuerzan la pregunta realizada anteriormente, relativa a por qué Aldo van Eyck, con sus antecedentes culturales coloniales en el Caribe, como ciudadano de un país con territorios en ultramar, y por su personal relación cercana y familiar con un territorio lejano de tradiciones primitivas que sin duda le influyeron en su infancia y adolescencia, todos sus escritos e investigaciones significativas sobre lo vernáculo, se refieren a otras culturas como la Bereber, la Dogon o la de los Pueblo ${ }^{70}$.

La respuesta dada desde esta tesis a dicha cuestión, no abordada por otras investigaciones, propone - además de otros factores- que la elección de determinadas etnias no es casual, sino que se debe al interés de Van Eyck por culturas que habrían sido capaces, mediante asentamientos construidos, de dejar una huella significativa e identitaria en territorios desérticos. En lugares inspiradores para dotar de identidad sus obras en la abstracción del territorio holandés.

Las características descritas de la selva de los pigmeos bambuti, son equivalentes a la selva tropical de Surinam, y están realmente alejadas de la naturaleza holandesa. La idiosincrasia y cultura polder de los Países Bajos es vivida por Van Eyck en uno de sus momentos cenit, con la reclamación y polderización de grandes extensiones del Zuiderzee. Con la construcción física del territorio y el desafío de generar nuevas poblaciones ex novo en un territorio sin apenas atributos, como en el caso de Nagele. Los nuevos territorios construidos artificialmente, en cierta forma tienen más que ver con las tierras de los Bereberes, los Dogon y los Pueblo. Desiertos húmedos, o desiertos secos, ambos afrontan retos parecidos.

Entre las tribus arcaicas africanas, como la Dogon, no existen términos específicos para designar diferenciadamente aldea de ciudad. La distinción, más que cualitativa es cuantitativa y así una ciudad será una aldea grande. En realidad, las poblaciones de los reinos africanos no son ciudades con el concepto utilizado en la historia urbana de Occidente y Oriente, sino que «son aglomerados semiurbanos, con esenciales funciones directivas, políticas y administrativas sobre el territorio circundante, pero sin suficientes caracteres distintivos que permitan considerar su evolución histórica con los mismos parámetros que se emplean en la historia urbana del Occidente o del Oriente» (Guidoni [1975] 1977)

En los asentamientos de culturas arcaicas y en concreto las de los Dogon y los Pueblo, la forma urbana representa su forma de ver el mundo. La escala del asentamiento permite su percepción en la amplitud del entorno desértico, y de esta forma, como en el caso de los Pueblo, formas geométricas simples: círculos, cuadrados o semicírculos, .colonizan el territorio con aldeas cada poca distancia, relacionadas entre sí, pero al mismo tiempo autónomas y con identidad. De nuevo como Nagele.

70 Desde 1947, Aldo van Eyck viajó y estudió numerosas culturas primitivas, desde Tierra de Fuego a Islandia o la Isla Navidad (Ligtelijn 1999, 298) 


\subsubsection{El arbolado protector}

[Topiaria]

\subsubsection{El tratamiento escultórico de la vegetación}

El tratamiento escultórico de la vegetación y del arbolado en la obra de Aldo van Eyck, es heredero de una arraigada tradición en los Países Bajos. Un repaso a sus proyectos, permite identificar maneras de trabajar con la vegetación que hunden sus raíces en la tradición del jardín holandés del XVII: las alineaciones de arbolado como defensa de los vientos dominantes, que caracterizan el paisaje de los Paises Bajos con alineaciones que marcan las divisiones de propiedad en las granjas y casas de campo, y masas vegetales que se recortan generando espacios habitables, en la mejor tradición topiaria en la que Holanda fue una potencia en su edad de oro, exportando la moda por este tratamiento del jardín, y con gran influencia en la jardinería inglesa desde que Guillermo III de Holanda ${ }^{71}$ ocupó el trono de Inglaterra en 1689.

Pero el interés por el mundo vegetal, tan presente en los proyectos de Aldo van Eyck, además le llega a través de madre. La madre de van Eyck, Nelly Bejamins había nacido en Surinam, al igual que su padre, físico y botánico, que llegó a supervisar el Jardín Botánico de Surinam, Surinamese Botanical Gardens. Tenía un don natural para el trabajo con las manos y las plantas, así como amplios conocimientos de botánica, en parte heredados de su padre y de su íntimo contacto con el entorno natural tropical de su juventud. Tanto su pequeño jardín en el número 49 de Russell Gardens en Golders Green, un típico y frondoso barrio de las afueras de Londres, como el de su siguiente casa en Wassenaar, un poco mayor, eran ambos auténticos microcosmos autónomos, cada uno un mundo completo que comprendía todas las estaciones, y a los que su marido P.N. van Eyck, dedico algunos de sus mejores poemas. Aldo van Eyck dice del jardín cultivado por su madre:

«Se veía tan exuberante que era casi irreal. Los transeúntes se asomaban constantemente por encima de la valla» ${ }^{72}$

Sobre ella, Francis Strauven dice: «Bajo sus dedos verdes, cada planta florecía. Ella creó un mundo poético personal dentro de los confines de su jardín: un pequeño mundo de fábulas en el que, por sus propios medios, se hizo eco la poesía de su marido, con flores que alternaban con el ritmo de las estaciones» ${ }^{73}$

Crió a sus hijos con libertad y al margen de convencionalismos, en un hogar donde el jardín cultivado por ella era un pieza esencial. Les inculcó el conocimiento de la botánica y el amor a la naturaleza, demostrando su hijo menor Aldo un especial interés ${ }^{74}$.

Esta interiorización de lo vegetal desde su infancia como algo natural, podría ser la causa de la escasez de referencias escritas explícitas al tema por parte de Van Eyck. Un pequeño escrito titulado "Sobre el arte del jardín y el paisaje", y alguna reseña ${ }^{75}$, son las únicas referencias escritas por Aldo van Eyck encontradas.

\footnotetext{
${ }^{71}$ Ver la topiaira en el Upper Lawn Pavilion, desarrollado en el capítulo anterior.

${ }^{72}$ «lt looked so luxuriant that it was almost unreal. Passers-by constantly peered over the fence» Aldo van Eyck sobre el jardín de su madre en Golders Green, en conversación con Francis Strauven. (Strauven 1998, 17) Traducción de Ana Rodríguez

${ }^{73}$ «Under her green fingers, every plant flourished. She created a personal poetic world within confines of her garden -a little world of fables in which she echoed the poetry of her husband by her own means, with blossoms that alternated with the rhythm of the seasons." (Strauven 1998, 17) Traducción de Ana Rodríguez

${ }^{74}$ Aldo mostro tanto interés que le regalo un terrarium con el que pudo aprender por sí mismo el cuidado de plantas y más tarde de reptiles, que incluían lagartos y serpientes. (Strauven 1998, 21)

75 Sobre una foto del Generalife en la Alhambra de Granada, ilustrando el escrito "The Enigma of Size", escribe: un seto, alto y esbelto, con una forma fijada durante siglos, lujo y simplicidad, un espacio que permanece, (Ligtelijn y Strauven. 2008, 485).
} 
El texto "On garden and landscape art", publicado en Aldo van Eyck Writtings. Collected articles and other writings 1947-1998 (Ligtelijn y Strauven. 2008, 128), es traducción al inglés de "Over tuin- en landschapskunt", manuscrito no fechado de una conferencia, que probablemente fue dada en 1957, en relación con la exposición de Roberto Burle-Marx, que tuvo lugar en el Amsterdam Stedelijk Museum entre el 18 de febrero y 18 de marzo de 1957.

En él, se puede apreciar el sentimiento de Van Eyck por lo vegetal, estableciendo una distinción no excluyente, entre quienes se acercan a la jardinería por mero amor a la naturaleza, por la espiritualidad de un trabajo manual que te pone en contacto con energía de la tierra y con las plantas como seres vivos, y quienes además están interesados en el resultado final del conjunto cultivado, es decir los preocupados por el diseño del jardín y el paisajismo, sobre los que dice: «ellos ven las plantas también como un elemento de construcción ${ }^{76}$, poniendo como referencia a Roberto Burle Marx. Van Eyck, expone la dificultad de la disciplina en su sentido verdadero, y la distingue de una utilización no intencionada, muy frecuente, en el diseño urbano de barrios y ciudades, donde lo vegetal es tratado como mera decoración, no como algo constituyente del entorno construido, aunque con la ventaja de que los arboles benefician cualquier lugar por su propia esencia «porque son autónomamente grandes y bellos, incluso aunque estén mal situados " ${ }^{77}$ Termina el texto explicando la necesidad de utilizar pocas especies, cada una en cantidad suficiente, para no generar confusión, frente a la práctica equivocada de plantar muchos ejemplares mezclados.

Una mirada atenta a esta cuestión, nos muestra como los proyectos de Van Eyck, desde los playgrounds y Nagele, están íntimamente relacionados y/o configurados a partir de lo vegetal. También el espacio de planta circular de la Ampliación de la Casa Visser, está intencionadamente excavado en la masa arbolada de la parcela, indicándonos las fotografías del estado anterior cómo con seguridad tuvo que quitar algunos de los arboles existentes entonces de pequeño tamaño, en un claro ejemplo de tratamiento escultórico de lo vegetal, como un material más del proyecto.

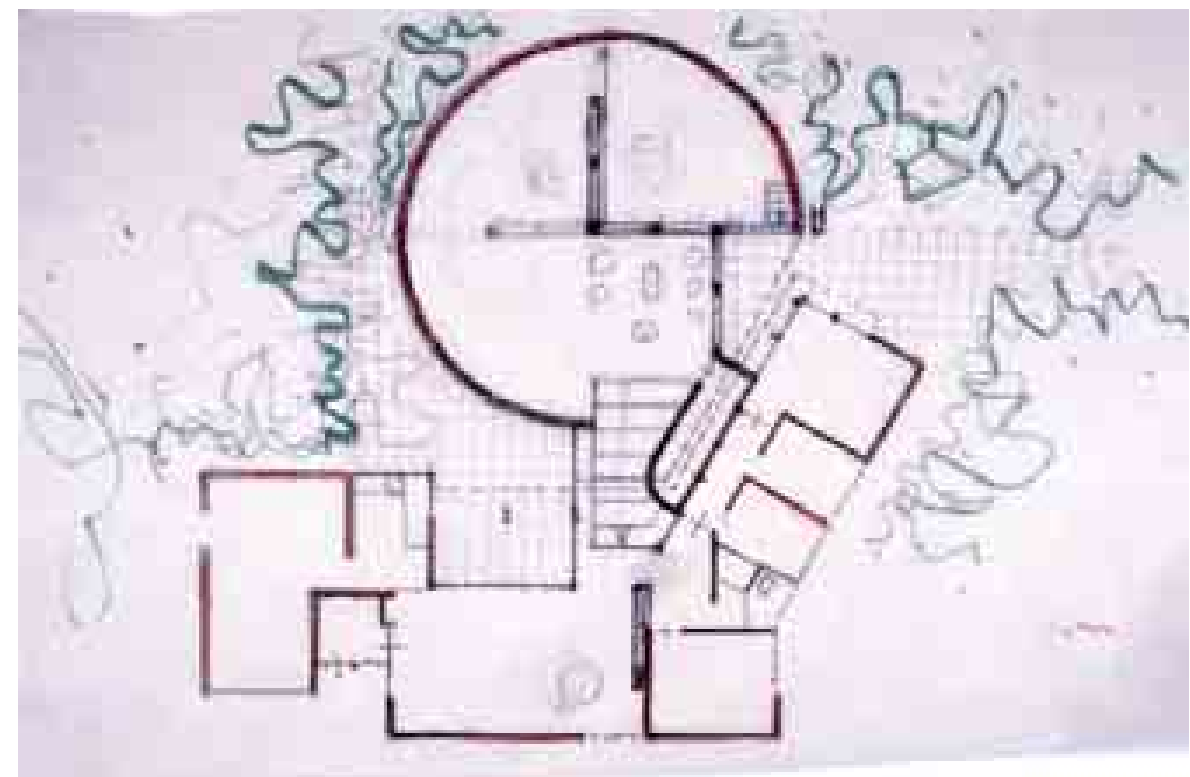

\section{Figura 3.45}

Croquis del proceso de proyecto para la Ampliacion de la Casa Visser por Aldo van Eyck, en el que se puede apreciar como la idea de espacio excavado en el arbolado, está presente de forma intencionada desde las primeras fases.

Dibujo inédito del Archivo Van Eyck. Copia digitalizada facilitada por Francis Strauven

76 «The see th plant also as a building element» (Ligtelijn y Strauven. 2008, 128). Traducción Ana Rodríguez.

77 «because they are autonomously large and beautiful, even if they are badly positioned»(Ligtelijn y Strauven. 2008, 128). Traducción Ana Rodríguez. 

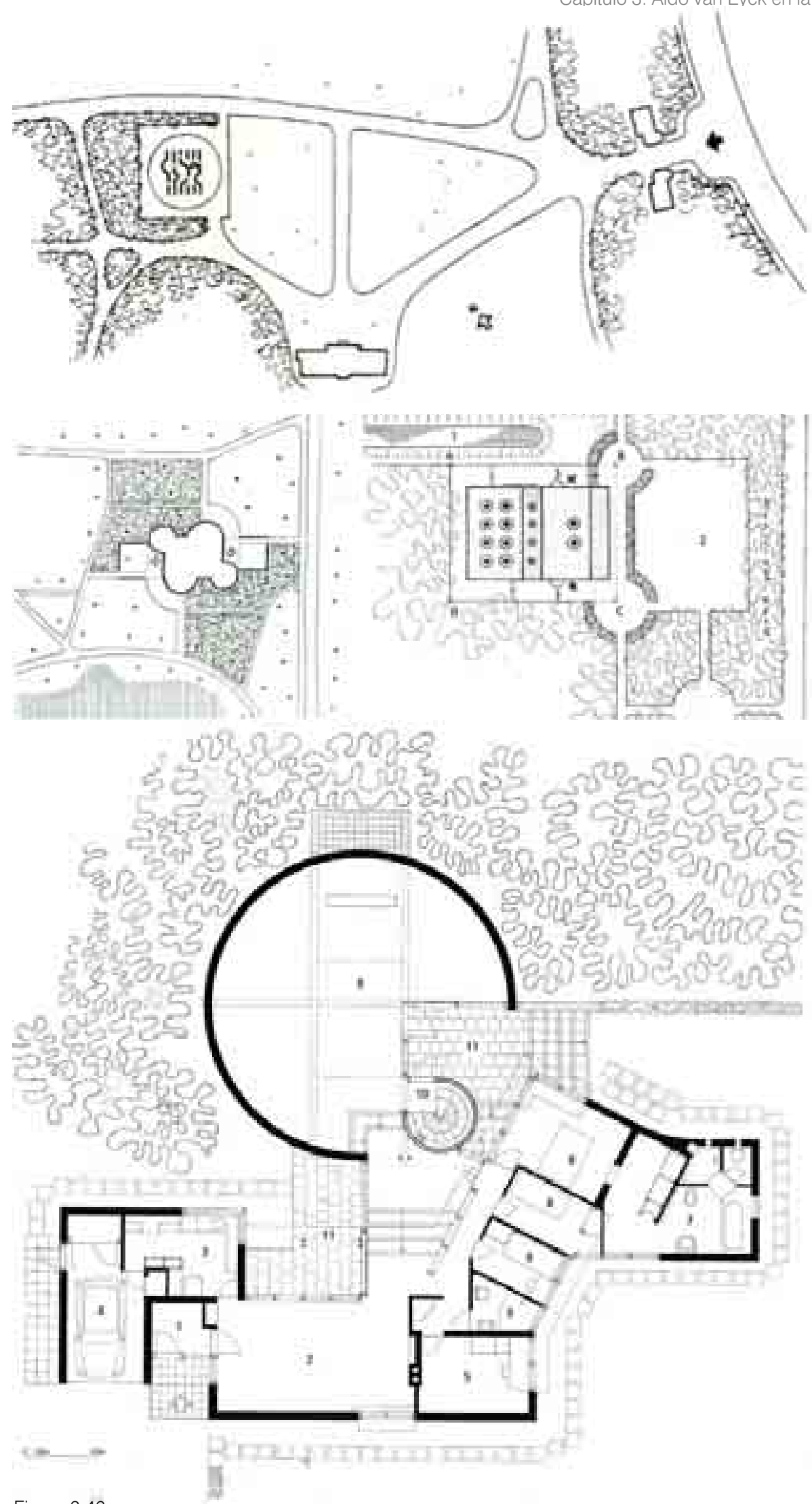

Figura 3.46

Tratamiento escultórico de lo vegetal en la obra de Aldo van Eyck. Grupo de proyectos 19631970.

* Superior, centro izquierda y centro derecha

Planos de situación del Sonsbeek Pavilion en Arnhem (1965-66), «The Wheels of Heaven» -las ruedas del cielo- (1963-1964) y de la iglesia católica romana Pastoor van Ats Church en la Haya (1963-66, 1968-69) respectivamente.

* Inferior

Planta de la Casa Visser después de la segunda ampliación por Aldo van Eyck, en el que se puede apreciar la idea de espacio excavado en el arbolado 


\subsubsection{La "Fine Dutch Tradition" y el jardín holandés del XVII}

La expresión "Fine Dutch Tradition", un término usado por Steenbergen y Reh, se refiere a esta antigua, única y típica arquitectura del paisaje holandesa y del planeamiento urbano, en los cuales el agua fue siempre un factor decisivo, útil, sobrio y hermoso. El término, fue introducido por Henk Engel al final de la década de 1970 para argumentar la arquitectura como producto del paisaje. La declaración refleja la importancia que tuvo la cultura del jardín en el dominio de un difícil territorio, y como su influencia alcanzó amplios espectros de la cultura holandesa en torno a 1700. La situación y el tamaño de los jardines en relación al sistema geométrico de canales de drenaje, demostraron que los jardineros holandeses fueron maestros en la combinación de la horticultura, la tecnología, la gestión del agua y el diseño arquitectónico. (Hooimeijer 2010)

Nagele, el único asentamiento moderno del Noordoostpolder, es en gran medida heredero de la mejor "Fine Dutch Tradition" materializada con esplendor en los jardines $^{78}$ de las casas de campo del XVII, cuando la compra de un terreno con dependencias estaba regulado de cara a la construcción de una residencia rodeada de jardines. Estas pequeñas propiedades en la vasta planicie del paisaje polder, formadas por una casa, un jardín y tierras, eran unidades agrícolas o de caza, siempre signo de riqueza y prosperidad, y se hicieron populares entre dirigentes y mercantes. El mejor testimonio de la vida en el campo en este periodo esta en el texto de Jan van der Groen Den Netherlandtsen Hovenir, publicado en Amsterdam en 1669, libro de gran influencia que se llegó a traducir al francés y al alemán. Para Van der Groen como jardinero, el hombre puede mejorar la naturaleza por medio del arte, «transformando el agua en tierra y la tierra en agua». Arte entendido como ciencia, de la combinación de horticultura, topografía y matemática. La exitosa experiencia de drenaje de los primeros grandes polders en Beemster y Schermer a principios de siglo, llevó al poeta Jacob Cats a escribir sobre Sorgvliet su casa de campo cerca de La Haya que «no es placer menor cuando uno transforma tierras húmedas en tierra fértil a través del arte» Van der Groen explica como el arte nos enseña que los huertos y los jardines de placer, tienen que estar protegidos contra los fríos vientos mediante grandes robles, álamos y olmos plantados a su alrededor. Así grandes avenidas proyectadas como cortavientos se realizaron como parte integrante de todos los jardines durante el XVII, caracterizándolos como recintos cerrados desarrollados hacia el interior. El arbolado considerado como «material de construcción» para el jardín en el que la diversidad de ejemplares y su tratamiento adquirieron una importancia fundamental.

Los pueblos del Noordoostpolder tienen una serie de características comunes. Todos disponen una superficie arbolada como barrera de protección contra el viento, y una zona verde donde se concentran los equipamientos: tres iglesias y tres escuelas de las religiones mayoritarias, mas una zona de comercio local ${ }^{79}$. Las variaciones en su espesor y superficie los diferencian entre sí. El drenaje del terreno y loteo de parcelas se lleva a cabo mediante un sistema modular de unidades regulares estándar de $300 \times 800 \mathrm{~m}$, organizados paralela y perpendicularmente, además de las direcciones resultantes de su adaptación a las vías radiales de polder.

\footnotetext{
${ }^{78}$ El proyecto de plantación de Nagele junto con el cementerio es básicamente obra de Mien Ruys, miembro de de 8. Aportaciones diversas de Jan Bijhouwer; de Pieter Verhagen de la oficina de Wieringermeer, en la concepción paisajística del Noordoostpolder.

${ }^{79}$ El programa de Nagele dado a de 8 por el Wieringermeer Board, además incluía un centro comunitario y oficina municipal, una oficina de correos, un estación de bomberos local, un bar y hotel, dos pequeños cafés, una clínica, cementerio, campos de deporte, piscina y área de negocio para las industrias del sector agrícola.(Strauven 1998)
} 
El resultado es un paisaje artificial, rigurosamente geométrico y sin acentos, en el que pueblos y granjas son como islas verdes en el área agrícola abierta del polder.

A diferencia del resto de asentamientos, con planimetrías irregulares, producto de su organización abierta entorno a vías que se cruzan, Nagele es una estructura cerrada que se organiza alrededor de un gran espacio verde central. Como otros, es en parte un Brinkdorp ${ }^{80}$, pueblo organizado en relación a una extensión arbolada, de brink, plaza verde tradicional rodeada de arboles en núcleos rurales, y dorp, pueblo, pero en Nagele hay una decidida voluntad de generar un gran espacio central, libre de circulación de vehículos, que también permite el libre paseo, en contraposición a los terrenos agrícolas polderizados circundantes en los que únicamente puedes desplazarte por los pasos previamente planificados: «un gran verde central; arboledas, bosques y lugares de diversión, reposo y aislamiento; éstos en lugar de la rigidez del vasto pólder o de las calles de la forma habitual de la aldea ${ }^{81}$ que diera respuesta a «un espacio para vivir aprox. 2500 personas; limitado visualmente -plásticamente definido- protector; un espacio en sintonía con las eternas necesidades de los hombres " ${ }^{82}$ como se enuncia en el primer panel de los cuatro que conforman la grid presentada por de 8 en Dubrovnik, bajo el título «physical and plastic content».

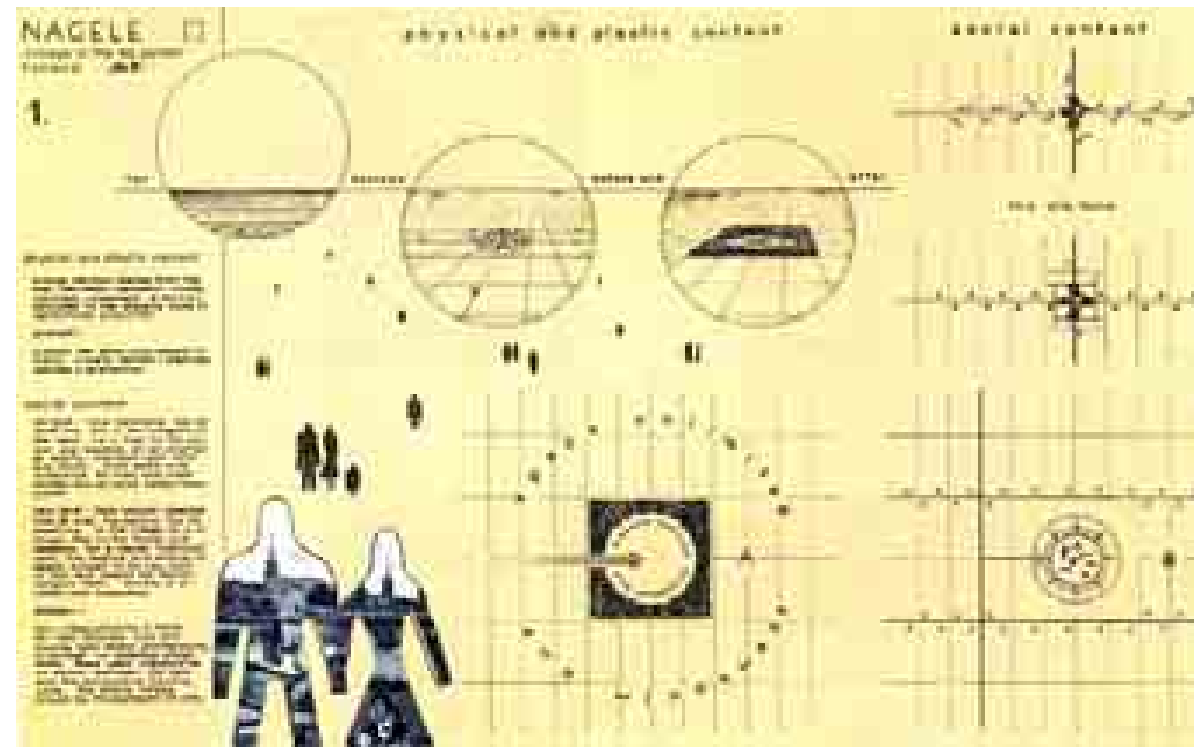

Figura 3.47

Panel 1 de la grid del nuevo asentamiento de Nagele en el CIAM X de Dubrovnik, 1956. (Risselada y Van den Heuvel. 2005)

El concepto urbano planteado se representa como un espacio central, circular y simbólico, recortado en una masa vegetal de perímetro exterior ortogonal cuadrado en dialogo con la qeometría del polder.

\footnotetext{
${ }^{80} \mathrm{El}$ arbolado que circunscribe el espacio verde central, es la condición indispensable para ser considerado un brinkdorp.

81 «a large central green; groves, Woods and places for fun, repose and seclusion; these rather than the rigidity of the vast polder or the streets of the usual village form» Traducción de Ana Rodríguez.

82 «a space for aprox. 2500 people to live in; visually limited -plastically defined- protective; a space tuned to the eternal needs of men» Traducción de Ana Rodríguez.
} 
Tres son los principios fundamentales en Nagele: la organización no jerárquica de los grupos sociales, una pantalla de arbolado como protección de los vientos dominantes, y un gran espacio verde central. Pero más que los principios, algunos comunes a otros asentamientos, es la solución obtenida, la forma de interpretarlos lo que singulariza la experiencia de Nagele, su proceso de búsqueda de una solución unitaria, con identidad. Se propone una nueva y complementaria perspectiva de estudio: su análisis a partir de la tradición jardinera holandesa del XVII y su relación con el territorio. Una mirada a grabados de jardines holandeses del XVII en Holanda, nos muestran un jardín regular, frecuentemente rectangular, delimitado por vegetación en la infinitud de un territorio completamente plano solo matizado por hileras de arboles coincidentes con la geometría de los polder. Un espacio de esparcimiento y recreo protegido de la indeterminación del territorio a su alrededor, en definitiva un lugar con identidad, y un modelo para Nagele.
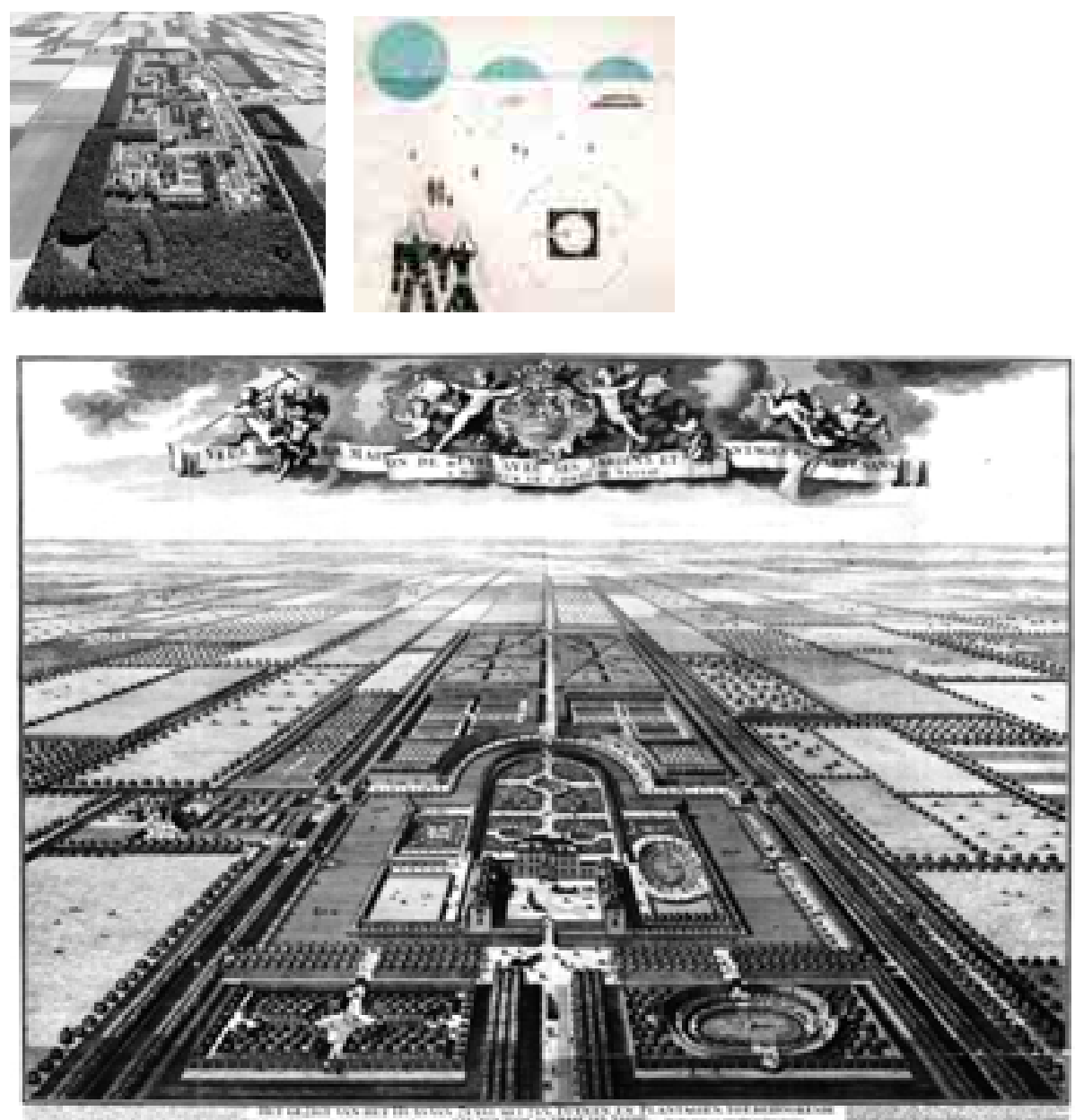

Figura 3.48

El jardín clásico holandés del XVII como referencia.

Selección comparada de imágenes por Ana Rodríguez a partir de la siguiente documentación:

* Inferior

Veue de la Maison de Zeyst avec ses Jardins, et Plantages appartenans à Monsieur le Comte de Nassau, Grabado de Daniel Stoopendaal, 1700.

Utrecht, Rijksarchief in de Provincie Utrecht, Topografische Atlas (Dixon Hunt 1988)

* Superior

Vista aérea del Nuevo asentamiento de Nagele. Punto de vista y encuadre de Ana Rodríguez a partir de imagen de Google Earth. A la derecha fragmento del la grid del nuevo asentamiento de Nagele en el CIAM X de Dubrovnik, 1956. 
Nagele es en palabras de Aldo van Eyck «a space within space» «an inmense greeen building without roof», concepto que como apunta Strauven, también está presente en algunos playgrounds, en los que a partir de una masa vegetal compacta, el espacio del juego se excava. Idea similar, «starry night», manejada por Liane Lefaivre y Alexander Tzonis. en Aldo van Eyck, Humanist Rebel: Inbetweening in a Postwar, como influencia de patrones clásicos.

Para ello, el arbolado de protección contra el viento tiene que tener una entidad suficiente, mayor que una única hilera de arboles, como en otros asentamientos, o en la primera solución de Verhagen para Nagele, en 1942.

Lo que aquí se propone es la importancia dada a la plantación, como heredera del desarrollo de la horticultura durante el siglo XVII, cuando los Países Bajos se convirtieron en los mayores exportadores de arbolado y plantas cultivadas en invernadero en Europa, especialmente para su tratamiento topiario. El tratamiento escultórico de lo vegetal, que a pequeña escala produce frecuentemente figuras de dudoso gusto, con cierta escala permite un tratamiento volumétrico arquitectónico que define y caracteriza espacios. Los grabados clásicos nos muestran abundantes ejemplos: representaciones desde el punto de vista del espectador en los que grandes setos recortados con un tratamiento arquitectónico, generan espacios verdes delimitados, y representaciones a vista de pájaro de la totalidad del jardín, en las que se aprecian zonas densamente plantadas por arbolado o por setos, en los que se recortan espacios y caminos. La fotografía aérea actual de cualquiera de ellos, corrobora la idea aún más claramente que los grabados, ya que para poder representar las alineaciones en los primeros, las copas no son de gran tamaño, algo que en la realidad se convierte en grandes masas verdes.

Esa relación entre densa plantación y espacios esculpidos, también está presente en el trabajo de Cornelis van Eesteren. El Bosque de Amsterdam, un gran parque público construido al sur de la ciudad; aun estando construido sobre un polder, su condición urbana le permite mayor libertad formal que Nagele, siendo una de las grandes propuestas de jardín moderno.

«La combinación de parajes cerrados, como un bosque, y de espacios abiertos con vistas es característica de paisajes de recreo como los de Veluwe. Un paisaje así une la realidad y el inconsciente, y de esta manera crea armonía entre nosotros. Y tan pronto como comprendamos la esencia del surrealismo, la relación entre inconsciente y realidad, de la cual son factores la vida y la muerte, seremos capaces de realizar más conscientemente el trabajo urbanístico completo, incluso el paisaje de recreo»

«Los objetos y elementos del plan urbanístico (ya sea internacional, nacional, o local) tienen, además de las características practicas de sus valores, un contenido emocional. Para el hombre inspirado, significan cada uno en sí mismo y en relación con los otros, algo más que su simple uso y su contenida material. Contienen una carga» ${ }^{83}$ (Van Eesteren 1948)

${ }^{83}$ Van Eesteren, Cornelis. 1948. "La concepción de nuestros asentamientos y paisajes agrícolas. Sus formas de expresion y configuración".

Publicado en castellano por Julian Galindo Gonzalez en Cornelis van Eesteren. La experiencia de Amsterdam 1929-1958. Barcelona: Fundación Caja de Arquitectos. 

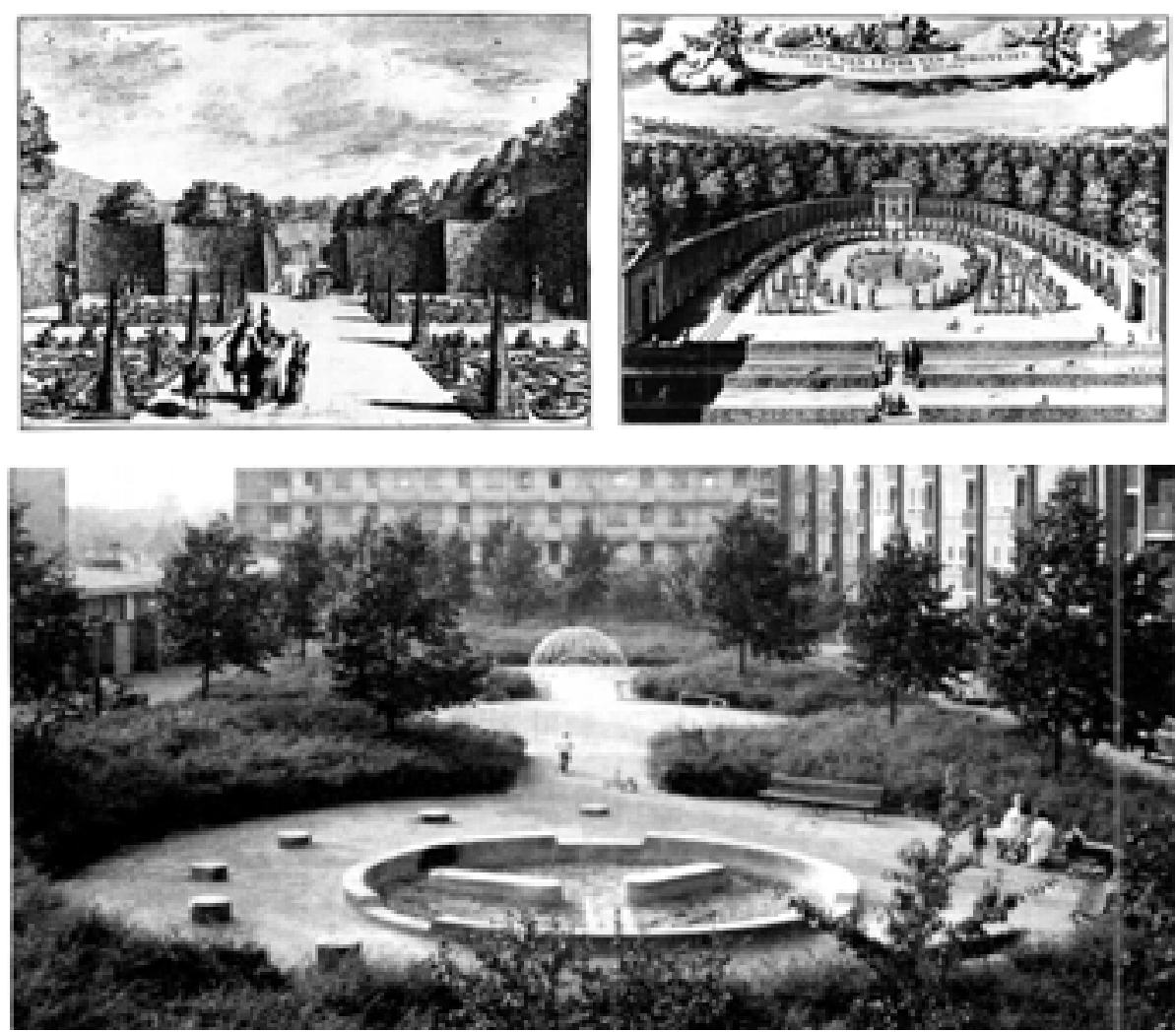

Figura 3.49

El arbolado y la vegetación como material constructive en la jardineria holandesa del XVII y en Van Eyck. Selección comparada de imágenes por Ana Rodríguez a partir de la siguiente documentación:

* Superior izquierda

Jardines de Clingendael. Grabado de L. Scherm y D. Stoopendaal, Amsterdam, N. Vissher, ca. 1720 (Dixon Hunt 1988)

* Superior derecha

Orangerie semicircular de los Jardines de Sorgvliet, cerca de la La Haya; estanque central rodeado de naranjos y jarrones con plantas exóticas, Jan van de Aveelen. Grabado. The Hague, Gemeentearchief (Dixon Hunt 1988)

* Inferior

Aldo van Eyck, Mendes da Costahof Playground 1957, construido en 1960 (Strauven 1988) 
El cinturón de arbolado de Nagele es el in-between entre el gran espacio abierto del polder, y el espacio cerrado de la plaza pública verde interior y la zona de viviendas, convirtiéndose así en un recinto delimitando y con identidad frente al espacio ilimitado que lo circunda. Hacia el exterior, la plantación protectora es acertadamente regular, como cabria pensar en un territorio polder, sin embargo el proceso seguido hasta alcanzar su forma definitiva, fue largo y complejo con decenas de dibujos ${ }^{84}$ de los arquitectos del grupo formado a tal efecto.

En una comparación con el resto de polders, la estructura concéntrica y radial del Noordoostpolder es bastante inusual. Su red de canales y vías generan superficies triangulares a las que la trama canónica ortogonal se tiene que adaptar. Los asentamientos se ubican precisamente en la confluencia de caminos, en espacios de acuerdo entre las distintas geometrías, y esa es la razón de la morfología irregular de las primeras propuestas para Nagele.

En los primeros dibujos de Kamerling, Bodegraven y del propio Van Eyck de febrero y marzo de 1948, la forma urbana, trata de adaptarse al espacio irregular sensiblemente triangular y con tres tramas diferentes de drenaje propuesto por el Wieringermeer Board, conformado por la carretera radial desde Emmerlord a Schokkerhaven, con la ruta periférica que une Schokland y Urk ${ }^{85}$, y una tercera vía desde Tollenbeek hacia el noroeste. Son configuraciones básicamente centralizadas y conceptuales, que basculan entre la idea del cruce de caminos y la formación de vía anular entre las viviendas y el espacio central ${ }^{86}$, dejando este libre de circulación, en la línea de la solución posteriormente adoptada.

La estructura final será posible por un ligero desplazamiento hacia el este del área de ubicación, situándose en gran parte sobre la trama ortogonal de canales con dirección norte-sur. En vez de cruzar la población, la vía importante de tráfico queda tangente al espacio central y de viviendas, ahora ya regular, ubicándose el puerto, los talleres, el campo de deporte y el cementerio al oeste de la vía, en los espacios irregulares. El cambio se produce entre los meses de finales de 1948 y principios de 1949: la propuesta de De 8 enviada al Wieringermeer Board el 10 de septiembre de 1948 todavía mantiene las tres direcciones, con una tímida ortogonalidad en la zona sur. Sin embargo el diseño de Martinus Kamerling fechado el 25 de mayo de 1949, ya muestra el perímetro rectangular característico de Nagele, superponiéndose con esta geometría la esquina superior noroeste del trazado, sobre la tercera dirección de drenaje, que no volverá a ser representada en ninguna de las propuestas posteriores, centradas a partir de ese momento en la organización de los bloques de vivienda.

El trazado definitivo incluirá un pequeño resalto en el límite oeste entre la zona norte y sur, separadas por el canal de agua que atraviesa el pueblo transversalmente en dirección este-oeste. Una forma rectangular, consecuencia de una intención, más que como el resultado de la trama de drenajes con la que no se corresponde exactamente, aunque también la alude.

\footnotetext{
${ }^{84}$ Ver Strauven, Francis. 1998. Aldo van Eyck. The shape of relativity. Amsterdam: Architectura \& Natura y DE 8. 1952. "Een plan voor het dorp Nagele". Forum 6/7 Juni/Juli 1952, 172-178.

${ }^{85}$ Dos islas de terreno previamente existentes que quedaron incorporadas al polder.

${ }^{86}$ En el desarrollo del proyecto se estudio hacer una via perimetral completamente exterior, que finalmente se desechó por motivos económicos y de acuerdo con la administración promotora. En De 8, 1952. "Een plan voor het dorp Nagele". Forum 6/7 Juni/Juli 1952, 172-178
} 


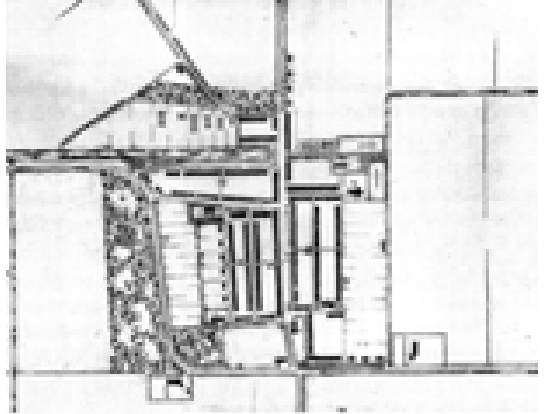

Figura

* Izquierda

Propuesta para Nagele, de B. Bureau Verhagen, Kuiper \& Gouwetor, 1942 (Strauven 1988)

* Derecha

Plan definitivo para Nagele de De 8, marzo 1954, dibujado por Aldo van Eyck. Planta incluida en el Panel 2 de la grid de presentación de Nagele por Aldo van Eyck $y$ de 8 en el CIAM X de Dubrovnik, 1956 (Strauven 1988)
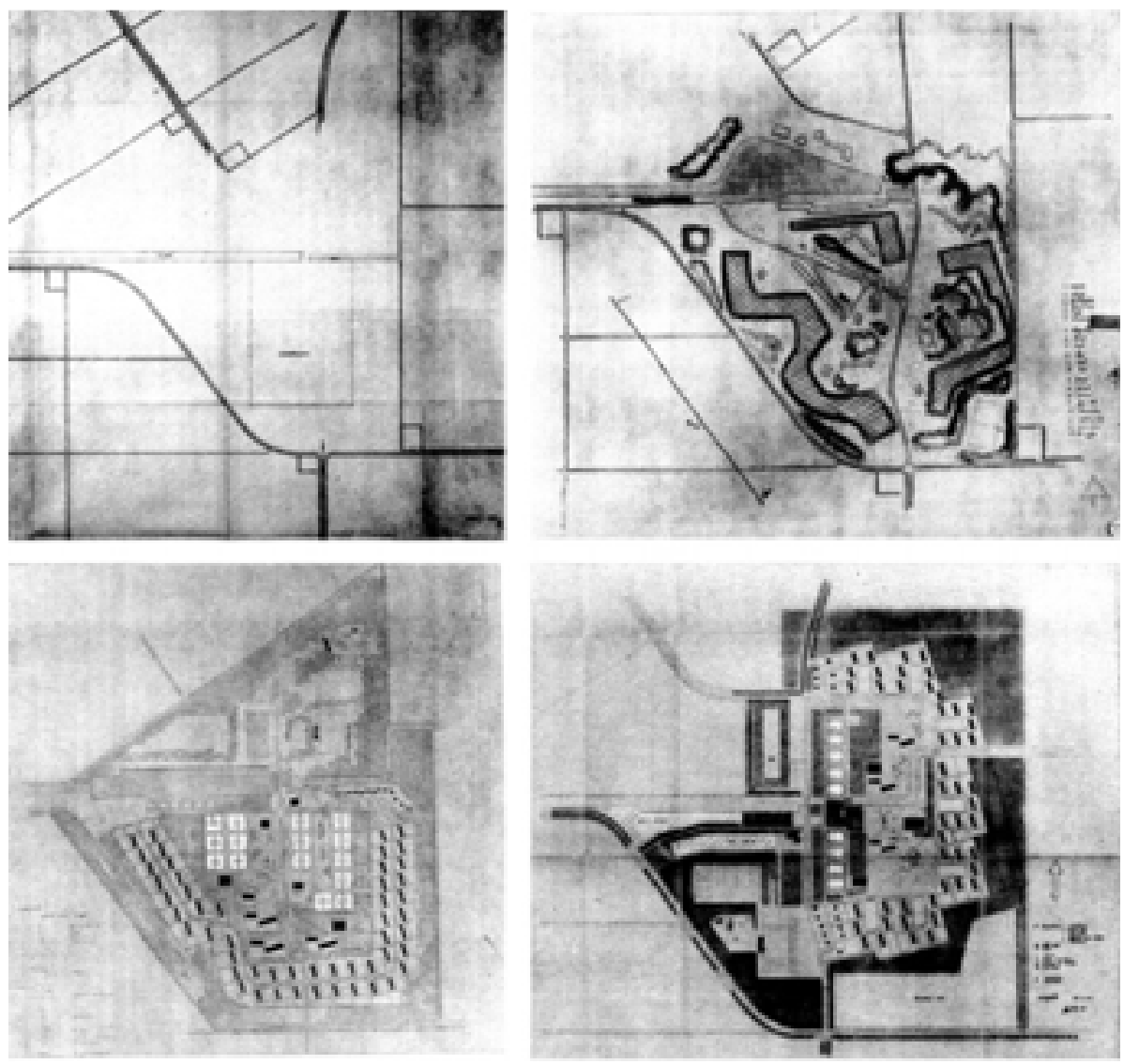

Figura 3.50

Estudios para la estructura urbana de Nagele, hasta su configuracion regular.

Selección cronológica de Ana Rodríguez a partir de los publicados por Francis Strauven en Aldo van Eyck: the shape of relativity.

* Imagen superior izquierda, plano para el emplazamiento de Nagele de la Wieringermeer Board, recibido por de 8 el 15 de enero de 1948

* Imagen superior derecha, boceto conceptual de M. Kamerling (reunión del 3 de febrero de 1948)

* Imagen inferior izquierda, propuesta de de 8 enviada al Wieringermeer Board el 10 de septiembre de 1948

* Imagen inferior derecha, diseño de Martinus Kamerling fechado el 25 de mayo de 1949. 


\title{
3.4. Una Kiva de los Indios Pueblo en Holanda
}

\author{
[Tipo]
}

A principios de los sesenta, Aldo van Eyck había alcanzado reconocimiento internacional con el Orfanato en Amsterdam. Después de sus esfuerzos para abordar la concreción del «problema del numero», una serie de encargos le van a permitir centrarse en el desarrollo espacial de edificios aislados y de menor escala. Proyectos con una fuerte carga simbólica y programas sin estrictas ataduras funcionales, que le dieron la oportunidad de materializar más libremente sus ideas sobre la nueva realidad: «The Wheels of Heaven»-las ruedas del cielo- (1963-1964), la iglesia católica romana Pastoor van Ars Church en la Haya (1963-66, 1968-69) y el Sonsbeek Pavilion en Arnhem (1965-66).

Como ya se ha comentado anteriormente, la Ampliación de la Casa Visser, pertenece a este grupo de proyectos, a su vez relacionados con los viajes a la región Dogon en febrero de 1960 y en diciembre de 1962 a Nuevo Méjico para conocer de primera mano la cultura de los Indios Pueblo. Viajes que significaron una reafirmación de sus ideas, y que este grupo de proyectos le permitió materializar.

A diferencia de las formas geométricas aisladas de los playgrounds y del proyecto urbano de Nagele, el periodo de los sesenta se caracteriza por la asociación del círculo con cuadrados u otras organizaciones lineales, esta vez bajo la influencia de sus estudios sobre los Dogon y los Pueblo, donde el círculo, o bien se asocia, o altera dicha organización, siempre con una carga simbólica que genera espacios significativos en cada obra.

Esta tesis aporta un enfoque inédito para analizar la Casa Visser, basado en la influencia de los viajes a la región Dogon y Pueblo, y en la misma línea del propuesto en epígrafes anteriores sobre cómo sus primeros viajes al Norte de África, fueron determinantes en los playgrounds y Nagele.

Bajo este prisma, la ampliación de Van Eyck de la casa construida por Rietveld, convierte a la Casa Visser en su conjunto en un pequeño asentamiento, una pequeña aldea en la que no solo se da respuesta a las necesidades básicas del hombre en su vida diaria, representadas aquí por la casa preexistente, sino también a las espirituales, en este caso la colección de arte, con un espacio simbólico de planta circular, semienterrado, con luz cenital en su centro, que reinterpreta el lugar sagrado y simbólico de un kiva de los Indios Pueblo.

Al igual que la casa Dogon en Banani, piezas independientes con significados distintos, se relacionan entre sí, formando un conjunto, una unidad espacial y de organización familiar, que dependiendo del número en que se repitan, darán lugar a poblados más o menos grandes, pero que en sí misma es, a su vez, una micro-aldea. Es decir, "la casa es la ciudad y la ciudad es la casa» de sus diagramas Arbol-Hoja presentados por Aldo van Eyck en el Congreso de Team 10 celebrado en Royamount en 1962, con el tema de debate centrado en la infraestructura urbana.

Partiendo de este planteamiento, en los epígrafes siguientes se proponen a su vez tres criterios de análisis, también inéditos, sobre las relaciones que se establecen entre la ampliación de Van Eyck y la preexistencia de Rietveld: el circulo y el centro, el espacio in-between, y la transparencia .

Criterios que representan la influencia de lo vernáculo de culturas primitivas y del espacio domestico en Holanda, tal y como lo expresan los interiores pintados por Pieter de Hoogh en el XVII.

Previamente, también se data exhaustivamente el proceso de los distintos proyectos realizados por Van Eyck y Rietveld, construidos o no, en el periodo que va desde 1954 hasta el año 2000, aportando además una serie de dibujos analíticos realizados específicamente para este trabajo que explican y facilitan la comprensión del proceso. 
el árbol

es la hoja y la hoja

es el árbol- la casa es

la ciudad y la ciudad es la casa

- un árbol es un árbol solo si

también es una gran hoja- una

hoja es una hoja, solo si es

también un pequeño árbol- una ciudad

no es una ciudad a menos que

también sea una casa grande-

una casa es una casa

solo si es también

una pequeña ciudad

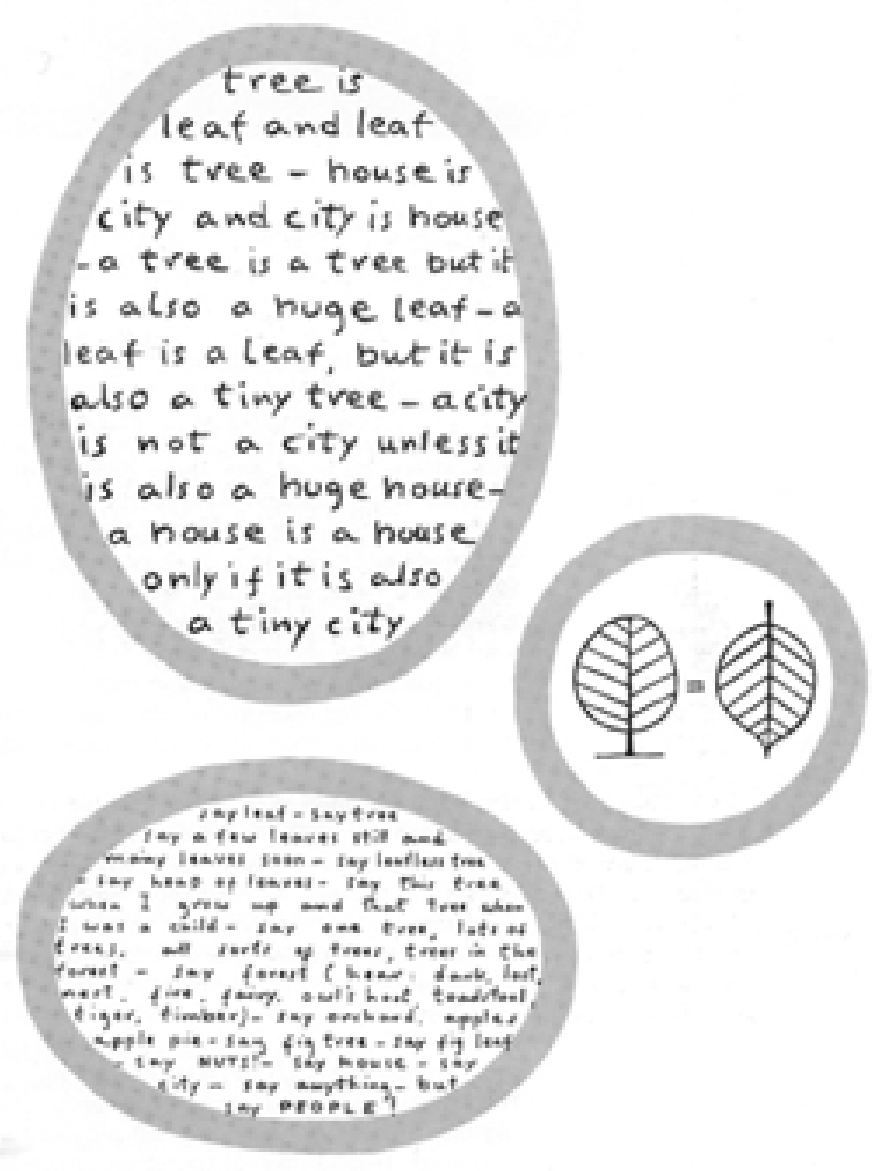

Figura 3.51

Diagramas Arbol-Hoja presentados por Aldo van Eyck en el Congreso de Team 10 celebrado en Royamount en 1962, con el tema principal de debate centrado en la infraestructura urbana. 


\subsubsection{Evolución de la Casa Visser 1955-2000.}

Cuando en 1954 deja de trabajar en Bijenkorf, para hacerlo como diseñador de muebles en la fábrica De Ploeg ${ }^{87}$ en Bergeijk, compra una parcela arbolada para hacerse una casa, tras el desencuentro inicial con Aldo van Eyck, ya comentado anteriormente, encarga el trabajo finalmente a Gerrit Rietveld en 1955-1956.

La parcela en esquina, no es grande ni especialmente interesante. Sensiblemente horizontal, su principal característica es la gran cantidad de arbolado de la zona boscosa en que se localiza, especialmente densa en el perímetro. Rietveld sitúa la casa en un pequeño claro, cerca del frente menor de parcela, coincidente con la calle secundaria, desde la que se accede, quedando el lindero mayor a la calle principal sin entrada. De esta forma, queda algo más de espacio libre de parcela en la parte posterior donde años después realizará la ampliación Van Eyck.

La vivienda se organiza en dos direcciones: en la paralela al frente de acceso con las zonas comunes, y en la coincidente con la dirección norte-sur del ala de dormitorios, girada de la anterior $117^{\circ}$. Respecto a esta característica, es necesario reseñar que las diversas publicaciones sobre la casa dan por sentado un ángulo de $120^{\circ}$ entre las dos direcciones, pero la geometría de los planos de Rietveld y del levantamiento posterior del proyecto de Van Eyck coincide en un ángulo ligeramente menor de $117^{\circ}$. Esta pequeña variación, bien pudiera deberse simplemente a un error de replanteo, o de dibujo, aunque se repite sistemáticamente en todas la plantas dibujadas de la casa. Por otra parte una variación de solo tres grados, genera diferencias significativas respecto a la planta de Rietveld. Sea cual sea el origen de este ángulo, intencionado o no, si es muy clara, y esto es lo verdaderamente relevante, la voluntad de Rietveld por coincidir con la dirección Norte-Sur. Un hecho no mencionado en ninguna de las publicaciones más relevantes en que esta publicada la casa, pero que se comprueba al estudiar algunos esquemas dibujados sobre los planos del proyecto y en particular el plano de situación. De esta forma, la casa se materializa más cerrada hacia el acceso y a la orientación norte, y abierta con un porche hacia el sur y una galería de distribución al oeste, quedando un espacio más privado de jardín, protegido de la calle principal por la inclinación del ala de dormitorios.

El proyecto de Rietveld para los Visser, una familia formada por la pareja Martin y Mia Visser y dos hijos, es una pequeña casa que llama la atención por lo reducido de su tamaño: un estar-comedor de $7 \times 4$ metros, una cocina de $2 \times 3 \mathrm{~m}$., el dormitorio principal y un despacho, ambos de 3,75x2,75 m, y dos dormitorios para los niños de 2x3 m.

En palabras del profesor Strauven, dieron a Rietveld cartre blanche, y su respuesta fue una espacie de vivienda de protección oficial, y a pesar de la admiración de los Visser por Rietveld, no quedaron muy contentos con la casa, (Strauven 1998, 533) según se desprende de los comentarios de Martin Visser en la mencionada entrevista:

87 La compañía, famosa por sus productos textiles, se había reconvertido hacia las artes industriales ante la escasez de material durante la Segunda Guerra Mundial. Su director desde 1937 Piet Blijenburg, formaba parte de la experiencia «Goed Wonen», Buena Vida, formada en 1946 por fabricantes, minoristas, diseñadores y arquitectos, para promover un estilo de vida saludable y moderno dentro del presupuesto de cada uno. Después de la guerra, Blijenburg reorganizó la producción textil con una estimación de crecimiento basada en la construcción anual de vivienda, con las grandes superficies acristaladas de la arquitectura nieuwe bouwen. También comenzó a desarrollar la división de artes industriales conocida como 't Spectrum, contratando a Martin Visser como director del programa y diseñador de la división de mobiliario. 

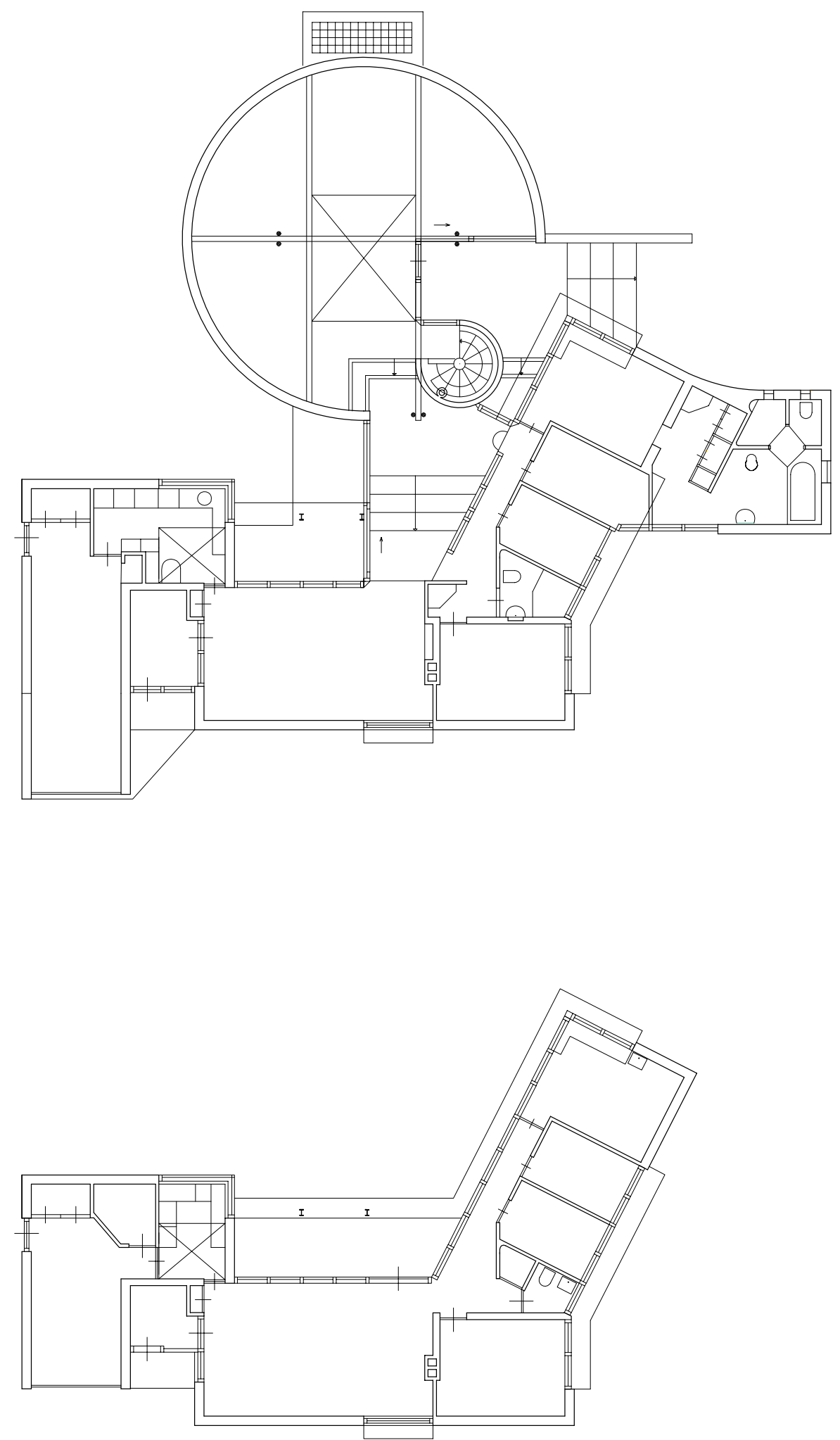

Figura 3.52

Casa Visser en Bergeijk. Estado final e incial.

Dibujos de Ana Rodríguez. Escala 1/200

* Superior

Ampliaciones de la Casa Visser realizadas por Aldo van Eyck en 1967-1969 y 1971

*Inferior

Proyecto construido por Gerrit Rietveld, 1955-1956 
«Pero la casa que nos construyó en 1956, tuvo algo como de corsé. Fijó el sitio de los muebles en el plano de planta. Así tuvimos que hacerlo. En efecto, nada se podía poner en otro sitio, sin causar las obstrucciones más inesperadas. Además había pintado las paredes en inmaculado amarillo, lila y azul claro. Hubiera sido altamente molesto colgar cuadros sobre estas paredes» (...)

«Tenía el ambiente de la ética De 8 y la Reconstrucción: "el lujo de la austeridad" como decía Rietveld. Nos visito un día con un grupo de arquitectos, y para aclarar a sus colegas que nosotros comprendíamos la casa de manera correcta decía: "que arenque ahumado (bokking) más bueno hay en la cocina". Es decir: vivimos en una casita bien arreglada, con paredes de color lila, en una zona un par de cuadros abstractos, y comemos arenque ahumado. Esa ética sabe usted, ese extraño, chiflado pensamiento calvinista que en aquellos tiempos era bastante retorcido» 88

Llegados a este punto, cabe preguntarse la razón de una casa tan pequeña. Hay unanimidad en este sentido, pero la cuestión, no abordada hasta ahora, es por qué un arquitecto como Rietveld, la construye así.

En primer lugar, es necesario decir que la casa, aun dentro de su austeridad, es magnífica, mínima y paradigma de rigor Nieuwe Bouwen. Brillantemente resuelta, varios factores parecen indicar que el origen de sus ajustadas dimensiones pudiera deberse a que los recursos que los Visser destinaron para su realización, fueran unos medios económicos excesivamente limitados.

En realidad, un estudio atento de los croquis y planos de proyecto, nos muestran que en las primeras aproximaciones, la casa era asombrosamente todavía más pequeña, con dimensiones menores en estar-comedor y cocina -un verdadero armario, y con un dormitorio menos en el ala de dormitorios.

Posteriormente, en la planta de distribución del Proyecto de Rietveld con el que se pide la licencia de obras, plano AVK-CV-JV-01 del Anexo AD-2 de documentación inédita reseñado en las páginas siguientes, se aprecia que aunque la solución es prácticamente como la construida, la cocina sigue siendo algo menor que la definitiva.

Finalmente, en la planta del levantamiento del estado previo a la intervención, en el proyecto de la primera ampliación hecha por Van Eyck, plano AVK-CV-JV-02 del mismo anexo, la solución definitiva para la cocina es algo mayor, avanzando todo el cuerpo de servicio por fuera de la marquesina que recorre y caracteriza la casa. El ancho de este crecimiento se materializa, además, en una ventana en esquina cuya anchura es dicha medida, aportando una solución de gran riqueza espacial y repercusión en la casa, ya que potencia una de las visuales diagonales que Van Eyck intensificará en su intervención.

\footnotetext{
${ }^{88} \mathrm{j} \ll$ Maar het huis dat hij in 1956 voor ons bouwde, had iets van een keurslijf. Hij had de plaats van de meubelen vastgelegd in de plattegrond. Daar hadden we ons maar aan te houden. Het was inderdaad zo dat er niets kon worden verplaatst, zonder de meest onverwachte opstoppingen te veroorzaken. Bovendien had hij de muren smetteloos geel, lila of lichtblauw laten schilderen. Schilderijen zouden tegen deze wanden bijzonder storend geweest zijn.»

«Het ademde de ethiek van de 8 en Opbouw, 'de weelde van de soberheid' zoals Rietveld het uitdrukte. Hij kwam een keer op bezoek met een groep architecten, en kennelijk om zijn collega's duidelijk te maken dat we het huis op de juiste manier begrepen en beleefden zei hij: 'Wat een lekkere bokking ligt daar in de keuken!' Zo van: we wonen in een heel net, gepast huisje, met lila muurtjes, ergens een paar abstracte schilderijtjes, en we eten bokking. Die ethiek weet $u$, die vreemde, verknipte Calvinistische gedachtengang, dat zat behoorlijk scheef in die tijd»

Publicada en holandés (Van Eyck. 1986, 80), y parcialmente en ingles (Strauven 1998, 533).

Traducción libre del holandés de Grietje Bouwmeester y Ana Rodríguez.
} 
Por otra parte, y casi al mismo tiempo, entre 1956 y 1958, Rietveld también construyó, la residencia familiar de R. D. van Daalen, directivo del consejo de administración de De Ploeg, muy cercana a la Casa Visser, y a diferencia de esta, la Van Daalen es una casa de dos plantas y considerable tamaño ${ }^{89}$, en una parcela también mucho mayor. Es decir, dos viviendas para dos empleados de la misma compañía, realizadas casi al mismo tiempo, y ambas muy cercanas entre sí, pero una realmente grande y otra muy pequeña. Todo parece indicar que fueron los recursos económicos de los que dispuso lo que ocasionó el tan criticado tamaño de su proyecto para Casa Visser.

En 1967, tres años después de la muerte de Rietveld, Martin Visser le encarga una ampliación de la casa para su colección de arte, iniciando un intenso y singular proceso de modificaciones y adiciones, unas construidas y otras no, que se prolongará hasta incluso después de la muerte de van Eyck con una última intervención a cargo de Hannie van Eyck a modo de homenaje póstumo por parte de Martin Visser. La primera de las ampliaciones, y más importante, será la determinante para la nueva configuración y carácter de la casa. Una gran estancia cilíndrica de 11 metros de diámetro, cerrada y cubierta en tres cuartas partes del círculo. 25 metros lineales de pared para colgar cuadros y objetos que se habían hecho necesarios al creciendo la colección, y el espacio intermedio in-between de relación con la preexistencia, con partes cubiertas y otras al exterior, dan como resultado algo nuevo, singular y extraordinario.

La ampliación de la Casa Visser materializa en Holanda una kiva de los Indios Pueblo para albergar la colección de arte de Martin Visser, contraponiendo su carga simbólica con la austeridad de la casa de Rietveld. En este caso la inversión de papeles es inesperada, ya que a diferencia de Upper Lawn y Espolla donde la preexistencia es vernácula, aquí la preexistencia es canónicamente moderna y la ampliación vernácula: Van Eyck elige un tipo arquitectónico de culturas primitivas en el desierto americano, ejemplificando a la perfección su teoría de las tres tradiciones enunciada en los Círculos de Otterlo.

Se data y analiza exhaustivamente el proceso de los distintos proyectos realizados por Van Eyck y Rietveld, construidos o no, en el periodo de casi 50 años, entre 1954 y el año 2000, aportando además una serie de dibujos analíticos realizados específicamente para este trabajo que explican y facilitan la comprensión del proceso.

1. Proyecto y construcción de la casa por Rietveld 1955-1956

2. Primera ampliación Aldo van Eyck Proyecto 1967- construcción 1968-1969. La mas importante, con el espacio de planta circular que cambia el carácter de la casa

3. Segunda ampliación, Aldo van Eyck y Theo Bosch, $1971^{90}$, y propuesta para otra más, no desarrollada. Una vez terminada la primera, los Visser decidieron construir un cuarto de baño más -el inicial solo era un aseo con ducha- en una segunda extensión. La solución dada añade el baño solicitado, más un vestidor y zona de armarios, al dormitorio principal, y también proponía una intervención mayor hacia el norte con otro circulo, quedando la casa de Rietveld como un gran in-between, aunque esta no se llegó a desarrollar, quedando restringida el mencionado cuarto de baño y una pequeña ampliación del garaje, que se había quedado muy reducido al agrandar la cocina en la primera extensión.

4. Pintado del cilindro en 2000, después de la muerte de van Eyck a cargo de Hannie van Eyck a modo de homenaje póstumo por parte de Martin Visser.

\footnotetext{
89 Tiene $1390 \mathrm{~m}^{2}$, y es la primera de una serie de grandes casas que hizo Rietveld para clientes acomodados a partir de la segunda mitad de la década de los cincuenta (Rietveld 2006, 198)

901971 es la fecha que consta en el plano AVK-CV-JV-05 del anexo de documentación inédita AD2, aunque en algunas monografías de Rietveld citan la fecha de 1974 sin especificar ningún dato más. Puede que el periodo completo fuera 1971-1974, aunque la intervención es menor.
} 

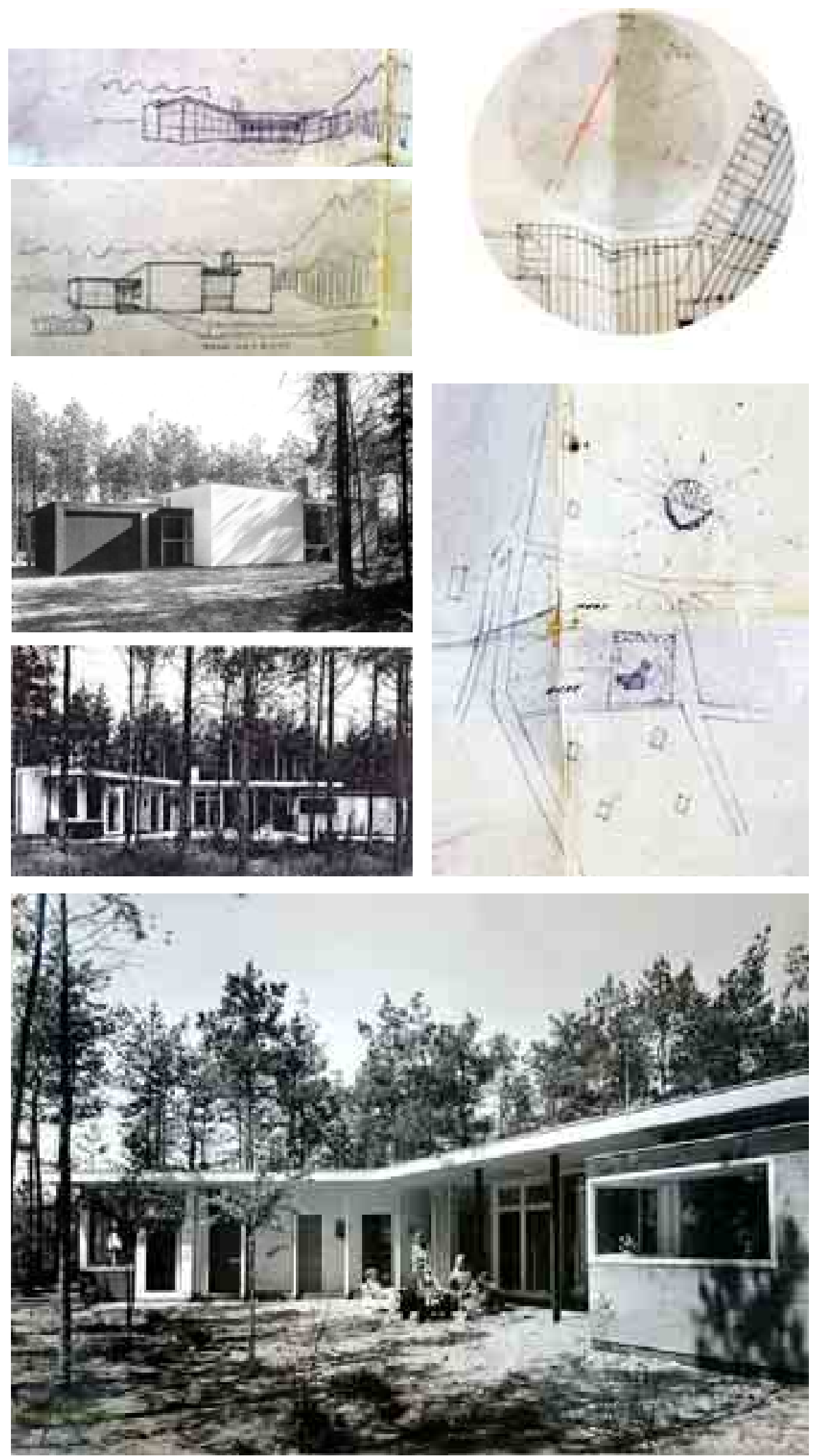

Figura 3.53

La Casa Visser realizada por Gerrit Rietveld, 1955-1956.

Fotografía inferior facilitada por Mrs. Joke Visser, segunda esposa de Martin Visser y actual propietaria de la casa. 


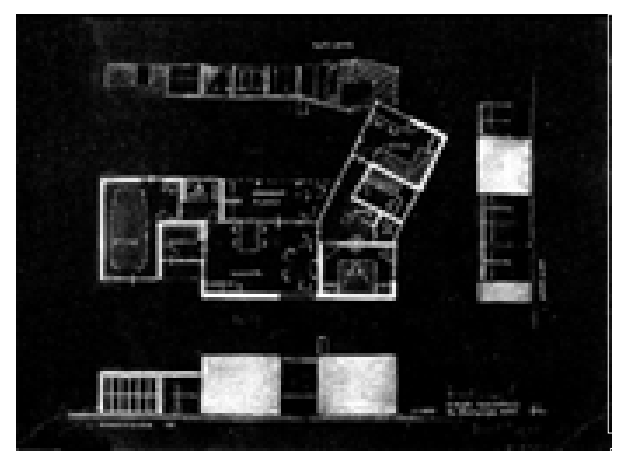

Figura 3.54

La Casa Visser realizada por Gerrit Rietveld,

1955-1956.

Planta dibujada a partir de un croquis de

Rietveld, en el que la casa era aún más pequeña, con 2 dormitorios, y la cocina y el salón más pequeños.

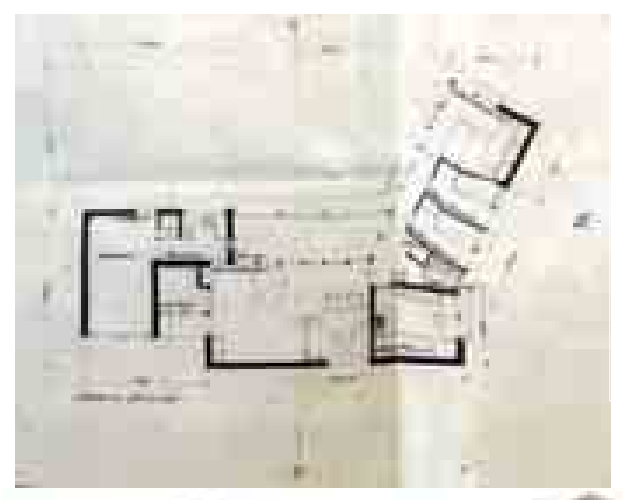

Figura 3.55

La Casa Visser realizada por Gerrit Rietveld, 1955-1956.

* Izquierda e inferior

Plano AVK-CV-JV-01 del anexo documental de documentación inédita.

Proyecto de Rietveld con el que se pide la licencia de obras.
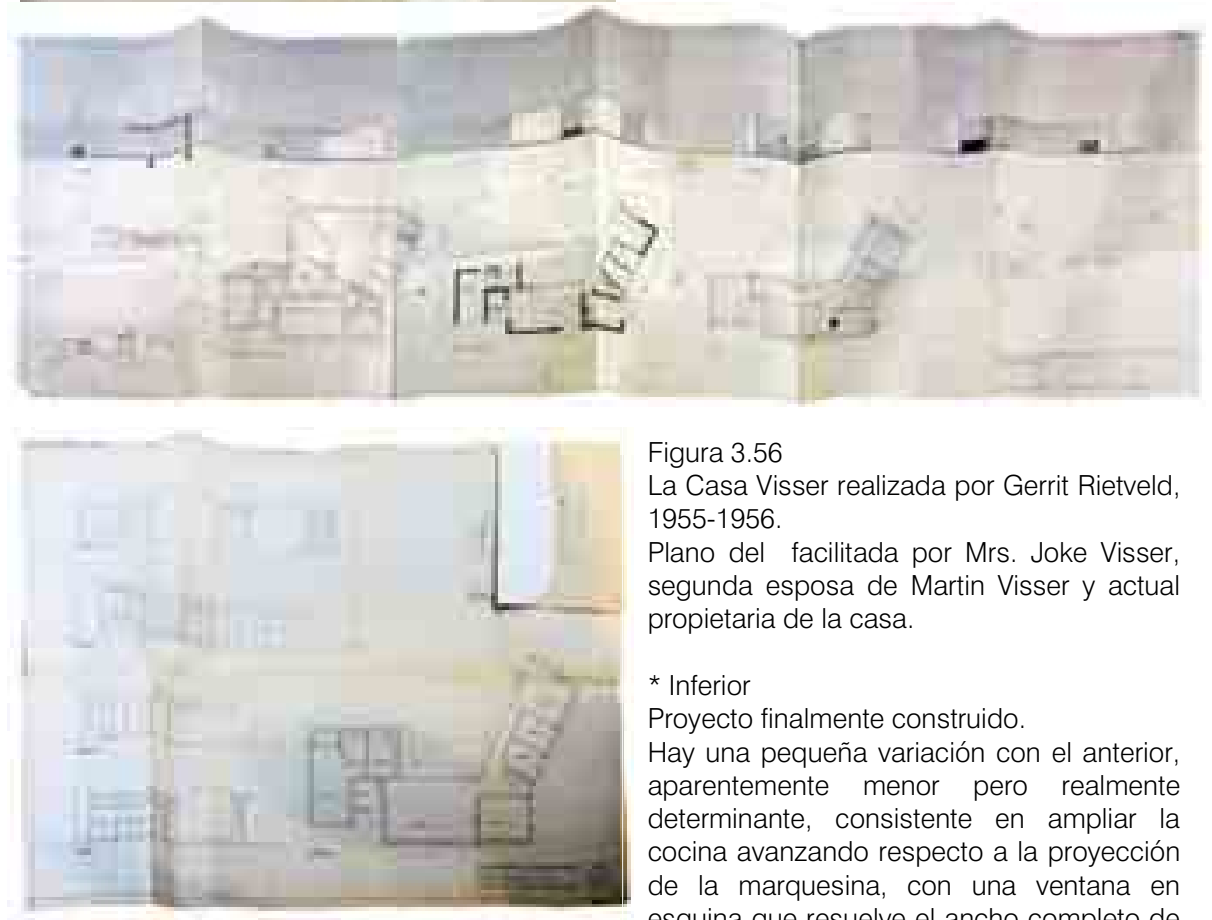

Figura 3.56

La Casa Visser realizada por Gerrit Rietveld, 1955-1956.

Plano del facilitada por Mrs. Joke Visser, segunda esposa de Martin Visser y actual propietaria de la casa.

\section{* Inferior}

Proyecto finalmente construido.

Hay una pequeña variación con el anterior, aparentemente menor pero realmente determinante, consistente en ampliar la cocina avanzando respecto a la proyección de la marquesina, con una ventana en esquina que resuelve el ancho completo de la extensión. Se genera así una visual en diagonal desde las zonas de estancia en el salón, más tarde potenciada por Aldo van Eyck en su primera ampliación. 


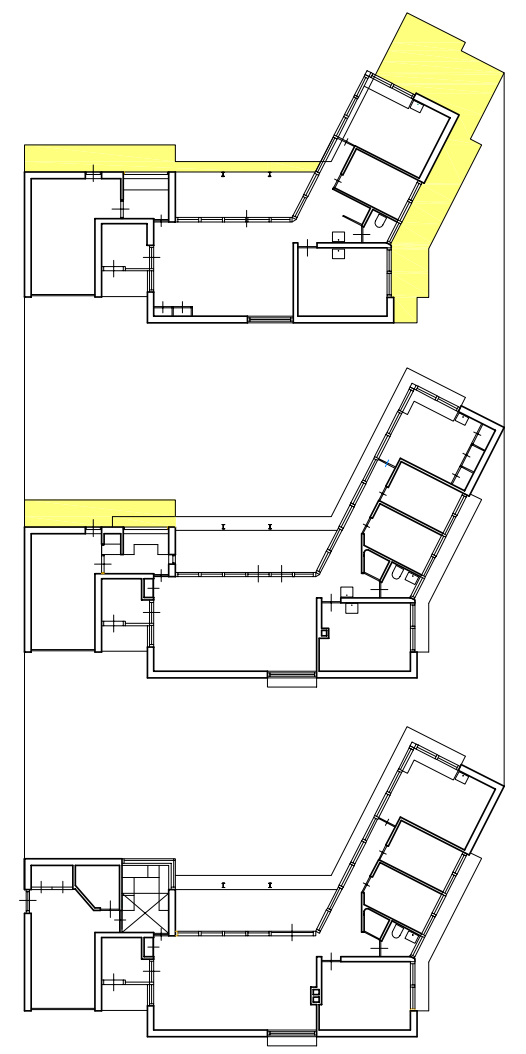

Figura

Casa Visser en Bergeijk realizada por Gerrit Rietveld en 1955-1956

Relación entre el proyecto construido y dos aproximaciones previas.

Zonas finalmente construidas y no previstas en los planos previos, en los que la casa era aún mas pequeña, marcadas en color amarillo

Dibujos de Ana Rodríguez. Escala 1/400

* Superior

Planta dibujada a partir de los primeros croquis de Rietveld, en el que la casa era aún más pequeña, con 2 dormitorios, y la cocina y el salón más reducidos.

\section{* Centro}

Planta dibujada a partir del proyecto de Rietveld con el que se pide la licencia de obras.

\section{* Inferior}

Proyecto finalmente construido.

Hay una pequeña variación con el anterior, aparentemente menor pero realmente determinante, consistente en ampliar la cocina avanzando respecto a la proyección de la marquesina, con una ventana en esquina que resuelve el ancho completo de la extensión. Se genera así una visual en diagonal desde las zonas de estancia en el salón, más tarde potenciada por Aldo van Eyck en su primera ampliación.

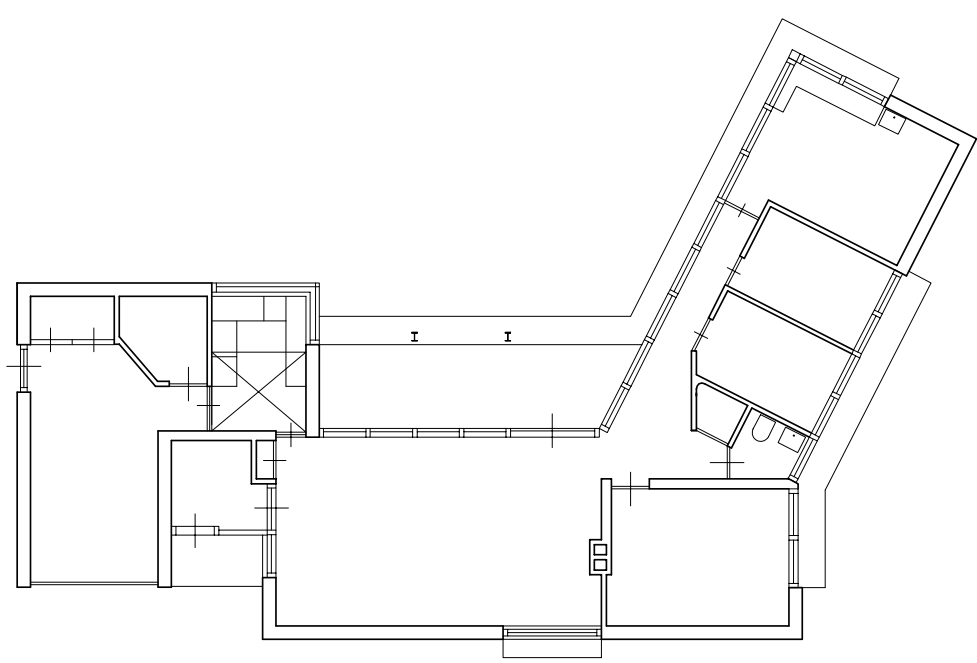

Figura 3.57

Casa Visser en Bergeijk realizada por Gerrit Rietveld en 1955-1956.

Planta del proyecto finalmente construido, realizada a partir del plano del estado inicial del primer proyecto de ampliación de Aldo van Eyck en 1967-1969

Dibujo de Ana Rodríguez Escala 1/200

Hay una pequeña variación con el proyecto de licencia, aparentemente menor pero realmente determinante, consistente en ampliar la cocina avanzando respecto a la proyección de la marquesina, con una ventana en esquina que resuelve el ancho completo de la extensión.

Se genera así una visual en diagonal desde las zonas de estancia en el salón, más tarde potenciada por Aldo van Eyck en su primera ampliación.

La dirección del ala de dormitorios se establece en $117^{\circ}$, no coincidente con los $120^{\circ}$ reseñados en varias publicaciones. Sin embargo si se demuestra una clara intención de coincidir con la dirección norte-sur. 

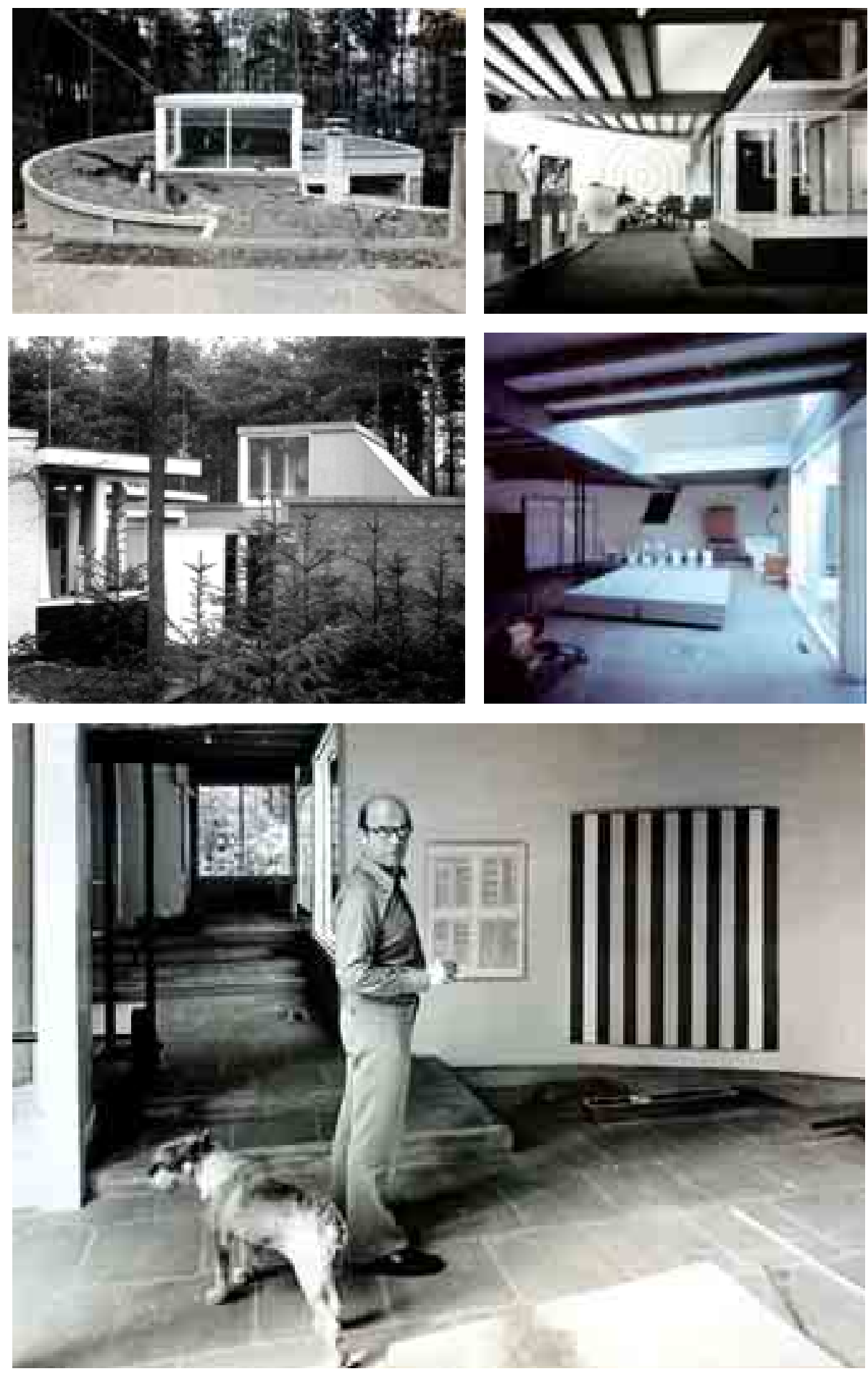

Figura 3.58

Ampliación de la Casa Viisser. Primera ampliación 1967-1969.

En primer plano Martin Visser.

Fotografías facilitadas por Mrs. Joke Visser, segunda esposa de Martin Visser y actual propietaria de la casa. 


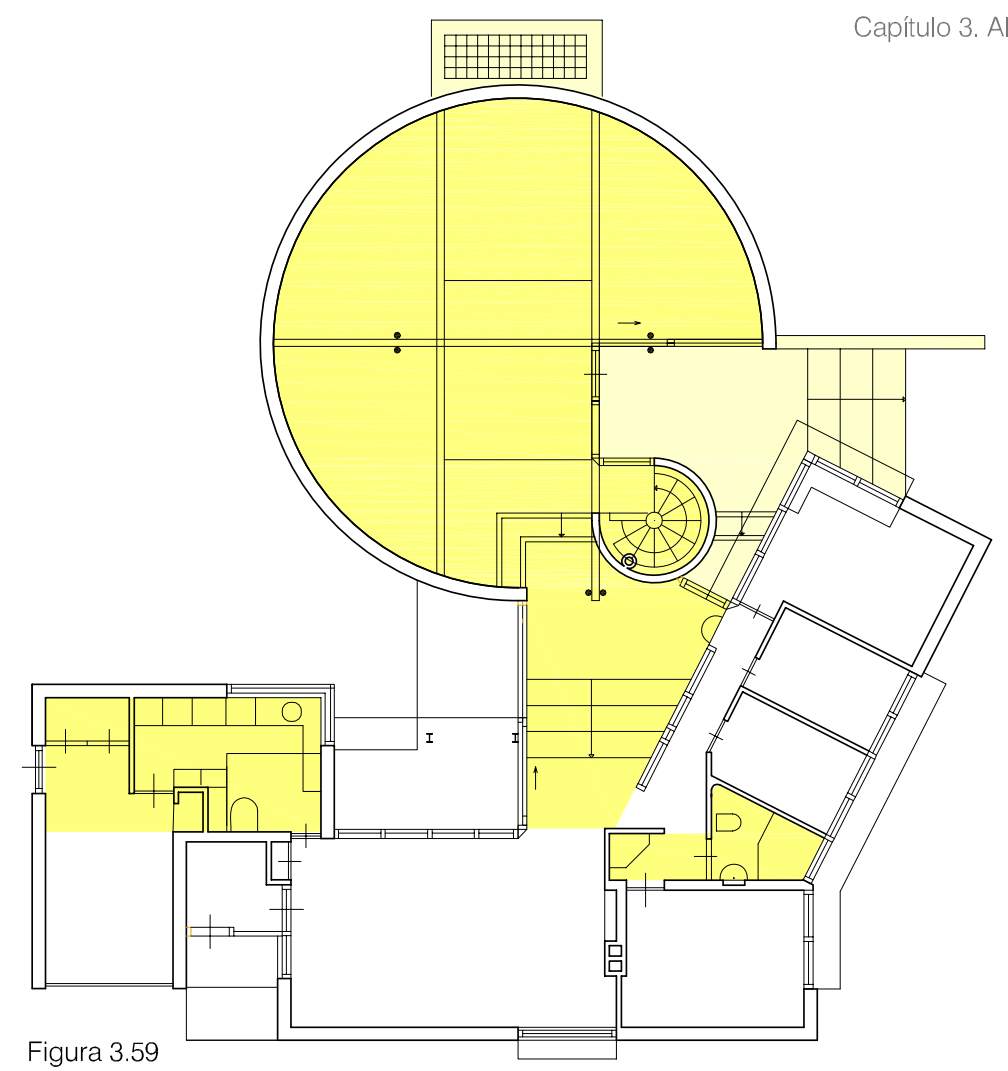

Casa Visser en Bergeijk.

Ampliación de la Casa Visser realizada por Aldo van Eyck en 1967-1969. Zonas ampliadas y/o transformadas en color amarillo.

Planta realizada a partir de los planos del proyecto de ampliación de Aldo van Eyck, para la casa construida por Gerrit Rietveld en 1956.

Dibujos de Ana Rodríguez. Escala 1/200
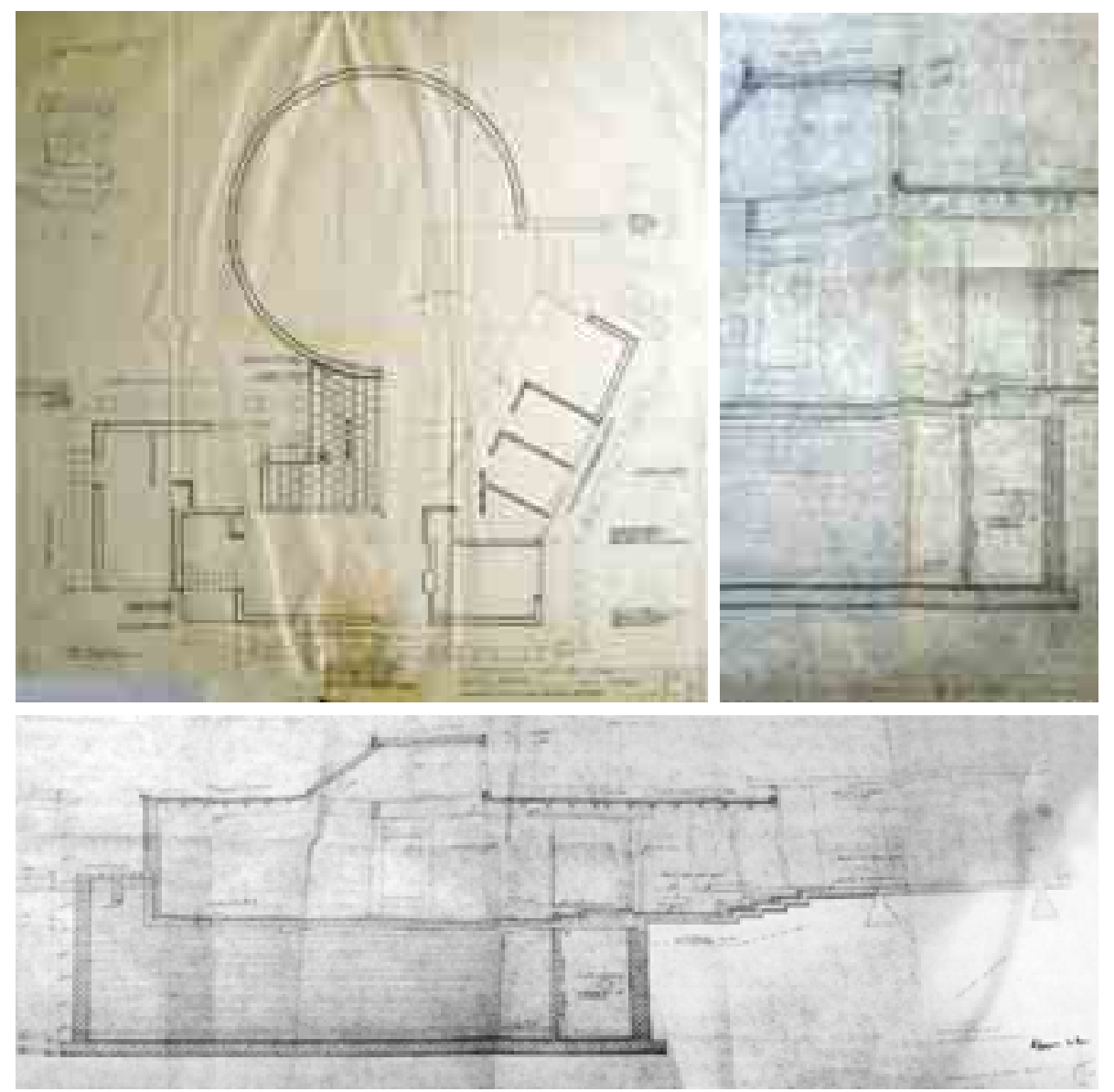

Figura 3.60

Proyecto de Ampliación de la Casa Visser realizada por Aldo van Eyck en 1967-1969.

Plano AVK-CV-JV-04 y Plano AVK-CV-JV-03 del anexo AD-2 documentación inédita.

Facilitados por Mrs. Joke Visser, viuda de Martin Visser y actual propietaria de la casa. 


\subsubsection{La segunda ampliación por Aldo van Eyck y Theo Bosch en 1971}

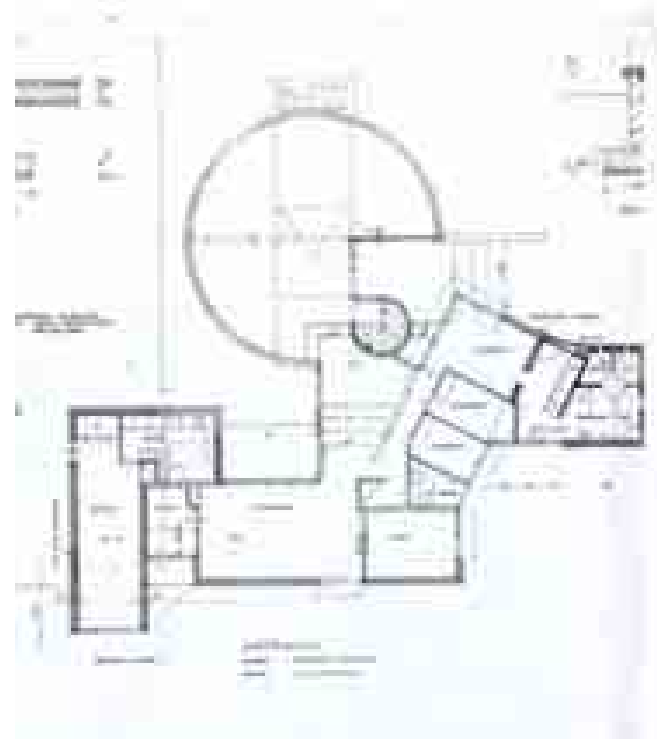

Figura

Segunda Ampliación de la Csa Visser

Plano AVK-CV-JV-05 del anexo de

documentación inedita AD-2

Plano de proyecto $100 \times 59,4 \mathrm{~cm}$

Fecha: Abril 1971

Escalas 1/1000, 1/100, 1/20

\section{Consta de:}

- 3 alzados: norte, sur y oeste

- 1 planta de distribución de la casa

- 1 planta de cimentación de la $2^{a}$ ampliación y su relación con la $1^{\text {a }}$ y la casa de Rietveld

- 1 planta del forjado de cubierta de la $2^{\mathrm{a}}$ ampliación y su relación con la $1^{\mathrm{a}}$ y la casa de Rietveld

- 4 detalles

- 1 plano de situación

\section{Caratula}

- Nombre del plano: $2^{a}$ uitbreiding (2a ampliación)

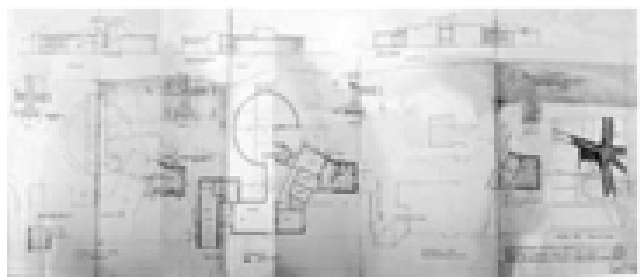

- Número plano: 3

- Arquitectos profesor Aldo van Ecyk y Theo Bosch

Facilitado por Mrs. Joke Visser, viuda de Martin Visser y actual propietaria de la casa
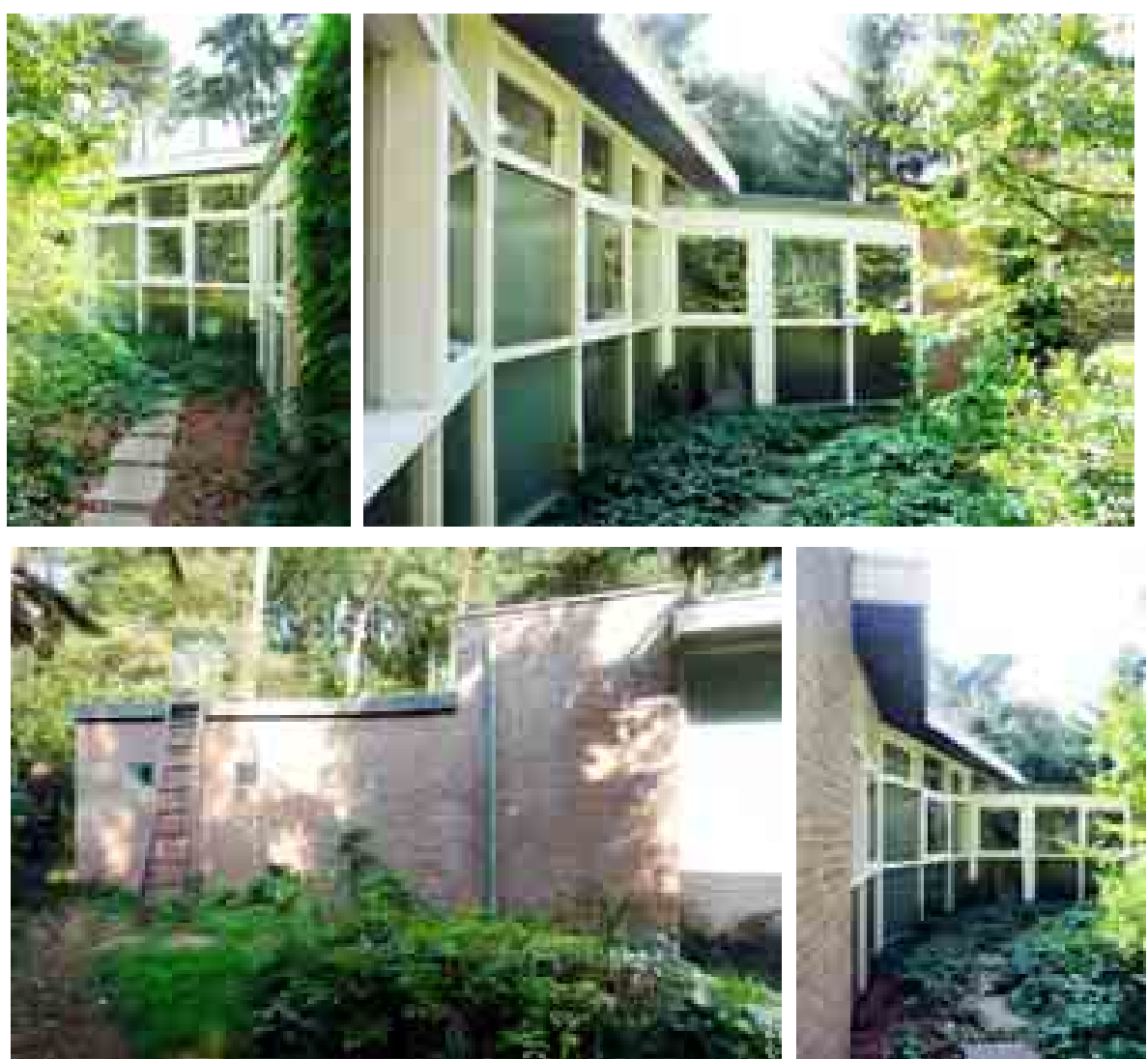

Figura 3.61

a Casa Visser.

Relación entre el ala de dormitorios y la segunda ampliación realizada por Aldo van Eyck y Theo Bosch en 1971. La extensión del nuevo cuarto de baño es de menor altura que el cuerpo construido por Rietveld en 1956.

Fotografias de Ana Rodríguez en septiembre de 2013 

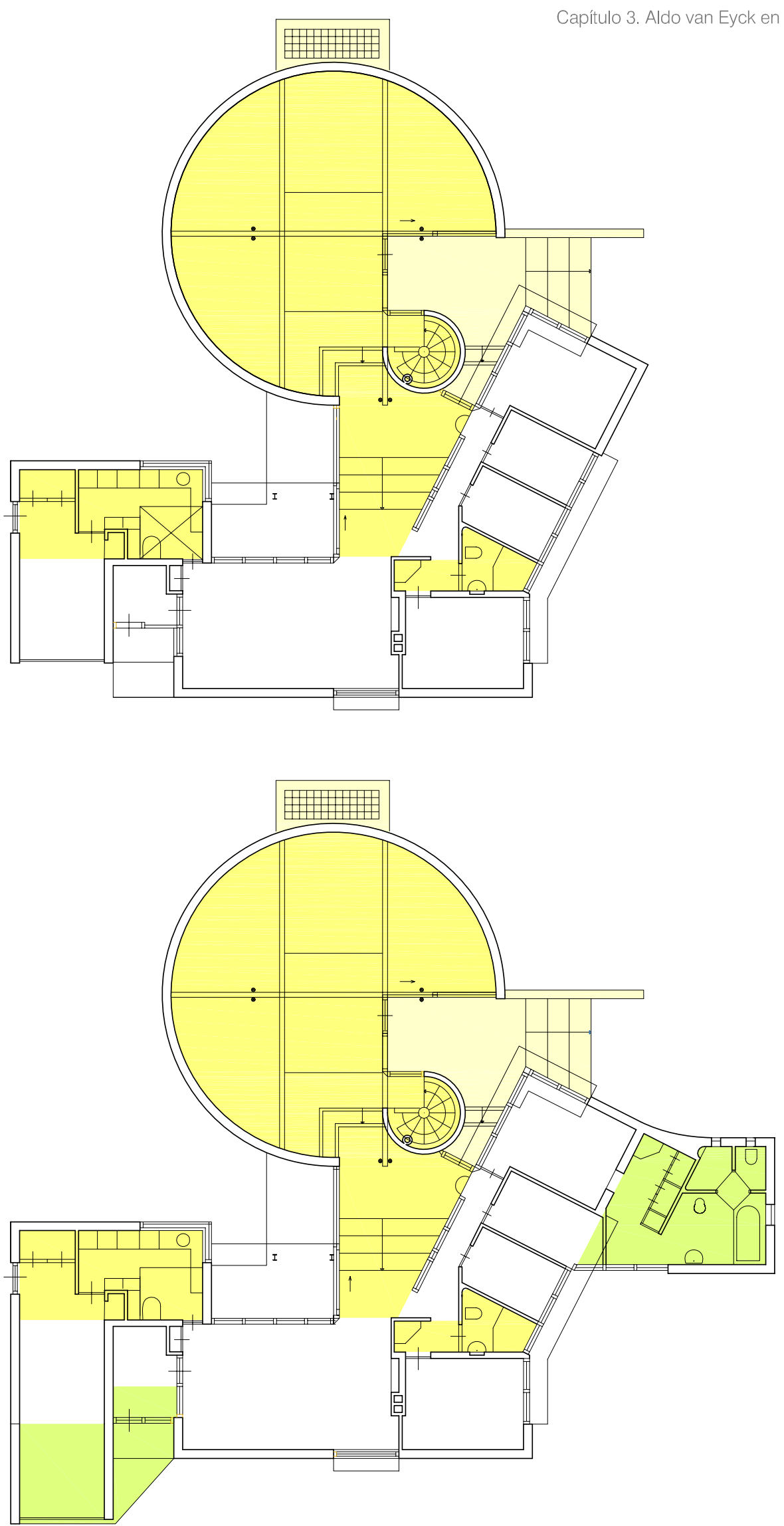

Figura 3.62

Casa Visser en Bergeijk. Plantas realizadas a partir de los planos de los dos proyectos de ampliacion de Aldo van Eyck, para la casa construida por Gerrit Rietveld en 1956.

Dibujos de Ana Rodríguez. Escala 1/200

* Superior

Ampliación de la Casa Visser realizada por Aldo van Eyck en 1967-1969. Zonas ampliadas y/o transformadas en color amarillo.

* Inferior

Ampliacion de la Casa Visser realizada por Aldo van Eyck y Theo Bosch en 1971. Zonas ampliadas y/o transformadas en color verde. 
3.4.1.4. Una propuesta no realizada y el homenaje póstumo de Martin Visser a Aldo van Eyck en 2000.
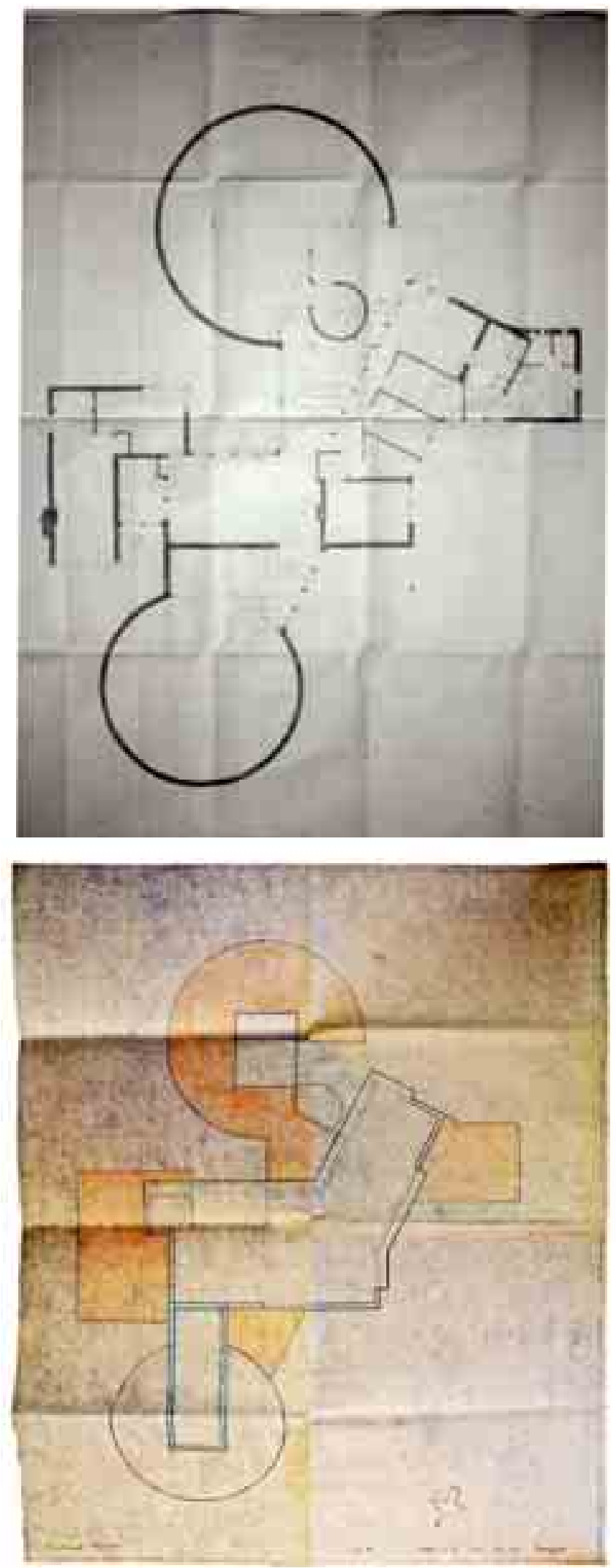

Figura 3.63

Ultimo proyecto de ampliación de la Casa Viisser propuesto por Aldo van Eyck, no realizado, consistente en un segundo espacio circular en la zona de entrada.

* Superior: planta del proyecto. Documentación del Archivo Van Eyck, facilitada mediante copia digitalizada por el profesor Francis Strauven

* Inferior: planta de cubierta del proyecto realizada con lápiz de color sobre copia de amoniaco, facilitada por Mrs. Joke Visser, segunda esposa de Martin Visser y actual propietaria de la casa. 


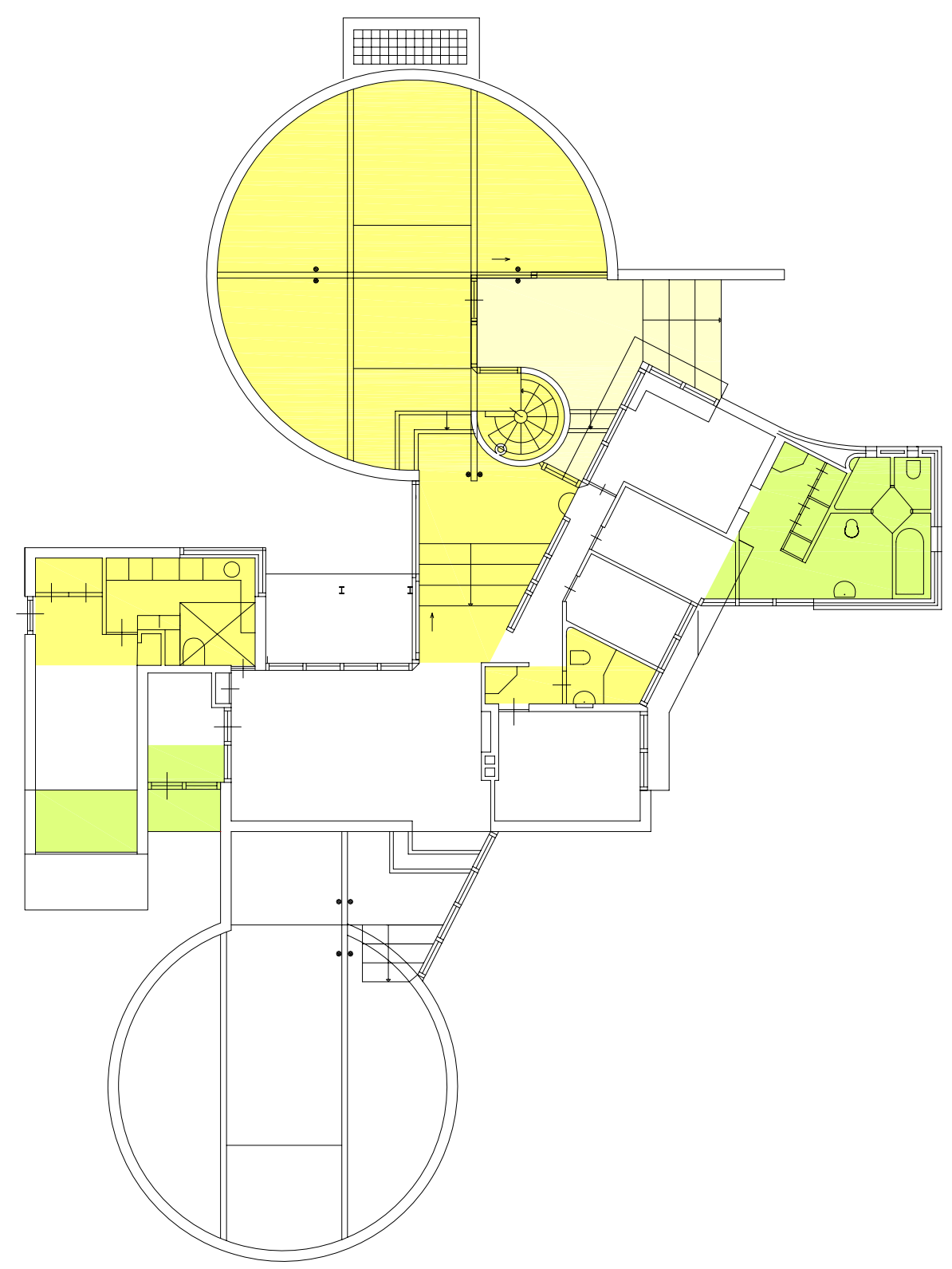

Figura 3.64

Casa Visser en Bergeijk.

Propuesta no construida para una ampliación más

Planta realizada a partir de los dibujos inéditos de Aldo van Eyck para otra ampliación más

- consistente en un segundo espacio circular-, para la casa construida por Gerrit Rietveld en 1956

En esta propuesta la casa de Rietveld quedaria como un gran In-between entre las dos ampliaciones.

Dibujo de Ana Rodríguez. Escala 1/200 


\subsubsection{Criterios de relación entre ampliación y preexistencia}

Los testimonios dados por Martin Visser como cliente y por el propio Aldo van Eyck, sobre la ampliación de la Casa Rietveld, conforman un relato de los hechos relevante de reseñar, para configurar el marco previo al análisis de la intervención.

Van Eyck dice sobre ella:

«Ávidos coleccionistas de arte contemporáneo me rogaron que remodelara la casa que G. Rietveld había construido para ellos doce años antes. El principal dilema era que se había dejado muy poca superficie de la pared, para sus pinturas y objetos de arte, entre todos los vidrios. Más allá de eso, había durado demasiado irse a la cama y levantarse de forma espartana. Así que algo había que hacer. Aunque por una vez una casa bastante inapropiada, seguía siendo una casa Rietveld.

Alterarla era, por sonoras razones, perturbador, porque los cambios requeridos pedian intervenciones radicales, no de menor importancia. Yo, sin embargo, traté de llevar a cabo lo que era necesario dejando la estructura arquitectónica y la fábrica de la casa original de Rietveld prácticamente intacta -allí, me siento, de forma fantasmal.

Un gran espacio cilíndrico $3 / 4$, que proporciona $25 \mathrm{~m}$ de superficie ininterrumpida de pared, se construyó frente a la sala de estar existente en el lado sur, a cierta distancia y accesible desde ella, precisamente, donde una vez estuvieron las puertas del jardín.

La conexión entre lo viejo y lo nuevo -donde se encuentran- es, por tanto mínima. El nivel del suelo se rehundió por debajo del existente de manera que, además de reducir su considerable volumen, la extensión podría insertarse bajo el voladizo de la cubierta de Rietveld dejando espacio para la misma franja de ventana horizontal que empleó para el anexo de la cocina-garaje existente.

El estrecho paso a lo largo de los dormitorios, originalmente acristalado de suelo a techo -brrrrr- ahora discurre por el interior en un ángulo oblicuo, con una barandilla a lo largo de los soportes originales en sustitución del antiguo paño de vidirio. La ampliación dell baño me propuse después fue un bien merecido extra!» 91

Martin Visser, a su vez, dice:

«Usted comprende que quisiéramos más espacio, más estancia para colgar cuadros y poner algunas esculturas. Nosotros teníamos la idea de ampliar la casa a través esa ventana grande en el salón. Pero Aldo desde el principio

\footnotetext{
91 «Avid collectors of contemporary art begged me to refashion the house G. Rietveld had built for them twelve years earlier. The chief dilemma was that there was far too little wall surface left for their paintings and art objects between all the glass. Beyond that, going to bed and getting up had too long been a spartan undertaking form more or less the same reason. So something had to be done. Although for once a rather inappropriate house, it was after still a Rietveld house.

Altering it for sound reasons was disturbing because the required changes called for radical, not minor interventions. I did, however, try to bring about what was necessary whilst leaving the architectural structure and fabric of Rietveld's original house practically untouched - still there, I feel, in a phantomlike way.

A large $3 / 4$ cylindrical space providing $25 \mathrm{~m}$ of uninterrupted wall surface was built opposite the existing living room on the south side, at some distance and accesible from it, precisely where garden doors once were. The conection between old and new -where they meet- is thus minimal. The floor level was sunk below the existing one so that, besides reducing its considerable bulk, the extensión could be inserted under Rietveld's projecting roof leaving room for the same horizontal window strip he employed for the existing kitchen-garage annex.

The narrow passageway along the bedrooms, originally glazed from floor to ceiling -brrrrr- now runs through the interior at an oblique angle, with a handrail along the original posts replacing the former fenestration.

The bathroom extensión I proposed later on was a well-deserved extra!» (Ligtelijn 1999, 150).

Traducción de Ana Rodríguez.
} 
estaba mirando a esa esquina de vidrio entre el salón y el corredor. En seguida vio que era un punto débil y quería hacer algo al respecto en la nueva ampliación. Tenía ya la idea la primera tarde. En sus primeros dibujos todavía intento continuar pensando en el mismo lenguaje de Rietveld, pero pronto lo abandonó. Entonces, de súbito tuvo la idea del círculo. Después ya no cambio. Pero la elaboración duró un tiempo. Meses después volvió y de nuevo estuvo sentado durante horas mirando hacia el exterior desde dicha esquina del salón y pensando en voz alta. Hablaba sin parar sobre cómo se podría hacer y cómo no. Es muy típico de él. No toma decisiones secretas artísticas de las que solo te permite admirar el resultado. Deja claro todo su proceso de pensamiento.

En un momento dado también aceptó nuestra sugerencia de ampliar la casa al otro lado. Después proyectó un segundo círculo al lado norte. (Deja ver un esquema donde la casa de Rietveld se ha convertido en un área entre dos ampliaciones circulares). Aquello podría haber sido estupendo, pero era imposible de pagar» ${ }^{92}$

El nuevo volumen de tres cuartos de cilindro de la primera ampliación, se percibe con rotundidad, como una forma autónoma y contrapuesta. Sin embargo, su posición rehundida sesenta centímetros respecto a la casa de Rietveld, posibilita que su línea de cornisa quede por debajo de la marquesina que recorre y caracteriza la primera. Se establece un dialogo de igualdad entre opuestos en el que ninguna de las dos construcciones queda subordinada a la otra, siendo seguramente el principal logro de Van Eyck. Conseguir una relación respetuosa con la obra de Rietveld, sin imponerse sobre ella, pero realizada desde un intervención de extraordinaria rotundidad.

La Casa Visser no ha sido estudiada en profundidad.

La mayor parte de las publicaciones se limitan a incluirla en el catalogo de obras de Rietveld, redibujando en algunos casos sus plantas, pero sin entrar a analizarlas. En este sentido, el texto más completo es el que le dedica Francis Strauven en Aldo van Eyck. The Shape of Relativity, que incluye algún fragmento traducido al inglés de la entrevista en holandés hecha por el mismo a Martin Visser en 1982.

Se proponen tres criterios de análisis, inéditos, sobre las relaciones que se establecen entre la ampliación de Van Eyck y la preexistencia de Rietveld: el circulo y el centro, el espacio in-between, y la transparencia, materializándose en la posición exacta del circulo, como muestran la serie de croquis inéditos sobre el desarrollo del proyecto que se muestran a continuación.

Criterios que representan la influencia de lo vernáculo de culturas primitivas y del espacio domestico en Holanda, tal y como lo expresan los interiores pintados por Pieter de Hoogh en el XVII, y en los que se profundiza en los epígrafes siguientes.

\footnotetext{
92 «U begrijpt dat we meer ruimte wilden, dat wè plaats wilden om schilderijen op te hangen en om enkele sculpturen neer te zetten. Zelf hadden we het idee het huis aan de andere kant, via dat grote raam in de woonkamer uit te breiden. Maar Aldo zat vanaf het begin naar die verglaasde hoek tussen woonkamer en gang te kijken. Hij zag onmiddellijk dat dit een zwak punt was, en daar wilde hij met de nieuwe uitbreiding iets aan doen. Het idee had hij eigenlijk al de eerste middag. In zijn eerste schetsen probeerde hij nog even verder te denken in dezelfde Rietveld-taal, maar daar stapte hij al gauw van af. Toen kwam in één klap het idee van de cirkel te voorschijn. Dat is daarna niet meer veranderd. Maar de uitwerking heeft nog wel een tijd op zich laten wachten. Maanden later kwam hij opnieuw kijken, en toen zat hij weer urenlang vanuit de woonkamer in die hoek naar buiten te staren en hardop te denken. Hij zat eindeloos te praten over hoe het niet en hoe het wel zou kunnen. Want dat is heel typerend voor hem. Hij neemt geen geheime artistieke beslissingen waarvan je alleen het resultaat mag bewonderen. Hij geeft zijn gedachtengang helemaal prijs. Op een bepaald moment is hij toen ook nog ingegaan op onze suggestie het huis aan de andere kant uit te breiden. Toen had hij aan de noordkant een tweede cirkel getekend. (Diept schets op waarin het Rietveldhuis een tussengebied geworden is tussen twee cirkelvormige uitbreidingen.) Dat zou prachtig geweest zijn, maar het was onbetaalbaar»

Publicada en holandés (Van Eyck. 1986, 80), y parcialmente en ingles (Strauven 1998, 533).

Traducción libre del holandés de Grietje Bouwmeester y Ana Rodríguez.
} 

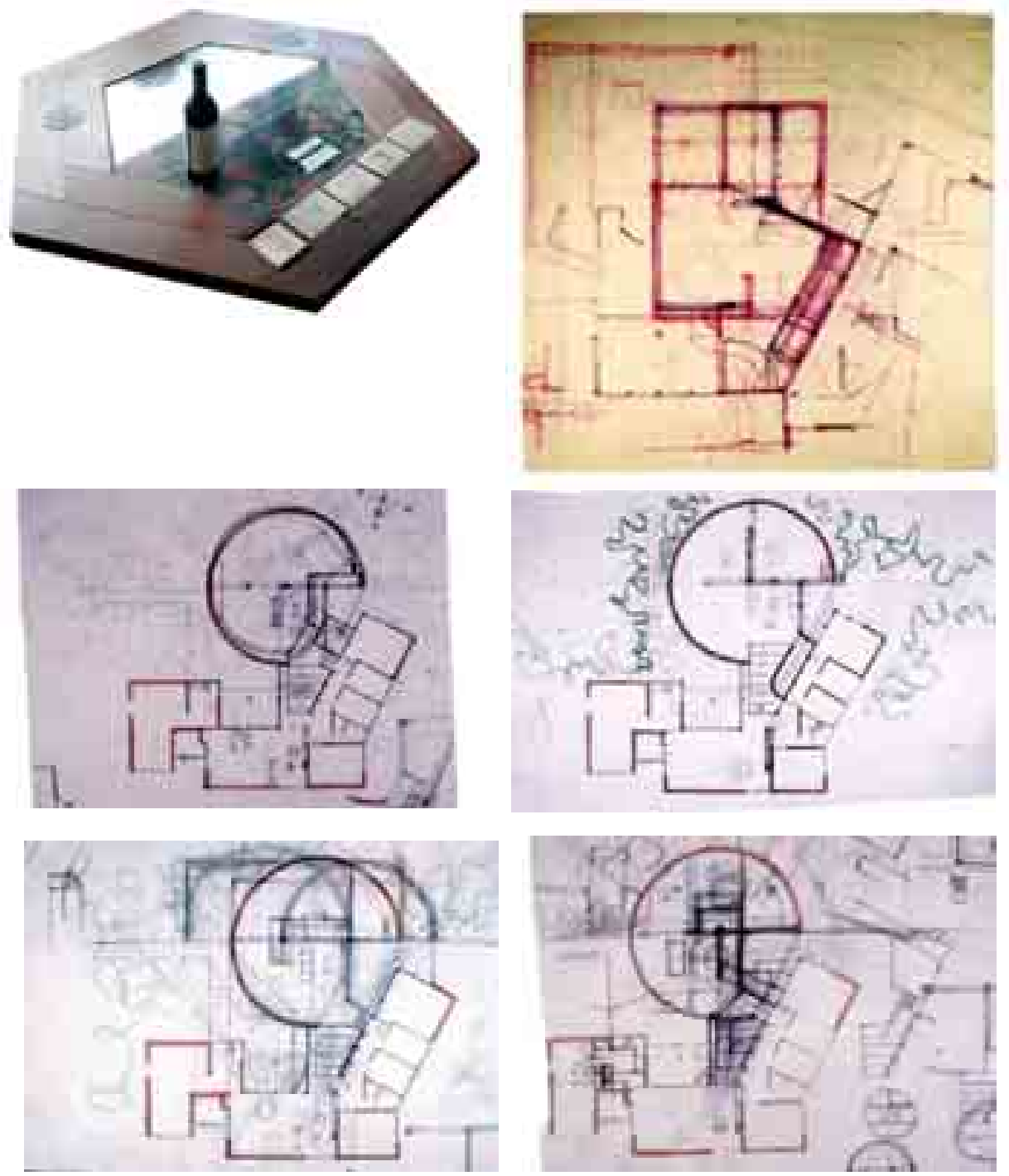

Figura 3.65

Proyecto de ampliación de la Casa Visser. Serie de croquis en color de Aldo Van Eyck sobre el desarrollo de la idea.

No están numerados ni fechados, por lo que el orden establecido (de arriba abajo y de izquierda a derecha) es en sí mismo una aproximación al proceso de proyecto.

En un primer momento, Van Eyck explora la geometría ortogonal para desecharla rápidamente. Una vez decidida la forma circular contrapuesta a la ortogonal, la cuestión se centra en la posición respecto a la casa de Rietveld, y en cómo afecta a las visuales, pero sobre todo al elemento de unión entre ambas. El in-beetween entre la tradición moderna y la vernácula.

Imagen superior a la izquierda, mesa del profesor Francis Strauven, regalada por Aldo van Eyck, con copias positivadas de los croquis y una botella de Matarromera.

Documentación del Archivo Van Eyck, facilitados mediante copia digitalizada por el profesor Francis Strauven DOCUMENTACIÓN INEDITA. 

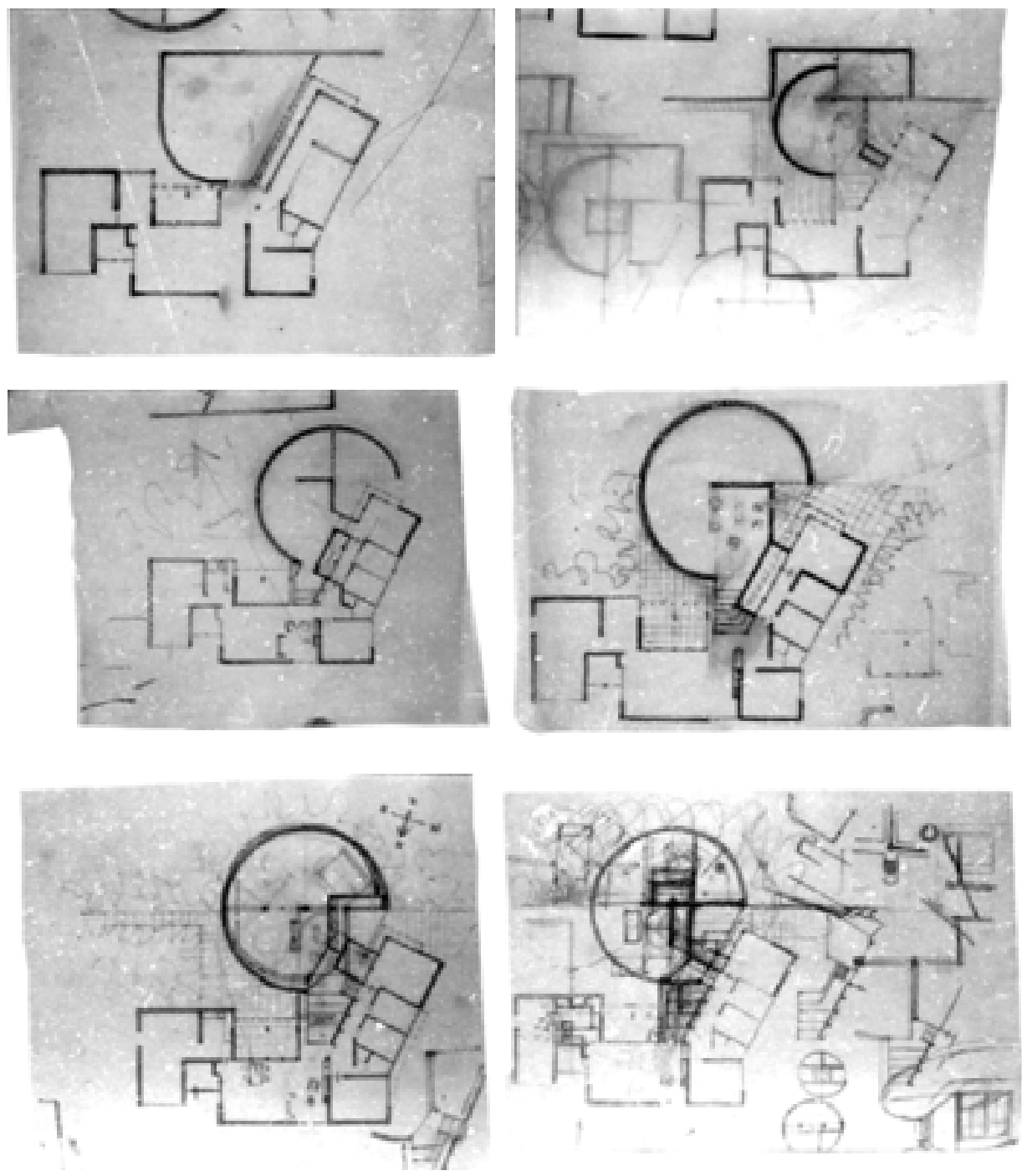

Figura 3.66

Proyecto de ampliación de la Casa Viisser. Serie de croquis de Aldo Van Eyck sobre el desarrollo de la idea.

No están numerados ni fechados, por lo que el orden establecido es en sí mismo una aproximación al proceso de proyecto.

Documentación del Archivo Van Eyck, facilitados mediante copia digitalizada por el profesor Francis Strauven

DOCUMENTACIÓN INEDITA. 


\subsubsection{Criterios de relación entre ampliación y preexistencia}

\subsubsection{El círculo y el centro.}

En abril de 1987, Aldo van Eyck impartió una conferencia sobre el círculo y el centro, en el Indesem $87^{93}$, celebrado en la University of Technology Delft. La exposición de aproximadamente una hora de duración, se desarrolló a través de un conjunto de imágenes en las que apenas salían edificios, sino una importante cantidad de objetos y utensilios de diferentes culturas arcaicas. Entre ellos, varios cuencos de cerámica de los Indios Pueblo y un tapiz de Thailandia para explicar las relaciones geométricas no jerárquicas, y la idea de equilibrio frente a la de simetría perfecta.

La conferencia permite disfrutar ${ }^{94}$ de un Aldo van Eyck pletórico, moviéndose por el estrado con una especie de larga lanza acabada en un pequeño tridente tribal de dos puntas, como si anduviera de caza por la sabana.

Resumida en un texto breve, y publicada con posterioridad por Marc Labadie y Bert Tjhie en Indesem 87: international design seminar; April 6-10 University of Technology Delft y a su vez recogida por Vincent Ligtelijn y Francis Strauven en Aldo van Eyck. Collected articles and other writtings 1947-1998, es especialmente pertinente por las explicaciones de primera mano, dadas por Van Eyck sobre las posibilidades de una geometría no central en las formas circulares.

Según Van Eyck, la arquitectura moderna ha sido temerosa de lo central, porque temía un centro jerárquico y estático. Pero la arquitectura no se puede entender sin reconocer que el centro existe: un centro abierto, no fijado, no estático.

En el momento en que se define el centro de un círculo, se está perdiendo algo, ya que el centro geométrico nos induce a pensar en ejes y segmentos radiales como un reloj o una rueda. En contraposición a esta forma de pensamiento mecanicista, Van Eyck dice:

«Yo prefiero pensar en el círculo como un disco o un anillo. No es cuestión de un centro. Es un movimiento muscular. La rueda, el reloj, interpretan un solo que nunca termina. El anillo y el disco están en diálogo continuo con lo que les rodea. De alguna manera parecen respirar. Hay un movimiento, hacia el exterior, hacia el interior. El centro está en todas partes.

El círculo interpretado así, no es una forma congelada, respira como nosotros y eso es lo que la arquitectura debe hacer. Lo abierto es el sello distintivo de la arquitectura contemporánea. Significa muchas cosas. No significa gran cantidad de vidrio. Significa abierta de espíritu» ${ }^{95}$

\footnotetext{
${ }^{93}$ International Design Seminar. En 1985, a raíz de la jubilación de Aldo van Eyck en el Departamento de Arquitectura de la University of Technology en Delft, se recuperó la realización de un evento que se había iniciado en los años sesenta: un seminario internacional de proyectos, que se celebró en enero de ese mismo año, con la participación del propio Van Eyck, y que en 1987, coordinado por Herman Hertzberger, se desarrolló del 6 al 10 de abril, con idea de continuidad en el tiempo.

${ }^{94}$ Conferencia accesible en internet desde varias páginas web.

95 « prefer to think of a circle as a disk or a ring. There's no question of a centre. It's just a muscular movement. The wheel, the clock, they perform a never-ending solo. The ring and disk are in a continuous dialogue with what is around them. They somehow seem to breathe. There is a movement, outwards, inwards. The centre is everywhere. The circle interpreted as such is not a frozen form, it breathes like we do and that's what architecture should do.

Open is the hallmark of contemporary architecture. It means many things. It doesn't mean a lot of glass. It means open in spirit» (Van Eyck 1987, 184-185). Traducción de Ana Rodríguez
} 

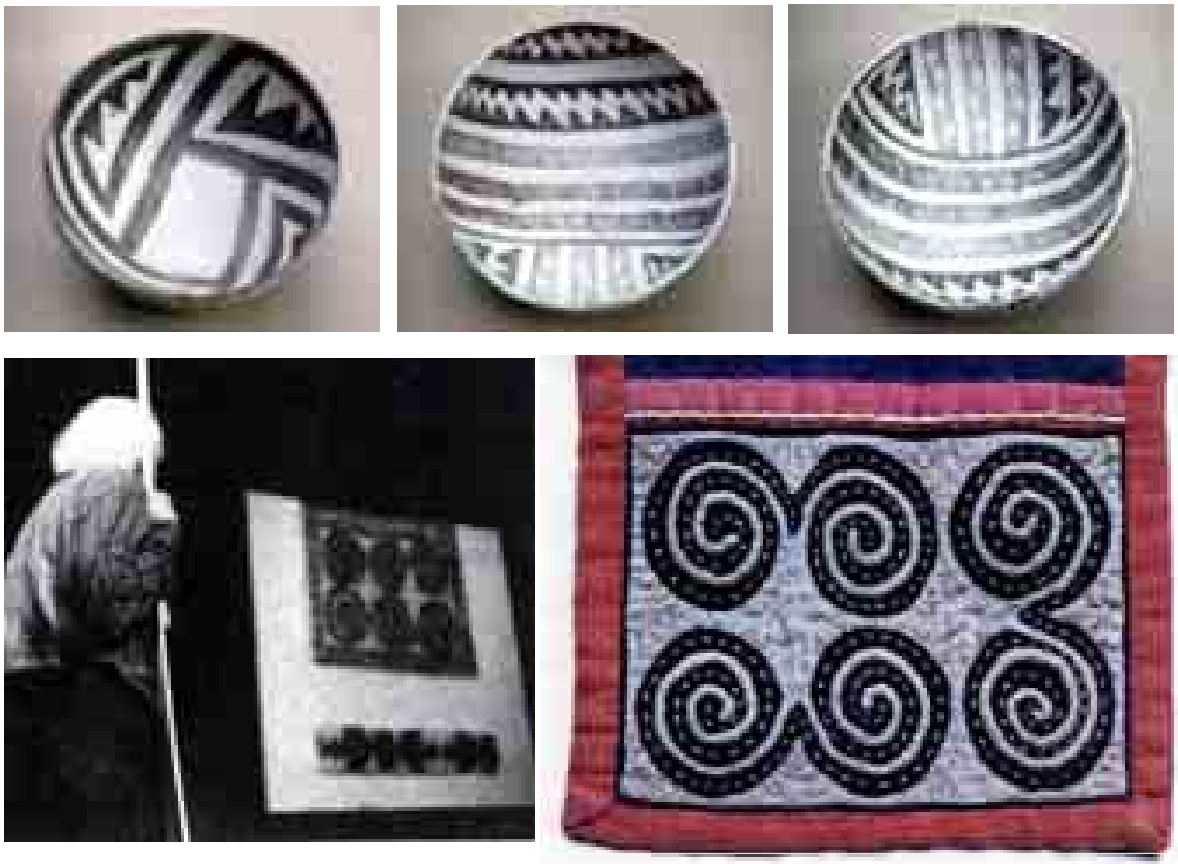

Figura 3.67

* Superior

Cuencos de cerámica preocolombina de los Indios Pueblo en Arizona, de planta circular decorados con patrones no basados en el centro geométrico y jerarquico del círculo. En el caso del cuenco de la derecha, con un patron de líneas paralelas en dos direcciones perpendiculares, se puede apreciar como el resultado da imagenees muy diferentes dependiendo de la posición yy el punto de vista. Imágenes de la conferencia en Indesem 87

* Inferior derecha

Textil de Thailandia, que muestra una forma simple y eficiente de romper la jerarquía de una composición tripartita. Mientras que las dos horizontales son simetricas, la tercera en vertiocal, rompe la simetría y a su vez la jerarquía. (Ligtelijn y Strauven. 2008, 553).

* Inferior izquierda

Aldo van Eyck en la conferencia del Indesem 87. En la fotografía de Jan Kapsenberg, se ve a van Euck sujetando la lanza mencionada anteriormente, con la diapositiva del tapiz tailandés al fondo (Van Eyck 1987, 185)

La respuesta dada por Van Eyck en la primera ampliación de la Casa Visser, materializa lo expresado en este mismo texto cuando habla de simetría, en el sentido no de elementos exactamente iguales a ambos lados de un eje jerárquico, sino de un equilibrio y una cierta equivalencia entre las partes.

Aunque el paso de conexión entre la casa de Rietveld y la primera ampliación, sensiblemente coincide con el hueco de la fachada norte de la primera, el centro de la planta circular, no está en el eje de dicho paso, sino que coincide con la jamba izquierda del hueco. El centro del lucernario formado por dos vigas de madera laminada que organizan espacial y estructuralmente la cubierta, tampoco coincide con en las dos direcciones con el centro del circulo, sino únicamente en la transversal.

Estas estrategias, se intensifican en la propuesta posterior no construida. El eje de segundo circulo, vuelve a pasar por el mismo punto que el anterior, en el lateral del hueco, sin coincidir con el eje del paso, que vuelve a ser del mismo ancho que este.

A su vez, las distancias entre las vigas estructurales de ambos círculos son las mismas, compartiendo uno de los ejes a partir de la cual se desplazan cada uno de los círculos en sentidos opuestos, generándose una equivalencia entre las partes, que no una simetría. El conjunto de leyes geométricas establecidas, con sus matices y variaciones dimensionales, generan espacios muy cualificados e intensos.

En la figura adjunta se muestra un análisis geométrico de las relaciones mas significativas entre de la casa de Rietveld y la ampliación de Van Eyck, basadas la equivalencia entre las partes, así como en su entendimiento del circulo, sin centro jerarquizado y geometría radial, con un patrón que recuerda el del cuenco de cerámica de la cultura Pueblo. 


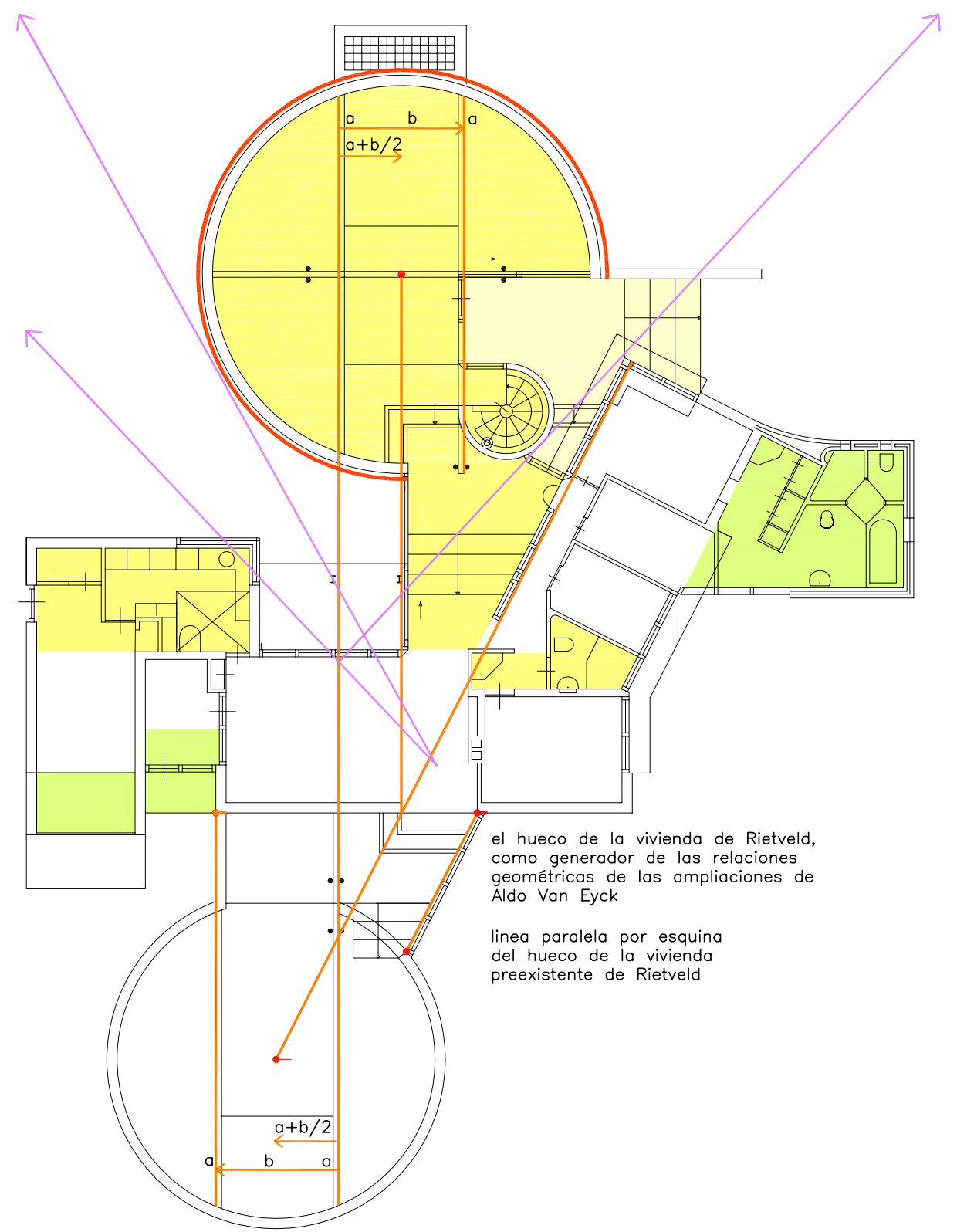

Figura 3.68

Casa Visser en Bergeijk.

Análisis geométrico realizado a partir de los planos de los dos proyectos de ampliación de Aldo van Eyck, y de los dibujos inéditos para otra ampliación más - consistente en un segundo espacio circular-, para la casa construida por Gerrit Rietveld en 1956

Dibujo de Ana Rodríguez. Escala 1/200

Resumen de las ampliaciones construidas:

- Color amarillo: Ampliación de la Casa Visser realizada por Aldo van Eyck en 1967-1969.

- Color verde: Ampliacion de la Casa Visser realizada por Aldo van Eyck y Theo Bosch en 1971

- Perímetro naranja del espacio de planta circular: Pintado del ladrillo después de la muerte de Aldo van Eyck, a modo de homenaje por Martin Visser. Realizado en 2000 por Hannie van Eyck.

Geometría de las ampliaciones construidas y no construidas -segundo espacio de planta circularLas relaciones geométricas, marcadas en color naranja, se fundamentan en:

1. El círculo y el centro.

El gran hueco de la fachada norte de la casa de Rietveld, es el elemento principal a partir del que se generan las relaciones geométricas del espacio circular de ampliación construido y también del no realizado, de forma que los espacios longitudinales de paso coinciden sensiblemente con el ancho de dicho hueco de dos metros.

Sin embargo, los centros de los círculos no coinciden con el eje de los pasos, aunque a primera vista puede parecerlo, sino que se establecen a partir de las jambas laterales del hueco

Estas pequeñas variaciones, establecen una intencionada tensión de no simetría y generan unos espacios de gran intensidad

2. Transparencia y búsqueda de visuales en diagonal, al igual que el la Iglesia Católica de la Haya y en el Sonsbeek Pavilion. Visuales diagonales marcadas en color magenta. 


\subsubsection{El espacio in-between}

La arquitectura tan solo acogerá nuestro retorno pacífico si trata de ser inclusiva y de no discriminar entre contrarios. No debe de negar ningún extremo de verdad. En mi caso particular, trato de alcanzar una complejidad formal que apoye y reafirme su aspecto más humano. El que me sienta capaz de dar cabida a una multiplicidad de sentidos e interpretaciones no quiere decir que cualquier sentido sea posible. Tratar de acoger los múltiples significados de los fenómenos dualistas implica exponer todo sentido primario. Creo que los edificios que pretenden semejante ideal y, por lo tanto, llegan a ser perfectamente accesibles en un sentido emocional, son los verdaderamente importantes. Hay algunos así, pero no muchos. (Van Eyck [1983] 1997, 86)

El significado mas amplio de in-between, se introdujo en el texto "La plus grande réalité du seuil" publicado en Forum 7, 1959 y "Das Gestalt gewordene Zwischen: the concretization of the in-between" en Forum 8 del mismo año.

Un umbral, en sentido genérico, es la transición y conexión entre ámbitos diferentes y constituye esencialmente el espacio para en el encuentro y el dialogo entre ellos. El valor de este concepto, es mas claro y explicito en el umbral por excelencia, que es la entrada de la casa, donde se encuentran y reconcilian la calle y el espacio privado. (Hertzberger 1991, 32)

Basándose en la filosofía del diálogo de Martin Buber, Van Eyck concebía lo intermedio como un lugar donde cosas diferentes puedan encontrarse y unirse, o más específicamente, como «el terreno común donde polaridades en conflicto puede llegar a ser dos fenómenos» La dualidad, los fenómenos duales, un concepto original de Van Eyck, deriva de la idea de que las polaridades reales (como sujeto y objeto, la realidad interior y exterior, grande y pequeño, abierto y cerrado, la parte y el todo) no son contradictorias, ni entidades mutuamente excluyentes, sino elementos característicos, dos mitades complementarias de una misma entidad, y además una verdadera entidad es siempre doble. Su lo intermedio entre dos no debe ser considerado como algo improvisado o insignificante, sino algo tan importante como el espacio propio para la reconciliación de opuestos. El momento en que tendencias contrarias encuentran el equilibrio, constituye un espacio lleno de ambivalencia, y por lo tanto es el espacio que corresponde a la naturaleza ambivalente del hombre.

Lo intermedio es «el espacio a imagen del hombre», un lugar que, al igual que el hombre, «respira dentro y fuera».

El concepto de in-between significa el ámbito de relación de dualidades contrapuestas, y trasciende a los espacios concretos, siendo aplicable también a ideas y conceptos: Los círculos de Otterlo, son la representación del in-between en el que se encuentran y reconcilian la tradición vernácula, la tradición clásica y la tradición moderna. Al igual que en el cuadro de Picasso de 1908 Mujer sentada con abanico, en el que determinados planos parecen pertenecer indistintamente al fondo o al sillón (Hertzberger 2000, 215), el espacio de encuentro entre opuestos debe poder brindar significados que pertenezcan a ambos polos.

La idea adquiere especial significado cuando la relación de lo nuevo se establece a partir de algo ya preexistente, como en la Hubertus House o en la Casa Visser, en la que el planteamiento abarca escalas diversas. En su conjunto, es un ámbito ideal inbetween en el que conviven y se relacionan las tres tradiciones, especialmente la vernácula y la moderna. Pero descendiendo de escala, entre la preexistencia de la obra de Rietveld y la ampliación de Van Eyck, se genera a su vez un espacio físico inbetween que pertenece a ambas zonas de la casa, y cuya configuración evoca el lugar de encuentro entre dependencias de la casa familiar de Bansiri en la aldea de Banani, en Mali, representada en la figura siguiente. Llegados a este punto se puede concluir que la Casa Visser es un ejemplo paradigmatico de los Circulos de Otterlo. 


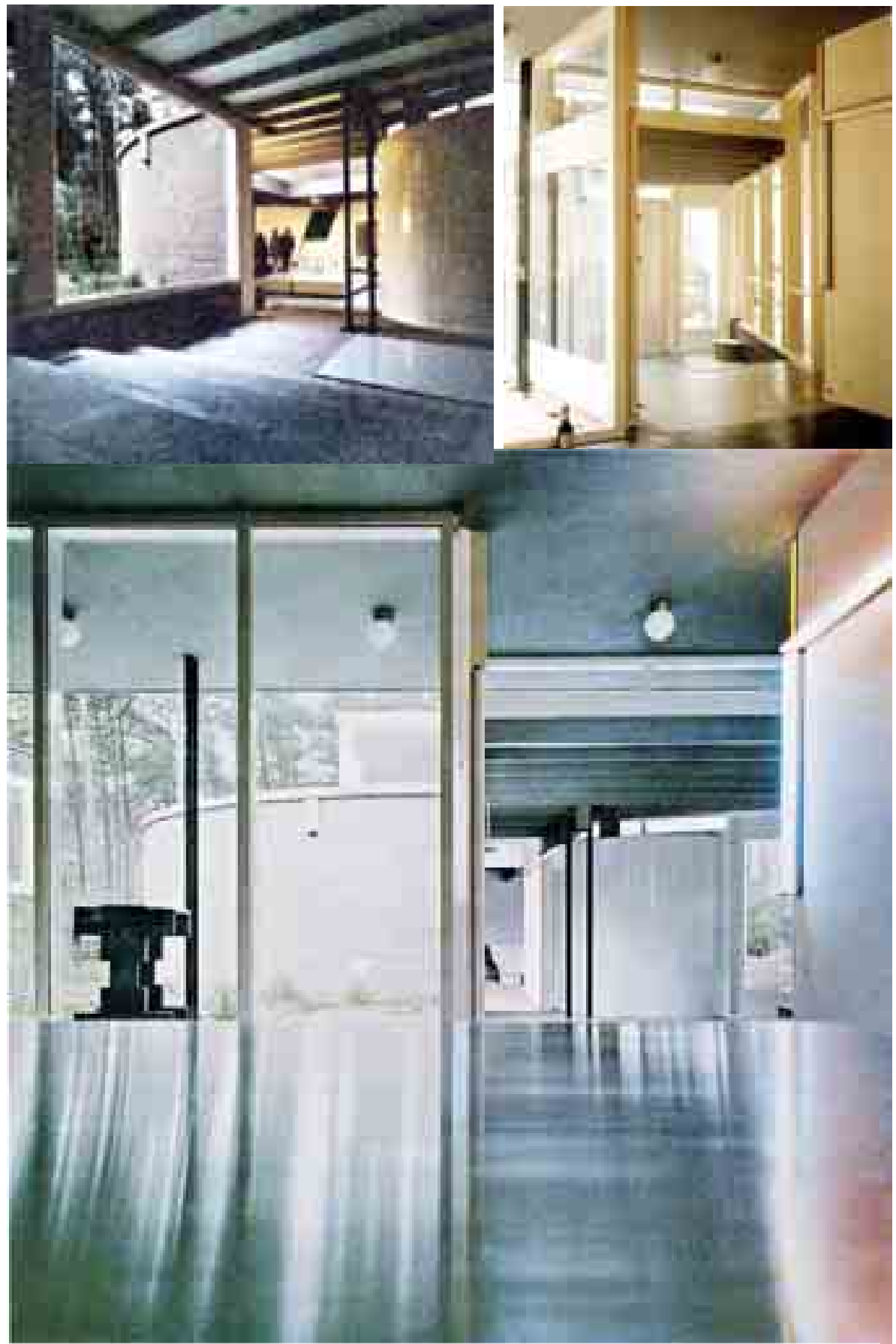

Figura 3.69

El in-between de la Casa Visser de Aldo vna Eyck.

Vistas de la conexión entre lo nuevo y lo preexistente desde el estar de la casa de Rietveld hacia la ampliación de Van Eyck.

El espacio intermedio de es interior y exterior, abierto y cerrado, longitudinal y transversal, mate y reflectante

* Superior izquierda e inferior

Fotografías de Jan Versnel (Restany 1970, 18). Las magníficas fotografías de la publicación en Domus, son posiblemente las únicas en color del momento. 


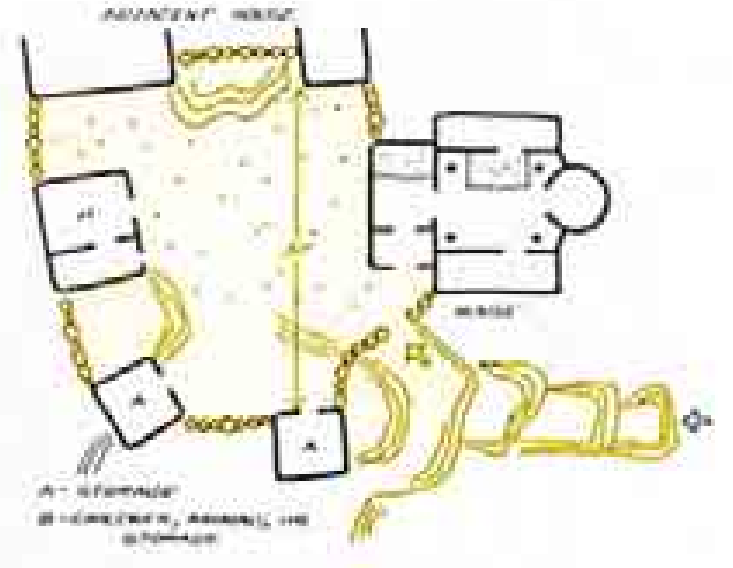

Figura 3.70

Análisis del espacio In-Between en la cultura Dogon

Ámbito intermedio de relación, entre la casa y las dependencias auxiliares, con un recorrido de llegada en distintos niveles, que hace al habitante más consciente de la relación entre las partes.

Matizado en color amarillo por Ana Rodríguez para su mejor comprensión, a partir de:

Casa familiar de Bansiri en la aldea de Banani, en Mali.

Dibujo de Aldo van Eyck en 1960 (Strauven 1988).

Figura 3.71

Análisis comparativo del espacio In-Between entre la Casa Visser. y la Casa familiar Dogon.

El ámbito intermedio de relación, entre la casa de Rietveld y la Ampliacion de Van Eyck, se plantea también como un recorrido en distintos niveles, que acentúa las partes y posibilita que el espacio cilíndrico quede por debajo de la marquesina de la casa inicial.

El cuerpo del cuarto de baño añadido en la segunda ampliación de Van Eyck y Theo Bosch, intensifica la relación inbetween.
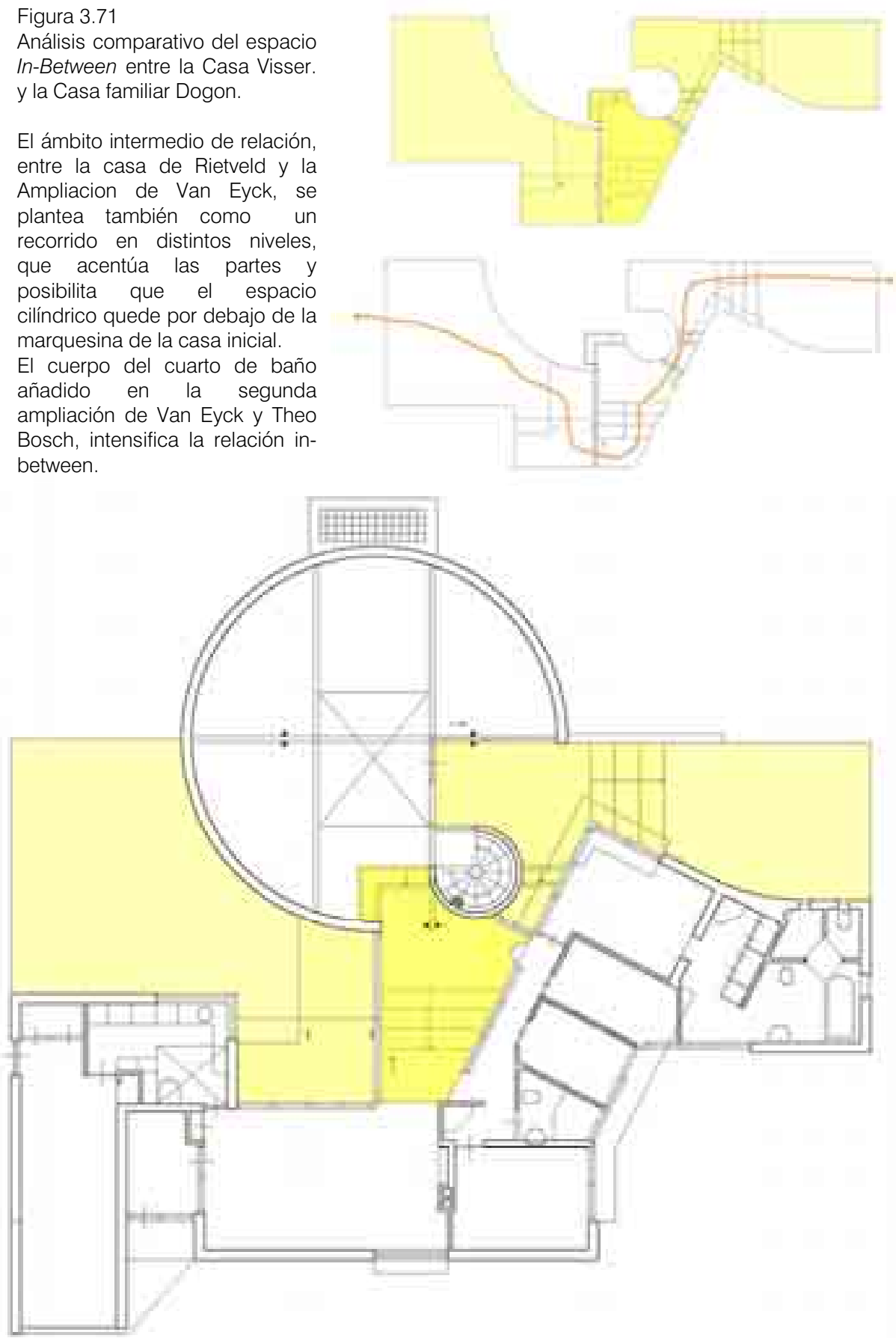


\subsubsection{Transparencia}

El interés de Van Eyck por la obra de Pieter de Hoogh (1629-1684), está presente en varios de sus escritos. En "Transparency. Thoughts formulated after the completion of the Amsterdam Hubertus House, 1982", public ado en Aldo van Eyck: Writings. Collected articles and other writings 1947-1998 (Ligtelijn y Strauven 2008), Van Eyck incluye un epígrafe sobre el pintor con un texto y una imagen del cuadro Mujeres junto al armario de la ropa blanca (1663), en la página anterior. El mismo texto ampliado y la misma imagen, que vuelve a reproducir al año siguiente, en la publicación que se hace con motivo de la Exposición Aldo van Eyck, celebrada en The National Gallery and Alexander Soutzos Museum en Atenas, entre el 17 de septiembre y el 23 de octubre de 1983:

«Variar la profundidad espacial y la distancia perceptible a través de la transparencia.

Además de un límite espacial cercano, mediante uno o varios más lejanos.

En este lado de un límite espacial que está más lejos mediante uno o varios más cerca.

Modulación de la profundidad espacial y de la distancia como se ve desde un lugar a otro, así como desde un lugar, es decir, ambas consecutivas y simultáneas.

Pieter de Hoogh nos muestra la belleza que se encierra a través de lo que la apertura y la transparencia pueden provocar, cuando pinta una puerta o ventana abierta, pasaje o callejón en una sola visual, así permite ver a través de varios espacios exteriores e interiores - a veces incluso tan lejos como las casas al otro lado de la calle o del canal- y siempre hay algunos personajes que articulan toda la profundidad una vez más. De Hoogh muestra que el tipo de apertura que provoca una sensación de recinto, no depende de la desmaterialización y de un montón de vidrio

Al igual que en el pabellón de escultura Sonsbeek, donde unas pocas aberturas en los muros eran suficientes para delimitar la considerable apertura lateral modulando la distancia perceptible; esas que en los muros de carga corren paralelas desde atrás en las casas Hubertus y también proporcionan vistas cruzadas» 96

En la introducción al capítulo 11 de Aldo van Eyck Writings. Collected Articles and Other Writings 1947-1988, los editores Vincent Ligtelijn y Francis Strauven, inciden en la misma idea. Después de construir en Amsterdam la Hubertus House y en reacción a desarrollos conservadores de la arquitectura holandesa, definió su concepto de lugar y profundizó en el fenómeno de la transparencia. Asumiendo que lo abierto es una condición preliminar de lo cercano, Van Eyck se opuso a la interpretación de lugar como una forma de cercanía que excluye la apertura, reconociendo de forma

\footnotetext{
96 «Varying spatial depth and perceptible distance through transparency. Beyond a space limit close by one or several further away.

On this side of a space limit which is further away one or several closer by.

Modulation of spatial depth and distance as seen from place to place as well as from one place, i.e. both consecutive and simultaneous.

Pieter de Hoogh shows us beautiful what enclosure through openness and transparency can bring about, when he paints an open door or window, passage or alley on a single line of view, thus allowing one to see right through several interior and exterior spaces - sometimes even as far as the houses across the street or canal- and always there are a few people articulating the entire depth once more. De Hoogh shows that the kind of openness that brings about a sense of enclosure, does not depend on dematerialization and a lot of glass.

Similar to the Sonsbeek sculpture pavilion, where a few openings in the walls were enough to enclosure considerable lateral openness modulating perceptible distance, those in the loadbearing walls running parallel from to back in the two converted Hubertus houses also provides cross views». (Ligtelijn y Strauven 2008, 494) Traduccion de Ana Rodríguez
} 
extraordinaria un antecedente de este punto de vista sobre lo abierto como una condición de cercanía en el trabajo de pintor del siglo diecisiete Pieter de Hoogh. (LIgtelijn y Strauven 2008, 466)

Pieter de Hoogh -apellido que también puede verse escrito como Hooch y Hooghe- fue un pintor holandés de la Edad de Oro en los Países Bajos. Su obra se caracteriza por la representación de escenas domesticas en el interior de las viviendas, con personajes femeninos y reflejando detalles de la vida cotidiana, idealizando las virtudes de la vida holandesa como la buena educación de los niños y un hogar bien administrado. Son interiores tranquilos y apacibles simbolizando la nueva situación del país ${ }^{97}$. Su pintura tiene un sofisticado tratamiento de la luz y de la perspectiva, potenciada por la precisión del dibujo de las baldosas del pavimento. Consigue una gran profundidad espacial mediante la gradación de distintos planos en la representación de dos o más salas contiguas, profundidad que se refuerza con una vista exterior representada con gran detalle, a veces incluso mayor que el de la escena principal. Coetáneo de Vermeer, se diferencia de este, precisamente en la visión del exterior, que en Vermeer se limita a la entrada de luz.

No es de extrañar el interés de Van Eyck por la pintura de Pieter de Hoogh como un buen ejemplo de la relatividad de los conceptos de espacio interior y exterior. Sus interiores adquieren una sensación de recogimiento y serenidad en gran medida debido a la relación con el espacio exterior que aparece a través de huecos y ventanas. En sus cuadros los huecos aparecen, diferentes entre sí, en distintos planos y alturas, consiguiendo un refinado tratamiento de la luz con varias temperaturas de color, que diferencian exterior del interior. A su vez, la profundidad espacial que obtiene mediante la gradación de espacios in-between, se potencia también con la generación de largas visuales ${ }^{98}$ normalmente no frontales.

Exactamente como en la Casa Visser.

Si bien estos temas están presentes en otros proyectos a lo largo de obra de Van Eyck, en la ampliación de la vivienda de Rietveld, son determinantes.

La decisión de situar la sala circular cerrando el espacio panorámico de la casa inicial, que en cierta forma, convierte en urbana, la sensación de vivienda aislada.

Se basa en estos criterios.

Busca profundidad espacial mediante la gradación de espacios.

Potencia visuales diagonales a partir de las ya planteadas por Rietveld.

Hace desaparecer el deslumbramiento de la radiación directa que previamente existía en la fachada sur porticada, obteniendo una luz característica de la orientación norte ${ }^{99}$. La luz del interior de la ampliación de la Casa Visser es suave, con predominio de un tono gris azulado, más bien frio, que contrasta con cualquier objeto o luz focal más cálida, como muestran las fotografías en color de Jan Versnel en los años setenta, y las actuales de la autora. Su comparación con los interiores de Pieter de Hoogh, denotan atmosferas similares.

Llegados a este punto se puede afirmar que la Casa Visser es deudora de lo vernáculo en doble sentido. Además de sus relaciones con la cultura de los Pueblo y los Dogon, es heredera del espacio domestico holandés, representado magistralmente por la pintura de Pieter de Hoogh.

\footnotetext{
${ }^{97}$ Las representaciones de interiores pacíficos eran populares en ese momento, después de terminar la Guerra de los Ochenta Años o Guerra de Flandes (1568-1648), en la que obtuvieron la independencia de España las provinicas holandesas septentrionales.Su precisión en reflejar el contexto cultural y social de la época, convierten su trabajo en un testimonio de gran valor sobre la sociedad holandesa del siglo XVII.

${ }^{98}$ Un holandés, necesita la visisón del horizonte.

${ }^{99}$ Hay frecuentes alusiones por parte de Van Eyck al exceso de grandes superficies vidriadas y apertura sin limitaciones, algunas de las cuales reseñadas en estas paginas.
} 

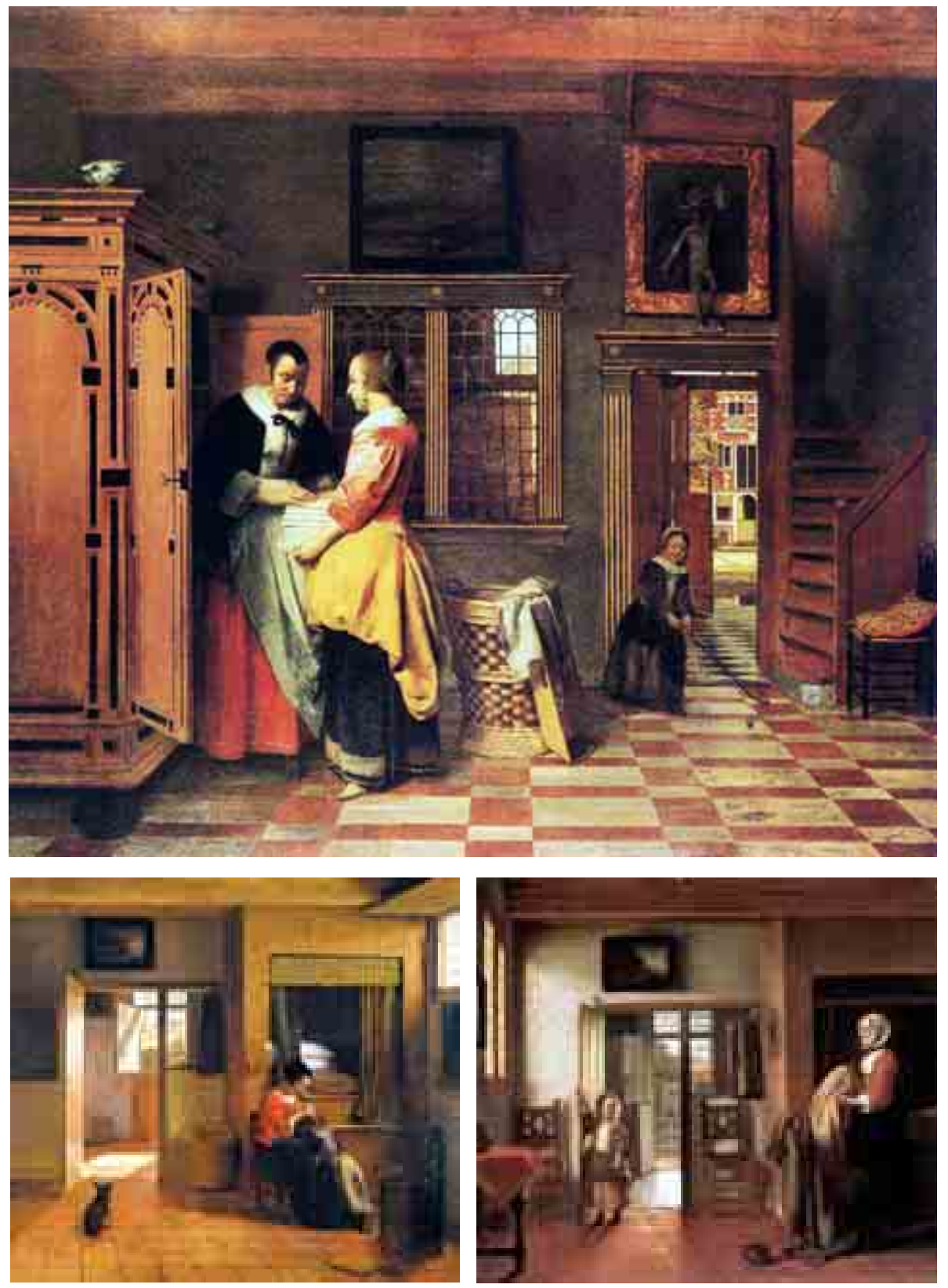

Figura 3.72

Pieter de Hoogh (1629-1683?), coetaneo de Vermeer, es considerado uno de los maestros de la Edad de Oro Holandesa.

* Superior: Mujeres junto al armario de la ropa blanca (1663)

* Inferior izquierda: Madre despiojando el pelo de su niño, también conocido como El deber de un Madre (1658-1660)

* Inferior derecha: El dormitorio (1658-1660) 

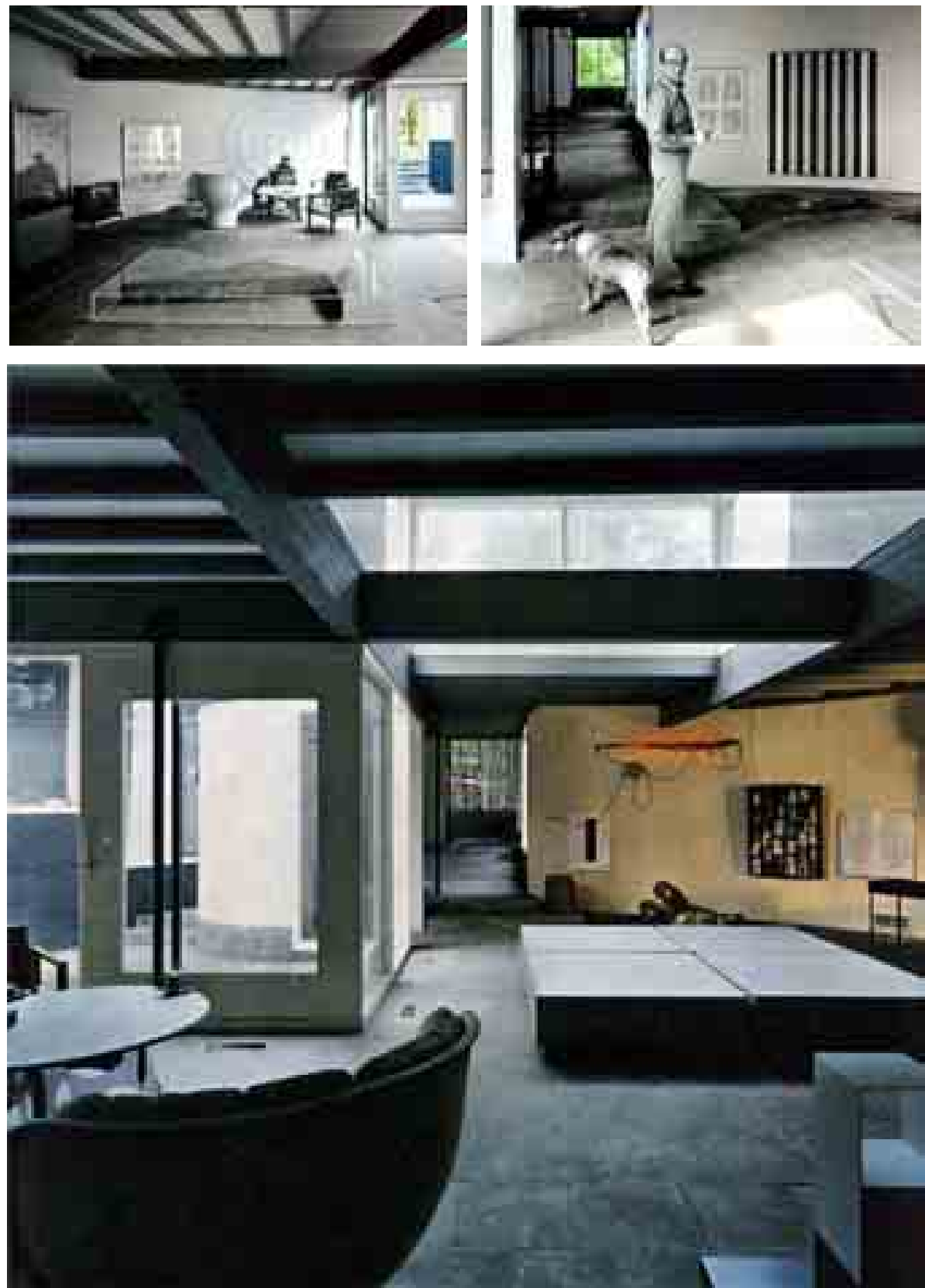

Figura 3.73

Transparencia en la Ampliación de la Casa Visser por Aldo van Eyck. Comparación con los interiores de Pieter de Hoogh -página anterior-. En dicha comparación pueden apreciarse similitudes en el intencionado establecimiento de largas visuales que se proyectan desde el interior del espacio doméstico hacia el exterior de la casa. Espacio interior y exterior se entrelazan al igual que los conceptos de transparencia e in-between.

* Superior izquierda y derecha

Fotografías facilitadas por Joke Visser, actual propietaria de la casa. Imágenes coloreadas por Ana Rodríguez para su mejor comprensión en el anaisis comparativo con las pinturas de Pieter de Hoogh.

* Inferior

Fotografía de Jan Versnel (Restany 1970,20) desde el espacio de planta circular hacia la ventana de la casa de Rietveld, generadora del eje de la ampliación de Van Eyck Las magníficas fotografías publicadas en Domus, son posiblemente las únicas en color del momento, posteriormente reproducidas en diversas publicaciones en blanco y negro. 


\title{
3.5. Ladrillo, madera y vidrio.
}

\author{
[Materialidad]
}

\section{Continuidad en la forma de construir, a partir de la casa de Rietveld}

La Ampliación de la Casa Visser, busca su diferenciación con la casa inicial de Rietveld, a través de la altura y relaciones volumétricas, más que en la condición material.

La obra de Van Eyck, como el mismo explica, se realiza en la misma forma que su predecesor. La sala circular de la primera ampliación se construye en ladrillo visto al exterior, de forma aislada y sin contacto con la preexistente. La conexión únicamente es posible a través del in-between que es mayoritariamente exterior, excepto un paso fundamentalmente transparente.

En las intervenciones menores realizadas en el año 1971 con Theo Bosch, consistente en la ampliación del dormitorio principal con un cuarto de baño, y una ligera extensión del garaje -que había quedado muy reducido después de la transformación hecha en la cocina en la primera ampliación-, la continuidad con la fábrica de ladrillo es literal.

En el garaje, una leve junta de trabajo marca la fabrica nueva, también pintada en negro, respecto a la preexistente.

Sin embargo en la ampliación del cuerpo de dormitorios, la continuidad es completa. El nuevo muro, con una suave curvatura de radio similar al de la sala circular, actúa de vestíbulo previo a la misma.

La diferenciación viene dada por un cambio de altura, de forma que la nueva extensión es más baja que lo construido por Rietveld.

Esta condición se explicita de dos maneras intencionadamente diferentes en cada lado. Mientras que en el cerramiento curvo y en continuidad apenas sin huecos de la fábrica de ladrillo, la diferencia de altura se concreta en un escalonamiento de dicho paramento, en el lado contrario con un gran ventanal de carpintería de madera pintada en blanco como la casa inicial, al acometer en un plano distinto, lo hace por debajo de la cornisa de la casa de Rietveld, al igual que en otros puntos de la casa.

\section{Las vigas de madera de una kiva.}

La estructura vertical es perimetral de muro de ladrillo de dos hojas, en la mejor tradición constructiva holandesa, excepto en el interior de la sala de planta circular, en la que para salvar la luz de once metros de diámetro, la planta circular se divide en sectores, con tres vigas de madera laminada: dos paralelas, sensiblemente en continuidad con el paso de conexión, y una tercera perpendicular en la que se fija en centro geométrico de la circunferencia de la sala. Las zonas en que se subdivide la cubierta se cubren con vigueta de madera de menor sección. El patrón geométrico de la planta del forjado, es decir el techo de la sala, evoca claramente el utilizado en la decoración del cuenco de cerámica precolombina de los Indios Pueblo, ya visto en epígrafes anteriores.

Este grupo de tres vigas apoyan en el muro circular y en tres apoyos formados por pares de soportes tubulares metálicos, que permiten el paso de la viga entre ambos. La unión se realiza por apoyo, mediante una pieza metálica que abraza la viga evocando los troncos y ramas naturales de madera de los soportes en las kivas de los Indizo Pueblos.

De esta forma, el sistema estructural, diferenciado y a la vista, del espacio circular de la primera ampliación, reinterpreta interrelacionadamente patrones geométricos de la cerámica de los Pueblo, la estructura de las kivas -también realizadas con madera vista- y los apoyos en horquilla de los troncos de madera natural utilizados como apoyo en sus construcciones. 

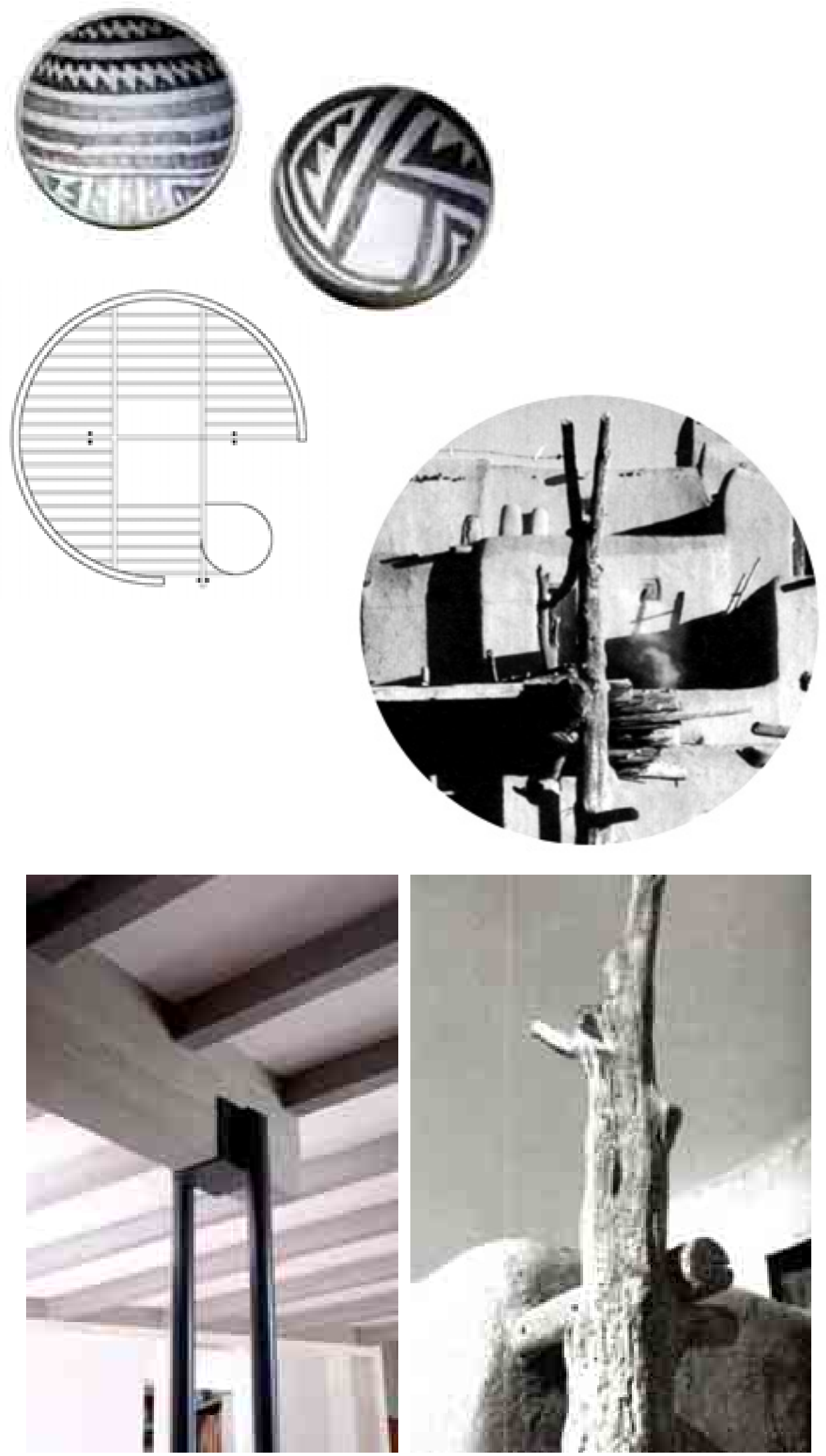

Figura 3.74

Ampliacion de la Casa Viisser

* Superior izquierda

Patron geométrico de la planta del forjado de madera del espacio de planta circular y cuencos de cerámica precolombina de los Indios Pueblo. Dibujo de Ana Rodríguez.

* Centro e inferiores

Union soporte de pares tubulares de acero / viga de madera laminada y detalles de apoyo en Taos Pueblo, Nuevo Mejico. 


\section{La transparencia del in-between}

Si el in-between es el ámbito donde se encuentran dualidades contrapuestas, este espacio de relación debe poder brindar significados que pertenezcan a ambos polos. Su traducción física en el espacio construido, necesariamente implica una materialidad que no ofrezca obstáculos y que pemita a cada uno de los opuestos, apropiarse de él. Por ello, la mayor parte del espacio intermedio entre la ampliación de Van Eyck y la casa anterior de Rietveld, es un exterior, al igual que el espacio de relación de la casa Banani o como el umbral de la casa Dogon, y se definen mediante el tratamiento del terreno, con escalonamientos en el primer caso y con la formación de un pequeño limite en el segundo.

De esta forma se potencian los accesos desde la parte privada de la parcela, a través de ese lugar intermedio, que se puede recorrer en sentido longitunal, atravesando la conexión entre lo nuevo y lo preexistente, construida enteramente con carpintería de madera pintada de blanco y vidrios de suelo a techo,

Dos huecos practicables permiten el paso transversal. Aunque el recorrido continuo es posible, el hueco practicable de menor tamaño con movimiento batiente, actúa como límite de dos sub-espacios in-between diferenciados: el relacionado con el estarcomedor de la casa de Rietveld, más abierto y luminoso, con una gran corredera que además de permitir el paso- conecta el porche con el in-between cerrado, y el posterior, a cota ligeramente inferior, mas umbrío, que relaciona el espacio circular con el exterior.

En la Casa Visser, la conexión física entre lo antiguo y lo nuevo, únicamente es posible a través del in-between que es mayoritariamente exterior, excepto un paso esencialmente transparente. Transparencia que se potencia por su relación geométrica con el lucernario cenital de la sala circular, verdadera prolongación vertical del mismo, y el ventanal de ancho dos metros en la fachada norte, autentico articulador de la casa construida por Rietveld

Se puede concluir que el espacio in-between se desarrolla esencialmente en el plano horizontal y se define arquitectónicamente en planta. Es un espacio mayoritariamente exterior, que se cualifica con el tratamiento de la pavimentación, mediante escalonamientos, límites, o cambios de textura, y cuando las necesidades funcionales requieren un lugar interior, la cualidad consustancial de su materialización en el plano vertical es la transparencia del vidrio.

Figura 3.75

* Izquierda, muchaco Dogon leyendo el Coran en el umbral de la entrada a su casa. Concepto de Doorstep. (Strauven 1998, 359)

* Derecha, niña en el umbral de una de las ventanas del Orfanato de Amsterdam. Concepto de Doorstep (Van Eyck 1983 a, 80
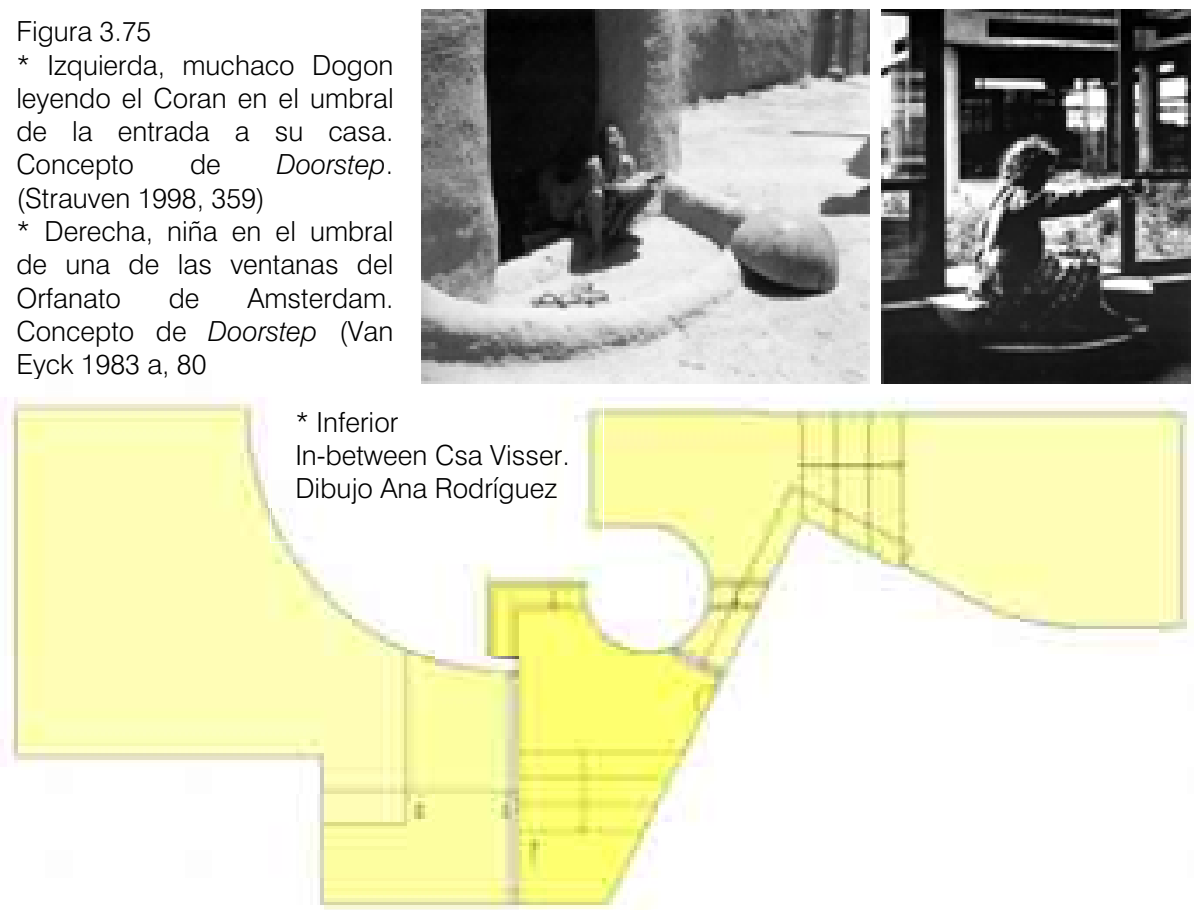

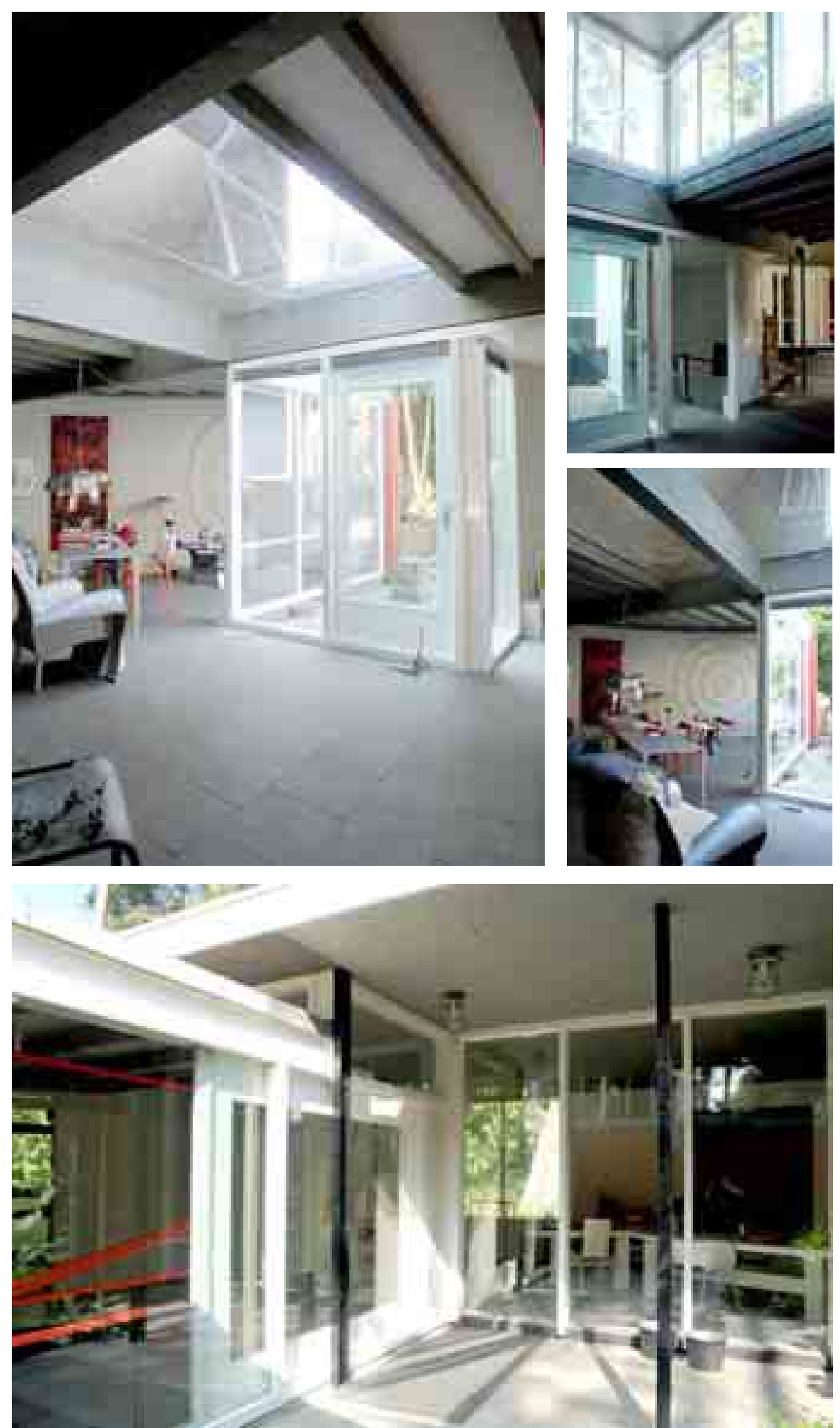

Figura 3.76

Ampliacion de la Casa Viisser. La transparencia del in-between.

La Casa Visser en septiembre de 2013. Fotografias de Ana Rodríguez. 


\section{El color diferenciador.}

La relación vital de Aldo van Eyck con la casa Visser, se prolonga incluso hasta después de su muerte ${ }^{100}$.

Además de la ampliación no construida de un segundo círculo, van Eyck estaba pensando en diferenciar, aún más si cabe, la construcción del cilindro de la preexistencia de la casa de Rietveld, ambas construidas en ladrillo visto. Para esa distinción, estaba pensando la conveniencia de pintar la superficie circular del nuevo espacio construido en el año sesenta y nueve, algo que debió dejar caer en alguna conversación informal con el señor Visser, que no mostro mucho entusiasmo con la idea por considerarla innecesaria.

Sin embargo, después de la muerte de Van Eyck en 1999, Martin Visser tras un tiempo meditándolo, decidió abordar este trabajo como homenaje póstumo a quien, de una u otra forma, había estado trabajando en la casa casi cincuenta años.

Cuando habló sobre ello con Hannie, esta se lo corroboró y le mostró los estudios de color $^{101}$ en los que había estado trabajando Aldo, por lo que finalmente y bajo su supervisión, en el año 2000 se pintó el cilindro en el color que muestran las fotografías $^{102}$ realizadas en septiembre de 2013.
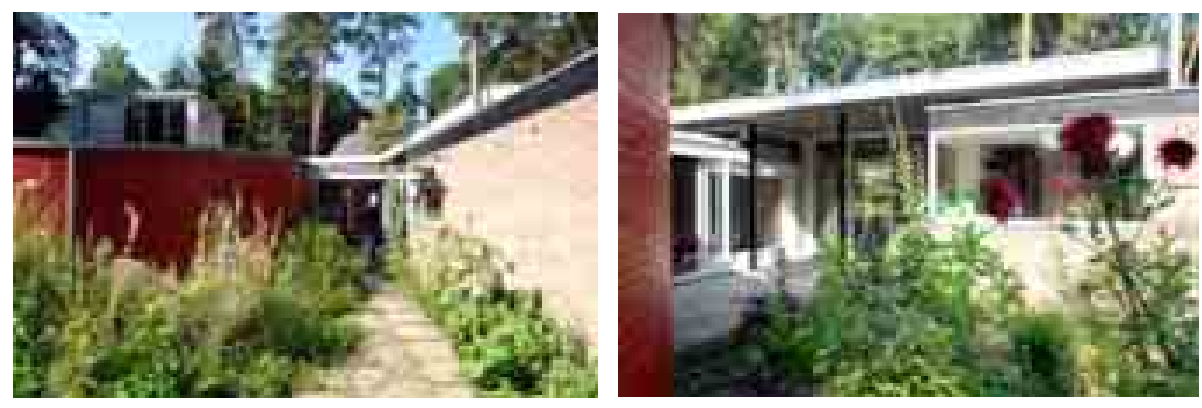

Figura 3.77

Ampliacion de la Casa Viisser. El color diferenciador

El volumen cilíndrico en primer término, pintado.en el año 2000, como homenaje póstumo de Martin Visser a Aldo van Eyck.

La Casa Visser en septiembre de 2013. Fotografias de Ana Rodríguez.

\footnotetext{
100 La información sobre esta historia fue dada por Joke Visser, segunda esposa de Martin Visser y actual propietaria, en la entrevista realizada en septiembre de 2013 en la misma casa.

${ }^{101}$ No existe certeza si Aldo van Eyck tenía hecha una elección definitiva sobre el color a utilizar.

102 Existen muy pocas fotografías en color del edificio tras las intervenciones de Ado van Eyck, pero una mirada atenta permite apreciar el ladrillo visto sin pintar del estado inicial del volumen cilíndrico.
} 


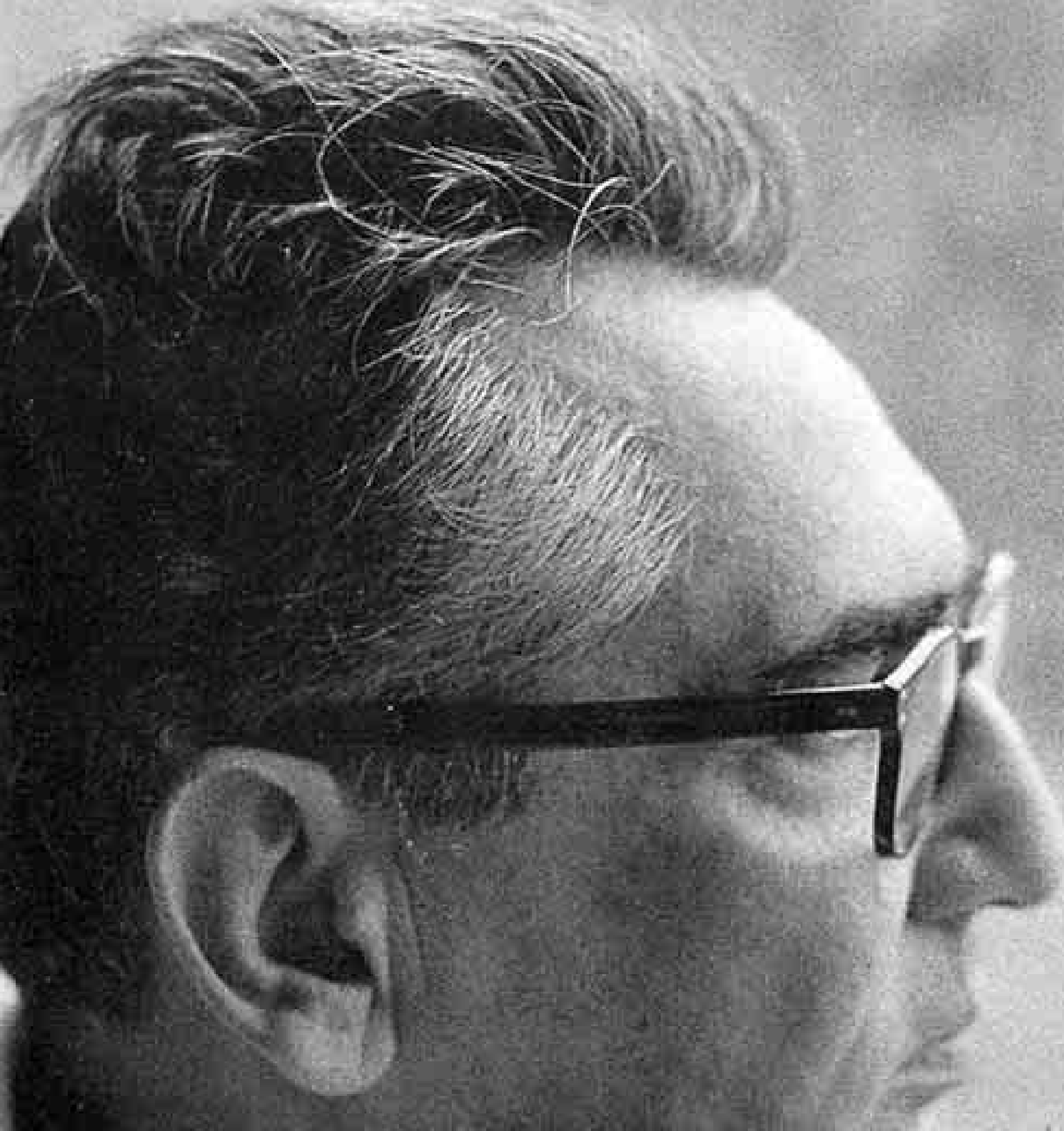




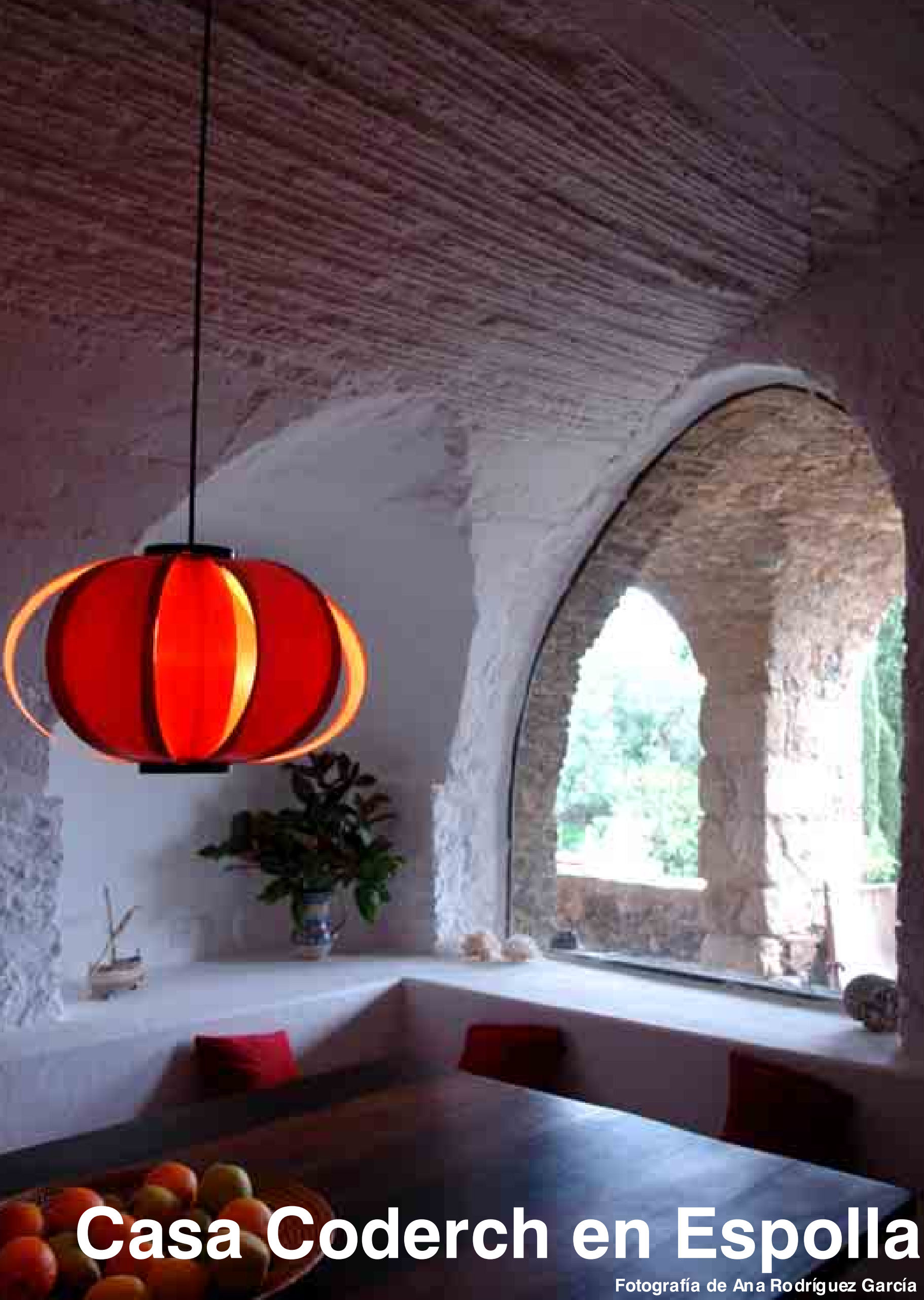

Fotografía de Ana Rodríguez García 
Capítulo 4

El hogar de Coderch: la Casa en Espolla 
Capitulo 4. El hogar de Coderch: la Casa en Espolla 


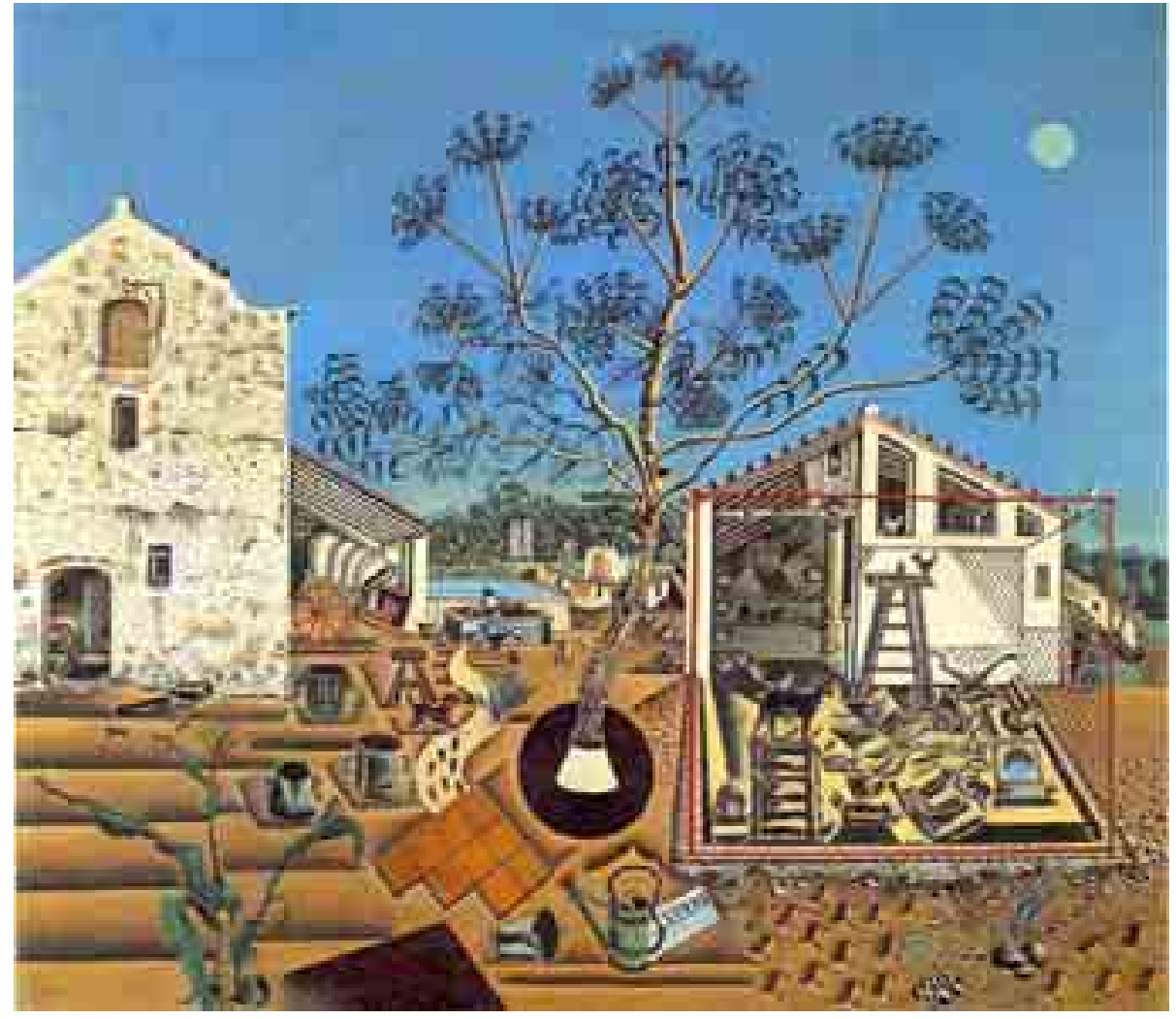

Figura 4.01

La masía (1921-1922), Joan Miró

$147 \times 132 \mathrm{~cm}$

National Gallery Washington DC 
Capitulo 4. El hogar de Coderch: la Casa en Espolla 


\section{Capítulo 4 \\ El hogar de Coderch: la casa en Espolla.}

José Antonio Coderch de Sentmenat, (1913-1984), miembro de Team 10 desde su congreso fundacional en Otterlo en 1959, desarrolla la primera mitad de su vida profesional en un contexto internacional de revisión crítica del Movimiento Moderno con una nueva actitud hacia la tradición.

Desde 1940, año en el que obtiene el titulo de arquitecto hasta principios de los sesenta, punto de inflexión en su vida, desarrolla su trabajo buscando aunar simultáneamente los mejores valores del movimiento moderno y la coherencia constructiva de la arquitectura popular.

Se profundiza en la interpretación moderna que hace Coderch de la tradición vernácula, por el valor individual de las propuestas constructivas en proyectos y obras de este periodo, y en su conjunto como parte de una corriente de pensamiento que reconoce la sabiduría de lo popular, el clima y la idoneidad de los materiales locales en el camino a seguir por la arquitectura contemporánea, en un momento y contexto muy determinado como el español.

«En Coderch admirábamos (yo pertenecía a su capillita) el carácter intransigente e individualista, su aparente independencia respecto a las escuelas internacionales, su aversión a integrarse en grupos de opinión, su aire de artista aislado -como el protagonista de El Manatial-, reforzado por una apariencia física adecuada al papel: un tipo elegante, enjuto, hispano, velazqueño, con unos ojos de mirada penetrante e inquisidora que te dejaba inmovilizado» (Tusquets 1998)

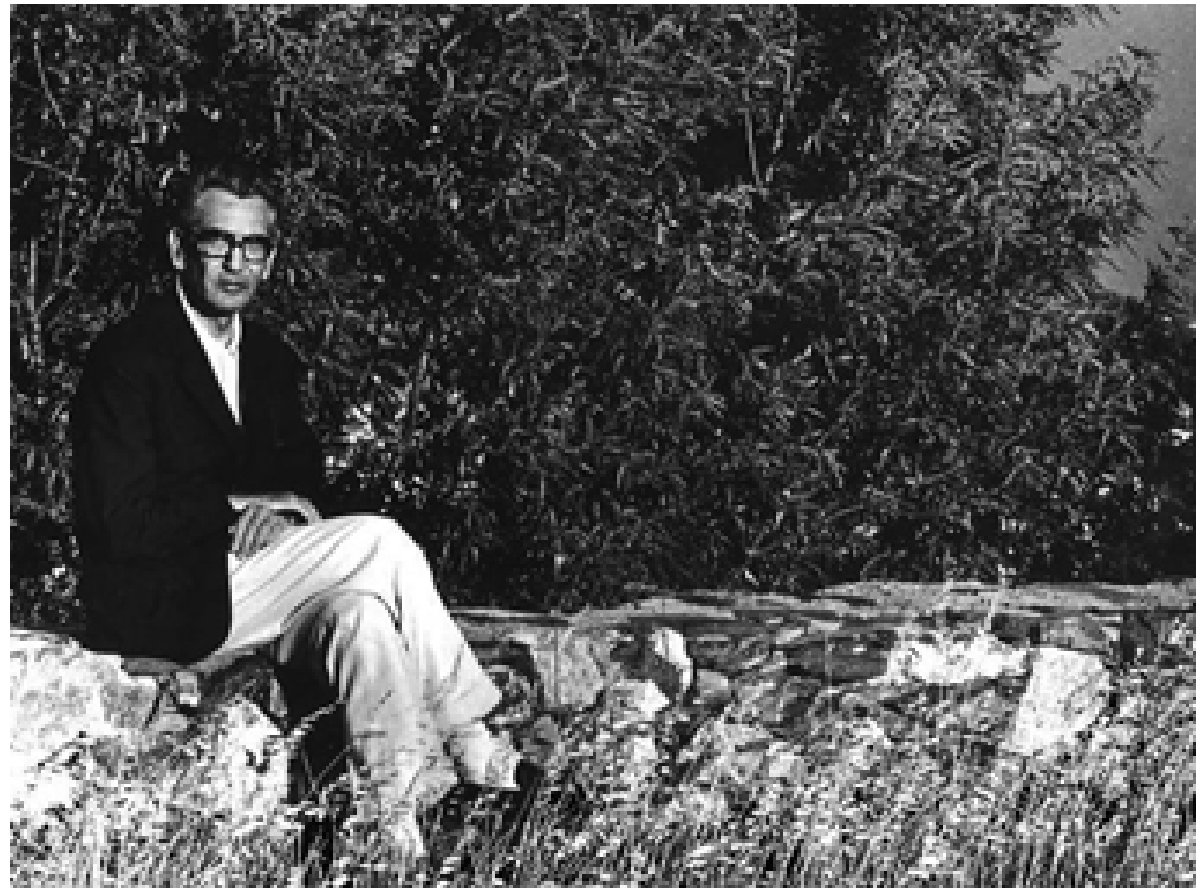

Figura 4.02

Coderch en Espolla.

Fotografía de Elvira Coderch. Archivo Coderch 
Entre 1941 recién terminada la carrera y 1960, José Antonio Coderch y Manuel Valls Vergés, también arquitecto barcelonés, mantuvieron una fructífera colaboración, que dio lugar a algunas de las aportaciones más valiosas de su generación en España.

Colaboración, compartiendo el mismo estudio, primero en la Plaza de Urquinaona y posteriormente, a partir de 1946, en la Plaza Calvó, en la parte baja -literalmente en el zócalo- de la casa construida por el propio Coderch para sí mismo, y en la que ya se aprecia con claridad el camino que desarrollarían en los años posteriores. Una de las peculiaridades de su asociación, es que cada uno de ellos fuera responsable único de su obra, aunque hubiera surgido de la maduración entre ambos. Gracias al compromiso y fortaleza de su relación, en las publicaciones se muestran como de ambos, en lo que Carlos Flores ${ }^{1}$ define como «una autoría coral o a dos voces -nunca a dos manos como los propios arquitectos se han esforzado siempre en declarar-»

Es la fase más intensa de su trabajo en equipo, aunque de una forma u otra siguieron colaborando hasta 1972, fecha en que Valls deja el estudio de la Plaza Calvó para iniciar un nuevo periodo con su hijo también arquitecto, Manuel Valls i Ferrer, manteniendo la amistad. Los últimos trabajos importantes de esta colaboración son el edificio de viviendas en la calle Compositor Bach de 1958 y el proyecto de la urbanización Torre Valentina en 1959, que Coderch presentará con gran éxito en el Congreso de Otterlo. De forma que el final de esta etapa coincide aproximadamente con su crisis personal y profesional, tras el desengaño de Torre Valentina finalmente no construida. De la profesional saldrá gracias a la Casa Tapies y uniéndose al Team 10. De la personal, se recuperará en gran medida gracias a la Casa en Espolla.

El estudio de Coderch fue siempre intencionadamente artesanal.

Una buena descripción del ambiente y carácter del estudio, lo da Juan Daniel Fullaondo en Nueva Forma, cuando con motivo del monográfico dedicado a Coderch, dice en notas de sociedad:

«Actuamos con voluntario desorden. Primera referencia, el propio estudio del arquitecto. Es curiosa la forma en que los personajes se retratan, de alguna manera, al configurar su propio ámbito de trabajo. Pienso en la blanca frialdad silenciosa, del de Fernández Alba, no se oye un ruido nunca, la espectacularidad de los numerosos de Fernando Higueras, sus guitarras, amplificadores y circuitos cerrados de televisión, el hábil, escenográfico desorden del de Oiza, la organización implacable, empresarial de Martorell, Bohigas y Mackay, (parecen las oficinas de la Krupp aquello)... El de Coderch es en este sentido, la anti-Krupp, pequeño, restringido, artesanal, con una puerta diminuta dando también a una pequeña, silenciosa plaza... llegamos a un escueto despacho lleno de fotografías por las paredes, heterogéneas, recortes, carteles... En clave catalana, recordaba la salita de estar de la casa de Oteiza. Por cierto, en el centro de una de las paredes, el catálogo del escultor para la Bienal de Sao Paulo, homenaje lejano a su colaboración en Milán. Un poco más allá una fotografía fantástica de Chillida, obra del mismo Coderch... También en lugar privilegiado, Frank Lloyd Wright... Le Corbusier no estaba, mejor dicho, estaba fuera, con una revista sobre Villa Saboya sobre la que se disparó Coderch, realmente fuera de sí... Hablamos un poco de todas ellas. Surgía el recuerdo de Wright, bien distinto del de Le Corbusier. Al parecer, un colaborador o amigo, no recuerdo bien, del gran maestro americano, pensaba hacerse una vivienda en España... ¿Qué arquitecto? Wright -es curioso lo informados que están todos estos hombres- le escribió una carta sugiriéndole el nombre de Jose Antonio Coderch» (Fullaondo 1974

1 Para una profundización en la colaboración de Jose Antonio Coderch y Manuel Valls, ver: FLORES, Carlos. 1998. «La arquitectura de José Antonio Coderch y Manuel Valls» En: Actas del Congreso Internacional De Roma a Nueva York: Itinerarios de la nueva arquitectura española 1950 / 1965, Pamplona el 29 y 30 de octubre de 1998 (Flores 1998) 

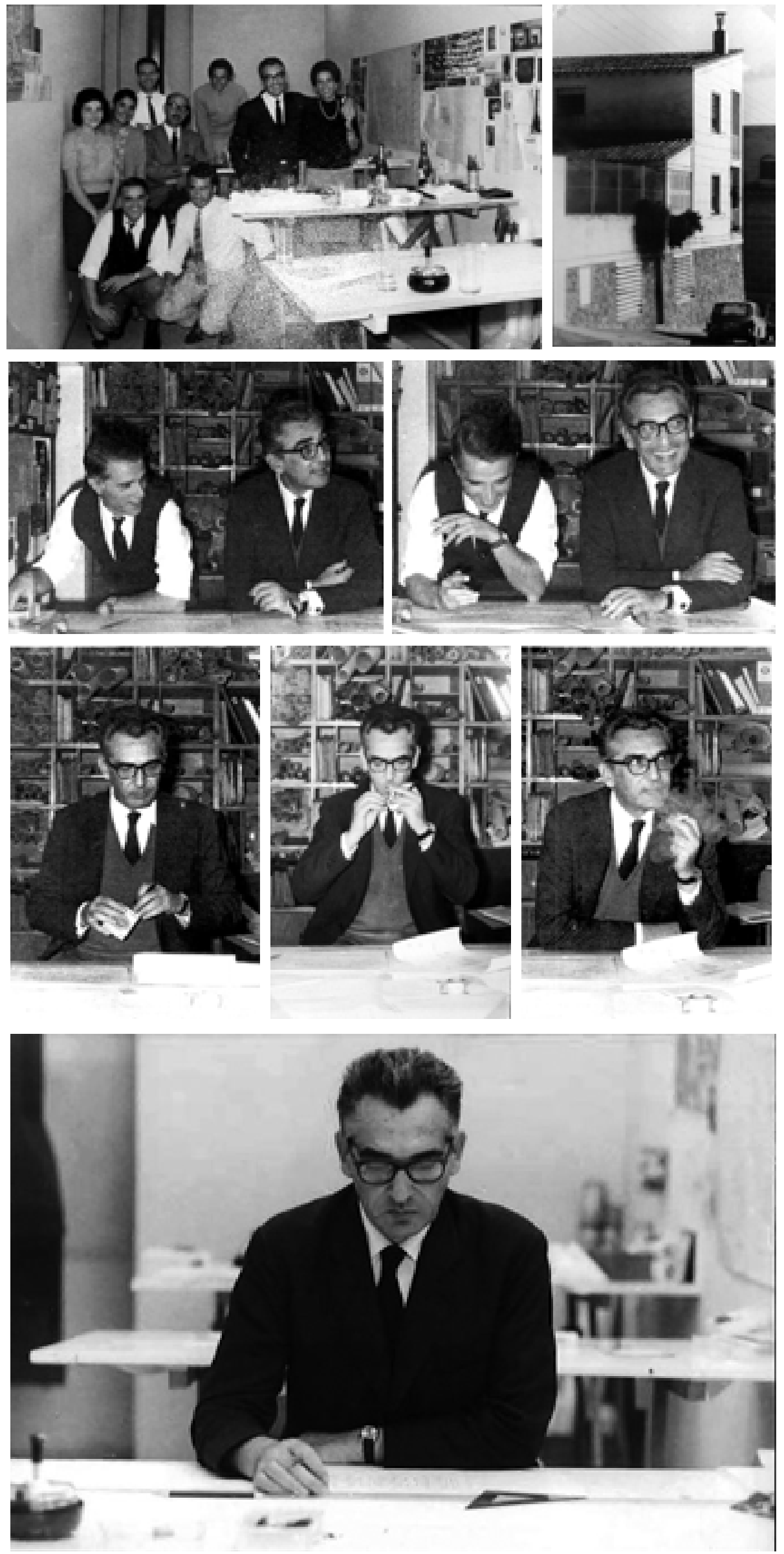

Figura 4.03

Estudio de Jose Antonio Coderch en el número 4 de la Plaza Calvó en Barcelona.

Archivo Coderch 


\subsection{José Antonio Coderch y lo popular. Tradición viva y "No son genios los que necesitamos ahora"}

\subsubsection{Coderch y la herencia de la arquitectura popular en España}

«La buena arquitectura no se ha hecho nunca por fórmula ni siguiendo al pie de la letra una doctrina: sería demasiado sencillo...

...Podemos, para obtener esto, aprovechar todos los medios que tenemos a mano, desde los más tradicionales a los más modernos; desde la piedra al ladrillo y hormigón armado, el acero y el cristal, siempre que estén controlados por un espíritu de orden, claridad y respeto a las construcciones milenarias, osatura espiritual de todas las grandes creaciones arquitectónicas» (Sert 1934)

"La influencia de los factores nacionales y regionales en la creación y el desarrollo de la arquitectura moderna me parecen decisivos, por los menos han sido decisivos para mí, ya que en una época en la que España estaba prácticamente aislada de toda influencia exterior fue la arquitectura regional la que me orientó en mi trabajo y me permitió realizar obras que luego fueron consideradas modernas»

(Coderch 1967) Historia de unas castañuelas

Las particulares circunstancias de la arquitectura española en la posguerra, por la situación política del país, merecen un comentario específico.

El aislamiento político después del año 1939 y la dificultad que supone para los arquitectos contactar con los movimientos culturales europeos, junto con la situación de carestía económica y la postura oficial del nuevo régimen político que prefirió ensalzar otra visión de la arquitectura frente a la desconfianza que le producía la arquitectura moderna, representada ideológicamente con claridad durante la Segunda República a través del GATEPAC y la Generación del 25, y sobre la que hace caer un manto de silencio, determinan poderosamente el marco de actuación de los arquitectos en la década de los cuarenta y primeros cincuenta. Se produce una arquitectura de tintes nacionalistas, formalmente ecléctica, y el ya conocido resurgimiento de algunas técnicas de construcción tradicionales, en especial la bóveda tabicada, ante la carestía de acero y cemento de calidad.

Sin embargo, el respeto y admiración por la arquitectura popular en España, viene de antes, siendo una de las características de nuestro Movimiento Moderno, con Fernando García Mercadal (1896-1985) y Josep Lluís Sert (1902-1983) al frente, necesaria de reivindicar: en los años 30 las páginas de la revista $A C$, instrumento de difusión del GATEPAC, ya muestran el universo que Coderch creará en el Pabellón de España de la Trienal de Milán de 1951.

El papel desempeñado Mercadal y Sert en relación con lo popular y su influencia en la arquitectura moderna en España es fundamental. En el movimiento moderno español convivirán de forma natural lo mejor de la tradición popular con la búsqueda de un nuevo lenguaje. Algo que ocurrirá no solo a nivel meramente formal, sino también material y constructivo, destacando singularmente el empleo de uno de los sistemas constructivos tradicionales mediterráneos por excelencia, que la vanguardia arquitectónica del momento asumirá como propio: la bóveda tabicada.

La relevancia de la cuestión requiere algo de extensión y explicación pormenorizada, especialmente en lo relacionado a esta última, ya que si bien la influencia de las artes populares en las vanguardias está reconocida, es necesario que en el ámbito de la arquitectura española se desmonte de forma definitiva, la equivocada y muy extendida creencia de que la construcción tabicada es recuperada en la posguerra. Si bien es cierto que su utilización se intensificó durante unos años por las circunstancias del país, en realidad es que nunca desapareció. Una mirada atenta a los edificios de vivienda colectiva anteriores a 1936, a las páginas de AC y a la revista Arquitectura entre otros, así lo demuestran. 
La insistencia sobre la importancia de este punto, viene ocasionada porque la huella de lo popular en la obra de Coderch se afianza y reinterpreta como el mismo reconoce, más que en el regionalismo de posguerra, a través de la vanguardia artística y arquitectónica de los años treinta. En el ámbito catalán, el binomio Sert-Miró, ambos relacionados con Coderch, supondrá un referente indiscutible en la interpretación de lo popular, pero también de Antoni Gaudí. Sert en su escrito "Homenaje a Joan Prats", publicado por Patricia Juncosa en Josep Lluís Sert. Conversaciones y escritos. Lugares de encuentro con las artes, explica los primeros años de su relación con Joan Miró ${ }^{2}$, y su influencia sobre él:

«Alrededor del año 1930, mi amigo Joan Prats hizo que conociera a Joan Miró y su obra"

«Con Joan Miró fuimos a Andalucía, a Ibiza y a menudo a su masía de Motnroig, en la provincia de Tarragona. Sus comentarios y su visión del paisaje, de la arquitectura popular, de los trabajos artesanales y de los objetos que nos rodeaban influyeron en mi obra. También le debo a él, y a mi amigo Joan Prats, una nueva visión y apreciación de la obra de Antoni Gaudí. En mis investigaciones para encontrar una expresión arquitectónica contemporánea, en el uso de las bóvedas y las raíces catalanas de mi trabajo, hay también una influencia de su ejemplo, procurando que las corrientes internacionales no ahogaran nuestro sentido de la medida y el equilibrio, valores que pueden considerarse muy nuestros"

«De entre los grandes artistas modernos, la obra de Joan Miró ha sido la que más ha influenciado a las jóvenes generaciones. Esta influencia nos aporta a todos una sensación de rejuvenecimiento» (Juncosa 2011)

En la relación Miró-Sert-Coderch es clave la figura de Joan Prats i Vallès ${ }^{3}$ (1891-1970). Gracias a él, Sert conoció a Miró, y años después, también por su mediación, Sert se puso en contacto Coderch. En Conversaciones con J.A. Coderch de Sentmenat de Enric Sòria, Coderch explica como conoció a Sert. En los primeros viajes que hizo a Barcelona después de la guerra, le preguntó a Prats qué arquitectos creía él que podía tener interés conocer su obra, y este le contestó que Coderch, dándole su dirección, después de lo cual Sert fue a verle: «un día llamó a la puerta y entró», «y después siguió viniendo otras veces» (Sòria 1997, 46)

${ }^{2}$ Sert conoció a Joan Miró y su obra alrededor de 1930, a través de Joan Prats, fundador en 1932 de ADLAN Amics de I'Art Nou (Amigos del Arte Nuevo), cuya sede estaba en el local del GATCPAC del Paseo de Gracia n’99, e íntimamente relacionada con este. Entre las actividades de ADLAN, además de organizar una importante exposición sobre Picasso en Barcelona, exponían la obra de Miró antes de ser enviada a Paris y Nueva York: «La exposición de las últimas realizaciones mironianas en Barcelona, antes de ser enviadas al extranjero, se acabó convirtiendo en una costumbre que se repetía cada nueva temporada, demostrando tanto el apoyo del artista a ADLAN como la veneración del grupo hacia su obra. El 18 de noviembre de 1932, pocos días después del nacimiento oficial de la entidad, se inauguró una muestra privada de las últimas obras de Joan Miró en la Galería Syra de Barcelona, rodeada de un cierto aire de clandestinidad y ante un reducido numero de admiradores, todos ellos miembros de ADLAN y GATCPAC. Este tipo de exposiciones se sucedieron en 1933 en el estudio de Sert de la calle Montaner y en 1934 en la Galeria Syra y en las Galeries d'Art Catalonia. También por mediación de Miró se organizaron representaciones del circo de Alexander Calder promovidas por ADLAN en 1932 y 1933" (Juncosa 2011)

${ }^{3}$ Joan Prats fue una figura determinante en la vida artística de Barcelona a lo largo de más de cincuenta años. Además de fundador de ADLAN y pintor en sus inicios, destacó sobre todo por potenciar las vanguardias artísticas antes y después de la guerra. Su apoyo incondicional a Joan Miró, con el que tenía una gran amistad, fue fundamental hasta su consolidación internacional. Se convirtió en el coleccionista privado más importante sobre el pintor y editó arriesgadamente en 1944 su serie de litografías negras, la Serie Barcelona. Promovió al final de su vida la construcción de la Fundación Miró de Barcelona, financiando incluso parte del proyecto. Apoyó y propició la difusión internacional de las generaciones de posguerra, Tapies, Cuixart, Brossa, entre otros. También fue una autoridad como heredero de una famosa familia de sombrereros de cuarta generación en Barcelona. Un sombrero Prats era garantía de calidad. José Antonio Coderch era además de amigo, cliente de sus sombreros. 


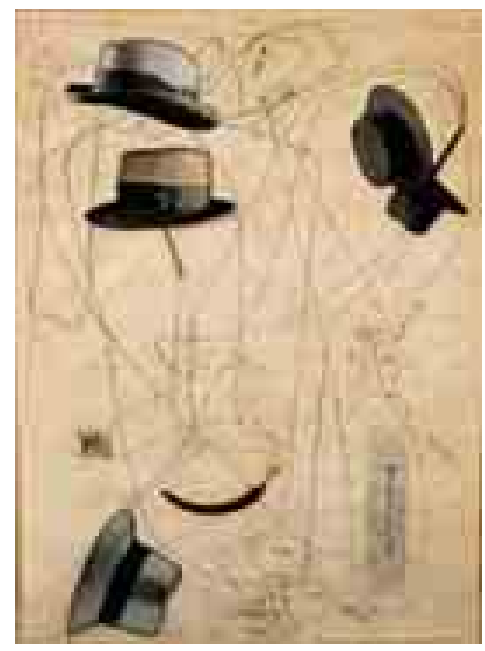

Figura 4.04

* Izquierda

Dibujo -collage de Joan Miró, realizado en 1933 con el título «Homenaje a Joan Prats».

En la tira gris vertical se lee: "Prats is quality" en referencia a la calidad de sus sombreros, que vestían Miró, Sert y Coderch entre otros.

\section{* Centro}

Anotación de Joan Miró sobre el Hotel del Mar, enviada a José Antonio Coderch, antes de conocerse personalmente, después de una estancia en el mismo Entre las notas del Archivo Coderch estas palabras del artista son muy apreciadas.

Información facilitada por Ana Coderch. Archivo Coderch.

* Inferior: Joan Miró y Josep Lluis Sert, fotografiados por José Antonio Coderch
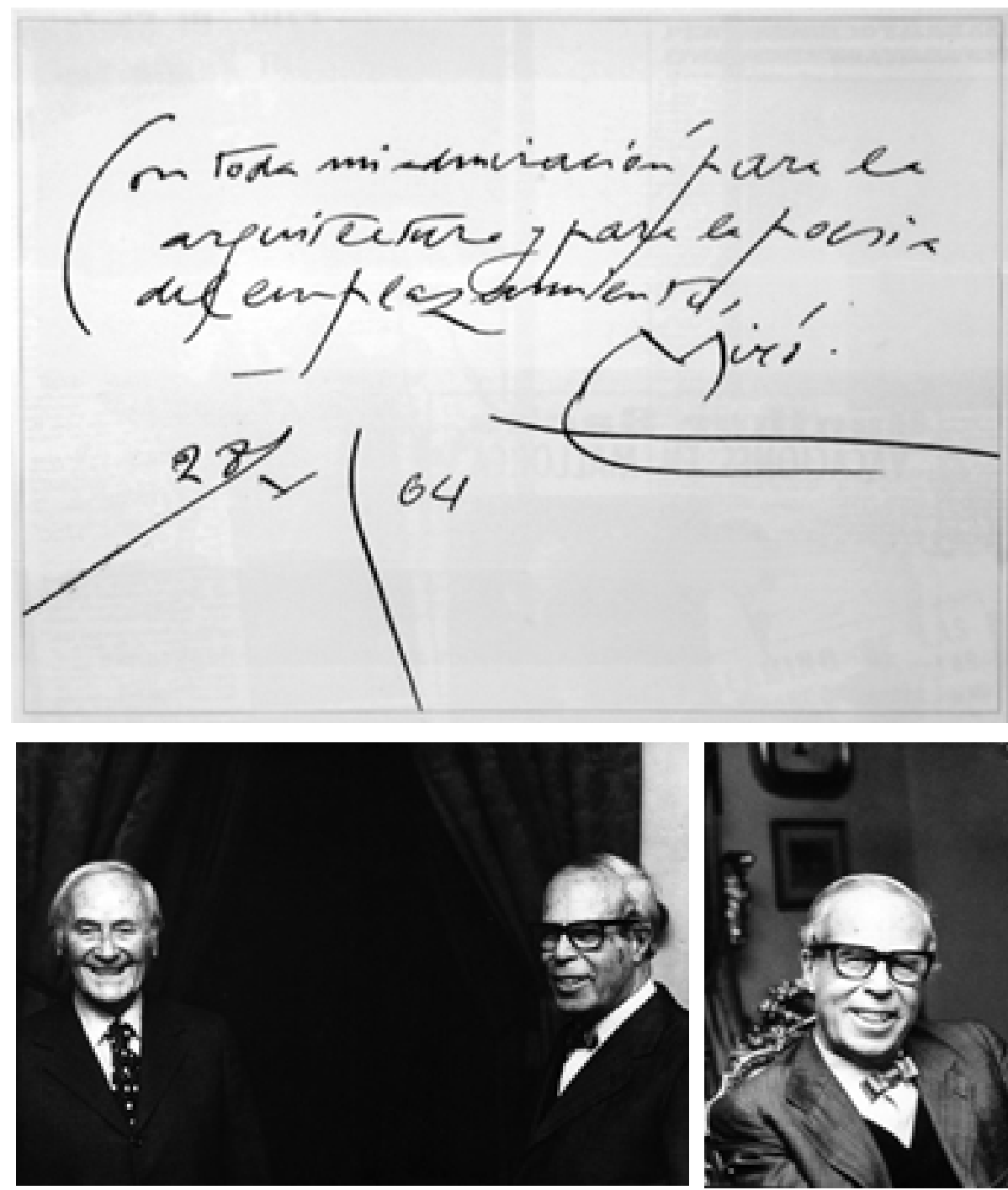
4.1.1.1. Lo popular, las vanguardias y el Movimiento Moderno español en los años 30

«nos impresionó mucho la primera vez que fuimos a lbiza el año treinta y dos. Fue un descubrimiento en el sentido de que vimos que muchas de estas cosas que se hacían en el centro y el norte de Europa, ya las teníamos aquí, no las teníamos que ir a buscar. Por ejemplo, los tejados planos y los volúmenes bastante primarios y sin decoración ya existían. Eran privilegios de la pobreza. Puig i Cadafalch tenía que irse a buscar en Nuremberg: la inspiración de la casa Almendro del gótico alemán. Nosotros defendíamos el gótico catalán, Santa María del Mar y Pedralbes, y teníamos discusiones con los profesores, que pretendían que las iglesias y los monumentos catalanes no terminaban en tejado como los del norte porque se les acababa el dinero, y no. Santa María es perfecta, aquellos desagües y aquel azotea...!»"

(L 'Avantguarda lúcida. Una conversa amb Josep-Lluís Sert, 1982)

EI GATEPAC, la revista AC y lo popular.

La revista $A C$, Documentos de Actividad Contemporánea, órgano de expresión y manifiesto de las ideas del GATEPAC, se publicó trimestralmente desde comienzos de 1931 hasta junio de 1937 con redacciones en las tres ciudades de los grupos Centro, Norte y Este: Madrid, San Sebastián y Barcelona, y especialmente impulsada por Sert y Torres Clavé. El estudio de sus 25 números, supone sin menoscabar otras, una fuente de primera mano y fundamental para entender el movimiento moderno español.

Con una imagen potente, desarrolla a través de sus artículos editoriales varias líneas de trabajo, algunas de las cuales tienen especial relación con lo popular y la tradición:

1. Interés por la arquitectura y construcción populares por su honestidad, sobriedad y sabiduría, y como posible fuente de inspiración en la búsqueda y desarrollo de una nueva arquitectura.

2. Interés por los aspectos constructivos y técnicos. En la mayor parte de los proyectos publicados, se hace una breve referencia de la memoria en sus aspectos constructivos.

3. Defensa de la verdadera arquitectura con independencia de la época, demostrando especial interés por demostrar respeto por la arquitectura del pasado. Se mantiene como constante una crítica durísima a los historicismos y academicismos, con grandes tachaduras rojas sobre los ejemplos criticados, tanto de la arquitectura del pasado como de los falsos modernos.

Destaca el interés por la honestidad y sabiduría de la construcción vernácula, como fuente de inspiración para una nueva arquitectura, quedando reflejado en numerosas referencias y en el número 18 del segundo trimestre de 1935, dedicado a la Arquitectura Popular.

\footnotetext{
4 «ens va impressionar molt la primera vegada que vam anar a Eivissa l'any trenta-dos. Va ser un descobriment en el sentit que vam veure que moltes d'aquestes coses que es feien en el centre i el nord d'Europa, ja les teníem aquí, no les havíem d'anar a buscar. Per exemple, les teulades planes i els volums bastant primaris i sense decoració ja existien. Eren privilegis de la pobresa. Puig i Cadafalch va haver d'anar-ho a buscar a Nuremberg: la inspiració de la casa Ametller del gòtic alemany. Nosaltres defensàvem el gòtic català, Santa Maria del Mar i Pedralbes, i teníem discussions amb els professors, que pretenien que les esglésies i els monuments catalans no acabaven en teulada com els del nord perquè se'ls acabaven els diners, i no. Santa Maria és perfecta, aquells desguassos i aquell terrat...!»

Josep Lluís Sert en entrevista publicada en 1982 por la revista Quadern d'arquitectura i urbanisme n¹52, p.77, preguntado por la influencia de la arquitectura vernácula en su obra. Traducción de Ana Rodríguez.
} 
En este sentido, es de reseñar el editorial del primer número de la revista, que se reproduce completo a continuación, por su interés como manifiesto ideológico, y dedicado al tema que nos ocupa, ya que frente al manifiesto CIAM, incorpora su postura respecto a la tradición.

Editorial del numero 1 de la revista A.C.

«Los sistemas arquitectónicos, históricos, no fueron obra de fantasía y de capricho, expresan los caracteres esenciales de una época y e una región; estructura social, procedimientos de construcción, materiales propios, necesidades económicas, exigencias espirituales.

Nuestra época se caracteriza por un gran movimiento universal de renovación.

Nuestras estructuras sociales aparecen. Las sociedades modernas tienden a ser regidas por las necesidades colectivas iguales para todos los cultos. Fábricas, escuelas, deportes. Habitaciones, espectáculos. Transportes, vías de comunicación. URBANISMO.

Se conocen nuevos procedimientos y materiales de construcción de uso universal.

Debemos adoptarlos. La estructura de un edificio cambia con los materiales. Las necesidades económicas -LEY DE ECONOMIA- exigen la rapidez sin olvidar la perfección. La industria (maquinismo) puede resolverlo produciendo elementos-tipo fabricados en gran cantidad. SERIE.

Estamos en presencia de un estado de espíritu nuevo que anula costumbres y tradiciones y que tiende a ser universal. La Arquitectura Contemporánea, debe estar de acuerdo con estos caracteres. Adaptar un sistema histórico, es falsear el sistema, y negar la época. En las Arquitecturas regionales, producto de las condiciones de clima, costumbres locales y materiales de que se dispone, solo el clima tiene un valor absoluto. Lo esencial subsistirá. Lo episódico, lo accidental, debe desaparecer.

Una división de la arquitectura universal fundándose en las condiciones de clima puede preverse.

Arquitectura meridional, terrazas, toldos lonas voladas, luz tamizada. Arquitectura septentrional, grandes superficies vítreas.

La Arquitectura responde a una utilidad, a un fin. Debe satisfacer la razón. Partir de elementos, programa, materiales, espacio, luz... desarrollándose racionalmente del interior (función) al exterior (fachada) e una manera simple y constructiva, buscando la belleza en la proporción, en el orden, en el equilibrio. Suprimir la decoración superflua superpuesta. Luchar contra el falso empleo de materiales, arquitectura de imitaciones. Llevar la arquitectura a su medio natural, es decir, al técnico, social y económico del que está actualmente separada, es el programa (aceptado por muchos, pero que pocos tratan de realizar), que el Grupo GATEPAC se propone llevar a la práctica coordinando esfuerzos y trabajando colectivamente» (García-Quiñones 2005)

Las referencias a la arquitectura popular se repiten con frecuencia como modelo a seguir en cuestiones diversas, incluso en las aparentemente más alejadas de la construcción moderna. Como ejemplo y también en el primer número, la página 26 en la que aparece la sección «Elementos Standard en la Construcción», en donde se 
expone el acuerdo del grupo desde su reunión constituyente, de ocuparse del estudio de la estandarización de algunos elementos de vivienda, como ya se ha hecho en otros países, así como la voluntad de mantenerse como sección.

En las paginas siguientes, 24 y 25, se pone como ejemplo para ilustrarlo, un grupo de viviendas de pescadores en San Pol de Mar, comparándolo con las viviendas en hilera de J.J.P. Oud en Weissenhof, bajo el titulo de «.....Aparece el Standard. »

En general, se desarrollan búsquedas de racionalización en las que conviven materiales tradicionales y estandarizados. En los 25 números de la revista AC, abundan ejemplos de esta coexistencia. En muchos casos posiblemente fuera forzada, pero no en otros muchos, en los que la tradición se incorpora como una línea más de investigación. (Rodríguez y Hernando 2007).

En este sentido resulta muy significativo, que en el desarrollo de un nuevo programa como son las casas de vacaciones, representada brillantemente por la caseta desmontable del Gatepac, Sert, la figura más representativa de nuestro movimiento moderno, lleva a cabo en El Garraf, unos prototipos para vivienda de vacaciones construidas con materiales tradicionales, incluso con bóveda tabicada en uno de los tipos. (Rodríguez y Hernando 2007).

\section{SAN POL DE MAR}

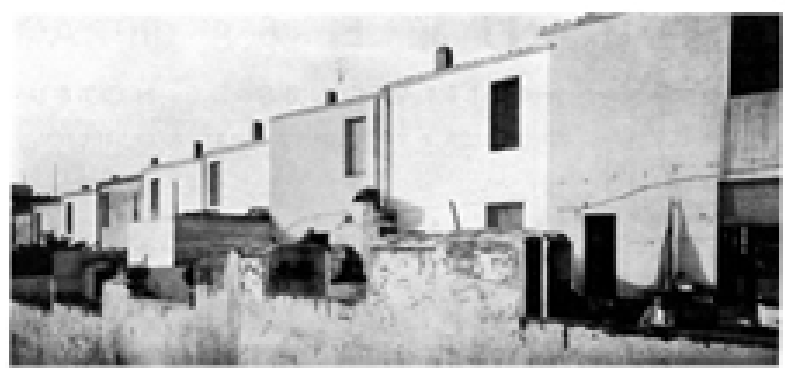

Aparece el Standard.

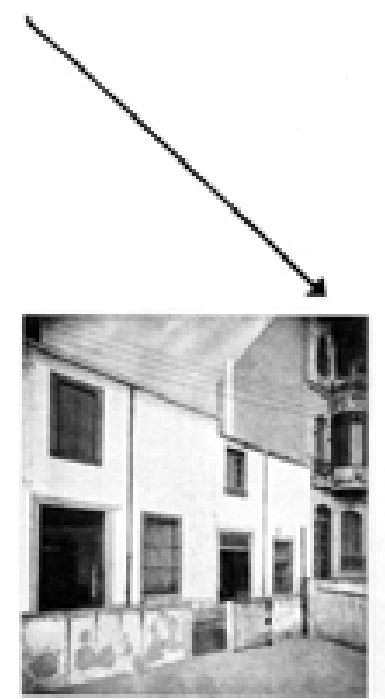

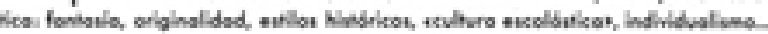

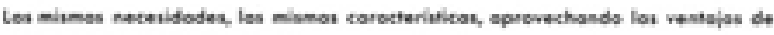
lo mederns nesite coeshuctiva.

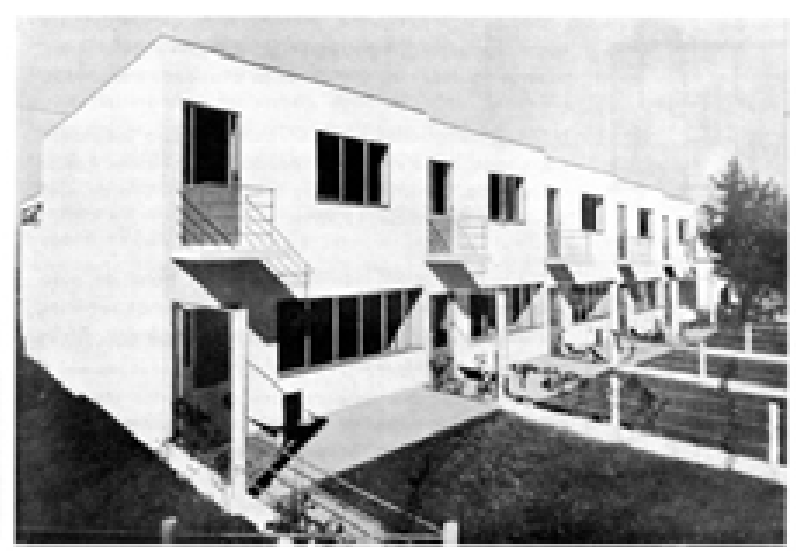

Figura 4.05

Referencia a lo «standard» comparando unas viviendas de pescadores en San Pol de Mary $y^{\text {s }}$ las viviendas en hilera de Oud en la Colonia Weissenhof. Revista AC n 1, 1931. 
Figura 4.06

* Derecha

Portada de AC. 18 de 1935, número dedicado a la arquitectura popular.
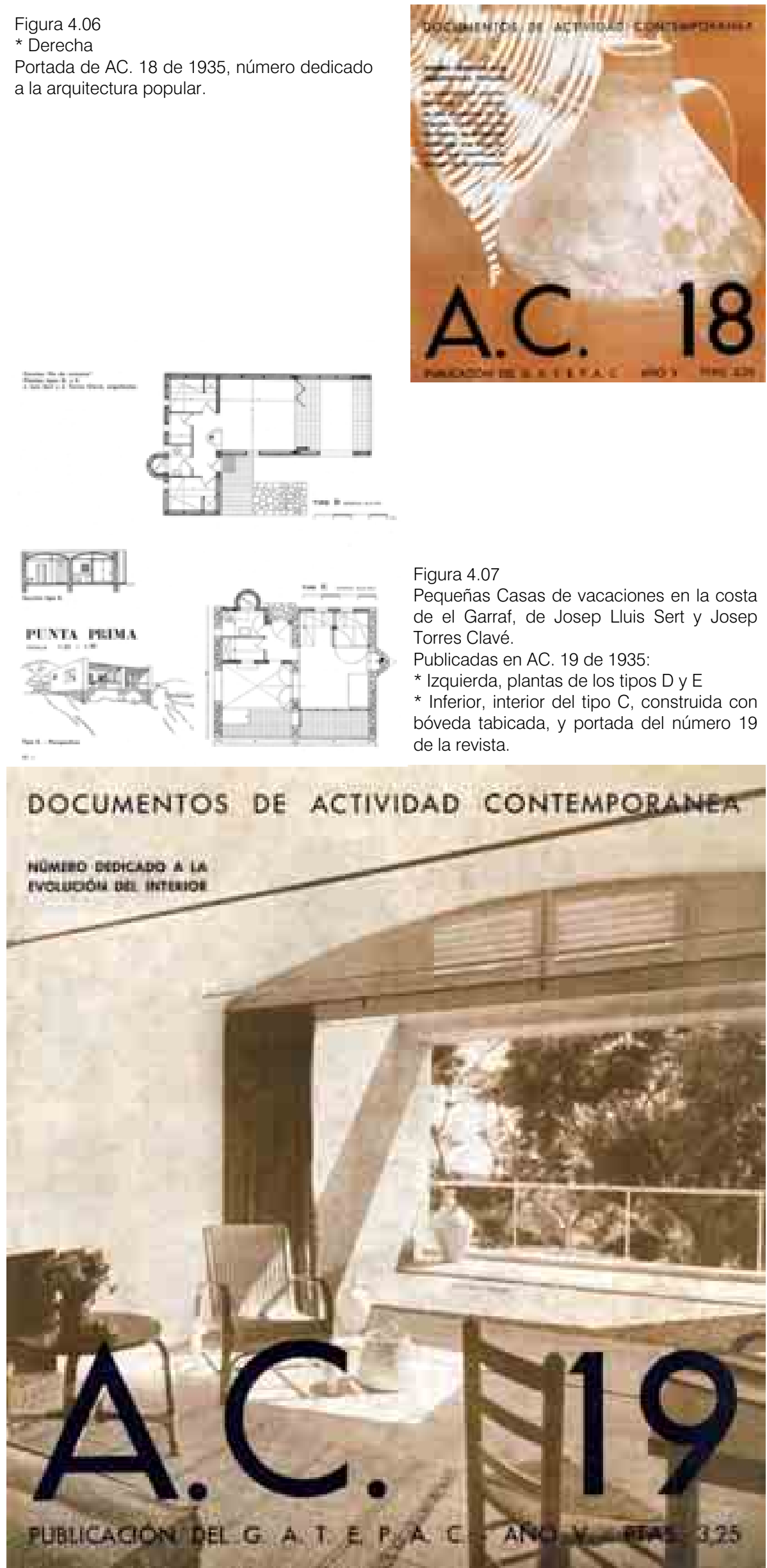
En Madrid, trabaja un grupo de arquitectos que se inician profesionalmente entre 1918 y 1923, a los que Carlos Flores denomina Generación del $25^{5}$, debido a la influencia, reconocida por ellos mismos, del viaje que realizan recién titulados a la Exposición de Artes decorativas de Paris de $1925^{6}$. Este grupo, junto con el arquitecto más influyente del momento en España, algo mayor que ellos, Secundino Zuazo (1887-1970), desarrollan una arquitectura racionalista con varias sensibilidades, pero con un esfuerzo común de desornamentación de búsqueda de nuevas soluciones frente al regionalismo dominante en ese primer cuarto de siglo, y que entronca con las corrientes europeas de vanguardia. Aunque en general como grupo la generación del 25 , no alcanza la modernidad y el radicalismo que se consiguen en las propuestas del GATEPAC, en él se gestan y construyen los primeros edificios realmente modernos en España: El Rincón de Goya en Zaragoza en 1928 de Fernando García Mercadal, la Estación de Servicio de Petróleos Porto-Pi en la calle Alberto Aguilera en Madrid, con estructura de hormigón armado, de Casto Fernández-Shaw, y la casa para el Marqués de Villora en la calle Serrano 130 en Madrid, de Rafael Bergamín, con una vuelta al ladrillo que tanto le había impresionado en Holanda. Otra figura clave en esta generación es el ingeniero de caminos Eduardo Torroja (1889-1961), que realiza sus principales colaboraciones con arquitectos en Madrid ${ }^{7}$.

Al igual que la construcción tabicada, convive en Barcelona de forma natural con las nuevas propuestas arquitectónicas, también se sigue realizando en Madrid ${ }^{8}$, junto con nuevas técnicas, en la arquitectura moderna racionalista madrileña, en la que además el empleo del ladrillo visto, alcanza gran desarrollo como una de las señas identidad del grupo. En el año 1934, simultáneamente a la realización del concurso para el Hipódromo, que ganaron Arniches, Domínguez y Torroja con una estructura de bóvedas de hormigón armado novedosa y espectacular, Carlos Arniches construye para la Institución Libre de Enseñanza, un nuevo pabellón en la Residencia de Señoritas de la calle Miguel Angel en Madrid, junto al edificio decimonónico existente. En el destaca la gran escalera interior construida con bóveda tabicada.

«Aunque la construcción era simplísima en cuanto a los materiales empleados, los detalles eran elegantes y resaltaban ese estilo casi rayano en el ascetismo absoluto. El único elemento que destacaba en el interior, a parte del efecto que producía la galería del pasillo, era la escalera, de una gran plasticidad, no sólo digna de mención desde el punto de vista estético y compositivo sino, muy especialmente, desde el constructivo, ya que se hizo íntegramente a la catalana» (Diez-Pastor 2003, 144).

\footnotetext{
${ }^{5}$ Rafael Bergamín (1891-1970), Luis Blanco Soler (1894-1988), Regino Borobio (1895-1976), Casto Fernández Shaw (1896-1978), Miguel de los Santos (1896-1991), Agustín Aguirre (18961985), Manuel Sánchez Arcas (1895-1970), Luis Lacasa (1896-1966), Fernando García Mercadal, Carlos Arniches (1897-1955), Martín Domínguez (1897-1970) y Luis Gutierrez Soto (1900-1977). (Flores 1989)

${ }^{6}$ En esta exposición, pudieron contrastar el neo-regionalista Pabellón de España del arquitecto P. Bravo, con las propuestas de Le Corbusier en el Pabellón de l'Esprit Nouveau, de Zajkowski en el Pabellón de Polonia, de Hoffman en el Pabellón de Austria, y de Mallet-Stevens en el Pabellón de Turismo, así como del uso del ladrillo en el pabellón holandés, que condujo a algunos a viajar a Ámsterdam y a Hilversum, influyendo sin duda, aunque sin ser el único factor, en el empleo del ladrillo visto en el racionalismo madrileño (Rodríguez y Hernando 2007, 767).

${ }^{7}$ Fruto de esta colaboración, en poco más de diez años se realizan tres obras importantísimas, hitos internacionales muestras del desarrollo y posibilidades del hormigón armado como nuevo material: El Mercado de Algeciras en 1935 con Sánchez Arcas, el Frontón Recoletos en el mismo año con Secundino Zuazo, y el Hipódromo de Madrid en 1936 con Carlos Arniches y Martín Domínguez. (Rodríguez y Hernando 2009a).

8 Prácticamente todos los edificios de vivienda colectiva, incluso los de planteamiento mas moderno y racionalistas, realizados en Madrid en los años treinta están construidos con escaleras de bóvedas tabicadas.
} 

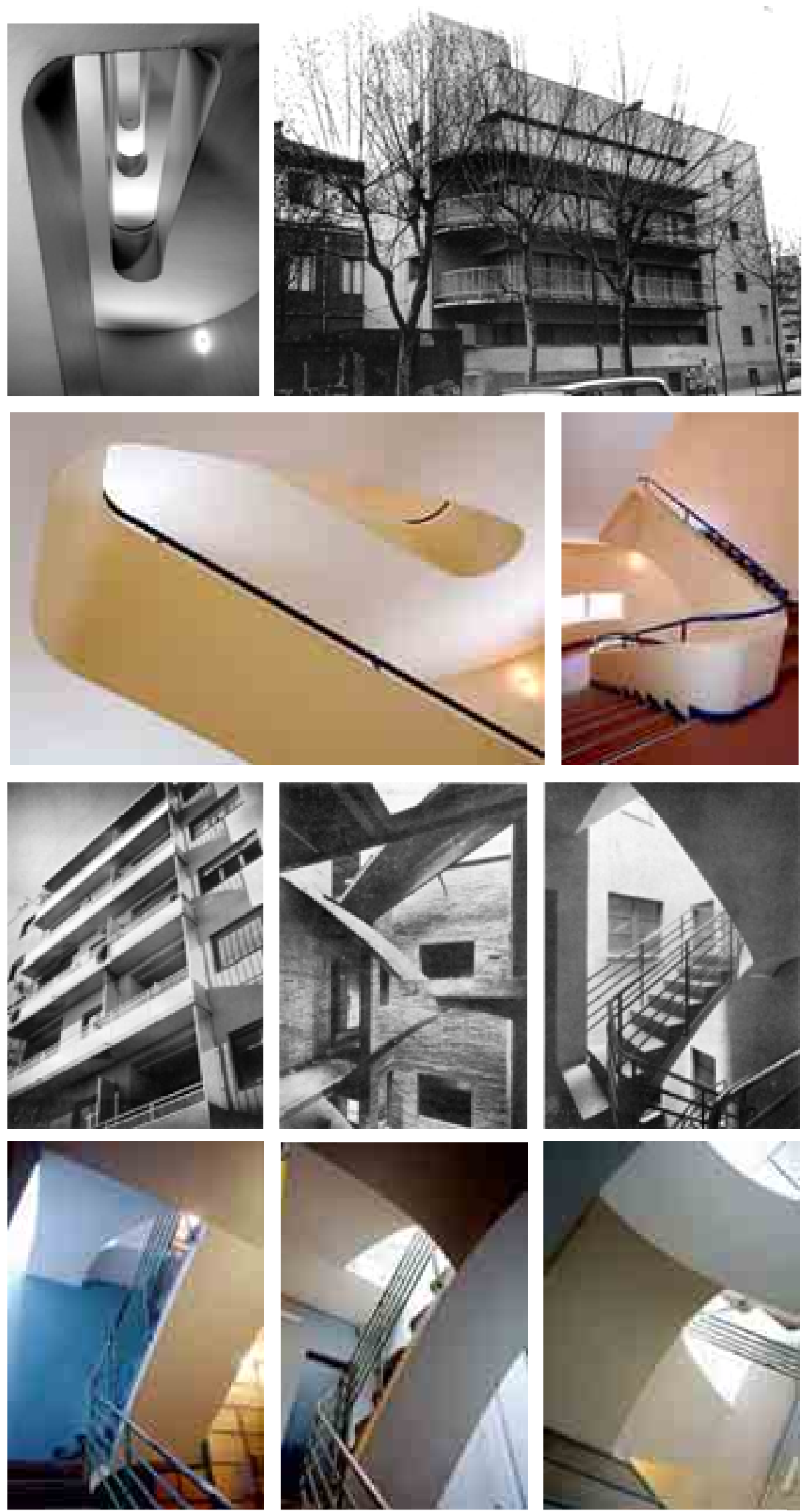

Figura 4.08

Espectaculares bóvedas tabicadas en escaleras de la modernidad española en los treinta

* Superior: Residencia de Señoritas Estudiantes en Madrid, 1932-1933 de Carlos Arniches.

Fotografías de la escalera en color y blanco y negro de Ana Rodríguez en 2007

* Centro: Viviendas de alquiler en la Calle Padua en Barcelona, de Sixto Illescas. Publicadas en AC. 16, 1934

* Inferior: Viviendas de alquiler en la Calle Padua en Barcelona, de Sixto Illescas.

Fotografías en color de Ana Rodríguez en 2007 
En 1918 la Sociedad Central de Arquitectos, empieza a publicar la revista Arquitectura a cargo del poeta y pintor José Moreno Villa, y en ella publican Bellido, Giner de los Rios, Bergamín, Yarnoz, Guitard, Lacasa, Sánchez Arcas, Blanco Soler, Anasagasti, Rivas Eulate, Salvador, Zuazo, Závala, López Otero, Torres Balbás, Garcia Mercadal, y Fernández Balbuena entre otros. Desde 1927 colabora asiduamente Theo van Doesburg, se publican noticias sobre los CIAM, el Werkbund, la obra de Le Corbusier y Gropuis, las investigaciones arqueológicas de Torres Balbás, se presentan las primeras obras menores adheridas al movimiento moderno, como son las tiendas de Domínguez, Arniches y Bergamín, y se publican los artículos de García Mercadal desde el extranjero y sus teorías sobre «arquitectura mediterránea», en defensa de una plástica pura, limpia, horizontal, desornamentada y racionalista (Bohigas 1998, 29)

En enero 1932, la Revista Arquitectura como órgano del Colegio Oficial de Arquitectos de Madrid, dedica su número completo a la memoria del fallecido Gustavo F. Balbuena, fundador entre otros de la revista. Escriben sobre él Secundino Zuazo, Torres Balbás, y J. Moreno Villa Este ultimo en un artículo titulado «Algo sobre su arquitectura» en el que fotografías de algunas de sus obras explican su evolución desde su formación academicista hasta sus posturas racionalistas modernas. Es de reseñar especialmente sus comentarios sobre el interés de Balbuena por la construcción y el ladrillo como material, y en particular por la construcción tabicada.

«Balbuena tenía hechos largos estudios, en sus correrías por Castilla y norte de España, acerca de este modo, tan nuestro de construir. Y le regocijaba la impresión que hacían a los extranjeros algunas obras de rasilla que veían ejecutar, sin acabar de entender cómo podían resultar resistentes y estables. Las bóvedas fabricadas para las escaleras, por ejemplo. El acabamiento y perfección en sus obras de ladrillo es sencillamente magistral» (Moreno 1932)

Repasando la revista Arquitectura en los años coincidentes con los de la revista AC, es decir desde 1931 hasta 1936 ya que en Madrid la revista del Colegio de Arquitectos deja de publicarse en la guerra, hay también referencias graficas y escritas a la construcción tabicada. Puede que no sean tan numerosas como en AC, pero no porque muchas de las obras publicadas no la empleen, sino porque la línea editorial es bastante diferente entre ambas revistas. En Arquitectura, no se publican imágenes de escaleras con la profusión que en AC, y además se publican más extensamente las grandes obras de hormigón armado material que en ese momento se desarrolla más en Madrid por la influencia directa de Eduardo Torroja.

Consecuencias de la Guerra Civil en la arquitectura moderna española. Sert y Bonet Castellana: Continuidad del GATEPAC en el exilio.

La guerra no solo acabó definitivamente con la arquitectura moderna en España, sino que truncó el desarrollo intelectual y profesional a varias generaciones completas de arquitectos, anulando cualquier posibilidad para continuar con el periodo anterior.

Los hay que mueren en la guerra, como Torres Clavé y Aizpurúa, y los arquitectos que se quedan en España, tanto del ámbito catalán como madrileño, sufren depuraciones e inhabilitaciones, algunas de por vida, con una contundencia tal que aniquila, incluso por supervivencia, cualquier posibilidad de continuidad de las ideas y el lenguaje modernos en los primeros años de la posguerra

Otro gran grupo termina su vida en el exilio, entre los que destacan Bonet Castellana en Argentina y el de mayor reconocimiento internacional Josep Lluís Sert, en Estados Unidos. En ambos casos, su interés por los espacios abovedados, especialmente en edificios de poca altura y de escala domestica, cuyo origen hemos visto en las bóvedas tabicadas de las casas de Garraf en los años del Gatepac, se mantendrán a lo largo de su vida. Este interés, en general ya no se traduce en construcciones 
tabicadas, casi con seguridad no por falta de interés en el sistema, sino por la imposibilidad de llevarlo a cabo en países tan ajenos a esta técnica. Una de las mejores cualidades de la vida profesional de Sert, fue la de saberse adaptar de la forma más adecuada a los medios disponibles. Buen ejemplo de ello fue la construcción con Luis Lacasa y la colaboración de Antonio Bonet que en ese momento trabajaba en París en el estudio de Le Corbusier, del Pabellón de España en la Exposición Universal de Paris en 1937, en el que Luis Lacasa supo entender enseguida, que el anteproyecto de Sert pensado con elementos industrializados, y totalmente diferente al suyo planteado con técnicas tradicionales españolas, era mucho más viable de realizar en Francia que el propio.

Antonio Bonet Castellana, que ingresó todavía como estudiante en el Gatepac en 1933, trabaja en esa época en el estudio de Sert y Torres Clavé, y forma con ellos la firma MIDVA (Muebles y Decoración para la Vivienda Actual), dedicada al diseño y a la producción de muebles en serie. En 1936 finaliza la carrera, y se traslada a París para trabajar en el Atelier de Le Corbusier. En 1937, colabora con Sert y Luis Lacasa en la construcción de el Pabellón Español para la Exposición Internacional de 1937, y en el estudio de Le Corbusier realiza, en colaboración de Roberto Matta, un anteproyecto para la Maison Jaoul, con formas abovedadas En 1938 se traslada a Buenos Aires, alcanzando un notable éxito como arquitecto, y realizando varios proyectos con formas abovedas, unas veces en hormigón y otras en fabrica armada y bóveda tabicada, como la casa Berlingieri en 1947, las casas en Martinez, 1941-57, en Buenos Aires, y la Galería Rivadavia también en Buenos Aires, 1957-59, con la utilización de bóvedas tabicadas en un edificio en altura. (fig. 11) (Flores 1961, 231)

Sert convierte en 1935, la casa tipo C de Garraf, imagen de portada del número 19 de la revista A.C., en el referente claro de la posibilidad de plantear arquitectura moderna y construirla con materiales tradicionales, en este caso con bóveda tabicada. Pero no es el único ejemplo de ese periodo. También las utiliza en el Parvulario de Viladecans de 1935, y con más claridad en el Pabellón escolar de Arenys de Mar, del mismo año. Posteriormente a la guerra, en su exilio en Estados Unidos, plantea numerosos proyectos con formas abovedadas, que piensa por los motivos explicados anteriormente en distintos materiales según las circunstancias. Así, aunque en general son de hormigón, en 1942 proyecta las Ratio Structures, un sistema prefabricado de construcción de una estructura modular sin programa, en el que las cubiertas abovedadas se plantean prefabricadas de madera, aunque ya en 1938, unos bocetos de Sert en Londres muestran un sistema de bóvedas prefabricadas metálicas realizado en planchas galvanizadas acanaladas. En julio de 1951, con motivo del CIAM VIII celebrado en Hoddesdon, Inglaterra, Sert y Le Corbusier se encuentran, y Sert le proporciona información sobre la construcción con bóveda tabicada y el nombre del maestro de obra catalán emigrado a Francia, Doménech Escorsa, como experto en el empleo de la técnica tabicada, según reflejan las anotaciones de Le Corbusier en su cuaderno. Hay constancia de más de una reunión, y este hecho tiene incidencia en tres proyectos que está desarrollando, las casas Jaoul en París, y la casa Sarabhai y las maisons des peons para el poblado del Gobernador de Chandigardh, ambas en la India. 


\subsubsection{Lo popular después de la guerra en la generación de José Antonio Coderch: Ser moderno y no parecerlo o no ser moderno y parecerlo.}

Las particulares circunstancias de la arquitectura española por la situación política del país, merecen un comentario específico: El aislamiento político español después del año 1939 y la dificultad que supone para los arquitectos contactar con los movimientos culturales europeos, junto con la situación de carestía económica y la postura oficial del nuevo régimen político que prefirió ensalzar otra visión de la arquitectura frente a la desconfianza que le producía la arquitectura moderna, representada ideológicamente con claridad durante la Segunda República a través del GATEPAC y la Generación del 25, y sobre la que hace caer un manto de silencio, determinan poderosamente el marco de actuación de los arquitectos en la década de los cuarenta y primeros cincuenta.

Se produce una arquitectura de tintes nacionalistas, formalmente ecléctica, y el ya conocido resurgimiento de algunas técnicas de construcción tradicionales, en especial la bóveda tabicada, ante la carestía de acero y cemento de calidad.

Sin embargo, el respeto y admiración por la arquitectura popular en España, viene de antes, siendo una de las características de nuestro Movimiento Moderno, necesaria de reivindicar: en los años 30, las páginas de la revista $A C$, instrumento de difusión del GATEPAC, ya muestran el universo de Coderch en el Pabellón de España de la Trienal de Milán de 1951.

Ha quedado documentado en el epígrafe anterior la importante influencia de lo popular en el movimiento moderno español en la década de los treinta, y cómo la utilización de algunos sistemas constructivos tradicionales como la bóveda tabicada se empleó dentro del planteamiento de búsqueda de una arquitectura verdadera, por lo que puede ser un buen ejemplo de análisis en la comparación de ambos periodos.

En los treinta, no es que la construcción tabicada ${ }^{9}$ sea la más empleada, o se anteponga al pensamiento moderno, sino que pervive y convive con nuevas técnicas de forma natural en un número importante de edificios, en viviendas unifamiliares y en vivienda colectiva, así como en edificios con otros usos, como es el caso de centros de enseñanza, sanitarios, o construcciones agrícolas, y con magníficos ejemplos en la realización de escaleras.

Este hecho, poco reseñado posiblemente debido a algunas extendidas creencias sobre el desinterés de la arquitectura moderna por aspectos que no sean estrictamente formales, seguramente se debe a esos valores de honestidad, sencillez, tradición local y climática, economía de medios y sobriedad, que tanto admiran de la arquitectura popular, y que tan bien representa la bóveda tabicada. De hecho, es la única de las construcciones abovedadas que el movimiento moderno asume como propia. Su uso como configurador espacial, está asociado a la escala humana de los proyectos, y alcanza sus mejores ejemplos en viviendas unifamiliares y grupos escolares, y con frecuencia asociado al concepto de repetición, tanto en ese periodo como posteriormente en ejemplos de Bonet Castellana, Sert y Le Corbusier.

\footnotetext{
${ }^{9}$ La construcción con bóvedas tabicadas se fundamenta en gran medida en el conocimiento del oficio, por lo que se hace difícil pensar su amplia utilización en la posguerra si la tradición constructiva hubiese desaparecido. Sobre este tema véase: Rodríguez, Ana y Rafael Hernando "La Bóveda tabicada y el Movimiento Moderno español" en Actas del Quinto Congreso Nacional de Historia de la Construcción, Burgos, 7-9 junio 2007, eds. M. Arenillas, C. Segura, F. Bueno, S. Huerta, Madrid: I. Juan de Herrera, SEdHC, CICCP, CEHOPU, 2007
} 
Por otra parte, es conocido el auge que la construcción con bóvedas tabicadas tuvo de forma temporal en la posguerra española, a través de Luis Moya, Asís Cabrero o Rafael Aburto. En su utilización influyó, además de la escasez de materiales del momento, la situación política del país y el nuevo régimen, que propugnaba una arquitectura antimoderna como se ha explicado anteriormente. No obstante, solo Moya $^{10}$ continuará realizándolas en el tiempo, con ejemplos espectaculares en el Museo de América de Madrid, pero alejado de planteamientos modernos. Tanto Aburto como Asís Cabrero, que las emplean en los cuarenta ${ }^{11}$, no las utilizaran en su obra posterior.

En comparación con el periodo de posguerra, la bóveda tabicada se empleó de forma más libre en la arquitectura de los años treinta. Cuando Sert y Torres Clavé la emplean en las casas da vacaciones del Garraf, lo hacen intencionadamente dentro de su investigación tipológica, estudiando alternativas y variantes del tipo, unos con bóveda tabicada y otros no, en un planteamiento que se prolonga en el exilio y conecta intensamente con Le Corbusier, en gran medida a través del propio Sert.

En ese sentido, y contrariamente a lo que se suele creer, la bóveda tabicada como ejemplo de la influencia de lo popular, ha tenido al menos la misma trascendencia en los radicales planteamientos del movimiento moderno que en los años cuarenta, sin menoscabar los magníficos ejemplos de su utilización en este periodo, en la obra de Asís Cabrero, Moya y Aburto entre otros.

De esta manera, en la posguerra española coinciden en el tiempo aunque ideológicamente opuestas, la tradición moderna anterior a la Guerra Civil de reconocimiento de los valores verdaderos de la arquitectura popular, con el resurgimiento de una arquitectura regionalista de exaltación nacional impulsada por el régimen franquista.

A pesar de las limitaciones del momento y del ambiente arquitectónico imperante, varios arquitectos de la misma generación de Coderch, como Jose María Sostres, Antonio Moragas, Alejandro de la Sota, Francisco de Asís Cabrero, Rafael Aburto, Fernández del Amo o Miguel Fisac entre otros, desarrollaran una obra relevante a partir del estudio de la arquitectura popular, que encuentra un medio favorable de expresión en la construcción de los poblados de colonización.

Sin poder contar con los arquitectos fallecidos, los expatriados, los sancionados, los suspendidos y los inhabilitados, y tampoco con los antiguos ó recientemente convencidos de una arquitectura «plenamente nacional y genuinamente española», pues son lo que pasan a ocupar los cargos de responsabilidad en la nueva estructura de la Administración, se genera una situación de falta de profesionales, en la que los proyectos los tendrán que realizar los arquitectos recién licenciados. Se encuentran un país devastado, en el que es necesario construir y reconstruir un elevado número de

\footnotetext{
${ }^{10}$ Luis Moya Blanco publica en 1947 el texto fundamental Bóvedas Tabicadas, editado en Madrid por la Dirección General de Arquitectura del Ministerio de la Gobernación. El trabajo de Moya se centra en la técnica constructiva de forma "atemporal", en la línea de Rafael Guastavino en Estados Unidos, y materializando bóvedas tabicadas de luces medias, mayores que las empleadas en los ejemplos citados de antes y después de la Guerra Civil.

${ }^{11}$ En los cuarenta varios proyectos de vivienda se realizan con bóveda tabicada de forma muy significativa: Aburto en 1943 desarrolla un proyecto no construido de Viviendas en Toledo. En 1946 construye las de Quintanar de la Orden, y en 1947 la Granja-escuela en Talavera de la Reina. También de 1947-1948 es el bloque de viviendas en la colonia Virgen del Pilar, una de las primeras realizaciones de vivienda pública de posguerra. De Francisco de Asís Cabrero, arquitecto jefe de la Obra Sindical del Hogar, en ellas se materializa una de las primeras rupturas con las directrices de la arquitectura oficial de estilo imperial de la época. Todas ellas utilizando técnicas tradicionales como la bóveda tabicada.
} 
edificios, sobre todo vivienda, con escasez de medios económicos, humanos y materiales. Por otra parte la construcción de esa arquitectura «plenamente nacional y genuinamente española» es compatible con una arquitectura popular, especialmente en poblados de colonización en zonas rurales y en núcleos de pequeño tamaño. Por ello esta generación de arquitectos, aunque en unas condiciones complicadas, tiene la oportunidad de empezar a trabajar muy pronto dentro los organismos oficiales o en estudio propio. Si bien dispondrán de oportunidades de trabajo, no vivirán la continuidad natural con la generación anterior. (Hernando de la Cuerda 2014)

A estos arquitectos que terminada la carrera a principios de los cuarenta, después de que hubiera quedado interrumpida por la guerra, y que combatieron con las tropas de general Franco, les unía la religión, algo imposible de obviar. Gabriel Ruiz Cabrero lo explica de la siguiente manera:

«Algo muy importante les unían: pertenecían a una facción muy precisa de entre las múltiples que habían constituido el bando que a sí mismo se llamaba nacional; eran los católicos, aquellos que habían empuñado las armas para defender su religión; que interpretaron la guerra como una cruzada, y salieron de ella con el convencimiento de que solo desde un entendimiento católico e la vida se podía regenerar la sociedad. Para ellos, la arquitectura era, sobre todo, el instrumento para construir espacios donde renovar la exigencia ética de la sociedad» (Ruiz Cabrero 2001, 13)

Carlos Flores en su ponencia «La Arquitectura de José Antonio Coderch y Manuel Valls, 1942-60", publicada en las Actas del Congreso Internacional De Roma a Nueva York. Itinerarios de la nueva arquitectura española 1950/1965 celebrado en Pamplona en octubre de 1998, lo explica con las siguientes palabras: «se esforzaran también por encontrar caminos alternativos -al margen de consignas políticas más o menos explicitas- hasta hallar soluciones homologables con la más positivo y válido que por aquellos años se estaba produciendo en Europa»

Probablemente el interés de estos arquitectos por lo vernáculo, proviene intuitivamente de su capacidad de observación de lo popular, favoreciendo su desarrollo el particular contexto español de posguerra aunque sus objetivos sean diametralmente opuestos.

En el caso concreto de Coderch, esa vía de investigación a partir de la arquitectura popular, más que a través de su contexto temporal, se transmitirá directamente desde de los números de la revista $\mathrm{AC}$.

Conocemos su reconocimiento reiterado y explícito a los artículos de la revista, cuando en una entrevista realizada el 22 de julio de 1967 por Baltasar Porcel para la revista Destino de Barcelona explica que todavía siendo estudiante por la interrupción de la guerra y quedándole dos cursos para terminar la carrera, le ocurrió un hecho decisivo en su formación:

«Por un extraño instinto fui al local del GATCPAC. Yo era teniente. Hice la guerra con los nacionales. Me presenté de uniforme y me llevé las revistas que había editado el grupo y que seguían allí. Estudiarlas me dio algo así como una conciencia ordenada, razonada, de lo que nebulosamente había pensado yo» o como en otra ocasión su socio Manuel Valls declaró que para ellos la revista AC era «como el pan nuestro de cada día» (Armesto y Diez 2008, 46, 90) 
Determinante para Coderch, fue a su vez la arquitectura popular de Ibiza, como en los treinta lo había sido para Sert. Federico Correa, en entrevista a la revista Arquitectura en 1987, lo recuerda así:

«Como ya he dicho, Coderch es inconformista por naturaleza, busca las raíces y ama la sencillez, la esencia de las cosas. Es, un gran idealista y sin embargo palpa la tierra y los materiales más enraizados. Todavía recuerdo la impresión que le causó la arquitectura de Ibiza. Hizo un viaje en bicicleta con Valls y volvió fascinado. Aprendió la lógica racionalista de la arquitectura popular, no por sus anécdotas, y esto no era ajeno, en principio, al Movimiento Moderno. Siempre entendió que lo moderno era cómo se usaban los materiales y no qué materiales se usaban. Evidentemente, no hacía falta vidrio y metal para ser moderno. Aalto fue una figura indiscutible del Movimiento Moderno utilizando la madera» (Mata y Lampreave 1987, 117)

El reconocimiento compartido con esa línea de trabajo de Coderch, podemos encontrarlo en las palabras de Alejandro de la Sota, en un escrito sobre la I Bienal Hispanoamericana ${ }^{12}$, a la que Coderch y Valls se habían adscrito en 1951, participando con la casa Garriga-Nogués y el campo de deportes de Sitges. En esos años, y en parte gracias a la bienal, se consolida una relación cercana y afín entre Coderch y Sota, una especie de reconocimiento mutuo y solidario en el esfuerzo por hacer arquitectura moderna en un contexto tan hostil.

"Coderch y Valls aman la sencillez del campesino y del pescador en sus obras; aman esta sencillez y penetran en ella sabiendo encontrar todo lo profundo que encierran. Somos algunos los que creemos en este camino, el de la cal y del barro, tal vez mucho más que en otros mas leídos y estudiados; este candor y limpieza de formas nos llena de felicidad» ${ }^{13}$ (Sota 1952, 18)

Coderch le responde agradeciendo el comentario en carta del 25 de marzo de 1952, posiblemente al sentirse reconocido por un compañero de profesión y mitigando el pesimismo que revela la nota:

«No sabes cuánto te agradecemos Manuel y yo tu cariñosa mención de nuestras obras, tan sobadas ya desde luego, expuestas en la Bienal. Leímos tu artículo en un momento de gran pesimismo y te hemos de agradecer que nos levantaras el ánimo cuando más lo necesitábamos» (Pizza y Rovira 2003, 107)

Pesimismo, soledad e incomprensión en la defensa de los planteamientos modernos: son sentimientos también compartidos por Sota, que en una carta sin fechar, seguramente de finales de 1951, y en la que comenta su artículo sobre Alvar Aalto en la visita a España y dice:

«Los que queremos algo, no se qué, ya no se nos tiene por locos, como hace no más de un par de años y ahora, de cualquier manera, vamos interviniendo cada uno en la medida de sus fuerza (...), o bien desde lo más profundo y recogido de su estudio, como tú, ideal al que sólo con tanta virtud puede aspirarse (...) Hablar de éxito en tus cosas es tonto, es preferible alegrarse al comprender los seguros pasos que hacía nuestra verdad vas dando» (Pizza y Rovira 2003, 107)

\footnotetext{
12 Iniciativa para reforzar vínculos con los países americanos de habla hispana. Se celebro en Madrid entre octubre de 1951 y febrero de 1952.

13 « Bienal Hispanoamericana» Boletín de Información de la Dirección General de Arquitectura, vol.VI, Madrid 1952, pag.18
} 
El pesimismo y frustración que denotan las palabras de Coderch y de la Sota, fruto del clima emocional de España después de guerra y de la soledad para afrontar el desarrollo de una arquitectura moderna ${ }^{14}$ que retomará el desarrollo anterior a la guerra, contrastan fuertemente con el sentimiento positivo y de progreso del resto de Europa. Unas palabras de Theo Crosby (1925-1994), poco después -en 1953- director técnico de Architectural Design, describen el tremendo contraste:

«Yo llegue a Londres en el dorado otoño de 1947. Estaba bonito, polvoriento, descolorido y roto. Las calles estaban tranquilas y vacías, y uno caminaba, sencilla y agradecidamente, a todas partes. La gran ciudad estaba curándose, herida pero viva, con energías subterráneas (...) Era un país azotado por la guerra y por la pobreza; (...) Pero la guerra dejó un maravilloso sentido de justicia y de igualdad, y había una creencia general en la responsabilidad social manifestada por el estado benefactor, los servicios de salud, la gratuidad de la enseñanza, el sistema de planificación. Esto dio un gran ímpetu a los grandes proyectos comunitarios de los años cincuenta: las trece ciudades nuevas, las nuevas y ampliadas universidades, el sistema nacional de parques, la provisión de casa sociales» (Robbins 1990a, 197-198)

En el contexto descrito, es precisamente a Coderch a quien hay que atribuir el descubrimiento e incorporación del tema de la arquitectura popular como fundamental en la arquitectura española a comienzos de los cincuenta (Ruiz Cabrero 2001, 14)

Ser una expresión autóctona del país, junto con la modernidad funcional y formal que representaba, permitió a toda esa generación asirse a algo propio en lo que apoyarse para recomenzar. Aunque es necesario matizar que también bajo el paraguas de lo popular, sectores más reaccionarios, pretendieron enmascarar unos principios alejados de la modernidad.

Es decir, no ser moderno y parecerlo o ser moderno y no parecerlo.

Una característica más de Coderch, diferenciadora en relación con su generación y con seguridad la más determinante. Es prácticamente el único arquitecto de los que trabajan en España después de la guerra, que tiene una relación de continuidad con el movimiento moderno desde el GATEPAC, con el apoyo explicito de Josep Lluis Sert para entrar en el CIAM, y cultiva de forma habitual contactos internacionales de diversa índole, confluyendo ambas cuestiones en su pertenecía al Team 10 a partir del Congreso de Otterlo.

\footnotetext{
${ }^{14}$ Gabriel Ruiz Cabrero, en El moderno en España, Arquitectura 1948-2000, explica la aparente contradicción de la modernidad española. Precisamente las dificultades para su desarrollo al quedar interrumpida drásticamente por la guerra, posiblemente ha favorecido que cuando se retomó, fuera con gran fortaleza y prolongándose en el tiempo.

Desde la Generación del 98, «la conciencia del retraso científico y la consecuente frustración que dominaba la cultura española desde principios del siglo XX produjeron una intensa, apasionada, ansia de modernidad»

Refiriéndose a la década de los ochenta cuando la crítica internacional en cierta forma descubre la arquitectura española contemporánea, Ruiz Cabrero dice: «la arquitectura moderna española, que demostraba una confianza en los "principios modernos", y un ansia por llevarlos a la práctica, que no eran comunes fuera, donde se permitían las dudas del post-moderno y otras» (Ruiz Cabrero 2001, 9-10)
} 


\subsubsection{La relación con Italia y la Trienal de Milán de 1951.}

Entre el 10 de mayo y el 9 de junio de 1949 se celebra en Barcelona, Palma de Mallorca y Valencia, convocada por la Dirección General de Arquitectura y el Consejo Superior de Colegios de Arquitectos, la V Asamblea Nacional de Arquitectos.

El evento significaba el comienzo de un lento cambio ${ }^{15}$ que se irá produciendo en la arquitectura española, pero sobre todo fue determinante para Coderch gracias al pronto reconocimiento de sus obras presentadas, en concreto la casa Garriga-Nogues en Sitges de 1947, por parte de los arquitectos extranjeros invitados de honor: Gio Ponti y Alberto Sartoris.

Un comentario de Gio Ponti en su discurso a la Asamblea, puede dar idea del tono general de las obras presentadas cuando dice: «quiero tener con mis compañeros españoles una confidencia. Encuentro entre vosotros incertidumbre y titubeo. Desechad eso, si me permitís el consejo; haced tranquila, serena y honradamente la arquitectura que salga de vosotros mismos» (Ponti 1949)

El reconocimiento de Ponti y Sartoris, permitirá a Coderch intensificar sus relaciones con Italia y publicar con frecuencia en Domus dirigida por Ponti, dando a conocer internacionalmente su trabajo.

Pero además, significó una especie de refuerzo a sus ideas, pues Ponti, figura a quien admiraba y quien en cierta forma consideraba su maestro, plaga su discurso de referencias a un modo de hacer en el que Coderch está inmerso buscando su propio camino, con citas expresas a la casa catalana y a Gaudí. La consciencia de esta búsqueda, la encontramos en las palabras del propio Coderch sobre la casa GarrigaNogues publicadas en el año 1978:

«Fue la primera obra con la que salimos, años después de acabar la carrera, de la profunda inexperiencia que nos poseía. Con ella nos presentamos a un Congreso Nacional de Arquitectura que se celebró en Barcelona, y gracias a los invitados extranjeros que asistían (Gio Ponti y Alberto Sartoris) se conoció y publicó fuera de España» (Capitel y Ortega 1978, 23)

Dos fragmentos del discurso de Ponti son especialmente relevantes respecto a la tradición vernacual:

«La tradición y las costumbres nos han legado un fondo impalpable e inmaterial del que proviene la civilización y el honor de los pueblos antiguos. Por ejemplo la primitiva casa catalana puede parecer, y quizá lo sea, el antípoda de lo que hoy se exige como normas de higiene. Ciertamente, de esa casa no se deriva ninguna enseñanza que haya de servir para el confort actual; pero si brota de ella un fruto de espiritualidad de la mayor y más sagrada importancia.

(...) Los arquitectos españoles podéis traer una noble aportación a la arquitectura moderna sin necesidad de seguir el estilo que impera en el mundo. Nuestra época es profundamente dramática. A caballo entre el definitivo fin de un pasado irrepetible y el futuro desconocido, los hombres de estos tiempos tenemos que trabajar apoyados únicamente en un riguroso y entrañable sentido de tradición y cultura» (Ponti 1949)

\footnotetext{
${ }^{15}$ Si bien supuso el inicio del cambio, para entender mejor el ambiente imperante en 1949 y en el que se desarrolló el congreso, ver las imágenes publicadas en «La V Asamblea Nacional de Arquitectos. Barcelona - Palma de Mallorca -Valencia» En : Cuadernos de Arquitectura nº10, 1949
} 


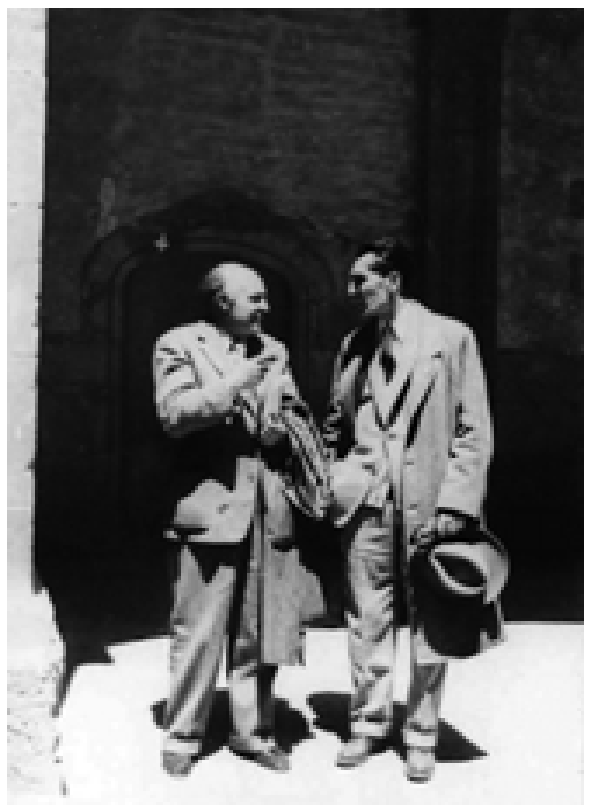

Figura 4.09

José Antonio Coderch con Gio Ponti

(Pizza y Rovira 2003, 75)

En el mismo año, 1951, José Antonio Coderch se encarga del Pabellón de España en IX Trienal de Milán, obteniendo el Premio Internacional y Medalla de Oro.

Un paño-expositor de fotografías, reinterpretación modificada de la persiana de lamas de madera y una superficie revestida con alfombrillas de paja larga usadas en preservar el lomo de los animales de carga, con varios estantes de vidrio, conforman dos de los tres paramentos que configuran el pequeño espacio de exposición en el que conviven objetos de artesanía popular y obras de Miró y Oteiza entre otros artistas. Coderch y su colaborador el poeta Santos Torroella, dan así respuesta a la convocatoria del evento que precisaba:

«ltalia invita a todas las naciones a presentar a la Triennale di Milano la documentación de las obras con las cuales la civilización moderna se expresa en arquitectura, en las industrias del arte y en el artesanado», "solo se admitirán obras de inspiración moderna, de efectiva originalidad y ejemplar factura. Quedarán excluidas las copias, las imitaciones y los productos que no respondan al uso y al gusto modernos»

El propio Coderch, en un informe dice

En la Triennale tienen cabida dentro del concepto de artes Decorativas los objetos antiguos y modernos de producción de artistas y artesanos, siempre y cunado los primeros, o sea los antiguos, estén de acuerdo con el gusto y corrientes modernas.

El pabellón, que tuvo un gran éxito y despertó el interés de Max Bill y Aldo van Eyck que estaban representando a sus países, significará un punto de inflexión en la obra de Coderch, alcanzando una comprensión de la tradición exenta de mimetismos. 
«Fue un verdadero galimatías compositivo y cromático, en parte por culpa nuestra, en parte por el tiempo de que disponíamos y, en parte también, por ciertos materiales llegados a última hora que tuvimos que aceptar. Aparte de sus grandes defectos, este pabellón me permitió conocer a Aldo van Eyck que nos ayudó mucho en los trabajos. A Max Bill le pareció bien y con este motivo nos invitó a cenar» (Capitel y Ortega 1978, 36)

«El arquitecto Van Eyck de la sección holandesa ha demostrado desde el principio mucho interés por el pabellón español ayudando incluso a los últimos trabajos. Pertenece al CIAM e indicó que propondría la constitución en España de un grupo adherido al CIAM. Actualmente los arquitectos españoles pertenecientes al citado organismo están todos fuera de España (expatriados) y no figuran como españoles. El arquitecto suizo Max Bill, visitó el pabellón con su señora elogiándolo mucho así como los objetos expuestos. El día de su regreso a Suiza nos invitó a comer...

...El arquitecto Rogers, nos ha dicho que el pabellón le gustaba mucho y nos ha invitado a su estudio» (Pizza y Rovira 2003, 98) 

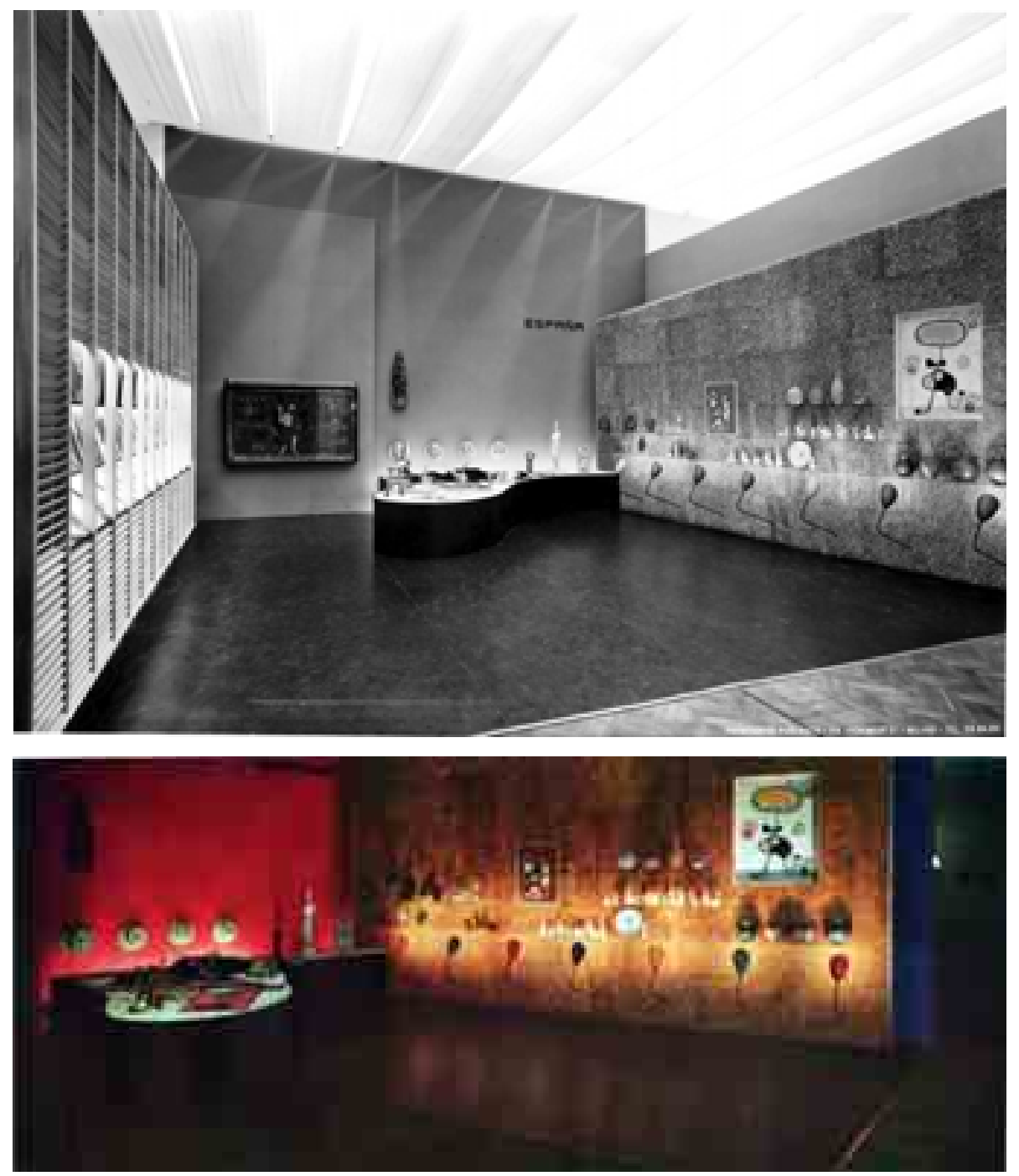

Figura 4.10

Pabellón de España en la Trienal de Milan en 1951. Medalla de oro.

* Superior

Imagen del conjunto. Archivo Coderch

* Inferior

Única foto en color del Pabellón de España en la IX Trienal de Milán en 1951 que se ha podido encontrar. Publicada en el numero 5 de 1951 de la revista Spazio, Rassegna delle Arti e dell'Architettura (1950-1953), dirigida por Luigi Moretti y reseñada en 2008 por Antonio Armesto en José Antonio Coderch (Armesto y Diez 2008, 26) 

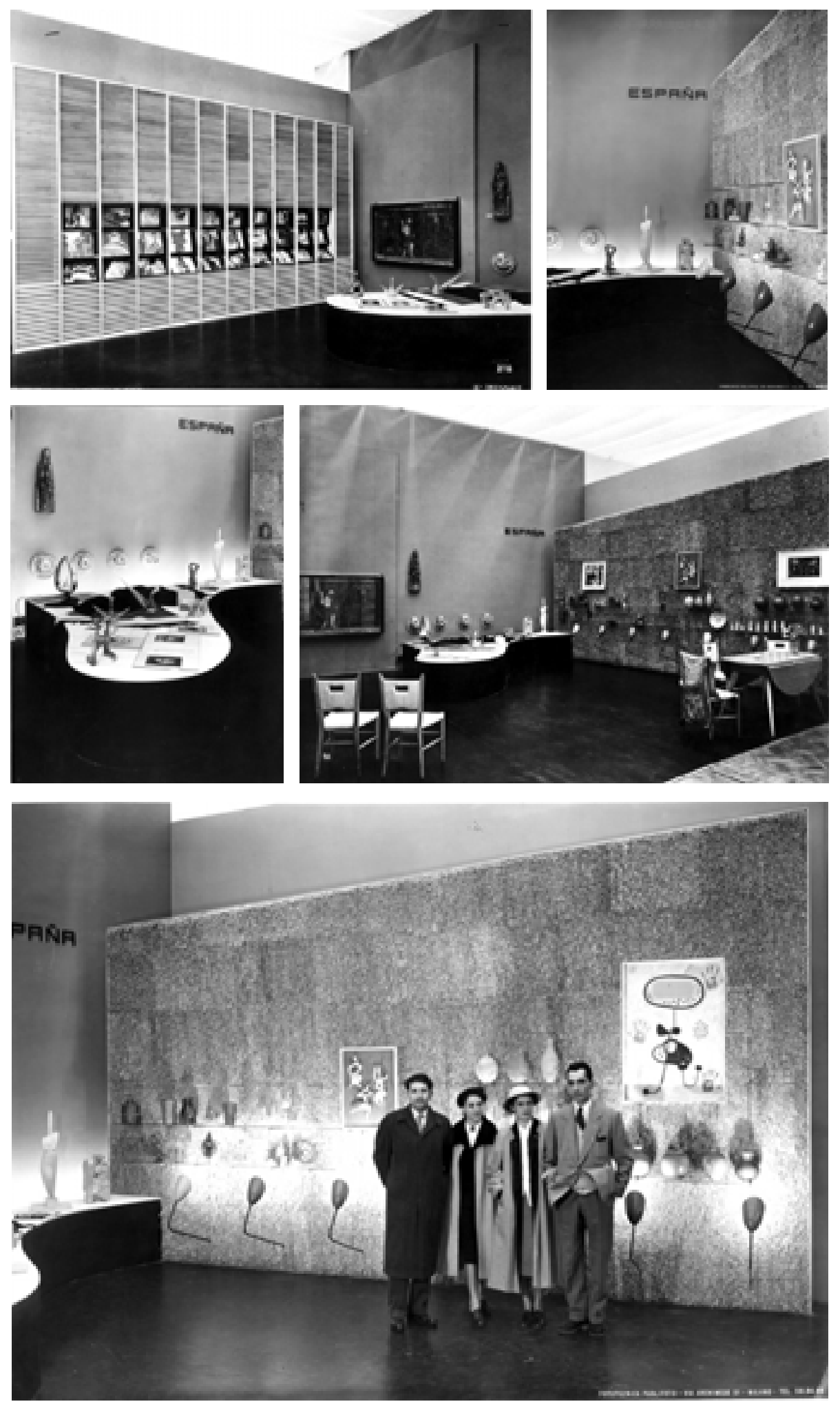

Figura 4.11

Pabellón de España en la Trienal de Milan en 1951. Medalla de oro. Imagen del conjunto. Archivo Coderch 


\subsubsection{Tradición viva y "No son genios lo que necesitamos ahora". Una reflexión sobre el escrito de J. A. Coderch en el contexto de Team 10.}

Han pasado más de 50 de años desde que José Antonio Coderch (1913-1984) escribiera No son genios lo que necesitamos ahora. Parece pertinente y necesaria una reflexión actual, con la perspectiva que confiere el paso del tiempo, comprobando la vigencia de sus principales valores, en el no muy estudiado contexto de su pertenencia al Team 10. Sin pasar por alto su retórica que, por qué no decirlo, no siempre le beneficia y responde a las peculiaridades históricas de nuestro pasado reciente y al carácter singular de la figura de Coderch.

El texto enviado a Jaap Bakema como secretario del Team $X$, se considera la aportación teórica más relevante de Coderch al grupo. Fue publicado en español y en ingles por primera vez en el número 384 de la revista Domus en noviembre de 1961. En diciembre del mismo año en la revista portuguesa Arquitectura, y en febrero de 1962 en el numero 38 de la revista Arquitectura del Colegio de Arquitectos de Madrid con comentarios de Luis Moya, P. A. López Quintas, Francisco de Inza y Juan Ramírez de Lucas.

Desde entonces fue reeditado en foros nacionales e internacionales, a veces con pequeñas variaciones, la más significativa en mayo de 1977 cuando es elegido por Coderch para su discurso de ingreso en la Real Academia de San Jorge bajo el titulo de Espiritualidad de la Arquitectura.

No es un texto formalmente moderno. Es un texto apasionado, comprometido, "imperfecto" y con un título provocador. No compartir alguno de sus párrafos, no debería significar dejar de reconocer sus valores.

Un artículo criticado y aplaudido, siempre controvertido, comentado entre otros por Carlos Flores, Antoni de Moragas, Enric Soria, Oscar Tusquets, Peter Smithson, Aldo van Eyck, etc.

...su influyente ensayo 'No son genios lo que necesitamos ahora' (1961) es su contribución más importante al discurso de Team 10. (Risselada y van den Heuvel 2005)

...Fue un genial arquitecto. Escribió el artículo "No son genios lo que necesitamos ahora", pero él realmente era un genio, un arquitecto fantástico, un artista. (Tuscano 1991)

.A veces la gente malinterpreta las cosas por la propia literalidad de la frase... .. De cualquier manera, el era un hombre impulsivo... sus opiniones, su crítica y austera actitud frente a al vida, deben ser juzgados en un singular contexto personal, ascético y tremendamente comprometido... (Mata 1987)

Se profundiza en el análisis de No son genios.. desde nuestro tiempo, reconociendo sus fortalezas y debilidades, los puntos convergentes y divergentes con sus contemporáneos en España, pero también en el exterior, principalmente en el contexto del Team $X$ y de sus relaciones con distintos miembros del grupo, por estar este aspecto menos investigado que otros. 

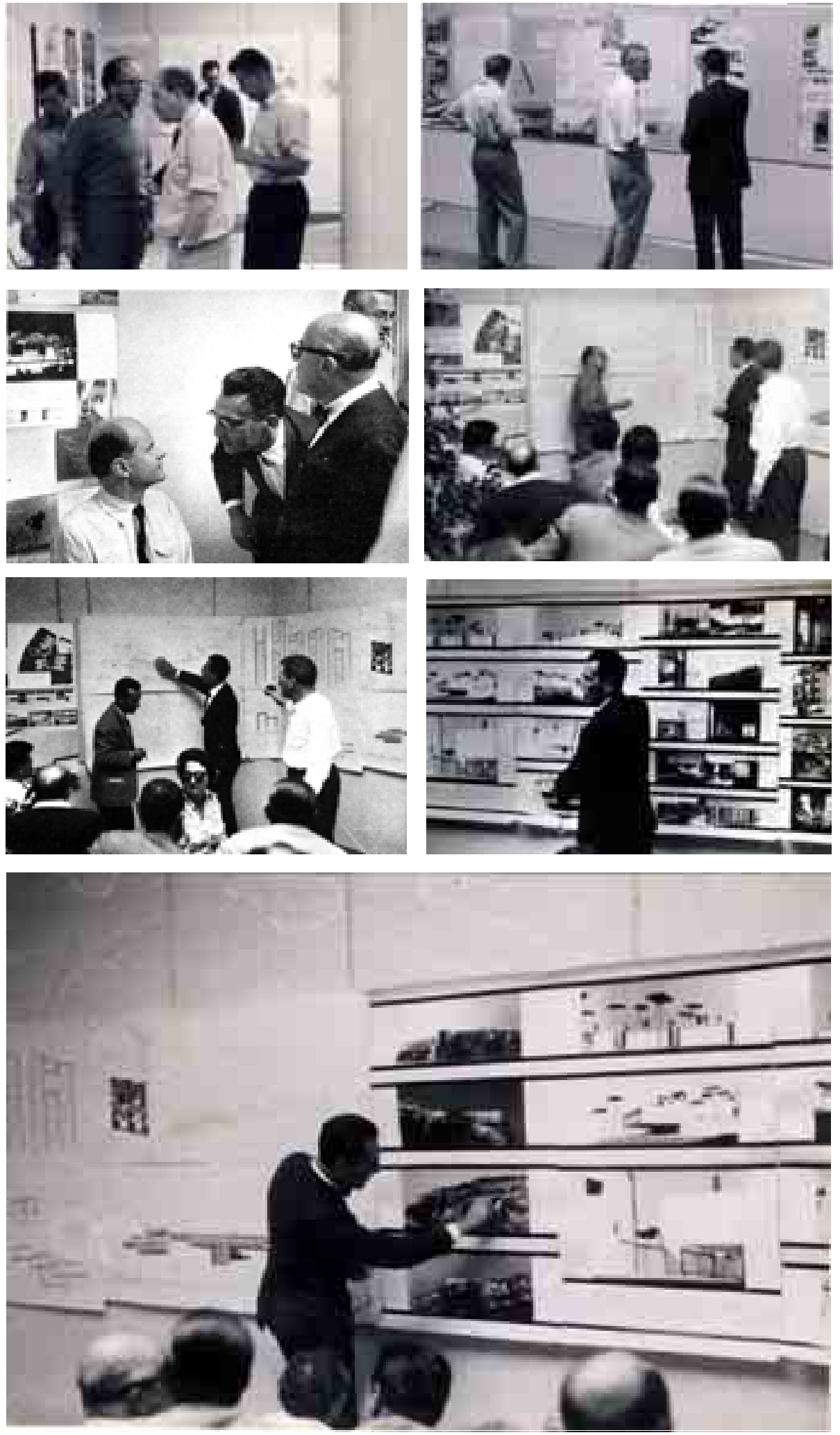

Figura 4.12

Imágenes del Congreso de Otterlo en 1959

* Superior

Aldo van Eyck en su presentación. A la derecha un grupo de asistentes, entre ellos Van Eyck, Alison Smithson y Coderch, observan la primera versión de los Circulos de Otterlo. (Strauven 1988)

* Inferior

Coderch en su presentación, explicando el proyecto de Torreo Valentina Arxiu Coderch 


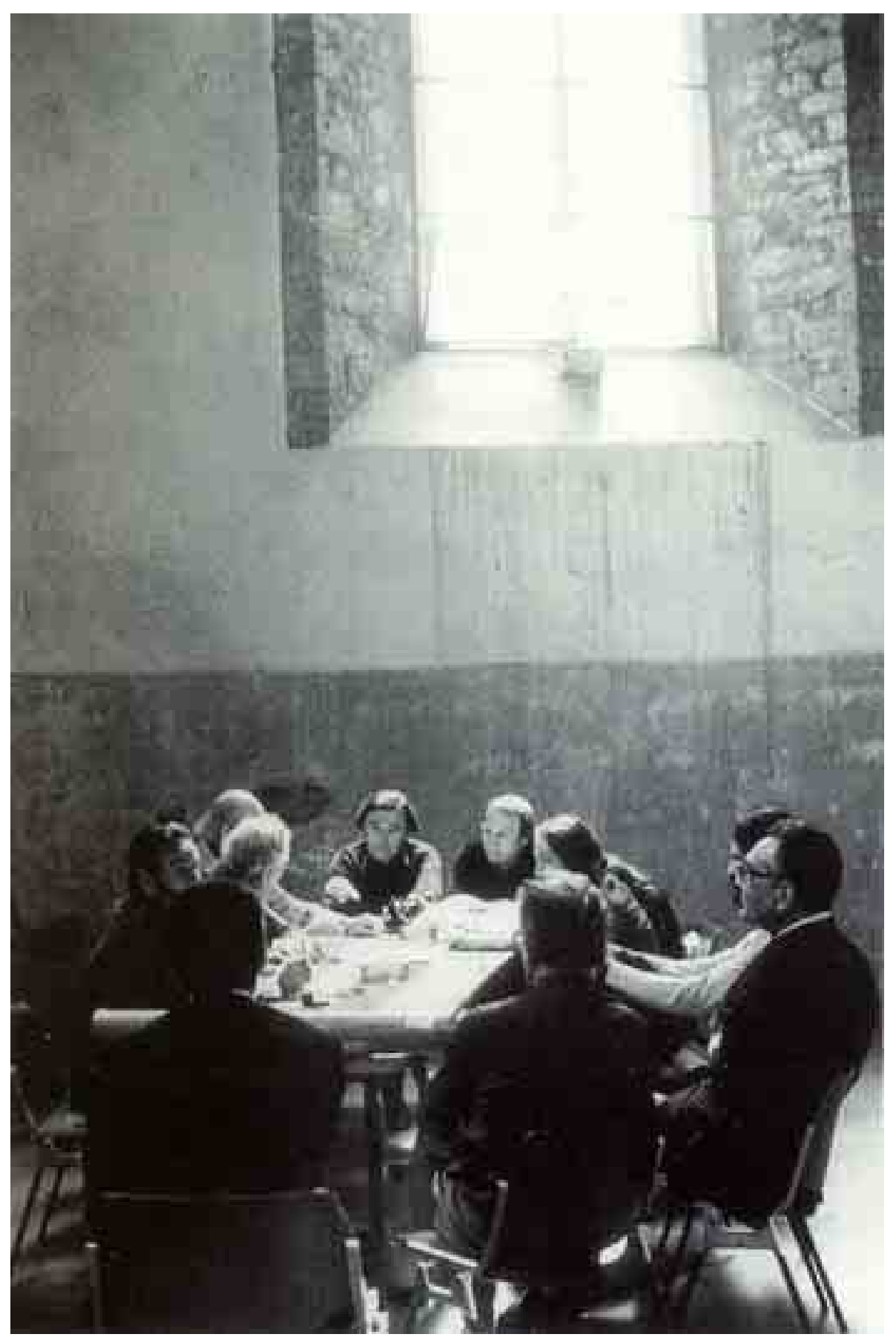

Figura 4.13

Team 10 en Spoleto, 1976 (Team 10 Archive, NAi) 


\subsubsection{Jose Antonio Coderch en el Team 10}

\begin{tabular}{|c|c|c|c|}
\hline Reunión / Localidad & Fecha & Coderch & Organizado \\
\hline $\begin{array}{l}\text { CIAM X } \\
1956 \\
\text { Dubrovnik, Yugoslavia }\end{array}$ & 3-13 agosto & -- & CIAM \\
\hline $\begin{array}{l}\text { CIAM La Sarraz } \\
1957 \\
\text { La Sarraz }\end{array}$ & 1-2 septiembre & -- & CIAM \\
\hline $\begin{array}{l}\text { CIAM'59. Fin CIAM } \\
1959 \\
\text { Otterlo, Países Bajos }\end{array}$ & 7-15 septiembre & Torre Valentina & $\begin{array}{l}\text { Van Ginkel / } \\
\text { Bakema }\end{array}$ \\
\hline $\begin{array}{l}\text { Team } 10 \\
1960 \\
\text { Bagnols-sur-Cèze, Francia }\end{array}$ & 25-30 julio & ¿? & Candilis \\
\hline $\begin{array}{l}\text { Team } 10 \\
1962 \\
\text { Royaumont, Francia }\end{array}$ & 12-16 septiembre & $\begin{array}{l}\text { Barceloneta } \\
\text { Problema barracas }\end{array}$ & Candilis/Woods \\
\hline $\begin{array}{l}\text { Team } 10 \\
1963 \\
\text { Paris, Francia }\end{array}$ & Diciembre & Asiste & Candilis/Woods \\
\hline $\begin{array}{l}\text { Team } 10 \\
1965 \\
\text { Berlín, Alemania }\end{array}$ & 25-29 septiembre & Invitado, no asiste & Woods \\
\hline $\begin{array}{l}\text { Team } 10 \\
1966 \\
\text { Urbino, Italia }\end{array}$ & 25-29 septiembre & Asiste & De Carlo \\
\hline $\begin{array}{l}\text { Team } 10 \\
1971 \\
\text { Toulouse-Le Mirail, Francia }\end{array}$ & 9-12 abril & Las Cocheras & Candilis \\
\hline $\begin{array}{l}\text { Team } 10 \\
1973 \\
\text { Berlin, Alemania }\end{array}$ & 2-4 abril & Invitado, no asiste & Schiedhelm \\
\hline $\begin{array}{l}\text { Team } 10 \\
1974 \\
\text { Rotterdam, Paises Bajos }\end{array}$ & 4-11 abril & Invitado, no asiste & Bakema \\
\hline $\begin{array}{l}\text { Team } 10 \\
1976 \\
\text { Spoleto, Italia }\end{array}$ & 2-6 junio & Asiste & De Carlo \\
\hline $\begin{array}{l}\text { Team } 10 \\
1977 \\
\text { Bonnieux, Francia }\end{array}$ & 9-12 junio & No asiste & Candilis \\
\hline
\end{tabular}

Figura

Reuniones del Team 10.

Elaborado por Ana Rodríguez según información de Risselada y Van den Heuvel, 2005

También se producen otros encuentros menores, en Paris y Londres en 1961, en Drottningholm Estocolmo en 1962, Paris 1967, y Milán 1968. Tienen un carácter diferente, en forma de grupos reducidos de trabajo con muy pocos participantes y sin sesiones críticas para explicar proyectos (excepto Londres diciembre de1969, en donde se expusieron algunos trabajos). 
Team $\mathrm{X}$ nace dentro de los CIAM, como continuación y desarrollo de las ideas del Movimiento Moderno, quedando el relevo oficialmente confirmado en 1959 en el congreso de Otterlo. Este grupo de arquitectos más jóvenes irrumpe, en el debate arquitectónico de posguerra, aspirando a desarrollar una ciudad moderna en términos de asociaciones e interrelaciones humanas, en el desafío que supone la construcción de vivienda colectiva a gran escala.

Plantean una nueva relación de aceptación de la tradición no mimética en la forma como fuente de conocimiento, de la especificidad entre proyecto y lugar, y en cómo llevar a término nuevas arquitecturas esenciales y verdaderas. También una forma de construir que refleje la personalidad de los materiales.

Josep Lluis Sert introdujo a José Antonio Coderch en los CIAM. En carta a Gio Ponti fechada el 31 de Agosto de 1959, Coderch así lo corrobora y escribe:

«Por fin he podido saber quién me había propuesto para tomar parte en el congreso. Fue José L. Sert al que no conocía entonces. El día 14 estuve cenando con él en su casa»

(Pizza y Rovira 2000)

En su primera participación en el Congreso de Otterlo presentó "Grupo de 150 viviendas, hotel y centro marítimo en Torre Valentina. Costa Brava". Desde entonces hasta el final, consta explícitamente en la documentación del grupo y en las revisiones que hace Alison Smithson para editar Team 10 Primer y Team 10 meetings, como miembro de Team 10 o perteneciente a los "core participants".

El registro de las reuniones se centra mayoritariamente en el trabajo realizado por Alison Smithson, material con el que posteriormente editó entre otras, las publicaciones ya mencionadas y por tanto es complicado conocer el papel desarrollado por cada uno de ellos. Sin menoscabar el ingente e insustituible trabajo desarrollado por Alison a título individual, la visión "oficial" del grupo nos ha llegado a través su mirada, con una elaboración material y emocionalmente valiosa pero inevitablemente personal.

En este sentido y de forma complementaria se ha tratado de consultar testimonios originales, que en relación con Coderch se articulan en tres tipos:

Son especialmente relevantes la serie de entrevistas realizadas por Clelia Tuscano en 1991 a varios miembros grupo con una mirada retrospectiva sobre aquellos años. Editadas por Max Risselada y Dirk van den Heuvel en Team 10, 1953-81: in search of a Utopia of the present, y posteriormente por Francis Strauven en Aldo van Eyck Writings. Un estudio atento en relación a la figura de Coderch, nos aporta una serie de testimonios que, por su valor en este caso concreto, a continuación se reproducen.

También hay que reseñar los comentarios de Peter Smithson, después de la muerte de Alison, en el texto Some thoughts in 1996 on the statement by Coderch written in August 1961, así como la entrevista realizada por Simona Pierini en julio de 2001 y publicada en Circo 2003.110 con el titulo Amigos de Coderch.

Por último la consulta del Arxiu Coderch antes de su cierre temporal, y del archivo Team 10 en el NAi de Rotterdam, han aportado documentos, algunos no publicados, con datos de gran interés.

Se considera que el conjunto de estas informaciones parciales, tratadas de forma conjunta pueden aportar una nueva perspectiva de estudio. 
George Candilis sobre José Antonio Coderch.

En 1959, la conferencia de Otterlo firmó el certificado de defunción del CIAM. Decidimos que Team 10 no se transformaría en otro CIAM. Esta opción fue tomada conjuntamente por todos los miembros, no en el espíritu de derechos exclusivos, sino debido al temor siempre presente de que el grupo llegara a institucionalizarse.

Team 10 era una organización informal; solo teníamos una secretaría que llevaba Bakema. Decidimos reunirnos con motivo de acontecimientos arquitectónicos como concursos o proyectos de construcción. Así es como hemos funcionado hasta ahora -o en cualquier caso- hasta el año que murió Bakema.

Conquistamos a algunos arquitectos de renombre: el inglés Brian Richards, Giancarlo de Carlo, Wewerka, lo mismo que Soltan, Guedes, Erskine y Coderch. No voy a mencionar Kurokawa o Alexander, que pronto abandonaron o fueron expulsados $^{16}$. (Tuscano 1991)

Ralph Erskine sobre José Antonio Coderch.

.. También me gustaba Coderch que era miembro del grupo, era muy inteligente: sus casas aterrazadas son muy buena arquitectura, y Van Eyck, por supuesto, que hablaba de una manera muy seductora de su iglesia en La Haya, con lucernarios circulares en el hormigón armado ${ }^{17}$. (Tuscano 1991)

\section{Giancarlo de Carlo}

... Otro carácter interesante era José Antonio Coderch. Fue un muy buen arquitecto, de derechas y sin embargo un oponente de la arquitectura académica que Franco favorecía, y pagó un precio por ello. Sus primeras obras eran muy sutiles. En Otterlo, inmediatamente se alió con nosotros y luego continuó viniendo a nuestras reuniones. Federico Correa solía venir con él, pero nunca le consideramos miembro del Team 10, no. Nunca solía mostrar su trabajo en las reuniones ${ }^{18}$. (Tuscano 1991)

${ }^{16}$ In 1959, the Otterlo conference signed CIAM's death certificate.

We decided that Team 10 would not be transformed into another CIAM. This option was taken conjointly by all the members, not in the spirit of exclusive rights, but due to the ever-present fear of the group becoming institutionalized.

Team 10 was an informal organization; we just had a secretariat that Bakema managed. We decided to meet up on the occasion of architectural events such as competitions or construction projects. That's how we've functionated up until now -or in any case- until, the year Bakema died. We won over some well known architects: the Englishman Brian Richards, Giancarlo de Carlo, Wewerka, as well as Soltan, Guedes, Erskine and Coderch. I won't mention Kurokawa or Alexander, who soon left or were pushed out.

(Traducción al castellano de la autora).

${ }^{17}$...I also liked Coderch who was a member of the group, he was very clever: his terrace houses are very good architecture, and van Eyck, of course, who spoke in a very seductive way of his church in The Hague, with round skylights in reinforced concrete.

(Traducción al castellano de la autora)

18 ....Another interesting carácter was José Antonio Coderch. He was a very fine architect, a rightwinger yet an opponent of the academic architecture Franco favoured, and he paid a price for it. His early works were very subtle. At Otterlo he immediately sided with us and then continued to come to our meetings. Federico Correa used to come with him, but we never considered him a member of Team 10, not did he. He never used to post his work at the meetings.

Traducción al castellano de la autora. 
Aldo van Eyck sobre Jose Antonio Coderch.

Sería muy difícil expresar cual fue la contribución específica de cada uno de nosotros. Por ejemplo, ¿qué podría decir de Antonio Coderch?, excepto que fue el arquitecto con más talento de todos. Un gran arquitecto. Era muy sensible, no discutía mucho, una figura solitaria; era estricto, moralmente estricto, pero no dogmático; era católico y puritano. Fue un genial arquitecto. Escribió el artículo "No son genios lo que necesitamos ahora", pero él realmente era un genio, un arquitecto fantástico, un artista. Era una persona complicada, un moderno en términos de arquitectura, un gran amante de Miró y Lorca y también un gran amigo de ambos; por otra parte, pertenecía a una especie de familia aristócrata catalana. En Team 10 daba la impresión de estar en contra de todo el mundo, pero siempre venía. No hablaba mucho, pero aún así era una persona altamente influyente en Team 10.

Una vez que expuso su edificio de viviendas junto al mar, participé en el debate diciendo: "Ahora has apuntado el hecho que son casas caras para ricos, así que al final tienes que hacer un juicio social sobre si construyes para los ricos o para los pobres". Y él respondió: "Esto puede ser fuente de inspiración para las casas pobres en el futuro. Las casas para los ricos son importantes porque se convertirían en una especie de ejemplo para todo el mundo". Y en Holanda rápidamente se volvió cierto: si construyes un gran balcón en una casa porque tienes el dinero para hacerlo, entonces, si es un buen edificio, se convierte en un estándar para los demás. Y eso es, en cierto modo, el trabajo del arquitecto $^{19}$. (Tuscano 1991)

Peter Smithson

...la posición individualista de Team 10 estaba generada por la procedencia étnica y por la cultura.

...nosotros éramos personas relativamente sencillas, nacidos en una cultura protestante. Aquella era gente muy exótica. Eran animales diferentes. Ahora todo esto ha desaparecido, porque existen la cultura europea y los ojos americanos. Ya no se da aquel sentido de la diferencia, de lo exótico...

... Coderch, en este sentido, era un verdadero animal exótico. Era un caballo. Si, se parecía a un caballo, noble y bello. Esta me parece una óptima descripción.

...para nosotros Coderch era un punto de interés. Un punto importante fue también su españolidad. Otros eran más fáciles de describir. Coderch era más misterioso. España para nosotros es lejanísima. Africa, más allá de los Pirineos.

19. It would be very difficult to formulate what the specific contribution of each of us was. For example, what should I say about Antonio Coderch? Except that he was the most gifted architect of the lot. A great architect. He was very emotional, he didn't argue much, a solitary figure; he was severe, morally severe, but not dogmatic; he was a puritan and catholic. He was a genius architect. He wrote the article "It isn't geniuses we need now", but he really was a genius, a fantastic architect, an artist. He was a complicated person, a modernist in terms of architecture, a great lover of Miró and Lorca and a great friend of them too; on the other hand, he was from a sort of basic Catalan aristocrat family. In Team 10 he gave the impression of being against the people around him, but he probably always came. He didn't say much, but still he was a highly influential person in Team 10.

Once he gave an expo of his housing near the sea, and I took part in the discussion saying: "Now you've got down to the fact that these are rich houses for rich people, so in the end you have to give a social judgment whether you build for the rich people or for the poor". And he answered: "This may bean inspiration for the poor houses in the future. The houses for the rich are important because they became a kind of example for everybody". And in Holland it quickly turned out to be the way: if you build a large balcony on a house because you have the money to build it, then, if it's a good building, it becomes a standard for other ones. And that is, in a way, the job of the architect.

(Traducción al castellano de Ana Rodríguez) 
..El papel de Coderch era el de ser arquitecto, y hacer de esto una profesión, un oficio en el sentido noble.

Mi hijo trabaja en Madrid y he ido dos o tres veces. Hemos ido recientemente a visitar un edificio de Coderch de los años sesenta, perfecto.

Estaba muy bien construido...

...Era un gentleman arquitecto.

No era un arquitecto tradicional. Parece extraño decirlo, porque era un profesional. Pero no trabajaba para ganar dinero. Trabajaba como hace un médico o un sacerdote, porque creía en algo.

Quizás era el único verdadero arquitecto, en este sentido, del Team X. Nosotros éramos mas "artistas"....

...El Team X era, para Alison y para mi, algo completamente central, emotivamente. Aldo van Eyck decía, cuando estaba enfadado, que no quisiera haber oído hablar nunca del Team X. Para Alison y para mí, esto era inconcebible. Para nosotros el Team $X$ era como un proceso. Explico: llegábamos con un huevo y salíamos con una gallina. Nosotros identificábamos nuestras ideas en el Team X. Es por esto que estábamos tan enfrentados con los periodistas. Ellos no traían huevos. No pretendían crecer.

Coderch, por el contrario, era importante.

¿Por su distinto modo de ser?

Quizás. Por ejemplo, Coderch era católico practicante, pero era una buena persona $^{20}$. (Pierini 2003)

Si bien Coderch en el Team 10, no fue tan claramente relevante en comparación con el núcleo duro formado por Aldo van Eyck, los Smithsons, Bakema, Candilis y posteriormente De Carlo, no necesariamente implica una aportación irrelevante o intrascendente. El papel protagonista de ese pequeño grupo, no es comparable prácticamente con nadie más.

De los 50 nombres que Max Risselada incluye en la lista de participantes, de uno u otro modo, en las reuniones del grupo a lo largo casi 30 años, 1953-1981, incluyendo el periodo final del llaud de Giancarlo de Carlo, gran parte de ellos tuvieron participaciones muy puntuales.

No en el caso de Coderch. Ya se ha mencionado su pertenencia al grupo como miembro nato, aunque no asistiera a los encuentros preparatorios entre congresos. En realidad, muy pocos lo hacían.

Coderch solo asistió a las conferencias, articuladas en torno a los debates derivados de la exposición de trabajos. De hecho el mismo participó en varías presentando sus propias obras, algo que realmente no muchos hacían. Hay que tener en cuenta lo que implicaba exponerse al debate y muchas veces posiciones encontradas, de las sesiones críticas, pues la exposición de proyectos servía como vehículo para debatir de diversos temas, no en abstracto, sino desde situaciones concretas.

\footnotetext{
${ }^{20}$ I have kept in my head all these years a single sentence from this statement, which I then, and now, think of being very Spanish.

"In Spain, my parents used it tell me, a gentleman, an aristocrat, is the person who finds himself unable to do certain things which even the law, the Church, and de majority approve of o permit." Of course one has to be careful with words, they adumbrate, often falsely, the thoughts, or more critically, the posture of the speaker.

But buildings...think of Mies'Farnsworth House, Le Corbuiser's Armé de Salut, Duiker's Zonnestraal, Kahn's Trenton Bath House.

Words may have helped (I doubt it), but it is the building that is the ethic. (Traducción al castellano de la autora)
} 
Posicionar el papel y responsabilidad del arquitecto en la sociedad y la ciudad modernas, en el ambiente de la reconstrucción después de la Segunda Guerra mundial, centra el debate arquitectónico internacional. En este contexto, el interés por construir les unía.

La doble actividad profesional y teórica de los Smithsons y van Eyck, no fue tan frecuente como pudiera parecer. En ese sentido Coderch, fundamentalmente representa como explica Peter Smithson, el papel del arquitecto que hace proyectos y los construye, y precisamente por eso es especialmente valorado. De hecho, el mayor interés de los Smithson fue siempre la realización de encargos, aunque mantuvieran una extraordinaria labor de difusión de sus planteamientos en escritos y publicaciones.

La relación entre las cosas, más que los objetos en sí, fundamenta los planteamientos arquitectónicos y urbanos del Team 10, postura que también se trasladará a la composición del grupo.

La heterogeneidad es uno de sus rasgos característicos de Team 10 y seguramente la clave de la fuerza. En la diversidad de personalidades que lo conforman, la singularidad de Coderch, encuentra acomodo con todas sus contradicciones.

Por otra parte, no hay que olvidar el contexto político español. Aunque no se hablara de política (según recogen varios textos entre ellos Peter Smithson), hay que pensar la seguramente incomoda o extraña posición de los participantes portugueses y españoles, procedentes de países con regímenes dictatoriales, en los años de la construcción de la Europa democrática, e inmersos en un grupo mayoritariamente progresista que se cohesionaba fundamentalmente a través de las relaciones personales. En el caso de Coderch, unido a su religiosidad, a su origen de familia aristócrata, y a su reconocido posicionamiento en la Guerra Civil en contra del gobierno de la Segunda Republica española legalmente establecido.

Coderch mantuvo una cordial relación con el grupo.

Sin establecer valoraciones sobre los grados de amistad, una lectura sensible, un rastreo minucioso y atento al detalle de la documentación existente, indica cuando menos admiración profesional, aprecio y respeto hacia Coderch.

Alison Smithson y Jose Antonio Coderch, se llevaban especialmente bien, según constatan Ana y José Antonio Coderch Jiménez, y lo corroboran algunos fragmentos de cartas, como el del borrador en castellano de la famosa enviada a Alison. La frase final, solo puede comprenderse en una relación de confianza y amistad. (Fochs 1989) «querida Alison, mi inglés es cada vez peor y me siento cada día más estúpido»

Por otra parte, es conocida la fuerte personalidad de Alison y su influencia en la aceptación de una persona dentro del grupo. Así lo cuenta Peter refiriéndose a Coderch «Era ella quien descubría a las personas. Era ella quien tomaba contacto con ellas: Ios invitados a las reuniones del Team X eran todos escogidos por Alison»

Coderch murió en 1984, relativamente joven, de una enfermedad degenerativa del sistema nervioso que duró varios años. Su último congreso será la reunión de Spoleto en 1976, a la que acude con sus hijos Gustavo y José Antonio, y un pequeño grupo de jóvenes arquitectos catalanes entre otros Oscar Tusquets y Cristian Cirici ${ }^{21}$.

Alison Smithson en un documento de 13 páginas titulado Team 10: The myth and the Message, hace una breve reseña de la participación de cada miembro, y de Coderch dice «José Coderch, after Otterlo until he would not travel any more» (Team 10 Archive, $\mathrm{NAi})$

\footnotetext{
${ }^{21}$ La información sobre la asistencia de estos últimos ha sido facilitada por el profesor Max Risselada.
} 

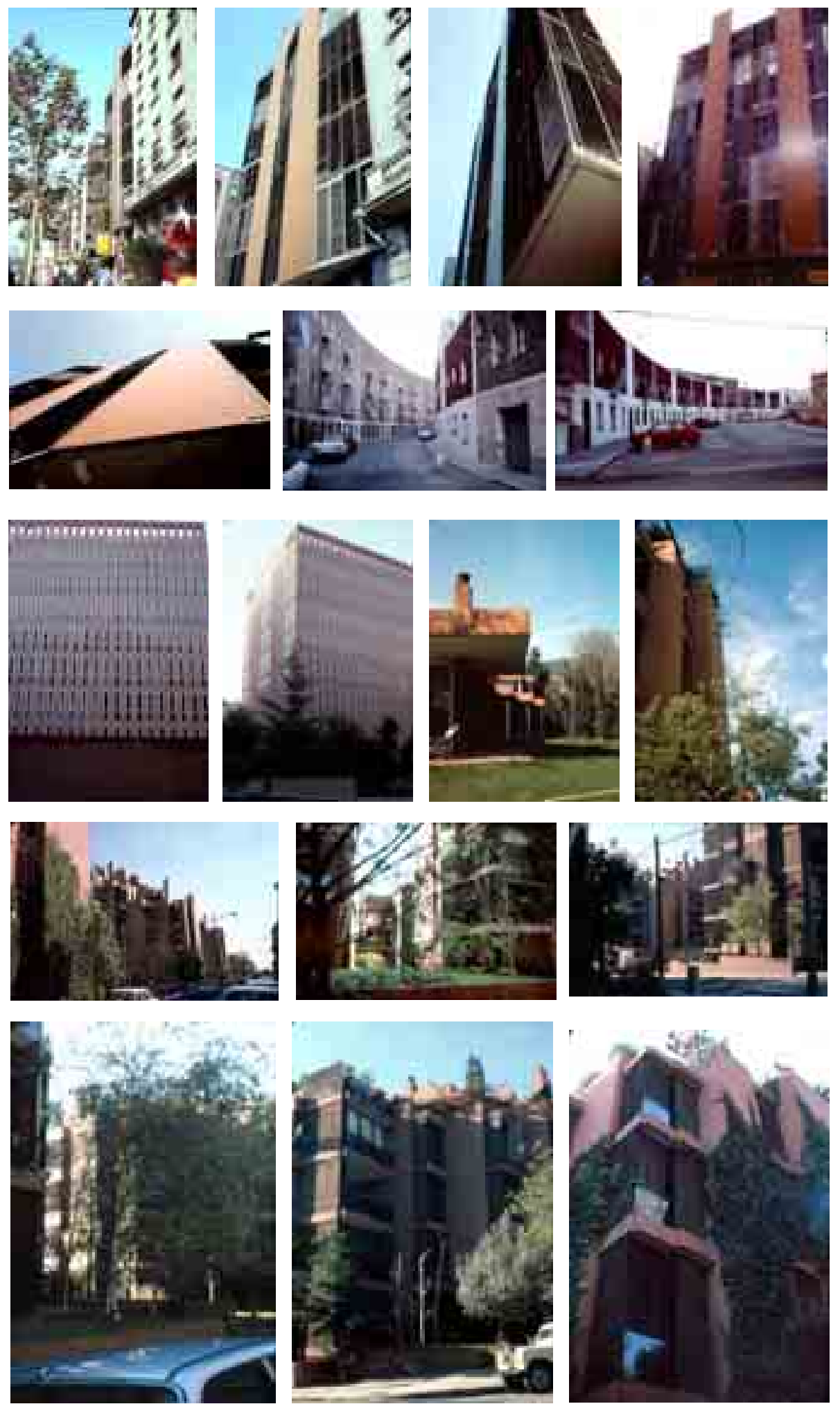

Figura 4.14 a

Colección personal de Peter Smithson de diapositivas con obra de los integrantes de Team 10. La colección se compone 204 diapositivas hechas por Peter Smithson, fotografiando obra de Bakema, De Carlo, Candilis, Coderch, Van Eyck, Guedes y una miscelánea de congresos de Team 10.

Sobre obras de José Antonio Coderch, hay 33 diapositivas fotografiadas por Peter Smithson: 5 diapositivas del Edificio de la Barceloneta, 2 diapositivas de las Viviendas de pescadores cerca del puerto de 1952, 2 diapositivas del Instituto francés, 1 diapositiva de la Casa Güell en Barcelona, 13 diapositivas de las Viviendas Banco Urquijo, 2 diapositivas de Viviendas en Cocheras, y 7 diapositivas de la Casa Tapies.

TTEN 0010 (761-0010) f32

(Team 10 Alison and Peter Smithson Archive, NAi, Rotterdam) 

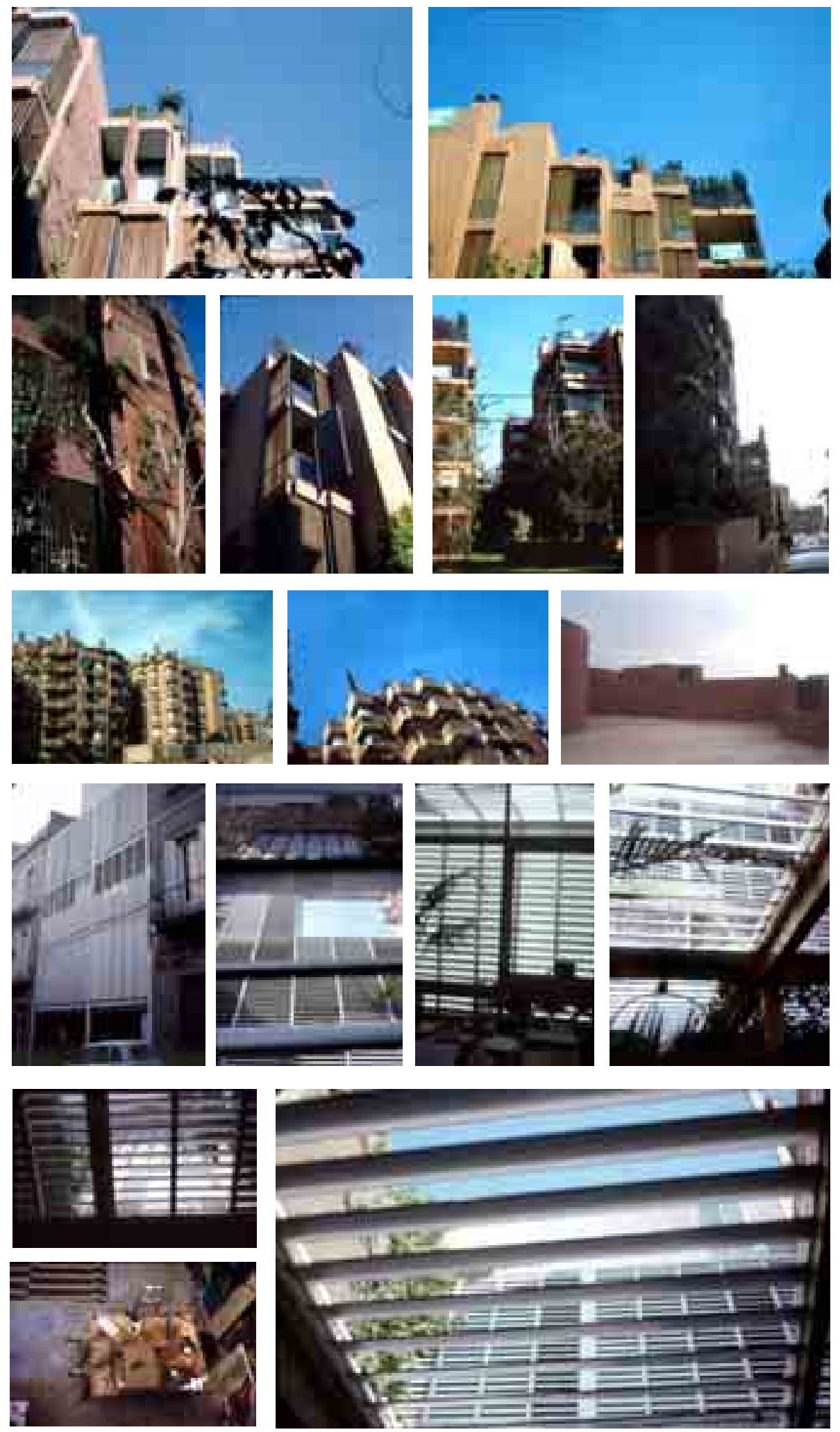

Figura 4.14 b

Colección personal de Peter Smithson de diapositivas con obra de los integrantes de Team 10. La colección se compone 204 diapositivas hechas por Peter Smithson, fotografiando obra de Bakema, De Carlo, Candilis, Coderch, Van Eyck, Guedes y una miscelánea de congresos de Team 10.

Sobre obras de José Antonio Coderch, hay 33 diapositivas fotografiadas por Peter Smithson: 5 diapositivas del Edificio de la Barceloneta, 2 diapositivas de las Viviendas de pescadores cerca del puerto de 1952, 2 diapositivas del Instituto francés, 1 diapositiva de la Casa Güell en Barcelona, 13 diapositivas de las Viviendas Banco Urquijo, 2 diapositivas de Viviendas en Cocheras, y 7 diapositivas de la Casa Tapies.

TTEN 0010 (761-0010) f32

(Team 10 Alison and Peter Smithson Archive, NAi, Rotterdam) 

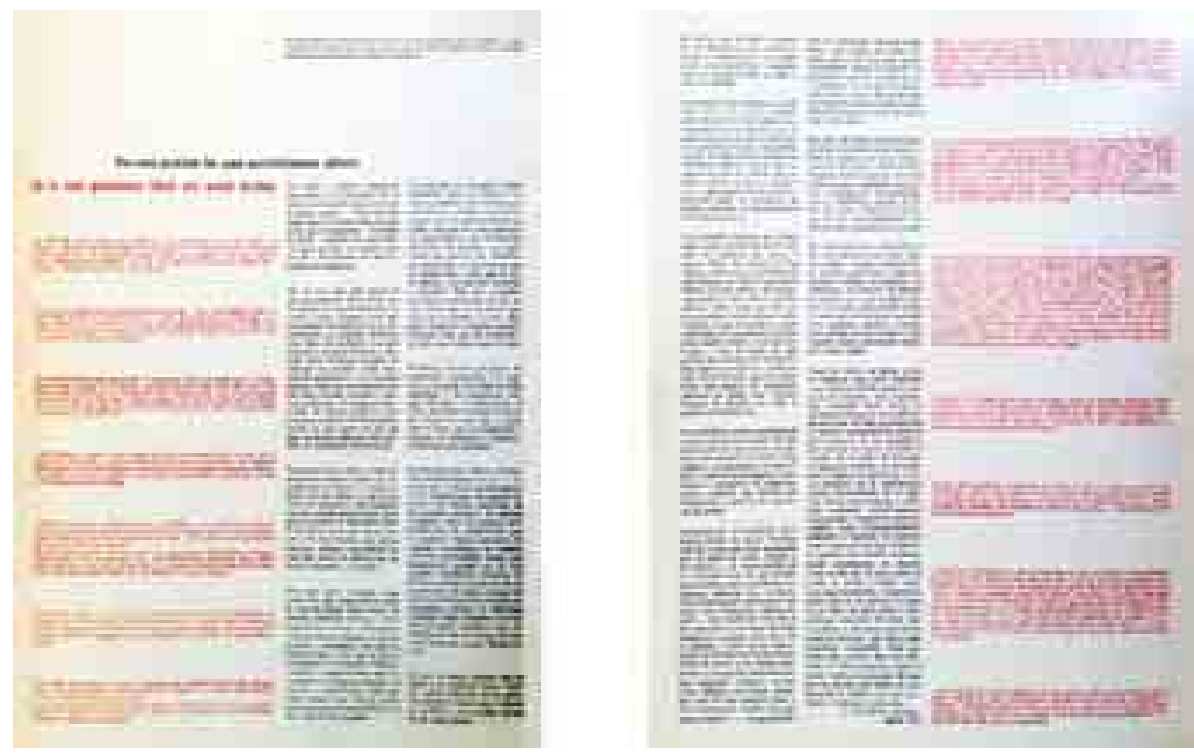

Figura 4.15

Primera publicación de No son genios lo que necesitamos ahora. Revista Domus n³84, 1961 


\subsubsection{Algunas reflexiones sobre No son genios...}

Muchos comentarios se han hecho de No son genios...

Los más recientes al hilo de la crisis actual, para poner en evidencia los desmanes ocurridos en los últimos años, pero olvidando en sus críticas, al menos aparentemente, todo lo de valor que también se ha hecho.

El poder de difusión de internet, en ocasiones lo está convirtiendo en bandera pirata de planteamientos contrapuestos, pero siempre interesados, demostrando muy poco respeto por su autor.

Al igual que el texto pretende desenmascarar la mediocridad que se esconde tras los falsos genios, cuya existencia es evidentemente escasa, tampoco debería emplearse para enmascarar la falta de talento.

Responsabilidad, sentido del deber, honestidad, honorabilidad. Generosidad y amor al trabajo, a la profesión, a la arquitectura, al medio que nos rodea. La tradición construida como fuente de aprendizaje sin renunciar a la técnica moderna. La puesta en valor del proceso frente a la búsqueda de soluciones predeterminadas. El compromiso con la ciudad y el territorio...Son grandes valores presentes en texto.

Sin embargo, no se puede pasar por alto su retórica y el maximalismo de algunas afirmaciones: masas, aristocracia, Ley, Iglesia.... Que trabajen con una cuerda atada al pie..., le confieren un tono muy superado.

Cabria preguntarse en qué medida responden al contexto político del país y en cuanto a su carácter y posicionamiento ideológico

En este sentido pueden ser pertinentes, una serie comentarios de Peter Smithson coincidentes con algunos de los aspectos ya mencionados

Recuerdo que, en nuestros encuentros, Coderch hablaba un inglés muy académico, y era como hablar con una traducción, todo sonaba muy radical. De lo que nunca se habló fue del problema de la guerra civil española. En el Team $\mathrm{X}$ tendíamos a ser de izquierda, así que todo lo que se decía nos parecía muy radical.» (Pierini 2003)

He mantenido en mi cabeza todos estos años una sola frase de esta declaración, que ya entonces, y ahora, pienso que es muy español.

"En España, mis padres solían decirme que un caballero, un aristócrata, es la persona que no hace ciertas cosas aun cuando la Ley, la Iglesia, y la mayoría las aprueben o las permitan."

Por supuesto, uno tiene que tener cuidado con las palabras, que eclipsan, a menudo erróneamente, los pensamientos, o de forma más crítica, la postura del orador.

Pero los edificios ... pensar en la Casa Farnsworth de Mies, el Armé de Salut de Le Corbuiser, el Zonnestraal de Duiker, la Trenton Bath House de Kahn.

Las palabras podían haber ayudado (lo dudo), pero es el edificio lo que es la ética. (Smithson 1996)

Paradójicamente, la tormentosa personalidad de Coderch, siempre se mantuvo un poco al margen de los agitados enfrentamientos dentro del grupo «el siempre mantuvo una cierta distancia respecto a las frenéticas discusiones del Team 10. Su influyente ensayo "No son genios lo que necesitamos ahora" (1961) es la más importante contribución al discurso de Team 10» (Risselada y van den Heuvel 2005).

En estas líneas, corroboradas posteriormente en conversación personal mantenida con él sobre este tema, el profesor Risselada deja intuir la relación existente entre la redacción de No son genios..., y el ambiente crispado a veces evidente. 
Personalmente considero este planteamiento revelador y aporta una nueva visión sobre el tema. En la consulta de los archivos he podido encontrar un documento inédito, que si bien no es definitivo, si refuerza esta hipótesis: Es una carta de Coderch a Bakema sobre sus impresiones del congreso de Otterlo, proponiendo algunas medidas para mejorar las siguientes reuniones. Refleja una mezcla de preocupación, interés e incomodidad por «la violencia de muchas de las intervenciones». El estar escrita el día 22 de mayo de 1962, con posterioridad a No son genios..., no menoscaba su valor.

La carta también refleja el interés de Coderch por el grupo. En la posdata, traslada a Bakema su decisión de pedir su aceptación de pertenecer a Team 10, a pesar de su conocido «...no me gustan los movimientos arquitectónicos o artísticos; hay gran falsedad en ellos.»

No se propone que Coderch escribiera No son genios... abstrayéndose de la realidad española, sino que su lectura desde el punto de vista planteado, en el contexto de Team 10, puede aportar claves diferentes y complementarias para su mejor entendimiento.

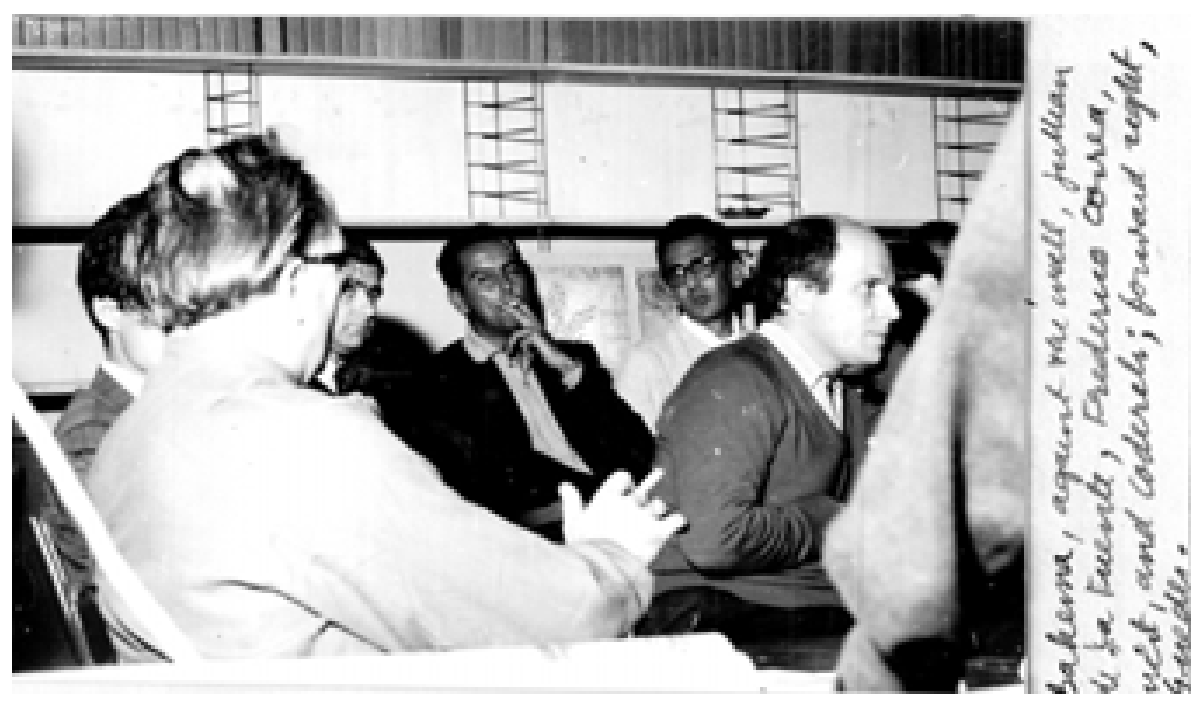

Figura 4.16

Reunión de Team 10. Centro al fondo Federico Correa y Jose Antonio Coderch (Team 10 Archive NAi) 


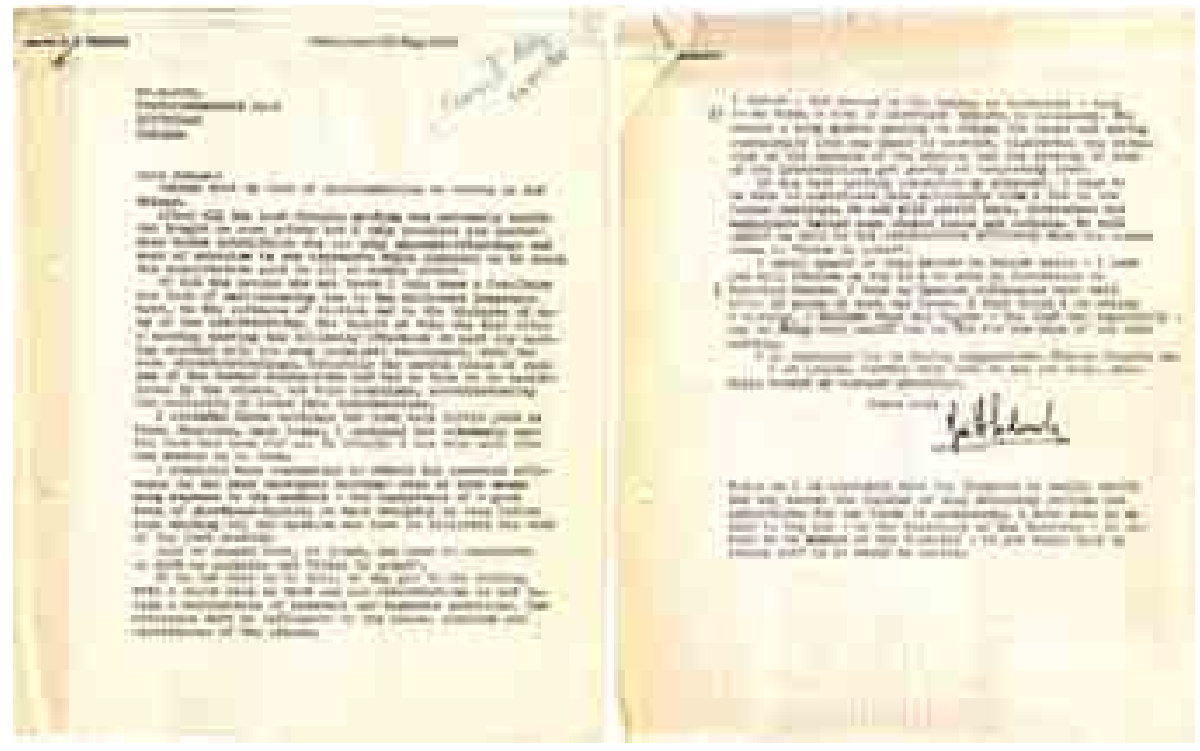

Figura 4.17

Carta de Coderch a Bakema, fechada el 22 de mayo de 1962 (Team 10 Archive NAi) 
A continuación se transcribe la carta completa

Barcelona 22-May-1962

Dear Bakema:

I Think that by lack of discrimination we attain so few things.

After all the last Otterlo meeting was extremely useful and taught us some points but I only realized its usefulness weeks later. There was too many missunderstandings and want of cohesion in our arguments which hindered us to reach the constructive goal we all warmly wished.

Of all the people who met there I only knew a few. There was lack of understanding due to the different languages used, to the quickness of diction and to the violence of many interventions. The result of this was that after a morning meeting the following afternoon or next day meeting started with the same passional excitement, with the same misunderstanding. Naturally the useful ideas of each one of the former discussions had had no time to be assimilated by the others, and this sometimes, notwithstanding the authority of Louis Khan interventions.

I attended these meetings but took very little part in them. Moreover, much later, I realized how extremely useful they had been for me. In Otterlo I was very much like the statue in D. Juan.

I consider very convenient to obtain the greatest efficency in the next September meeting -even if that means more expence to the members- the assistance of a good team of shorthand-typists so that everyday or even before each meeting all the members may have in ciclostyl the text of the last meeting.

Also we should have, at least, on hour to assimilate as much as possible and "faire le point".

If we are able to do this, we may get to the meeting with a clear head so that our interventions do not become a reiteration of personal and dogmatic positions. Our attitudes must be influenced by the ideas, opinions and experiences of the others.

I insist - and excuse me for being so insistent- that to do this, a team of shorthand typists is necessary. The record-tape system needing to change the tapes and moving continually from one place to another, distracted the attention of the members of the meeting and the meaning of many of the interventions got partly or completely lost.

If the next meeting considers my proposal, I hope to be able to contribute more efficiently than I did in the former meetings. We all will profit more, understand and assimilate better each others ideas and methods. We will profit as well in the constructive efficiency when the moment comes to "faire le point".

I avail myself of this letter to insist again -I hope you will forgive me for it- to send an invitation to Federico Correa. I know my Spanish colleagues very well after 22 years of work and trade. I don't think I am making a mistake. I believe Oiza and Correa -the last one especially- may be really very useful for us and for the aims of our next meeting.

I do apologise for my daring suggestions. Please forgive me.

I am looking for very much to see you soon, meanwhile accept my warmest greetings.

Yours ever

$\mathrm{P}: \mathrm{S}$.

As I am convinced that the Team-ten is really useful and may become the impulse of many necessary reforms and initiatives for our trade of Architects, I have made up my mind to beg you -as the Secretary of the Team-10- to accept 
me as member of the Team-ten - if you think that my taking part in it would be useful $\left.\right|^{22}$.

\section{Barcelona 22 de mayo 1962}

Querido Bakema:

Creo que por la falta de discernimiento alcanzamos tan pocas cosas.

Después de todo la última reunión de Otterlo fue extremadamente provechosa y nos enseñó algunos puntos, pero solo me di cuenta de su utilidad semanas más tarde. Había demasiados malos entendidos y falta de cohesión en nuestros argumentos que nos impedían llegar a la meta constructiva que todos cordialmente deseábamos.

De todas las personas que se reunieron sólo conocía a unos pocos. Hubo falta de comprensión debido a los diferentes idiomas, a la rapidez de la dicción y a la violencia de muchas intervenciones. El resultado de esto fue que después de una reunión en la mañana, la siguiente reunión por la tarde o al día siguiente comenzaba con la misma excitación pasional, con el mismo malentendido. Naturalmente, las ideas útiles de cada uno de los debates anteriores no habían tenido tiempo de ser asimiladas por los demás, y esto a veces, a pesar de la autoridad de las intervenciones de Louis Khan.

Asistí a estas reuniones, pero participé muy poco en ellas. Por otra parte, mucho más tarde, me di cuenta de lo extremadamente provechosas que habían sido para mí. En Otterlo yo estuve muy parecido a la estatua de D. Juan.

Considero muy conveniente para obtener la mayor eficiencia en la reunión del próximo mes de septiembre -incluso si eso significa más coste para los miembros- la ayuda de un buen equipo de taquimecanógrafos para que todos los días o incluso antes de cada reunión todos los miembros pueden tener en ciclostil el texto de la última reunión.

También deberíamos tener, al menos, una horas para asimilar tanto como sea posible y "hacer balance".

Si somos capaces de hacer esto, podíamos llegar a la reunión con la cabeza clara para que nuestras intervenciones no se conviertan en una reiteración de las posiciones personales y dogmáticas. Nuestras actitudes deben ser influidas por las ideas, opiniones y experiencias de los demás.

Insisto - y me disculpo por ser tan insistente- que para hacer esto, es necesario un equipo de taquimecanógrafos. El sistema de de cinta de grabación necesita cambiar las cintas y moverse continuamente de un lugar a otro, distraería la atención de los miembros de la reunión y el significado de muchas de las intervenciones se perdería en parte o completamente.

Si la próxima reunión considera mi propuesta, espero poder contribuir más eficientemente de lo que lo hice en las reuniones anteriores. Todos nos beneficiaremos más, de comprender y asimilar mejor las otras ideas y métodos. Aprovecharemos también en la eficiencia constructiva, cuando llegue el momento de "hacer balance".

Aprovecho esta carta para insistir de nuevo -espero que me perdones por ello- en enviar una invitación a Federico Correa. Conozco a mis colegas españoles muy bien después de 22 años de trabajo y profesión. No creo cometer un error. Creo que Oiza y Correa -el último sobre todopueden ser realmente muy provechosos para nosotros y para los objetivos de nuestro próximo encuentro.

Pido disculpas por mi atrevimiento. Por favor, perdóname.

Espero realmente verte pronto, mientras tanto, acepta mis más cálidos saludos.

Siempre tuyo

P.D. Como estoy convencido de que el Team-ten es realmente útil y puede convertirse en el impulso de muchas reformas e iniciativas necesarias para nuestra profesión de Arquitectos, he tomado la decisión de pedirte que -como el Secretario del Team-10- me aceptéis como miembro del Team-ten -si pensáis que mi participación fuera provechosa.

(Traducción al castellano de Ana Rodríguez.) 


\subsubsection{Cronología no exhaustiva de publicaciones, reseñas y comentarios sobre No son genios lo que necesitamos ahora}

1961

- Publicación del escrito por primera vez en español y en ingles como "It is not geniuses that we need to-day", en el número 384 de la revista Domus, en el mes de noviembre, junto con una amplia documentación grafica y fotográfica del Edificio de viviendas en la calle Compositor Bach de 1958.

- Revista portuguesa Arquitectura, en diciembre se publica la versión original del texto, junto con cinco proyectos de Coderch y Valls (la casa Ugalde, viviendas en la Barceloneta, en la calle de la Maquinista, en la calle Compositor Bach, y vivienda en Camprodón, Gerona), y comentario de Nuno Portas como director de la revista.

1962

- En el mes de febrero en el numero 38 de la revista Arquitectura del Colegio de Arquitectos de Madrid, con comentarios de Luis Moya, P. A. López Quintas, Francisco de Inza y Juan Ramírez de Lucas.

- En el mes de septiembre/octubre de la revista Hogar y Arquitectura $n^{\circ} 42$, se publica un comentario de Antoni de Moragas sobre No son genios..., con el título "La arquitectura catalana hoy".

En el mismo número Carlos Flores publica "¿Son o no genios lo que necesitamos ahora?", posteriormente incluido en Sobre arquitecturas y arquitectos (opiniones y convicciones desde finales de un milenio), publicado por el Colegio de Arquitectos de Madrid en la colección Textos dispersos.

- Publicado por primera vez en inglés por Alison Smithson con el título "It's Not Geniuses We Need Now" en la primera versión del Team 10 Primer, en Architectural Design en diciembre de 1962

1966

- Artículo-entrevista con el título "No son genios arquitectónicos lo que necesitamos ahora. Declaraciones de don José Antonio Coderch, en la edición de Andalucía del ABC del 11 de marzo de 1966, con motivo de una conferencia dada el dia anterior.

1974

- Publicación del escrito en inglés en Team 10 Primer, editado por Alison Smithson, Cambridge, Massachusetts: MIT Press en el mes de noviembre.

- Publicación de No son genios... en la revista Nueva Forma n0106 del mes de noviembre editada por Juan Daniel Fullaondo.

1976

- Se publica en el mes de febrero "It Is not geniuses that we need now" en A+U : Architecture and Urbanism n⿳ 62, numero monografico dedicado a Coderch.

- Comentario de Helio Piñón en el artículo "Tres décadas en la obra de José Antonio Coderch" publicado en la revista Arquitecturas bis nº11.

1977

- De las versiones del escrito, la más significativa es de mayo de 1977 cuando es elegido por Coderch para su discurso de ingreso en la Real Academia de San Jorge bajo el titulo de Espiritualidad de la Arquitectura. Discurso de Ingreso del Académico electo IImo. Sr. Don Jose Antonio Coderch de Sentmenat. Leido en la Sala de Actos de la Academia el martes 31 de mayo de 1977.

- Comentario de Josep Muntañola i Thronberg en "Coderch, o la imagen transformada de la tradición" publicada en Coderch de Sentmenat, catálogo de la exposición homenaje celebrada en el Museo de Arte Contemporáneo de Madrid, en Marzo de 1980. 
1978

- Comentario de Antón Capitel en el prólogo "José Antonio Coderch, del mar a la ciudad", firmado en diciembre de 1976, de la monografía J. A. Coderch: 1945-1976, editada a cargo de Antón Capitel y Javier Ortega y publicado por Xarait en 1978.

1979

- Publicacion del discurso de ingreso "Espiritualidad de la Arquitectura" en Carrer de la Ciutat $n^{\circ} 6$. Se publica en paralelo con el texto de Coderch el artículo de Josep Quetglas "El miedo a Coderch".

1980

- Publicación de "No son genios lo que necesitamos ahora" (Espiritualidad de la Arquitectura) en Coderch de Sentmenat, catálogo de la exposición homenaje celebrada en el Museo de Arte Contemporáneo de Madrid, en Marzo de 1980

1983

- En "José Antonio Coderch, o las coincidencias imposibles. Reflexión sobre algunos ejemplos de arquitectura residencial" publicado en Annals dárquitectura n० 3 revista editada por la ETSAB de la Universidad Politécnica de Cataluña desde 1983 a 2001, Antonio Pizza hace una amplia reseña.

1984

- Comentario de Oriol Bohigas en el artículo "José Antonio Coderch, contra los gregarios", publicado el 8 de noviembre en El País con motivo de su fallecimiento 1986

- Comentario a No son genios... en Historia de la arquitectura moderna de Leonardo Benevolo, en la versión castellana de la $5^{a}$ edición ampliada, en el capítulo dedicado a España en el periodo 1940-1980, escrito por Josep Ma Montaner.

1987

- Se publica en francés "Nous n'avons plus besoin de génies" en Techniques et Architecture no 371 abril-mayo

- Comentario en "José Antonio Coderch de Sentmenat" por Javier Carvajal, publicado en el número monográfico de la revista Arquitectura n²68, de septiembre-octubre, dedicado a Coderch.

1989

- No son genios...se vuelve a publicar en la monografía de Carles Foch J.A. Coderch de Sentmenat 1913-1984 en la editorial Gustavo Gili.

1993

- No son genios... es incluido en inglés en el libro de Joan Ockman Architecture Culture 1943-1968: A Documentary Anthology, publicado en Nueva York por la editorial Rizzoli.

1996

- En la publicación Web Architecture Magazine WAM 01, de julio-agosto, "Sobre 'No son genios...'" de Carles Muro \& Ton Salvadó en inglés y castellano y comentario de Enric Soria en castellano. En el mismo espacio, Peter Smithson publica "Some thoughts in 1996 on the statement by Coderch written in August 1961"

1998

- Comentario de Carlos Flores en la ponencia "La arquitectura de José Antonio Coderch y Manuel Valls" publicada en las Actas del Congreso Internacional De Roma a Nueva York: Itinerarios de la nueva arquitectura española 1950 / 1965, celebrado en Pamplona el 29 Y 30 de octubre de 1998 
2000

- Nota en The CIAM Discourse on Urbanism 1928-1960, de Eric Mumford y publicado por el MIT Press, con prólogo de Kenneth Frampton

- Comentario de Oscar Tusquets en "Recuerdos de un grandísimo arquitecto", en El País/Quadern. Serie "Els quatre gats en el mes de mayo

2003

- No son genios...se incluye en Un siglo de vivienda social 1903-2003, Luis Rojo de Castro con motivo de la Exposición organizada por el Ministerio de Fomento, el Ayuntamiento de Madrid-EMV.

2005

- Comentario en Team 10, 1953-81: in search of a utopia of the present, editado por Max Risselada y Dirk van den Heuvel y publicado en Rotterdam por el NAi.

- Comentario en An Architect's Guide to Fame, editado por Paul Davies y Torsten Schmiedeknecht y publicado en Oxford por Architectural Press

2006

- Publicación de No son genios... en José Antonio Coderch. Casas, número monográfico de $2 \mathrm{G}$ libros sobre Coderch, editado por Rafael Diez, con comentario de Kenneth Frampton de homenaje a Coderch.

2008

Antonio Armesto y Rafael Diez en las notas biográficas del libro José Antonio Coderch, publicado por Santa \& Cole, sugieren la relación del escrito de Coderch y los conceptos de tradición y talento individual del poeta y crítico T.S. Eliot.

2012

- Enric Soria publica el comentario de 1996 en el espacio web HASXX_teoria, Historia de la Arquitectura del Siglo XX, el martes 14 de enero

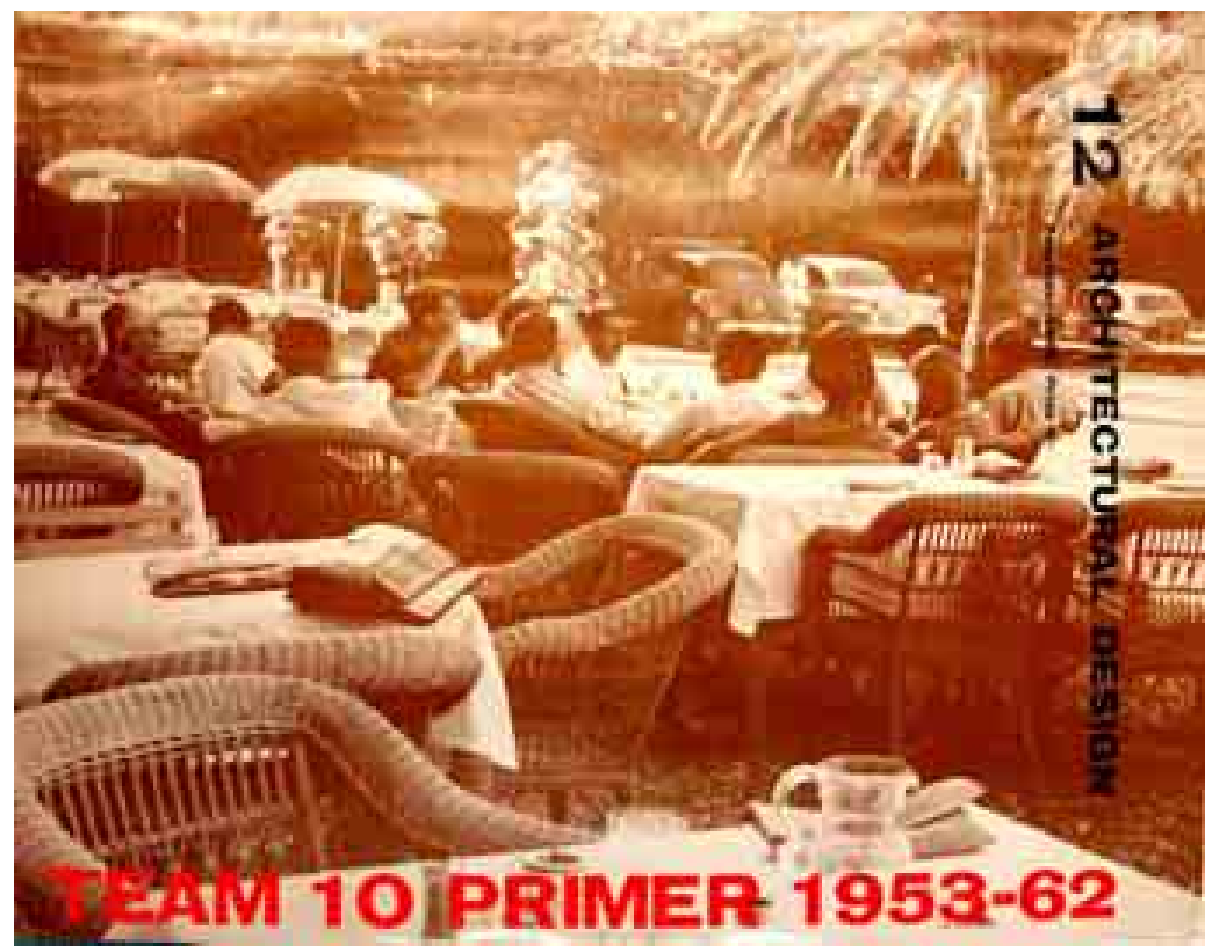

Figura 4.18

Primera publicación de Team 10 Primer en Architectural Design n¹2, diciembre 1962. Portada 


\subsection{Cardos para ahuyentar los malos espíritus} [Mito]

\subsubsection{El fuego del hogar}

«El problema esencial para nosotros era el proyecto de una lámpara de luz de ambiente. Una vez realizada se vió que la luz producida daba intimidad y se parecía a la del fuego de una chimenea» (Capitel y Ortega 1978, 50)

A partir de esta reflexión de Coderch, Antonio Armesto ha estudiado ampliamente la lámpara de Coderch, cuya luz es como la de una brasa ardiendo, tenue y muy cálida. Nos remitimos a dicho texto con el que coincidimos al igual que el realizado sobre las chimeneas. Se aporta una analogía complementaria. Cuando la casa está iluminada por la noche, en cierta forma se convierte toda ella en la misma lámpara, donde las finas hojas de madera que le dan su característica forma son en este caso las curvaturas de las arquerías, como nos muestra la imagen inferior.
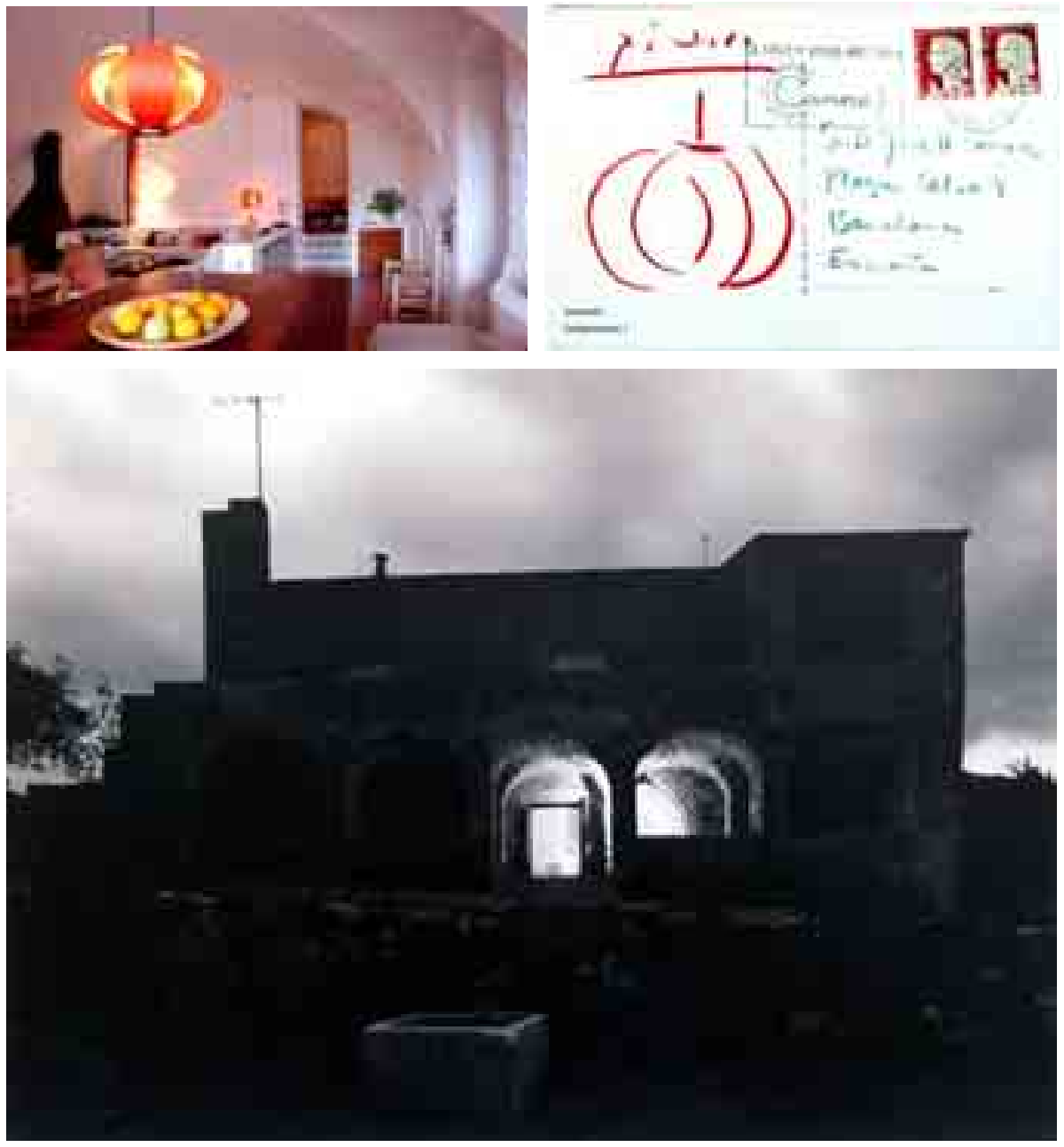

Figura 4.19

* Superior izquierda

La lámpara Disa de Coderch en la Casa de Espolla. Fotografía de Ana Rodríguez

* Superior derecha

Dibujo de la lámpara Disa enviado por Picasso. Archivi Coderch

* Inferior

La casa de noche e ilumnada, evocando la lámpara Disa.

Fotografía de Catalá Roca. Archivo Coderch 


\subsubsection{Cardos que ahuyentan los malos espíritus}

El mito como relato de algo fabuloso que se supone acontecido en un pasado remoto casi siempre impreciso, es consustancial a lo vernáculo, y está presente en las obras de estudio, las cuales además se encuentran en lugares con una fuerte carga simbólica. En Espolla se encuentran un gran número de dólmenes y menhires, dándose en la sierra de L'Albera una de las concentraciones de monumentos megalíticos más importantes de Cataluña,

Hasta qué punto es casualidad esta coincidencia es imposible de determinar, pero si podemos afirmar que en la intencionada elección del lugar, Espolla, va implícita la aceptación de ese universo de leyenda, fábula y mito, quedando conscientemente testimoniado por Coderch en textos y fotografías de las casa y el territorio.

La Casa de José Antonio Coderch en Espolla fue fotografiada por Francesc Catalá Roca, al igual que la mayoría de su obra. Exceptuando publicaciones relativamente recientes, posteriores a la muerte de Coderch, las imágenes en blanco y negro que ilustran las publicaciones en las décadas de los sesenta, setenta, ochenta y noventa son de Catalá Roca.

El reportaje de Espolla consta de una serie de vistas de las estancias abovedadas de la planta baja junto con otras del exterior de la casa y vistas del conjunto. También aparecen fotografiados una serie de motivos, en principio no relacionados directamente con la arquitectura de la casa, como flores secas o fotografías de antepasados familiares.

Entre ellas, una fotografía de la puerta de entrada a la planta baja desde la arquería que cubre el antiguo paso público. De centrada composición, nos muestra una doble puerta: la exterior, nueva con bastidor de acero pintado en negro y vidrio, abierta hacia el exterior, y la interior de madera, la original de la casa, abriendo hacia adentro. Una mirada atenta nos permite descubrir en la parte superior de la antigua puerta de madera, una especie de flor seca, grande y radial.
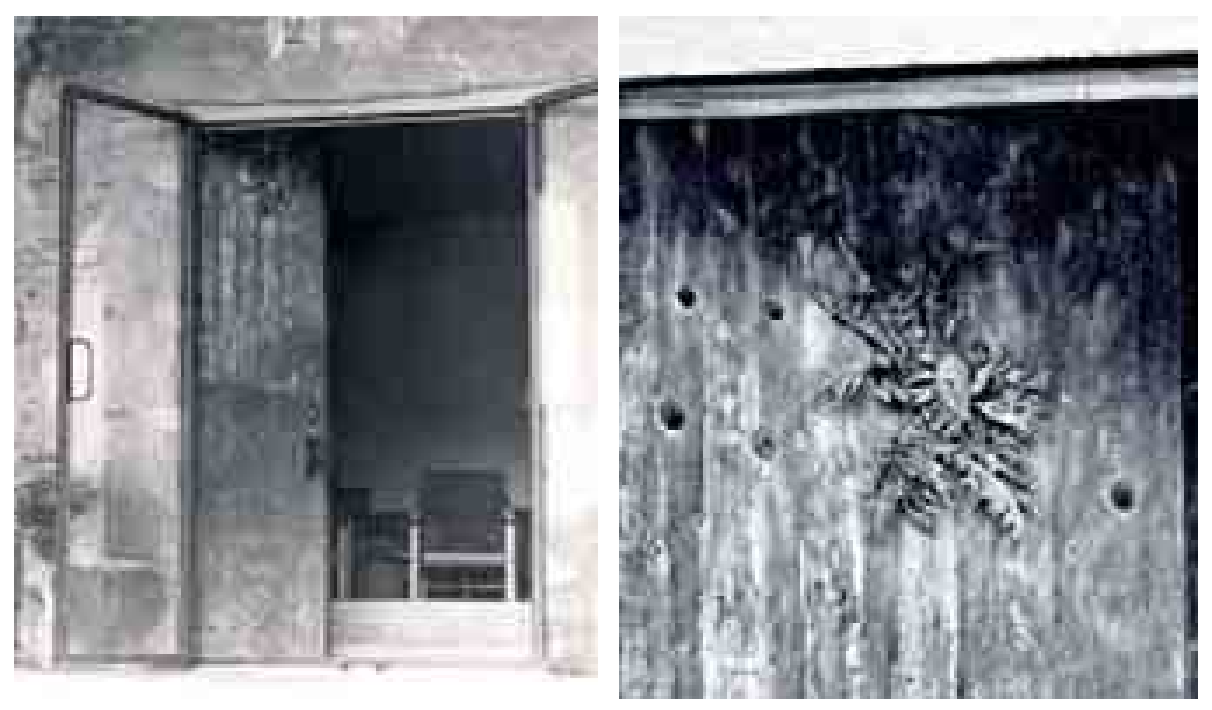

Figura 4.20

- Puerta de acceso a la Casa de Espolla desde la galería con arcos de planta baja. Sobre la puerta una Carlina acaulis, cardo de brujas o cardo de sol. Este símbolo solar era cortado en otoño por los aldeanos para colgarlo en las entradas y espantar a los malos espíritus en el País Vasco, Navarra y el Pirineo.

Coderch mantuvo siempre esta tradición, y la última carlina que consiguió sigue todavía hoy guardando la Casa de Espolla. 
Es una carlina acaulis, y representa una costumbre ancestral de colocarlas en la puerta de la casa como protección.

Pertenece a la familia de las Asteraceae y es natural de Europa central y Pirineos, creciendo en las laderas soleadas de montañas, pastizales y prados.

Sus propiedades medicinales procedentes de los principios activos de la raíz, son conocidas desde el mundo antiguo, como diurético y antibiótico. Contiene un aceite esencial que se utiliza en el tratamiento de eczemas, acné, y dolencias cutáneas. El nombre científico de carlina acaulis fue dado por Linneo en su obra Systema naturae $(1735-1770)^{23}$

Así lo atestigua entre otros Francisco Carbonell y Bravo en su obra de 1802 Elementos de farmacia fundados en los principios de la chímica modern, definiendo la carlina como: «Carlina es una planta oficinal llamada por Linneo Carlina acaulis, de que se usa la raíz: esta es de color gris por defuera, blanca por adentro, de olor y sabor aromático agradable»
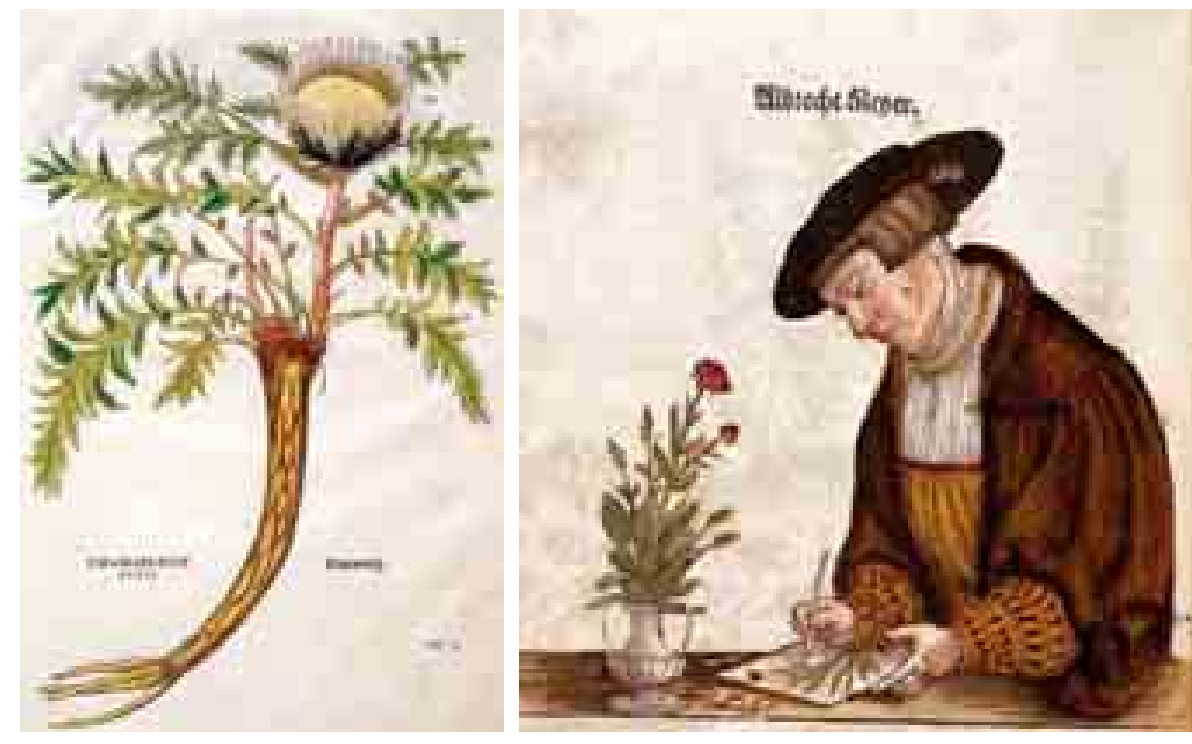

Figura 4.21

Dibujo de Albrecht Meyer de la Chamaeleon albus, la actual Carlina acaulis después de la clasificación de Linneo, en De historia stirpium commentarii insignes -Comentarios notables sobre la historia de las plantas- de Leonhart Fuchs (1501-1566) publicada en 1542 en Basilea, e ilustrada por Meyer en colaboración con el pintor Heinricus Füllmaurer y el grabador Veit Rudolph, según consta en la propia obra de forma poco habitual en aquel momento, incluyendo además el retrato de los mismos.

Escrita desde el punto de vista de un medico, más que como una clasificación botánica al modo moderno, describe las propiedades medicinales y curativas de las plantas, estando considerada como uno de los herbarios con imágenes más importantes anteriores a Linneo, con la característica añadida de incorporar especies americanas. (Fuchs 1542)

${ }^{23}$ Systema naturae per regna tria naturae, secundum classes, ordines, genera, species, cum characteribus, differentiis, synonymis, locis 
En noviembre de 1915, el Dr. Juan Cadevall y Diars, académico numerario, publica Las carlinas de Cataluña. Un híbrido litigioso, en las Memorias de la Real Academia de Ciencias y Artes de Barcelona, Tercera época, en el número 2 del volumen XII.

El artículo tiene como objeto aclarar los malos entendidos en el uso de los términos científicos para designar la carlina acaulis y la carlina acanthifolia.

En botánica las plantas acaules son las plantas sin tallo, o con el extremadamente corto, aparentemente inexistente. El termino latinizado acaulis, de tallo caulis, proviene del griego «privado de tallo». La confusión viene dada porque el género Carlina, presenta una especie parecida y perfectamente acaule, sin tallo, que se denominó acanthifolia, mientras que la designada como carlina acaulis, puede ser normalmente acaule, es decir sin tallo, pero tampoco es raro que lo tenga de 15 a 25 centímetros. Mientras que la acanthifolia es frecuente en montes de mediana altura, la carlina acaulis que nos ocupa, se halla con bastante menor profusión y solamente en zonas apartadas de alta montaña. Es una planta que se da en altitudes elevadas en el centro y norte de Europa y en España solo en el norte especialmente en los Pirineos, en lugares retirados de alta montaña en laderas y prados secos y soleados.

El profesor Cadevall y Diars puntualiza el origen de su primer nombre carlina, debido a la creencia popular que los «ángeles» enseñaron a Carlomagno como debía emplearla contra la peste, librando a su ejército de ella; nombrando así la planta en su honor:

«Carlina vulgo quasi carolina, quod credatur hane herbam. Carolo magno ab Angelo demonstratam fuisse, tanquam certissimum ad pestem ab exercitu suo propulsandam. Caspari Bauhini ${ }^{24}$, Pinacia Theatri Botanici Lib.X. sect, VI.» (Cadeval y Diars 1915)

Se le conoce en España con una gran cantidad de nombres populares; en castellano: ajonjera, angelica-carlina, camaleón, canduncho, carasol, cardabela, cardina, cardineta, cardito, cardo ajonjero, cardo ajonjero blanco, cardo de San Pelegrín, cardo dorado, cardonerita, cardo rizado, cardullo, carlina ; en catalán card cardener, cardiguera, carlina borda, escardassa, cardiguera, carlina, y en euskera eguzkilore, astalarr, basalarr, kardalora, etc.

La carlina tiene un componente mágico-religioso ancestral. Es el símbolo solar por excelencia en el norte de España con varias leyendas más o menos parecidas.

Es una planta bienal que crece casi pegada al suelo y brota en forma de roseta de hojas recortadas y espinosas, parecida al cardo. Solía ser recogida en otoño por los campesinos para colocarla en las puertas de granjas, caseríos, masías y establos como una representación del sol y que desempeña las mismas funciones místicas atribuidas a él, ahuyentando a los genios de las enfermedades y a los malos espíritus, e impidiendo la entrada a las brujas, en la creencia de que éstos no podrían entrar en ella sin arrancar o contar los numerosos pelillos de la flor, amaneciendo sin haber terminado sin haber podido entrar en la casa, teniendo que volver a la oscuridad del mundo subterráneo hasta la noche. En otras versiones, la mera visión de la eguzkilore, de eguzki sol y lore flor en la puerta del caserío les hacía creer que era el mismo sol y que ya despuntaba el alba por lo cual tenían que esconderse.

También protege la casa de la tempestad, del rayo, y trae paz y prosperidad.

\footnotetext{
24 Gaspard Bauhin, botánico y médico suizo que publicó en el año 1623 Pinax Theatri Botanici, libro ilustrado con la clasificación y descripción de 6000 especies, convirtiéndose en uno de los hitos de la historia e la botánica
} 
Carlos Flores en La España popular, raíces de una arquitectura vernácula, se refiere a ella, en la relación a como los cultos paganos alcanzaron un gran desarrollo entre los pueblos de la España prerromana, y aunque su importancia fue decayendo con el desarrollo del cristianismo, todavía quedan muchas huellas del culto al sol y la luna en las tradiciones populares ${ }^{25}$. De esta forma las creencias religiosas, no siempre profundas, se entremezclaron, en la cultura popular más que en ningún ámbito, con supersticiones y temores ancestrales.

La colocación de ciertos elementos protectores en zonas concretas de la vivienda como las puertas, obedeció a ello durante siglos, si bien desde hace unas décadas su persistencia es más cuestión de costumbre o recurso ornamental. (Flores 1979)

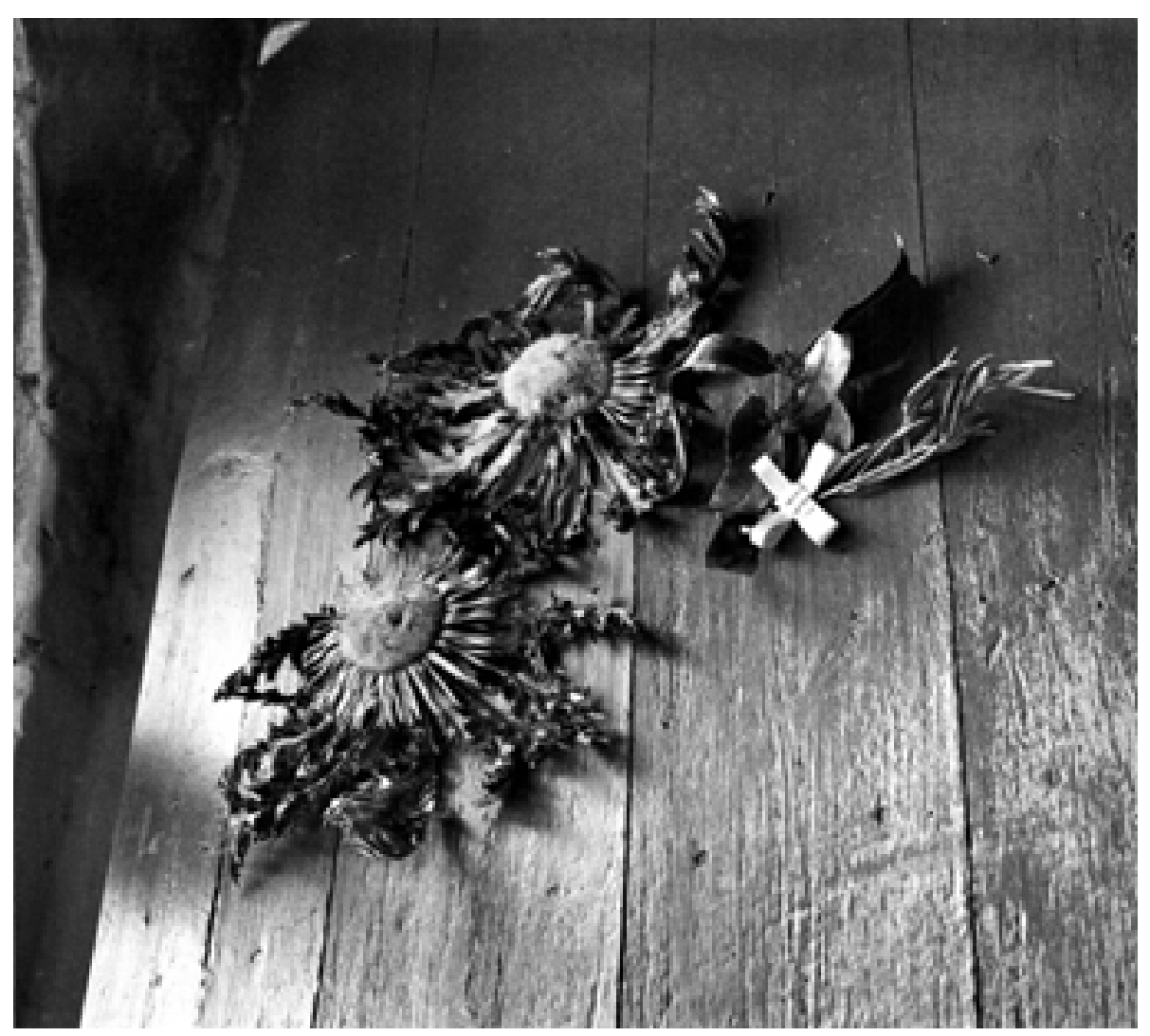

Figura 4.22

Les carlines i la creu de palma ens donen la benvinguda a Can Maspons de Bigues Las carlinas y la cruz de palma nos dan la bienvenida en Can MAspons de Bigues

Estas imágenes, son un intencionado tributo a la tradición catalana de las casas pairales, constatado por Coderch y Catalá Roca.

En conversación con su hija Ana Coderch Jiménez, actual propietaria de la casa, explicaba cómo era el propio Coderch quien encargaba a un campesino que le trajera de la montaña carlinas para colocarlas en la puerta, (el mismo salía al campo y recogía elementos vegetales y minerales que después colocaba en la casa), de forma que esta siempre estaba guardada. La última carlina en la puerta de la casa en Espolla se mantuvo en buen estado hasta hace relativamente poco tiempo, muchos años después de su muerte.

\footnotetext{
${ }^{25}$ En las masías catalanas son muy frecuentes y con gran protagonismo los relojes de sol.
} 

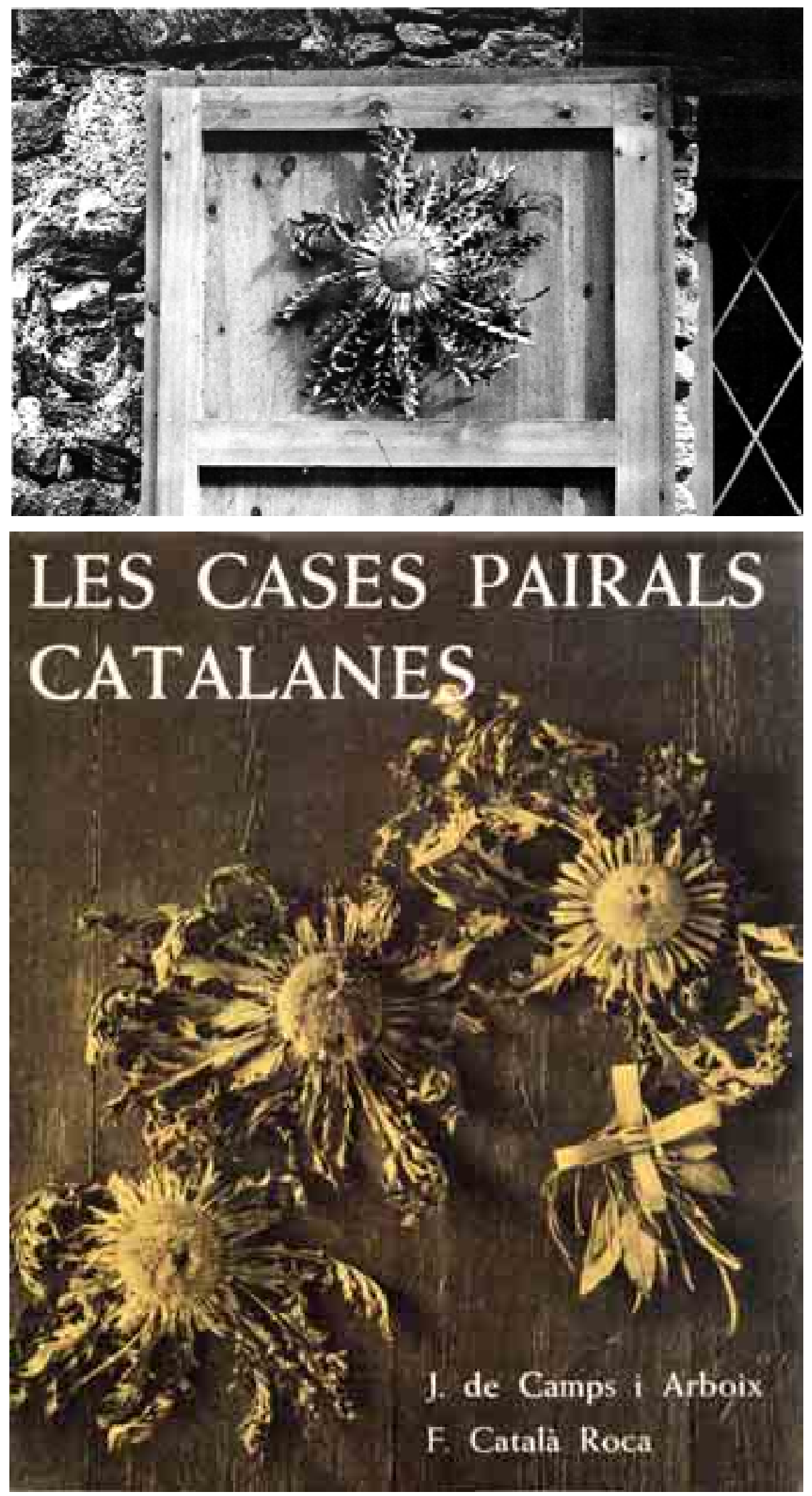

Figura 4.23

El bosc és de pins en els espadats muntanyencs i les pollacredes creixen pels fondals.

El bosque es de pinos en los escarpados montañosos y las choperas crecen por hondonadas 


\subsection{Espolla y Coderch}

[Lugar, Topos: Toponimia, Topografía, Topofilia, Topiaria]

\subsubsection{El campo catalán: Masía y territorio.}

«Están casi todas las montañas de Cataluña habitadas y cultivadas, siempre verdes y hermosas, con agrado y admiración de los que las ven. Toda ella parece una población, porque apenas hay distancia notable sin ella. En sus mayores asperezas se descubren castillos y lugares; y entre aquellas soledades se hallan edificios y casas que algunas de ellas, con ser de labradores, parecen palacios de príncipes. Entre los riscos y peñas hay viñas y sembrados, bosques y frutales, que de lejos se muestran como pastos alegres y provechosos, o de la agricultura, o de la misma naturaleza. Apártense en varias partes los montes unos de otros y dejan en medio llanos y campos espaciosísimos, y regiones enteras de tanta fertilidad y abundancia, que ninguna de las otras provincias de España se les antoja, forman entre sí valles amenísimos llenos de fuentes y varios sotos y vegas cubiertas de flores y frutos, que en lo agradable y delicioso, pueden igualarse a los jardines más curiosos» (Torres Balbás 1930, 490)

Esta cita de Cataluña ilustrada, libro I, cap. XII, p.59 de Esteban de Corbera, citado por M. P. Sandiumenge en 1929 en La Masía catalana, breve estudio de la casa rural catalana, y a su vez reseñada por Leopoldo Torres Balbás en La Vivienda Popular en España, dibuja una imagen certera del campo catalán.

Insiste en lo notable de la identificación entre edificaciones y paisaje, así como la manera en la que se resuelve la construcción y el emplazamiento, como por ejemplo la construcción de las bóvedas, que tanto abundan donde no hay bosques, el aprovechamiento de los lugares más abrigados en las laderas mas soleadas, la disposición de caminos en rampa para la subida más fácil de los animales, o el emplazamiento más adecuado de las eras según el viento (Torres Balbás 1930, 498)

El paisaje dl campo catalán está estructurado por las relaciones que se establecen entre las masías, como se percibe cuando se contempla.

Forman una especie de red interconectada, que más que integrarse en el paisaje por mimesis, lo construye, reinterpretando la herencia del mundo greco-latino, entendiendo el territorio como algo acotado, estructurado y perceptiblemente transformado por el hombre.

La masía no se implanta en el paisaje aleatoriamente, sino que lo hace de forma muy determinada: Yago Bonet Correa lo explica con precisión, cuando dice «domina visualmente un territorio y al mismo tiempo está "arraseda", como se dice en catalán, esto es, en una posición protegida y orientada», «su locus ha sido escogido con amoroso cuidado y observación paciente» en una orientación mayoritariamente al sur, en lugares muy concretos que por sus características poseen microclimas de mayor bonanza que otros lugares en el mismo territorio. De esta manera se conforman puntos análogos en el paisaje, en la formación de la red estructura ya mencionada. (Bonet Correa 1981, 7)

En las páginas siguientes veremos como la Casa Coderch en Espolla, su emplazamiento y relación con el territorio, coincide con las descripciones dadas del campo en Cataluña, donde el paisaje se construye a partir de la tradición histórica de una determinada estructuración social y productiva del territorio. 


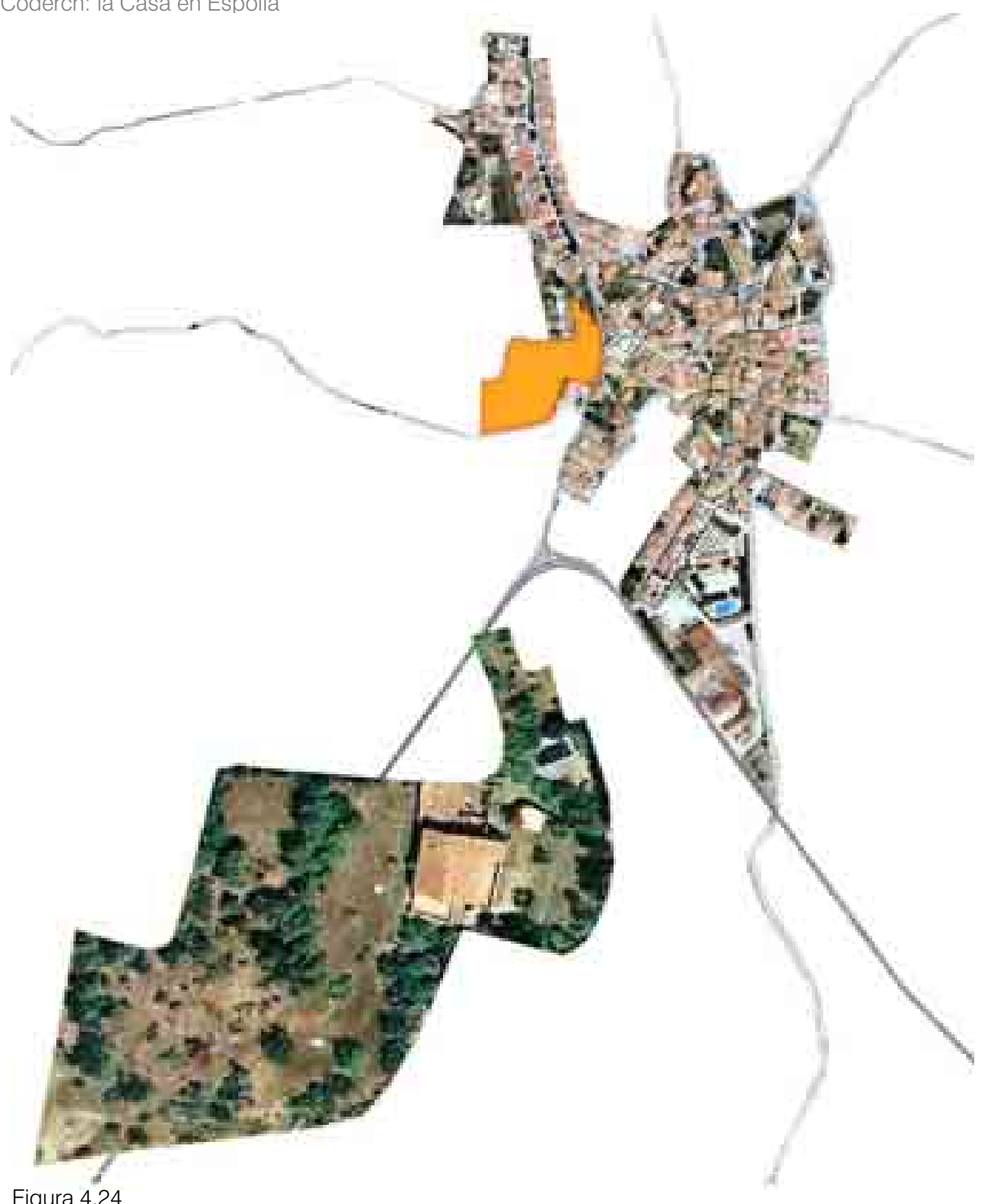

Figura 4.24

El territorio de Espolla.

La casa de Coderch se enclava en un lugar preponderante, apreciándose su importancia debido a su posición elevada -el Mas del Puig-, es decir la masia del montecillo, la que está en alto. Su posición es a la vez límite en su parte alta con terreno propio que se proyecta hacia el territorio, y centro del pueblo en la inferior, junto al arroyo que singulariza la trama urbana.

Fotomontajes de Ana Rodríquez con la colaboración de Isabel Negro

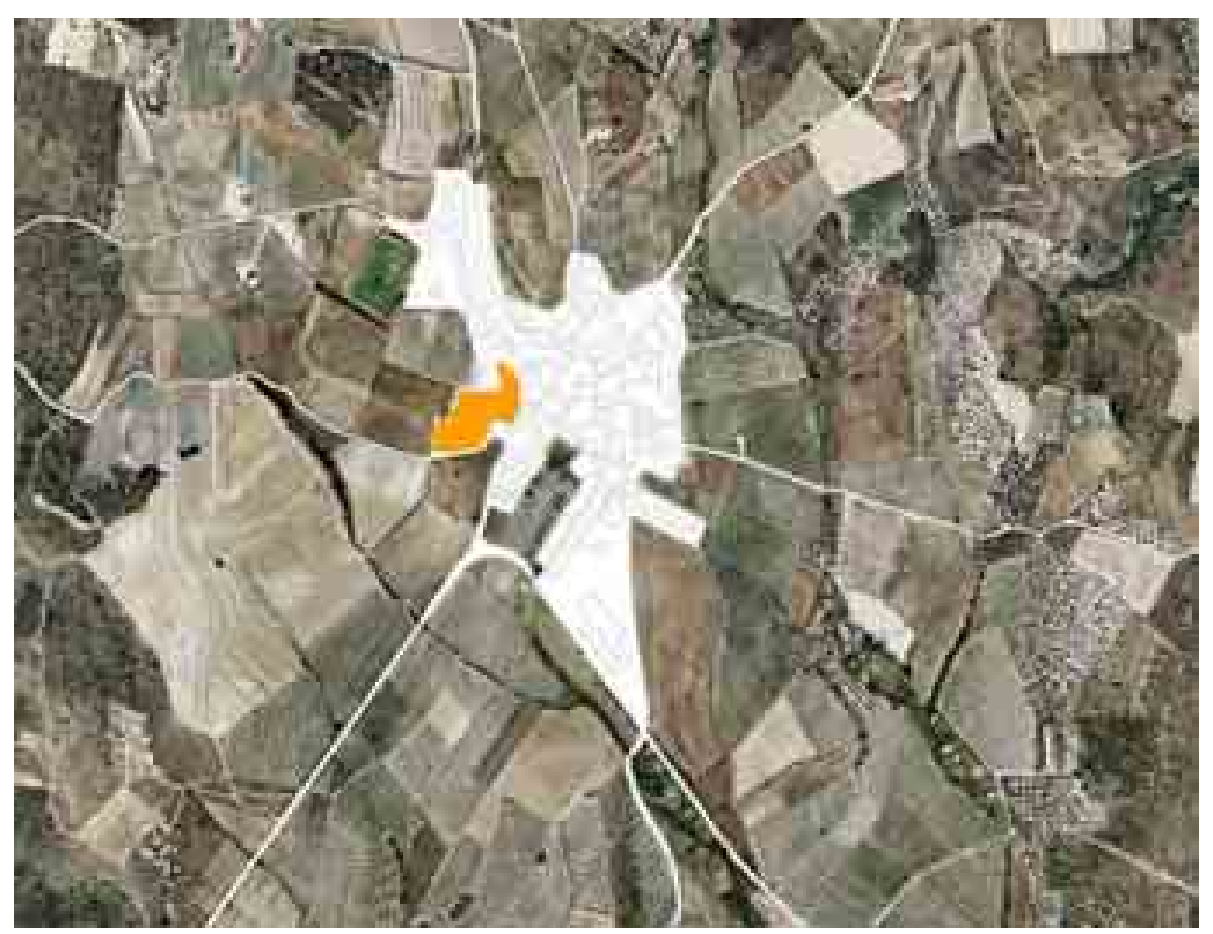




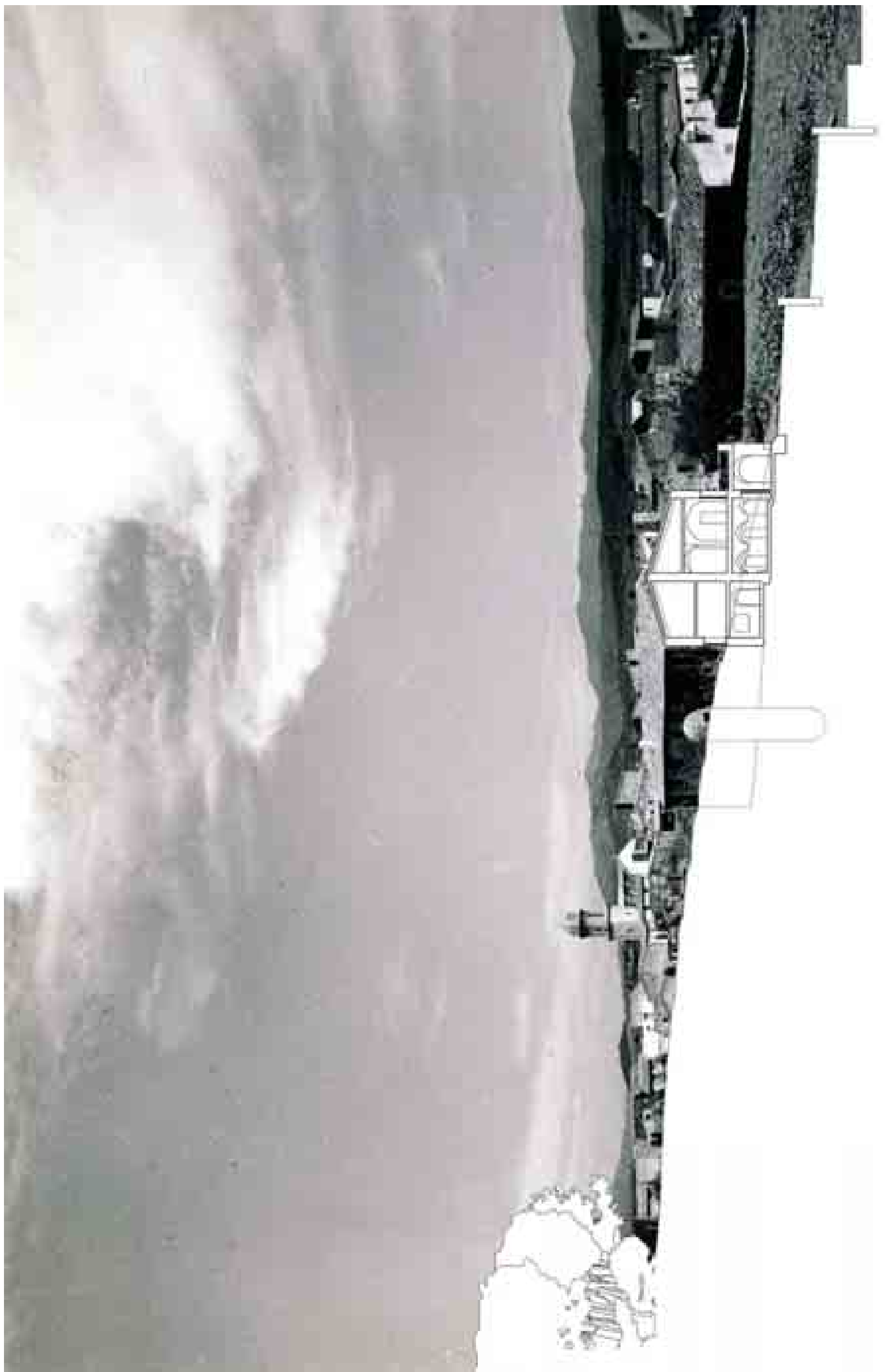

Figura 4.25

El Mas del Puig en Espolla. Es decir la masía del montecillo, la que está en alto. Su posición es a la vez límite en su parte alta con terreno propio que se proyecta hacia el territorio, y centro del pueblo en la inferior, junto al arroyo que singulariza la trama urbana.

Dibujo y fotomontaje a partir de una imagen de Catalá Roca, de Ana Rodríguez con la colaboración de Isabel Negro 


\subsubsection{El Mas del Puig \\ [Toponimia]}

En la lengua catalana, mas es una casa de labranza, una unidad de explotación agrícola tradicional integrada por la casa, los establos, los cultivos, los almacenes, y demás posesiones.

A su vez, "puig» es un monte o una elevación del terreno, y "pairal» es una masía o casa adscrita a una finca rústica, sede de un linaje organizado como unidad de explotación rural que tiende a ser económicamente autosuficiente, con un patrimonio importante acumulado a lo largo de generaciones y conservado gracias a la institución del hereu, el primogénito heredero.

La casa de Coderch se enclava en un lugar preponderante en Espolla, apreciándose su importancia debido a su posición elevada -el Mas del Puig-, es decir la masía del montecillo, la que está en alto, y al papel, históricamente simultáneo, como límite en su parte alta con terreno propio que se proyecta hacia el territorio, y centro del pueblo en la inferior, junto al arroyo que singulariza la trama urbana.

\subsection{La tierra de Espolla. 24 fotografías de Catalá Roca. [Topografía]}

\section{Características de la comarca del Alto Ampurdán}

El pueblo de Espolla, en la Sierra de la Albera, pertenece a la Comarca de I'Alt Empordà, concretamente a su sector septentrional. Es una zona limitada al Norte por Les Alberes y la frontera francesa; al Sur por la «plana de L'Alt Empordà»; al Este por la sierra de Roda, y al Oeste por La Garrotxa, al pie de las montañas de la Mare de Déu del Mont. Son infrecuentes las masías aisladas, ya que la densidad de población ha sido históricamente baja, organizándose el territorio con núcleos urbanos concentrados, de origen fortificado, en los que los «masos» ocupan una posición preponderante. Las casas suelen ser de dos o tres plantas en un trazado urbano irregular y con fuertes pendientes.

Es un territorio de relieve accidentado y vegetación mediterránea de encina, alcornoque y matorral. Con una pluviometría irregular, tradicionalmente se ha cultivado el olivo y la vid, quedando las superficies destinadas a regadío reducidas a los márgenes de arroyos y pequeños cursos de agua.

Muy característico es el fuerte viento de tramontana que sopla con frecuencia

Su accidentada topografía condiciona frecuentemente la edificación, pudiéndose encontrar diversas soluciones especiales para resolver las particularidades de cada emplazamiento. Las más frecuentes son las escaleras exteriores de comunicación entre la planta baja y primera, y también la disposición irregular de habitáculos en planta baja, junto con las galerías abovedadas en el frente principal, mayoritariamente orientado al sur como ya se ha mencionado, construidas normalmente con posterioridad a la casa primitiva, como un volumen que sobresale formando una terraza en la planta primera. Otro elemento característico de la zona que se repita con cierta frecuencia, es la ubicación de los pozos de agua en las fachadas del edificio, como los dos impresionantes construidos en las esquinas de Can Oliveres en Campmany (Alonso de Medina i Alberich 1977), apenas a once kilómetros de Espolla

En el entorno hay una de las mayores concentraciones megalíticas de Cataluña- Así, viñedos, cultivos, bosques, montañas y dichos monumentos son relatados en las fotografías que encargó José Antonio Coderch a Catalá Roca, e inéditas hasta ahora, para dar a conocer y defender el territorio de Espolla ante las prácticas de tiro que el ejercito solía hacer allí. 

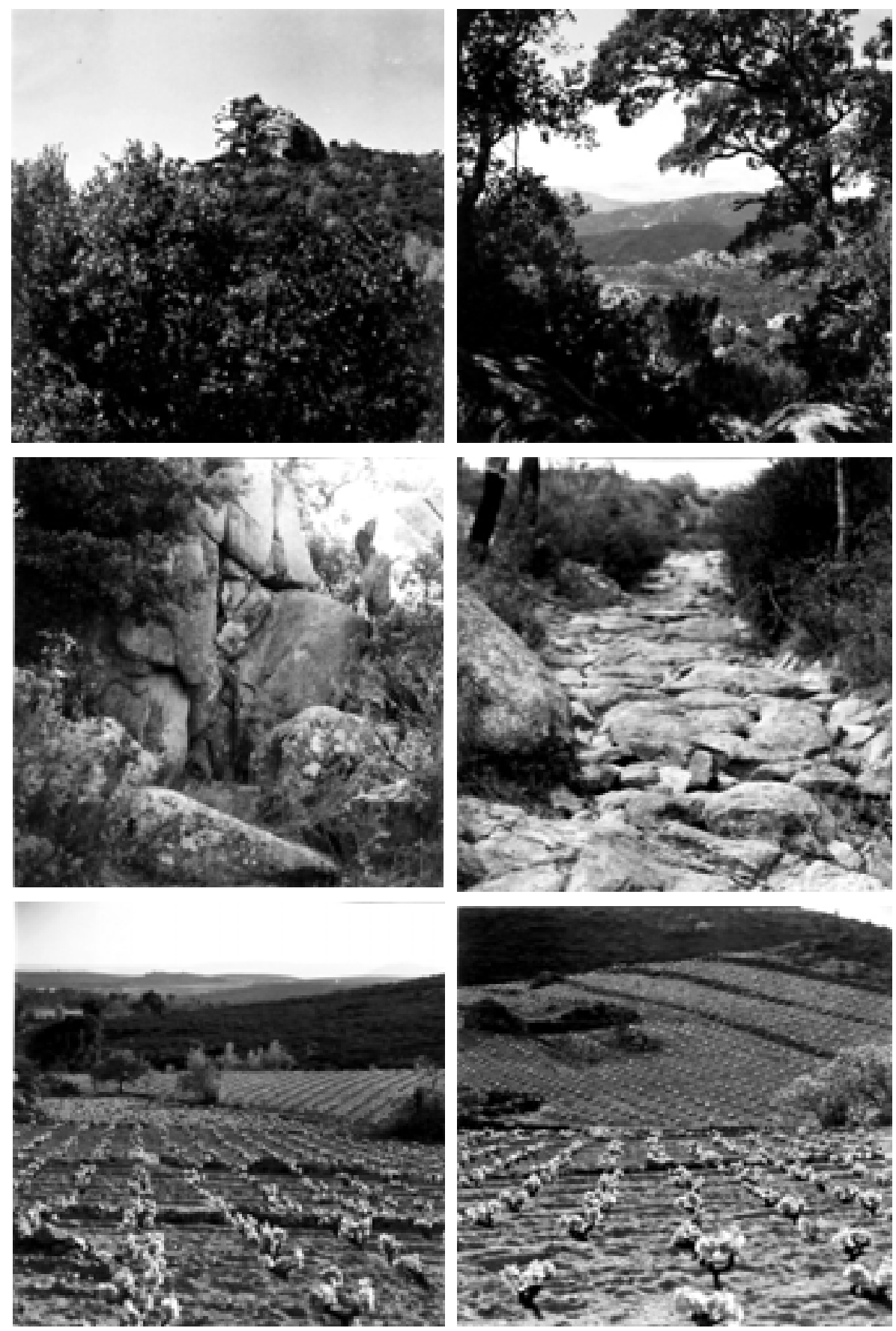

Figura 4.26 a

Serie de fotografías del paisaje y territorio de Espolla encargadas por José Antonio Coderch y realizadas en 1966 por Catalá Roca como parte del conjunto de las realizadas de la casa Coderch en Espolla.

De izquierda a derecha y de arriba hacia abajo:

01. B-18049 La Roca d'Els Cantons

02. B-18050 Paraje "Comaderneus" vista parcial

03. B-18054 Paraje "Comaderneus" Fuente

04. B-18064 Paraje "La Murtra" trozo de la llamada "Calzada de Anibal"

05. B-18065 Paraje "Puig Cabell" fincas de cultivo

06. B-18069 Paraje "Puig Cabell" cepas al brotar 

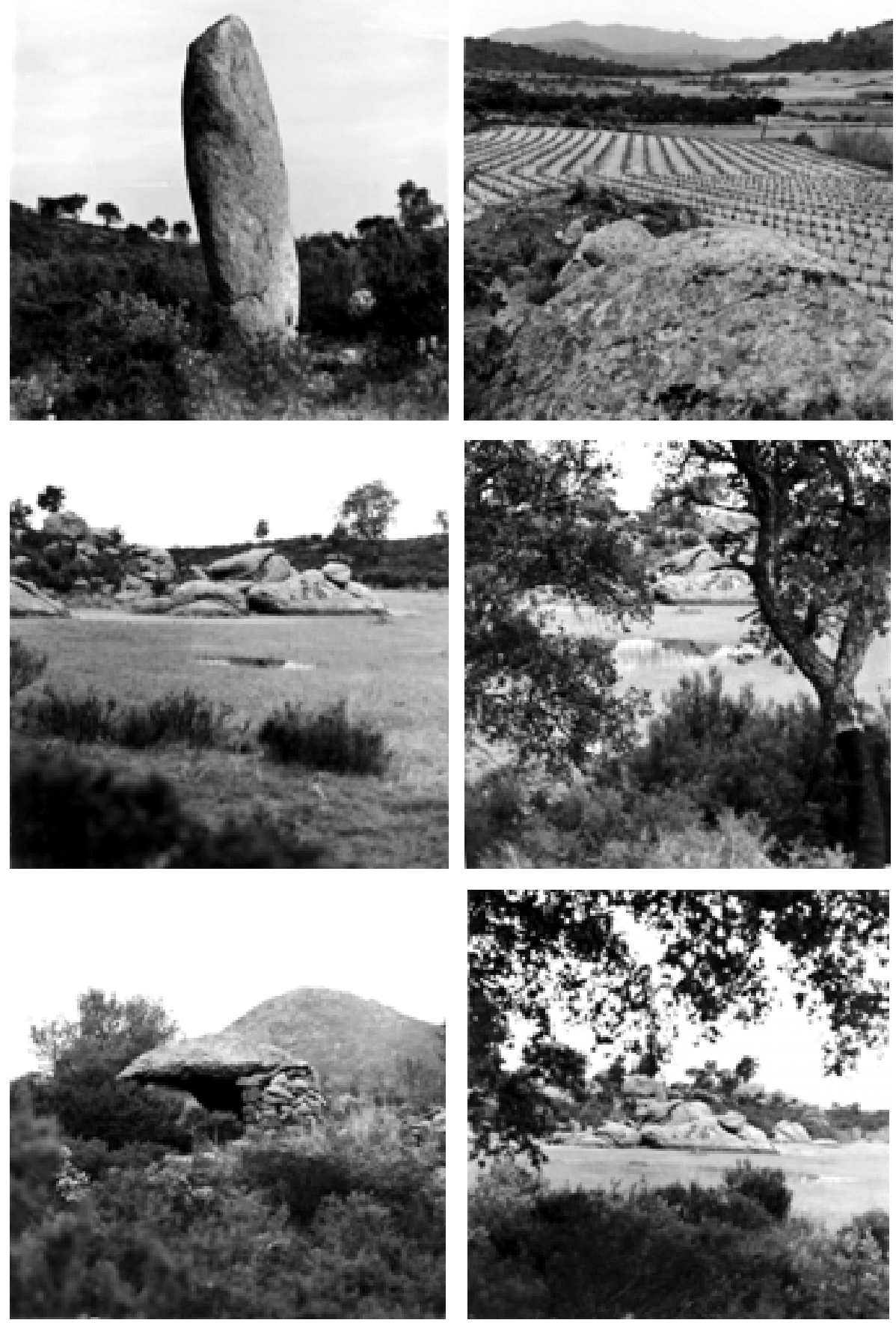

Figura 4.26 b

Serie de fotografías del paisaje y territorio de Espolla encargadas por José Antonio Coderch y realizadas en 1966 por Catalá Roca como parte del conjunto de las realizadas de la casa

Coderch en Espolla.

De izquierda a derecha y de arriba hacia abajo:

07. B-18071 Menhir en el paraje de "La Murtra"

08. B-18074 Paraje "Puig Cabell" "Les Sorreres" y "El Pal" panorámica

09. B-18076 Paraje "La Murtra" estanque

10. B-18079 Paraje "La Murtra" estanque

11. B-18083 Paraje "La Murtra" estanque

12. B-18080 Dolmen "La Barraca de I'alarb" en el camino de la Murtra 

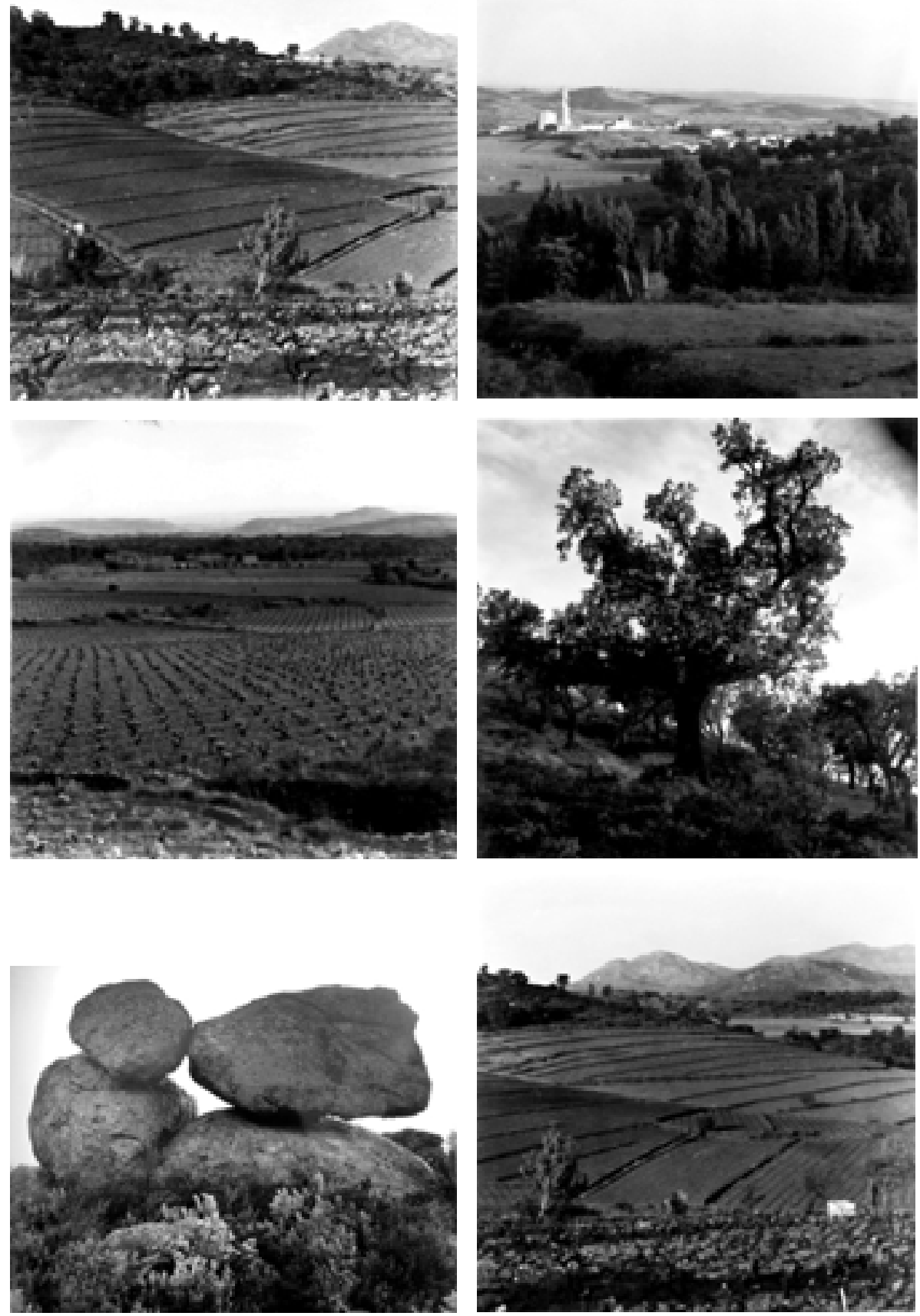

Figura 4.26

Serie de fotografías del paisaje y territorio de Espolla encargadas por José Antonio Coderch y realizadas en 1966 por Catalá Roca como parte del conjunto de las realizadas de la casa Coderch en Espolla.

De izquierda a derecha y de arriba hacia abajo:

13. B-18085 Detalle de algunos viñedos en el camino del Castellar

14. B-18086 Espolla desde el camino de "Les Sorreres" vista parcial

15. B-18088 Parajes "Puig Cabell" y "La Gotina" viñedos

16. B-18089 "Les Sorreres" alcornocal

17. B-18092 Rocas erosionadas junto al camino de "Puig Cabell"

18. B-18094 Camino "d’Els Vilars" viñedos con el Puig de la calma al fondo 

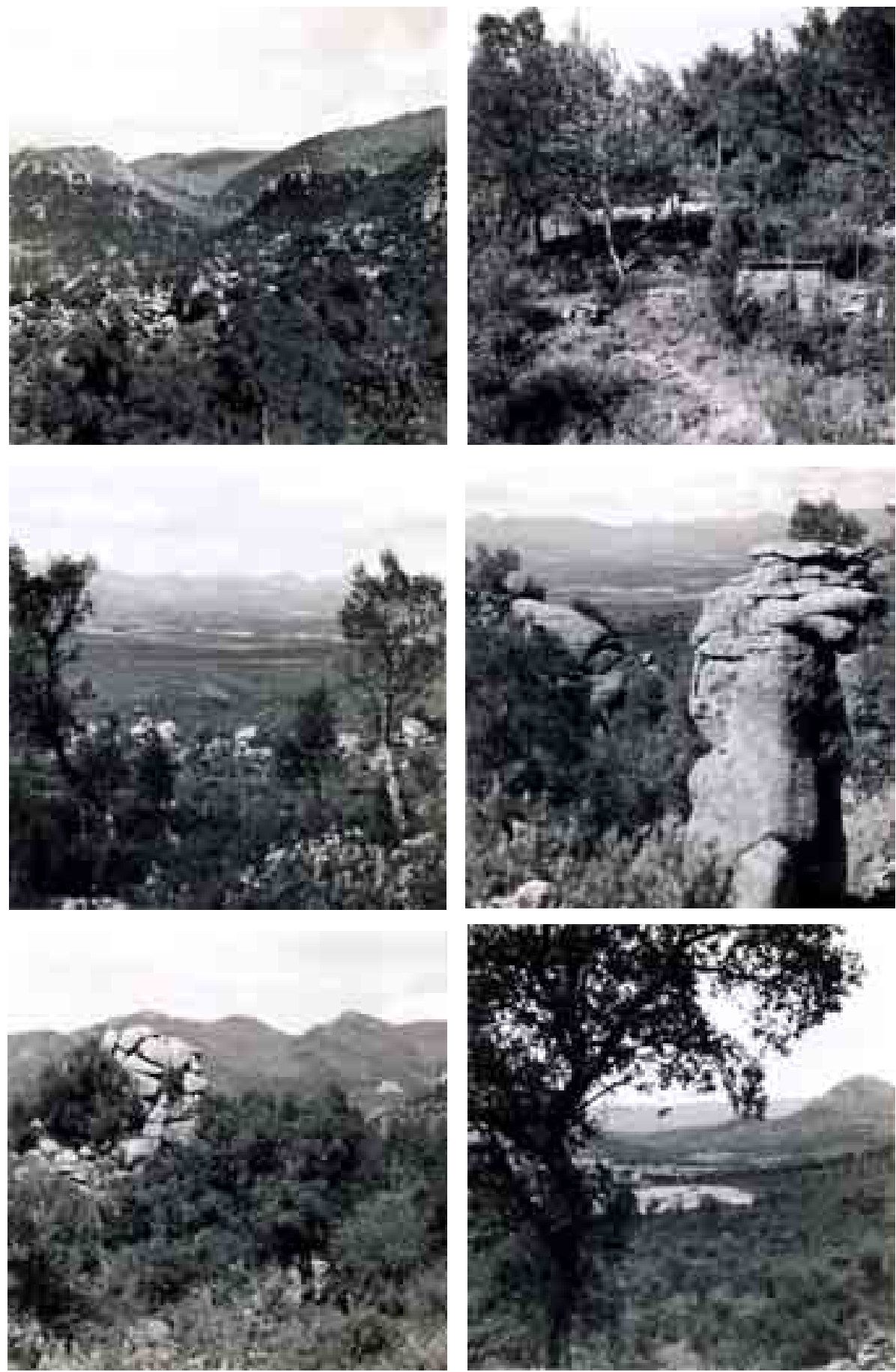

Figura $4.26 \mathrm{~d}$

Serie de fotografías del paisaje y territorio de Espolla encargadas por José Antonio Coderch y realizadas en 1966 por Catalá Roca como parte del conjunto de las realizadas de la casa Coderch en Espolla.

De izquierda a derecha y de arriba hacia abajo:

19..B-18097 Paraje "Els Rocaters"

20. B-18103 La Fuente de la Viuda

21. B-18104 Panorámica desde "Els Rocaters"

22. B-18108 Formaciones graníticas en "els Rocaters"

23. B-18109 entregada a D. Luis Mascort Marianni el 24-III-77

24. B-18113 El valle de "La Gotina" desde el coll del pal. Al fondo derecha, Els Rocaters y Puig Castellar. 
Serie de fotografías del paisaje y territorio de Espolla encargadas por José Antonio Coderch y realizadas en 1966 por Catalá Roca como parte del conjunto de las realizadas de la casa Coderch en Espolla.

01. B-18049 La Roca d'Els Cantons

02. B-18050 Paraje "Comaderneus" vista parcial

03. B-18054 Paraje "Comaderneus" Fuente

04. B-18064 Paraje "La Murtra" trozo de la llamada "Calzada de Anibal"

05. B-18065 Paraje "Puig Cabell" fincas de cultivo

06. B-18069 Paraje "Puig Cabell" cepas al brotar

07. B-18071 Menhir en el paraje de "La Murtra"

08. B-18074 Paraje "Puig Cabell" "Les Sorreres" y "El Pal” panorámica

09. B-18076 Paraje "La Murtra" estanque

10. B-18079 Paraje "La Murtra" estanque

11. B-18083 Paraje "La Murtra" estanque

12. B-18080 Dolmen "La Barraca de l'alarb" en el camino de la Murtra

13. B-18085 Detalle de algunos viñedos en el camino del Castellar

14. B-18086 Espolla desde el camino de "Les Sorreres" vista parcial

15. B-18088 Parajes "Puig Cabell" y "La Gotina" viñedos

16. B-18089 "Les Sorreres" alcornocal

17. B-18092 Rocas erosionadas junto al camino de "Puig Cabell"

18. B-18094 Camino "d’Els Vilars" viñedos con el Puig de la calma al fondo

19..B-18097 Paraje "Els Rocaters"

20. B-18103 La Fuente de la Viuda

21. B-18104 Panorámica desde "Els Rocaters"

22. B-18108 Formaciones graníticas en "els Rocaters"

23. B-18109 entregada a D. Luis Mascort Marianni el 24-III-77

24. B-18113 El valle de "La Gotina" desde el coll del pal. Al fondo derecha, Els Rocaters y Puig Castellar. 


\subsubsection{En busca de las raíces. Espolla: vivir, trabajar, morir [Topofilia]}

\subsubsection{La recuperación de la casa familiar}

Quizá la forma más certera de explicar lo que significa Espolla, en cuyo pequeño cementerio quiso ser enterrado, para Coderch es a través de sus propias palabras:

«En seguida que he ganado algo de dinero me he comprado mi casa pairal de Espolla al Alt Empordà. Es como retornar a los orígenes, enlazar con el pasado; con mi abuela, llena de historias fantásticas que me encandilaban, y sus gatos; con mi padre que me decía: "Hay cosas que un Coderch no puede hacer"; con los payeses» (comillas en el original) (Porcel 1967, 27).

«Yo soy ampurdanés, de Espolla, aunque nacido en Barcelona....

....El arreglo de mi casa pairal supone algo importante para mí. Es quizá el hecho más importante de mi vida». (Pizza y Rovira 2003)

«Esta casa la vendió el hereu sin hijos, hermano de mi bisabuelo, poco antes de morir....Y hace ya 17 o 18 años, hacia 1960, cuando yo estaba con la depresión, vino a verme Quim Masramón, mi gran amigo, que era arquitecto de la Diputación de Gerona, y me dijo: "Tengo que ir a Espolla. ¿No es tu pueblo?" Llevaba una fotografía y me sacó de la cama. Me explicó que pasaba por allí, vio la casa y se dijo: "Cómo me gustaría que fuera esta la casa". Entró y vió un escrito en un dintel de la época de mi tatarabuelo Narciso, que hizo reformas en la parte de arriba justo antes de la Revolución Francesa, "Hoc facit Narcisus Coderch". Del año mil setecientos y pico. Y así fui allí con él...La familia dijo que estaba loco. Pero era la casa madre, la que a mí me interesaba más. Así que estuvo fuera de la familia durante 60 años» (comillas y cursiva en el original) (Soria 1979)

La Casa de Espolla supuso algo esencialmente vital para José Antonio Coderch. Según sus propias palabras es quizá el hecho más importante de su vida. Significa la conexión con el pasado, con sus ancestros familiares, con la tradición del campo catalán, con sus raíces más profundas. De las tres casas estudiadas, es sin duda la que genera una relación más personal y emotiva entre el autor y su obra, al confluir una serie de circunstancias que esta tesis aporta como posibles.

En realidad, la casa había dejado estar en la familia varios años y el último Coderch que había vivido en Espolla fue su abuelo en otra casa sin terreno, enfrente de esta. Por como cuenta el hallazgo de su amigo Quim Masramón, no parece que tuviera un contacto cercano con Espolla. Por tanto, no es algo que le venga dado, sino un acto voluntario para enraizarse en esa tradición. Un universo que busca y construye a partir de la recuperación de la casa.

Coderch fue un hombre con contradicciones significativas, que con su sensibilidad padeció emocionalmente con intensidad. Hizo la guerra con Franco sin renegar nunca de ello, pero sin embargo fue muy crítico con determinadas posturas del régimen en cuanto a la arquitectura que promovía, y también frente a la incultura, ineptitud y corruptelas de muchos cargos oficiales. Sin duda pagó un precio por ello. Con la excepción de las viviendas de la Barceloneta para el ISM y el breve periodo de tiempo como arquitecto municipal de Sitges, después no volvió a trabajar con encargos para la administración, lo que en su época fue bastante inusual en un arquitecto con su prestigio. 
La enfermedad degenerativa que vivió durante varios años hasta su muerte, pudiera haber estado relacionada con episodios depresivos anteriores, el más importante el ocurrido tras el desengaño de Torre Valentina, que le sumió en una crisis personal, profesional y económica. De la económica y profesional salió a partir del encargo de la Casa Tapies y uniéndose al Team 10, y de la personal sin duda salió en gran parte gracias a la Casa de Espolla.

Para Coderch, Espolla va más allá de una exploración arquitectónica, aunque sin duda lo es. Se convierte en la referencia que le dará fuerza, estabilidad y serenidad. Encuentra en la cultura de la tierra, el ancla que necesita frente a sus contradicciones y desengaños.

La Casa de Espolla, su territorio y su paisaje le conectan con lo más ancestral, sencillo y verdadero. Con el Pirineo y el Mediterráneo. Con la carlina y el fuego del hogar. Con la tramontana y la farigola que crece sobre sus restos en el cementerio de Espolla.

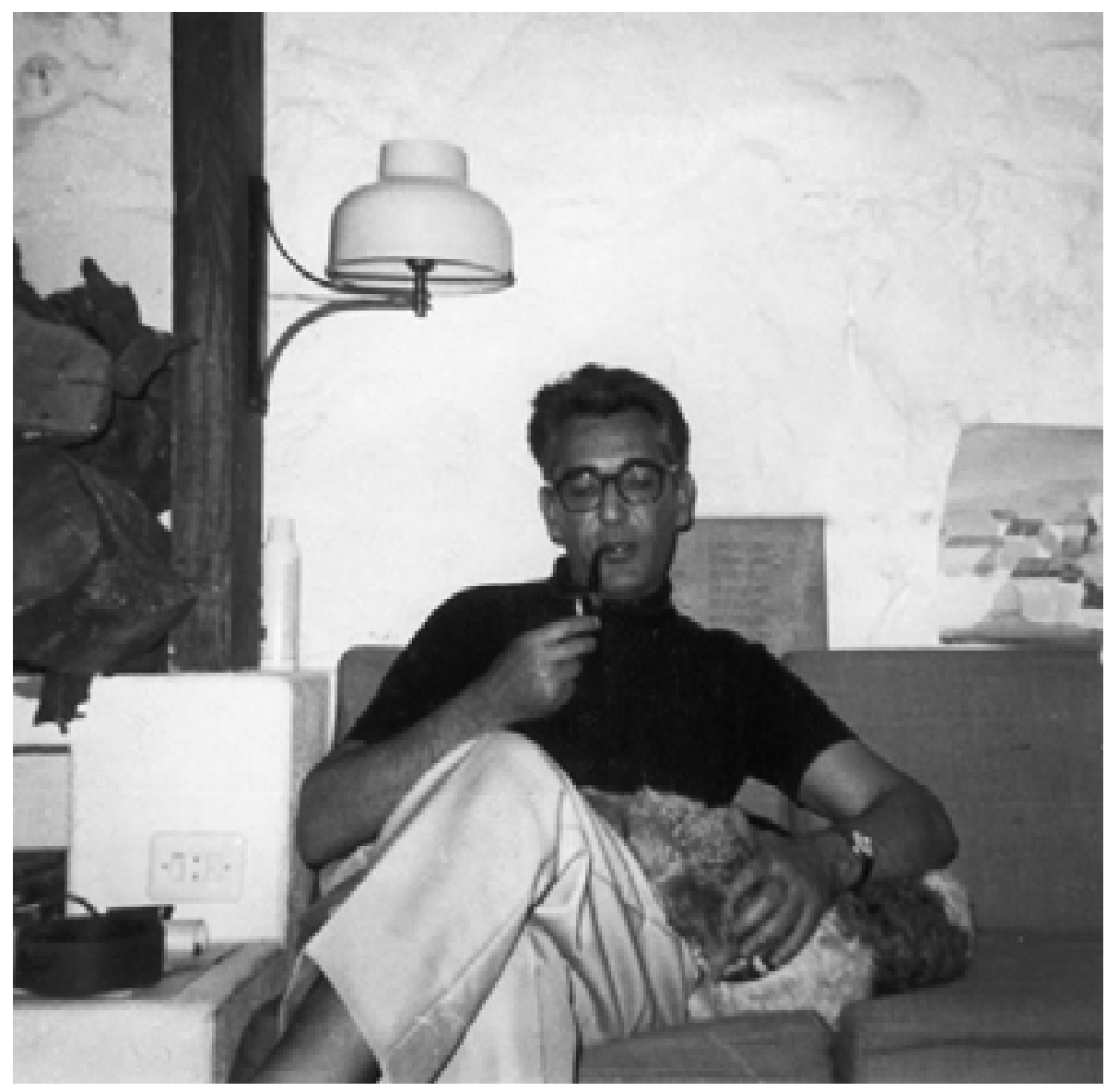

Figura 4.27

José Antonio Coderch en Espolla.

La imagen, muestra un Coderch relajado y familiar. La fotografía realizada por su hija Elvira Coderch y publicada en su blog Flores y Palabras con el siguiente comentario:

: «Mi padre con Rif, nuestro fox terrier (1966-67)»

Del mismo blog se rescatan unas notas que explican como varias de las mejores fotografías de Coderch, están hechas por su hija:

«Me gusta recordar a mi padre en su faceta de fotógrafo. No sólo por lo que supo enseñarme, el amor a la fotografía que me transmitió, sino por lo que él mismo disfrutaba con ese hobby.

En ocasiones, era un toma y daca: "ahora me haces tú, ahora te hago yo". Era divertido. Algunas de mis mejores fotos de él las hice así, aunque el mérito era en gran parte suyo, pues él preparaba las condiciones ideales: elegía el carrete, el lugar, me aconsejaba sobre el diafragma y la velocidad... y luego yo idisparaba! Además, él hacía el trabajo posterior de laboratorio, y eso puede mejorar o empeorar la calidad de la fotografía en un tanto por ciento muy considerable» 


\subsubsection{Cipreses, frutales y el bosquecillo de pinos. [Topiaria]}

En Respuestas al cuestionario Marcel Proust, publicado en 1964, Coderch responde entre otras preguntas varias relacionadas con árboles y flores

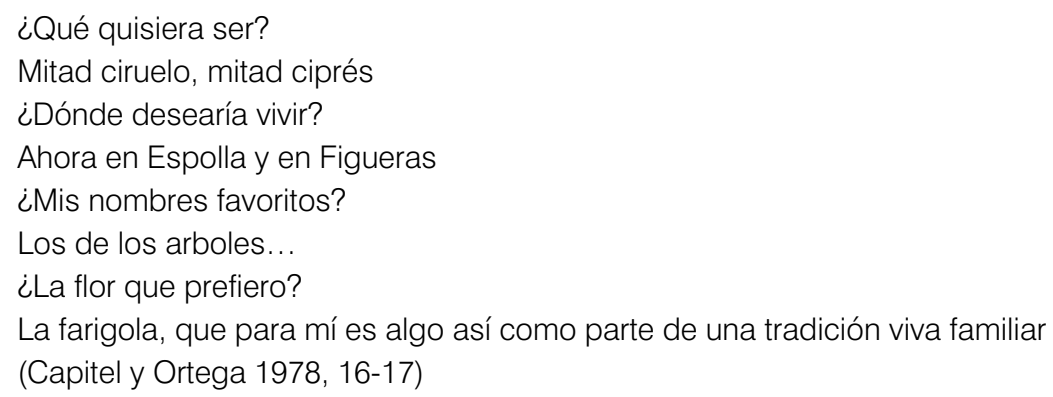

La farigola ${ }^{26}$ es el «Thymus vulgaris», es decir el tomillo en catalán y lenguas afines. Por deseo expreso de Coderch, la farigola crece sobre sus restos en el cementerio de Espolla donde falleció y está enterrado junto a su esposa Ana Maria Giménez Ramos, sin duda también participe activa del proyecto de jardinería.

En el plano de plantaciones, se ve un proyecto completo de acondicionamiento vegetal de la parcela, con especies típicamente mediterráneas. En la parte posterior, se plantaron 200 pinos y una masa de robles del país, a modo de bosquecillo, como protección de la tramontana. También en la parte norte un grupo de olivos, actualmente desaparecidos. En los bancales aterrazados de la parte delantera se plantan almendros, naranjos, algún laurel y tres higueras entre otros: farigola, manzanilla, retama, granadina, arce, chumberas, granadas...Además, estaba planteado que una hilera de cipreses rodease toda la parcela, en parte para protegerse de la mirada ajena, y en parte para tapar construcciones adyacentes en la parcela colindante, que pasó de ser una edificación baja de piedra a una vivienda unifamiliar de gran volumen, que además de dejar a la vista una gran medianera sin tratar, en cierta forma pretendía imitar la arquería de la galería de la casa de Coderch. Esta hilera, finalmente solo rodea la finca en su parte sur, la más urbana, integrándose de es ta manera la masa boscosa de la zona norte, de forma mas natural con el territorio hacía el que se proyecta.

Figura 4.28

Croquis de la parcela con las plantaciones, en el que también esta expresivamente representado la singular posición y morfología urbana de la finca, en origen con una servidumbre de paso de un camino que la atravesaba y pasaba por debajo de la galería su-este de la casa.

Archivo Coderch

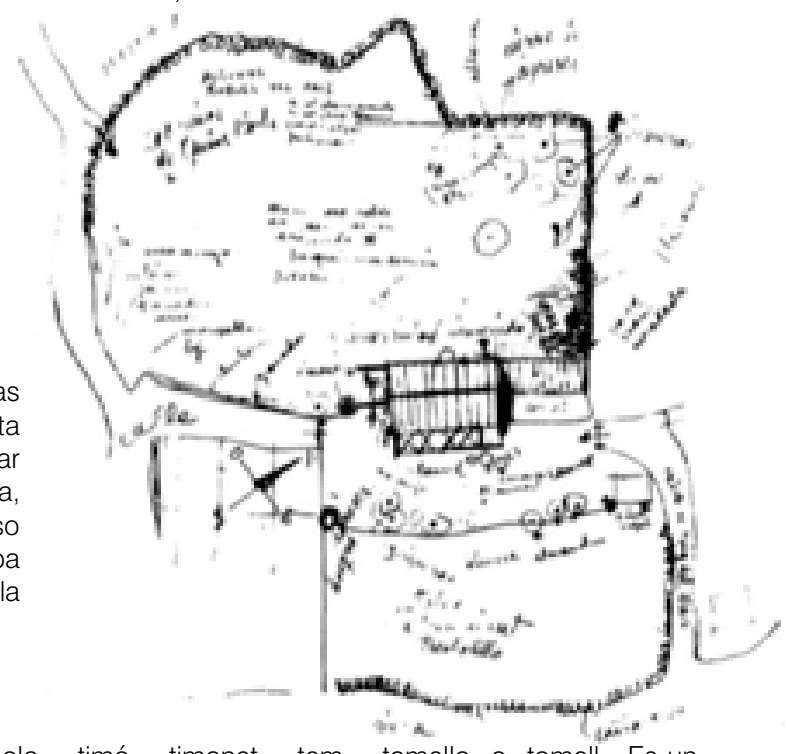

${ }^{26}$ Recibe también los nombres de «frígola», «timó», «timonet», «tem», «tomello» 0 «tomell». Es un sub-arbusto de la familia de las labiades. Se le llama farigola de forma común en parte del Cataluña roeintal, del latín vulgar «ferricula», mientras que Cataluña occidental y comarcas limítrofes se le llama «timó», del latín culto «thymus.». En las Islas Baleares, se le llama «frígola» y en Menorca también es conocido como «tem». «Tomello» es mas frecuente en la región de Valencia. 

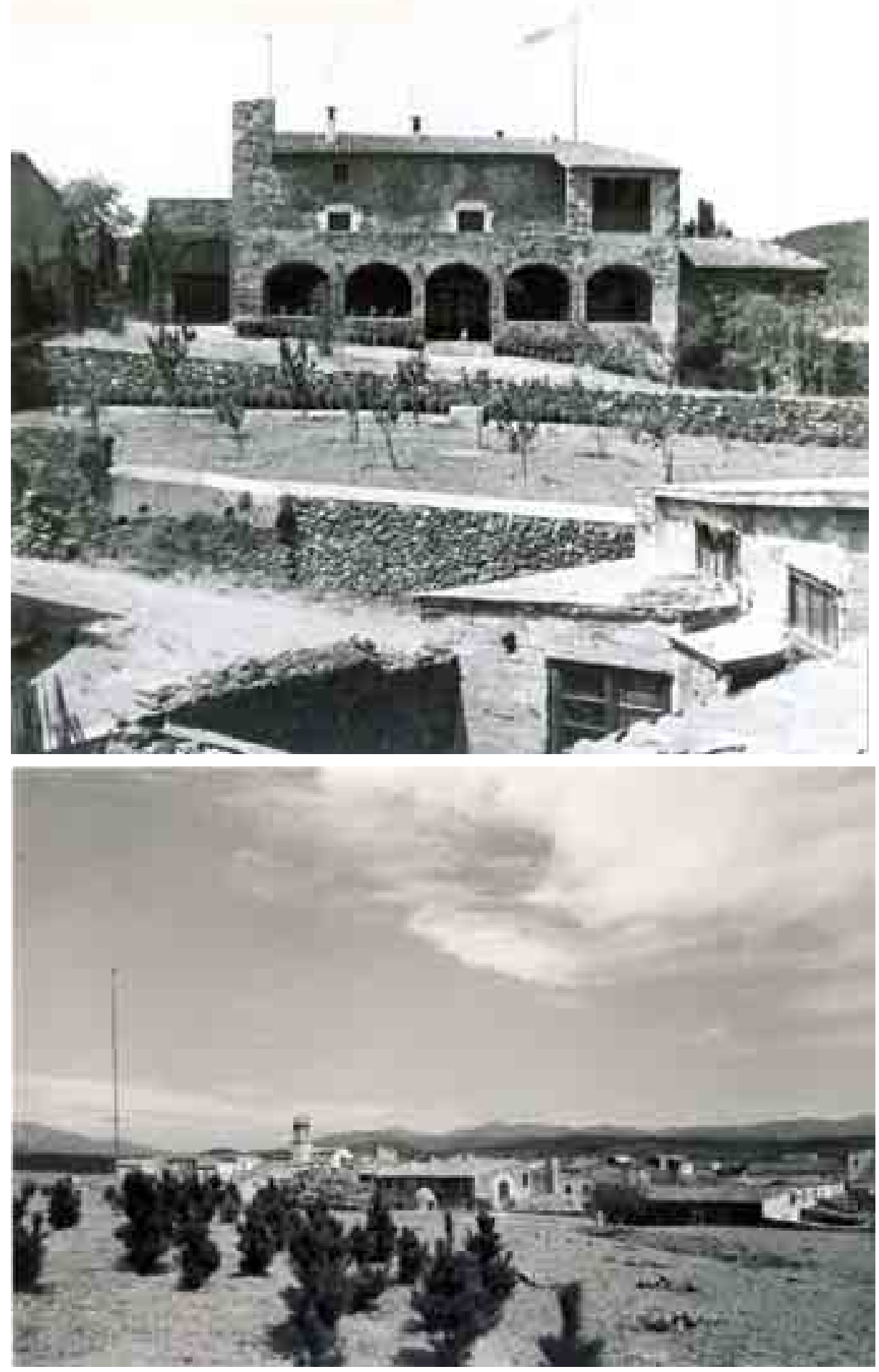

Figura 4.29

Las plantaciones realizadas por Coderch en la parcela

En las dos imágenes pertenecientes a la serie de fotografías realizadas por Catalá Roca en los sesenta, se ve el arbolado recién plantado.

En la fotografía superior, se ven los frutales, sobre todo almendros y algún naranjo, en los bancales aterrazados en la parte delantera de la parcela para salvar la pendiente hasta la calle.

En la inferior, se puede comprobar cómo la masa arbolada de la parte posterior de la parcela, compuesta principalmente por ejemplares de hoja perenne tipo pino piñonero, y aparentemente de crecimiento natural, en realidad fue plantada por Coderch, como muestra el primer plano de la imagen.

Es de reseñar que estas imágenes ya no son posibles de ver, debido precisamente a lo crecido de la plantación, especialmente por la hilera de cipreses que rodean la parcela en su parte m.as pública.

Archivo Coderch 


\subsection{Coderch y la casa pairal [Tipo]}

La casa, con características propias de la zona, está parcialmente excavada en la roca, construida con gruesos muros de mampostería de piedra delimitando las estancias de la vivienda. Pero lo que determina espacialmente cada estancia son las bóvedas de cañón y crucería que las cubren.

Coderch pone en valor la planta de acceso, originalmente destinada a los animales, como vivienda independiente, con las bóvedas como generadoras del espacio. Las de las dos salas principales construidas con mampostería de piedra según la técnica vernácula local de utilización de caña y tabla de madera para la cimbra, y el resto bóvedas tabicadas, manteniendo en todos los casos sus diferentes texturas a la vista.

Pairal en lengua catalana significa que pertenece a los padres, a los antepasados, pudiéndose traducir al castellano como paterno o solariego.

A su vez, el termino solariego, según el María Moliner tiene tres acepciones.

En la primera quiere decir «De solar o linaje noble, y se aplica normalmente a una casa». En la segunda se refiere a cuando en la Edad Media se aplicaba al colono que vivía en una tierra del rey, de la iglesia o de una señor, sometido al poder personal de ellos, y por último en la tercera es el adjetivo que se aplica a los bienes rústicos que pertenecen por entero a sus dueños.

Es decir, la casa pairal, es la casa paterna de los antepasados, y lleva implícitas de forma simultánea los tres significados dados por María Moliner

Sobre ella se aporta el escrito de Antoni Gaudí, titulado «La Casa Solariega» posiblemente escrito entre 1878 y 1883 . Coincide en el tiempo y en concepto con la Casa Vicens. Se caracteriza además de ser uno de los escasos textos de Gaudí no relacionados con un proyecto concreto, es el única de su época escrito en catalán, por lo que Laura Mercader que lo ha recogido en su libro Antoni Gaudí. Escritos y Documentos plantea que pudiera hacer sido escrito para el periódico La Reinaxenca o para el Butlletí de la Associació d'Excursions Catalana. Antoni Gaudí dice:

«La casa es la pequeña nación de la familia.

La familia, como la nación, tiene historia, relaciones exteriores, cambios de gobierno, etcétera.

La familia independiente tiene casa propia, la que no lo es tiene casa de alquiler.

La casa propia es el país natal, la de alquiler es el país de la emigración; por ello la casa propia es el ideal de todo el mundo.

No se concibe la casa propia sin familia, sólo se concibe así la de alquiler.

A la casa de familia se le ha dado el nombre de casa solariega. Con este nombre, ¿quién no recuerda algún bonito ejemplo en el campo o en la ciudad? El espíritu de lucro y los cambios de costumbres han hecho desaparecer de nuestra ciudad la mayor parte de las casas solariegas. Las que quedan gozan de una situación tan oprimida e indeficiente que acabará con ellas.

La necesidad de la casa solariega no es solo de una época y familia determinadas, es la necesidad de todos y de siempre. La independencia de la habitación, la buena orientación y la abundancia de aire y de luz de que carecen generalmente las viviendas urbanas se va a buscar en esa infinidad de casas de los alrededores; dándose el caso extraño de tener la mayor parte de las familias dos habitaciones en sus residencias cotidianas (y aún cosa más extraña, la que tiene más condiciones es la que menos sirve).

Para encontrar estas cualidades, a los habitantes de las ciudades extranjeras no les importa apartarse del centro de las mismas; si bien se lo permiten los numerosos medios de comunicación, que afortunadamente nosotros también empezamos a tener. 
Justo es pues que, aprovechando los medios que tenemos, pensemos en la verdadera casa de familia, y que juntando la habitación urbana y la casa de campo nazca la casa solariega. Al objeto, imaginemos una, ni grande ni pequeña, una que podríamos llamar ordinaria, enriqueciéndola y agrandándola se convertirá en palacio, empequeñeciéndola y economizando materiales y adornos será la modesta habitación de la familia acomodada.

Figurémonos que un solar del Ensanche, grande según las posibilidades del propietario, situado en un barrio más o menos aristocrático según su fortuna y posición, está rodeado por una pared, que sostiene el terreno del jardín a la altura suficiente para no ser visto desde la calle, coronada por un pretil calado.

Una pequeña galería abierta junto a la puerta interrumpe este terrado. Dentro del solar, por un lateral se desarrolla una larga rampa, camino de carruajes; enfrente se presenta una escalinata, desde cuya cima se descubre el jardín y por entre el follaje de las albas y de los plátanos, la casa. Las habitaciones, agrupadas según la necesidad de su orientación, forman un conjunto pintoresco. Así, las amplias ventanas de los dormitorios miran a oriente; el despacho y la sala de familia, al mediodía; el comedor de invierno y las salas de vivita, a poniente, y al norte, el estudio, el comedor de verano y otras dependencias. Separadas de esta agrupación, y en la misma dirección, están la cocina y sus dependencias auxiliares. Entre el dormitorio y el estudio, sombreado por acacias y laureles, se sorprende un porche ornado con terracotas que sirven de nido a los gorriones del entorno. En el ángulo opuesto, un invernadero de hierro y cristal, jardín de invierno, comunica con las habitaciones de recibo y puede ser habilitado como salón para las grandes fiestas de familia. Por todas partes la sencillez en el interior campea por sistema; el buen gusto por guía, y la satisfacción de las necesidades y comodidades por obligación. Todo es formal. Allí se encuentran representados los recuerdos de familia, las gestas históricas, las leyendas de la tierra, las delicadas concepciones de nuestros poetas, los espectáculos y escenas de la madre naturaleza; todo aquello que tiene significación y aprecio.

En fin, la casa que imaginamos tiene dos objetivos: primero, por sus condiciones higiénicas, hacer de los de allí crecen y se desarrollan seres fuertes y robustos, y segundo, por las condiciones artísticas, dotarlos en lo posible, de nuestra proverbial entereza de carácter. En una palabra, hacer de los hijos que en ella nazcan verdaderos hijos de la casa solariega.»

\subsubsection{La masía catalana}

Torres Balbás en la Vivienda Popular en España, hay citado anteriormente, dedica un capítulo importante a las masías en Cataluña.

Aunque Cataluña, por la complejidad de su geografía con territorios de altitudes muy diferentes a nivel del mar y en la región pirenaica, tiene una arquitectura popular muy variada dependiendo de las condiciones específicas, «es indudable que existe un tipo de casa campesina en Cataluña diferente d los de las comarcas inmediatas.» (Torres Balbás 1930, 491)

Respecto al origen de la masía y a como su estructura territorial ha perdurado, es debido

La vivienda más típica es la de la familia de clase media o popular acomodada, en la que el segundo hijo queda en el campo llevando la vida del labrador, del payés, mientras que el mayor, el hereu, vivía y gastaba en la ciudad. De esta forma, en el campo se mantenía el hogar tradicional e inalterable. La riqueza, variedad e importancia de la arquitectura popular campesina en Cataluña, cuya expresión más 
alta y típica es la masía, viene debida a varias razones, entre ellas las intensas relaciones comerciales con Italia y la cercanía con Francia.

La masía no adquirió cierta importancia hasta el siglo XVI, debido a la fuerte organización feudal de Cataluña., ya que la masía suponía cierta independencia del masover-el colono-. En los documentos que nos han llegad desde la Edad Media se relatan varios tipos de vivienda, desde el más modesto o tugurium, una pobre construcción en madera, después la cabana y la cabanela, hasta la habitación rural o mas, la casa de campo aislada. Según Puig y Cadafalch, de origen romanomediterráneo como las costumbres y familia catalanas, a la que se le superpone la tradición local, perdurando en el románico y en el gótico. Sin embargo para otros autores como José Danés, Luis Bonet y Jerónimo Martorell, la tradición se interrumpió con la invasión musulmana, ya que cuando se empiezan a construir casas campesinas de importancia, se inspiran en las iglesias de la comarca, de manera que en las tierras fronterizas o de grandes llanuras no fáciles de defender, las viviendas aisladas son escasas, y cuando se dan aparecen agrupadas alrededor de una torre.

Es a partir de finales del siglo XV y en el XVI, cuando la revolución social de lo remences, incrementó de forma considerable la vida en el campo, con la división de las grandes propiedades. El siervo se convierte en pequeño propietario, trabajando la tierra en su propio provecho con una mayor producción. Para contralar mejor la propiedad construye su casa en el mismo terreno que trabaja, y así surge la masía, dando lugar a la pagesia e iniciándose un largo periodo de prosperidad para este tipo de construcción, que comenzó siendo de gran modestia en el siglo XVI, evolucionando hasta su edad de oro en el siglo XVII, cuando los campesinos se han convertido frecuentemente en ricos propietarios, lo que en cierta manera les convierte en los señores feudales para los que en origen trabajaron. Tienen colonos que trabajan la tierra en lugar de siervos y aunque si armas como antaño, siguen ejerciendo de hecho la autoridad al ser los propietarios de la tierra.

Respecto al carácter de la casa

Las habitaciones con paredes encaladas son espaciosas, y el centro de la vivienda en el invierno es la gran campana de la chimenea del llar con los escaños para sentarse.

Respecto a los muebles y utensilios de la casa, Torres Balbás citando a Pla Cargol dice:

«Los muebles de la casa son sencillos: La mesa de encina o de roble de amplio cajón, en el que se guarda el oloroso pan; las sillas de esparto, los cacharros relucientes, barnizados, colocados en la repisa que vuela sobre la amplia campana del llar, dan a la cocina del campesino un carácter de fortaleza, bella íntima y no sujeta al capricho de la moda. En el piso alto, la amplia sala central con las cajas de novia, oliendo a manzana y el macizo armario de ropa blanca, dando la impresión de las cosas perdurables: el hereu los dejará al morir tal como los vió de niño; los muebles poseen la patina que da el tiempo, y la masía ha permanecido inmutable durante años y años mientras varias generaciones han ido pasando por ella» (Torres Balbás 1930, 498)

En la vida familiar, las piezas más importantes son la galería y la cocina. De día y con buen tiempo la vida se hace en la galería, y de noche o cuando hace mal tiempo en la cocina. Así la sala principal es más un lugar para celebraciones y acontecimientos, además de ser el local de relación con las visitas.

Normalmente las galerías constituyen la crujía más moderna de las masías, y se orientan principalmente al sur o sureste, abriéndose a la orientación soleada y cerrándose hacia la umbría, que se dedica a cuadras y almacenes Es frecuente un poyo a modo de basamento, desde el que salen los machones de mampostería o 
sillería de los que arrancan los arcos. La crujía de la galería es muy práctica para proteger a la casa y sus habitantes de las inclemencias atmosféricas. En verano, al ser abiertas resultan frescas, y en invierno, la declinación baja del sol, hace que este penetre hasta su interior resultando abrigadas. (Torres Balbás 1930, 501)

«La planta baja de estas casas cúbrese casi siempre con bóvedas; en la parte correspondiente a la galería suelen ser por arista; las de las restantes crujías, de cañón seguido, o con lunetos que dan luz a puertas y ventanas» (Torres Balbás 1930, 502) 

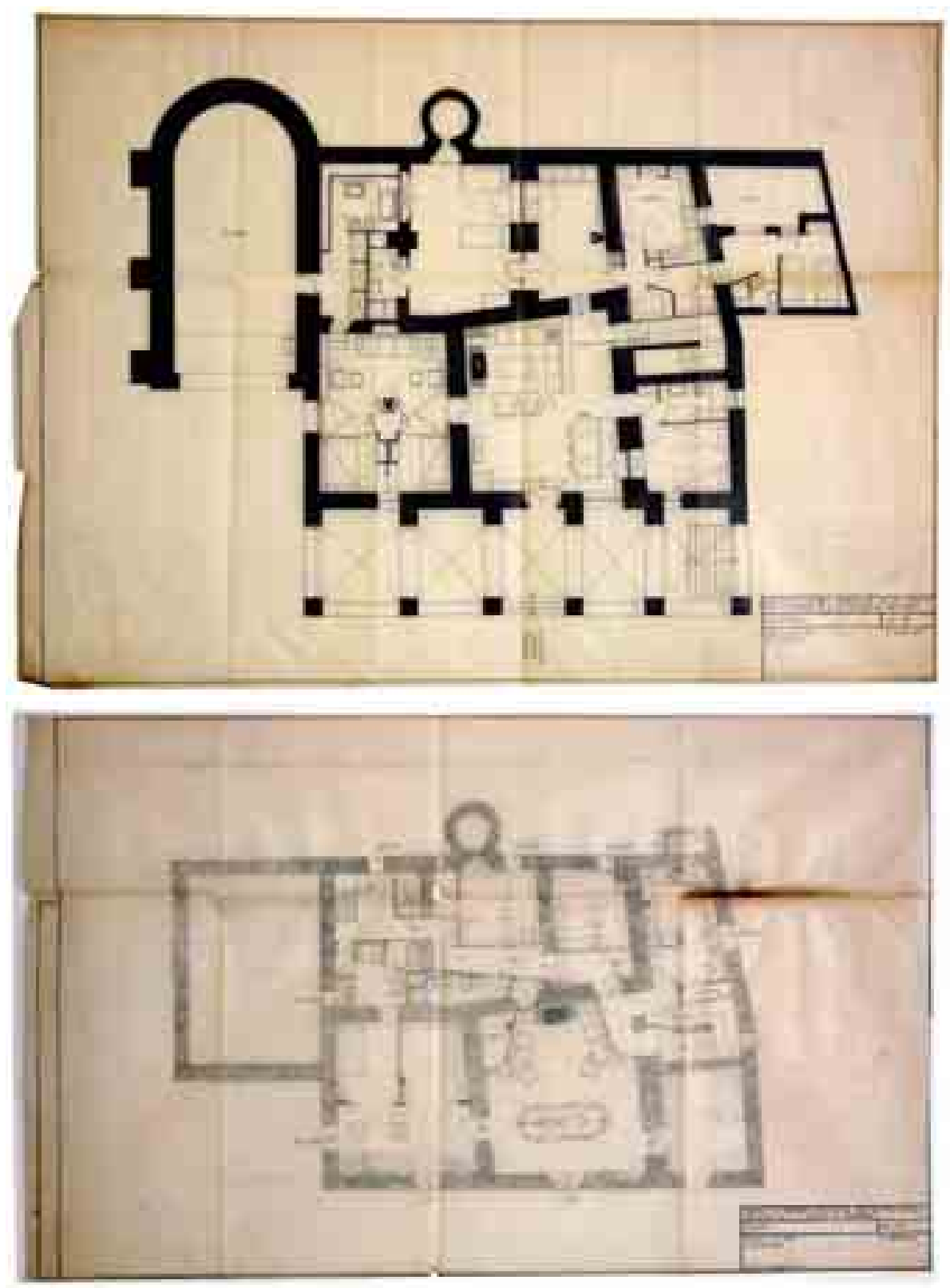

Figura 4.30

Planos de proyecto de la Rehabilitación de la Casa en Espolla, según estaba previsto inicialmente, aunque durante la obra se cambio de idea y se dejó la planta primera sin acondicionar, haciéndose solo la planta baja.

* Superior: Planta baja

* Centro: Planta primera

* Inferior: Modificación realizada del proyecto inicialmente previsto para acondicionar el dormitorio personal de José Antonio Coderch en planta primera, única habitación reformada de dicha planta, donde se refugiaba del bullicio de la casa en vacaciones. Archivo Coderch

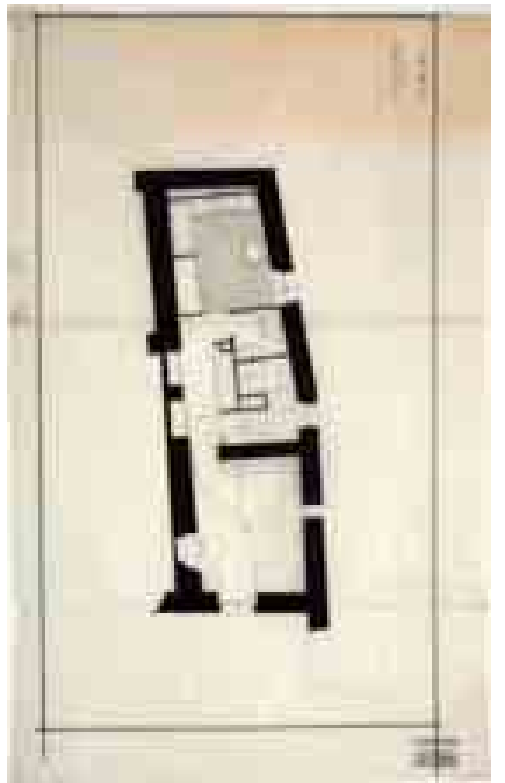



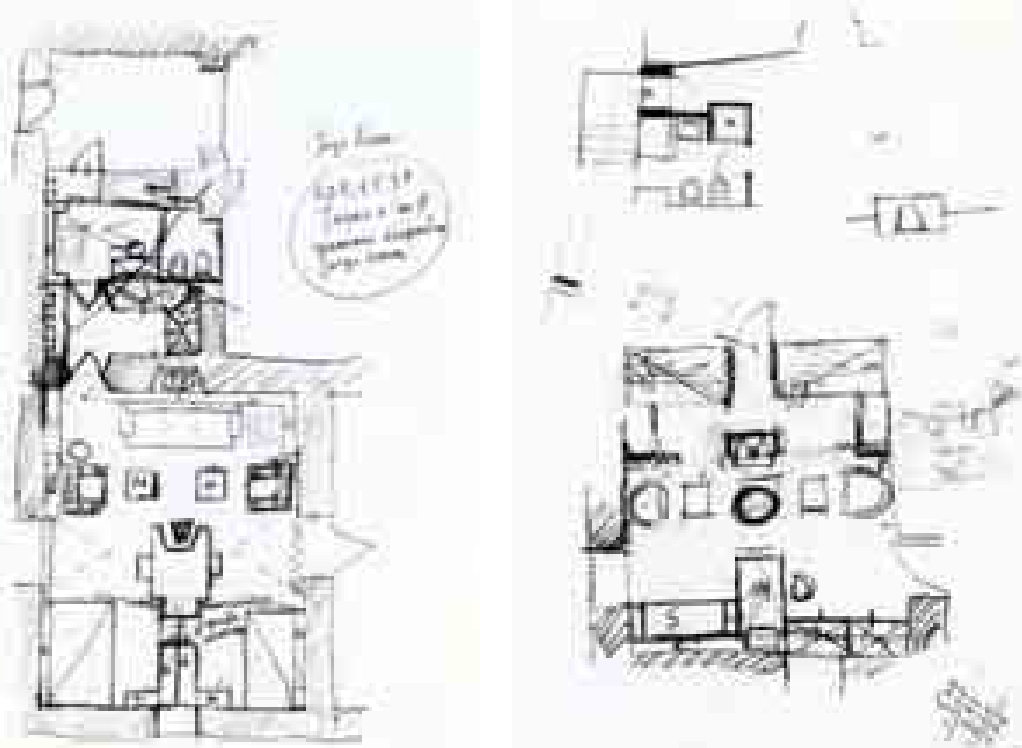

Figura 4.31

Croquis a lápiz de habitaciones en planta baja, tratadas como apartamentos independientes, aprovechando la condición de espacio -raum de la casa.

* Inferior:

Dibujo a lápiz de la planta baja, con anotaciones sobre la nueva bóveda que construye para el garaje aprovechando desnivel existente Archivo Coderch

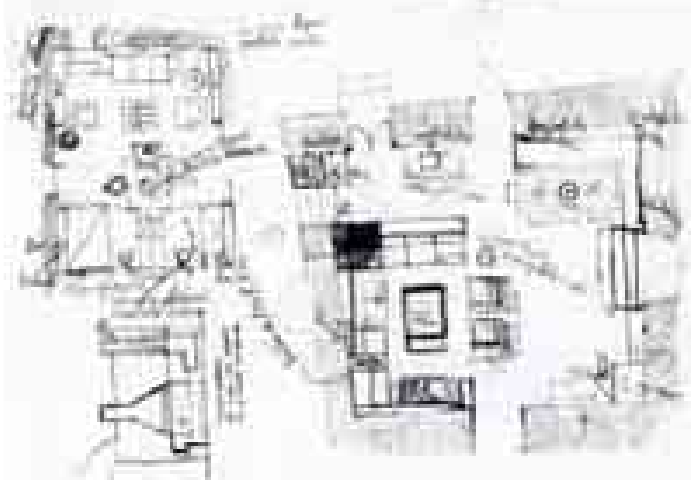

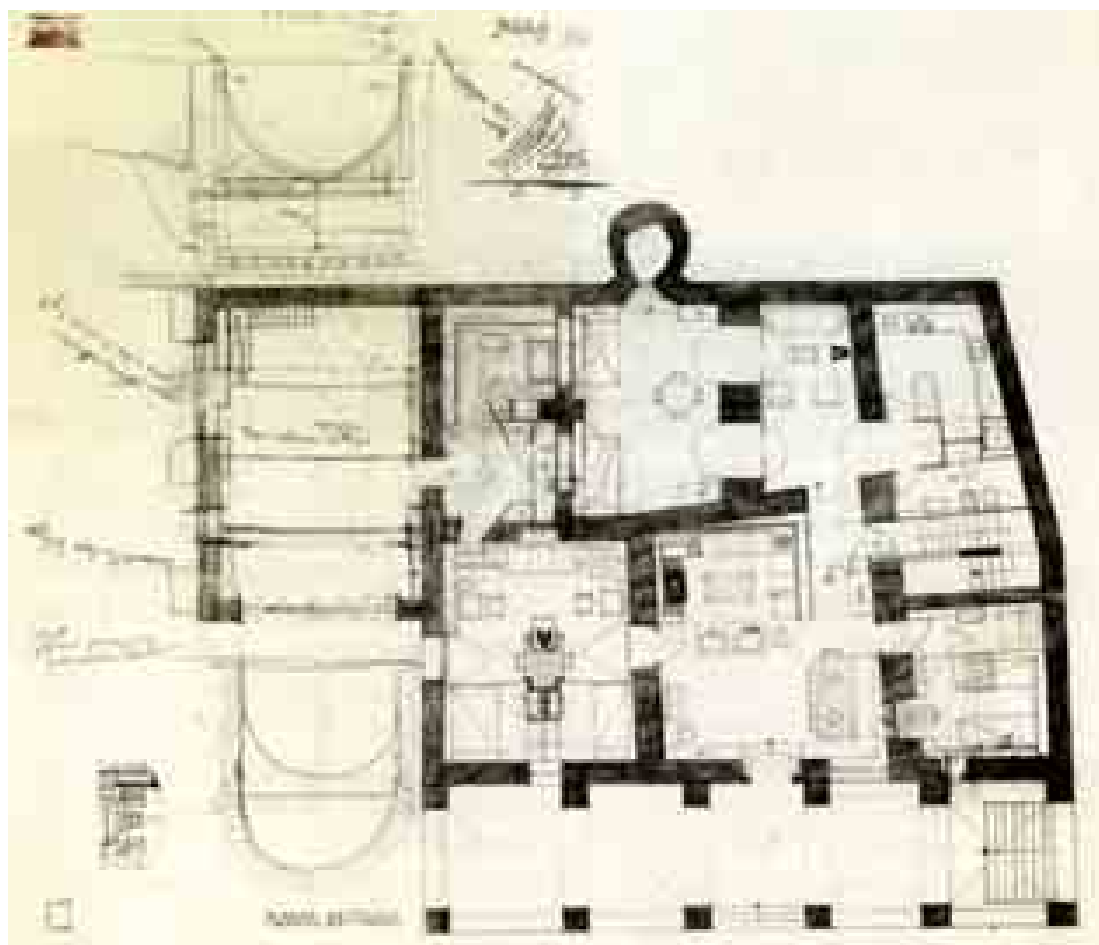




\subsubsection{Desarrollo de la solución dada a la casa a partir de una serie de 40 fotografías inéditas realizadas por José Antonio Coderch durante el proceso.}

En el mes de diciembre de 1992, en el número 294 de la revista Arquitectura, Gabriel Ruiz Cabrero publica un artículo con el título «Una larga conversación y un regalo».

El regalo: Una serie de 80 fotografías de El Escorial hechas por José Antonio Coderch en el año 1959, y que posteriormente regalo a Francisco Asís Cabrero, aparecen publicadas en sus páginas.

La larga conversación: la amistad entre Coderch y Asís Cabrero nacida en el periodo en que Coderch estuvo en Madrid, recién terminada la carrera, trabajando en las oficinas de la Obra Sindical del Hogar de la que Cabrero era Arquitecto Jefe. Amistad de la que también participaban otros compañeros que allí desarrollaban proyectos y que procedían de distintos lugares de España formando un grupo variopinto, pues ninguno era de Madrid: Abaurre de Sevilla, Aburto del País Vasco, Cabrero montañés y Coderch de Cataluña.

En un momento de juventud, cuando se inicia la vida profesional con energía, incertidumbre y carencias, Ruiz Cabrero apunta tres rasgos compartidos por los jóvenes arquitectos: «la presencia del maestro», en este caso Secundino Zuazo, en cuyo estudio Coderch trabajaba por las tardes, los «viajes» de aprendizaje y la «Conversación excitada de una reducida hermandad» refiriéndose a cómo ese periodo significó una oportunidad de aprendizaje en grupo ocasionado por el continuo intercambio de pareceres que en gran medida se ponían en común tomando el aperitivo después de trabajar por la mañana en las oficinas de la OBS. Así «los descubrimientos, las dudas de cada uno, las enseñanzas de Zuazo se compartían en la tertulia»

En las reuniones también aparecían como protagonistas, las fotografías que Coderch hacía de edificios que le interesaban y con el tiempo de sus propias obras, que según su costumbre siempre llevaba en la chaqueta para comentar y compartir. Ruiz Cabrero dice:

«Sacaba las fotografías, las extendía sobre la mesa, entre escuadras, gomas, y cartabones unas veces, otras veces entre las copas, los vasos y las botellas, y contemplaba, comentaba, preguntaba, opinaba y respondía. Viajaban así las obras con él y sus imágenes se desplegaban en cualquier lugar, como las cartas de una baraja. Pasaban de mano en mano, se escogían, se desechaban, se ordenaban de formas distintas facilitando el juego variable y apasionante de la arquitectura. Con frecuencia el juego se prolongaba en papeles y servilletas, donde se intentaban detalles y figuras. Juegos de mesa que, como todos los juegos, no eran, al fin, sino un entrenamiento para la actividad principal y así en la oficina con frecuencia, los primeros croquis para un encargo, que como arquitecto cualquiera realizaba, eran tomados por otro que los desarrollaba y luego por un tercero y así hasta que se cumplía el proyecto» (Ruiz Cabrero 1992, 105)

Forma de actuar de Coderch a la que también se refiere su hija en relación a la pasión por la fotografía. En su blog Flores y palabras, Elvira Coderch dice:

«No voy a decir que su faceta perfeccionista no apareciera aportando algo de tensión a las sesiones fotográficas (fuera al realizar las fotografías o en el laboratorio pequeño que tenía en casa), pero la imagen que predomina en mi memoria es la de un gran disfrute. Daba gozo verle traer, muy ufano, ocho o diez copias de las últimas fotografías que había hecho y regalárselas a todo el que las quisiera. Parecía un niño con zapatos nuevos» 
En este marco, se encuadran la serie de fotografías realizadas por José Antonio Coderch en 1964 sobre el proceso seguido en la Casa de Espolla, y que esta tesis ha sacado a la luz, incorporándose a partir de ahora en el Archivo Coderch. Su historia hace necesaria una explicación.

En el transcurso de esta tesis, se ha consultado varias veces el Archivo Coderch, pudiendo acceder a la totalidad de los documentos disponibles ${ }^{27}$ en ese momento sobre la Casa de Espolla.

En general son conocidos por haber sido objeto de diversas publicaciones, aunque aún así se han encontrado varios documentos relevantes no publicados, como la serie de fotografías de Catalá Roca sobre el paisaje de Espolla y un borrador manuscrito de Coderch en defensa de la zona y en contra de las prácticas de tiro militares.

En cualquier caso, la documentación no es muy extensa y no refleja bien las intervenciones realizadas, seguramente debido a ser la casa propia y a haberse realizado muy sobre el terreno. A I mismo tiempo, su consideración de obra menor en relación a otras, pudo originar una selección de documentación poco exhaustiva para su incorporación al Archivo cuando este se estableció en la Escuela Técnica Superior de Arquitectura del Vallés.

A pesar de tener en cuenta estas circunstancias, siempre nos pareció extraño la ausencia total de plano, croquis, fotografía o cualquier otro documento sobre el estado inicial de la casa antes de la intervención, así como de las operaciones y proceso que se siguió, máxime cuando el propio Coderch, dejo explícitamente reseñado la complejidad y duración de las obras cuando en 1978 con motivo de la monografía a cargo de Antón Capitel y Javier Ortega, J. A. Coderch: 1945-1976, reseñó en dicha publicación:

«Esta casa de nuestros mayores, que pude recuperar hace 14 años, due restaurada respetando al máximo el edificio. Mientras realizábamos las obras hubo una especie de dialogo con él, y sus gruñidos y quejas nos ayudaron mucho para tratarlo con el debido respeto. Fue una obra muy larga por sus dificultades, por nuestra falta de experiencia en restauraciones y naturalmente por dificultades de financiación»

(Capitel y Ortega 1978, 87)

¿Cómo Coderch con su pasión por la fotografía, no iba a documentar nada del proceso, cuando aquí es precisamente el proceso, la experiencia más importante de cara a la solución final?

¿Cómo no lo iba a hacer en su propia casa, lo que hacía habitualmente con otros edificios aunque no fueran obras suyas?

Resultaba imposible de creer y teníamos la certeza que habían existido aunque por algún motivo hubieran desaparecido.

Finalmente nuestra completa seguridad y la generosidad de Ana Coderch que las buscó fuera de los lugares habituales, posibilitaron el hallazgo de un mazo de fotografías hechas por el propio Coderch, y que a partir de ahora se encuentran incorporadas al Archivo Coderch. Está compuesto por 40 imágenes, las cuales algunas tienen doble copia para poder trabajar sobre ella:

- Serie de 20 tomas, algunas con copias repetidas, en un sobre manuscrito por él con la siguiente anotación: «Colección completa de fotos del Más del Puig (Espolla) sacadas en junio/julio 1964. Son 20 fotos si se cuenta la 5 bis» además de otras dos pequeñas series

- Serie de 8 tomas en papel brillante y formato alargado en blanco y negro

- Serie de 8 tomas en blanco y negro

- Serie de 4 tomas en blanco y negro + 8 tomas en color

\footnotetext{
${ }^{27}$ Algunos documentos no estuvieron disponibles por estar utilizándose para publicar
} 


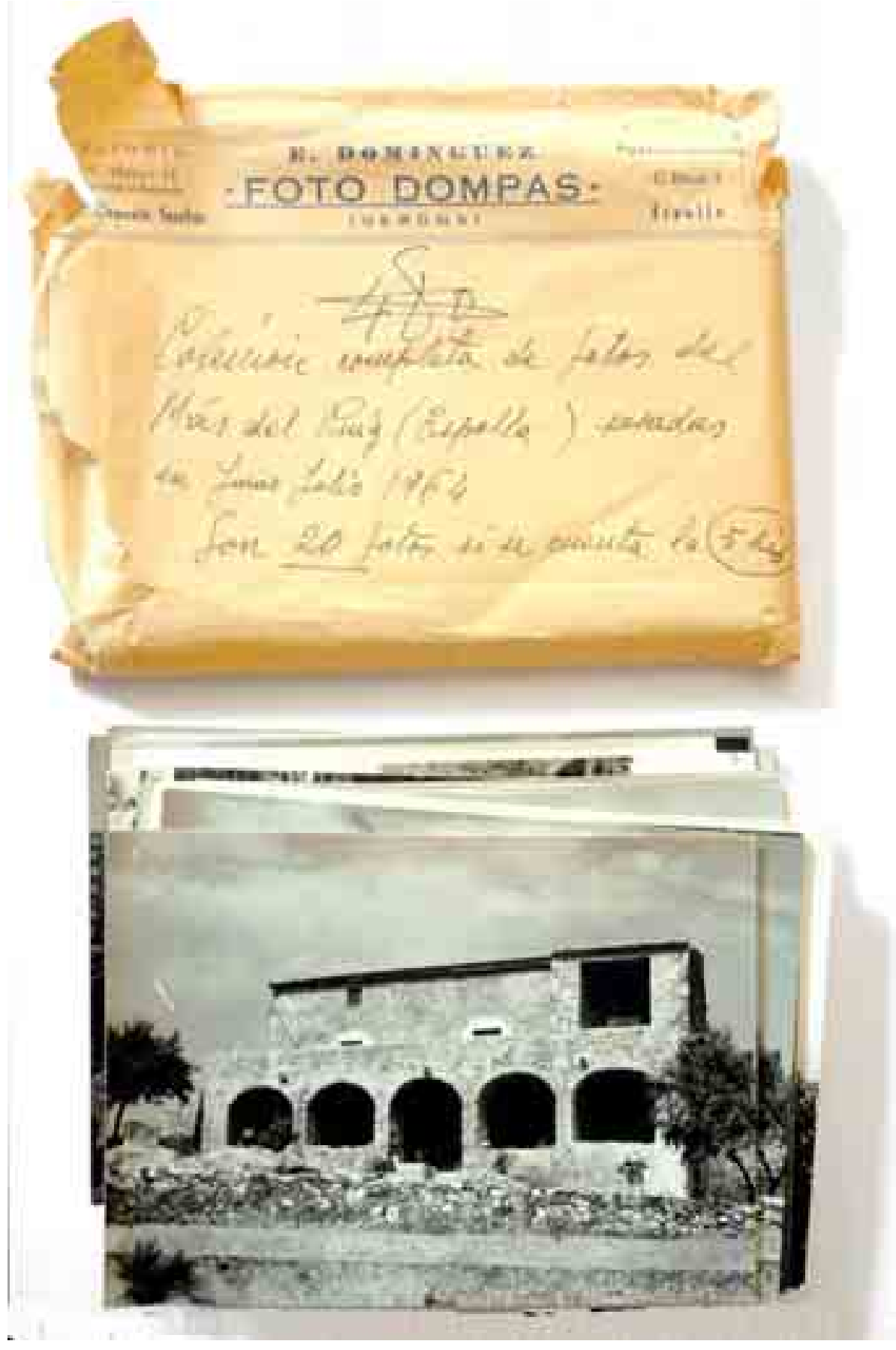

Figura 4.32

Colección de fotografías realizadas por Jose Antonio Coderch, durante el desarrollo de la obra de su Casa en Espolla, simultáneamente testimonio documental y método de trabajo. Colección inédita hasta ahora, han salido a la luz desde esta tesis doctoral.

Consta la citada serie de 20 imágenes, más otras series complementarias hasta alcanzar el número de 40

Incorporadas al Archivo Coderch. 


\subsubsection{Análisis de las imágenes y proceso.}

Del análisis de las imágenes se desprende lo siguiente. La relación de trabajos que se aporta, no es completamente exhaustiva. Se refiere a las principales intervenciones que quedan a la vista en el exterior de la casa, lo que no excluye que se hicieran, y de hecho seguro que fue así, otras no visibles especialmente relacionadas con el acondicionamiento del terreno y la parte baja de la edificación.

La decisión tomada por Coderch de acondicionar las antiguas cuadras de la planta baja de masía para habitarla con su familia, vino ocasionada por lo que podríamos llamar «causas oficialmente aceptadas» dadas por otros autores, por la falta de dinero y la posibilidad de hacer en el futuro otra vivienda para los hijos en la planta primera. Desde esta tesis se aporta además, de forma complementaria y no excluyente, un tercer factor a considerar: el distanciamiento intencionado de Coderch con cualquier tipo de ostentación, muy del gusto de una cierta burguesía rural, como muestran las fotografías de Catalá Roca de los interiores de las salas de numerosas masías, publicadas junto con Joaquim Camps i Arboix en el libro Les Cases Pairales Catalanes. Lo que es a su vez relevante, es que la decisión no se tomo al principio del proyecto, sino con la obra en marcha. De hecho parte de los muebles a construir en fábrica de ladrillo, empezaron a hacerse en la sala principal de planta primera, quedando a medio terminar como congelados en el tiempo. Algo ocurrió además de quedarse sin dinero después de terminar la sustitución de la cubierta, sin duda una obra costosa y larga ya que la resolución moderna de las cubiertas antiguas, es por su geometría irregular, laboriosa de llevar a cabo, pues los planos no son realmente planos si se quiere obtener una línea de alero recta y horizontal. Desde nuestra opinión, lo que ocurrió es que al empezar los trabajos vió que no acababa de funcionar el espacio de la planta primera, en parte porque los muebles de obra que se estaban realizando, no adquirían el mismo sentido que si están en continuidad con el terreno o con la roca natural, complementándola y modificándola, como ocurría en la pequeña casa de vacaciones Coderch-Mila en Cadaqués, rehabilitación de una vivienda de pescadores. En la casa de Espolla, las bóvedas apuntadas y molduradas de la planta superior, generan un espacio completamente diferente y ajeno al que resulta de las de primitivas, irregulares y texturadas bóvedas de la planta baja, que es el que quiere para si Coderch. Y es también en ese espacio telúrico, en el que tiene además que «tallar» el terreno, en el que sus muebles de fábrica adquieren sentido, reinterpretando una vez más el mobiliario construido e imbricado con la construcción de fábrica habitual en la arquitectura popular y de forma significativa en la masía.

Las principales operaciones realizadas son :

- Sustitución de la cubierta.

- Acondicionamiento de las antiguas cuadras de la planta baja. Incluye el tratamiento de los diferentes escalonamientos en acuerdo con la pendiente natural del terreno, e implica con bastante seguridad haber desmontado parte del terreno existente en pendiente e irregular, para hacer un espacio habitable. En ambas plantas se hace un exhaustivo estudio de los huecos de paso, aprovechando, modificando, abriendo nuevos - los mínimos- y cerrando otros que se convierten en muebles y hornacinas aprovechando el espesor de los muros. Se rehace el pozo adosado a la fachada posterior y se aprovecha para hacer llegar luz y ventilación natural a dos habitaciones. También se obre un pequeño patio en planta baja en la edificación de menos altura entre los contrafuertes en talud con el mismo objetivo.

- Acondicionamiento del acceso desde el exterior a la planta primera, realizando un espacio libre de entrada, bajo el que construye el garaje para el coche aprovechando el desnivel. Espacio de bastante altura cubierto con una bóveda tabicada de nueva 
construcción, reforzada en la parte superior con una armadura muy ligera y hormigón ligero y aislante Durisol, y con un forjado ligero intermedio quedando la parte superior de almacenaje e instalaciones con acceso directo desde la vivienda.

- Acondicionamiento de la parcela, con la realización de los aterrazamientos en la parte delantera. Si ya existían, en cualquier caso las fotografías parecen indicar debieron rehacerse, incluyendo la abundante plantación realizada de distintas especies.

- Tratamiento de todas las fachadas con apertura de huecos nuevos y ampliación de algunos a hueco de paso. Colocación de persianas de tablilla de madera pintada de verde en todos ellos

- Realización del gran hueco al paisaje explicado con más detalle en epígrafes siguientes

- Una vez que la casa está prácticamente terminada, y a partir de los estudios realizados con las fotografías decide incorporar el machón vertical que remata , acentúa y se contrapone al hueco mirador del lado opuesto

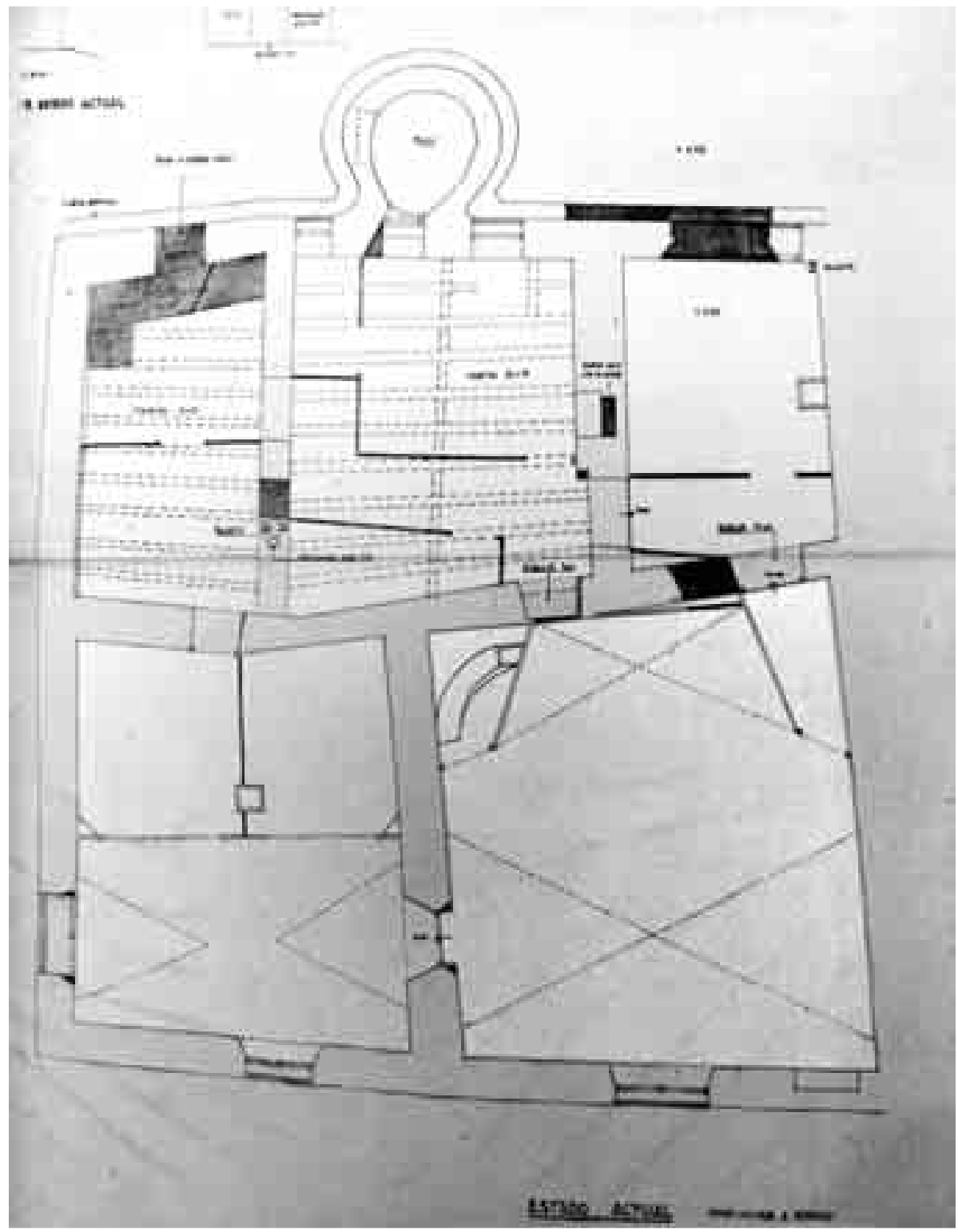

Figura 4.33

Estado anterior a la intervención de Coderch

Plano de trabajo detallando la zona central de Planta primera, con las partes a demoler marcadas en negro. Es el único plano del estado anterior que se ha podido encontrar hasta el momento. Facilitado por José Antonio Coderch Giménez, hijo de José Antonio Coderch 

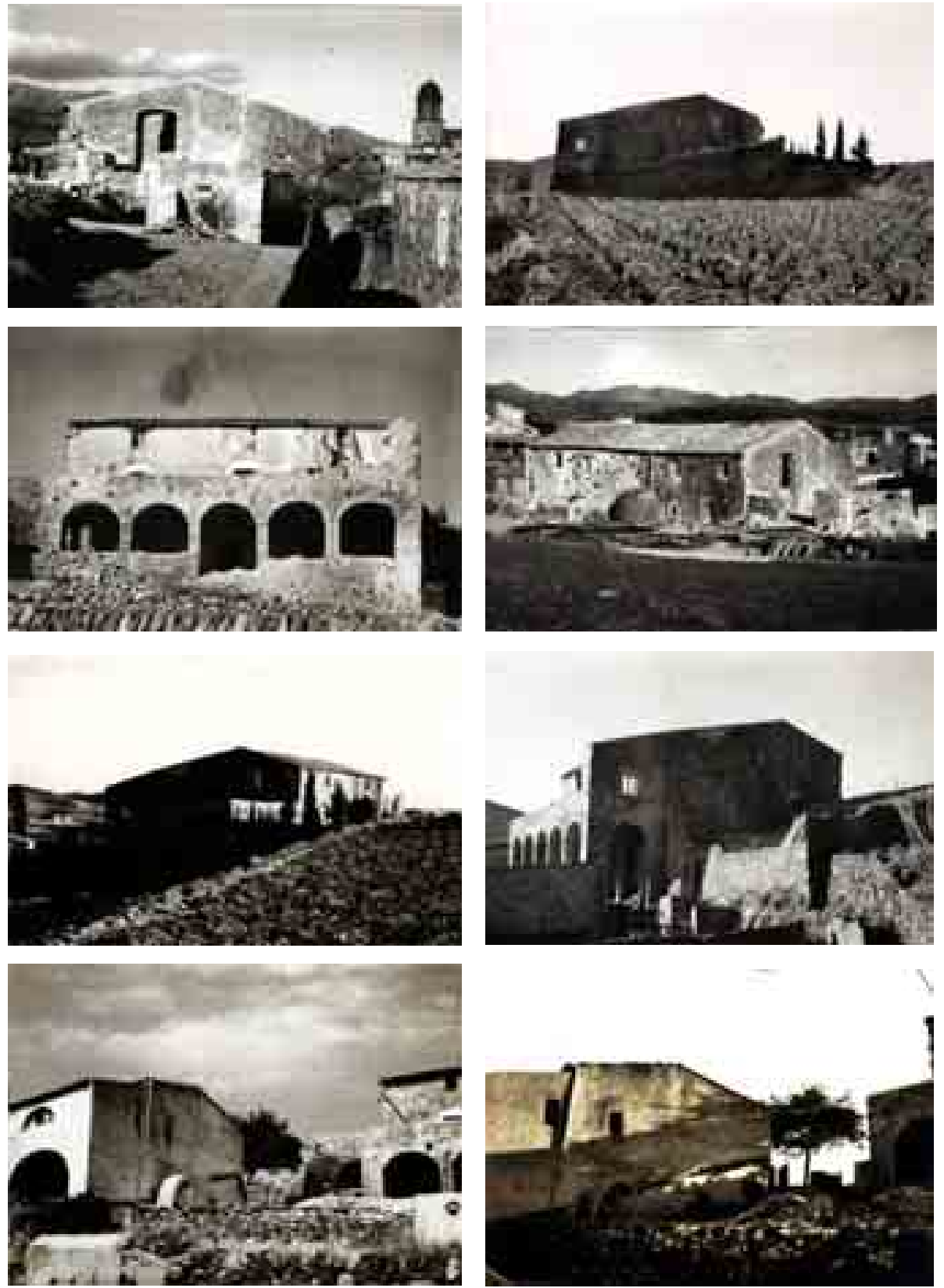

Figura 4.34

Serie de 8 fotografías en blanco y negro, papel brillante y formato alargado.

Se corresponden con el estado inicial de la casa.

Perteneciente a la Colección de 40 fotografías realizadas por José Antonio Coderch, durante el desarrollo de la obra de su Casa en Espolla, simultáneamente testimonio documental y método de trabajo.

Colección inédita hasta ahora, han salido a la luz desde esta tesis doctoral

Incorporadas al Archivo Coderch. 

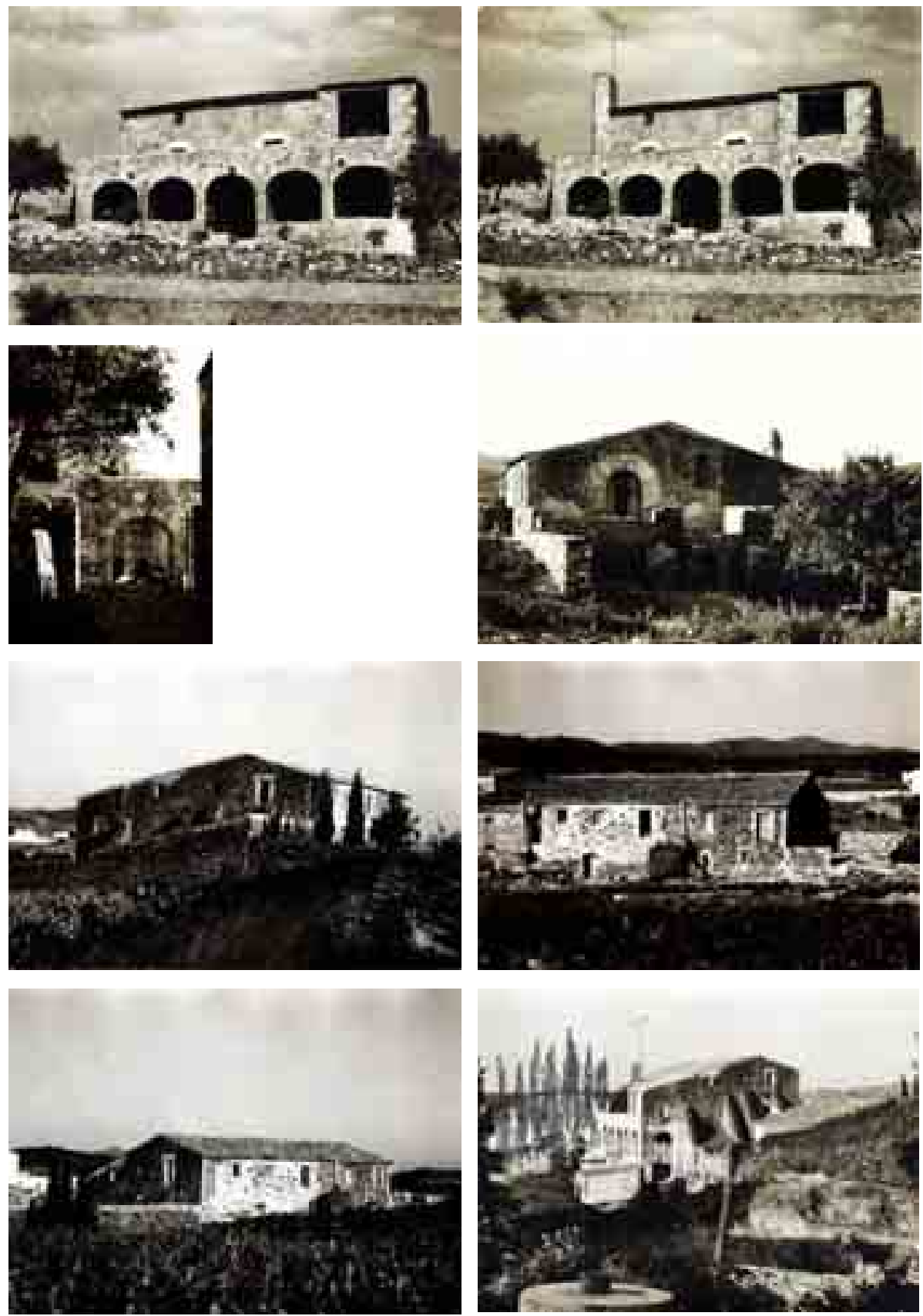

Figura 4.35 a

Serie de 20 tomas en blanco y negro con varias copias duplicadas para trabajar sobre ellas. Se corresponden con el proceso llevado durante las obras. También reflejan lo que se ve desde la casa, su preocupación por la enorme y desafortunada medianera de la nueva casa del vecino, la casa de su abuelo en la parte opuesta del pueblo, etcétera.

Perteneciente a la Colección de 40 fotografías realizadas por José Antonio Coderch, durante el desarrollo de la obra de su Casa en Espolla, simultáneamente testimonio documental y método de trabajo.

En sobre manuscrito por Coderch con la siguiente nota:

«Colección completa de fotos del Más del Puig (Espolla) sacadas en junio/julio 1964. Son 20 fotos si se cuenta la 5 bis»

Colección inédita hasta ahora, han salido a la luz desde esta tesis doctoral Incorporadas al Archivo Coderch. 

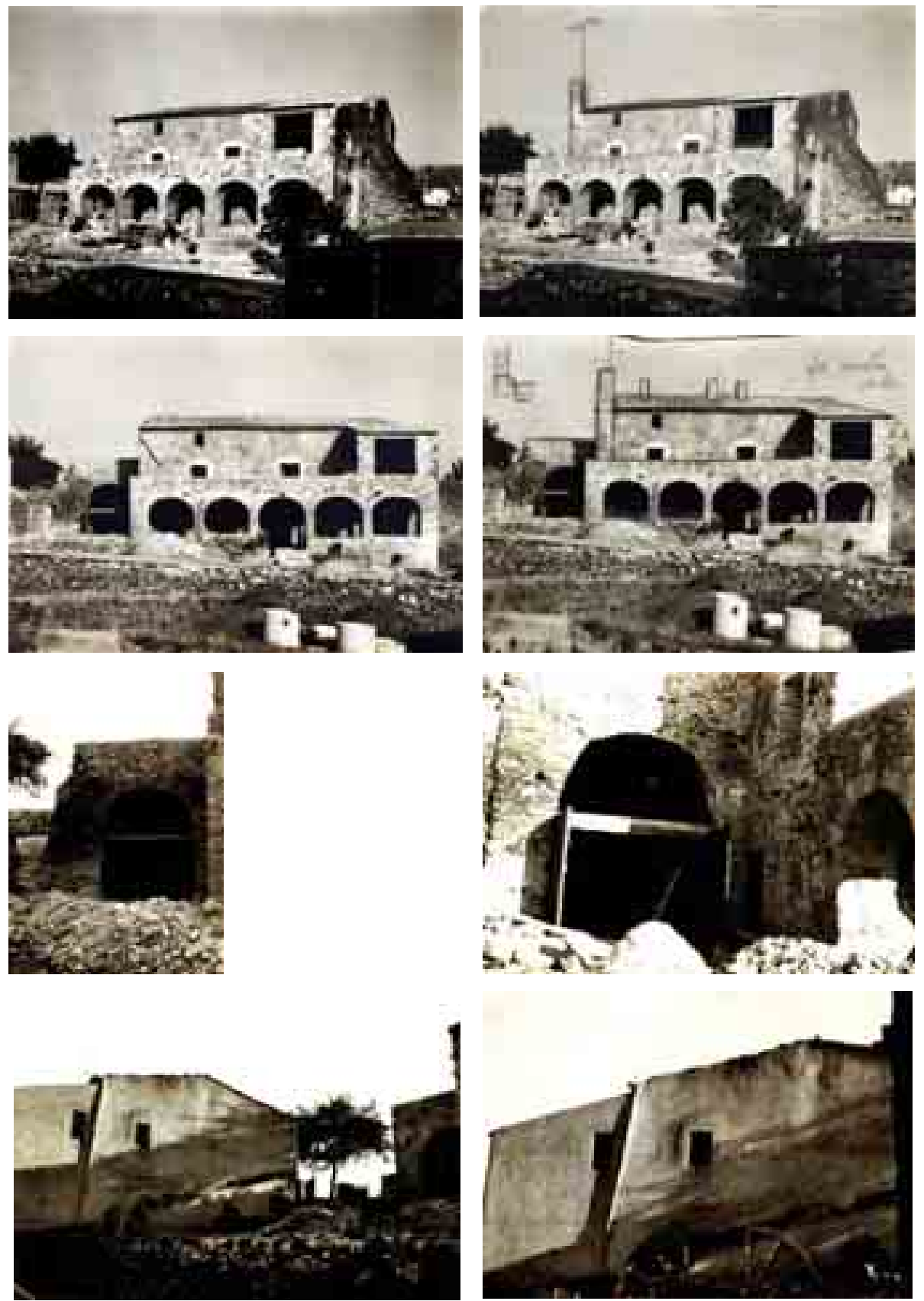

Figura 4.35 b

Serie de 20 tomas en blanco y negro con varias copias duplicadas para trabajar sobre ellas.

Se corresponden con el proceso llevado durante las obras. También reflejan lo que se ve desde la casa, su preocupación por la enorme y desafortunada medianera de la nueva casa del vecino, la casa de su abuelo en la parte opuesta del pueblo, etcétera.

Perteneciente a la Colección de 40 fotografías realizadas por José Antonio Coderch, durante el desarrollo de la obra de su Casa en Espolla, simultáneamente testimonio documental y método de trabajo.

En sobre manuscrito por Coderch con la siguiente nota:

«Colección completa de fotos del Más del Puig (Espolla) sacadas en junio/julio 1964. Son 20 fotos si se cuenta la 5 bis»

Colección inédita hasta ahora, han salido a la luz desde esta tesis doctoral.

Incorporadas al Archivo Coderch. 

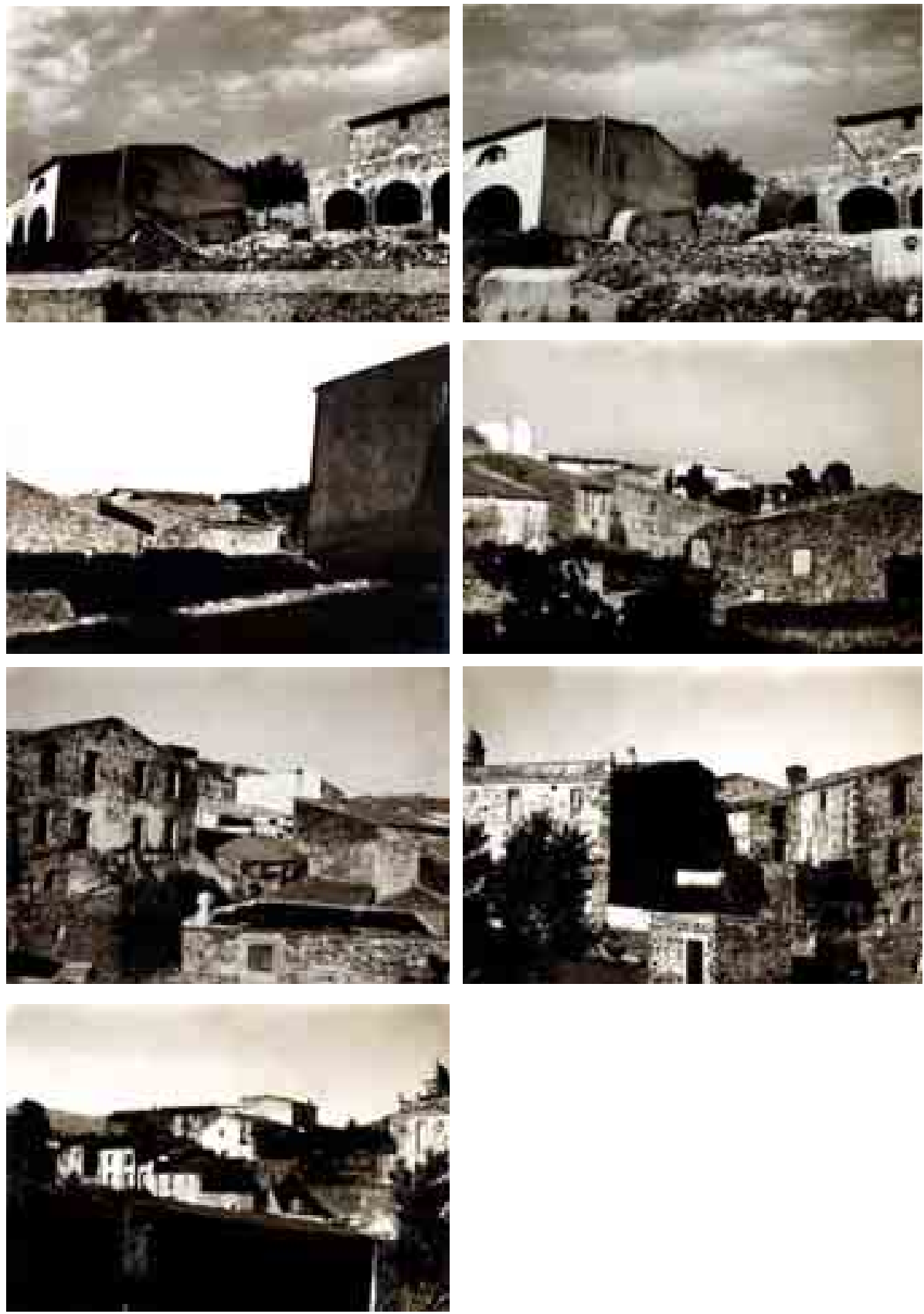

Figura $4.35 \mathrm{c}$

Serie de 20 tomas en blanco y negro con varias copias duplicadas para trabajar sobre ellas

Se corresponden con el proceso llevado durante las obras. También reflejan lo que se ve desde la casa, su preocupación por la enorme y desafortunada medianera de la nueva casa del vecino, la casa de su abuelo en la parte opuesta del pueblo, etcétera.

Perteneciente a la Colección de 40 fotografías realizadas por José Antonio Coderch, durante el desarrollo de la obra de su Casa en Espolla, simultáneamente testimonio documental y método de trabajo.

En sobre manuscrito por Coderch con la siguiente nota:

«Colección completa de fotos del Más del Puig (Espolla) sacadas en junio/julio 1964. Son 20 fotos si se cuenta la 5 bis»

Colección inédita hasta ahora, han salido a la luz desde esta tesis doctoral. Incorporadas al Archivo Coderch. 

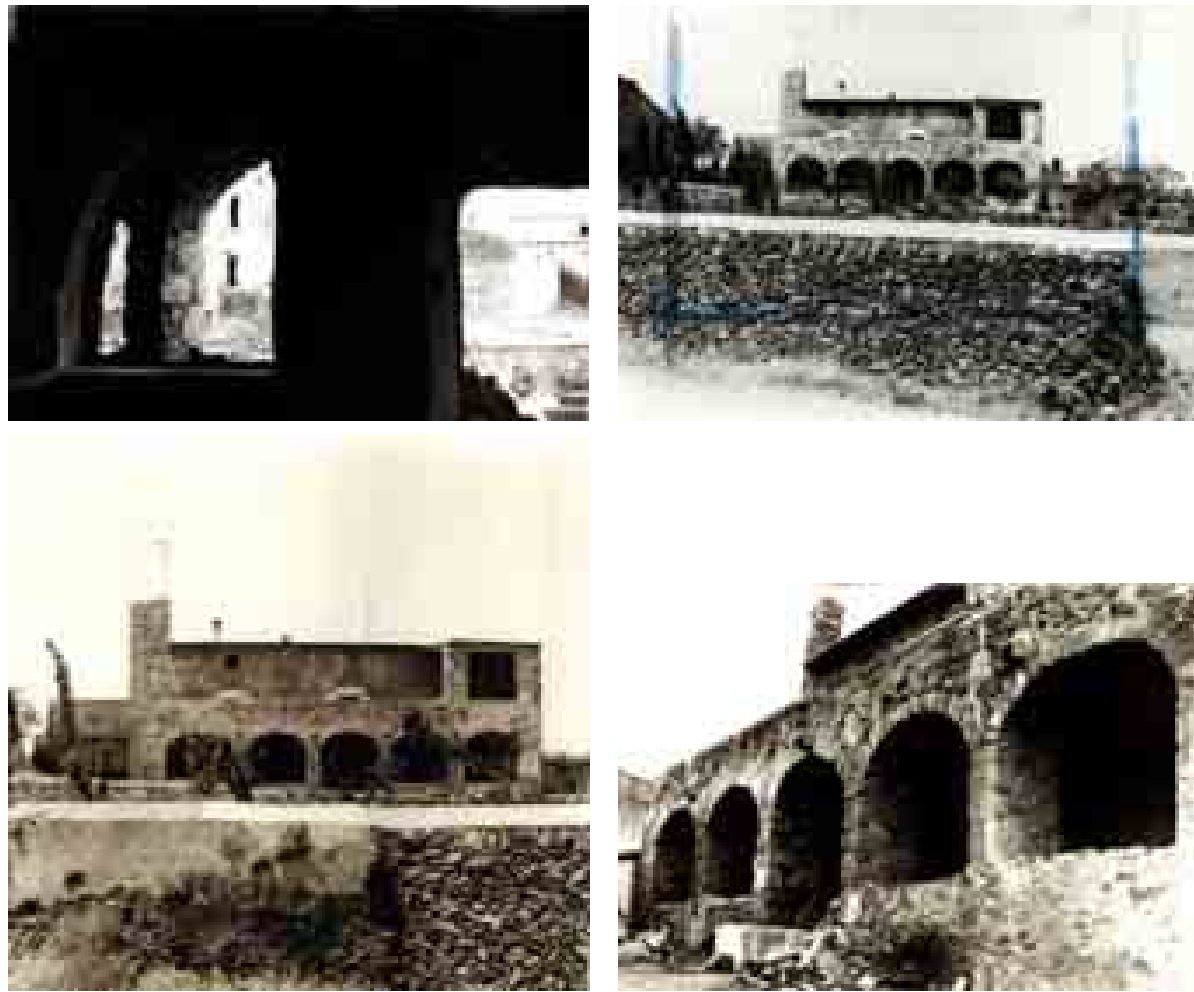

\section{Figura 4.36}

Serie de 4 fotografías en blanco y negro. +8 en color abajo reseñada, aunque parecen sueltas. De las 8 en color, cabe destacar el dormitorio personal de José Antonio Coderch en la planta primera, única zona acordonada de esta planta y desde la que salía al hueco que se abre al paisaje, donde le gustaba retirarse fuera del bullicio de la casa.

Perteneciente a la Colección de 40 fotografías realizadas por José Antonio Coderch, durante el desarrollo de la obra de su Casa en Espolla, simultáneamente testimonio documental y método de trabajo.

Colección inédita hasta ahora, han salido a la luz desde esta tesis doctoral. Incorporadas al Archivo Coderch.
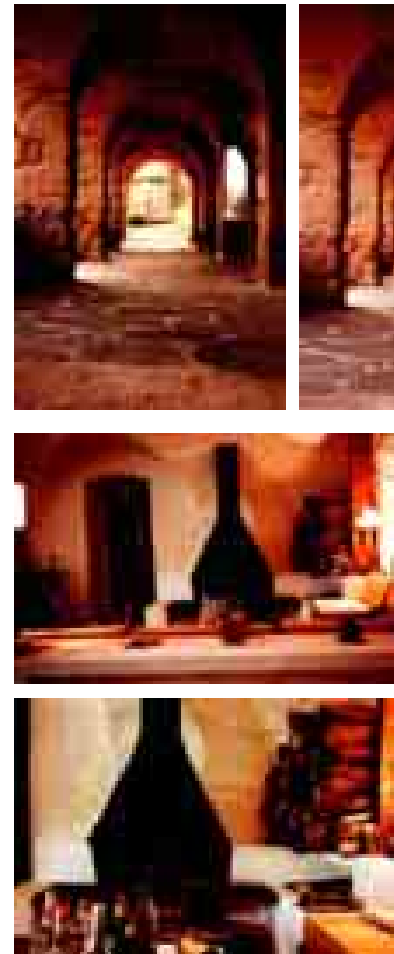
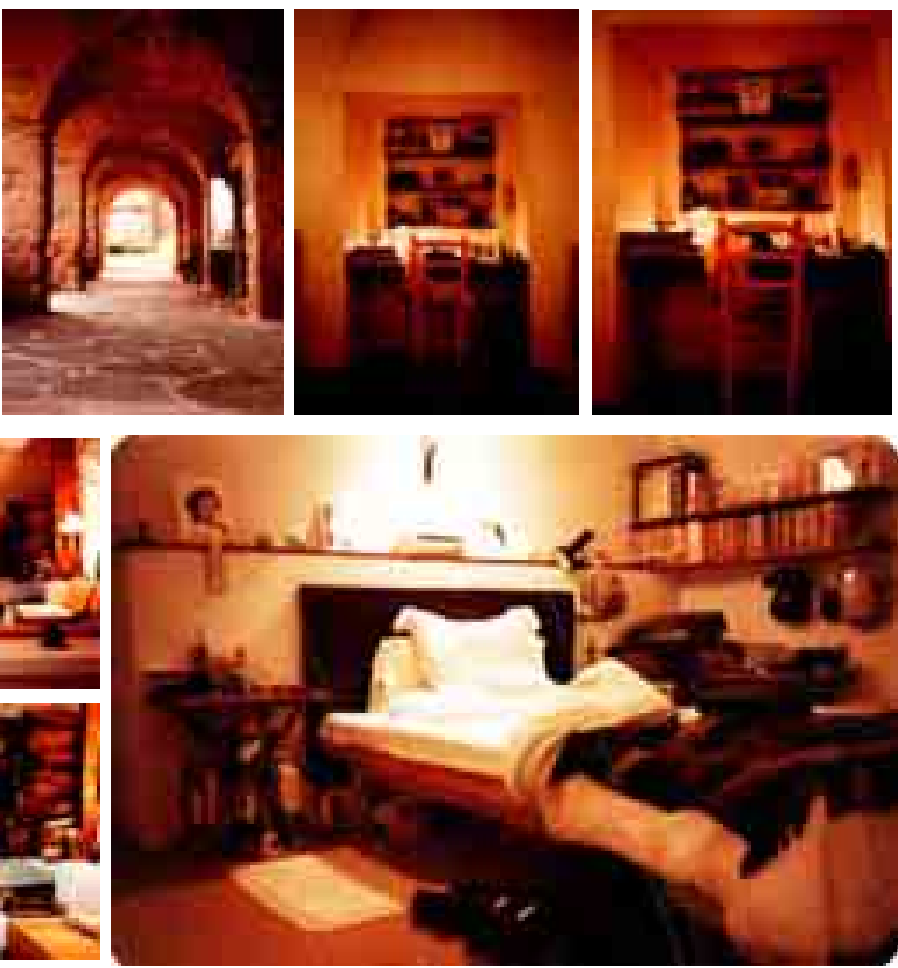

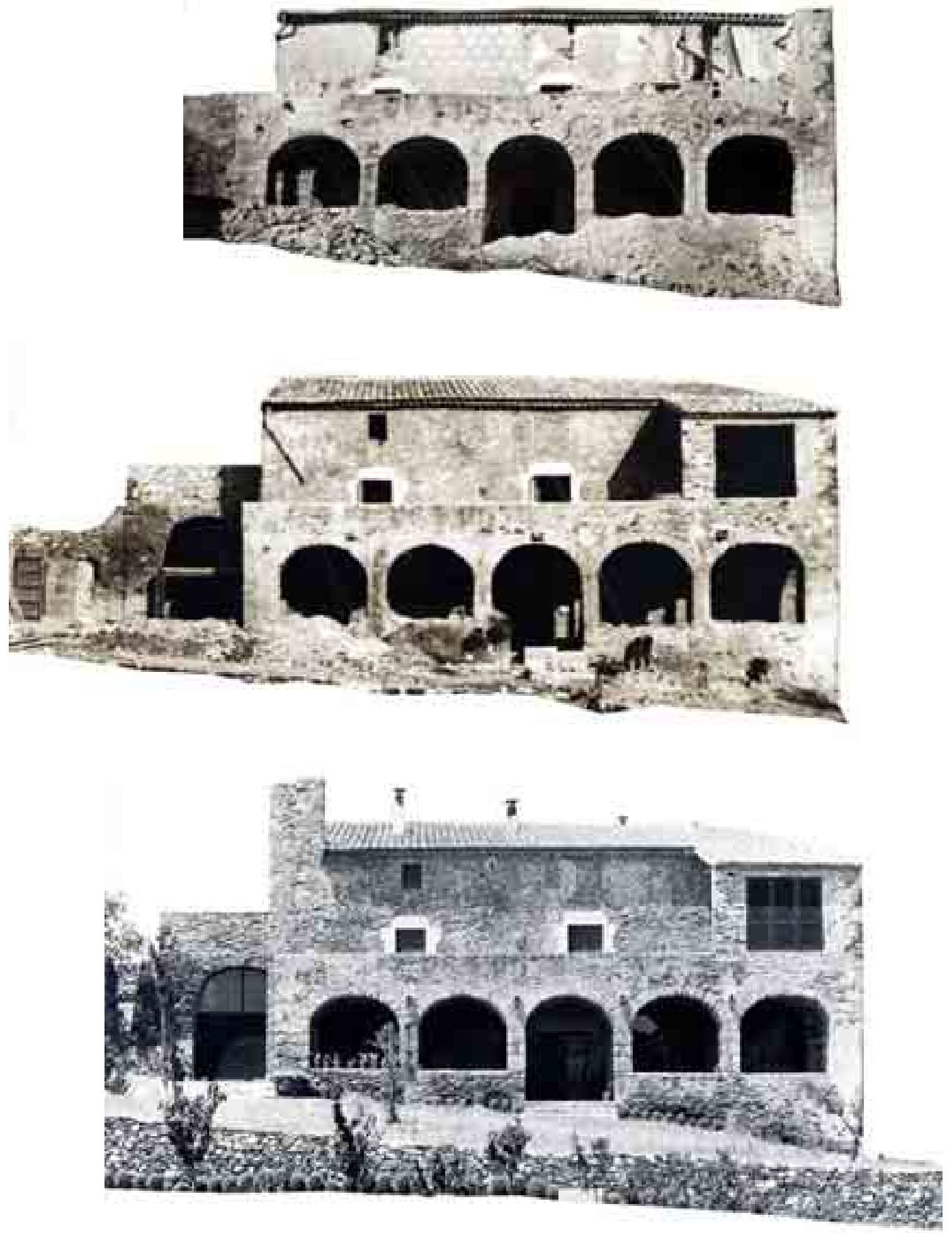

Figura 4.37

Análisis sobre la evolución de la fachada principal a partir de las fotografías de la colección de 40 de fotografías de la Casa en Espolla con la incorporación de la inferior de Catalá Roca para hacer una comparación completa entre estado inicial, intermedio y final.

Realizadas por el propio José Antonio Coderch para trabajar en el proceso de construcción de la casa. Copias dobles y en un de las dos, Coderch dibujaba a lápiz o marcaba en la superficie de la foto, sus ideas de proyecto para ver como quedaban antes de su construcción. El recrecido de la izquierda, aparece en varias imágenes con distintos puntos de vista como tanteo para ver su efecto antes de realizarlo

Material Inédito, encontrado e incorporado al Archivo Coderch, a partir de este trabajo.

Tiene el valor añadido de ser fotografías hechas por Coderch y dibujadas también por el. Archivo Coderch 

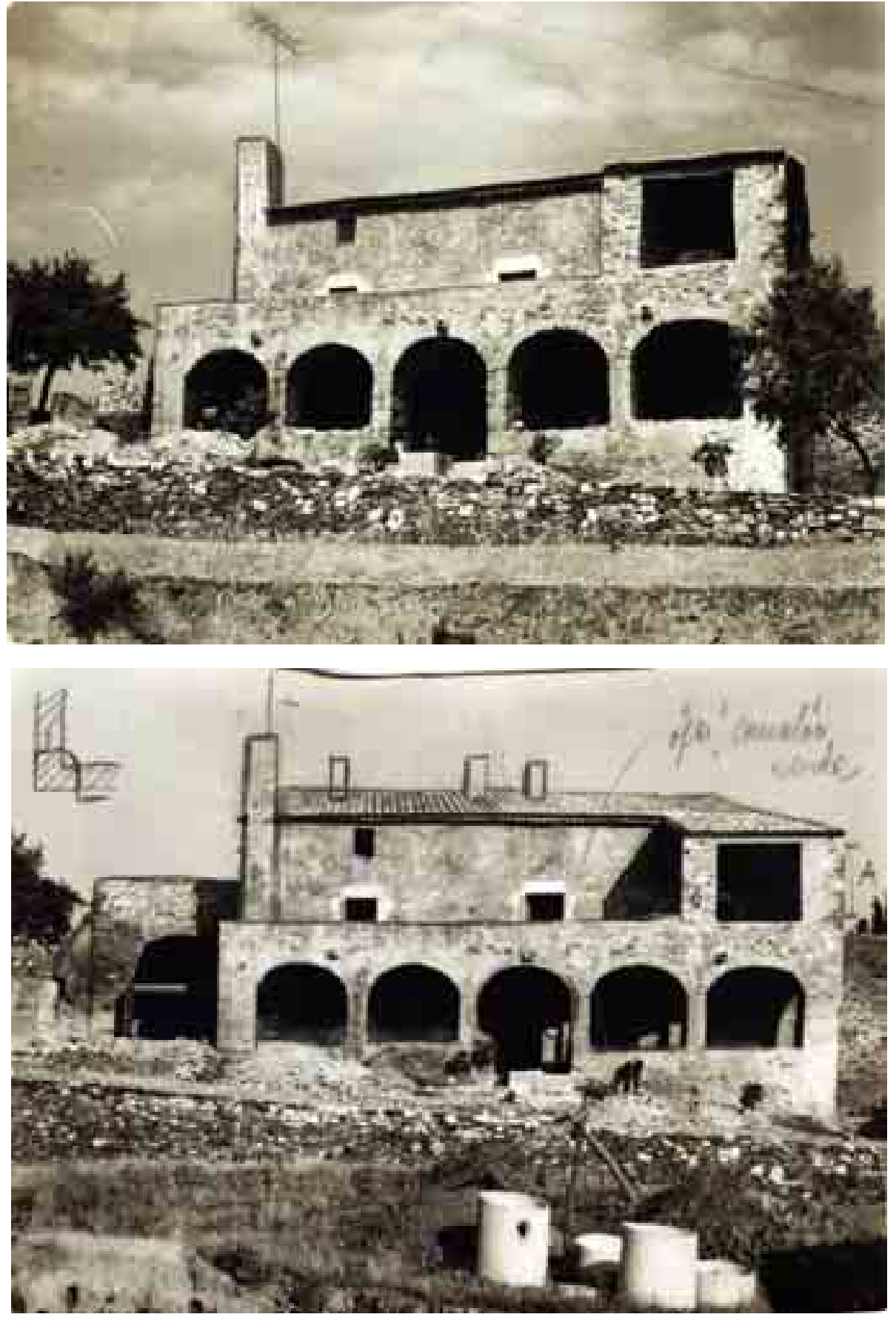

Figura 4.38

Colección de 40 de fotografías de la Casa en Espolla

Realizadas por el propio José Antonio Coderch para trabajar en el proceso de construcción de la casa. Copias dobles y en un de las dos, Coderch dibujaba a lápiz o marcaba en la superficie de la foto, sus ideas de proyecto para ver como quedaban antes de su construcción. El recrecido de la izquierda, aparece en varias imágenes con distintos puntos de vista como tanteo para ver su efecto antes de realizarlo.

En este caso, estudios sobre el machón añadido en el alzado principal, una vez realizada la intervención en el mirador.

Material Inédito, encontrado e incorporado al Archivo Coderch, a partir de este trabajo.

Tiene el valor añadido de ser fotografías hechas por Coderch y dibujadas también por el.

Archivo Coderch 

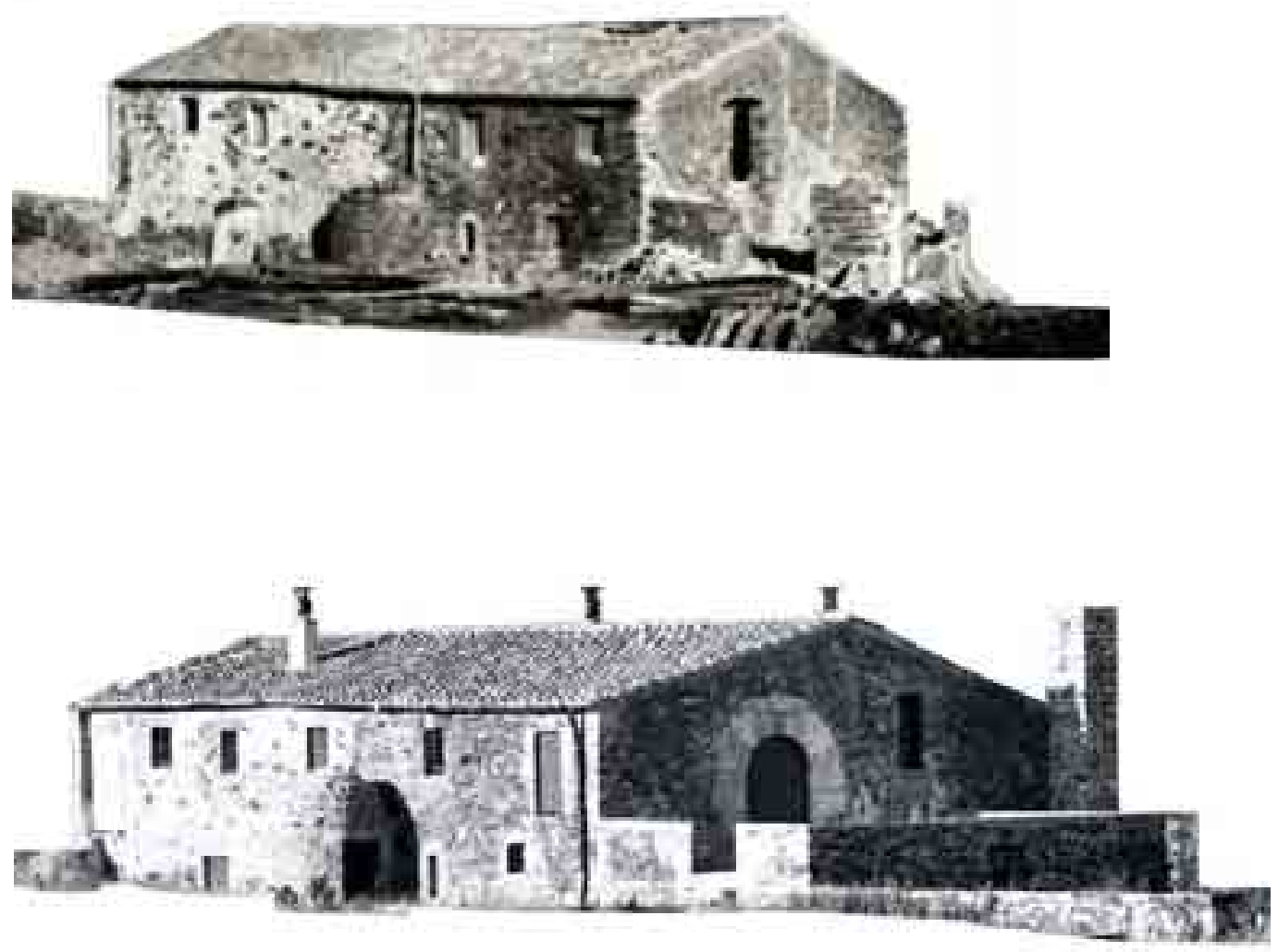

Figura 4.39

Análisis sobre la evolución de la fachada principal a partir de las fotografías de la colección de 40 de fotografías de la Casa en Espolla con la incorporación de la inferior de Catalá Roca para hacer una comparación completa entre estado inicial, intermedio y final. Análisis y tratamiento fotográfico de Ana Rodríguez.

En este caso, estudios de las fachadas posterior y lateral con el machón añadido en el alzado principal, una vez realizada la intervención en el mirador. Archivo Coderch 

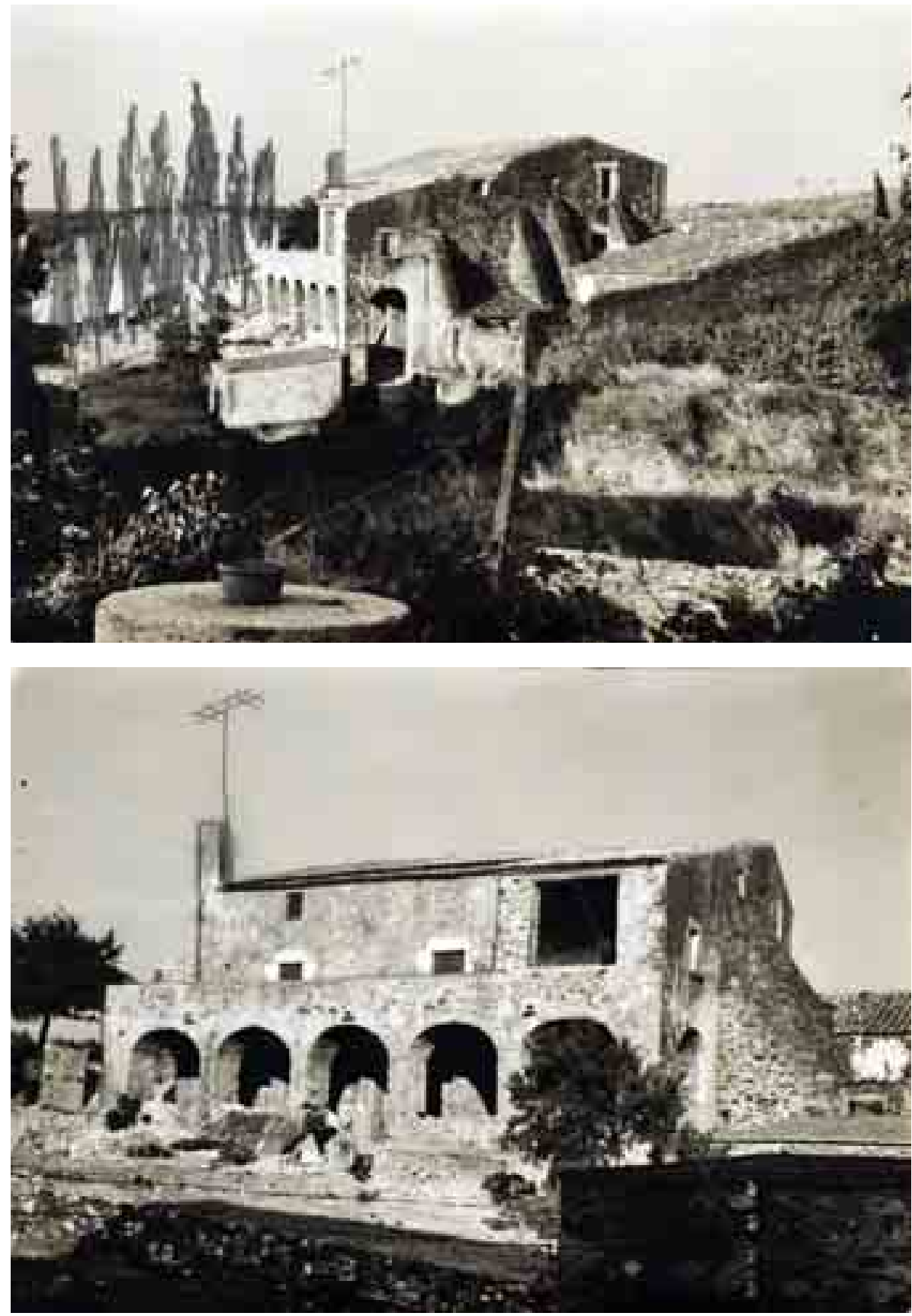

Figura 4.40

Colección de 40 de fotografías de la Casa en Espolla

Realizadas por el propio José Antonio Coderch para trabajar en el proceso de construcción de la casa. Copias dobles y en un de las dos, Coderch dibujaba a lápiz o marcaba en la superficie de la foto, sus ideas de proyecto para ver como quedaban antes de su construcción. El recrecido de la izquierda, aparece en varias imágenes con distintos puntos de vista como tanteo para ver su efecto antes de realizarlo.

En este caso, estudios sobre el machón añadido en el alzado principal, una vez realizada la intervención en el mirador y plantación de cipreses cubriendo la medianera del vecino, construida con posterioridad a la compra de la casa por parte de Coderch.

Material Inédito, encontrado e incorporado al Archivo Coderch, a partir de este trabajo.

Tiene el valor añadido de ser fotografías hechas por Coderch y dibujadas también por él. Archivo Coderch 

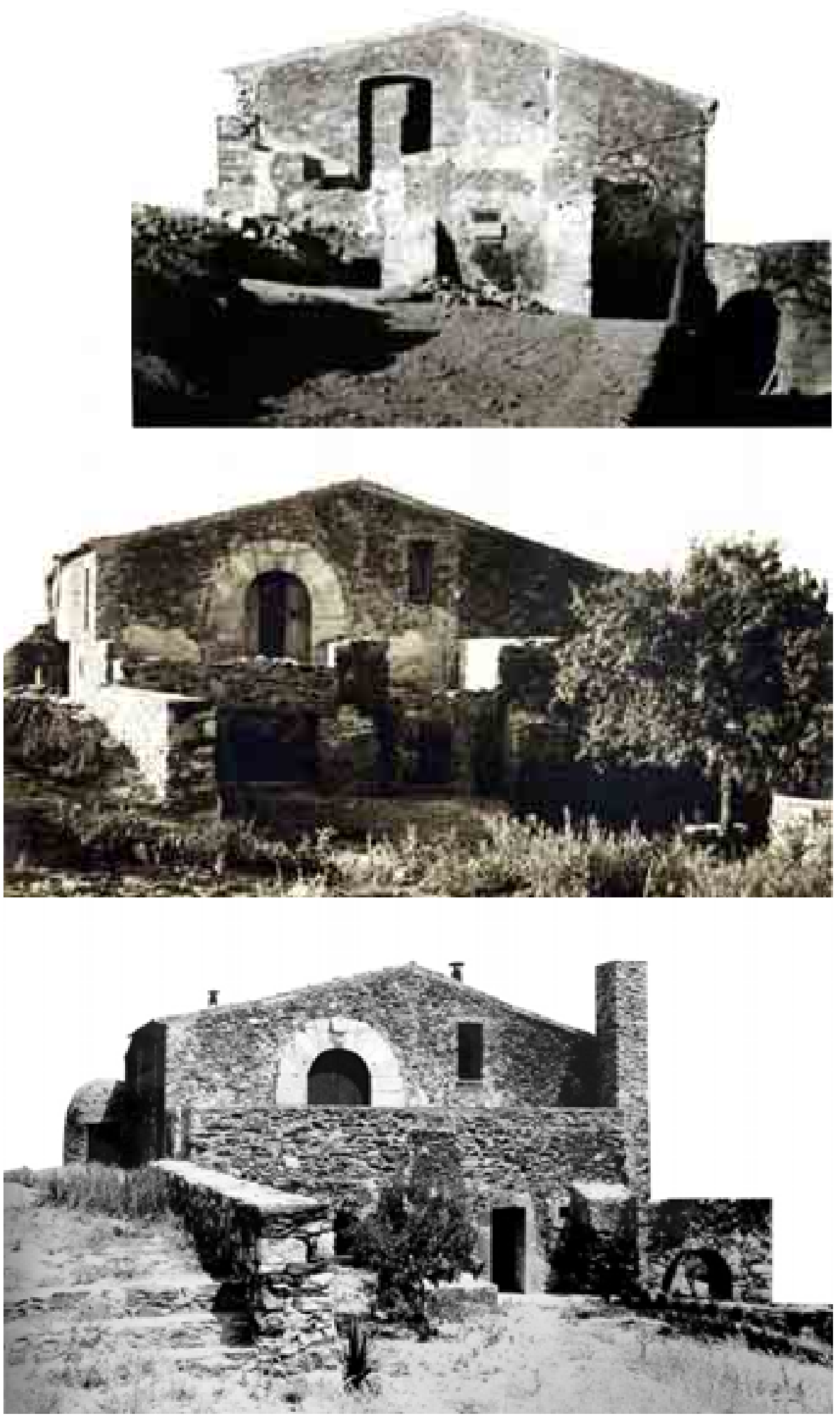

Figura 4.41

Análisis sobre la evolución de la fachada lateral a partir de las fotografías de la colección de 40 de imágenes de la Casa en Espolla con la incorporación de la inferior de Catalá Roca para hacer una comparación completa entre estado inicial, intermedio y final. Análisis y tratamiento fotográfico de Ana Rodríguez. 

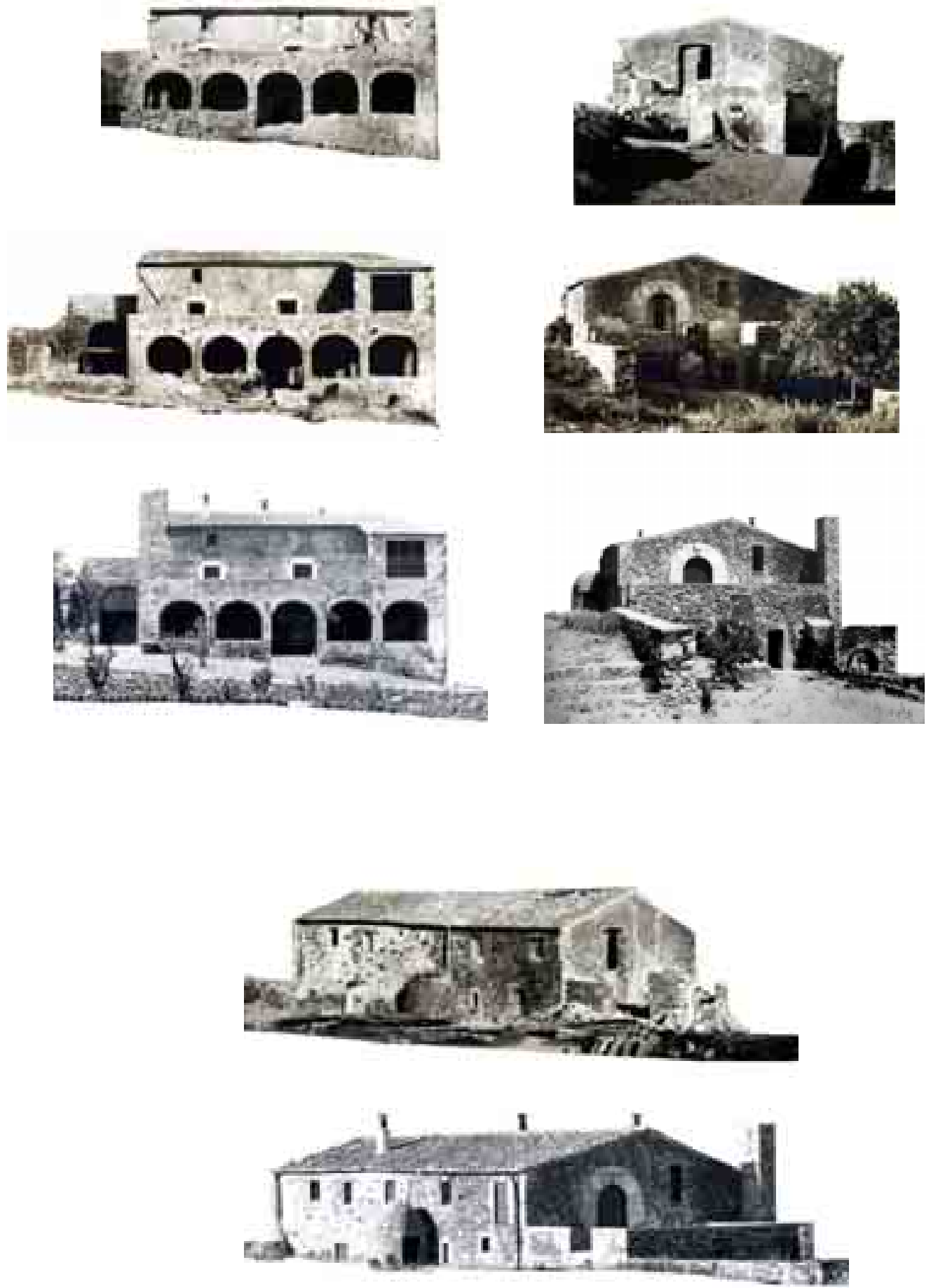

Figura 4.42

Resumen del análisis sobre la evolución de las fachadas a partir de las fotografías de la colección de 40 de imágenes de la Casa en Espolla con la incorporación de alguna de Catalá Roca para hacer una comparación completa entre estado inicial, intermedio y final.

Análisis y tratamiento fotográfico de Ana Rodríguez. 


\subsubsection{La transgresión del tipo tradicional}

La masía, pintado por Joan Miró (1893-1983), entre 1921 y 1922, es la imagen escogida para abrir el presente capítulo sobre las huellas de lo vernáculo y lo popular en la Casa de José Antonio Coderch en Espolla.

La elección no es casual, pues el cuadro, representación de otra casa familiar en el campo catalán, expresa certeramente y mejor que la redacción de esta tesis, el significado vital, intelectual y afectivo del artista con sus raíces, y como a partir de ellas transciende en su arte universal.

Miró y Coderch ambos catalanes, comparten historia, tradiciones y una profunda relación con la cultura popular campesina catalana, y aunque con posturas ideológicas diferentes, mantuvieron amistad. Un tercer personaje, Ernest Hemingway (1899-1961), del otro lado del mundo, propietario del cuadro casi durante toda su vida, compartió con Miró desde una cultura diferente esos lazos íntimos y afectivos con la tierra, con España y sus tradiciones más profundas.

El cuadro es un referente inmejorable y por ello se hace necesario explicar un poco de su apasionante historia ${ }^{28}$, de forma previa al análisis del Mas del Puig en Espolla.

La masía, uno de los cuadros más importantes de Joan Miró, tiene por tema la casa familiar de vacaciones a las afueras de Mont-roig del Camp, al sur de la provincia de Tarragona, y marca un punto de inflexión en su carrera. Es un cuadro de transición, entre La casa de la palmera de 1918, y premonitorio de los posteriores Tierra labrada de 1923 o Paisaje Catalán de 1924 que provocaron el asombro de los surrealistas en París. Pero ante todo, es la representación poética del amor de Miró por Mont-roig, de esa necesidad de expresar su total identificación con los campos y montañas del sur de Cataluña, que tanta salud e inspiración le proporcionaron desde la niñez.

La propiedad, con una mansión señorial de principios del siglo XX blanca y con una torre, el Mas d'en Ferretes y posteriormente Mas Miró, había sido comprada en 1911 por la madre de Joan Miró, Dolores Ferrá y Oromí, al marqués de Mont-roig, un indiano que había hecho fortuna en Cuba a finales del XIX, quien la había construido a su vuelta de ultramar acorde a la representatividad de su nuevo estatus.

Desde esa fecha hasta su muerte, el pintor paso los veranos y largas temporadas allí posteriormente incorporó Mallorca-, donde gestó su obra según sus propias palabras en la primera entrevista publicada del pintor, hecha por Francesc Trabal y aparecida en La Publicitat de Barcelona en 1928:

"OS aseguro que donde soy más feliz es en Cataluña, en Mont-roig, que es donde creo que es más Cataluña; el puro catalán creo que es de Tarragona. Soy mucho más feliz yendo en suéter y bebiendo en porrón entre los campesinos de Mont-roig que en París entre duquesas en grandes palacios y con esmoquin. Toda mi obra está concebida en Mont-roig, nunca pensando en París; que detesto...Recuerdo una vez que Doménec Carles y yo nos dirigíamos al Club de Natación; el criticaba furiosamente la luz de aquí y loaba la de París. Yo tengo un menosprecio absoluto, en cambio, por el paisaje de señora parisina. La ferme me hacía sentir una agresividad incluso física» (Fernández de Castro 2015, 99)

\footnotetext{
${ }^{28}$ Para un conocimiento más extenso consultar la obra de Alex Fernández de Castro, La masía. Un Miró para Mrs. Hemingway, Publicacions de la Universitat de València PUV, 2015. Posiblemente el trabajo más completo y exhaustivo sobre esta obra, su gestación, y las relaciones de Miró y Hemingway con el cuadro y entre ellos. Los datos referenciados han sido tomados de él.
} 
Joan Miro y Ernest Hemingway coincidieron en París a principios de los años veinte previos a la consagración de ambos, imbuidos en la vanguardia intelectual del momento. Eran pobres, buscaban su propio desarrollo artístico y compartían el mismo círculo de amigos, lo que seguramente ocasionó que se conocieran.

Desde el primer momento, Hemingway supo que el cuadro significaba un punto de inflexión, el comienzo de una nueva forma de pintar inventada por Miró. Lo compró en 1925 como regalo para Hadley, su primera esposa, perdiéndolo temporalmente cuando la abandonó, y volviéndolo a recuperar en 1934 para no volver a separarse de él. Actualmente pertenece a la National Gallery de Washington DC, donado por Mary Welsch, viuda de Hemingway después de su muerte.

Aunque era consciente del valor histórico y material que alcanzaría, fue su carga poética lo que le fascinó. En La Masía, Miró había conseguido reflejar en un cuadro todo lo que Hemingway había visto y sentido en sus viajes por España. Alex Fernández de Castro en su libro La Masía, un Miró para Mrs. Hemingway, dice:

«Que Miró hubiera sido capaz de representar tan magistralmente un país del que Hemingway acababa de enamorarse tuvo que influir mucho, tal vez más que cualquier otra consideración, en su decisión de pagar por «La masía» un dinero que no tenía- Pocos escenarios tuvieron para Hemingway tanto peso como España, pocos paisajes se vieron tan ampliamente reflejados en su obra» (Fernández de Castro 2015, 88)

Joan Miró citado en el mismo libro sobre el proceso de elaboración del cuadro dice:

« Hice una exposición en La Licorne de París. Después volví aquí. Y otra vez Mont-roig me acogió con toda su claridad y toda su vida. Entonces quise acabar todo aquel periodo mío que desde Mont-roig veía tan claro, e hice La ferme. iNueve meses de trabajo constante y pesado! iNueve meses cada día pintando y borrando y haciendo estudios y volviéndolos a destruir! La ferme fue el resumen de toda mi vida en el campo. Desde un gran árbol a un pequeño caracol, quise poner todo lo que yo quería del campo. Creo que es insensato dar más valor a una montaña que a una hormiga (y eso los paisajistas no lo saben ver), y por eso no dudaba en pasarme horas y horas para darle vida a la hormiga. Durante los nueve meses que trabaje en La ferme, trabajaba en ella siete $u$ ocho horas diarias. Sufría terriblemente, bárbaramente, como un condenado. Borraba mucho. Y comenzaba a deshacerme de influencias extranjeras para ponerme en contacto con Cataluña»

«En París, al ponerme a trabajar de nuevo en el cuadro, comprendí en seguida que había algo que no funcionaba. Echaba en falta el motivo. Entonces, para poder trabajar del natural, para hacer las hierbas que se ven en primer plano, fui a coger algunas al Bois de Boulogne, y para poder continuar con el cuadro, acabé pidiendo que me enviaran hierbas autenticas de Mont-roig en el interior de un sobre. Llegaron todas secas, claro. Pero al menos, gracias a esas flores, pude continuar el trabajo» (Fernández de Castro 2015, 95)

Fernández de Castro también cita a Hemingway en un artículo que escribió para la revista Cahiers d'Art en 1934, en el que afirmaba:

«Cuando lo conocí, Miró tenía muy poco dinero y muy poco que comer y trabajó todo el día durante nueve meses para pintar un cuadro enorme y maravilloso titulado «La masía». No quería venderlo ni apartarse de él. Nadie podía mirarlo y no saber que había sido pintado por un gran pintor y cuando estas pintando cosas en las que la gente debe creer es bueno tener algo que ha tardado tanto en hacerse como lo que una mujer tarda en dar a luz a un hijo y eso hace que hasta los más ignorantes consideren probado que eres un gran pintor según lo que ellos entienden por pintura. Después de que Miró pintara «La masía» y 
Joyce escribiera Ulises tenían derecho a que la gente creyera en lo que hicieran a continuación incluso si no los entendían o a pesar de que ambos hayan continuado trabajando muy duro. Si has pintado «La masía» o has escrito Ulises, y a continuación sigues trabajando muy duro, no necesitas una Alice B.Toklas» (Fernández de Castro 2015, 138)

Termina el artículo con un párrafo revelador sobre su pasión por este cuadro:

«Tiene en él todo cuanto sientes hacía España cuando estás allí y todo lo que sientes cuando estás lejos y no puedes volver. Nadie como él ha sido capaz de pintar dos cosas tan contradictorias. Aunque Juan Gris pintó lo que es saber que nunca podrás ir. Picasso es muy diferente. Picasso es un hombre de negocios. Pero esto ya es demasiado largo y lo que hay que hacer es mirar el cuadro: no escribir sobre él» (Fernández de Castro 2015, 139)

El paralelismo que se puede establecer entre el cuadro de Miró y la Casa en Espolla de Coderch, es significativo en cuanto a su relación personal, en que en ambos casos el tema es la casa familiar en el campo catalán, y que los dos reinterpretan lo popular en su sentido más profundo.

Cuando Coderch recupera la casa de sus antepasados, ante escándalo de propios y extraños, el arquitecto de prestigio, un hombre serio de estirpe aristocrática, y figura de respeto a la que los campesinos de Espolla pedían consejo cuando tenían problemas o decisiones importantes que tomar, se traslada a vivir con su familia a las antiguas cuadras de la masía.

Además de las causas dadas por otros autores sobre esta decisión, como la falta de dinero y la posibilidad de hacer en el futuro otra vivienda para los hijos en la planta primera, esta tesis aporta de forma complementaria un tercer factor a considerar: el distanciamiento intencionado de Coderch con cualquier tipo de ostentación, muy del gusto de una cierta burguesía rural, como muestran las fotografías de Catalá Roca de los interiores de las salas de numerosas masías, publicadas junto con Joaquim Camps i Arboix en el libro Les Cases Pairales Catalanes.

Es decir, que el mismo impulso que llevo a Joan Miró a pintar la Masía 1921-1922, la vivienda de los masoveros, los cuidadores de la finca, el gallinero y las dependencias de servicio más humildes de Mas Miró ${ }^{29}$, como los protagonistas de la composición del cuadro, en lugar de la casa principal, es seguramente el mismo que condujo a José Antonio Coderch a vivir en las antiguas cuadras y dependencias auxiliares del Mas del Puig en Espolla.

A preferir los telúricos espacios abovedados, tallados en la roca y cubiertos con bóvedas arcaicas de potente textura y herencia romana, frente a las bóvedas apuntadas construidas con bóveda tabicada y terminadas con molduras.

A pesar de su pobreza, la fuerza de esta vida popular, su identificación con la tierra y los animales, su conocimiento transmitido de forma oral y de generación en generación de padres a hijos, los objetos y útiles del trabajo en el campo, lo esencial de sus construcciones, materiales y texturas, y en definitiva la armonía con la naturaleza, es lo que cautivó a Miró, a Hemingway y a Coderch entre otros.

${ }^{29}$ Estas construcciones parecen en el cuadro de Miró, las más importantes de la finca, si se desconoce la imagen del conjunto de la masía, con su zona noble de considerables dimensiones y coronada por una torre. 
Miró no representó las zonas de la casa donde vivía, la masía de gusto indiano comprada por sus padres, representación de un estatus social de una cierta burguesía agraria.

No es un caso aislado, una somera exploración por las fotografías de Catalá Roca de los interiores de las salas de numerosas masías, publicadas junto con Joaquim Camps i Arboix en el libro Les Cases Pairales Catalanes, pone de manifiesto la forma de vida de una cierta burguesía rural, ostentosa en algunos casos al menos en apariencia.

Llegados a este punto, posiblemente se podría concluir que es precisamente la voluntad de no querer identificar su obra con esta burguesía agraria que también era parte de ese mundo, y a la que en cierta forma familiarmente pertenecía aun no siendo del campo, fue sin duda fue un aspecto relevante en la decisión de Miró de focalizar La masía en las dependencias de trabajo.

Lo mismo puede decirse de Coderch. Un hombre austero

Su decisión de transformar las antiguas dependencias para animales y aperos de labranza -en la planta baja literalmente tallada en la roca- dejando sin uso la planta noble con un marcado carácter representativo de una burguesía rural, expresa también un intencionado deseo de no identificarse con la representación de ese status social, en un acercamiento voluntario a lo popular esencialmente pobre, más que a lo vernáculo.

\section{Figura 4.43}

Croquis del espacio abovedado de planta baja con los muebles e iluminación previstos.

Archivo Coderch

* Inferior

Fotografías de huecos en la planta baja que dan a la galería. El principal a la derecha fue abierto por Coderch en la intervención, realizando para ello un inusual acuerdo entre las superficies abovedadas.

Fotografías de Ana Rodríguez
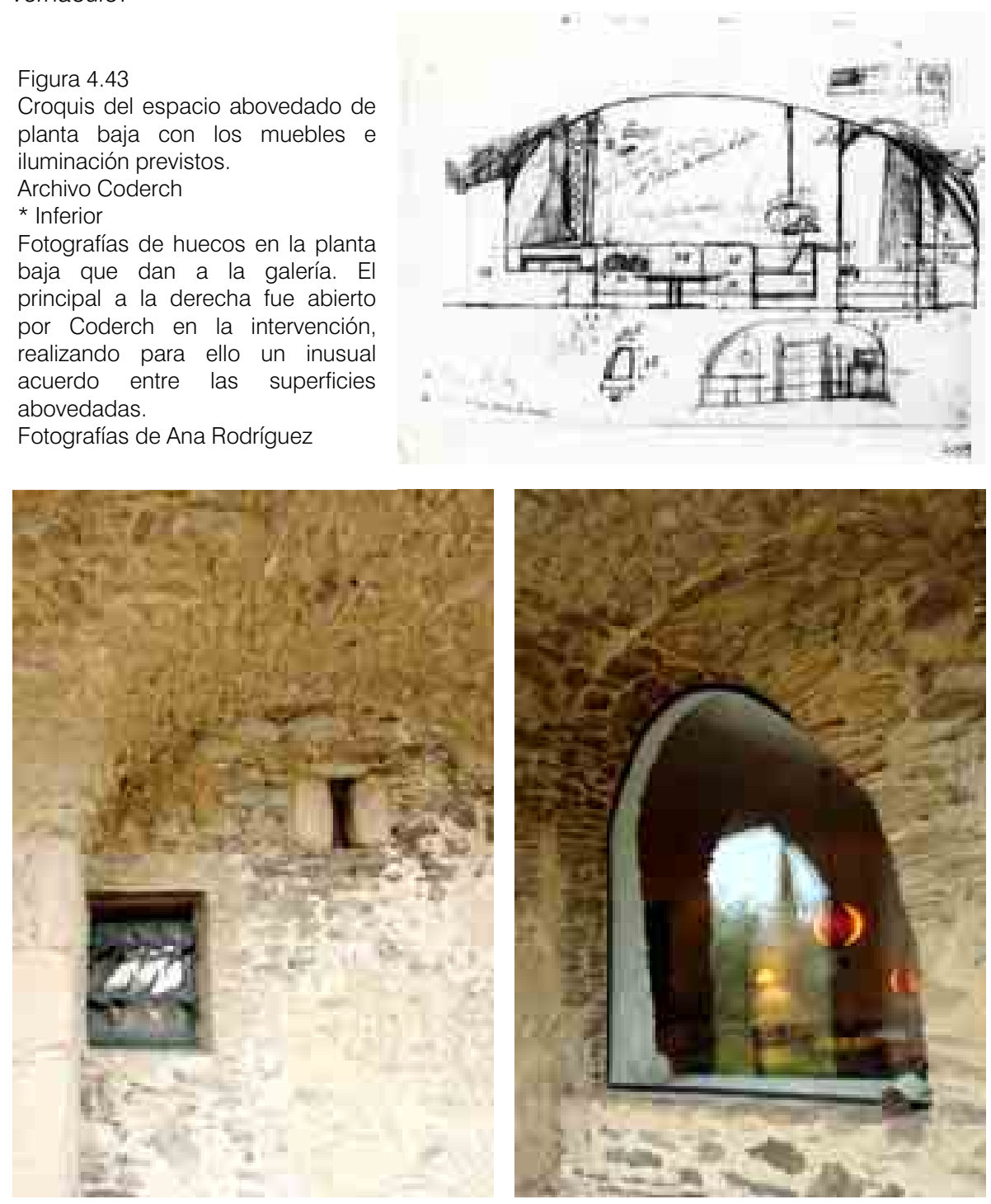

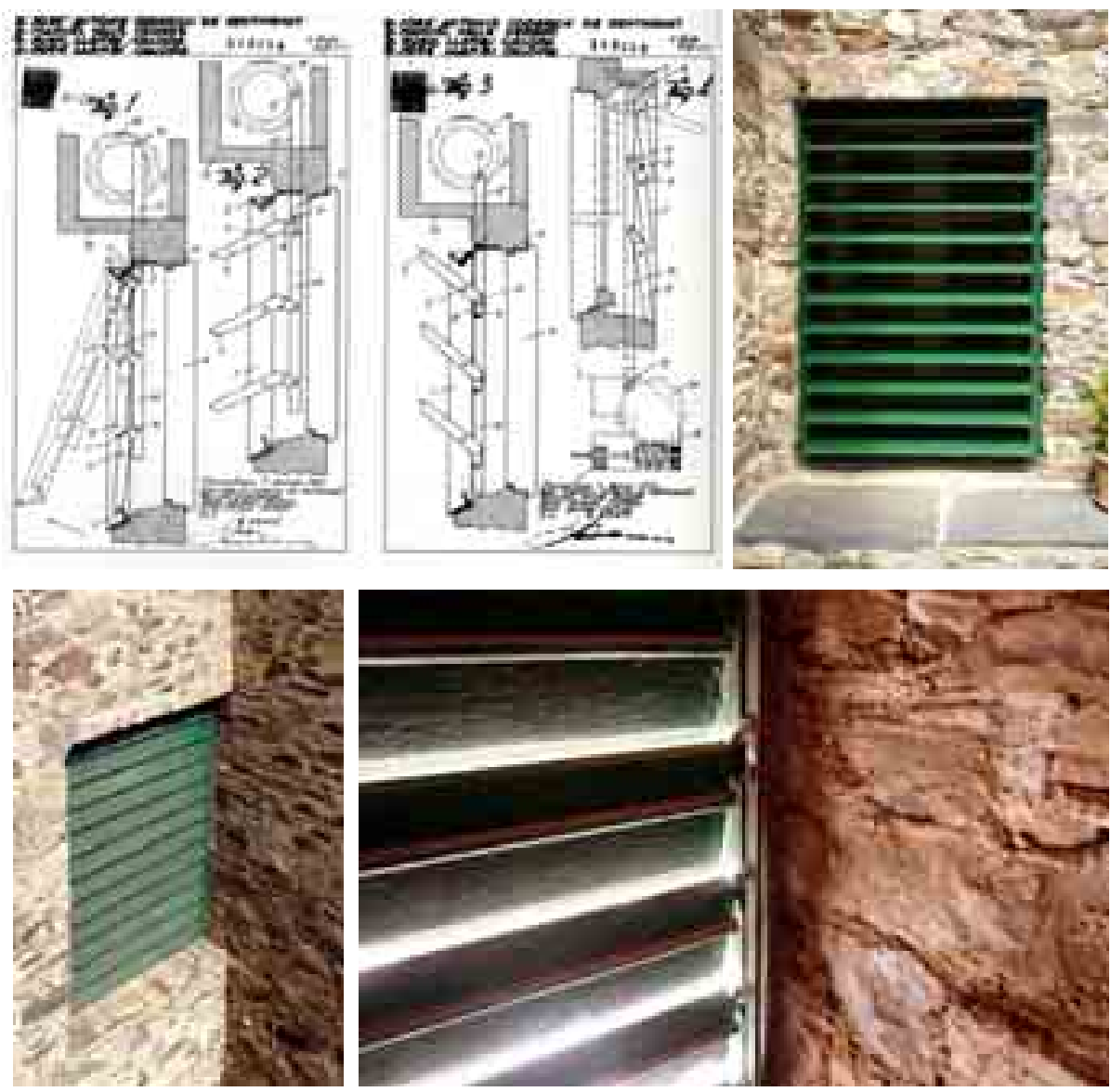

Figura 4.44

En la Casa de Espolla, todos los huecos disponen de una persiana exterior de lamas de madera pintada en color verde. Por las características de la construcción preexistente y su fuerte condición urbana, las persianas se adaptan a los huecos que había, con una solución en todos los casos, como la dada en las viviendas de la Barceloneta, es decir la versión de tabla ancha reinterpretada de la persiana tradicional de tablillas, aunque en este caso formalmente limitada por el tipo de hueco.

* Superior izquierda

Patentes de la persiana Llambí de tabla ancha

La Patente de Invención 208250 con el nombre «Nuevo sistema de persiana de tablillas» y la

Patente de Invención 208251 titulada ««Perfeccionamientos en la construcción de persianas de tablillas»

* Superior derecha e inferiores

Imágenes en color de alguna de las persianas de la Casa Coderch en Espolla.

.Fotografías de Ana Rodríguez García 


\subsection{Piedra y madera. Interpretaciones modernas de la tradición vernácula en la casa de Espolla}

«Ví a Coderch en verano cuando fuimos a la casa solariega de Espolla. Lo encontré bien. Siempre es el mismo, Coderch. Es una persona muy especial. Tiene un interés por la cualidad de las cosas, un gran aprecio. Yo le tengo mucho respeto. En muchas cosas, especialmente políticamente, no estamos de acuerdo. Nos conocemos hace muchos años... Está muy bien eso (mirando la casa Ugalde, Quaderns núm. 144.) $)^{30}$,

(L 'Avantguarda lúcida. Una conversa amb Josep-Lluís Sert, 1982)

La búsqueda continuada y simultánea de los mejores valores del movimiento moderno y la coherencia constructiva de la arquitectura popular, definen el trabajo de Coderch. Se destacan dos temas significativos de sus exploraciones en lo material, que dan una visión suficientemente amplia y representativa de la influencia de la arquitectura vernácula como fuente de conocimiento en la búsqueda de nuevas respuestas a las necesidades de la sociedad contemporánea: La reinterpretación de la persiana tradicional de tablillas de madera, y su interés por la arquitectura excavada en el terreno en sus diversas variantes -tallada en roca, excavada en otro tipo de terrenos, o troglodita aprovechando formaciones naturales- con abundantes manifestaciones en distintos lugares de España.

Ambos confluyen de forma significativa en su Casa de Espolla

La variedad de interpretaciones de la persiana tradicional de tablillas de madera, es sin duda la constante más significativa y con resultados más brillantes en el trabajo de Coderch. Su análisis nos permite recorrer en el tiempo la totalidad de su obra.

José Antonio Coderch tuvo especial interés en la arquitectura popular excavada en la tierra, como lo demuestran fotografías sueltas en la documentación del Archivo Coderch. De hecho, cuando presenta en el Congreso de Royamount el estudio sobre una posible solución al problema de las barracas, en el que plantea un sistema aplicable a la construcción de viviendas baratas en terrenos en pendiente, Coderch da respuesta a la vivienda de bajo coste, con una propuesta especialmente singular, que en cierta forma sistematiza en unidades de pequeña escala la construcción en pendiente y tallada en roca de su experiencia particular en la Casa en Espolla, y a su vez reinterpreta de forma general la arquitectura popular excavada, subterránea y troglodita de muchos lugares de España.

Al abordar la recuperación de la casa de sus antepasados en Espolla, que representa el encuentro con sus raíces, la conexión más profunda y primitiva, la relación con la tierra, afronta sin muchas referencias como el mismo dijo, el reto de poner en valor la estructura original de muros y bóvedas de fábrica. Para acondicionar como espacio habitable las antiguas cuadras y dependencias auxiliares de la planta baja, tendrá que «tallar» el terreno en pendiente, en un proceso seguramente ya iniciado en los orígenes de la construcción, pero no lo suficiente para vivir como casa para vivir. Gruesos muros bóvedas primitivas de mampostería de piedra intrínsecamente relacionadas con una forma de construir de herencia romana, que se basa precisamente en las operaciones de adición y sustracción de tierras, y que en la que se profundiza en los siguientes epígrafes, no habiendo sido abordada hasta ahora en la Casa Coderch en Espolla.

${ }^{30}$ «Jo vaig veure Coderch a l'estiu quan vam anar a la casa pairal d'Espolla. El vaig trobar bé. Sempre és el mateix, Coderch. Es una persona molt especial. Té un interes per la qualitat de les coses, una gran apreciació. Jo li tinc molt respecte. En moltes coses, especialment políticament, no estem d'acord. Ens coneixem de fa molts anys ... Està molt bé això (mirant la casa Ugalde, "Quaderns" núm. 144.)» Entrevista a Josep Lluís Sert en 1982, "L 'Avantguarda lúcida. Una conversa amb Josep-Lluís Sert" en Quaderns d'arquitectura i urbanisme. nº 152, p. 77.

Traduccion al castellano de Ana Rodríguez. 

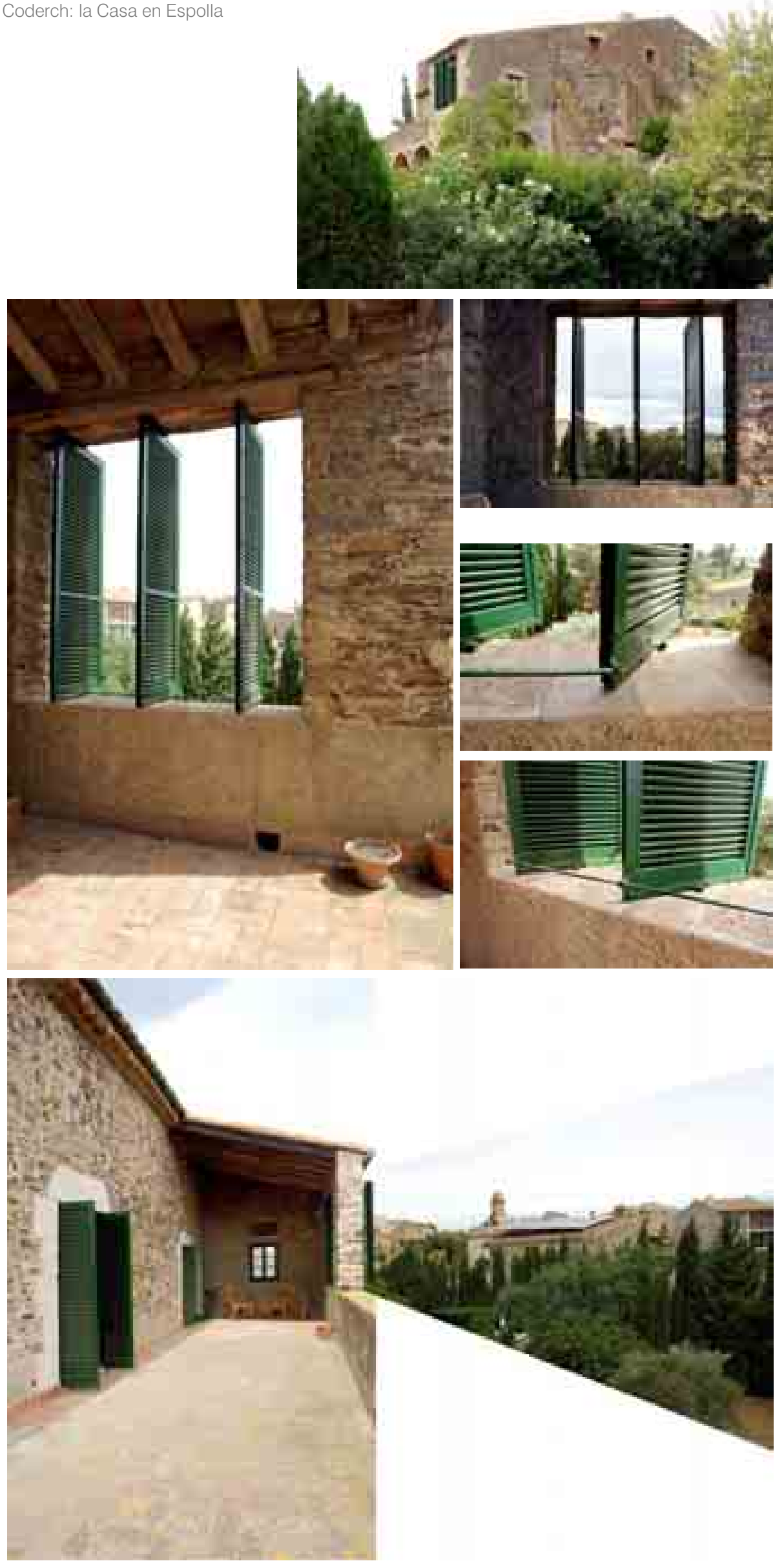

Figura 4.45

Ventana al paisaje, como una de las intervenciones que caracterizan la casa, con una interpretación de la persiana de tablilla de madera. En este caso, tres hojas verticales de gran tamaño, se mueven solidariamente pivotando sobre ejes verticales, mediante un sencillo sistema de accionamiento mecanico horizontal.

Fotografías de Ana Rodríguez García 


\subsubsection{La construcción ensamblada}

\subsubsection{De la persiana tradicional de tablillas de madera a la Llambí de tabla ancha. Descripción y variaciones.}

Tras una etapa inicial, es a partir de 1951 cuando alcanza una comprensión de la tradición exenta de mimetismos con obras como el Pabellón de España en IX Trienal de Milán, que obtuvo el Premio Internacional y Medalla de Oro, y el edificio de viviendas en la Barceloneta en el que la reinterpretación de un sistema anónimo y vernáculo de control solar en el mediterráneo como la persiana de tablillas de madera alcanzan su mejor expresión.

Así, el 7 de marzo de 1953 registra como Patente de Invención la persiana de lamas anchas de madera "Llambí"con su socio Manuel Valls Vergés y los hermanos Llambí, Juan y José Llambí Calopa, dedicados por tradición familiar a la ebanistería y a la carpintería de taller y quienes se encargarán de su producción industrial hasta el presente, con la introducción de mejoras y nuevas versiones.

En realidad registran dos. La Patente de Invención 208250 con el nombre Nuevo sistema de persiana de tablillas y la Patente de Invención 208251 titulada Perfeccionamientos en la construcción de persianas de tablillas.

La persiana tradicional de tablillas de madera, cuya función principal es la protección de la radiación solar, normalmente está constituida por una serie de pequeñas tablas horizontales distribuidas uniformemente en cuatro hojas que se pliegan de dos en dos, quedando alojadas a ambos lados del hueco, normalmente en el espesor del muro de fabrica. Las tablillas pueden ser fijas o en las soluciones mas desarrolladas móviles con inclinación regulable, girando hasta ciento ochenta grados agrupadas en dos secciones por cada hoja, mediante un listón vertical de madera fijado en el punto medio del borde de cada tabla.

En la primera patente, las aportaciones más relevantes de Coderch y sus socios, se basan en establecer un sistema de movimiento con accionamiento lateral, permitiendo lamas de mayor tamaño en sección y longitud que la tradicional. En este mismo documento, se contempla una variante con la posibilidad de apertura basculante sobre el eje horizontal superior.

La segunda patente, refleja la incorporación de una varilla de acero sobre la que gira cada lama, y que actúa como reja de protección del hueco.

Es en el edificio de viviendas para pescadores para el ISM en la Barceloneta donde se experimentará por primera vez la persiana Llambí de lama ancha, fabricada de modo artesanal en pino Flandes pintada de blanco. Así, mientras que la tablilla tradicional no mide más de $5 \mathrm{~cm}$ de ancho y $20 \mathrm{~cm}$ de largo, la nueva solución tenía una medida de $137 \mathrm{~mm}$ y $62 \mathrm{~cm}$ de longitud, montadas sobre un bastidor de chapa de acero galvanizado (Armesto y Diez 2008).

Posteriormente la nueva versión, producida de forma industrial, obtiene de una escuadría de sección 6"x3", 4 tablillas con un ancho de 144 mm según la información técnica y comercial de la empresa Llambí. En el modelo reforzado con varilla de acero como reja de protección se fija el ancho de la tablilla en 148 mm y una separación ente varillas de $12 \mathrm{~cm}$.

A lo largo de los años, Coderch desarrollará nuevas posibilidades para la persiana de lamas, en madera y en otros materiales. Podemos establecer algunas variantes fijando un parámetro de análisis.

Según el movimiento del bastidor:

Bastidores fijos en el edificio de viviendas para el ISM en la Barceloneta en 1951-1955 y en el edificio de viviendas en la calle Johann Sebastián Bach en 1958-1960 entre otros; bastidores correderos en las casas Dionisi en 1953, Catasús en 1956, Gili en 
1965 y especialmente en la casa Uriach de 1961, en donde las persianas se proyectan mas allá de la pared quedando en parte exentas en las esquinas; bastidores pivotantes de eje vertical unidos entre si como las tres hojas de tablilla estrecha en la casa de Espolla en 1964, o bastidores pivotantes de eje vertical independientes entre si como en el edificio de viviendas de la calle Encarnación en 1966; bastidores abatibles hacia el exterior en el conjunto de viviendas para el Banco Urquijo; bastidores colocados en horizontal como pérgola en la casa Gili, en la casa Luque en 1965, en la casa Raventós de 1970, en la casa Güell en 1971 y en la casa-estudio Tapies.

Según el movimiento de la lama:

Lamas horizontales fijas en la Casa Garriga-Nogués de Sitges en 1947; lamas pivotantes de eje horizontal en el edificio de viviendas para el ISM en la Barceloneta, en el de la calle Johann Sebastián Bach, y en la casa-estudio para el pintor Tàpies en 1960; lamas pivotantes de eje vertical en el edificio de viviendas de la Via Augusta en 1966.

Según la sección de la lama:

Lamas de sección rectangular estrechas y anchas colocadas en horizontal, ya explicadas anteriormente; lamas verticales de sección triangular, en grandes superficies en el Hotel del Mar de Palma de Mallorca en 1962, en el edificio de viviendas Girasol en Madrid de 1966 y en el conjunto de viviendas para el Banco Urquijo en Barcelona en 1967; lamas verticales de sección cuadrada en el Instituto Francés en 1972.

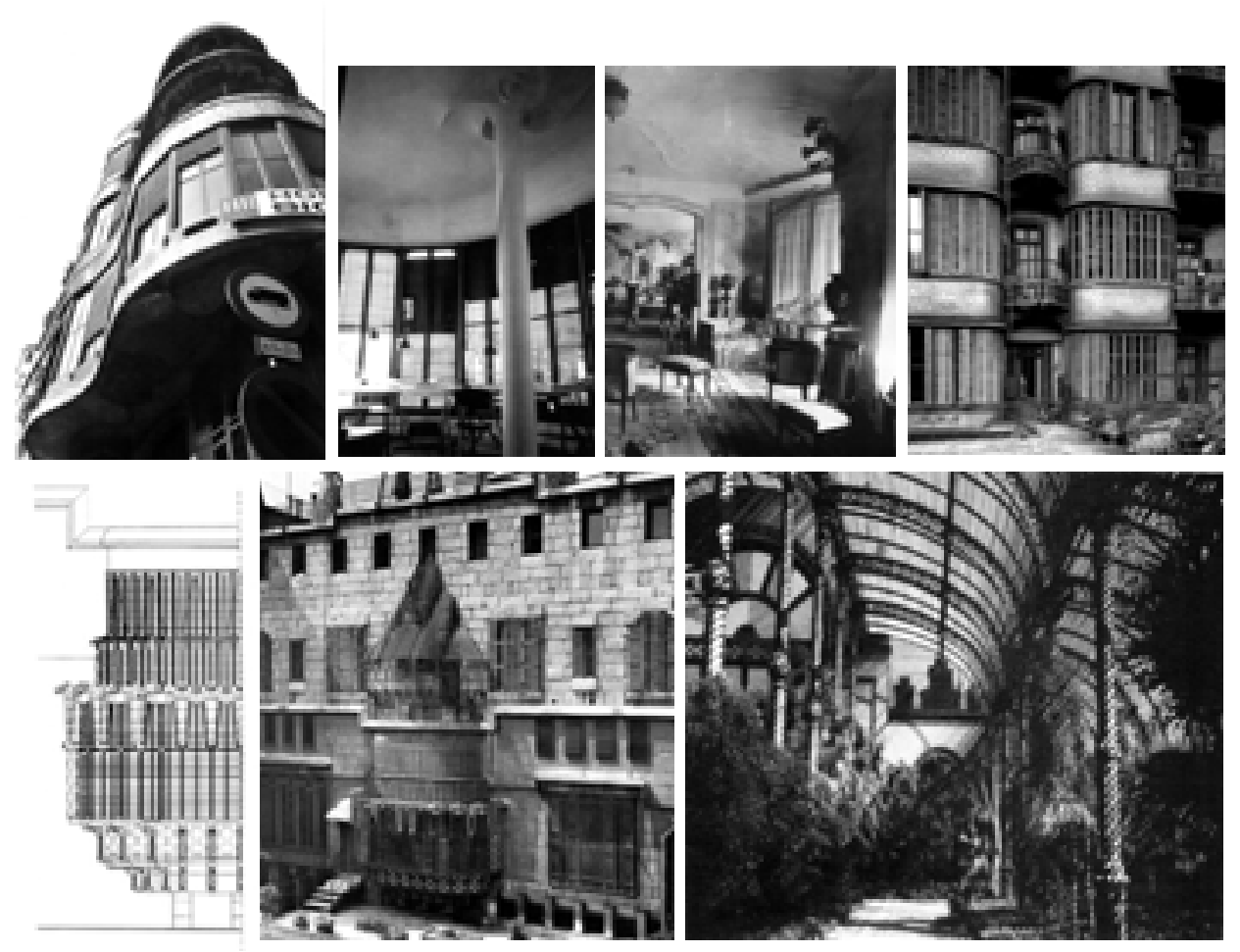

Figura 4.46

Referentes catalanes en el estudio de la protección solar con lamas

* Superior, de izquierda a derecha

- Exterior e interior de la galería del piso principal en la Casa Planelles de Jujol (Sola-Morales 1990)

- Luz tamizada en la sala interior de un piso de La Pedrera de Antonio Gaudí

- Detalle de la fachada posterior de la Casa Calvet de Antoni Gaudí, 1898-1904

* Inferior de izquierda a derecha

- Palacio Guell de Gaudí. Dibujo de las persianas orientables en la fachada posterior.

- Palacio Guell de Gaudí. Imagen de las ersianas orientables en la fachada posterior.

- Umbráculo del Parque de la Ciudadela en Barcelona de Josep Fontseré, 1883.

(Paricio [1997] 1999, 4-6) 


\subsubsection{La casa persiana.}

En el Mediterráneo, donde parte del año la sombra es un lujo, la ciudad tradicional, construida con estructuras de fábrica en las que dimensiones y proporción de ventanas y balcones vienen determinados por los sistemas constructivos empleados, ha conseguido por un proceso de siglos de prueba y error, soluciones de gran eficacia para el control del soleamiento mediante contraventanas exteriores de tablillas de madera

A partir de la interpretación de un elemento anónimo y vernáculo, y de las innovaciones técnicas realizadas sobre él, Coderch es capaz de trascender generando nuevas soluciones. Entender la persiana de tablas como un elemento arquitectónico autónomo, independiente del hueco y con personalidad propia, le permite extrapolarlo a formas y tamaños que exceden las dimensiones y posición habitual de una ventana o balcón.

Manteniendo su concepto de elemento para la protección solar, la privacidad y la seguridad, Coderch libera la persiana de limitaciones dimensionales y de escala, llegando a convertirse en el elemento definidor del proyecto, haciendo desaparecer las ventanas de la imagen del edificio. La persiana y el hueco no solo configuran el aspecto interior, sino que tienen «espesor» generando espacios habitables fuertemente caracterizados.

Así, el montaje de la exposición del Pabellón de España de la Trienal de Milán en 1951, el mueble expositor, es una interpretación de las persiana de tablilla fija, que junto con la solución dada en las Viviendas de la Barceloneta, marca ese punto de inflexión. En relación con este proyecto, y sin negar las conocidas semejanzas con las viviendas para empleados de la fábrica de sombreros Borsalino en barrio Mangiagalli de Alessandria realizadas por Ignazio Gardella (1905-1999) entre 1948 y 1952, se propone como referentes, la herencia de Gaudí y Jujol en el estudio de la persiana de lamas, o el Umbráculo del Parque de la Ciudadela de Barcelona de Josep Fontseré. Una mirada atenta permite ver la influencia que sin duda ejercieron sobre Coderch.

En otras ocasiones en el interior de patios, la persiana se coloca en horizontal como una pérgola de sombra, y en otras como en la casa Tapies toda la fachada y el edificio mismo es como una gran persiana de lamas.

En la Casa de Espolla, todos los huecos disponen de una persiana exterior de lamas de madera pintada en color verde. Por las características de la construcción preexistente y su fuerte condición urbana, ya explicadas, las persianas se adaptan a los huecos que había, con una solución en todos los casos, como la dada en las viviendas de la Barceloneta, es decir la versión de tabla ancha reinterpretada de la persiana tradicional de tablillas, aunque en este caso formalmente limitada por el tamaño del hueco.

Una excepción singulariza y caracteriza la casa: la ventana al paisaje que Coderch construye en la terraza de la planta primera, Un gran hueco definido con tres hojas verticales, compuestas a su vez con tablilla estrecha fija, que se mueven solidariamente de forma pivotante con eje vertical, mediante un sencillo mecanismo que básicamente es el mismo que permite el movimiento en sus patentes de tabla ancha, pero en este caso con otra escala y colocado para su accionamiento en horizontal en la parte inferior del hueco.

Se puede concluir que como en todas sus obras, también en Espolla, la persiana configura la imagen de la Casa, a pesar de la limitación que podía suponer la preexistencia de unos huecos determinados. Incluso podría asegurarse que la indagación que realiza en el gran ventanal con vistas, se convierte además en un banco de pruebas para la exploración de nuevas interpretaciones que irán sucediéndose posteriormente, después de la definición de la Llambí de tabla ancha colocada en la Barceloneta y aquí. 


\subsubsection{La construcción excavada}

Estudio sobre una posible solución del problema de las barracas, una singular propuesta para viviendas de bajo coste.

En septiembre de 1962, Coderch participa en la reunión de Team 10 en la abadía de Royaumont al norte de París, presentando dos proyectos de vivienda de bajo coste. El famoso edificio de bloque de viviendas de pescadores en la Barceloneta construido para el ISM Instituto Social de la Marina, y una propuesta de conjunto urbano mediante unidades de vivienda para realizar en serie, basado en un estudio realizado en junio de 1952 con el nombre Memoria estudio sobre una posible solución del problema de las barracas.

El estudio consta de una memoria razonada con un avance estimado de presupuesto, el diseño y calculo del elemento estructural prefabricado, y un fotomontaje realizado con Luis Marsán con un negativo montado en distintas posiciones para representar variaciones en el conjunto.

La memoria de este estudio nos ha llegado a través de la carta que escribe Coderch a la administración pública solicitando cincuenta mil pesetas para construir dos elementos tipo "a fin de poder presentar y proyectar esta solución a gran escala con conocimiento de causa" (Coderch 1952).

Plantea con el ingeniero Eustaquio Ugalde, una solución realizada con piezas prefabricadas en hormigón pretensado con forma de $U$ y tapial encalado con diferentes colores construido por los propios usuarios.

Proyecta un asentamiento urbano tipo, de vivienda en serie, con interés en el espacio público ya que delante de cada vivienda se plantarían árboles, a realizar en terrenos de poco valor económico y en pendiente para favorecer la variedad en la urbanización, en los que los poderes públicos realizarían la infraestructura general, consistente en los servicios generales de abastecimiento de agua, recogida de aguas fecales, y un número determinado y suficiente para ser económicamente rentable, de unidadesmodulo base para dos viviendas construidas mediante un pieza prefabricada en forma de $U$ de hormigón pretensado con un coste estimado de veinte mil pesetas cada uno. El resto sería realizado por los propios habitantes de las viviendas, bajo la dirección de un arquitecto director, construyendo "las paredes de tapial encaladas con distintos colores y con sus huecos reducidos, constituyen un elemento de valor estético indudable" (Coderch 1952).

En su carta, refuerza los argumentos que justifican la utilización de estas unidades prefabricadas apuntando experiencias similares en aluminio desarrolladas en Inglaterra y Francia. El conocimiento de estas experiencias, desconocidas para él hasta su publicación en la revista francesa L'Architecture d'Aujourd'hui, le producen sorpresa y verificación en sus planteamientos y se refieren a L'elément coque de Jean Prouvé y The Shell-Unit System de Oscar Singer, publicados en el numero 40 de la revista en abril de 1952, aunque patentados con anterioridad. (Armesto y Diez 2008, 50)

Cada elemento prefabricado albergaría dos viviendas, solucionando en una sola operación la cimentación, el suelo, la pared posterior de contención de tierras, y un techo en voladizo. Explícitamente justifica su realización en hormigón pretensado ya que de esta manera también se resuelve el problema de posibles humedades gracias a la gran densidad e impermeabilidad de este material, insistiendo en este punto al hablar de la colaboración en estas piezas de Eustaquio Ugalde, amigo y cliente para el que realiza la muy conocida Casa Ugalde. 
Para explicar la idea, preparó un fotomontaje que presentó en Royaumont, y que posteriormente llegaría a ser bastante conocido. En 1969 fue portada del numero 14 de la revista Auca en Santiago de Chile, y a él se refiere en varias ocasiones como en la respuesta 1 y 2 de su escrito Cuestionario I, comentando dicha reunión del Team 10.

«Como decía con ocasión de nuestras ultimas reuniones en Royaumont, no tenemos vitalidad suficiente para "parir" 1000 viviendas realmente vivas,... (comillas en el original)»

«He hecho un fotomontaje muy arbitrario con las casas de un mismo pueblo, todas semejantes unas a otras, privándolas de toda relación entre ellas y con el paisaje. El conjunto conservaba, sin embargo toda su vitalidad y frescura. Si los arquitectos hubieran decidido arbitrariamente pequeñas diferencias entre las viviendas, no habría obtenido yo sino un resultado pobre y desolador. Este es el caso de la casi totalidad de los conjuntos residenciales modernos»

(Fochs 1989, 217).

En 1969 fue portada del numero 14 de la revista Auca en Santiago de Chile

«Hace ya tiempo presente a un Congreso una fotografía, un fotomontaje, que hice hacer por un no arquitecto porque había casas en un pueblecillo de las afueras de Madrid, cuyo nombre no recuerdo, casas muy humildes, todas de una planta; todas tenían una ventana grande, una ventana chica y una puerta. Aquello me gustaba mucho, todas eran iguales; pero sin embargo, existía una gran variedad, no tenían esa monotonía de los que nosotros hacemos, y se me ocurrió pensar que quizá los cambios que nosotros introducimos, en general, en las casas, por conseguir variedad, por evitar la monotonía, resultan falsos; en cambio, las que se han hecho con completa arbitrariedad por los que iban a habitar las casas, resultaban muy bien; entonces hice recortar (porque suponía que esta poesía podría venir de la interrelación de unas casas con otras) todas las casas y la hice montar y resultó una fotografía preciosa. Se las he enseñado a muchos arquitectos y todos preguntan que dónde está ese pueblo tan bonito, o sea que es un hecho cierto, suficientemente probado, que la iniciativa de la familia tiene una importancia vital; pero claro esto está contra la línea del progreso» (Coderch 1969) 

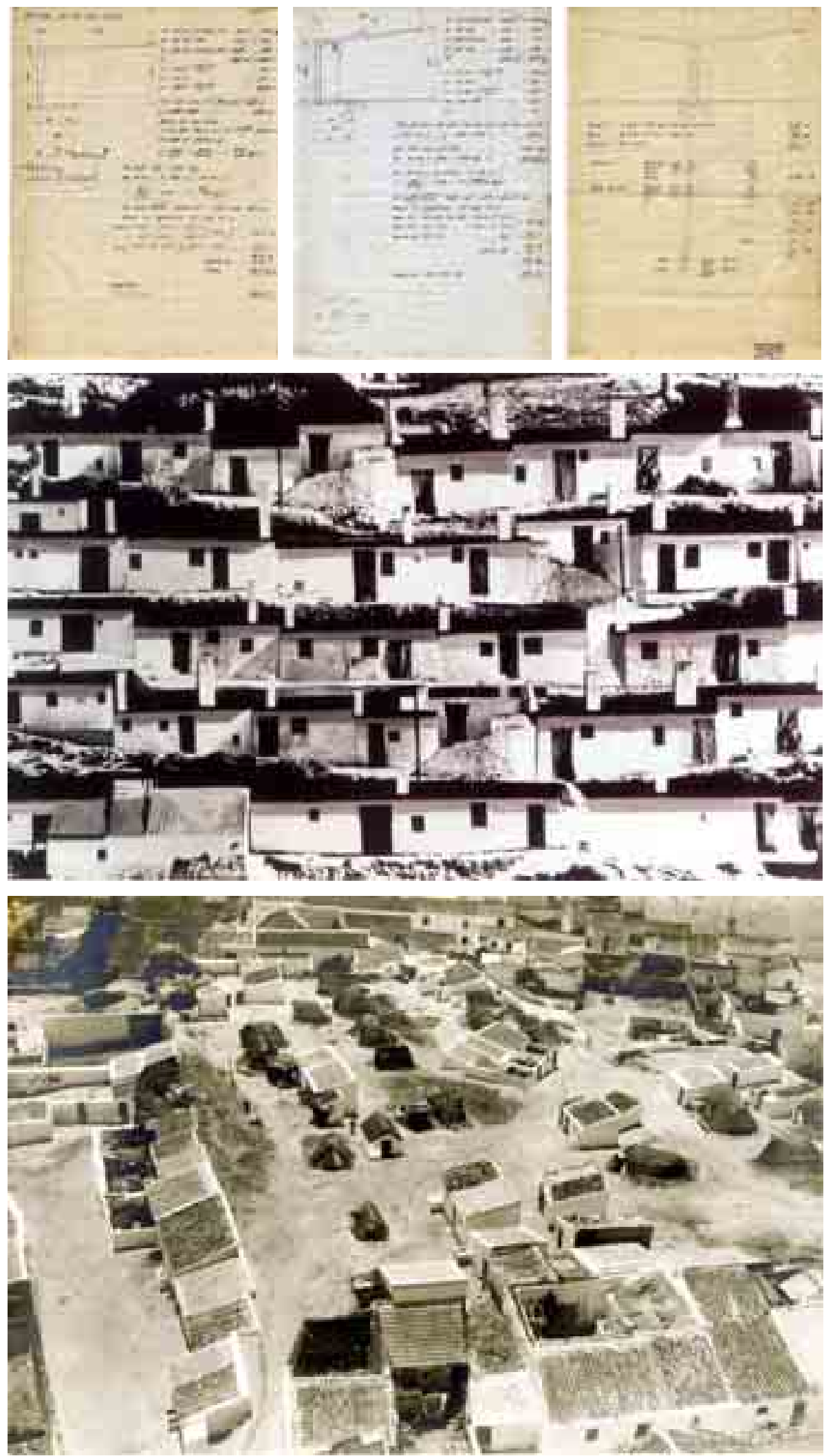

Figura 4.47

* Superior: Memoria para el «Estudio sobre una posible solución del problema de las barracas, una singular propuesta para viviendas de bajo coste», presentado en el Congreso de Royamount.

* Centro: Fotomontaje presentado en Royaumont, y que posteriormente llegaría a ser bastante conocido. En 1969 fue portada del numero 14 de la revista Auca en Santiago de Chile.

* Inferior: Fotografía de arquitectura subterránea encontrada en el Archivo Coderch sin referenciar. 


\subsubsection{La casa excavada}

Cómo realizar nuevos crecimientos urbanos con viviendas de bajo coste para dar alojamiento digno a la población de los movimientos migratorios del campo a las ciudades, originados en Europa tras la Segunda Guerra mundial, es uno de los principales temas en el debate arquitectónico internacional y en el seno del Team X.

La respuesta dada por Coderch, es de carácter teórico, ideal, aunque realizada con elementos muy concretos y cercanos. Es una respuesta singular, alejada de modelos ya propuestos.

Plantea un sistema de actuación basado, como otros, en la repetición de unidades iguales prefabricadas industrialmente, en el establecimiento de una ley de crecimiento, en este caso condicionada por un terreno en pendiente, y en la búsqueda de la variedad dentro de una actuación unitaria.

Algunos rasgos interesantes son la participación de los propios habitantes, que justifica el empleo de tapial encalado para los cerramientos, una técnica muy común en la construcción popular española tradicional, y el planteamiento de consolidación en fases, ya que en un principio se realizaría la urbanización completa y todas las unidades prefabricadas, pudiéndose completar cada una de las viviendas con el paso del tiempo.

Pero la diferencia fundamental viene dada por la necesidad de ubicarse en un terreno en pendiente, lo que la hace menos universal, más vernácula y enraizada con las características del lugar donde se ha de establecer. En el fotomontaje se aprecia como las cubiertas de cada frente de viviendas se encuentran ligeramente por debajo de la cota de la calle, estando las viviendas semienterradas con un solo frente de fachada. Coderch, dentro de su interés por las construcciones populares, había estudiado las viviendas excavadas en la tierra que se dan en varios lugares de España como Granada. Estas construcciones se suelen establecer en la pendiente de las colinas, en terrenos arcillosos que cuando están húmedos son blandos para excavar, pero secos son duros y resistentes, cuestión que resuelven de forma sencilla mediante chimeneas de ventilación. Esta técnica de construcción vernácula, junto con el clima español, mas seco que húmedo, propician que estas primitivas viviendas no tengan graves problemas de humedad, y al estar enterradas regulan de forma pasiva los grandes saltos térmicos propios de nuestro clima. De hecho, se dan fundamentalmente en lugares muy calurosos, ya que mantienen una temperatura fresca en su interior.

Podríamos decir que la propuesta de Coderch para un Sistema aplicable a la construcción de viviendas baratas en terrenos en pendiente, en realidad está planteando una interpretación evolucionada, mejorada, normalizada y en parte prefabricada, de un conjunto de casas-cueva. 

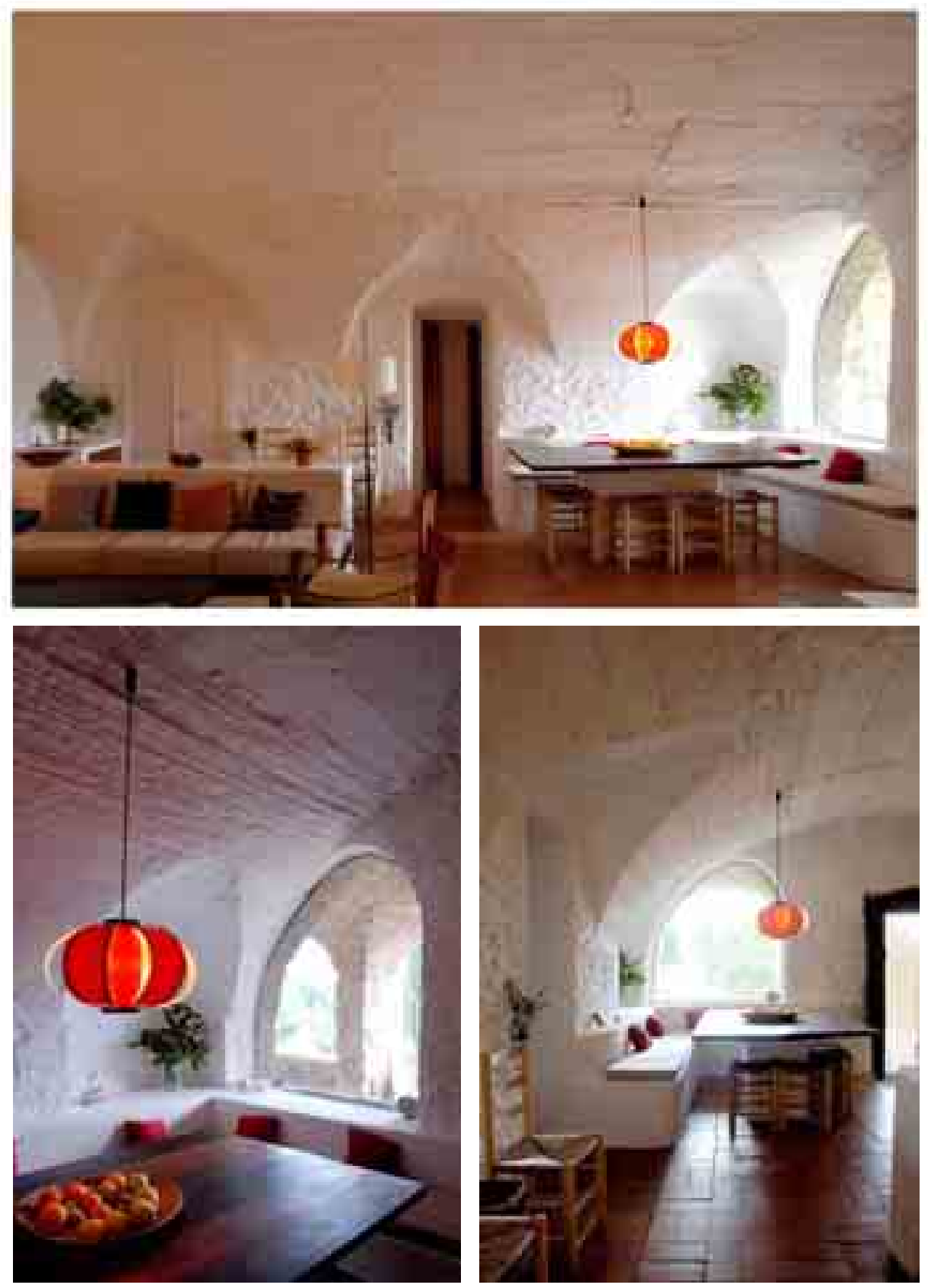

Figura 4.48

Fotografías de la Casa en Espolla realizadas por Ana Rodríguez García

En ellas se aprecia con claridad la textura y características de las bóvedas construidas sobre encofrado de tierra y cañizo. 


\subsubsection{La casa de Espolla tallada en la roca.}

La casa, con características propias de la zona, está parcialmente excavada en la roca, construida con gruesos muros de mampostería de piedra delimitando las estancias de la vivienda. Pero lo que determina espacialmente cada estancia son las bóvedas de cañón y crucería que las cubren.

Coderch pone en valor la planta de acceso, originalmente destinada a los animales, como vivienda independiente, con las bóvedas como generadoras del espacio.

Las de las dos salas principales construidas con mampostería de piedra según la técnica vernácula local de utilización de caña y tabla de madera para la forma, y el resto bóvedas tabicadas, manteniendo en todos los casos sus diferentes texturas a la vista.

En el caso de las bóvedas de fabrica, generan un espacio de gran intensidad por quedar a la vista la fuerte textura del molde con que fueron hechas, apreciándose claramente las marcas de la caña en el arranque, hasta aproximadamente un tercio de la altura, a partir de donde se produce un cambio de un encofrado de tabla..

Una mirada atenta nos hizo pensar desde el principio que estaban construidas sin encofrado, sobre el terreno antes de retirarlo. Una vez dada la forma principal, la curvatura mayor, embocaduras, lunetos, etcétera, se terminaban de moldear con la caña seguramente gracias a que se adapta bien sin mucho esfuerzo. Una vez realizada, terminarían de retirar las tierras.

Es un tipo de construcción frecuente en la zona que Coderch conocía. Según información dada por Ana Coderch, su padre explicaba con admiración como se construían esas bóvedas sobre la tierra.

Sin embargo no se han encofrado textos que lo referencien de manera clara o expliquen la técnica. A continuación se aportan tres, siendo un tema de investigación específico a desarrollar

La primera se encuentra en la Guia de L'Arquitectura Popular de les Comarques Gironines de Maria Assumció Alonso de Medina i Alberich, que explica como en la zona, los terrenos cultivados han de desempedrarse previamente, por la gran abundancia de piedra granítica y pizarrrosa de la zona, siendo las fábricas mas frecuentes de mampostería de piedra, y también fácil la obtención de ladillo cerámico. Aunque hay abundancia de arbolado, no se trabaja bien la madera, por lo que predominan las formas abovedadas de cubrición. Las plantas bajas se cubren sistemáticamente con bóvedas de cañón o arista construidas con piedra amorterada a la romana en las edificaciones mas antiguas, y rebajadas tabicadas en las más tardías. En la costa norte del Alto Ampurdan, donde la cantidad e arboles es menor aunque en la Edad Media estuviera densamente arbolada, la reducida dimensión de la mampostería con la que se construyen los muros, obliga frecuentemente a la incorporación de arcos de descarga embebidos en los muros y grandes contrafuertes en talud. Además el grueso de los muros permitía en el interior abundancia de hornacinas para utensilios. Dice específicamente sobre las bóvedas:

«Son características las bodegas en las plantas bajas, cubiertas con bóveda, construidas con piedra a sardinel a la romana, sobre encofrado de tierra y cañizo»

(Alonso de Medina i Alberich 1977, 7)

Está claro que esta forma de construir solo es ventajosa si el espacio no es muy alto, en espacios en contacto con el terreno, y si no hay unas exigencias en cuanto al acabado. Condiciones que se cumplen en el caso de Espolla, donde no hay que olvidar que la planta baja no era habitable en principio. 

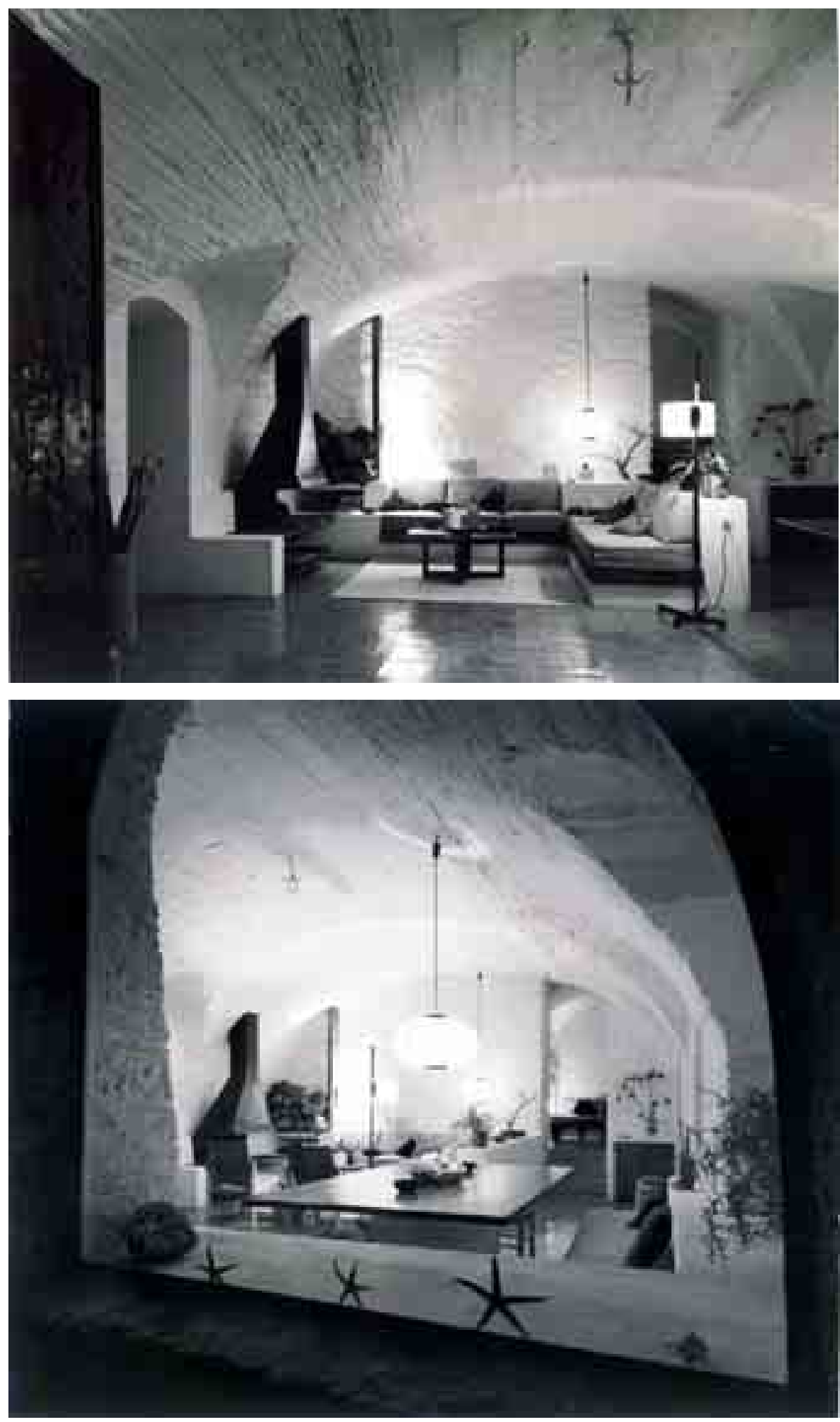

Figura 4.49

Serie de fotografías de la Casa en Espolla encargadas por José Antonio Coderch y realizadas en 1966 por Catalá Roca

En ellas se aprecia con claridad la textura y características de las bóvedas construidas sobre encofrado de tierra y cañizo. Archivo Coderch 

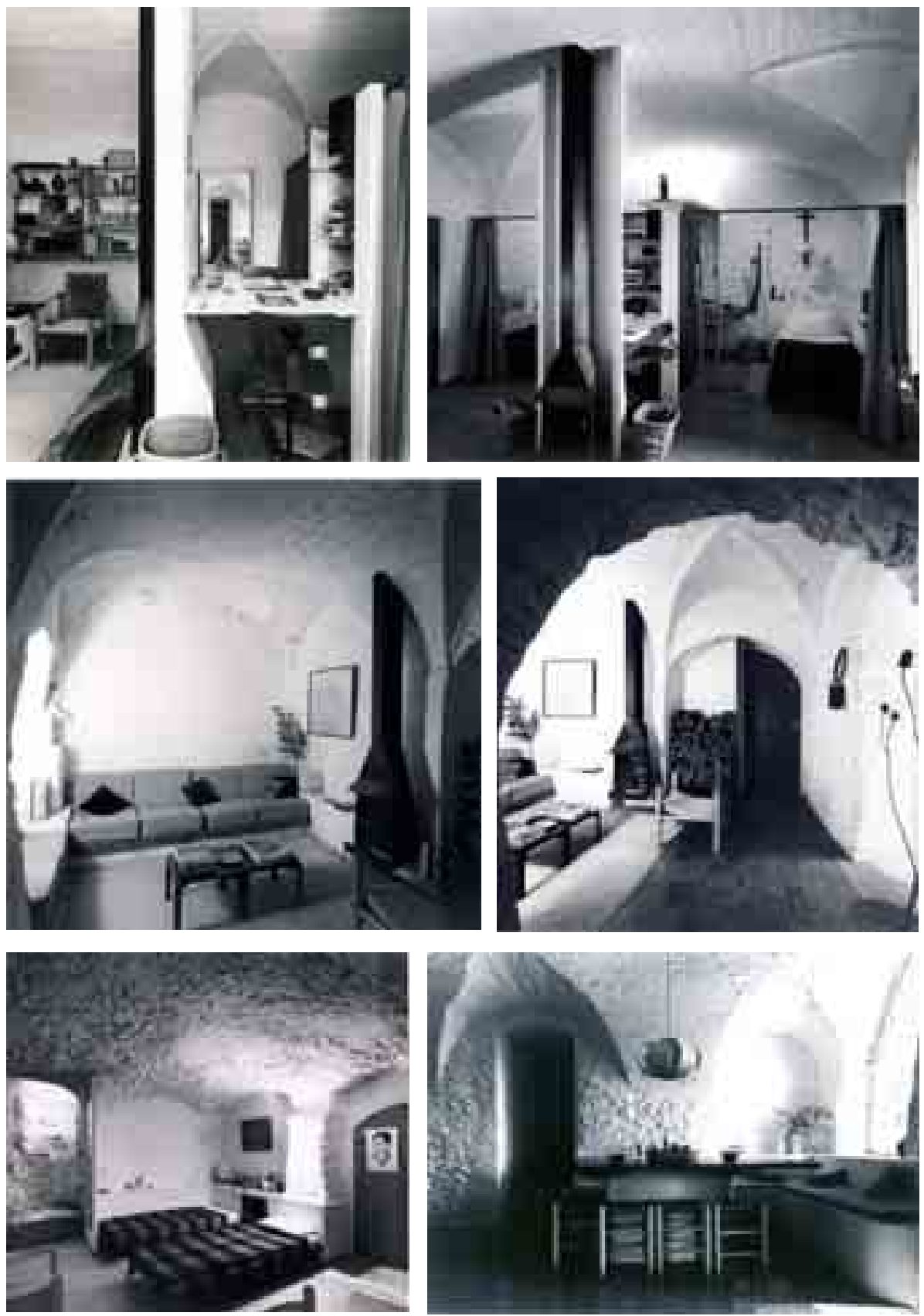

Figura 4.50

Serie de fotografías de la Casa en Espolla encargadas por José Antonio Coderch y realizadas en 1966 por Catalá Roca

En ellas se aprecia con claridad la textura y características de los distintos tipos de bóvedas existentes en la planta baja

* Superior y centro.

Bóvedas tabicadas

* Inferior izquierda

Otro tipo de bóveda de herencia romana en la habitación iluminada por el pozo de agua, con la

huella de los guijarros a la vista.

* Inferior derecha

Bóvedas construidas sobre encofrado de tierra y cañizo.

Archivo Coderch 

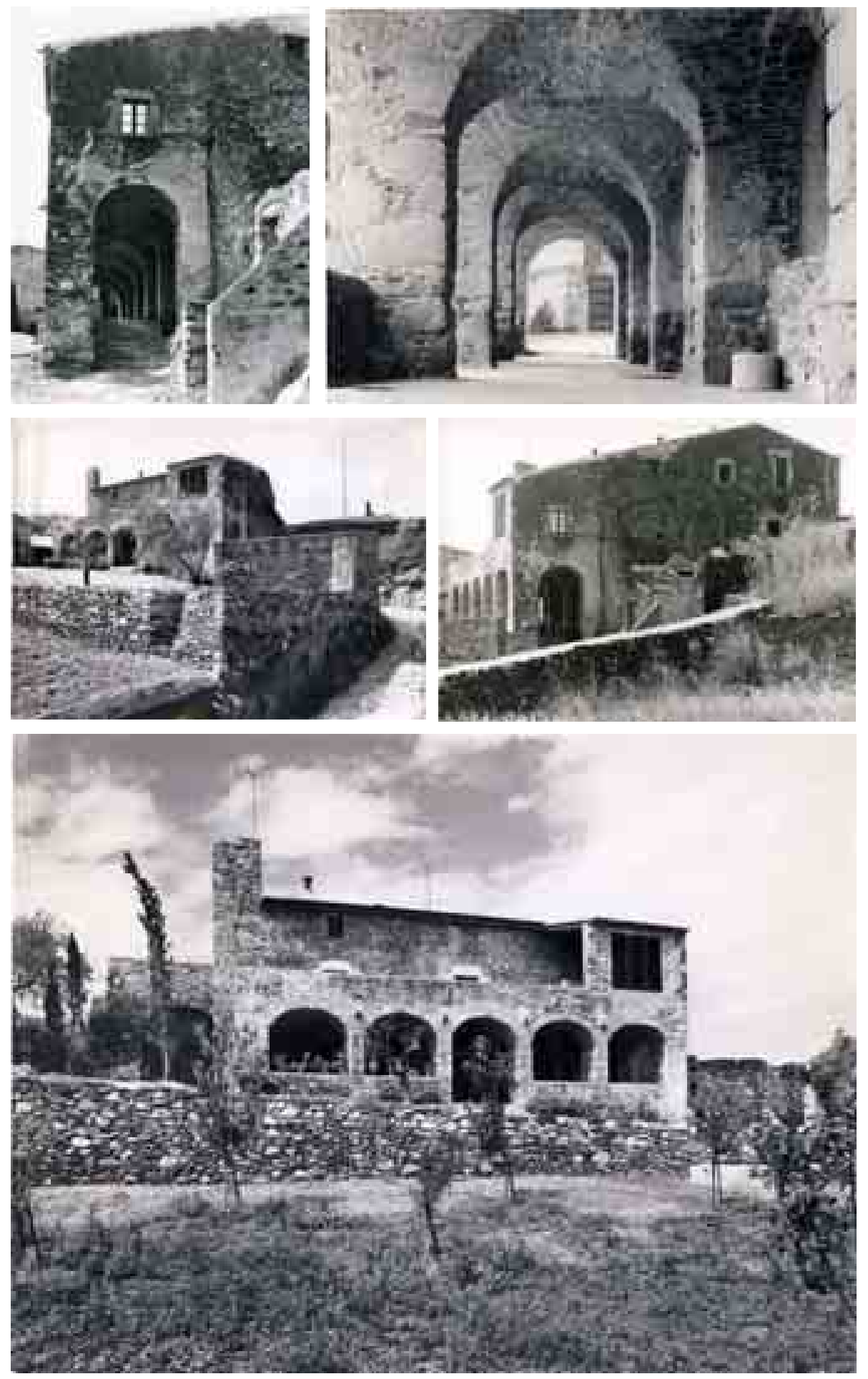

Figura 4.51

Serie de fotografías de la Casa en Espolla encargadas por José Antonio Coderch y realizadas en 1966 por Catalá Roca 
En este sentido, una segunda referencia se ha encontrado en El Arte de construir en Roma de Choisy.

La construcción romana se caracterizó por no tener reglas rígidas al construir. Si bien partían de métodos muy sistematizados, las necesidades y recursos variaban enormemente según los diferentes lugares del imperio, por lo que las técnicas y materiales se adaptaban según las circunstancias. En la construcción de bóvedas ocurría lo mismo. Un caso particular consistía en prescindir por completo de cimbras, hormigonado la bóveda sobre un molde formado por el propio terreno. Sobre este tipo de construcción romana, Choisy dice:

«Otra posibilidad apreciada por los romanos, cuando la bóveda era pequeña y estaba situada poca altura del suelo, era prescindir de cimbras y armaduras, y verter el hormigón sobre un núcleo de tierra que servía de molde. Ejemplos de esto son la bóveda descubierta en un cementerio romano de Vienne y las bóvedas que aligeran el basamento de uno de los templos principales del Palatino, donde las tierras que sirvieron de molde no se retiraron y permanecen en el lugar en el que los constructores las amontonaron.

Así pues, los procedimientos para economizar cimbras provisionales podían variar, pero la idea central que les daba origen permanecía inmutable» (Choisy [1873] 1999, 80)

Por último, y aunque de tradición muy lejana, en China se construyen bóvedas de esta forma, que se recogen en BODOLEC, Caroline. 2005. L'architecture en voûte chinoise un patrimoine méconnu-. Paris: Maisonneuve \& Larose, abriendo un campo de nueva investigación.

\subsubsection{Estrategia constructiva y compromiso urbano}

A diferencia del Upper Lawn Pavilion y de la Ampliación de la Casa Visser, con actuaciones más rotundas, Coderch interviene en su casa pairal, con una serie de operaciones puntuales, que aunque reconocibles, parece que siempre hubieran estado allí. Sin embargo, la comparación de imágenes antiguas con las finales, demuestra que la transformación es mayor de lo que en un principio pudiera parecer. La Casa de Coderch, después de su intervención, adquiere un carácter más atemporal. A partir de una casa de pueblo se transforma, intensificando y descubriendo sus mejores valores, como la significativa interpretación de la persiana de lamas.

La casa de Coderch se enclava en un lugar preponderante en Espolla, apreciándose su importancia debido a su posición elevada -el Mas del Puig-, es decir la masía del montecillo, la que está en alto, y al papel, históricamente simultáneo, como límite en su parte alta con terreno propio que se proyecta hacia el territorio, y centro del pueblo en la inferior, junto al arroyo que singulariza la trama urbana.

El proyecto de Coderch asume como prioritaria, sobre otras, esta condición urbana de la casa, que también la diferencia del pabellón de los Simthson en Fonthill y de la Van Eyck en Bergeijk. En este sentido, Coderch elige una estrategia con la que los habitantes de Espolla pudieran sentirse representados, reconocidos, con pautas culturalmente aceptadas a lo largo del tiempo, aunque reinterpretadas desde posiciones modernas, como única manera posible. Como Alejandro de la Sota, cuando construye desde la memoria, sin recordar exactamente qué, trabajando con fragmentos de recuerdos de una memoria colectiva inconsciente, materializados desde la posición culta y moderna de Coderch. 
Capitulo 4. El hogar de Coderch: la Casa en Espolla 
Análisis comparado y Conclusiones 

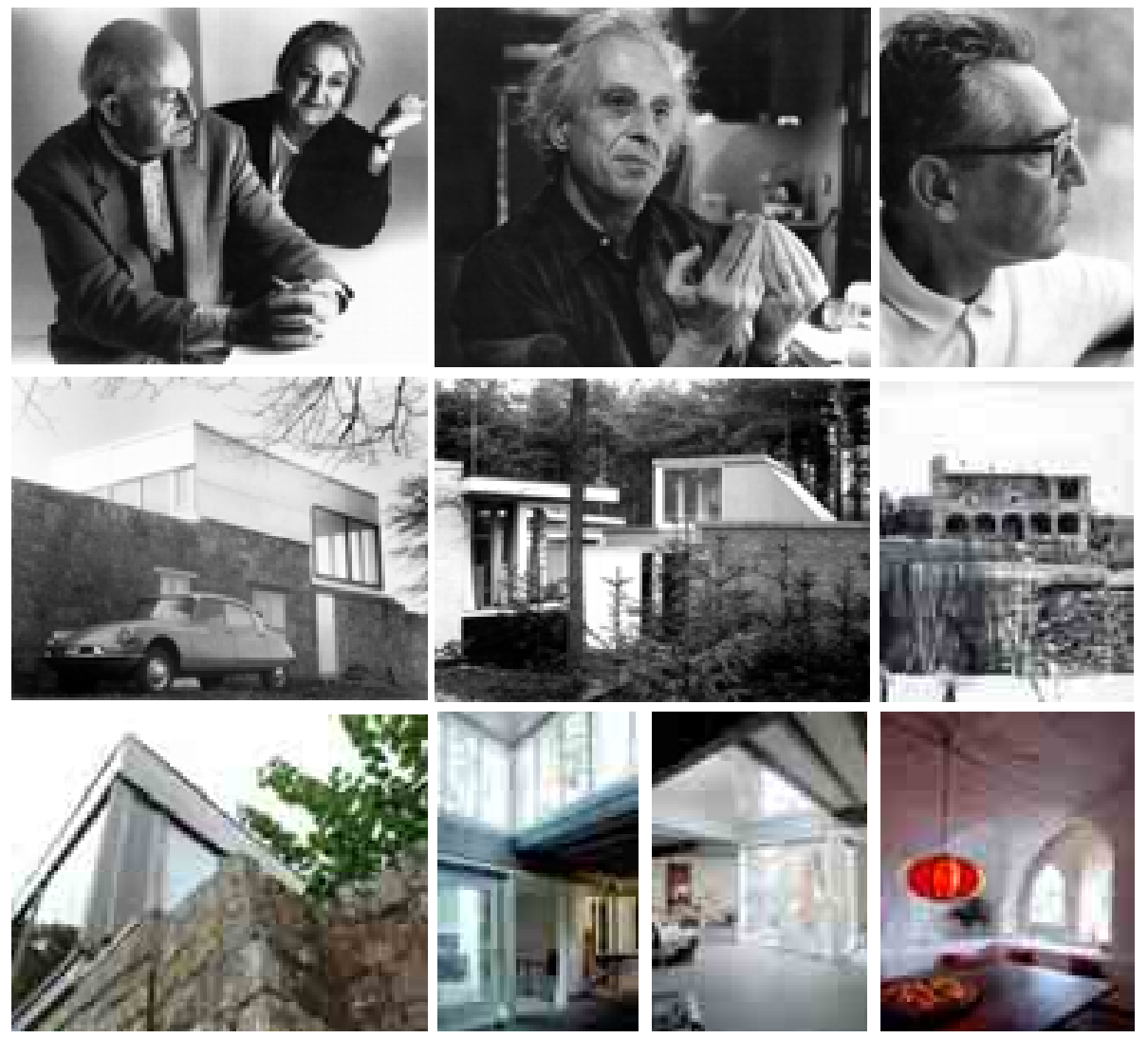

Izquierda

* Superior

Alison y Peter Smithson 1928-1993 y 1923-2003

* Centro

Upper Lawn Pavilion,

Wiltshire, Inglaterra

1959-1962

* Inferior

Upper Lawn Pavilion

en Agosto de 2010

Fotografía Ana Rodríguez
Centro

* Superior

Aldo van Eyck

1918-1999

* Centro

Ampliación de la Casa Visser

Bergeijk, Paises Bajos

1967-1969

* Inferior

La Casa Visser

en Septiembre de 2013

Fotografía Ana Rodríguez
Derecha

* Superior

Jose Antonio Coderch

1913-1984

* Centro

La Casa Coderch en Espolla, Gerona 1963-1964

* Inferior

La Casa Coderch

en Septiembre 2012

Foto Ana Rodríguez 


\section{Análisis comparado y Conclusiones}

Las conclusiones de este trabajo, que aquí se sintetizan, se encuentran recogidas en los cuatro capítulos que estructuran el documento de la tesis doctoral. El desarrollo lineal seguido en el análisis del Upper Lawn Pavilion de Alison y Peter Smithson, de la Ampliación de la Casa Visser de Aldo van Eyck y de la Casa en Espolla de José Antonio Coderch, necesario para poder abordar la investigación con una cierta metodología, no favorece una lectura transversal.

En este sentido, por entenderse necesario y de interés, las presentes conclusiones se plantean además como un análisis comparado de las tres obras en los puntos de análisis más relevantes, junto con una pequeña explicación que permita un relato contextualizado. Se ha procurado hacerlo sintéticamente, aunque la cantidad de variables manejadas, no ha permitido un texto breve, ya que dicha comparación revela a su vez nuevos matices que enriquecen e intensifican los resultados, y que a continuación se enuncian numerados para facilitar su lectura. 
1. La relación vernáculo y arquitectura moderna esta en el debate arquitectónico de la Europa de posguerra. Si bien no es un tema nuevo, es en los cincuenta y sesenta cuando florece extraordinariamente teniendo en ello, aunque no exclusivamente, un papel relevante los miembros de Team 10. Dan soporte teórico y crítico, - los Círculos de Otterlo de van Eyck son posiblemente la primera formulación teórica del tema -, y sobre todo materializan diversas exploraciones en proyectos construidos.

El matiz no es menor, ya que si bien como grupo supusieron el fin de los CIAM, nacen en su seno y como continuadores del Movimiento Moderno con el respaldo generoso ${ }^{1}$ de los mayores, Le Corbusier el primero. Son inapelablemente modernos y no tienen que disculparse por nada.

Huellas significativas de lo vernáculo, lo primitivo y lo popular recorren la obra de Alison y Peter Smithson, Aldo van Eyck y José Antonio Coderch, siendo el Upper Lawn Pavilion, la ampliación de la Casa Visser en Bergeijk y la Casa de Espolla brillantes interpretaciones modernas de la tradición.

Una consideración más antes de pormenorizar el análisis comparado y las conclusiones del trabajo. Aun siendo tres obras conocidas, la tesis aporta el estudio de temas inéditos sobre las tres casas, partiendo a su vez de puntos de vista no planteados anteriormente: considerar el Upper Lawn Pavilion heredero de las construcciones de jardín inglesas y del Arts and Crafts; considerar la Ampliación de la Casa Visser como un pequeño asentamiento primitivo en el que la ampliación es la interpretación de una kiva; y por ultimo reivindicar el trabajo de Coderch como miembro significativo de Team 10 y entender la Casa en Espolla como el universo personal que, además de conectarle con sus raíces más profundas, le reconcilia con las contradicciones y desencantos que vive en los complejos años cincuenta en España.

2. Alison y Peter Smithson, Aldo van Eyck y José Antonio Coderch, eran intelectuales, cultos, y brillantes arquitectos. En los cincuenta y sesenta, después de la formulación sin retorno del Movimiento Moderno, así como de sus logros respecto a la vivienda social que pertenece por derecho propio a la arquitectura moderna, son conscientes de que hay que seguir avanzando. Es decir, y dicho coloquialmente después de «ir y volver», fijan su mirada en la tradición vernácula, primitiva y popular como fuente de conocimiento para seguir implementando los principios del Movimiento Moderno.

Una mirada intelectual, culta y profesional, no exenta de emotividad y significado.

Una mirada plenamente consciente de la irremediable desaparición de una cultura y formas de vida con un acerbo centenario, y de la imposibilidad de su reproducción, donde solo es posible la datación, el aprendizaje y la reinterpretación desde la arquitectura contemporánea.

Mirada que, una vez consolidada la arquitectura moderna, ha de buscar necesariamente formas de dialogo con lo vernáculo, lo primitivo y lo popular, una herencia recibida rica, ancestral, y local a la vez que universal, en la que se fundamentan la mayor parte de las formas urbanas y el control del territorio hasta finales del siglo XIX.

Una mirada ineludible para la arquitectura moderna.

\footnotetext{
${ }^{1}$ Theo Crosby lo expresa muy bien cunado dice: «La muerte del CIAM en 1956 es tal vez el único ejemplo conocido de una organización internacional de sorprendente éxito que se suicidó cuando estaba en lo más alto de su poder y de su influencia» (Robbins 1990a, 198)
} 
3. Los conceptos de vernáculo, primitivo y popular, aceptados entre expertos e interesados en la materia, en el lenguaje coloquial se intercambian frecuentemente, especialmente los dos últimos, a causa de diferencias culturales, idiomáticas y temporales sincrónicas / diacrónicas.

El término vernáculo de origen latino parece ser empleado mayoritariamente, al menos hasta ahora, en el mundo anglosajón, mientras que en España el término utilizado es popular. Esta cuestión es relevante e ineludiblemente relacionada con el nivel de riqueza: mientras que en Inglaterra, además del rural, existe un vernáculo urbano, y el término también abarca construcciones ricas, en nuestro país la construcción popular es esencialmente pobre, como lo era mayoritariamente el mundo rural español.

Una consideración más. Aldo van Eyck nunca utilizó la palabra «primitivo» para referirse a esas culturas, a las que consideraba tan sofisticadas como la occidental en sus manifestaciones artísticas y de lenguaje, acuñando la expresión «Vernacular of the Hearth» que forma parte de los Círculos de Otterlo. Van Eyck era alérgico al significado desdeñoso del término y no quería establecer ninguna desigualdad en categoría con la tradición clásica y la moderna. Cuando le era inevitable se refería a ellas como «archaic o distanct cultures».

Se puede decir por tanto que, aunque con los matices expuestos, vernáculo y popular, son términos bastante parecidos, pudiendo ser el segundo una variante del primero. Su uso vendrá determinado en esta tesis por el sentido de la cultura donde se emplean de forma habitual. También se acepta el termino vernáculo como más genérico, que en cierta forma puede englobar todos, adoptando así el sentido dado por de Van Eyck.

De esta forma, la tesis explora las huellas de lo vernáculo en su acepción más general, y de forma más precisa y matizada, la huella de lo vernáculo en el Upper Lawn Pavilion de los Smithsons, la huella de lo primitivo en la ampliación de la casa Visser, y la huella de lo popular en la Casa Coderch en Espolla.

Para ello, se ha tratado de sistematizar el estudio de lo vernáculo, determinando una serie de parámetros que permitan su aplicación a otras obras, ante la dificultad evidenciada para definir con precisión los términos primitivo, vernáculo o popular. El desarrollo de la tesis respalda los parámetros de análisis aportados: mito, topos toponimia, topografía, topofilia y topiaria-, typos y tekton, en una aproximación analítica a la definición de vernáculo de Kenneth Frampton, dada por negación cuando habla de regionalismo crítico. Refiriéndose a este dice: «no tiene como intención denotar lo vernacular tal y como era producido en tiempos por la interacción combinada del clima, la cultura, el mito, y la artesanía»

Si bien la interacción combinada del topos, del typos y del tekton, dan lugar a lo construido en general, las arquitecturas vernáculas, primitivas, y populares, están «especialmente» ligadas al lugar, son «especialmente» representativas de tipos arquitectónicos y resultan «especialmente» expresivas de, y por, lo material, siendo la asunción de el mito, como parte consustancial de una cultura determinada, lo que «especialmente» caracteriza a la arquitectura vernácula respecto de otras manifestaciones arquitectónicas. Es una cuestión de intensidad. No es que otras arquitecturas no participen de dichos parámetros, sino que las arquitecturas vernáculas lo hacen «especialmente».

En este sentido, el factor tiempo es fundamental, ya que sus características y singularidades, resultan de una evolución lenta y paulatina, en la que los cambios se producen de forma tan menor y tan prolongada en el tiempo, que son imperceptibles en el momento. A su vez, dichos procesos centenarios, les confieren un grado de esencialidad e intensidad que es lo que en gran medida las define.

Finalmente cabe decir, que el método es lo suficientemente determinado para sistematizar los casos de estudio y otros posibles, pero lo suficientemente flexible para dar cabida al universo de singularidades y circunstancias particulares de cada proyecto. También abre un camino a perfeccionar, a partir de la estructura básica desarrollada en la tesis. 
4. El mito como relato de algo fabuloso que se supone acontecido en un pasado remoto casi siempre impreciso, es consustancial a lo vernáculo, y está presente en las obras de estudio, las cuales además se encuentran en lugares con una fuerte carga simbólica. Upper Lawn está muy cerca de Stonehenge y Avebury, considerándose el condado de Wiltshire como el territorio origen de Inglaterra. En Espolla se encuentran un gran número de dólmenes y menhires, dándose en la sierra de L'Albera una de las concentraciones de monumentos megalíticos más importantes de Cataluña, y la casa Visser está a muy poca distancia del mayor cementerio merovingio del norte de Brabantia. Hasta qué punto es casualidad esta coincidencia es imposible de determinar, pero si podemos afirmar que en la intencionada elección del lugar, especialmente en Upper Lawn y Espolla, va implícita la aceptación de ese universo de leyenda, fábula y mito, quedando conscientemente testimoniado por los Smithsons, y Coderch en textos y fotografías de las casas y el territorio.

Con la trasposición de una Kiva a Holanda, para ampliar la Casa Visser, Van Eyck tiene como objetivo precisamente dotar de simbolismo un terreno con menos atributos que los anteriores, en el que el espacio de planta circular de la ampliación, realizado para albergar la colección de arte de moderno de Martin Visser, más que un espacio expositivo, es un espacio simbólico de la obra de arte.

La agrupación de formas cuadradas y circulares es común en los asentamientos de diversas culturas primitivas como los Dogon y los Pueblo. Las relaciones urbanas se fundamentan en la contraposición de significados entre unas y otras: las formas cuadradas corresponden a dormitorios y unidades habitacionales de uso común, mientras que las circulares, en las que se celebran ritos y ceremonias o representan el mundo celeste, se identifican con lo sagrado, simbólico o espiritual. Los círculos generan lugares de mayor intensidad y significado. En la Casa Visser, Van Eyck trata de reinterpretar el simbolismo de una kiva como un espacio sagrado para el arte, sorprendiendo incluso la literalidad de algunos de sus elementos.

La elección de esta obra de Van Eyck como una de las tres de estudio, se basó al comienzo de esta tesis doctoral, en la entonces vaga intuición de que la figura circular de la ampliación estaba relacionada con los lugares de especial significado en los asentamientos de culturas primitivas. La investigación realizada ha corroborado que la intuición era acertada.

5. La comprensión del Upper Lawn Pavilion, de la ampliación de la Casa Visser y de la Casa de Espolla, hace pertinentes preguntas, cuyas respuestas revelan la relación con el lugar como el parámetro más relevante y decisivo. ¿Por qué los Smithsons y Coderch compran una antigua construcción rural en vez de un terreno libre, que en el caso de los primeros es además muy modesta? ¿Por qué allí y no en otro lugar?

Las referencias a Rutter, Britton, Turner y Pevsner seleccionadas por Alison y Peter al comienzo del libro Upper Lawn, Folly Solar Pavilion para describir la finca Fonthill a la que pertenece Upper Lawn, pone de manifiesto su interés por la tradición y cultura inglesa, así como por situar su casa de vacaciones y a sí mismos en ellas. Muestran también una clara voluntad por hacerlo en la historia del Movimiento Moderno. Su comparación con la Casa Farnsworth y la Casa de los Eames formando la trilogía de los tres pabellones desarrollada en varios textos, así lo demuestra. Pero la respuesta de los Smithson, se diferencia claramente en la elección del lugar. No es un lugar indeterminado en la naturaleza y no es de nueva planta, sino que se autoimponen necesariamente un dialogo con la preexistencia del cottage del siglo XVIII, en un intencionado tributo a la cultura vernácula, sus tradiciones, y formas de construir. Upper Lawn entendido como fragmento de un enclave, es un fragmento moderno, del enclave vernáculo que es la granja y su cercado, rodeada por los terrenos del dominio de la finca Fonthill, que es a su vez un fragmento significativo de la cultura inglesa, sus tradiciones y forma de vida. 
Sin Upper Lawn no puede entenderse a los Smithson, y es la intencionada elección de este lugar, con todo su significado histórico y de tradición vernacular, lo verdaderamente relevante.

El mismo análisis es aplicable a la Casa de Espolla de Coderch, que además es la casa de sus antepasados, y es contrapuesto a la lectura sobre la Casa Visser.

¿Por qué Van Eyck interpreta un tipo vernáculo del otro lado del mundo? La respuesta, paradójicamente está también en la relación cultural con el lugar.

La relación cultural con el paisaje y el territorio de cada país, es determinante en los planteamientos urbanos y arquitectónicos de Team 10 como quedó certificado en el CIAM IX de Dubrovnik: Mientras que los Smithson están trabajando sobre nuevos tipos de vivienda y sus escalas de asociación según el lugar, Van Eyck y De 8 en Opbouw (algunos de cuyos miembros también viajaron con Van Eyck al Norte de Africa), investigan sobre como conferir identidad a los nuevos asentamientos en los polder. Mientras los proyectos británicos responden a la especificidad de un pueblo o ciudad concreta, los de los holandeses, situados en la nada de los territorios recientemente drenados, tendían a establecer los nuevos asentamientos a partir de un explícito lenguaje geométrico y universal. Después de un primer viaje a Túnez en 1947, Aldo vuelve intencionadamente al Norte de Africa en 1951, en concreto al Sahara argelino en busca de "lo elemental", de las formas primarias del lenguaje visual que le conducirá a conocer de primera mano culturas no occidentales. En un territorio sin atributos, la abstracción geométrica permite a Van Eyck dotar de identidad a sus proyectos, buscando conscientemente referentes en culturas primitivas con territorios inhóspitos y desérticos: el Sahara argelino, los Dogón y los Indios Pueblo se convierten en fuentes de aprendizaje.

Se puede concluir que en las tres casas la noción de lugar es siempre determinante aunque con dos estrategias diferentes: por acción positiva cargada de matices y significado en la cultura inglesa y catalana, y por omisión en la cultura polder en los Países Bajos.

6. Las tres casas reinterpretan o rompen con la ortodoxia de tipos tradicionales vernáculos, en un proceso no casual sino deliberadamente buscado.

El Upper Lawn Pavilion, en relación con el paisaje, representa los tipos de construcciones para el jardín, de larga y profunda tradición en Inglaterra, país origen del Pintoresquismo y seguramente único en producir una teoría completa sobre el paisaje y el proyecto de exterior, con referencias claras a arquitectos y jardineros del Movimiento Arts and Crafts como Herbert Kitchin, Edwin Lutyens y Gertrude Jekill. La pequeña casa de fin de semana de los Smithsons, sin ser explícitamente alguno de ellos, evoca simultánea e intencionadamente la idea de folly, gazebo, pavilion, garden room y glass-room. Sin duda, en ningún otro país habría sido posible el Upper Lawn Pavilion.

Pero también y desde interior, el espacio diáfano de ambas plantas, evoca tipos domésticos medievales: un espacio único con el fuego en el centro donde dormían, comían y guisaban el propietario, su familia, los huéspedes y siervos. Un tipo de espacio habitable de tradición sajona, el hall sajón, propio de Inglaterra, en donde la colonización romana apenas tuvo influencia sobre la arquitectura doméstica - a diferencia de la construcción militar- al hacer, el clima húmedo de la isla, incompatible la traslación de atrios descubiertos y otros elementos de la villa romana.

La ampliación de la Casa Visser materializa en Holanda una kiva de los Indios Pueblo para albergar la colección de arte de Martin Visser, contraponiendo su carga simbólica con la austeridad de la casa de Rietveld: magnífica, mínima y paradigma de rigor Nieuwe Bouwen. En este caso la inversión de papeles es inesperada, ya que a diferencia de Upper Lawn y Espolla donde la preexistencia es vernácula, aquí la preexistencia es canónicamente moderna y la ampliación vernácula: Van Eyck elige un 
tipo arquitectónico de culturas primitivas en el desierto americano, ejemplificando a la perfección su teoría de las tres tradiciones enunciada en los Círculos de Otterlo.

Esta tesis aporta un enfoque inédito para analizar la Casa Visser, basado en la influencia de los viajes a la región Dogon y Pueblo, en 1960 y 1961.

Al igual que las formas geométricas aisladas de los los playgrounds y del proyecto urbano de Nagele también se proponen en la tesis influenciadas por los primeros viajes de Van Eyck al Norte de África, la ampliación de la Casa Visser y otros proyectos de los sesenta y setenta se caracterizan por la asociación del círculo con cuadrados u otras organizaciones lineales, esta vez bajo la influencia de sus estudios sobre los Dogon y los Pueblo, donde el círculo, o bien se asocia, o altera dicha organización, siempre con una carga simbólica que genera espacios significativos.

Bajo este prisma, la ampliación de Van Eyck de la casa de Rietveld, convierte a la Casa Visser en su conjunto en un pequeño asentamiento, una pequeña aldea en la que no solo se da respuesta a las necesidades básicas del hombre en su vida diaria, representadas aquí por la casa preexistente, sino también a las espirituales, en este caso la colección de arte, con un espacio simbólico de planta circular, semienterrado, con luz cenital en su centro, que reinterpreta el lugar sagrado y simbólico de un kiva de los Indios Pueblo. Al igual que la casa Dogon en Banani, piezas independientes con significados distintos, se relacionan entre sí, formando un conjunto, una unidad espacial y de organización familiar, que dependiendo del número en que se repitan, darán lugar a poblados más o menos grandes, pero que en sí misma es, a su vez, una micro-aldea. Es decir, «la casa es la ciudad y la ciudad es la casa» de sus diagramas Arbol-Hoja presentados por Aldo van Eyck en el Congreso de Team 10 celebrado en Royamount en 1962, con el tema de debate centrado en la infraestructura urbana.

Por último, y ante escándalo de propios y extraños, Coderch, el arquitecto de prestigio, un hombre serio de estirpe aristocrática, y figura de respeto a la que los campesinos de Espolla pedían consejo cuando tenían problemas o decisiones importantes que tomar, se traslada a vivir con su familia a las antiguas cuadras de la masía.

Además de las causas dadas por otros autores sobre esta decisión, como la falta de dinero y la posibilidad de hacer en el futuro otra vivienda para los hijos en la planta primera, esta tesis aporta de forma complementaria un tercer factor a considerar: el distanciamiento intencionado de Coderch con cualquier tipo de ostentación, muy del gusto de una cierta burguesía rural, como muestran las fotografías de Catalá Roca de los interiores de las salas de numerosas masías, publicadas junto con Joaquim Camps i Arboix en el libro Les Cases Pairales Catalanes. Lo que en esta tesis se propone es que el mismo impulso que llevo a Joan Miró a pintar en la Masía, 1921-1922, la vivienda de los masoveros, los cuidadores de la finca, el gallinero y las dependencias de servicio más humildes de Mas Miró, como los protagonistas de la composición del cuadro en lugar de la casa principal, la masía de gusto indiano comprada por sus padres, es seguramente el mismo que condujo a José Antonio Coderch a vivir en las antiguas cuadras y dependencias auxiliares del Mas del Puig en Espolla. A preferir los telúricos espacios abovedados, tallados en la roca y cubiertos con bóvedas arcaicas de potente textura y herencia romana, frente a las bóvedas apuntadas construidas con bóveda tabicada y terminadas con molduras.

A pesar de su pobreza, la fuerza de esta vida popular, su identificación con la tierra y los animales, su conocimiento transmitido de forma oral y de generación en generación de padres a hijos, los objetos y útiles del trabajo en el campo, lo esencial de sus construcciones, materiales y texturas, y en definitiva la armonía con la naturaleza, es lo que cautivó a Miró, a Hemingway y a Coderch entre otros.

Llegados a este punto, se puede concluir que la decisión de Coderch de transformar las antiguas dependencias para animales y aperos de labranza -en la planta baja literalmente tallada en la roca- dejando sin uso la planta noble con un marcado carácter representativo de una burguesía rural, expresa un intencionado deseo de no identificarse con la representación de ese status social, en un acercamiento voluntario a lo popular esencialmente pobre, más que a lo vernáculo. 
7. El parámetro de lo material, es especialmente relevante, ya que el mayor interés de los Smithson, Van Eyck y Coderch, fue construir, identificando actitud ética y materialidad. El enunciado del brutalismo por los Smithsons y sus referencias a Tomas Maldonado lo corroboran, siendo también reconocible en la obra de Van Eyck y Coderch. Como consecuencia, la condición material de las tres obras es extraordinaria, fundamentada en las relaciones que se establecen entre preexistencia y nueva construcción, a partir de dos estrategias contrapuestas: la más evidente de dialogo entre opuestos con la contraposición nuevo/preexistencia y moderno/antiguo, y la más sutil, y poco estudiada, de la continuidad en las acciones realizadas en la mampostería vernácula de piedra de los muros de Upper Lawn y Espolla, y en el ladrillo de la Casa Visser. En todos los casos y por las intencionadas soluciones dadas por sus autores, una mirada atenta siempre puede identificar la nueva construcción en relación a la preexistente.

El Upper Lawn Pavilion de los Smithsons es el que evidencia de forma más clara la contraposición entre opuestos. La decisión de sustituir la antigua edificación por un pequeño pabellón prismático, apoyado sobre el muro, reinterpretando la antigua construcción, establece dicho dialogo de forma clara y rotunda.

El muro antiguo: macizo, robusto, de mampostería de piedra, opaco, irregular, rugoso, grueso, extensión del terreno, estereotómico, arcaico.

En contraposición la nueva construcción: ligera, de madera y vidrio, modulada y prismática, lisa, transparente en el vidrio y reflectante en el revestimiento de láminas de aluminio, fina, perteneciente al aire y al cielo, tectónica, moderna.

Una idea y dos estrategias contrapuestas para llevarla a cabo material y constructivamente. Una pregunta y dos respuestas. Un Qué y dos Cómo:

El más evidente de dialogo entre opuestos con la contraposición del nuevo pabellón y el antiguo muro de mampostería vernácula.

El más sutil, poco estudiado, de la continuidad en las acciones realizadas en el muro de piedra. En el pasado, las técnicas tradicionales evolucionaban mediante pequeños cambios apenas perceptibles hasta pasado un periodo lo suficientemente amplio que posibilitara su visibilidad respecto al origen y que resulta de la suma de microacciones en el tiempo. En este sentido, las nuevas modificaciones se integran con naturalidad y suavemente en la fábrica, junto a las de épocas anteriores. Esta puesta en valor de un modesto muro de mampostería no resulta de una actitud historicista conservacionista. En la arquitectura de los Smithson es igual de importante una brizna de hierba que un castillo.

La Ampliación de la Casa Visser, busca su diferenciación con la casa inicial de Rietveld, a través de la altura y relaciones volumétricas, más que en la condición material. La obra de Van Eyck se realiza en la misma forma que su predecesor. A diferencia del Upper Lawn Pavilion, en el que lo nuevo y lo preexistente se contraponen y/o entrelazan en continuidad, la sala circular de la primera ampliación se construye en ladrillo visto al exterior, de forma aislada y sin contacto con la preexistente, siendo la conexión únicamente posible a través del in-between que es mayoritariamente exterior, excepto un paso fundamentalmente transparente.

Si el in-between de la Casa Visser, es el ámbito donde se encuentran dualidades contrapuestas, su traducción física en el espacio construido necesariamente implica una materialidad que permita a cada uno de los opuestos, hacerlo suyo. Por ello, la mayor parte del espacio intermedio entre la ampliación de Van Eyck y la casa anterior de Rietveld, es un exterior, al igual que el lugar de relación de la casa Banani o como el umbral de la casa Dogon, todos configurados mediante el tratamiento del terreno.

En la Casa Visser, lo que no es exterior como el paso de conexión, es esencialmente transparente. Transparencia que se potencia por su relación geométrica con el lucernario cenital de la sala circular, verdadera prolongación vertical del mismo, y el ventanal de ancho dos metros en la fachada norte, autentico articulador de la casa construida por Rietveld. 
Se puede concluir que el espacio in-between se desarrolla esencialmente en el plano horizontal y se define arquitectónicamente en planta. Es un espacio mayoritariamente exterior, que se cualifica con el tratamiento de la pavimentación, mediante escalonamientos, límites, o cambios de textura, y cuando las necesidades funcionales requieren un lugar interior, la cualidad consustancial de su materialización en el plano vertical es la transparencia del vidrio

En las intervenciones menores realizadas en el año 1971 con Theo Bosch, la continuidad con la fábrica de ladrillo es literal. La diferenciación viene dada por un cambio de altura, de forma que la nueva extensión es más baja que lo construido por Rietveld, condición que se explicita de dos maneras intencionadamente diferentes: mediante el encuentro a distinta altura entre planos diferentes y un escalonamiento cuando el muro es en continuidad.

A diferencia del Upper Lawn Pavilion y de la Ampliación de la Casa Visser, con actuaciones más rotundas, Coderch interviene en su casa pairal, con una serie de operaciones puntuales, que aunque reconocibles, parece que siempre hubieran estado allí. Sin embargo, la comparación de imágenes antiguas con las finales, demuestra que la transformación es mayor de lo que en un principio pudiera parecer. La Casa de Coderch, adquiere tras su intervención, un carácter más atemporal. A partir de una casa de pueblo se transforma, intensificando y descubriendo sus mejores valores, como la significativa interpretación de la persiana de lamas.

La casa de Coderch se enclava en un lugar preponderante en Espolla, apreciándose su importancia debido a su posición elevada -el Mas del Puig-, y al papel, históricamente simultáneo, como límite en su parte alta con terreno propio que se proyecta hacia el territorio, y centro del pueblo en la inferior, junto al arroyo que singulariza la trama urbana.

El proyecto de Coderch asume como prioritaria, sobre otras, esta condición urbana de la casa, que también la diferencia del pabellón de los Simthson en Fonthill y de la Van Eyck en Bergeijk. En este sentido, Coderch elige una estrategia con la que los habitantes de Espolla pudieran sentirse representados, reconocidos, con pautas culturalmente aceptadas a lo largo del tiempo, aunque reinterpretadas desde posiciones modernas, como única manera posible. Como Alejandro de la Sota, cuando construye desde la memoria, sin recordar exactamente qué, trabajando con fragmentos de recuerdos de una memoria colectiva inconsciente, materializados desde la posición culta y moderna de Coderch.

Construcción industrial, construcción vernácula preindustrial, y el dialogo entre ambas. Materiales industriales novedosos e intencionadas preexistencias, coexisten en igualdad y mostrando sus cualidades naturales. Su interés por las cualidades del material, la tectónica y cultura constructiva preindustrial y artesanal, encuentra en las construcciones vernáculas, una fuente de aprendizaje para hacer arquitectura moderna, al incorporar matices que se hibridan de forma natural y refinadamente con los sistemas industriales modernos, resultando las tres obras brillantes ejemplo de esta fusión.

Hacer es pensar. Bajo esta contundente afirmación, el filósofo norteamericano Richard Sennett enuncia en su libro The Craftsman, como los artesanos tienen «conciencia material»; toman conciencia a partir de los materiales. La «antropomorfosis» identifica los materiales con nosotros y atribuye metafóricamente cualidades humanas a cosas inanimadas, como hablar de la honestidad de los materiales. El contraste acentúa el carácter de cada material y nos prepara para una reflexión sobre los mismos, que no se produce si todas las cualidades son indiferenciadas. Las habilidades artesanales son necesarias para establecer estas asociaciones y el valor consciente de los objetos. Este es el prisma bajo el que se han analizado los ejemplos de estudio y sus autores, como artesanos modernos de la arquitectura. Sin renunciar a pensar con el ojo, también quieren pensar con la mano. 
8. En Team 10, más importante que los objetos son las relaciones que se establecen entre ellos. La elección como ejemplos de estudio del Upper Lawn Pavilion, la ampliación de la Casa Visser y la Casa de Espolla, todos proyectos realizados a partir de una preexistencia, se fundamenta intencionadamente en esta idea.

Con distintos grados de intervención según las características de cada caso, los tres ejemplos comparten su transformación en algo moderno, completamente nuevo y diferente a lo anterior, que sin embargo se mantiene reconocible y en un dialogo de igualdad. No son una mera rehabilitación, ampliación o sustitución, sino tres transformaciones que ofrecen una vida mejor y trascienden con mucho el punto de partida. Interpretan modelos vernáculos, cada uno de forma diferente, pero siempre los mejoran, los ponen en valor e incluso cambian su escala aun cuando en Upper Lawn, el nuevo pabellón tiene un volumen menor que el cottage original.

9. Las casas son tres interpretaciones que reflejan los modos de hacer de los Smithsons, Van Eyck y Coderch. La condición espacial de Upper Lawn es aunque aparentemente sencilla, abierta y cerrada, cambiante, experimental y fluida, donde todo es continuo e indeterminado para elección de sus habitantes. En contraposición, en la Casa Visser, el espacio de relación in-between es complejo, asombroso, transparente y fantástico, pero es determinado, estático y ya definido.

Por último el espacio de Espolla, es un espacio raum- condicionado por la estructura de muros de carga de la masía, pero a su vez coincidente con las unidades habitables que conforman las casas de Coderch. Espolla es un refugio protector que evoca la esencia más profunda y primigenia del hogar. Con operaciones puntuales y reconocibles, Coderch consigue transformar unas antiguas cuadras en un espacio de gran intensidad.

10. Al igual que Yi Fu-Tuan cuando define topofilia, como el lazo afectivo entre las personas y el lugar o el ambiente circundante, y aclara que si bien puede ser difuso como concepto es vivido y concreto en cuanto experiencia personal, lo vernáculo, lo primitivo y lo popular, aunque difícil de definir, es abordable e intenso desde lo vivido cada uno.

Si bien las tres casas comparten actitud y un mismo marco conceptual, también evidencian diferencias significativas intensificando, de forma no excluyente, alguna de sus características particulares, bien por su propia esencia y la del lugar al que pertenecen, bien por las estrategias de dialogo que establecen con lo preexistente, como ya se ha señalado, o bien por las actitudes de sus hacedores.

El análisis del Upper Lawn Pavilion, de la Ampliación de la Casa Visser y de la Casa en Espolla, nos muestra matices diversos en el acercamiento personal de sus autores a lo vernáculo, pudiéndose identificar a través de ellos tres miradas, diálogos o planteamientos: la mirada intelectual y abstracta de Van Eyck a partir de lo vernáculo más universal, la mirada de los Smithson con una fuerte conciencia histórica y la mirada intensamente emocional de Coderch. Conviene insistir en que esta afirmación no se refiere a una matización excluyente, sino más bien al plus de intensidad con el que estos matices se dan en cada uno de los autores en relación a sus obras.

Aldo van Eyck se autoimpone la misión de llevar a la arquitectura moderna al camino iniciado con antelación por la ciencia con la teoría de la relatividad y por el arte de las vanguardias del siglo XX, y del que la arquitectura parecía haberse parcialmente descolgado -en su sentido simbólico y espiritual-, al trabajar con grandes escalas urbanas y territoriales que debían dar respuesta a la enorme necesidad de vivienda de la sociedad moderna. Explora culturas primitivas con formas de vida ancestrales, cuya arquitectura aparentemente sencilla, esencial y simbólica, había sido capaz de dar respuesta a las necesidades vitales de sus habitantes a lo largo de siglos. 
La gran pregunta es por qué Aldo van Eyck, con antecedentes culturales coloniales en el Caribe, además de su personal relación cercana y familiar con un territorio lejano de tradiciones primitivas que sin duda le influyeron en su infancia y adolescencia, todos sus escritos e investigaciones significativas sobre lo vernáculo, se refieren a otras culturas como la Bereber, la Dogon o la de los Pueblo. No hay ninguna investigación que dé respuesta explícita a esta pregunta, o siquiera la haya planteado, y es probable que en ella incidan varios factores. Desde esta tesis se propone que la elección de determinadas etnias no es casual, sino que se debe al interés de Van Eyck por culturas que habían sido capaces, mediante asentamientos construidos, de dejar una huella significativa e identitaria en territorios desérticos. En lugares inspiradores para dotar de identidad sus obras en la abstracción del territorio holandés.

En junio de 1927, The van Doesburg publica en el número 98 la revista Arquitectura el artículo «Actividad de la arquitectura moderna holandesa Il» en el que expone. «Ya he dicho que Holanda no cuenta con tradición arquitectónica (como Italia, España, Francia, etc.) y que por esto era terreno favorable para examinar a fondo los problemas de la arquitectura» (Van Doesburg 1927, 218)

Rotunda afirmación que puede explicar por qué Van Eyck busca así, a través de sus viajes, una tradición vernácula universal reflejo de «los principios arcaicos de la naturaleza humana». Viajes fundamentales en sus planteamientos y arquitectura, y que podemos agrupar sintéticamente en dos periodos: Los realizados al norte de Africa entre 1947 y 1952 en busca de "lo elemental", de las formas primarias del lenguaje visual., coincidiendo con el desarrollo del proyecto de Nagele y los Playgrounds realizados para la municipalidad de Amsterdam, para los que serán determinantes, y los hechos en 1960 y 1961 a la región Dogon y al territorio de los Indios Pueblo respectivamente, a su vez también decisivos en los proyectos de la década de los sesenta y primeros setenta, a los que pertenece la Ampliación de la Casa Visser

Alison y Peter Smithson habitaron el Upper Lawn Pavilion dos décadas, en las que educaron a sus hijos en una recreación de la cultura inglesa y su historia, siendo sin duda una experiencia vital decisiva en el ámbito de la intimidad.

Mientras el Upper Lawn Pavilion fue propiedad de los Smithsons, apenas fue publicado pero, después, con la edición en 1986 de Upper Lawn, Folly Solar Pavilion, su diario vital en el pabellón, dejan un legado extenso y detallado sobre su experiencia vital. Un legado en absoluto improvisado, y minuciosamente datado a lo largo de veinte años, en el que muestran con naturalidad su intimidad familiar, en un generoso ejercicio por mostrar las relaciones indisociables entre la arquitectura y sus habitantes. Generosidad que nos permite ver a Alison desayunando recién levantada o a Peter autorretratándose, seguramente en pijama y zapatillas, en el reflejo de la puerta de aluminio.

Privacidad asociada al interés ya señalado de los Smithsons por posicionarse ellos mismos y su pabellón de retiro en la historia de Fonthill y en la arquitectura moderna, en una unión indisoluble e inusual del espacio vital familiar y del arquitectónico profesional, en la que la exposición de su intimidad tiene sentido, no tanto en sí misma, sino en relación a la arquitectura moderna del Upper Lawn Pavilion en su dialogo con la tradición vernácula inglesa.

Por último, la Casa de Espolla supuso algo esencialmente vital para José Antonio Coderch. Según sus propias palabras es quizá el hecho más importante de su vida. Significa la conexión con el pasado, con sus ancestros familiares, con la tradición del campo catalán, con sus raíces más profundas.

De las tres casas estudiadas, es sin duda la que genera una relación más personal y emotiva entre el autor y su obra, al confluir una serie de circunstancias que esta tesis aporta como posibles. 
Coderch fue un hombre con contradicciones significativas, que con su sensibilidad padeció emocionalmente con intensidad. Hizo la guerra con Franco sin renegar nunca de ello, pero sin embargo fue muy crítico con determinadas posturas del régimen en cuanto a la arquitectura que promovía, y también frente a la incultura, ineptitud y corruptelas de muchos cargos oficiales. Sin duda pagó un precio por ello. Con la excepción de las viviendas de la Barceloneta para el ISM y el breve periodo de tiempo como arquitecto municipal de Sitges, no volvió a trabajar con encargos para la administración, lo que en su época fue bastante inusual en un arquitecto con su prestigio.

La enfermedad degenerativa que vivió durante varios años hasta su muerte, pudiera haber estado relacionada con episodios depresivos anteriores, el más importante el ocurrido tras el desengaño de Torre Valentina, que le sumió en una crisis personal, profesional y económica, de la que salió en gran parte gracias a la Casa de Espolla.

Para Coderch, Espolla va más allá de una exploración arquitectónica, aunque sin duda lo es. Se convierte en la referencia que le dará fuerza, estabilidad y serenidad. Encuentra en la cultura de la tierra, el ancla que necesita frente a sus contradicciones y desengaños. La Casa de Espolla, su territorio y su paisaje le conectan con lo más ancestral, sencillo y verdadero. Con el Pirineo y el Mediterráneo. Con la carlina y el fuego del hogar. Con la tramontana y la farigola que crece sobre sus restos en el cementerio de Espolla. 
Bibliografía y Fuentes Documentales 


\section{Bibliografia}

ABAD MONLLOR, Enrique. 2013. «Nagele (1947-1954). Un nuevo asentamiento de viviendas en un nuevo paisaje neerlandés». En: Jornadas internacionales de investigación en construcción: vivienda: pasado, presente y futuro: resúmenes y actas. Madrid: Consejo Superior de Investigaciones Científicas, CSIC, Instituto Eduardo Torroja

ACKERMAN, James S. [1990] 1997 La Villa. Forma e ideología de las casas de campo. Traducción de Isabel Balsinde. Madrid: Akal Ediciones.

ADDIS, Bill. 2007. Building: 3000 years of design engineering and construction. London/New York: Phaidon Press.

ADDIS, Bill. 2011. "Casas prefabricadas de aluminio: los orígenes de esta industria moderna de Inglaterra en 1945» En: S. Huerta, I. Gil Crespo, S. García, M. Taín, eds. Actas del Séptimo Congreso Nacional de Historia de la Construcción, Santiago 26-29 octubre 2011, Madrid: Instituto Juan de Herrera.

ALLISON, Peter. 2005. «Upper Lawn: la restauración invisible. Conversación con Sergison Bates. Upper Lawn: the invisible restoration. A conversation with Sergison Bates» En: 2G n³4, 92-105. Barcelona: Gustavo Gili.

ALONSO DE MEDINA I ALBERICH, Ma Assumpció. 1977. Guía de l'Architectura Popular de les Comarques Gironines. Barcelona: Publicacions del Col.legi d'Arquitectes de Catalunya.

AMADES, Joan. 1938. La Casa. Barcelona: J. Olañeta editor.

AMADES, Joan, y Llorenç Prats. 1982. La casa. Arxiu de tradicions populars ; 37. Palma de Mallorca: Olañeta.

ARAUJO, Ramón y Enrique Seco. 1986. La casa en serie. Madrid: Departamento de Publicaciones ETSAM.

ARGAN, Giulio Carlo. 1983. El arte moderno, 1770-1970. Valencia: Fernando Torres.

ARMESTO, Antonio. y Rafael Diez. 2008. José Antonio Coderch. Barcelona: Santa \& Cole

ARMESTO, Antonio. 2014. Escritos fundamentales de Gottfried Semper. El fuego y su protección. Traducción de Manuel García Roig. Barcelona: Fundación Caja de Arquitectos.

ASHBI, James. 1999. «The Aluminium Legacy: the History of the Metal and its Role in Architecture» En: Construction History. Vol. 15 pp. 79-90. Edita The Construction History Society

ASIS CABRERO, Francisco de. 1992. Cuatro libros de arquitectura. 4 volumenes. Madrid: Fundación Cultural COAM

ASPLUND, Erik Gunnar. 1950. Gunnar Asplund architect: 1885-1940. Stockholm: Tidskriften Byggmastaren.

ASPLUND, Erik Gunnar. 2002. Escritos 1906/1940. Biblioteca de arquitectura ; 10. El Escorial, Madrid: El Croquis editorial. 
AVERMAETE, Tom. 2005. Another Modern: The Post-War Architecture and Urbanism of Candilis-Josic-Woods. Rotterdam: NAI Publishers.

AZARA, Pedro. 2000. La fundación de la ciudad: mitos y ritos en el mundo antiguo. Arquitext 12. Barcelona: UPC.

AZARA, Pedro. 2005. Castillos en el aire: mito y arquitectura en Occidente. Colección Hipótesis. Barcelona: Gustavo Gili.

BAART, Theo; Cary Markerink y Anneke van Veen. 1988. Nagele. Amsterdam: Fragment

BAART, Theo; Warna Oosterbaan y Cary Markerink. 2006. Nagele [revisited]. A Modernistic Village in the Polder. Rotterdam: NAi Publishers

BACHELARD, Gaston. [1957] 1965. La poética del espacio. Madrid: Fondo de Cultura Económica.

BAKEMA, J. B. 1966. Manual del Team 10. Buenos Aires. Nueva visión.

BALDELLOU, Miguel Ángel. 1995. Lugar, memoria y proyecto: Galicia 1974-1994. Colección de Arquitectura. Madrid: Electa.

BALDELLOU, Miguel Ángel, y Antón Capitel. 1995. Arquitectura española del siglo XX. Summa Artis : historia general del arte 40. Madrid: Espasa-Calpe.

BANHAM, Reyner. 1967. El Brutalismo en Arquitectura ¿Ética ó Estética? Traducción de Juan Eduardo Cirlot. Barcelona: Editorial Gustavo Gili

BARÓN PALMA, Emilio. 1996. T. S. Eliot en España. Almería: Servicio de publicaciones. Universidad de Almería.

BENÉVOLO, Leonardo. 1999. Historia de la arquitectura moderna. $8^{a}$ ed. revisada y ampliada. Barcelona: Gustavo Gili.

BENTON, Tim y Sandra Millikin. [1977] 1982. El Movimiento Arts and Crafts. Madrid: Adir ediciones.

BERDINI, Paolo. 1996. Walter Gropius. Estudio paperback. Barcelona: Gustavo Gili.

BERGER, John. 1980. Mirar. Barcelona: Gustavo Gili.

BERGER, John. 2000. Modos de ver. Barcelona: Gustavo Gili.

BETHELL, M. A.1944. Shakespeare \& the popular dramatic tradition. Introduction by T. S. Eliot. Westminster: Staples Press Limited.

BILL, Max. 2004. Max Bill. Arquitecto. Architect. 2G : revista internacional de arquitectura, 29-30. Gimmi, Karin (Ed.) Barcelona: Gustavo Gili.

BODOLEC, Caroline. 2005. L'architecture en voûte chinoise -un patrimoine méconnu-. Paris: Maisonneuve \& Larose

BOHIGAS, Oriol. 1998. Modernidad en la Arquitectura de la España Republicana. Barcelona: Tusquets. 
BONET CORREA, Yago. 1981. “Cuando se contempla el campo catalán» En: W.AA. 1981. La Masía. Historia y Tipología de la casa rural catalana. 2C Construcción de la Ciudad. Marzo 1981 n 17-18. p.7 Barcelona.

BONET CORREA, Yago. 2007. La arquitectura del humo. Barcelona: Fundación Caja de Arquitectos.

BONILLO, Jean-Lucien. 2006. La modernité critique: Autour du CIAM d'Aix-en-Provence Marseille: Editions Imbernon.

BRADLEY-HOLE, Kathryn. 2004. Lost Gardens of England from the Archives of Country Life. London: Aurum Press

BROEK, Johanes Hendrik van den y Jacob Berend Bakema. 1961. «Chiesa a Nagele». Casabella n²57, 32-37

BROWN, Jane. 1982. Gardens of a Golden Afternoon. The Story of a Partnership: Edwin Lutyens and Gertrude Jekyll. Editor: allen Lane

BROWN, Jane. 1989. The Art and Architecture of English Gardens. Designs for the garden from the collection of the Royal Institute of British Architects 1609 to the present day. London: Weidenfeld and Nicolson,

BRUNSKILL, R. W. [1971] 2000. Vernacular Architecture. An Illustrated Handbook. London: Faber and Faber Limited.

BRUNSKILL, R. W. [1997] 2008

Houses and Cottages of Britain. Origins and Development of Traditional Buildings. Yale University Press in association with Peter Crawley.

BUBER, Martin. [1923] 2005. Yo y Tu. Traducción de Carlos Díaz. Madrid: Caparrós Editores.

BULLOCK, Nicholas. 2002. Building the post-war world: modern architecture and reconstruction in Britain. London: Routlegde.

CADEVALL I DIARS, Joan. 1915. Las Carlinas de Cataluña: un hibrido litigioso. Barcelona: Sobs. de López Robert y $\mathrm{C}^{\mathrm{a}}$., impresores, Conde Asalto, 63

CAMERLO, Marcelo (Ed.). 2005. Otras vías = Other ways. 1 Homenaje a Pikionis. Ávila: Colegio Oficial Arquitectos Castilla y León Este.

CAMPS I ARBOIX, Joaquim de. 1976. La masía catalana: historia, arquitectura, sociología. $3^{\text {a }}$ ed. Biblioteca biográfica catalana. Barcelona: Aedos.

CAMPS I ARBOIX, Joaquim de, y Catalá Roca, Francesc. 1965. Les cases pairals catalanes. Edicions Destino

CAMPBELL, James W.P. 2003. Brick: a World History. London. Thames \& Hudson.

CANIZARO, Vincent B. 2007. Architectural Regionalism: Collected Writings on Place, Identity, Modernity, and Tradition. New York. Princeton Architectural Press.

CAPITEL, Antón. y Javier Ortega. 1978. J. A. Coderch: 1945-1976. Madrid: Xarait 
CAPITEL, Antón. 1986. Arquitectura española, años 50 - años 80. Madrid: Ministerio de Obras Públicas.

CARO BAROJA, Julio. 1979. Cuadernos de campo. Madrid: Ediciones Turner S.A.

CASID, Jill H. 2005. Sowing Empire. Landscape and Colonization. Minneapolis: University of Minnesota Press

CASINO, David. 2013. «Ground notations. Estrategias de enraizamiento en Alison y Peter Smithson» / "Ground Notations. Grounding strategies by Alison and Peter Smithson». Revista europea de investigación en arquitectura, REIA 01/2013, pp. 26-38.

CHOISY, Auguste. [1873] 1999. El arte de construir en Roma. Textos sobre teoría e historia de las construcciones. Madrid: Instituto Juan de Herrera.

CIRLOT, Juan Eduardo. 1979. Diccionario de símbolos. Barcelona: Editorial Labor, S.A.

CIRLOT, Juan Eduardo. 1950. El arte de Gaudi. Barcelona: Ediciones Omega.

CLARKE, Ethne y George Wright. 1988. English Topiary Gardens. London: Weidenfeld and Nicolson,

CLOUZOT, Henri. 1925. Tissus Nègres. Paris: Librairie des Arts Décoratifs; A. Calavas, Éditeur.

CODERCH DE SENTMENAT, José Antonio, y Manuel Valls. 1950. «House at San Gervasio, Barcelona; Architects: J. A. Coderch de Sentmenat \& M. Valls», n. ${ }^{\circ}$ 106; pp. 440-42.

CODERCH DE SENTMENAT, José Antonio y Manuel Valls. 1957. «Points de vue sur la situation des jeunes architectes en Espagne». En: L'Architecture d'Aujoud'hui september 1957

CODERCH DE SENTMENAT, José Antonio. 1952. «Memoria estudio sobre una posible solución del problema de las barracas». En: Nueva Forma n¹06. Madrid, 1952.

CODERCH DE SENTMENAT, José Antonio. 1961. «No son genios lo que necesitamos ahora» «lt is not geniuses that we need today». En: Domus n 384, Milan1961

CODERCH DE SENTMENAT, José Antonio. 1967. «Historia de unas castañuelas». En: Nueva Forma $n^{\circ} 106$. Madrid, 1967.

CODERCH DE SENTMENAT, José Antonio. 1969. «Portada de la revista Auca». Auca 14. Santiago de Chile.

CODERCH DE SENTMENAT, José Antonio. 2006. Casas = Houses. $2 \mathrm{G}$ libros. Barcelona: Gustavo Gili.

COLOMINA, Beatriz. 2006. El lawn en guerra. Barcelona: Actar

CORREA, Federico. 1977. «Aldo Van Eyck: una conversación biográfica» En Arquitecturas Bis, $n^{\circ} 19$ noviembre 1977; pp. 1, 17-21

COSTE, Anne. s.f. «The Llambi company, Barcelona: a unique relationship between a manufacturer of blinds and shutters and architects». Construction History. 
DE 8. 1952. «Een plan voor het dorp Nagele». Forum 6/7 Juni/Juli 1952, 172-178

DEPLAZES, Andrea. 2005. Constructing Architecture. Materials Processes Structures. A Handbook. Basel: Birkhäuser.

DEPLAZES, Andrea. 2010. Construir la Arquitectura. Del material en bruto al edificio. Un Manual. Barcelona: Gustavo Gili.

DICKSON, Elizabeth. 1986. The English Garden Room. Boston. Little, Brown.

DIEZ BARREÑADA, Rafael. 2002. Coderch: variaciones sobre una casa. Arquia-tesis. Barcelona: Fundación Caja de Arquitectos.

DIÉGUEZ PATAO, Sofía. 1997. La Generación del 25. Primera arquitectura moderna en Madrid. Madrid: Cátedra.

DIXON HUNT, John. 1988. The Dutch Garden in the Seventeenth Century. Dumbarton oaks colloquium on the history of landscape architecture, XII. Washington DC: Dumbarton oaks trustees for Harvard University.

DOMINGO SANTOS, Juan. 2013. La tradición innovada. Escritos sobre regresión y modernidad. Barcelona: Fundación Caja de Arquitectos.

DOMINGUEZ, Martín. [1966] 2010. «Le Corbusier en recuerdos y presupuestos personales» Originalmente publicado en: La Torre. Revista General de la Universidad de Puerto Rico, $n^{\circ}$ 52. Compilado en Guerreo, Salvador (ed.). 2010. Le Corbusier. Madrid 1928. Una casa -Un palacio. Madrid: Publicaciones de la Residencia de Estudiantes, pp-277-288.

ELIOT, T.S. [1920] 1960. The Sacred Wood. Bristol: University Paperback

ELIOT, T.S. [1979] 2000. Poesías reunidas 1909-1962. Traducción de José María Valverde. Madrid: Alianza Editorial S. A.

ENGELS, F. 1974. El problema de la vivienda y las grandes ciudades. Ciencia urbanística ; 15. Barcelona: Gustavo Gili.

ESPEGEL ALONSO, Carmen. 2006. Heroínas del espacio. Memorias culturales. Valencia: Ediciones Generales de la Construcción.

ESPEGEL ALONSO, Carmen. 2010. Aires modernos: E.1027: maison en bord de mer: Eileen Gray y Jean Badovici 1926-1929. Razón común ;2. Madrid: Mairea.

FANNELLI, Giovanni. 1978. Architettura, edilizia, urbanistica: Olanda, 1917-1940. Firenze: Francesco Papafava.

FANNELLI, Giovanni, y Roberto Gargiani. 1999. El principio del revestimiento: prolegómenos a una historia de la arquitectura contemporánea. Akal arquitectura 21. Tres Cantos: Akal.

FARIELLO, Francesco. [1967] 2004. La arquitectura de los jardines: de la antigüedad al siglo XX. Barcelona: Editorial Reverté

FEDUCHI, Luis. 1974-1984. Itinerarios de arquitectura popular española. 5 volúmenes. Barcelona: Blume. 
FERNÁNDEZ DE CASTRO, Alex. 2015. La masía, un Miró para Mrs. Hemingway. Valencia: Publicacions de la Universitat de València

FERNANDEZ-GALIANO, Luis. 1991. El fuego y la memoria. Sobre arquitectura y energía. Madrid. Alianza Editorial.

FERNÁNDEZ-GALIANO, Luis.1999. «El Laberinto y la vida: Aldo van Eyck, 1918-1999». En: Arquitectura Viva. 1999, no 64 enero-febrero; p. 112. Madrid.

FERNÁNDEZ VEGA, Pedro Angel. 1999. La casa romana. Akal universitaria Serie interdisciplinar 209. Madrid, Tres Cantos: Akal.

FIOL COSTA, Carme y Andreu Arriola. 2004. Barcelona periferia cubista. Barcelona: Ajuntament de Barcelona

FLORES. Carlos [1961] 1989. Arquitectura Española Contemporánea I, 1880-1950. Madrid: Aguilar.

FLORES, Carlos. 1962. «¿Son o no genios lo que necesitamos ahora?» En: Hogar y Arquitectura $n^{\circ} 42$

FLORES, Carlos. 1973. Arquitectura popular española. 5 volúmenes. Madrid: Aguilar.

FLORES, Carlos. 1979. La España popular: raíces de una arquitectura vernácula. Madrid: Aguilar.

FLORES, Carlos. 1982. Gaudí, Jujol y el modernismo catalán. Imagen de España. Madrid: Aguilar.

FLORES, Carlos. 1989. Arquitectura española contemporánea. Madrid: Aguilar.

FLORES, Carlos. 1996. Arquitectura de España :1929-1996 = Architecture of Spain: 1929-1996. Barcelona: Fundación Caja de Arquitectos.

FLORES, Carlos. 1998. «La arquitectura de José Antonio Coderch y Manuel Valls» En: Actas del Congreso Internacional De Roma a Nueva York: Itinerarios de la nueva arquitectura española 1950 / 1965, Pamplona el 29 y 30 de octubre de 1998

FRAMPTON, Kenneth. 1999. Estudios sobre cultura tectónica: poéticas de la construcción en la arquitectura de los siglos XIX y XX. Tres Cantos: Akal.

FRAMPTON, Kenneth. 2000. Historia crítica de la arquitectura moderna. $10^{\mathrm{a}}$ ed. Barcelona: Gustavo Gili.

FREIXA, Jaume. 2006. Sert: Mig segle d' arquitectura 1928-1979. S.I. Fundació Caixa Catalunya.

FOCHS, Carles. 1989 (Ed.). J.A. Coderch de Sentmenat 1913-1984. Barcelona: Editorial Gustavo Gili S.A.

FOCILLON, Henri. 1983. La vida de las Formas y Elogio de la mano. Traducción de Jean-Claude del Agua. Madrid. Xarait Ediciones.

FULLAONDO, Juan Daniel. 1974. «Notas de sociedad». Nueva Forma, n 106, pp. 2-13. 
FULLAONDO, Juan Daniel. 1974. «En torno a la arquitectura popular». Arquitectura $n^{\circ}$ 192, diciembre 1974, pp. 73-86.

FULLAONDO, Juan Daniel. 1994. Mirando hacia atrás con cierta ira (a veces). Historia de la arquitectura contemporánea española ; 1. Madrid: Kain.

FULLAONDO, Juan Daniel. 1995. Los grandes olvidados. Historia de la arquitectura contemporánea española ;2. Madrid: Munilla-Lería.

FULLAONDO, Juan Daniel. 1997. Y Orfeo desciende. Historia de la arquitectura contemporánea española ; 3. Madrid: Molly.

FULLAONDO, Juan Daniel. 2007. Juan Daniel Fullaondo: escritos críticos selección y comentarios María Teresa Muñoz. Madrid: Mairea Libros.

GALLEGO JORRETO, Manuel. 2013. «Arquitectura y Memoria» Conferencia en el Aula Castelao de la Semana Galega de Filosofía.

GARCÍA, Rafael. 2010. Arquitectura moderna en los Países Bajos, 1920-1945. Akal / textos de arquitectura ; 13. Tres Cantos (Madrid): Akal.

GARCÍA GRINDA, José Luis. 2004. La arquitectura tradicional. León. Fundación Hullera Vasco-Leonesa.

GARCÍA GRINDA, José Luis. 2007. Arquitectura tradicional. Arquitectura preindustrial, industrial y del hierro. Editor: Junta de Castilla y León

GARCÍA LORCA, Federico. 2014. Poemas de la Vega. Barcelona: Círculo de Lectores, S.A.

GARCÍA MERCADAL, Fernando. [1930] 1981. La casa popular en España. Barcelona: Editorial Gustavo Gili.

GARCÍA MERCADAL, Fernando. [1949] 2003. Parques y Jardines. Su historia y sus trazados. Edición conmemorativa del LXXV Aniversario del Rincón de Goya con presentación de José Laborda Yneva. Zaragoza: Institución «Fernando el Católico»

GARCÍA MERCADAL, Fernando. 1984. Arquitecturas regionales españolas. Madrid. Consejería de Cultura, Deportes y Turismo. Comunidad de Madrid.

GARCÍA-QUIÑONES, Belén. 2005. AC. Publicación del G.A.T.E.P.A.C. Edición facsímil de los 25 números de la revista, publicados entre 1931 y 1937. Barcelona: Fundación Caja de Arquitectos.

GARCÍA-ROSALES GONZALEZ-FIERRO, Gonzalo. 2015. Operación H, o la poética experimental. Una aproximación a las vanguardias de los años cincuenta y sesenta en España. Tesis doctoral, Universidad de Alcalá UAH

GEIST, Sidney. 1975. Brancusi: the sculpture and drawings. New York: Harry N. Abrams.

GIBERT, J. [1947] 1985. La Masía catalana. Origen, esplendor i decadencia. Barcelona: Editorial Milla.

GIEDION, Sigfried. 1951. A decade of new architecture. Zurich: Girsberger. 
GIEDION, Sigfried. 1979. Espacio, tiempo y arquitectura: el futuro de una nueva tradición. $5^{\mathrm{a}}$ ed. Madrid: Dossat.

GIEDION, Sigfried. 1997. Escritos escogidos. Colección de Arquilectura ; 33. Murcia: Colegio Oficial de Aparejadores y Arquitectos Técnicos de Murcia.

GIEDION, Sigfried. 2009. Espacio, tiempo y arquitectura: origen y desarrollo de una nueva tradición. Ed. definitiva. Estudios universitarios de arquitectura ; 17. Barcelona: Reverté.

GIL CRESPO, Ignacio Javier. 2013. «Fundamentos constructivos de las fortificaciones fronterizas entre las coronas de Castilla y Aragón de los siglos XII al XV en la actual provincia de Soria». Tesis Doctoral. Madrid: I. J. Gil.

GINER DE LOS RÍOS, Bernardo. 1952. 50 años de arquitectura española (1900-1950). Colección cultura para todos ; 10. México: Patria

GINER DE LOS RÍOS, Bernardo. 1980. 50 años de arquitectura española. II, (19001950). Colección archivos y documentos ;2. Madrid: Adir.

GRACIA SORIA, Francisco de. 1992. Construir en lo construido: la arquitectura como modificación. Madrid: Nerea.

GRAVAGNUOLO, Benedetto. 1988. Adolf Loos: teoría y obras. Madrid: Nerea.

GREGOTTI, Vittorio. [1966] 1972. El territorio de la arquitectura. Barcelona: Editorial Gustavo Gili.

GRIERA, Antonio. 1949. La toponimia en el dominio catalán. Zaragoza: Consejo Superior de Investigaciones Científicas.

GRIERA, Antonio. s.f. La Casa Catalana. Vocabulario

GRIERA, Antonio. 1974. La casa catalana. $2^{a}$ ed. Barcelona: Polígrafa.

GONZALEZ DE CANALES, Francisco. 2003. Una estancia en el exterior. Estampas de Puck y arquitecturas análogas. En: DC Papers 9+10, pp.83-101

GONZÁLEZ DE CANALES, Francisco. 2012. Experimentos con la vida misma. Arquitecturas domésticas radicales entre 1937 y 1959. Barcelona: Actar

GUIDONI, Enrico. [1975] 1977. Arquitectura primitiva. Traducción de Juan Novella Domingo. Madrid: Aguilar.

GULLI, Ricardo. 2002. «La huella de la construcción tabicada en la arquitectura de Le Corbusier». En las Bóvedas de Guastavino en América. Libro del catálogo de la exposición, editado por S. Huerta, 73-85. Madrid: Instituto Juan de Herrera, CEHOPU.

MATA, Sara de y Ricardo Sánchez Lampreave. 1987. «Entrevista a Federico Correa» En: Arquitectura $n^{\circ}$ 268. Madrid: Colegio Oficial de Arquitectos..

MEYER; Hannes. 1989. Hannes Meyer: 1889-1954: architekt urbanist lehrer. Berlin: Ernst \& Sohn.

HARTSUYKER, Hendrik. 1961. «Nagele, ein neues Dorf auf neuem Land». Werk n5, 164-170 
HEIDEGGER, Martin. [1950] 2010. Caminos de bosque. Traducción de Arturo Leyte Coello. Madrid: Alianza Editorial.

HEIDEGGER, Martin. [1951] 1994. Conferencias y artículos (construir, habitar, pensar) Traducción de Eustaquio Barjau. Barcelona: Ediciones del Serbal.

HERNANDO DE LA CUERDA, Rafael. 2014. «Pioneros de la arquitectura moderna española. Discontinuidad entre la segunda y tercera generación» En: Actas del I Congreso Nacional Pioneros de la arquitectura moderna española: vigencia de su pensamiento y obra, Madrid 9 y 10 de Mayo 2014, pp. 430-439. Madrid: Fundación Alejandro de la Sota, Madrid,

HERTZBERGER, Herman. 1986. Aldo van Eyck. Amsterdam: Stichting Wonen.

HERTZBERGER, Herman. 1991. Lessons for strudents in architecture. Rotterdam: 010 Publishers

HERTZBERGER, Herman. 2000. Space and the Architect. Lessons in architecture 2. Rotterdam: 010 Publishers

HERTZBERGER, Herman, Addie van Roijen-Wortmann y Francis Strauven. 1982. Aldo van Eyck, Amsterdam: Stichting Wonen.

HITCHCOCK, Henry Russell. 1981. Arquitectura: siglos XIX y XX. Manuales Arte Cátedra. Madrid: Cátedra.

HONNECOURT, Villard de. [1986] 1991. Villard de Honnecourt. Cuaderno. Siglo XIII. Presentado y comentado por Erlande-Btandenburg, Alalin et.al. Madrid: Ediciones Akal

HOOIMEIJER, Fernande Lucretia. 2010. «Rotterdam: "Dynamic Polder City = Land+ Water+ Culture». En: Nakhara: Journal of environment design and planning, Vol.6 Dynamic City: land, water and culture, pp.45-58

HUERTA FERNÁNDEZ, Santiago. 2009. «Historia de la Construcción: la fundación de una disciplina». Actas del Sexto Congreso Nacional de Historia de la Construcción. Valencia 21 - 24 de octubre de 2009 Volumen I, pp. xiii - xix.

HUERTA FERNÁNDEZ, Santiago. 2015. «Construction History: The building of a discipline» Keynote. En: Proceedings of the Fifth International Congress on Construction History, June 2015, Chicago, Illinois. Edited by Brian Bowen, Donald Friedman, Thomas Leslie, John Ochsendorf. Construction Society of America.

HUERTA FERNÁNDEZ, Santiago e Ignacio Javier Gil Crespo. 2015. «Construyendo la Historia de la Construcción». En: Actas del Noveno Congreso Nacional y Primer Congreso Internacional Hispanoamericano de Historia de la Construcción. Segovia 13 17 de octubre de 2015 Volumen I, pp.41-60. Madrid: Instituto Juan de Herrera.

HULTEN, Pontus; Natalia Dumitresco, y Alexandre Istrati. 1987. Brancusi. New York: Harry N. Abrams.

IBELINGS, Hans y Francis Strauven. 2000. Arquitectos contemporáneos en los Países Bajos y Flandes. Rekkem: Fundación Flamenco-Neerlandesa $=$ Stichting Ons Erfdeel

IBELINGS, Hans. 2008. «Un Universo paralelo». En Arquitectos no 184; pp.46a-46b Madrid: Consejo Superior de los Colegios de Arquitectos de España. 
JAFFÉ, Aniela. [1964] 1995 «El simbolismo en las artes visuales», en El hombre y sus símbolos Carl Gustav Jung. Barcelona: Ediciones Paidos Ibérica S.A. pp.230-271

JASCHKE, Karin. 2011. «Aldo van Eyck and the Dogon Image = Aldo van Eyck y la imagen Dogon». En : Buckley, Craig y Rhee Pollyana (eds), Architects'journeys: bulidings, travelling, thinking = Los viajes de los arquitectos: construir, viajar, pensar. New York: GSAPP Books, Pamplona T6 Ediciones; pp. 72-103

JEKYLL, Gertrude. 1981. Gardens for Small Country Houses. Woodbridge, Suffolk: Antique Collectors Club. Cornell University Library

José Antonio Coderch. Casas [Jose Antonio Coderch. Houses]. 2005. Vol. 33. Barcelona: Gustavo Gili.

JUJOL, Josep María. 1989. «Josep Maria Jujol, arquitecto 1879-1949» Quaderns d'Arquitectura i Urbanisme ; 179-180. Barcelona: Collegi Oficial d'Arquitectes de Catalunya.

JUNCOSA, Patricia. 2011. Josep Lluís Sert. Conversaciones y escritos. Lugares de encuentro para las artes. Traducción de Moisés Puente. Barcelona. Editorial Gustavo Gili.

JUNG, Carl G. [1964] 1995. El hombre y sus símbolos. Traducción de Luis Escolar Bareño. Barcelona: Ediciones Paidós Ibérica S.A.

KAHN, Lloyd. [1979] 1985. Cobijo. Traducción de José Corral. Madrid. Herman Blume

KIPLING, Rudyard: 1987. Puck de la colina de Pook. Versión en castellano de Jorge Ferrer-Vidal, Editorial Anaya, Madrid

KRUCKER, Bruno. 2002. Complex Ordinariness. The Upper Lawn Pavilion by Alison and Peter Simthson. Zurich, gta Verlag, ETH Zurich.

KÜPER, Marijke, e Ida van Zijl. 1992. Gerrit Th. Rietveld, 1888-1964: the complete works. Utrecht: Centraal Museum.

LAMPÉREZ Y ROMEA, Vicente. 1993. Arquitectura civil española del los siglos I al XVIII. Madrid: Giner

LANDSBERG, Sylvia. [1995] 2003. The Medieval Garden. University of Toronto Press.

«L'avantguarda lúcida : una conversa amb Josep-Lluis Sert». 1982. Quaderns d'arquitectura i urbanisme, n. ${ }^{\circ}$ 152: 74-77.

LE CORBUSIER. 1999. Le Corbusier et Pierre Jeanneret: oeuvre complète. Basel: Birkhäuser.

LE CORBUSIER. 2002. Voyage d'Orient: carnets. English ed. Milano: Electa.

LEFAIVRE, Liane y Alexander Tzonis. 1999. Aldo van Eyck, Humanist Rebel: Inbetweening in a Postwar World. Rotterdam: 010 Publishers

LEFAIVRE, Liane e Ingeborg de Roode (Eds.). 2002. Aldo van Eyck. The playgrounds and the city. Rotterdam: NAi Publishers 
LEJEUNE, Jean-Francois and Michelangelo Sabatino. 2010. Modern Architecture and the Mediterranean. Vernacular dialogues and contested identities. London: Routlegde.

LEWERENTZ, Sigurd. 1989. Sigurd Lewerentz, 1885-1975: the dilemma of classicism. London: Architectural Association.

LIGTELIJN, Vincent. 1999. Aldo van Eyck: Works. Basel; Boston; Berlin: Birkhäuser

LIGTELIJN, Vincent y Francis Strauven. 2008 (Eds.). Aldo van Eyck. Writings. Collected articles and other writtings 1947-1998. Amsterdam: Sun Publishers

LOOS, Adolf. 1993 a. Escritos I, 1897-1909. Biblioteca de arquitectura ; 1. Madrid: El Croquis Editorial

LOOS, Adolf. 1993 b. Escritos II, 1910-1932. Biblioteca de arquitectura ; 2. Madrid: El Croquis Editorial

LUTYENS, Edwin. [1979] 1986. Edwin Lutyens. Serie Architectural Monographs. London: Academy Editions; New York: St. Martin's Press.

MARC, Olivier. [1972] 1977. Phychology of the house. London: Thames and Hudson

MARCHAN FIZ, Simón. 1974. La arquitectura del siglo XX. Documentación/Debates. Madrid: Alberto Corazón.

MARCHÁN FIZ, Simón. 2010. La disolución del clasicismo y la construcción de lo moderno. Ediciones Universidad de Salamanca

MARTí ARÍS, Carlos. 2005. La cimbra y el arco. La cimbra. Barcelona: Fundación Caja de Arquitectos.

MARTÍ ARÍS, Carlos. 2014. Las variaciones de la identidad: ensayo sobre el tipo en arquitectura. Arquithemas. Barcelona: Fundación Arquia.

MARTINELL BRUNET, César. 1975. Construcciones agrarias en Cataluña. Estudios históricos. Barcelona: La Gaya Ciencia.

MARTíN SALVÁN, Paula (Ed.). 2006. El espíritu del lugar: jardín y paisaje en la Inglaterra moderna. Madrid: Abada Editores SL.

MAY, John. 2010. Handmade Houses and Other Building: The World of Vernacular Architecture. London. Thames \& Hudson.

Mc.CAIG, lain y Brian Ridout. 2012. Timber. English Heritage Practical Building Conservation. Ashgate Publishing and English Heritage.

MELIÁ, Josep. 1971 Joan Miró. Barcelona: Dopesa.

MERCADER, Laura (ed). 2002. Antoni Gaudí. Escritos y documentos. Barcelona: EL Acantilado.

MEYER, Han; Inge Bobbink y Steffen Nijhuis. 2010. Delta Urbanism: The Netherlands. Chicago: American Planning Association.

MOHOLY-NAGY, L. 1946. Vision in motion. Chicago: Institute of design book. 
MONTANER, Josep Maria. 1982. «España 1940-1980» En Historia de la arquitectura moderna de Leonardo Benévolo, en la versión castellana de la $5^{a}$ edición ampliada. Barcelona: Gustavo Gili

MONTANER, Josep María. 1988. «La Arquitectura de la Tercera Generación». En: El Croquis. 1988, nº 36 noviembre

MONTANER I MARTORELL, Josep María. 1993. Después del Movimiento Moderno. Arquitectura de la segunda mitad del siglo XX. Barcelona: Editorial Gustavo Gili.

MORAGAS, Antoni. 1962. «La arquitectura catalana hoy». En: Hogar y Arquitectura $n^{\circ} 42$

MORENO MANSILLA, Luis. 2000. «El Sur de los arquitectos nórdicos: dos vistas de Siena, y un paseo por la mirada». En: Arquitectura $n^{\circ}$ 322. Madrid: Colegio Oficial de Arquitectos de Madrid.

MORENO MANSILLA, Luis. 2002. Apuntes de viaje al interior del tiempo. Arquia-tesis. Barcelona: Fundación Caja de Arquitectos.

MORENO VILLA, José. 1932. «Algo sobre su arquitectura». En Revista Arquitectura 153, 19-23. Madrid: Colegio Oficial de Arquitectos de Madrid.

MOSTAFAVi, Mohsen. 2005. Architecture is not made with the brain: the labour of Alison and Peter Smithson. Architecture Landscape Urbanism ; 9. London: Architectural Association Publications.

MUMFORD, Eric. 2000. The CIAM Discourse on Urbanism 1928-1960. MIT Press

MUNTAÑOLA THORNBERG, Josep. [1974] 2001. La arquitectura como lugar. Barcelona: Edicions UPC.

MUNTAÑOLA THORNBERG, Josep. 2000. Topogénesis. Fundamentos de una nueva arquitectura. Barcelona: Edicions UPC.

NATHAN ROGERS, Ernesto. [1958] 1965. Experiencia de la arquitectura. Buenos Aires: Ediciones Nueva Visión.

NEWMAN, Oscar. 1961. CIAM '59 in Otterlo. Stuttgart. Krämer.

NORBERG-SCHULZ, Christian. [1979] 1983. Arquitectura Occidental. La arquitectura como historia de formas significativas. Traducción de Alcira González Malleville y Antonio Bonnano. Barcelona: Editorial Gustavo Gili.

NORBERG-SCHULZ, Christian. 1980. Genius loci: towards a phenomenology of architecture. New York. Rizzoli.

OCKMAN, Joan. 1993. Architecture Culture 1943-1968: A Documentary Anthology, Nueva York: Rizzoli.

OKU, Kaya. 2009. The architecture of Gerrit Rietveld. Tokyo: TOTO Publishing.

OLIVER, Paul. 1997. Encyclopedia of Vernacular Architecture of the World. 3 volúmenes. Cambridge. Cambridge University Press.

ONIONS, C.T. 1986. A Shakespeare Glossary. Enlarged and revised throughout by Robert D. Eagleson. Oxford at the Clarendon Press 
PALLASMAA, Juhani. 2009. The Thinking Hand. Existencial and Embodied Wisdom in Architecture, Chichester (West Sussex): John Wiley \& Sons Ltd.

PALLASMAA, Juhani. [2009] 2012. La mano que piensa. Sabiduría existencial y corporal en la arquitectura. Traducción de Moisés Puente. Barcelona: Gustavo Gili

PALLASMAA, Juhani. [2012] 2014. Los ojos de la piel. La arquitectura y los sentidos. Traducción de Moisés Puente y Carles Muro. Barcelona: Gustavo Gili

PARICIO, Ignacio. [1997] 1999. La protección solar. Barcelona: Bisagra.

PARNELL, Steve. 2012. «AR's and AD's post-war editorial policies: the making of modern architecture in Britain». En: The Journal of Architecture, 17:5, pp.763-775

PEDRET, Annie. 2013. TEAM 10: an archival history. London: Routledge.

PETER, John. 1994. The Oral History of Modern Architecture: Interviews with the Greatest Architects of the Twentieth Century. New York Harry N. Abrams, Inc.

PETERS, Tom. 1996. Building the Nineteenth Century. Cambridge, Massachusetts Institute of Technology Press.

PETERS, Tom F. 2010. «Una cultura americana de la construcción». En Geometría y Proporción de las Estructuras, Ensayos en honor de Ricardo Aroca. S. Huerta, P. Cassinello, J.M. Prada Poole, y R. Sánchez Lampreave, (eds.). Libro editado con ocasión del Simposio Internacional en homenaje a Ricardo Aroca, pp. 359-373. Madrid: Outer Ediciones

PEVSNER, Nikolaus. 1957. Esquema de la arquitectura europea. 1 ed. en español. Biblioteca de arquitectura ; 2. Buenos Aires: Infinito.

PEVSNER, Nikolaus. 1958. Pioneros del diseño moderno: de William Morris a Walter Gropius. Buenos Aires: Infinito

PEVSNER, Nikolaus. 1976. Los orígenes de la arquitectura moderna y del diseño. Barcelona: Gustavo Gili

PEVSNER, Nikolaus y Bridge Cherry. 1963. Wiltshire (The buildings of England). London: Penguin Books.

PIERINI, Simona. 2003. «Amigos de Coderch». En:Circo 2003.110, Madrid: Circo M.R.T.

PIKIONIS, Dimitris. 1989. Dimitris Pikionis, Architect 1887-1968: a sentimental topography. London: Architectural Association.

PIÑON, Helio. 1976. «Tres décadas en la obra de José Antonio Coderch». En :Arquitecturas bis $n^{\circ} 11$.

PIZZA, Antonio. 1983. «José Antonio Coderch, o las coincidencias imposibles. Reflexión sobre algunos ejemplos de arquitectura residencial». En: Annals dárquitectura $n^{\circ} 3$

PIZZA, Antonio. y Josep María Rovira. 2003. J.M. Coderch 1940-1964. En busca del hogar. Editado por Antonio Pizza y Joseph M. Rovira. Barcelona: Col legi d'Arquitectes de Catalunya. 
PONTI, Gio. 1949. «El arquitecto Gio Ponti en la Asamblea» En: Revista Nacional de Arquitectura $n^{\circ}$ 90, junio.

PORCEL, Baltasar. 1967. José Antonio Coderch o la moral creadora. Barcelona: Ediciones Destino.

QUESADA LÓPEZ, Fernando. 2012. Del cuerpo a la red: cuatro ensayos sobre la descorporeización del espacio. Inmersiones. Madrid: Ediciones Asimétricas.

QUESADA LÓPEZ, Fernando (Ed.). 2015. Comunidad, común, comuna. Madrid: Ediciones Asimétricas.

QUEST-RITSON, Charles. 2003. The English Garden. A Social History. London: Penguin Books

QUETGLAS, Josep. 1979. «El miedo a Coderch». En Carrer de la Ciutat n6.

RAHOLA AGUADE, Victor, y Stefano Cortellaro. 2007. «Variaciones de la persiana de librillo en la obra de Coderch [Variations on folding shutters in the work of Coderch». Quaderns d'arquitectura i urbanisme, n. ${ }^{\circ} 253$, pp. 78-81.

RAPOPORT, Amos. [1969] 1972. Vivienda y cultura. Traducción de Conchita Díez de Espada. Barcelona: Editorial Gustavo Gili

REH, Wouter, Clemens Steenbergen y Diederik Aten. 2007. Sea of Land. The polder as an experimental atlas of Dutch landscape architecture. Stichting Uitgeverij NoordHoland

RESTANY, Pierre. 1970. «Dall'Olanda: una casa per una collezione. Intervento di Aldo van Eyck in un edificio di Rietveld». En Domus 491, ottobre 10/1970, pp.16-20

RIETVELD, Gerrit Thomas. 1996. Gerrit Th. Rietveld 1888-1964, [exposición en la sala de las Arquerías de los Nuevos Ministerios del MOPTMA, del 12 al 14 de abril de 1996]. Madrid: Centro de Publicaciones.

RIETVELD, Gerrit Thomas 2006. Casas = houses. 2G : revista internacional de arquitectura 39-40. Barcelona: Gustavo Gili.

RIETVELD, Gerrit Thomas 2010. Rietvelds's universe. Rotterdam: Nai Publishers.

RISSELADA, Max. 1988. Raumplan versus plan libre : Adolf Loos and Le Corbusier, 1919-1930. Delft: University Press

RISSELADA, Max y Dirk van den Heuvel. 2005. Team 10, 1953-81: in search of a utopia of the present. Rotterdam: NAI Publishers

RISSELADA, Max. 2011. Alison \& Peter Smithson. A Critical Anthology. Barcelona: Ediciones Polígrafa

ROBBINS, David. 1990 a. The Independent Group: Postwar Britain and the aesthetics of plenty. Cambridge (Mass): The MIT Press.

ROBBINS, David. 1990 b. El Independent Group: la postguerra británica y la estética de la abundancia. Valencia: Instituto Valenciano de Arte Moderno 
RODRÍGUEZ GARCIA, Ana y Rafael Hernando de la Cuerda. 2000. «La aportación de Hendrik Petrus Berlage en la construcción de fábrica y nuevos sistemas estructurales en la transición del siglo XIX al XX». Actas del III Congreso Nacional de Historia de la Construcción. Sevilla, 26-28 octubre de 2000. 2 volúmenes. Edita Instituto Juan de Herrera. Volumen II, pp. 937-946

RODRIGUEZ GARCIA, Ana y Rafael Hernando de la Cuerda. 2007. «La bóveda tabicada y el movimiento moderno español». En Actas del V Congreso Nacional de Historia de la Construcción. Burgos, 7-9 junio 2007. Edita Instituto Juan de Herrera. Volumen II, pp. 763-773

RODRIGUEZ GARCIA, Ana y Rafael Hernando de la Cuerda. 2009 a. «Timbrel Construction and Reinforced Concrete in Madrid Rationalism (1925-1939)» En: Proceedings of the Third International Congress on Construction History. Brandenburg University of Technology Cottbus, $20^{\text {th }}-24^{\text {th }}$ May 2009. Edited by Karl-Eugen Kurrer, Werner Lorenz, Volker Wetz. Volumen III, pp. 1257-1264

RODRIGUEZ GARCIA, Ana y Rafael Hernando de la Cuerda. 2009 b. «Racionalización de sistemas y materiales de construcción en el movimiento moderno español, 19271937». En: Actas del VI Congreso Nacional de Historia de la Construcción. Valencia, 21 24 octubre 2009. Edita Instituto Juan de Herrera. Volumen II, pp. 1168-1178

RODRIGUEZ GARCIA, Ana. 2003. «H. P. Berlage and Amsterdam Stock Echange, a reflection of the meaning of Construction». Proceedings of the First International Congress on Construction History. Madrid, 20th-24th January 2003. Edita Instituto Juan de Herrera. Volumen III, pp. 1753-1763

RODRIGUEZ GARCIA, Ana. 2005. «Los nuevos materiales, impulsores de la arquitectura moderna. El hormigón armado en la obra de H.P. Berlage» Actas del IV Congreso Nacional de Historia de la Construcción. Cádiz, 27-29 enero de 2005. Edita Instituto Juan de Herrera. Volumen II, pp. 953-963

RODRÍGUEZ GARCÍA, Ana. 2011. «Tradición y nuevos materiales. Los Smithson en Upper Lawn 1958-1962, un pabellón experimental sobre una granja inglesa del siglo XVIII». S. Huerta, I. Gil Crespo, S. García, M. Taín, eds. Actas del Séptimo Congreso Nacional de Historia de la Construcción, Santiago 26-29 octubre 2011, Madrid: Instituto Juan de Herrera.

RODRIGUEZ GARCIA, Ana. 2012. «Modern interpretations of the vernacular tradition in the work of J.A.Coderch, 1940-1964». En: Nuts \& Bolts of Construction History. Culture, Technology and Society, Vol. 1. Paris: Picard, 211-219

RODRÍGUEZ GARCIA, Ana. 2013 a. «El entramado de madera del Upper Lawn Pavilion de Alison y Peter Smithson. Una interpretación moderna de técnicas tradicionales» Huerta, Santiago y Fabián López Ulloa, eds. Actas del Octavo Congreso Nacional de Historia de la Construcción. Madrid, 9-12 de octubre de 2013, Madrid: Instituto Juan de Herrera.

RODRÍGUEZ GARCIA, Ana. 2013 b. «El Upper Lawn Pavilion de Alison y Peter Smithson. La transformación de una preexistencia» The Upper Lawn Pavilion by Alison and Peter Smithson. Transforming a pre-existence. En: :Jornadas Internacionales de investigación. Patrimonio, Territorio, Paisaje. Alcalá, 7 y 8 de octubre de 2013. Universidad de Alcalá en colaboración con la Universidad Autónoma de Aguascalientes 
RODRIGUEZ GARCIA, Ana. 2014. «No son genios lo que necesitamos ahora. Una reflexión sobre el escrito de J.A. Coderch en el contexto de Team 10". En: Actas del I Congreso Nacional Pioneros de la arquitectura moderna española: vigencia de su pensamiento y obra, Madrid 9 y 10 de Mayo 2014. pp. 852-862. Madrid: Fundación Alejandro de la Sota.

RODRIGUEZ GARCÍA, Ana. 2015. «Nagele. Identidad, modernidad y tradición». En: Quesada, Fernando (ed.) 2015. Comunidad, Común, Comuna, pp.119-147. Madrid: Ediciones Asimétricas

RODRIGUEZ GARCIA, Ana. 2015. «Thinking with the eye, thinking with the hand; looking for a modern construction between industry and craftsmanship. The Upper Lawn Pavilion by Alison and Peter Smithson 1959-1962». En Proceedings of the Fifth International Congress on Construction History, Chicago June 3-7th 2015. Volumen 3, pp-213-220. Editado por la Construction History of America

ROSSI, Aldo. 1981. La arquitectura de la ciudad. $5^{a}$ ed. amp. Punto y línea. Barcelona: Gustavo Gili.

ROTH, Alfred. 1975. La nouvelle architecture: présentée en 20 exemples = Die neue architektur = The new architecture. Zürich; München: Architectur Artemis.

ROVIRA, Josep M. 2006. Sert: de la ciutat funcional al disseny urbà. Dédal ; 1. Barcelona: Universitat Politècnica de Catalunya.

RUDOFSKY, Bernard. 1964. Architecture without Architect. New York: MOMA.

RUIZ CABRERO, Gabriel. 1985 a «Dos obras de Alejandro de la Sota en León» En: Arquitectura. $n^{\circ} 252$ enero-febrero; pp. 43-56. Madrid: Colegio Oficial de Arquitectos

RUIZ CABRERO, Gabriel. 1985 b. «Dieciséis proyectos de Velázquez Bosco: la Mezquita-Catedral de Córdoba» En: Arquitectura nº 256 septiembre-octubre; pp. 47-56. Madrid: Colegio Oficial de Arquitectos.

RUIZ CABRERO, Gabriel. 1989. Spagna architettura, 1965-1988. Milano: Electa

RUIZ CABRERO, Gabriel. 1992. "Una larga conversación y un regalo», «A long conversation and a gift». En: Arquitectura $n^{\circ}$ 294, diciembre 1992, pp.105-111

RUIZ CABRERO, Gabriel. 1995. «Los Principios y lo principal». En: Arquitectos $n^{\circ} 138$, vol. 95/3, pp.61-62

RUIZ CABRERO, Gabriel. 2001. El moderno en España: arquitectura 1948-2000. Madrid: Tanais.

RUSKIN, John. 1988. Las siete lámparas de la arquitectura. Biblioteca. ; 2. Barcelona: Alta Fulla.

RUTTER, John. 1823. Delineations of Fonthill and its Abbey. London: Charles Knight and Co

RYBCZYNSKI, Witold. [1986] 2009. La casa. Historia de una idea. Traducción de Fernando Santos Fontenla. Donostia-San Sebastián: Nerea. 
SANCHEZ MERINA, Francisco Javier. 2002. «Entrevista con Peter Smithson». En: Debates en la Arquitectura Anglosajona sobre el uso de la palabra Historia . Tesis doctoral UPC

SCHREGENBERGER, Thomas. 2003. " As Found is a small affair, it is about being careful». Werk, Bauen und Wohnen 6-2003, Zürich CH

SEGURA MUNGUÍA, Santiago. 2005. Los jardines en la Antigüedad. Edición a cargo de Javier Torres Ripa. Bilbao: Universidad de Deusto

SEMPER, Gottfried. 2014. Escritos fundamentales de Gottfried Semper: el fuego y su protección. Editado por Antonio Armesto (ed.). Arquithemas. Barcelona: Fundación Arquia.

SENNETT, Richard. 2008. The Craftsman. New Haven: Yale University Press

SENNETT, Richard. [2008] 2009. El Artesano. Editorial Anagrama S.A

SERRANO AVILÉS, Ramón. 2009. « As found y la experiencia del fragmento. Debate entre imagen y preexistencia en la producción artística británica de la inmediata posguerra». Cuaderno de Notas 12. Madrid: Departamento de Composición de la E.T.S. Arquitectura, UPM

SERT, Josep Lluís. 1982. «L 'Avantguarda lúcida. Una conversa amb Josep-Lluís Sert» En: Quaderns d'arquitectura i urbanisme. nº 152

SERT, Josep Lluís. 2011. Josep Lluís Sert: conversaciones y escritos: lugares de encuentro para las artes. Barcelona: Gustavo Gili.

SHAKESPEARE, William. 1961. A midsummer Night's Dream. Edited by J.W.Lever, M.A. Longmans, Green \& Co Ltd

SMITHSON, Alison. 1960. «Ciam Team 10» En AD: The Architectural Design. 1960, nº 5 mayo; p. 175-178:

SMITHSON, Alison. 1974. Team 10 primer. Cambridge, Massachusetts : MIT Press,

SMITHSON, Alison (ed.). 1982. The Emergency of Team 10 out of CIAM: Documents. Compiled by Alison Smithson. London

SMITHSON, Alison. [1983] 2001. As in DS. An eye on the road. Baden: Lars Múller Publishers.

SMITHSON, Alison. 1991. Team 10 Meetings 1953-1984. Edited by Alison Smithson. Delft: Publikatieburo, Faculteit der Bouwkunde, Technische Universiteit Delft.

SMITHSON, Alison and Peter Smithson. 1956. «But Today We Collect Ads» Ark: the Journal of the Royal College of Art; n¹8 November; pp. 185-186

SMITHSON, Alison and Peter Smithson. 1957. «Alison and Peter Smithson: Answer on the Brutalism». Architectural Design, April 1957

SMITHSON, Alison y Peter Smithson. [1965] 1981. The heroic period of modern architecture. London/Milan. Rizzoli. 
SMITHSON, Alison. 1967. Urban structuring: estudies of Alison \& Peter Smithson. London; New York: Studio Vista; Reinhold Publishing Corporation.

SMITHSON, Alison y Peter Smithson.1970. Ordinariness and light, urban theories 19521960 and their application in a building Project 1963-1970. Cambridge, Massachusetts: The MIT Press.

SMITHSON, Alison y Peter Smithson.1973. Without Rhetoric. An Architectural Aesthetic 1955-1972. Londres: Latimer New Dimensions.

SMITHSON, Alison y Peter Smithson. 1982. The Shift. Architectural Monographs, $\mathrm{n}^{\circ} 7$, 1982.

SMITHSON, Alison y Peter Smithson. 1985. The 1930 's. Berlín. Alexander Verlag.

SMITHSON, Alison y Peter Smithson. 1986. Upper Lawn; Folly Solar Pavilion, Barcelona: Edicions de la Universitat Politécnica de Catalunya UPC.

SMITHSON, Alison y Peter Smithson. 1990. "The as found and the found ". Robbins, David Ed. The Independent Grou : Postwar Britain and the aesthetics of plenty Cambridge (Mass): The MIT Press.

SMITHSON, Alison y Peter Smithson. 1993. Italian Thoughts, Stockholm.

SMITHSON, Alison y Peter. 1994. Changing the Art of Inhabitation. Mies'pieces, Eames 'dreams, The Smithsons. Artemis London 1994

SMITHSON, Alison y Peter.1994. Cambiando el arte de habitar. Piezas de Mies, Sueños de los Eames, Los Smithsons. Barcelona: Gustavo Gili

SMITHSON, Peter. 1967. «Alvar Aalto and the ethos of the second generation». En: ARK Arkkitehti Arkitekten 7-8, 1967, p.21

SMITHSON, Peter. 1996. «Some thoughts in 1996 on the statement by Coderch written in August 1961». En: Web Architecture Magazine WAM 01. 1996 julio-agosto

SMITHSON, Peter. 1997. «Some thoughts in 1996 on the statement by Coderch written in August 1961» Edición analógica Web Architecture Magazine WAM 1-2, febrero 1997

SMITHSON, Peter. 2001. The Charged void: Architecture. Alison y Peter Smithson, New York: The Monacelli Press.

SOLÁ-MORALES RUBIÓ, Ignasi de. 1980. Eclecticismo y vanguardia: el caso de la arquitectura moderna en Catalunya. Colección Arquitectura y Crítica. Barcelona: Gustavo Gili.

SOLÁ-MORALES RUBIÓ, Ignasi de. 1990. Jujol. Barcelona: Ediciones Polígrafa, SA

SOLÁ-MORALES RUBIÓ, Ignasi de. 1995. Diferencias: topografía de la arquitectura contemporánea. Barcelona: Gustavo Gili.

SOLÁ-MORALES RUBIÓ, Ignasi de. 2004. Eclecticismo y vanguardia y otros escritos. $2^{\mathrm{a}}$ ed. ampl. Barcelona: Gustavo Gili.

SORIA, Enric. 1979. J.A. Coderch de Sentmenat. Conversaciones. Barcelona: Editorial Blume 
SORIANO, Federico y Alberto Nicolau. 1993. «Alison \& Peter Smithson». En: Arquitectura $n^{\circ} 292$, Enero 1993. Madrid: Colegio Oficial de Arquitectos

SOTA, Alejandro de la. 1982. «Por una arquitectura lógica» En: Puente, Moises (ed.) 2002. Alejandro de la Sota: escritos, conversaciones, conferencias. Barcelona: Gustavo Gili; pp. 70-71

SOTA, Alejandro de la. 2002. Alejandro de la Sota: escritos, conversaciones, conferencias. Puente, Moises (ed. )Barcelona: Gustavo Gili.

SPAETH, David. 1986. Mies van der Rohe. Barcelona: Gustavo Gili.

SPELLMAN, Catherine y Karl Unglaub 2004. Peter Smithson. Conversaciones con estudiantes. Un espacio para nuestra generación. Barcelona: Gustavo Gili.

St JOHN WILSON, Sir Colin Alexander. 1995. The Other Tradition of Modern Architecture: the Uncompleted Project. London: Academy Editions.

STANLEY, Wells. 1985. Shakespeare. An Illustrated Dictionary. Oxford paperback reference. Revised edition. Oxford University Press.

StEENBERGEN, Clemens [et.al]. 2009. The Polder Atlas of The Netherlands: Pantheon of the Low Countries Thoth Publishers

STRAUVEN, Francis. 1998. Aldo van Eyck: the shape of relativity. Amsterdam: Architectura \& Natura

STRAUVEN, Francis. 2007. «Aldo van Eyck - Shaping the New Reality. From the Inbetween to the Aesthetics of Number». CCA Mellon Lectures 12, 24 May 2007; pp.1-20 Study centre mellon lectures. Montreal: Canadian Centre for Architecture

STRAUVEN, Francis. 2008. «Aldo van Eyck, shaping the new reality» [Vídeo] Conferencia 6 de octubre de 2008, Salón de actos de la Fundación Arquitectura COAM. Madrid: Fundación Arquitectura COAM.

TÁVORA, Fernando. 1998. Távora. DPA, Documents de Projectes d'Arquitectura ; 14. Barcelona: Edicions UPC.

THACKER, Christopher. 1979. The History of Gardens. Berkeley and Los Angeles, California: University of California Press.

TORRES BALBÁS, Leopoldo. 1930. La vivienda popular en España. Folklore y Costumbres de España ; 3. Barcelona: Alberto Martín.

TORRES BALBÁS, Leopoldo. 1954. Resumen histórico del urbanismo en España. Madrid: Instituto de Estudios de Administración Local.

TRIGUEIROS, Luz (ed). 1993. Fernando Tavora. Lisboa: Editorial Blau, Lda.

TUAN, Yi-Fu. [1974] 2007. Topofilia. Traducción de Flor Durán de Zapata. Barcelona. Melusina.

TURNER, John. 1986. English Garden Design. History and Styles since 1650. Woodbridge, Sufflok: Antique Collectors Club

TUSCANO, Clelia. 2005. «Voices of Team 10. Clelia Tucano interviews: Giancarlo de Carlo, Ralph Erskine, Aldo van Eyck, Gerorges candilis, Balkrishna Doshi, Herman 
Hertzberger, Peter Smithson, Alison and Peter Smithson, Giancarlo de Carlo». En: Team 10, 1953-81: in search of a utopia of the present; pp.314-344. Rotterdam: NAI

TUSQUETS BLANCA, Oscar. 1998. Todo es comparable. Barcelona: Anagrama.

TUSQUETS, Oscar. 2000. «Recuerdos de un grandísimo arquitecto». En El País / Quadern. Serie Els quatre gats mayo 2000

URRUTIA, Angel. 2002. Arquitectura española contemporánea. Documentos escritos, testimonios inéditos. Madrid: COAM.

UTZON, Jorn. 2010. Jorn Utzon: conversaciones y otros escritos. Barcelona: Gustavo Gili.

VAN DEN HEUVEL, Dirk y Max Risselada. 2004. Alison and Peter Smithson - from the House of the Future to a house of today, Rotterdam: 010 Publishers.

VAN DEN HEUVEL, Dirk. 2004. «Picking up, Turning over and Putting with...». En: Alison and Peter Smithson - from the House of the Future to a house of today, Rotterdam: 010 Publishers.

VAN DOESBURG, Theo. 1927. «Actividad de la arquitectura moderna holandesa II» En: Arquitectura n98, junio, pp. 213-220. Madrid: Colegio Oficial de Arquitectos.

VAN EESTEREN, Cornelis. 1948. «La concepción de nuestros asentamientos y paisajes agrícolas. Sus formas de expresion y configuración». Publicado en castellano por Julián Galindo González en Cornelis van Eesteren. La experiencia de Amsterdam 19291958. Barcelona: Fundación Caja de Arquitectos.

VAN EYCK, Aldo. 1953. «Bouwen in de Zuidelijke Oasen». Forum n¹, 28-37

VAN EYCK, Aldo. 1959 a. «Talk at the Otterlo Congress». En: Ligtelijn, Vincent y Francis Strauven (eds.). 2008. Aldo van Eyck. Writings. Collected articles and other writtings 1947-1998. Amsterdam: Sun Publishers, pp199-201

VAN EYCK, Aldo. 1959 b. «ls architecture going to reconcile basic values?». En: Ligtelijn, Vincent y Francis Strauven (eds.). 2008. Aldo van Eyck. Writings. Collected articles and other writtings 1947-1998. Amsterdam: Sun Publishers, pp.202-205

VAN EYCK, Aldo. [1962] 2006. The Child, the City, and the Artist. Strauven, Francis y Vincent Ligtelijn (eds.). Amsterdam: Sun Publishers

VAN EYCK, Aldo. 1970. «Ampliación de la casa del coleccionista Visser, en un edificio de Rietveld, Bergeyk (Holanda)». En Domus no 491 octubre; p. 16-20

VAN EYCK, Aldo.1982. «Transparency». En: Ligtelijn, Vincent y Francis Strauven (eds.). 2008. Aldo van Eyck. Writings. Collected articles and other writtings 1947-1998. Amsterdam: Sun Publishers, pp.494-497

VAN EYCK, Aldo. 1983 a. Aldo van Eyck, Projekten 1948-1961. Van de Beek, J. (ed.). Groningen: Akademie van Boukunst

VAN EYCK, Aldo. 1983 b. Aldo van Eyck, Projekten 1962-1976. Van de Beek, J. (ed.). Groningen: Akademie van Boukunst 
VAN EYCK, Aldo. 1986. Niet om het even... wel evenwaardig, van en over Aldo van Eyck. Strauven, F. (ed.). Rotterdam: Stichting Rotterdam-Maaskant

VAN EYCK, Aldo. 1987. "The circle and the centre». En: Indesem 87: International Design Seminar; April 6-10 University of Technology Delft. Labadie, Marc y Bert Tjhie (eds.). 1988. Delft: Delft University Press, pp.184-185

VAN EYCK, Aldo. [1983] 1997. «Una Iglesia Católica en La Haya». En: Arquitectura 311, $3^{\circ}$ trimestre 1997. Madrid: Colegio Oficial de Arquitectos de Madrid COAM pp.84-87

VAQUERO GÓMEZ, José Ángel. 2014. Lo popular en la arquitectura moderna en España: Coderch, Fisac, De la Sota, Fernández del Amo. Tesis Doctoral UPM. Madrid: J. A. Vaquero

VELASCO BARRAL, Carlos- 2014. La modernidad paradigmática de la arquitectura popular. Orígenes y evolución de su descubrimiento en las publicaciones periódicas de arquitectura en España 1897-1958. Tesis Doctoral UPM. Madrid: C. Velasco Barral.

VENTURI, Robert. [1966] 1978. Complejidad y contradicción en la arquitectura. Barcelona: Gustavo Gili

VENTURI, Robert. 1998. Aprendiendo de las Vegas: el simbolismo olvidado de la forma arquitectónica. Barcelona: Gustavo Gili.

VICENTE GARRIDO, Henry. 2013. Arquitecturas desplazadas: Rafael Bergamín y las arquitecturas del exilio español en Venezuela. Madrid: H. Vicente.

VIDAL OLIVERAS, Jaume. 1977. «El Tiempo del Arte. Conversación con Santos Torroella». Kalias. Revista de Arte, n. ${ }^{\circ} 17-18$, pp. 86-113.

VIDOTO, Marco. 1997. Alison + Peter Smithson. Obras y Proyectos. Barcelona: Gustavo Gili

VILA, Marc-Aureli. 1980. La casa rural a Catalunya. Barcelona. Edicions 62.

VILCHEZ VILCHEZ, Carlos. 1999. Leopo/do Torres Balbás. Granada: Editorial Comares

VITRUVIO, Marco Lucio. 1980. Los Diez Libros de Arquitectura. Barcelona: Editorial Iberia S. A.

VIOLANT I SIMORRA, Ramón. 1944. La Casa Pallaresa y la vida pastoril: guía y comentario de las instalaciones. Instituto de Historia de Barcelona. Archivo Histórico de la Ciudad.

W.AA. Plinio el Viejo. Historia Natural. Libros XII-XVI. Traducción y notas de Manzanero Cano, F., García Arribas, I., Arribas Hernáez, Ma.L., Moure Casas, A.Mª. y Sánchez Bermejo, J.L.. Madrid: Editorial Gredos 2010

V.AA. 1974 La arquitectura de/ siglo XX. Traducción de J. Martínez de Velasco y Simón Marchan Fiz. Madrid: documentación/debates.

W.AA. [1961] 1988. Arquitectura Popular em Portugal. 3 volumenes. Lisboa: Associacao dos Arquitectos Portugueses.

W.AA. 1981. La Masía. Historia y Tipología de la casa rural catalana. Barcelona. 2c Construcción de la Ciudad. Marzo 1981 n 17-18. 
W.AA. 1981. Zorg voor de omgeving. Over de betekenis van vormgeving. Gravenhage. Ministerie van Cultuur.

W.AA. 1983. AX BAX. Aldo van Eyck. AOHNA 1983. Athens. The National Gallery and Alexander Soutzos Museum.

W.AA. 1983. CIAM. Volkshuisvesting Stedebouw. Housing Town Planning. Delf. Rijksmuseum Kröller-Muller/Auke van der Woud The Nederlads

W.AA. 1984. William Morris (1834-1896). Directora del catalogo de la exposición Dra. Lynne Walker Madrid: Dirección General de Arquitectura y Vivienda. MOPU.

W.AA. 1987. Coderch. Arquitectura $n^{\circ} 268$, de septiembre-octubre 1987. Madrid: Colegio Oficial de Arquitectos de Madrid

W.AA. 1990. Zijn vak is het tot stand brengen van verbeelde orde. Aldo van Eyck. Rotterdam-Delf-Amsterdam. OASE n 26-27.

W.AA. 1996. Gerrit Rietveld 1888-1964. Madrid: Publicaciones Ministerio de Obras Públicas, Transportes y Medio Ambiente.

V.AA. 1999. Rearrangements, A Smithsons celebration. Rotterdam-Delf-AmsterdamGroningen-Utrech. OASE no 51.

W.AA. 2001. El territorio i la casa. Segarra-Urgell. 2n Cúrset d'estiu d'arquitectura popular.

W.AA. 2004. Cases de poble. Evolució, arquitectura i retauració dels nucles rurals. Figueres. Brau Edicions.

W.AA. 2011. Rietveld's universe. Rotterdam: NAi Publishers.

W.AA. 2014. Bernard Rudofsky. Desobediencia crítica a la modernidad. Granada: Centro José Guerrero.

WEAVER, Lawrence [1913] 1990. Houses and gardens by E. L. Lutyens. Woodbridge, Suffolk: Antique Collectors' Club

WEIDLINGER, Paul. 1956. Aluminium in Modern Architecture. Volume II. Engineering Design and Details. Louisville, Kentucky: Reynolds Metals Company

WILLIAMS, Raymond.1973. The Country and the City. Oxford University Press

WILLIAMS, Raymond [1973] 2001. El campo y. la ciudad. Buenos Aires, Barcelona, Méjico: Paidos.

WOOD, Martin. 2006. The Unknown Gertrude Jekyll. London: Frances Lincoln

YEOMANS, David. 2003. The repair of historic timber structures. London: Thomas Telford Publishing.

ZERBST, Rainer. 1989. Gaudi. Obra Completa. Köln: Taschen GmbH.

ZIJL, Ida van. 2010. Gerrit Rietveld. London: Phaidon. 


\section{Diccionarios}

BEIGBEDER ATIENZA, Federico. 2009. Diccionario politécnico de las lenguas española e inglesa $=$ Polytechnic dictionary of Spanish and English languajes [sic]. $3^{\mathrm{a}}$ ed., rev. y ampl. Madrid: Díaz de Santos.

COROMINAS, Joan. 1980. Diccionario crítico etimológico castellano e hispánico. Biblioteca románica hispánica. V, Diccionarios ; 7. Madrid: Gredos.

ERNEST WEEKLEY, M.A. 1921. An Etimological Dictionary of Modern English . London: John Murray, Albermarle Street, W.

FERRATER MORA, José. 1969. Diccionario de filosofía. Buenos Aires: Editorial Sudamericana.

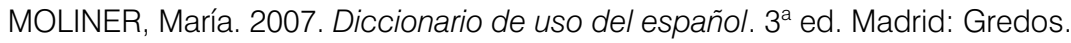

REAL ACADEMIA ESPAÑOLA 2006. Diccionario esencial de la lengua española. Madrid: Real Academia Española, Espasa Calpe.

HARPER, Douglas. [2001] 2015. Online Etimology Dictionary.

http://www.etymonline.com

Online Merriam-Webster Dictionary.

http://www.merriam-webster.com

\section{Documentación online}

* Team 10 online. http://www.team10online.org/

* Documentación publicada online por las siguientes instituciones: la Fundación Plan Delta Stichting Deltawerken, la organización para el Proyecto de estudio sobre los pueblos del Polder del Nordeste 'DNA' van de Noordoostpolder-dorpen, Investiga la memoria de los Países Bajos Doorzoek het Geheugen van Nederland, y Museo del Mar del Sur Zuiderzee Museum. 


\section{Archivos y fuentes documentales}

En la realización de la tesis se han consultado los siguientes archivos:

* The Alison and Peter Smithson Team 10 Archive, en el Nederlands Architectuurinstituut NAi de Rotterdam

* The Bakema Team 10 Archive, en el Nederlands Architectuurinstituut NAi de Rotterdam

* Arxiu Coderch en la Universidad Politécnica de Cataluña

* gta archives CIAM Archives ETH Zurich

* The Alison and Peter Smithson Archive. Special Collections, Frances Loeb Library, Graduate School of Design, Harvard University. (a través de copias digitalizadas en alta calidad facilitadas por el profesor Max Risselada)

* Aldo van Eyck Archive en Loenen aan de Vecht.

(a través de copias digitalizadas en alta calidad facilitadas por el profesor Francis Strauven. 
